\title{
Constitutionele interpretatie : een rechtsvergelijkend onderzoek naar de vaststelling van de reikwijdte van het recht op persoonlijkheid
}

Citation for published version (APA):

Janssen, H. L. (2003). Constitutionele interpretatie : een rechtsvergelijkend onderzoek naar de vaststelling van de reikwijdte van het recht op persoonlijkheid. [Doctoral Thesis, Maastricht University]. Sdu Uitgevers. https://doi.org/10.26481/dis.20030207hj

Document status and date:

Published: 01/01/2003

DOI:

10.26481/dis.20030207hj

Document Version:

Publisher's PDF, also known as Version of record

Please check the document version of this publication:

- A submitted manuscript is the version of the article upon submission and before peer-review. There can be important differences between the submitted version and the official published version of record.

People interested in the research are advised to contact the author for the final version of the publication, or visit the DOI to the publisher's website.

- The final author version and the galley proof are versions of the publication after peer review.

- The final published version features the final layout of the paper including the volume, issue and page numbers.

Link to publication

\footnotetext{
General rights rights.

- You may freely distribute the URL identifying the publication in the public portal. please follow below link for the End User Agreement:

www.umlib.nl/taverne-license

Take down policy

If you believe that this document breaches copyright please contact us at:

repository@maastrichtuniversity.nl

providing details and we will investigate your claim.
}

Copyright and moral rights for the publications made accessible in the public portal are retained by the authors and/or other copyright owners and it is a condition of accessing publications that users recognise and abide by the legal requirements associated with these

- Users may download and print one copy of any publication from the public portal for the purpose of private study or research.

- You may not further distribute the material or use it for any profit-making activity or commercial gain

If the publication is distributed under the terms of Article $25 \mathrm{fa}$ of the Dutch Copyright Act, indicated by the "Taverne" license above, 
Constitutionele interpretatie 


\section{Constitutionele interpretatie}

Een rechtsvergelijkend onderzoek naar de vaststelling van de reikwijdte van het recht op persoonlijkheid

\section{PROEFSCHRIFT}

ter verkrijging van de graad van doctor aan de Universiteit Maastricht, op gezag van de Rector Magnificus, Prof.dr. A.C. Nieuwenhuijzen Kruseman, volgens het besluit van het College van Decanen, in het openbaar te verdedigen op vrijdag 7 februari 2003 om 14.00 uur

door

HELEEN LOUISE JANSSEN 


\section{Promotor:}

Profmr. A.W. Heringa

Beoordelingscommissie:

Prof.mr. L.F.M. Verhey (voorzitter)

Prof,mr. C. Flinterman (Universiteit Utrecht)

Dr. J.G.C. Schokkenbroek (Council of Europe)

Prof.mr. F.A.M. Stroink

Prof.dr. B.E.F.M. de Witte

(C) 2003 Sdu Uitgevers BV, Den Haag

Omslagontwerp: Villa $Y$, Den Haag

Van deze studie is een handelsuitgave verschenen bij Sdu Uitgevers BV onder ISBN: 9054093668 


\section{Inhoud}

\section{Hoofdstuk 1}

Algemene inleiding

1.1 Vaststelling van de reikwijdte wan grondrechten

1.1.1 De wetsanalogie 6

1.1 .2 De rechtsanalogie 7

1.1.3 Het constitutionele spanningsveld 9

1.2 Vraagstelling $\quad$ II

1.2.1 Rechtsvinding in het licht van de constitutionele verhouding tussen rechter en wetgever 11

1.2.2 Consistentie van rechtspraak en coherentie van rechtsnormen $\quad 13$

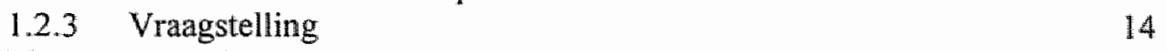

$\begin{array}{lll}1.3 & \text { Plan van aanpak } & 14\end{array}$

1.4 Afbakening 15

\section{Hoofdstuk 2}

\section{Structuur en reikwijdte van het recht op persoonlijkheid}

$\begin{array}{lll}2.1 & \text { Definitie van het recht op persoonlijkheid } & 17\end{array}$

2.1.1 Inleiding: op zoek naar een werkdefinitie 18

2.1.2 Geen sluitende definitie 19

2.1.3 Elementen van het recht op persoonlijkheid 21

2.1.4 Het recht op persoonlijkheid is een amorf concept 24

2.1.5 Omschrijving van een werkdefinitie van het recht op

2.2 Het constitutioneelrechtelijke begrippenkader $\quad 26$

$\begin{array}{lll}2.2 .1 \quad \text { Inleiding } & 26\end{array}$

$\begin{array}{ll}2.2 .2 \text { Constitutie } & 27\end{array}$

$\begin{array}{ll}2.2 .3 \text { Grondwet } & 28\end{array}$

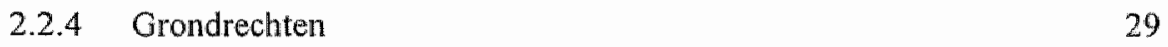

2.3 Verenigde Staten: de Constitutie en de Amendementen 31

2.3.1 Het Vierde en het Vijfde Amendement 33

2.3.2 Het Negende Amendement 35

2.3.3 Het Veertiende Amendement: 'due process" en 'liberty' 36

2.3.4 "Privacy" in de rechtsprakak 40

2.4 Duitsland: het Grundgesetz 41

2.4.1 Art. 79 lid 3 Grundgesetz: de Eeuwigheidsclausule 42

2.4.2 Art. 1 lid 1 Grundgesetz: menselijke waardigheid 44

2.4.3 Art. 2 lid 1 Grundgesetz: vrije ontplooiing van de
persoonlijkheid

2.4.4 Het 'allgemeines Persönlichkeitsrecht' 47

2.4.5 Privaatrechtelijke notie wan het 'allgemeines Persönlichkeitsrecht' 50

2.5 Europese Unie: het Verdrag van de Europese Unie 51

2.5.1 Het EU-Verdrag: grondwet en grondrechten 51 
2.5.2 Het EU-Handvest van fundamentele rechten

2.5.3 Het Gemeenschapsrecht en het Europese Verdrag van de Rechren van de Mens

2.6 Raad van Europa: het Europees Verdrag voor de Rechten van de Mens $\quad 57$

2.6.1 Het EVRM: grondwet en grondrechten 57

2.6.2 Art. 8 EVRM: het recht op 'privé-leven" 58

2.6.3 Derdenwerking van Art. 8 EVRM 61

2.7 Nederland: de Grondwet 61

2.7.1 Art. 10 Grondwet: eerbiediging van de persoonlijke levenssfeer $\quad 62$

2.7.2 Art. 11 Grondwet: het recht op lichamelijke onschendbaarheid $\quad 63$

2.7.3 Art. 8 EVRM: het recht op eerbiediging van 'privé-leven' 64

2.7.4 Het "algemene persoonlijkheidsrecht"

2.7 .5 Privaatrechtelijk begrip van het "recht op persoonlijkheid" 65

2.8 Slot

\section{Hoofdstuk 3}

Constitutionele verhouding tussen rechter en wetgever

Werkwijze van de rechter in de ontvankelijkheidsfase en de toetsingsfase

\subsection{Inleiding}

3.1.1 De constitutionele verhouding tussen rechter en wetgever

3.1.2 De rechterlijke talkopvatting

3.2 De werkwijze van het Amerikaanse Hooggerechtshof $\quad 72$

3.2.1 Federale rechtsmacht van het Hof 72

3.2.2 De rechtsgang naar het Hof: het certiorari-systeem 75

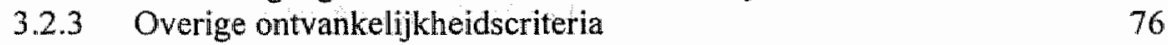

3.2.4 De rechterlijke taakopvatting van het Hof 78

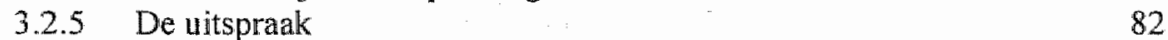

3.2.6 Checks van de wetgever op de rechtsmacht van het Hof 84

3.3 De werkwijze van het Duitse Federale Constitutionele Hof 87

3.3.1 Federale rechtsmacht van het Hof 87

3.3.2 Ontwankelijkheidscriteria 91

3.3.3 De uitspraak 92

3.3.4 Checks van de wetgever op de rechtsmacht van het Hof 96

3.3.5 Rechterlijke taakopvatting van het Hof 98

3.4 De werkwijze van het Europese Hof van Justitie van de EG $\quad 102$

3.4.1 Internationale rechtsmacht met federale trekken 102

$\begin{array}{ll}3.4 .2 & \text { Ontwankelijkheidscriteria } \\ & 105\end{array}$

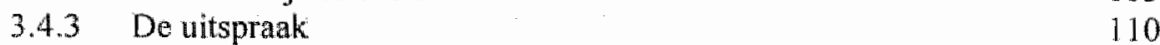

3.4.4 Checks van de wetgever op de rechtsmacht van het Hof 112

3.4.5 Rechterlijke taakopvatting van het Hof 113

3.5 De werkwijze van het Europese Hof voor de Rechten van de Mens 115

3.5.1 Rechtsmacht van het Hof 115

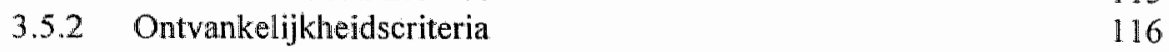

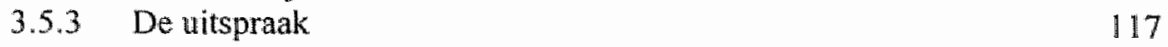


3.5.4 Checks van de verdragswetgever op de rechtsmacht van het Hof $\quad 119$

3.5.5 Rechterlijke taakopvatting van het Hof 120

3.6 De werkwijze van de Hoge Raad 123

3.6.1 Rechtsmacht van de Hoge Raad 123

$\begin{array}{ll}3.6 .2 & \text { Ontvankelijkheidscriteria } \\ 3.326\end{array}$

$\begin{array}{ll}\text { 3.6.3 De uitspraak } & 127\end{array}$

3.6.4 Checks van de wetgever op de rechtsmacht van de Hoge Raad $\quad 129$

3.6.5 Rechterlijke taakopvatting van de Hoge Raad 130

3.7 Conclusies en slot $\quad 1.32$

3.7.1 Inleiding 132

3.7.2 Rechterlijk mandaat en ontvankelijkheid 133

3.7.3 Ambtshalve aanvulling van de rechtsgronden en constitutionele
verhouding 134

3.7.4 Uitspraakbevoegdheden in het licht van de rechterlijke taakopvatting 135

3.7.5 Verticale begrenzingen van rechterlijke bevoegdheden 136

$\begin{array}{ll}3.7 .6 & \text { Wijziging van de grondwet of het verdrag } 136\end{array}$

3.7.7 Benoeming en samenstelling van de rechterlijke instanties 137

3.7.8 Beperking van de rechtsmacht van de rechter 138

3.7.9 Slot: de rechterlijke taakopvatting 138

\section{Hoofdstuk 4 \\ Constitutionele interpretatie}

Deel A

Rechtsvindingsmethoden bij de uitleg van grondwet en verdrag

4.1 Inleiding

4.1.1 Opzet

4.1.2 Rechtsvindingsfase, ontvankelijkheidsfase en toetsingsfase $\quad 144$

4.2 De noodzaak van constitutionele rechtsvinding 145

4.2.1 "Constitutionele" rechtsvinding 145

4.2.2 Leemte of open textuur van de normen gelieerd aan het recht op persoonlijkheid 146

4.2.3 'Moeilijke gevallen' 151

4.2.4 Het forum: wie moet worden overtuigd van de rechtsvinding? 153

4.3 Het interpretatiedebat in de verschillende rechtsstelsels 157

4.3.1 Verenigde Staten 157

$\begin{array}{ll}\text { 4.3.2 Duitsland } & 164\end{array}$

$\begin{array}{ll}\text { 4.3.3 Europese Gemeenschappen } & 172\end{array}$

4.3.4 Raad van Europa 181

4.3.5 Nederland 190

4.3.6 Slot: het interpretatiedebat in de stelsels vergeleken 194

$\begin{array}{lll}4.4 \text { De analogie } & 200\end{array}$

4.4.1 De analoge redeneerwijze 200

4.4.2 Inductie in de analoge redenering 203 
4.4.3 Wetsanalogie: een voorbeeld uit de jurisprudentie 204

4.4.4 Rechtsanalogie: een voorbeeld uit de jurisprudentie 205

4.5 Enkele kanttekeningen bij de analoge redenering 207

4.5.1 Algemene opmerkingen naar aanleiding van de gegeven voorbeelden

4.5.2 Analogie ter invulling van systematische teleologische en dynamisch-evolutieve uitleg

4.5.3 Bedenkingen tegen de analoge redeneerwijze

Deel $\mathbf{B}$

Grondsllagen van de normen in de wetsanalogie en de rechtsanalogie

4.6 Het rechtskarakter van de in de analogie betrokken normen 216

$\begin{array}{lll}4.6 .1 & \text { Inleiding } & 216\end{array}$

$\begin{array}{lll}4.6 .2 & \text { Rechtsnormen } & 217\end{array}$

4.6.3 Rechtskarakter van het recht op persoonlijkheid 223

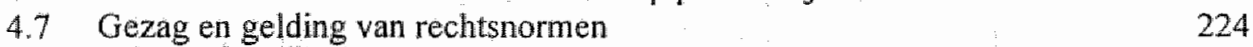

4.7.1 Inleiding 224

4.7.2 Gelding van rechtsnormen: de grens van het recht 226

4.7.3 Hart en Dworkin: vaststelling van geldigheid van rechtsnomen $\begin{array}{ll}\text { door de rechter } & 230\end{array}$

4.7.4 Legitimatie van rechtsnormen in de rechtspraak: precedentwerking 232

$\begin{array}{lll}4.8 & \text { Slot } & 239\end{array}$

4.8.1 Inleiding 239

4.8.2 De juridische status van het rechtsbeginsel en van de norm van hoger recht

4.8.3 De juridische status van het resultaat van de extensieve interpretatie en van het nieuw gepositiveerde recht

4.8.4 Constitutioneelrechtellijke bezwaren tegen de analogie in de rechtsvinding

\section{Hoofdstuk 5}

Analoge rechtsvinding in de jurisprudentie van het Amerikaanse Hooggerechtshof

5.1 Inleiding

5.2 Rechtsontwikkeling door het Amerikaanse Hooggerechtshof

5.3 Ontwikkeling van het recht op persoonlijkheid met analoge redeneringen 251

$5.3 .1 \quad$ Inleiding 251

5.3.2 Toegang tot het gebruik van voorbehoedmiddelen 251

$\begin{array}{lll}5.3 .3 & \text { Het recht op abortus } & 258\end{array}$

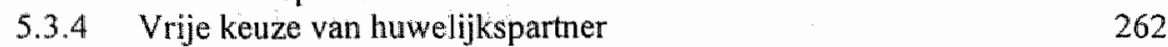

5.3.5 Het recht familiebetrekkingen te vestigen en te onderhouden 265

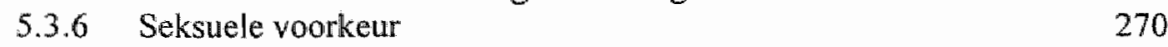

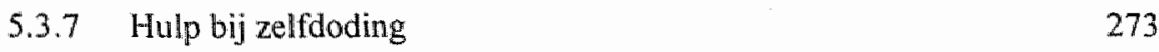


5.4 Bevindingen $\quad 275$

5.4.1 Inleiding : 275

5.4.2 Ontwikkeling van de grondslag voor de normen van hoger recht 276

5.4.3 Het recht op persoonlijkheid: bevindingen in interpretatie en reikwijdte

5.4.4 De analoge redenering 281

5.4.5 Terminologie : $\quad 287$

\section{Hoofdstuk 6}

Analoge rechtsvinding in de jurisprudentie van het Duitse Federale Constitutionele $\mathbf{H o f}$

6.1 Inleiding

6.2 Rechtsontwikkeling door het Duitse Federale Constitutionele Hof

6.2.1 Constituerende uitspraken van het Hof over Art. 1 lid 1 en Art. 2 lid $1 \mathrm{GG}$

6.2.2 Grenzen aan het recht op persoonlijke ontplooing ex

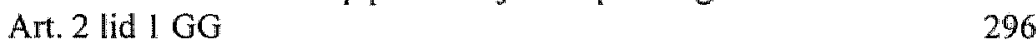

6.2.3 Constitutioneel recht en privaatrecht 298

6.3 Ontwikkeling van het recht op persoonlijkheid met analoge redeneringen 299

$\begin{array}{ll}6.3 .1 & \text { Inleiding } \\ 6.3 .2 & 299\end{array}$

6.3.2 Het recht op zelfbeschikking 299

6.3.3 Het recht alleen te worden gelaten en het recht op resocialisatie 305

$\begin{array}{lll}6.3 .4 & \text { Het recht op abortus } & 307\end{array}$

6.3.5 Het recht op het eigen beeld en het gesproken woord 311

6.3.6 Het recht op 'informationele zelfbeschikking' 313

$\begin{array}{ll}\text { 6.3.7 Het recht de biologische afstamming te kennen } & 31.7\end{array}$

6.3.8 Aspecten van de geestelijke, fysieke en seksuele integriteit 321

$\begin{array}{lll}6.4 & \text { Bevindingen } & 323\end{array}$

6.4.1 Inleiding 323

6.4.2 Ontwikkeling van de grondslag voor de normen van hoger recht 324

6.4.3 Het recht op persoonlijkheid: bevindingen in interpretatie en reikwijdte

$\begin{array}{ll}\text { 6.4.4 De analoge redenering } & 327\end{array}$

6.4.5 Terminologie 332

\section{Hoofdstuk 7}

Analoge rechtsvinding in de jurisprudentie van het Hof van Justitie van de $E G$

$7.1 \quad$ Inleiding

7.2 Rechtsontwikkeling door het Hof van Justitie van de EG 335

7.3 Ontwikkeling van het recht op persoonlijkheid met analoge redeneringen 338

$\begin{array}{ll}\text { 7.3.1 Het recht op 'privé-leven' } & 338\end{array}$

7.3.2 Het recht op medische zelfbeschikking 341 
7.3.3 Het recht op de naam 344

7.3.4 Erkenning van de transseksuele en homoseksuele identiteit 346

7.4 Bevindingen $\quad 353$

7.4.1 Ontwikkeling van de grondslag voor de normen van hoger recht 353

7.4.2 Het recht op persoonlijkheid: concretiseringen $\quad 354$

7.4.3 De analoge redenering 355

7.4.4 Terminologie 356

Hoofdstuk 8

Analoge rechtsvinding in de jurisprudentie van het Europese Hof woor de rechten van de Mens

8.1 Inleiding

8.2 Rechtsontwikkeling door het Europese Hof voor de Rechten van de Mens

8.3 Ontwikkeling van het recht op persoonlijkheid met analoge redeneringen

8.3.1 Geestellijke en fysieke integriteit

8.3.2 Seksuele oriéntatie en seksuele identiteit

8.3.3 Culturelle identiteit

8.3.4 Bescherming yan bedrijfsmatige activiteiten $\quad 372$

8.3.5 Persoonlijke identiteit $\quad 377$

8.3.6 Aspecten van de leefomgeving 381

8.3.7 Hulp bij zelfdoding 385

8.3.8 Het recht op menselijke waardigheid als grondslag voor opheffing van strafrechtelijke immuniteit

8.3.9 Het recht op leven als grondslag voor afwijzing van een beroep op de wet bij verdediging van de staat 388

8.4 Bevindingen

8.4.2 Het recht op persoonlijkheid: concretiseringen

8.4.3 De analoge redenering

8.4.4 Terminollogie

\section{Hoofdstuk 9}

Analoge rechtsvinding in de jurisprudentie van de Hoge Raad

9.1 Inleiding

9.2 Ontwikkelling van het recht op persoonlijkheid met analoge redeneringen

9.2.1 Het recht op fysieke integriteit

9.2 .2 Hulp bij zelfdoding

9.2.3 Verplichtingen van de werkgever jegens de werknemer

9.2.4 Het medisch inzagerecht

9.2.5 Het geestelijk welzijn van het individu

9.2.6 Het recht om de biologische afstamming te kennen

9.2.7 Het recht na boetedoening niet te worden geconfronteerd met

9.2.8 Een recht op beroepsmatige ontplooiing 
9.3.1 Inleiding 417

9.3.2 Ontwikkeling wan de grondslag voor de normen van hoger recht 418

9.3.3 De analoge redenering 419

9.3.4 Terminologie $\quad 420$

Hoofdstuk 10

Bevindingen en conclusies

10.1 Ìnleiding

10.2 Het recht op persoonlijkheid in Grondwet en Verdrag

10.2.1 Recht op persoonlijkheid: positiveringen in Grondwet en Verdrag

10.2.2 Reikwijdte van de Grondwettelijke en Verdragsbepalingen

10.2.3 Reikwijdte van de ongeschreven rechten

10.2.4 Beperkingsmogelijkheden

10.3 De analogie levert steeds een grondrechtelijke extensie op

10.3.1 Technisch-juridische en analoge rechtsvinding

10.3.2 Rationalisatie achteraf

10.3.3 Bestendiging

10.4 De rechterlijke houding naar de analoge redeneermethode

10.4.1 Aanwaarding of afwijzing van de analoge redeneermethode

10.4.2 Constitutioneelrechtelijke bezwaren tegen de analoge redeneermethode

10.5 De rechterlijke taakopvatting in constitutionele interpretatie

10.5.1 Rechterlijke terughoudendheid of activisme

10.5.2 De constitutionele verhouding en de variatie in hantering van de analogie

10.5.3 Uitgangspunt: voorkeur voor een "terughoudende' taakopvatting

10.6 De analogie als strategie om netelige kwesties in de constitutionele verhoudingen te omzeilen

Summary

Lijst van verkort aangehaalde literatuur

Jurisprudentie

Zakenregister

Dankwoord 
$\therefore$

:
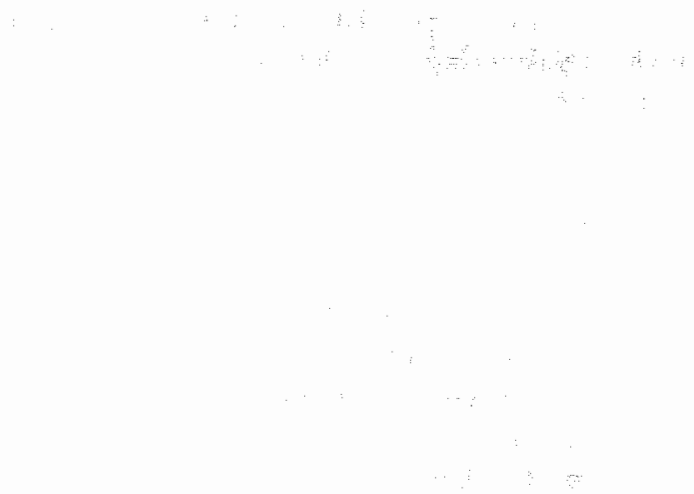

:

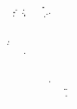




\section{Hoofdstuk 1}

\section{Algemene inleiding}

\subsection{Vaststelling van de reikwijdte van grond rechten}

Een rechter die gevraagd wordt, een oordeel te geven over de grondwettigheid van overheidsingrijpen dient steeds vast te stellen welke de reikwijdte is van het grondrecht waarop de individuele aanspraak is gebaseerd. Concrete geschillen dwingen de rechter te komen tot vaststelling van betekenis en reikwijdte van het ingeroepen grondrecht. Vanwege het feit dat grondrechten veelal vage normen inhouden, lijkt bij interpretatie vaak de noodzaak te bestaan om bij de oplossing van voorgelegde geschillen terug te vallen op aan de constitutie ten grondslag liggende rechtsbeginselen, of althans op normen die als onderdeel worden gezien van die constitutie. Teneinde de reikwijdte van het grondrecht vast te stellen, bepaalt de rechter aan de hand van "onderliggende' structuren van of 'natuurrechtelijke noties' boven de grondwet, welke individuele aanspraken grondrechtelijke bescherming dienen te verkrijgen. Dit fenomeen doet zich onder meer voor bij de interpretatie van het hier te onderzoeken Duitse Grundgesetz, de Nederlandse Grondwet en de Amerikaanse Constitution met de Bill of Rights, alsmede bij de interpretatie van bepalingen in het Europees Gemeenschapsverdrag (EG-Verdrag) en het Europese Verdrag voor de Rechten van de Mens (EVRM). Deze 'grondwetten' zullen worden onderzocht op de mate waarin de rechter voor de vaststelling van de reikwijdte van de constitutionele bepalingen soms terugvalt op normen die ten grondslag liggen aan of in rangorde staan boven de constitutie. Die normen worden hierna aangeduid als 'normen van hoger recht'.

De notie 'normen van hoger recht' vormt een overkoepelend begrip van 'rechtsbeginselen' en 'andere beginselachtige normen'; het is een soort vergaarbak van alle 'hogere' rechtsnormen. Bij 'andere beginselachtige normen' kan worden gedacht aan hogere normen die in een samenleving op een bepaáld tijdstip gelden, maar die niet zijn gepositiveerd in wetgeving of rechtspraak. 'Rechtsbeginselen' bezitten de juridische kwaliteit van positivering wel; op dat punt onderscheiden zij zich aldus van die andere categorie normen. Met 'normen van hoger recht' wordt aldus in het midden gelaten met welk type norm we precies te maken hebben - met een rechtsbeginsel of een 'andersoortige beginselnorm' - indien wordt gesteld dat de rechter de betekenis van een grondrecht tracht te achterhalen aan de hand normen van hoger recht. ${ }^{1}$ Het begrip norm

1 Er had eveneens woor cen andere benaming voou deze notie - bijwooubeeld fundameritele notic of onge schreven rechtsbeginsel - kunnen worden gekozen; doorshggevend was het uitgangspunt dat begrippen die eem bepaalde dogmatiek vooropstellen werden afgewezen. "Fundamenteel rechl" zou bijvoorbeeld sterk kunnen wijzen in de tichting van materiele grondrechtsnoties, terwijl in het begrip 'fundamentele noties" ean relatie met "rechtsnormen" ontbreekt. Met de keuze voor "norm van loger recht" kan een open benadering naar de wijze waarop de rechter 'recht vindt' in het kader van constifutionele interpretatie worden gehandhaafd. Het is bovenal een pragmatische benadering van de hogere nomen. Beantwoording van de vraag of de rechter zich nu op de juiste rechtsnorm beroept stant niet centraal in dit boek; het doel wan dit boek is veeleer gelegen in het xichtbaar maken wan het fienomeen rechts- 
van "hoger" recht doet overigens vermoeden dat het steeds om normen gaat die zich in letterlijke of in overdrachtelijke zin 'boven de constitutie' bevinden. Wanneer de rechter in de rechtsvinding bijvoorbeeld steunt op natuurrechtelijke noties, zou er van normen die zich 'boven' de constitutie bevinden sprake kunnen zijn. Omgekeerd verlaat de rechter zich ook op rechtsbeginselen die 'ten grondslag liggen' aan de constitutie. In dergelijke gevallen ligt het minder voor de hand om te spreken van een 'norm van hoger recht', Toch worden ook normen, die 'ten grondslag liggen" aan de constitutie geacht te vallen onder de "norm van hoger recht".

De vaststelling van de reikwijdte van grondrechten aan de hand van 'normen van hoger recht" manifesteert zich in de regel in uiteenlopende interpretatiemethoden en redeneerwijzen. In dit boek zal met name de hantering van twee redeneervormen in de rechtsvinding worden uitgediept, te weten de wetsanalogie en de rechtsanalogie. Deze redleneermethoden worden in de rechtspraak gebruikt voor de vaststelling van de inhoud en reükwijdte var wetten; in dit opzicht vormen de grondrechten geen uitzondering. Een analogie kan noodzakelijk zijn wanneer een individuele aanspraak wordt gebaseerd op een grondwettelijke bepaling, die zich niet direct lijkt te lenen voor toepassing op de aanspraak in concreto. Toepassing van de grondwetsbepaling kan bijvoorbeeld problematisch zijn omdat de bepaling niet of niet voldoende specifiek geschreven is voor toepassing in het voorliggende geschil. En kan in een dergelijk geval sprake zijn van een leemte, al zal in het geval van de interpretatie van grondrechten eerder sprake zijn van een vage norm waarvan niet duidelijk is of de reikwijdte zover strekt dat deze de voorliggende individuele aanspraak kan dekken. Ook kan er sprake zijn van afwezigheid van heldere voorwaarden voor toepassing in een concreet geschil. De ingeroepen constitutionele bepaling schrijft bijvoorbeeld niet voor hoe de bepaling moet worden toegepast. Door afwezigheid van toepassingscriteria die een indicatie geven van bescherming van bepaalde gedragingen of van rechtsgevolgen lijkt de bepaling zelf een beginselachtige uiting te zijn. Dit fenomeen doet zich bij grondrechten voor, en hangt in hoge mate samen met de wijze waarop veel grondrechtelike bepalingen geformwleerd zijn. Zij hebben vaak het karakter van een vage norm. Het Duitse Grundgesetz (GG) opent met een fraai voorbeeld van een grondwetsbepaling die een vage norm inhoudt:

Art. I lid $\mathbb{G}$ GG: 'Die Wurde des Menschen ist unantastbar. Sie ist zu achten und zu schutzen ist Verpflichtung aller stantlichen Gewalt'.

De bepaling expliciteert bijwoorbeeld niet aen specifieke groep geadresseerden of concrete gevallen en geeft geen nadere regels voor toepasselijkheid. Een juridische consequentie bij de toepasbaarheid van deze regel is evenmin geformuleerd. Art. 1 lid $1 \mathrm{GG}$ draagt het karakter van een vage norm, en voor de toepassing ervan zal de rechter eerst aan de hand van de reikwijdte moeten bepalen, in welke mate de individuele aanspraak bescherming dient te verkrijgen onder Art. 1 lid 1 GG. Bij andere constitutionele bepalingen doet dit verschijnsel, afwezigheid wan nadere regels voor toepasselijkheid, zich

vinding met normen die niet of niet zichtbar zijn gepositiveerd in wet of rechtspraak. 
eveneens voor. Ondanks de afwezigheid van heldere toepassingscriteria blijkt de rechter soms toch bereid, individuele aanspraken in te lezen in Art. 1 lid $\mathbb{Q G G}$. "Menschenwürde" houdt volgens het Duitse Federale Constitutionele Hof het volgende in:

'Dem Menschen kommt in der Gemeinschaft ein sozialer Wert- und Achtungsansprach zu; deshalb widerspricht es der menschlichen Würde, den Menschen zum bloßen Objekt des Staates zu machen $[\ldots]$ oder ihn einer Behandlung auszusetzen, die seine Subjektqualität prinzipiell in Frage stellt [...].,

De vraag die in dit verband rijst is niet alleen, in welke gevallen de Duitse rechter de toepasselijkheid en de beschermingsomvang van het fundamentele recht op 'menselijke waardigheid' vaststelt, maar vooral ook waarop die vaststelling is gebaseerd. Welke argumenten voert de rechter aan, om te komen tot de kwalificatie van de individuele aanspraak onder het recht op "Menschenwürde'? De consequentie van de erkenning van een individuele aanspraak als grondrecht is dat deze aanspraak "grondrechtelijke bescherming' verkrijgt. Met grondrechtelijke bescherming wordt in dit verband gedoeld op een mate van rechtsbescherming van een aanspraak, waarbij aan een inbreuk op een recht in het algemeen zware eisen worden gesteld. De preciezere betekenis van en de criteria voor 'grondrechtelijke bescherming' verschillen in de stelsels. De idee van 'grondrechtelijke bescherming van een individuele aanspraak' lijkt in de onderzochte stelsels echter een gemeenschappelijkheid te kennen, in die zin dat een eventuele inbreuk op een aanspraak die grondrechtelijke bescherming geniet in beginsel enkel met zwaarwegende redenen kan worden gerechtvaardigd. De vaststelling van betekenis en reikwijdte van het grondrecht is daarmee van groot belang in het gehele rechterlijke besluitvormingsproces, omdat in het geval van erkenning van de individuele aanspraak in beginsel hoge eisen worden gesteld aan de rechtvaardiging van de inbreuk op het grondrecht middels wetgeving in formele zin of andere besluiten.

Het Veertiende Amendement uit de Amerikaanse Bill of Rights kent eveneens een bepaling, waarvan de termen en condities van de toepassing nog vastgesteld dienen te worden omdat dat artikel die niet nader specificeert. De reikwijdte van dit Amendement is niet eenduidig; desondanks is de Amerikaanse rechter bereid geweest een aantal individuele aanspraken in te lezen in het Veertiende Amendement, dat luidt:

'No State shall make or enforce any law which shall abridge the privileges or immunities of citizens of the United States; nor shall any State deprive any person of life, liberty, or property, without due process of law [...]'.

Een voorwaarde van toepasselijkheid van het Veertiende Amendement die in deze formulering is terug te vinden is bijvoorbeeld de categorie geadresseerden, die aanspraak kan maken op rechtsbescherming: enkel Amerikaanse staatsburgers kunnen aanspraak maken op 'privileges', terwijl het leven, de vrijheid of het eigendom van om het even welk individu worden beschermd. In deze bepaling is echter niet helder wat begrepen dient te worden onder het begrip 'liberty'. Ook het bereik van de term 'property' is niet 
af te leiden uit de formulering. In de rechtspraak zijn de contouren van deze begrippen langzaam maar zeker wat duidelijker geworden, maar volledige scherpte van de grenzen van "liberty" en "property" is nog niet bereikt. Vraag is, of dat laatste ook wenselijk of zelfs mogelijk is. De Amerikaanse rechter moet, evenals zijn Duitse collega ter zake van Art. $19 G$, vaststellen welke de omvang is van het begrip "liberty"; in dat verband bepaalt hij of de aanspraak van de klager onder dat begrip te brengen is.

Vaststelling van betekenis en reikwijdte van het grondrecht geschiedt aan de hand van interpretatie- of uitlegmethoden. Enkele gangbare vitlegmethoden - tekstuele en wetshistorische interpretatie - blijken niet altijd de gewenste resultaten voort te brengen in constitutionele interpretatie. Tekstuele interpretatie, eén van de meest gehanteerde interpretatiemethoden in de rechtspraak, leent zich bijvoorbeeld niet goed voor de vaststelling van de reikwijdte van het Duitse constitutionele begrip "Wüde des Menschen". De tekst biedt nauwelijks concreet houvast om te bezien of een individueel belang bescherming van dit grondwetsartikel kan genieten. Hantering van enkel historische interpretatie leidt in sommige gevallen tot niet-toepasselijkheid van de geschreven grondrechtelijke norn, terwijl dat niet als wenselijk wordt gezien. Afgezien van de vraag of dat de juiste interpretatiemethode is, wordt dat resultaat kennelijk in menig opzicht doo" de rechter niet bevredigend gevonden. Zo werd bijvoorbeeld met het aanbireken van het digitale tijdperk aan de hand van geschillen bijvoorbeeld eerst duidelijk, welke repercussies het opslaan en bewaren van privacygevoelige gegevens kon hebben op het privé-leven van het individu. Het Duitse Federale Constitutionele Hof zag zich begin jaren tachtig gedwongen om de mate waarin de staat gegevens van haar burgers kan opslaan en verwerken, aan banden te leggen. Geklaagd werd over een inbreuk op het recht op privé-leven. Federale wetgeving, die medewerking van de burgers verplichtte in de vorm van het moeten overleggen van privé-gegevens, werd door het Duitse Hof niet op alle punten in overeenstemming beoordeeld met het 'allgemeines Persönlichkeitsrecht'. Indien deze rechter de ingeroepen grondrechtsnorm strikt tekstueel geinterpreteerd zou hebben, dan had hij nauwelijks bescherming kunnen bieden aan de individuele aarspraak: de Duitse Grondwet bevat namelijk geen expliciete bepaling ter zake van een 'allgemeines Persönlichkeitsrecht', een recht op prive-leven, of meer specifick een recht om niet mee te hoeven werken aan een census of aan het vergaren van gegevens van burgers. ${ }^{6}$ De wetgever heeft kennellik niet gekozen voor expliciete vastlegging van een recht op privé-leven of een meer specifiek toegesneden recht. Vraag is dan op welke wijze de Duitse rechter de aanspraak op grondrechtsbescherming construeert, en hoe hij daarbij rekening houdt met de grondwetgever.

Een ander voorbeeld van interpretatie aan de hand van normen die niet zijn geexpliciteerd in de Grondwet is te vinden in de rechtspraak van het Amerikaanse Hoogge-

6 Art. $10 \mathrm{GG}$ beschermt het brief-, post en telefoongeheim. Hieronder valt niet respect voor het privé leven van het individu in rumere zin. Ook kan worden gesteld dat een toegesneden bepaling ontbrak varwege het teit dat de gevolgen van technologische ontwikkelingen nog nitet waren verdisconteerd in een (grond) wettelijke norm ondat die ontwikkelingen niet te waren voorzien. 
rechtshof. Naar de letter van de Amerikaanse Bill of Rights bestaat er geen grondrecht op abortus, en kan gerust worden gesteld dat de Amerikaanse grondwetgever uit 1787 niet de intentie had om zwangerschapsafbreking te rekenen tot de grondwettelijk beschermde aanspraken van het individu. Had het Amerikaanse Hooggerechtshof een zuiver tekstuele interpretatie van het recht op 'liberty' aangehouden, dan zou vaststelling van de precieze omtrekken van dat recht niet direct naar voren komen. De rechter koos voor een systematische benadering van de individuele aanspraak, waardoor erkenning wan het recht op abortus wel mogelijk werd geacht.? Een systematische interpretatie kan, wanneer dat aangewezen is, wat vaker leiden tot toepasbaarheid van vage grondwetsbegrippen in concrete gevallen: de rechter beziet dan in welke context de ingeroepen norm moet worden opgevat. Daarnaast hebben de rechters in wisselende mate ook de dynamisch-evolutieve interpretatiemethode gehanteerd. De bewoordingen worden dan uitgelegd in het licht van 'present day conditions'. De teleologische, systematische en dynamisch-evolutieve methoden hebben, in vergelijking met de tekstuele en de historische methoden, vaker geleid tot extensieve interpretatie van de reikwijdte van grondrechten. ${ }^{10}$

Naast de hiervoor aangehaalde interpretatiemethoden is ook een aantal redeneerwijzen te onderscheiden, waarbij in dit boek de aandacht in het bijzonder uitgaat naar de analoge redenering. In de analoge redenering wordt er vanuit gegaan dat een bestaande rechtsregel die bedoeld is voor een ander, maar vergelijkbaar geval, wordt toegepast op een concreet geval dat eigenlijk niet door de betreffende regel wordt bestreken. De analoge redenering is een instrument waarmee een bepaalde toepassing of 'lezing' van een rechtsregel wordt gerechtvaardigd. Redeneerwijzen zijn in dit verband te onderscheiden van interpretatiemethoden, al zijn het geen strikt gescheiden werkwijzen. De redeneerwijze is een vehikel waarmee de keuze voor de inhoudelijke argumenten, die worden aangevoerd om te pleiten voor het hanteren van een bepaalde interpretatiemethode, wordt gerechtvaardigd. Als redeneerwijze kan de analogie een bijdrage leveren in alle interpretatiemethoden, zowel in de methoden die een tekstuele uitleg van het grondrecht geven, als in de methoden die een historische benadering of een dynamischevolutieve invulling van de rechtsnorm bepleiten. Hieronder zal een aantal voorbeelden uit de rechtspraak worden geschetst die aantonen dat de analoge redenering kan leiden tot extensieve interpretatie en in sommige gevallen zelfs kan leiden tot schepping van nieuwe rechtsnormen door de rechter. In dit verband wordt een onderscheid gemaakt tussen een wetsanaloge redenering en een rechtsanaloge redenering, die kort zullen worden toegellicht.

7 Roe t. Wade, 410 U.S. 113 (1973); zie par. 5.3.3 voor de uitwerking van deze uitspraak.

8 Bij de teleologische interpretatieme thode geschiedt de witleg van de wet un het licht van het doel en de functie van de daarin geformuleerde normen waarbij rekening moet worden gehouden met de actuele maatschappelijke context, terwijl bij de systematische methode de betekenis wan de formulering van een rechtsnorm nader wordt vastgesteld door te wijzen op het recht als systeem (Pontier 1998, p. 32-36).

9 Deze imterpretatiemethode ligt in het verlengde van de teleologische interpretatiemethode.

10 Met extensieve interpretatie wordt op verruiming van het toepassingsgebied wan een regel, terwijl restrictieve interpretatie wijst op een inperking win het toepassingsbereik van een regel. 


\subsection{De wetsanalogie}

Indien de rechter zich geconfronteerd ziet met een aanspraak die niet direct kan worden gekwalificeerd onder een 'bestaand' grondrecht, kan de rechter stellen dat een norm van hoger recht een extensieve lezing van dat bestaande grondrecht rechtvaardigt. De kwallficatie likt op het moment dat de individuele aanspraak wordt gedaan op dat grondrecht op het eerste gezicht niet passend, omdat het grondrecht bijvoorbeeld nog niet dermate extensief is uitgelegd in de jurisprudentie, of omdat de grondwetgever het voorliggende geschil niet heeft meegenomen in de gevallen waarvoor de grondrechtelijke bepaling geschreven is. Een belangrijk aspect van een wetsanalogie is, dat de rechter voor de kwalificatie van de aanspraak aanknoopt bij een bestaand grondwetsartikel. Dit in tegenstelling tot de rechtsanalogie: de rechter kan in een dergelijk geval niet aanknopen bij een bestaande grondrechtsbepaling. Er is in dat geval geen grondrechtsartikel waaronder de individuele aanspraak eventueel kan worden gekwalificeerd. Daarover hierna meer; hier volgt eerst een voorbeeld van de wetsanaloge redenering.

Een voorbeeld van een wetsanaloge redenering is te vinden in de zaak Niemietz $t$. Duitsland" Aan het Europese Hof voor de Rechten van de Mens (EHRM) werd de volgende individuele aanspraak voorgelegd: verdienen professionele activiteiten en bedrijfspanden grondwettelijke bescherming onder het aspect "woning' ex Art. 8 lid I EVRM? ${ }^{12}$ Niemietz, een advocaat met een kantoor aan huis, werd verdacht van het anoniem versturen van een smaadbrief. Teneinde de identiteit van de afzender vast te stellen, doorzocht de politie het kantoor van deze advocaat. De advocaat riep het recht op onschendbaarheid van de woning in, maar het EHRM kwalificeerde de aanspraak van Niemietz niet onder het begrip 'woning". Het begrip 'privê-leven' ex Art. 8 lid $\mathbb{1}$ bood in de optiek van het Hof betere aanknopingspunten voor eventuele grondrechtelijke bescherming van de aanspraak van Niemietz. Het Hof accepteerde zijn aanspraak in een analoge redenering. Art. 8 lid 1 leek onvoldoende specifiek toegesneden op de aanspraak, maar de aanspraak kon echter met hantering van een nieuwe lezing van het recht op privé-leven evenwel worden gekwalificeerd onder Art. \& EVRM:

'Respect for private life must also comprise to a certain degree the right to establish and develop relationships with other human beings" 13

De reikwijdte van het in Art. 8 EVRM gepositiveerde begrip 'privé-leven' werd vastgesteld met behulp van een nieuwe benadering, namelijk die waarin het privé-leven wordt opgevat als een sfeer waarin het individu relaties moet kunnen vestigen en ontwikkelen. Dat recht, relaties te vestigen en te ontwikkelen met andere individuen wordt in dit verband opgevat als een rechtsnorm die voortvloeit uit het recht op privé-leven. Het recht op privé-leven verkrijgt hierdoor in sterke mate het karakter van een norm van hoger recht, waaruit nieuwe rechtsnormen kunnen worden geconcretiseerd. Het

11 Niemiesz t. Duitsiand, EHRM 16 december 1992, Serie A vol. 251-B.

12 Art. 8 lid 1 luidt: 'Een ieder heeft recht op respect voor zijn privé leven, zujn familie- en gezinsleven, ziju woning en zijin correspondentie".

13 Nirmietz 1 . Dwilsland, par. 29. 
Hof oordeelde vervolgens dat het begrip 'prive-leven' de aanspraak van Niemietz kon herbergen; Art. 8 EVRM omvat aldus niet alleen het enge begrip 'privé-leven' in die zin dat enkel activiteiten die zich afspelen in de huiselijke sfeer daartoe dienden te worden gerekend, maar dat eveneens activiteiten buitenshuis binnen de strekking van 'privé-leven' vallen. De activiteiten buitenshuis moeten, willen zij onder het begrip 'privé-leven' begrepen worden, wel te maken hebben met het vestigen en ontwikkelen van relaties. Tot het vestigen en ontwikkelen van die relaties konden, aldus het Hof, in enkele gevallen eveneens professionele activiteiten behoren:

'since it is, after all, in the course of their working lives that the majority of people have significant, if not the greatest, opportunity of developing relationships with the outside world ${ }^{14}$

Via de norm van hoger recht - hier het recht op privé-leven - sloeg het Hof een brug tussen enerzijds de individuele aanspraak op constitutionele bescherming van een deel van professionele activiteiten, en anderzijds het erkende recht op afscherming van het persoonlijke leven binnenshuis. Beide vloeien als het ware logisch voort uit het recht op privé-leven, al is de eerstgenoemde component nog niet eerder in de rechtspraak opgeworpen. De erkenning van Niemietz' aanspraak onder Art. 8 geschiedde op basis van de aanname dat vestiging en ontwikkeling van relaties behoren tot het domein van het privé-leven. De analogie is in dit verband gelegen in de aanname van de rechter, dat er naast een 'binnenleven' waarvan reeds werd aangenomen dat dat bescherming verdient, ook een 'buitenleven' bestaat dat in sommige gevallen grondrechtsbescherming dient te genieten. Afwijzing van vergelijkbaarheid van binnen- en buitenleven in sommige gevallen, aldus het Hof, zou neerkomen op ongelijke behandeling van gelijke gevallen: het had eerder geschillen inzake afluisteractiviteiten in de privé-woning (het 'binnenleven') beoordeeld waarbij eveneens professionele activiteiten (dat valt onder het zogenoemde 'buitenleven') werden geobserveerd.

\subsubsection{De rechtsanalogie}

Het tweede fenomeen, de rechtsanalogie, is in veel opzichten nauw verwant aan de wetsanalogie; ook daar wordt geredeneerd aan de hand van aan de grondwet ten grondslag liggende normen van hoger recht. Een aantal aanspraken op grondwettelijke bescherming werd aan de rechter voorgelegd waarbij de individueelrechtelijke aanspraak in het geheel niet kon worden aangeknoopt bij een grondrechtelijke bepaling uit de Grondwet of uit het Verdrag. Waar Niemietz nog een beroep deed op het begrip "woning' ex Art. 8 EVRM, zijn er in de rechtspraak enkele gevallen bekend waarin geen enkele grondwettelijke bepaling zich leende voor het inlezen van de door het individu geclaimde aanspraak. Individuen die zich bijvoorbeeld voor de Amerikaanse rechter beriepen op een recht te kiezen voor abortus, of voor de Nederlandse rechter op een recht de identiteit van de biologische ouders te kunnen vernemen, konden zich in geen van beide gevallen beroepen op bestaande grondrechtelijke bepalingen, omdat die over deze onderwerpen niets of niets vergelijkbaars hadden vastgelegd. De individuele aan- 
spraak leende zich in deze gevallen met andere woorden niet voor $\mathrm{kwalificatje}$ onder én van de grondrechtelijke bepalingen, zoals in Niemietz $t$. Duitstand wel - zij het indirect-het geval was.

Ondanks de onmogelijkheid, de aanspraak in te lezen in één van de grondwetsbepalingen acht de rechter het soms blijkbaar aangewezen om aan deze individuele aanspraken grondrechtelijke bescherming toe te kennen. De oplossing wordt eveneens gevonden via een analoge redenering, maar op een iets andere wijze dan hiervoor onder Niemietz werd beschreven. De rechter verheft nu niet een grondrechtelijke bepaling (zoals Art. 8 EVRM in Niemietz), maar een norm van hoger recht tot uitgangspunt in zijn analoge redenering. Een fraal voorbeeld van de rechtsanaloge redenering is te vinden in Valkenhorst van de Hoge Raad. ${ }^{15}$ In deze zaak claimde een kind het recht, te weten wie zijn biologische vader was. De moeder had geweigerd het kind mede te delen wie de verwekker was. De instelling waar het kind ter wereld was gekomen, weigerde eveneens inzage in de gegevens te verstrekken die het in staat zouden kunnen stellen van de afstamming kennis te nemen. Het kind had de laatste hoop op de instelling gevestigd, omdat de moeder reeds was overleden. In de Nederlandse Grondwet of andere wet is echter geen bepaling opgenomen ter zake van het recht op dergelijke kennisneming van de afstamming; evenmin kent de Grondwet een bepaling waarbij à la Niemietz zou kunnen worden aangeknoopt. Een toepasbare bepaling ontbrak aldus, maar aan de thand van het "algemene persoonlijkheidsrecht" bouwde de Hoge Raad een redenering op waaruit als het ware logisch volgde dat een aanspraak, de biologische afstamming te kunnen kennen, grondrechtelijke bescherming dient te verkrijgen:

'Uitgangspunt voor de beoordeling van het middel is dat het aan grondrechten als het recht op het respect woor het privé-lewen, het recht op vrijheid van gedachte, geweten en godsdienst en het recht op vrijheid van meningsuiting ten grondslag liggende algemene persoonlijkheidsrecht mede omvat het recht om te weten van welke ouders men afstamt."

Dit 'algemene persoonlijkheidsrecht' heeft in sterke mate het karakter van een norm van hoger recht en niet van een rechtsregel, hetgeen af te leiden valt uit een tweetal aspecten. Nadere concretisering voordat toepassing kan plaatsvinden is noodzakelijk; het kent immers geen voorwaarden voor toepassing of een specificatie van de rechtsgevolgen die van toepassing zijn bij schending van het recht. ${ }^{16}$ Daarnaast ligt het persoonlijkheidsrecht, aldus de Hoge Raad, 'ten grondslag' aan verscheidene in de Grondwet opgenomen individuele rechten waardoor er een hiërarchie of rangorde in het stelsel van rechtsnormen wordt aangebracht. De Hoge Raad onderscheidt enkele geschreven en ongeschreven rechtsnormen, en stelt dat die voortwloeien uit het algemene persoonlijkheidsrecht. 'Ongeschreven grondrechten' kunnen een grondslag vormen voor individuele aanspraken. Het recht, kennis te kunnen nemen over de afstamming is éen voorbeeld van een ongeschreven recht. Uit de norm van hoger recht - het persoon-

15 Valkehhorst, HR 15 aprill 1994, NJ 1994/608.

16 De voorwalarden voor" toepassing en de rechtsgevolgen zijn niet weergegeven in her "algemene persoonlijkheidstecht"; het is niet gecodificeerd en tot Valkenhorst een ongeschreven en onbenoemd recht gebleven. 
lijkheidsrecht - vloeien enerzijds de gepositiveerde rechten op vrijheid van gedachte, geweten en godsdienst en het recht op vrijheid van meningsuiting voort, en anderzijds het tot dan toe nog niet eerder genoemde recht op kennis van de afstamming.

Hier doet zich wederom een analogie voor: het recht kennis te kunnen nemen van de afstamming wordt binnen het grondrechtelijke normenkader op hetzelfde niveau geplaatst als de vrijheid van meningsuiting en recht op privé-leven. Deze rangschikking wordt gerechtvaardigd door aan deze normen ten grondslag liggende algemene persoonlijkheidsrecht. Niemietz kent zoals boven al werd gesteld, eveneens de structuur van de analogie. De analogie in Niemietz heeft tot op zekere hoogte echter een ander karakter dan de analogie in de Valkenhorst. In Niemietz werd het aanknopingspunt voor de vergelijking gevormd door een geschreven recht, namelijk het recht op privé-leven ex Art. 8 EVRM; in Valkenhorst bleek het aanknopingspunt voor de vergelijking een norm van hoger recht van 'het algemene persoonlijkheidsrecht'. In Valkenhorst blijkt de norm van hoger recht de enige factor die het bestaan van het recht om de biologische afstamming te kennen, legitimeerde.

\subsubsection{Het constitutionele spanningsveld}

Een belangrijke overeenkomst tussen de twee analogieën is dat grondrechtelijke normen van hoger recht de rechter in beide functies een instrument aanreiken, om tot een uitleg van grondrechtelijke bepalingen dan wel van concretisering van ongeschreven rechten te komen. In dit boek zullen de beide analogieën bij de analyse van de rechtspraak waar mogelijk worden onderscheiden. Dat wil overigens niet zeggen, dat de redeneermethoden in de praktijk van de rechtspraak ook consequent worden gescheiden. Rechters geven lang niet altijd expliciet aan of en vanuit welke optiek zij analoog redeneren. Evenmin geven zij inzage in de kwestie of de norm van hoger recht, zoals hiervoor het 'algemene persoonlijkheidsrecht' zoals gepositiveerd in Valkenhorst, wel een norm is die behoort tot het positieve recht. Dat is in elk geval in én opzicht wat bevreemdend: de analoge wijze van constructie van rechtsnormen heeft tot gevolg dat de rechter nieuwe reikwijdten van bestaande normen toevoegt en in sommige gevallen zelfstandig nieuwe rechtsnormen bedenkt. ${ }^{17}$ In dit verband wordt in de interpretatie dan ook wel een onderscheid gemaakt tussen 'rechtsvinding' en 'rechtsvorming'. Over rechtsvorming wordt gesproken indien rechtsvinding leidt tot toevoeging van een nieuwe betekenis van de bestaande rechtsnormen. Uitspraken van rechters waarin een nieuwe betekenis wordt toegekend kunnen een aanvulling vormen op het positieve recht; de rechter beperkt zich dan niet alleen tot het opsporen van rechtsnormen en toepassing ervan, maar levert ook een bijdrage aan de 'vorming' van het recht. ${ }^{18}$ Een

1720 werd in Niemievz een nieuwe reikwijdte gegeven aan de rechtsregel imhoudende hell recht op priveleven ex Art. 8 EVRM; deze reikwijdte is als "nieuw' aan te merken vanuit het gezichtspunt, dat het miet eevder was voorgekomen dat de daar opgeworpen individuele aanspraak werd erkend en dat het evenmin voor de hand lag, dat deze daaronder zou vallen. In Valkenhorst werd daamaast een nieuwe rechtsregel toegevoegd aan het arsenal van erkende grondrechten, namelik het recht van het individu, kennis van de afstamming te kunnen vememen.

18 Tak 1994, p. 267 e.y. en Pontier 1998, p. 10. In de jurisprudentieanalyse wordt de aandacht met nume 
scherpe scheiding tussen beide activiteiten, rechtsvinding en rechtsworming, is niet te geven; eerder is sprake van een glijdende schaal.

Tegen de achtergrond van de constitutionele verhouding tussen rechter en wetgever zijn rechtsvinding en rechtsvorming niet geheel spanningsvrij: in het kader van de verdeling van werkzaamheden tussen rechter en wetgever roept zij een spanning op omdat het scheppen van nieuwe rechtsnormen en het aanbrengen van een hiërarchie in de normen in beginsel tot de activiteiten van de wetgever. In dit verband bestaat er in sommige gevallen zware kritiek op de wets- en rechtsanaloge redenering. Met name op de rechtsanaloge redeneerwijze is in de literatuur en in dissentings bij rechterlijke uitspraken forse kritiek geuit. ${ }^{19}$ Centraal in de kritiek van commentatoren staat dat de rechter zelf aan het wetgeven is geslagen, en dat de rechter wanneer hem dat belieft wetgeving buiten toepassing kan verklaren of vernietigen. De kritiek lijkt zich te verharden naarmate het geschil zich in een hogere instantie bevindt: er lijkt dan weinig correctie meer mogelijk van de rechterlijke uitspraak, terwijl een grondrechtsschending door de hoogste rechter in beginsel vernietiging van formele wetgeving met zich meebrengt. De hier te onderzoeken rechters hebben soms vergaande bevoegdheden, maar dat wil niet zeggen dat die bevoegdheden in door de rechter bedachte constructies naar believen kunnen worden toegepast. Vraag is, hoe de rechters in de te onderzoeken rechtsstelsels omgaan met deze constitutionele spanningsverhouding, en op welke wijze zij invulling geven aan de "rechterlijke taakopvatting".

Er rijzen eveneens vragen over de legitimiteit van de analoge redenering. De vraag of, alsmede de wijze waarop de individuele aanspraak in het voorliggende geschil in de reeks van vergelijkingsgevallen moet worden ingepast, is in zeer hoge mate afhankelijk van de waardering van de rechter. Dat hangt sterk samen met het gezichtspunt dat de rechter hanteert bij zijn vergelijking die de analogie met zich meebrengt. De vraag naar de waardering van de te vergelijken gevallen hangt naw samen met de aard van de analoge redeneerwijze. De rechter dient namelijk de te vergelijken gevallen te kiezen aan de hand waarvan hij tot de rechtvaardiging van zijn lezing van het grondrecht concludeert. De vergelijking biedt het belangrijkste aanknopingspunt op basis waarvan de rechter de individuele aanspraak zal erkennen als recht. Wanneer hij nu kiest voor een vergelijkbaarheid van een reeks gevallen die op een hoog abstractieniveau een norm van hoger recht kennen, zal erkenning van een individuele aanspraak eerder voor de hand liggen dan wanneer de vergelijkbaarheid van de reeks gevallen op een concreet niveau wordt gezocht.

gericht op uitspraken die zouden kunnen worden anngernerkt als rechtswormend, in die zin dat naar uitspraken werd gezocht waarin bestaande rechtsnormen extensief worden uitgelegd of zelis nieuwe rechtsnornen worden toegevoegd. In dit boek wordt de rechterlijke activiteit die betrekking heeft op het opsporen van de toepasselijke norm in beginsel steeds worden aangeduid als 'rechtswinding'.

19 In het Amerikanse Hooggerechtshof, het Duitse Federale Constitutionele Hof en het Europese Hof voor de Rechten van de Mens wordt gestemd over de gewenste uitkomst van een concrete zaak. Een gewone meerderheid is voldoende om de uitkomst te bepalen. Voor de tegenstemmers is het mogelijk on de opvatting over de zaak te geven in een 'dissenting opinion' (zie respectievelijk par. 3.2.5, 3.3.3 en 3.5.3). 
Omgekeerd kan worden gesteld dat een vergelijking van beide aanspraken niet aangewezen is vanuit de gedachte dat het gebruik van voorbehoedmiddelen in het kader van familiebetrekkingen en gezinsplanning past, terwijl seksuele voorkeur daar haaks op staat. Beide aanspraken bewegen zich evenwel onder een aanspraak op seksualiteit, maar zijn niet vergelijkbaar onder een norm van de 'familiebetrekking' of de 'gezinsplanning', die wordt geacht ten grondslag te liggen aan een recht op toegang tot voorbehoedmiddelen ${ }^{20}$ In dit geval hebben we te maken met een vergelijking op concreet niveau, die kan leiden tot de vaststelling dat seksuele voorkeur niet en gebruik van voorbehoedmiddelen wel onder privacy wordt beschermd. Er is dan geen sprake van een analogie; vergelijkbaarheid onder de norm van hoger recht - in casu een recht op persoonlijke autonomie - wordt dan afgewezen. Afwijzing van vergelijkbaarheid van de casus zal meestal niet leiden tot oprekking van bestaande normen ${ }^{21}$

Problematisch lijkt nu te zijn dat er geen algemene eenduidige richtlijnen bestaan voor het niveau waarop moet worden gezocht naar vergelijkbare gevallen om de 'juiste' rechtwaardiging vast te kunnen stellen. ${ }^{22}$ In de analoge redenering maakt de rechter een keuze voor de te hanteren norm waaronder vergelijking zal plaatsvinden, en waardeert hij het vergelijkingsmateriaal in het licht van die norm. Een waardering door de rechter komt in het kader van de constitutionele verhouding tussen rechter en wetgever kan in beginsel een spanningsverhouding creëren. Uitgangspunt is dat rechter het recht 'vindt' op basis van hetgeen de wetgever heeft neergelegd in het positieve recht. Wanneer de rechter de analoge redeneermethode hanteert voor de vaststelling van de reikwijdte van een grondwetsbepaling of voor de positivering van een 'ongeschreven' grondrecht zoals in Valkenhorst, neemt het element van autonome rechtsvinding toe. ${ }^{23}$ Een bepaalde mate van autonome rechtsvinding wordt, mits beoefend binnen de grenzen van de rechterlijke taakopvatting, niet altijd als afkeurenswaardig aangemerkt. Vraag is welke de grenzen van die rechterlijke taakopvatting zijn.

\section{$1.2 \quad$ Vraagstelling}

\subsubsection{Rechtsvinding in het licht van de constitutionele verhouding tussen rechter en wetgever}

Rechterlijke interpretatie van grondrechtsnormen wordt in de te onderzoeken stelsels soms als problematisch ervaren: deze normen wekken vanwege hun vage karakter de indruk een vergaarbak te zijn waaronder naar believen allerlei soorten aanspraken zouden kunnen worden erkend. Een scherpe kritiek op de hantering van vage normen in de jurisprudentie werd als volgt verwoord:

20 Het Amerikaanse Hooggerechtshof koos in Bowers t. Hardwick voor deze benadering, en niet voor de hierwoor genoemde vergelijking onder de norm van hoger recht met een hoog abstractiegehalte.

2) Hierop voortbordurend kan worden gesteld, dat de norm van hoger recht in beginsel steeds een hoog abstractiegehalte kent.

22 Kaufman 1982 , p. 36.

23 Wiarda 1999, p. 116. 
'Das allgemeine Persörlichkeitsrecht ist der Tummelplatz richterlichen Dezisionismus und verstoft deshalb gegen das oberste Primzip des Rechtsstaats, gegen die Gewaltenteilung. Mit ihm und der Menschenwürde läft sich im Grunde alles - und damit gar nichts - begrün$\operatorname{den}^{2}{ }^{24}$

Ramm legt in zijn kritiek op rechtswinding met vage normen het constitutionele knepunt bloot. De rechter verschaft zichzelf met een vage norm zoals hier het "allgemeines Personlichkeitsrecht in de interpretatie een soort 'carte blanche" waarmee nagenoeg alle wetgeving in formele zin kan worden onderworpen aan rechterlijke toetsing. ${ }^{25}$ In de constitutionele verhouding tussen rechter en wetgever wordt dat in principe als onwenselijk ervaren. Daarnaast leidt het gebruik wan bepaalde rechtsvindingstechnieken die de rechter tot zijn beschikking heeft soms tot kritiek; over hantering van de dynamisch-evolutieve unterpretatie wordt bijvoorbeeld wel gezegd dat deze de rechter bij uitstek ruimte biedt om zijn eigen opvatting in een juridisch jasje te verpakken. ${ }^{26}$ De analoge redenering is in de optiek van sommigen een fraaie redeneertruc langs welke allerlei rechten gecreeserd kunnen worden omdat er geen richtlijnen of maatstaven bestaan voor de waardering aan de hand waarvan de vergelijking wordt voltrokken. De analoge redenering stelt, zo luidt een veel geuite kritiek op deze wijze van constitutionele interpretatie, de rechter bij uitstek in staat zijn persoonlijke opvatting te verpakken in een subjectief recht, dat legitiem lijkt - maar het wellicht niet is. Dat hangt samen met de hiervoor gesignaleerde afwezigheid van maatstaven die de rechter kunnen leiden tot het juiste niveau van vergelijkung. Deze kritiek wordt in de verschillende stelsels in wisselende mate geuit, al lijkt het debat hierover in de Verenigde Staten het meest fel in vergelijking met de andere onderzochte rechtsstelsels. Het recht op toegang tot een rechter, of het recht op abortus zijn voorbeelden van individuele aanspraken die in de rechtspraak van het Amerikaanse Hooggerechtshof via een rechtsanaloge redenering werd verheven tot grondrecht: een geschreven of ongeschreven grondrecht bleek miet voorhanden, waarna de rechter zelf. Harde kritiek op de analoge redeneerwijze werd geuit door de rechters, die in hun dissenting of concurring de tekstuele of historische interpretatiemethoden ter vaststelling van de reikwijdte van grondrechten vooropstelden. Rechter Rehnquist, die zich in de minderheid bevond, liet zich zeer kritisch uit ten aanzien van het door meerderheid in het Hof gepositiveerde recht op toegang tot een rechter:

"The "fundamental constitutional right of access to the courts" which the Court announces today is created wirtually out of whole cloth with little or no reference to the Constitution. from which it is supposed to be derived? ${ }^{27}$ 
De meerderheid in het Hooggerechtshof refereerde niet aan een grondwettelijke bepaling uit de Bill of Rights waarvan interpretatie had kunnen leiden tot een extensieve interpretatie van een positief recht. De meerderheid in het Hof had zijn redenering daarentegen aangeknoopt bij een aantal beginselachtige noties - normen van hoger recht - die werden afgeleid uit opmerkingen in dissentings en uit obiter dicta uit de jurisprudentie. Vraag is of deze bronnen woldoende grondslag bieden yoor erkenning van de in het geding zijnde individuele aanspraken. De kritiek op extensieve contitutionele rechtsvinding of op rechtsvinding die leidt tot positivering van nieuwe rechtsnormen door de rechter blijkt niet gering, hetgeen samenhangt met de hiervoor gesignaleerde bezwaren die samenhangen met constitutioneelreclitelijke uitgangspunten. Interpretatie van grondwettelijke bepalingen dient rationeel en controleerbaar te zijin.

\subsubsection{Consistentie van rechtspraak en coherentie van rechtsnormen}

In de rechtspraak van de te onderzoeken stelsels tekent zich een aantal hoofdlijnen af ter zake van de regels bij rechtsvinding met normen van hoger recht. De interpretatie van het recht behoort objectief en controleerbaar te zijn, en terug te voeren op juridische argumentatie. Respect voor juridische argumentatie in het rechtsvindingsproces houdt idealiter onder meer in dat de rechter de bestaande normenhiërarchie respecteert en dat hij een consequente terminologie hanteert ter zake van de rechtsormen die hij benut in het rechtsvindingsproces. Dit komt de transparantie van het rechterlijke besluitvormingsproces ten goede. Het is echter onvermijdelijk dat de rechter bij uitleg van bestaand recht of schepping van nieuw recht zelf een schemaische ordening aanbrengt in het geldende recht. ${ }^{28}$ Er bestaat reeds een constitutionele normenhiërarchie, waarmee de rechter bij zijn interpretatie rekening dient te houden. Deze normenhiêrarchie dwingt de rechter op bepaalde wijze om te gaan met normen, zodat hij de coherentie van die normen niet verstoort. Idealiter hanteert de rechter de verschillende soorten normen op dusdanige wijze, dat in de constitutionele normenhiërarchie geen innerlijke tegenstrijdigheden ontstaan.

Welke de bijdrage van de rechter is in dit verband is de vraag: in welke mate vertroebelt de rechter in de onderzochte rechtspraak de bestaande normenhierarchie - of levert hij in de onderzochte jurisprudentie juist een bijdrage aan de coherentie van dat systeem? De eis van consistentie in de rechtsvinding geldt ook voor de individuele uitspraak. In het bijzonder zal worden gelet op de consistentie van de gevolgde redenering in de individuele uitspraak, alsmede op de wijze waarop de individuele uitspraak past in het geheel van de jurisprudentie. Ook komen empirische bevindingen aan bod over de vraag in welke mate de analogie als rechtsvindingsmethode in de onderzochte con-

28 Rozemond 1998, p. 41. Zie ook het hiervoor gegeven voorbeeld bij Niemietz 1. Duirsland waarin het EHRM de rechtsregel van het recht op privé-leven splitste in enerzijds de algemeen aanvaarde categorie aanspraken op een afgescherme leven waarin het undividu ongestoord zichzelf moet kunnen zijn, en anderzijds een 'nieuwe' categorie aanspraken die te maken hebben met een recht op privé-leven in de meer opembare sfeer. Hierdoor lijkt het alsof de rechter een 'tussenlaag' heeft gecreberd: de binnen- en de buitenwereld zijn twee specificaties van het recht op privé-leven waaronder concrete aanspraken kunnen worden gekwalificeerd. 
stitutionele rechtspraak leidt tot woorspelbaarheid van erkenning van individuele aanspraken. $^{29}$

\subsection{Vraagstelling}

Samenvattend worden onderdeel 1.2 .1 en 1.2 .2 ondergebracht in drie centrale vragen:

1. Wat is de a ard en de omvang van de analoge redeneermethode op het terrein van het recht op persoonlijkheid?

2. Hoe kunnen variaties in hantering van de analogie worden verklaard?

3. In hoeverre hangt de rechterlijke bereidheid, een nieuwe individuele aanspraak te aanvaarden onder het systeem van grondrechtelijke bescherming, samen met de constitutionele verhouding tussen rechter en wetgever? Welke functie komt de analoge redenering in dit verband toe?

\subsection{Plan van aanpak}

Deze vraagstelling laat zien dat de kern van dit boek is gelegen in jurisprudentieanalyse. Doelstelling is allereerst om een fenomeen te beschrijven, en daarbij na te gaan hoe de rechterlijke redenering met 'normen van hoger recht' verloopt en of er vaste lijnen in de rechtspraak op het terrein van het recht op persoonlijkheid te onderkennen zijn. De vraag naar de analoge redeneerwijze wordt niet primair vanuit theoretisch of normatief perspectief onderzocht; er wordt niet gezocht naar de ideale rechterlijke rechtsvinding en evenmin naar een beoordeling van de analoge redenering. De benadering is eerst en vooral empirisch. De aandacht gaat daarbij vooral uit naar de wijze van redeneren, en niet zozeer naar de materiele betekenis die een rechterlijke uitspraak heeft voor een bepaald beginsel of grondrecht. In beginsel is dan elke rechterlijke uitspraak die een wets- of rechtsanaloge redenering bevat ter vaststelling van de reikwijdte van grondrechten relevant en dient in het onderzoek te worden betrokken.

Het aantal rechterlijke uitspraken, waarin de analogie voor de vaststelling van de reikwijdte of voor de positivering van nieuwe rechten wordt gehanteerd, is in beginsel te overzien. In beginsel is getracht, een volledig beeld van de redeneringen in de rechtspraak te geven op het terrein van het recht op persoonlijkheid. De uitspraken zijn veelal aanleiding geweest voor rechterlijk ingrijpen in wetgeving die in strijd werd geacht met grondrechten alsmede in horizontale verhoudingen. De keuze voor een meer empirische benadering - hoe redeneert de rechter? Welke factoren zijn van invloed op de redenering? - houdt niet in dat een waardering van de wets- en rechtsanaloge rechtsvindingsmethoden geheel wordt vermeden. Er wordt niet enkel vanuit een vooropgezet theoretisch normatief kader gewerkt, waaraan de bevindingen worden getoetst en gewaardeerd.

29 Het ligt echter uitdrukkelijk niet in de bedoeling, een normatieve theorie ontrent een ideale (analoge) redeneerwijze te ontwikkelen. 
Het boek is als volgt opgebouwd. In het tweede hoofdstuk wordt een beeld geschetst van de te onderzoeken rechtsnormen op het terrein van het recht op persoonlijkheid in de grondwetten en verdragen. Het derde hoofdstuk behandelt de rechtsmacht van de verschillende rechters: daarin wordt nagegaan welke de rechtsmacht is, hoe de rechters omgaan met vragen van ontvankelijkheid, welke soorten uitspraken zij kunnen doen en welke controlemechanismen er bestaan op rechterlijke besluiten. In beginsel worden enkel de uitspraken van de hoogste rechterlijke instanties besproken, en het is aangewezen om in dat verband te onderzoeken welke mogelijkheden er bestaan om rechterlijke uitspraken te corrigeren. Ook wordt in dat hoofdstuk een korte algemene schets gegeven van de taakopvatting van de betreffende rechter: benadert hij een grondrechtelijke aanspraak vanuit de gedachte dat deze een vermoeden ten faveure van de individuele rechtsbescherming toekomt, of gaat de rechter uit van grondwettigheid van wetgeving? Meer in het algemeen wordt ingegaan op de constitutionele verhoudingen tussen rechter en wetgever, en wordt onderzocht welke begrenzingen van rechterlijk optreden bestaan in de ontvankelijkheidsfeer en in de toetsingssfeer. In het vierde hoofdstuk worden de rechtsvindingsmethoden die worden gehanteerd bij de uitleg van de grondwet en het verdrag beschreven, en worden de wets- en rechtsanalogie uiteengezet.

In de daaropvolgende hoofdstukken worden enkele 'moeilijke' casus in de jurisprudentie op hantering van de wets- en rechtsanalogie geanalyseerd, en wordt bezien welke de consequenties zijn van het gebruik van de analoge redeneringen. Zo wordt beschreven welke factoren hebben bijgedragen in de legitimatie van de extensieve interpretatie of de rechtvaardiging van de schepping van nieuwe rechtsnormen. Ook wordt beoordeeld in welke mate de rechter een eensluidende terminologie hanteert wanneer hij via de analoge redenering normen van hoger recht positiveert. De uitspraken van de rechterlijke instanties - achtereenvolgens het Amerikaanse Hooggerechtshof (hoofdstuk 5), het Duitse Federale Constitutionele Hof (hoofdstuk 6), het Hof van Justitie van de EG (hoofdstuk 7), het Europese Hof voor de Rechten van de Mens (hoofdstuk 8) en de Nederlandse Hoge Raad (hoofdstuk 9) zullen worden onderzocht. In hoofdstuk 10 worden de gevonden resultaten in vergelijkend opzicht onderworpen aan analyse en kritiek. Zo worden de consequenties van hantering van wets- en rechtsanalogie voor de positie van de rechter ten opzichte van de wetgever vergelijkend in kaart gebracht, en word bekeken welke constitutioneelrechtelijke bezwaren er bestaan tegen de hantering van de analoge redeneermethode door de hoogste rechter in geschillen die zijn gerelateerd aan het recht op persoonlijkheid. Verschillen in benadering zullen tegen de achtergrond van de constitutionele verhoudingen in de rechtsstelsels worden verklaard.

\subsection{Afbakening}

Ter zake van de afbakening van het onderzoek wordt hier een aantal keuzes verantwoord, die in de verschillende hoofdstukken nog nader zullen worden uitgewerkt. 
Allereerst speelt het onderzoek zich af op een deelaspect van het terrein van de constitutionele rechtspraak, namelijk dat van het recht op persoonlijkheid. ${ }^{30}$ In de tweede plaats zijn rechtsvinding voorwerp van onderzoek. De nadruk wordt gelegd op de analoge redeneerwijze die tot nieuwe percepties van het recht op persoonlijkheid in de rechtspraak leidt. In de derde plaats vormt, voor zover daarvan kan worden gesproken, 'de' grondrechtelijke normenhiërarchie een onderdeel in dit boek. Enkel op het gemeenschappelijke vlak van deze drie terreinen worden uitspraken gedaan, waarbij een gedegen fundering aan de hand van de drie losstaande terreinen onontbeerlijk is. Zoveel mogelijk is getracht, de rechtstheoretische karakteristieken van constitutioneel reckt, rechtsvindingstheorie en normenhiërarchie die van betekenis zijn voor dit boek, te betrekken bij de oordeelsvorming over het onderwerp. Daarnaast is gekozen voor rechtsvergelijkend onderzoek in vijf rechtsstelsels, die ieder een eigen verantwoording vragen op het genoemde gemeenschappelijke vlak. In dit verband dient een aantal beperkingen in acht te worden genomen, die het mogelijk maken de onderzoeksvragen in het bestek van dit boek zinvol te beantwoorden.

Centraal in dit boek staat de rechtspraak van het Amerikaanse Hooggerechtshof, dat de Amerikaanse Constitution met de Bill of Rights interpreteert, de jurisprudentie van het Duitse Federale Constitutionele Hof dat het Grundgesetz interpreteert, de jurisprudentie van het Europese Hof voor de Rechten van de Mens (EFIRM) dat het Europees Verdrag voor de Rechten van de Mens (EVRM) interpreteert, de rechtspraak van het Europese Hof van Justitie (HvJ EG) dat het Europese Gemeenschapswerdrag (EG-Verdrag) interpreteert en ten slotte de rechtspraak van de Hoge Raad die de Nederlandse Grondwet interpreteert. Alle rechterlijke instanties spreken recht in laatste instantie over hun grondwet of verdrag. ${ }^{31}$ Het Amerikaanse stelsel kent een zeer levendig debat over dit onderwerp, dat in de Europese stelsels - nog - niet ten volle wordt gevoerd. De jurisdicties van rechterlijke instanties in de vijf stelsels zijn, evenals de te interpreteren constituties, zeer verschillend. Dat neemt niet weg, dat zij allen in beginsel vergelijkbare problemen kennen met 'rechtsvormend optreden' van de hoogste rechterlijke instantie. Het in kaart brengen van de manier waarop de verschillende rechters omgaan met deze problemen is zinvol voor de Nederlandse situatie; het levert welliclit nieuwe invalshoeken op voor de wijze waarop de rechter constitutionele interpretatie percipieert en bedrijft. Het rechtspraakonderzoek is afgesloten op 1 juni 2002; de rechtspraak van latere datum werd incidenteel verwerkt. 


\section{Hoofdstuk 2}

\section{Structuur en reikwijdte van het recht op persoonlijkheid}

\subsection{Definitie van het recht op persoonlijkheid}

Zonder definitie van een juridische gemeenschappelijkheid is het nauwelijks mogelijk om een valide uitspraak te doen over een vergelijking van de rechtsontwikkelingen die zich voordoen in de rechtspraak in de rechtsstelsels. Zoals in de inleiding uiteen gezet, bevinden zich in dit onderzoek een aantal vergelijkingsmomenten, die tezamen moeten kunnen leiden tot uitspraken over de redeneermethoden van de rechter op het terrein van het recht op persoonlijkheid die hout srijden. ${ }^{1}$ Het onderzoek concentreert zich in het kader van het recht op persoonlijkheid meer specifiek op de rechtspraak van de hoogste rechterlijke instantie en de mate waarin deze heeft bijgedragen aan rechtsontwikkeling in het recht op persoonlijkheid.

Het eerste vergelijkingsmoment is de aanwezigheid van een recht op persoonlijkheid of een daaraan verwant recht in de grondwet of in de constitutie en jurisprudentie daarover. Er zijn talloze rechterijke uitspraken die in de verschillende stelsels werden gedaan over rechten die te maken hebben met het recht op persoonlijkheid. De aandacht gaat hier echter met name uit naar die uitspraken, waarin de rechter in zijn uitspraak iets nieuws toevoegt aan één van die rechten: hij rekt bestaande bepalingen op, of positiveert nieuwe, aan het recht op persoonlijkheid gerelateerde rechten. Het tweede vergelijkingsmoment stelt de interpreterende rechter centraal, die in het rechtsstelsel als hoogste instantie bindende uitspraken doet over de interpretatie van het recht op persoonlijkheid. Het derde vergelijkingsmoment wordt gevormd door de aanwezigheid van vergelijkbare redeneerpatronen in de jurisprudentie van deze rechters, wanneer zij bijdragen aan rechtsontwikkeling op het terrein van het recht op persoonlijkheid. Alle onderzochte rechterlijke instanties maakten gebruik van de analoge redeneermethode om aan het recht op persoonlijkheid of rechten daaraan gelieerd een extensieve uitleg te geven. In enkele gevallen werd nieuw recht gecreeerd als gevolg van de uitkomst van de analoge redenering.

In het tweede hoofdstuk ligt het accent op het uitdiepen van het eerste vergelijkingsmoment: onderzocht wordt, in welke mate de grondwet of het verdrag melding maken van een recht op persoonlijkheid. Nu is het recht op persoonlijkheid niet in alle rechtsstelsels in even sterke of heldere mate gepositiveerd in de grondwet of in het verdrag. Het is van belang om te onderzoeken in hoeverre de rechten zijn gepositiveerd door de grondwets- of verdragswetgever, om naderhand een inschatting te kunnen geven van de activiteiten die de rechter in de rechtsvinding heeft ontplooid. Om te bezien of het recht

1 Zie 'Afbakening" in hoofdstuk 1 ; hierin werd gewezen op de vergelijkbaarheid van de materitte norm (het recht op persoonlijkheid, dat hierna wordt gedefinieerd), de vergelijkbaarheid van de rechtsvindingsurthothon en de aanwezigheid wan een normenhiërarchie. 
op persoonlijkheid in een andere hoedanigheid deel uitmaakt van de grondwet in ruimere zin wordt eveneens nagegaan of het recht op persoonlijkheid op andere wijze een plaats in de constitutie heeft veroverd. ${ }^{2}$

Het recht op persoonlijkheid maakt als materiẻle rechtsnom deel uit van de constitutie van alle rechtsstelsels. Voor het Amerikaanse, het Duitse en het Nederlandse rechtsstelsel ligt het enigszins voor de hand dat wordt gesproken van een constitutie. Het constitutionele karakter van de Raad van Europa en het EVRM en van de Europese Gemeenschappen en het EU-Verdrag is echter minder vanzelfsprekend. Men kan zich afvragen of het noodzakelijk is dat alle rechtsstelsels in alle facetten voldoen aan de kwalificatie van 'constitutie' om toch een voldoende valide onderzoek te plegen naar de rechtsontwikkeling door de rechter' op het gebied van het recht op persoonlijkheid. In dit hoofdstuk wordt voor een ruime definitie van het begrip constitutie gekozen. Deze defunitie valt uiteen in een aantal kenmerken die een constitutie in zich moet dragen, wil zij zichzelf een met recht een 'constitutie" noemen. De vraag of alle stelsels daaraan voldoen zal niet definitief worden beantwoord. Wat wel van belang is, dat er enkele elementen uit die definitie te halen zijn, die voor de vergelijkbaarheid van de rechtsstelsels en voor de beantwoording van de probleemstelling van grote betekenis zijn. Op deze basis is het reeds mogelijk na te gaan, in welke mate de analoge rechtsvinding invloed heeft op de constitutionele verhoudingen tussen rechter en wetgever. Verder wordt een privaatrechtelijke context van het recht op persoonlijkheid geschetst; omdat de rechtsontwikkeling in de civiele rechtspraak in enkele gevallen van betekenis is geweest voor de ontwikkeling van het constitutionele recht op persoonlijkheid.

Van belang is nu, witeen te zetten welke structuur deze rechten in de grondwet of het verdrag hebben, en welke individuele aanspraken zich door deze rechten beschermd weten. Deze beschrijvingen zullen straks van belang zijn voor de inschatting, in welke mate de interpreterende rechter bijdraagt aan rechtsontwikkeling op het terrein van het recht op persoonlijkheid. Tenslotte wordt in het kader van de omschrijving van de structuur en reikwijdte aandacht geschonken aan de voorwaarden waaronder de aan de orde zijnde grondrechten mogen worden beperkt. Beperking van grondrechten staat in beginsel los van de interpretatiefase, en speelt pas een rol in de toetsingsfase: in de interpretatiefase wordt reikwijdte van het recht vastgesteld, terwijl beperkingen eerst relevant worden nadat de reikwijdte van het grondrecht is vastgesteld en de individuele aanspraak is erkend onder het grondrecht. ${ }^{3}$

\subsection{Inleiding: op zoek naar een werkdefinitie}

In het onderzoek naar rechtsontwikkeling langs de weg van rechterlijke interpretatie moest noodzakelijkerwijze een keuze voor een onderwerp in de grondwet worden gemaakt. In de constitutionele rechtspraak van de vijf rechtsstelsels zijn zoals boven

2 Voor de definitie van 'constitutie", "grondrecht" en "grondwet' zie hiema par. 2.2.

3 Zie voor het onderscheid tussen de interpretatiefase en de toetsingsfase par. 4. 1 .

4 Ruimte- en tijdgebrek dwongen onder meer tot deze lkeuze. In de eerste plats bleek het niet binnien de 
reeds gesteld, interessante aanwijzingen van rechterlijke rechtsontwikkelingen aangetroffen ter zake van het recht op persoonlijkheid. Het recht op persoonlijkheid in grondwet en verdrag manifesteert zich echter op uiteenlopende wijze. Het recht op persoonlijkheid komt in het EVRM in Art. 8 tot uitdrukking; daarin wordt echter niet letterlijk een recht op persoonlijkheid weergegeven, maar een recht op prive-leven. In de Nederlandse grondwet wordt in Art. 10 over persoonlijke levenssfeer gesproken. De Duitse grondwet kent een bepaling over geheime communicatie, maar vermeldt niets specifieks over een 'persönliche Privatsphäre'. De Duitse grondwet kent een aantal deelaspecten van het recht op persoonlijkheid: er zijn bijvoorbeeld individuele rechten aangetroffen die een recht op huisvrede, een recht op geheime communicatie en een recht op algemene handelingsvrijheid moeten garanderen. Met name het laatstgenoemde recht biedt interessante aanknopingspunten voor het recht op persoonlijkheid: aan ieder individu komt een recht op persoonlijke ontplooiing toe, aldus Art. 2 lid 1 GG. Dat recht lijkt te duiden op een ruim en open begrip van een recht op persoonlijkheid. De Amerikaanse Bill of Rights verankert een begrip van het recht op persoonlijkheid in engere zin, dat wil zeggen dat er, net als in de Duitse grondwet specifieke grondrechtbepalingen zijn die aspecten van de persoonlijkheid beschermen zoals het recht op huisvrede. Vraag is nu, of en hoe op basis van dergelijke uiteenlopende omschrijvingen kan worden gekozen voor een gemeenschappelijke noemer van het recht op persoonlijkheid in de rechtsstelsels. Voordat nu onderzocht wordt, in hoeverre een recht op persoonlijkheid aanwezig kan worden geacht in de grondwet of het verdrag, wordt eerst een werkdefinitie van het recht op persoonlijkheid gekozen en toegelicht.

\subsubsection{Geen sluitende definitie}

Deze hiervoor genoemde formuleringen zoals het recht op vrijheid, het reclnt op algemene handelingswrijheid, het recht op persoonlijke ontplooiing, het recht op respect voor de persoonlijke levenssfeer en het recht op privé-leven zullen hiernavolgend worden gebundeld in het begrip persoonlijkheid. Het recht op persoonlijkheid wordt in dit verband een overkoepelend karakter toegedicht, dat wordt geacht het recht op leven, het recht op respect voor geheime correspondentie, telefoonverkeer en het briefgeheim, het recht op familie- en gezinsleven, het recht op respect voor huisvrede en het recht op fysieke en geestelijke integriteit te omvatten. Daarnaast omvat het recht op persoonlijkheid ook rechten die samenhangen met de keuze van het individu van de intichting van het eigen leven; hierin ligt het element van individuele zelfbeschikking opgesloten. Tot op zekere hoogte dient het individu een zekere autonomie te bezitten ter zake van dergelijke keuzes, ook al lijkt de samenleving niet volledig in te sternmen met de

gegeven tijd haalbaar, een onderzoek met een ruimere benadering op te zetten diat vijf rechtsstelsels beslaat. De ruimte die gegeven wordt aan de uitwerking van de verschillende rechtsstelsels laat niet toe, dat er zeer uiteenlopende indiwiduele aanspraken in de beschouwingen worden betrokken. Daarnast had ook aandacht geschonken kunnen worden aan rechterlijke interpretatie aan de hand van rechtsbeginselen van horizontale of verticale machtenscheiding. Ook hiervoor bleek de ruimte onvoldoende, en zou meer tijj nodig zijjn. Interessante bevindingen ten aanzien van deze onderwerpen zijn wel gesignaleerd, en bieden aanleiding voor verder onderzoek. Er is een aantal keren naar deze beginselen verwezen, voor zover dat relevant is in het kader van deze studie. 
woorkeuren en zijn zij niet vastgelegd in grondwetteljke documenten. In dit verband kan worden gedacht aan bijvoorbeeld voorkeuren voor homoseksuele relaties of de wens van de vrouw, de zwangerschap af te breken. Een werkdefinitie van een recht op privacy had eveneens aanknopingspunten geboden, maar na literatuuronderzoek ${ }^{5}$ ontstond een algemene indruk, dat het recht op privacy een ietwat enger bereik claimt dan het recht op persoonlijkheid. ${ }^{6}$ Daamaast gaat de voorkeur uit naar een recht op persoonlijklieid omdlat dat op dat begrip nog niet in die mate 'beslag is gelegd" door rechtspraak en literatuur. Andere begrippen zouden kunnen impliceren, dat bij een bestaande notie in een bepaald stelsel wordt aangeknoopt. Het is juist de bedoeling niet de voorkeur te laten uitgaan naar één wan de bestaande begrippen in de stelsels in het licht van de beoordeling van de rechterlijke uitspraken; dat komt de vergelijking van de ontwikkeling in de rechtsvinding ten goede. Persoonlijkheid is een abstracter begrip dan

5 Zie woor een keuze uit de omvangrijke literatuur over privacy in de Verenigde Staten onder meer Warren en Brandeis 1984 (1890), p. 75-103, Westim 1984 (1967), p. 56-74; Prosser 1984 (1960), p. 104155, Bloustein 1964, p. 962-1007, Dixon 1965, p. 1-22; Mckay 1965, p. 63-86. Ower een recht op 'personhood" wordt in de Amerikaanse literatuur nauwel liks gesproken. Het begrip 'personhood' kontt sterk overeen met het begrip "persoonlijkheid". Voor de Nederlandse discussie omtrent het begrip van persoonlijkheid en privacy zie onder neer De Brauw en Van Veen 1965; De Graaf 1977, Verhey 1992, p. 191 e.k., Verhey 1995, p. 145-168; AJ. Nieuwenhuis 2001 en Blok 2002. De betekenis van het recht op persoonlijkheid in het EVRM is onder meer beschreven door Loucaides 1991, p. 175-197, Van Dijk en Van Hoof 1998, 489-541; Heringa 1999, Katem 3.8; Heringa bepleit hier de anname van een "meer algemeen persoonlijkheidsnecht onder Art. 8 EVRM'. Het Duitse begrip van het recht op persoonlijkheid is onder meer beschreven door Scholz 1975, p. 80-130 en 265-290; Jarass 1989, p. 857-884, Hesse 1990, p. 173-175, Von Münch en Kunig 2000, p. 65-192 (met name p. 130-143) en Nehmellman 2002.

6 In de litieratuur wordt valk gekozen voor een werkdefinitie van 'privacy". Er wordt dan in beginsel geduid op een terrein van individuele gedragingen, dat een wat minder ruime omvang heeft dan het recht op persoonlijkheid. Privacy makat als deelverzameling deel wit van een groter geheel van het recht op persoonlijkheid; het recht op persoonlijkheid is verbonden met de ontplooining van de persoonlijkheid op jeder terrein. Toch lijken sommige werkdefinities van privacy goed aan te sluiten bij het hier gekozen recht op persoonlijkheid. Verliey kiest bijwoorbeeld voor een overkoepelend begrip van "privacy" (Vorhey 1992, p. 191 e.w), evenals A.J. Niewwenhuis (A.J. Nietwenhuis 2001, p. 11 e.v.) en Blok 2002. $\mathrm{Z} \mathrm{j}$ hanteren dit begrip als synoniem voor persoonlijke lewenssfeer, prive-sfeer en prive-leven (temzij het onderscheid relevant is). Zie ook De Graaf 1977, p. 169; hij pleit evenzeer voor een overkospelend begrip wan prixacy, nwar werwerpt expliciet een overkoepelend recht op prive-leven.. Hij wijst inwisselbarhe d van de begrippen privacy en prive-lewen af. Naar zinn mening beschermt het recht op prive feven een beperkter aantal feitencomplexen dan privacy. Zijn definitie van het priveleven is echter eveneens een ruime; "dat deel dat van het functioneren van de persoon dat zozeer met zijn indivicualite it samenhangt, dat hij geen ongewenste inmenging van en kennisneming door andere hoeft te dulden' (Zie De Graat 1977, p. 93). Deze definitie sluit alan bij een meer abstracte benadering van priwacy.

7 In het Amerikaanse recht wordt gesproken over het recht op privacy. Het Amerikaanse priwacybegrip heef echten een minder onvattend bereik dan de werkdefinitie in dit boek die "het recht op porsoonlijkheid" bestrijkt. Het priwacybegrip in het Amerikananse recht vormt een "deelverzancling" van het meer omvattende begrip "recht op persoonlijkheid". Er bestat in de Verenigde Staten geen aparte categorie van persoonlijkheidsrechten, of "right to personhood" (zo ook Blok 2002). Toch kurnen in rechtspraak en literatuur sterk aanwerwante noties worden aangetroffen. Zij zijn in de rechtspraak tot ontwikkeling gekomen onder het begrip "privacy". Zie bijwoorbeeld Warren en Brandeis 1890, p. 195; zij wezen op de inhoud van privacy als zou die niet alleen het privé-eigendom omvatten, maar eetr "inviolable personality". 
privacy, hetgeen de mogelijkheid biedt om individuele aanspraken die in de perifere sferen liggen, te bestuderen.

Er zijn nu, wat de definitie betreft, verschillende wijzen om thet recht op persoonlijkheid te benaderen. In de eerste plaats kan worden gezocht naar een sluitende definitie van het recht op persoonlijkheid. Een sluitende definitie is echter nauwelijks te geven en evenmin aangetroffen in de rechtsstelsels. Noch in de rechtspraak, noch in literatuur of in de 'travaux préparatoires' zijn omschrijvingen van het techt op persoonlijkheid aangetroffen waarvan kan worden gezegd, dat zij voldoende duidelijk grenzen trekken ter zake van aanspraken die er wel en aanspraken die er niet onder behoren te vallen. De aard van het recht op persoonlijkheid leidt in de afzonderlijke stelsels tot afbakeningsproblemen en mist wat de reikwijdte betreft scherpte. ${ }^{9}$ Een tweede wijze van definiëren van het recht op persoonlijkheid komt neer op een opsomming van de verschillende elementen, die tot dusverre erkenning in het rechtsstelsel hebben gevonden. ${ }^{10}$ In zeer uiteenlopende situaties is door individuen aanspraak gemaakt op het recht op privé-leven, en kunnen 'categorieën' van situaties worden aangelegd waarbinnen deze individuele aanspraken onder het recht op persoonlijkheid werden erkend. De aanspraken die onder het recht op persoonlijkheid werden gedaan, varieerden van een recht op zwangerschapsafbreking, een recht op "informationele zelfbeschikking" - het recht van het individu om niet allerlei gegevens over zichzelf te hoeven onthullen, het recht om zelf een naam te kiezen, een recht op informatie van de overheid omtrent het eigen leefmilieu of een recht op het genot van een roes die weroonzaakt wordt door softdrugs. Zo ontstaat een gevarieerd beeld van mogelijke aanspraken. Enkele gemeenschappelijke lijnen zijn in de stelsels wel te onderkennen.

\subsubsection{Elementen van het recht op persoonlijkheid}

Er zijn individuele aanspraken gedaan die te maken hebben met de geestelijke of fysieke integriteit van het individu. "Aanspraken die bijvoorbeeld te maken hebben met een recht, te kiezen voor geboortebeperkende middelen hangen nauw samen met een recht op fysieke integriteit, omdat het individu kiest voor afwijzing van fysieke consequenties van zijn intieme gedragingen. Het recht op het gebruik van een leugendetector om een bekentenis af te dwingen is in Duitsland aangemerkt als een inbreuk op de geestelijke integriteit van het individu. Indringende verhoren om iemand aan het praten te krijgen behoeven miet te volgen uit lichamelijk contact, maar kunnen in bepaalde situaties eveneens worden aangemerkt als een inbreuk op de geestelijke integriteit. ${ }^{12}$ Daar-

8 Er wordt hier geen principiele scheiding tussen privacy ent persoonligkheid gemaakt; privacy is een bestanddeel van het recht op persoonlijkheid.

9 A.J. Nieuwentuis 2001 , p. 11

10 Met constitutie wordi in dit verband gedoeld op de reciten zoals neergelegd in grondwets- of verchagstekst, met insluiting van ongeschneven recht, rechtsbeginselen. Zie eveneens hieronder.

11 Zie bijvoorbeeld $X$ en $Y$. Nederland, EHRM 26 mart 1985, Serie A wol. 91; Tagebuch, 80 BVerfGE 367, 373 (1989); Castello-Roberts l. Verenigd Koninkrijk, EHRM 25 maart 1993, Serie A vol. 247-C;

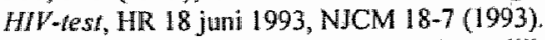

12 In dit opzicht vertoont het recht op persoonlijkheid een owerlapping met het recht van het individu, om 
naast is een reeks aanspraken op intieme gedragingen te herkennen. ${ }^{13}$ Hiertoe behoren de individuele aanspraken op een seksuele voorkeur en erkenning van geslachtelijke identiteit. Ook persoonlijke keuzen, zoals het gebruik van geboortebeperkende middelen, abortus of euthanasie kunnen tot dit domein van intimiteit worden gerekend. In de stelsels wordt echter niet eensluidend gedacht over de mate waarin deze aspecten van persoonlijkheid grondrechtelijke bescherming dienen te verkrijgen. ${ }^{14}$ Dit verschil in inzicht staat echter niet in de weg aan de kwalificatie van deze aspecten onder de hier te hanteren definitie van een recht op persoonlijkheid. Het aspect van het recht op persoonlijkheid betreffende intieme gedragingen verzet zich enerzijds tegen waameming en onderzoek van deze activiteiten; anderzijds houdt zij soms ook een wrijheid in, dergelijke activiteiten te kunnen ontplooien. In enkele rechtsstelsels kan ter zake een actief handelen van de staat worden verwacht. In de rechtsorde van alle stelsels blijkt eveneens een element van persoonlijkheid aanwezig, dat een recht op afscherming van een eigen territorium waarborgt. Verschillende stelsels kennen van oudsher al het huisrecht. "In beginsel werd dat recht ingevuld met een ruimtelijke benadering, maar sinds uiteenlopende wijzen van "binnendringen" in de huiselijke sfeer tot de mogelijkheden behoren, werd dit element van het recht op persoonlijkheid niet meer eenduidig vanuit de ruimtelijke benadering ingevulld. ${ }^{16}$ Met de opkomst van afluisterapparatuur en infrarood-onderzoekstechnieken heeft het aspect wan de afscherming van de persoonlijkheid noodzakelijkerwijze een minder ruimtelijke dimensie gekregen. Het huisrecht waarborgt echter niet onschendbaarheid van alle handelingen in de woning. Dat strookt eveneens met de minder ruimtelijke benadering van het aspect van het recht op privéleven als onderdeel van het recht op persoonlijkheid in verband met een recht op een 'eigen territorium'. Er zijn nu eenmaal handelingen, die ook in de intimiteit van de eigen woning verboden zijn, zoals bijvoorbeeld incest of het mishandelen van dieren.

Er lijkt zich in sommige stelsels een aanspraak op het vestigen en onderhouden van relaties te nestelen in de rechtsordes yan de stelsels als een aspect van een recht op persoonlijkheid. ${ }^{17}$ Het familieleven dat hiertoe kan worden gerekend, raakt aan enkele

In cen strafproceduro niet te hoeven getuigen tegen zichzelf (Aussageverpflichtung, 56 BVerfGE 37, 43 (1981) $)$. Het aspect op het recht op persoonilikheid dat hier in het geding is zon kunnen worden

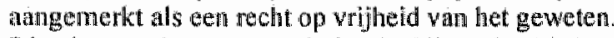

13 Dith element is terug te vindem in bijvoorbectd de uitspraken Griswold $t$. Commecticut 381 U.S. 479 (1965) ter zake van geboortebeperkende middelen, Roe $t$. Wade, 410 U,S. $113(1973)$ in verband met de keuze voor abortas; Dudgeon t Verengd Konnkrijk, EHRM 22 oktober 1981, Serie A vol. 45 vanwege het feit dat homoseksualiteit strafban was; Ethancisie, HR 27 november 1984, NJ $1985 / 106$ watarin het recht op wandig sterven werd witgesproken; Xl. Europese Commissie, zaak C-404/92, Hof van Justitie van de EG 5 oktober 1994 (in dezo zak is een aspect van geheimhouding van de gezondheidstoestand te herkennen; er is eveneens een aspect van de hiema te bespreken afscheming van porsoonsgegevens aanwezig) en Tramssexuelle, 49 BerfGE 286, 289 (1978).

14 Zive bijwoombeld Bowers t. Mardwich, 47 U.S. 186 (1986), warin het Amerikaanse Hooggerechtshof homoseksuele activiteiten niet rekende tot de actwiteiten die "priwacy" beoogt te beschermen.

15 Zic thierna bij de bespreking van de grondwets-en verdragsartikelen.

16 Zie bijwoorbeeld Katz t. Verenigde Staten, 389 U.S, 347,351-352 (1967) en de uitwerking in par. 2.3.1.

17 Zir bijvoorbeeld Marckx t. Belgie, EHRM 13 juni 1979, Serie A vol 31 ; Michael H. Gerald $D ., 491$ U.S. I10 (1989); M.L.B L.S.L.J., 519 U.S. 102 (1996); Gezamentike ouderlijke macht, HR 4 nei 1984, NJ 1985/510. In Duitsland worden deze aspecten van privacy voomamelijk beschouwd onder Art. 6 
hiervoor genoemde handelingen zoals geestelijke en fysieke integriteit en een zelfbeschikking ter zake van de wijze waarop men zijn of haar leven in gezinsverband wenst in te richten. Er zijn voor het Amerikaanse Hooggerechtshof bijvoorbeeld aanspraken gedaan op 'privacy" omdat de gezinssamenstelling voor de staat een reden was, toewijzing van een woning te weigeren. Wat familiebetrekkingen betreft kan worden gedacht aan een bepaalde wijze van opvoeden ${ }^{18}$, of een woorkeur voor een bepaalde (erkende) vorm van onderwijs. ${ }^{19}$ Daarnaast heeft zich in de rechtsstelsels een zelfstandige notie van gezins- en familieleven ontwikkeld, die deels raakt aan rechten die verbonden zijn met het recht op persoonlijkheid. Een recht op communicatie makt ook deel uit van het recht op persoonlijkheid.

Er bestaat in de rechtsstelsels een geldige aanspraak op het recht, ongestoord te kumnen communiceren; ongeacht of de inhoud van de communicatie nu een persoonlijk karakter heeft of niet. Dit element van het recht op persoonlijkheid is sinds de opkomst van moderne communicatiemiddelen als e-mail en internet overigens volop in ontwikkeling. Enigszins verbonden met de opkomst van technische (communicatie)middelen is de wens van het individu, zich af te schermen tegen waarneming en onderzoek waar het gaat om registratie, bewerking, doorgifte en openbaarmaking van persoonsgegevens. Wat dit aspect van het recht op persoonlijkheid aangaat, zijn verschillende benaderingen denkbaar van de wijze waarop het individu zich beperkt acht wanneer niet zorg vuldig wordt omgesprongen met registratie, bewerking, doorgifte of openbaarmaking van persoonlijke data. Een onbeperkte reproductie is mogelijk, waardoor controle op verspreiding van gegevens niet meer te handhaven is. Dat kan evenzeer schadelijk zijn als het gaat om gegevens die op het eerste gezicht niets 'persoonlijks" onthullen, maar die door koppeling aan andere databestanden kunnen verworden tot schadelijke gegevens. Daarnaast bestaat de vrees, dat de wens om alles van de burger tot in detail vast te leggen, kan leiden tot een 'Entpersönlichung' van het individu. Het verwordt daarmee tot een object van de staat, en dat is nu juist een gedachte, die niet past bij een recht op persoonlijkheid en de veronderstelling, dat het individu een ruimte toekomt waarin het zichzelf kan zijn en autonoom bepaalde beslissingen kan nemen. ${ }^{20}$ Een verwante benadering is, dat het individu in staat moet zijn om zijn eigen leven in te richten; indien zijn leven in allerlei gegevens vastligt, liggen veranderingen in dat leven niet voor de hand. "Een obstakel kan in dit verband iemands verleden zijin, dat in de weg staat aan de inrichting van zijn leven. Aan het recht op een rustige terugkeer in de maatschappij nadat is geboet voor een misdrijf ligt ten grondslag, dat het individu een 'nieuwe' start moet kunnen maken in zijn leven, zonder dat zijn verleden voortdurend wordt nagedragen. ${ }^{22}$

Grundgesetz, dat het recht op respect voor het familie-en gezinsleven rebelt.

18. Meyer t. Nebraska, 262 U.S. 390 (1923).

19 Pierce t. Society of Sisters, 268 U.S. 510 (1925).

20 Dit aspect van privacy speelde onder meer in Mikrozensus, 27 B VerfGE 1,6 (1969) en Wolkszh/hmg, 65 BVerfGE $1,41(1983)$.

21 A.J. Nieuwenhuis 200 , p. 34

22 Zie bijwoorbeeld Lebach, 35 BVerfGE 202, 220 (1973) en Van Gasteren, HR 6 jathuari 1995, NJ 
Persoonsgegevens kunnen uitenlopende gedaanten aannemen; het kan gaan om informatiegegevens, maar eveneens om afbeeldingen waaronder iemands portret. Het individuele belang is steeds het opwerpen van een barrière tegen een ongebreidelde blootstelling aan de openbaarheid. Nauw verbonden met dit laatste element is het recht dat de eer en de goede naam van het individu beschermt; het ziet toe op negatieve gevolgen van het naar buiten brengen van een beeld dat niet strookt met de weergave van het individu zoals het dat zelf will afgeven. Niet alle negatieve beelden kumnen worden beschouwd als schendingen van het recht op eer en goede naam; het moet gaan om een " $\mathrm{kwalijke}$ toeschrijwing". "In enkeile rechtsstelsels is eveneens een uitgesproken tweedeling ten aanzien van het recht op persoonlijkheid aangetroffen: in enkele gevallen wordt een aanspraak gemaakt op afscherming van het persoonlijk leven, op afscherming van gemaakte keuzes, van een gemoedstoestand, terwijl in andere aanspraken onder het recht op persoonlijkheid juist werd opgekomen voor een vrijheid van handelen. ${ }^{24}$

\subsubsection{Het recht op persoonlijkheid is een amorf concept}

Uit deze indeling blijkt dat het recht op persoonlijkheid aan een breed scala van individuele aanspraken bescherming kan bieden. De hier opgesomde aspecten van het recht op persoonlijkheid blijken echter niet duidelijk af te grenzen; daarnaast is in veel individuele aanspraken een overlap van verschillende elementen van het recht op persoonlijkheid te vinden. ${ }^{25}$ Aanspraken op het personen- en familierecht steunen bijvoorbeeld op elementen van het recht op een familieleven, en eveneens op die van geestelijke integriteit. Claims ter zake van een recht op resocialisatie dragen aspecten van het recht op eer en een goede naam en het recht op zelfbeschikking in zich. ${ }^{26}$ Gedragingen die zich beschermo weten in de privé-sfeer van de woning kunnen daarbuiten beschermd zijn; hier vullen het aspect van het eigen territorium en het recht, relaties te vestigen en te ontwikkelen elkaar aan. ${ }^{27}$ Een eenduidige categorisering van het recht op persoon-

$1995 / 422$.

23. A.J. Nieuwenhuis 2001, p. 35. In de rechtsprabk zijn de volgende sprekende voorbeelden tangetroffen: Ferdi E, HR 21 januari 1994, NJCM 19-6 (1994); Soraya, 34 BVertOE 269 (1973) en Eppler, 54 BVerTGE $148,154(1980)$

24. Alexy, 1996, p. 332 e.v., Scholiz en Konrad 1998, p. 66. In de Dutse grondwet is het recht op persoonlijke ontplooiing vastgelegd, dat een recht tot handelen van het individu inpliceert. In de rechtspraak is het "allgeneines Personlichkeitsrecht" tot ontwikkeling gekomen, dat eerder een respectvolle bejegening woor individuele ketuzes die niet direct op een handelen duiden, inhoudt (zie par. 2.4.4). In sontunge opxichten heeft de stant een verplichting het individu bij te stan in de verwezenlijking van individuele keuzes.

25. Herboven is een opsomming wan allerlei aspecten die nawar mijn mening behoren tot een recht op persoonlijkheid gegeven; classificaties zijn zeer wel denkbar. Zie bijwoorbeeld Prosser 1984 (1960) die een engere definitie van priwacy hanteert waarin plaats is voor vier deelelementex: in de eerste plaats inbreuk op de privé-zaken van het individu; in de tweeda plaats de openbaarmaking van privế-aspecten van iemands prive-leven; in de derde plaats publiciteit die het individu in een verkeerd daglicht plaatst en in de vierde plats de toe-eigening van een eigenschap van een individu dat daarvoor geen toestemming heeft gegeven (Prosser $\$ 984$ (1960), p. 107). Zie ook Blok (2002).

26 Lebach, 35 BVerfGE 202, 220 (1973).

27 Niemier 1. Duitsland, EHRM 16 december 1992, Serie A vol. $251-\mathrm{B}$. 
lijkheid blijkt lastig en bij nader inzien onmogelijk. Het recht op persoonlijkheid kan in het geding zijn, maar niet in al die situaties wordt een inbreuk op dat recht gemaakt. Observatie door mede-individuen is aan de orde van de dag, maar in enkele situaties kunnen observaties niet door de beugel. Het gaat bijvoorbeeld om situaties en intieme gedragingen waarbij men er niet op rekent, te worden waargenomen. Die zouden kunnen worden gekarakteriseerd als een omschrijving van 'aspecten van het leven van het individu waarvan men aanneemt dat zij gevrijwaard behoren te blijven van het evaluatiev: oordeel van anderen'. ${ }^{28}$ Gevreesd mag worden, dat een dergelijke omschrijving niet uitblinkt in helderheid voor toepassing. In de Duitse rechtspraak, en naar het lijkt ook in de rechtspraak van het EHRM, is een sferentheorie tot ontwikkeling gekomen waarmee is getracht om privé- en publieke sfeer wan elkaar af te bakenen. Ook deze benadering heeft zich niet als standvastig bewezen: steeds bleek, dat naar aanleiding van bijvoorbeeld technologische ontwikkelingen de sferen moesten worden 'bijgesteld'. Daarnaast zijn sommige feitencomplexen te kwalificeren in zowel de private als in de publieke sfeer. In de rechtspraak van beide stelsels is dan ook geen sprake van elkaar uitsluitende sferen, maar eerder van een flexibel concept dat de rechter behulpzaam kan zijn bij het kwalificeren van feitencomplexen. Voor iedere nieuwe casus moet echter weer opnieuw worden vastgesteld, welke de omtrekken van het bij het recht op persoonlijkheid betrokken aspect zijn. Deze flexibiliteit in de sferenleer leidt evenmin tot een onderscheidend vermogen van een definitie van het recht op persoonlijkheid.

\subsubsection{Omschrijving van een werkdefinitie van het recht op persoonlijkheid}

Zovele benaderingen, beschrijvingen en classificaties van het recht op persoonlijklheid zijn mogelijk. Voor een omvattende beschrijving of voor een sluitende categorisering van individuele aanspraken van het recht op persoonlijkheid wordt in het kader van dit onderzoek niet gekozen. Het streven hiernaar wordt aan anderen gelaten, ${ }^{29}$ en is niet van doorslaggevend belang voor beantwoording van de onderzoeksvraag naar de wijze van redeneren in de rechtspraak. Het recht op persoonlijkheid beweegt zich op een hoger abstractieniveau dan de geschreven en ongeschreven grondrechten en overstijgt het privaatrechtelijke- en het constitutioneelrechtelijke begrippenkader. Het wordt hier opgevat als een algemeen verzamelbegrip waaronder bijwoorbeeld de in de Amerikaanse en EG-rechtspraak ontwikkelde notie "privacy" en het recht op prive-leven zoals vastgellegd in het EVRM en de Nederlandse grondwet vallen. Ook het Duitse recht op vrije ontplooiing van de persoonlijkheid wordt hier begrepen onder de werkdefinitie van het recht op persoonlijkheid. Een sluitende werkdefinitie is geen noodzakelijke voorwaarde om jurisprudentieonderzoek te verrichten naar rechtsvinding op het ter rein van het recht op persoonlijkheid. Wanneer in het vervolg over het recht op persoonlijkheid wordt gesproken, wordt hiermede gedoeld op een algemene handelingsvrijheid van het individu. Naast een actieve handelingscomponent omvat deze ook een passieve

28 A. N. Nieuwenhuis 2001, p. 42 .

29 Zie bijvoorbeeld Warren en Brandeis 1984 (1890), p. 75-103; De Braww en Van Veen 1965; De Graaf 1977 ; Bloustein 1984 , p. 156-202; A.J. Niewwenhuis 2001 , met name hoofdstuk 3 en Nebrimelman 2002 
component, die inhoudt dat het individu recht heeft op een respectvolle bejegening voor individuele keuzes die niet direct op een handelen duiden. ${ }^{30} \mathrm{Er}$ is opzettelijk gezocht naar vergelijkbare materiêle normen en vergelijkbare, nog niet eerder gedane individuele aanspraken op het terrein van het recht op persoonlijkheid die de rechter in concrete casus moest beoordelen.

Afbakening van de te onderzoeken aspecten van het recht op persoonlijkheid kan ook in negatieve zin plaatsvinden. Wat in het jurisprudentieonderzoek niet wordt beschouwd onder het recht op persoonlijkheid, zijn uitspraken die handelen over andere gepositiveende grondrechten in de respectievelijke grondwetten en verdragen dan die hieronder volgen. Voor wat betreft de Duitse grondwet wordt onderzocht, welke rechtsontwikkelingen zich hebben voorgedaan omtrent Artt. $\mathbb{1}$ lid 1 en 2 lid 1 GG. Bij het Nederlandse jurisprudentieonderzoek staat, voor zover relevant, het recht op persoonlijke levenssfeer ex Art. 10 Grondwet, het recht op lichamelijke onschendbaarheid ex Art. 11 Grondwet en Art. 8 EVRM centraal. In de Amerikaanse jurisprudentie wordt met name aandacht geschonken aan het Vijfde en Veertiende Amendement, terwijl in de rechtspraak van het EHRM Art. 8 EVRM een centrale positie inneemt. In de jurisprudentie van het Hof van Justitie van de EG wordt gezocht naar noties die samenhangen met het recht op persoonlijkheid; het EG-Verdrag codificeert niet als zodanig een recht op persoonlijkheid, persoonlijke levenssfeer of een recht op privé-leven. ${ }^{31}$ In de rechtspraak van het Hof van Justitie van de EG werd voor de erkenning van de individuele aanspraak met name aangeknoopt bij het recht op privé-leven ex Art. 8 EVRM.

De werkdefinitie van het recht op persoonlijkheid wordt gekozen op basis van een meer pragmatische benadering, en hier als volgt omschreven: het vormt een overkoepelende notie van grondrechten en ongeschreven rechten die allen centreren rond een kern van een recht op ontplooing van het individu, waarvan zelfbeschikking en persoonlijke autonomie de kern vormen. ${ }^{32}$ Afscherming van persoonlijke keuzes en het respectvol bejegend worden staan centraal in het recht op persoonlijkheid. Normen die hiermee samenhangen en die in het rechtsstelsel kunnen worden getraceerd in de rechtspraak of in de wetgeving, zullen in de beschouwingen worden betrokken.

\subsection{Het constitutioneelrechtelijke begrippenkader}

\subsubsection{Inleiding}

In beginsel kan er niet vanuit worden gegaan, dat het begrip "grondwet" of "grondrecht" in de Duitse doctrine exact dezelfde betekenis heeft als in de Nederlandse heersende opvatting. De relevantie van het onderscheid doet zich bijvoorbeeld gevoelen bij de

30 Vgl. Alexy 1996, p. 332.

31 Het EU-Handvest wan de fundamentele rechten is nog met juridisch bindend. Het Handvest codificeert in Art. 12 een recht op privé-leven; zie par. 2.5 .

32 Deze werkdefinitie omschrijft een ruime opvatting, die wergelijking van de rechtsprak van de verschillende stelse/s mogelijk maakt. 
vraag naar de gelding van het ingeroepen grondrecht. Een hieraan gerelateerde vraag is, of ongeschreven rechten worden geacht te zijn ingesloten, indien gesproken wordt over "de grondrechten", Ook hier lopen de opvattingen tussen de rechtsstelsels niet alleen uiteen, maar bestaat ook binnen de rechtsstelsels hierover geen eenduidige opvatting. Hieronder wordt getracht, een keuze te maken, zonder het debat over definities ter zake van het begrip constitutie, grondwet en grondrecht te willen sluiten. Een recht op persoonlijkheid wordt in de tekst van grondwet of het verdrag in ieder geval alls gepositiveerd aangemerkt, indien het letterlijk wordt genoemd. In sommige grondwetten zijn echter ook deelaspecten van het recht op persoonlijkheid vastgelegd; gewezen kan worden op bijvoorbeeld een recht op familie- en gezinsleven, een recht op huisvrede of een recht op lichamelijke integriteit. Beantwoording van de vraag naar het rechtskarakter van grondrechten is van belang omdat straks moet worden bepaald op welke wijze de rechter een 'nieuwe lezing' van een bestaande grondwetsnorm of nieuw gepositiveerde rechten legitimeert. Daarnaast is een vergelijkend onderzoek naar de begrippen wenselijk in verband met de vergelijkbaarheid van de stelsels. Het Verdrag van de Europese Unie heeft een andere structuur en doelstelling dan de Duitse grondwet. Het EVRM ontbeert een constitutioneel kader van horizontale en verticale machtenscheiding. Betoogd zal worden dat, hoewel deze stelsels niet alle vereisten van een constitutie of grondwet in huis hebben, er geen problemen behoeven te ontstaan voor het analyseren van de jurisprudentie ter zake van rechtsontwikkeling op het terrein van het recht op persoonlijkheid.

\subsubsection{Constitutie}

Een formele definitie van het begrip 'constitutie' houdt de aanwezigheid van een wet in, die de belangrijkste onderdelen de machtsuitoefening van bestuur, wetgever en rechter vestigt en beheerst. ${ }^{33}$ Raz geeft naast deze formele benadering eveneens een meer materiële invulling van het begrip constitutie. Hij signaleert zeven eigenschappen die een constitutie van een organisatie in zijn optiek in huis dient te hebben, wil deze zich constitutioneel kunnen noemen. ${ }^{34}$ De eerste eigenschap komt overeen met de hiervoor gegeven formele definitie: er dient een wet te zijn die de hoogste normen ter zake van machtsuitoefening van bestuur, rechter en wetgever vastlegt. In de tweede plaats dient de constitutie van een organisatie enigermate stabiel te zijn. Deze constitutie kan worden geamendeerd, maar biedt aan de politieke en rechtsinstituten een stabiel kader waarbinnen zij met een zekere continuitteit hun taken kunnen uitvoeren. Constituties zijn vaak vastgelegd in éen of een overziclatelijk aantal geschreven documenten, maar van groter belang is dat het rechtsnormen vastlegt die superieur zijn. Daarmee strijdende rechtsnormen zijn nietig of niet toepasselijk. Er dient in het rechtsstelsel eveneens

33. Vgl. Alkema 1996, p. 91: Het begrip "constitutie" wordt omschreven als het geheel van tuttonome regels die de structuur van een rechtsstelsel normeren en die eveneens een substantiale werandering van deze. structuur mogelijk maken". Voor een Duitse benadering, zie Starck: "Within German jurispinudence it is generally agreed that the Basic Law (Grundgesetz: GG) contains binding law, that it is normative in the strongest possible sense. Thus the Basic Law states that legislation must conform to the constitutional order and that the executive and judiciary are bound by statute and law [...l.' (Starck 1995, p. 48).

Raz 1998, p. 152 e.v. Zje ook Craig 2001, p. 126. 
een rechter aanwezig te zljn die bindende uitspraken doet over deze strijdigheid of toepasselijkheid. Amendering van de constitutie windt in beginsel plaats aan de hand van een verzwaarde amenderingprocedure. In hiet algemeen leggen constituties ook ideeën vast over democratie en individuele rechtsbescherming.

Nu varieren de accenten op de genoemde eigenschappen wan stelsel tot stelsel, maar aanwezigheid van de afzonderlijke elementen wordt voor de kwalificatie van een constitutie in het algemeen noodzakelijk geacht. Voor de beantwoording van de onderzoekswraag is aanwezigheid van alle genoemde elementen die duiden op "constitutionaliteit" echter niet noodzakelijk. Het onderzoek stelt de uitleg van een grondrecht door de hoogste rechter centraal. Tegen de achtergrond van dit accent is het van belang, een gemeenschappelijkheid te definièren, die in alle stelsels aanwezig is. Om van een gemeenschappelijkheid te kunnen spreken dienen naar mijn mening drie van de hiervoor genoemde aspecten in de constitutie van het rechtsstelsel aanwezig te zijn wil men de in de inleiding opgeworpen onderzoeksvraag op zinvolle wijze kunnen beantwoorden. Van belang is in elk geval de eis, dat er een document is, dat rechtsnormen vastlegt die superieur zijn ten opzichte van alle andere wetgeving die in het rechtsstelsel tot stand komt. Vanwege de toespitsing van het onderzoek op de wijze van rechtsvinding op het terrein van het recht op persoonlijkheid is in elk geval van belang, dat het document grondrechten codificeert, die kunnen worden aangemerkt als superieure rechtsnormen. Deze grondrechten hoeven niet letterlijk een grondrecht op persoonlijkheid te stipuleren, maar het is well van belang dat er aanwijzingen in de constitutie zijn die duiden op een potentielle bescherming van grondrechten. Daarnaast is van belang, dat de te onderzoeken rechter in laatste instantie een bindende uitspraak doet over de betekenis van aspecten wan het recht op persoonlijkheid.

\subsubsection{Grondwet}

Tot de grondwet worden hier niet gerekend de grondrechtsbeginselen, gewoonterecht en ongeschreven rechten. ${ }^{35}$ Tot de grondwettelijk vastgelegde individuele rechten behoren die normen, die in het document van de grondwet zijn geexxpliciteerd. In de Duitse grondwet zijn dat de in Artt. 1-19 GG, Art. 20 lid 4, 33, 38, 101, 103 en 104 neergelegde normen; zij geven uitdrukking aan de gepositiveerde fundamentele undividuele rechten. ${ }^{36}$ In de Nederlandse grondwet behoren de Artikelen 1 tot en met 23 tot deze categorie grondrechtbepalingen, alsmede de hierna te bespreken bepalingen van het EVRM met bijbehorende protocollen. ${ }^{37}$ Voor het EVRM zijn deze rechten in de Artt. 1 tot en

3520 ook Kortmann 2001, p. 27. Anders Van Gerven 2000, p. 27. In diens optiek omvat een grondwet, zuiver in abstracto ongeschreven regells of conventies, het Statuut voor het Koninkrijk der Nederlanden en supranationaal en intemational recht en organieke wetten. Grondrechtsbeginselen kunnen tot de grondrechten behoren (zie hierna par. 2.2.4); gewoonterecht en ongeschreven rechten behoren in elk geval tol de grondrechten (zie ook par. 2.2.4).

36 Alexy 1996, p. 56 en Hesse 1990 , p. 117

37 In de Nederlandse rechtsorde hanteert de rechter de monistische benadering op grond van Art. 93 en 94 Grondwet. De grondrechtencatalogus wan het EVRM bevat mitsdien grondrechtsbepalingen die direct wan betekenis zijn in het Nederlandse grondwetssysteem. Wat de protocollen betreft bevatten het Eerste, het Wierde en het Zesde Protocol grondrechtbepalingen die directe werking hebben in het Nederlandse 
met 18 meergelegd, almede in de protocollen. ${ }^{38}$ De Amerikaanse grondwet stipuleert grondrechtbepalingen die individuele rechten inhouden in de Amendementen 1 tot en met IX, XIII tot en met XV, XIX, XXIV en XXVI. Het EU-Verdrag bevat eveneens aanwijzingen ter zake, al bestaat er geen overeenstemming over de vraag in hoeverre sprake is van grondrechtbepalingen als in voornoemde systemen. Art. 6 lid 2 EU. Verdrag verwijst allereerst naar de verplichting van de Unie, de grondrechten uit het EVRM en de gemeenschappelijke constitutionele tradities van de Lid-Staten te waarborgen. Het EU-Verdrag formuleert deze verplichtingen als algemene beginselen van het Gemeenschapsrecht". In het EU-Verdrag is geen sprake van een bindende catalogus van grondrechtbepalingen; evenwel hebben enkele als grondrechten aan te merken bepalingen immiddels hun neerslag gevonden in het EU-Verdrag. ${ }^{39}$ Verder mag het EUHandvest hier niet onvermeld blijven; dat is als Verklaring gehecht aan het Verdrag van Nice en heeft vooralsnog geen bindende kracht. ${ }^{40}$

\subsubsection{Grondrechten}

Het recht op persoonlijkheid en daaraan gelieerde individuele rechten worden in het vervolg aangemerkt als grondrechten indien zij in de grondwet of in de rechtspraak van het rechtsstelsel tot witdrukking zijn gekomen of zijn gepositiveerd. Het begrip "positivering' behoeft in dit verband enige uitleg. ${ }^{41}$ "Tot de grondrechten behoren de rechten die reeds hun erkenning hebben gevonden in de grondwet. Het zijn rechten waarower de nodige zekerheid bestaat; die kenbaar zijn. In de rechtspraak en doctrine worden deze rechten dan ook erkend als rechtsgrondslag, waarop individuele aanspraken kunnen worden gevestigd. Een recht wordt in het vervolg aangemerkt als gepositiveerd indien grondwet of verdrag letterlijke melding maken van een recht op persoonlijkheid, of van éen van de gelieerde rechten. ${ }^{42}$ Het komt ook voor dat een recht niet is gepositiveerd in grondwet of verdrag, maar wel is gepositiveerd in de rechtspraak. ${ }^{43}$ In dergelijke gevallen heeft de rechter een individuele aanspraak op een norm erkend als rechtsnom, waaruit grondwettelijke bescherming voortvloeit. Indien sprake is van een dergelijke erkenning wordt in het vervolg gesproken over een ongeschreven recht, dit ter onderscheiding van het geschreven grondrecht. ${ }^{44}$ Ook indien het recht in een verdrag tot uitdrukking komt wordt gesproken van 'grondrecht' of 'fundamenteel recht'.

grondwetssysteem. Zie ook in paragrat 27.

38. In het Eerste, thet Vierde, het Zesde en het Zevende Protocol zijn evereens undividuele rediten ge formuleerd. Het "Tiende Protocol is tot op heden nog niet in werking getreden.

39 Zie par. 2.5.1.

40. Zie Pb. 2000, C $364 / 1$ over de beslissing van uitstel wan het bindend karakter van het Handwest.

41 Zie par, 4.6 en 4.7 over positivering en gelding van rechtsnormen.

42 Zie hiervoor bij de definitie van het recht op persoonlijkheid in paragraat 2.1 cn met name par. 2.1 .5 warin de te onderzoken grondwetsbepalingen zijit gegeven.

43 Over hoe de in de rechtspraak gepositiveende rechten zich in beginsel verhouden tot de rechten die inn de grondwet of in het verdrag zijn gepositiveerd, zie ook hoofdstuk $4 \mathrm{~B}$

44 Beide normen maken dan wel deel uit van de categorie "positief recht", all ligt dat in het geval wan erkenning van een nieuwe rechtsnorm door de rechter niet vanzellsprekend woor de trand (par. 4.6). De termen "grondrechten" en "fundamentele rechten" hebben in dit onderzoek ere identieke betekenis. 
Hiermee verwant is de kwestie in hoeverre grondrechtelijke rechtsbeginselen behoren tot de grondrechten. In de literatuur lijkt deze vraag in beginsel negatief beantwoord te worden, hoewel over dit punt beslist geen eenstemmigheid bestaat. ${ }^{45}$ Rechtsbeginselen behoren in elk geval wel tot de constitutie, maar zij maken niet vanzelfsprekend deel uit van de lijst van grondrechten. ${ }^{46}$ Wanneer deze vraag nu wordt gesteld ter zake van erkenning van rechtsbeginselen in de rechtspraak, ligt een veilige stellingname van een precieze kwalificatie evenmin voor de hand. In de rechtspraak zijn, zo zal blijken, normen tot stand gebracht die de indruk wekken dat zij tot het geldend recht behoren, terwijl na onderzoek van de redenering blijkt dat dat niet vanzelfsprekend het geval is. Een rechter kan bijwoorbeeld in zijn rechtsvinding overtuigend doen voorkomen alsof de individuele aanspraak al behoort tot de in de rechtspraak gepositiveerde rechtsnormen. De vraag dringt zich dan op, of een aanspraak, die in de rechterlijke uitspraak wordit erkend als een recht maar nog geen bestendiging heeft gevonden in wetgeving of rechtspraak, toch kan behoren tot de in de rechtspraak erkende rechtsnormen en kan leiden tot rechtsgeldige vaststellingen in de constitutionele interpretatie.

Regelmatig zal in het onderzoek worden gesproken over een 'individuele aanspraak'. Indien over een individuele aanspraak wordt gesproken wordt gedoeld op een aanspraak van het individu op een 'rechtsnorm'. Een individuele aanspraak is echter niet altijd evident geẽnt op een gepositiveerde rechtsnorm. Deze kan zich richten op in de wet gepositiveerde rechten, hoewel op voorhand nog niet duidelijk is of het betreffende recht zover strekt. Daarnaast komen individuele aanspraken voor die refereren aan notmen die geen neerslag hebben in grondwet of verdrag, noch in de rechtspraak als geldende rechtsnorm zijn aanvaard. De individuele klacht houdt kortweg een aanspraak in waarvan nog niet gezegd is, of deze door de rechter wordt erkend als kwalificeerbaar onder één van de gepositiveerde rechtsnormen. De rechtskwaliteit van de individuele aanspraak wordt door de rechter onderzocht in de interpretatiefase. In de interpretatiefase kan de aanspraak worden erkend: er bestaat dan een subjectief recht. Aangenomen wordt dat dat in beginsel is gebaseerd op een erkende, geldige rechtsnorm. Deze fase zal steeds central staan in het jurisprudentieonderzoek - de vraag naar de wijze waarop de rechter bepaalt, dat de aanspraak grondrechtelijke bescherming dient te verkrijgen. Is de individuele aanspraak eenmaal erkend, dan staat daarmee nog niet vast of de

45. Her is afgegan op wat de belangrijkste handboeken stellen ter zake van dit standpunt. Voor auteurs die een zelfte opvating over het begrip grondrecht hanteren, zie onder meer $L$. Verhey 1992, p. 13; Hesse 1990, p. 117; Alkena is van mening dat sommige ongeschreven rechtsbeginselen behoren tot de grondwett omdat zij daar systematisch well thishoren, ook al zijn zij daar niet opgeschreven (Alkema 1996, p. 92). Zie verder par, $4.6 .2 \mathrm{e.}$.

46 Dat hangt samen met het rechtskarakter vai rechtsbeginsellen: zij dienen nog mader geconcretiseerd te worden, terwill dat bij rechtsregels niet het geval is. Rechtsregels zijn daardoor in hogere mate afdwingbar. Van grondrechten zou ik hier willen bepleiten, dat zij ook direct afdwingbaar zijn. Zic verder par. 4.6 en 4.7 voor het onderscheid tussen rechisregels en rechtsbeginselen. Tegelijkertijd kan worden gesignaleerd, dat sommige in de grondwet opgenomen rechtsnormen cen rechtsbeginselachtig karakter bezitten. Het recht op menselijke waardigheid in de Duitse grondwet, zo zal blijken, is van die aard. In dat verband wordt er hier van uit gegaan dat een rechtsbeginsel in de Duitse grondwet is gepositiveerd (par. 2.4). 
aanspraak ook gehonoreerd dient te worden. Deze beslissing valt in beginsel niet reeds in de interpretatiefase, maar pas in de toetsingsfase. ${ }^{47}$

\subsection{Verenigde Staten: de Constitutie en de Amendementen}

De Amerikaanse grondwet, de Constitution daterend wan 1787, is het oudste grondwettelijke document in functie. ${ }^{43}$ Spoedig na de totstandkoming van de grondwet in 1787 kwam de Amerikaanse "Bill of Rights" tot stand. Dit handvest legde voor de burger een aantal grondrechtelijke waarborgen neer tegenover de federale overheid. De grondwettelijke waarborgen tegenover de statelijke overheden waren in beginsel al vastgelegd in de afzonderlijke statelijke constituties. De grondwet beschrijft de staatsinrichting (de Artikelen I-VI); de Bill of Rights omvat oorspronkelijk een tiental Amendementen. De Amendementen bevatten enkele fundamentele rechten. Hiertoe behoren onder meer het recht op vrijheid van religie, vrijheid van meningsuiting en vrijheid van vergadering, de immuniteit van de woning en het recht op een eerlijk proces. ${ }^{49}$ De Bill of Rights werd door de opstellers van de grondwet van 1787 niet gezien als een noodzakelijk onderdeel van de grondwet en werd door hen in eerste instantie daarin ook niet opgenomen. Onder druk van de antifederalisten in de staten, die de grondwet slechts wilden ondertekenen op voorwaarde dat een Bill of Rights zou worden geincorporeerd, werd in $\$ 791$ de Bill of Rights in de vorm van tien Amendementen toegevoegd aan de grondwet. Zij zagen in bijvoorbeeld het Tiende Amendement, een belangrijk element in de verticale machtenscheiding, een waarborg tegen een centralistisch ingestelde regering op federaal niveau. ${ }^{50}$ Tegenstanders van de Bill of Rights waren er eveneens: zij zagen met name een bedreiging in het feit dat er slechts enkele fundamentele rechten in waren neergelegd. Deze onvrede resulteerde in de toevoeging van het Negende Amendement in 1791: "The enumeration in the Constitution, of certain rights, shall not be construed to deny or disparage others retained by the people'. Het laat zich vertalen, als dat er nog andere fundamentele rechten kunnen bestaan dan de in de Bill of Rights gepositiveerde rechten. Dat wil overigens niet zeggen, dat daarmee voor de rechter een "carte blanche' in de Bill of Rights is neergelegd, die rechterlijke rechtsontwikkeling bij woorbaat legitimeert. ${ }^{5 t}$ Het Dertiende $^{52}$, Veertiende ${ }^{537}$ en Vijftiende Arnendement ${ }^{5 / 4}$ date. ren van na de Amerikaanse burgeroorlog en zijn typische uitvloeiselen daarvan. ${ }^{55}$

47 Zie par. 3.1.

48 Murphy 1995, p. 116.

49 Respectievelijk het Eerste, het Vierde, het Zesde Amendement.

50 Het Tiende Amendement luidt: "The powers not delegated to the United States by the Constitution, nor prohibited by it to the states, are reserved to the states respectively, or to the people'.

51 Op lnet Negende Amendement wordt thieronder teruggekomen in par. 23.2.

52 Het Dertiende Amendement schafte de slavernij at..

53 Het Veertiende Amendement verbiedt op federaal niveau vrijhefdsbeperkingen zonder "due process of law ${ }^{*}$ "maar richt zich specifiek tot de staten, zie par. 2.3.3.

54 Het Vijtiende Amendement kent het stemrecht an alle Amerikaanse burgers toc, ongeacht buidskleur of ras.

55 Ackerman 1991, p. 266 e.v. 
De geschiedenis van de constitutionele rechtsontwikkeling wordt in de Amerikaanse literatuut met name beschreven aan de hand van de rechtspraak door het Hooggerechtshof. ${ }^{56}$ Het recht op persoonlijkheid wordt in de constitutionele rechtspraak niet erkend als een recht op 'personhood', maar als een 'right to privacy". ${ }^{37}$ Bedacht dient te worden dat in dat verband niet een enge definitie van privacy wordt bedoeld, maar een meer omvattende notie als onderdeel wan een recht op persoonlijkheid. De Bill of Rights kent niet één specifieke bepaling, die een omvattend recht op privacy afzonderlijk beschermt. Wel zijn in de verschillende Amendementen elementen te ontwaren die wijzen op een aanwezigheid van deelelementen van het recht op persoonlijkheid.

De supervisie van het Amerikaanse Hooggerechtshof over het grootste deel van de grondrechten in de Bill of Rights in geschillen tussen individuen en staten was niet van meet af aan aanwezig. In beginsel richtten de grondrechten in de Bill of Rights zich op individuele aanspraken tegen handelingen van de federale overheid, en niet tegen die van de staten. ${ }^{58}$ Het Veertiende Amendement richtte zich bij uitzondering eveneens tot de staten. Het Hof interpreteerde het Veertiende Amendement in de loop van de tijd echter zo, dat het de staten eveneens gebonden achtte aan het grootste deel van de grondrechten die zijn opgenomen in de Bill of Rights. ${ }^{59}$ Het Hof hanteerde hiervoor de zogenoemde "incorporatietechniek" 60 "De "due process"-formule die in het Veertiende Amendement besloten ligt, werd door het Hof niet louter formeel uitgelegd, maar verkreeg eveneens een materiële invulling. Met name aspecten van de strafrechtelijke procedure, die door de staten werden voorgeschreven, boden het Hof een mogelijkheid te komen tot een materiêle invulling: het Veertiende Amendement schrijft voor dat het een staat verboden is het individu de vrijheid, het leven of de eigendom te ontnemen zonder daarbij processuele waarborgen in acht te nemen. Die waarborgen werden nu juist gevonden in het Vijfde en het Zesde Amendement van de Bill of Rights. Niettoepassing van de in het Vierde, Vijfde en Zesde Amendement neergelegde waatborgen zou een ontkenwing betekenen van processuele waarborgen, zo werd geredeneerd. De waarborgen in de Bill of Rights fungeerden in dit verband als algemene rechtsbeginselen die het Hof benutte voor de inwulling van 'due process of law' in het Veertiende Amendement. De toepassing van de Amendementen vond plaats op casuïstische basis; ondertussen is het grootste deel van de Amendementen ook van toepassing op statelijke handelingen. ${ }^{61}$ Zo creeerde het Hof de mogelijkheid de staten aan te spreken

56 Zie onder meer Gunther en Sulliwan 1997; N. Redlich, B. Schwartz en J. Attanasio 1996; Rotunda 1995; Ducat 1996 en Stone, Seidman, Sunstein en Tushnet 1996.

57 Tribe 1988, Fried 1968.

58 De nogelijkheid tot rechterlijke toetsing van de hoogste wetgeving was evenmin vastgelegd in de grondwet, ale hiervoor par. 3.2.1.

59 Zie bijwoorbeeld de zakien Twining t. New Jersey, 211 U.S. 78 (1908), Palko t. Connecticut, 302 U.S. 319 (1937), waarin de het Vijfde Amendement, dat van oorsprong was geschreven voor federale handelingen, van toepassing werd verk/aard op een geschil tussen individu en staat; zie eveneens Duncan t. Louisianta, 391 U.S. 145 (1968) waarin het Vijfde en het Zesde Amendement van toepassing werden verklaard op een geschil tussen een individu en staat. Zie verder Gunther en Sullivan 1997, p. 432 e.v.

60 Voor een overzicht wan de incorporatie van de eerste acht Amendementen, zie Ducat en Chase 1992, p. 626 .

61 Een aantal grondrecluten is echter miet gehincorporeerd, zie Ducat en Chase 1992, p. 627. 
op grondrechtelijke verplichtingen via het Veertiende Amendement, en bond het Hof de staten, voor wie de Bill of Rights in eerste instantie niet was geschreven, aan de federale grondrechten. Via de incorporatie wist het Hof zijn jurisdictie aanzienlijk uit te breiden; het had nu iets te zeggen over een aantal grondrechten, warover oorspronkelijk alleen de statelijke rechter in laatste instantie een uitspraak kon doen. Het recht op persoonlijkheid, in Amerikaans verband het recht op privacy, is niet afzonderlijk via de incorporatietechniek geschaard onder het arsenaal grondrechten dat het Hof kan hanteren in de rechterlijke toetsing. Het begrip privacy heeft via rechterlijke rechtsvinding in 1965 zijn beslag gekregen in de Amerikaanse constitutie. Warren en Brandeis pleitten al in 1890 voor een recht op privacy. ${ }^{62}$ Hun pleidooi was het gevolg van de wijze waarop de pers het privé-leven van prominenten onder de aandacht bracht. Het feit dat in die tijd de eerste massaoplagen van kranten verschenen, en dat een groot aantal mensen daarvan kennis kon nemen droeg bij aan de noodzaak van erkenning van privacy. $\mathrm{Zij}$ omschrijven het recht op privacy als 'the right to be let alone', het recht om met rust te worden gelaten.

\subsubsection{Het Vierde en het Vijfle Amendement}

Het Vierde Amendement legt het recht op fysieke integriteit, het huisrecht en het recht op briefgeheim vast. ${ }^{63}$ Deze aspecten wormen allen onderdelen van het recht op persoonlijkheid. In geen van de hier opgesomde rechten gaat het om absolute rechten. Aan de betekenis van de elementen van persoonlijkheid werd in de loop der tijd door het Hooggerechtshof invulling gegeven; zij waren niet vanaf de invoering wan het Vierde en het Vijfde Amendement aanwezig. Het Hof heeft de inhoud en de omtrekken van de rechten in het Vierde en het Vijfde Amendenent aldus moeten construeren. Sinds Katz t. Verenigde Staten (1967) legt het Hof het element van het huisrecht in het Vierde Amendement ruimer uit. ${ }^{64}$ Tot Katz was een enge benadering van het huisrecht - zie Olmstead t. Verenigde Staten - vaste rechtspraak. ${ }^{65}$ Verschil tussen beide uitspraken was, dat het Hof in het eerste geval alleen een ruimtelijke benadering van het huisrecht hanteerde. In Katz aanvaardde het Hof echter dat op het Vierde Amendement ook een inbreuk kan worden gemakkt zonder dat daarvoor een fysiek binnendringen on informatie te vergaren noodzakelijk is. Het afluisteren van een publieke telefoon werd geacht te vallen onder de beschermingssfeer van het Vierde Amendenent:

'For the Fourth Amendment protects people, not places. What a person knowingly exposes to the public, even in his own home or office, is not a subject of Fourth Amendment protection. [...] But what he seeks to preserve as private, ever in an area accessible to the public, may be constitutionally protected". ${ }^{66}$

62. Warren en Brandeis 1984 (1890).

63 Het Vierde Amendement luidt: "The right of the people to be secure in their persons, houses, papers, and effects, against unreasonable searches and seizures, shall not be violated, and no Warrants shall issue, but upon probable cause, supported by an Oath or affirmation, and particularly describing the place to be searched, and the persons or things to be seized".

65 Olmsteadt. Werenigde Staten, 277 U.S. 438 (1928)

66 Katz t. Verenigde Staten, 389 U.S. 347, 351-352 (1967). 
Voor het recht op persoonlijkheid is deze extensieve interpretatie van het Vierde Amendement interessant, mede omdat het Hof niet meer zoals voorheen specifiek aanslluiting zocht bij een inbreuk op huisvrede. Niet langer stond de ruimtelijke benadering centraal bij de uitleg van dit Amendement - de beschermingszone lijkt met het individu als het ware mee te kunnen bewegen. De technologische mogelijkheden ter zake van het affuisteren dwongen de rechter om opnieuw de uitleg en de grenzen van het grondrecht te onderzoeken. Om nu vast te stellen in welke mate de belangen die het Vierde Amendement beoogt te beschermen grondrechtelijke bescherming dienen te verkrijgen, heeft het Hof in de loop der tijd een tweetal criteria ontwikkeld. In de eerste plaats vraagt de rechter zich af, of het individu van een redelijke verwachting van bescherming van privacy mocht uitgaan, en in de tweede plaats of de Amerikaanse samenleving bereid is, die verwachting van privacy te honoreren. ${ }^{67}$ Deze afbakeningscriteria missen echter de nodige scherpte. Het Hof heeft steeds een casuîstische benadering gehanteerd ten aanzien wan deze criteria. Het is niet goed mogelijk om aan de hand van jurisprudentiële lijnen te voorspellen, welke individuele aanspraken grondrechtelijke bescherming zullen genieten. Met ingewikkelde jurisprudentiẻle lijnen en verfijningen ter zake van de reikwijdte van het Vierde Amendement, alsmede vanwege de voortschrijdende technologische ontwikkelingen is het niet mogelijk on algemene uitspraken te doen over de precieze reikwijdte van het recht op priwacy onder het Vierde Amendement. In beginsel vormen de aspecten van het Vierde Amendement vrij specifieke vertalingen van onderdelen van privacy. Dat uitgangspunt leidde tot een concentratie op de interpretatie van de afzonderlijke begrippen van het Vierde Amendement. Voor de rechtsontwikkeling door de rechter van het recht op persoonlijkheid is het Veertiende Amendement, in vergelijking met het Vierde Amendement, van groter betekenis geweest. Dit verschil in betekenis hangt onder meer samen met de aanwezigheid van het algemene vrijheidsbegrip 'liberty" . 8 Het Vijfde Amendement bevat eveneens elementen van het recht op persoonlijkheid. ${ }^{69}$ Enkele auteurs zijn de opvatting toegedaan, dat er een recht op privacy ten grondslag ligt aan het recht van het individu om niet tegen zichzelf te hoeven getuigen. Het recht bestaat als voortvloeisel van het Vijfde Amendement, maar van positivering van privacy als grondslag voor dat recht kan niet worden gesproken. ${ }^{70}$ Het recht om niet mee te hoeven werken aan zelfincriminatie wordt in de Duitse rechtspraak wel beschouwd als een concretisering van het recht op persoonlijkheid. ${ }^{71}$ Van belang woor de rechtsontwikkeling op het gebjed van het recht op persoonlijkheid, te weten het recht op privacy, is het verbod het individu

68 Zive par, 2.3.3.

69 Het Vijfde Amendement luidt: No person shall be held to answer for a capital, or otherwise infamous crithe unless on a presentment or indictment of a Grand Jury, except in cases arising in the land or navill forces, or in the Militia, when in actual serwice in time of war or public danger; nor shall any person be subject for the same offence to be twice put in jeopardy or life or limb; nor shall be compelled in any criminal case to be a witness against himself, nor be deprived of life, liberty, or property, without due process of law; nor shall private property be taken for public use, without just compensation ".

70 Zue bijwoorbeld Gerste in 1970, p. $245-264$. In de rechtspratak van het Hof is het verbod op zelf-incriminatie tot op heden niet in verband gebracht met een begrip van 'privacy'.

71 Aussageverpthichung, 56 BVertGE 37,43 (1983) 
dat aan een strafrechtelijke procedure is onderworpen te beroven van leven, vrijheid of eigendom

'[...], without due process of law' $[\ldots]$.

Deze formulering is identiek aan de formulering in het Veertiende Amendement, die in de rechtsontwikkeling van privacy een hoofdrol heeft vervuld. Het verschil tussen het Vijfde en het Veertiende Amendement was oorspronkelijk gelegen in het feit dat het Vijfde Amendement zich tot de federatie richtte en bet Veertiende Amendement tot de staten. Vanwege de incorporatie geldt het Vijfde Amendement nu ook voor staten. ${ }^{72}$ Ook andere Amendementen dragen elementen van een recht op persoonlijkheid in zich. Het Eerste amendement stipuleert een wrijheid van godsdienst, meningsuiting en een vrijheid van vereniging; het Hof heeft erkend, dat een wereniging het recht toekomt, bepaalde informatie over zijn leden geheim te houden indien die geheimhouding de uitoefening van het recht op vrijheid van vereniging ten goede komt. ${ }^{73}$ Het individu behoeft zijn voorkeur voor een politieke partij evenmin te onthullen; het heeft een recht op geheimhouding van zijn politieke overtuiging. ${ }^{74}$

\subsubsection{Het Negende Amendement}

Het Negende Amendement is, afgaand op de formulering, in het Amerikaanse constitutionele debat tot op heden een omstreden bepaling. Het stipuleert ruwweg dat er nog andere fundamentele rechten kunnen bestaan dan de in de Bill of $\mathbb{R}$ ights opgesomde rechten. In dit verband werpt zich de vraag op, in hoeverre het Negende Amendement een rechtsgrondslag biedt aan niet-gepositiveerde individuele aanspraken, en in welke mate het Hof nieuwe rechten kan positiveren onder dit Amendement. Commentatoren zijn het er in beginsel over eens, dat het Negende Amendement als zodanig geen grondslag biedt om nieuwe rechten te creëren. ${ }^{75}$ Daar houdt de overeenstemming echter op te bestaan. In het debat zijn twee tegenover elkaar staande standpunten aan te wijzen ter zake van de betekenis van het Negende Amendement. Tribe is wan mening, dat het Negende Amendement een interpretatieregel inhoudt:

"In fact, it is the only rule of interpretation explicitly stated in the Constitution. It tells each reader: whatever else you're going to do to explain why "liberty" does not include the grandmother's right to live with her grandchild [...] you camnot advarnce the argument that those rights are not there just because they are not enumerated in the Bill of Rights. ${ }^{76}$

In deze optiek kunnen angeschreven grondrechten, mits gebaseerd op één van de geexpliciteerde grondrechten in de Bill of Rights, worden gerekend tot de rechten die de

72 Omdat het Hooggerechtshof zich bij de uitleg van het hierwoor geciteende "due process' nist beperkte tot een formeleve eerlijkheid wan het proces maar meer een inhoudelijke bettekenis hechtte an 'due process" kon de norm uit het Veertiende Amendement met het Vijfide worden ingevuld.

73 NAACP t. Alabama, 357 U.S. 449 (1958).

74 Sweezy 1. New Hampshire, 354 U.S. 234 (1957), voorbeeld ontleend atan A.J. Nieuwenhuis 2001, p. 58.

75 Zie onder meer Ely 1980, p. 34-40; Kotulak 1994; DeRosa 1996 , net mame p. 87 \% $109 ;$; Bork 1990, p. 183-1185 en Tribe en Dorl 1991, p. 54-55

76 Tribe 1991, p. 54 (cursief van Tribe), zie ook Tribe 2000, p. 34. 
Bill of Rights beoogt te beschermen. Daartegenover zijn meningen aan te wijzen, die aan het Negende Amendement een beperkter betekenis toekennen: erkel de grondrechten die letterlik zijn vermeld kunnen dienen als grondslag voor erkenning van indïviduele aanspraken. "In wezen ontkent deze stroming elke betekenis van het Negende Amendement. Daartussenin ligt bijwoorbeeld Ely's opvatting, die stelt dat zolang geen overeenstemming bestaat over de betekenis van het Negende Amendement, de rechter zich verre dient te houden van het hanteren van een dergelijke open clausule als grondslag voor erkenning van individuele aanspraken. ${ }^{78}$ In ${ }^{\mathrm{s}}$ Hofs jurisprudentie zijn in elk gevall twee uitspraken aan te wijzen waarin het Negende Amendement werd aangehaald - tezamen met andere grondrechtartikelen overigens - en als grondslag diende voor erkenning van nieuwe individuele aanspraken. Eén van die uitspraken stond aan de wieg van de positivering van het recht op privacy in de rechtspraak. ${ }^{79}$ De betekenis wan het Negende amendement strekt in verband met dit onderzoek niet alleen tot vestiging van het recht op privacy als materieel grondrecht; het is in beginsel eveneens van 'institutionele' betekenis in de taakopvatting van de rechter en de mate waarin hij zich inlaat met rechtsontwikkeling.

\subsubsection{Het Veertiende Amendement: "due process" en 'liberty"}

Het Veertiende Amendement dat is ingevoerd in 1868, is van grote betekenis geweest voor de ontwikkeling van de aan het recht op persoonlijkheid gerelateerde Amerikaanse begrippen "liberty" en "privacy" " ${ }^{80}$ Het Veertiende Amendement zegt niet letterlijk liets over het recht op "privacy", wel over 'liberty". Het Amendement geeft evenmin expliciete verwijzingen naar een recht op persoonlijke levenssfeer of menselijke waardigheid. Elementen van "privacy", zo stelt een aantal commentatoren, zitten wel werborgen in het Veertiende Amendement. 'liberty' wordt hier in beginsel verstaan als een individuele handelingsvrijheid. De rechtspraak van het Hooggerechtshof laat zien dat het vrijheidsbegrip werd gehanteerd als een kapstok om een aantal uiteenlopende individuele aanspraken te erkenmen. Het Hof beoordeelde bijvoorbeeld individuele aanspraken op het recht, wrijelijk te kunnen kiezen voor een gezinssamenstelling die afwijkt van het kerngezin, of het recht op menselijke voortplanting onder vrijheid als belangen of rechten die het Veertiende Amendement beoogt te beschermen.

77. Zie onder meer Justice Black in zijn dissenting bij Griswold t. Connecticut, 381 U.S. 479 (1965) en Bork 1990, p. 183 e.v.

78 Ely 1980, p. 41.

79 Griswold t. Connecticut, 381 U.S. 479 (1965). De andere uitspraak was Richmond Newspapers, inc $t$. Virginia, 448 U.S. 555 (1980), waarin de vraag aan de orde was of de pers een constitutioneel recht op toegang tot strafrechtelijke procedures in de rechtszaal toekomt. Het Eerste Amendement bood in dat verband onvoldoende grondslag voor het recht iets te horen, waarvan de spreker nu juist niet wenst dat een ander - in dit geval de pers - het hoort. Een samentrekking met het Negende Amendement bood deze grondslag blijkbaar wel, maar er was in het Hof echter niet een meerderheid aan te wijzen die met deze redenering instemde (zie Tribe en Dorf 1991, p. 54).

80 Het Veertiende Amendement, eerste paragraaf luidt: "All persons born or naturalized in the United States and subject to the jurisdiction thereof, are citizens of the United States and of the State wherein they reside. No State shall make or enforce any law which shall abridge the privileges and immunities of citizens of the United States, nor shall any State deprive any person of life, liberty, or property, without due process of law; nor deny to any person within its jurisdiction the equal protection of the laws'. 
Deze ontwikkeling van het Veertiende Amendement werd mogelijk vanwege een door het Hof gehanteerde extensieve wijze van interpretatie. Voorheen werd al kort gerefereerd aan het systeem van incorporatie - een proces waarin het Hof via de extensieve interpretatie van de eisen van 'due process' de staten bond aan de materièle eisen van de meeste overige Amendementen. In wezen interpreteerde het Hof de formule "due process op wetsanaloge wijze: aan de hand van de andere grondrechten in de Bill of Rights werd aan 'due process' nadere materiêle betekenis gegeven. De materiele rechten zoals neergelegd in de Amendementen fungeerden in dat kader als constitutionele rechtsbeginselen, die aan de eisen van 'due process' ten grondslag liggen. Met de eis van "due process" vond nog iets anders merkwaardigs plaats: het Hof hanteerde deze formulering in het Veertiende Amendement eveneens als aanleiding, fundamentele waarden of rechtsbeginselen in te lezen, waarvan de oorsprong niet te ontwaren is in de tekst van de Bill of Rights. Was dat bij de incorporatie nog wel het geval - in latere rechtspraak kan worden gesignaleerd dat het Hof bereid was, het bestaan van ongeschreven rechtsnormen aan te nemen, op basis waarvan invulling werd gegeven aan het begrip 'due process'. Deze invulling stond los van (strafrechtelijke) procedurele vereisten, die in de incorporatie steeds op de voorgrond hadden gestaan. In die gevallen was er steeds aanknoping bij bestaande grondwetsnormen, namelijk de Amendementen waaruit het Hof putte voor de invulling van "due process". In de rechtspraak kwamen daarnaast interpretaties tot stand die waren gebaseerd op ongeschreven rechtsnomen. Deze ontwikkeling zette in met Lochner $t$. New York, een zaak waarin het Hof statelijke wetgeving verbood die de contractsvrijheid van arbeiders en werkgevers aan banden legde. ${ }^{81}$ Het materiele recht op contractsvrijheid, dat niet is vastgelegd in de Bill of Rights, werd ingelezen als een vrijheid uit het Veertiende Amendement. Op basis van deze ongeschreven rechtsnorm werd geoordeeld dat de bestreden federale of statelijke wetgeving als strijdig moest worden aangemerkt met het Veertiende Amendement. Het Veertiende Amendement leek het Hof ruimte te bieden voor een vergaande extensieve interpretatie, maar er kwam ook kritiek op deze vergaande uitleg waarbij individuele aanspraken werden erkend op basis van ongeschreven grondslagen. ${ }^{82}$ De belangrijkste kritiek is wel dat 's Hofs benadering kan leiden tot de legitimatie van persoonlijke voorkeuren, en dat willekeurige aanspraken erkenning vinden als subjectieve grondrechten.

Op het Veertiende Amendement is een grondwettelijk beperkingsregime van toepassing dat in de Amerikaanse constitutionele theorie wordt kortweg aangeduid met het leerstuk van de 'stricht scrutiny" test, de "rational basis test" en de "double standard". De met het Veertiende Amendement strijdig geachte wetgeving wordt in beginsel beoordeeld aan de hand van de maatstaf van "due process". "Due process" zou vertaald kunnen worden als een eis dat de gevolgde wetgevingsprocedure moet hebben plaatsgevonden met 'daarbij passende zorgvuldigheid'. Van belang is nu, dat het Hof een inbreuk op het Amendement kan aanmerken als een inbreuk op een "fundamenteel

82 Zie de dissenting van Rechter Holmes bij Lochner t. New York, 198 U.\$. 45 (1905). 
recht". Indien de kwalificatie van "fundamentality" aan een grondrechtsaanspraak wordt toegekend vindt er in de regel een intensieve toetsing - "strict scrutiny" - van de aangevochten maatregel plaats. ${ }^{83}$ Drie hoofdregels van toetsing zijn in dat geval van toepassing: er vindt een omkering van de anderszins gebruikelijke vooronderstelling van grondwettigheid van wetgeving plats tenzij de van toepassing zijnde bewijslast wordt vervuld $^{84}$, deze bewijslast bestaat eruit dat aangetoond wordt dat de uitoefening van het recht een: "clear and present danger" oplevert of dat de beperking "a compelling state interest" dient en tenslotte dient de inbrenk op het recht noodzakelijk te zijn, waarbij een proportionaliteitstoets wordt gehanteerd. ${ }^{85}$ Inbreuken op het hierna te bespreken recht op privacy dienen in principe aan deze test te worden onderworpen omdat privacy een "fundamental" norm inhoudt. 86

Indien een recht waarop inbreuk is gemaakt, echter niet wordt erkend als 'fundamental' dan zal het Hof de beperkende maatregel niet intensief toetsen. Die test komt in bet kort neer op een marginale toets. Zodra een beperkingsgrond aangewezen kan worden en het legitieme doel wordt gediend met deze beperkingsgrond, is het Hof al snel bereid aan te nemen dat de beperking op het grondrecht geoorloofd is. ${ }^{87}$ Tot de fundamentele rechten worden in principe de in de Bill of Rights gepositiveerde rechten gerekend. ${ }^{88}$ Het Vierde en het Vijfde Amendement kennen aldus een strenge toets van wetgeving indien de individuele aanspraak hieronder wordt erkend. Ten aanzien van beperkingen op het Veertiende Amendement hanteert het Hof bij aanspraken op economische rechten de "rational basis test'. ${ }^{89}$

83 In Skimner 1. Oklahoma, 316 U.S. 535 (1942) stelde het Hof, dat wanneer een "basic civil right of man" in het geding is, een "strict scrutiny' test aangewezen is. In Skinner bleek voortplanting te behoren tot eén van die "basic civil rights', waardoor sterilisatie van de betrokkene in verband met diefstal kon worden afgewend (zie voor Skimner ook par. 4.2 e.v.). Dit is een van de vroege zaken waarin clle "strict serunity' test van toepassing werd verklaard op fundamenteelrechtelijke aanspraken (voortplanting); Skinners anspraak werd echter beoordeeld onder "liberty" in het kader wan gelijke behandeling. Naderthand werden beperkingen op het reclit op 'privacy' eveneens onderworpen an de "strict serunity" test zonder dat de kwestle werd beoordeeld vanuit gelijke behandeling. Het Hof bepaalde - zonder duidelijke maatstaven - dat erkende aanspraken onder "privacy" behoren tot fundamentele rechten - de zogenoemde "preferred freedoms" (Gunther en Sullivan 1997, p. 530).

84 Harris t. Mckae, 448 U.S. 297 (1980).

85 Ducat en Chase 1992, p. 94.

86 Hierover bestatan overigens verschillen wan opvatting. Enkele rechters in het Hof zijn van mening, dat het recht op abortus, dat woorviloeit uit het recht op privacy, aan een "rational basis test" moet worden onderworpen ondat de grondwet geen letterlijke vermelding makkt wan dat recht ea ondat abortus niet te traceren is in de historische wortels van de Amerikaanse samenleving (rechter Scalia, dissenting, in Webster t. Reproductive Health Services, 492 U.S. 490 (1980)). Tot dusverre is deze opvatting niet de heersende in het Hof.

87 Nieuwenhuis 2001 , p. 66.

88 Een criterium dat relatief recentelijk is toegevoegd woor de vaststelling van fundamentality is dat het moet gaan on een recht 'deeply rooted in this Nation's history and tradition', zie Bowers t. Hardwick, 478 U.S. 186 (1986). In deze zaak moest het Hof beoordelen of het recht op privacy ook een fundamenreel recht op seksuele voorkeur omvat; deze aanspraak voldeed nict an het vereiste dat deze is ingebed in de 'hisstorische tradities van de Amerikaanse samenleving".

89 Deze test houdt in dat een wet niet ongrondwettig wordt verklaard indien "any state of facts reasonably may be conceived to justify it' (McGowan t. State of Maryland, 366 U.S. 420 (1961). 
Het Hof heeft voor de vaststelling van 'fundlamentality' van de individuele aanspraken onder het Veertiende Amendement echter geen eenduidige criteria ontwikkeld ${ }^{90}$ Voorspelbaarheid in de toepassing van de 'rational basis' test of van de 'strict scrutiny' test wordt daarmee lastig. Een criterium dat regelmatig terugkeert in de rechtspraak on vast te stellen of van "fundamentality" kan worden gesproken, is dat een recht voldoende wortel moet hebben geschoten in de historie en in het (rechts)bewustzijn van de natie." Bijna altijd heeft de kwalificatie van 'fundamentality' fatale gevolgen voor de aangevochten wetgeving; omgekeerd leidt afwijzing van de kwalificatie van "fundamentality" in het algemeen steeds tot het in stand houden van wetgeving. De vraag naar de 'juiste' kwalificatie - 'fundamentality' of geen 'fundamentality' - wordt in het Amerikaanse debat gevoerd onder de problematiek van de 'double standard" ${ }^{92}$ Deze houdt in dat bijvoorbeeld economische wetgeving - die in het algemeen geen fundamentality-belangen raakt - door het Hof marginaal wordt getoetst, terwijl wetgeving die de individuele vrijheid betreft wordt onderworpen aan een strenge toets van grondwettigheid. Het Hof heeft aan de wetgever in beginsel een ruime beoordelingsmarge gelaten waar het gaat om wetgeving op het terrein van bescherming van gezondheid, veiligheid en bevordering van werkomstandigheden; daarentegen komt de wetgever een smalle beoordelingsmarge toe waar het gaat om wetgeving die raakt aan de rechten die zijn neergelegd in het Veertiende Amendement. ${ }^{93}$ 'Strict scrutiny' speelt in beginsel een belangwekkende rol in specifieke gevallen die het gelijkheidsbeginsel betreffen. ${ }^{94}$ Ook aanspraken die worden gekwalificeerd onder het hierna te bespreken recht op privacy komt steeds een classificatie van 'fundamentality' toe. ${ }^{95}$ Ter zake van het begrip 'liberty' vaart het Hof aldus geen eenduidige koers.

90 Ducat en Chase 1992, p. 93 d.w. Zie ook Hoffman: "The methodology is so indistinct that one is apt to conclude that a right is simply fundamental when a majority of the Court says it is' (Hoffman 1997. p. 179).

91: Ducal en Chase 1992, 1.93.

92 Gunther en Sullivan, p. $529-530$ en A.W. Heringa 1996, p. 126 e.v.

93 Zie Cnited States i. Carolene Products $C_{0 ., 304}$ U.S. 144 (1938), warain rechter Stone in zijn voetnoot het volgende onderscheid maakte tussen toepasselijkheid van een marginale toetsing en wan een intensieve toetsing: "It is unnecessary to consider now whether legislation which restricts those politioal processes which can ordinarily be expected to bring about repeal of undesirable lagislation, is to be subjected to more exacting judicial scrutiny under the general prohibitions of the 14 th Amendment than are most other rypes of legislation. [...] Nor need we enquire whether similar considerations enter into the review of statutes directed at particular religious $[\ldots]$ or racial minotities $[\ldots]_{0}$ whether prejudice against discrete and insular minorities may be a special condition, which tends seriously to cuntail the operation of those political processes ordinarily to be relied upon to prottect minorities, and which may call for a correspondingly more searching jud ucial inquiry".

94 Zie voor een extensieve beschouwing hierower Gerards 2002 , met name hoofilstuk 5.

95 "Strict in theory, fatal in fact" is een gevleugelde uitdrukking geworden in hat Amerikanse constitutionele debat, die bijna als een wetmatigheid aangeeft dat marginale toetsing de aangevochter wet in stand laat en omgekeerd een intensieve toets bijna altijd leidt tot nietigheid van de aangewochten wet (Gunther 1972, p. 8). 


\subsection{4 'Privacy" in de rechtspraak}

Zoals voorheen al vastgesteld, zijn de in de Amendementen genoemde aspecten van het recht op persoonlijkheid verder uitgekristalliseerd in de rechtspraak. Naast de uitwerking van de in de Amendementen gepositiveerde elementen van persoonlijkheid heeft het Hof eveneens een ongeschreven recht op privacy erkend. ${ }^{96}$ Dat ongeschreven recht op privacy lijkt echter yan andere aard te zijn dan de afzonderlijke elementen die hiervoor in verband met de Amendementen aan de orde zijn geweest. Het heeft een grotere reikwijdte dan de afzonderlijke elementen van privacy die in de Amendementen te onderkennen zijn. Het omvat aanspraken die te maken hebben met aspecten van individuele zelfbeschikking zoals huwelijk, voortplanting, gebruik van voorbehoedmiddelen, familiebetrekkingen, het opvoeden van kinderen en hun educatie. ${ }^{97}$ Het recht op privacy werd woor het eerst expliciet gepositiveerd in 's Hofs uitspraak Griswold t. Connecticut $(1965){ }^{98}$ Over de wijze van legitimatie van het bestaan van dit recht alsmede over de reikwijdte van dit recht op privacy bestond en bestaat echter veel onenigheid. ${ }^{99}$ Een recht op privacy is immers niet tekstueel vastgelegd in de Amendementen, en de vraag rijst in hoeverre het Hof bevoegd is aan aanspraken onder niet in de grondwet gepositiveerde normen grondwettelijke bescherming toe te kennen. ${ }^{100}$ De individuele aanspraken op privacy werden afgeleid uit een samentrekking van een aantal Amendementen. Het Hof betrok voor de legitimatie van het recht op privacy het Eerste, het Vierde, het Vijfde en het Negende Amendement in zijn beschouwingen. De kernrechten in deze amendementen worden, aldus het Hof, omringd met een aantal 'penumbra', of halfschaduwen waarin zich sterk aanverwante rechten bewegen. Deze wat meer perifere rechten, die samenhangen met de kern van de afzonderlijke grondrechten in de grondwet vormen tezamen voldoende draagvlak voor het aannemen van het bestaan van een fundamenteel recht op privacy. De seksuele voorkeur of het verzoek tot hulp bij zelfdoding konden echter niet worden gerekend tot de belangen die het ongeschreven recht op privacy beoogt te beschermen. De beoordeling van de vraag of de individuele aanspraak bescherming onder privacy dient te verkrijgen is aan het Hof, dat zijn beslissing in belangwekkende mate laat afhangen van de vraag in hoeverre normen en waarden in de samenleving worden erkend als traditionele waarden. ${ }^{10 t}$

\subsection{5 'Privacy' in het Amerikaanse privaatrecht}

In de "law of torts" kwan het begrip privacy al eerder tot ontwikkeling; de eerste signalen dateren uit het begin van de $20^{\mathrm{e}}$ eeuw. ${ }^{102}$ Naderhand zijn er ruwweg vier typen van

96 Dixon 1971, Gunther en Sullivan 1997, p. 518 e.v

97 Zie Planned Parenthood t. Casey, 505 U.S. 833 (1992).

98 Griswold i. Conmecticut, 381 U.S. 479 (1965) over hat recht van het echtpaar, te kiezen voor geboortebeperkende middelen, dit tegen het verbod van de staat Connecticut in.

99 Zie bijwoorbeeld Black, dissenting bij Griswold t. Connecricut, 381 U.S. 479 (507 e.k.) 1965; Bork 1990, p. 95 e.v.

100 Justice Black in zijn dissenting bij Griswold t. Connecticut (zie ook par. 4.3.1 en 5.3.2).

101 Zie voor nadere uitwerking van 'privacy' hoofdstuk 5.

102 Het lierboven aangehaalde artikel wan Warren en Brandeis werd expliciet in Pavesich $t$. New England Life Insurance genoend als grondslag voor het bestaan van een civielirechtelijke claim op schade- 
onrechtmatige daad erkend, die in de rechtspraak tot verdere ontwikkeling zijn gekomen. ${ }^{103}$ Het binnendringen in de privé-zaken van het individu is onrechtmatig vanwege de "mental distress" die dat met zich meelbrengt. ${ }^{104}$ Publicatie van aspecten van andermans privé-leven, het in een verkeerd daglicht plaatsen van een persoon alsmede het zich toe-eigenem van een naam of afbeelding van een ander kunnen eveneens wor.den aangemerkt als inbreuken op de civielrechtelijke privacy. ${ }^{105}$ Van belang is hier, dat privacy in het Amerikaanse privaatrecht in beginsel niet het nemen van beslissingen ter zake van de invulling van het eigen leven lijkt te beschermen. ${ }^{106}$ De constitutionele privacy komt aldus dichter in de buurt van het recht op persoonlijkheid dan de privatrechtelijke.

\subsection{Duitsland: het Grundgesetz}

De Duitse grondwet, het Grundgesetz (GG) van de Bondsrepubliek Duitsland is de tweede poging na de grondwet van de Weimar Republiek om een democratische, constitutionele rechtsorde vast te leggen. ${ }^{107}$ De huidige grondwet vestigt de constitutie als het hoogste formele recht geldend binnen de nationale rechtsorde. In de grondwet zijin de ervaringen van het toentertijd directe verleden, het afglijden van het parlementaire systeem naar een totalitair regime, duidelijk merkbaar. ${ }^{108}$ Een aantal grondrechten in de grondwet is overgenomen uit de Weimarer Verfassung, maar het belangrijkste verschil met de laatstgenoemde constitutie is gelegen in het feit dat de Weimarer Verfassung de grondrechten slechts erkende als instructienormen, terwijl de huidige grondwet de grondrechten erkent als inroepbare rechten. De positivistische stroming die heerste ten tijde van de Weimarer Verfassung, weigerde te erkennen dat fundamentele rechten van de grondwetgever afkomstig zijn. Hiermee werd de betekenis voor de rechtspraak sterk teruggedrongen. ${ }^{109}$ De heersende mening is dat de grondwet een grondwet is die afdwingbare rechten en verplichtingen herbergt. De grondrechten in de huidige grondwet dragen deels een beginselachtig karakter, dat met name voortvloeit uit de open en onbepaalde formulering van de constitutioneelrechtelijke waarborgen. ${ }^{10}$ De formuleringen van de bepalingen zijn deels open, onder meer omdat de bepalingen in de grondwet de uitwerking zijn van een compromis tussen de toentertijd over de constitutie onder-

vergoeding. Een onderneming had een foto van de kunstenaar Pavesich zonder diens gebrukt in exn advertentie. Het Supreme Court van Georgia oordeelde dat deze handelwijze van de ondememing onreclitmatig was vamwege het feit dat Pawesich woorden in de mond werden gelegd. Pavesich had aldus. niet langer de controle over zichzelf, hetgeen een belangrijk onderdeel is wan "the right to be let alone" (zie Pavesich t. New England Life Insurance, 122 Ga. 190,50 S.E. 68 (1905)).

103 Prosser 1984 (1960), p. 107 e.v.

104 Prasser $1984(1960)$, p. 109.

105 Prosser $1984(1960)$, p. 109-114.

106 Nieuwenhuis 2001, p. 79 .

107 Het Duitse Grundgesetz werd op 8 mei 1949 aangenomen in de Parlementaire thaad en trad op 24. mei 1949 in werking.

108 Maglera 1983,89

109 Kommers 1997 , p. 38.

\#10 Battis en Gusy 1991, p. 16. 
handelende socialistische, liberale en christelijke partijen. "II Ook is een oorzaak gelegen in het feit dat de constitutie een gedateerd document is. ${ }^{112}$ De grondwet stipuleert een recht op ontplooiing van de persoonlijkheid in Art. 2 lid $1 \mathrm{GG}$. Er zijn verder onderdelen van het recht op persoonlijkheid in de grondwet gepositiveerd, zoals het recht op fysieke integriteit, bescherming van het huisrecht en het brief- en telefoongeheirn. Voor het recht op persoonlijkheid is daarnaast met name de algemene handelingsvrijheid ex Art. 2 lid 1 GG van belang, evenals het recht op menselijke waardigheid ex Art. 1 lid $1 \mathrm{GG}$. Uit een contaminatie van de algemene handelingsvrijheid en het recht op menselijke waardigheid heeft het Duitse Federale Constitutionele Hof een overkoepelende rechtsnorm afgeleid. Deze rechtsnorm, het 'Allgemeines Persönlichkeitsrecht ${ }^{313}$, is aan te merken als een verzameling deelaspecten van het recht op persoonlijkheid.

\subsubsection{Art. 79 lid 3 Grundgesetz: de Eeuwigheidclausule}

Van belang voor de structuur van de Duitse grondwet is, dat als reactie op de Weimarer Republiek de 'immanentiebepaling' ex Art. 79 GG in de grondwet van 1949 werd vastgelegd. ${ }^{114}$ Dat artikel geeft aan welke bepalingen in de grondwet "eeuwigheidswaarde" hebben, en mitsdien niet gewijzigd mogen worden. 15 $\mathrm{Na}$ de Tweede Wereldoorlog heerste de overtuiging, dat van de fouten van Weimar geleerd diende te worden, en dat aan centrale constitutionele elementen in de grondwet een versterkte mate van stabiliteit diende te worden gegeven. In de grondwet werd dat bereikt door bijvoorbeeld de versterking van de positie van de regering in de constructieve matie van wantrouwen $^{116}$, beperking van de rol van de indirect gekozen Bondspresident beperkt tot repre-

111 De uitgangspunten van menselijke waardigheid en de democratische sociale rechtsstaat vinden hun wortels in verschillende filosofische stromingen die het Duitse constitutionele denken hebben gevormd. Hierbij moet met name worden gedacht aan de klassiek-liberale stroming, de socialistische stroming en de christelijk-natuurrechtelijke beweging. Allen hebben zij hun invloed doen gelden op de vornming van het Grundgesetz in 1949. Zij vertegenwoordigen zeer witeenlopende meningen op het vlak van politieke en filosofische benadering van de constitutie, maar allen woeren zij naar een gemeenschappelijke kernopvatting ter zake van de rol en invulling van de staat en de waardigheid van de menselijke persoan. Zie Heidenheimer en Kommers 1975 , p. 264 en Kommers 1997, p. 36-37.

112 Sommige grondwetsbepalingen werden als doelstelling aangegeven, die in de toekomst stapsgewijs gerealiseerd zullen worden, bijvoorbeeld het beginsel van de 'Sozialstaat' ex art. 20 lid 1 GG. In de jaren na de oorlog had men bij dit concept een andere voorstelling dan in de liujdige welvaartsstaat. De toenmalige politieke en financiele situatie van het land noopte tot een dergelijk ruim concept omdat er atan concretere sociale grondrechten - recht op arbeid, recht op bijstand - op dat moment geen nadere invulling kon worden gegeven. Zie bijvoorbeeld ook Mitbestimmung, 50 BVerfGE 290, 336 (1979), voor het bewust open laten wan de wijze waarop de economische inrichting van het land moet worden uitgewerkt.

113 Hierna ook aangeduid als "het algemene persoonlijkheidsrecht".

114 Art. 79 GG lid 1: "das. Grundgesetz kann nur durch ein Gesetz geändert werden, das den Wortlaut des Grundgesetzes ausdrücklich ändert odler ergänzt. [...] Lid 3: "Eine Änderung dieses Grundgesetzes, durch welche die Gliederung des Bundes in Länder, die grundsatzliche Mitwirkung der Lander bei der Gesetzgeber oder die in den Artikeln 1 und 20 niedergelegten Gundsatze berührt werden, ist unzulassig'. Zie voor een uitwerking van Art. 79 GG Bryde 2000, p. 227-263.

115 Battis en Gusy 1991, p. 6.

116 Voordat de motie van wantrouwen wordt uitgesproken dient reeds een opvolger van de kanselier te worden aangewezen door de Bondsdag, zie Art. $67 \mathrm{GG}_{\text {. }}$ 
sentatie ${ }^{117}$ en de keuze voor de 'wehrhafte Demokratie". In dat concept werd een aantal naoorlogse constitutionele uitgangspunten verankerd, waaronder de procedure tot verbodenverklaring van een politieke partij ${ }^{118}$, de mogelijkheid van grondrechtverwerking $^{119}$ alsmede het in Art. 79 lid 1 GG neergelegde rechtsstatelijke gebod van tekstaanpassing wanneer de betekenis van de grondwet "ausdrucklich" veranderd wordt. ${ }^{120}$ Art. 79 lid $3 \mathrm{GG}$ verklaart de menselijke waardigheid en de federale republiek tot immanente waarden. ${ }^{121}$ Art. 79 lid 3 GG komt hiermee expliciet tegemoet aan érn van de hiervoor genoemde elementen van een constitutie, namelijk die van stabiliteit en continufteit. De wetgever heeft de boodschap willen geven dat deze waarden niet amendeerbaar zijn. Art. $1 \mathrm{GG}$ vormt een overkoepelend uitgangspunt voor de Artt. 2 tot en met $19 \mathrm{GG}$; in die zin geldt Art. 79 lid 3 indirect eveneens voor de overige geschreven grondrechten. ${ }^{122}$ Het gaat hier om de onmogelijkheid van de grondwetgever, de 'Grundsätze' te amenderen.

Art. $79 \mathrm{GG}$ duidt op een regel van interpretatie, in belang vergelijkbaar met het Negende Amendement in de Amerikaanse grondwet. Vraag is in hoeverre Art. 79 GG extensieve interpretatie of toevoeging van ongeschreven rechten vanwege rechtsvinding door het Hof kan beperken. De grenzen van Art. 79 lid 3 GG zijn niet zozeer door de wetgever geëxploreerd, als wel door het Federale Constitutionele Hof nader afgebakend. Het Hof lijkt in zijn rechtspraak gekozen te hebben voor een tamelijk formele uitleg van deze bepaling in de grondwet, al is deze stellingname niet onomstreden. ${ }^{123}$ In de literatuur is echter geen eenduidig antwoord gekomen op de vraag, in hoeverre grondwetswijziging langs de weg van rechterlijke interpretatie mag plaatsvinden. ${ }^{124}$

117 Art. 54 GG.

118 Art. 21 lid $2 \mathrm{GG}$.

119 Art. 18 GG.

120 Andere voorbeelden van de naoorlogse veranderingen zijn onder meer de bescherming van de menselijke waardigheid in Art. $1 \mathrm{GG}$, de opening van de grondwet met de fundamentele rechten, de afschaf* fing wan de doodstraf in Art, $102 \mathrm{GG}$ en de denazificatievoorschiriften in Art. $139 \mathrm{GG}$.

121 Batiis en Gusy 1991, p. 6. Zie ook Hesse 1990, p. 12.

122 Zie voor deze constructie bijvoorbeeld Abhörurteil, 30 BVerfGE 1, 26 e.v. (1970). Art. 79 lid 3 GG geldt alleen woor geschrewen grondrechten, zie Hesse p. 275 e.v.

123 In het Abhörurteil kreeg het Hof de vrag voorgelegd, in hoeverre een beperking bij wet op Art. 10 lid 2 GG (Brief-, post- en telefoongeheim) in overeenstemming waren met de eis van immanentie van Art. 79 lid 3 GG. Het Hof gaf aan Art. 79 lid $3,0 G$ een formele uitleg, die inhield dat de kern van het recht op menselijke waardigheid geraakt moet zijin. Dat was in casu niet het geval. De beslissing werd met 5 tegen 3 genomen, hetgeen een mipte meerderheid is (zie ook de dissenting van de rechters Geller, Von Schlabrendorff en Rupp). Zij waren zeer kritisch over de uitleg die het Hof gaf aan Art. $10 \mathrm{GG}$; de interpretatie kwam in hun optiek overeen met een wijziging van de grondwet door het Hor.

124 Walter 2000 , p. 540 e.v. definieert vier legitimerende factoren wan de rol van het Hof in de wijziging wan de grondwet door middel van recliterlijke interpretatie. Tot die factoren behoren in zijn optiek een democratische legitimatie van het Hof omdat de rechters worden verkozen; de eisen van onpartijdigheid en onathankelijkheid; de 'tekstfactor' die eist dat wezenlijke veranderingen een wetgevende activiteit behoeven en ten slotte een controlemogelijkheid door de Senat van het Hof (zie voor de Senaat par. 3.3.1). Kritisch tegenover de rol van het Hof in dit verband is Böckenforde (Bockenforde 1993, p. 3 e.w.). Haberle ziet in het probleem van verandering van de grondwet door rechtsontwikkeling door het Hof vooral een interpretatievraagstuk (Habberle 1974, p. 11 e.v.). 


\subsubsection{Art. I lid I Grundgesetz: menselijke wardigheid}

Art. $1 \mathrm{GG}$ wordt aangeduid als het owerkoepelende beginsel voor het respect wan de fundamentele rechten in de constitutie, waaruit de gepositiveerde subjectieve grondrechten voortwloeien. Het legt het recht op menselijke waardigheid vast. ${ }^{125}$ Art. 1 lid 3 $\mathrm{GG}$ vermeldi daartoe een binding voor de wetgevende, rechtsprekende en uitvoerende macht In rang staat Art. 1 lid 1 GG hoger dan de andere grondrechten. ${ }^{126}$ De op Art. 1 $\mathrm{GG}$ volgende bepalingen vormen nadere uitwerkingen van het recht op menselijke waardigheid. Art 1 lid 1 heeft een rechtsbeginselkarakter. ${ }^{127}$ Aan het recht op menselijke waardigheid is door de Duitse grondwetgever een immanente waarde toegekend. ${ }^{\text {lis }}$ Het recht behoort tot de vaste waarden die de structuur van de grondwet bepalen. Het is niet goed mogelijk gebleken ${ }_{y}$ een sluitende materiële definitie te geven wan de menseIijke waardigheid. ${ }^{129}$ In de rechtspraak zijn uitspraken over aspecten van menselijke waardigheid die werden bedreigd aangetroffen, maar een eenduidige begrenzing aan de reikwijdte van het recht is niet aangetroffen. De materiële betekenis van het recht is met name in de rechtspraak tot ontwikkeling gekomen. Het vaakst werden opsommingen van mogelijke aanspraken aangetroffen. ${ }^{30}$ De rechtsnorm heeft niet alleen een objectiefrechtelijk, maar eveneens een subjectiefrechtelijk karakter. De wetgever heeft geen beperkingsgronden aangegeven in de formulering van Art. 1 lid 1 GG; het Hof heeft evenmin beperkingen op het recht op menselijke waardigheid aanwaard. Eén belangrijke begrenzing is in de rechtspraak wel tot ontwikkeling gekomen, namelijk de 'Gemeinschaftsbezogenheit' van het individu. ${ }^{13 !}$

125 Hesse 1990, p. 128, Kommers 1997, p. 298. Art. 1 GG luidt: 1. Die Würde des Menschen ist unantastbar. Sie zu acliten und zu schützen ist Verpflichtung aller staatlichen Gewalt. 2. Das Deutsche Volk bekennt sich darum zu unverletzlìchen und unveräußerlichen Menschenrechten als Grundlage jeder menschlichen Gemeinschaft, des Friedens und der Gerechtigkeit in der Welt. 3. Die nachfolgenden Grundrechte binden Gesetzgebung, vollziehende Gewalt und Rechtsprechung al unmittelbar geltendes Recht:

126 Kunig 2000, p. 67, Kommers 1997, p. 32. Zie ook KPD-Verbotsurtell, 5 BVerfGE 85, 204 (1956).

127 Kunig 2000, p. 67. Zie Elfes, 6 BVerfGE 32, 36 (1957): 'Er (de menselijke waardigheid, H.L.J.) gehrort zu den tragenden Konstitutionsprinzipien".

$128 \mathrm{Zie}$ Kunig 2000 , p. 67 . Art. 19 lid 2 pleit eveneens voor deze benadering, omdat het 'Wesensgehalt' van een grondrecht gehandhiafd moet worden. Dat vooronderstelt een andere benadering dan een wettelijk voorschrift. Het luidt: 'In keinem Fall darf ein Grundrecht in seinem Wesensgehalt angetastet werden'.

129 Voor discussie en verwijzingen zie onder meer Kunig 2000, p. 64-83.

130 Een aanspraak op het recht op menselijke waardigheid werd gedaan in verband met de weigering van cen burger mee te werken an een volkstelling. Het Hof formuleerde de aanspraak op Art. I. lid I GG als volgt: 'Es widerspricht der menschlichen Würde, den Menschen zum bloßen Objekt im Staat zu machen', Mikrozensus, 27 BVerfGE $\mathbb{1}, 6$ (1969). Andere anspraken die betrekking hadden op menselijke waardigheid betroffen onder meer het recht op leven (Schwangerschaftsabbruch l, 39 BVerfGE 1, 41 (1975), het recht op behoud van identiteit en lichamelijke integriteit in verband met foltering en hell gebruik van leugendetectors (79 BVerfGE 29, (1988)), waarheldsserum of hypnose in een straftechtelijk onderzoek en het toepassen van levenslange vrijheidsstraf (Lebenslange Freiheitssirafe, 45 BVerfGE 187, 227 (1977).

131 Investitionshilfe, 4 BVerfGE 7, 15 (1954). 


\section{4 .3 Ant. 2 lid I Gundgesetz: wrije ontplooing van de persoonlijkheid}

Het eerste lid van Art. 2 GG erkent een recht op vrije ontplooing van de persoonlijkheid, en het tweede lid een recht op fysieke integriteit ${ }^{132}$ alsmede een recht op leven. ${ }^{133}$ In de abortusbeslissingen gaf het Hof een belangwekkende betekenis aan Art. 2 lid 2 $\mathrm{GG}$ in verband met het ongeboren leven. ${ }^{134}$ Art. 2 lid $1 \mathrm{GG}$ positiveert een belangrijk uitgangspunt in de Duitse constitutionele doctrine: er bestaat een grondwettelijke ordening van geschrewen en ongeschreven rechten, die allen binnen bepaalde grenzen grondwettelijke bescherming verdienen. De ongeschreven rechten zijn in dat licht geen abstracte en natuurrechtelijke vrijheden, maar afdwingbare rechten die in Art. 2 lid 1 GG een grondslag vinden. ${ }^{135}$ De reikwijdte van de grondwetsbepaling is, zo kan rustig worden gesteld, ruim. De veronderstelling dat het recht ook onbenoemde grondrechten dekt heeft geleid tot een verhit debat over de vraag, in hoeverre Art. 2 lid $1 \mathrm{GG}$ niet is verworden tot een formule is die het Hof in staat stelt, om het even welke individuele aanspraak van een grondrechtelijke grondslag te voorzien. ${ }^{136}$ Het Hof heeft Art. 2 lid 1 GG tot dusverre ruim uitgelegd en niet willen beperken tot bijvoorbeeld een intieme privé-sfeer. ${ }^{137}$ Deze extensieve interpretatie creẻert namelijk een rume bevoegdheid van het Hof: dat kan langs deze weg bijna iedere willekeurige individuele aanspraak in behandeling nemen en vervolgens overheidshandelen op grondwettigheid toetsen. ${ }^{138}$ Deze omvangrijke toetsingsbevoegdheid doet in sterke mate denken aan de in het Amerikaanse debat gesignaleerde "substantive due process". Gesteld zou kunnen worden dat het Hof op deze wijze systematisch heeft gewerkt aan een 'gesloten' systeem van grondrechten, en dat Art. 2 lid $1 \mathrm{GG}$ deze benadering van de grondwet door het Hof als het ware legitimeert. Hierover bestaat echter geen eensgezindheid: het Hof heeft de grenzen van Art. 2 lid 1 GG deels zelf geïnterpreteerd. De tussen de reikwijdte van grondrechten liggende individuele aanspraken worden met Art. 2 lid 1 GG bestreken;

132 Onder inbreuken op de fysieke integriteit worden verstaan onder meer proeven op mensen, gedwongen castratie of sterilisatie, lichamelijke straffen en gedwongen ruggenmergpunctie in een strafrohtelijke procedure; voorbeelden ontleend aan Pioroth en Schlink 1999, p. 90 e.v.

133 Art. 2 GG Inidt: lid 1. "Jeder hat das Recht auf die freite Entfaltung seiner Persünlichkeit, soweit er nicht die Rechte anderer verletzt und nicht gegen die verfassungsmalige Ordinung oder das Sittengesetz verstoBt". Lid 2. "Jeder hat das Recht auf Leben und korpertiche Unversehrtheit. Die Freiheil dor Persorn ist unverletzlich. In diese Rechte darf nur auf Grund eines Gesetzes eingegriffen werden'. In de abortusbeslissingen kende thet Hof atun het ongeboren leven grondrechtelijke bescherming op het recht op leven

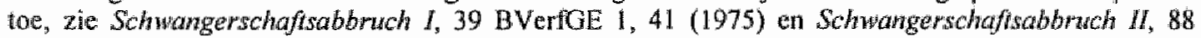
BVerfGE 203 (1993).

134. Schwangerschafisabbruch 1, 39 BVerfGE I (1975) eff Schwangerschaftsabbruch II, 88 BVerfCE 203 (1993).

135 Hesse $1990,173$.

136 Art. 2 lid 1 is én van de in Art. 93 lid I sub 4 a GG genoemde grondrechten, waarop een grondrechtelijke aanspraak bij het Constitutionele Hot kan worden gebaseerd. Voor discussie en verwijzingen, zie Hesse 1990, p. 173 e.k., Pieroth en Solnink 1999, p. 85 en 90.

137 Elfes, 6 BVerfGE 32, 36 (1957), zie ook Reiten im Walde, 80 BVerfGE 137 (1989) waarin het Hof de kritiek pareert dat de reikwijdte wan het grondrecht zozeer zou zijn opgerekt dat het grondrecht een lege huls dreigt te worden en als grondslag voor een individuele aanspraak niet meer serieus te nemen is.

138 In dit opzicht is sprake van een ontwikkeling waarin Art. 2 lid $1 \mathrm{GG}$ tot een 'due process' formule verwordt, zie darover Scholz 1975 , p. 84 en Currie 1989. 
in die zin heeft het artikel een vangnetfunctie. ${ }^{139}$ Interpolatie door de constitutionele rechter lijkt aldus door de grondwet te worden gelegitimeerd. ${ }^{140}$ Van belang is overigens dat met de individuele aanspraak eerst dient te worden aangesloten bij éen van de andere grondrechten: Art. 2 lid $1 \mathrm{GG}$ heeft een subsidiair karakter. ${ }^{41}$

Art 2 lid 1 GG kent een aantal beperkingsgronden, waarvan één regelmatig terugkeert in de rechtspraak. De rechten van anderen en de zedenwet zijn de minst gehanteerde, die van de 'verfassungsmaßige Wertordnung' is daarentegen de meest benutte beperkingsgrond. ${ }^{142}$ Het laatste uitgangspunt heeft de eerste twee als het ware overvleugeld. "143 Met het begrip van de "verfassungsmäßige Wertordnung" wordt bedoeld:

"clie Gesamtheit der Normen die formell und materiell mit der Verfassung in Einklang stehen. ${ }^{144}$

Zowel geschreven als ongeschreven rechtsnormen maken deel uit van 'die Gesamtheit der Normen". "Hs Het Hof bepaalt aan de hand van de "verfassungsmäBige Wertordnung", welke normen in de constitutie dwingen tot een beperking van de ingeroepen grondrechtsnorm. ${ }^{146}$ De formulering van de "verfassungsmäßige Wertordnung" duidt op een omvangrijke beperkingmogelijkheid. Een ruime beperkingsmogelijkheid van Art. 2 lid $1 \mathrm{GG}$ is het gevolg van de ruime reikwijdte wan het recht. Een beperking op Art. 2 lid I GG kan met de 'verfassungsmäß3ige Wertordnung' in overeenstemming zijn, mits voldaan is aan twee criteria. Het formele criterium stelt de eis, dat het orgaan dat de vrijheid heeft beperkt, daartoe ook bevoegd moet zijn. De materiële eis kent daarentegen een aantal deelcriteria. De beperking mag niet in strijd zijn met het grondwettelijk waardensysteem en de eisen van een democratische rechtsstaat. De kern van het grondrecht mag met de beperking niet worden aangetast. Ten slotte past het Hof bij de

139 Scholz 1975 , p. 82 , Jarass 1989 , p. 857.

140 Elfes, 6 BVerfGE 32,37 (1957), G 10,67 BVerfGE 157, 171 (1984).

141 Een greep wit de varieteit vari de aanspraken: het aangaan van overeenkomsten (Pretrgesetz, 8 BVerfGE 274. (1958), het uitweizen max het butenland (E)es, 6 BVerfOE 32 (1957)), bronumerijden zonder helm (59 BVerfGE 275 (1982)) en het recht op het seksuele prive-teven (Homosexwelle, 6 BVerfGE $389,432(1957))$.

142 De zedenwet heeft zelden een rol gespeeld in de beoordeling van de grondwattigheid van beperkingsgronden. Het Hof heeft de zedenwet in Homosexullie geaceepteerd als rechumatige beperkinggrond: de strafbaarheid var honoseksualliteit werd in overeenstemming geacht net de - in 1957 heersende opwattingen in de samenleving (Homosexuelle, 6 B VerfGE 389,432 (1957).

143 Kunig $2000_{3}$ p. 134.

144 Elfes, 6 B VerfGE 32,38 (1957). Her begrip "verfassungsmalige Wertordnung" zou kunnen worden verthald als "constitutionele orde."

145 Ter zake wan beperkingen op Art. 2 lid 1 GG kunnen aldus ook ongeschreven reclut (recluterstecht) en gewoonterecht een beperkingsgrond opleveren (74 BVerfGE 129, 152).

146 In deze formult is in zekere zin een cirkelredenering aanwezig: een beperking van de algemene handelingsvrijheid ex Art. 2 lid $1 \mathrm{GO}$ is rechtmatig indien zij in overeenstemming is net het recht in het algemeen en de grondwet in het bujzonder. Maar de vaag is mu juist of de gewraakte beperking in overeenstemming met Artikel $21 \mathrm{GG}$ is. Hierdoor zou Art. 2 lid $1 \mathrm{GG}$ zijn betekenis als grondslag voor een grondrechtelijke indiwiduele aanspraak kumen verliezen. Zeer kritisch over het argument van de Wertordnung als beperkingsgrond is Coerlich; hij is van mening dat dit argument geen legitimiteit kan toekomen: hel heeft een verhullend karakter en de inhoud van het begrip lijkt op geen manier te kumnen worden blootgelegd (Goerlich 1973, p. 187). 
beoordelling van de grondwettigheid van de handeling van de staat eveneens de reeds genoemde proportionaliteitstoets toe. Het uitgangspunt bij de proportionaliteitstoets ter zake van beperkingen op de algemene handelingswrijheid is dat het individu een autonomie alsmede een eigen verantwoordelijkheid toekont. Naarmate de vrijheidsbeperking op de autonomie en de eigen verantwoordelijkheid groter is, wordt de proportionaliteitstoets zwaarder aangezet.

Van belang is dat an het recht op algemene handelingsvrijheid in beginsel geen vermoeden ten gunste van de individuele vrijheid wordt toegekend ${ }^{147}$ In dit verband is er enige vergelijking te maken met de benadering van het Amerikaanse Hooggerechtshof, dat individuele aanspraken onder het vrijheidsbegrip uit het Veertiende Amendement niet vanzelfsprekend de kwalificatie 'fundamentality' toekent. In de Amerikaanse situatie leidt die kwalificatie steeds tot afwijzing van intensieve toetsing, en tot het in stand houden van de aangevochten wetgeving. Ter zake van Art. 2 lid $1 \mathrm{GG}$ lijkt, afgaand op het bovenstaande, een marginale toetsing uitgangspunt, zij het dat de marginale toets in de Duitse constitutionele rechtspraak niet behoeft te leiden tot dezelfde consequentie als in de Amerikaanse situatie. Verder wordt de eis van de toepassing van de zogenoemde 'Wechselwirkungslehre' ten aanzien van Art. 2 lid 1 GG niet gesteld. ${ }^{48}$ Het Hof combineert in zijn rechtspraak bij toepassing van Art. 2 lid $\| \mathrm{GG}$ een ruime uitleg ten aanzien van de soorten handelingen die onder de algemene handelingsvrijheid worden beschouwd, maar trekt aanzienlijk engere grenzen wanneer het gaat om de mate van bescherming die de individuele aanspraken moet toekomen. Gesteld kan worden dat het Hof ter zake van de erkenning van de aanspraken ruimhartig is, maar de honorering van individuele aanspraken op grondrechtsbescherming niet steeds vanzelfsprekend is. Teneinde de omvang van rechtsbescherming die de erkende aanspraak dient te verkrijgen, stelt het Hof vast of en in welke mate de aanspraak van betekenis is voor de "privater Lebensgestaltung'. ${ }^{149}$ Indien de aanspraak niet is verbonden met dit aspect van de handelingsvrijheid, kan er geen grondrechtelijke bescherming ex Art. 2 lid 1 GG aan deze aanspraak worden verleend.

\subsubsection{Het 'allgemeines Persönlichkeitsrecht'}

In het kader van het recht op persoonlijkheid is het in de Duilse rechtspraak ontwikkelde 'allgemeines Persönlichkeitsrecht' van groot belang. ${ }^{150}$ Het beschermt de intieme privé-sfeer en een recht van het kind op het kennisnemen van zijn afstamming. ${ }^{151}$ Bin-

147 Kunig 2000, p. 136-137.

148 Kunig 2000 , p. 137. De wisselwerkingsdoctrine staat in diect verband met het interpretatiemaxime van de "praktische Konkordanz" (zie hierna par, 4.3.2).

149 "Hieraus ergibt sich, dab dem einzelnen Bürger eine Sphatre privater Lebensgestaltung werfassungskraftig vorbehaiten ist, also ein letzter unantastbarer Bereich nuenschlicher Freilheil besteht, der der Einwirkung der gesamten offentlichen Gewalt entzogen ist. Ein Gesetz, das in ihn eingreifen wirde, koonnte nie Bestandteil der "verfassungsmafligen Ordnung" sein; es maßte durch das Bundeswerfassungsgericht für nichtig erklärt werden", Elfes, 6 BVerfGE 32, 41 (1957).

150 Zie ook Nelimelman 2002 voor uiteenzetting wan de achtergrond van dit recht.

15॥ Voor het recht op privé-leven is in de Duitse grondwet geen afzonderlijke specifieke bepaling te vinden (Art. $10 \mathrm{GG}$ handelt over het brief- en telefoongeheim en is door het Hof niet zodanig nitgelegd als zou 
nen begrenzingen erkent het recht de mogelijkheid, het leven naar eigen inzicht gestalte te geven zonder inmenging van buitenaf. Ook is de wijze waarop het individu zijn fysieke beeld of gesproken woord naar buiten brengt, tot op zekere hoogte beschermd onder het algemene persoonlijkheidsrecht. Indien het individu op bepaalde wijze in de openbaarheid wordt afgeschilderd, kan het persoonlijkheidsrecht grondslag voor een aanspraak bieden, bijvoorbeeld indien het overgebrachte beeld of het woord niet overeen kwam met de werkelijkheid. ${ }^{152}$

Het algemene persoonlijkheidsrecht is geschoeid op de leest van Art. 2 lid $\mathbb{\|}$ GG. Het vormt een "Teilbereich" of een deelverzameling van het recht van vrije outplooing van de persoonlijkheid. ${ }^{153}$ De toevoeging van Art. 1 lid $1 . \mathrm{GG}$ onderscheidt het algemene persoonlijkheidsrecht echter van het recht op vrije ontplooiing van de persoonlijkheid ex Art. 2 lid 1 GG. De toevoeging van Art: 1 lid $1 \mathrm{GG}$ heeft tot gevolg, dat minder individuele aanspraken onder het algemene persoonlijkheidsrecht worden erkend in vergelijking met de vrije ontplooiing van de persoonlijkheid ex Art. 2 lid 1 GG. De rechter is met andere woorden tot dusverre bereid gebleken om een groter aantal diverse individuele aanspraken onder Art. 2 lid 1 GG te erkennen, dan onder het algemene persoonlijkheidsrecht ex Art. 2 lid 1 en 1 lid $1 G^{~ G G . ~}{ }^{154}$ Een hiermee samenhangend verschijnsel is dat op het algemene persoonlijkheidsrecht andere beperkingsgronden van toepassing zijn dan op Art. 2 lid $1 \mathrm{GG}$ alleen het geval is. Op de beperkingsmethodiek wordt hieronder teruggekomen. Daarnaast bestaat een inhoudelijk onderscheid tussen de vrije ontplooiing van de persoonlijkheid en het algemene persoonlijkheidsrecht: grofweg kan worden gesteld, dat Art. 2 lid $1 \mathrm{GG}$ een algemene handelingsvrijheid in zich draagt; dit wijst op een actief element in het handelen waarvan het individu grondwettelijke bescherming vraagt. Een aanspraak op het algemene persoonlijkheidsrecht daarentegen houdt niet zozeer een handeling in, als wel een respect voor een bepaalde mate van afscherming in alsmede op het respectvol bejegend worden. ${ }^{155}$ Beide benaderingen dragen elementen van het recht op persoonlijkheid in zich, en de aanspraken kunnen elkaar eveneens overlappen. Van belang voor dit onderzoek is dat zowel het algemene persoonlijkheidsrecht alsmede de concretiseringen daaruit in dat kader enkel door de rechter tot stand zijn gebracht. Het algemene persoonlijkheidsrecht makt geen deel uit wan de geschreven grondrechten. Het Hof heeft wan het algemene

het een recht op het intieme prive-lewen omvattenj. Het wit het algemene persoonlijkheidsrecht afgeleide recht van het kind, kemais over de alstamming te kunnen vememen is te vinden in Faterschafsauskangt, 96 B VertGE $56,63(1997)$

152 Andere voorbeelden van in de jurisprudentie erkende individuele aanspraken onder het algemene persoonlijklaeidsrecht betreffen het recht op bescherming van het dagboek, het recht op geheimhouding wan medische gegevens, het recht op selksuele zelfbeschikking, het recht op de keuze van de naam, het recht om niet gedane witlatingen in de mond gelegd te krijgen, het recht om niet aan zelfincriminatie te hoeven meewerken en het recht op kennis van de biologische afstamming.

153 Scholz 1975, p. 91; Jarass 1989, p. 857; Hesse 1990, p. 175; Kunig 2000, p. 144-145.

154 Jarass 1989, p. 857 en Kunig 2000, p. 145.

155 Het onderscheid wordt in de literatuur ondersteund door onder meer Scholz 1975, p. 92 en door Alexy,

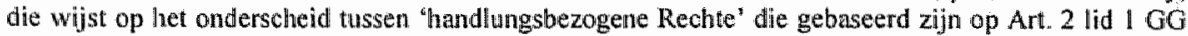
en "zustandsbezogene Rechte", die hun grondslag vinden in Art. 2 lid 1 GO in verbinding met Art. 1 lid 『GO (Alexy 1996, p. 332 e.v.). 
persoonlijkheidsrecht geen sluitende definitie gegeven. Het Hof beperkt zich bij de beoordeling van nog niet eerder gedane individuele aanspraken niet tot de in de jurisprudentie ontwikkelde concretiseringen, maar lijkt juist open te staan voor nieuwe ontwikkelingen. Het algemene persoonlijkheidsrecht is een open norm waarvan de omvang zich laat merken aan de hand van geconcretiseerde rechten. ${ }^{156}$

Beperkingen op het algemene persoonlijkheidsrecht zijn eveneens in de rechtsprakk ontwikkeld. De toetsing van de beperkingen verloopt in beginsel via de methode die is uiterengezet bij Art. 2 lid 1 GG. De toetsing van de aangevochten wet is bij vermeende schending van het algemene persoonlijkheidsrecht strenger dan die bij inbreuken op de algemene handelingsvrijheid ex Art. 2 lid $\mathbb{I} G \mathrm{G}$, omdat de beperkingen op dat grondrecht niet bij formele wet moeten worden gesteld. ${ }^{157}$ Een belangrijke aanwijzing voor de door het Hof gehanteerde beperkingsmethodiek is gelegen in de zogenoemde sferenleer, al kan niet worden gesteld dat de sferenleer een synoniem is voor de beperkingsmethodiek. ${ }^{158}$ Er bestaat verschil wan mening over de mate waarin het Hof de beperkingsmechanismen die van toepassing zijn op de algemene handelingsvrijheid tot een doctrine heeft verheven die van toepassing is op het algemene persoonlijkheidsrecht, al zijn er wel enkele lijnen te ontwaren in de beperkingmethodiek. ${ }^{159}$ Een beperking van het persoonlijkheidsrecht vergt een zwaarder verantwoording van de zijde van de staat, naarmate de privế-sfeer waarop inbreuk wordt gemaakt, intiemer is. ${ }^{160}$ Van belang in de interpretatiefase is dan ook, in welke mate de individuele aanspraak kan rekenen op het behoren tot een intieme privé-sfeer. In de eerste plaats bestaat er een kern van privé-sfeer, met daaromheen de intieme privé-sfeer. De kern laat een inbreuk op het persoonlijkheidsrecht niet toe, maar niet helemaal duidelijk is waar de grens tussen de kern en de intieme privé-sfeer verloopt. ${ }^{161}$

'Hieraus ergibt sich, daß dem einzelnen Bürger eine Sphäre privater Lebensgestaltung verfassungskräftig vorbehalten ist, also ein letzter unantastbarer Bereich menschlicher Freiheit besteht, der der Einwirkung der gesamten offentlichen Gewalt entzogen ist'. ${ }^{162}$

Buiten dit bereik van intimiteit is een meer openbare sfeer te ontwaren. Individuele aanspraken die worden gekwalificeerd in deze sfeer, moeten in beginsel eerder een in breuk op de privé-sfeer tolereren: aan de imbreuk worden minder strenge eisen gesteld. De proportionaliteitseis die in de toetsingsfase an de orde komt, zal in dat verband

156 Scholz 1975, p. 268

157 Jarass 1989 , p. $86 \mathrm{l}$ en Kunig. 2000, p. 153; zie eveneens Arztliche Schwergepflicht, 32 BVerrGE 373 , 379 (1972) Anders: Nehmelman 2002, p. 49.

158 Als grondlegger wan het idee van de sferentheorie in verband met Art. 2 GG wordt Hubmann wal aangewezen (Hubmann 1953); zie voor een toegankelijke witwerking Nehmelman 2002, p. 31 e. . Z if voor een onderverdeling bijvoorbeeld Schotz 1975 , p. 265 e.v., Pieroth er Sclulink 1999, p. 86-87.

159 Pieroth en Schlink zijn van mening dat het Hof van deze sferentheorie al afscheid heeft genomen, maar dat in de literatuur hardnekkig wordt vastgehouden aan deze theorie (Pieroth en Schlink 1999, p. 86). Nehmelman wigt op het onderscheid lussen sferenleer en beperkingsmethoden; 2 ij vallen grotendeels samen maar zijn echter niet identiek (Nehmelman 2002, par. 2.42.2).

160 Scholz 1975, p. 266; Kunig 2000, p. 152.

161 Tagebuch, $80 \mathrm{BVer}(\mathrm{GE} 367,373(1989)$.

162 Elfes, $6 \mathrm{BVerfGE} 32,41(1957)$. 
aldus op andere wijze worden ingevuld dan in de intieme sfeer. Een eenduidig criterium woor een scheiding tussen beide sferen is niet te geven; het Hof plaatst de individuele aanspraken in het algemeen op casuistische wijze in ém van de sferen.. ${ }^{163}$ Overigens geeft het Hof niet steeds nauwkeurig aan of de individuele aanspraak op bescherming van het persoonlijkheidsrecht in de intieme of in de meer openbare sfeer wordt gekwalificeerd. In de literatuur lijkt niet zozeer bezwaar te bestaan tegen de omwang van de reikwijdte van het algemene persoonlijkheidsrecht; er bestaat in die zin minder kritiek op het algemene persoonlijkheidsrecht dan op de algemene handelingsvrijheid. Er bestaat wel weerstand tegen de onzekerheid ten aanzien van de vraag, of en wanneer het Hof een individuele aanspraak zal erkennen. Een zekere mate van inkadering, en wellicht positivering van het algemene persoonlijkheidsrecht zou kumnen bijdragen aan een scherpere omschrijving van het recht, en aan grotere voorspelbaarheid van erkenning en van nadere concretiseringen. Tegelijkertijd bestaat het gevaar, dat een dynamische interpretatie verloren kan gaan.

\subsubsection{Privaatrechtelijke notie van het "allgemeines Persönlichkeitsrecht"}

Het grondrechtelijke en privaatrechtelijke algemene persoonlijkheidsrecht zijn sterk met ellkaar verweven, al lijkt de constitutioneelrechtelijke variant een ruimere strekking te kennen. ${ }^{164}$ In het privaatrecht werd de discussie over het bestaan van een algemeen persoonlijkheidsrecht echter eerder gevoerd dan in constitutionele kring. In de rechtspraak van het Bundesgerichtshof is het concept voor het eerst in de rechtspraak in 1954 als grondslag voor een individuele aanspraak erkend. ${ }^{165} \mathrm{Er}^{\mathrm{r}}$ werd in het kader van onrechtmatigheid ex Art. 823 lid 1 BGB een beroep op gedaan; het Bundesgerichtshof (BGH) erkende dat het oproepen van een verkeerd beeld van een persoon in een openbare publicatie kon leiden tot een schadevergoedingsverplichting. ${ }^{166}$ Het individu komt een "Achtung der Wüde und der freie Entfaltung der Persönlichkeit" toe, hetgeen thet $\mathrm{BGH}$ baseerde op een contaminatie van Art. 1 lid $1 \mathrm{GG}$ en Art. 2 lid $1 \mathrm{GG} .{ }^{167}$ De invulling van één van de schadevergoedingsgronden ex Art. 823 lid 1 BGB aan de hand van het algemene persoonlijkheidsrecht was hiermee een feit. ${ }^{168} \mathrm{Het}$ algemene persoonlijkheidsrecht bood vervolgens een grondslag aan uiteenlopende schadevergoedingsaanspraken. Via Art. 823 lid 1 BGB werden aanspraken gedaan op het algemene persoonlijkheidsrecht ter bescherming van de eer en goede naam ${ }^{169}$, ter bescherming van de

163 Het Hof heeft op de hantering wan de sferen als onderdeel van de vaststelling wan de reilkwijdte wan het algemene persoonlijkheidsrecht regelmatig kritiek te verduren gehad vamwege de onmogelijkheid. swherpe criteria te formuleren voor de platsing in de ene of de andere sfeer (Pieroth en Schlink 1999 , p. 86 ).

164 Zile voor madere witwerking Nehmetman 2002, p. 18 e.\%.

165 Het Bundesgerichtshof is op federanl miveau de hoogste civicle en de hoogste strafrechter. De eerste uitspraak door het $\mathrm{BGH}$ ter zake van het algenene persoonlikheidsrecht werd gedan in Leserbref, 13 BOHZ $334(1954)$

166 Tagebwch, 80 BVerfGE 367,373 (1989).

167 Leserbriz, 13 BGHZ 334 (1954).

168 Het algenene peusoonlijkheidsrecht werd ingeroepen als "ein sonstiges Recht".

169 Zie bijwoorbeeld 39 BGHZ 124, NJW 1963,602. 
privé-sfeer ${ }^{170}$ en het onrechtmatig gebruik van beelden en namen ${ }^{171}$ en ter zake van ongewenste publicaties van de pers. ${ }^{172}$ In het Duitse recht wordt overigens niet van horizontale werking van het persoonlijkheidsrecht gesproken maar wordt de doorwerking in private verhoudingen aangemerkt als dat het in Art: 2 lid I en 1 lid 1 GG neergelegde persoonlijkheidsrecht 'Ausstrahlungswirkung' of indirecte 'Drittwirkung" heeft. ${ }^{173}$ Het algemene persoonlijkheidsrecht verkreeg in de rechtspraak van het Bundesgerichtshof de status van een 'objektive Schutznorm', die in de 'Wertordnung' of in het 'Wertsystem" een status van een grondwettelijke waarde verkrijgt waarmee ook in een privaatrechtelijke rechtsverhouding rekening moet worden gehouden. ${ }^{174}$ Het persoonlijkheidsrecht verkrijgt dan rechtsbeginselachtig karakter, dat zich in de privaatrechtelijke geschillen manifesteert en dient te worden meegewogen. Het Federale Constitutionele Hof hanteerde het begrip van het algemene persoonlijkheidsrecht in de zaak Soraya, een van oorsprong civiele zaak waarin werd geklaagd over onrechtmatige persuitlatingen. ${ }^{175}$ Het algemene persoonlijkheidsrecht bood, aldus het Hof, een grondslag om een recht op immateriele schadevergoeding te erkennen. Het Hof toetste deze grondslag die door het Bundesgerichtshof was geconstrueerd op grondwettigheid. Het zou daarna nog enige tijd duren, voordat het Constitutionele Hof het algemene persoonlijkheidsrecht als zodanig zou hanteren in zijn rechtspraak. ${ }^{176}$

\subsection{Europese Unie: het Verdrag van de Europese Unie}

\subsubsection{Het EU-Verdrag: grondwet en grondrechten ${ }^{177}$}

De toevoegingen van het Verdrag van Maastricht en het Verdrag van Amsterdam aan het EG-Verdrag hebben geleid tot het ontstaan van het Verdrag van de Europese Unie. Het Verdrag van de Europese Unie kan niet zoals dat in de Verenigde Staten, Duitsland en Nederland wel het geval is, worden aangemerkt als een grondwet van een staat. ${ }^{178}$

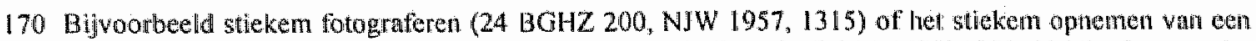
gesprek op een band, dat later word gebruikt als bewijs (27 BGHZ 284, NJW 1958, 1344) of cen mededeling over iemands gezondheidstoestand door familieleden in de openbaarheid (24 BGHZ 72, NJW $1957,1146)$

171 Zie bijwoobeeld de Paul Dahlke-zaak, 20 BGHZ 345, NJW 1956, 1554 en Herrenrehter-zak, 26 BGHZ 349, NJW 1958,828.

172 Soraya, 34 BVerfGE 269 (1973).

173 Jarass 1989 , p. 858 .

174 Pieroth-Schlink 1999, p. 20, Hesse 1990, p. $126 \mathrm{en} \mathrm{Kunig} \mathrm{2000,} \mathrm{151.} \mathrm{Het} \mathrm{Bundesverfassungsgericht}$ Wheeft deze comstructie erliwend een geschil tussen twee individuen in Lath, 7 BVer IGE 198, 205 (1958),

175 Soray 34 BVerfGE 269, 281 (1973).

176 Eppler, 54 BVerfGE 148, 153 e.v. (1980).

177 Met het Verdrag van de Europese Unie wordt bedoeld de tot EU-Verdrag samengewoegde theksten van het oorspronkelijke Unieverdrag van Maastricht (1993) en het EG-Verdrag. Waar relevant, zal onderscheidenlijk gesproken worden over het EU- of EG-Verdrag. Voor dit onderzoek is het oorspronkelijke EG-Verdrag van groter belang; het Hof van Justitie heeft over dit Verdrag de meest uitgebreide jurisdictie, en in het kader van het $\mathrm{EO}$-Verdrag heeft het Hof aan rechtsontwikkeling gedaan op het terrein wan het recht op persoonlijklue id.

178 Zie onder meer het Duitse Federale Constitutionele Holi in EWG-Werordnumgen, 22 BVerfoE 293 
Structuren, die duiden op aanwezigheid van grondrechten en op elementen van machtenscheiding lijken niet expliciet aanwezig in het verdrag. De Europese Unie wordt well gekarakteriseerd als een "conglomerat van verschillende (staats-, H.L.J.) structuren". ${ }^{779}$ Er zijn in de loop der tijd evenwell uitspraken gedaan over de constitutionaliteit" van de EU. Het constitutionele karakter van de verdragen werd door het Hof bijvorbeeld afgeleid uit de ongeschrewen constitutionele beginselen, die aan het EUVerdrag ten grondslag liggen. Het Hof van Justitie van de EG heeft de Eerste Pijler meermaals aangeduid met de term 'constitutioneel handvest". naast ook beginselen van machtenscheiding en de aanwezigheid van bindende grondrechten in het rechtsstelsel vastgesteld. Het beginsel van machtenscheiding heeft betrekking op zowel verdeling van bevoegdheden tussen de instellingen onderling, alsook op de verdeling van bevoegdheden tussen de Lid-Staten en de instellingen. ${ }^{181}$ Het Hof heeft met jurisprudentie een bijdrage van grote betekenis geleverd aan verhoging van het constitutionele gehalte van de verdragen. ${ }^{182}$ Het heeft bij de toepassing en interpretatie van het verdrag constitutionele beginselen gepositiveerd, die wijzen op aanwezigheid van fundamentele rechten in de Gemeenschapsrechtsorde. ${ }^{183}$ Daarnaast zijn beginselen als voorrang van het Gemeenschapsrecht, directe werking en de aanwezigheid van grondrechten als rechtsbeginselen door het Hof ontwikkeld in de rechtspraak.

Desondanks kan van het EG-Verdrag, worden gesteld dat zij in elk geval de voor dit onderzoek noodzakelijke elementen bevatten. De aanwezigheid van die elementen leidt - tegen de achtergrond van de voorgestelde probleemstelling - tot vergelijkbaarheid van de EG met de andere rechtsstelsels, die zich wel laten typeren als staten met een grondwet. Een algehele kwalificatie van de EG als constitutie is daarom niet noodzakelijk. Refererend aan de kenmerken die een rechtsorde kenmerken als constitutie kan worden gesteld dat de EG-rechtsorde in elk geval de kenmerken van een constitutie in zich draagt die noodzakelijk zijn voor de vergelijking met de andere rechtsstelsels. Er is een rechterlijke instantie in de rechtsorde aanwezig die bindende uitspraken doet over de verenigbaarheid van handelingen wan de Gemeenschapsinstituten en van de handelingen van de Lid-Staten ter zake van rechtsnormen die gelieerd zijn aan het recht op persoonlijklieid. Het EG-Verdrag dient daarbij als hoogste en bindend referentiekader, al noemt het EG-Verdrag niet expliciet een recht op prive-leven, op persoonlijke levenssfeer of privacy. Deze rechtsnormen zijn evenwel erkend in de EG-rechtsorde als rechtsbeginselen van Gemeenschapsrecht, en hebben in die hoedanigheid gediend om

(1967); Les Werts t. Ewopes Parlemen, zalk 294/83 (1986), Jur. p. 1339 (1986), par. 23; Opinie 1/91 (1991) $1-6084,6102$ (par. 69 e.v.); Weller 1999, p. 221; Hirsch Ballin 2000, p. 16; De Witte 2000, p. 45 en Sohilling 1996, p. 47. De laatste auteur categoriseert verseheidene soorten constituties, waaronder constituties die worden gesloten niddels een verdrag.

179 Zie Barents en Brimkhorst 2001, p. 25 e.\%.

180 Les Verts t. Europees Parlement, zaak 294/83, r.0. 23; Opinie van het Hof van Justitie 1/91 (1991) I6084,6102 , par. 69 e.v.

181 Zle voor een schets van de ontwikkeling en verwijzingen onder meer De Witte 1995, p. 139 e.v.

182 Luisa Fernandez Esteban 1995, p. 130 en Craig 2001, p. 129.

183 Zie voor ontwikkeling en wardevolle verwijzingen onder meer Tridimas 1999, p. 2020 e. . en Craig en De Bürca 1998, p. 296 e. . 
handelingen van de Instellingen en van Lid-Staten te toetsen op overeenstemming met EG-rechtelijke normen. Het ontbreken van individuele rechtsbescherming in de vorm van een geschreven grondrechtcatalogus is echter geen reden om het EG-Verdrag als onvergelijkbaar rechtsstelsel aan te merken.

In beginsel heeft het Hof bindende rechtsmacht met betrekking tot de handelingen van de Instellingen, en niet met betrekking tot die van de Lid-Staten. Niet ontkend kan echter worden, dat het Hof, afgaande op de jurisprudentie, ook naar de Lid-Staten bindende uitspraken kan doen: via de prejudiciële procedure spreekt het Hof de facto een eindoordeel uit over de verenigbaarheid van nationaal met EG-recht. ${ }^{184}$ De grondrechten, ook het recht op privacy, maken sinds de zaak Nold expliciet als ongeschreven rechtsbeginselen deel uit van de rechtsorde. ${ }^{\text {trs }}$ Een aantal van de door het Hof ontwikkelde grondrechtelijke normen is inmiddels gecodificeerd in de verdragen. Het Hof typeert deze normen als rechtsbeginselen van de rechtsorde van de Gemeenschap; zij maken als ongeschreven grondrechten deel uit van die rechtsorde. In het Verdrag van Amsterdam worden grondrechtelijke normen in zeer algemene zin erkend en gecodificeerd in Art. 6 lid 2 EU-Verdrag. ${ }^{186}$ Enkele individuele rechten staan verspreid in het EG-Verdrag; echter bedacht moet worden dat het grootste deel wan deze rechten een economische achtergrond heeft en een economische invulling verkrijgt. Er is echter, zoals in de andere rechtsstelsels, geen sprake van een bindende grondrechtencatalogus. Het Handwest van de EU, dat aan het Verdrag van Nice als Verklaring is gehecht, heeft. nog geen verbindende kracht. ${ }^{187} \mathrm{Na}$ de afkondiging van het Handvest rees de vraag of dat tot gevolg zou hebben dat het Handvest nauwelijks van betekenis zou zijn. Langzaamaan begint duidelijk te worden dat het Gerecht van Eerste Aanleg het Handvest beschouwt als een document waarin rechtsnormen zijn opgenomen die ten grondslag liggen aan de gemeenschappelijke constitutionele tradities van de Lid-Staten en die de Instellingen binden. ${ }^{188}$ Het vormt in die optiek een neerslag van de tussen de Lid-Staten bestaande consensus; met deze benadering behoeft de rechter niet de gewenste consensus op te sporen maar kan deze direct ontlenen aan het Handvest. Hierdoor ontstaat de indruk, dat door het Gerecht aan het Handvest althans de facto rechtswerking wordt toegekend. ${ }^{189}$ Het Hof van Justitie is tot dusverre nog niet zover gegaan, het Handwest als rechtsgrondslag voor individuele aanspraken te beschouwen.

184 Mancini en Keeling 1994, p. 8.

185 Nold, zaak 4/73 (1974), Jur. p. 491 (1974).

186 Art. 6 lid 2 EU-Verdrag luidt: 'De Unie eerbiedigt de grondrechten, zonals die worden gewarborgd door het op 4 nowember 1950 te Rome ondertekende Europees Verdrag tot bescherming van de rechten van de mens en de fundamentele wrijheden en zoals zij uit de gemeenschappelijke constitutionele tradities wan de Lid-Staten voortwloeien, als algemene beginselen wan het Gemeenschapsrecht".

187 Zie hiena par. 2.5 .2

188 Zaak T-54/99 max mobil Telekommunikation Serwice GmbH \&. Commissie, GwEA 30 januari 2002, EHRC 2002/5.4 (par. 48) en Zaak T-177/01, Jego-Quéré e.a. t. Commissie, GvEA 3 mei 2002, E1HRC $2002 / 55$ (par. 42)

189 Deze rechtswerking verloopt via de foor het Getecht van Eerste Aanleg gehanteerde constructie van toetsing van het Commissiebeshit aan algemene beginselen van EGi-recht. Deze constructic verhult dat rechtstreeks wordt getoetst aan het Handvest (zie Gerards in haar annotatie bij max.mobil t. Commissie, EHRC 2002/54). 
Allereerst staan in het EG-Verdrag enkelle Unieburgerschapsrechten, die het karakter hebben van grondrechten. ${ }^{190}$ De economische vrijheden, vrij verkeer van goederen, vrij verkeer yan personen, vrije vestiging en vrij verkeer van kapitaal bergen eveneens grondrechten in zich, en hebben het Hof vaker voor de taak gesteld, uitleg te geven aan bescherming aan bijvoorbeeld de reikwijdte van aanspraken op gezondheid en van het leven van personen." Deze "grondrechten' hebben vrijwel allemaal een economische dimensie, die erop is gericht de interne markt te openen en te voorkomen dat Lid-Staten een concurrentievoordeel zouden genieten indien $z$ ij de grondrechten uit het verdrag niet zouden respecteren. ${ }^{192}$ Daamaast is voor het bestaan van grondrechten in de EGrechtsorde het hiervoor al kort aangestipte Art. 6 lid 2 EU-Verdrag van belang, dat in het Verdrag van Amsterdam is ingevoegd. Het codificeert een rechtspraktijk die in de jurisprudentie van het Hof al lang geleden was ontstaan: grondrechten uit het EVRM alsmede grondrechten die voortvloeien uit de gemeenschappelijke tradities van de LidStaten maken deel uit van de Gemeenschapsrechtsorde in de hoedanigheid van rechtsbeginselen. De afwezigheid van verwijzingen naar beginselen van democratie en fundamentele rechten en vrijheden hangt samen met de van oorsprong functionele opzet van de $\mathbb{E G}^{193}$ Het doel van de oprichtingsverdragen was vooral, een economisch integratieproces in gang te zetten: dat verklaart deels de economische invulling van de wel in het verdrag aanwezige grondrechten. Kwesties van politieke en staatkundige vormgeving werden door de opstellers van de verdragen niet aangesneden.

At snel na oprichting van de Gemeenschappen bleek dat economische bestuurshandelingen van de Gemeenschapsinstellingen in strijd konden komen met fundamentele rechten die niet in het verdrag waren vastgelegd. Beroepen op het recht op eigendomsvrijheid en het recht op beroepskeuzevrijheid tegen handelingen van de Instellingen werden dan ook al vroeg bij het Hof gedeponeerd. Deze rechten waren echter niet opgenomen in éen van de verdragen, en het Hof wees de aanspraken op deze rechten in beginsel dan ook af. ${ }^{194}$ De jurisdictie van het Hof reikte echter niet zover, dat het de aanspraken kon toetsen aan de grondrechten in de Lid-Staten. Het probleem van de afwezigheid van een grondrechtscatalogus deed zich steeds meer gevoelen in verband met vergaande economische interventies in het kader van de gemeenschappelijke landbouwpolitiek. ${ }^{195}$ De afwezigheid van toetsingsmogelijkheden voor het Hof en de on-

1902 ic woor bepalingen in het EG-Verdrag: Art. 12 (discriminatieverbod nat nationaliteit), Art. 17 (unieburgerschap), Art. I8 (recht op wrijheid van reizen en verbltjf yan EU-onderdanen), Art. 19 (kiesrecht), Art 20 (diplonatieke beschenning van EU-onderdanen), Art. 21 (petiotierechi), Art. 141 (gelike beloning van mannen en vrouwen) en Art. 173 (mogelukkeid beroep in te stellen tegen handelingen van de Instellingen).

191 Zie Art. 30 EG-Verdrag dat de gevallen stipuleent warin beperkingen op de in en uitwoer geoorlootid zijn. In Commissie t. Dwitsland, zaak C-62/90 (1992), Jur. p. 1-2575 (1992) beriep de Lid-Staat zich bijvoorbeeld op beperking van imvoer van geneesmiddelen wit hat buttenland, temeinde de volksgezondhe id in her land te beschemen.

192 Barents an Brinkhorst $2001,0.62$.

193 Inmide is zijn de beginselen van democratie en fundamentele rechten vastgelegd, zie hiervoor Art. 6 lid 1 EU-Verdrag.

194. Zie onder meer Siork: Hoge Autoriteit, zaak US8 (1959), Jur " p. 43 (1959).

$\llbracket 95$ Zie Hawer, zaak 44/79 (1979), Jur. p. 3727 (1979). 
vrede die ontstond in de Lid-Staten - grondrechten op nationaal niveau werden ondergeschikt geacht aan het EG-Verdrag - werkten het gevaar in de hand, dat de nationale rechters zelf een grondrechtelijke toetsing van EG-recht zouden opnemen. Hieruit zou een bedreiging van de eenvormigheid van het EG-recht kunnen voortvloeien, die het Hof uiteindelijk afwendde met de ontwikkeling van een eigen doctrine ter zake wan grondrechten. ${ }^{196}$ De aanwezigheid van gemeenschappelijke constitutionele tradities in de Lid-Staten en hun gebondenheid aan de grondrechten van het EVRM vormden in de ontwikkeling van 's Hofs doctrine de belangrijkste leidraad. ${ }^{197}$ Het recht op privacy is niet als grondrecht gecodificeerd in de verdragen. Het maakt sinds het Hof uitspraak deed in Panasonic deel uit van de Europese rechtsorde als beginsel van Gemeenschapsrecht. ${ }^{198}$ In die hoedanigheid is het recht op privacy door het Hof gepositiveerd als rechtsbeginsel in de rechtspraak. Wat de beperkingmethodiek van grondrechten en in het bijzonder het recht op privacy betreft zijn verschillende opvattingen denkbaar. In het EG-Verdrag is geen toetsingsschema van beperkingen op het recht op privacy vastgelegd, ook niet ten aanzien van de "EG-grondrechten". In de rechtspraak zijn toetsingsschema"s van beperkingen op privacy aangetroffen, die in de verte doen denken aan het toetsingsschema van het EHRM. Er werd bijvoorbeeld alleen vastgesteld of de wet in kwestie een legitiem doel diende. ${ }^{199}$ Recente rechtspraak toont echter aan, dat het Hof soms well bereid is, een toetsingsschema van beperkingen te aanvaarden dat zeer vergelijkbaar is met dat van het EVRM, toegepast door het EHRM. ${ }^{200}$

\subsubsection{Het EU-Handvest van findamentele rechten}

Er zijn in de loop der tijd uiteenlopende initiatieven genomen om grondrechten op te nemen in het EG-Verdrag, maar die strandden op politieke onwil van de Lid-Staten. ${ }^{201}$ Eén optie was aansluiting bij het EVRM, maar het negatieve advies van het Hof deed deze mogelijkheid gauw van tafel verdwijnen. ${ }^{202}$ Het Hof achtte voor een dergelijke stap verdragwijziging noodzakelijk, en de vraag op welke wijze en in hoeverre samenwerking tussen het EHRM en het Hof zou plaatsvinden bleek niet oplosbaar. Een tweede optie was het tot stand brengen van een eigen catalogus van grondrechten. Die is in de vorm van een Europees Handvest op 7 december 2000 als Verklaring bij het Ver-

196 Solange 1, 37 BVerTGE 271. (1974) was een belangrijke aanleiding in verband net de ontwikkeling wan de grondrechtendoctrime wan het Duitse Federalle Consitutionele Hof.

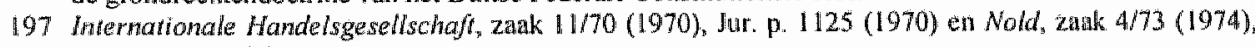
Jur. p. 491 (1974).

198 Panasonic t. Commissie, zaak $\$ 36 / 791(1980)$, Jur. p. 2033 (1980).

199 Panasonic (. Commissie, zaak 136779 (1980).

200 Conmoly t. Commissie, zaak C-274/00 (2001), EHRC 2002/11 en Cwik t. Commissie, zaak C-340/00.

201 Zite bijwoorbeld de gezamenlijke verklaring van de EG-Instellingen van 1977 (Joint Deelaration on Fundamental Rights of the Parliament, the Council and the Commission, 5 april $1977, \mathrm{~Pb}, \mathrm{C} 103 / 1 \mathrm{)}$ ) De volgende woorbelden zin ontleend aan Barents en Brinkhorst 2001, p. 68: de Verlklaring over Democratie die werd aangenomen tijdens de conferentie van staats-en regeringsleidters van ds EG in Kopen-

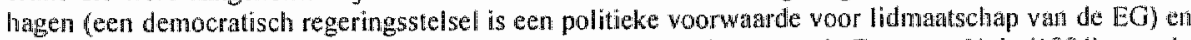
het ontwerp wan het Europees Parlement ter zatke var het verdrag woor de Europese Unie (1984), warnat een sanctiemechanisme was neergelegd voor emstige en voortdurende schendingen van beginselen wan democratie en rechtstat (1984, of C 77/32).

202 Zie Advies 2/94 ter zake van toetreding wan de Gemeenschap tot het EWRM (1996), p. 1-1759. 
drag van Nice aangenomen, maar nog niet in werking getreden. ${ }^{203}$ Een aantal rechten in het Handvest is van belang voor het recht op persoonlijkheid. Het Handvest codificeert in Art 12 een recht op eerbiediging van het privé-lewen. ${ }^{204}$ In Art. 1 Handvest is het recht op menselijke waardigheid opgenomen, terwijl het recht op eerbiediging van de menselijke integriteit is opgenomen in Art. 3. Onder Art. 3 worden fysieke en geestelijke integriteit eveneens begrepen. Van het Handwest gaat aldus geen bindende werking uit. Dat will niet zeggen dat aan het Handvest geen betekenis toekomt in de imterpretatie van het Hof; er gaat echter geen juridische binding vanuit. ${ }^{205}$ Het heeft voorlopig de status van plechtige proclamatie. De vraag is reeds gerezen of een bindende status van het Handwest niet wenselijker is dan de huidige niet-bindende. Het Hof heeft tot dusverre bepalingen wit het Handvest niet expliciet in zijn rechtsvinding willen hanteren; het Gerecht wan Eerste Aanleg is in dit opzicht recentelijk stoutmoediger geweest. Het heeft in twee uitspraken gerefereerd aan het recht op toegang tot een rechter zoals dat is vastgelegd in Art. 41 Handvest. ${ }^{206}$

\subsubsection{Het Gemeenschapsrecht en het Europese Verdrag van de Rechten van de Mens}

In de zaak Nold identificeerde het Hof het EVRM als één van de bronnen van grondrechten voor het $\mathrm{EG}$-recht, maar in die zaak werd verder geen specifieke verwijzing aangetroffen naar de betekenis van EVRM-rechten voor het EG-recht. ${ }^{207}$ In Rutili stipuleerde het Hof dat bij de uitleg van EG-Verdragsregels rekening diende te worden gehouden met de beperkingsmethoden die zijn neergelegd in de leden 2 van de Artt. 8 tot en met 11 van het EVRM. ${ }^{208}$ Ter zake van aanspraken op het recht op privé-leven bleek het EVRM van grote inspiratie woor het Hof van Justitie. Formeel is het Hof niet gebonden aan het EVRM, maar in de praktijk blijkt een bepaalde mate van de facto bin-

203 Handvest van de Europese Unie, (2000, O.J. C 364/1). Enkele tijdschriften wijdden een (deel van cen) aflevering aan het Handvest, zie Maastricht Journal of European and Comparative Law (2001) vol. 8 afl. I (met bijdragen val onder meer A.W. Heringa en L.F.M. Verhey, L.F. Besselink, B. de Witte en K. Lemaerts en E. de Smijter); NJCM Bulletin 2000, vol. 25 afl. 5 (p. 924-967).

204 Art. 12 van het Handwest luidt. 'Benieder heen recht op eerbiediging van zijn privéleven, zijn goede

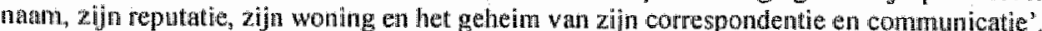

205 Er wend reeds gespeculeerd over de vraag hoe de Luxemburgse rechter om zou gan met het Handvest Zou de rechier het Handwest negieren en woortgan op de weg wan het ontlenen van rechtsbeginselen aan de gemeensehappelijke tradities van de Lid-Sitaten, zou het Handvest als aanknopingspunt dienen bij de interpretatie en positivering var grondrechten, of zou er rechtstreeks wonden getoetst aan het Handvest? Zie onder meer Mededeling van de Commissie over de arard van het Handvest vain de Grondrechten van de Europese Unie, COM (00)644 (10 oktober 2000); De Witte 2001, p. 81 e.v; Conclusie van A-G Tizzano bij BECTU, (2001) bij zank C-173/99, Jur, 2001, 1-4881, Conclusie A-G Jacobs bij Union de Prquehos Agricoltores 1. Raad, zaak C-50/00 van 21 mant 2002, par. 39

206 Het Gerecht van Eerste Aanleg heeft het Handvest inmiddels meerdere keren genoemd als grondstag voor cen individuele aamsprak, zie zaak T-54/99 max, mobil Telekommmikation Service GmbH: Commissie, GVEA 30 januari 2002, EHRC 2002/54 (par, 48) en Zaak T-177/01, Jego-Quéré e.a. t. Commissie. GVEA 3 mei 2002, EHRC $2002 / 55$ (par. 42). In een recente zaak heeft het Hof de vaststelling wan het Gerecht, dat bet individu een recht op toegang toti de rechter toekomt zoals gefornuleerd in het Handvest, afgewezen (zie Union de Pequeños Agricollores t. Raad, zaak C-50/00, HVI EG 25 juli 2002).

207 Nold t. Conmissie, zaak $4 / 73$.

208 Rurili t. Minister van Binnenlandse Zaken, zaak 36/75, (1975), Jur. p. 1219 (1975), par. 32 
ding niet te kunnen worden ontkend. ${ }^{209}$ Dat houdt echter weer niet in, dat de interpretaties van Art. 8 EVRM door het Luxemburgse en het Stratsburgse Hof geheel synchroon lopen. ${ }^{210}$ Het Luxemburgse Hof accepteerde niet, dat rechtspersonen een aanspraak zouden kumnen doen op Art. 8 EVRM. Het Straatsburgse Hof was onder omstandigheden bereid te bezien of een bedrijfsrumte kan rekenen op grondrechtelijke bescherming onder Art. 8 EVRM. ${ }^{211}$ Ook ter zake van andere EVRM-rechten werden verschillende interpretaties gegeven. ${ }^{212}$ De verschillen in witleg worden toegeschreven aan de verschillende contexten waarin op de rechten een aanspraak wordt gedaan, alsmede aan het feit dat het Luxemburgse Hof een meer economische benadering hanteert vanuit de doelstellingen van het verdrag. Er zijn ook uitspraken aan te wijzen, waarin het Luxemburgse Hof zich juist verliet op Straatsburgse de vaststelling van de reikwijdte van fundamentele rechten. De definitie van een transseksueel en zijn aanspraak op privacy werd bijwoorbeeld geheel geent op de rechtspraak van het Straatsburgse Hof. $^{213}$

\subsection{Raad van Europa: het Europees Verdrag voor de Rechten wan de Mens}

\subsection{Het EVRM: grondwet en grondrechten}

De Lid-Staten van de Raad van Europa sloten het EVRM in 1950 om de vrijheidsrechten te garanderen. Het EVRM legt afdwingbare individuele rechtsbescherming vast; het Europees Hof voor de Rechten van de Mens (EHRM) doet in geschillen tussen individuen en staten als hoogste rechter bindende uitspraken over de interpretatie van de rechten die in het EVRM zijn neergelegd. Het EVRM ontbeert echter een institutionee], kader zoals 'vereist' in een constitutie: bevoegdheden van andere actoren dan die van de rechterlijke macht zijn niet vastgelegd. ${ }^{214}$ Het institutionele kader waarin horizontale en verticale machtenscheiding worden toebedeeld, ontbreekt aldus in het EVRM. Aan de formele definitie van een constitutie lijkt niet te zijn voldaan. ${ }^{215}$ Van belang in het

209 Pescatore 1988, p. 441.

210 Met het Luxemburgse Hof wordt bedoeld het Hof van Justitie wan de EO, terwijl met foet Stratlsburgse Hof het EHRM word geduid.

21 I Zie respectievelijk Hoechst t. Commissie, gevoegde zaken 46/87 en 227/88 (1989), Jur. p. 2859(1989), Niemierz t. Dwitsland, EHRM 16 december 1992 , Serie A vol $251-\mathrm{B}$, par. 29 e. en recentelijk T-305. 94 Limburgse Vinyl Commissie, GwEA 20 april 1999, Jur. 1999, p. Il-931 (zie voor de witwerking wath de vergelijking hierna 8.3.4).

212 Zie bijvoorbeld Orhem 1. Commissie, zaak 374/87 (1989), Jar. p. 3283 (1989). Namr de interpretat lie van het Stratsburgse Hof in Funke 1. Frankejk (EHRM 25 tebruari 1993, Serie A vol. $256-A$ ) kin het individu niet worden gedwongen, te getuigen tegen zichzelf", maar de Luxemburgse rechter dacht hier anders over - dat recht geldt, blijkens Orkem, niet voor rechlspersonen.

213 P. S. en Cornwall Couwy, zaak $13 / 94$ (1996), Jur p. 1.2143 (1996). Hel ging hier om de anmlknoping wan het Luxemburgse Hof bij de Straatsburgse vaststelling, dat de groep transseksuelen eden identificeer" bare groep

214 Alkema 2000, p. 45.

2.15 Alkema 2000, p. 62 . In dit verband kan eventueel fragnentarisch van een constifutie op livet wak van machtenscheiding nussen het EHRM en de verdragsstaten gesproken worden: de aanwezigheid van de doctrine in de rechtspraak van de "nnargin of appreciation" wijst op het besef van een verdeling van be- 


\section{Hoofostuk 2}

kader van dit onderzoek is dat er een finale arbiter in het rechtsstelsel bestaat, die in laatste instantie een bindende uitspraak kan doen over de rechtsnormen in het EVRM. Indien het Hof ter zake van handelingen van de staten strijdigheid met het EVRM vaststelt, is de verdragsbepaling in beginsel superieur. In monistische stelsels als het Nederlandse is implementatie van het EVRM niet, in dualistische stelsels is transformatie wan het EVRM naar het nationale recht wel noodzakelijk. In dualistische stelsels zoals Duitsland heeft het EVRM de status van een nationale wet. In die hoedanigheid staat het EVRM in rang onder de nationale grondwet, het Grundgesetz. Dit doet niet af aan het feit dat het Hof de hoogste rechterlijke instantie is die een bindende uitspraak doet over de interpretatie van het EVRM. Duitsland heeft eveneens de rechtsmacht van het Hof aanvaard, en dient zich neer te leggen bij de interpretatie die het Hof aan het EVRM geeft. ${ }^{216}$ Het EVRM legt in de preambule een aantal uitgangspunten neer ter zake van de democratie en de rechtsstaat. De vergelijkbaarheid van het EVRM met de andere rechtsstelsels wordt aangenomen vanwege het bestaan van de afdwingbare en effectieve individuele rechtsbescherming van grondrechten.

\subsubsection{Art: 8 EVRM: het recht op 'privé-leven"}

De belangrijkste bepaling waarin het recht op persoonlijkheid tot uiting komt, is Art. 8 EVRM. Art. 8 EVRM kent bescherming toe aan het recht op respect voor het privéleven, het familie- en gezinsleven, het recht op respect voor de woning en briefwisseling. Deze afzonderlijke rechten worden beschouwd als onderdelen van het recht op persoonlijkheid. In de praktijk worden de individuele aanspraken meestal gericht op Art. 8 EVRM in zijn geheel. Beroep op slechts één van de in Art. 8 EVRM genoemde onderdelen leidt in beginsel niet tot uitsluiting op één van de andere elementen van Art. 8. ${ }^{217}$ Het recht op privacy is tot dusverre niet omschreven als een afgrensbaar recht; het heeft tot op heden een zekere mate van vaagheid behouden. De raadgevende Vergadering heeft in een Resolutie een algemene formulering van het recht op privacy gegeven:

'The right to privacy consists essentially in the right to live one's own life with a minimum of interference. 11 concerns private, family and home life, physical and moral integrity. honour and reputation, avoidance of being placed in a false light, non-revelation of irrele-

woegdheden ter zake van de invulling en toepassing wan de grondrechten in het EVRM. Die verdeling viudt plats tussen de besluitvormende bevoegdheid van thet Hof enerzijds en die vain de staten anderzijds. Zie voor uitwerking van de 'margin of appreciation' Schokkenbroek 1996. Op dit punt wordt
ingegatn in par. 3.5.5.

216 ln het Nederlandse stelsel is de rechter ap grond van Art. 93 en 94 Grondwet werplicht rekening to houden met het EVRM (en andere eenieder verbindende bepalingen van intemational recht); in Duitsland heeft het EVRM rechtskracht verkregen na transformatie tot mationale wet (Hesse 1990, p. 117),

Ook de Duitse rechter dient het EVRM eveneens te respecteren (zie Frowein 1992, p. 121).
217 Wan Dijk en Van Hoof $1998 . Z$ ie echter $X$ en $Y t_{\text {. }}$ Zwitserland, was in het geval van een vader en zijn wriendin geen sprake is van gezinsleven, mar wel van privé-leven (Besluit Commissie 14 juli 1977 , zaak $7289 / 75$ en $7349 / 76)$, en $X$ en $Y$ s. Verengigd Konink $i j k$, waarin de homoseksuele relatile niet onder de notie van gezinsleven wordt beschouwd maar wel onder die van privé-leven (Besluit Commissie 3
mei 1983 , zak $9369 / 81$ ). 
vant and embarrassing facts, unauthorised publication of private plotographs, protection from disclosure of information given or received by individual confidentiality". ${ }^{218}$

De opstellers van het EVRM hebben geen sluitende omschrijving van het recht op privé-leven of van de andere aspecten van Art. 8 gegeven. De reikwijdte van Art. 8 EVRM is met name in de Straatsburgse rechtspraak tot ontwikkeling gekomen. ${ }^{219}$ Deze ontwikkeling zette zich eerst in vanaf het begin van de jaren zeventig. ${ }^{220}$ Het EHRM heeft zich evenmin gewaagd aan een uitputtende definitie van Art. 8 EVRM; dat acht het zowel onmogelijk als niet noodzakelijk. ${ }^{221}$ De Commissie ${ }^{222}$ en het Hof hebben evenwel elementen aangereikt, die constituerend zijn voor de invulling van Art. 8 EVRM. Eén omschrijving luidt als volgt:

"The right to respect for private life is of such a scope as to secure to the individual a sphere within which he can freely pursue the development and fulfilment of his personality" "223

Op zeer uiteenlopende feitencomplexen heeft het EHRM het recht op privé-leven van toepassing verklaard. Er worden verschillende onderverdelingen aangedragen in de literatuur; hier worden, zonder volledigheid wa te streven, enkele voorbeelden gegeven van terreinen die in de rechtspraak onder" Art. 8 zijn beoordeeld. De eerste onderscheiding is al in de verdragsbepaling zelf aangebracht. ${ }^{224}$ Het recht op privé-leven heeft vooral relief verkregen in de rechtspraak van het EHRM. Aanspraken werden gedaan in verband met zeer uiteenlopende feitencomplexen en bestonden onder andere wit aanspraken op een recht, geînformeerd te worden ter zake van de kwaliteit van de Jeefomgeving, belangen die te maken hebben met de erkenning van de persoonlijke of seksuele identiteit in het maatschappelijk verkeer, het recht om persoonlijke gegevens af te schermen van de openbaarheid, het recht op etnische identiteit, kennis van de persoonlijke ontwikkeling en geestelijke en fysieke integriteit. ${ }^{225}$ De Commissie behandelde een zaak over abortus; de vraag rees of een aanspraak op het ongestraft laten plegen van abortus onder Art. 8 EVRM kon worden beoordeeld. ${ }^{226}$ De Commissie erkende

218 Zie bijwoorbeeld de Raad van Europa, die in een poging het priveśleven te onischrijyen de volgende uitspraak over de inhoud van dat recht deed: (voorbeeld ontleend aan Van Dijk en van Hoof 1998, p. 489; zie verder Resolutie 428 (1970), Council of Europe, Collected Texts, Straatsburg 1979, p. 908). In de Travaux Prêparatoires is evennin een goede omschrijwing te vinden wan het recht op privé-leven.

219 Zie De Boer 1990, p. 26 e.v. voor de rechtspraak tot 1990; ema zie onder meer Heringa 1999.

220 A.J. Nieuwenhuis $2001, \mathrm{p} .117$.

221 Zie bijvoorbeeld Niemietz ". Duitsland, EHRM 16 December 1992, Serie A vol. no. 251-B, par, 29 en Costello-Raberts i. Verenigd Koninkrijk, EHRM 25 maart 1993, Serie A vol. 247.C par. 36.

222 Sinds de inwerkingtreding van het Elfde Prolocol is de Europese Commissie opgegaan in het Horf: De interpretatie die de commissie tot dan toe had gegeven aan de uilleg van verdragsbepalingen is evenwel nog immer van betekenis. Zie par. 3.5.2.

223 Besluit Conmissie 19 mei 1976, zaak 6959/75, Briggemann en Scheuten t. Duitstand, zie evencens Niemietz t. Duitsland, EHRM 16 december 1992, Serie A vol. 251-B, par. 30.

224 Zie voor uitwerking wan deze in Art. 8 EVIRM genoemde rechten onder meer Staal 1995, p. 211 e.v. en Van Dijk en Van Hoof 1998, met name hoofdstuk 7 par. 8.

225 Zie voor onderverdelingen onder meer Verhey, die een onderscheid aanbrengt fussen 'informationele privacy" en "relationele privacy". Daarnaast specificeert hij nog enkele afzonderlijke categorieèn zoals het recht op lichamelijke integriteit (Verhey 1992, p. 199 e.v.). Zie verder Van Dijk en Van Hoof 1998. p. 491-503; Heringa 1999, p. 2 e.v. en A.J. Nieuwenhuis 2001, p. 127 e.v.

226 Besluit Commissie 19 mei 1976 , zaak 6959/75, Bringgemann en Scheuten t. Duitsland. 
deze aanspraak onder Art. 8 EVRM. Het Hof heeft steeds een extensief interpretatiebeleid gevoerd ten aanzien van Art. 8. Dat houdt niet in dat Art. 8 onbegrensd is; in Botta lijkt het Hof op de grenzen van de reikwijdte van Ant. 8 te zijn gestuit. ${ }^{227}$

Beperkingen van het recht op privé-leven vinden steeds plaats in de toetsingsfase, wanneer het besluit, de aanspraak te erkennen onder Art. 8 EVRM, gevallen is. Beperkingen zijn mogelijk indien zij zijn voorzien bij wet en noodzakelijk in een democratische samenleving, in het belang van eén of meer in Art. 8 lid 2 EVRM genoemde doelcriteria. Het voorzienbaarheidscriterium is door het Hof verder uitgewerkt in zijn rechtspraak; het vereist niet dat er sprake is van een beperking in de vorm van een formele wet. In de rechtspraak ontwikkelde rechtsnormen kunnen, mits voorzienbaar, eveneens een rechtsgeldige bepetkingsgrond vormen. ${ }^{228}$ Dit soort normen dient eveneens voldoende toegankelijk te zijn, hetgeen inhoudt dat het individu er notie van moet kunnen nemen. De eis van het gerechtvaardigd doel is van belang in verband met de legitimiteit van de achter de beperking gelegen doelstelling. De notie van noodzakelijkheid van de beperking in een democratische samenleving stelt het Hof in staat, de toetsingsintensiteit van de gewraakte handeling van de staat te variëren. De mate waarin streng of minder streng wordt getoetst hangt onder meer samen met de aard van de inbreuk of de positie van de klager; het hof hanteert hier een proportionaliteitstoets. ${ }^{229}$ In beginsel laat het Hof de mate waarin het intieme privé-leven is aangetast meewegen. ${ }^{230}$ Er kan in dit opzicht echter niet worden gesproken van een sferenleer zoals bet Duitse Federale Constitutionele Hof die wat stelselmatiger hanteert. Het Hof hecht in dat opzicht sterk aan de castuistische benadering, die het steeds zegt te hanteren. Van groot belang in de toetsingsfase is eveneens de 'margin of appreciation', die het bestaan van een beoordelingsruimte voor de nationale autoriteiten mogelijk maakt. In sommige gevallen kent het Hof een ruime beoordelingsmarge toe, die in beginsel tot gevolg heeft dat er een marginale toetsing plaatsvindt van de gewraakte wet. Dat wil overigens niet zeggen, dat een marginale toets steeds leidt tot instandhouding van de nationale wet; het is mogelijk gebleken, dat het EHRM ondanks marginale toetsing toch schending van het EVRM vaststelde. Een beoordelingsmarge wordt aan de nationale autoriteiten overgelaten in verschillende omstandigheden. Wanneer goede zeden, sociaal-economische wetgeving of specifieke discretionaire bevoegdheden aan de orde zijn, is het Hof in beginsel genegen een beoordelingsmarge aan te nemen. ${ }^{231}$

227 Borka t. lialiè, EHRM 24 tebruari 1998, JB 1998/70. Zie ook hierna par. 8.3.1.

228 Naarmate het Hof in een specifieke zaak heeft aanvard dat sprake is van een intiene prive-sfeer, zal het Hof strengere eisen stellen ter zake van het voorzienbaarheidscriterium.

229 Ter zake van de positie van de klager, zie bijvoorbeeld Campbell t. Perenged Konimkrijk, EHRM 25 mant 1992, Serie A vol. 233. Het Hof beoordeelde in deze zaak, in hoeverre het openen van correspondentie van gedetineerden in een wet vastgelegd dient te zijn.

230 Zie bijvoorbeedd Lustig-Prean en Becket t. Verenigd Koninkrijk, EHRM 27 september 1999, JB 1999/ 261.

231 Zie ook par. 2.5 .5 . 


\subsubsection{Derdenwerking van Art. 8 EVRM}

In beginsel wordt het handelen of nalaten daarvan wan een staat ter beoordeling aan het Hof woorgelegd. ${ }^{232}$ Zaken die op nationaal niveau worden beoordeeld onder horizontale werking, verkrijgen in Straatsburgs perspectief echter verticale werking. ${ }^{23 / 3}$ Verticale werking van het EVRM is uitgangspunt. ${ }^{234}$ In de rechtspraak is echter erkend, dat elementen wan horizontale werking niet zijn uitgebannen. $Z$ ij kunnen in ieder geval op indirecte wijze een rol spelen: de verwerende stat kan bijvoorbeeld onvoldoende effectieve rechtsbescherming hebben geboden in een conflict over het recht op privacy tussen twee particulieren. Art. 8 kent primair een onthoudingsplicht voor de staat, maar positieve verplichtingen van de staat kunnen juist ook leiden tot een werplichting tot handelen door de staat ${ }^{235}$ Deze noodzaak kan bestaan omdat overheidshandelen in sommige gevallen een effectieve bescherming van Art. 8 EVRM kan sorteren. ${ }^{236}$ In de rechtspraak van het EHRM is het bestaan van positieve verplichtingen ter zake van Art. 8 EVRM relatief vaak aangenomen.

\subsection{Nederland: de Grondwet}

In werband met de constitutionaliteit van de EG-rechter en het EHRM werd voorheen de vraag gesteld, in hoeverre de uitspraken van de betrokken rechters vergeleken kunnen worden met de uitspraken van de rechters van de overige rechtsstelsels: de EGrechter heeft geen geschreven grondwet tot zijn beschikking, terwijl het EHRM niet te maken heeft met een 'wetgever'. De Nederlandse situatie kent eveneens een eigenaardigheid: de Hoge Raad is niet toegerust met jurisdictie ter zake van uitleg van de grondwet wanneer de gewraakte wetgeving afkomstig is van de formele wetgever. ${ }^{237}$ Deze rechter oordeelt als een civiele- en strafrechtelijke instantie en als belastingrechter. ${ }^{238}$ Dat neemt niet weg, dat deze rechter als laatste instantie bindende uitspraken doet over de strekking en reikwijdte van de Nederlandse grondwet. In Nederland geldt vanwege het gematigd monistisch karakter van de Nederlandse rechtsorde een nationaal-en een internationaal-rechtelijk regime. Voor Nederland relevante internationaal. rechtelijke aspecten van het recht op persoonlijkheid zijn vastgelegd in Art. 8 EVRM en Art. 17 IVBPR. Daarnaast zijn Artt. 10 en 11 Grondwet belangrijke bronnen van dat recht. Het recht op persoonlijkheid is niet als zodanig in de Nederlandse grondwet geformuleerd - er wordt gesproken over een recht op eerbiediging van de persoonlijke

232 Art. 34 EVRM stipuleer dai verzoekschriften kunnen worden ingediand varwege een vermeende schending van eén wan de verdragspartijer.

233 Heringa 2000 , p. 1 .

234. Herimga 2000 , p. 1 .

235 Voor uitwerking van positieve verplichtingen zue Van der Velde 2002.

236 Zie bijvoorbeeld Airey t. lerland, EHRM 9 oktober 1979, Serie A val, 32 en $X$ en $Y$ t. Nederland, EHRM 26 maart 1985, Serie A vol. 91.

237 Zie ook par. 3.6 .

238 Zie par. 3.6.1 e.y. Er is geen rechtspraak van enige bestuursrechter opgenomen in dit onderzoek. De rechtspraak van bestuursrechters lant in beginsel geen rechtsontwikkeling zien op het terrein van het recht op persoonlijkheid en aanwerwante rechten. 
levenssfeer. ${ }^{239}$ Voor het eerst werd aan het recht op persoonlijke levenssfeer in de Nederlandse literatuur aandacht geschonken in de Preadviezen van De Brauw en Van Veen in 1965. ${ }^{240}$ Daarin werd het recht op een persoonlijke levenssfeer benaderd vanuit een meer fysieke invalshoek, maar eveneens in overdrachtelijke zin en aldus niet tot een ruimtelijk begrip beperkt. De Brauw definieerde thet recht op privé-leven als 'het geheel der omstandigheden waaronder het individu bepaalde gedragingen en uitingen aan de waarnemingen van de gemeenschap wil ontrekken'. ${ }^{241}$ De Nederlandse grondwet beschermt de ruimtelijke component van oudsher met het huisrecht. ${ }^{242} \mathrm{Bij}$ de amendering van de grondwet in 1983 werden daaraan het recht op de persoonlijke levenssfeer, het tellefoongeheim en het recht op onaantastbaarheid van het menselijk lichaam toegevoegd. ${ }^{243}$ Het bestaan van een fysieke en een meer overdrachtelijke ruimteoverstijgende - component is min of meer overeind gebleven. De Nederlandse grondwetgever heeft geen scherpe afbakening van het recht op een persoonlijke levenssfeer gegeven. Er lijkt in de Nederlandse situatie een sterke verwevenheid te bestaan tussen Art. 10 Grondwet en Art. 8 EVRM.

\subsubsection{Art. 10 Grondwet: eerbiediging van de persoonlijke leverssfeer}

Sinds de amendering van 1983 biedt Art. 10 Grondwet een algemene bescherming aan de persoonlijke levenssfeer. Aan lid 1, het recht op eerbiediging van de persoonlijke levenssfeer, kunnen directe aanspraken worden ontleend. Invoering van het recht werd door de regering noodzakelijk geacht als voorwaarde voor een menswaardig bestaan. ${ }^{244}$ Technologische ontwikkelingen alsmede de heersende overtuiging dat een behoefte aan bescherming van de persoonlijke levenssfeer is toegenomen hebben er eveneens toe geleid dat dit grondrecht afzonderlijk werd opgenomen. Van de inhoud en reikwijdte werden echter geen duidelijke omtrekken vastgesteld. ${ }^{245}$ De afbakening van het grondrecht is volgens de regering een taak voor onder meer de rechter die op casuilstische basis verdere inhoud en reikwijdte dient vast te stellen. De regering sprak bij de grondwetsherziening over een marge waarbinnen de rechter een vormende taak toekomt, maar gaf geen grenzen van die marge aan. De regering ging bij het recht op persoonlijke levenssfeer uit van een fysieke en een meer overdrachtelijke component: enerzijds gaat het om situaties waarin het individu het recht heeft, zich af te schermen en niet geobserveerd te worden, terwijl anderzijds een reeks van gedragingen die onder Art. 10 Grondwet vallen, als voorbeeld worden genoemd. Art. 10 leden 2 en 3 Grondwet regelen afzonderlijk het recht op het vastleggen en verstrekken van persoonsgegevens. Deze artikelen dragen eerder het karakter van een instructienorm voor de wetgever, dan

239 Zie voor uitgetyreide (historische) beschouwingen over het recht op earbiediging van de persoonlijke levenss feer Blok 2002, met name hoofdstuk 3.

240 P.J.W. De Brauw en Th. W. Van Veen 1965.

241 P.J.W. De Brauw en Th. W. Van Veen 1965, p. 11.

242 Zie het haisrecht, wastgelegd in Art. 12 grondwet.

243 Zie voor uitgebreidere beschouwingen onder meer A.J. Nieuwenhuis 2001 en Verhey 1992.

244 Bijlage Handelingen III 1975/1976, 13872 nr. 3, p. 39.

245 De regering stelde het volgende: 'de persoonlikke levenssfeer bevat tal wan terreinen, welke zeer uiteenlopend van aard en problematick zijn en waarwan sommige nog volop in ontwikkeling zijn', zie Bijlage Handelingen II 1975/1976, 13872 nr. 3, p. 40. 
dat het individu er direct aanspraken aan kan ontlenen. ${ }^{246}$ Beperkingen op privacy kunnen worden gesteld bij of krachtens de wet; de grondwet gaat in beginsel uit van competentiecriteria. ${ }^{247}$ Daarnaast zijn de beperkingsgronden ex Art. 8 EVRM van belang. ${ }^{248}$

\subsubsection{Art. 11 Grondwet: het recht op lichamelijke onschendbaarheid}

Het recht op lichamelijke onaantastbaarheid werd afzonderlijk opgenomen bij de grondwetsherziening van 1983. De regering was van oordeel, dat dit element van het privé-leven reeds voldoende werd afgedekt door Art. 10 Grondwet, maar kennelijk werd een aparte regeling voor dit onderwerp noodzakelijk geacht. ${ }^{249}$ Naast afscherming van het lichaam wordt ook de zelfbeschikking over het lichaam gedekt door dit artikel. ${ }^{250}$ Een sluitende begripsomschrijving werd echter niet gegeven. ${ }^{251}$ Een aantal belangwekkende opmerkingen werd door de regering bij de totstandkoming van dit artikel gemaakt: uit Art. 11 Grondwet kon geen recht op actieve euthanasie voortvloeien. In dit opzicht werd er aldus een barrière geplaatst voor rechterlijke interpretatie. Het grondrecht kent naast een onthoudingsplicht eveneens een verplichting van de overheid te zorgen voor daadwerkelijke verwezenlijking van het recht op lichamelijke onaantastbaarheid. Het recht op geestelijke integriteit behoort in beginsel tot de rechten die Art. 10 Grondwet beoogt te beschermen. ${ }^{252}$ Beperkingen op Art. 11 Grondwet behoeven een grondslag in de wet in formele zin. Delegatie behoort tot de mogelijkheden. Ook hier zijn enkel competentiecriteria vastgelegd, en kunnen de beperkingsgronden ex Art. 8 EVRM worden benut voor het aanbrengen van beperkingen. Grondwettelijke bepalingen kunnen in de Nederlandse rechtsorde in beginsel niet leiden tot buiten toepassing laten of tot onverbindendverklaring van wetten in formele zin. ${ }^{253}$ Dat verklaart deels de vooraanstaande rol die Art. 8 EVRM wordt toebedeeld: via Art. 94 kumnen wetten in formele zin evenwel buiten toepassing worden gelaten in het individuele geval of in het algemeen onverbindend worden verklaard vanwege strijd met een eenieder verbindende verdragsbepaling.

246 Heringa en Zwart 1991, p. 57 en Verhey 1992, p. 198.

247 Dit competentiecriterium schept naast de mogelijkheid wan beperking door de formele wetgever de optie var delegatie. Deze mogelijkheden werden opzettelijk ruim gehouden omdat op dat moment nog niet kon worden overzien welke beperkingen in de toekonnst eventueel noodzakelijk zouden blijken (Bijlage Handelingen II 1975-1976, 13872 nr. 3, p. 41.

248 Zie hieronder in par. 1.7.3.

249 Bijlage Handelingen 1978-1979, 15463 nr. 1-2, p. 4 en Zwart 1985, p. 256.

250 Bijlage Handelingen 1978-1979, $15463 \mathrm{mr} .1-2, \mathrm{p} .5$. Onder anderen de volgende handelingen kunnen in het geding zijn in verband met Art. 11: Vijfstraffen, mishandeling, gedwongen medicatie, gedwongen toediening van woedsel, operaties en het ondergaan van medische keuringen.

251 Bijlage Handelingen 1978-1979, 15463 ur. 1-2, p. 4.

252 A.J. Nieuwenhuis 2001 , p. 150.

253 Zie het Harmonisatiewerarrest, HR 14 april 1989, NJ 1989/469 ter zake van thet toetsingswerbod van formele wetgeving en Doorbraakarrest, HRR 12 april 1978, NJ 1979/533 voor de uitzondering die in sommige gevallen - wanneer de wetgever in formele zin de ingreuk op een grondrechtelijke aanspraak niet heeft verdisconteerd-mogelijk is. 


\subsubsection{Ant 8 EWRM: het recht op eerbiediging wan 'privé-leven'}

Art. 8 EVRM maakt via Art 94 Grondwet als een eenieder verbindende bepaling deel uit wan de Nederlandse rechtsorde. In de jurisprudentie tot halverwege de jaren zeventig speelde Art. 8 EVRM nawwelijks een rol van betekenis. ${ }^{254}$ De Nederlandse rechter heeft zich na die tijd voor de reikwijdte van Art. 8 EVRM laten inspireren door de Straatsburgse interpretaties ter zake. ${ }^{255}$ Onder de daar tot stand gebrachte interpretaties heeft de rechtsontwikkeling op het terrein van privacy een hoge vlucht genomen. ${ }^{256}$ Het lijkt er in de Straatsburgse rechtspraak de laatste jaren steeds meer op, dat privacy een overkoepelend recht is, terwijl het familie- en gezinsleven, de onschendbaarheid van de woning en het briefgeheim als verbijzonderingen te beschouwen zijn van privacy. ${ }^{257}$ Het recht op lichamelijke onaantastbaarheid in Art: 11 Grondwet vindt in Europees verband bescherming onder Art. 8 EVRM. De notie wan privacy in het EVRM schept niet meer helderheid in vergelijking met de Nederlandse notie. Beperkingen zijn mogelijk op grond van Art. 8 EVRM lid 2. De inbreuk moet bij wet zijn voorzien, dat wil zeggen kenbaar zijin en voorzienbaar. De beperking dient eveneens noodzakelijk te zijn in een democratische samenleving. Art. 17 IVBPR beschermt tegen een aantasting van de persoonlijke levenssfeer. Ook dit verdragsartikel werkt door in de Nederlandse rechtsorde. Het legt de bescherming van de goede naam vast, naast de in Art. 8 EVRM genoemde rechten. Beide internationale verdragen leggen een aantal materiële beperkingscriteria aan, waarvan de Nederlandse rechter tot dusverre in wisselende mate gebruik heeft gemaakt. De toetsing aan de maatstaven van de internationale verdragen wordt door de Hoge Raad echter meestal summier gemotiveerd. ${ }^{258}$

\subsubsection{Het "algemene persoonlijkheidsrecht"}

In de jurisprudentie van de Hoge Raad is relatief recentelijk een recht op algemene persoonlijkheid tot ontwikkeling gekomen. ${ }^{259}$ Het algemene persoonlijkheidsrecht ligt, aldus de Hoge Raad, ten grondslag an uiteenlopende in de grondwet gepositiveerde grondrechten. ${ }^{260}$ Het recht is in een privaatrechtelijk geschil tot ontwikkeling gekomen, maar de Hoge Raad koos afgaand op de in het geschil aan de orde zijnde aanspraak voor een grondrechtelijke notie. De Hoge Raad spreekt in verband met het algemene persoonlijkheidsrecht niet over een beginsel, maar over een recht. De vraag rijst of die opmerking terecht is, gezien de positionering die door de rechter wordt toegekend aan het recht: die doet eerder vermoeden dat het om een rechtsbeginsel gaat. ${ }^{261}$ In dit op-

254 Verhey 1992, p. 232

255 Zie bijwoorbeeld de zogenoende woorjaarsbesctikkingen HR 4 mei 1984 , NJ $1985 / 510$ en IIR 21 maart $1986, \mathrm{NJ} 1986 / 585-588$ voor rechtsvinding door de Hoge Raad op het terrein wan het personen- en familierecint.

256 Overkleeft-Verburg 2000, p. 166

257 Verhey 1992, p. 200

258 Verhey 1992, p. 205 .

259 Zie voor uitgebreide materide beschonwingen en en vergeljiking met Duitsland Nehmelman 2002.

260 Wakenhorst, 15 april 1994, NJ 1994/608.

261 Zo stelt Verhey in zijn noot bij Valkenhorst: "In vergelijking tot de in de Grondwet gecodificeerde rechten beweegt het algemene persoonlijkheidsrecht zich op een hoger abstractieniveau en heeft aldus een 
zicht doet de positivering van het recht in de rechtspraak denken aan de ontwikkelingen die in de Duitse rechtspraak hebben platsgevonden: ook daar heeft het Bundesgerichtshof in een privaatrechtelijk geschil het algemene persoonlijkheidsrecht gepositiveerd. En bestaat veel onzekerheid over de reikwijdte van het recht; de rechter heeft ter zake grenzen aangegeven. Door de wetgever is de notie van het algemene persoonlijkheidsrecht enkele keren gehanteerd. ${ }^{262}$ Het door de Hoge Raad gepositiveerde algemene persoonlijkheidsrecht zal dienen als voorwerp van nader onderzoek ter zake van de vraag, of en in hoeverre de rechter in het kader van de constitutionele verhoudingen nieuwe rechten kan positiveren.

\subsubsection{Privaatrechtelijk begrip van het 'recht op persoonlijkheid'}

Het privaatrechtelijk recht op persoonlijkheid is in de wet in een aantal varianten vastgelegd. De auteurswet kent bijvoorbeeld het pontretrecht en persoonlijkheidsrechten. ${ }^{263}$ Een algemene norm zoals in Art. 10 Grondwet neergelegd bestaat niet in het privatrecht. Toch heeft de notie van persoonlijke levenssfeer uitwerking gekregen in de jurisprudentie, ook al was grondrechtelijke normering tot 1983 niet gepositiveerd ${ }^{264}$ De meeste individuele aanspraken op een privaatrechtelijke notie van het recht op persoonlijkheid kwamen terecht bij de Hoge Raad als civiele rechter via de onrechtmatige daadsactie. Enkele deelaspecten van het recht op persoonlijkheid die door de civielrechtelijke rechter werden beoordeeld, zijn onder meer inperking van het recht op het verzamelen, het vastleggen en het openbaren van gegevens en het recht om niet lastig te worden gevallen door medeburgers. ${ }^{265}$ De reikwijdte van het grondrecht en van het privaatrechtelijke recht op privacy is in veel opzichten vergelijkbaar, maar zij hoeft niet noodzakelijkerwijze samen te vallen. ${ }^{266}$ De uitspraken van de civiele rechter zijn in de Nederlandse situatie van belang, ondat de Hoge Raad als hoogste nationale rechter een bindende interpretatie geeft van de aan privacy gerelateerde grondrechten. De Hoge Raad doet dat in de hoedanigheid van civiele of strafrechter. Erkenning van individuele aanspraken op het recht op persoonlijkheid kwam het vaakst voor in de uitspraken van de civiele rechter.

ruimer toepassingsbereik', aldus Verhey 1994, p. 655; zie ook Kortmann 1996, p. 152.

262 Zie Regels inzake de bescherming van persoonsgegevens (Wet bescherming persoonsgegevens), MVT Kamersiukken II 1997-1998, 25 892, nr. 3, p. 7 e.v., met name p. 10; zie ook Wijziging van boek I van het Burgerlijk wetboek over adoptie door personen van hetzelfde geslacht, Kamerstukken II 1999-2000, 26673 , nir. 5, p. 44 .

263 Respectievelijk Art. 2 Il en 25 Aw; zie ook Ferdi E., HR 21 Januari 1994, NJ 1994, 473. Zie Nehmelman 2092.

264 Zie bijwoorbeeld Fluoridering, Hof 18 december 1973, NJ 1974/64.

265 Zie onder meer Edamse Bijstandswrouw, HR 9 januari 1987, NJ 1987/928, Frerdi E, HR 21 janwari 1994, NJCM 19-6 (1994).

266 Nieuwenhuis 2001, p. 177. 


\subsection{Slot}

Het recht op persoonlijkheid dekt, afgaande op de grondwettelijke- en verdragsbepalingen, een breed scala aan aspecten die op de één of andere manier raken aan het recht van het individu, een eigen leven te kunnen leiden en in te richten zonder inmenging van buitenaf. Afgaande op de situaties die als aspecten van het recht op persoonlijkheid werden aangemerkt, kan een gemeenschappelijke classificatie van een aantal deelaspecten van het recht op privacy worden opgesteld. In de eerste plaats vormt de woning een plaats bij uitstek waar men geen inmenging van buitenaf behoeft te tolereren. In de tweedle plaats wordt in de rechtsstelsels erkend, dat het individu in beginsel over het eigen lichaam mag beschikken. Daarnaast moet het individu vrijelijk relaties aan kunnen gaan met anderen. Hieronder vallen familie- en gezinsrelaties. De mate waarin seksuele relaties worden begrepen onder dit aspect van privacy verschilt in de stelsels. Tevens wordt geheime communicatie in alle rechtsstelsels tot op zekere hoogte erkend als element van privacy. Ten slotte dient het individu in zekere mate invloed op registratie en gebruik van eigen persoonsgegevens te kunnen uitoefenen, om onjuiste of onvolledige beeldvorming bij andere te voorkomen. Persoonsgegevens worden in dit verband ruim opgevat; het gaat hier niet alleen om het vastleggen van data, maar eveneens om beeldmateriaal.

De mate waarin deze elementen in grondwet of verdrag zijn gepositiveerd wisselt. Qua structuur van het recht op persoonlijkheid vertonen grondwet en verdrag verschillen. Het Amerikaanse vrijheidsbegrip werd opgevat als rechtsnomen met een vaag karakter, evenals het Duitse grondrecht op handelingsvrijheid. Het recht op privé-leven in het EVRM en het recht op vrijheid van de persoonlijke levenssfeer in de Nederlandse grondwet zijn eveneens aan te merken als vage normen die een nadere concretisering behoeven. Daarnaast werden in de Amerikaanse, het Duitse en het Nederlandse rechtspraak respectievelijk het recht op 'privacy", het 'allgemeines Persönlichkeitsrecht' en het 'algemene persoonlijkheidsrecht' gepositiveerd door de rechter. De vraag rijst, waarom het noodzakelijk werd geacht om aan de bestaande vage norm een nieuwe norm toe te voegen. Kennelijk bleken de bestaande vage normen in sommige opzichten niet voldoende bescherming te bieden. Opvallend is dat ter zake van de Amerikaanse privacy en het Duitse algemene persoonlijkheidsrecht een ander beperkingsregime geldt in vergelijking met de beperkingen die kunnen worden aangebracht bij de handelingsvrijheid in beide stelsels: ter zake van 'liberty' uit het Veertiende Amendement en het recht op persoonlijke ontplooiing ex Art. 2 lid 1 GG kunnen meer beperkingen worden gesteld. Voor het Nederlandse persoonlijkheidsrecht zijn deze vragen nog niet beantwoord. De Hoge Raad heeft aangegeven dat het recht op persoonlijkheid een rechtsnorm is die zich beweegt boven de geschreven en ongeschreven grondrechten, en lijkt daarmee aan de rechtsnorm een rechtsbeginselachtig karakter toe te kennen. De rechtspraak van het EHRM kent geen door de rechter gepositiveerde norm die verder is gaan functioneren als zelfstandige rechtsgrondslag voor erkenning van individuele aanspraken op het vlak van het recht op persoonlijkheid. Het EHRM heeft daarentegen het recht op privé-leven extensief geïnterpreteerd. Het EG-Verdrag positiveert geen recht op privé-leven, maar het maakt sinds Panasonic als rechtsbeginsel van Gemeen- 
schapsrecht deel uit van de Gemeenschappelijke rechtsorde. Codificatie van individuele rechten in Art. 6 lid 2 EU-Verdrag is het gevolg van een rechtsontwikkeling in de jurisprudentie van het Luxemburgse Hof. Het Handvest kan zich in dit opzicht verder ontwikkelen als bron waaraan rechtsnormen kunnen worden ontleend en waarover consensus bestaat in de Lid-Staten. Enkele stelsels leggen regels neer voor de interpretatie. Deze interpretatieregels zijn tot op zekere hoogte terug te voeren op de historische context waarin de grondwet tot stand kwam.

Het Duitse recht op ontplooiing van de persoonlijkheid ziet niet alleen toe op aspecten van het recht op persoonlijkheid zoals een afgeschermde ruimte of een fysieke integriteit; het stelt de persoonlijkheid van het individu voorop. Het Amerikaanse begrip "liberty' uit het Veertiende Amendement vertoont hiermee op het eerste gezicht grote overeenkomsten. In de andere stelsels worden eerder aspecten van de persoonlijkheid beschermd. Hierdoor wordt de indruk gewekt dat de Duitse en de Amerikaanse grondwettekst het meeste houvast bieden voor erkenning van individuele aanspraken. Dat betekent echter niet vanzelfsprekend dat de in de andere stelsels genoemde rechtsnormen niet de potentie hebben om uit te groeien naar een meer alomvattend recht. De rechtspraakanalyse zal meer duidelijkheid geven over de mate waarin de rechters invulling hebben gegeven aan de hiervoor beschreven rechtsnormen. Vraag is welke invulling de rechter heeft gegeven aan het privé-leven ex Art. 8 EVRM, aan de notie van privacy van het Hof van Justitie van de EG en aan het Nederlandse recht op een persoonlijke levenssfeer.

Het afgrenzen van het recht op persoonlijkheid en van de verbijzonderingen ervan is niet goed mogelijk. De privé-sfeer lijkt met het individu mee te kunnen bewegen. Voor de in de grondwetten en verdragen gepositiveerde rechten die zijn gerelateerd aan een recht op persoonlijkheid zijn in beginsel (ruime) beperkingmogelijkheden gecreëerd. Dat is vanuit het oogpunt van de ruime reikwijdte van de algemene formuleringen niet verwonderlijk. De mate waarin de beperkingsmogelijkheden zich in grondwet en verdrag aandienen vertoont een gevarieerd beeld. Het EVRM kent in Art. 8 lid 2 een materieel toetsingskader, terwijl de Nederlandse grondwet in principe een stelsel van competentiecriteria voorschrijft. De Duitse 'verfassungsmäßige Ordnung' ex Art. 2 lid 1 GG kent zowel formele als materiële beperkingmogelijkheden. Het EVRM en de Duitse rechter hanteren beiden een proportionaliteitstoets. Het EG-Verdrag legt geen toetsingsmethodiek voor beperkingen op het recht op privacy vast, hetgeen tot op zekere hoogte samenhangt met het feit dat dit recht niet is gecodificeerd in het EG-Verdrag. De rechtspraak laat echter geen uitgewerkte beperkingsmethodiek zien. Tenslotte werd ook aandacht besteed aan het recht op persoonlijkheid in het privaatrecht. In Duitsland, Nederland en de Verenigde Staten is de privaatrechtelijke bescherming van het recht op persoonlijkheid voorafgegaan aan de constitutioneelrechtelijke bescherming. In Duitsland en Nederland lijkt van de privaatrechtelijke rechtsontwikkelingen een inspirerende werking te zijn uitgegaan, die de constitutionele rechtsvinding in een later stadium theeft bevrucht. 
De in de rechtsstelsels gesignaleerde eigenschappen van het recht op persoonlijkheid hebben de reehters in de stelsels genoopt tot een standpuntbepaling ten aanzien van de interpretatie van dat recht. De formulering van de aspecten van het recht op persoonlijkheid in grondwet, verdrag en constitutie is, vanwege basis van individuele aanspraken daarop, aanleiding geweest tot nadere plaatsbepaling en reikwijdte van die aspecten door de rechter. Een aanzwellende stroom van individuele aanspraken op én of meer aspecten van het recht op persoonlijkheid noodzaakte de rechter steeds weer tot het vaststellen van de omtrekken van het recht. Het recht blijkt in de afgelopen twee decennia een steeds belangrijker buffer te vormen tegen de inmenging in het persoonlijke leven van buitenaf. Binnen bepaalde grenzen is de rechter verplicht, grondrechtsbescherming te effectueren. Tegelijkertijd dient de rechter constitutionele grenzen waarbinnen hij rechtsbescherming kan bieden te respecteren. De rechter wordt in zekere opzichten vrijheid gelaten ter zake van de interpretatie, omdat de grondwetgever niet concreet heeft aan willen en kunnen geven welke de begrenzingen zijn van de grondrechten. Dat houdt echter niet vanzelfsprekend in, dat de rechter een omvangrijke beoordelingsruimte toekomt, de grenzen van de reikwijdte vast te stellen. Een aantal factoren in het constitutionele bestel beperkt hem in de vrijheid, de omtrekken van het recht op persoonlijkheid en de daaraan gelieerde rechten vast te stellen. Hiertoe behoren in belangrijke mate factoren die samenhangen met de constitutionele verhouding waarbinnen de rechter opereert. Vanwege een constitutionele verdeling van werkzaamheden dient hij zich in principe niet bezig te houden met de taken die aan de wetgever of eventueel aan lagere rechters zijn toebedeeld. Een belangrijke grens is bijvoorbeeld die van de rechterlijke jurisdictie, die bepaalt welke bevoegdheden de rechter heeft ten aanzien van toepassing van grondrechten. Het onderzoek naar begrenzingen die zijn gelegen op het vlak van de omvang van de rechtsmacht - de institutionele begrenzingen - en begrenzingen naar de wetgever - de interinstitutionele begrenzingen - zijn voorwerp van studie in hoofdstuk 3 . 


\title{
Constitutionele verhouding tussen rechter en wetgever
}

\author{
Werkwijze van de rechter in de ontvankelijkheidsfase en de \\ toetsingsfase
}

\subsection{Inleiding}

\subsubsection{De constitutionele verhouding tussen rechter en wetgever}

Met constitutionele verhoudingen wordt hier gedoeld op de taakverdeling tussen de rechter enerzijds en grondwetgever of wetgever" anderzijds.' In dit onderzoek staat in beginsel een speciale constitutionele verhouding centraal: die tussen de hoogste reehter en de formele wetgever. ${ }^{2}$ Door de hiervoor gesignaleerde karakteristiek van het recht op persoonlijkheid in de grondwetten en de verdragen is de druk op de rechter om te beslissen over dergelijke individuele aanspraken aanzienlijk toegenomen: de rechter dient vanwege een aanzwellende stroom aanspraken steeds vaker te beslissen over de reikwijdte van het recht op persoonlijkheid en aanverwante rechten, terwijl de grondwetgever in grondwet of verdrag geen concrete aanwijzingen van de reikwijdte van die rechten heeft neergelegd. Het lijkt er sterk op, dat de rechter zelf de grenzen van rechtsontwikkeling moet exploreren. Tot op zekere hoogte lijkt een rechtsvormende taak van de rechter in de stelsels wel te worden geaccepteerd; er wordt in beginsel echter vanuit gegaan dat de rechter zijjn activiteiten in dit verband "doseert". In dit hoofdstuk wordt bekeken welke factoren die 'dosering' waar het gaat over rechtsontwikkeling als gevolg van rechtsvinding. De in de grondwet of het verdrag neergellegde aanwijzingen lijken nauwelijks concrete begrenzingen van een interpretatiebewoegd-

1 De positie van de uitwoerende macht wordt niet in thet bijzonder in de beschouwingen betrokken. De witvoerende macht is in beginsel belast met de uitvoering van regells binnen de door de wet gestelde kaders. In de uitwoering wordt het bestuur eveneens geconfronteerd met wetsinterpretatie. Het bestuin dient de wijze waarop grondwetgever en rechter fundamentele rechten interpieteren te respecteren. Het bestum kan niet, nadat techter en grondwetgever hebben geoordeeld over strekking en reikwijdte van "privacy", een afwijkende bindende uitspraak doen. De rechispraak van de bestuurstechter kan in het kader van interpretatie van het recht op persoonlijkheid wel weer interessante gezichtspunten opleveren (zie bijvoorbeld 2.6.1), maar zij wordt desondanks nivet in het bijzonder betrokken in de beschouwingen. Naast de takwerdeling tussen wetgever en rechter wordt cveneens de takkverdeling tussen federale en statelijke rechters en wetgevers an de orde gesteld voor zover relevant; deze dimensie in de constitutionele verhoudingen speelt in de Verenigde Staten, în Duitsland en in beperkte mate in de EG een rol

2 In de Verenigde Staten is dat de verhouding tussen het Hooggerechtshof en de federale on de statelijke wetgever; in Duitsland is dat de relatie tussen het Federale Constitutionele Hof en de Federale wetgever of de wetgever van een Bondsland; in de Nederlandse situatie worden in dat verband de Hoge Raad en de formele wetgewer bestudeerd. In het kader van de Raad van Europa wordt met de constitutionele verhouding gedoeld op de verhouding tussen het EHRM enerzijds en de verdragswetgever - de verdragspartijen - die het EVRM hebben geratificeerd anderzijds. Het gaat dan meer specifiek om de wetgeving die door nationale autoriteiten it de verdragsstaat tot stand worden gebracht. In het Gemeenschapsrecht wordt de hier bedoelde constifutionele verhouding bestreken door enerzijds thet Hof wan Justitie en anderzijds de Lid-Staten - als agenten van EG-recht of op zichzellf stanand - en de Instellingen als wetgewende organen van de Gemeenschap. 
heid te geven. ${ }^{3}$ Toch zijn er elementen in de grondwet en het verdrag te ontwaren, die eer indicatie geven van de grenzen van grondwetsuitleg in het licht van de hiervoor genoemde constitutionele verhouding tussen rechter en wetgever, of die tot op zekere hoogte bepalen of de rechter bereid is extensief te interpreteren. De rechter ontleent aan constitutionele uitgangspunten en aan grondwettelijke verdeling van werkzaamheden inspiratie om zijn rechterlijke taakopvatting in te vullen. Vraag in dit verband is wat er onder het begrip 'rechterlijke taakopvatting' moet worden verstaan.

\subsubsection{De rechterlijke taakopvatting}

De rechterlijke taakopvatting wordt hier gedefinieerd als een afweging - in het licht van de constitutionele verhouding tussen de rechter en de wetgever - die de rechter zal maken tussen beoordeling van de individuele aanspraak, de geëigendheid van het rechterlijke proces om het geschil op te lossen, de abstractie van de voorgelegde vraag en de betekenis van de uitspraak aan het einde van zijn rechterlijk besluitvormingsproces. ${ }^{4}$ De rechterlijke taakopvatting is geen onveranderlijk begrip; zij lijkt om uiteenlopende redenen te kunnen variëren. Die redenen kunnen te maken hebben met de aard van de individuele aanspraak: indien de rechter voorziet dat hij zich bij de beoordeling van een aanspraak in een tamelijk onmogelijke positie - indien hij zich bijvoorbeeld tot op grote hoogte zal moeten inlaten met vaststelling van regels - ten opzichte van de wetgever zal manoeuvreren, zal hij zich andermaal bedenken over de vraag of het aan hem is de aanspraak in overweging te nemen. Een ander voorbeeld is dat de rechter de beoordeling van de aanspraak wel billijk acht en dat hij de aanspraak erkent als grondrechtelijk beschermenswaardig, maar dat hij in het geval van vaststelling van een schending niet overgaat tot nietigverklaring van de gewraakte wet. Hij laat in dat geval de oplossing van het conflict aan de wetgever over vanwege het feit dat hij de voor de meest passende oplossing aan de wetgever wil overlaten. In bijvoorbeeld de Nederlandse situatie wordt dan gesproken van rechterlijke terughoudendheid.

Het leerstuk van de rechterlijke taakopvatting kan zich in het rechterlijke besluitvormingsproces op drie verschillende momenten manifesteren: in de ontvankelijkheidsfase, in de rechtsvindingsfase of interpretatiefase en in de toetsingsfase. In de ontvankelijkheidsfase zou rechterlijk een rechterlijke taakopvatting kunnen worden herkend op het moment dat de rechter bereid is de gegeven ontvankelijkheidscriteria extensief uit te leggen, zodanig dat een individuele aanspraak die in beginsel niet binnen die criteria valt toch beoordeeld kan worden. In de rechtsvindingsfase zou men van rechterlijk activisme kunnen spreken wanneer de rechter bijvoorbeeld bereid is tot extensieve interpretatie van de ingeroepen rechtsnorm, en wel zodanig dat er een 'nieuwe' wetsuitleg of een 'nieuw' recht wordt gecreëerd - een functie die in deze optiek aan de wetgever is toebedacht. Hij kan trachten ruimte creëren met het oog op

3 Zie respectievelijk par. 2.3 .2 en 2.4.1.

4 Heringa 1996, p. 48. In het Amerikaanse debat wordt de taakopvatting wel aangeduid met het begrip 'judicial activism" of "judicial restraint', zie Lamb 1982 en Schick 1982; in de Nederlandse discussie wordt zij gevoerd onder het begrip 'rechterlijke terughoudendheid' en 'rechterlijke voortvarendheid" (Martens 2000, p. 747). 
een mogelijk ruime uitlegging wan de ingeroepen norm omdat de wetgever er telkens maar niet in slaagt om de voorliggende problematiek het hoofd te bieden. ${ }^{5}$ In de ontvankelijkheidsfase kan de rechter voor beoordeling van de zaak of juist voor afstand van rechtsmacht kiezen. In de toetsingsfase is die keuze niet meer aan de orde: de rechter heeft de zaak immers al ter beoordeling aangenomen.

De eerste aanwijzingen in grondwet en verdrag waaraan de rechter inspiratie ontleent bij de invulling van zijn rechterlijke taakopvatting kan worden gevonden in de wettelijke regels die duiden op de omvang van de rechtsmacht. Per stelsel wordt bekeken, welke regels er met betrekking tot de rechtsmacht en de ontvankelijkheid zijn vastgelegd en welke doctrines er op dat vlak tot ontwikkeling zijn gekomen. Het is van bellang om naar deze fase in het rechterlijk besluitvormingsproces te kijken, omdat hier indicaties bestaan voor de rechterlijke taakopvatting die deels een verklaring geven voor de variaties tussen de stelsels in de rechtsvinding ter zake van het recht op persoonlijkheid. Een tweede demarcatielijn die betrekking heeft op de rechtsvindingsactiviteit van de rechter en die een aanwijzing geeft over de rechterlijke taakopvatting in de constitutionele verhouding wordt gevonden in de interpretatiemethoden die de rechter ter beschikking staan bij de vaststelling van de toepasbare regel en de omvang van die regel. Op dit vlak bestaat nauwelijks 'regelgeving', maar zijn in de stelsels interpretatiedoctrines tot ontwikkeling gekomen. Deze interpretatiedoctrines en interpretatiemethoden komen in hoofdstuk 4 aan de orde.

Naast de ontvankelijkheidsfase en de interpretatiefase is een derde fase te onderscheiden in het rechterlijk besluitvormingsproces. In de toetsingsfase - de fase die volgt na de vaststelling van de toepasselijke norm en de kwalificatie van de individuele aanspraak daaronder - zijn eveneens elementen te vinden die duiden op een bepaalde perceptie van de rechterlijke takopvatting. Er bevinden zich in deze fase toetsingsmatstaven die door de rechter kunnen worden gehanteerd met het oog op rechterlijke tegemoetkoming aan spanningen in de constitutionele verhouding. Gedacht kan bijvoorbeeld worden aan de opmerking van de Nederlandse rechter die 'in de gegeven staatsrechtelijke verhoudingen' een terughoudende opstelling hanteert, en 'mitsdien niet wil overgaan tot het zelf voorzien in een rechtstekort'. Het kan dus voorkomen, dat de rechter afziet van het werbinden van rechtsgevolgen aan een geconstateerde grondrechtsschending vanwege de constitutionele verhouding met 'de' wetgever.

5 Zie bijvoorbeefd het $M S$-Stakingsarrest, waarin de Hoge Raad een extensieve interpretatie gaff van Art. 6 lid 4 ESH (HR 30 mei 1986, NJ 1986/688).

6 Zie HR 12 mei 1999 , NJ $2000 / 170$ en par. 3.6.3. 


\subsection{De werkwijze wan het Amerikaanse Hooggerechtshof}

\subsubsection{Federale rechtsmacht wan het Hof}

Art. III van de Constitution ziet op de federale rechterlijke macht. Deze rechterlijke macht is voor wat betreft federale kwesties in hiërarchie boven, en voor de overige kwesties naast de statelijke rechterlijke colleges geplaatst. Art. III rept niet van de structuur en organisatie van het Hof; deze kwesties zijn overgelaten aan de federale wetgever. ${ }^{7}$ De jurisdictie van het Hof is neergelegd in Art. III $\$ 2$; deze geldt onder meer ten aanzien van 'cases' en 'controversies' ter zake van de grondwet, federale wetgeving en internationale verdragen; geschillen waarbij de Verenigde Staten betrokken zijn en conflicten tussen burgers uĭt verschillende staten. ${ }^{8}$ Eén wan de belangrijkste bevoegdheden van de rechterlijke macht, en het Hof in het bijzonder, is niet terug te vinden in de tekst van Art. III: de bevoegdheid wetgeving te toetsen op grondwettigheid. ${ }^{\text {g }}$ Bij strijd met de grondwet dient deze wetgeving buiten toepassing te worden gelaten. Het Hof heeft zich deze bevoegdheid via interpretatie van de grondwet in de beroeinde zaak Marbury t. Madison in 1803 als het ware 'toegeeigend'. 10 De belangrijkste constitutionele kwestie in Marbury t. Madison was, welke van de federale machten - wetgever, rechter of uitvoerende macht - de uiteindelijke uitlegger is van de grondwet. Het Hof signaleerde een conflict tussen een grondwettelijke bepaling en een federale wet - behoorde het tot de rechtsmacht van het Hof, de federale wet vervolgens ongrondwettig te verklaren en buiten toepassing te laten?" Rechter Marshall redeneerde als volgt: het woornaamste doel van een geschreven grondwet is het vestigen en consolideren van de hoogste wet. Daaruit volgt, dat een federale wet die daarmee in

7 Zo is bijvoorbeeld niet vastgelegd, hoeveel rechters in het Hof zitting hebben.

8 Verder beoordeelt het Hof kwesties aangaande ambassadeurs, ministers en consuls en casus waarin een staat als partij optreedi. In dergelijke gevallen heeft het Hof rechtsmacht in eerste aanleg; voor de overige zaken heeft het appellate jurisdiction'. De beoordeling van misdaden, behalve in het geval van "imperachment", zat worden gedaan door een jury.

9 In beginsel betrof de bewoegdheid het toetsen van federale wetgeving op grondwettigheid, maar wia de incorporatie werd naderhand evencens statelijke wetgeving door het Hof op overeenstemming met de grondwet beoordeeld (zie par. 2.3).

10 Mambury 1. Madison, 1 Cranch 137;2 L. Ed. 60 (1803).

11. Achtergrond in deze zalak was een politiek conflict tussen John Adams en de Federalists, en zijn opvolger John Jefferson en de Republikeinen. Net voordat Adams zijn functie neerlegde, benoemde hij een. afantal rechters voor het District Columbia. Adams had de opdracht tot benoeming reeds getekend, maar deze nog niet afgegeven ten tijde van het feitelijk beeindigen van zijn functio. De regering-Jefferson weigerde de aanstellingen te voltrekken. Enkelen van de aanstaande rechters, onder wie William Marbury, klaagden tegen deze weigering bij het Hof. Zij wilden de aanstelling uitgevoerd zien en klaagden daartoe Jeffersons stantssecretaris, James Madison aan. Justice Marshall zag zich gedwongen, onder meer de vraag te beantwoorden in hoeverte een verzoek om een bevelschrift tot benoeming door het Hof kon worden afgegeven. De toenmalige Judiciary Act voorzag in de bevoegdheid van het Hof "to issue [...] writs of mandamus [...] to persons holding office under authority of the United States". Middels deze federale wet kon het Hof het verzoek homoreren. Echter, Art. III \& 2 van de grondwet erkent jurisdictie van het Hof in eerste aanleg alleen in 'Cases affecting Ambassadors, other public Ministers and Consuls, and those in which a State shall be a Party'. De Federale wet was aldus in strijd met de bepaling van de grondwet. 
strijd is, nietig is. ${ }^{12}$ Het is volgens Marshall nadrukkelijk de taak en de plicht van de rechterlijke macht vast te stellen wat het recht betekent; het is niet de taak van de wetgever. Ontkenning van dit uitgangspunt zou namelijk betekenen dat rechterlijke instanties de grondwet zouden moeten negeren. Deze benadering zou de fundamenten wan de grondwet ondermijnen:

"It is emphatically the province and duty of the judicial department to say what the law is.
Those who apply the rule to particular cases, must of necessity expound and interpret that
rule. If two laws conflict with eachother, the courts must decide on the operation of each.
[... So if a law be in opposition to the constitution; if both the law and the constitution
apply to a particular case, so that the court must either decide that case conformably to the
law, disregarding the constitution; or conformably to the constitution, disregarding the law;
the court must determine which of these conflicting rules governs the case. This is the very
essence of judicial duty".

Het eerste deel van rechter Marshalls standpunt, de superioriteit van de grondwet boven federale wetgeving, werd aanvaard. De wijze waarop Marshall vervolgens de omvang van de taak van de rechterlijke macht daaruit afleidde, wordt echter tot op heden betwist: nergens stipuleert de grondwet expliciet welke de gevolgen zijn indien de rechter vaststelt dat een wet conflicteert met de grondwet. De vraag naar wie dan wel de ultieme uiltegger van de grondwet is wordt aldus niet in de grondwet beantwoord. ${ }^{14}$ Voorstanders van Marshalls redenering beargumenteren, dat juist de rechterlijke macht deze taak toekomt omdat bijwoorbeeld de rechters vrij zouden zijn van de politieke druk waarmee het Congress juist te kampen heeft. ${ }^{15}$ Tegenstanders bestrijden dat standpunt omdat zij van mening zijn dat deze taak, waarin politieke keuzes juist onvermijdelijk lijken te zijn, een rechterlijke instantie niet toekomt. ${ }^{16}$

Gesteld kan worden, dat het toetsingsrecht van het Hof sindsdien wordt erkend. De rechtsmacht van het Hof is aangegeven in Artikel III; slechts 'cases and controversies' kunnen worden beoordeeld. Er dient aldus sprake te zijn van een echt bestaand geschil;

12 "It is a proposition too plain to be contested, that the constitution controls any legislative act repugnant ito it; or, that. the legislature may alter the constitution by an ordinary act. Between these alternatiwes there is no middle ground. The constitution is either a superior, paramount law, unchangeable by ordinary means, or it is on a level with ordinary legislatiwe acts, and like other acts, is alterable when the legislature shall please to alter it". Marburyt Madison, 5 U.S. (1 Cranch) 137, $2 \mathrm{~L}$. Ed.60 (1803).

13. Zie Marbury L Madison, 5 U.S. (1 Cranch) 137, 2 L. Ed. 60 (1803).

14. Inmiddels is wel algemeen aanvard dat het Hooggerechtshof de bevoegdheld tot rechterlijhe toetsing bezit. Veel discussie bestaat thans nog over de wijze waarop die bevoegdheid werd afgeleid uit de betekenis van de grondwet; de daartoe gethanteerde redenering is thans middelipunt daarwam.

15. Ondersteuning van rechterlijke toetsing is expliciet terug te vinden in de Federalist Papers. Hamilton. Jay en Madison schreven in deze Federalist: Papers commentaren ter verdediging van de voorgestelde Constitution. In constitutionele interpiretatie worden deze Papers beschouwd als historisch waardevolle commentaren op de Constitution (Gunther en Sullivan 1997, p. 16). De Federalist Papers genummerd 78 tot en met 82 , geschreven door Hanilton, hebben betrekking op de functie wan de rechterlijke macht. Met name Federalist Paper nr. 78 van Hamilton levert argumenten die weer terug te vinden zijn in Marbury t. Madison. Voor verschillende argumenten zie: Learned Hand 1958, p. 1-30; Black Jr. 1960 en Bickel 1962.

16 Zis onder meer voor tegenstanders wan rechterlijke toetsing door het Hof: "Thayer 1967 en Wechster $1961, p .4-10$. 
abstracte toetsing wordt hierdoor in beginsel uitgesloten. Het Hof is tot dusverre niet bereid gebleken, over te gaan tot advisering omdat het bij honorering van dergelijke verzoeken al snel wan mening is dat het de grenzen van rechterlijke terughoudendheid overschrijdt. $^{17}$ Aanleiding ontvankelijkheid te weigeren was voor het Hof het gevaar dat het zich zou inlaten met beoordeling van discretionaire presidentiêle bevoegdheden.

Een volgende punt is dat de rechtsmacht zich beperkt tot kwesties die de federale rechter toekomen; in dit opzicht is een afbakening aangebracht ten opzichte van de rechtsmacht van statelijke rechters. ${ }^{18}$ In de meeste zaken is de federale rechtsmacht echter niet exclusief in die zin dat zij enkel aan de federale rechter toekomt; over het algemeen hebben statelijke rechters een 'concurrent jurisdiction'. Het federale recht staat in beginsel boven het statelijke recht, aldus Art. VI van de grondwet. ${ }^{19}$ Indien nu een statelijke rechter een casus beoordeelt aan de hand van federaalrechtelijke maatstaven, is naderhand herziening door het Hof in beginsel mogelijk, zij het dat daarop wel een aantal beperkingen in acht dient te worden genomen. ${ }^{20}$ Deze beperkingen komen voort uit het beginsel van federale staatsopbouw; het Hof heeft in zijn rechtspraak een aantal belangrijke lijnen uilgezet. In Martin t. Hunter's Lessee (1816) legde het Hof de basis voor de mogelijkheid tot herziening van rechtspraak wan statelijke rechters. ${ }^{2 i}$ De federale rechter zal zich bij de beoordeling over de statelijke kwestie aan de hand van federaal recht dienen te beperken tot behandeling van de voorgelegde federale vraag - kwesties die enkel van belang zijn voor het recht van de betrokken staat zal de federale rechter niet in beschouwing nemen. De vraag zal door de federale rechter worden getoetst op juiste interpretatie en toepassing van de federale regel. Belangrijkste ratio achter deze bevoegdheid is dat de federale rechter op deze wijze de uniformiteit van toepassing van federaal recht kan verzekeren. Op de hoofdregel van mogelijkheid tot herziening van beslissingen van statelijke rechters door de federale rechters heeft het Hof een aantal uitzonderingen geaccepteerd, waarin het federale jurisdictie ter zake van beslissingen van statelijke rechters afwijst. Deze uitzonderingen

17 Reeds in 1793 verwierp het Hof de uitnodiging, een advies te geven aangaande de Amerikaanse neutraliteit in een geschil tussen Frankrijk en het Verenigd Koninkrijk: "The three departments of the government being in certain respects checks upon each other, and our being judges of a court in the last resort, are considerations which afford strong arguments against the propriety of our extrajudicially deciding the questions alluded to, especially as the power given by the Constitution to the President, of calling on the heads of departments for opinions, seems to have been purposively as well as expressly united to the executive departments", voorbeeld ontleed aan Gunther en Sullivan 1997, p. 28.

18 De belangrijkste criteria in Artikel III zijn in de eerste plaats of er sprake is van een geschil betreffende federale regels, en in de tweede plats of er een rechtsstrijd is tussen burgers van verschillende staten.

19 De zogenoemde Supremacy Clause luidt onder Art. IV sub 2: "This Constitution, and the Laws of the United States which sthill be nude in Pursuance thereof; and all Treaties made, or which shall be made, under the Authority of the United States, shall be the supreme Law of the Land; and the Judges in ewery State shall be bound thereby, any Thing in the Constitution or Laws of any State to the Contrary notwithstanding'.

20 Zie $\$ 1257$ van Title 28 van de Judiciary Act.

21 Martin t. Hinter's Lessee, I Wheat. (14 U.S.) 304 (1816). Deze uitspraak meet zich voor wat het afgrenzen van de federale rechterlijke bevoegdheid in belang met Marbury $t$. Madison (Gunther en Sulliwan 1997, p. 60). 
worden samengevat onder de zogenaamde "Abstentiondoctrine". 22 De taakopvatting van het Hof, in afwijking van hetgeen de bevoegdheidstoedeling in de Judiciary Act aanreikt, is mede ingegeven door 'comity', hetgeen te maken heeft met een coöperatieve opstelling naar en respect voor het functioneren van de statelijke rechters en voor de federale staatsopbouw in het algemeen. De begrenzing tussen federale en statelijke rechtspraak lijkt een "verschuifbare maatstaf" op te leveren waar het gaat on een discretie tot ontwankelijkheidsverklaring door het Hof. De omwang van 's Hofs discretie wordt echter enigszins beperkt: indien het Hof ongemotiveerd op deze grond vaak zou besluiten tot niet-ontvankelijkheid, terwij! de Judiciary Act die bevoegdheid ruimschoots toekent, zou dat besluit niet zonder meer geloofwaardig overkomen.

\subsubsection{De rechtsgang naar het Hof: het certiorari-systeem}

Geschillen komen bij het Hof terecht via een beroepsprocedure of via "certiorari". In het eerste geval schrijft de wetgever voor ter zake van welke klachten beroep kan worden ingesteld bij het Hof; het Hof is verplicht deze zaken in behandeling te nemen. Een grote groep klachten, waaronder de het grootste deel van de onderzochte aanspraken op het recht op persoonlijkheid - in de Amerikaanse situatie aanspraken op "liberty" en 'privacy', ${ }^{23}$, komt via de procedure van certiorari bij het Hof terecht. Het Hof heeft in deze procedure een belangrijke selectiebevoegdheid: het kan kiezen over welke kwesties het een uitspraak zal doen. ${ }^{24}$ Met behulp van selectie kan het Hof een constitutionele koers uitstippelen; de selectie geschiedt niet alleen op basis van ontvankelijkheidscriteria, maar ook op basis van opportuniteit. ${ }^{25}$ Jaarlijks krijgt het zesduizend verzoeken ${ }^{26}$, waarvan slechts een fractie uiteindelijk wordt beoordeeld op grondwettigheid. ${ }^{27}$ Ter zake van het verlenen van certiorari beslissen de rechters met vier stem-

22. In Railraad Commission of Texas t. Pullman Ca. I. U.S., 312 U.S. 496 (1941) formuleerde het Hof enkele redenen waarom federale jurisdictie over beslissingen van statelijke rechters niet gewenst was: conflicten tussen federale en statelijke rechters als gevolg van onduidelijkheden over het recht van de staat dienen zover als mogellijk woorkomen te worden, en voor vaststelling wan het geldende statelljke recht is de statelijke rechter de eerst aangewezene teneinde vergissingen door federale rechlers zoveel mogelijk te voorkomen. Een zaak kan aldus worden terugverwezen waat de statelijke recthter teneinde oplyeldering te verkrijgen over de betekenis van dat statelijke recht, watana de casus, indien nodig, wer kan worden voorgelegd aan de federale rechter.

23 Zie par. 2.3 .3 en 2.3 .4 .

24 Deze categorie van zaken, die veruit het vaakst wordt aangebracht bij het Hof, wordt in de Verenigde Staten 'wrilt of certionary" genoemd. Section 1254 van Title 28 van de U.S. Code verschaft het Hof de bevoegdheid van revjew by writ of certiorari' ten aanzien van uitspraken van federale rechters Section 1257 bepaalt de rechtsmacht ten aanzien van de statelijke rechters. Indien het om herziening van uilspraken van statelijke rechters werzocht wordt, dient de uitspraak in de hoogste instantie in de stant te zijn gedaan, en het moet een 'federal question' betreffen.

25 Heringa 1996, p. 8.

26 Lazarus 1999 , p. 31

27 Deze diseretie heef niet immer bestaan: tot 1891 had het Hof in het geheel geen bevoegdheid, zaken te selecteren en trad het ais beroepsrechter op. Sinds 1891 is een groot deel van de verplichte rechtsmacht afgeschaft - met name na de inwerkingtreding van de Judiciary Act van 1925. Sedertien had het Hof de bevoegdheid, zijn werkzaamhedem te beheersen. In 1988 heef het Congress bijma alle gevallen van verplichte aanname afgeschaft en is de discretie van het Hof wellhaast volledig. Zie woor een nadere uiteenzetting over hoe het proces van een petition for certiorari verloopt Heringa 1995 , p. 15 te. en 
men voór het in behandeling nemen van een kwestie.. ${ }^{28}$ Een verzoek kan zonder nadere motivering worden afgewezen. De redenen waarom een verzoek tot beoordeling door het Hof niet wordt aangenomen, zijn echter verschillend van aard. ${ }^{29}$ Naast juridischtechnische aspecten en aspecten van processuele aard spelen in de geneigdheid tot het beoordelen van de verzoeken ook politieke overwegingen een rol. Ongelijke rechtsbedeling tussen verschillende staten kan, maar hoeft niet perse een grond te zijn woor in behandeling nemen van een verzoek. Als federale hoogste instantie heeft het Hof in beginsel een harmoniserende rol waarin het streeft naar eenheid en uniformiteit van de toepassing van het federale recht. Echter, verscheidenheid wordt niet altijd ongewenst geacht: teneinde nieuwe rechtsvragen en rechtsontwikkelingen te laten uitkristalliseren kan het juist gepast zijn, tot op bepaalde hoogte rechtsongelijkheid te laten voortbestaan. ${ }^{30}$ Verzoekschriften van de zijde van de federale regering en van de "SolicitorGeneral" worden in driekwart van de gevallen ontvankelijk verklaard. Kwesties die worden begeleid met 'amicus curiae briefs' worden eveneens vaker ter beoordeling aangenomen. ${ }^{31}$ Een niet onaanzienlijke factor in de bereidheid een verzoek aan te nemen is gelegen in de strategie van de individuele rechters van het Hooggerechtshof. ${ }^{32}$ Indien een rechter bijvoorbeeld wenst te voorkomen dat de beslissing van een zaak een in zijn optiek onwenselijke jurisprudentie vestigt, kan hij ertoe overgaan tegen beoordeling van de kwestie te stemmen. Daartoe zal de rechter een inschatting moeten maken van de positie van de andere rechters en over de stemverhoudingen. Naast de 'grant of certiorari' dient een casus ook andere criteria van 'justiciability' te doorstaan, wil het Hof tot een beoordeling van de zaak komen.

\subsubsection{Overige ontvankelijkheidscriteria}

Er is een aantal criteria ontwikkeld ter zake van de vraag welke kwesties voor constitutionele beoordeling door het Hof in aanmerking komen, waarbij onder meer nagegaan dient te worden, wie een zaak aanbrengt, in welk stadium van het conflict het Hof een kwestie kan beoordelen, en de constitutionele vragen die in aanmerking komen voor beoordeling. "Ter zake heeft het Hof doctrines van "constitutional limits" en van

Lazaras 1999 (m.n. deel II: A Clerk's eye view').

28 De beslissing over het wel of niet in behandeling nemen wan een zaak wordt beslist met vier stemmen vóor afdoening in lyet Hof. Sommige zaken zullen vrijwel altijd worden aangenomen, zoals bijvoorbeeld doodstratzaken. De uitspraak in een zaak wordt maderhand beslist op basis wan een gewone meerderheid. Het Hof telt negen rechters; momenteel zijn dat rechter Scalia (1986 door Reagan benoemd), Rehuquist (1972, Nixon), Day O'Connor (1981, Reagan), Souter (1990, Bush), Breyer (1994, Clinton), Kennedy (1988, Reagan), Stevens (1975, Ford), Thonas (1991, Bush) en Ginsburg (1993, Clinton). Voorzittend rechter is Justice Relunquist (1972, door Nixon benoemd), gekozen op ancienniteit. Rechter Ginsburg is als laatste benoemd in deze samenstelling van het Hooggerecltsthof.

29 In het Reglement wan het Hof in Rulle 10 zijn enkele algemene richtlijnen wastgelegd.

30 Zie bijvoorbeeld in U.S. t. Mendoza, 464 U.S. 154, 160 (1984).

31 In een dergelijke "brief" worden door vooraanstaande juristen argumenten aangevoerd die het Hof dienen te overtaigen van de ernst van de kwestie. De schrijwers van deze 'briefs' geven in hun document eveneens aan, hoe de onderhavige kwestie naar constitutionele maatstaven dient te worden beoordeeld.

32 Perry 1991, p. 198 e.v.; Heringa 1996, p. 19.

33 Voor literatuur die uitgebreid op deze aspecten van ontvankelijkheid in gaat, zie onder meer Hart en Wechsler 1996. 
"prudential limits" ontwikkeld. Wat de "constitutional limits" aangaat wordt de ontvankelijkheid vastgesteld aan de hand van de eisen en grenzen die de grondwet daar omtrent stelt. ${ }^{34}$ Art. III $\$ 2$ sub I stipuleert dat er sprake dient te zijn van "cases" en "controversies". ${ }^{35}$ De "prudential limits' zijn niet expliciet in de grondwet neergelegd, maar zijn door het Hof als elementen van een wijs belleid, voortvloeiend uit zijn rechtsprekende taak, ontwikkeld. ${ }^{36}$ Heringa geeft een aantal overwegingen ter zake van de rechtvaardiging van het bestaan van deze eis, die sterk verband houden met de constitutionele verhouding warin het Hooggerechtshof zich met de federale en de statelijke wetgever bevindt. ${ }^{37}$ De beperking op basis van "cases' en "controversies" is gerechtigd vanuit de structuur van de scheiding van machten: de rechter kan geen eigen beleid maken en is aangewezen op de "incidentaliteit" van zaken. In de tweede plaats dient het Hof het gebruik van zijn middelen te doseren; het is gebaat bij zorgvuldig gebruik. ${ }^{38}$ In de derde plaats kan de rechter geen abstracte herziening uitvoeren vanuit de gedachte van 'cases' en 'controversies'. In de jurisprudentie heeft het Hof deze achterliggende beginselen uitgewerkt onder uiteenlopende criteria, zoals eisen met betrekking tot de kwaliteit van de eisende partij. ${ }^{39}$ De criteria wan "mootness" - de zaak is te laat aangebracht - en van 'ripeness' - de zaak is te vroeg aangebracht - betreffen nietontvankelijkheid vanwege de verkeerde timing waarop een verzoek wordt voorgelegd. De eisen van standing en timing zijn echter geen onveranderlijk concepten maar eerder maatstaven die multi-interpretabel zijn. Als gevolg hiervan is het soms mogelijk, dat een individuele aanspraak kan leiden tot een toetsing met het karakter van een abstracte herziening, terwijl het Hof op andere momenten juist zeer strenge eisen kan stellen aan de ontvankelijkheidseisen. ${ }^{40}$ In het laatste geval kan dat tot gevolg hebben, dat het Hof afstand wan zijn rechtsmacht doet.

35 Het geschil moet zich lenen voor rechterlijke beoordeling lenen, terwijl de procespartij voldoende belang moet hebben bij beoordeling door het Hof.

36 Heringa 1996 , p. 37.

37 Heringa 1996 , p. 38.

38 Valley Forge Christian College t. Americans United for Separation of Church and State, 545 U.S. 464 (1982) en Bickel 1962, p. 115-116.

39 Warth t. Seldin, 422 U.S. 490 (1975).

40 Een zaak is "not ripe" indien deze te vroeg wordt aangebracht, terwijl een zaak "moot" wordt geacht indien ornstandigheden die zich voordoen na het aanbrengen van het verzoek ertoe leiden, dat de aanwankelijke strijd met de grondwet is verdwenen. Het conflict bestant dan niet meer. In de beroemde abortuszaak Roe t. Wade bijwoorbeeld was het Hof bereid, ook al was klaagster in casu niet meer zwanger, de klacht ontwankelijk te verklaren wanwege de anders fysieke onmogelijkheid, een dergelijke klacht door het Hof op grondwettigheid te laten toetsen. Echter, in DeFunis t. Odegaard, 416 U.S. 312 (1974), verwierp het Hof de ontvankelijkheid, terwijl die redenerend vanuit de situatie van feitelijke onmogelijkheid in Roe juist wel verwacht kon worden. Waar het Hof juist bereid was een 'effet utile'benadering te kiezen woor de ontwankelijkheid van Roe, weigerde het in DeFunis in de mootnessdoctrine een extensief te interpreteren. Het Hof kan deze vereisten laten divergeren; de mate warin het een strenge toets hanteert ten aanzien van de vaststelling van mootness, hangi nauw samen met de omstandigheden in de casus alsmede eigen rechterlijke taakopvatting. Zie ook Perry 1991, p. 107. 


\subsubsection{De rechterlijke taakopwatting van het Hof}

Een eis van ontvankelijkheid die direct is gerelateerd aan de constitutionele verhouding tussen Hof en wetgever, is het criterium van de political question doctrine' ${ }^{41}$ In de loop van de twintigste eeuw ontwikkelde het Hof zijn 'political question doctrine', waarin ontvankelijkheid wordt verworpen ondat de gestelde vraag of het voorgelegde conflict dermate ongeschikt is voor beslechting door de rechter, dat tot niet-ontvankelijkheid moet worden geconcludeerd. ${ }^{42}$ Een heldere en consistente lijn van uitspraken is aan de hand van de political question doctrine moeilijk te traceren in de rechtspraak. ${ }^{43}$ In de literatuur wordt het leerstuk van de political question overigens aangeduid als een soort laatste redmiddel, waarmede het Hof in staat is verzoeken tot beoordeling buiten de rechtszaal te houden, als deze niet reeds in de certiorari-procedure of de standingcriteria was blijven steken. ${ }^{44}$ Het Hof heeft in de jurisprudentie een aantal algemene regels geformuleerd die richtinggevend zijn voor de wijze waarop het Hof zijn taakopvatting invult. In Ashwander t. Tennessee Valley Authority ${ }^{45}$ formuleerde rechter Brandeis een aantal basisregels. ${ }^{46}$ Algehele rode lijn in die taakopvatting is dat wetgeving en besluiten in beginsel worden geacht grondwettig te zijn en dat over vermeende ongrondwettigheid geen uitspraak wordt gedaan, tenzij dat absoluut noodzakelijk is. ${ }^{47}$

41 Zie hierover Heringa 1996, hoofidstuk 6; Flinterman 1995, p. 45-54; Ducat en Chase 1992, met name p. 126-132, 137-14: en 321 -326", Tribe 2000, p. 365 e.w. Deze doctrine komt voort unt de voomoende "prudential limsts". Hoewel deze doctrine geen functie vervult in hef kader van de te onderzoeken rechtspraak - bij mijn weten is de doctrine geen aanleiding geweest voor afwijzing van beoordeling van de individuele ansprak - is het goed om er kort aandacht aam te besteden deze doctrine raakt in beginsel de kem wan de dialoog die wanuit de rechter met de wetgever wordt gevoerd.

42 Het Hof heeft enkele criteria vastgesteld in Baker t. Carr aan de hand waarvan het beoordeelt of het te maken heeft met een political question, maar deze criteria vragen leder voor zich eveneens om interpretatie en toepassing in het concrete geval. Kort samengevat weigert het Hof beoordeling, indien nalar de toebedeling van de grondwet wan een zaak aan een andere staatsmacht toekomt; bij gebrek aan heldere juridische natatstaven warmee het conflict opgelost kan worden alsmede het bestaan wan factoren die beslechting door een rechter politiek onwenselijk doen zijn.

43 Onderwerpen als onder mear geloolstorieven (Powell t. MCCormack, 395 U.S. 486 (1969)), buitenlandse betrekkingen (Baker i. Carr, 369 U.S. 186 (1962)) en invulling van de republikeinse staatsworm $(0$ "Brien 1. Brown, 409 U.S. I (1972)) zijn in het verleden door het Hof als "non-justicjable" beoordeeld (voorbeelden ontleend aan Heringa 1996, hoofdstuk 6).

442 Zie onder meer Gunther and Sullivan 1997, p. 53.

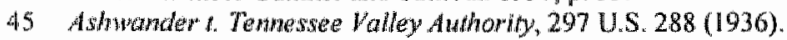

46 Zje onder neer Kommers 1998, p. 34 en in het bijzonder hoofdstuk 3; Gunther en Sullivan 1997, p. 29; Heringa 1996, p. 117 .

47 Rechter Brandeis, concurying in Ashwander: "The Court developed, for its own govenance in the cases confessedly within its jurisdiction st series of rules under which it has avoided passing upon a large part of all the constitutional questions pressed upon it for decision. They are: 1) The Court will not pass upon the constitutionality of legislation in a friendly, nonadversary proceeding, declining because to decide such questions is legitimate only in the last resort, and as a necessity in the determination of a real, ernest, and wital controversy berween individuals. $[\ldots]$ 2) The Court will not anticipate a question of constitutional law in advance of the necessity of deciding it. [...] 3) The Court will not formulate a rule of constitutional law broader than is required by the precise facts to which it is to be applied. [...] 4) The Court will not pass upon a constitutional question although properly presented by the record, if there is also present some other ground upon which the case may be disposed of. [... 5) The Court will not pass upon the validity of a statute upon complaint of one who fails to show that he is injured by its operation. [...] 6) The Court will not pass upon the constitutionality of a statute at the instance of one 
Uit de regels komt ook een verbod naar voren, dat stipuleert dat het Hof een regel wan constitutioneel recht niet ruimer mag formuleren dan vereist is om het geschil tot een oplossing te brengen. Een belangrijk uitvloeisel wan de vooronderstelling van grondwettigheid van wetgeving is onder meer het gebod om zo mogelijk tot een grondwetsconforme interpretatie te komen. ${ }^{48}$ Ook ligt er een subsidiariteit in de regels besloten: indien een andere beslechting van het geschil mogelijk is dient die eerst te worden aangewend.

In verband met deze in de rechtspraak tot ontwikkeling gekomen formulering wordt in het Amerikaanse debat over de omvang van de rechterlike taakopvatting eveneens het onderscheid "judicial restraint' en 'judicial activism" gehanteerd, die hier worden wertaald met respectievelijk terughoudendheid en activisme. Deze benadering wan de rechterlijke taakopvatting raakt de kern van de constitutionele verhouding tussen federale de rechter en de federale en statelijke wetgevers. Met een kwalificatie van "activisme" of 'terughoudendheid' geeft de rechter een indicatie van zijn 'respect" voor de taak van de wetgever, zo luidt de gedachte die aan deze doctrine ten grondslag ligt. Van belang in verband met het onderscheid tussen 'activism' en 'restraint' is dat er geen scherpe lijnen tussen beide benaderingen aan te brengen zijn. Enkele kenmerken zijn. wel te geven. Zo wordt door sommigen het hanteren van het instrument van grondwettigheidstoetsing van wetgeving aangemerkt als een ultieme daad van rechterlijk activisme. ${ }^{49}$ Er kunnen in afzonderlijke gevallen wel karakteristieken van de benadering van de rechter worden gegeven, maar op voorhand kan niet op basis van criteria worden vastgesteld welke gedraging het predikaat activisme of terughoudendheid verkrijgt. $^{50}$ Een activistische rechter kan er bijvoorbeeld in beginsel toe neigen, de regels ter zake van ontvankelijkheid extensief uit te leggen om rechterlijke beoordeling van bijvoorbeeld wetgeving in formele zin mogelijk te maken. Bij de interpretatie van de grondrechten kan de rechter er bijvoorbeeld eerder toe neigen, een in beginsel enge formulering van een grondrecht juist ruim uit te leggen: hij beperkt zich bij de uitleg van een grondrecht niet tot de tekstuele uitleg, maar zoekt naar de betekenis van het recht aan de hand van normen van hoger recht. Dat kunnen zowell rechtsbeginselen zijn als rechtsnormen die tot dusverre nog geen vaste voet in het rechtsnormensysteem hebben verkregen." Zo kan een aanleiding tot ambtshalve aanvulling van de rechtsgrond ontstaan; die is in beginsel eerder mogelijk in een extensievere uitleg, dan wanneer een restrictieve uitleg wordt aangehouden. ${ }^{52}$ Een rechter die een vermoeden uitspreekt ten faveure van de individuele rechtsbescherming zou kunnen worden aan-

who has availed himself of benefits. [...] 7) When the validity of an act of Congress is drawn into question, and even if a serious doubt of constitutionality is raised, it is a cardinal principle that this Court will first ascertain whether a construction of the statute is fairly possible by which the question may be avoided.

48. Zie regell 7) van rechter Brandeis.

49. Ducat en Chase 1992, p. 93.

50 Abraham 1982, p. 201.

51 Zie par. 4.6 voor de typering van 'normen wan hoger recht'.

52 Een voorbeeld van een rechterlijke takopwatting die terughoudendheid dicteent is te vinden in de dis. senting van rechter Frankfurter in West Virginia Board of Education t. Barnette, 319 U.S. 624 (1943). 
gemerkt als activistisch indien zijn rechisvinding leidt tot extensieve interpretatie van het grondrecht. ${ }^{53}$ De woorkeur voor individuele rechtsbescherming lijkt in beginsel te worden uitgesproken met de kwalificatie van "fundamentality" wordt aan aanspraken toegekend die onder "privacy" worden erkend ${ }^{55}$ Zo kan worden gesteld, dat een rechter die een voorkeur voor de individuele rechtsbescherming als één van de onderliggende structuren van de grondwet niet respecteert, activistisch handelt: hij wijst de beoordelingsmaatstaven die de grondwetgever heeft vastgelegd, dan af. Een rechter die onder verwijzing naar "fundamentality' wetgeving nietig verklaart, hetgeen in de Amerikaanse situatie steeds het gevolg lijkt te zijn van deze kwalificatie, wordt soms eveneens een activistische takopvatting toegedicht - vanwege ingrijpen in wetgevende activiteiten. Deze betiteling van activisme zal zwaarder worden naarmate de rechter de kwalificatie van "fundamentality" als toetsingsmaatstaf vaker hanteert. Vraag is dan in hoeverre de rechter zich houdt aan hetgeen de wet hem opdraagt, en in welke mate hij zich daarbij mag of zelf's dient te verlaten op normen wan hoger recht. ${ }^{56}$

In de toetsingsfase kan een rechter eveneens een bepaalde taakopvatting in het licht van de constitutionele verhouding tussen hem en de wetgever hanteren. Wanneer de rechter terughoudend zegt te beslissen, zal hij wetgeving eerder onderwerpen aan een marginale toetsing, de zogenoemde 'rational basis test'. Vaststelling van een eventuele strijdigheid met de 'privacy' ligt in de Amerikaanse situatie niet voor de hand wanneer een marginale toets plaatsvindt. ${ }^{57}$ Wanneer het Hof een benadering ten faveure van het recht op individuele rechtsbescherming tot uitgangspunt verheft, heeft dit veelal tot gevolg dat wetgeving aan een intensieve toetsing wordt onderworpen. In dergelijke gevallen heeft het Hof een aantal keren wan zowel dissenters als commentatoren het verwijt gekregen, dat het zich inliet met regelgevend en beleidsmakend optreden en aldus de in de grondwet neergelegde constitutionele verhoudingen niet respecteerde ${ }^{58}$ Het Warren-Court (1953-1969) is bijwoorbeeld achteraf regelmatig verweten activistisch te zijn. Het voerde een rechterlijk interpretatie'beleid' dat steeds een sterke voor-

53 Dit sluit niet uit dat activisme zich ook bij grondwetsuitleg woordoet die niet le lid tot extensieve interpretatie. Ook dan kan interpretatie tot gevolg hebben dat wetten door het Hof ongrondwettig worden verklakard en kan het voorkomen dat het Hof van actuvisme wordt beticht (zie bijvoonbeeld Atkins I. Virginia, (nr. 00-8452, 20 juni 2002)). In die zaak werd het verbod op de doodstraf bij zwalkzinnigen erkend op basis van ear groeiende consensus.

54 Par. 2.3.3.

55 Par. 2.3.3.

$\$ 6$ Deze vragen liggen ten grondslag aan de discussie in constitutionele interpretatie over de rechterlijke takkopvalting. Herop $z a l$ in hoofdstuk 4 over constitutionele interpretatie en in hoofdstuk 5 over de Amerikanise jurisprudentie nog uitvoerig op worden teruggekomen.

57 De kwalificatie wan "fundamentality" heeft steeds tot gevolg, dat een intensileve toets van de aangevochter wet volgde. Intensieve toetsing had steeds tot gevolg, dat de gewrakte wet niet un stand kan blijven, terwijl na een marginale toets de wet kan blijven woortbestaan. 'Strict in theory, falal in fact' is een gevleugelde uiturukking geworden in het Amerikaanse constiutionele debat, die bijna als een wetmatigheid aangeeft dat marginale toetsing de aangevochten wet in stand laat en omgekeend een intensieve toets bijna altijid leidt to nietigheid wan de aangevochten wet (Gunther 1972, p. 8).

58 Dit verwijt kreeg bet Hof onder meer in de zaken Roe t. Wade (410 U.S. 113, (1973)), Bromin t. Board of Education (347 U.S. 483, (1954)) en Bakert. Carr (369 U.S. 186, (1962)). 
keur uitsprak ten faveure van de individuele rechtsbescherming. ${ }^{59}$ Dat had regelmatig tot gevolg dat federale of statelijke wetgeving geen stand kon houden, en dat er mitsdien werd ingegrepen in de takstelling van de wetgever. ${ }^{60}$

"s Hofs activistische benadering - nietigverklaring van wetgeving in verband met strijd met grondrechten - was eind jaren "60 een belangrijke aanleiding voor toenmalig president Nixon, rechters met een meer terughoudende taakopvatting te benoemen in het Hof. Een zelfde ontwikkeling deed zich een aantal decennia eerder voor in het zogenoemde 'Lochner-tijdperk' (1905-1937), waarin het Hof gedurende een aantal decennia opvallend vaak statelijke sociaal-economische wetgeving strijdig met het Veertiende Amendement van de grondwet verklaarde. ${ }^{61}$ Roosevelt benoemde in 1937 nieuwe leden in het Hof; hij veronderstelde dat zij een terughoudender taakopvatting zouden hanteren dan het Hof vootheen had gedaan. ${ }^{62}$ Van belang is dat de voorkeur voor een activistische of juist een terughoudende rechterlijke takopvatting niet kan worden afgeleid uit de politieke stroming waarmede een rechter of een samenstelling van het Hof sympathiseert. ${ }^{63}$ De verschillende 'Courts" hebben zich zowel met links georiënteerde als ook met rechts-liberale stromingen geïdentificeerd; beide politieke onderstromen kunnen worden getypeerd als activistische 'Courts'. worden gedacht aan de uitspraak Trop $t$. Dulles, waarin voorzittend rechter Warren de meerderheidsopinie schreef en zijn mening geeft over de gepaste rechterlijke taakopvatting. Het conflict handelde in de kern om de vraag, in hoeverre het verlies van de Amerikaanse nationaliteit wegens desertie in overeenstemming was met het Achtste Amendement -- het verbod van 'cruel' en "unusual punishment":

59 Onder het voorzitterschap wan rechter Warren in het Hooggerechtshof is het recht op "privacy" tot ontwikkeling gekomen.

60 Zie bijwoorbeeld Trop t. Dulles, 356 U.S. 86 (1958).

61 De reeks uitspraken werd ingeleid met de zaak Lochner t. New York, 198 U.S. 45 (1905), vandaar de betiteling die in de Amerikanse literaturur niet ongebruikelijk is (Guntluer en Sullivan 1997, p. 460).

62 Met het zogenoemde Court-packing Plan wilde Roosevelt had als belangrijkste en meest effectieve regel, dat rechters ouder dan 70 werden geacht terug te treden. Wanneer zij dat niet vrijwillig zouden doen zou de president de bevoegdhelid hebben, een extra rechter te benoemen, met dien werstande dat het aantal rechters in het Hof maximaal 15 kon bedragen. 6 wan de 9 rechters waren ouder dan 70 in 1937, hetgeen kon leiden tot een influx van rechters met een meer 'terughoudende' taakopvatting (in die zin dat zij grondwettigheid van de wetgeving vooronderselden). Voordat het echter zover kwam wijzigde het Hof zijn jurispnudentie ter zake wan sociaal-economische wetgeving drastisch; cerste tekenen hiervan kwamen in de zaken Nebbia t. New York, 291 U.S. 502 (1934) en West Coast Hotel t. Parrish, 300 U.S. 379 (1937) - aok wel genoemd "the switch in time that saved the Nine" ("nine" slat op het aantal rechters in het Hooggerechtshof). Er bestat echter meningsverschil over de mate warin dat nu veroorzaakt zou zijn door de "dreiging" wan het Court Packing P'lan', opvallend is in ieder geval dat de twee ontwikkelingen samenvielen (zie Gunther en Sullivan 1997, p. 183).

63 De rechtspraak in het Lochmer-tijdperk zou bijvoorbeeld aan te merken zijn als passend binnen de meer conservatief-liberale opwatting, dat de staat niet sturend (zoals in een sociaal-democratische opvatting) moet optreden, maar verdeling van de middelen aan de marktwerking dient over te laten. Het Hof hanteerde in deze periode een activistische instelling. Daartegenover hanteerde het Warren-Court, tock juist eerder links georienteerd, cen activistische houding ten aanzien van fundamentele rechten. Zie over dit onderscheid onder meer Cox 1987, p. 135.

64 A. Cox, p. 135. 


\begin{abstract}
"We are oath-bound to defend the Constitution. This obligation requires that congressional enactments be judged by the standards of the Constitution. The judiciary has the duty of implementing the constitutional safeguards that protect individual rights. When the Government acts to take away the fundamental right of citizenship, the safeguards of the Constifution should be examined with special diligence. The provisions of the Constitution are not time-worn adages or hollow shibboleths. They are vital, living principles that authorize and limit governmental powers in our Nation. They are the rules of government. When the constitutionality of an Act of Congress is challenged by this Court, we must apply those rules. If we [...] do not, the words of the Constitution become little more than good advice. [..] We are sworn to do no less. We cannot push back the limits of the Constitution merely to accommodate challenged legislation. ${ }^{65}$
\end{abstract}

De wraag ter zake van de hantering van de 'juiste' rechterlijke taakopvatting lijkt, afgaande op dit voorbeeld, aldus sterk samen te hangen met de rechterlijke perceptie van hetgeen de grondwet hem opdraagt. De vraag is of de rechter in dat verband vooral op de tekst dient af te gaan, of dat hij zelf vanuit een grondwetssystematiek normen mag afleiden.

\title{
3.2.5 De uitspraak
}

Uitspraken worden gedaan op basis van gewone meerderheidsbeslissingen, de majority vote. ${ }^{66}$ Indien de president van het Hof zich met zijn opvatting bij de meerderheid bevindt, beslist hij wie de meerderheidsopinie schrijft. Indien hij zich niet in die meerderheid bevindt, zal de president naar anciënniteit beslissen, wie de opinie voor de meerderheid schrijft. De verschillende opinies circuleren onder de leden; getracht wordt een meerderheid voor het eigen standpunt te verkrijgen. Coalities kunnen in dit stadium worden gesmeed totdat de opinies afgerond zijn, en het oordeel wordt uitgesproken. Naar aanleiding van de meenderheidsbeslissing kunnen de leden die zich daarin niet kunnen vinden hun 'dissenting' of 'concurring' kenbaar maken, die eveneens wordt gepubliceerd bij de uitspraak. De openbaarmaking van dissentings en concurrings verschaft een inzicht in de argumenten die in overweging zijn genomen in de rechterlijke besluitvorming. Mede omdat de tegenstellingen in de constitutionele rechtspraak wak scherp zijn, ziet een rechter zich genoodzaakt - zowel in de majority vore als in de concurring of in de dissenting - de mening zo overtuigend mogelijk neer te zetten. Aan concurrings en dissentings wordt regelmatig argumentatie ontleend voor latere zaken, zowel door de rechters als door de bij het proces betrokken partijen. In de jurisprudentie komt echter niet altijd even helder natar voren welke rechters zich op welk onderdeel van de uitspraak bij de meerderheid bevinden. ${ }^{67}$ Daarnaast valt op dat

65 Trop Dulles, 356 U.S. 86 (1958).

66 Deze kan onvatten lhet oordeel van de meerderheid van het Hof in de vorm wan een majority opinion; sprake kan zijn wan de concurring opinion waarin het oordeel van de betreffende rechter aansiluit bij hel oordeel van de meerderheid, maar waarin hij een afwijkende redenering aanhoudt om tot het resultaat van de meerderheid te komen. Ook kan de rechter een mening hebben die afwijkt van de redenering en het resultatat van de meerderheid: dan is sprake van een dissenting opinion.

67 Zie bijwoorbeeld de woor het recht op persoonlijkheid - in casu abortus - belangwekkende zaak Planned Parenthood of Southeastern P.A. t. Casey, 505 U.S. 833 (1992). In deze zaak werd beslist over een aantal aspecten met betrekking tot het recht op abortus aan de orde; de gefragmentariseerde besluit- 
in zaken die handelen over 'liberty' en 'privacy" vaak ernstige verdeeldheid van stemmen bestaat. Veel zaken op dat terrein worden beslecht met een $5-4$ beslissing, hetgeen afdoet aan de kracht van de meerderheidsopinie. ${ }^{68} \mathrm{Er}$ is dan slechts een kleine verandering van samenstelling wan het Hof nodig, om een tegengestelde jurisprudentielle lijn in te zetten ter zake van het recht op vrijheid en het recht op "privacy". 69

De uitkomst van zaken, vooral die waarin een individuele aanspraak op "liberty" en 'privacy' wordt gedaan, wordt in het Hooggerechtshof openlijk bepaald door de ideologische voorkeur van de rechters die zitting hebben in het Hof. ${ }^{70}$ Dat is het gevolg van zowel de benoemingsprocedure alsook het soort zaken waarover het Hof oordeelt. Veelal moet hij oordelen over aanspraken (abortus, homoseksualiteit, hulp bij zelfdoding, familiebetrekkingen) waarover ethische, maatschappelijke en politieke inzichten enorm uiteenlopen, ook binnen het Hof. Daarnaast hebben ook zaken waarin de positie van het Hof ten opzichte van de statelijke wetgever en rechter moet worden bepaald, alsmede zaken waarin de constitutionele verhouding tussen Hof en federale wetgever nader moet worden ingewuld een belangwekkende plaats op het 'docket' van het Hooggerechtshof. Het belang van de politieke filosofie van de rechter kan een rol spelen in de uitkomst van de zaak vanwege de wijze waarop zij worden benoemd: de president kan zijn voorkeur voor conservatieve of meer liberale kandidaten laten gelden. Hierdoor is aanwezigheid van een eigen ideologische voorkeur gelegitimeerd, hetgeen ook doorklinkt in het stemgedrag van de rechters. Dat heeft ook consequenties voor de jurisprudentie; er worden regelmatig coalities gevormd om een meerderheid van stemmen voor of tegen een bepaalde beslissing verenigd te krijgen. De laatste twee decennia heeft zich dit regelmatig geuit in majority votes waarin met 5 tegen 4 werd beslist. De doorslaggevende stem komt dan van één rechter; deze stem, de 'swingvote', geeft de doorslag. Bij onderwerpen, waarover de opvattingen sterk uiteenlopen, kan in dit opzicht onzekerheid ontstaan over de ontwikkeling van de jurisprudentie: precedenten kunnen immers met één stem worden bijgesteld. ${ }^{71}$ De betekenis van de concurrings

vorming makkt echter nivel op het eerste gezicht inzichtelijk welke aspecten van de uitsprak worden gesteund door de meerderheid.

68 Onder meer wanwege deze reden is bij het Duitse Hof gekozen woor acht rechters die tot besluitvorming moeten konnen: lhet stemverschil bedraagt dan tenminste twee stemmen.

69 Ter zake van rechterlijke besluitworming op het wlak wan "liberty" en "privacy', die uitmondt in een 5 u beslissing, kan momenteel worden gesteld dat er vier fechters zijn die een terughoudende visie vam het Hof voorstaan en daartegenover vier rechters die een activistischer standpunt innemen. De uiteindelyke beslissing komt dan neer op een rechter. Ter zake van de aanspraken op 'privacy" komt dat in de huidige samenstelling wan het Hof neer op de stem van Justice $\mathrm{O}^{\prime} \mathrm{Connor}$, die door woormalig president Reagan werd benoemd. Ten tijde wan de laatste presidentswerkiezingen was het onderwerp van rechterlijke benoemingen een punt waaraan serieuze aandacht werd geschonken: gezien hel feit dat enkele van de rechters in de huidige samenstelling wan het Hof zich in de komende regeerperiode terug zouden kumnen trekken maakt de weg vrij voor de nieuwe president, rechters te benoemen die zijn opwattingen zijin toegedaan (zie ockk hiema par. 2.2.6)

70 Zie ook Gerands 2002, p. 383 e.v.

71 Sommige uitspraken over controversitele onderwerpen geven een beeld te zien waarin precedenten niet lijken te worden gerespecteerd (zie Semimole Tribe of Florida t. Florida, 517 U.S. 44 (1996), cen zaak warin de immuniteit van de staten werd uitgebreid op grond wan een niet-overtuigend pleidool dat precedentwerking geheel negeerde) en er soms zelfs een inconsistentie optreedt in de hantering van 
en dissentings neemt in dit verband toe: hieruit valt enigszins af te leiden en tot op zekere hoogte te hoe een bepaalde rechter zal stemmen.. ${ }^{72}$

De uitspraken van het Hooggerechtshof binden de andere staatsmachten, dus ook de wetgever. De uitspraken hebben in beginsel geen erga omnes effect, maar vanuit de redenering dat het Hof de ultieme uitlegger van de grondwet is maken diens uitspraken deel uit van de grondwet; de uitspraken binden dus eenieder ondat de grondwet dat rechtsgevolg heeft ${ }^{73}$ Vragg in dit verband is welke consequenties aan een vaststelling van ongrondwettigheid verbonden worden door het Hof. Een relativering van de vaststelling van een schending in de vorm van een beperking in de omvang van de gevolgen is in beginsel niet mogelijk. Het Hof hanteert in dit opzicht het uitgangspunt, dat het niet als een wetgever regels over de gelding van zijn uitspraken kan geven: achterliggende gedachte is dat overgangsrecht een taak is van de wetgever die de rechter niet behoort over te nemen. Aan dit uitgangspunt ligt, zo wordt wel gesteld, een gedachte van rechterlijke terughoudendheid ten grondslag: de grondwet schrijft geen variabele gevolgen voor van ongrondwettigheid. Voorstanders van dit standpunt zien in overgangsrecht dat door de rechter wordt gecreëerd een middel om de tegenstand en weerstand tegen jurisprudentie te relativeren, en een manier om onwelgevallige rechtspraak zo beperkt mogelijke effecten te geven. ${ }^{74}$ Het geven van een temporele werking van uitspraken behoort evenmin tot de bevoegdheid van het Hof. In aperte uitzonderingsgevallen is het Hof bereid tot beperkende maatregelen. ${ }^{75}$ Het Hooggerechtshof kent in de toetsingsfase ter zake van de mogelijke uitspraken aldus weimig verschuifbare maatstaven, die de gevolgen van de uitspraak in de constitutionele verhouding enigszins kunnen relativeren. Ingrijpen in de consequenties wordt aldus gezien als een onwenselijk rechterlijk ingrijpen, en zou kumnen worden aangemerkt als een activistische stellingname van de rechter: hij neemt een taak van de wetgever op zich. Dat geldt aldus ook voor uitspraken op het vlak van thet recht op persoonlijkheid: indien het Hof schending door een wet vaststelt is het gevolg nietigverklaring van de wet. De onmogelijkheid om de uitspraak enigszins aan te passen aan de omstandigheden van het geval legt in beginsel een zware claim op de voorafgaande besluitvorming ter zake van de reikwijdte van het ingeroepen recht.

\subsubsection{Checks van de wetgever op de rechtsmacht wan het Hof}

De uitspraken van het Hof op het terrein van het recht op 'liberty' of 'privacy' creeren bij vaststelling van schending ongenoegen bij de federale of statelijke wetgever. het gevolg is nietigverklaring van de wet. Met zijn ongrondwettigheidsuitspraken doorkruiste het Hof bijwoorbeeld het statelijke verbod op het verbranden van de Ameri$\mathrm{kaanse} \mathrm{lag}^{76}$, een statelijk verbod op gebruik van voorbehoedsmiddelen ${ }^{77}$ een statelijk

stare decisis (Planned Parenthoad t. Casey, 505 U.S. 833 (1992), uitgewerkt in par. 5.3.3).

72 Momenteel zijn rechter $0^{\circ}$ Connor en Kennedy de swingwoters in het Hof (Lazarus 1999, p. 515).

73 Heringa $1996, p, 141$.

74 Heringa 1996, p. 146-147 en Fallon en Meltzer 1991, p. 1739.

75 Heringa 1995, p. 56 .

76 Texas t. Johmson, 491 U.S. 397 (1989) en U.S. Eichman, 496 U.S. 310 (1990). 
verbod op abortus ${ }^{78}$, een statelijk verbod op woningtoewijzing naar gezinssamenstelling ${ }^{79}$ en een statelijk verbod van homoseksuele activiteiten. ${ }^{80}$ Een antwoord van de grondwetgever op deze beslissingen bleek in beginsel tot de theoretische mogelijkheden te behoren, en niet zozeer tot de praktische. De grondwet biedt expliciet de mogelijkheid tot amendering ${ }^{81}$ maar gezien het feit dat het erg moeilijk is gebleken om een meerderheid te vinden voor een verandering in de grondwet is dit een relatief weinig gebruikt middel om de uitspraken van het Hof te beïnloeden of te corrigeren. ${ }^{82}$ In 1795 zette het Congress met het Elfde Amendement een uitspraak van het Hof opzij, zodat het voortaan niet langer mogelijk was een rechtszaak tegen een staat aan te spannen. Het reeds besproken Veertiende Amendement is een correctie van ontsporingen van uitspraken van het Hof met betrekking tot het Amerikaanse staatsburgerschap van voormalige slaven. ${ }^{83}$ Gezien de brede opzet en formulering van de constitutionele bepalingen, kan in dit verband ook worden opgemerkt dat een amendement weliswaar kan worden toegevoegd teneinde de uitleg van constitutionele bepalingen bij te sturen, maar het Hof rekent immer nog de uitleg van dat Amendement tot zijn taak. Indien bijvoorbeeld het recht op leven zou worden verankerd in de grondwet, teneinde de abortusrechtspraak te corrigeren, is het Hof immer nog de 'ultimate interpreter' die aan de notie van het recht op leven invulling zal moeten geven. ${ }^{84}$ Tegelijkertijd kan van een dergelijk initiatief wel de politieke boodschap uitgaan naar het Hof, dat de grondwetgever kennelijk voldoende draagvlak ziet voor een bepaalde interpretatie van het recht. Daarvoor dient het wetsvoorstel uiteraard wel te worden aanvaard. Indien dat draagvlak ontbreekt zal het Hof neigen naar een terughoudender interpretatie met betrekking tot beoordeling van het recht op leven. De vraag die hier rijst is of een dergelijk Amendement iets zou toevoegen aan de uiteindelijke uitleg door het Hof van de bepalingen in de grondwet. ${ }^{85}$ Omgekeerd heeft het Hof met zijn rechtspraak aangetoond, dat een tekstuele verandering in de grondwet niet steeds noodzakelijk lijkt voor een aangepaste interpretatie. Van het hiervoor geschetste voorbeeld van het Court-packing Plan van Roosevelt in 1937 bleek voldoende bedreiging uit te gaan om een onwenselijk geachte

Griswold t. Connecricur, 381 U.S. 479 (1965).

78 Roe 1. Wade, 410 U.S. 113 (1973).

79 Moore t. East-Cleveland, 431 U.S. 494 (1977).

80 Bowers t. Hardwick, 478 U.S. 186 (1986), Zie voor meer voorbeelden Vile 1994, p. 24 e.v.

81 Art. V luidu: "The Congress, whenever two-thirds of both Houses shall deem it necessary, shall propose Amendments to this Constitution or, on the Application of the Legishatures of two thirds of the several States, shall call a Convention for proposing Amendments, which, in either Case, shall be valid to all lntents and Burposes, as part of this Constitution, when ratified by the Legislatures of threefourths thereof, or by Conventions in threefourths thereof, as the one or the other Mode of Ratification may be proposed by the Congress [... ]".

82 Gunther en Sullivan 1997 , p. 74 .

83 Dred Scott t. Sandford, 60 U.S. (19 How.) 393 (1857).

84. Tribe 2000, p. $89 \mathrm{e} . \mathrm{v}$.

85 In de analyse van Vile worden de meeste constitutionele amendementen ingediend met het oog op het intitieren wan verandering, of om ongewenste verandering in de lezing van de Constitution te wijzigen. Ook het handhawen wan een bestaande situatie zou een belangrijke aanleiding kunnen zijn tot amendering van de Constitution. In Vile's onderzoek is van deze gevallen echter geen sprake geweest (zie Vile 1994, p. 29). 
jurisprudentielyjn drastisch om te buigen. ${ }^{86}$ Het document van de grondwet bleef echter dezelfde uitgangspunten behouden zonder dat er een Amendement aan te pas was gekomen."

Algemeen wordt aangenomen dat het Congress de bevoegdheid heeft, de rechtsmacht van het Hof te veranderen. ${ }^{88}$ Er zijn stemmen opgegaan om met dit instrument de jurisdictie van het Hof op het vlak van gebed op school en abortus te ontnemen maar tot op heden is het bij woorstellen gebleven. ${ }^{89}$ Scherpe begrenzingen wan deze bevoegdheid van het Congress zijn niet expliciet in de grondwet aangegeven, maar er is wel geopperd dat een terughoudend gebruik van dit instrument door het Congress zou sporen met het respect voor de kernfunctie van het Hof. Het enkel tegengaan van onwenselijke rechtspraak zou niet erg geloofwaardig overkomen als motief voor beperking van de jurisdictie. Buiten de tekst van de grondwet zijn er praktisch-ideologische bezwaren: beperking van de rechtsmacht heeft zijn repercussies op de functie van het bewaren van de rechtseenheid door het Hooggerechtshof. In de literatur is wel het volgende geopperd:

"it is politically healthy, that the limits of congressional power never have been completely" clarified. In some circumstances, may not attempts to restrict jurisdiction be an appropriate and important way for the political branches to register disagreement with the court? And is it not enormously significant that, ever since McCardle, such attempts have, in the main, been just that - that Congress has not significantly cut back the Supreme Court's jurisdiction in a vindicative manner despite the great unpopularity of some of its rulings? ? $^{90}$

De mogelijkheden van het Congress lijken aldus beperkt - niet in de laatste plaats in het licht van de constitutionele verhoudingen als vastgesteld onder Marbury $t$. Madison voor wat de taak van het Hof betreft. Anderzijds hebben de initiatieven wel aangetoond, welke politieke discussies worden gevoerd binnen de wetgevende gelederen, die het Hof wellicht af en toe hebben gemaand tot voorzichtigheid. De rechters in het Hof worden voor het leven benoemd. In de benoemingsprocedure van de rechters lijkt op het eerste gezicht een effectief instrument te schuilen waarmee de rechtspraak in een gewenste richting kam worden gestuurd. ${ }^{91}$ Het is een geaccepteerd gegeven dat de president in de nominatie een persoon kan woorstellen, die zijn eigen politieke en ideologische ideeen deelt. Een voorstel voor nominatie wordt door de Senaat slechts

87

\section{Par. 32.4 .}

Trilbe 1995. Ackerman vertegenwoordigt de opwatting dat deze methode een manier is om de grondwet te amenderen buiten de in Art. V neergelegde procedure (Ackerman 1983, p. 47 e.w.).

88 Art. III \$2 sub 2: "In all Cases affecting Ambassadors, other public Ministers and consuls, and those in which a State shall be party, the Supreme Court shall have original jurisdiction. In all other Cases before mentioned $_{\text {t }}$ the supreme Court shall have appellate Jurisdiction, both as to Law and Fact, with such Exceptions, and under such Regulations as the Congress shall make'.

89 Een voorstel kwan van senator Jesse Helms in 1979 waarin de jurisdictie van het Hof met betrekking tot schoolgebeden zou worden afgenomen. Het woorstel zou echter tot gevolg hebben, dat dergelijke zaken door geen enkele federale rechter meer beoordeeld zouden kunnen worden, waarop de kritiek werd geleverd dat een dergelijke beperking in strijd zou komen met Marbury t. Madison.

90 Hart en Wechsler 1996, p. 370.

91 Gunther en Sullivan 1997, p. 75. 
verworpen op grond van aperte ongeschiktheid of laakbaar gedrag. President Roosevelt benoemde tijdens zijn ambtstermijn acht rechters, waarvan hij hoopte dat zij allen zijn 'New Deal'-politiek zouden steunen. Dat idee leek aanvankelijk te werken - totdat de rechters ten opzichte van elkaar verschillende visies ontwikkelden waarin de mate van rechterlijk activisme in de bescherming van individuele rechten een twistpunt werd. ${ }^{92}$ lets gelijkwaardigs gebeurde na het Warren-Court, dat onder meer de uitspraken had gedaan in Griswold t. Comecticut en Roe $t$. Wade. ${ }^{93}$ Tot op zekere hoogte kunnen president en senaat de toekomstige koers van het Hof proberen te sturen maar de invloed moet echter niet worden overschat - het Hof zal in het algemeen niet zeer afwijkend zijn van de politieke hoofdrichting van de regering. ${ }^{94}$ De president kan de door hem benoemde rechter geen mandaat meegeven.

\subsection{De werkwijze van het Duitse Federale Constitutionele Hof}

\subsubsection{Federale rechtsmacht van het Hof}

De Duitse grondwet stipuleert onder meer in Artt. 93 en $100 \mathrm{GG}$ nauwkeurig welke materiële terreinen behoren tot de rechtsmacht van het Hof. ${ }^{95}$ Het Hof heeft niet, zoals

92 Hetzelfde owerkwam Nixon, die met de benoemingen van rechter Burger (door Nixon tot voorzitter benoemdj en rechter Rehnquist, Blackmun en Powell hoopte op een Hof dat na het Warren Court (tot 1969) een terughoudender taakopvatting ter zake van individuele grondrechten zou gaan hanteren. Echter, de stemverhoudingen toonden al snel aan, dat ook dit Hof een minder conservatieve koers voer dan Nixon had gehoopt (Gunther en Sullivan 1997, p. 76).

93 Griswold t. Connecticut, 381 U.S. 479 (1965) en Roe t. Wade, 410 U.S. 113 (1973). De zeer conservatieve jurist Bork was genomineerd door de conservatieve president Reagan in 1987, die graag zag dat de rechtspraak van het tijdperk van het Warren-Court zou worden bijgestuurd. Het Warren-Court had gedurende een aantal decennia een extensieve benadering bij de interpretatie van de grondwet gekozen. Reagan had vót deze nominatie reeds rechters O'Connor en Scalia benoend en wenste de conservatieve vleugel in het Hooggerechtshof verder te versterken. De Senaat verwierp Reagans keuze; uiteindelijk werd de meer gematigde rechter Kennedy in $\$ 988$ benoemd (zie Lazarus $2000^{\text {" }}$ "Robert Bork and Civil War').

94 In de aanloop naar de presidentswerkiezingen wordt tevoren bijwoorbeeld gespeculeerd ower de samenstelling van het Hof in de nabije toekomst, waarbij gekeken wordi naar de recliters die wellicht met pensioen zullen gaan warvoor de nieuwe president dan een nieuwe nominatie kan voorstellen. Indien meerdere vacatures zullen moeten worden vervuld kan een president aldus een Hof samenstellen dat politiek-ideologisch de opvattingen van de president deelt. Dit is echler geenszins een garantie voor een "president-gezind ${ }^{x}$ Hof Hierbij doet het voorbeeld opgeld, waarin president Bush in 1990 rechter Souter benoemde omdat hij verwachtte dat Souter een zeer conservatieve lijn zou volgen in zijn opinies; dat bleek naderhand echter minder het geval dan Bush wellicht had gehoopt. Zie eveneens "Tribe: 'Picking judges is too important a task to be left to any President' (Tribe 1985 (I), p. 170 e.v.).

95. Tot de rechtsmacht van het Hof behoren de beoordeling van grondwettigheid van politieke partijen (Art. $21 \mathrm{GG}$ ); toetsing van verkiezingsresultaten (Art. 41 lid $2 \mathrm{GG}$ ), ontslag van de federale president (Art. 61 GG), geschillen tussen hoge statelijke organen (Art. 93 lid 1 sub I GG), Abstracte rechterlijke toetsing (Art. 93 lid 1 sub 2 GG, en onder meer benut voor de beoordeling van grondwettigheid wan federale wetgewing ter zake wan het recht op abortus), geschillen tussen federatie en staten (Artt. 93 lid 1 sub 3 en 84 lid $4 \mathrm{GG}$ ), concrete rechterlijke toetsing of het stellen van een prejudiciele vraag (Art. 100 lid 1 GG), ontslag van rechters (Art. 98 GG), interstatelijke constitutionele geschillen (Art. 99 GO), toepasselijkheid van internationaal recht (Art. 100 lid 2 GG), toepasselijkheid van federaal recht (Art. 126 GG) en, vooral van belang voor het recht op persoonlijkheid, de beowdeling van klachten ower grond- 
zijn Amerikaanse tegenhanger, het terrein van constitutionele toetsing moeten 'veroveren". Binnen het Hof zijn de taken verdeeld tussen twee Senaten. De jurisdictie over de verschillende terreinen is in beginsel strikt verdeeld tussen de Eerste en de Tweede Senaat van her Hof. Oorspronkelijk was het de bedoeling, de Tweede Senaat de meer 'politiek gevoelige kwesties' zoals politieke geschillen ter zake van horizontale en verticale machtenscheiding en geldigheid van verkiezingen toe te bedellen, en de Eerste Senat over "nonpolitieke" kwesties zoals individuele klachten en prejudicièle wragen te laten beslissem. Er ontstond al gauw een disbalans in de werkverhouding; de Eerste Senat had vanwege de grote stroom individuele klachten een veel grotere werklast dan de Tweede Senaat. Daarop besloot het federale parlement een deel van de bewoegdheden van de Eerste naar de Tweede Senaat over te hevelen, waarbij de Tweede Senaat zijn oorspronkelijke mandaat behield. ${ }^{97}$ De Tweede Senaat oordeelt sindsdien over de procedurele waarborgen van de grondwet. ${ }^{98}$ De Eerste Senaat behandelt klachten ter zake van materiële grondrechten.

Het Plenum, waarin beide Senaten samenkomen, beslist over de rechtseenheid van uitspraken. Hoewel de rechtsmacht overzichtelijk verdeeld lijkt te zijn in de wet, rijzen er soms toch meningsverschillen tussen de Senaten ter zake van de juiste uitleg van de grondwet. Het gaat om kwesties waarin de ene Senaat van mening is, dat die betrokken dient te worden in interpretatievragen ter zake waarvan de andere Senaat in eerste instantie bevoegd is. In dergelijke gevallen dient dan een plenaire vergadering te worden ingeroepen teneinde rechtseenheid te bewaren in de grondwetsinterpretatie. In de zaak Sterilisation bijvoorbeeld beoordeelde de Eerste Senaat de vraag, of er na een mislukte sterilisatie schadevergoeding kan worden geëist voor de kosten van het ter wereld gekomen kind in het licht van een recht op menselijke waardigheid ex Art. 1 lid 1 GG. ${ }^{100}$ De Tweede Senaat achtte overleg met de Eerste Senaat over de juiste interpretatie van het recht op menselijke waardigheid noodzakelijk, omdat de Tweede Senaat enkele jaren eerder in een abortuszaak ook al over dat recht had geoordeeld. ${ }^{101}$ De Tweede Senaat was namelijk van oordeel, dat de Eerste afweek van de interpretatie in de abortusuitspraak. ${ }^{102}$

GG) en, vooral wan belang woor het recht op persoonlijkheid, de beoordeling van klachten over grondrechten (Art. 93 lid 1 sub 4 a GG).

96 Zie par. 3.3.1.

97 Kommers 1997, p. 18.

98 De abstracte herziening van de wetgeving ter zake van het recht op abortus werd beoordeeld door de Tweede Senaat; aan hem is de beoordeling van abstracte herziening opgedragen.

99 Art. 13 en 14 Bundeswerfassungsgerichtsgesetz (hierna BVerfGG). De klacht wan het individu over de mislukte sterilisatie kwam daarentegen bij het Hof terecht wia de prejudiciële procedure ex Art. 100 lid 1 Go bij de Eerste Senaat terecht.

10096 BVerfGE 375 (1997). Zie ook NJW 1998 (8), p. 519-524.

101 Schwangerschafisabbruch $1 I_{\mathrm{r}} 88$ BVerfGE 203 (1993).

102 In Schwangerschafisabbruch $I /$ had de Tweede Senaat het recht op leven van het ongeboren kind titgelegd in het licht van het recht op menselijke waardigheid. Met name de uitleg ter zake van het recht op menselijke waardigheid verhield zich niet, aldus de Tweede Senaat, met het door de Eerste Senaat ingewomen standpunt in Steril isation: de Eerste Senaat achte de mogelijkheid on schadevergoeding toe te kennen na een mislukte sterilisatie niet in strijd met de menselijke waardigheid van het ter wereld gekomen kind. De Tweede Senaat daclut hier anders over. 
Van de verschillende terreinen die behoren tot de rechtsmacht van het Hof worden hier de voor het recht op persoonlijkheid relevante onderdelen - abstracte en concrete rechterlijke toetsing en individuele klachten - beschreven. Abstracte rechterlijke toetsing houdt in dat het Hof een wettelijke norm kan toetsen zonder dat een rechtsbelang geschonden is. Deze procedure bij het Hof leidt vaak tot verhitte debatten, ondat het Hof direct controle uitoefent over politieke besluitvorming en de daaruit voortvloeiende resultaten. Het instrument van de abstracte toetsing raakt de kern van de constitutionele verhouding tussen rechter en wetgever op tweeerlei wijze. Enerzijds kan het Hof direct de werkzaamheden van de wetgever nietig verklaren; maar anderzijds is het ook (een deel van diezelfde) de wetgever die de werkzaamheden wil laten toetsen. Het resultaat van abstracte toetsing is nagenoeg altijd omstreden, omdat dat bijna altijd leidt tot een nederlaag van een politieke stroming of opvatting. ${ }^{103}$ Het Hof kan zich niet onttrekken aan abstracte toetsing als eenmaal een dergelijke vraag is ingediend. Het kan zich bijvoorbeeld niet verschuilen achter toepassing van het subsidiariteitsbeginsel, dat geldt in de Duitse federale rechtsmachtverdeling. Op het terrein van het recht op persoonlijkheid heeft het Hof een tweetal federale wetten over abortus abstract getoetst. ${ }^{104}$ De abstracte rechterlijke toetsing van statelijke of federale wetgeving kan enkel plaatswinden op verzoek van de Bondsregering, een regering van é̉n van de staten of eenderde meerderheid van de Bondsdag. ${ }^{105}$ Een besluit van het Hof inhoudende de ongrondwettigheid van de betwiste wet leidt in beginsel tot de nietigheid ervan. ${ }^{106}$ Het verzoek tot toetsing wordt gehonoreerd, indien gegronde twijfel gerezen is over de grondwettigheid van de wetgeving. In dit verband kan het Hof ook uitspraak doen over grondwetswijzigingen. Het Hof wordt overigens zeer kwetsbaar geacht in kwesties van abstracte rechterlijke toetsing. Verzoeken tot abstracte rechterlijke toetsing worden vaak bij het Hof aangebracht door politieke partijen die geen andere uitweg zien om een punt naar voren te brengen, omdat zij bijvoorbeeld worden overstemd door meerderheden in de coalitie. ${ }^{107}$ Hoewel op deze bevoegdheid veel kritiek is uitgeoefend, is er in de Bondsdag nog geen meerderheid te vinden geweest die abstracte rechterlijke toetsing wilde afschaffen.

In het geval van een vraag om concrete rechterlijke toetsing kan iedere rechter zich tot het Hof wenden. ${ }^{108}$ De vragen kunnen betrekking hebben op uiteenlopende wetten van de Bond en van de afzonderlijke staten, en eveneens op toetsingen van de grondwet. Ook kan de grondwettigheid van internationale verdragen, waaronder het EU-Verdrag

103 Schltilich 1997, p. 87

104 Achtereenvolgens Sighwangenschafisabbruch I, $39 \mathrm{BVErfGE} 1$ (1975) en Schwangerschafisabbrwch $/ 1$, 88 BVerfGE 203 (1993). Zie ook par. 6.3.4. hiema.

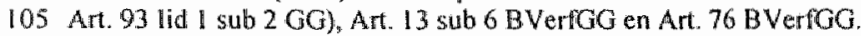

106. De verzoekers van abstracte herziening kunnen ook wetgeving Iaten toetsen die in beginsel niet binnen hun eigen bevoegdheid walt: de regering van een deelstant kan ook wetgeving van een andere deelstaat voorleggen aan het Hot.

107 in Schwangerschaffsabbrach 1, 39 BVerfGE 1 (1975) bestond het 'consortium' wan klagers uit 193 leden van de Bondsdag, alsmede uit een groep van CDU-politici uit de delstaten Baden-Wurttemberg, Saarland, Beieren en Sichleswig-Holstein.

108 Art 80 lid 1 BVerfGG. 
door het Hof worden getoetst. ${ }^{109} \mathrm{Na}$ de individuele klachten vormt deze wijze van rechterlijke toetsing de grootste werkverschaffer voor het Hof. Concrete rechterlijke toetsing komt voort uit constitutionele vragen die een lagere rechter heeft naar aanleiding van de beoordeling van een geschil. ${ }^{10}$ Het is niet noodzakelijk dat de partijen in het geding de grondwettigheid betwisten; voldoende is dat de rechter de toepasselijke wet in strijd acht met de grondwet. Lagere rechters hebben een verwijzingsplicht; hogere rechters kunnen kiezen voor een verwijzing. Het Hof neemt de zaak in beginsel niet ter beoordeling aan indien het geschil zonder beoordeling van grondwettigheid van de wet kan worden opgelost. Van belang is verder, dat het Hof de bij de wet betrokken wetgever - federaal of statelijk - moet betrekken in de zaak. ${ }^{110}$

Het grootste deel van de werkbelasting van het Hof wordt gevormd door de individuele klachten. ${ }^{112}$ Eenieder, die daartoe gerechtigd is, kan een klacht indienen wanneer een vermeende schending van grondrechten heeft plaatsgevonden. ${ }^{113}$ Inmiddels lijken alle handelingen die worden beknot door overheidsmaatregelen aan het Hof te kunnen worden voorgelegd, omdat het Hof aan het recht op persoonlijke ontplooiing ex Art. 2 lid 1 GG een nagenoeg onbegrensde uitleg heeft gegeven. De omvang van toetsbare grondrechten is met deze ruime uitleg aanzienlijk opgerekt, hetgeen tot gevolg heeft dat het Hof zich over bijna iedere willekeurige vermeende schending kan uitlaten. De extensieve interpretatie van Art. 2 lid 1 GG heeft scherpe kritiek uitgelokt, omdat het Hof met zijn ruime benadering nagenoeg elke overheidsmaatregel kan onderwerpen aan grondwettelijke toetsing. ${ }^{1 / 4}$ In dit opzicht is een vergelijking met het Amerikaanse debat over 'substantive due process', waarin dezelfde kritiek wordt geleverd op het Amerikaanse Hooggerechtshof, niet geheel onterecht. ${ }^{115}$ Naast een beroep op de grondrechten kan eveneens geklaagd worden over een schending van het rechtsstaatbeginsel of het beginsel van de sociale staat ex Art. 20 GG; beide gronden zijn tot ontwikkeling gebracht via extensieve lezing van Art. 2 lid 1 GG. ${ }^{116}$ Op een grondrecht mogen beperkingen worden aangebracht, die in overeenstemming zijn met de 'verfassungsmäßige Ordnung' - de constitutionele rechtsorde - ex Art. 2 lid 1 GG. ${ }^{17}$ Klachten bij het Hof

109 Mcastrichtorte $\mathrm{l}_{\text {, }} 89$ BVerfGE 155 (1993).

110 Art. 100 lid 1 GG, Artt. 80-82 BVerfGG.

111 Art. 82 jo. 77 BVerfoG.

112 Konmers 1997 , p. 14.

113 Art. 93 lid 1 sub $4 a$ GG noemt naasit de grondrechten in hoofdstuk I de volgende grondrechten: Art. 20 lid 4, Art. 33, 38, 101, 103 en 104 GG. Een beroep op het Europees Verdrag voor de Rechten wan de Mens kan door het Hof niet als zodanig worden beoordeeld (zie 64 BverfGE 135 (157)).

114 Het Hof heeft deze kritiek eemnaal beantwoord in "Reiten im Walde ", waarin de vraag rees in hoeverre pardrijden in het bos kan worden beschouwd als een handeling die bescherning dient te genieten onder Art. 2 lid 1 GG (80 BverfGE 137, 152 (1989)). Zie Hesse 1991, p. 173 e.w. en Scholz 1975, p. 84.

115 Zle par. 23.

116 Art. $20 \mathrm{GG}$ benoemt niet expliciet het rechtsstaatbeginsel, maar wel enkele onderdelen ervan zoals nachtenscheiding, binding aan de grondwet, en binding aan de wet van bestuur en rechter. Hoewel de discussie over de wraag of het rechtsstaatbeginsel nu wel of niet in Art. $20 \mathrm{GG}$ is gecodificeerd al lange tijjd woedt, neemi het Hof het rechtsstaatbeginsel al geruime tijd aan als grondslag voor de erkenning van individuele anspraken.

117 Zie par. 2.43 . 
kunnen worden ingediend na uitputting van alle andere rechtsmiddelen. ${ }^{118}$ Andere eisen van standing zijn niet dermate ingewikkeld, dat de klager op deze gronden moet vrezen voor afwijzing van zijn klacht. ${ }^{119}$ De drempel om een klacht in te dienen is laag; belangrijkste eis is dat een klacht 'offensichtlich begründet' dient te zijn. Een klaclat kan worden ingediend tegen elke handeling van de staat, dus ook tegen rechterlijke beslissingen. ${ }^{120}$ Sinds 1962 kan het Hof een boete opleggen, indien blijkt dat er misbruik wordt gemaakt van de procedure. ${ }^{121}$ Jaarlijks wordt een groot aantal individuele klachten ingediend; hiervan wordt gemiddeld $2,5 \%$ angenomen ter beoordeling door het Hof. ${ }^{122}$

\subsubsection{Ontvankelijkheidscriteria}

Het Hof kan in beginsel geen aannamebeleid voeren zoals het Amerikaanse Hooggerechtshof dat doet met de certiorari-procedure. ${ }^{123} \mathrm{Er}$ zit echter wel enige rek in de vereisten die gelden voor de ontvankelijkheid. Allereerst kan de klacht worden aangenomen voor zover haar 'verfassungsrechtliche Bedeutung' toekomt: de klacht dient een belangwekkende grondrechtelijke vraag te behelzen ter zake waarvan het Hof lijnen kan uitzetten voor de toepassing van het betreffende grondrecht door rechters, wetgevers en bestuur. ${ }^{124}$ In de tweede plaats moet de klacht enig uitzicht bieden op succes, en kan een te verwachten groot nadeel eveneens nopen tot ontvankelijkheid. ${ }^{125}$ Het tweede criterium is in 1987 ingevoerd om het Hof een instrument te bieden, de aanzwellende stroom klachten te kanaliseren. Met beide vereisten kan het Hof een beperkt aannamebeleid voeren, maar het is moeilijk een beeld te krijgen van de precieze redenen van afwijzing van klachten; zij worden niet gepubliceerd. Art. 2 lid 1 GG biedt een kapstok voor zeer uiteenlopende individuele aanspraken, terwijl een eng ontvankelijkheidsbeleid niet goed mogelijk lijkt met de huidige uitgangspunten in de wet. De beide Senaten hebben voor de beoordeling van het grate aantal klachten ieder Kamers ingesteld ${ }^{126}$; de

118 Art 93 lid 1 sub 4 a GG en 90 tot en met 95 BVerfGG. Een klacht moet worden ingediend binnen een maand na de rechterlijke ultspratk wartegen wordt opgekomen-zie Art. 93 lid I BVerfGG, of binnen een jaar na inwerkingtreding indien wordt geklaagd tegen wetgeving, zie Art. 93 lid 3 BverrGG. Een uitzondering op het wereiste van uitputting van rechtsmiddelen kan worden gematkt in hel geval dat. het individu onevenredig grote schade dreigt op te lopen wanneer aan het verenste wordt vastgehouden (Volkszahlung, 65 BVerfGE 1, 1983).

I 19 Er is geen eis vam rechisbijstand, gerechtskosten worden niet verlangd. Ongeveer enderde vam de klachten wordt geformuleetd door advocaten (Kommers 1997, p. 15)

120 Art. $90 \mathrm{BVer}$ GG.

121 Art. 34 lid 2 BVerfGG. Het Hof heeft in 199966 keer een dergellike boete gegeven (bron: www. bundesverfassusngsgericht de; geradpleegd op 31 juli 2002).

122 In de periode $1951-1997$ werden in totaal 112.852 individuele klachten ingediend; daarvan werden 2901 klachten ontvankelijk verklaard (bron: www bundesverfassungsgerichtde; geraadpleegd op 3 ! juli 2002).

123 Art. 93a hid 2 BVerfGG. Er werden evenwel voorstellen gedaan voor een dergelijk systeem (Schlaich, p. 171).

124 Schlailch 1997 p. 171

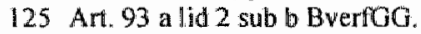

126 Er is wel eens geklaagd over dit systeem, dat toegang tot eer wechter zou werhinderen; hei Hof wees die klacht af met een beroep op de bevoegdheid die de grondwet creèrt, om Kamers in te stellen (zie 7 BVerfGE 241 (1958)). 


\section{HoOFDSTUK 3}

met drie leden bemande Kamers beoordelen de klachten op ontvankelijkheid. ${ }^{17}$ Deze drie leden kunnen een klacht afwijzen undien alle drie leden van mening zijn dat de klacht nifet-ontvankelijk is of geen vooruitzicht biedt op slagen. ${ }^{1.28}$ Indien één lid de klacht ontvankelijk acht, wordt de klacht in behandeling genomen. Een Kamer motiveert in de regel de afwijzingen, maar deze beslissingen worden, zoals hiervoor gesteld, niet gepubliceerd. Na aanname door de Kamer beslist de Senaat over ontvankelijkheid; de Senaat kan na de positieve beslissing van een Kamer nog steeds beshiten tot nietontwankellikheid. ${ }^{129}$

\subsubsection{De uitspraak}

De uitspraak dient te worden gesteund door een meerderheid van de acht rechters. Een meerderheid in de Senaat wordt aldus gevormd door vijf rechters. De rechters hebben allen een eigen specialisatie; in overleg met de president van de Senaat wordt vastgesteld, welke rechter bij welke soort zaak zal optreden als rapporteur. De rapporteur stelt een votum op voor de beslissing van de zaak. ${ }^{130}$ Dit votum dient naderhand als uitgangspunt voor de besluitvorming. Idealiter wint de rapporteur een meerderheid voor zijn standpunt, en onderhandelt met de andere rechters over de lijn van de uitkomst. Wanneer hij de meerderheid niet voor zich weet te winnen, is hij evenzeer de aangewezene om de uiteindelijke mening van het Hof weer te geven. ${ }^{131}$ In enkele gevallen is het voorgekomen, dat een patstelling optrad in de Senaat: er kon geen meerderheid voor een standpunt worden verkregen. In dergelijke gevallen blijft de aangevochten rechterlijke uitspraak in stand. De zaak wordt dan terugverwezen naar de bevoegde instantie. $^{132}$

Het Hof honoreert de individuele aanspraak in beginsel voor zover het de aangevochten wet of wetsbepaling in strijd acht met de grondwet. Het Hof beperkt zich bij het onderzoek naar de grondwettigheid echter niet alleen tot de door de klager aangevoerde gronden, het Hof kan ambtshalve toetsingsgronden aanvullen. Deze bevoegdheid leidt het Hof af uit de betekenis van de individuele klachtprocedure in de constitutionele rechtsorde:

'Nachdem die Verfassungsbeschwerde zulässig ist, ist das Bundesverfassungsgericht bei der materiellrechtlichen Prufung nicht mehr darauf beschränkt zu untersuchen, ob eine der gerdigten Orundrechtsverletzungen vorliegt. Es kann die verfassungsrechtliche Unbedenk-

127 Tot en met 1999 hadden beide Senaten elk drie kamers; sinds 2000 heeft de Tweede Senat vier kamers (bron: www bundesvertassungsgericht del, geraadpleegd op 31 juli 2002).

128 Art. 93 b BVerfGG.

129 Ook hier bestaat geen publicatieplicht, maar het Hof motiveert dergelijke beslissingen meestal wel en publicert zijn afwijzingen regeimatig. Enerzijds is een voorportaal, de Kamer, waarin het grootste deel van de klachten wordt beoordeeld praktisch gezien onontkoombaar; aan de andere kant is niet altijd duidelijk welke criteria de Kamer precies hanteert, wanwege de niet-openbaarheid wan de ontwankelijkheidsbesluiten.

130 Kommers 1997, p. 25.

131 In witzondertijke gevallen kan $\|_{i j}$ een andere rechter vragen om de eindbeslissing te schrijven; dit gebeurt echter zelden (Kommers 1997, p. 26).

132 Tagebuch, 80 EverfGE 367 (1989). 
lichkeit des angegriffenen Urteils vielmehr unter jedem in Betracht kommenden verfassungsrechtichen Gesichtspunkt prüfen:. 133

Deze bevoegdheid is niet gecodificeerd in de grondwet of in de formele wetgeving ter zake van de procedureregels van het Hof, maar het gevolg van rechterlijke interpretatie In verband met de taakopvatting van de rechter kan in dit verband gesproken worden van een activistische benadering door het Hof, al hangt de mate van activisme samen met de vraag, hoe vaak het Hof ambtshalve aanvullingen pleegt ter zake van aanspraken - meer in het bijzonder aanspraken op de algemene handelingsvrijheid ex Art. 2 lid I GG of het algemene persoonlijkheidsrecht ex art. 2 lid 1 jo. 1 lid 1 GG. In beginsel biedt Art. 2 lid 1 GG ruimte voor zeer uiteenlopende aanspraken, en zal kwalificatie van de aanspraak niet gauw problemen opleveren.

De uitspraken van het Hof over de grondwettigheid van wetten hebben kracht van wet en er geldt een publicatieplicht van de uitspraken die leiden tot instandhouding of nietigheid van de gewraakte wet. ${ }^{134}$ In dit opzicht heeft het Hof een met de wetgever vergelijkbare positie: diens uitspraken kunnen een wet terzijde stellen. Vraag is dan, of het Hof vaak over gaat tot een nietigverklaring van de aangevochten regeling. De wet geeft een aantal regels voor de uitspraken, maar het Hof heeft naast de in de wet geregelde mogelijke dicta een aantal eigen formuleringen ontwikkeld. Het Hof stelt vast welk grondwettelijk voorschrift werd geschonden en preciseert welke handeling of welk nalaten daaraan debet was. Tegelijkertijd is het Hof bij wet de bevoegdheid verleend on aan te geven of de schending in casu plaatsvond, of dat de handeling of het nalaten in het algemeen een voortdurende schending oplevert. ${ }^{135}$ Indien een klacht wordt gehonoreerd die tegen een rechterlijke uitspraak was gericht, dient het Hof de beslissing van de lagere rechter op te heffen en de zaak te retourneren aan de bevoegde rechter. ${ }^{136}$ In de praktijk komt het er echter regelmatig op neer, dat het Hof zelf in de zaak voorziet:

'Denn bei Anwendung der verfassungsrechtlichen Kriterien unter Berücksichtigung der vom Bundesverfassungsgericht erhobenen Beweise besteht kein Spielraum melur für die richterliche Entscheidung; vielmehr muB der Antrag des Beschwerdefuhrers in vollem Umfang Erfolg haben. Bei einer Zurückverweisung könnten die Gerichte des Ausgangsverfahrens somit die Entscheidung des Bundesverfassungsgerichts nur wiederholen'. ${ }^{37}$

In beginsel komt de bevoegdheid on de vraag naar de mate van speelruimte ten opzichte van de lagere rechter te beantwoorden niet toe aan het Hof. Met doelmatig-

133 Zie Inkompatibilitatkirchliches Amt, 42 BVerfGE 312, 325 (1976); Familiennachzug, 76 BVerfGE 1, $74(1987)$.

134 Art. 31 lid 2 BVerfGG laidt: "In den Fallen [... ] hat die Entscheidung des Bundesverfassungsgerichts Gesetzeskraft. Das gilt auch in den Fallen des par. $13 \mathrm{Nr} .8$ a (uitspraken ter zake van individuele klachten), wenn das Bundeswerfassungsgericht ein Gesetz als mit dem Grundgesetz vereinbar oder unvereinbar oder für nichtig erklärt. Soweit ein Gesetz als mit dem Grundgesestz oder sonstigem Bundesrecht vereinbar oder unvereinbar oder für nichtig erklärt wird, ist die Entscheidungsformel durch das Bundesministerium der Justiz im Bundesgeseizblatt zu veroffentlichen [...]".

135 Art. 95 lid 1 BVerfGG.

136 Art. 95 lid 2 BVerfGG.

137 Zie bijvoorbeeld Lebach, 35 BVerfGE 202, 244 (1973). 
heidsargumenten heeft het Hof die bevoegdheid echter wel naar zich toe getrokken. Daarnaast dienen volgens de grondwet in herziening van rechterlijke uitspraken eventuele wetten, die strijdig blijken te zijn met de grondwet; door het Hof in beginsel nietig te worden verklaard. Was de klacht indirect of direet tegen wetgeving gericht en succesvol, dan dient het Hof de wet eveneens nietig te verklaren. ${ }^{138}$ Ook op dit punt is het Hof deels een eigen koers gaan varen: het doet soms uitspraken, waarin een vaststelling van ongrondwettigheid volgt, maar niet de nietigheid wordt vastgesteld. Het Hof had met deze variant voor ogen, gevolgen van nietigheid af te wenden. De vaststelling van enkel ongrondwettigheid zonder nietigheid maakt een interim-toepassing wan de strijdige rechtsnorm mogelijk, omdat in dergelijke gevallen wat tijd en mogelijkheden aan de wetgever worden gelaten voor een oplossing. Het Hof spreekt met vaststelling van ongrondwettigheid aldus de verplichting van de wetgever uit, de ongrondwettige toestand ongedaan te maken. ${ }^{139}$ De wet wordt door het Hof niet altijd ex tunc nietig verklaard; zoals voorheen gesteld kan het Hof een interim-periode laten bestaan, of aan de wetgever een termijn opleggen waarbinnen de ongrondwettige toestand moet zijn opgeheven. Het Hof hanteerde tot dusverre de bevoegdheid tot het stellen van een termijn niet heel dikwijls. ${ }^{140}$ Het Hof voert voor een variatie in de uitspraken argumenten met betrekking tot de rechterlijke taakopvatting aan die leiden tot een diametraal tegengestelde opvatting in vergelijking met die van de Amerikaanse rechter. De Amerikaanse rechter stelt dat er voor rechterlijke toevoegingen ter zake van dicta geen plaats is. Interessant is aldus dat beide rechters zich beroepen op een terughoudende rechterlijke taakopvatting. Zij lijken hun grondwet ieder op een andere wijze te percipiëren: de Duitse aanvaardt dat de rechter vanuit de systematiek normen mag afleiden en toepassen, terwijl de Amerikaanse rechter juist een verbod tot een dergelijke activiteit ziet in zijn grondwet. ${ }^{141}$

In sommige gevallen herschreef het Duitse Hof als het ware de gewraakte wet. ${ }^{142}$ De autoriteit van's Hofs uitspraken is dermate groot dat een uitspraak van het Hof soms een hoger rang wordt toebedeeld wetgeving in formele zin. $^{1 * 3}$ Op sommige uitspraken is echter veel kritiek gelleverd, omdat het parlement naderhand nauwelijks mogelijkheden zag om van de herschrijvingen af te wijken - emstige afwijkingen zouden immers komen te staan op ongrondwettigverklaring van de wet. Waar het kan, bedient het Hof

138 Art. 95 lid 2 en 3 BVerfGG. Het Hof heeft in dit verband sons verzuind tot expliciete nietigheidsverklaning over te gaan (Erich Honecker, Fermsehawhahmen in Gerichtssaal, 91 BVertGE 125, 139 (1994). Hier betwijfelde het Hof de noodzak wan nietigverklaring.

139 Zie bijwoorbeeld Volkszihlung, 65 BVerfGE \(1983), warin het Hof aan het parlement aangaf wat er in de volkstellingenwet verander diende te worden voordat deze de toets wan grondwettigheid zou kun. men doorstatin.

140 Zie bijwoorbeeld Finarzansgleich, 72 BVerfGE 330 (1986), waarin het Hof van deze bevoegdheid gebruik muakte.

141 Het Amerikaanse Hooggerechtshof heeft niet steeds dezelfote opvatting hierover gehad; zoals voorheen gesteld waren er "Courts" die bereid bleken, een met de Duitse reciver vergelijkbare taakopvatting te Wanteren (zie par. 3.2.4). De lastste jaren lijkt het Amerikaanse Hooggerechtshof, waar het aanspraken op "liberty" en "privacy" betreft, wel de hier geschetste lijn ter zake van dicta aan te houden.

142 Zie bijwoorbeeld Schnangerschoftsabbuch l, 39 BVerfCE 1 (1975).

143 zeidler 1984, p. 93. 
zich van grondwetsiconforme interpretatie: getracht wordt, de aangevochten wet zo te interpreteren dat strijdigheid met de grondwet langs deze weg wordt opgeheven. ${ }^{144}$ Het Hof gaat in beginsel uit van grondwettigheid van wetten, en heeft dat uitgangspunt al vroeg in zijn rechtspraak erkend. Grondwetsconforme interpretatie biedt het Hof een instrument om de uitspraak van nietigheid van de wet te vermijden, en gedachtevorming over eventuele nieuwe wetgeving aan de wetgever over te laten. Het Hof heeft in veel gevallen keuze tussen enerzijds interpretatie van de wet die leidt tot ongrondwettigheid, en anderzijds tot grondwettigheid van de wet. Het Hof zal met het oog op de regel wan 'favor legis', indien mogelijk, aansluiten bij de tweede interpretatie. ${ }^{45}$

Sinds 1971 kunnen de rechters afzonderlijk een dissenting of een concurring van het oordeel geven; in negen van de tien gevallen doet het Hof echter unaniem uitspraak. ${ }^{406}$ Sommige auteurs schrijven het relatief lage aantal dissentings toe aan een institutionele loyaliteit van de rechters aan het Hof, alsmede aan een afkeer van gepersonaliseerde rechtspraak. ${ }^{147}$ De reden om het 'Sondervotum' in te voeren hing nauw samen met de veelvormigheid van bestaande constitutionele interpretatiemethoden:

"Seine Einführung ist Ausdruck für den in einigen Fragen des Verfassungstechts unleugbar vorhandenen Pluralismus in Methode und Ergebnis der Verfassungsinterpretation. [...] Das Sonderwotum wie auch die Mitteilung der Abstimmungsverhältmisse und die Wiedergabe verschiedener Ansichten der Richter in den Urteilsgründen zeigen, daß das Verfassungsrecht auch innerhalb des Gerichts in der Diskussion war und ein künfiger Wandel in der Rechtsprechung möglich erscheint". 148

In dit verband wordt wel geopperd, dat een uitspraak aan autoriteit verliest, indien niet alle rechters instemmen met de uitkomst. De casus is in het voorliggende geval definitief beslist; het debat over de juiste interpretatie echter, dat in het Hof heeft plaatsgevonden en juist door middel van dissentings zichtbaar wordt, is nog niet afgerond. Vanuit deze optiek kan dan worden gesteld, dat de weg voor rechtsontwikkeling open ligt, maar dat vooralsnog de meerderheid instemt met de op dat moment aangenomen interpretatie. In de Duitse situatie bedraagt het verschil tussen meerderheid en minderheid minimaal twee stemmen. In principe bezitten dissentings niet voldoende normatieve binding om een rechtsontwikkeling in de rechtspraak te legitimeren. ${ }^{149}$

144 Notaufnahme, 2 BVerfGE 266, $282(1953)$.

145 Uiteraard zijn er grenzen aan de grondwetsconforme interpretatie. de mate waarin het Hof grondwetsconform tracht te interpretenen, leidt soms tot acrobatische interpretaties. Het Hof heeft hiertoe twee hoofdijnen in zijn rechtspraak ontwikkeld. In de eerste plasts dient deze vorm van interpretatie zich enkel te richten op de tekst wan het wettelijke voorschrift; in de weede plats dienen de beginselien, de doelstelling en de kem vary het voorschrift in tact te worden gelaten (zie onder meer Gegendarstellung, $63 \mathrm{BVer}$ GE 131, 147 e.w. (1983). Deze uitgangspunten bieden in veel gevallen onvoldoende duidelijkheid; aansluiting bij de letterlijke tekst sluit grondwetsconforme interpretatic in enkele gevallen daurentegen geheel uit. Het Hof valt in dergelijke gevallen dan geheel terug op de tweede hoofdlijn (zie Ziwht dienst, 69 BVer:GE 1, 55 (1985): "Von Bedeutung ist lediglich, daB eine Auslegung dem Willen des Gesetzgebers nicht zuwiderläuft').

146 Kommers 1997 , p. 26.

147 Kommers 1997, p. 26.

148 Schlaich 1997, p. 38-39.

149 Schlaich 1997, p. 41. 


\subsubsection{Checks wan de wetgever op de rechtsmacht wan het Hof}

Beide Senaten hebben ieder acht leden, die voor 12 jaren worden gekozen; herverkiezing is uitgesloten. De kandidaten moeten om verkozen te worden een degelijke staat van dienst als rechter hebben. De helft van de rechters in elke Senaat wordt gekozen door de Bondsdag, en de helft door de Bondsraad ${ }^{151}$ De Bondsdag kiest op indrecte wijze via de 'WahlmännerausschuB', die een afspiegeling vormt van de vertegenwoordigende partijen in de politiek. ${ }^{152}$ De Bondsraad kiest direct; een tweederde meerderheid is vereist voor een keuze. De voorkeur voor een rechter wordt wel gezien als eén van de besluiten ter zake waarvan Bondsdag en Bondsraad hun politieke voorkeur kunmen laten gelden en invloed kunnen uitoefenen op de samenstelling van de hoogste rechterlijke unstantie. ${ }^{153}$ De invloed wordt echter gerelativeerd door het kiessysteem; in de Bondsdag zijn compromissen vaak onontkoombaar omdat de partijen elkaars voorkeur kunnen wegstemmen. In de Bondsraad lopen de voorkeuren in beginsel niet zozeer langs partijlijnen, danwel langs de lijnen van de belangen van de Länder. ${ }^{154}$ Over de wijze van verkiezing van de rechters is in Duitsland een voortdurend debat gaande. ${ }^{199}$ Indien uitgegaan wordt van het standpunt dat het Hof een rechterlijke instantie is als de andere in Duitsland, gaat men uit van de volgende premissen en doet de benoemingsprocedure er in beginsel niet zoveel toe:

'Dagegen ist es illegitim, weil mit der grundgesetzlichen Zuordnung der Verfassungsrichtsbarkeit zur "dritten Gewalt" unvereinbar, das Verfassungsgericht durch fraktionsproportionale Besetzung zum Spiegelbild des Parlaments zu machen. [...] Dem Verfassungsgericht dauren weder Melurheits- noch Minderheitswertreter [...] angehören, sondern nur solche Richter, die zu allen politischen und parlamentarischen Gruppen und Mächten gleiche Distanz haben und halten ". 156

Wordt constitutionele rechtspraak echter wel een rol toebedeeld in het politieke proces, dan verandert het perspectief op de benoemingsprocedure: langs deze weg kan dan worden getracht, een zo getrouw mogelijke vertegenwoordiging van de in het parlement aarwezige politiek partijen te bereiken. ${ }^{157}$ Het uitgangspunt van een 'gewone" rechterlijke macht lijkt niet geheel te zjjn verwezenlijkt. Er zijn uiteenlopende oorzaken aan te wijzen voor een voortschrijdende ontwikkeling van de rol die het Hof in het politieke proces heeft. Van invloed op deze ontwikkeling zijn in elk geval de abstracte toetsing van het Hof en de mate waarin de wetgever daarvan gebruik heeft gemaakt, alsmede het politieke gewicht dat wordt gehecht aan de uitspraken van het Hof. ${ }^{158}$ Ook het feit dat uitspraken wan het Hof de kracht van wet verkrijgen kan naar mijn mening

150 Artt. 2 lid 1 en 4 leden 1 an 2 BVerfGG.

151 Ant 5 lid 1 BVerfoG.

152 Zie ook Bowend'Eert 2000, p. 5.7.

153 Hesse 1991, p. 264.

154 Kommers 1997, p. 23.

155 Schlaich 1997, p. 34; Bockenforde 1974, p. 106; Haberle 1976, p. 4 e.v.

156 Bettermann 1981, p. 745 .

157 Haberle 1976, p. 24.

158 Sohlaich 1997, p. 35 . 
niet wijzen op een 'gewone' rechterlijke instantie. ${ }^{159}$ In de andere stelsels is een dergelijk expliciete toekenning van de kracht van wet in het geval van ongrondwettigheid van wetgeving niet aangetroffen.

Wijziging van de Duitse grondwet door de grondwetgever is mogelijk; dararwoor zijn tweederden van de stemmen in de Bondsdag en tweederden van de stemmen in de Bondsraad noodzakelijk. De grondwetgever heeft van deze mogelijkheid relatief vaak gebruik gemaakt, al zijn ter zake van Art. 1 lid 1 en 2 lid $1 \mathrm{GG}$ na de inwerkingtreding van de grondwet geen wijzigingen ingevoerd. Ook is de grondwetgever niet overgegaan tot codificatie van het in de rechtspraak ontwikkelde 'allgemeines Personlichkeitsrecht", ${ }^{150} \mathrm{Bij}$ een grondwetswijziging dient evenwel de beperking door de "Ewigkeitsklausel" ex Art. 79 lid 3 GG in acht te worden genomen. "6l Het Hof heeft in zijn jurisprudentie aan deze eis evenwel een relatief formele uitleg gegeven. ${ }^{162}$ Het overboord zetten van de rechtsbeginselen van menselijke waardigheid en machtenscheiding zijn ongeoorloofd:

"zu verhindern, daß die geltende Verfassungsordnung in ihrer Substanz, in ihren Grundlagen auf dem formal-legalistischen Weg eines verfassungsåndernden Gesetzes beseitigt und zu nachträglicher Legalisierung eines totalitären Regimes mißbracht werden kann". ${ }^{16 \%}$

Het Hof gaat in dit verband uit van een onaantastbare kern van de afzonderlijke grondrechten, die niet mag worden 'geraakt'. Of die kern door de wetgever wordt gerespecteerd, kan worden nagegaan aan de hand van de jurisprudentie. Het Hof heeft in dit opzicht als hoogste uitlegger van de grondwet het laatste woord. ${ }^{164}$ De kwestie in hoeverre de interpretaties van het Hof binnen de grenzen blijven van Art. 79 lid $3 \mathrm{GG}$ hebben geleid tot discussies over de aanvaardbaarheid van de rechtspraak van het Hof in het kader van Art. 79 lid $3 \mathrm{GG} .^{165}$ In dit verband kan men zich afvragen, in hoeverre de extensieve interpretatie van Art. 2 lid 1 GG of de positivering van het algemene persoonlijkheid als grondrechtsnorm te verantwoorden is in het kader van Art. 79 lid 3 GG. ${ }^{166}$ De aanvaarding van het vage normkarakter van beide rechtsnormen lijkt erop te duiden dat de grondwetgever juist heeft gekozen voor de mogelijkheid wan grond-

159 Art. 31 lid 2 BVerroG

160 sinds de inwerkingtreding van de grondwet in 1949 zijn er in totala 48 grondwetsannendementen doorgevoerd (zie voor een owerzich http//user cs.tu-berlin de/; deze werd op 31 juli 2002 getatadpleegd). De grondrechten die in werband worden gebracht met het recht op "privacy" zijn sinds de inwerkingtreding wan de grondwet niet meer gewijzigd, hetgeen geldt woor de meeste grondwetsartikelen. Art. $10 \mathrm{GO}$, het recht op brief-, post en telefoongeheim is het enige artikel dat is gewijzigd bij wet in 1968 . In 1969 is het individueel klachtrecht expliciet in Art. 93 lid I sub $4 a \mathrm{GC}$ gecodificeerd; woorheen was het enkel vastgelegd in het BVerfGO (vanaf 1951). Vanaf 1969 verkreeg de individuele klacht "Verfassungsrang" vanwege invoering ervan in Art. 93. GO (19. Gesetz zur Änderung des Grundgesetzes, BCBL. 1 p. 97 e.w), zie Hesse 1991, p. 142-143.

$\$ 6.1$ Zic par. 1.4 .1

162 Bryde 2000, p. 245.

163 Abhörhurteil, 30 B VerfGE 1, 24 (1970).

164 Walter 2000, p. 521 .

165 Zie onder meer Abhöhurtel, 30 BVerfoE 1, 24 (1970) en de daarbij geuite dissentings" Walter 2000 , Böckenforde 1993, Haberle 1974 .

166 Ramm 1989, p. 1595 e.w. 
wetsalanpassing in de rechtspraak. ${ }^{167}$ Dat valt niet alleen te rijmen met de open textuur van de normen, maar ook met het mandaat dat het Hof door de grondwetgever is toegekend. Daarnaast ziet Art. 79 lid 3 op de geschreven grondwet; her gehele constitutionele recht wordt niet door Art. 79 lid 3 gedekt, Een geldige, ongeschreven rechtsnorm behoeft niet steeds tot een grondwetswijziging te leiden. Geredeneerd wordt dat het vereiste van codificatie van deze normen zou leiden tot de situatie waarin een nietregelen van ongeschreven normen zou leiden tot ongeldigheid van ongeschreven normen. ${ }^{168}$ Uit deze aspecten komt het open karakter van de Duitse grondwet tot gelding. 169

\subsubsection{Rechterlijke taakopvating wan het Hof}

Het Hof heeft vanwege zijn interpretatie van zijn mandaat op voornoemde punten en vanwege extensieve interpretatie van grondrechten regelmatig aanleiding gegeven tot debatten over de verhouding tussen het Hof en wetgever. ${ }^{170}$ In het Duitse debat over de verhouding tussen wetgever en Hof wordt gesproken van 'richterliche Selbstbeschränkung', een term die in veel opzichten gellijkenis toont met de Amerikaanse "judicial restraint" of met de Nederlandse term "rechterlijke terughoudendheid". "Het begrip duildt in de Duitse discussie ook op de constitutionele verhouding tussen rechter en wetgever. ${ }^{172}$ Zowel ter zake van abstracte en concrete rechterlijke toetsing, alsook in de beoordeling van individuele klachten lijkt het Hof ten opzichte van de federale en statelijke wetgevers nagenoeg over onbegrensde bevoegdheden te kunnen beschikken. Hoewel het aantal geschillen in abstracte rechterlijke toetsing klein is, trekken de uit-

167 In de literatuur wordt een onderscheid gemaakt tussen echte en onechte grondwetswijzigingen. Walter onderscheidt drie typen van "onechte" grondwetswijzigingen die in de rechtspraak kunnen worden gesignaleerd. Hij hanteert voor de vaststelling of sprake is van een onechte grondwetswijziging een relatief formele benadering van onder meer het gelijkheidsbeginsel, van instructienormen en van het eigendomsbegrip. De interpretaties van Art. 1 lid 1 en 2 lid 1 GG kunnen in beginsel leiden tot "echte" grondwetswijzigingen, al stelt Walter woorop, dat de keuze voor de open texturur juist impliceent dat de grondwetgever grondwetswijzigingen in de rechtspraak nogelijk heeft willen maken (Waiter 2000 , p. $528-529$ )

168 Bryde 2000 , p. 233. In lyet Duitse constitutionele debat wordt aandacht besteed aan de vraag, wanneer de constitutionele rechter de grenzen van rechtsvinding overtreedt, en bijstelling van de grondwet noodzakelijk wordt. Zie onder neer Huber 1971 , p. 329 e.v ; Ramm 1989, p. 1595 Isensee 1996, p. 1088 en Walter 2000, p. 540.

169 Dawrover bestaat geen overcenstemming; sommigen zijn van mening, dat er - met name vanwege de betekenis van Art 2 lid $1 \mathrm{GO}$ - sprake is vam een gesloten systeem. Met Art. 2 lid I GG legitimeert de grondwetgever interpolaties (extensieve interpretatie en ontwikkeling wan nieuwe uit Art. 2 lid I. GG geconcretiseerde normen) door de rechter; zie Maunz/Ding, GG, Art. 1, par. 13." "Es ist kein Fall denkbar, in tem ein stutatsrechtlicher Angriff auf die Menschenwurde nicht bereits durch ein spezielles Grundrecht [...] aufgefangen wurde, wenn mam nur Art. 1 \&..] als Wertmaßstab in die Spezialinterpretation des jeweiligen Grundrechts einbezieht. Selbst wo das Grundgesetz im Spezialkatalog luckenhaft geblieben ist, wüde ein staatlicher versto gegen die Menschenwurde mindestens bereits durch das Hauptfreiheitsrecht [...] oder das Hauptgleichlneitsrecht abgewahrt, ohne daß die Konstruktion des Ant. I I als eines subjektiven offentlichen Rechts bemult zu werden braucht"

170 Benda 1979 , p. 471 e.v., Kommers 1997, 34 e.v., 55 e.w, Schlaich 1997, p. 338 e.v. (met veel verwijzingen).

171 Grundlagennertag, 36 BVerfoE 1,14 (1973).

172 Dreier en Schwegemann 1976, p. 43 e.k. 
spraken die abstracte toetsing betreffen diepe sporen in het politieke landschap. ${ }^{173}$ In de laatste jaren toetste het Hof in abstracto bijvoorbeeld wetten die het gevolg waren wan een heroriëntering van wetgeving na de hereniging met de voormalige DDR: abortus, eigendomsrechten en bevoegdheid tot ontslag door de huidige (staats)werkgevers van voormalige stasi-ambtenaren. ${ }^{174}$

Van belang in het licht van de constitutionele verhouding tussen rechter en wetgever is "s Hof's bevoegdheid, een ongrondwettige grondwetswijziging nietig te verklaren. Deze bevoegdheid is niet alleen buitengewoon boeiend in het licht van de constitutionele verhouding tussen rechter en wetgever; interessant is ook de argumentatie waarmee het Hof haar zich heeft toegeëigend. ${ }^{175}$ Het Hof heeft haar afgeleid uit de gehele structuur van de grondwet:

"Ein Teil der Wissenschaft und Rechtsprechung verneint deshalb allgemein die Prüfungsfunktion der richterlichen Gewalt gegenüber der Verfassung selbst. Zur Begründung wird vornehmlich angeführt, daß der Richter sich mit einer solchen Prüfung verfassungsgebende Gewalt anmaße und sich vom Grundsatz der Gewaltenteilung zu weit entferne'.

Het niet toetsen van wetgeving zou juist indruisen tegen de taak die het Hof expliciet is opgedragen. Ook zijn er argumenten die pleiten vóór het bestaan van de bevoegdheid, die direct kan worden afgeleid uit de structuur van de grondwet:

'Demgegenüber wird von anderer seite eingewandt $[\ldots]$ daß das Grundgesetz selbst ein Gericht (het Hof, H.L.J.) dazu bestimmt habe, die Unantastbarkeit der im Grundgesetz getroffenen Grundentscheidung zu gewährleisten [...]. Nicht mit der Ausübung einer solchen Normenkontrolle, sondern gerade mit ihrer Ablehnung würde deshalb [...] das Bundesverfassungsgericht sich über den Willen der Verfassung hinwegsetzen und damit die Rechtssicherheit gefährden $[\ldots]^{\text {, }}$, $^{176}$

Het Hof is tot dusverre twee keer een discussie aangegaan over ongrondwettigverklaring van grondwetswijzigingen, maar heeft uiteindelijk geen schending vastgesteld. Het Hof lijkt deze bevoegdheid met terughoudend te hanteren, hetgeen juist ook samenhangt met de constitutionele verhouding tussen rechter en wetgever. Het Hof lijkt zich ervan bewust te zijn, dat toetsing van grondwetgeving een instrument is dat vraagt om toepassing wanneer dat 'echt' aangewezen is. ${ }^{177}$ Het Hof moet zuinig zijn met het krediet dat het heeft; een veelvuldig hanteren van het instrument zou vooral leiden tot irritatie in de rechtsgemeenschap. In verband met EG-recht rees bij de regering de

173 Tussen 1959 en 1999 beoordeelde het Hof in total 140 verzoeken om abstracte rechterlijke toetsing; dat zijn er gemiddeld drie per jaar. In 1992 werden bij het Hof acht verzoeken aangebracht, die samenhingen de lhereniging met de voormalige DDR (bron: www bundeswerfassungsgericht.de, laatstelijk geraadpleegd op 31 juli 2002).

174 Zie Schwangerschaftsabbruch II, 88 BVertGE 203 (1993) en Stasi-Fragen, 96 BVerfGE 171 (1997).

175 De bevoegdheid is niet expliciet in de grondwet opgenomen.

$\$ 76$ Het Hof heeft de doctrine van ongrondwettigheid van grondwetswijzigingen aangenomen in Gleichberechtighung, 3 BVerfGE $225,234-235$ (1953).

177 In total is de grondwet 48 keren gewijzigd, waarbij de ene keer sprake was van een meer omvangrijke wijziging dan de andere. In Abhörurteil, 30 BVerfGE 1, 33-47 (1970) pleitten met name de dissenvings voor aanname van ongrondwettigheid wan de wijziging van hat recht op brief-, post- en telefoongeheim. 


\section{HoOfDSTUK 3}

wrag in hoeverre de woorgestelde grondwetswijziging, die noodzakelijk werd geacht voor de ondertekening van het Verdrag vam Maastricht, in overeenstemming was met de owerige bepalingen van de grondwet. ${ }^{178}$ De vraag werd aan het Hof ter beoordeling voorgelegd. Een van de hoofdvragen in die uitspraak was welke de grenzen zijn die kunnen worden gested aan bevoegdheidsoverdracht van de Lid-Staat naar de Europese Gemeenschap - en welke rechter daarover het laatste woord heeft. Het Hof achtte zich daartoe in laatste instantie bevoegd. Zolang de bevoegdheid over deze kwestie bij het Hof $b l i j f t$, kan de concrete vraag over grondwettigheid van ondertekening van het Verdrag van Maastricht achterwege blijven. ${ }^{~} 79$

De grondwet als maatstaf geeft richting aan de bevoegdheidsgrenzen. Tegelijkertijd bestaat in veel opzichten ruimte voor het waststellen van de grenzen van die matstaven. door het Hof zelf. In dit werband merken enkele commentatoren niet geheel onterecht op, dat de begrenzing van de bevoegdheid van het Hof door de grondwet deels een fictieve is. De discussie over de rechterlijke taakopvatting wordt in beginsel gevoerd vanuit het standpunt van de traditionele machtsverdeling. Aan deze benadering is het uitgangspunt verbonden, dat het Hof een "gewone" rechter is. Het incidentele karakter van de rechtspraak onderkent deze typering. het Hof heeft een retrospectieve en controlerende functie. Het feit dat aan de uitspraken van het Hof kracht van wetgeving wordt verbonden, dat het zich uitlaat over politieke rechtsstrijd en het feit dat het overgangsrecht kan vaststellen kunnen op zichzelf niet leiden tot de vaststelling dat het Hof een activistische taakopvatting hanteert: die bevoegdheden zijn het Hof immers toegekend. De grondwet is voor de wetgever handelingsnorm; voor het Hof houdt deze normen voor rechterlijke controle in. ${ }^{180}$ In dat verband is ook van belang te bezien, met welke intensiteit het Hof zijn controlerende functie uitvoert. Het beginsel van proportionaliteit, dat ook bij de toepassing van Art. 2 lid 1 GG en het algemene persoonlijkheidsrecht wordt gehanteerd, verleent het Hof een maatstaf om de intensiteit van de toetsing vast te stellen.

Het Hof heeft meer in het algemeen in zijn rechtspraak regelmatig gewezen op een beoordelingsruimte die de wetgever toekomt, en mitsdien geen rechterlijke beoordeling toelaat. ${ }^{\mid B \|}$ Die ruime bestaat in beginsel vooral daar, waar geen concrete toetsingsnorm is vastgesteld. Het Hof heeft in zijn rechtspraak een drietal criteria ontwikkeld, die aangeven met welke intensiteit het wetgeving beoordeelt. ${ }^{182}$ In beginsel past het Hof op

178 Macastrichthrte il, 89 B VerfoE 155 (1993).

179 Van de beantwoording van de onderliggende vraag kan echter niet worden gezegd, dat zij van mindere politicke betekenis is; zij behelsde onder meer de verhouding tussen het Europese Hof van Justitie en het Duitse Federale Constitutionele Hof en de verhouding in de bevoegdheidsverdeling tussen de Bond en de Staten. Zie voor discussie hierover (vanuit zowel Duitse als EG-rechtelijke unvalshoek) onder meer Lerche 1990, p. 409 e.v.; Everling 1994, p. 1 e.v. en Herdegen 1994, 235 e.v. en Kumm 1999. p. 351 e.v.

180 Sehlaich 1997, p. 347 .

18 Z Zie bijwoorbeeld Bundestagsaufldsung, 62 BVerfGE 1,51 (1983).

182 Mitbestimntwng, 50 BVerfGE 290, 333 (1979): De eerste wondt de 'Evidenzkontrolle genoemd, en is an te merken als een marginale toets die zich beperkt tot formele aspecten van de besluitworming door de wetgever: "Dleser Mabstab verlangt, daB der Gesetzgeber sich an einer saclugerechten und vertret- 
individuele aanspraken die werden erkend onder het algemene persoonlijkheidsrecht ex Art. 2 lid 1 in contaminatie met Art. 1 lid $1 \mathrm{GG}$ een intensieve toetsing toe. $\mathrm{Zij}$ worden in de rechtspraak echter niet als harde criteria gehandhaafd en vertonen in dit opzicht eerder het karakter van een glijdende schaal van de noodzakelijke toetsingsintensiteit. Uit de toepassing van de criteria volgt echter niet, dat bij een marginale toetsing geen schending wordt vastgesteld, en bij een intensieve toetsing steeds sprake is van schending. ${ }^{183}$ In dit opzicht onderscheidt de Duitse toetsingsmethodiek zich van de Amerikaanse. ${ }^{184}$

Ten aanzien van de bevoegdheid wan lagere rechters in een concrete rechterlijke toetsingsprocedure lijkt het Hof het subsidiariteitsbeginsel niet altijd voldoende in acht te nemen. Het Hof doet vanuit efficiencyoverwegingen zelf zaken af en lijkt daarmee de bevoegdheid van de lagere rechter niet te respecteren. De omvang van de toetsing door het Hof ten opzichte van de lagere rechter is in dit verband een kwestie waarover het laatste woord nog niet gezegd is. Met behulp van extensieve interpretatie van grondrechten - in het bijzonder van Art. 2 lid $1 \mathrm{GG}$ - in de individuele klachtenprocedure lijkt het Hof voor zichzelf een rol te hebben gecreeerd van "Superrevisionsgericht'. ${ }^{185}$ Het Hof heeft in zijn jurisprudentie juist het tegendeel willen benadrukken; het ziet zichzelf niet als instantie die de uitspraken van lagere rechters in volle omvang toetst. $^{186}$

baren Beurteilung des erreichbaren Materials orientiert hat. Er muß die ihm zugallnglichen Erkenntnisquellen ausgeschöpft haben, um die voraussichtlichen Auswirkungen seiner Regelung so zuverlässig wie möglich abschaitzen zu können und einen VerstoB gegen Verfassungsrecht zu vermeiden. Es handelt sich also eher um Anforderungen des Verfahrens.' Het tweede houdt een 'Vertretbarkeitskontrolle' in: 'Die verfassungsgerichtliche Prufung ist darauf beschrämkt, ob der Gesetzgeber seinen Einschatzungsspielraum 'in vertretbarer Weise' gehandhabt hat", zie Entziehungsanstalt, 91 BVerfGE 1, 29 (1994). Daarnaast is ook intensieve toetsing mogelijk: "Nach diesen Maßstaben ist eine strenge Prufung [...] gebofen. Bei der Altersgrenze für die Vornamenstunderung handelt es sich um eine Differenzierung, die an personenbezogene Merkmale anknüpt und sich erheblich auf das allgemeine Personlichkeiltsrechit auswirkt. Art. 2 Abs. 1 schutzt in Verbindung mit Art. 1 Abs. 1 GG die engere peröniche Lebenssphture, insbesondere auch den Intim- und Sexualbereich [...], und gewahrleistet das Recht des Einzelnen, grundsatzlich selbst zu bestimmen, aus welchem Anlab und in welchen Grenzen er persönliche Lebenssachwerhalte offenbart [...]. Dem Schutz dieser Rechtsguter dient das 'Transsexuellengesetz', zie Transsexuelle II, 88 BVerfGE 87, 97 (1993).

183. Het recht op leven ex Art: 2 lid 2 GG is een geprioriteerd grondrechl, waarvoor geldt dat in geval van schending een intensieve toetsing van de wetgeving volgt (Schwangerschafsabbruch 1,88 BVerfGE 203, 244 (1993)). In Schleyer (46 BVerfGE 160, 164 (1977)) oordeelde het Hof dat aan de wetgever moest worden overgetaten, hoe een levensbedreigende situatie in een ontvoering moest worden opgelost. Er werd wel intensief getoetst, maar de keuzemogelijkheden dienden door de wetgever te worden onderzocht.

184 Zie par. 3.2.4.

185 Luith $_{3} 7$ BVerfGE 198, 207 (1958).

186 "Sinn des Instituts der Verfassungsbeschwerde ist es, daß alle Akte der gesetzgebenden, vollziehenden und richterlichen Gewalt auf ihre "GrundrechtmaBigkeit" nachprufbar sein sollen ( 90 BVerfGG),

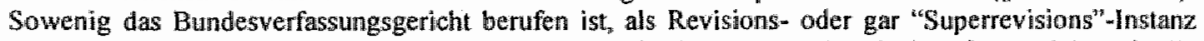
gegenüber den Zivilgerichten tatig zu werden, sowenig darf es von der Nachproflung solcher Urteile allgemein absehen und an einer in ihnen etwa zutage tretenden Verkernung grundrechtilicher Normen und MaBstabe voribergehen ${ }^{2}$, Lüh, 7 BVerfGE 198, 207 (1958). 


\subsection{De werkwijze wan het Europese Hof van Justitie van de EG}

\subsubsection{Internationale rechtsmacht met federale trekken}

De rechtsmacht van het Hof - afdoen van directe beroepen en beslissen op prejudiciële vragen - vormt een essentieel instrument waardoor het gemeenschapsrecht kan worden toegepast en uitgelegd in het licht van de doelstellingen en de taken van Artt. 2 en 3 EG-Verdrag. ${ }^{187}$ Het Hof heeft een monopolie ter zake van de interpretatie van het $\mathrm{EG}$ Verdrag. Het EG-Verdrag stipuleert echter geen expliciete grenzen voor de omvang van de jurisdictie van het Hof op het terrein van schending van het recht op persionlijkheid. De jurisdictie van het Hof van Justitie is in algemene termen neergelegd in art. 220 EG-Verdrag:

"Het Hof wan Justitie verzekert de eerbiediging van het recht bij de uitlegging en toepassing van dit Verdrag".

De formulering van Art. 220 duidt eerder op een afwijzing van een wetspositivistische benadering; hierop duidt de formulering dat het Hof eerbiediging van het recht dient te verzekeren. ${ }^{188}$ Dit algemene mandaat lijkt het Hof deels te hebben opgevat als een kwalificatie als 'constitutioneel' rechter, die belast is met uitleg van het EG-Verdrag en toetsing van handelingen wan nationale overheden voor zover die binnen de werkingssfeer van het EG-Verdrag vallen. ${ }^{189}$ De ontwikkeling van het EG-recht is voor een groot deel het gevolg van rechtersrecht van het Hof. Voor de vaststelling van de omtrekken van de jurisdictie heeft het Hof Art. 220 extensief uitgelegd. In beginsel is de jurisdictie van het Hof door het verdrag geattribueerd; de jurisprudentie overziend kan echter de vraag worden opgeworpen, in hoeverre het Hof een 'inherente' jurisdictie heeft - zeker ten aamzien van grondrechtelijke aanspraken. ${ }^{190}$ De wijze waarop grondrechten, die oorspronkelijk geen functie vervulden in de EG-rechtsorde, door het Hof binnen de EG-rechtsorde zijn getrokken als rechtsbeginselen van Gemeenschapsrecht is in dit verband een fraai voorbeeld. ${ }^{191}$ Ook de ontwikkeling in de rechtspraak van het Hof van de uitgangspunten van suprematie en directe werking van EG-recht zijn voorbeelden van interpretatie van jurisdictie waarin het Hof de grenzen van zijn bevoegdheden heeft verkend. ${ }^{192}$

De preciezere bevoegdheden van het Hof, het handhaven van uniformiteit door middel van prejudicièle uitspraken en het afdoen van directe beroepen, worden nader uit-

187 Barents en Brinkhorst 2001 , p. 249.

188. Ukrow 1995, p. 92-93.

189 Weiler 2000 , hoofdstuk 2 .

190 Craig en De Búrca 1998, p. 87; Arnull 1990, p. 707.

191 Weiler 2000 , p. 44.

192. Eén voorbeeld in dit verband kan niet ontbreken: het Hof heeft in Les Verts $t$. Europees Parlement zaak 294/83 (1986), Jur. p. 1339 (1986) cen besluit van het Europees Parlement onderworpen aan rechterlijke toetsing, terwijl het EG-Verdrag rechterlijke toetsing van handelingen van het Europees Parlement niet erkendie. Omgekeerd heeft het Hof het Europees Parlement toegelaten als procespartij, ook al behoorde het Europees Parlement op dat moment niet tot de limitatief opgesomde partijen die konden klagen, Parlement t. Raad, zaak C-70/88 (1991), Jur. p. I-4529 (1991). 
gewerkt in de Artikelen 228 tot en met 241 EG-Verdrag. Voor de beantwoording van de centrale onderzoeksvraag is het niet noodzakelijk gedetailleerd in te gaan op alle mogelijke geschillen die zich kunnen voordoen tussen partijen, warover het Hof rechtsmacht heeft; in dit verband wordt enkel stilgestaan bij de rechtsmacht van het Hof over klachten over schendingen van grondrechten. Klachten over schendingen van grondrechten komen op uiteenlopende wijzen bij het Hof terecht: in een enkel geval werd direct beroep gedaan op het Hof via Art. 230, terwijl het Hof in de meeste gevallen in antwoord op een prejudiciële vraag van een nationale rechter een oordeel uitsprak over eventuele grondrechtsschendingen. Beide procedures worden hieronder in het licht van klachten over grondrechtsschendingen verder uitgewerkt. Eên van de bijzonderheden in het EG-recht is, dat niet alleen individuen maar ook staten in enkele gevallen getracht hebben een aanspraak te doen op fundamentele rechten. In dat verband wordt de rechtsmacht van het Hof eveneens belicht.

Het Hof wordt in het algemeen gezien als eén van de belangrijkste stuwende krachten achter de integratie van gemeenschapsrecht in de nationale rechtsordes. Een extra dimensie in het EG-recht is, dat het Hof een directe relatie onderhoudt met de Lid-Staten via de nationale rechters. ${ }^{193}$ Momenteel bestaat het Hof uit vijftien rechters en 8 Advocaten-Generaal. ${ }^{194} \mathrm{Zij}$ worden door de regeringen van de Lid-Staten benoemd voor zes. jaar; deze benoemingseis mag echter niet leiden tot de conclusie dat EG-rechters nationaalrechtelijke belangen moeten verdedigen. ${ }^{195}$

Het Hof kan zaken zowel plenair als in Kamers beoordelen. ${ }^{196}$ De toegenomen werklast leidt tot het verdelen van zaken over Kamers. Het Hof heeft een Advocaat-Generaal, die een geschreven opinie geeft over de achtergrond wan de zaak en een voorschot geeft voor de oplossing van het geschil. In de veel gevallen wordt de Advocaat-Generaal gevolgd, maar het Hof behoeft een afwijzing van diens mening niet te motiveren. ${ }^{19 \%}$ Het zwaartepunt in de procedures voor het Hof ligt op de geschreven en niet op de mondelinge verhandelingen. In de laatste jaren is de roep om hervormingen in de structur en samenstelling van het Hof luider geworden, hetgeen samenhangt met de toege. nomen werklast van het Hof en de toekomstige uitbreiding met een aantal staten. ${ }^{198}$

193 Die verloopt via de prejudiciele procedure ex art. 234.

194 Art. 222.

195 Toch is waar te nemen, dat Lid-Staten "hun' nationale rechter enigermate zier als verlengstuk. Howel de te benoemen rechter niet uit de Lid-Staat hoeft te komen, is dit tot dusverre altijd het geval. Bij de discussies over de uitbreiding wan de EU met nieuwe Lid-Sitaten is het lastig, een nieuwe verdew. sleutel' te bedenken: Lid-Staten geven 'verworvenheden" (een eigen rechter in het Hof) niet zomaar op. Ook hier dienen compromissen te worden gesloten bij het debat over de aankomende uitbreiding natr het Oosten.

196 Alleen zaken wan grote impontantie worden door een voltallig Hof beoordeeld. ln de regel worden zaken beoordeeld door een Kamer van drie, wijf of zeven rechters (zie Art. 15 wan het Protocol betreffende het Statuut van het Hof wan Justitie).

197 Craig en De Búrca 1997, p. 83.

198 Zie bijwoorbeeld Bijdrage van het Hof en het Gerecht aan de Intergouvemementele Conferentie, 2000; Rodiriguez lglesias 2000; Craig an De Bürca 1998, p. 81. 


\section{Rechterlijke beoordeling van besituiten van de Instellingen jegens individuen}

Art. 230 EG-Verdrag kent aan het Hof de bevoegdheid toe een 'grondwettigheidstoets' toe te passen op handelingen van de Instellingen van de Gemeenschap. ${ }^{199}$ Ook individuen kunnen volgens Art, 230 lid 4 een aanspraak maken op een dergelijke toets; het Hof onderwerpt de door het individu aangevochten handeling aan EG-recht. Toetsing aan liet recht houdt in EG-verband niet alleen toetsing aan rechtsnormen uit het verdrag of secundaire wetgeving in, maar eveneens toetsing aan rechtsbeginselen die tot de gemeenschapsrechtsorde behoren. Hiertoe lijkt de taak van 'verzekering van eerbiediging van het recht' ex Art. 220 ook voldoende ruimte te bieden. Art. 230 lid 4 EGVerdrag richt zich tot zowel natuurlijke als rechtspersonen.

\section{De prejudiciele procedure}

Art. 234 schept de mogelijkheid voor de nationale rechter, een vraag van communautair recht voor te leggen aan het Hof. ${ }^{200}$ De vragen rijzen in uiteenlopende nationaalrechtelijke geschillen waarbij ook individuen partij kunnen zijn. Individuele aanspraken op grondrechten komen in beginsel het vaakst via de prejudiciêle procedure op de rol van het Hof, omdat het individu in beginsel veelal te maken krijgt met indirecte, dat wil zeggen nationaalrechtelijke toepassing van Europees recht. Het grootste deel van EG-wetgeving wordt uitgevaardigd in de vorm van verordeningen en richtlijnen die door de Lid-Staten moeten worden nageleefd en uitgevoerd; de staat treedt in dit opzicht op als 'agent' van de EG. Individuele klachten behelzen bijvoorbeeld verkeerde of niet-toepassing van communautair recht door de Lid-Staat - bij correcte toepassing zouden de in het geding zijnde grondrechten niet zijn geschonden. ${ }^{201}$ Ook is een situatie denkbaar waarin het individu juist meent in zijn grondrechten is getroffen, omdat de Lid-Staat uit hoofde van zijn communautaire verplichtingen het EG-recht toepast. ${ }^{202}$ Art. 234 geldt enkel binnen de werkingssfeer van het EG-Verdrag ${ }^{203}$; het Hof heeft in beginsel geen prejudiciële rechtsmacht ten aanzien van verdragen waarvan enkel LidStaten lid zijn. ${ }^{204}$ Een prejudiciële uitspraak is bindend voor de nationale rechter, ook al

199 Voor de toepasselijkheid van de tern 'grondwettigheidstoets' zie Lenaerts 1983, p. 209; deze lijkt hier gepast omdat het Hof de bevoegdheid heeft, de handelingen inhoudelijk te toetsen aan het verdrag en de daarbij behorende uitvoeringsregelingen.

200 De procedure is enigszins te vergelijken met de Duitse concrete rechterlijke toetsing, waarin de lagere vechters vragen over de interpretatie van de grondwet kunnen voorleggen aan het Federale Constitutionele Hof Zie voor algemene beschouwingen over deze procedure Barents en Brinkhorst 2001 (met name Hoofdstuk 6) en Craig en de Bürca 1998, met name hoofdstuk 10.

201 Zie bijvoorbeeld Defremne $I I_{\text {, zaak }} 149 / 77$, warin een werkneemster klaagde op grond van Art. 141 over seksediscriminatie door de staat, terwijl Art. 141 - volgens klaagster, en later volgens het Hof een verbod ter zake inhoudt.

202 Zie bijvoorbeeld Stcruder, zaak $29 / 69$ (1969), Jur. p. 419 (1969) waarin werd geklaagd over de consequenties van de implementatie van EG-recht, die een schending van fundamentele mensenrechten tot gevolg had.

203 Art. 46. EU-Verdrag.

204 Hurd, zaak 44/84 (1986), Jur. p. 29 (1986) en Denmirel, zaak 12/86, (1987), Jur. p. 3719 (1987), par. 24. 
stelt Art. 234 dat niet expliciet; het bindend karakter vloeit voort uit Art. 10 EGVerdrag. ${ }^{205}$

\section{Schending wan de grondrechten door een Lid-Staat}

Het Hof heeft schendingen van grondrechten vastgesteld in de situatie waarin een LidStaat derogeerde van regelingen van gemeenschapsrecht in het licht van het voeren van een nationaal beleid. In dit opzicht heeft het Hof regelmatig beoordeeld, in welke mate derogaties van Lid-Staten van bijwoorbeeld Art. 30 - gevallen waarin beperkingen op in- en uitvoer geoorloofd zijn - door de beugel konden. Soms deed de Lid-Staat, ter ondersteuning van zijin nationale beleid, een beroep op grondrechten. In een heel enkel geval trachtte een Lid-Staat een derogatie te rechtvaardigen aan de hand van een aan het recht op persoonlijkheid gerelateerd recht. In Commissie t. Duitsiand bestreed de Commissie een Duitse maatregel, die inhield dat zeer stringente beperkingen werden opgelegd aan individuen, die hun medicijnen voor privé-gebruik wensten te betrekken wit een andere Lid-Staat. ${ }^{206}$ De maatregel hield mogelijk een toegestane derogatie van Art. 30 in, en was getroffen met het oog op bescherming van de volksgezondheid. Deze zaak kwam voor het Hof via de procedure van Art. $228^{207}$

\subsubsection{Ontvankelijkheidscriteria}

Directe beroepen ex art. 230

Gesteld kan worden dat het Hof tot dusverre zeer strenge criteria hanteert voor de ontvankelijkheid van directe beroepen onder Art. $230{ }^{208}$ De klagende partij dient rechtstreeks en individueel getroffen te zijn door de handeling van de Instelling. ${ }^{209}$ Het Hof heeft in zeker opzicht een speelruimte gecreëerd, om te beoordelen of de klagende partij aan de eisen van standing voldoet. De zogenoemde 'niet-gepriwilegieerde' kla-

205 Eierkontor, zakk 29/68 (1969), Jur, p. 165 (1969) en Bertedert, zaak $52 / 76$ (1977), Jur. p. 163 (1977).

206 Commissie t. Dwitstand, zaak $62 / 90$ (1992), Jur, p. 1-2575 (1992).

207 Zie par. 7.3.1 woor de uitwerking van deze zak.

208 Art. 230 vierde al inea; zie ook Plawmann t. Commissie, zaak 25/62 (1963), Jur. p. 126 (1963) dat dt standaarduitgangspuraten biedt voor de beoordeling van ontwankelijkheid. Het Hof lijkt de eisen tets te Iaten wieren sinds Codorniu i. Raad, zaak C-309/89 (1994), Jur. p. 1-1853 (1994) en Extramat t. Raad, zaak C-358/89 (1991), Jur. p. 1-3893 (1991). Het GvEA heeft onlangs in Jégo Quéré d. Conwwssie bepaald dat de ontvankelijkheidseis van Aut. 230 ten aanzien van individuen ruimer dient te worden uitgelegd omdat anders het rechtsbeginsel van recht op toegang tot een rechter zou worden geschonden (T-254/99, Jégo-Quéré t. Commissiè, GEA 3 mei 2002, EHRC 2002/55). In Unión de Puquénos Agricow lrores t. Raad, zaak C-50700, HWJ EG 25 juli 2002 over de kwestie van ontwankelijkheid van individuele: beroepen heeft het Hof onlangs uitspraak gedaan; het wess een extensicve interpretatie van Art. 230 ter zake van individuele beroepen af. A-G Jacobs pleitte in zijn Conclusie bij die zatk (Conclusie van $A-G$ Jacobs bij Unión de Pequeños Agricoliores $i$. Raad, zaak C-50\%00 van 21 mart 2002) voor het loslaten van de strenge ontvankelijkheidseisen). Zie voor een recestuelijhk overzicht met verwijzingen van do rechtspraak wan het Hof Arnull 2001, p. $7-52$.

209 Art. 230 leden 4 en 5 . Indien een beschikking wordt angevochten door het individu dat daardoor rechtstreeks is getroffen rijzen er relatief weing problemen. Lastig wordt het bijwoorbeeld als de beslissing is gericht aan persoon X, terwijl Y tracht aan te tonen dat hij rechtstreeks en individueel getroffen is. Een andere situatie die problematisch is, is die warin het besluit niet een beschikking maar in de vorm van een verordening is genomen. De klager dient dan aan te tonen dai hij individueel is geraakt. 
ger $^{210}$ lijkt in dit opzicht soms de dupe te zijn van een streng ontvankelijkheidsbeleid van het Hof. Het Hof neemt niet in alle beroepen gemakkelijk aan, dat door de nietgeprivilegieerde klager aan de ontwankelijkheidseisen voldaan is; uit de jurisprudentie kunnen wel enkele lijnen worden gedestilleerd, die neerkomen op het volgende. Ontvankelijkheild wordt eerder aangenomen, indien het geschil zich op bepaalde, door Art. 2 en 3 EG-Verdrag geprioriteerde beleidsterreinen van de Gemeenschap bevindt. Er wordt wel een onderverdeling gemaakt van klachten, ingediend door niet-geprivilegieerde personen op vier voor het EG-recht belangrijke beleidsterreinen. ${ }^{211}$ Ter zake van klachten op het terrein van anti-dumpingmaatregelen, mededingingszaken, klachten aangaande staatssteun en klachten die het democratische gehalte van de Gemeenschap betwisten woert het Hof een relatief liberaal ontvankelijkheidsbeleid. ${ }^{212}$ In de literatuur worden uiteenlopende redenen aangevoerd voor de variatie van het ontvankelijkheidsbeleid. Rasmussen wijst op het bestaan een achterliggend beleid van het Hof, nietgeprivilegieerde klagers te dwingen, naar de nationale rechter te stappen:

"If the restriction of the citizen's access to the Court was not to amount to a pure denial of justice or rather a denial of remedies, it was necessary simultaneously to enlarge the responsibility of the national courts and tribunals to provide the citizen with an effective protection of his Community rights? ${ }^{213}$

In het uiterste geval zou het Hof controle kunnen uitoefenen en eenheid van rechtsuitlegging kunnen bewaren via de prejudiciële procedure. Een belangrijke indicatie voor terughoudendheid is te vinden in het karakter van de bestreden rechtsnorm: indien die een discretionaire bevoegdheid in zich draagt is het Hof over het algemeen terughoudend in ontvankelijkheid. ${ }^{214}$ Het gemeenschappelijk landbouwbeleid is bijvoorbeeld een beleidsterrein, waarin zich dergelijke normen met beoordelingsruimte bevinden. Het Hof heeft in een aantal directe beroepen individuele aanspraken op grondrechten beoordeeld. De meeste beroepen via Art. 230 hadden betrekking op mededinging, terwijl ook een aantal beroepen werd ingesteld tegen besluiten op het terrein van het personeelsbeleid van de Commissie. ${ }^{215}$

210 Geprivilegicerde klagers zijn Lid-Staten, Raad, Commissie, Europees Parlement, Rekenkamer en Europese Centrale Bank (zie Art. 230 leden 2 en 3).

$21 \|$ Craig en De Bürca 1998 , p. 473 e.v.

212 Anti-dumping: Timex Corporation t. Raad en Commissie, zank 264/82 (1985), Jur. p. 849 (1985); mededinging: Metro t. Commissie, zaak $26 / 76$ (1977), Jur. p. 1875 (1977) staatssteun: Cofaz 1. Commissie, zaak 169/84 (1986), Jur. p. 391 (1986); het democratisch gehalte van de Gemeenschap: zie Les Verts t. Evropees Parlement, zaak 294/83 (voorbeelden ontleend aan Craig en De Bürca, p. 473 e.v.). Overigens wordt betwijfeld, of deze lijnen immer nog zo te onderscheiden zijn in de jurisprudentie (Craig en De Búrcá 1998, p. 473).

213 Rasmussen 1980, p. 122-127. Vraag is, of de weg naar de nationale rechter via de prejudiciële procedure woldoende bevredigend is in het licht van het recht op toegang tot een rechter gezien het feit dlat de nationale rechter zelf moet beoordelen in hoeverre een vraag aan het Hof moet worden woorgelegd (zie ook T-254/99, Jégo-Quéré 1. Commissie, GEA 3 mei 2002, EHRC 2002/55).

214 Hartley 1994, p. 383.

215 Zie voor mededinging bijwoorbeeld Brescia t. Hoge Aworiteit, zaak 31/59 (1960), Jur. p. 98 (1960); Stork r. Hoge Antoriteit, zaak 1/58 (1959), Jur. p. 43 (1959); Nold t. Hoge Autoriteit, zaak 40/59 (1960), Jur p. 885 (1960); Nold t. Commissie, zaak $4 / 73$ (1974), Jur. p. 491 (1974); Panasonic 1. Commissie, zaak 136/79 (1980), Jur. p. 2033 (1980); AM\&S i. Commissie, zaak 155/79 (1982), Jur. p. 1575 (1982); 


\section{Procedure tegen een Lid-Staat vanwege de Commissie bij het Hof}

De Commissie kan bij het Hof een procedure opstarten vanwege schending van EGrecht door een Lid-Staat onder Art. 228. Voorafgaand aan de procedure bij het Hof brengt de Commissie eerst een met redenen omkleed advies uit en stelt de staat in de gelegentheid te reageren. ${ }^{216}$ De Commissie wordt ter zake van vermeende verdragsschendingen door Lid-Staten vaak 'getipt' door individuele klagers ${ }^{217}$; het behoort echter tot de discretie van de Commissie om een procedure op te starten.

\section{Prejudiciele procedure ex Art. 234}

De betekenis van de prejudiciële procedure voor de integratie van het Gemeenschapsrecht in de rechtsordes van de Lid-Staten kan nauwelijks worden overschat. ${ }^{218}$ De prejudiciële vraag dient een interpretatievraag op het terrein van het $\mathbb{E G - r e c h t ~ i n ~ t e ~}$ houden. ${ }^{219}$ In dit verband rijst de vraag of het Hof een aannamebeleid kan voeren en in welke mate het gebruik heeft gemaakt van een eventuele speelruimte. In beginsel heeft het Hof steeds een pro-aannamebeleid gevoerd. Dat kan worden opgemaakt uit verschillende gewoonten van het Hof. Het Hof corrigeerde bijvoorbeeld prejudiciele vragen van nationale rechters, indien zij in 'onbewerkte vorm' ongeschikt zijn voor beoordeling. ${ }^{220}$ Het Hof hanteerde een open en flexibele benadering ter zake van de aanname van de prejudiciele vragen; zij boden een uitgelezen kans de samenwerking tussen nationale rechters en EG-rechter te versterken. ${ }^{221}$

Barrières voor het stellen van prejudiciële vragen dienden in die optiek zoveel mogelijk te worden beperkt. Vanaf Foglia (1980) trad er echter een kentering op in de positieve benadering van het Hof ter zake van de aanname van prejudiciële vragen. ${ }^{222}$ Belangrijkste grond voor weigering tot het beantwoorden van een prejudiciële vraag is wanneer het Hof deze vraag niet kan herleiden tot Gemeenschapsrecht. ${ }^{223}$ Nationale

Whams Boekwezen t. Commissie, gevoegde zaken 43/82 en 63/82 (1984), Jur. p. 19 (1984); Orkewn $t$ Commissie, zaak 374.87 (1989), Jur. p. 3283 (1989); zie voor personeelskwesties Prais 4. Ratad, zalak 130/75 (1976), Jur. p. 1589 (1976) en X 1. Commissie, zaak C $404 / 92$ (1994), Jur. p. $1-4737$ (1994).

216 Ant. 226

21710 th Annual Report (1992), OJ C 233/7 (1993), \& Ith Annual Report (1993), OJ C 154/6 (1994) en 13th Annual Report (1995), OJ C 303/8 (1996).

2182 Zie onder meer Barents en Brinkhorst 2001 , p. 236 e.v; Craig en De Búrca, hoofdsuk 10; Scheruners en Waelbroeck 1992, p. 390 e.w.

219 Er kunner ook vragen worden gesteld over de geldigheid van secundaire wetgeving van de Instellingen en over de uitlegging wan statuten van bij besluit van de Raad ingestelde organen, wanneer die statuten daarin voorzien. Met het Verdrag wan Amsterdam zijn enkele wijzigingen opgetreden: in de Derde Pijler (politiole en justitiele zaken) kan onder Art. 35 EU-Verdrag een prejudiciele vraag worden gestelid, mits de Lid-Staten insternmen met jurisdictie van het Hof op dat terrein, terwijl Titel IV valn het EGVerdrag (visa, asiel en immigratie) een loge drempel opwerpt voor prejudiciele vragen wan nationale rechters in Art. $68 \mathbb{E}$ G-Verdrag.

220 Zie bijwoorbeeld Casta 1 . ENEL, zaak 6/64 (1964), Jur. p. 585 (1964).

221 Craig en De Bürca 1998, p. 436.

222 Foglia I, 104/79 (1980), Jur. p. 745 (1980), par. 8-13.

223 Hiermee verwante situaties waarin het Hof een werzoek afgewezen heeft zijn zaken waarin teen hypothetische vraag werd gesteld. Hierwoor heeft het Hof zowel pragmatische als ook meer principiele gronden 


\section{HoOFOS MU 3}

rechters hebben het Hof uiteenlopende prejudiciêle vragen woorgelegd met daarin grondrechtelijke aanspraken van individuen. ${ }^{224}$ Grondrechten behoren dan wel tot de EG-rechtsorde, zij kunnen echter niet als zelfstandige rechtsgrondslag fungeren in de ontvankelijkheid yan een prejudiciele vraag. Er dient een connexiteit te zijn met een verdragsbepaling, anders gaat het Hof over tot niet-ontwankelijkheid van de vraag. Het Hof heef, om te beoordelen of de connexiteit tussen de voor de nationale rechter opgebrachte aanspraak op een grondrecht enerzijds en een verdragsrecht anderzijds bestaat, een soort test ontwikkeld.

Indien deze test niet met goed gevolg wordt doorstaan, zal het Hof aangeven dat het geen jurisdictie heeft. De zaak ERT is instructief ter zake van de bereidheid, een prejudiciele vraag aan te nemen. Art. $46 \mathbb{E G - V e r d r a g ~ - ~ b e s t u u r l i j k e ~ v o o r s c h r i f t e n ~ b i j ~ d e ~}$ vrijheid van dienstenverkeer - heeft via Art. 55 EG-Verdrag onder meer tot doel, nationale belemmeringen op het vrije verkeer van diensten zoveel mogelijk te beperken. Een onderneming in een nationaalrechtelijk geschil meende door een nationale belemmering in zijn recht op vrije meningsuiting te zijn getroffen, zonder dat deze kon aantonen dat was voldaan aan alle voorwaarden van Art. 46 - de onderneming ervoer bijvoorbeeld wel economische nadelen, maar er was geen sprake van discriminatie naar nationaliteit zoals Art. 46 vereist. Het Hof besloot na toetsing van de vraag naar de connexiteit toch een toetsing van de nationale maatregel uit te voeren. Eigenlijk had die nationale wet vanwege het ontbreken van één van de wettelijke kwalificaties ${ }^{225}$ door de nationale rechter moeten worden beoordeeld, maar omdat er voldoende aanknopingspunten bij het EG-Verdrag bleken te bestaan voor beschouwing van het feitencomplex onder Gemeenschapsrecht, beoordeelde het Hof de zaak. ${ }^{226}$ Het Hof nam genoegen met de constatering, dat toekenning van exclusieve uitzendrechten aan éen onderneming in strijd kan komen met bepalingen van EG-recht waardoor een discriminerend effect kan optreden:

'In particular, where a Member State relies on the combined provisions of Articles 56 and 66 in order to justify rules which are likely to obstruct the exercise of the freedom to provide services, such justification, provided for by Community law, must be interpreted in the light of the general principles of law and in particular of fundamental rights. ${ }^{227}$

Het Hof was in casu bereid, de connexiteit tussen de grondrechtelijke claim en het EGrecht aan te nemen.

aangegeven (zie bijwoorbeeld Zabala, zaak C-422 tot en met 424/93 (1995), Jur. p. 1-1567 (1995). Ook neemt het Hof een vraag niet aan indien de interpretatie van EG-recht niet keidt tot oplossing van het inhoudelijke geschill. Feiten dienen voldoende helder te worden geschetst, en de wetgeving warvan interpretatie aan het Hof wordt gevraagd dient in beginsel in werking te zijn getreden (Lourenco Dias, zaak C-343/90 (1992), Jur. p. I-4673 (1992).

224 In het EG-recht hebben overigens niet alleen natuturlijke personen, maar met name rechtspersonen een beroep gedaan op grondrechten.

225 In casu het discriminerend effect.

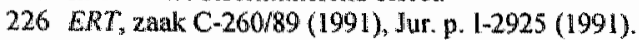

$227 E R T$, zaak C-260/189, par. 43 (cursief H.L.J.). 
Dat was echter niet het geval in Cinéthèque. ${ }^{228}$ In Cimétheque stelde de nationale rechter een prejudicielle vraag over de toelaatbaarheid onder vrijheid van meningsuiting als beginsel van gemeenschapsrecht ex Art. 10 EVRM van een nationale maatregel, die verkoop van filmmaterial op video gedurende een bepaalde periodle verbood, zolang dat filmmateriaal nog te zien was in bioscopen. Het Hof constateerde in dit geval dat het conflict niet viel onder communautair recht omdat het geen verband kon vaststellen tussen aanspraak op Art. 10 EVRM en eén der verdragsdoelstellingen. De maatregel had geen discriminerende werking naar Art. 28 EG-Verdrag en had niet tot doel het reguleren van handelsbetrekkingen. ${ }^{229}$ In deze zaak was het Hof aldus niet bereid een connexiteit vast te stellen; mitsdien viel de prejudiciêle vraag buiten de jurisdictie van het Hof.

In Demirel werd een Turks onderdaan een verblijfsvergunning in een Lid-Staat geweigerd. ${ }^{230}$ Omdat zij de verblijfsvergunning wegens voorgenomen hereniging met familie had aangevraagd, claimde zif rechtsbescherming van haar famillie- en gezinsleven ex Art. 8 EVRM. Voor de connexiteit werd aangeknoopt bij een associatieverdrag tussen Turkije en de Gemeenschap. Het Hof liet de beoordeling van deze individuele aanspraak echter geheel over aan de nationale rechter, omdat het associatieverdrag geen direct inroepbare bepaling inhoudt voor individuen. ${ }^{23.1}$ Een connexiteit kon niet worden vastgesteld:

"In this case, however, as is apparent from the answer to the first question, there is at present no provision of Community law defining the conditions in which Member States must permit the family reunification of Turkish workers lawfully settled in the Community. [...] In those circumstances, the Court does not have jurisdiction to determine whether national rules such as those at issue are compatible with the principles enshrined in Article 8 or the European Convention on Human Rights*. ${ }^{232}$

In de zaak Grogan moest het Hof oordelen over de connexiteit tussen enerzijds het recht op vrije verlening van diensten en anderzijds het recht op vrijheid van meningsuiting. ${ }^{23}$ Het lerse Hooggerechtshof had het Europese Hof van Justitie om een prejudiciêle beslissing gevraagd ter zake van de vraag, in hoeverre een verbod op verspreiding van informatie over abortus - abortus is verboden bij wet in Ierland - in overeenstemming was met het vrije verkeer van dienstverlening in de EG. Het verbod op de informatieverspreiding over die dienstverlening werd door het Hof echter niet strijdig bevonden met Art. 49 EG-Verdrag. De individuele aanspraak leek op het eerste gezicht te kunnen worden gekwalificeerd onder Art. 49 EG-Verdrag, maar het Hof onderzocht nauwkeurig, in welke mate sprake was van belemmering van vrijheid van diensten. Daartoe werd de connexiteit tussen de aanspraak op het grondrecht enerzijds en ver-

228 Cinéthèque, gevoegde zaken $60 \mathrm{en} 61 / 84$ (1985), Jur. p. 2605 (\$985).

229 Cinétheque, gevoegde zaken 60 en 61/84, par. 26.

230 Demirel, zaak $\llbracket 2 / 86$.

231 Demirel, zaak $12 / 86$, par. 23 en 24.

232 Demirel, zaak 12/86, par. 28. Zie voor een kritische bespreking van deze uitspraak in het licht van de ontwankelijkheildsbevoegdheid van het Hof Guild 2000 , met name p. 68 e.w.

233 Saciety for the Protection of Unborn Children t. Grogan, zaak C-159/90 (1991), Jur. p. I-4685 (1991) . 
dragsdoelstelling anderzijds gezocht: de link tussen de activiteit van de studenten en de uitvoering van abortus in buitenlandse klinieken was in de optiek van het Hof niet voldoende overtuigend om een verbod op verspreiding wan informatie te zien alls beperking van het vrije verkeer van dienstwerlening:

The situation in which students associations distributing the information at issue in the main proceedings are not in comperation with the clinics whose addresses they publish [...]. The information to which the national court's questions refer is not distributed on behalf of an economic operator established in another Member States. ${ }^{234}$

De test is van belang, omdat het Hof hiermee enigszins een aannamebeleid ten anzien van prejudiciele vragen kan voeren. Het Hof heeft met de eis van connexiteit tussen grondrecht en verdragsrecht een verschuifbare maatstaf tot zijn beschikking, waarmee het tot op bescheiden hoogte een selectief ontvankelijkheidsbeleid kan voeren. Bij prejudiciêle vragen waarin grondrechtelijke aanspraken werden gedaan in EG-rechtelijk verband bleek het Hof meer dan eens behoefte te hebben aan een dergelijke ruimte. Uit de jurisprudentie zijn wel enige lijnen te trekken. In Cinétheque was een kwestie aan de orde, die te maken had met beleidskeuzes op het terrein van een nationaal cultuurgoed, de film. De discriminerende factor ontbrak, maar het feitencomplex leek in het licht van de gemeenschapsdoelstellingen geen ongerustheid bij het Hof teweeg te brengen. Daarentegen was in ERT een zaak aan de orde die direct gevolgen kon hebben voor de EG-beginselen en doelstellingen. Moreelpolitieke beleidskeuzes lagen bij deze individuele aanspraak niet zo voor de hand. Het Hof leek hier meer bereid connexiteit aan te nemen tussen aanspraak en verdragsrecht. In Demirel kon het Hof de vraag onbeantwoord laten, omdat het geen jurisdictie heeft ter zake van individuele aanspraken op associatieverdragen. Hier ontbrak de connexiteit op meer formele gronden. ${ }^{235}$

\subsubsection{De uitspraak}

De uitspraken zijn collegiaal en vertegenwoordigen de eindbeslissing van het gehele Hof. Dat houdt niet per se in, dat alle rechters die betrokken waren bij de besluitvorming, het eens waren met deze beslissing. ${ }^{236}$ Het uiten van een dissenting behoort

234. Society for the Protection of Umborn Children t. Grogan, znak C-159/90, par 25-26.

235 Hef Hof neemt ten anzien wan de doorwerking en zijn jurisdictie ten opzichte van internationale verdragen niet altijd een formele benadering in acht. Hier kwam dat argument wellicht goed uit, ontat toelating van vreemdelingen ten tijde van Demirel nog een bijna nagenoeg nationaalrechtelijk beleidsterrein was, hoewel or al tekenen waren van samenwerking van Lid-Staten. Wellicht achtte het Hof het nog te vroeg, om zich uit te laten over dergelijike kwesties. Het Verdrag van Amsterdam geeft het Hof beperkte jurtisdictie ten anizien van immigratie- en asielzaken in prejudicitale procedures (Artt. 68 EGVerding).

236. Zie Art. 15 Statuut van het Hof van Justitie, dat aangeeft welke meerderheden noodzakelijk zijn in de Kamers van dric, vijt of negen rechters of in het vollallige Hof om tot een beslissing te komen: het Hof kan slechts in oneven getal op geldige wijze beslissen. De in voltallige zttting genomen beslissingen wan het Hof zijn geldig, wanneer negen rechters tegenwoordig zin. De beslissingen van de vilt drie of vijf rechters bestaande kamers zijn geldig wanneer zij door drie rechters zijn genomen. De beslissingen van de wit zeven rechters bestaande kamers zijn geldig wanneer zij door vijf rechters zijn genomen. De eisen van meerderheden tonen aan, dat een gewone meerderheid niet voldoende is om een witsprak getdig te: verklaren. 
niet tot de mogelijkheden; er wordt wel geopperd dat de wijze waarop de uitspraak is geformuleerd - helder of voor verschillende interpretaties vatbaar - samenhangt met het compromiskarakter dat de uitspraken van het Hof plegen te dragen. ${ }^{237}$ De uiteenlopende meningen dienen zoveel als mogelijk te worden gedekt door de beslissing, hetgeen kan resulteren in ambiguiteiten en vage formuleringen. Het EG-Verdrag heeft zelf voorzien in de gevolgen van onwettigheid van EG-wetgeving. Art. 231 woorziet dat indien een handeling van éen der Instellingen onwettig wordt verklaard, nietigheid volgt. In het geval van onwettigheid van een verordening kan het Hof de consequenties van de nietigheid zelf bepalen. Art. 233 vult deze bepaling aan: de Instelling dient noodzakelijke maatregelen te treffen ter uitvoering van het besluit van het Hof. De ratio achter Art. 231 is dat nietigheid gevolgen kan hebben voor hen die rechten ontlenen aan de onwettige regel, en dat het Hof enige ruimte is gegeven, deze gevolgen zoveel mogelijk te verzachten. Indien het Hof nietigheid van een regel naar aanleiding van een prejudiciele procedure vaststelt wijken de gevolgen in theorie af omdat het besluit van nietigheid gericht is aan de nationale rechter. In de praktijk heeft nietigheid in een prejudiciele procedure vergelijkbare effecten als bij de directe beroepen: nietigheid sorteert een erga omnes effect zodat alle nationale rechters de regel als nietig dienen aan te merken. ${ }^{238}$ Ook voorziet het Hof intussen in prejudicielle procedures in overgangsmaatregelen indien de nietigheid van een regel vergaande consequenties heeft. ${ }^{239}$

De rechters kunnen bij de uitspraak wan het Hof geen afwijkende opinies uiten. De uitspraak wordt gepresenteerd als product van een overleg dat door alle rechters wordt gedragen. Het overleg wordt achter gesloten deuren gevoerd. In de literatuur zijn verschillende uiteenlopende redenen aangevoerd voor deze geslotenheid van de gelederen van het Hof. Schermers formuleert er een aantal. ${ }^{240}$ In de eerste plaats wormt het autoriteitsargument een ondersteuning voor de geslotenheid. Een tweede argument voor geslotenheid hing samen met het feit dat rechters voor zes jaren in het Hof worden benoemd. ${ }^{241} \mathrm{Zij}$ keren mogelijk na zes jaren terug in de nationale rechterlijke macht; persoonlijke opinies zouden in dit verband ongewenst kunnen zijn omdat een rechter repercussies zou kunnen ondervinden bij terugkeer in eigen land. Afwezigheid van dissentings dwingt de rechters tot het sluiten van compromissen, hetgeen als wenselijk werd aangemerkt; op deze manier zou er een vermenging kunnen optreden alsmede invloed kunnen uitgaan van alle betrokken nationale rechtsordes. Ten slotte zou het eenmaal uiten van een dissenting kunnen leiden tot een situatie, waarin een rechter zich moreel verplicht voelt, bij de eenmaal geuite mening te blijven.

verklaren.

237 Craig en De Bürca 1998, p. 86

238 Craig en De Bủrca 1998, p. 512; zie ook International Chemical Corporation, zaak 66/80 (1981), Jur. p. 1191 (1981).

239 Sociéré de Prodaits de Mais, zaak $112 / 83$ (1985), Jur. p. 719 (1985), par. 16-18; Barber, zaak C-262/88 (1990), Jur. p. I-1889 (1990), par. 44-45.

240 Schermers en Waelbrouck $1992, p_{4} 496$ e.v.

241 Art. 223 


\subsubsection{Checks van de wetgever op de rechtsmacht wan het Hof}

De jurisdictie van het Hof is in de eerste plaats geregeld in het EG-Verdrag. Het Hof heeft zijn mandaat in het algemeen extensief weten uit te leggen, en daarmee een ferme stempel weten te zetten op de integratie van de Europese rechtsorde in de nationale rechtsordes. De uitspraken yan het Hof zijn lang niet altijd met enthousiasme ontvangen, maar serieuze pogingen, de rechtsmacht van het Hof in te dammen zijn er tot dusverre (nog) niet geweest. ${ }^{242}$ Daarnaast zijn voor de rechtsmacht ook het Statuut van het Hof van Justitie en het reglement van procesvoering van belang. ${ }^{243}$ De raad kan unaniem de bepalingen van het Statuut of het reglement voor de procesvoering aanpassen. Het Statuut regelt de status van de rechters en de advocaten-generaal en legt enkele procedurevoorschriften vast, waaronder het geheim van de raadkamer. ${ }^{244}$ In beginsel zijn bepalingen met bijzonder institutioneel of politiek belang in het Statuut vastgelegd, en is het reglement een uitvoering wan het Statuut. De toekomstige toetreding van een aantal staten dwingt tot herowerweging van het aantal rechters dat het Hof dient te hebben om zich van zijn taak te kunnen kwijten. ${ }^{245}$ De hoge werkdruk noopt tot het overwegen van nieuwe of andere procedures. ${ }^{246}$ Wijzigingen zijn in beginsel mogejijk, maar daarvoor is tot op heden unamieme instemming van de Raad vereist. Daarnaast valt in het debat over uitbreiding op, hoe "ondenkbaar" het kennelijk is voor de Lid-Staten, geen rechter in het Hof te hebben. ${ }^{247}$ Een rotatiesysteem, waarbij de grote Lid-Staten permanent een rechter en de kleinere Lid-Staten een beperkte tijd een rechter in het Hof hebben, lijkt tot dusverre het meest aanvaardbaar. De verdragswetgever heeft gereageerd op de rechtspraak van het Hof; in het Verdrag van Amsterdam is een aantal aanpassingen ingevoerd, die de jurisprudentiële ontwikkelingen codificenen. De verdragswetgever, de Lid-Staten gezamenlijk, heeft voornamelijk positief gereageerd op de rechtsontwikkeling van het Hof. Hiertoe behoren de erkenning van grondrechten als rechtsbeginselen binnen de EG-rechtsorde zoals gecodificeerd in Art. 6 lid 2 EU-

242 De Britse regering had bij de voorbereidingen woor het Verdrag wan Amsterdam een voorstel gelanceerd, dat het mogelijk zou moeten maken dat uitspraken van het Hof in een hoger beroepspracedure herzien zouden kunnen worden.

243 Protocol betreffende het Statuut van het Hof van Justitie van de EG en het Reglement voor de proceswoering van het Hof van Justitie van de $\mathrm{EG}$.

244 Art. 32 Statuut.

245 Ook andere oorzakin zijn van belang voor de veranderende rol van het Hof: de naar omvang en inhoud toenemende wetgevende activiteiten van de Instellingen en de verbeterde kennis van hat gemeenschapsrecht bij juristen en burgers in de Lid-Staten leidt tot een voortdurende groei van het aantal zaken.

246 Wegens grote toevloed wan zaken aan het eind van de jaren tachtig werd het Gerecht van Eerste Aanleg opgericht, watrvan de bevoegdheden in de loop der jaren steeds verder zijn uitgebreid. De oprichting wan het Gerecht heeft echter de kwantitatieve problemen miet afdoende kunnen oplossen; het aantal nieuwe zaken is gestegen van 130 in 1975,279 in 1980 naar 385 in 1988 in het jaar van opricluting van het Gerecht. In 1999 zijn 927 mieuwe zaken ingediend, waar van 543 bij het Hof en 384 bij het gerechit, watdoor het aantal aanhangige zaken per 1 januari 2000 is gestegen tot 1628 . De procesduur van een prejudiciele procedure is gestegen van lets meer dan zes maanden in 1975 naar bijna achttien maanden in 1988 en 21 maanden in 1999 (Rodriguez lglesilas 2000).

247 Afkeuring ter zake van voorstellen in de richting van de uitbreiding van het aantal rechters, zie Koopmans 1991, p. 24. 
Verdrag, en bijvoorbeeld de erkenining in het EG-Verdrag van de standing van het Europees Parlement.

Anderzijds zijn er tendensen waar te nemen, waar de verdragswetgever juist terughoudend is geweest met het toekennen van jurisdictie aan het Hof. In dit verband valt te denken aan de rechtsmacht op het terrein van visa, asiel en immigratie zoals ingevoerd met het Verdrag van Amsterdam. ${ }^{248}$ De Lid-Staten wilden kennelijk nog niet zover gaan: zij stelden hier beperkingen aan het voorleggen van prejudiciele vragen. ${ }^{249}$ Ter zake van het Statuut heeft het Hof de Lid-Staten verzocht de huidige vereiste unanimiteit binnen de Raad voor de wijziging van het Statuut te veranderen in een gekwalificeerde meerderheid. ${ }^{250}$ Dit zou het Hof, met het oog op de toename van de werklast en de diversificatie van haar taak, in staat stellen met meer souplesse te kumnen reageren op de veranderende omstandigheden. ${ }^{251}$

\subsubsection{Rechterlijke taakopvatting wan het Hof}

De rechterlijke taakopvatting jegens de constitutionele verhouding tussen rechter en wetgever (zowel de Lid-Staten als verdragswetgever alsook de Instellingen als gewone wetgever) manifesteert zich in uiteenlopende maximes, maar niet is gebleken dat het argument van rechterlijke terughoudendheid een betrouwbare maatstaf is om vast te stellen of er daadwerkelijk een terughoudendheid jegens de wetgever in acht wordt genomen. ${ }^{252}$ Verwijzingen naar de rechterlijke taakopvatting zijn ook te winden in de rechtspraak van het Hof. Een eerste begrenzing tussen de werkzaamheden van wetgever en rechter wordt door het Hof getrokken wanneer rechtstoepassing over gaat in besluitvorming ter zake van doelmatigheid en politieke opportuniteit. ${ }^{253}$ Het beleidsterrein van landbouw kent normen die kunnen worden getypeerd als beleidsnormen; het Hof is in beginsel dan ook geneigd, de wetgever in dit verband veel ruimte te laten en marginaal te toetsen. Het EG-Verdrag kent het Hof tegelijkertijd een aantal belangrijke bevoegdheden toe, waarbij interpretatieruimte bestaat ter zake van de reikwijdte van die bevoegdheden. De bevoegdheid, handelingen van de Instellingen nietig te verkllaren, is door het EG-Verdrag toegekend, en niet, zoals in de Verenigde Staten, in de jurisprudentie tot ontwikkeling gekomen. ${ }^{254}$

248 Niet ondenkbaar is dat op deze terreinen in de toekomst kwesties kunnen rijzen die het met name het recht op familieleven kummen raken.

249 Art. 68 EG-Verdrag.

250 Bijdrage van het Hof en het Gerecht aan de Intergouvemementele Conferemtic 2000 en Rodriguez Iglesias 2000.

251 Ook werd voorgesteld, aan het Gerecht van eerste Aanleg de bevoegdheid zou worden toegekend, te antwoorden op prejudiciele vragen. De verdragswetgever heeft het verzoek waarin het Hof zelf zijn reglement vaststelt, verworpen, evenals het voorstel van wijziging van unanimiteit naar gekwalificeerde meerderheid voor de vaststelling wan het Statuut of het reglement woor proceswoering.

252 Ukrow 1994 , p. 159.

253 Timex t. Raad, zaak 264/82.

254 Dubinsky 1994, p. 342 
Met de ruine taakopwatting is het Hof in staat gebleken, op veel terreinen een bijdrage te leveren aan een dynamische integratiegedachte die in de preambule wan het EGVerdrag verscholen ligt:

Vastberaden, de grondslagen te leggen voor een steeds hechter verbond tussen de Europese volkeren" ${ }^{255}$

Deze aariknoping bij het verdrag is verklaarbaar vanuit de gedachte dat het Hof op deze wijze wilde laten zien, trouw te zijn aan hetgeen de "founding fathers" voor ogen stond met het EG-Verdrag er gaat een voortschrijdende ontwikkeling van het verdrag uit. Deze dynamiek legitimeert, tezamen met de open formuleringen van de jurisdictie van het Hof, een actieve opstelling van de rechter, zo lijkt de jurisprudentie weer te geven. Deze benadering van het Hof wordt door een zekere retoriek gekenmerkt en is doorgaans zeer effectief gebleken.

In termen van 'rechterlijk dynamisch beleid" heeft het Hof een belangwekkende bijdrage in de ontwikkeling van het EG-recht geleverd, ook in tijden waarin de Lid-Staten minder 'integratiegezind' bleken. Interpretatiemethoden hebben het Hof op gezette momenten een instrument verschaft om verschillende benaderingen van uitleg van het EG-recht te creëren. Of in dit verband van rechterlijk activisme moet worden gesproken is niet eenduidig: het verdrag biedt zelf een aantal open formuleringen die multiinterpretabel zijn. Gesteld wordt wel dat het Hof activistisch was met de verklaring, dat de Europese rechtsorde een 'sui generis' karakter heeft, dat een andere toepassing en afdwinging van naleving vraagt dan in klassiek internationaal recht tot op dat moment gangbaar was. Het Hof hield in zijn legitimatie van deze stelling vast aan hetgeen verdragspartijen zelf waren overeengekomen, hetgeen de aanvaardbaarheid van de redenering diende te vergroten. Ook 's Hofs introductie van de suprematie en directe werking van EG-recht getuigen tot op zekere hoogte van activisme: met de invoering van deze mechanismen voegde het Hof zelfstandig een aantal elementen aan de structuur van het verdrag toe, die door de Lid-Staten in de oprichtingsverdragen niet zo expliciet waren neergelegd. ${ }^{256}$ Het Hof heeft in de ontwikkeling van die noties laten doorschemeren, de Lid-Staten te houden aan de door henzelf gecreèerde verplichtingen. Het Hof heeft in dit verband een systematische interpretatie toegepast, en de voornoemde normen afgeleid uit het systeen wan EG-trechtsmormen.

Het Hof is net als de rechters in de andere stelsels gebonden aan het incidentele karakter van klachten en kan niet zelf een beleid instigeren. Dat behoeft echter niet in de weg te staan aan rechtsontwikkeling in Luxemburg. In principe spreekt het Hof zich uit over

255 Rasmussen ziet in deze formulering een "leitmotiv" of een teleologisch nitgangspunt, dat woor een deel de actieve houding bij de ontwikkeling en integratie van het EG-Verdrag in de nationale rechtsonde verklaart (Rasmussen 198\%. p. 30). Hij ziet een parallel met de Amerikasnse rechtspraak, die in de beginjaren een zelfde benadering te zien gaf. Het Amerikanse Hof nam biji de federale geschillenbeslechting de "more perfect union: als "leiltmotiv".

256 Von Gend en Loos, zalak $26 / 62$ (1963), Jur. p. 1 (1963) en Costa t. ENEL, Zarak 6/64 (1964), Jur p. 585 (1964) Beide zaken kwnen voor wht betreft contouren en vestiging van de rechtsonde worden vergeleken met het Amerikaanse Marbury : Madison. 
het voorliggende geschil, maar in sommige uitspraken zijn constituerende beginselen door het Hof gepositiveerd die het concrete karakter van het voorliggende geschil verre overstijgen. ${ }^{257}$ Een belangwekkende begrenzing van de rechterlijke taakopvatting is eveneens te vinden in het feit dat het EG-Verdrag een economische achtergrond heeft. Rechtsontwikkeling op het terrein van de grondrechten ligt dan enkel voor de hand voor zover deze rechten als een 'spill over' van het economische beleid kunnen worden aangemerkt.

\subsection{De werkwijze van het Europese Hof voor de Rechten van de Mens}

\subsubsection{Rechtsmacht van het Hof}

Sinds de inwerkingtreding van het Elfde Protocol kent de raad van Europa enkel een permanent Hof dat individuele klachten beoordeelt op schendingen van het EVRM. ${ }^{258}$ Voorheen kende het EVRM een semi-permanent Hof en een Commissie, maar de stijgende werkdruk als gevolg van het gestaag aantal groeiende klachten leek een wijziging van samenstelling en verdeling van de werkzaamheden te rechtvaardigen. ${ }^{259}$ De rechtsmacht van het huidige Hof is omschreven in Art. 32 EVRM en kent het Hof in beginsel een ruim mandaat toe:

'De rechtsmacht van het Hof strek' zich uit tot alle kwesties met betrekking tot de interpretatie en de toepassing van het Verdrag en de Protocollen die daarbij aan het Hof worden voorgelegd zoals bepaald in de artikelen 33,34 en 47'.

De kerntaken van het Hof bestaan uit het geven van beslissingen over de ontvankelijkheid van ingediende individuele of interstatelijke verzoekschriften, het tot stand brengen van minnelijke schikkingen, het vaststellen van gegrondheid van klachten en, bij vaststelling van een schending, het toekennen van een genoegdoening. ${ }^{260}$ Het Hof breidde zijn competentie in De Wilde, Ooms en Versyp uit naar een terrein dat voorheen exclusief aan de Commissie leek toebedeeld, namelijk de beoordeling van preliminaire verweren. ${ }^{261}$ Het aantal zaken, waarin het vroegere Hof de eerdere besilissing van de Commissie herzag is echter beperkt gebleven. ${ }^{262}$ Art. 32 kent de ontwankelijkheidsverklaring als bevoegdheid aan het Hof toe.

257 Fan Gend en Loos, zaak 26/62 en Costa t. E.N.E.L., zaak 6/64.

258 Voorheen werden werkzaamheden tussen Hof Commissie verdeeld. Gezien de relatief recente inwerkingtreding van het Elfde Protocol zal, waar relewant, eveneens de oude situatie aun de orde komen.

259 Hier kan slechts een indruk wonden gegeven var de toename van de werkdruk van het Hof: in de jaren 1955-1982 ontwing de Commissie in total 10.210 klachten over schending van het EVRM; in het jaar 2000 ontving het Hof al 10.486 klachten over schending (zie www.echr.coe. int) In het jaar 2000 verklatarde het Hof 6.796 klachten niet-ontvankelijk en beoordeelde het 695 klachiten.. Het Hof stelde 421 keer een schending van een verdragsverplichting vast; 20 keer stelde het geen schending vast; 243 werd een minnelijke schikking getroffen (ter zake van de overige elf klachten deed het Hof geen onder. zoek naar de merites van de zaak of kende het billijke genoegdoening toe).

260 Arti. $28-29,38-39$ en 41 EVRM.

261 De Wilde, Ooms en Versyp t. België, EHRM 18 juni 1971, Serie A vol. 12, par. 47 e.v.). Zie Van der Velde 1997, p. 43 e.v. en Van Dijk en Van Hoof 1998, p. 208 e.v.

262 Het Hof heeft zijn bevoegdheid ex Art. 32 ruim geinterpreteerd; ook vragen ter zake wan de ontwanke- 
Het Hof heeft evenveel rechters als het aantal verdragspartijen; momenteel zijn er 41 rechters bij het Hof. Het Hof kent vier secties, elk bestaande uit tien rechters. Uit elke sectie wordt een kamer van zeven rechters gevormd. De President van de sectie en de rechter die is gekozen voor de betrokken staat waartegen het verzoekschrift is ingediend hebben altijd zitting in de Kamer; de anderen worden volgens een roulatiesysteem aangewezen door de President. Naast de Kamers kent het Hof een Grote Kamer, waarin zeventien rechters zitting hebben. De rechters worden benoemd voor een periode van zes jaar en zijn herkiesbaar. Niet alleen individuen kunnen een klacht ter beoordeling aan het Hof voorleggen, ook staten kunnen een klacht indienen over elke vermeende niet-nakoming van het verdrag door een andere staat. Bij het Hof zijn geen statenklachten aangebracht ter zake van het recht op persoonlijkheid; nadere beschouwing van deze bevoegdheid blijft achterwege. ${ }^{263}$ Hetzelfde geldt voor de adviesbevoegdheid van het Hof; daar is tot op heden nog geen gebruik van gemaakt. ${ }^{264}$

\subsubsection{Ontvankelijkheidscriteria}

De wijze waarop kwesties met betrekking tot interpretatie en toepassing van de in Titel I opgesomde rechten waaronder het recht op persoonlijkheid kunnen worden voorgelegd is in Artt. 33, 34 en 47 omschreven. Voorwaarden voor ontvankelijkheid zijn geregeld in Art. 35. Onder het oude toezichtstelsel werd de ontvankelijkheidsjurisprudentie vooral gecreëerd door de Commissie. Sinds de inwerkingtreding van het Elfde Protocol beoordelen de Kamers de ontvankelijkheid van verzoekschriften ${ }^{265}$, maar het Hof acht zich eveneens bevoegd om onder bepaalde voorwaarden een oordeel uit te spreken over ontvankelijkheid. Het wordt aannemelijk geacht, dat het Hof na het Elfde Protocol de door de Commissie uitgezette lijnen blijft volgen. ${ }^{266}$ Niet-ontvankelijkheidsbeslissingen dienen te worden gemotiveerd. Van alle ontvankelijkheidscriteria die het EVRM opsomt, is een aantal van belang voor de mate waarin het Hof enige speelruimte heeft ter zake van de aanname van zaken. Hiertoe behoren de voorwaardien dat het verzoek niet in wezen gelijk mag zijn aan een zaak die al eerder door het Hof is onderzocht en geen nieuwe feiten bevat, de eisen van ratione personae, ratione materiae, ratione loci of ratione temporis en dat het verzoekschrift kennelijk ongegrond is. ${ }^{267}$ Een beperkte beoordelingsruimte lijkt zich te bevinden in de eis dat het verzoekschrift binnen zes maanden nadat de definitieve nationale beslissing genomen is. ${ }^{268}$ Het begrip

lijkheid kunnen aldus door het Hof worden beoordeeld. Zaken die in het verleden door de Commissie niet-ontwankelijk werden verklaard, bleven echter wel buiten bereik van de jurisdictie wan het Hof. De huidige formulering luidt, dat het liof werzoekschriften niet-ontvankelijk verklaart.

263 Huussen en Van der Velde 1999, p. 19; Van der Velde 1997.

264 Art. I lid 1, Tweede Protocol. De adviesbevoegdheid is zeer restrictief geformuleerd; er lijkt nauwelijks gebruik gemaakt te kunnen worden wan deze bevoegdheid (Van de Velde 1997, p. 87 e.v. en Van Dijk ell yan Hoof 1998 , p. 264 e. $y$.).

265 Art. 29 lid jo. Art. 28 EVRM; voorafgaand aan het oordeel van de Kamer zal eerst een comite de klacht beoordelen. Pas wanner het verzoekschrift wordt onderzocht door een Kamer bestaat de mogelijkheid dat het ontvankelijk wordt werklaard.

266 Huussen en Van der Velde 1999, p. 5 (deel 1.2).

267 Klein 2000 , p. 705 e. .

268 Zie Huussen en Van der Velde 1999, p. 13 (deel 1.2) voor de algemene vereisten ter zake wan de eis van 
"uitputting van nationale rechtsmiddelen" is een autonoon verdragconcept, dat in de jurisprudentie tot ontwikkeling is gekomen.

De Commissie en het Hof hebben een omvangrijke jurisprudentie gecreeerd ter zake van het slachtoffervereiste, dat is gekoppeld aan de bevoegdheid ratione personae. De Commissie heeft dit begrip enigszins ruim uitgelegd, maar ook grenzen gesteld aan personen die klachten kunnen indienen. Van belang in dit verband is, dat de Commissie steeds geweigerd heeft om volledig abstracte klachten over wetgeving of handelingen te beoordelen, die via bijwoorbeeld de actio popularis werden aangebracht. Het Hof voert in beginsel geen abstracte toetsing uit over nationale wetten of handelingen, maar een potentieel handelen of nalaten kan echter wel tot gevolg hebben dat een klager direct wordt getroffen. ${ }^{269}$ In het algemeen wordt dit type klachten met grote terughoudendheid in behandeling genomen. De wet of handeling dient een irreparabel karakter te hebben, als zij eenmaal wordt toegepast. Een voortdurende inbreuk op een verdragsrecht door het bestaan van een wet die echter niet (meer) wordt toegepast dient door de klager te worden aangetoond. ${ }^{270}$ De ontwankelijkheidsverklaring heeft in dergelijke zaken tot gevolg, dat er naderhand een zekere "verkapte" abstracte toetsing kan plaatsvinden. ${ }^{271}$ Daarmee is echter nog niets gezegd over de later toe te passen intensiteit van de verdragstoetsing van nationale wetgeving.

\subsubsection{De uitspraak}

Het Hof kan uitspraken doen in drie samenstellingen: in comite's wan drie rechters, in Kamers van zeven rechters of in een Grote Kamer van zeventien rechters. ${ }^{272}$ Uitspraken worden met redenen omkleed en toegezonden aan het Comité van Ministers. ${ }^{273}$ Het Comité kan, indien het dat noodzakelijk acht, een staat uitnodigen om informatie te verschaffen omtrent genomen maatregelen ter uitvoering van de einduitspraak. De uitspraak van een Kamer geldt als einduitspraak indien geen mogelijkheid meer bestaat dat de zaak wordt verwezen naar de Grote Kamer. Uitspraken van de Grote Kamer

uitputting van nationale rechtsmiddelen; de vrasg wanneer hieraan is voldaan verschill niet alleen van land tot land maar is ook athankelijk wan de omstandigheden in het individuele gewal. Zij namen eveneens war dat de interpretaties niet altijd consistent en duidelijk zijn afgebakend. Hier likt het Hof (en de vroegere Commissie) aldus behoefte aan ruimte te hebben.

269 Klass t. Duitsland, EHIRM 6 september 1978, Serie A vol. 28, par. 33.

270 In Soering i. Verenigd Koninkrijk (EHRM 7 juli 1989, Serie A vol. 161, par. 90) overwoog het Hof dat de uitlevering zou kunnen leiden tot tentitwoerlegging wan een door het EVRM niet te tolereren verw dragsschending In Norris t Verenigd Koninkrifk (EHRM 26 oktober 1988, Serie A vol. 142, par. 31 en 32 diende de kllager aantonen dat hij het risico liep, direct te worden getroffen boor een strafrechtelijk verbod op homoseksualiteit (zie voor invuling van dit vereiste ook Klass $t$. Duitsland, EHRM 6 sep. tember 1978, Serie A vol. 28, par. 33 en Marckr t. Belgié, EHRM 13 jumi 1979, Serie A vol. 31, par. 27); daarmaast moest hij aannemelijk maken dat het enkele bestaan van deze wet cen voortdurende inbreuk opleverde van zijin recht op privé-leven ex Art. 8 EVRM.

271 Schokkenbroek 1996, p. 93. In Klass t. Duirsland bleek bijvooubeeld dat de klager nooit zalf was afgeluisterd na de anpassing wan het recht op vrije en geheime communicatie in Ant. 10 Grundgesetz (par. 13).

272 Art. 27 EVRM.

273 Art. 46 lid 2 EVRM. 
gelden als einduitspraken. De einduitspraak is enkel bindend voor de verdragsstaat die partij is bij het geschil; formeel zijn de beslissingen van het Hof niet bindend voor de andere staten. De praktijk is evenwel een andere; de uitspraken van het Hof genieten een groot gezag bij de verdragsstaten. ${ }^{274}$ Indien een verdragsschending wordt geconstateerd kan het zijn, dat niet-betrokken staten zich genoopt zien de eigen wetgeving aan te passen, omdat zij bijvoorbeeld voorzien dat de er vanuit het eigen land eveneens kilachten zouden kunnen worden ingediend. ${ }^{275} \mathrm{Er}$ is formeel echter geen erga omnes effect van de uitspraken. Art. 46 lid I verplicht de staten zich te houden aan de einduitspraak van het Hof in de zaken waarbij zij partij zijn. Uitspraken hebben geen erga omnes effect voor wat betreft onderdelen in de uitspraak die boven het concrete geschil uitstijgen. Het Hof heeft hierover zelf geen expliciete uitspraak gedaan. ${ }^{276}$ Voor de Nederlandse rechtsorde hebben de uitspraken een sterke maar geen dwingend bindende werking. ${ }^{277}$ In dit opzicht kan worden gesteld, dat de Nederlandse rechter een incorporatiegedachte hanteert en voor zover mogelijk rekening houdt met de uitspraken van thet Hof waarbij Nederland zelf geen partij is.

De uitspraak van het Hof waarin een verdragsschending wordt vastgesteld, brengt geen nietigheid van de wettelijke bepaling of uitvoeringsmaatregel met zich mee. ${ }^{278}$ Het EVRM schrijft niet voor op welke wijze de staten effectieve tenuitvoerlegging van de uitspraak dienen te verzekeren; het Hof acht zich in beginsel niet bevoegd de staat te verplichten, de wet te wijzigen. In een enkel geval laat het Hof doorschemeren, welke instantie zich met de reparatie van de schending moet bezighouden, maar dat is eerder uitzondering dan regel. ${ }^{279}$ Het Hof heeft een voorkeur voor een snel herstel van verdragsschendingen, ook al stelt het EVRM geen termijnen voor reparatie. ${ }^{280}$ In dit ver-

274 Huussen en Van der Velde 1999, p. 3 (deel 1.2); Van der Velde 1997, p. 74 e.v. Het EVRM heeft eveneens gezag bij het Hof van Justitie van de EG, dat het EVRM sinds tot uitgangspunt heeft verheven voor de invulling van fundamentele rechten als rechtsbeginselea van Gemeenschapsrecht, zie par. 2.5.3.

275 Het Hof publiceert een lijst op internet warin wordt aangegeven, welke matregelen de staten hebben getroffen, on de verdragsschending ongedaan te maken, zie wwwechr.coe int in de lijst "effects of recent judgements". De lijst is samengesteld uit resoluties dic zijn aangenomen door het Comité van ministers van de Raad van Europa, die een controlerende functie hebben ter zake van de nal eving van de uitspraken van het Hof.

276 Zie blijwoorbeeld Pellegrin t. Frankrijk, EHRM 8 december 1999, EHRC 2000/13, waarin het Fiof stelde dat zijn rechtspraak tot onzekerheid had geleid ten aanzien van de omvang wan de verplichtingen die voortvloeien uit Art. 6 lid IEVRM, alsmede lerland 1. Verenigd Koninkrijk, EHRM 18 januari 1978 , Serie A vol. 25: "The Court's judgements in fact serve not only to decide those cases brought before the Court, but more generally, to elucidate, safeguard and develop the rules instituted by the Convention, thereby contributing to the observance by the States of the engagement undertaken by them as Contracting Parties [...].

277 Schokkenbroek 2000, p. 6; deze stelt dat niet precies duidelijk is welke de reikwijdte van doorwerking var Straatsburgse uitspraken is. Zie ook Alkena 1995, p. 80 e.v. en Schokkenbroek 1996, p. 296.

278 Van der Velde 1997, p. 63 en Frowein en Peukert 1996, p. 725; zie bijvoorbeeld Marckx t. België, EHRM 13 juni 1979 , Serie A vol. 31 par. 58.

$279 X$ en Y Nederland, EHRM 26 maart 1985, Serie A vol 91, par. 27.

280 Zie bijwoorbeeld Marckx $t$. Belgie, BHRM 13 juni 1979, Serie A vol 31, naar aanleiding waarvan eerst in 1987 matregehen in werking traden die een einde moesten maken aăn het met Ant. 8 strijdige onderscheid tussen wettige en onwettige kinderen (Resolutie DH (88) 3,4 maan 1988). Voorafgaand aan deze maatregelen constateerde het Hof nog een gelijksoortige schending van Art. 8 in Vermeire $t$. Bel- 
band is een bevoegdheid voor het Comite van ministers geereèerd, dat toezicht dient te houden op de naleving van de uitspraken door de staten. Het Comite komt in de praktijk vaak niet toe aan een integrale beoordeling van de informatie met betrekking tot de door de staten getroffen maatregelen; de beoordeling is in het algemeen marginaal. ${ }^{281}$ Waar het Comité zich vroeger tevredenstelde met voorgenomen maatregelen, moeten de staten nu aantonen dat de uitvoering van maatregelen daadwerkelijk zal plaatsvinden. ${ }^{282}$

In dit verband is van belang, of de betrokken staat ter zake yan internationaal recht een monistische of een dualistische benadering hanteert: de nationale rechter in een monistisch rechtsstelsel kan, wanneer dat aangewezen is, nationale wetgeving onderwerpen aan een verdragstoetsing met een direct beroep op verdragsverplichtingen. In een dualistisch stelsel ligt dat anders; daar dienen verdragsverplichtingen eerst in het nationale recht te zijn omgezet voordat de nationale rechter daaraan een rechtsgrondslag voor een beoordeling kan ontlenen. ${ }^{283}$ Eerder kan de nationale rechter geen beroep doen op verdragsbepalingen. ${ }^{284}$ Beide systemen kennen schakeringen. ${ }^{285}$ Een monistische benadering wordt in de regel als 'verdragsvriendelijker' aangemerkt dan een dualistische benadering. ${ }^{286}$ Regel 74 van het Reglement van het Hof stipuleert uitdrukkelijk dat het aantal stemmen, dat wordt geteld voor de uitspraak dient te worden vermeld. Ook is het mogelijk, dat rechters een dissenting of concurring weergeven. Hiervan wordt regelmatig gebruik gemaakt.

\subsubsection{Checks van de verdragswetgever op de rechtsmacht van het Hof}

Met de 'wetgever' wordt in dit verband gedoeld op de verdragsstaten, die partij zijn bij de Raad van Europa en het EVRM. Zij kunnen het EVRM amenderen met verdragswijzigingen. Die hebben tot op heden niet plaatsgevonden; althans niet in de sfeer van

gie, EHRM 29 november 1991, Serie A vol. 214-C.

281 Van der Velde 1997, p. 135.

282 Van der Velde 1997 , p. 137.

283 Zie hierover uitgebreid Schokkenbroek 1996 , hoofdstuk 6.

284 In thet Verenigd Koninkrijk is in april 2000 de Hunnan Rights Act in working getreden, die het EVRM directe werking verleent in het rationale recht. Eerder konden recluters zich niet enkel op een verdragsbepaling beroepen, al waren enkele Britse rechters wel bereid aan het EVRM toepassing te verlenen. Zij hanteerden hiertoe een teleologische interpretatie: de Britse wetgever had bij de ondertekening van het EVRM de intentie dat het recht in overeenstemming zou zijin met het EVRM, zie Warbrick 1994, p. 34 e.v. In Duitsland heeft het EVRM de status van federale wet, en staat in hiererchie onder het Grundgesetz (Hesse 1990, p. 117).

285 Van Dijk en Van Hoof 1998 , p. 66 e.v.

286 Of dat terecht is valt te betwisten. De Nederlandse rechter heef een zekere diseretie bij het vaststellen van de eenieder verbindendheid van verdragsbepalingen. Dat kan soms leiden tot merkwaardige situaties, waarin eśn en dezelfde verdragsbepaling op de ene individuele aanspraak niet kan worden toegepast, terwijl de bepaling op een ander feitencomplex well wan toepassing is (zie bijvoorbeeld HR 12 oktober 1984, NI 1985/230). De Nederlandse rechter laat eenieder verbindendheid tot op grote hoogte afhangen van de gevolgen die de toepasselijkheid heeft: eenieder verbindendheid wordt bijwoorbeeld ontzegd wanneer toepassing tot gevolg heeft dat de recliter keuzes moet maken ter aanzien van de nadere invulling van het recht - en daarmee een wetgevende taak op zich neemt (Burkens, Kummeling. Vermeulen en Widdershoven 2001, p. 338). 
inperking van de bevoegdheden van het Hof. Om de werkdruk te verlichten is in 1998 het Elfde Protocol in werking getreden. Dit Protocol diende bij te dragen aan een efficientere rechtsgang. Het lijkt er echter op, dat het aantal klachten in de laatste vijf jaar dermate exponentieel is toegenomen, dat de wijzigingen van het Elfde Protocol niet meer het verwachte effect met zich meebrengen. In het Elfde Protocol is de jurisprudentie wijziging ter zake van de rechtsmacht van het Hof zoals neergelegd in De Wilde, Ooms en Versyp opgenomen; dit lag voor de hand omdat de Commissie, die voorheen bevoegd was op het wak van ontvankelijkheidsbeslissingen, is afgeschaft. Voor het Comite van ministers is als "wetgever" geen afzonderlijke rol weggelegd. Het Hof stelt zelf zijn Reglement vast; voor wijzigingen is een meerderheid van stemmen van de leden van het Hof vereist.

\subsubsection{Rechterlijke taakopwaiting wan het Hof}

Het Hof heeft zoals reeds gesteld in de ontvankelijkheidssfeer een beperkt aantal maatstaven tot zijn beschikking, om een restrictief beleid of juist een extensief beleid te voeren. Het lijkt erop, dat het Hof niet zozeer een ontvankelijkheidsbeleid heeft gevoerd, of dat een 'political question' in de ontvankelijkheidsfase is afgewezen. ${ }^{287}$ Dat is deels verklaarbaar vanuit de gedachte, dat het Hof niet zozeer opereert in een spanningsveld met een wetgever, die direct zijn bevoegdheidsterrein bedreigd ziet. Er is geen directe bedreiging van de afbakening van bevoegdheden, zoals in een staat waarin wetgever en rechter directer op elkaar zijn aangewezen. Dat verklaart tot op grote hoogte waarom een 'political question doctrine' in de rechtspraak van het Hof niet ontwikkeld is. Voor de rechterlijke taakopvatting is het van belang na te gaan, welke maatstaven het Hof in de toetsingsfase - wanneer beoordelingsbevoegdheid eenmaal is aanvaard - tot ontwikkeling zijn gekomen. Van belang in dit opzicht is allereerst dat het Hof een aantal keren expliciet heeft gesteld, van een vermoeden ten faveure van de individuele rechtsbescherming uit te gaan. ${ }^{288}$ De mogelijkheid om abstract te toetsen kent het Hof formeel niet, maar er is cen aantal uitspraken aan te wijzen waarin het Hof abstracte rechterlijke toetsing dicht benaderde ${ }^{289}$ Het Hof typeert zijn rol ten opzichte wan de nationale autoriteiten als subsidiair: het Hof heeft aanvaard dat de nationale wetgever tot op zekere hoogte een discretie toekomt met betrekking tot de verdragsbepalingen. Het heeft daanaast regelmatig gesteld, dat de nationale autoriteiten in een

28720 ook AJkema 2000, p. 45. Hij wijst erop dat het Hof met betrekking tot de rechterlijke taakopvatting waar het de constitutionele verhoudingen betreft de 'margin of appreciation' hanteent.

288 Zie voor deze benadering met het oog op Art. 8 EVRM bijwoorbeeld Klass e.a. t. Duitsland, EHRM 6 september 1978 , par. 42.

289 Het slachtoffervereiste werd bijvoorbeeld ruim geinterpreteerd. In sommige zaken was geen sprake wan concrete schendingen in de klacht, maar werd geklagad over een potentiele scheriding van het EVRM vanwege het bestaan van een wet, ook all werd die niet toegepast (zie Norris t. Herentigd Konimkrijk, EHRM 26 oktober 1988. Serie A vol. 142, par. 30 e.v.). In Klass t. Dustsland onderzocht het Hof het bestaan van wetgeving, die wel tot doel had te worden toegepast, al was het in het voorliggende geschil niet op voorhand duidelijk dat toepassing had plaatsgevonden (Klass L. Duitsland, EHRM 6 september 1978, Serie A vol 28). Her Hot waagt zich in beginsel niet aan mogelijke toekomstige verdragsschendingen, maar een uitzondering wordt gemaakt voor vitleveringszaken (zie Soering $t$. Verenigd Koninkrijk, EHRM 1989, par. 90; voorbeeld ontleend aan Schokkenbroek 2000, p. 8-9). 
betere positie verkeren om in te schatten of een schending heeft plagtsgevondert. In dat verband neemt het Hof soms een terughoudende takkopvatting aan wanneer het moet beslissen of een verdragsbepaling geschonden is; hiertoe heeft het de doctrine van de "margin of appreciation" ontwikkeld. 290

Ten aanzien van Art. 8 EVRM is deze doctrine ook toegepast; zij raakt de kern van de constitutionele verhouding tussen Hof en nationale wetgever. ${ }^{291}$ Er zijn drie beoordelingssituaties waarin het Hof de "margin" ter hand neemt. ${ }^{292}$ Allereerst speelt deze een rol wanneer er sprake is van situaties waarin de EVRM-bepaling een belangenafweging of een evenredigheidstoets tot gevolg heeft. ${ }^{293}$ In de tweede plaats wordt de "margin" regelmatig ingezet bij de beoordeling van de toepasselijkheid en de consequenties van vage normen in het verdrag. Hiertoe behoort ook het voor het recht op persoonlijkheid. relevante begrip 'respect' voor privé-leven. Ten slotte hanteert het Hof de 'margin" wanneer beoordeeld moet worden in hoeverre de nationale autoriteiten nalatig zijn geweest bij het nakomen van een positieve verplichting die kan voortvloeien uit het EVRM. Schokkenbroek benadrukt dat de situaties niet altijd te onderscheiden zijn; met name ter zake van Art. 8 laat de rechtspraak zien dat er een margin bestaat vanwege de vage term 'respect' voor het privé-leven met daaraan gekoppeld een positieve verplichting. Met de 'margin of appreciation' heeft het Hof een instrument tot zijn beschikking, om de toetsingsintensiteit te laten variören: wordt een ruime margin toegekend, dan volgt in principe een marginale toets, terwijl een enge margin juist een intensievere toetsing van de nationale regelgeving tot gevolg heeft. Er kan voor de rechtspraak van het Hof echter niet worden gesteld, dat een marginale toetsing steeds een in stand laten van de nationale wetgeving tot gevolg heeft, zoals dat wel in de Amerikaanse rechtspraak terug te vinden is.

Een aantal factoren draagt verder bij aan de mate waarin intensief of juist marginaal wordt getoetst. ${ }^{294}$ Schokkenbroek onderscheidt vier categorieën. Het Hof onderzoekt regelmatig of er een Europese consensus bestaat in de rechtspraktijk van de verdragspartijen ter zake van juridische benaderingen en oplossingen van geschillen. ${ }^{205}$ Wanneer een nationale wetgever zich, afgaande op het bestaan van een consensus in de Raad van Europa over een bepaald onderwerp, in een uitzonderingspositie bevindt, zal het Hof in beginsel een strengere toets hanteren. De consensusbenadering is geen vast gegeven; waar het Hof in het verleden aan een staat een margin liet vanwege afwezigheid var consensus kan enkele jaren later - na ontwikkeling van een meer gemeenschappelijke opvatting - eventueel wel streng getoetst worden. ${ }^{296}$

290 Het Hof hanteerde dit begrip woor het eerst expliciet in Handyside $t$. Vereniga Koninkijk, EHRM 7 december 1976, Serie A vol 24. Zie Mahoney 1990, p. 78.84, Schokkenbroek 1996 en Schokkenbroek 2000, p. $18 \mathrm{e.v}$, waaraan de navolgende beschrijwing grotendeels wordt ontleend.

291 Schokkenbroek 2000, p. 29.

292 Schokkenbroek: 2000 , p. 20 e.v.

293 Dit geldt voor Ari. 8 lid 2 EVRM: er dient een noodzakelijkheidstoetsing plaats te winden.

294 Schokkenbroek 2000, p. 23 e.w.

295 Zie Heringa 1999 voor een uitgebreide uiteenzetting over het "consensus principle".

296 Zie bijvoorbeeld de zaken Rees 1. Verenigd Koninkrijk, EHRM 1990, Cossey t. Verangd Koninkrijk en 
Er bestaat wel kritiek op de diepgang van het onderzoek naar het bestaan van de consensus. ${ }^{297}$ Vaste matstaven bestaan hiervoor niet in de rechtspraak. In dit verband zou een systeem als dat van bijvoorbeeld Advocaten-Generaal van grote waarde kunnen zijn. De opinies van de Advocaat-generaal bij de rechtspraak van het Luxemburgse Hof laten bijvoorbeeld met enige regelmaat zien aan de hand van welke maatstaven rechtsvergelijkend onderzoek is uitgevoerd. ${ }^{298}$ Het omslagpunt naar het ontstaan van een consensus wordt in de Straatsburgse rechtspraak niet zichtbaar gemaakt aan de hand van traceerbare maatstaven. Heringa karakteriseert het aanhaken bij het bestaan van een consensus ondanks deze mankementen als een wenselijke ontwikkeling: staten worden gehouden aan hun eigen bijdragen aan de internationale rechtsorde en aan hun eigen nationale rechtsontwikkelingen. Dit maakt het in principe "lastiger' om het Hof te beschuldigen van een activistische taakopvatting: het Hof houdt de verdragspartijen aan de eigen rechtsontwikkeling. ${ }^{299}$ Zolang het Hof echter niet inzichtelijk maakt op welke nationale en internationale ontwikkelingen het zich baseert lijkt met het consensusbeginsel geen sprake te zijn van een rationeel controleerbaar argument. ${ }^{300}$

De omvang van de "margin" wordt, behalve door een consensus, ook regelmatig bepaald door de aard van het doel dat met de nationale wet werd nagestreefo en de beleidscontext waarin die wet tot stand werd gebracht. ${ }^{301}$ Indien de individuele aanspraak in strijd is met een recht van anderen, dat in wetgeving zijn uitdrukking heeft gevonden, hangt de 'margin' af van de vraag of dat andere recht één van de rechten is die het EVRM beoogt te beschermen. In het geval van wetten die te maken hebben met sociaal-economisch beleid laat het Hof veelal een ruimere beoordeling aan de staat. ${ }^{302}$ Een derde factor die van invloed is op de omvang van de 'margin' wordt gevormd door de aard van de activiteiten van de klager en van de belangen die het recht waarop de individuele aanspraak rust, beoogt te beschermen. De 'margin' zal in beginsel enger

B. l. Framkrijk; hierin signaleerde het Hof eer groejende consensus ten aamzien van de positie wan transseksuelen maar het het aan de stat een rume "margin". In Goodwin t. Verenigd Korinkrijk (EHRM 25 juli 2002, EHRC 2002/74) heeft het Hof echter recentelijk wastgesteld dat er voldoende consensus bestond voor tot het vastleggen van eenduidige maatstaven voor alle verdragspartijen, en bleck het niet langer bereid om nen rume margin of appreciation the hanteren.

297 Zic de dissening van Martens bij Cossey /. Verenigd Koninkrijk, zie Heringa 1999, p. 23

298 Zie bijvoorbeeld Opinie van A-G Mischo bij Foechst t. Commissie (Opinie bij gevoegde zaken Hoechs, Dow Bewehax, Dow Iberica, Alcwia en Empresa Nacronal del Petroleo t. Commissie) van 21 februari 1989). Over de juiste benadering kan men van mening verschillen; de grondslag voor de consensus wordt in eflk geval zichtbaar gemalkt. Dic zichthoarheid ontbreakt bij het Strantsburgse Hof in het algemeen.

299 Heringa 1999, p. 33 .

300 De argumentatio met de consensus als grond woor een veranderende rechtsopvarting lijkt bij de lleden wan de Ragd wan Europa relatief stilzwigend te worden anvaard. In de rechtspraak wan het Hoog. gerechishof wan de Verenigde Staten hebben enkele rechters zich echter zeer kritisch uitgelaten over het lanteren van de consensus als matstaf woor een dymamisch-evolutieve interpretatie (Zie Aukins t. Virginia (nr. 00-8452, 20 juni 2002; zie de dissemongs van, rechters Scalia, Thomas en Rehnquist).

301 Schokkenbroek 2000, p. 24.

302 Powell en Kaywer t. Verenigd Konmkrik, EHRM 21 februari 1990, Serie A vol.. 172, par. 44 (ter zake van economisch beleid); zie ook Jane Smith t. Werenigd Koninkrijk, EHRM 18 januari 2001, EHRC $2001 / 19$, par. 119 (ter zake van huisvestingsbeleid). 
zijn indien de activiteiten waarvan klager bescherming wenst zich bevinden in de kern van het recht, indien de omstandigheden waarin de klager verkeert de uitoefening van het recht belangrijk maken, of wanneer de activiteit wordt beschouwd als een essentieel aspect van de persoonlijke ontplooiing. ${ }^{30.3}$ Ter zake van het recht op persoonlijkheid is van belang dat wanneer de individuele aanspraak wordt erkend als een 'most intmate aspect of private life' het Hof eerder geneigd is om een intensieve toetsing van de wetgeving te laten volgen. In dit opzicht lijkt het Hof uit te gaan van het bestaan van een kernsfeer en een meer perifere sfeer van privé-leven. Wetgeving die een inbreuk maakt op het intieme aspect van privé-leven (bijvoorbeeld seksuele voorkeur) kan bijvoorbeeld eerder rekenen op een intensieve toetsing dan inbreuken die zich eerder bevinden in een meer openbare sfeer. ${ }^{304}$ Een factor van belang kan verder gelegen zijn in het bestaan van noodsituaties waarin met spoed risicobeoordelingen moeten worden verricht. Het Hof heeft met de 'margin' een verschuifbare maatstaf tot zijn beschikking, waarmee het op grond van de voornoemde aspecten de constitutionele verhouding tussen EHRM en staat als het ware inschat.

\subsection{De werkwijze van de Hoge Raad}

\subsection{Rechtsmacht van de Hoge Raad}

In dit onderzoek wordt uit de Nederlandse rechtsorde enkel de jurisprudentie van de Hoge Raad belicht die aanknopingspunten geeft voor rechtsontwikkeling op het terrein van het recht op persoonlijkheid. Vraag is nu in hoeverre de Hoge Raad kan worden aangemerkt als hoogste rechterlijke instantie die in zijn rechtspraak heeft gewerkt aan rechtsontwikkeling op voornoemd terrein; de Nederlandse rechtsorde kent ten slotte ook bestuursrechtspraak en een strafrechtelijke component in de Hoge Raad. De jurisprudentie van de Raad van State heeft tot dusverre nog niet geleid tot rechtsvinding op het vlak van het recht op persoonlijkheid. Er zijn geen uitspraken aangetroffen waarvan kan worden gezegd dat zij hebben geleid tot een verdere ontwikkeling van Ait. 10 Grondwet, Art. 8 EVRM of concretiseringen het van algemene persoonlijklieidsrecht. Ook zijn er geen nieuwe noties van het recht op persoonlijkheid in diens rechtspraak gevonden. Recentelijk heeft de CRvB een extensieve interpretatie van Art. 8 EVRM gegeven, die verder lijkt te strekken dan het EHRM tot op heden bereid was aan te nemen. ${ }^{305}$

De grondwet behandelt 'de rechtspraak' in Hoofdstuk $6{ }^{306}$ De Hoge Raad is belast met de cassatie van rechterlijke uitspraken wegens schending van de wet en van het recht,

$303 X$ en Y t. Nederland, EHRM 1985, par. 24.

304 Zie respectievelijk Srith en Grady 1. Verenigd Koninkrijk, EHRM 27 september 1999, 1999-VI en Leander t. Zweden, EHRM 26 maart 1987, Serie A vol. 116, par. 59.

305 CRvB 29 januari 2002, nr. 01/515ZFW; zie ook par. 9.2.5.

306 Art. 112 Grondwet draagt berechting van geschillen over burgerlijke rechten en plichten op aan de rechterlijke macht, waartoe ook de Hoge Raad behoort. Op basis van Art. 16 Grondwet wijst de wet de gerechten aan die behoren tot de rechterlijke macht, terwijl Art. 117 Grondwet de benoeming wan de 
zo luidt het mandaat aan de Hoge Raad. ${ }^{307}$ De Hoge Raad is bij de uitoefening gebonden aan het geldende recht. Dat lijkt te duiden op een interpretatiebegrenzing, al is niet direct evident welke grenzen er met 'het geldend recht' worden getrokken. In de grondwet, de Wet rechterlijke organisatie en het EHRM is een aantal begrenzingen ter zake van de constitutionele verhouding tussen Hoge Raad en wetgever vastgelegd, die soms in tegengestelde richting lijken te wijzen. De rechter en dus ook de Hoge Raad mag allereerst geen recht weigeren onder verwijzing naar onduidelijkheid van de wet. ${ }^{308}$ Doel van cassatie is bevordering van de rechtseenheid en rechtszekerheid, alsmede het leveren van een bijdrage aan de rechtsontwikkeling. ${ }^{309}$ Met het leveren van een bijdrage aan rechtsontwikkeling wordt een bijdrage aan rechtsvorming door sommige auteurs gelijkgesteld. ${ }^{310}$ De taak die de rechter is toebedeeld lijkt de rechter tot rechtsontwikkeling te dwingen wanneer daartoe noodzaak bestaat. ${ }^{311}$ Art. 94 grondwet draagt aan de rechter op wettelijke bepalingen die in strijd zijn met eenieder verbindende verdragsbepalingen buiten toepassing te laten. De niet-toepassing betreft zowel formele als materièle wetgeving. De wet stelt daarnaast expliciet dat vernietiging van een uitspraak dient te volgen indien schending met het recht heeft plaatsgevonden. ${ }^{312}$ Deze aspecten lijken in beginsel te duiden op een mandaat dat omvangrijk is; daarmee is nog niets gezegd over de wijze waarop de Hoge Raad het invult in het licht van de constitutionele verhouding tussen hem en de wetgever.

$\mathrm{Er}$ is echter een belangwekkende beperking in de rechterlijke taakuitoefening in de grondwet neergelegd: het is de rechter verboden, grondwettelijke toetsing te verrichten van wetgeving afkomstig van regering en Staten-Generaal. ${ }^{313}$ Daarnaast geldt in beginsel een verbod van intensieve toetsing van de innerlijke waarde of billijkheid van de gewraakte wet, alsmede de regel dat de rechter geen regels mag vaststellen die boven het concrete geval uitstijgen. ${ }^{3 / 4}$ Vraag is nu, op welke wijze de Hoge Raad invulling

leden van de Foge Raad regelt.

307 Art. 118 lid 2 Grondwet Zie ook Hirseh Ballin 1988, 1. 211-240 voor een beschouwing van de staats:rechititike positie wan de cassatierechter.

308 Art. 13 Wet algemene bepalingen (hiena: Wet ab). Uit Art. 6 EVRM zou eveneens een recht op een rechterlijke uitsprak kunnen worden afgelleid; het EHRM heeft in zijn rechtspraak tiet recht op toegang tot een rechter ex Art. 6 id I EVRM verder uitgewertht en gesteld dat er ook inhoudelujke eisen worden gesteld aan die toegang. De toegang moet concreet en effectiaf zijn, en miet illusoir en theoretisch (zie bijvoorbeeld Garcia Mamibardo it. Spanje, EHRM 15 fehruari 2000, EHRC 2000/30). Zlie ook Koopmans 1992 , p. $52-53$

309 Art. 101 a Ro.

310 Martens 2000, p. 748.

3.1 Waar het accent woor 1988 - de invoering wan Art. 101 a Ro-lag op het casseren van de uitspraken van lagere rechters die zich niet aan de wet wilden conformeren staat nu de vorming van recht in de uitspraken van de Hoge Raad centraler; "de sloper is in de bouw gegaan" (zie Barendrecht 1998, p. 16).

312 Art 99 Ro.

313 Art. 120 Grondwet Huidt: "De rechter treedt niet in de beoordeling wan grondwettigheid wan wetten en verdragen",

314 Artt. 11 en 12 Wet ab. Art. 11 Wet ab: "De regter moet volgens de wet regt spreken: hij mag in geen geval de innerlijke waarde of billikheid der wet beoondelen'. Art. 12 Wet ab luidt: 'Geen rechter mag bij wege van algemeene verordening, dispositie of reglement, witspraak doen in zaken welke aan zijne beslissing onderworpen zijn" 
heef gegeven aan het mandaat dat hem is opgedragen, de beperkingen - waarvan het toetsingsverbod naar mijn mening tot de belangrijkste behoort - in ogenschouw nemend. Over de consequentie van deze constitutionele figuur voor de verhouding tussen rechter en formele wetgever wordt verschillend gedacht. Vranken meent; dat het toetsingsverbod weliswar een uiterst belangrijke en diep ingrijpende regel is, maar dat het qua omvang een betrekkelijk beperkte uitzondering vormt op de algeneen geldende hiërarchie van rechtsregels. Hij wenst de uitzondering niet te verheffen tot een fenomeen met vergaande invloed op de positiebepaling van de rechter in het constitutionele bestel als geheel. ${ }^{315}$

Tegenover Vrankens mening bevindt zich die waarin het toetsingsverbod juist wel wordt gezien als een factor van belang in de constitutionele verhouding:

'By conscious or subconscious influence, the presence of this restraining power, aloof in the background, but none the less always in reserve, tends to stabilise and rationalise the legislative judgement [...] to hold the standard aloft and visible for those who must run the race and keep the faith".

In dit verband wordt wel gesteld dat de rechter bij een harde demarcatielijn als Art. 120 Grondwet geen ruimte zal zien de grenzen van zijn mandaat op te zoeken wanneer hij apert het noodzakelijk acht om handelingen van de wetgever op grondwettigheid te toetsen. Het bestaan van de mogelijkheid tot toetsing houdt een extra controlemechanisme in. ${ }^{317}$ Vraag is of een vaststelling van ongrondwettigheid zonder consequenties dan toch kan leiden tot het afgeven van een signaal aan de wetgever. De Hoge Raad stelde in Harmonisatiewetarrest in een obiter dat de gewraakte wet eigenlijk niet door de beugel kon, maar kon er gezien het toetsingsverbod geen gevolg aan geven. Het obiter kon de wetgever niet zijn ontgaan; de uitspraak van de Hoge Raad leidde later mede tot gedeeltelijke bijstelling van de wet. ${ }^{318}$ Het correctiemechanisme op gebrekkige wetgeving wordt vanuit de gedachte van democratische legitimatie in beginsel geacht te werken langs de weg van de verkiezingen. In individuele gevallen kan toetsing

315 Asser-Vranken 1995, p. 49.

316 Cardozo 1921, p. 93, alsmede Heringa 1990, p. 67.

$3 \| 7$ Niet is daarmee gezegd, dat de rechter dat mechanisme bij iedere gelegenheid ter hand zal nemen, maar dat het bestaan ervan de wetgever bij woorbaat kan dwingen kritisch naar de wetgeving te kijken. In Duitsland hebben commentatoren ook wel gesteld dat het bestaan van constitutionele toetsing juist heef geleid tot een 'terughoudendheid' bij de wetgever, omdat er soms vanuit wordt gegaan dat de recliter hoogstwaarschijnlijk zijn corrigerende functie zal uitoefenen; zie Prakke 1992, p. 25.

318 In de Human Rights Act van het Verenigd Koninkrijk is de bevoegdheid voor enkelle rechters weg. gelegd, on een 'declaration of incompatibility' uit te spreken, wanneer zij van mening zijin dat een wet in strijo is met het EVRM (zie Art. 4 Human Rights Act). Hier lijkt de uitspraak van de Hoge Raad, zij het noodgedwongen, een gelijkardig effect te hebben gehad: de rechter constateerde in Harmonisatiewet een flagrante schending met een ongeschreven rechtsbeginsel, zonder daaraan effect te kutnen verlenen. Het Harmonisatiewel-arrest blies de discussie over het toetsingsverbod in rechtsgeleerde kring en in de nationale politiek nieuw leven in. Ook de regering bleek het signal yan de Hoge Raad op te pakken. In februari 1991 kwam de regering met een voorlopig standpunt in de Nota inzake rechterlijke toetsing dat zij voor advies voorlegde aan de Raad van State, de Hoge Raad en diens procureurgeneraal. De vraag die in deze nota centraal stond, was niet langer of er een vorm van constitutionele toetsing moest worden ingevoerd maar op welke wijze deze gestalte zou moeten krijgen. 
van gebrekkige wetgeving echter op effectievere wijze leiden tot grondwettige individuelle rechtsbedeling,

Vaststelling wan ongrondwettigheid met daaraan gekoppeld cen onverbindendheid van de wet leidt echter niet altijd tot een handelen door de wetgever - in sommige gevallen blijft die lang treuzelen met het tot stand brengen van nieuwe regelgeving, terwijl de rechter met een beroep op een terughoudende taakopvatting niet gekomen is met een alternatieve oplossing. ${ }^{320}$

\subsubsection{Ontwankelijkheidscriteria}

Bij cassatie in het belang der wet wordt toegang tot de hoogste rechterlijke instantie verkregen, zonder dat partijen daarop invloed kunnen uitoefenen. De toegang tot de Hoge Raad wordt bij cassatie in het belang der wet geheel bepaald door de procureurgeneraal. Hij selecteert zaken die hiervoor in aanmerking komen. De Hoge Raad heeft geen ruimte om een ontvankelijkheidsbeleid te voeren in deze; ter zake van cassatie in het belang van het recht geldt in beginsel hetzelfde. De Hoge Raad kan zaken, die echter geen stof opleveren voor beantwoording van rechtsvragen in het belang van de rechtseenheid of rechtsontwikkeling vereenvoudigd afdoen. ${ }^{321}$ Een afwijzing van ontvankelijkheid dient te worden gemotiveerd. ${ }^{322}$ Cassatie in het belang van het recht kan in beginsel niet gaan over beoordeling van de feiten, maar de Hoge Raad heeft soms wel geoordeeld over feiten in zogenoemde gemengde beslissingen. ${ }^{323}$ Of een vraag feiten of het recht behelst blijft ten slotte een interpretatievraag die de Hoge Raad moet beantwoorden. In dit verband lijkt aldus een kleine beoordelingsmarge te bestaan. Met de bestaande regels ter zake van cassatieklachten wordt het strijdperk tot op grote hoogte verkleind. Ten aanzien van de feiten kunnen partijen geen gebreken uit de vorige instanties herstellen; evenmin mogen nieuwe feiten worden aangevoerd. De Hoge Raad mag evenmin iets bijdragen aan de verbetering van de feitelijke grondslag van het geschil. Hij moet uitgaan van hetgeen is terug te vinden in de bestreden uitspraak en in de gedingstukken. ${ }^{324}$ Ambtshalve aanvulling van rechtsgronden is slechts in heel bescheiden mate mogelijk; de eis zelf kan echter niet worden gewijzigd. ${ }^{325}$

319 In durgelijke gevalten wordt dan gesproken van buiten toepassing laten van de wet in formele zin in het indiwiduele geval. De grens tussen 'buiten toepassing laten' in het individuelle geval en buitenwerkingstellung wan een wet in het algemeen is echter vloeiend: vanuit de gedachte van gelijke behandeling kan buiten toepassing laten in het individuele geval al gauw leiden tot een algehele onverbindendwerklaring van de wet. Vanut die optiek zal de rechter relatief terughoudend omgan met het instrument van buitentoepassing laten van een wet in formele zin in het individuele geval.

320 Zle bijvoorbeld HR 12 oktober $1984, N\rfloor 1985 / 230$ waarin de HR stelde dat voor hem geen rechtsvormende tnak was weggelegd.

321 Art $101 \mathrm{aRO}$.

322 Art. 101 a Ro.

323 Asser-Vranken 1995, p. 36.

324 Art. 419 leden 2 en 3 Rv.

325 Vranken 1995, p. 35 . Art. 48 Rv. ziet op de mogeligkhetd van aanvulling van rechtsgronden, maar in thet licht war de lijdelijkheid van de civiele rechter is de rol van de Hoge Raad als aanvuller van rechtsgronden zeer beperkt. 


\subsubsection{De uitspraak}

Indien de Hoge Raad vaststelt dat een schending van grondrechten heeft plaatsgevonden, staan uiteenlopende dicta tot zijn beschikking. Art. 99 Ro verplicht hem tot vernietiging van lagere rechterlijke uitspraken, maar stelt niets omtrent ongrondwettig geachte wetgeving. Welke opties in het gegeven geval van toepassing zijn is afhankelijk van een aantal factoren. De achterliggende gedachte om af te zien van vernietiging van de gewraakte wet lijkt direct te zijn verbonden met de taakopvatting van de rechter in het licht van de constitutionele verhouding tussen hem de wetgever. Terughoudendheid bij onverbindendverklaring van wetgeving past de Nederlandse rechter om verschillende redenen. Het wegvallen van de geldigheid van een wet kan onder omstandigheden een situatie in het leven roepen die schadelijk is voor het rechtsverkeer. ${ }^{326}$ In sommige gevallen heeft de rechter wel voorzien in overgangsrecht, maar dat is tot dusverre zelden het geval geweest. ${ }^{327}$ Allereerst hangt de bereidheid om tot onverbindendverklaring van de wet over te gaan af van de aard van de regel of handeling die wordt bestreden. Wordt geklaagd over een grondrechtelijke schending vanwege een wet in formele of materiele zin, dan geldt Art. 94 Grondwet: schending van een eenieder verbindend verdragsrecht behoort in principe te leiden tot niet-toepassing van de wet. ${ }^{328}$ In het geval van een schending van een grondrecht door een wet in materièle zin staat ook toetsing aan de grondwet of rechtsbeginselen open. ${ }^{329}$ Indien in een onrechtmatige daadsactie ex 6:162 BW wordt geklaagd over een schending van grondrechten, heeft de rechter een gevarieerd pakket van maatstaven tot zijn beschikking, afhankelijk van de aard van de schending. ${ }^{330}$

Indien nu schending door een formeelwettelijke bepaling van een eenieder verbindende verdragsbepaling wordt geconstateerd, blijkt het allerminst vanzelfsprekend dat de rechter daar in zijn uitspraak consequenties ex Art. 94 Grondwet aan verbindt. In dit verband heeft de Hoge Raad het in de wet vastgelegde instrumentarium van uitspraakmogelijkheden verfijnd, zodat het mogelijk werd tussen de verplichting ex Art. 94 Grondwet enerzijds en het toetsingsverbod ex Art. 120 Grondwet gesignaleerde spanningsveld te laveren. ${ }^{331} \mathrm{Hij}$ kan vaststellen, dat het recht niet geschonden is ondat er geen sprake is van een eenieder verbindende bepaling. ${ }^{372}$ Ook bestaat de moge lijkheid, dat hij een schending constateert en dat de klacht gegrond is, maar dat hij de keuze ten aanzien van de vraag hoe de schending moet worden weggenomen overlaat aan de

326 Koopnrans 1992 , p. 63.

327 Stolker 1993 , p. 54.

328 Met name op het terrein van het personen-en familierecht heeft de rechter op basis van Ant. 8 EVRM formele wetgeving in concrete gevalien buten werking gesteld. In wettig/onwewh (HR 18 jamuari 1980 , NI 1980/463) werd een formeelwettelijke bepaling in concreto getoetst aan het EVRM, en buiten toepassing gelaten. Zie bijwoorbeeld ook gezamenlike ouderlijke mach (HR 4 mei 1984, NJ1985/510) en gezamenlijke owderlije macht voor ongehuwden (HR 21 maant 1986, N1 1986/585).

329 Zie bijwoorbeeld Landbannwliegers, HR 16 juni 1986 , NJ 1987/251.

330 Zie bijvoorbeeld par. 9.2 .1 en 9.2 .7 .

331 Stolker geeft een fraai overzicht weer van de door de Hoge Raad ontwikkelde strategieèn (Stolker 1993, p. 60 e.v.); deze indeling word hier gevolgd.

332 HR 12 oktober 1984 , NJ $1985 / 230$. 
wetgever. ${ }^{333}$ Toewijzing zou in strijd kunnen komen met het stelsel van de wet of met een duidelijke regel in de wet. ${ }^{344}$ Het kan voorkomen dat toewijzing van onverbindendverklaring de rechter dwingt tot het nader vormgeven - die nadere vormgeving zou in strijd komen met zijn rechterlijke taakopvatting. De rechter moet dan kiezen uit een aantal uiteenlopende oplossingen, en die oplossingen vergen ieder weer een nadere uitwerking, een taak die de rechter in het algemeen aan de wetgever overlaat. Ook kan de rechter de mening zijn toegedaan dat er onvoldoende consensus bestaat. ${ }^{335}$ Aanwezigheid van belangrijke waardeconflicten die zijn ontstaan als gevolg wan het ter discussie stellen van deze waarden kan de rechter doen beslissen, zijn taak eng uit te leggen. Het formuleren van algemene regels, die de ene fundamentele waarde boven de andere stellen, wordt door de rechter uitgesteld: hierover dient de wetgever zich uit te laten. ${ }^{336}$ Men kan zich afvragen in hoeverre het terecht is dat de rechter zich in dit verband terughoudend opstelt, en aan de hand van welke maatstaven een consensus geformuleerd wordt. ${ }^{337}$ De rechter heeft in een aantal gevallen echter wel over waardeconflicten geoordeeld; de kwestie ter zake van het recht op hulp bij zelfdoding en kwesties binnen het personen- en familierecht illustreren juist dat de rechter wel een taak voor zichzelf weggelegd zag.

In enkele gevallen kan toewijzing van onverbindendverklaring leiden tot doorkruising van wetgeving die in ontwikkeling is, en leiden tot rechterlijke terughoudendheid. Vraag is hier in hoeverre een kwalificatie van rechterlijke terughoudendheid terecht is, of omgekeerd in hoeverre de kwalificatie van activisme in de gevallen waarin de rechter zich over waardeconflicten uitsprak waarin de wetgever niet tot handelen kwam. In de Amerikaanse situatie werd een rechter die zelfstandig uitspraakvariaties bedenkt sceptisch bezien: hij sleutelt aan het door de wetgever opgestelde systeem van rechterlijke uitspraken. Omgekeerd kan vanuit het perspectief ex Art. 6 EVRM dat niet alleen formele maar eveneens materiële eisen stelt aan de rechterlijke uitspraak worden geredeneerd dat de rechter zich niet activistisch opstelt indien hij een taak oppikt die de wetgever heeft "laten liggen".

Ook zijn overgangsrechtelijke aspecten niet vanzelfsprekend te herleiden tot terughoudendheid. In een recente uitsprak heeft de Hoge Raad nog eens uiteen gezet welke zijn visie is op het in de rechtspraak tot ontwikkeling gekomen leerstuk. ${ }^{33^{8}}$ Uitgangs- $^{2}$ punt was, dat de Hoge Raad een grondrecht geschonden achtte, maar dat het niet vanzelfsprekend bleek dat de rechter daar consequenties aan verbond. Of er concrete rechtsbescherming moest worden geboden door de rechter, onderzocht de Hoge Raad aan de hand van drie vragen. In de eerste plaats vroeg de Raad zich af, of buiten toepassing laten van de regeling de belanghebbende zou baten. Indien dat het geval was,

333 Naamrecht, HR 23 september"1989, NJ 1989/740, en HR 12 mei 1999 , NJ $2000 / 170$.

334 Zie bijvoorbeeld Qwil/Te Poel, HR 30 jaminari 1959, NJ $1959 / 548$.

335 Var Gerven 1981, p. $20 \mathrm{e} . \%$

336 Vam Gerven 1981, p. 23.

337 Stolker 1993, p. 70.

$338 \mathrm{HR} 12$ mei 1999, NJ 2000/170, met mame overwegingen 3.14 e.v.(voorbeetd ontleend aan Martens 2000, p. 750 ). 
beoordeelde hij in de tweede plaats of hij zelf zou voorzien in het rechtstekort, of dat hij het zou overlaten aan de wetgever. De Hoge Raad hanteert bij het maken van de keuze het volgende uitgangspunt:

"Voor het zelf in het rechtstekort voorzien pleit dat de rechter daardoor aan de belanghebbende direct een effectieve rechtsbescherming kan bieden, mar ertegen pleit dat in de gegeven staatsrechtelijke verhoudingen de rechter bij zulk ingrijpen in een wettelijke regeling een terughoudende opstelling past:.

Vervolgens hangt af van de keuzemogelijkheden hoe de rechter zal oorclelen. Indien voldoende duidelijk is - te beoordelen aan de hand van het stelsel van de wet en de daaraan ten grondslag liggende beginselen, of de wetsgeschiedenis - hoe het rechtstekort kan worden weggepoetst, kan de rechter zelf daarin voorzien. Als dat echter niet duidelijk is - er moet bijvoorbeeld een keuze worden gemaakt uit een aantal mogelijkheden waaraan rechtspolitieke keuzes kleven, dan dient de rechter die voorlopig over te laten aan de wetgever. Aan de voorlopigheid kan echter een einde komen, indien de wetgever op de hoogte is van de strijdigheid van de regel met een grondrecht, en aldus in gebreke blijft. ${ }^{340}$ In beginsel een terughoudende taakopvatting, wanneer het gaat on formele wetten.

Indien de uitspraak van de Hoge Raad vemietiging van de bestreden uitspraak to gevolg heeft, doet hij het geding in beginsel zelf af. ${ }^{341}$ Indien daarentegen nog moet worden beslist over feiten waaromtrent nog geen uitspraak is gedaan, verwijst de Raad het geding. Art. 422 Rv erkent de mogelijkheid dat de Hoge Raad naar bevind van omstandigheden een oordeel kan geven over punten waaromtrent nog geen uitspraak is gedaan. Deze bepaling dient echter te worden gelezen in samenhang met de grondwettelijke grenzen.

\subsubsection{Checks wan de wetgever op de rechtsmacht van de Hoge Raad}

De rechters in de Hoge Raad worden voor het leven benoemd ${ }^{342}$ bij koninklijk besluit. ${ }^{343}$ Tot dusverre heeft de interpretatie van de grondwet door de rechter tegen de achtergrond van de constitutionele verhoudingen geen aanleiding gegeven voor een verandering van het systeem van benoemingen. In dat verband rijst de vraag, of en in hoeverre verkiezingen of een beperktere aanstellingsduur het probleem van de legitimiteit uit de wereld helpen. ${ }^{3.44}$ De Hoge Raad doet regelmatig uitspraken die spanning teweeg kunnen brengen in de constitutionele verhouding - zelden worden die uitspraken teruggevoerd op een eventuele onevenwichtige samenstelling van de Hoge Raad ${ }^{345}$

$339 \mathrm{HR} 12$ mei 1999, NJ $2000 / 170$, overweging 3.14

340 HR 12 mei 1999, NJ 2000/170, overweging 3.15 .

341 Art 420 Rv.

342 Barendrecht spreekt in dit werband van een soort coopptatie (Barendrecint 1992, p. 125).

343 Art. 117 Grondwet.

344 Zie hierover De Werd 1994, p. 297 e.v. en Bovend'Eert 2000.

345 Barendrecht 1992, p. 125. 
Tot dusverre is er geen aanleiding gezien, het systeem te veranderen naar een systeem waarin de samenstelling wan het beslissend orgaan een afspiegeling vormt van de parlementaire werhoudingen. ${ }^{346}$ Dat zou wellicht eerder opgeld doen wanneer de Hoge Raad toetsingsrecht zou verkrijgen ${ }^{347}$, al lijken de opvattingen ook hier terughoudend: een rechter die politieke legitimatie draagt zou wel eens politiek ter verantwoording kunnen worden geroepen, en men erkent wat explicieter dat het rechtsprekend orgaan een functie toekomt in het politieke proces. ${ }^{348}$ Vraag is dan of die functie nu volledig kan worden ontkend. De aan deze visie ten grondslag liggende afwijzing van betrokkenheid in het politieke proces heeft ongetwijfeld ook zijn weerslag op de wijze waarop de rechter zijn taakopvatting percipieert, al kunnen hier geen harde maatstaven voor worden vastgesteld. De Amerikaanse of de Duitse rechter, die zich bewust zijn van een zekere "politieke functie" kennen eveneens rechterlijke terughoudendheid met verwijzing naar de democratische legitimatie van rechterlijke beslissingen. In die stelsels aanvaardt de rechter echter in meer opzichten dat zijn rol een bijdrage levert in de constitutionele verhoudingen. Ook kent de Hoge Raad geen afwijkende en concurrings' en dissentings in zijn uitspraken. Hij doet uitspraken in collegiale setting; er wordt gestreefd naar beslissingen die - naar buiten toe althans - door alle rechters worden gedragen.

De laatste omvangrijke wijziging van de grondwet heeft in 1983 plaatsgevonden. Tot op heden zijn er geen wijzigingen ingevoerd, die een eventuele onwenselijke lijn van jurisprudentie ter zake van het recht op persoonlijkheid moesten corrigeren. Herziening van de grondwet in de Nederlandse situatie is een tijdrovende en omvangrijke operatie. Wiet alleen de zittende volksvertegenwoordiging, maar ook de volkswertegenwoordigers die daarna worden verkozen, dienen zich te kunnen vinden in de wijziging. ${ }^{399}$ Een wijziging wordt met tweederden van het aantal uitgebrachte stemmen aangenomen. ${ }^{350}$

\subsubsection{Rechterlijke taakopvatting van de Hoge Raad}

In het Harmonisatiewetarrest heeft de Hoge Raad de bevoegdheid ter zake van toetsing van formele wetgeving onwelwillend doch expliciet afgewezen met een beroep op het toetsingsverbod ex Art. 120 Grondwet. ${ }^{351}$ De wetgever heeft de rechter in dit verband uitdrukkelijk verboden formele wetten te toetsen, en aan willen geven dat het staatsrechtelijke primaat bij de wetgever ligt. Sinds de jaren " 80 staat de betekenis van deze constitutioneelrechtelijke figuur ter discussie, maar vooralsnog heeft de Hoge Raad geen uitspraken gedaan waarin het toetsingsverbod expliciet terzijde is geschoven. ${ }^{352}$

346 Bovend'Eert vraag zicla af of de visie terecht is dat de wijze van samenstelling en benoeming van de Hoge Raad niet in conflict komen met vragen van machtenscheiding en democratische legitimatie.

347 De Werd 1994, p. 295.

348 Batendrecht 1992, p. 126.

349 Art. 137 lid 2 Grondwet.

350 Art. 137 lic 4 Grondwet.

351 Harmonisatie wetarrest, HR 14 april 1989, NJ1989, 469

352 Het is onmogelijk een volledig overzicht te geven over dit debat; zie voor discussie over dit verbod en waardevolle verwijzingen onder meer Advies Hoge Raad inzake toetsingsrecht 1992, Burkens, Kummeling, Vermeulen en Widdershoven 2001, p. 180-192; Heringa 1990; p. 67 e.v., Hoge Raad der Ne- 
Het verbod wordt tot op grote hoogte gerelativeerd door de mogelijkheid, formele wetten te toetsen aan internationale verdragen. ${ }^{353}$ Vraag in dit verband is warom de wetgever tot op heden nog niet is overgegaan tot afschaffing ervan: de facto kennen wij al een toetsingsrecht. ${ }^{354}$ Het toetsingsverbod, dat in de Nederlandse situatie aldus sterk samenhangt met een uitgesproken prinaat van de (formele) wetgever, is vanwege een aantal belangrijke ontwikkelingen onderhevig aan erosie. Ontwikkelingen in de samenleving nopen in toenemende mate tot meer 'juridische' oplossingen, waarin de wetgever niet altijd een tijdig en deugdelijk voorziet. De snel veranderende technische ontwikkelingen, of het toenemend aantal taken dat door de staat wordt opgevat, maken het bijvoorbeeld lastig om te adequaat te anticiperen op de vraag om juridische oplossingen. In gevallen waarin de maatschappelijke discussie nog niet is uitgewoed, of het voorstellingsvermogen van de regelgever tekortschiet rest de wetgever dan de mogelijkheid vage normen te stellen die door andere organen dienen te worden ingevuld, of een discretionaire bevoegdheid toe te kennen aan een orgaan dat ook in lastig situaties voor het individuele geval een oplossing weet te vinden. In sommige gevallen is dat orgaan de rechtsprekende macht: de rechter wordt met concrete problemen geconfronteerd en heeft niet de mogelijkheid oplossingen voor zich wit te schuiven of te wachten tot over het probleem meer duidelijkheid bestaat: hij mag geen recht weigeren. Via de rechtsprekende macht is het internationaal recht, waarop vaker een beroep wordt gedaan, een sterker invloed op het Nederlandse recht gaan uitoefenen. ${ }^{355}$ Vanuit die optiek is de betekenis van Art. 94 Grondwet in de rechtspraak toegenomen.

De achterliggende gedachte bij de rechterlijke taakopvatting van de Hoge Raad is tot op zekere hoogte terug te voeren op het primaat van de wetgever, maar het toetsingsverbod blaast een flinke toon mee. ${ }^{356}$ Het primaat van de wetgever is eveneens in de andere stelsels aanvaard, maar het sluit een rechtsvormende taak in de vorm van een mogelijke rechterlijke toetsing van wetgeving in formele zin niet uit: rechterlijke controle over wetgeving van de hoogste orde is er expliciet aanvaard en verklaarbaar vanuit de gedachte, dat wetgever en rechter beide aan "the rule of law" gebonden zijn. Het argument van het primaat van de wetgever is aldus niet bewredigend als verklaring voor

derlanden, Toelichting op de jaarcijfers 1995 en 1996, p. 13 e.w.; Van Houten 1997; Martens 2000 , p. 750 e.v.; Wiarda 1999, p. 56 ev; Haak 2002; Prakke 1992, Koopmans 1992 en Barendrecht 1992; hett Rapport van de Commissie Franken over Grondrechten in het digitale tijdperk, Handelingen TK 27460, nr. $l$, p. 40 e.v. en recentelijk de nota van de regering over constitutionele toetsing van formele wetten IK 2001-2002,28355 nr. 2, p. I e.v.

353 Sommige auteurs spreken in dit verband wan een 'de facto toetsingsrecht', zie bijvoorbeeld Heringa 1990, p. 67.68 .

354 Hirsch Ballin liet zich - nar mijn mening terecht - kritisch uit over het waarom van het toetsingsverbod enerzijds en de erkenning van mogelijkheid tot toetsing aan intemationale normen anderzijds: "Misplatatste gevoellens van stuperioriteit (ten opzichte van andere verdragsstaten bij het EVRM, H.L.J.) zouden nog eens lkunnen worden versterkt door de mening dat het politiek proces te onzent zo goed en harmonieus functioneert dat een rechterlijke toetsing - en zeker cen toetsing doof intemationale rechters - overbodig is. De rechtspraak op basis van het EVRM wordt dan gezien als teken van onwenselijke 'juridisering" die het "primaat van de politiek' doorkruist' (Hirsch Ballin 2000, p. 622). In dezelfde zin Schuyt 1988 , p. 331 e.v.

355. Wiarda (Koopmans) 1999, p. 71, Martens 2000, p. 749 e.v.

356 Martenis 2000, p. 751 . 
de positiebepaling door de Hoge Raad. Martens vestigt in dit verband de aandacht op de traditionele plaatsbepaling van de rechterlijke macht in het Nederlandse staatsbestel, waarvan het in 1848 ingevoerde toetsingsverbod als een duidelijke demarcatielijn deel uitmaakt. ${ }^{357}$ 'De traditionele plaatsbepaling' refereert volgens Martens aan de spanningsverhouding tussen de politiek die weigert het toetsingsverbod ter discussie te stellen en de rechter die de "goede verhoudingen in de trias" graag wil handhaven. ${ }^{358}$ In de andere stelsels lijkt de constitutionele verhouding tussen rechter en wetgever - waar het rechterlijke toetsing van wetgeving in formele zin betreft - meer open en over te worden gelaten aan een dynamische relatie tussen rechter en wetgever. Die dynamiek leidt bij beide staatsrechtelijke actoren tot een bewustzijn van een controlemogelijkheid en mogelijk tot verscherpt handelen. In de Nederlandse rechtsorde wordt een vertrouwen in een dergelijke verhouding tot op heden niet expliciet uitgesproken, althans niet met de schrapping van het toetsingsverbod. ${ }^{359}$ In het licht van het toetsingsverbod dat de taakopvatting van de Hoge Raad tot op grote hoogte beînvloedt is het interessant om te bezien op welke wijze deze rechter invulling geeft aan de rechtsvinding op het terrein van het recht op persoonlijkheid: vraag is, of en in hoeverre het toetsingsverbod een betekenis kan toekomen.

\subsection{Conclusies en slot}

\subsubsection{Inleiding}

In de inleiding bij dit hoofdstuk is de vraag gesteld welke constitutionele randvoorwaarden aanwezig zijn die de rechter begrenzen in zijn rechtsvormende taak in het licht van de constitutionele verhouding tussen hem en de wetgever. Institutionele begrenzingen aan de rechtsvormende taak van de rechter vloeien direct voort uit de functie van de rechterlijke maclut. Hiertoe behoren het mandaat zoals dat is neergelegd in de grondwet of in de wet, de ontvankelijkheid, de mogelijkheid tot ambtshalve aanvulling van de rechtsgronden en de uitspraakbevoegdheden. Tot interinstitutionele begrenzingen aan de rechisvormende taak van de rechter behoren de regels die de constitutionele verhouding tussen rechter en wetgever direct betreffen, zoals de mogelijkheid van de wetgever, de grondwet of het verdrag te herzien, de invloed op de benoeming en samenstelling van de rechterlijke instantie en de mogelijkheid, het rechterlijke mandaat in omvang te beperken. De interinstitutionele begrenzingen op de rechterlijke taakuitoefening is in een horizontale en, voor zover relevant, een verticale component opgesplitst. De vraag naar de wijze waarop de institutionele en interinstitutionele begrenzingen zijn

357 Murtens 2000 , p. 751 .

358 Martens 2000 , p. 751 .

359 In thet licht van deze beschouwing kan ik me dan ook niet vinden in hetgeen door Vranken is geopperd (zie par. 3.6.1) over het toetsingsrecht: het toetsingsverbod is een principieler staatsrechtelijke regel en leidt de pragmatische benadering - we hebben de facto toetsingsrecht - niet tot een tegemoetkoming aan "the rule of law'. De recentelijk een nota van de regering-Kok ter zake van constitutionele toetsing van formele wetten, TK 2001 2002, $28355 \mathrm{nr}$. 2, p. I e.v. stell het toetsingsverbod ter discussie, wellicht vornt deze een aanleiding tot heroverweging van het toetsingsverbod. 
ingericht, werd belicht om te bezien welke begrenzingen in het stelsel bestaan ter zake van de rechterlijke taakopvatting:

\subsubsection{Rechterlijk mandaat en onwankeliktheid}

Het mandaat van de rechter is door de Amerikaanse rechter op belangwekkende punten "veroverd: het Hooggerechtshof heeft zich het toetsingsrecht en de bevoegdheid om zich uit te laten over federale en statelijke wetgeving via extensieve interpretatie van de constitutie toegeëigend. Alllereerst werd het toetsingsrecht in de rechtspraak ontwikke]d; daarna werd via incorporatie de catalogus van grondrechtelijke normen uitgebreid waaraan kon worden getoetst. In eerste instantie waren dat rechtsnormen uit de Bill of Rights; naderhand is de Amerikaanse rechter ook rechtsbeginselen gaan 'inlezen' in de open begrippen in het Veertiende Amendement.

Het Hof van Justitie van de EG heeft eveneens een mandaat geclaimd dat niet in het EG-Verdrag expliciet is neergelegd door te stellen dat grondrechten in de hoedanigheid van rechtsbeginselen deel uitmaken van de $\mathbb{E G - r e c h t s o r d e . ~ V a n ~ e e n ~ i n c o r p o r a t i e ~ a l s ~ i n ~}$ de Amerikaanse situatie kan echter niet worden gesproken. Het Luxemburgse Hof heeft aan zijn mandaat zoals neergelegd in Art. 220 EG-Verdrag een extensieve interpretatie gegeven. Het Duitse Hof ontleent zijn omvangrijke rechtsmacht aan de Duitse grondwet en specifieke wettelijke bepalingen, en heeft zijn rechtsmacht niet hoeven 'bevechten' zoals de Amerikaanse rechter. Het Straatsburgse Hof ontleent zijn mandaat aan het EVRM, dat door het Hof extensief is geïnterpreteerd. De Duitse en de Straatsburgse rechter hebben een specifiek mandaat met betrekking tot de uitleg van respectievelijk de grondwet en het EVRM. Gemeenschappelijk ter zake van het mandaat hebben de rechters dat zij als laatste instantie een bindende uitspraak doen over grondrechten in hun grondwet of verdrag. De Nederlandse Hoge Raad heeft geen specifieke mandaat ter zake van de grondwet; hij opereert als een "gewone" civiele- of strafrechter. Hij casseert, net als de Amerikaanse rechter.

Het Amerikaanse Hof kan als casserende rechter met het "certiorari-systeem" een heus ontvankelijkheidsbeleid voeren. De Nederlandse rechter kan dat nawwelijks, evenals de Duitse rechter. Het EHRM heeft enigszins ruimte bij de toepassing van bepaalde ontvankelijkheidscriteria. Het Hof van Justitie in Luxemburg kent eveneens wat ruimte; het meet zichzelf in dit opzicht soms een eng gedefinieerde jurisdictie aan, waardoor het zijn ontvankelijkheid enigszins kan relativeren. Er kan voor het Hof van Justitie van de EG echter niet worden gesproken van een echt beleid: de economisch geprioriteerde doelstellingen van het EG-Verdrag houden geen specifieke opdracht tot een specifieke grondrechtenbescherming in. Het ligt voor de hand dat het Luxemburgse Hof hier afstand van rechtsmacht doet wanneer connexiteit tussen de grondrechtelijke aanspraak en Gemeenschapsrecht niet kan worden aangetoond. Dat is begrijpelijk vanuit twee gezichtspunten: in de eerste plaats hanteert dit Hof voor de waarborging van de grondrechten geen geschreven normen - een bindende lijst ontbreekt tot dusverre, en in de tweede plaats dicteert Art. 2 EG-Verdrag, dat de doelstellingen en de enkele constituerende beginselen van de Gemeenschap omvat, een prioriteit voor een economische benadering. In dat verband kan van een benadering ten faveure van de individuele 
rechtsbescherming, in EG-verband in beginsel niet worden gesproken. Deze benadering kan wel aanwezig zijn wanneer het Hof een rechtsverhouding tussen individu en Instelling beoordeelt.

Enige speelruimte in het ontvankelijkheidsbeleid komt in alle stelsels van pas bij de beslissing om over een individuele aanspraak te willen oordelen. Nu wordt de beperking op de discretie in het ontvankelijkheidsbeleid in de stelsels die geen 'certiorari' hanteren enigszins getemperd door de aanwezigheid van verschillende eisen waaraan moet worden voldaan. Verschuifbare maatstaven ter zake van de ontvankelijkheid lijken zich te verbergen in meer specifieke criteria, zoals bijvoorbeeld de eis van standing. Indien de rechter een zaak wil beoordelen, laten deze criteria een restrictieve of juist extensieve interpretatie toe, zodat beoordeling alsnog onmogelijk of juist mogelijk wordt. In verband met de mate waarin een ontvankelijkheidsbeleid kan worden gevoerd is het incidentele karakter van rechtspraak van belang: de rechter kan nu eenmaal geen beleidsterreinen naar zich toe trekken; hij dient af te wachten welke individuele aanspraken aan hem worden voorgelegd. Zijn taak is rechtspreken; de ruimte om aan rechtsontwikkeling te werken is in beginsel een 'bijproduct' en geen vooropgesteld doel van de rechtspraak. De Amerikaanse rechter kan het meest een ontvankelijkheidsbeleid voeren, maar is eveneens afhankelijk van de uitspraken die worden voorgelegd. Hierdoor wordt de discretie tot op grote hoogte getemperd.

\subsubsection{Ambtshalve aanvulling van de rechtsgronden en constitutionele verhouding}

Hoewel de rechter in beginsel gebonden is aan de wijze waarop de individuele aanspraak aan hem wordt voorgelegd, bestaan er soms toch mogelijkheden om de in de aanspraak genoemde rechtsgronden ambtshalve aan te vullen. In de meeste gevallen is deze bevoegdheid het gevolg van extensieve interpretatie van de rechterlijke taak. Deze extensieve interpretatie van de rechterlijke taak zou kunnen duiden op een activistische taakopvatting, omdat de rechter een mogelijkheid ziet de aanspraak te herformuleren. Wanneer de formulering valt binnen het kader van het geldend recht lijkt er niet veel aan de hand te zijn. Een aanspraak die op het eerste buiten de jurisdictie ligt en er na herformulering binnen valt lijkt al wat meer te duiden op een activistische taakopvatting. De mate waarin ambtshalve aanvulling van rechtsgronden kan plaatsvinden hangt tot op grote hoogte samen met de aard van de aanspraak en de ruimte die de rechtsnormen laten waarop de aanspraak rust. De normen centrerend rond het recht op persoonlijkheid laten in beginsel tot op grote hoogte ruimte voor interpretatie waardoor de kwalificatie van activisme niet zo voor de hand ligt. Het hangt echter van de voorkeur voor de te volgen interpretatiemethode af of een aanvulling als activistisch moet worden betiteld. Tekstuele benadering van de grondrechten knoopt op het eerste gezicht het meest aan bij de door de grondwetgever bedoelde norm, terwijl een dynamisch-evolutieve benadering ook andere aspecten van de grondrechtsnorm aanspreekt. ${ }^{360}$ Eén van die aspecten is dat sommige rechters in de grondrechten een vooronderstelling ten faveure van individuele rechtsbescherming lezen. Vanuit die gedachte kan een dyna-

360 Zie hierna hoofdstuk 4 voor de in de stelsels gehanteerde constitutionele interpretatiemethoden. 
misch-evolutieve lezing van grondrechten juist binnen de grenzen van de rechterlijke taakopvatting komen te vallen: de rechter doet immers wat hem is opgedragen. Vraag is of de grondwet of het verdrag deze vooronderstelling ook werkelijk dicteren.

De rechtspraak van het Amerikaanse Hof laat in dit opzicht door de tijd heen een gevarieerd beeld zien; in het ene geval lijkt het vermoeden ten voordele van de individuele rechtsbescherming een grotere rol te spelen dan in het andere geval. De indruk bestaat dat dat samenhangt met de wijze waarop een bepaald "Court" is samengesteld. In de historie van het Hooggerechtshof is gebleken dat sommige "Courts" meer geneigd waren om vanuit voornoemd uitgangspunt individuele aanspraken te willen beoordelen. ${ }^{361}$ Er kan in dit verband echter geen voorspelling worden gedaan vanuit een vaste trend; het blijft in dit opzicht bij een indruk. Het Hof van Justitie van de EG toont zich in verband met ambtshalve aanvulling van individuele aanspraken op grondrechten juist weer terughoudend, hetgeen samenhangt met het feit, dat op het rechtsnormenpakket waarmee het Hof een beoordeling van een zaak te lijf gaat, in beginsel een zware economische aanspraak rust. Wanneer de zaak zich echter buiten het terrein van economische politiek en discretionaire bevoegdheden beweegt, lijkt het Hof eerder genegen, ook een benadering in het voordeel van de individuele rechtsbescherming te kiezen, al is er nog niet veel rechtspraak die aanleiding geeft om van een vaste lijn te spreken. Wanneer het gaat om de 'constitutionele EG-verdragsrechten' wan het individu lijkt het Hof juist wel genegen een takopvatting ten faveure van de EG-rechtelijke individuele rechtsbescherming aan te nemen.

\subsubsection{Uitspraakbevoegdheden in het licht van de rechterlijke taakopvatting}

Het soort uitspraken dat een rechter kan doen is niet onbegrensd; de grondwet of specifieke wetten leggen uitgangspunten en in sommige gevallen regels vast. Er bestaat een relatie tussen de rechterlijke taakopvatting enerzijds en het soort aan uitspraken dat hij hanteert anderzijds. In beginsel leidt strijdigheid tot onverbindendverklaring of nietigheid van de betrokken wet, maar de indruk bestaat dat die consequentie door de rechters niet in alle gevallen aanvaardbaar wordt geacht. In alle stelsels is een variatie in rechtsgevolgen van de strijdigheid ontstaan. Aan de hand van deze in de rechtspraak gegroeide praktijk zou kunnen worden gesteld dat de rechter zich met deze tactiek een activistische taakopvatting aanmeet. De rechter doet enerzijds wel een beroep op de constitutionele verhoudingen wanneer hij de gevolgen van een schending van grondrechten tempert, maar evengoed kan worden gesteld dat hij in dergelijke gevallen aan de door de (grond)wetgever gegeven dicta sleutelt. De rechter kan de gevolgen verzachten om tegenstand tegen bepaalde jurisprudentie te verminderen.

Afwijzing van onverbindendverklaring of nietigheid zou juist kunnen worden aangemerkt als het maken van een beleid waarbij nieuwe lijnen in de jurisprudentie worden uitgezet zonder dat de gevolgen hiervan direct voelbaar zijn. Het Luxemburgse Hof is wel expliciet de mogelijkheid toegekend, de consequenties van uitspraken te lenigen,

36॥ Zie ook hoofdsttik 6. 
hetgeen kennelijk door de Lid-Staten als wenselijk werd geacht. De expliciete toekenning hangt samen met de angst van Lid-Staten, met gebrekkige wetgeving van de Instellingen te worden geconfronteerd. De Nederlandse rechter hanteert het argument van de rechterlijke taakopvatting in relatie tot de uitspraak die volgt na een vaststelling van schending, zo is de indruk, relatief het minst terughoudend. De Amerikaanse rechter lijkt het meest direct gevolgen te verbinden aan de door de wetgever gegeven uitspraakmogelijkheden. Indien het Amerikaanse Hooggerechtshof vaststelt, dat een federale of statelijke wet strijdig is met de grondwet, dan wordt de nietigheid van de betreffende wet vastgesteld. Alleen in aperte uitzonderingsgevallen is het Hof bereid temporele werking te geven aan zijn uitspraken. De uitspraken van het EHRM brengen in beginsel geen nietigheid met zich mee, wanneer strijdigheid wordt vastgesteld. Dat wil echter niet zeggen, dat aan diens uitspraken geen consequenties worden verbonden door de getroffen staten of door staten, die een zelfde met het EVRM strijdige wetgeving of rechtspraak in stand houden.

\subsubsection{Verticale begrenzingen van rechterlijke bevoegdheden}

De verticale begrenzingen of federalle bevoegdheidsafbakeningen spelen enkel een rol in het Duitse, het Amerikaanse en tot op zekere hoogte het EG-rechtsstelsel, en hebben te maken met de verdeling van de rechtssprekende bevoegdheden tussen de federatie en de staten. In slechts enkele gevallen is de federale rechtsmacht een exclusieve. Ten aanzien van grondrechten geldt op uiteenlopende terreinen in beginsel een concurrerende rechtsmacht. In die gevallen moet steeds worden onderzocht of de federale rechtsmacht bevoegdheid heeft ten aanzien van statelijke wetgeving. Federale besluiten gaan in beginsel voor statelijke besluiten, maar ook hier laat de rechtspraak een beeld zien waarin de federale rechter zelf uitleg heeft gegeven aan de omvang van zijn bevoegdheden ten opzichte van de statelijke rechter. Het Amerikaanse Hof heeft afwisselend een eigen bevoegdheid afgewezen, en op andere momenten juist een extensieve uitleg gegeven aan de hoofdregel van suprematie van federaal recht. Het Duitse Hof heeft zijn bevoegdheden ten opzichte van de statelijke rechter uitgelegd in het licht van de opvatting, dat de Duitse verticale machtenscheiding wordt beheerst door een beginsel van een 'federale eenheidsstaat'. In beide rechtsstelsels is interpretatie van de verdeling van werkzaamheden aangewezen, en kan dit een argument opleveren om af te zien of juist over te gaan tot beoordeling van een individuele aanspraak. De Luxemburgse rechter opereert formeel niet in een federaal rechtssysteem, maar kent eveneens in een verdeling van werkzaamheden tussen het Hof en nationale wetgevers. De eis van connexiteit tussen individuele aanspraak bij een verdragsbepaling kan worden aangemerkt als een criterium dat raakt aan een verticale bevoegdheidsverdeling. De verticale machtsbegrenzing stelt beperkingen aan de taakopvatting van de rechter; het is van belang om in concreto na te gaan in hoeverre de verticale machtsbegrenzing voor de rechter een betekenis toekomt in zijn taakopvatting ter zake van het recht op persoonlijkheid.

\subsubsection{Wijziging van de grondwet of het verdrag}

In alle stelsels lijkt het erop, dat amendering van de grondwet geen praktische oplossing biedt voor het bijsturen van onwenselijk geachte jurisprudentie. Dat hangt onder 
meer samen met het feit dat de amenderingsprocedure lang duurt en verzwaarde besluitvorming noodzakelijk is. De Duitse wetgever is in dit opzicht het actiefst gebleken. In geen van de stelsels zijn grondwetswijzigingen of verdragswijzigingen aangenomen met het oog op bijsturing van de jurisprudentie op het terrein van het recht op persoonlijkheid. Omgekeerd lijkt de grondwetgever juist een enkele keer in de jurisprudentie ontstane lijnen te hebben gecodificeerd bij verdrags- of grondwetsherziening. Deze invulling van bevoegdheid door de grondwet- of verdragswetgever geeft an dat de grondwetgever aan de rechter een zekere ruimte laat om bestaande grondrechten werder uit te werken en nieuwe ontwikkelingen in de samenleving te verdisconteren in rechtsnormen.

De Duitse rechter heeft zich een bevoegdheid, een grondwetsamendement ongrondwettig te verklaren, toegeëigend. Deze bevoegdheid is in de andere rechtsstelsels, voor zover al mogelijk, niet aan de orde geweest. De bevoegdheid tot afkeuring van grondwetswijzigingen maakt het Duitse Hof jegens de grondwetgever tot een zeer machtige instelling. Wellicht is 's Hofs schepping van deze bevoegdheid - niet direct het hanteren, want het Hof betracht terughoudendheid - verklaarbaar in het licht van het relatief grote aantal grondwetswijzigingen dat in de afgelopen decennia is doorgevoerd. Het problematisch karakter van wijzigingen met betrekking tot aspecten van het recht op persoonlijkheid hangt deels samen met het feit dat het moeilijk of nagenoeg onmogelijk is, ten aanzien van hete hangijzers zoals het recht op hulp bij zelfdoding of andere ethische kwesties een vereiste meerderheid voor herziening te vinden. Ook is het lastig een meerderheid te vinden voor specifieke levensstijlen die grondrechtelijke bescherming zouden moeten genieten. Vanuit dit gezichtspunt klemt de vraag, in welke mate een meerderheid te vinden is voor de erkenning van een persoonlijke voorkeur of levensstijl, en of aan de rechter een rol toekomt als beschermer van de minderheidsopvatting. In de beschrijving van hetgeen het recht op persoonlijkheid omvat, is een aantal aspecten van het recht op persoonlijkheid de revue gepasseerd waarvan niet eenduidig kan worden gesteld dat zij zullen worden geapprecieerd door een meerderheid of minderheid in de samenleving. Individuele aanspraken op aantal deelonderwerpen van het recht op persoonlijkheid - abortus, erkenning van transseksualiteit het onderhouden van homoseksuele relaties, het willen kennen van de biologische afstamming, het willen huwen met eem persoon van een andere etniciteit - hebben in de verschillende rechtsstelsels geleid tot verhitte debatten over de juiste ethische benadering.

\subsubsection{Benoeming en samenstelling van de rechterlijke instanties}

Niet kan worden ontkend, dat de uitspraken van de hoogste rechterlijke instanties allen tot op zekere hoogte worden betrokken in het politieke proces bij totstandkoming van wetgeving. Een grote mate van betrokkenheid van andere staatsrechtelijke actoren bij de benoeming van de rechters die deel uitmaken van de rechterlijke instantie ligt dan voor de hand. Enkel in het Amerikaanse debat lijkt de benoeming van rechters openlijk groot gewicht te worden toegekend in verband met het ombuigen van onwenselijke jurisprudentie. De benoemingen zijn aan te merken als politiek; in de andere stelsels vindt dit debat niet op dezelfde wijze plaats. Amerikaanse rechters kunnen hun politieke voorkeuren openlijk uitspreken. In de andere stelsels is deze benadering niet aan- 
getroffen. Dat wil geenszins zeggen, dat aan het benoemen en samenstellen van de rechterlijke instantie in de andere stelsels geen belang wordt gehecht. In Duitsland is de benoemingenprocedure van de constitutionele rechters complexer dan die van het Hooggerechtshof in de Verenigde Staten. Met de rechterlijke benoemingen kan niet direct invloed kan worden uitgeoefend op onwenselijk geachte lijnen in de jurisprudentie, dat toonden enkele voorbeelden uit de Amerikaanse historie aan. Tegelijkertijd kan een signaal van de regerende partijen uitgaan met een benoeming, vooral in de Verenigde Staten. In de andere stelsels is dit minder aan de orde.

\subsubsection{Beperking van de rechtsmacht van de rechter}

De wetgever kan erwoor kiezen, de omvang van de rechtsmacht van de rechter te beperken; deze bevoegdheidsbeperking is tot dusverre eerder theoretisch gebleken, dan dat hij praktisch tot uitvoer is gebracht. In de literatuur is wel gepleit voor beperkingen van jurisdictie met betrekking tot bepaalde terreinen, waaronder het met het recht op persoonlijkheid gerelateerde recht op abortus in de Verenigde Staten. Er zijn echter wel aanverwante strategieën gesignaleerd, die hadden moeten leiden tot rechterlijke terughoudendheid. In dit verband kan worden gedacht aan het feit, dat de Europese LidStaten hun fiat voor een bindend grondrechtenhandvest hebben onthouden. Deze weloverwogen keuze stelt het Hof van Justitie enigszins voor een begrenzing: toepassing in concreto van de rechten uit het Handvest ligt nu niet voor de hand; de verdragswetgever heeft een duidelijk signaal afgegeven. Tegelijkertijd kan de onthouding van het fiat niet direct leiden tot een niet-toepassing van een reeds wijdverbreide praktijk van het Hof, namelijk de applicatie van EVRM rechten op individuele aanspraken. Nu hanteert het Hof van Justitie die terughoudend, maar er zijn kennelijk geen onoverkomelijke barrières om de aan het Handvest identieke EVRM grondrechten in sommige gevallen toe te passen.

\subsubsection{Slot: de rechterlijke taakopvatting}

Vanwege het toetsingsverbod van wetgeving in formele zin is het mandaat van de Hoge Raad met meest expliciet begrensd, en is de betekenis van de grondwet als check op dat type wetgeving gerelativeerd. Deze beperking wordt tot op zekere hoogte gecompenseerd door de mogelijkheid wetgeving in formele zin te toetsen aan eenieder verbindende verdragsbepalingen. Het primaat van de wetgever bestaat in de overige stelsels eveneens, doch het wordt niet noodzakelijk geacht deze te ondersteunen met de gedachte van een toetsingsverbod. Voldoende lijkt te zijn dat de bevoegdheid van rechterlijke toetsing in deze stelsels wordt aangemerkt als een uitgangspunt van de gebondenheid van alle constitutionele actoren aan het recht. De toetsingsbevoegdheid wil niet zeggen dat er in de andere stelsels geen problemen rijzen ter zake van de rechterlijke taakopvatting in het licht van de constitutionele verhoudingen; die problemen bestaan in die stelsels eveneens.

Problematisch in het licht van de rechtsstaatgedachte blijkt de kwestie in welke mate de hoogste uitlegger van grondwet of verdrag zelf kan worden gecorrigeerd. Over de rechterlijke taakopvatting in verband met de correctiemogelijkheid is vooral in de Verenig- 
de Staten veel geschreven, zeker in vergelijking met de overige stelsels. Dat is grotendeels te verklaren vanuit een historische achtergrond. ${ }^{362}$ Dat heeft Hof in verschillende politiek gevoelige conflicten uitspraak gedaan, waar de Europese rechters de reikwijdte van hun rechtsmacht pas later zouden exploreren en zich op dat moment nog niet over dergelijke conflicten hadden uitgelaten. In de laatste decennia is de situatie in de Europese stelsels evenwel veranderd. Het Duitse Hof heeft de notie, dat alleen de wetgever geschikt is om over belangrijke politiek gevoelige kwesties te beslissen en dat een rechter daarover nooit zou mogen beslissen, al lang geleden in de ban gedaan. Het Straatsburgse en het Luxemburgse Hof die met een grondwet werken die qua structuur en open textuur te vergelijken is met die van de Verenigde Staten, hebben ook hun inventiviteit laten gelden om op politiek gevoelige kwesties te antwoorden. Zij wezen deze activiteit niet af met een beroep op een terughoudende taakopvatting. ${ }^{363}$

In hoofdstuk 3 is getracht een beeld te schetsen van de institutionele en interinstitutionele grenzen op de rechterlijke besluitvorming die van invloed zijn op de rechterlijke taakopvatting. De rechterlijke taakopvatting kan worden geprojecteerd op een schaal met aan het ene uiterste het activisme en het andere de terughoudendlheid. Algemene opvatting lijkt te zijn, dat wanneer rechterlijke besluitvorming of aspecten daarin als activistisch wordt herkend, de stellingname ten opzichte van deze rechtspraak in beginsel negatief is. Het ruime mandaat dat de rechter ter zake van grondrechtelijke interpretatie is toegekend, laat in beginsel een rechterlijk aandeel in stand dat van betekenis kan zijn in het meer politieke proces van wetgeving. Problematisch met het begrippenpaar 'activisme' en 'terughoudendheid' is dat zij, afhankelijk van de perceptie van de beoordelaar, in sommige situaties inwisselbaar blijken. ${ }^{364}$ De kwalificaties die de rechters zelf hechten aan hun taakopvatting lijkt niet in alle gevallen betrouwbaar; aan een keuze vanuit de gedachte van terughoudendheid kan vanuit een ander perspectief juist een kwallificatie van activisme worden gehecht. Vraag is op welke wijze de rechterlijke taakopvatting met de kwalificaties 'activisme' en 'terughoudendheid' in de interpretatiefase een betekenis toekomt, en vanuit welk perspectief deze kwalificatie wordt toegekend. Hiertoe zullen in het volgende hoofdstuk de constitutionele interpretatiemethoden worden uitgewerkt.

362 Koopmans 1988, p. 317. De opstellers van de grondwet namen hun missie, het vastleggen van een machtenscheiding, serieus. $\mathrm{Zij}$ kenden de rechterlijke macht een met de andere machten vergelijkbare plats toe. Er bestond dan ook al vroeg veel aandacht voor de wijze waarop deze machtenscheiding zich zou ontpoppen. De toepassing van de grondwet door het Hof leidde al gauw tot de principiele kwestie of het Hof ook wetgeving zou mogen herzien: het Hof beantwoordde deze vraag in Marbury 1. Madison positief.

363 Zie ook Koopmans 1988, p. 318.

364 Zie het voorbeeld bij het uitbreiden van de uitspraakmogelijkheden: in de Amerikaanse situatie is dit een voorbeeld van ontoelaatbaar rechterlijk activisme, terwijl het in de Nederlandse en de Duitse situatie wordt gehanteerd en tot ontwikkeling is gekomen vanuit de gedachte van rechterlijke terughoudendheid. Iets vergelijkbaars geldt voor de situatie waarin aanvullingen op de individuele aanspraken worden gepleegd vanuit de gedachte van indiwiduele rechtsbescherming, waarin de kwalificatie van activisme niet zo voor de hand ligt, terwijl wanneer die gedachte niet wordt aanvaard juist eerder kan worden gesproken wan rechterlijk activisme. 


\section{Hoofdstuk 4}

\section{Constitutionele interpretatie}

\section{Deel A \\ Rechtsvindingsmethoden bij de uitleg van grondwet en verdrag}

\subsection{Inleiding}

In dit onderzoek wordt jurisprudentie onderzocht op rechtsnormen die op het moment van positivering nog niet werden 'gekend', maar die rechtens bindend blijken en die inhoud geven aan bestaande rechtsnormen. In enkele uitspraken gaven deze normen betekenis aan ongeschreven rechtsnormen, dat wil zeggen rechtsnormen die tot op dat moment niet waren geëxpliciteerd in grondwet of verdrag, maar die volgens de rechter evenwell behoren tot het arsenaal van geldende rechtsnormen. Een voorbeeld ter zake schept helderheid; een fraaie uitspraak in dit verband is Valkenhorst, waarin de Hoge Raad het algemene persoonlijkheidsrecht positiveerde en een tot dan toe onbenoemd recht op kennis van de afstamming daaruit concretiseerde. "Het is echter expliciet uitgesproken in de wet, en heeft in deze bewoordingen destijds geen neerslag gekregen in de toelichtingen op de wet. De Hoge Raad hanteerde dit adagium in de zaak Valkenhorst. De rechter kon zich kennelijk niet rechtstreeks op een grondwetartikel baseren, maar achtte de aanspraak blijkbaar dermate 'gerechtvaardigd' en ook impliciet aanwezig, dat een grondrechtelijke norm voor deze aanspraak kon worden geconstrueerd.

Er rijst direct een aantal vragen. Het algemene persoonlijkheidsrecht is, zonder nadere specificatie van de inhoud, een onduidelijk adagium dat niet geschikt lijkt om houvast te bieden in concrete situaties. Het geeft een op 'het recht' betrekking hebbende norm weer, maar het ontbeert een structuur die directe toepasbaarheid impliceert. Kwestie is dan of in dit opzicht gesproken kan worden van een rechtsnorm, in de zin van een norm die deel uitmaakt van het positieve recht. Het zou een rechtsbeginsel kunnen zijn, maar daarvoor is het noodzakelijk om uit te werken, wat er onder een rechtsbeginsel wordt verstaan. Verduidelijkt zou moeten worden welke de positie is van rechtsbeginselen ten opzichte van andere rechtsnormen, en welke de houding van de rechter zou moeten zijn indien hij rechtsbeginselen hanteert bij het vervullen van zijn taak. Naast deze specifieke vragen moet ook worden uiteengezet, op welke manier rechtsbeginselen te herkennen zijn in de rechtspraak. Rechtsbeginselen zijn niet altijd expliciet in wettelijke bepalingen uitgedrukt; het algemene recht op persoonlijkheid is hier een duidelijk voorbeeld van. Indien deze normen niet in de wet zijn gepositiveerd, maar tegelijkertijd kennelijk in de rechtspraak kunnen fungeren als ratio voor extensieve interpretatie van wetsartikelen of zoals in Valkenhorst als grondslag voor ongeschreven rechten klemt

1 Valkenhorst, 15 april 1994, NJ 1994/608; zie ook in de inleiding en par. 92.6. Zoals voorheen gesteld, heeft dit verschijnsel zich eveneens voorgedaan in de andere rechisstelsels. Een analyse van alle afzonderlijke stelsels is te vinden in de Hoofdstukken 5 tot en met 9. 
eveneens de vraag, in welke mate de concretiseringen, zoals in Valkenhorst het recht kennis omtrent de afstamming te kunnen verkrijgen, uit het algemene persoonlijkheidsrecht zijn aan te merken als 'geldende rechtsnormen'.

Gesteld zou kunnen worden dat de concretiseringen uit het algemene persoonlijkheidsrecht kunnen worden getypeerd als resultaten van extensieve interpretatie of als ongeschreven rechten. In dit verband zouden de 'gevonden' of 'ontdekte' normen zich slechts onderscheiden van wettelijke voorschriften door de situatie dat de eerstgenoemde normen niet zijn opgeschreven en vastgesteld door een wetgever, maar door de rechter. Deze concretiseringen zouden dezelfde geldigheid kunnen bezitten als wettelijke voorschriften: de rechter verbindt rechtsgevolgen aan de concretisering in het voorliggende geschil. De rechter blijkt langs deze weg tot op zekere hoogte in staat rechtsregels te scheppen. Vraag is of dat behoort tot de taak die hem vanuit de constitutionele taakverdeling toekomt. In het vorige hoofdstuk is ingegaan op de rechtsmacht en de jurisdictie van de rechter, maar in geen van de stelsels kon worden geconstateerd dat het maken van regels formeel behoort tot de rechterlijke taak. Tegelijkertijd werden er in de rechtsstelsels wel tendensen zichtbaar in het debat, die aanduidden dat de rechter tot op zekere hoogte een rechtsvormende taak toekomt, maar onomstreden is die opvatting zeker niet. De discussie spitst zich in dit hoofdstuk met name toe op de vraag tot welke hoogte de rechter een rechtsvormende taak toekomt. Voor zover de rechtsvormende taak al rechtsschepping zou inhouden rijst de vraag waarop de rechter een bevoegdheid baseert om rechtsscheppend op te treden.

Op de hier opgeworpen vragen wordt niet een antwoord gezocht dat voorgoed een einde maakt aan de meer rechtstheoretisch georiënteerde discussies in de rechtsstelsels. Het standpunt bijvoorbeeld, dat naast rechtsregels abstractere normen bestaan die rechtsgeldigheid kunnen toekomen, wordt in alle rechtsstelsels - zij het uiteenlopend betwist. Rechterlijke rechtsvinding waarin abstracte normen zoals rechtsbeginselen de doorslaggevende grondslag vormen voor de legitimatie van ongeschreven rechten wordt dan problematisch: niet duidelijk is steeds, of de door de rechter opgebrachte normen behoren tot het geldend recht. Tegelijkertijd is deze gang van zaken in de rechtspraak niet ongewoon, en gesignaleerd in alle rechtsstelsels; in het ene wat vaker dan in het andere als het gaat om geschillen die op éen of andere manier te maken hebben met het recht op persoonlijkheid. Van belang voor het onderzoek is nu een positie te betrekken ter zake van de vraag hoe rechtsbeginselen gepositioneerd kunnen worden ten opzichte van het geldende recht en aan te geven welke het rechtskarakter is van de in de analogie betrokken normen. De rechterlijke motivering van de wijze van rechtsvinding verkrijgt in dit verband een centrale betekenis: het is de bron waaruit kennis kan worden vernomen ter zake van de gebezigde redenering. ${ }^{2}$

2 Er zal echter niet in het algemeen worden ingegaan op de motiveringsproblematiek. Dï onderwerp word: hoofdzakelijk belicht vanuit het perspectief van de analoge wijze van rechtsvinding. De motivering wordt gevonden in jurisprudentie waarin normen worden "ontdekt" door de rechter die kennelijk kunnen gelden als grondslag voor exttensieve interpretatie of als grondslag voor ongeschreven rechten. 
De analoge redeneerwijze biedt bruikbare handvatten voor de vaststelling van nieuwe reikwijdten van bestaande grondrechten of positivering van ongeschreven rechten. De wijze waarop de analoge redenering precies functioneert in de rechtsvinding zal hieronder worden uitgelegd. ${ }^{3}$ De analoge redenering blijkt bij uitstek de mogelijkheid te scheppen, abstracte normen een functie te laten vervullen in het vinden van een op het voorliggende geschil toegesneden oplossing. De analoge redenering houdt kortgezegd in dat de rechter aan de hand van door hem samengesteld vergelijkingsmateriaal de lezing van een door hem geconstrueerd recht legitimeert. Precedenten zijn in dit opzicht een belangwekkende bron van inspiratie voor dat vergelijkingsmateriaal, maar ook wettelijke normen of samenstellingen van wettelijke normen alsmede het bestaan van een consensus in de samenleving kunnen samen of afzonderlijk vergelijkingsmateriaal opleveren om het bestaan van normen als geldend recht te rechtvaardigen. In dit hoofdstuk wordt in het kader van de analoge redenering aldus ook ingegaan op de betekenis van dergelijke bronnen.

Naar aanleiding van gevonden resultaten zou men kunnen stellen, dat er een theorie moet kunnen worden opgesteld over hoe de rechter tot rechtsvinding zou moeten komen. Dat is echter niet de bedoeling van dit boek; vooropgesteld wordt hier te beschrijven wat er in de rechtsvindingsfase plaatsvindt aan de hand van de door de rechter gegeven motivering. In dat opzicht heeft dit onderzoek tot op zekere hoogte een descriptief karakter. De bedoeling is om de in de rechtspraak gevonden resultaten te beoordelen in het kader van de constitutionele verhouding tussen de rechter en de wetgever. In het kader van de constitutionele verhouding is in hoofdstuk 3 een aantal lijnen van de bevoegdheden van de rechter uiteengezet en is geschetst in welke mate er institutionele en interinstitutionele mechanismen bestaan, die de rechterlijke instantie "in its boundary' behouden. Daarnaast werden in hoofdstuk 3 door de rechter ontwikkelde ongeschreven regels gesignaleerd die tot doel hebben de constitutionele verhouding met de wetgever nader te structureren; in dit opzicht is de rechterlijke taakopvatting van belang gebleken. Problematisch met die taakopvatting bleek evenwel te zijn, dat zij niet altijd een "betrouwbare" matstaf oplevert voor de vaststelling van de rechterlijke taakopvatting. Een recliter die creatief met zijn rechtswindingsinstrumentarium ongat wordt in de regel aangemerkt als activistisch, terwijl een collega die "dicht bij de oorspronkelijke tekst' blijft eerder wordt gehonoreerd met het predikaat van rechterlijke terughoudendheid. Vraag is meer specifiek of er binnen de interpretatieregels materiele controlemechanismen bestaan, die een rechter normeren wanneer hij een analoge redenering hanteert - in het licht van de constitutionele betrekkingen tussen hem en de wetgever.

\subsection{Opzet}

Het A-deel van dit hoofdstuk behandelt de belangrijkste doctrines in de rechtsstelsels ter zake van methoden van rechtsvinding. In dit hoofdstuk wordt kort ingegaan op de technisch-juridische interpretatiemethoden, die de rechter hanteert voor de uitleg van 
grondrechten. Meer in het algemeen wordt ingegaan op de doctrines die in de stelsels bestaan op het terrein van de technisch-juridische interpretatiemethoden. In beginsel kennen alle rechtssystemen de volgende interpretatiemethoden: de grammaticale of tekstuele methode, de historische interpretatiemethode, de systematische methode en de teleologische methode. Tevens wordt het bestaan van een dynamisch-evolutieve interpretatiemethode in alle stelsels aangenomen, maar de legitimiteit ervan is niet onomstreden. Ten slotte kennen alle rechtsstelsels tot op zekere hoogte de rechtsverge lijkende interpretatie. Er bestaat geen eenstemmigheid over een hiërarchie van interpretatiemethoden, en evenmin een handleiding hoe wetten op de juiste wijze worden geinterpreteerd. De methoden zullen kort de revue passeren, waarbij ook wordt ingegaan op hun betekenis voor de uitleg van de grondwet of het verdrag in het algemeen. Daarnaast wordt in het A-deel ingegaan op de analoge redeneermethode, zoals díe hierna volgend in elk van de rechtsstelsels wordt geanalyseerd. In het B-deel worden de theoretische grondslagen van de rechtsnormen die in de analogie worden gebezigd vervolgens nader uitgediept. Hiervoor werd al de vraag opgeworpen, welke het rechtskarakter is van een norm als 'het algemene persoonlijkheidsrecht' zoals gepositiveerd door de Hoge Raad: is dat een rechtsbeginsel of een rechtsregel, en wat is de rechtskracht ervan? In dat verband zal kort worden ingegaan op de belangrijkste hedendaagse heersende benaderingen ter zake van het gezag van normen. Ten slotte wordt een positie betrokken ter zake van het gezag van rechtsbeginselen en rechtsregels in de rechtspraak. Daarnaast worden de hierboven al opgemerkte bronnen van de te onderzoeken normen onderzocht op juridische betekenis. Zowel het A- als het B-deel van dit hoofdstuk staan in direct verband met de constitutionele context waarin de rechter opereert.

\subsubsection{Rechtsvindingsfase, ontvankelijkheidsfase en toetsingsfase}

In het proces van rechterlijke besluitvorming zijn drie momenten te vinden, die tezamen leiden naar de uitkomst in een concrete casus. Zij zijn te onderscheiden, maar in de praktijk van de besluitvorming echter worden zij niet gescheiden van elkaar. ${ }^{4} \mathrm{De}$ rechtsvindingsfase staat in dit hoofdstuk centraal, en wordt gepresenteerd als een uitgangspunt. In de rechtsvindingsfase geeft de rechter een invulling aan drie premissen. Hiertoe behoort in de eerste plaats de vaststelling van de toepasselijke rechtsregel (q). In de tweede plaats bakent hij het juridische relevante feitencomplex en de individuele aanspraak af (p), en stelt ten derde de omtrekken van de toepasselijke rechtsregel vast tegen de achtergrond van dat feitencomplex en individuele aanspraak (r). Er kan in de rechtsvindingsfase nog een nadere afbakening worden aangebracht. In beginsel wordt

4 "Tussen de rechtsvindingsfase en de toetsingsfase is in de praktijk niet zo"n scherp onderscheid aan te brengen. Vaak gebeurt het, dat de rechter in de toetsingstase nog weer toekomt aan een vaststelling van de reikwijdte, die men eigenlijk in het interpretatiestadium zou verwachten. Dit doet zich bijvoorbeeld. voor in casus waarin tot een belangenafweging moet worden gekomen. Belangenafweging vindt plaats in de toetsingsfase; het kan zijn dat een nadere duiding wan het in het geding zijnde belang noopt tot bijvoorbeeld een madere vaststenling van de omtrekken van de rechusregel. Het onderscheid tussen interpretative of reclatsvinding enerzijds en toepassing van de rechtsnorm anderzijds wordt hier zinvol geacht, ondat de rechter in beginsel in de eerste fase de omtrekken van het grondrecht schetst. 
in dit onderzoek vooral gekeken naar de invulling van de toepasselijke rechtsregel zoals hierboven aangeduid met (q), de vraag naar de toepasselijke rechtsregel.

In de toetsingsfase, de fase waarin de rechtsnorm in concreto wordt toegepast op het feitencomplex of de individuele aanspraak, wordt - op basis van de invulling van de premissen in rechtsvindingsfase - een deductieve argumentatie opgebouwd die uiteindelijk moet leiden tot de oplossing van het geschil. Een uitstap naar de toetsingsfase lijkt is soms onvermijdelijk, omdat sommige rechters in de toetsingsfase komen tot een verfijnder vaststelling van de reikwijdte van het toepasselijke recht. In de toetsingsfase kunnen bijvoorbeeld correcties met het oog op de constitutionele verhouding worden toegepast, maar de toepasbare regel is dan al wel vastgesteld. ${ }^{5}$ De toetsingsfase is wel weer van groot belang in verband met de controlemechanismen op de rechtsvindingsactiviteit: in hoofdstuk 3 hebben we gezien dat in de toetsingsfase een aantal instrumenten besloten kan liggen, die de resultaten van een creatieve rechtsvinding relativeren. In hoofdstuk 2 is in dit verband al gesteld, welke de beperkingsmogelijkheden zijn op de rechten centrerend rond het recht op persoonlijkheid.

\subsection{De noodzaak van constitutionele rechtsvinding}

\subsection{1 'Constitutionele' rechtsvinding}

Het begrip "constitutionele interpretatie' verdient in dit verband nog bijzondere aandacht. In het Duitse en Amerikaanse rechtsstelsel is de term constitutionele interpretatie een veelvuldig gebezigd begrip, waarmee in het algemeen de rechtsvindingsactiviteiten van de interpreterende rechter worden aangeduid. ${ }^{6}$ In deze stelsels is dit begrip tot ontwikkeling gekomen omdat de rechtsvindingsactiviteiten ter zake van de uitleg van de constitutie zich in verschillende opzichten onderscheiden van de interpretatie van de overige wetten in het betreffende stelsel. Ook speelt de functie van de interpreterende rechter in de rechtsorde een belangrijke rol: het Duitse Federale Constitutionele Hof en het Amerikaanse Hooggerechtshof zijn beide als hoogste instantie uitgerust met de bijzondere bevoegdheid van rechterlijke toetsing van formele wetgeving. In de Nederlandse context heeft het begrip constitutionele interpretatie geen bijzondere plaats, omdat de Hoge Raad als hoogste Nederlandse instantie deze bevoegdheid ontbeert ten aanzien van formele wetgeving. ${ }^{7}$ De controverses die constitutionele interpretatie met zich meebrachten in de hoogste Duitse en Amerikaanse rechterlijke instanties hebben zich tot dusverre niet in vergelijkbare mate voorgedaan in het Nederlandse stelsel. In het Duitse en Amerikaanse stelsel ligt het eerder voor de hand, dat constitutionele rechtspraak een eigen terrein verworven heeft waarin het bestaan van bijzondere

$5 \quad$ Zie voorbeelden in hoofdstuk 3 bij de variaties in de dicta.

6 In de Amerikaanse literatuur wordt de term verwoord als "constitutional interpretation"; de Duitse wariant in de Duitse literatuur en rechtsprak is "Verfassungsinterpretation " of 'Verfassungs-antuslegung".

7 De Nederlandse recliter komt wel de bevoegdheid toe wetgeving vait lager rang ongrondwettig te vertarem. 
problemen als gevolg van interpretatie van de constitutie erkend is: ${ }^{8}$ In beide Europese constituties heeft het begrip constitutionele interpretatie evenmin een vaste plaats verworven.

\subsubsection{Leemte of open textuur van de normen gelieerd aan het recht op persoonlinkheid}

Interpretatie van constitutionele bepalingen is altijd noodzakelijk, ook waar de bepalingen het karakter lijken te hebben van concrete, voor eén opvatting vatbare voorschriften." De noodzaak van interpretatie is echter lang niet altijd zichtbaar in de rechterlijke uitspraak, omdat de rechter een 'Vorverständnis' heeft, een vooropgezette vooronderstelling van de betekenis van de norm. In het overgrote deel van de rechtspraak zijn rechtsnormen als het ware al geinterpreteerd en blijft de interpretatie als zichtbare fase in de rechterlijke besluitvorming achterwege, omdat de rechter er vanuit gaat, dat geen onenigheid bestaat over de betekenis van de rechtsnorm of over de toepasselijkheid op het feitencomplex. De overeenstemming hierover is het "Vorverständnis": de interpretatie behoeft in de fase van rechtsvinding in het besluitvormingsproces niet telkens herhaald te worden omdat de invulling van de betekenis van de toepasselijke rechtsregel op grond van bijvoorbeeld jurisprudentie vastgelegd is. ${ }^{10} \mathrm{Bij}$ de constitutionele interpretatie lijkt van een routineuze uitleg lets minder snel sprake te zijn, omdat de rechter vanwege een open textuur van de rechtsnormen eerder wordt gedwongen nader uit te leggen waarom de ingeroepen rechtsnorm van toepassing is op het voorliggende geschil. In alle stelsels is in beginsel in ruime mate rechtspraak ter zake van de vaststelling van de betekenis en reikwijdte van grondwettelijke bepalingen voorhanden. Er is een omvangrijke jurisprudentie, maar telkens blijken zich toch weer nieuwe feitencomplexen voor te doen die vragen om nadere verantwoording van de toepasbaarheid van de grondwetsbepaling in kwestie. Kenmerkend voor fundamentele rechten in de grondwet of in het verdrag is dat de meestal open geformuleerde norm onvoldoende toegesneden op het concrete geval."

Naast een open textuur kan ook een leemte aanleiding zijn voor het scheppen van ongeschreven recht. In de rechtsvindingsfase ter zake van grondrechten lijkt in beginsel echter niet zozeer sprake van een leemte: deze is in grondwetsinterpretatie een enigszins bizarre figuur, omdat aanvaarding van het bestaan van leemten uit gaat van een.

De opyatting wan constitutionele interpretatie in Nederland is aardig verwoord in de MvT bij het voorstel van overwegingswet inzake klassieke grondrechten: "De in de Grondwet geformuleerde grondrechten nemen in de bierarchie van rechtsregels in het rechtssysteem een hoge plaals in, doch zijn wat hum inhoud betreft, onderworpen aan het proces van interpretatie, rechtswinding en rechtsvorming dat voor alle geschreven regels geldt. [... J Elke beslissing komt tot stand binnen kader waarin factoren als tekst, wordingsgeschiedenis, rechtspraak, doctrine, rechtsovertuiging, matschappelijke en andere behoefte of functie van het grondrecht een rol spelen. Dit is in het algemeen het procédé van rechtsvinding en er is geen reden om aan te nemen dat dit bij de grondrechten anders zou liggen" (Kamerstukken II $1975-76,13872$ ar. 3 bla 21$)$

9 De Waard 1987 , p. 59 .

10 De Waard 1987, p. 61 .

11 Zie voor de formulering van het recht op persoonlijkheid hootidstuk 2. 
gesloten systeem van de grondwet of het verdrag. De wetgever heeft in die optiek met zijn ruime formuleringen zoveel als mogelijk 'overal aan gedacht'; zo is de vooronderstelling. ${ }^{12}$ Ontbrekende rechtsregels in de constitutie zijn in constitutionele rechtsvinding vanwege de open textuur van de normen lastig als leemten te kwalificeren. Indien de rechter dan overgaat tot extensieve interpretatie of tot schepping van nieuwe rechtsnormen kan de vraag worden opgeworpen, in hoeverre de rechter zich zelfstandig een interpretatieruimte toemeet. ${ }^{13}$

Sommige constituties voorzien in een wijze waarin leemten kunnen worden opgevuld. ${ }^{14}$ Vraag is in dat verband, wanneer sprake is van een leemte. In meest eenvoudige zin is daarvan sprake indien de wet zwijgt ter zake van de toepasselijke rechtsregel voor een specifieke groep van juridische conflicten. ${ }^{15}$ In beginsel is de vraag naar leemten van groot belang, omdat de wijze waarop een leemte is ontstaan bepaalt in welke mate de rechter bereid zal zijn, aan een geclaimd recht tegemoet te komen. Daar waar de wetgever expliciet heeft gekozen voor het niet erkennen van een recht, zal de rechter zich in zijn besluitvorming terughoudend opstellen. ${ }^{16}$ Gesignaleerd is dat de formuleringen van de rechten gelieerd aan het recht op persoonlijkheid in de rechtsstelsels een zeer open karakter hebben. ${ }^{17}$ Deze vaststelling van de open textuur zegt op zichzelf nog niets over de wijze waarop de rechter uitleg dient te geven aan het ingeroepen grondrecht. Vanwege de open textuur is het bestaan van een leemte in de grondwet niet evident. Daarnaast kan moeilijk bestreden worden, dat het bestaan van een leemte of open textuur eveneens te maken heeft met de perceptie van de interpreet. Een meer positivistisch ingesteld uitlegger zal bijwoorbeeld niet snel aannemen dat de wet leemten vertoont, of dat de textuur dermate open is dat een ongeschreven recht kan worden ontwaard uit de structuur van de wettekst. Hij percipieert de wet als een gesloten systeem, en zal zich in beginsel eerder aansluiten bij een tekstuele benadering van een bepaling:

"[The] llaw is every bit as offënsive to me as it is to my Brethren [who], reciting reasons why it is offensive to them, hold it unconstitutional. I cannot [join] their conclusion. [The] Court talks about a constitutional ["right of privacy"]. [...] [I] get nowhere in this case by talk about a constitutional "right of privacy" as an emanation from one or more constitutional provisions. ${ }^{.18}$

12 Scholten 1974, p. 75.

13 Zie woor uitgebreide discussie hierover Barak 1989, met name hoofdstuk 2, p. 78-83.

14 Het $Z$ witserse Burgerlijk wetboek voorziet in een regel, die stipuleert dat de rechter aan moet vullen wat ontbreekt als ware hij de wetgever ("A défaut d'une disposition légale applicable, le juge prononce selon le droit couturnier el, à défaut d'une coutume, selon les règles qu'il établirait s'il avait à faire acte de Iégislateur', zie Art. 1 lid 2 van het Zwitsers Brugerlijk Wetboek). Het Oostenrijkse Burgerlijk wetboek stelt dat wanneer zich in bij de beoordeling van geschil een leemte voordoet en interpretatie of analogie de rechter niet kunnen helpen, de rechter het probleem dient op te lossen naar maatstaven van beginselen van natuurrecht (Art. 7 van het Oostenrijkse Burgerlijk Wetboek van 18\|1).

15 Larenz 1991 , p. 370 e.v.

16 Zie bijwoorbeeld het Harmonisatiwetarrest, HR 14 april 1989, NJ 1989/469, waarin de Hoge Raad zich de formele wet niet wenste te toetsen aan het beginsel vam rechtszekerheid, ondat de wetgever de verwachtingen wan de klagers welbewust in zijn wetgewing had meegewogen - en niet had gehonoreerd.

17 Zie hoofdstuk 2.

18 Rechter Black in zijn dissenting bij Griswold t. Connecticut, 381 U.S. 479 (1965), de zaak waarin het 
Daartegenover bestaat de benadering, dat de wet juist geen gesloten systeem vormt, maar dat latere invoeging van nieuwe normen in beginsel mogelijk blijft. In die optiek bestaat de mogelijkheid in het rechtsvindingsproces ongeschreven rechten te erkennen in grondwettelijke context. In de Amerikaanse literatuur wordt deze wijze van rechtsvinding waarbij ongeschreven recht door de rechter wordt erkend ook wel 'reasaning by interpolation' genoemd. ${ }^{19}$ Via een analoge redeneringen wordt een ongeschreven recht tussen de gepositiveerde rechten gevoegd. In de vroege Amerikaanse rechtspraak zijn hiervan fraaie voorbeelden te vinden. In McCulloch t. Maryland (1819) diende de vraag te worden beantwoord, of de Federatie of de staat Maryland het laatste woord diende te hebben over het oprichten van een publiekrechtelijke financiële instelling. ${ }^{20}$ De Amerikaanse grondwet zweeg ter zake van de precieze beantwoording van deze vraag. Het Amerikaanse Hooggerechtshof ging uit van een open grondwettelijk systeem bij de oplossing van dit geschil op het terrein van de horizontale machtenscheiding:

'A constitution, to contain an accurate detail of all the subdivisions of which its great powers will admit [...], would partake of the prolixity of a legal code, and could scarcely be embraced by the human mind. [...] Its nature, therefore, requires, that only its great outlines should be marked, its important objects be designated, and the minor ingredients which compose those objects be deduced from the nature of the objects themselves. [.] we must never forget, that it is a constitution we are expounding'. ${ }^{21}$

Vanuit deze gezichtshoek bestaat aldus wel ruimte voor het aannemen van het bestaan van open normen. Er wordt in de Verenigde Staten echter fel gedebatteerd over de vraag in welke mate de grondwet leemten kan bevatten, of de textuur invulling toelaat en of er kan worden gesproken over een flexibel of rigide grondrechtssysteem. Rigiditeit en flexibiliteit worden op formele en materiële wijze gedefinieerd. In formele zin wordt van een rigide grondrechtssysteem gesproken indien in de grondwet een zware herzieningsprocedure is vastgelegd en van een flexibele grondwet indien deze herzieningsprocedure relatief eenwoudig is. In materieel opzicht vormen flexibiliteit en rigiditeit eveneens elkars tegenpolen. Indien zonder formele herziening van het constitutionele recht belangrijke wijzigingen in het grondrechtssysteem mogelijk zijn wordt van een flexibel grondrechtssysteem gesproken. In een dergelijk systeem is ruimte voor aanpassing aan zich wijzigende politieke en maatschappelijke omstandigheden door regering, parlement en rechter, zonder dat de geschreven normen in de grondwet zelf ter discussie staan of tekstueel gewijzigd dienen te worden. ${ }^{22}$ Indien de grondwet daarentegen steeds aanpassing behoeft, om de zich wijzigende omstandigheden te kunnen

verbod op het gebruik van voorbehoedmuddelen ongnondwettig werd verklaard vanwege het grondwettelijk recht op 'privacy'. 'Privacy' is een ongeschreven recht, dat vila een analoge redenering in de

19 Denning en Reynolds 1997, p. 1092.

20 McCulloch t. Maryland, 17 U.S (4 Wheat.) 316 (1819).

21 McCulloch $t$. Maryland, 17 U.S. (4 Wheat.) 316 (1819); het cursief was reeds vermeld in de uitspraak. Rechter Marshall, die de opinie voor de meerderheid: schreef, benaderde de grondwet als een open systeem van rechtsnormen, waarbinnen ruimte bestaat voor het inlezen van ongeschrewen rechtsnormen.

22 Kortmann 1997, p. 83. 
meenemen, wordt van materiële rigiditeit gesproken. Een scherpe typering van flexibilliteit of rigiditeit van "de" grondwetten is niet te geven. Dergelijke typeringen hangen nauw samen met het onderwerp dat aan de orde is en de formulering erwan in de grondwettelijke bepaling. Een objectieve maatstaf ter bepaling van de mate van fiexibiliteit is in dit verband niet voorhanden. ${ }^{23}$ Materiële flexibiliteit van het grondrechtssysteem impliceert een bereidheid, te accepteren dat het systeem niet noodzakelijk een sluitend deductief systeem van positiefrechtelijke grondrechtsnormen is, maar dat andersoortige normen dan gepositiveerde grondrechtsnormen eveneens een richtinggevende functie in dat systeem kunnen vervullen. Indien enkell positiefrechtelijke normen een functie vervullen in de systeemopbouw van de grondwet, wordt daarentegen eerder van een rigide systeem gesproken. Voor wat betreft materiële flexibiliteit behoeft dat systeen niet enkel te zijn opgebouwd naar een deductief schema, volgens hetgeen grondrechten enkel nadere specificaties vormen van geschreven grondrechtsbepalingen. Systeemopbouw kan in een flexibel grondrechtssysteem eveneens langs andere wegen gedijen. Indien naast gepositiveerde normen ook ongeschreven grondrechtsnormen en beginselen worden betrokken in de rechtsvinding, en naast deductieve ook andere systeemopbouw wordt aanvaard, ontstaan ruimere mogelijkheden voor interpretatie van grondrechtsnormen. Herformulering van de geschreven norm door de grondwets- of verdragswetgever is dan lang niet altijd noodzakelijk. In de rechtspraak werd de inductieve wijze van systeemopbouw van het grondwettelijke systeem verschillende keren gesignaleerd:

Een inductieve redenering in het Amerikaanse rechtssysteem werd gevolgd ter zake van de mogelijkheid tot rechterlijke toetsing van wetgeving die in Marbury t. Madison werd geïntroduceerd. ${ }^{24}$ In de Amerikaanse grondwet is geen expliciete bevoegdheid voor het Hof tot rechterlijke toetsing te vinden. Uit het systeem van de grondwet werd deze bevoegdheid afgeleid. ${ }^{25}$ Een ander voorbeeld van een niet-deductieve systeemopbouw is te vinden in de rechtspraak van het Hof van Justitie van de EG. Art $10 \mathrm{EG}$ Verdrag. Het zogenoemde loyaliteitsartikel stipuleert dat de Lid-Staten maatregelen treffen om nakoming van gemeenschapsverplichtingen te verzekeren. ${ }^{26}$ Het Hof van Justitie lleidde in $Z$ wartveld uit de formulering het beginsel af van een verplichting tot wederzijdse samenwerking, terwijl het verdragsartikel enkel expliciet refereert aan een dergelijke plicht van de Lid-Staten naar de Gemeenschapsinstellingen. ${ }^{27}$ De wederzijdse verplichting is met andere woorden niet een logisch-noodzakelijke consequentie van de formulering van Art. $10 \mathrm{EG-Verdrag,} \mathrm{maarr} \mathrm{werd} \mathrm{door} \mathrm{het} \mathrm{Hof} \mathrm{van} \mathrm{Justitie} \mathrm{wel} \mathrm{op}$

23 Hieronder wordt ingegaan op materiete flexibiliteit van de grondwet; de formele flexibiliteit is atwn de orde geweest in hoofdstuk 2 warin de constitutionele amenderingsprocedures werden besproken.

24 Marbury t. Madison, 5 U.S. (1 Cranch) 137 (1803).

25 Zie par. 3.2.1

26 Art. $10 \mathrm{EG}$-Verdrag luidt: "De lidstaten treffen alle algemene of bijzondere maatregellen welke geschikt zijn on de nakoming wan de uit dit verdrag of uit handelingen van de Instellingen der Gemeenschap voortwlloeiende verplichtingen te verzekeren. $\mathrm{Zij}$ vergemakkelijken de vervulling van har takk. $Z \mathrm{Zij}$ onthouden zich van alle maatregelen welke de werwezenlijking van de doelstellingen van dit verdrag in gevaar kunnen brengen*.

27 Zwartweld e.a. t. Europese Commissie, zaak C-2/88 (1990), Jur. p. I-3365 (1990), par. 17. 
deze niet daarvoor geschreven basis geaccepteerd als bron voor vorming van nieuw recht. $^{28}$

In alle stelsels zijn in de rechtspraak en literatuur de open en gesloten typeringen van de grondwet of het verdrag gesignaleerd. Ten aanzien van sommige onderwerpen in de Duitse grondwet wordt een expliciet gesloten systeem aanvaard, waarbuiten vorming van nieuw recht tot duswerre niet heeft plaatsgevonden. Art. 79 lid $3 \mathrm{GG}$ is hiervan een witing: aan de federale staatsopbouw en het recht op menselijke waardigheid mag niet worden getornd. ${ }^{29}$ Over de betekenis van het Negende Amendement uit de Amerikaanse grondwet bestaat in dit verband veel discussie: laat dat Amendement nu een flexibele benadering van de grondwet toe, of juist niet? $?^{30}$ Aanvaarding van flexibiliteit is een heikel punt, ondat het van belang is voor de ruimte die wordt gegeven aan de uitlegger van de grondwet of het verdrag: met name materiële flexibiliteit veronderstelt nuimte voor de interpreet.

De Duitse auteur Durig aanvaardt bijvoorbeeld niet dat het Duitse Grundgesetz een flexibel grondwetssysteem kent. Dürig stelt dat via het algemene vrijheidsrecht ex Art. 2 lid $1 \mathrm{GG}$ een aanvulling plaatswindt met grondrechten die in de Artt. 3-19 GG niet geexpliciteerd zijn. ${ }^{31}$ De speciale vrijheidsrechten ex Art. 3-19 GG zijn in Dürigs optiek enkel preciezere aanduidingen van het algemene vrijheidsrecht ex Art. 2 lid 1 GG. Zij mogen niet als concretiseringen van een beginsel worden opgevat. Dat zou indruisen tegen het deductieve systeem, volgens hetgeen het Grundgesetz is opgebouwd, aldus Dürig. ${ }^{32}$ Alexy, een andere gezaghebbende Duitse commentator, stelt daarentegen dat zich binnen het grondwetssysteem echter ook grondrechten bevinden, die niet als precisering van Art. 1 of 2 GG kunnen worden aangemerkt. ${ }^{33}$ Teneinde te kunnen komen tot de vaststelling van bijwoorbeeld het recht op een bestaansminimum, of het recht op zelfbeschikking kon het Hof volgens Alexy met argumentatie enkel op basis van enkel Art. 1 of Art. 2 GG niet volstaan. ${ }^{34}$ Daartoe was betrekking van niet in de grondwet gepositiveerde rechtsbeginselen in de interpretatie noodzakelijk, voordat de aanspraak

28 De wederzijds verplichting tot samenwerking werd door het Hof in een obiter al opgemerkt in Luxemburg t. Parlement, zagk 230/81 (1983), Jur. p. 255 (1983), par. 37. Door de Luxemburgse regering werd bij het Hof gehlagigd over een Resolutie van het Europese Parlement, waarin het had besloten de zetel voor de vergaderingen te verplaatsen van Luxenburg natar Straatsburg. De Lid-Staten hebben de bevoegdheid de zetel van het Parlement te bepalen, maar het Parlement is bevoegd geschikte maatregelen te treffen teneinde behoorlijk functioneren van het crgaan te verzekeren. Hier kon aldus een patstelling ontstaan tussen de bevoegdheden; het Hof stelde in cen obiter: 'Furthermore, the Parliament is authorized, $[\ldots]$ to adopt appropriate measures to ensure the due functioning and conduct of its proceedings. However, in accondance with the above-mentioned mutual duties of sincere cooperation, the decisions of the Parliament in turn must have regard to the power of the governments of the Member States [...].

29 Zie par. 2.4.1.

30 Zie par. 2.3.2.

31 Dürig in: MaunzDürig, $\mathrm{GG}$, Art. 3, par. 254.

32 Hier wordt aangenomen dat vaststelling van een afgeleide uit een beginsel een keuzevrijheid impliceert. Juist deze keuzevrijheid druist in tegen de opvatting dat een deductie slechts ến logisch-noodzakelijke consequentie heef

33 Alexy 1996 , p. 339.

34 Alexy 1996, p. 339. 
kon worden erkend. Deze benadering van het Duitse Hof pleit eerder voor de liypothese van een niet-gesloten systeem van de grondwet, alsmede voor de opvatting, dat systeemopbouw van het Grundgesetz niet enkel wia deductieve, maar ook langs inductieve weg kan gedijen. ${ }^{35}$ Het grondwettelijke systeem is gesloten, voor zover het algemene vrijheidsrecht Art. 2 lid 1 GG de negatieve vrijheid volledig beschermt, maar het systeem is open voor zover het bestaan van het vrijheidsrecht ex Art. 2 lid I aan de mogelijkheid van definitie van nieuwe rechten niet in de weg staat.

In de Amerikaanse grondwet doet zich een soortgelijke situatie voor ter zake van het Veertiende Amendement. Deze vaststelling kan pleiten voor hypothese van een gesloten stelsel. Echter, het feit dat in de Amerikaanse constitutionele rechtspraak het recht op bijwoorbeeld zwangerschapsafbreking tot ontwikkeling is gekomen onder het Veertiende Amendement, mag, evenals in de Duitse constitutionele rechtspraktijk, leiden tot de voorlopige conclusie dat de Amerikaanse grondwet eveneens een open karakter heeft. ${ }^{36}$ Dit recht op abortus is, evenals het recht op bijwoorbeeld "informationele zelfbeschikking' in het Duitse systeem, niet een nadere specificering van het recht op 'liberty', omdat andersoortige normen naast "liberty" noodzakelijk waren om dat recht te vestigen onder het beschermingsregime van de grondwet. ${ }^{37}$ De Nederlandse rechtspraktijk wijst, afgaande op de rechtspraak van de Hoge Raad, de pretentie dat een gesloten grondwetssysteem wordt gehanteerd in beginsel af. ${ }^{38}$ De aanvaarding door de Hoge Raad van het recht van het kind, de kennis van zijn afstamming te kunnen vernemen, is geen nadere specificering van een reeds gepositiveerd grondrecht. ${ }^{30}$ De vaststelling, dat in alle stelsels grondrechten, zoals bijvoorbeeld het recht op informationele zelfbeschikking, het recht de afstamming te kennen of het recht op een existentieel bestaansminimum - aanwezig zijn, die niet kunnen worden aangemerkt als een nadere precisering van gepositiveerde grondrechten, sterkt het vermoeden dat in alle stelsels wordt aanvaard - echter niet onbetwist - dat sprake is van open grondrechtssystemen. ${ }^{40}$

\subsection{3 "Moeilijke gevallen'"1}

De rechter die een geschill moet beslechten zal zich moeten orienteren aan de grenzen van de grondwet en rechtspreken volgens de normen die behoren tot "het recht". Voor sommige geschillen lijkt een toepasselijke norm echter niet in het positieve recht te zijn

36 Aangenomen wordt, dat het recht op abortus in de Verenigde Staten behoort tot de geldende reclitsnormen (Planned Parenthood t. Casey, 505 U.S. 833 (1992) en Stenberg t. Carhart, 28 juni 2000, no. 99-830). Het lijkt er in de rechtspraak op dat het recht iedere keer weer dient te worden herbevestigd in zijn bestaan. Zie ook par. 5.3.3.

37 Roe t. Wade, 410 U.S. 113 (1973).

38 Kortmann 1997 , p. 31 .

39 Valkenhorst, HR 15 aprill 1994, NJ 1994/608.

40 Hesse betoogt dar het Hof zich in navolging van de in Duitse statatsrechtkringen zeer gezaghebbende Dürig heeft bekend tot een gesloten grondrechtssysteem. In hoeverre deze stelling juist is wordt hier niet nader uitgewerkt; de geanalyseerde rechtspraak geef in hoofdstuk 5 een ander beeld te zien (Hesse 1991 , p. 128-9).

41 De typering wordt ontleend aan Dworkin 1977, hoofdstuk 5. 
opgenomen: er kan sprake zijn van een nog niet voorziene maatschappelijke of technologische ontwikkeling - althans een waarop de wetgever nog geen antwoord heeft geformuleerd. Het kan zijn dat de ontwikkelling niet voorzien is, maar even goed doet. zich de situatie voor dat de wetgever niet in stat is gebleken een adequate regeling te formuleren. In Valkenhorst wenste een kind eerst van de moeder en later van de instelling waar het ter wereld was gekomen te vernemen wie de verwekker was. De Nederlandse wet kent niet een recht om de afstamming te kennen, maar de rechter construeerde aan de hand van gepositiveerde rechtsnormen een algemene regel waaruit het een recht orm de afstamming te kennen afleidde. Op de redeneerwijze wordt verderop ingegaan; hier is het aangewezen om stil te staan bij het type geschillen waarvoor geen positiefrechtelijke regel is geformuleerd, maar ter zake waarvan wel een oplossing noodzakelijk wordt geacht. Het gaat in dit verband om een onderscheid tussen 'eenvoudige' en moeilijke' gevallen. ${ }^{42}$

Wanneer de feiten duidelijk zijn, het juridisch kader relatief gemakkelijk is af te bakenen en de toepasselijke rechtsnormen voorhanden zijn levert een concrete zaak in beginsel geen rechtsvindingsproblemen op: dat is een typering van een "eenvoudige" zaak. Wanneer de toepassing van de rechtsnorm echter niet soepel verloopt, hetgeen bijvoorbeeld het geval kan zijn bij een wage norm, is het lastiger om vast te stellen wat de precieze rechtsgevolgen moeten zijn. Indien in de rechtsvindingsfase vragen rijzen met betrekking tot de toepasselijkheid van de norm wordt gesproken van 'moeilijke gevallen. In Jane Smith t. Verenigd Koninkrijk achtte het EHRM het recht op privéleven ex Art. 8 van toepassing: het Hof was van mening dat het nomadisch bestaan een aspect vormt van de culturele identiteit van zigeuners en mitsdien een bestanddeel is van het privé-leven. ${ }^{43}$ In dit geval was een norm gegeven, maar niet zonder meer toepasbaar op de omstandigheden in het voorliggende geval: het EHRM diende te rechtvaardigen, waarom het nomadisch bestaan deel uitmaakt van het privé-leven onder Art. 8. Van een tweede categorie van moeilijke gevallen is sprake wanneer als gevolg van veranderde of nog in beweging zijnde opvattingen de gangbare interpretatie van de toe: passelijke norm als achterhaald wordt beschouwd. ${ }^{44}$ Dat leidt niet altijd tot bijstelling van de norm door de rechter, maar in sommige gevallen bestaat ruimte om de norm via een extensieve interpretatie aan te passen." Ten slotte is er een groep van gevallen aan te wijzen, watrin niet duidelijk is of de ingeroepen norm wel behoort tot het geldend recht. De atanspraak op kennis van de afstamming in de Nederlandse situatie was hier een voorbeeld van, evenals het recht op abortus in de Amerikaanse rechtspraak. ${ }^{46}$ Een toepasselijke norm lijkt in dergelijke gevallen te ontbreken.

42 Vranken hanteert het onderscheid eveneens met een antal kenmerken; diens lijn word hier grotendeels gevolgd (Asser-Wranken 1995, p. 57-70).

43 Jane Swith t. Kerenigd Koninkriw, EHRM 18 januari 2001 , EHRC 2001/19.

44 Zie bijvoorbedd de erkenning van het EHRM van een recht op geslachtelijke identiteilt fGoodwin 4 Verenigd Koninkwijk, EHRM 11 jull 2002, EHRC 2002/74).

45 De ruimte bestond bijwoorbeeld niet in verband met aanspraken op een homohuwelijk in Nederlsand (HR 19 oktober 1990, NJ 1992/129) of en consensuele homoseksuele relatie in de Verenigde Staten (Bowers $t$. Hardwick, 478 U.S. 186 (1986).

46 Zic achtereenwolgens Valkenhors, HR 15 april 1994, NJ 1994/608 en de uitwerking ervan in par. 9.2 .6 
Wanneer de rechter een moeilijk geval ter beoordeling krijgt zal hij in de rechtsvindingsfase aan moeten geven, welke norm van toepassing is op het voorliggende geschil en waarom. In dit onderzoek staat steeds de onduidelijkheid met betrekking tot de toe te passen rechtsnorm centraal. De hierna te bespreken rechtspraak is dan ook met name onderzocht op uitspraken waarin de rechtsvindingsactiviteit werd gehinderd door vragen die betrekking hadden op de reikwijdte van de toe te passen norm of op de rechtsgeldigheid van de toe te passen norm. Van belang is dat de moeilijke gevallen eerder uitzondering zijn dan regel. Dat wil niet zeggen dat de betekenis van de uitspraken over moeilijke gevallen daarmee afneemt. Ter zake van de moeilijke gevallen komt het vooral aan op de vraag of de rechter bereid is de kwestie te beoordelen, of dat hij wacht totdat de wetgever met een regeling komt. In dit verband is belichting van de vraag hoe de rechter omgaat met moeilijke gevallen zeer interessant vanwege de constitutionele verhouding tussen rechter en wetgever. Vraag in verband met de interpretatie van aanspraken op het terrein van het recht op persoonlijkheid is, welke koers de rechter heeft gekozen in moeilijke gevallen, en hoe de keuze werd ingekleed in het licht van de constitutionele verhouding. Een hieruit voortvloeiende kwestie is of er enige voorspelbaarheid mogelijk is ter zake van de bereidheid tot extensieve of wellicht creatieve rechtswinding over te gaan. Getracht wordt deze vragen voor de afzonderlijke stelsels te beantwoorden in de hoofdstukken 5 tot en met 9 . Hieraan voorafgaand wordt ingegaan op de vraag, wie de rechter met zijn uitspraak wil overtuigen, en op de interpretatiemaximes die de rechter tot zijn beschikking heeft bij het vaststellen van de reikwijdte van rechten.

\subsubsection{Het forum: wie moet worden overtuigd van de rechtsvinding?}

In hoofdstuk 3 werd besproken, welke institutionele en interinstitutionele factoren een begrenzing vormen van de rechterlijke besluitvorming. De besproken factoren hebben betrekking op de constitutionele verhouding tussen de rechter en de wetgever. De wetgever is in de staatsrechtelijke arena een belangrijke factor met wie de rechter, als het aankomt op een verdeling van taken en verantwoordelijkheden, rekening zal moeten houden in zijn besluitvorming. Dat houdt geenszins in, dat er verder geen actoren of partijen meer te bedenken zijn, die met grote belangstelling de verrichtingen van de rechter volgen. Die zijn er wel, al volgen zij die verrichtingen vanuit een ander perspectief: deze actoren hebben niet zozeer direct te maken met de verdeling van de taken en verantwoordelijkheden van de rechter, maar kunnen wel anderszins worden geconfronteerd met de consequenties van de uitspraak en kunnen veelal indirect of achteraf hun mening over de door de rechter gehanteerde werkwijze laten gelden. Met de aanvaarding door hen houdt de rechter in zijn besluitvorming tot op zekere hoogte rekening. ${ }^{47}$ Tot het forum behoren in ieder geval de partijen in het geding en meer in het algemeen de publieke opinie. Daarnaast kan er een juridisch forum worden ontwaard, waarvan andere rechtstoepassers dan de hier besproken rechters, wetenschappers en

en Roe t. Wade, 410 U.S. 113 en de witwerking ervan in par. 5.3.3 
bijvoorbeeld advocaten deel uitmaken. ${ }^{48}$ De rechter is niet alleen gebaat bij aanvaarding van zijn besluitvorming in een concrete casus door de wetgever, maar ook bij acceptatie ervan in bredere kring: het komt de legitimiteit en aanvaardbaarheid van zijn uitspraken ten goede. Het Amerikaanse Hooggerechtshof formuleerde het belang van de aanvaarding van de rechterlijke uitspraken bij een zo groot mogelijk forum als volgt:

\begin{abstract}
'As Americans of each succeeding generation are rightly told, the Court cannot buy support for its decisions by spending more money and, except to a minor degree, it cannot independently coerce obedience to its decrees. The Court's power lies, rather, in its legitimacy, a product of substance and perception that shows itself in the people"s acceptance of the Judiciary as fit to determine what the Nation's law means and to declare what it demands. ${ }^{49}$
\end{abstract}

Deze rechter is zich bewust van het beperkte instrumentarium dat hem ter beschikking staat om zijn uitspraken werkelijk zo breed mogelijk aanvaard te zien. Indien er beslist moet worden over kwesties waarover in de samenleving geen consensus maar juist een scherpe verdeeldheid bestaat, wordt het moeilijker om een ruimer draagvlak voor de rechterlijke beslissing te vinden. Het Hooggerechtshof zag dat in Casey als volgt:

\footnotetext{
"Because not every conscientious claim of principled justification will be accepted as such, the justification claimed must be beyond dispute. The Court must take care to speak and act in ways that allow people to accept its decisions on the terms the Court claims for them, as grounded in truly principle, not as compromises with social and political pressures having, as such, no bearing on the principled choices that the Court is obliged to make. Thus, the Court's legitimacy depends on making legally principled decisions under circumstances in which their principled character is sufficiently plausible to be accepted by the Nation'.50
}

In dit verband worden alle partijen die bij de rechterlijke uitspraak op de een of andere manier een belang hebben, aangemerkt als 'forum'. In beginsel hebben niet alle partijen in het forum gelijkmatige belangstelling voor alle stadia in de rechteriijke besluitvorming. ${ }^{51}$

Er kan een forum worden geschetst dat zover mogelijk overeenkomt met de werkelijkheid. Dat forum bestaat uit verschillende belangstellenden: de rechtsgemeenschap, waar binnen zich bijvoorbeeld andere rechters wetenschappers en andere rechtsbeoefenaren bevinden; de uitvoerende macht, de wetgever en de publieke opinie. Deze groepen binnen het forum hebben uiteenlopende verwachtingen, die elkaar ook deels overlappen. De publieke opinie zal zich in eerste instantie richten op het resultaat van de rechterlijke besluitvorming, dat zich in de regel manifesteert na de toetsing. Dat hangt voor een deel samen met de afwezigheid van specialistische kennis die het lezen van een rechterlijke uitspraak inzichtelijk maakt. Dergelijke kennis draagt bij aan het plaatsen van de uitsprak in een groter geheel, in de context van bestaande jurisprudentie bijvoorbeeld, of bestaande rechtsnormen. In de publieke opinie - en deels ook in de gelederen van de uitvoerende en wetgevende macht - is die specialistische kennis

51 Ponthorea 1993, p. 170 e.v. 
afwezig. In beginsel zal vooral de rechtsgemeenschap zich op meer richten dan alleen lhet resultaat van de toetsing. Deze groep heeft in vergelijking met de publieke opinie meer inzicht in de toepasselijke rechtsnormen en rechtspraak. Mitsdien kunnen zij beoordelen, in welke mate het besluit - in al zijn onderdelen - cohereert met of juist interfereert in het bestaande normensysteem. De andere rechters die het recht dienen toe te passen en de rechtswetenschap zijn in dat aspect geïnteresseerd: zij beoordelen, in welke mate de rechterlijke besluitworming in alle onderdelen bijdraagt aan opheldering en verbetering van het rechtssysteem.

De rechter overtuigt in het beste geval alle leden van het forum, zowel degenen die het gehele besluitvormingsproces volgen, ais de partijen bij het geschil die belang hebben bij een voor hen rechtvaardige uitkomst. Vanuit dit standpunt lijkt het toegenomen belang van jurisprudentie als zelfstandige bron van recht tot op zekere hoogte te verklaren. $^{52}$ De constitutionele rechter dient zich in elk geval te richten op de bij het geschil betrokken partijen, en hun vragen en middelen voldoende gemotiveerd te behandelen. Een daaraan gekoppelde kwestie is dan, of hij gehouden is om meer algemene, boven het concrete geschil uitstijgende uitspraken te doen, met bijvoorbeeld de intentie om de publieke opinie of het juridisch forum te overtuigen van het gevonden resultaat. Er kleven echter problemen aan het uitspreken van een voorkeur voor een bepaald deel van het forum. De belangen van de verschillende groeperingen die deel uitmaken van het forum kunmen tegengesteld zijn. De belangrijkste taak van de rechter is om in een concreet geschil tegengestelde normen en waarden met elkaar in overeenstemming te brengen. Indien hij zich in zijn motivering toespitst op het forum dat enkel belang heeft bij de uitkomst, kan dat in sommige gevallen ten koste van de kwaliteit van zijn argumentatie gaan. Het kan bijwoorbeeld voorkomen, dat de rechter wel tot een door de publieke opinie gewenst resultaat komt, maar dat de daartoe gevolgde redenering niet deugt. Ook kan de rechter zich richten op een wolgens hem door de wetgever gewenst resultaat, hoewel dat resultaat niet wordt aanvaard bij de opvattingen in grote delen van de samenleving of bij die van het juridisch forum. Het resultaat mag dan met instemming door de wetgever worden begroet, maar het kan zijn dat de aandacht in de motivering voor consistentie en coherentie van het rechtsnormensysteem verslapt en dat de gevolgde redenering niet op alle aspecten hout snijdt. Hij richt zich dan met zijn drang tot overtuiging van een bepaald forum op enkele aspecten in zijn besluitvorming, en dat kan ten koste gaan van de innerlijke consistentile en coherentie van het systeem van rechtsnormen.

Over dit aspect, kwaliteit van de argumentatie, wordt in verschillende argumentatietheorieen uitgebreid gedebatteerd. ${ }^{53}$ Het is zinvol om te bezien in welk daglicht het forum moet worden bezien in relatie tot de argumentatie die de rechter zal kiezen om dat forum te overtuigen. In de argumentatietheor"e is het forum steeds een sleutelbegrip om te komen tot een vaststelling van een "ideale" argumentatiemethode. De rechtvaardiging voor de ene of de andere methode is gekoppeld aan een werkelijk bestaand

52 Par. 4.6 en 4.7 .4

53 Perelman 1983, p. 40 e.v; Aarnio 1987, p. 221 e.v; Alexy 1991, p. 197 e.v. 
forum, of aan een ideaaltypisch forum. Het hiervoor geschetste forum is een werkelijk bestaand forum. Een ideaaltypisch forum is daarentegen gespitst op deugdelijkheid van alle facetten van de rechterlijke besluitvorming. Het ideaaltypische forum staat in de optiek van Perelman meer borg voor een rationele en objectieve argumentatie in vergelijking met een forum dat belang heeft bij een bepaald aspect van de rechterlijke uitspraak. Rationaliteit en objectiviteit van rechterlijke besluitworming leiden in beginsel tot grotere aanvaardbaarheid van een rechterlijke uitspraak, is hierbij de gedachte. Ook waardeoordelen kunnen in die optiek een objectieve waarde verkrijgen indien zij berusten op een rationeel navolgbare argumentatie. Op deze benadering valt beslist één en ander af te dingen. Het ideaaltypische forum zoals geschetst door Perelman miskent het bestaan van sociale en culturele verschillen in een samenleving. Mitsdien is het lastig, aldus Alexy, om van een min of meer universele opvalting van rationaliteit te kunnen spreken ${ }^{54}$ Wanneer wordt erkend dat die verschillen bestaan, ontvalt de kracht van het ideaaltypische forum: er lijken zich toch weer groepen in het forum te bewegen die eigen belangen en aanspraken gehonoreerd willen zien in de rechterlijke uitspraak. De waarborg van Perelmans ideaaltypische forum komt daarmee op losse schroeven te staan. Aarnio stelt eveneens dat het ideaaltypische forum niet overeenstemt met de werkelijkheid in de samenleving. ${ }^{55} \mathrm{Hij}$ spitst de benadering van het forum dan ook niet toe op de samenstelling ervan, maar gaat er vanuit dat het forum, de samenleving in het geheel, in elk geval enkele basiswaarden in het recht onderschrijft. Hierop berust de hypothese, dat over dergelijke basiswaarden een consensus kan groeien. ${ }^{56} \mathrm{Hij}$ verlaat daarmee het idee dat het forum op alle punten een universele opvatting vertegenwoordigt en erkent dat er aspecten in het recht zijn waarover zeer uiteenlopend wordt gedacht. Een basiswaarde is dan niet zozeer dat er een universele aanvaarding bestaat van rechterlijke uitspraken, maar meer dat aan de rechterlijke besluitvorming rationaliteit ten grondslag dient te liggen. ${ }^{57}$

Rationaliteit dient uitgangspunt te zijn wanneer de vraag wordt gesteld, welke belangen van welke groep van het forum dienen te worden gerespecteerd. Rationaliteit kan in sommige opzichten diametraal tegenover het rechtvaardigheidsgevoel dat bij sommige leden van het forum heerst komen te staan, maar dat 'verbijzonderbare' rechtvaardigheidsgevoel mag in beginsel niet de overhand krijgen op de rationaliteit van de rechterlijke beslissing. In de analyse van de rechtspraak zall aandacht worden geschonken aan de wijze waarop de rechter tracht 'het' forum tracht te overtuigen. In het bijzonder bij de beoordeling van geschillen omtrent het recht op persoonlijkheid ligt het voor de hand dat bepaalde groepen in het forum moeten worden overtuigd van de rechtvaardigheid van de rechterlijke beslissing. Dat hangt samen met het karakter van dat recht: er bestaan in de samenleving diametraal tegenovergestelde opvattingen over de mate waarin de staat zich mag inlaten met persoonlijke keuzen van het individu, en over de mate waarin het individu zelf gestalte mag geven aan die keuzes. Juist individuele

55 Aarmio 1987, p. 224 e.v.

56 Aarnio 1987, p. 224.

57 Aarnio 1987, p. 225. 
aanspraken samenhangend met de persoonlijkheid kunnen niet altijd rekenen op de instemming van een meerderheid van het forum als het gaat on erkenning van bijvoorbeeld voorkeur voor homoseksuele of interraciale relaties, het willen ondergan van een abortus, de erkenning van het nieuwe geslacht, of het willen kennen van de biologische afstamming ook al brengt dat onrust in het bestaande familieverband met zich mee. In de jurisprudentieanalyse wordt teruggekomen op de betekenis van het forum in de rechterlijke besluitvorming.

\subsection{Het interpretatiedebat in de verschillende rechtsstelsels}

Voor alle stelsels wordt geschetst welke doctrines er bestaan in verband met het constitutionele interpretatiedebat. Van belang is dat niet een gedetailleerde beschrijving wordt gegeven van erkende interpretatiemethoden, maar dat aan de hand van de meest gebruikte methoden wordt gekeken welke het meest worden benut voor de uitleg van grondrechtsnormen, en welke uitlegmaximes in dat verband tot ontwikkeling zijn gekomen. In het Duitse rechtsstelsel bestaat bijvoorbeeld het interpretatiebeginsel van de 'praktische Konkordanz', dat inhoudt dat een harmoniërende uitleg aan grondrechten dient te worden gegeven. In de rechtspraak van zowel het Luxemburgse als het Straatsburgse Hof is een uitlegprincipe ontwikkeld dat stipuleert dat aan de verdragsrechten een 'effet utile' dient te worden gegeven, hetgeen inhoudt dat ingeroepen bepalingen niet zo mogen worden uitgelegd, dat de daarin neergelegde rechten illusoir worden. Wat de schets van de interpretatiemethoden verder laat zien is een structurering van het debat over interpretatie tegen de achtergrond van de constitutionele werhouding tussen rechter en wetgever. In beginsel worden interpretatierichtlijnen gezocht die het gehele interpretatievraagstuk in een rechtsstelsel beheersen - deze maximes kunnen ook van belang zijn voor de analoge redenering. Vraag is bijwoorbeeld, of er een hièrarchie van interpretatiemethoden bestaat, en of er voor een bepaalde methode een sterke voorkeur bestaat bij de uitleg van grondrechten. De tekstuele methode lijkt de constitutionele verhouding tussen rechter en wetgever namelijk in een rustiger vaarwater te laten dan een dynamisch-teleologische uitleg.

\subsubsection{Verenigde Staten}

\section{Constitutionele interpretatie}

Interpretatiedoctrines worden in het Amerikaanse debat van groot belang geacht voor de wijze waarop redeneringen worden opgebouwd in de rechtspraak, alsook woor de wijze waarop het constitutionele recht is georganiseerd. ${ }^{58}$ Het debat over de rechterlijke

58 Er kan slechts een suggesties worden gedaan ter zake van de Amerikaanse discussie over constitutionele interpretatie; de literatuur ter zake is overwloedig: Bicke\#1962; Black 1983; Bobbitt 1982; Bobbitt 1991; Bork 1990; Brest 1975; K. Burgess-Jackson 1989; W. Brugger 1994; Cardozo 1921 (herdiruk 1949); Denning en Reynolds 1997; DeRosa 1996; Ducat en Chase 1992; Ely 1980; Fallon 1987; Grey 1984; Grey 1978; Gunther en Sullwan 1997; Heringa 1996; Hoffman 1997; Kotulak 1988; Nagel 1989; Posner 1995; Scalia 1997; Sunstein 1999; Tribe 1985 (1); Tribe 1985 (11); Tribe and Dorf 1991; Tribe 
taakopvatting in rechtsvinding gaat in de Verenigde Staten vooral over constitutionele interpretatie en de mate waarin een methode leidt tot spanningen in de verhouding met de democratisch gelegitimeerde wetgever of lagere federale wetgever of rechter. Hieronder wordt getracht, de belangrijkste lijnen in de benadering van rechtsvinding kort uiteen te zetten, ${ }^{59}$ In zijn ideale vorm leidt het geheel van constitutionele doctrines tot een coherent analytisch kader waarmee conflicten in individuele casus kunnen worden beslist. Voorstanders van een strikte toepassing van doctrines stipuleren dat het gebruik van interpretatiedoctrines leidt tot een terugdringen van rechterlijke discretie in constitutionele rechtspraak, daar de rechter in zijn beslissing gebonden is aan het geheel van doctrines die op logische wijze met elkaar in verband staan. Met name ter zake van de redeneringen die worden opgebouwd in de constitutionele rechtspraak bestaat veel discussie over de juiste hantering van de correcte methoden. Sommigen zijn van mening dat juist in de constitutionele interpretatie ruimte bestaat voor het gebruik van persoonlijke politiek-ethische inzichten, hetgeen samenhangt met het open karakter van de rechtsnormen. Een dergelijke benadering zet de constitutionele verhouding tussen rechter en wetgever onder druk: onder voorwendselen van toepassing van grondrechtelijke normen kan de rechter in stat worden geacht met zijn subjectieve bevindingen de rechtsvinding te sturen.

Critici van het 'geloof' in doctrines daarentegen bestrijden niet dat doctrines een handig hulpmiddel zijn bij het opbouwen van de redenering in een concrete casus, maar zijn eveneens van mening dat doctrines juist kunnen worden gemanipuleerd teneinde een gewenst resultaat uit de redenering te verkrijgen. ${ }^{60}$ Enkele van de uitlegdoctrines vragen op hun beurt wederom om nadere interpretatie, zodat de functie van een doctrine als een eenduidige richtingaanwijzer in het reclitsvindingsproces niet langer opgaat. Zo dient het Hooggerechtshof bij de vraag of sprake is van een "fundamental right' steeds vast te stellen of het geclaimde recht deel uitmaakt van het vage "concept of ordered liberty'. Critici stellen dat deze uitlegdoctrines een misplaatst vertrouwen in zekerheid oproepen, omdat zij suggereren dat een 'juist' en logisch resultaat voortvloeit uit de mechanische toepassing van de formules en tests die deze doctrines vereisen. ${ }^{61}$ De discussie over het bestaan van een recht op 'privacy" is onderdeel van een ruimere discussie over grondwetsinterpretatie in de Verenigde Staten. ${ }^{62}$ In de Amerikaanse doctrines is een aantal opvattingen tot ontwikkeling gekomen die jeder op hun eigen

2000; Tushnet 1999; Wechsler 1961.

59 In dit verband wordt geen volledigheid geclaimd; voor uitgebreider beschouwingen zie de hiervoor onder noot 58 aangehaalde literatur.

60 Dworkin haalt hierbij een voorbeeld van Judge Leamed hand aan: "He argued for judicial restraint, and said that the Supreme Court had done wrong to declare school segregation illegat in the Brown case. It is wrong to suppose, he said, that claims about moral rights express anything more than the speaker's preferences. If the Supreme Court justifies its decisions by making such claims, rather than by relying on positive law, it usurping the place of the legislature [...]' zie. Dworkin 1977, p. 140.

61 Zie daarover onder meer Nagel 1989 , p. $12 \Downarrow$ e.v.

62 Zie par. 2.33 en hoofdstuk 5 voor verdere uitwerking wan het recht op 'privacy'; in herinnering wordt geroepen het feit dat dit recht niet woordelijk in de grond wet is vastgelegd en dat er geen eenduidigheid bestaat over de grondslag van het recht dat door het Hof werd gepositiveerd. 
manier consequenties hebben voor de grondslag en de reikwijdte van het recht op 'privacy' en meer in het algemeen het recht op 'privacy'. 6.3

\section{Tekstuele interpretatie}

Een vaste rangorde van interpretatiemethoden wordt in het algemeen verworpen, al wordt wel gesteld dat bijvoorbeeld de tekstuele benadering van de grondwet de eerste methode is waaraan de lezing van de Constitution moet worden onderworpen omdat de grondwet opgeschreven is. ${ }^{64}$ Constitutionele interpretatie aan de hand van enkeld de strikte tekstuele benadering leidt in de optiek van sommigen steeds tot een juiste uitlleg van de grondwet. ${ }^{65}$ In de optiek van anderen zou louter tekstuele lezing wan de grondwettelijke bepalingen de grondwet tekort worden gedaan; én van de opvattingen in het debat over de juiste interpretatiemethode is dan ook dat met tekstuele interpretatie van de grondwet niet alleen de expliciete bewoordingen van het document worden bedoeld. Interpretatie van de tekst betekent tevens dat de woorden in hun context moeten worden gelezen; isolatie van de woorden binnen de constitutionele bepalingen wordt niet als wenselijk gezien terwijl ook rekening dient te worden gehouden met het voorkomen van dezelfde formuleringen elders in de Constitution. ${ }^{66}$ Dat laatste draagt bij in de consistentie van constitutionele interpretatie. ${ }^{67}$ Dat tekstuele interpretatie het vertrekpunt voor constitutionele interpretatie vormt, is te zien aan de wijze waarop het debat over de juiste uitleg gestructureerd is: die hangt samen met de juiste lezing van de tekst. In dit verband kunnen drie stromingen worden onderscheiden. De eerste stroming, die van de 'originalists', stelt dat de grondwet naar de letter moet worden gelezen. In dat geval zal een extensieve uitleg van grondwettelijke bepalingen niet voor de hand liggen. De stroming van de "interpretevists" hecht in mindere mate strikt aan de

63 Bij deze indeling wordt grotendeels het schema van Tribe gevolgd, dat in de literatuur wordt onderschreven. Zie Tribe 2000 , p. 1-78. Fallon gaat een stapje werder met zijn uiteenzetting over constitutionele interptetatie en geeft een explicietere rangonde aan van do ie wolgen methodes - iets wai hij nu niet weer zon willen pretenderen (Fallon 1987, p. 1189-1286). Zijn indeling suit aan bij die van Tribe.

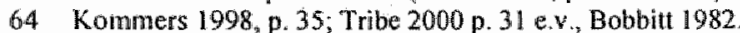

65 Anders zie bujvoorbeeld rechter H. Black, die word gezien als een van de meest strilkte "lextualists". hetgeen betekent dat de letterlijke tekst aangehouden moet worden bij interpretatje: 'I simply' believe that "Congress shall make no law" means Congress shall make no law", Black 1969, p. 45.

66. Tribe 2000, p. 38 .

67 Een fraai voorbeeld hienaan is terug the vinden in de jnterpretatie van het woord "necessary" door Rechter Marshall in de zaak McCwhoch I. Maryland, 17 U.S. (4 Wheat) $316,414-415$ (1819). Hij contrasteerde het begrip 'necessary' in de Necessary and Proper Clause (xie Art. Ilid 8 onder 18) met de frase 'absolutely necessary" in de Import/Export Clause, waarna de noodzaak tot wetgeving door Congress kon worden geinterpreteerd in Art. I lid 10 sub 2. In McCulloch 1. Maryland: "The argument on which most reliance is placed, is drawn from the peculiar language of this clause. Congress is not empowered by it to make all laws, which may have relation to the powers conferted on the government; but such only as may be "necessary and proper" for carrying them into execution. [...] is it trute, that thisz is the sense in which the word "necessary" is always used? Does it always import an absolute physical necessity [...]?' Om tot een interpretatie te komen wordt een vergelijking gemaakt met de betekenis wan "necessary" in lid 10: "It is, we think, impossible to compare the sentence which prohibits a sitate from laying imposts, or duties on imports and exports, except what may be absolutely necessary for executing its inspection Haws". Voornoemde constitutionele bepalingen in het geheel zijn niet vergelijkbaar; de notie 'necessary' wordt in de twee bepalingen echter eender ingevuld. 
letter vain de grondwet; in het verlengde of in de periferie van de bepalingen in de grondwet aanvaarden zij well 'ontdekking' van aanverwante grondrechten. De grondwet moet daarvoor wel een.eenduidige, aanwijsbare basis bieden. De derde stroming ten slotte, die van de non-interpretevisits, aanvaardt dat een bron voor fundamentelle rechten ook buiten de letterlijke tekst van de grondwet gevonden kan worden. ${ }^{68}$

\section{Originalists, intentionalists en interpretivists}

In de stroming van de "originalists" bevindt zich een afscheidingsbeweging: de kern wan luet meningsverschil tussen intentionalists en originalists is gelegen in de voorkeur voor de autoriteit die de juiste interpretatie dicteert. De intentionalist hanteert een tekstuele benadering zoals de toenmalige wetgever de tekst bedoeld heeft. ${ }^{69}$ De originalist daarentegen houdt vast aan de betekenis van de tekst zoals die in de samenleving. gold ten tijde van de totstandkoming vam de grondwet. ${ }^{70}$ Beide uitgangspunten vertegenwoordigen in de optiek van interpretevisits een onhoudbare positie omdat door originalists en intentionalists wordt aangeknoopt bij opvattingen van eind achttiende eeuw. In de visie van de interpretevists dient de tekst te worden bezien tegen de achtergrond van de normen en waarden in de huidige samenleving, ook al dateren de formuleringen uit een geheel andere tijd. ${ }^{71}$ Een mogelijk compromis tussen originalists en intentionalists enerzijds en interpretevists anderzijds is de visie van de 'moderate interpretivists" die de opvatting huldigen dat de huidige betekenis van de tekst tezamen met de algemene of abstracte uitgangspunten zoals bedoeld door de schrijvers van de Constitution centraal dient te staan. ${ }^{72}$ Er valt een en ander af te dingen op de extreme standpunten van intentionalists, originalists en de interpretevists. Belangrijkste kritiek op de opvattingen van de intentionalists is wel dat de pretentie dat de meest objectieve interpretatiemethode zou worden gevolgd, lastig vol te houden is: ook de opvatting van de Framers dient te worden 'gevonden' en 'aangetoond' als zijnde de juiste lezing van de tekst. ${ }^{73}$ Een subjectief element van de rechtsvinder in de interpretatie lijkt ook in de

68 Dworkin 1977, met nome hoofdstuk 5. Ely onderscheidt "interpretevists' en 'non-interpretevisits', zie Ely 1980, p. 12 e.v.; 20 nok Brugger 1994, p. 404 e.v. en Beatly 2001, p. 79 e.v. Ook andere stromingen hebben zith in het interpretatiedebat ontwikkeld, zoals bijwoorbeeld die van 'legal realism' die de input van de ervaring en het werkelijke leven in de interpretatie betrekt, de 'critical legal studies moventent', die cen meer sceptische en utopische vorm van 'Iegal realism' vertegenwoordigt (zie Brugger 1994, p. $405 \mathrm{e.v}$ ).

69 Een intentionalistbenadering is te vinden in de opvattingen wan R. Bork: 'Judges must accept any value choice the legislature makes unless it runs clearly contrary to a choice made in framing the Constitu* tion', Bork 1971, p. 11.

70 Cooley 1972, p. 55; het doel wan de Constitution voor zover het gaat on erkenning van rechten is -"to embed certain rights in such a manner that future generations cannot readily take them away'.

71 Bobbitt 1982, p. 25 e.w. Zie ook bijwoorbeeld rechter Brennan, dissenting in Michael H. H. Gerald D., 491 U.S. 110,141 (1989): "the document the plurality construes today [...] is not the living charter that I have taken to be our Constitution; it is instead a stagnant, archaic, hidebound document steeped in the prejudices and superstitions of a time long past'.

72 Brest 1980, p. 223 e.v.

73 Er bestaat geen officiele documentatie wan de Philadelphia Convention, waar de Constitution werd vastgesteld. Enkele afgevaardigden hebben wel aantekeningen genaakt, maar deze zijn incompleet. Verder is het haast onmogelijk in thet geval compromissen die gesloten zijn tussen de afgewaardigden, aan to tonen weike mening de theersende is. En wie geldt er als 'founding Father', als Framer? In de 
hantering van deze methode onvermijdelijk. ${ }^{74}$ De problemen met een originalist benadering zijn eender, hoewel wat meer verhuld: teneinde de juiste betekenis van de tekst te achterhalen vormen woordenboeken en etymologische bronnen uit die tijd een hulpmiddel. Deze bronnen zijn echter niet eenduidig en vergen van de uitlegger eveneens interpretatie en verantwoording van de keuze voor nadruk op de ene of andere bron. Indien de originalist erin slaagt een overtuigende interpretatie aan te voeren rijst de vraag in hoeverre de Amerikanen in de huidige samenleving zich gebonden achten aan de opvattingen omtrent staatsinrichting en fundamentele rechten zoals die ruim tweehonderd jaren geleden golden. ${ }^{75}$ Problematisch bij de interpretivists is het uitgangspunt dat de tekst van de Constitution dient te worden bijgesteld naar 'standards' van de 'living Constitution' die op hun beurt in het geheel niet vastliggen. ${ }^{76}$ Brennan bevindt zich onder de aanhangers van de "non-interpretevists".

Zoals hierboven reeds kort werd aangestipt, worden deze standards nader ingevuld door onder meer constitutionele rechtsbeginselen, waarvan het bestaan als geldende rechtsnormen niet eenstemmig door het juridisch forum worden aanvaard. Vooral de intentionalists en originalists hebben problemen met deze wijze van interpretatie: de methode kan leiden tot grondwetswijzigingen die door de rechter worden gecreserd, terwijl de grondwetgever juist in speciale amenderingsprocedures heeft voorzien. ${ }^{77}$ Van de rechters die zitting hebben in het huidige Hof komen Rehnquist, Scalia en Thomas het dichtst bij de filosofie van de originalists. ${ }^{78}$

Intentionalists, originalists, interpretevists en non-interpretevists staan allen voor de opgave invulling te geven aan abstracte begrippen als 'liberty' in het Veertiende Amendement en aan 'privacy'. Vraag is of 'liberty' als in het Vijfde en Veertiende Amendement dient te worden opgevat als een ruime beginselachtige bepaling die nog nadere invulling behoeft (non-interpretevists), of dat het begrip enkel dient te worden geijkt aan de rechten die direct (originalists en intentionalists) of indirect (interpretevists) voortvloeien uit de Bill of Rights. In de Amerikaanse literatuur en rechtspraak wordt voor de wijze van invullen gesproken over een algemene of juist een meer specifieke benadering valn abstracte begrippen als 'liberty'. In een specifieke benadering zal de interpreet, die invulling wenst te geven aan 'liberty' in verband met een concreet ge-

totstandkoming van de Constitution zijn afgevaardigden opgestapt (Hamilton, die toch wordt gezien als zeer wooraanstaand in het proces wan de totstandkoming); welke betekenis dient aan zijn mening to worden gehecht? En welke waarde dient te worden gehecht aan de intentie van de ratificerende staat?

74 Tribe 2000 , p. 57 en Dorf 1997, p. 1777.

75 When we are deating with words that ane also a constituent act, like the Constitution of the United States, we must realize that they have called into life a being the development of which could not have been foreseen completely by the most gifted of its begetters. It was enough for them to realize and hope that they had created an organism; it has taken a century and has cost their successors much sweat and blood to prowe that they created a nation. The case before us must be considered in the light of our whole experience and not merely in that of what was said a hundred years ago" ${ }^{2}$,echter Holmes in Missaturi i. Holland, 252 U.S. 416 (1920).

76 Scalia 1997 , p. 44 e.v.

77 Zie Black in zijn dissenting bij Harper t. Virginic State Board of Elections, 383 U.S. 663 (1966).

78 Heringa 1996, p. 123. 
schil, trachten 'zo dicht mogehijk' te blijven bij de in het geschil spelende aanspraken. Invulling aan de hand van een meer abstracte norm van 'liberty' staat toe, dat er eerder ruimte ontstat voor een extensiever interpretatie van 'liberty'. De rechter is in dat geval bereid, witspraken te doen over 'liberty' die boven het concrete geschil lijken uit te stijgen.

De zaak Michciel H. $t$. Gerald D. bijvoorbeeld, leidde binnen het Hof tot een verdeeldheid amtrent de vaststelling van de juiste benadering van het recht op 'liberty', meer specifiek family life." In deze casus claimde de biologische vader op basis van "liberty" in het Veertiende Amendement en het daaruit afgeleide recht op 'family life' omgang met zijn kind. Dat kind was in een huwelijk waarvan de biologische vader geen deel uitmaakte geboren. Zijn claim werd door de meerderheid in het Hof verworpen, zelfs waar de vader aantoonde dat voor $98 \%$ vaststond dat hij de biologsiche vader was. Rechter Scalia, originalist, schreef de meerderheidsopinie:

'clue process required not merely that the interest denominated as a "liberty" be "fundamental" (a concept that, in isolation, is hard to objectify), but also that it be an interest traditionally protected by our society[... The legall issue here reduces to whether the relationship between the persons in the situation of Michael and the child has been treated as a protected family unit under the historic practices of our society [... ]".

De invulling die Scalia geeft aan 'family life' met 'tradition' leidt tot een specifieke, concrete benadering van het recht op family life. Middels deze specifieke interpretatie beargumenteent hij dat voor een recht van een 'overspelige biologische vader' geen basis ligt in de historische constitutionele traditie, en kon met verwijzing naar de specifieke benadering van family life in het traditionele kader de claim van de biologische vader worden afgewezen. Justice Brennan stelt daartegenover juist een meer algemene benadering van 'liberty' en het daaruit voortvloeiende recht op family life uit het Veertiende Amendment. In zijn dissenting bekritiseert Brennan de gevolgen van Scalia's specifieke beradering van het recht:

'In construing the Fourteenth Amendment to offer shelter only to those interests specifically protected by historical practice, [... . the plurallity ignores the kind of society in which our Constitution exists. We are not an assimilative, homogeneous society, but a facilitative, pluralistic one, in which we must be willing to abide someone else's unfamiliar or even repellent practice because the same tolerant impulse protects our own idiosyncracies. In a community such as ours, "liberty" must include the freedom not to conform".

Brennan kiest met deze benadering voor een hogere abstractiegraad van het recht op "liberty" en het afgeleide recht op family life. Het gaat volgens Brennan niet on de vraag of een overspelige vader een recht heeft op omgang met het kind dat staande een ander huwelijk is geboren, maar om een meer algemene familiebetrekking tussen ouder en kind. De overspeligheid komt in het meer algemene verband geen functie meer toe, zoals dat in de meer concrete situatie nog wel het geval was. Die benadering leidt

79 Mchoel H. 1. Gerald $D_{3} 491$ U.S. $110(1989)$. Het concept van gezinsleven is in de Amerikamse constitutionele rechtspraak een afgeleide van "liberty" onder thet Veertiende Amendment. Zie ook Moore $t$. East Cleveland, 431 U.S. 494 (1977) en Zablocki t. Redharl, 434 U.S. 374 (1978), zie ook par. 5.3.5. 
evenwel tot de tegenovergestelde uitkomst van Scalia's interpretatie van het begrip. Het debat tussen Brennan en Scalia over de juiste benadering van abstracte begrippen als "liberty" wordt in verschillende latere uitspraken voortgezet. ${ }^{80}$ Scalia bestrijdt Brennan's opvatting omdat die zou leiden tot een soort 'containerbegrip' waaronder iedere aanspraak wel zou kunnen worden erkend. Dat hadden de Framers van de grondwet volgens Scalia niet voor ogen:
"Justice Brennan's approach does not establish a rule of law at all, but only a 'totality of the circumstances-test'. The difference between Justice Brennan and me has to do with whether the changes are to be adopted as progressive by the American people or decreed as pro- gressive by the Justices of this Court" 81

De aanvaarding van een abstractiegraad van de constitutionele bepaling lijkt consequenties te hebben voor de uitleg die de bepaling uiteindelijk krijgt: een vergaande concretisering van een constitutionele bepaling leidt al gauw tot een restrictieve interpretatie, terwijl een hogere abstractiegraad meestal leidt tot het omgekeerde, eerder een extensieve interpretatie van de grondwettelijke bepaling. ${ }^{82}$ Indien de constitutionele bepaling een beginselachtig karakter krijgt toegedicht, is het eerder mogelijk de tekst van de Constitution aan te passen aan de condities van de huidige samenleving, terwijl aanpassing aan de condities bij een meer specifieke invulling van de grondwetsnorm juist lastig wordt. ${ }^{83}$

De achterliggende gedachte voor de benadering wordt in belangrijke mate ingegeven door de betekenis van de bepaling in de grondwet in de staatsinrichting: is de achterliggende bedoeling van de grondwetsnorm een richtlijn voor staatshandelen, of dient de grondwetsnorm juist ter conservering van een bestaand instituut of gewoonte. Beide uitgangspunten genereren elk een afzonderlijke rechterlijke taakopvatting. Indien het verbod op staatshandelen wordt gezien als belangrijkste dynamiek achter de bepalingen in de grondwet zal de interpreet waarschijnlijk eerder een meer abstracte benadering in de bepalingen aanvaarden. Is het uitgangspunt dat de grondwet een richtlijn is voor staatshandelen, dan aanvaardt men daarentegen eerder dat in de grondwet een gedachte ten faveure van de individuele rechtscherming in verborgen ligt. Dworkin stelde in dit verband, dat de grondwet met vage normen eerder refereert aan morele concepten, dan dat er afgebakende begrippen werden vastgelegd. ${ }^{84}$ De rechter heeft in die optiek tot taak fundamentele waarden te beschermen en kan de grondslag daarvoor ontlenen aan de grondwet. Een rechter die vanuit dit gedachtengoed rechtspreekt zal in beginsel niet kunnen worden aangemerkt als activistisch: hij doet immers hetgeen de grondwet hem opdraagt. Wanneer de rechter interpreteert vanuit de opvatting dat de grondwet een bestaand instituut of gewoonte beschermt zal hij onderzoeken in hoeverre de individuele

80 Zie onder meer Burnham t. Superior Court, 495 U.S. 604 (1990).

81 Burnhamt. Superior Court, 495 U.S. 604 (1990).

82 In het citaat zit een fraaie verwijzing naar het forum: in casu wordt de samenleving als forum aangesproken.

83 Tribe 2000 , p. 62 : 'Provisions that do the Jatter are best read more concretely, as nailing down an historic practice by securing it against the winds of change".

84 Dworkin 1977, hooldstuk 5. 
aansprak in een concreet geschil aansluit bij de belangen die de grondwet beoogt te beschermen vanuit een meer "traditioneel" perspectief. Dat betekent niet dat nog niet eerder gedane aanspraken geen grondwettelijke bescherming kunnen verkrijgen, maar het zal in beginsel lastiger zijn om ze als grondwettelijk beschermenswaardig aan te merken: de rechter zoekt immers naar een bevestiging ervan in de wortels van de samenleving. In de uitspraken van het Hof zijn scherpe tegenstellingen te ontwaren ter zake van de vraag, vanuit welke interpretatievisie het begrip "liberty" moet worden benaderd; de meningen ter zake lijken sterk gepolariseerd. Dat hangt naar mijn indruk samen met het feit dat een kleine meerderheid noodzakelijk is om een besluit te nemen, en de mogelijkheid van de rechters, afwijkende en concurrerende meningen te geven. ${ }^{85}$ De vraag die naar mijn mening steeds centraal staat in het interpretatiedebat is die naar de legitimiteit van de extensieve lezing van de grondwet, die inlezing van ongeschreven rechten en rechtsbeginselen aanvaardt.

\subsubsection{Duitsland}

\section{Constitutionele interpretatie}

In de Duitse literatuur wordt onderkend, dat de open structuur van de grondwettelijke normen leidt tot interpretatieproblemen. ${ }^{86}$ De begrippen als 'Menschenwürde', "Allgemeines Freiheitsrecht' en 'Sozialer Rechtsstaat' lijken het Hof een 'carte blanche' te bieden waaruit allerlei, zelfs met elkaar tegenstrijdige, argumenten kunnen worden ontleend. ${ }^{87}$ Algemeen wordt in de Duitse doctrine aangenomen, dat de technisch-juridische interpretatiemethoden niet leiden tot de enige, juiste vaststelling van de betekenis en oorsprong van de constitutionele normen. ${ }^{88}$ Het Hof bekent zich in beginsel tot deze witlegmethoden - dat betekent echter niet dat het die methoden volgens een vast stramien en consequent praktiseert. ${ }^{89}$ Naast de technisch-juridische methoden hanteert het Hof eveneens 'Verfassungsmaximen'. Voorbeelden van deze in de rechtspraak ontwikkelde noties zijn de 'Einheit der Verfassung' en de daarmee nauw samenhangende "praktische Konkordanz". 90

In de Duitse methodendiscussie zijn verschillende stromingen te onderscheiden. ${ }^{91} \mathrm{De}$ discussie over grondwetsinterpretatie van na de Tweede Wereldoorlog wordt met name

Wassermann 1984, p. 96 e.t.; Hesse 1991, p. 22; Battis en Gusy 1991, p. 15-18 en Alexy 1996, p. 502.

87 Hesse 1991, p. 22; Alexy 1996, p. 502; Battis en Gusy 1991, p. 18 .

88 Hesse $1991, \mathrm{p}, 24$.

89 Koch 1986, 347. De klassieke school wan interpretatie werd in 1840 in Duitsiland gevestigd door Von Savigny, die de tekstuele, de stucturele en de historische interpretatie onderscheidde (Von Savigny 1840 , mat name p. 213 e.v.). Later werd dataran een vierde methode toegevoegd, namelijk die van de teleologische interpretatic. Deze klassieke school heeft later in de andere rechtssystemen eveneens in grote mate ananlung gevonden, en wordt hier ander adngeduid met de "traditionele interpretatie".

90 Brugger 1994 , p. 398 e.v; zie ook hierna.

91 Hier komen de in de literatutu meest gehanteerde benaderingen aan bod; er zijn ongetwijfeld vertakkingen en andere visies te onderscheiden, terwijl de methoden onderling soms met elkaar verweven zijn. Ook zijn verschillende benamingen voor dezelfoe stromingen aangetroffen. Hier wordt voortgebouwd op de onderscheidingen zoals uiteengezet door Koch 1986, p. 348 ien Buckenförde 1976, 
beheerst door de vraag; welke benadering iets toe kan voegen aan de rationaliteit van wetsinterpretatie: welke houdt in het bijzonder rekening met de eigenheden van de grondwet? De eerste benadering bouwt voort op de Savignyaanse uitlegmethoden en houdt niet in het bijzonder rekening met de structuur van open normen in de grondwet: Deze "klassisch-hermeneutische Methode" houdt in dat de grondwet dient te worden uitgelegd naar de methoden die worden gebezigd bij gewone wetsinterpretatie. ${ }^{92}$ Dat volgt uit het door deze theorie gestelde gegeven dat de codificatie van de grondwet een voorwaarde en tegelijkertijd resultaat is van de rechtsstaat - hetgeen inhoudt dat de rechter is gebonden aan de wet. De grondwet kan enkel op deze wijze worden gestabiliseerd. ${ }^{93}$

Op deze visie is kritiek gekomen vanuit de "topisch-problemorientiente Methode" en de "wirklichkeitswissenschaftlich orientierte Verfassungsinterpretation"; zij bekritiseerden de benadering van de grondwet als gewone wet en vormden beide reacties op de strikte legistische interpretatiemethoden. In de benadering van de "Topik" interpreteren grondwetsnorm als uitgangspunt genomen, maar het probleem ter zake waarvan deze norm moet worden uitgelegd. ${ }^{95}$ De anknoping bij het concrete geschil werd verwelkomd, omdat de klassieke methoden niet leidden tot bevredigende uitleg van de grondwetsbepalingen; Topik maakte daarentegen de betrokken grondwetsbepaling hanteerbaar. In de Topik wordt de norm niet in één betekenis verabsoluteerd, zoals eerder bij de 'klassisch-hermeneutische Methode' het geval is, maar veeleer toegesneden op het concrete geschil.. ${ }^{96}$ Van de bepaling wordt slechts een deel belicht; van de juiste interpretatie van de norm in volle omvang is geen sprake. Een van de kritiekpunten op de Topik op de hypothese van het bestaan van het 'Vorverständnis' is dat de rechter in de afbakening van het relevante feitencomplex, alsmede bij de afbakening van het relevante deel van de norm een rechterlijke beoordelingsruimte creeert die kan leiden tot een ongewenste irrationele factor in de constitutionele interpretatie."

In de derde stroming wordt de 'wirklichkeitswissenschaftlich orientierte Verfassungsinterpretation" tot uitgangspunt verheven: de grondwet wordt gekenschetst als een

p. 2089 e.v.

92 Een uitwerking van dit standpunt is te vinden in Forsthoff 1959, p. 35 e.w. Naar de klassieke interpretatiemethoden wan Von Savigny geldt dat slechis de tekstuele, grammaticale en historische uitlegmethoden een bindend resultaat kunnen geven. Tegenwoordig wordt onder "Klassieke interpretatie" methoden" eveneens de teleologische methode verstaan, die in Von Savigny's model niet was opgenomen. Niet kan worden volgehouden, dat de teleologische methode geheel doordrong tot de klassieke interpretatiemethoden via de systematische methode. De methoden werken op elkaar en versterken elkaars werking, maar van een gehele werwanging wan de ene methode voor de andere kan geen sprake zijn omdat de systmatische methode geen materitte norm tot resultaat behoeft te hebben, terwifl de teleologische methode die consequentie wel heeft.

93 Deze benadering heeft nauwelijks aanhang meer (Koch 1986, p. 345).

94 De topisch-problemorientierte Methode wordt wervolgens aangeduid met 'Topik'.

95 Voor het leerstuk wan de Topik zie Viehweg 1974.

96 Koch 1986, p. 348.

97 Deze kritiek op de Topik wordt gepareerd met de stelling, dat de rol van het 'Vorverstandnis' van de rechter dient te worden gellimiteerd door de formulering van een 'Konsens aller, vernunftig und gerecht Denkenden" (H. Ehmke) in een omvattende grondrechtstheorie (Larenz 1991, p. 388). 
rechtsorde in een integratieproces, waarin de staat "verwerkelijkt" wordt." De taak van de rechter is in dit verband, zich oriênterend aan de sociale werkelijkheid, te komen tot de toepassing van de afzonderlijke grondwetsbepalingen. ${ }^{99}$ Deze benadering ontwikkelde zich als gevolg van de kritiek aan het adres van de klassieke interpretatiemethoden, omdat deze laatste de sociale werkelijkheid buiten beschouwing laat. De "hermeneutisch-konkretisierende Verfassungsinterpretation' tracht op weer andere wijze een rationele binding aan de grondwet tot stand te brengen, die het midden houdt tussen Topik en de klassieke uitlegmethode. ${ }^{100}$ In deze optiek dient interpretatie van de grondwet te worden gezien als concretisering en wordt de beoordelingsmarge die de rechter heeft bij de uitleg van de norm geaccepteerd als een noodzakelijk kwaad, hetgeen wordt beperkt door de binding aan de normtekst. De wijze van invulling van de grondwettelijke norm leunt sterk op de tekstuele uitlegmethode, maar knoopt aan bij de Topik waar het gaat on een strikte afgrenzing van het probleem en een daarbij behorende strikte oriëntering aan het relevante onderdeel van de grondwetsbepaling. De bepaling wordt zo specifiek mogelijk toegesneden op oplossing van het probleem. ${ }^{\text {10 }}$ Op deze stroming is de 'methodische Rationalisierung der Konkretisierungsvorgang' als reactie gekomen, waarin getracht wordt het concretiseringsproces zoveel mogelijk te structureren en te rationaliseren en het hoofd te bieden aan de beperking die voortvloeide uit de binding aan de tekst. De constitutionele bepaling vormt de kern van een normatieve ordening. Teneinde toepasselijk te zijn in het individuele geval dient deze norm 'ver-bestimmt' te worden; daarbij wordt geaccepteerd dat de bepaling tegelijkertijd inhoudelijk verduidelijkt, gedifferentieerd en verder ontwikkeld wordt. ${ }^{102}$ In deze methode worden rechtsnorm en werkelijkheid als gejijktijdig werkende elementen in de normconcretisering gezien; door de wisselwerking tussen vaststelling van norm en feitencomplex komt tot uitdrukking, wat naar de constitutionele norm in het individuele geval rechtvaardig is. In Mephisto geeft het Hof een redenering die hierbij aansluit:

"Wie weit die Verfassungsgarantie der Kunstfreiheit reicht und was sie im einzelnen bedeutet, läßt sich ohne tieferes Eingehen auf die sehr verschiedenen Äußerungsformen kinnstlerischen Betaitigung in einer für alle Kunstgattungen gleichermaßen gultigen Weise nicht erschopfend darstellen. Für die zwecke dieser Entscheidung bedarf es jedoch einer so weit ausgreifenden Erörterung nicht [...]. Es genügt deshalb, auf die spezifischen Gesichts-

98 Zie Smend 1968, p. 188-196.

99 Beckenforde 1976, p. 2094 en Wassermann 1984, p. 102.

100 Zie onder meer Hesse 1991, p. 25 e.v.

101 Deze methode stelt echter niet het concrete geschil als uitgangspunt, maar ge"dt het "primaat wan de constitutionele tekst" (Hesse 1991, Böckenforde 1976, p. 2096). Deze visie kent eveneens beperkingen, omdat de constitutionele tekst nu juist niet alleen dekt wat de tekst meldt, maar dat er meer achter schuilgaat. Hesse wil de interpretatie, ongeacht de extensie daarin die noodzakelijk is voor de concretisering, aan 'etwas Gesetztes gebunden halten', hetgeen lastig is indien miet van een eenduidig verbindende norm sprake is hetgeen vak het geval is bij grondwetsbepalingen.

102 Bockenförde 1976, p. 2090 . In deze methode worden rechtsnorm en werkelijkheid als gelijktijdig werkende elementen in de normconcretisering gezien. Door de wisselwerking tussen norm en feitencomplex wordt vastgesteld, wat naar de constitutionelle norm in het individuele geval rechtvaardig is. Zie eveneens Ossenbihl 1976, p. 2106. 
punkte einzugehen, die bei der Beurteilung eines Werkes der erzählenden Kunst in Betracht kommen können [...]. ${ }^{103 i}$

De 'Folgenanalyse' heeft eveneens geleid tot een karakteristieke benadering van constitutionele interpretatie: indien de rechter zich van een 'Folgenanalyse' bedient, betrekt hij in de uitleg van de norm de consequenties, die aan een voorgestane interpretatie verbonden zijn. In de rechtspraak van het Hof is deze benadering in talloze uitspraken te vinden. ${ }^{104}$ In het Apotheker-Urtell stelde het Hof."

'Die entscheidende Frage ist mithin, ob bei Wegfall der Niederlassungsbeshränkungen des Bayrischen Apothekengesetzes mit hinreichender Wahrscheinlichkeit die Entwicklung im oben bezeichneten Sinn verlaufen und dadurch die geordnete Arzneimittelversorgung so gestört wïrde, daß eine Gefährdung der Volksgesundheit zu befürchten wäre. Das Bundesverfassungsgericht hat sich nicht davon überzeugen vermocht, daß diese Gefahr droht? ${ }^{105}$

De geschetste benaderingen zijn aan te merken als reacties op de resultaten die de klassieke methoden - strikt tekstueel, systematisch en historisch interpreteren van de grondwet - voortbrachten. In de Duitse constitutionele interpretatie wordt eveneens onderscheid gemaakt tussen interpretatie en rechtsontwikkeling: in de individuele casus dient de vage norm te worden toegesneden op het concrete geschil. Teneinde concrete toepassing mogelijk te maken dient de bepaling tegelijkertijd inhoudelijk verduidelijkt en gedifferentieerd te worden. Ontwikkeling van de norm lijkt daarbij onvermijdelijk. Waar de verschillende interpretatiebenaderingen met name in de literatuur tot ontwikkeling zijn gekomen, heeft het Hof zelf eveneens een aantal beginselen ter zake van constitutionele interpretatie in de rechtspraak ontwikkeld, zoals de 'Wertordnung', de 'Einheit der Verfassung' met daaruit voortvloeiend concordantie en het integratiebeginsel, alsmede de 'Wechselwirkungstheorie', die het interpretatieproces richting geven. Het Hof hanteert bij de constitutionele interpretatie veelvuldig de systematische en teleologische interpretatiemethoden; de tekstuele en historische benaderingen zijn naar 's Hofs eigen bewoordingen van ondergeschikt belang. ${ }^{106}$

\section{Tekstuele en historische interpretatie}

Voor het Hof is de tekstuele interpretatie het eerste uitgangspunt ${ }^{107}$, maar het blijkt zeker niet het enige of het doorslaggevende uitgangspunt voor de uitleg van de grondwetsnormen. Voor de keuze van de invulling van de begrippen wordt in de tekstuele interpretatie in Duitsland een onderscheid gemaakt tussen algemeen juridisch spraakgebruik en tussen historisch en tegenwoordig spraakgebruik. ${ }^{108}$ Het laatst gemaakte onderscheid is voor de Dwitse rechtspraak met betrekking tot de grondwet niet zo van

103 Mephisto, 30 BVerfGE 173, 189-190 (1971).

104 Volgens Wassermann e.a. werd in ongeveer de helft van de uitspraken gekeken naar de gevolgen van de interpretatie door het Hof (Wassermann 1984, p. 110).

105 Apotheken-urteil, 7 BVerfGE 377, 415 (1958); zie ook Blinkfür-Besch/uß (25 BVerfGE 256, 263 e.v. (1969) en het Parteispenden-urteil, 8 BVerfGE 51, 65 (1958).

106 Ossenbühl 1976, p. 2109.

107 8 BVerfGE 28, 41 (1958)

108 Zie Larenz 1991, 320-324. 
belang omdat het Grundgesetz nog relatief jong is, en omdat het Hof in zijn rechtspraak over het algemeen naar de objectieve uitleg van de grondwet ne"igt. ${ }^{109}$ De tekstuele benadering biedt een kader waarbinnen de uitleg van de term dient te worden gezocht, hetgeen een aanknopingspunt vormt woor de regel, dat de rechter aan het recht gebonden is. Naast flexibiliteit, de nuanceringen en het aanpassend vermogen van constitutionele interpretatie leidt de open textuur van de grondwettelijke normen tot een situatie waarin geen oplossing voor het voorliggende geschil naar voren komt uit tekstuele interpretatie. "Verfassungsmäßige Ordnung' ex Art. 2 lid 1 GG is bijvoorbeeld een begrip dat met tekstuele uitleg niet woldoende reliêf verkrijgt voor toepassing in de rechtspraak. De tekstuele interpretatie van begrippen als 'Verfassungsmäßige Ordnung' staat zelden op zichzelf - zij hebben een systematische dimensie. De betekenis van grondwetsbepalingen wordt bijvoorbeeld gezocht in een context die bestaat uit andere grondwetsbepalingen, paragrafen uit de grondwet, of uit de gehele grondwet. Het Hof heeft meermaals benadrukt, dat de subjectieve will van de wetgever in de interpretatie van de grondwet geen doorslaggevende rol speelt. " grondwettelijke regel komt bij de uitleg in zoverre betekenis toe, als zij de juistheid van de rechtsvinding, die via andere, kennelijk zwaardere, methoden heeft plaatsgevonden, onderstreept: ${ }^{112}$ Critici menen echter, dat het Hof niet onder de subjectieve historische interpretatie uitkan, omdat het, gezien de niet-democratisch gelegitimeerde samenstelling van het Hof enerzijds en de verreikende bevoegdheden van het Hof anderzijds, de bron van zijn eigen autoriteit anders zou ontkennen, en de legitimiteit van zijn beslissingen zou ondergraven. ${ }^{113}$ Historische interpretatie staat in die optiek in een spanningsverhouding met de objectieve uitlegmethode, omdat subjectieve uitleg binding aan de wet suggereert, terwijl de objectieve uitleg tegemoet komt aan de gedachte dat het verloop van tijd en ontwikkelingen in de samenleving in de uitleg wordt verdisconteerd.

\section{Systematische en teleologische interpretatie}

Volgens de Duitse literatuur bergt de systematische interpretatiemethode twee uitgangspunten in zich: niet alleen dient de consistentie in het systeem van de grondwet gerespecteerd te worden; eveneens heeft deze uitlegmethode tot doel, "integratie" van

109 Larenz, 1991, p. 320-324; Anwailer 1997, p. 86.

110 Larenz 1991, P. 320-321; Wassermann 1984, p. 114; zie ook Gehö be Hofiberehl 9 BVerfoE 89,104 $(1959) ; 14$ BVerfGE 260, 262 (1962) en 35 BVerfCE 263, 278 (1973).

111 Van "subjectieve wetshistorische interpretatie" wordt gesproken indien de nechter een beroep doet op de wetsgeschiedenis die hij afleidit vit de geschiedenis van de totstandkoming van de wet zoals die is vastgelegd in bijwoorbeld de travaux preparatoires; van "objectieve wetshistorische interpretatie" wordt gesproken wanneer voor de betekenis van de rechtsnorm rekening wordt gehouden met de geschiedenis van de inhoud van de rechtsmorn of door aansluiting te zoeken bij schrijvers, of meer in het algemeen bij de matscluapelijke context van de periode watrin de norm werd vastgelegd (Pontier 1998, p. 33. 35). Zie voor de positie van het Duitse Hof onder meer Wohnungsbayforderung, BVerfGE 299,312 (1952); Preisgeserz 8 BVerfGE 274, 307 (1958); Hesse 1991, p. 21; Wassermann 1984 p. 116.

112 Wohmingsbauforderang, I BVertGE 299, 312 (1952); Nachkonstitutioneller Bestatigungswille II BVerfGE 126, 131 (1960).

113 Wassermann 1984, p. 116; zie ook Rastede, 79 BVerrGE 127,145 (1988). 
de grondwetsnormen te bevorderen. ${ }^{114}$ Dat laatste wijst op een eis van coherentie, waarin de normen niet alleen met elkaar samenhangen, maar elkaar ook onderling versterken. De inhoud van de normen wordt beter zichtbaar naarmate het aantal beslissingen dat is gebaseerd op systematische interpretatie toeneemt. Binnen de systematische interpretatie hanteert het Hof niet alleen de geschreven normen in het grondwetsartikel, paragraaf, titel of van de grondwet als geheel, maar betrekt het voor de vaststelling van de betekenis van een norm eveneens ongeschreven constitutioneel recht en algemene rechtsbeginselen in de vaststelling van de betekenis. ${ }^{115}$ In de Duitse literatuur wordt in verband met de constitutionele interpretatie gewezen op de eenheidsstichtende of integrerende werking van grondwettelijke normen. ${ }^{116}$ Indien het Hof moet beslissen over een conflict tussen bijvoorbeeld de Bond en de Länder neemt het niet een strikt tekstuele benadering - voor zover al mogelijk - van de verticale machtenscheiding als uitgangspunt maar betrekt het eveneens 'eenheidsstichtende' standpunten in zijn rechtsvinding. In een geschil ter zake van verticale machtenscheiding hecht het Hof waarde aan de aan machtenscheiding 'tegengestelde' noties als wederzijdse afstemming, coördinatie, informatie en een medewerkingsplicht. Wanneer het Hof deze koers kiest, steunt het op een set van normen die het indirect afleidt uit de grondwet en die op hun beurt het in de grondwet gegeven uitgangspunt van de machtenscheiding aanvullen. De systematiek wordt afgeleid uit de Artikelen 72 en 74 GG, waarin de mogelijkheid tot concurrerende bevoegdheden is gegeven, alsmede de samenwerkingsplicht die het Hof afleidt uit de wetgevingsprocedure ex Art. $77 \mathrm{GG}$ en de wijze van amendering van de grondwet ex art. 79 lid 2 GG. Een andere daarop voortbordurende benadering is dat de grondwet moet worden benaderd als eenheid, en dat grondwettelijke bepalingen niet geilsoleerd moeten worden uitgelegd:

'Eine einzelne Verfassungsbestimmung kann nicht isoliert betrachtet und allein aus sich
heraus ausgelegt werden. Sie steht in einem Sinnzusammenhang mit den übrigen Vorschrif-
ten der Verfassung, die eine innere Einheit darstellt. Aus dem Gesamtinhalt der Verfassung
ergeben sich gewisse verfassungsrechtliche Grundsätze und Grundentscheidungen, denen
die einzelnen Verfassungsbestimmungen untergeordnet sind. Das Grundgeselz geht, wie
sich insbesondere aus Art. 79 Abs. 3 ergibt, ersichtlich von dieser Auffassung aus'. 17 ,

In de Duitse literatuur wordt deze benadering aangeduid als een bijzonder uitgangspunt in de constitutionele interpretatie. ${ }^{118}$ Het gaat hier niet om een onderscheidenlijke rechtsvindingsmethode, maar om een expliciete voorkeur binnen de systematische interpretatie. De rechtvaardiging voor deze voorkeur in de systematische interpretatie wordt door het Hof onder meer gelezen in de in Art. 79 lid 3 GG neergelegde 'Ewig-

114 Wassermann $1984_{\mathrm{f}}$ p. 118

115 Zie bijwoorbeeld Förderstufe, 34 BVerfGE 165, 183 (1972)

116 Anweiler 1997, p. 96 e.v. Hesse, p. 28; Wassermann 1984, p. 118 . Hesse spreekt van 'Funktionelle Richtigkeit'.

117 Südweststaat, I BVerfGE 14, 32 (1951)

118 Battis en Gusy 1991, p. 19, Hesse 1991, 27; 107; Wassermann 1984, p. 107, Zie ook Kirchenbausseuer 19 BVerfGE 206, 220, (1965): 'Die Einheit der Verfassung ist das vomehmstes Integrationsprinzip der Verfassung als eines logischen-teleologischen Sinngebildes, weil das Wesen der Verfassung darin bestehe, eine einheitliche Ordnung des politischen und gesellschaflichen Lebens der staatlichen Gemeinschaft zu sein". 
keitsklausel." Uit de benadering van de constitutie als één geheel vloeit eveneens de bijna vanzelfsprekende eis van consistentie voort: tegenstrijdigheden met andere grondrechtsnormen dienen te worden vermeden. Ook de regel van de 'praktische Konkordanz', waaronder wordt verstaan dat met elkaar conflicterende rechtsbelangen dienen te worden geharmoniseerd ${ }^{120}$ wordt als een grondslag van de systematische interpretatie opgevat. In de eis van concordantie ligt een "Optimierungsgebot" van de grondwettelijke bepalingen besloten. ${ }^{12 !}$ In Liuth is door het Hof ter zake van het recht op vrije meningsuiting het uitgangspunt van 'praktische Konkordanz' fraai weergegeven:

Das Grundrecht auf freie Meinungsäußerung ist als unminttelbarster Ausdruck der menschlichen Persönlichkeit in der Gesellschaft eines der vornehmsten Menschenrechte uberhaupt [...] Aus dieser grundlegenden Bedeutung der Meinungsäußerungsfreiheil für den freiheitlichen-demokratischen Staat ergibt sich, daß es vom Standpunkt aus dieses Verfassungssystems nicht folgerichtig wäre, die sachliche Reichweite gerade dieses Grundrechts jeder Relativierung durch einfaches Gesetz [..] zu uberlassen. [...] Die allgemeinen Gesetze müssen in ihrer das Grundrecht beschränkenden Wirkung ihrerseits im Lichte der Bedeutung dieses Grundrechts gesehen und so interpretiert werden, daB der besondere Wertgehalt dieses Rechts [...] auf jeden Fall gewährt bleübt ${ }^{\prime \prime}{ }^{122}$

Juist yoor constitutionele interpretatie is dit uitgangspunt zo belangwekkend, omdat bij grondrechtsnormen - in vergelijking met de meeste 'gewone' wetsnormen - veeleer sprake lijkt van beginselachtig geformuleerde rechten die ernaar neigen elkaar niet uit te sluiten indien twee grondrechten collideren, zoals een gewone wetsbepaling de neiging tot uitsluiting juist wel heeft. ${ }^{123}$ Gewone wetsbepalingen zijn of geldig, of niet geldig; van grondrechten met een rechtsbeginselachtig karakter kan dat niet zonder meer worden gesteld. De uitleg van constitutionele bepalingen aan de hand van het concordantiebeginsel door het Hof sluit hierbij aan, evenals de veel gehanteerde belangenafweging in de toetsingsfase. De passage in Lüth duidt eveneens aan, dat het Hof het grondrecht plaatst in de systematiek van de grondwet, hetgeen aansluit bij de notie van de "Einheit der Verfassung". Ook de notie van grondwetsconforme uitleg draagt elementen van concordantie in zich, hoewel bij de uitleg van wetgeving van lagere rang de voorrang van de constitutionele bepalingen vermoed wordt. ${ }^{24}$

De teleologische methode onderscheidt zich van de systernatische uitleg vanwege de benadering vanuit een achter de wet gelegen doelstelling van waaruit de rechtsnorm

119 Pent. 2.4.1.

120 Hesse 1991, p. 27; Battis on Gusy 1991, p; 19; Anweiler 1997, p. 95. Zie bijwoorbeeld 7 BVerfGE 198 (208), Luth (1958).

121 De "praktische Konkordanz" is neergelegd in Art. 19 lid 2 GG. "In keinem Falle darf ein Grundrecht in seinem Wesensgehalt angetastet werden'.

122 Lith, 7 BVerfGE 198, 208 (1958).

123 In Diewstphichnerweigerwng 28 BWerfGE 243,261 (1970) stelt het Hof: 'Die schwachere Norm darf nur in so weit zurthckgedrangt werden, wie das logisch und systematisch zwingend erscheint; ihr sachlicher Grundwertgehalt muB in jedem Fall respektiert werden'. In deze zaak dienden twee strijdige belangen tegen elkaar te worden afgewogen, namelijk het belang van het individu op gewetensvrijheid terzake wan diestplicht en het belang van de staat, een veiligheidssysteem op te bouwen die het voortbestaan wan de stat verzekert.

124 Zite bijwoorbeeld Noiaufnahme, 2 BVerfGE 266, 282 (1953) 
wordt ingevuld. In de Duitse doctrine lijken teleologische en systematische interpretatie elkaar voor een groot deel te overlappen daar waar in de systematische methode wordt gekozen voor een buiten de wet gelegen norm - ongeschreven rechtsnormen en algemene rechtsbeginselen - wordt betrokken in de vaststelling van de wettelijke bepaling. ${ }^{125}$ Een fraail voorbeeld van teleologische interpretatie werd in Soraya gegeven; het Hof vulde hier echter op grond van een teleologische constructie wettelijke normen aan. ${ }^{126}$ In die zaak moest het Hof beslissen, of de civiele rechter immaterièle schadevergoeding kon toekennen in het geval van een inbreuk op het "allgemeines Persönlichkeitsrecht'. Een weekblad had een gefallsificeerd interview met prinses Soraya verspreid; het Hof kende aan de prinses een aanzienlijke schadevergoeding toe. Toekenning van schadevergoeding in dit geval lag niet in de lijn van de wetsbepalingen ter zake van immateriële schadevergoeding in het BGB, die slechts kon worden toegekend in bij de wet bepaalde gevallen. Het "allgemeines Persönlichkeitsrecht" vormde echter één van de in Art. 823 lid 1 BGB genoemde gronden voor schadevergoeding. Niet aan de hand van de bij de wet vastgestelde gevallen van immaterielle schadevergoeding, maar in het kader van de onrechtmatige daad stelde het Hof vast dat schade moest worden vergoed:

'Das Recht ist nicht mit der Gesamtheit der geschriebenen Gesetze identisch. Gegenüber den positiven Satzungen der Staatsgewalt kann unter Umständen ein Mehr an Recht bestehen, das seine Quelle in der verfassungsmäßige Rechtsordnung als einem Sinnganzen besitzt und dem geschriebenen Gesetz gegenüber als Korrektiv zu wirken vermag; es zu. finden und in Entscheidungen zu verwirklichen, ist Aufgabe der Rechtsprechung [...] Die Aufgabe der Rechtsprechung kann es insbesondere erfordern, Wertvorstellungen, die der Verfassungsmäßigen Ordnung immanent, aber in den Texten der geschriebenen Gesetzen nicht oder nur unvollkommen zum Ausdruck gelangt sind, in einem Akt des bewertenden Erkennens [...] ans Lichit zu bringen und in Entscheidungen zu realisieren'.

In deze beslissing gaf het Hof invulling aan een civielrechtelijke bepaling aan de hand van een niet nader in de grondwet benoemde constitutionele norm.

\section{Rechtswergelijkende interpretatie}

In de recentere literatuur is het belang van deze uitlegmethode erkend; in de constitutionele rechtspraak zijn eveneens woorbeelden te vinden van de rechtsvergelijkende benadering door het Hof. ${ }^{127}$ In het reeds vermelde Lüh greep het Hof voor de uitleg van Art. 5 lid $2 \mathrm{GG}$ ter zake van de beperking van het recht op vrije meningsuiting terug op de Franse werklaring van de Rechten wan de Mens van 1789 , alsmede op en cital van het Amerikaanse Hooggerechtshof teneinde het geven van prioriteit aar het recht op vrije meningsuiting in de relatie met andere grondrechten te kunnen rechtvaardigen. ${ }^{128}$ Het Hof duidt soms expliciet aan dat de rechtsvergelijking wordt bedreven

125 Zie hiervoor onder 'systematische interpretatie'. Aan de teleologsiche methode wordt hier verder geen afzonderlijke aandacht besteed (zie Larenz 1991, p. 328 e.w.).

126 Sioraya, 34 BVerfGE 269,287 (1973). Zie ook híerna par. 6.3 .5$.

127 Starck 1997, p. $102 \rrbracket$ e.v. Haberle 1997, p. 45 e.v.. Haberle kenschetst de rechlsvergelijkde interpretatie als een 'funfte Auslegungsmethode', Haberle: 1989, p. 913.

128 Luth, 7 B VerfGE 198,208 (1951): "Das Grundrecht auf freie MeinungsauBerung istit als unmitelbarster? 
met het doel, te komen tot de toekenning van de juiste gewichten aan de relevante elementen van de grondwettelike bepaling, wanwege bijvoorbeeld het feit dat met de andere interpretatiemethoden geen goed beeld wordt verkregen van de reikwijdte en consequenties wan een bepaalde lezing. ${ }^{129}$ Aan deze interpretatie kleeft het probleem van de vaststelling van de omtrekken van het concept in het andere rechtsstelsel.

\section{Grondwetsconforme willeg}

Tot een vast uitlegmaxime van het Hof behoort de grondwetsconforme uitleg; het beaamt het bestaan van een vermoeden van grondwettigheid van de aangevochten wetten en van grondwetswijzigingen ${ }^{130}$ Achterliggende gedachte is om een wet niet nietig te verklaren indien een aan de grondwet conformerende uitleg tot de mogelijkheden behoort. Vanuit het gezichtspunt van de constitutionele verhouding tussen rechter en wetgever is dit maxime van groot belang: het stelt de rechter tot op zekere hoogte in staat een rechterlijke taakopvatting te kiezen, die veelal als terughoudend wordt gekenschetst: de rechter grijpt immers niet in in de aangevochten wet. Wanneer het Hof vaststelt dat geen grondwetsconforme uitleg mogelijk is, geeft het dat in het algemeen gemotiveerd aan. ${ }^{131}$ In dergelijke gevallen toetst het Hof de gewraakte wet of wettelijke bepaling steeds intensief. Een vaststelling dat een grondwetsconforme interpretatie niet mogelijk is kan soms leiden tot spanning in de constitutionelle verhoüding. Bij een nietigverklaring laat het Hof in principe aan de wetgever over op welke wijze de nietigheid moet worden hersteld, terwijl de betekenis van een wet bij een grondwetsconforme interpretatie sterk teruggedrongen kan worden.

\subsubsection{Europese Gemeenschappen}

\section{Verdragsinterpretatie door het Hof}

In Art. 220 EG-Verdrag zijn 'recht' en 'verdrag' door het Hof niet als gelijke rechtsnormen uitgelegd. Voor de uitleg van het verdrag dienen eveneens andere maatstaven in het recht te worden aangewend dan alleen het verdrag zelf. ${ }^{132}$ In Art. $220 \mathrm{EG}$ Verdrag is impliciet erkend dat ieder internationaal verdrag aanvulling behoeft van algemene rechtsbeginselen, met name indien het verdrag, zoals het EG-Verdrag niet

Ausdruck der menschllichen Persönlichkeit in der Gesellschaft eines der vomehsten Menschenrechte Uberhaupt (un des droits les plus precleux de l'homme mach Artikel 11 der Erklarung der Menschenund Burgerechte von 1789)", en: "Es ist in gew"ssem Sinn die Grundlage fur jede Freiheit iberhaupt, "the matrix, the indispensable condition of nearly ewery other form of freedom" (Cardozo)". Zie ook bijm woorbeeld Betriebsbethetwgsrech, 32 B VerlGE 54,70 (1971), waarin wordt verwezen naar de Oostenrijkse, $Z$ witserse, Italimanse en Amerikaanse invullingen van het concept van 'woming" in verband met binnentreden.

129 Dienstpflichnerweigerung , 28 BVerfGE 243,258 (1976).

130 Hesse $1991_{1}$, p. 30

131 zie voor zaken warin het Hof grondwetsconforme uitleg gemotiveerd afwees: Besolduhgsrech 8 BVerfOE 28, 34 av. (1958); Bestimm wheit wer Rechsverordrung 8 BVerfGE 71, 78 e.4. (1958); Forderstufe 34 BVerfoE 165, 199 (1972).

132 Everling 1988, p.53. 
wortelt in een lange en gevestigde traditie. ${ }^{133}$ Over interpretatie zegt het EG-Verdrag niet veel, maar een aanwijzing voor rechtsvergelijkende interpretatie is te vinden in verband met aansprakelijkheid van de Gemeenschap voor onrechtmatige daden van de Instellingen en hun personeelsleden. ${ }^{34}$ Het Hof heeft deze aanwijzing als het ware 'gegeneraliseerd' als rechtsbron voor de uitleg van het gehele EG-Verdrag. ${ }^{135} \mathrm{De}$ rechtsontwikkeling door het Hof van Justitie werd gegenereerd vanuit de volgende situatie: bij afwezigheld wan nadere regels over de inrichting van het rechtssysteem bestond voor het Hof de noodzaak zelf algemene regels te stellen. ${ }^{136}$ Het EG-Verdrag hield met name teclmisch-juridische details in, terwijl op hoofdlijnen - doorwerking van EG-recht en voorrangswerking van verdragbepalingen - niets expliciet was vastgelegd. Uit het samenstel van de meer gedetailleerde regelgeving leidde het Hof de hoofdlijnen af. Hiervoor gebruikte het Hof in de eerste plaats de systematische en de teleologische uitlegmethoden.

\section{Tekstuele en historische interpretatie}

In de interpretatie van het Gemeenschapsrecht geldt, evenals in het internationale recht en in andere rechtsstelsels, dat de tekst in de eerste plaats benaderd dient te worden aan de hand van de betekenis wan de woorden. ${ }^{137}$ Het Hof van Justitie neemt overigens, zoals verderop zal blijken, zelden genoegen met alleen tekstuele interpretatie bij de uitleg van het $\mathrm{EG}$-Verdrag. ${ }^{138}$ Daarvoor is de textuur van de verdragsbepalingen in het algemeen te ruim, en dienen problemen zich aan bij de keuze van de taal waarin de bewoordingen van het verdrag worden uitgelegd. Het Hof heeft over dat knelpunt reeds in de zaak Stauder in 1969 gesteld, dat de noodzaak bestaat immer to éénduidige uitlegging van het Gemeenschapsrecht te komen. ${ }^{139}$ Het Hof vertoonde in de beginjaren van de Gemeenschap eerder de neiging strikt aan de verdragstekst vast te houden dan in latere jaren. ${ }^{40}$ Geïsoleerde interpretatie van verdragsbepalingen wordt in beginsel als onwenselijk ervaren.

Autonome termen in het $\mathrm{EG}$-Verdragsrecht heeft het Hof in zijn jurisprudentie reeds vroeg ontwikkeld. In Steenkolenmijnen bepaalde het Hof, dat voor wat betreft tekstuele interpretatie van 'subsidie' en 'steunmaatregelen" de betekenis in het normale spraakgebruik diende te worden aangehouden. ${ }^{141}$ In een zaak betreffende de definitic wan "werknemer" formuleerde het Hof zijn stelling scherper: indien de Lid-Staten aan die: notie hun eigen invulling zouden kumen geven, zouden bepáalde categorieën personen, die nu rechtsbescherming onder het EG-Verdrag genieten op dit terrein, kunnen

133 Anweiler 1997, p. 8. Zie art. 38 lid l sub c van het statuut wan het Internationaal Gerechtshof.

134 Art. 288 lid 2 EG-Verdrag.

135 Koopmans 1991, p. 927.

136 Koopmans (Wiarda 1991), p. 55 .

137 Anweiler 1997, p. 145; Bredimas 1978, p. 34; Schermers en Waelbroeck 1992, p. 11.

138. Schermers en Waelbroeck | 992, p. 12.

139 Stouder, zaak 29/69 (1969), Jur. p. 419, 425 (1969).

140 Bredimas 1978, p. 34; Schermers en Waelbroeck 1992, p. 15; Arweliler 1997, p. 168.

141 Sreenkolenwijnen in Limburg, zaak 30/59 (1961). Jur. p. 93 (1961). 
wordlen buitengesloten, hetgeen zeer onwenselijk is in het kader van de doelstellingen van het verdrag. ${ }^{12}$ Het Hof koos voor deze interpretatie vanuit de gezichtshoek van de doelstellingen wain het verdrag - zeker waar het tot zijn taak rekent, de uniforme untleg van het EG-Verdrag te garanderen. ${ }^{1 A 3}$ Vanwege het onderscheidenlijk karakter van de rechtssystemen van de Lid-Staten in de Gemeenschap heeft het Hof zorgvuldig gewaakt voor het 'voortrekken' van de terminologie uit een stelsel; het wilde het gelijkheidsbeginsel in de benadering van de verschillende taalversies van het verdrag respecteren. Daartoe moest het Hof soms teruggrijpen op een meer autonome invulling wan de verdragstekst, waarbij de Lid-Staten zich in deze autonome invulling nog wel zouden moeten kunnen herkemnen om de interpretatie aanvaard te krijgen. Deze benadering heeft tot op zekere hoogte bijgedragen aan de acceptatie van doorwerking en suprematie van EG-Verdragsrecht in de nationale rechtsordes. In de oudere jurisprudentie aangaande het EG-Verdrag zijn sporen van de historische interpretatiemethode te traceren; uitlegging wan het secundaire recht biedt in dit opzicht meer aanknopingspunten. ${ }^{144}$ In Humblet zoekt het Hof voor de uitlegging aansluiting bij de bedoeling van de verdragspartijen. ${ }^{145}$ Het Hof kan geen gebruik maken van de travaux préparatoires omdat zij geheim zijn. ${ }^{146}$ Niet-openbare documenten worden bij voorkeur vanuit rechtsstatelijk oogpunt en het beginsel van equality of arms niet gebruikt bij de interpretatie, ook al is de inhoud van de betreffende documenten bekend bij het Hof. ${ }^{147} \mathrm{De}$ historische uitleg neemt geen eerste plaats in de interpretatiestrategie van het Hof bij de uitleg van het $E G$-Verdrag in.. ${ }^{14 \%}$

\section{Systematische interpretatie}

In ongeveer de helft van de gevallen, waarin het Hof tot uitleg van een verdragsnorm dient te komen, maakt het gebruik van de systematische uitlegmethode. ${ }^{149}$ Het Hof be-

142 Zie Unger, zalak 75/63 (1964), Jur. p. 369 (1964).

143 Deze taakopvatting wordt bijvoorbeeld in Van Gend en Loos geuit: "dat bovendien de opdracht aan het Hof van Justitie, on door middel van artikel 177 (oud, wu art. 234 EG-Verdrag) de eenheid in de uitleg wan het verdrag door de nathonale gerechten te verzekeren [...]', Van Gend en Loos, zaak 26162 (1963), Jur p. 1, p. $23(1963)$

144 zie daarvoor Anweiler 1997, p. 247.

145 Honblet, zaalk $6 / 60$ (1960), Jur. p. 575 (1960): "Nevertheless it is not sufficient for the Court to adopt the literal interpretation and the Conrt considers it necessary to examine the question whether this inter pretation is confirmed oy other criteria concerning in particular the common intention of the high contracting parties and the ratio llegis. In this respect the fact is that it is not possible to discover any common view taken by the Member States which might serve as a criterion for the interpretation $[. .$.$) .$ The opinions of the governments put forward during the parliamentary debates on the ECSC do not touch on this question:"

146 Scherners en Waebroeck 1992, p. 15; Bengoetxea 1993, p. 71.

147 Anweiler 1997, p. 249.

148 Hierwoor pleit het door het Hof ingenomen standpunt in Vam Gend en Loos in 1962: "dat het gemeenschapsrecht derhal ve, evenzeer als het, onafhankelijk wan de wetgeving van de Lid-Staten, ten laste van, particulieren verplichtingen in het leven roept, ook gesigend is rechten te scheppen welke zij wit eigen hoofde geldig kunnen maken". Enkele Lid-Staten hadden betoogd op basis van de bedoeling van de verdragspartijen, het historisch argument aldus, dat de bepalingen uit het EG-Verdrag slechts aan de LidStaten waren gericht.

149 Anweiler 1997, p. 173 
perkt zich daarbij vaker tot uitleg van een groep van normen waaruit de inhoud van de uit leggen norm wordt gedestilleerd, in plaats van dat het normen binnen een groep eén voor één analyseert. ${ }^{150}$ Het Hof kijkt eveneens naar de plaatsing van het te interpreteren verdragsartikel in het verdrag; de artikelen 2 en 3 bijwoorbeeld zetten de doelstellingen van de Gemeenschap uiteen en zijn vaker aangehaald bij de interpretatie van de bepalingen verderop in het EG-Verdrag. ${ }^{151}$ Verdragsartikelen die op het eerste gezicht niet met elkaar in verband lijken te kunnen worden gebracht, worden door het Hof via een gemeenschappelijk beginsel aan elkaar verbonden: in de zaak Sirena rees de vraag, of de uitoefening van de rechten betreffende een merknaam zouden mogen leiden tot beperking van de werking van Art. 81 en 82 EG-Verdrag. Het Hof bepaalde, dat hoewel merknamen niet direct vallen onder het domein van beide verdragsartikelen, de uitoefening van het betreffende recht wel door deze artikelen geraakt zou kunnen worden. Het redeneerde naar een analogie met Art. 30 EG-Verdrag hetgeen bij uitzondering beperkingen en verboden toestaat op de invoer, dat het beginsel dat aan Art. 81, 82 en 36 EG-Verdrag ten grondslag ligt, de uitoefening van rechten betreffende merknamen zonder acht te slaan op de belangen van de Gemeenschappelijk markt verhindert. ${ }^{152}$ Een fraai voorbeeld waar het Hof het gehele verdragssysteem hanteert teneinde tot een uitlegging van een aspect van de vervoerspolitiek ex Art. 71 EG-Verdrag te komen is de uitspraak ERTA unt 1971. In dit conflict tussen de Commissie en de Raad was ter zake van de rechtsgrondslag de vraag gerezen, of de Gemeenschap bevoegd was, een internationaal verdrag ter zake af te sluiten. Het Hof redeneerde, dat naar de verdragssystematiek diende te worden gekeken omdat Art. 71 geen antwoord

150 Zie bijwoorbeeld Costa-ENEL, zaak 6/64 (1964), Jur. p. 585 (1964): 'Overwegende dat de gevraagde uitlegging van artikel 37 ertoe dwingt, gezien de ingewikkeldheid van de tekst en gezien het onderlinge verband tussen de leden 1 en $2_{;}$deze leden te beschouwen in het licht van het hoofdstuk waarvan zij deel uitmaken; dat dit hoofdstuk is getiteld "Afschaffing van de kwantitatieve beperkingen tussen de Lid-Staten" [...]'; eveneens Manghera, zaak 59/75 (1976), Jur. p. 91 (1976): "For the purposes of inter"preting article 37 as regards the nature and scope of adjustment prescribed it must be considered in its contrext in relation to the other paragraphs of the same article and it its place in the general scheme of the Treaty. [...] It follows from these provisions and their structure that the obligation lidid down in paragraph 1 ains at ensuring conpliance with the fundamental nile of the free movement of goods throughout the common market, in particularly by abolition of guantitative restrictions and measures having equiwalent effect in trade between Member States".

151 The position of these articles (artikel 23, art. 9 oud en 13 lid 2 (opgeheven met de inwerkingtreding van het Verdrag van Amsterdam) EG-Verdrag, H.L.J.) at the beginning of that part of the Treaty reserved for the "Foundations of the Community" is sufficient to undicate their crucial role in the construction of the common market", zie Bresciani, zaak 87/75 (1976), Jur. p. 129 (1976).

152 ". . I since national rules concerning the protection of industrial and commercial property have not yet been unified within the framework of the Community, the national character of dhis protection is liketly to create obstacles, both to the free movement of proprietary products, and to the community system of competition. In the sphtere of provisions rellating to the free moment of products, prohibitions and restrictions on imports justified on the grounds of protection of industrial and commercial property are allowed by Article 36 (oud, nu Art. 30 EG-Verdrag) [...]. Article 36, although it appears in ihe chapter of the Treaty dealing with quantitative restrictions on trade between Member States, is based on a priticiple equally applicable to the guestion of competition, in the sense that even if the rights recognized by the legislation of a Member State on the subject of industrial and commercial property are not affected [...] by Articles 85 (nu Art 81 EG-Werdrag) and 86 (nu Art 82 EG-Verdrag) of that Treaty, their exercise may still fall under the prohibitions imposed by those prowisions", Sirema, zaak 40/70 (1971), Jur. p. 69 (1971). 
gaf op deze vraag; daaruit concludeerde het dat de bevoegdheid tot het aangaan wan dit verdrag bij de Gemeenschap diende te liggen.. ${ }^{153}$ Ook heeft het Hof voor de uitleg van verdragsbepalingen herhaaldelijk teruggegrepen op de andere oprichtingsverdragen. ${ }^{154}$

\section{Teleologische interpretatie}

Herhaldelijk heeft het Hof aangeduid, dat de teleologische uitlegmethode de meest gebruikte interpretatiewijze van het EG-Verdrag is. ${ }^{155}$ Het is uitdrukkelijk niet het doel van het verdrag, details en eventualiteiten vast te leggen. Aan de hand van de teleologische methode interpreteert het Hof de verdragsbepalingen aan de hand van met name de in artikelen 2 en 3 EG-Verdrag neergelegde doelstellingen. De teleologische uitleg is een methode die het Hof, evenals de systematische methode of in combinatie daarmee, beter in staat stelt, coherentie in zijn jurisprudentie te handhaven. ${ }^{156}$ Deze uitlegmethode wordt zelfs niet gezien als een "ultimum remedium" dat eerst wordt gebruikt indien de andere methoden, zoals de tekstuele, falen. Het werzekeren van de naleving van dle constitutie brengt in het algemeen met zich, dat bij de witleg ervan gekozen dient te worden voor een methode die niet vasthoudt aan rigide noties, maar én die de uitlegger in staat stelt de constitutionele doelstellingen verder te bevorderen. ${ }^{157}$ Tezelfdertijd rijst in dit verband de vraag, in hoeverre deze uitlegmethode de weg opent voor variaties in de interpretatie van de EG-Verdragstekst door het Hof. Binnen de teleologische interpretatiewijze hanteert het Hof nog een specifieke wijze van uitleg van het verdrag, teneinde te kunnen komen tot de opvulling van leemten en invulling van vage normen. Andere normen, zoals bijwoorbeeld algemene beginselen van gemeenschapsrecht, vormen in dit verband belangwekkende bronnen van recht. Het sluit in deze benadering niet aan bij geëxpliciteerde doelstellingen uit Artikel 2 en 3 EG-Verdrag, maar bij constitutionele tradities die de Lid-Staten van de EG gemeenschappelijk hebben. De invulling van normen aan de hand van beginselen is aan te merken als een teleologie: de rechter onderzoekt aan de hand van achterliggende doelstellingen welke de inhoud is van een verdragsnorm. De teleologie lijkt te worden losgelaten, wanneer de rechter de verdragsbepaling invult aan de hand van normen die niet expliciet in het verdrag zijn opgenomen, maar er, blijkens de jurisprudentie van het Hof, wel deel van uitmaken. Met behulp van deze beginselen van gemeenschapsrecht is het Hof in staat gebleken, om tot op zekere hoogte een kader van constitutionele normen op te bouwen, los van de geexpliciteerde doelstellingen ex Artt. 2 en 3 EG-Verdrag. Het Hof ontwaar-

153 De commissie claimde, dat de Raad bij het sluten van het ERTA-Verdrag voorbij was gegaan atan de Artt. 71, 300 en 308 EG-Verdrag, waaruit zou moeten worden afgeleid dat de Commissie bewoegd was het betreffende verdrag te sluiten. Naar Art. 71 is de Kaad bevoegd, regels te stellen op dit terrein. Wat betreft de onderhandelingen voorafgaand an internationale overeenkomsten echter ${ }_{\text {zijn }}$ Commissie en Raad samen bevoegd. Aan dit aspect was de Raad geheel voorbij gegan. Het Hof neemt voor de oplossing wan het conflich het EG-Verdrag in zijn geheel in beschouwing: het systeem van de interne Gemeenschapsregels mag niet worden onderscheiden van het systeem van de exteme (in dit verband intemationale) betrekkingen (ERTA, zaak 22/70 (1971), Jur. p. 263 (1971).

1.54 Anweiler 1997, p. 182 e.v.

155 Anweiler 1997, p. 198 e.v.; Bredimas 1978, p. 71 ; Pontier 1995, p. 37.

156 Bredimas 1978, p. 80 .

157 Bredimas 1978, p. 80 . 
de ze in de onderliggende structuur van de constitutie. In de zaak Les Verts bijvoorbeeld, veranderde het Hof met behulp van teleologische interpretatie de lezing van art. 230 het EG-Verdrag zoals die tot dan toe werd opgevat. ${ }^{158}$ In het EEG-Verdrag werd het Europees Parlement niet genoemd als Gemeenschapsorgaan, waarvan de handelingen op wettigheid door het Hof van Justitie konden worden gecontroleerd. Het Hof stelde:

[...] art. 173 refers only to acts of the Council and the Commission. However, the general scheme of the Treaty is to make a direct action available against all measures adopted by the institutions which are intended to have legal effects. [...] The European Parliament is not expressly mentioned among the institutions whose measures may be contested because, in its original version, the EEC-Treaty merely granted it powers of consultation and political control rather than the power to adopt measures intended to have legal effects vis-a-vis third parties".

In deze redenering vult het Hof uitdrukkelijk de oorspronkelijke bedoeling van de wetgever opnieuw in. De leemte betreffende de jurisdictie van het Hof wordt opgevuld als had de wetgever de nieuwe rol van het Europees Parlement over het hoofd gezien bij de toedeling van controlemechanismen in het EEG-Verdrag. ${ }^{159}$

Een beginsel dat het Hof reeds sinds de beginperiode heeft gehanteerd is het zogenoemde "effet utile" van de verdragsbepalingen. ${ }^{160}$ In Van Gend en Loos zocht het Hof met behulp van teleologische uitleg nar de doelstellingen die aan het verdrag ten grondslag liggen, die aldus verder gingen dan de in het verdrag geexpliciteerde doelstellingen:

'Overwegende dat de voorrang van het gemeenschapsrecht wordt bevestigd door artikel 189 , bepalend dat de verordeningen verbindend zijn en rechtstreeks toepasselijk in elk van de Lid-Staten; dat deze bepaling, die zonder enig voorbehoud is neergeschreven, van iedere betekenis zou zijn ontbloot indien een Staat de gevolgen ervan eenzijdig zou kunnen te niet doen door een wettelijk voorschrift uit te vaardigen, dat boven de gemeenschapsbepalingen uit zou gaan., 161

In sommige gevallen bleek de teleologische uitlegmethode met hantering van hel effectiviteitsbeginsel niet toereikend teneinde een bevredigende uitleg te geven aan een verdragsbepaling; het Hof bezigde in dat geval het aan "effet utile" gerelateerde "effernécessaire'. 162 Indien het Hof deze benadering hanteert, neemt het een aantal rechtsnormen, geschreven of ongeschreven, tezamen, en leidt daaruit een resultaat af. Het Hof gaat uit van een 'acquis', een axioma in het Gemeenschapsrecht, dat het naar eigen zeggen afleidt uit constructies van de doelstellingen van de verdragstekst of van de verdragstekst in combinatie met andere documenten. Bij het nastreven van de doelstellingen dient niet alleen recht gedaan te worden aan de effectiviteit van Gemeenschaps-

158 Les Verts, zaak $294 / 83$ (1986), fur p. 1651 (1986).

159 Zie in dit verband ook Rogers, zaak 87/82 (1983), Jur. p. 1579 (1983).

160 Anweiler 1997, p. 219.

161 Fan Gend en Loos, zaak $26 / 62$ (1962).

1:62 Bredimas maakt van deze methode als enige meldirg (Bredinas 1978, p. 78 ev.). 
recht, dat impliciet in deze methode opgesloten ligt; er gaat eveneens een noodzaak uit van deze wijze van interpreteren om de doelstellingen van de Gemeenschap-in-wording te realiseren. Het Hof kan, met andere woorden, niet anders dan op déze wijze interpreteren wil het zijn taak naar behoren kunnen vervullen. Fraai voorbeeld in de rechtspraak van het Hof is wederom de zaak ERTA, waarin het een 'implied power' afleidde uit de noodzakelijke bevoegdheden ter verwezenlijking van de doelstellingen van het verdrag:

'Although it is true that articles 74 and 75 (oud) do not expressly confer on the Community authority to enter into international agreements, nevertheless the bringing into force $[\ldots]$ of Regulation $543 / 69$ of the Council on the harmonization of certain social legislation relating to road transport necessarily vested in the Community power to enter into any agreements with third countries relating to the subject-matter governed by that Regulation. ${ }^{363}$

Via teleologische interpretatie heeft het Hof eveneens de beginselen van suprematie en rechtstreekse toepasselijkheid van EG-recht bevestigd, hetgeen in het kader van een aanvankelijk intergouvernementele afspraak als uitzonderlijk wordt bestempeld. De EG-Verdragstekst maakt geen expliciete of impliciete melding van suprematie of directe inroepbaarheid van de EG-Verdrag. Het Hof werkte eerst het beginsel van rechtstreekse toepasselijkheid uit. Het Gemeenschapsrecht werd op deze wijze onderdeel van de nationale rechtsordes, waarna zich, als vanzelfsprekend, de kwestie van suprematie aandiende. Rechtstreekse toepasselijkheid vergde een effectieve garantie, hetgeen resulteerde in de uitwerking van de notie van suprematie. De vestiging van beide beginselen heeft in een evolutionair proces vorm gekregen in de jurisprudentie van het Hof, waarbij de teleologische en de systematische uitlegmethoden de meest logische aanknopingspunten boden. Zij stelden het Hof in de gelegenheid, uit te stijgen boven de meer traditionele regels die in het internationale recht gelden, zoals interpretatie die de soevereiniteit van de verdrägspartijen zoveel mogelijk in tact laat. Een interessante vraag is of het Hof de notie van 'effet utile' bij de interpretatie van grondrechten heeft aangewend. Het ligt, gezien het mandaat op het economische terrein, niet voor de hand dat het Hof steeds een benadering ten faveure van de individuele rechtsbescherming hanteert. ${ }^{164}$

\section{Dynamisch-evolutieve interpretatie}

De dynamisch-evolutieve uitlegtechniek wordt door het Hof eveneens gebruikt. De algemene benadering daarin is dat de Lid-Staten zich hebben verbonden aan een project, waarvan de doelstelling niet een statische was maar waarin getracht wordt een politiek evenwicht te bewaren: de oprichtingsverdragen hebben veeleer tot doel, bij te

163 ERTA, zank 22/70 (1971), overwaging 28. Het arrest vervolgt: "This grant of power is moreover expressly recognized by Article 3 of the said Regulation which prescribes that "The Community shall enter into any negotiations with third courtries which may prove necessary for the purpose of implementing this Regulation". Since the subject-matter falls within the scope of Regulation $543 / 69$, the Community thas been empowered to negotiate and conclude the agreement in question since the entry into force of the said Regulation.

Zive par. 3.4 
dragen aan een voortschrijdend proces, de Europese integratie: ${ }^{165}$ Daarin is onder meer verdisconteerd de openheid naar nieuwe ontwikkelingen, die in zichzelf wederom naar een versterkte doelstelling - Europese integratie - neigen. ${ }^{166}$ De hoofddoelstelling van de te interpreteren bepaling dient te worden gehandhaafd; de nadere uitwerking ervan is onderhevig aan een dynamische evolutie. Het Hof heeft in CILFIT de dynamischevolutieve benadering uitdrukkelijk een plaats gegeven binnen de communatutaire interpretatiemethoden. ${ }^{167}$ Het bezigen van deze uitlegmethode kan verstrekkende gevolgen hebben voor de constitutionele verhouding tussen het Hof en verdragswetgever. Het Hof kan aan verdragsbepalingen een dynamische uitleg geven waarin eén of meer LidStaten zich niet herkennen, maar waaraan zij echter wel gebonden zijn. Formeel kan men stellen dat de Lid-Staten de 'Herren der Verträge' zijn, maar in de praktilik blijkt dat de door het Hof uitgezette jurisprudentielijnen niet worden gecorrigeerd door de Lid-Staten in de vorm van een verdragswijziging. ${ }^{168}$ Handhaving van de eenheid van uitlegging en toepassing van het EG-Verdragsrecht lijkt in de optiek van het Hof een gekoesterd goed te zijn. Het Hof heeft in dit verband het uitlegmaxime 'eenheid van het verdragsrecht' ontwikkeld. Dat laatste werd onder meer afgeleid uit de functie van de prejudiciële procedure. ${ }^{169}$

\section{Rechtsvergelijkende interpretatie}

Het Hof heeft zich voor de interpretatie van het EG-Verdragsrecht verlaten op concepten uit de rechtsordes van de Lid-Staten, concepten van internationaal publiekrecht, alsmede op recht van staten niet zijnde EG-Lid-Staten. ${ }^{170}$ De internationaalrechtelijke

165 Ukraw 1995, p. 93 e.v.

1.66 Zije bijwoorbeel Opinie 1/78 yan het Hof wan 4 oktober 1979 over Art. 300 lid 2 (228 lid 2 oud) in verband met het sluiten van een internationale overeenkomst met derde landen terzake wan rubber. In deze opinie beantwoordt het Hof naar aanleiding van de vraag, wie bevoegd is de betreffende overeenkomst te sluiten - Raad of Commissie. Gaat het hier om handelsbelangen van de $\mathrm{EG}_{\text {, of om enkel }}$ om de belangen van de rubberexporterende staten? Indien het laatste slechts een rol speelde, zou dalt pleiten voor een benadering, waarin enkel de Raad de bevoegdheid had tot het sluiten wan de overeenkomst. Het Hof gaf in casu een dynamisch-evolutieve lezing van Art. 133 EG-Verdrag (113 oud), waarbij het vaststelde dat beide belangen in de overeenkomst een rol speelden. Een coherente handels. politiek zou niet meer kunnen voortbestaan, indien de Gemeenschap niet de mogelijkheid zou kemnen, haar bevoegdheden ook zou kunnen uitbreiden naar een nieuwe categorie van internationale overeenkomsten. Deze nieuwe categorieën worden bijwoorbeeld gevormd doordat factoren die in de overeenkomsten eerst een ondergeschikte rol speelden, zich op een later tijdstip tot een belangrijke factor ontwikkelen in de economische betrekkingen tussen twee partijen.

167 'Finally, ewery provision of Community law must be placed in its context and interpreted in the light of the provisions of Community law as a whole, regard being had to the objectives thereof and to its state of evolution at the date on which the provision in question is to be applied", CILFTT, zaak 283/81 (1982). Jur. p. 3415 (1982).

168. De Lid-Staten kunnen het EG-Verdrag wijzigen of zich terugtrekken uit de Gemeenschap, maar beide lijken eerder theoretische mogelijkheden voor de Lid-Staten om zich te onttrekken aan de uitspraken van het Hof. In dit verband kan het Hof worden aangenuerkt als én van de "Herren der Verträge', een betiteling die in beginsel alleen de Lid-Staten werd toebedeeld (zie ook Ukrow 1995, p. 96). De wrees woor divergenties is evenwel aanwezig bij het Hof, dat steeds benadrukt dat de eenheid wan het EGrecht gehandhaafd dient te worden.

169 Wan Gend en Loos, zaak 26/62.

170 Zie Lenz 1993 , p. 585 e.v. voor voorbeelden. 
en nationale concepten bieden het Hof vooral beginselen en uitgangspunten, en nauwelijks op maat gesneden oplossingen. Het Hof heeft het meermaals tot zijn taak gerekend, een gemeenschappelijke noemer te traceren uit bijvoorbeeld de verschillende nationalirechtelijke noties. In eén van zijn eerste oordelen liet het Hof zich uit over de term 'detournement de pouvoir', een term uit het Franse publiekrecht maar bekend in het publiekrecht in andere rechtsstelsels. A-G Lagrange verrichte een rechtsvergelijkend onderzoek in de rechtsordes van de Lid-Staten naar de betekenis van deze term, teneinde op Gemeenschapsniveau te komen tot één opvatting van het begrip. ${ }^{171} \mathrm{De}$ openheid van de constitutie voor deze wijze van redeneren is, sinds de oprichting van de Gemeenschap, onder meer terug te voeren op Art. 288 EG-Verdrag, hetgeen verwijst naar de algemene beginselen die de Lid-Staten gemeen hebben indien vanuit nietcontractuele aansprakelijkheid schade is veroorzaakt door de Instellingen. Het Europese Unie-Verdrag (EU-Verdrag) verwijst eveneens naar de gemeenschappelijke constituthonele tradities en het Europese Conventie voor de Rechten van de Mens, wanneer het gaat om de eerbiediging van de grondrechten. ${ }^{172}$

Het Hof zal niet gauw overgaan tot het opstellen van een lijst met specifieke toepassingen van de nationaalrechtelijke beginselen; dat is politiek gezien niet wenselijk en het vergt onderzoek. ${ }^{173}$ Vaker verrichten Advocaten-Generaal dit type onderzoek. De jurisprudentie van het Hof laat veeleer een voorkeur van grote لijnen zien, toepassing van beginselen met een algemener karakter, die binnen de rechtsordes van de LidStaten een status van universaliteit genieten. ${ }^{174}$ Hoe het Hof te werk gaat indien het interpreteert aan de hand van rechtsvergelijkend onderzoek, kan worden geillustreerd aan de hand van de zaak $A . M$ \& $S$. Europe $L t d .{ }^{175}$ In deze zaak kwam de wraag aan de orde in hoeverre de Europese Commissie gebonden is aan het uitgangspunt dat de bedrijfsjurist verbonden aan een onderneming zich beroept op geheimhouding. De Britse rechtstraditie erkende het bestaan van een dergelijk beginsel, maar de Franse regering en de Europese Commissie trokken het bestaan ervan in de Gemeenschapsorde in twijfel. In de Franse rechtstraditie bestond geen bekendheid met het beroepsgeheim op deze terteinen van het recht. Het Hof verzocht de partijen, teneinde de conflicterende standpunten in kaart te brengen en te verzoenen, rechtsvergelijkend onderzoek te produceren aan de hand waarvan kon worden vastgesteld, in hoeverre een dergelijk beginsel bestat in de nationale rechtsorde; tevens verzocht het Hof om de visie van beide partijen op het bestaan van het beginsel van geheimhouding in de Europese rechtsorde. ${ }^{176}$

171 In eerste instantie greep het Hof daarbij terug op de invulling van détournement de pouvoir zoals die wordt gegeven door de Consel d"état. Nacerhand werd door het Hof van Justitie eveneens de Duitse, wat ruimere imvulling betrokken in de uitleg van détoumement de pouvoir. Zie de opinie van $A \cdot G$ Lagrange bij Assider, zaak $3 / 54$ en $15 a^{2}$ zalk 454 (1954), Jur. p. 191 (1954); ook Schermers en Waelbroeck 1992 ; p. 13. Zie ook M. Luisa Fernandez Esteban 1995, p. 136.

172 Art. 6 lid 2 EU-Verdrag.

173 Koopmans 1991, p. 499.

174 Zie ook Heringa 1996, p. 143.

175 A.M \& S. Europe Lid, zakk $155 / 79$ (1982), Jur. p. 1575 (1982).

176 The Court consixters, in view of the issues of fact and of l aw which were emphasized at the hearing $[. .$. that it is necessary, for the purposes of giving judgement, to examine more thoroughly the dispute between the parties with regard to certain specific aspects of the matters in question so as to clarify their 


\subsubsection{Raad wan Europa}

\section{Algemene interpretatieregels bij het EVRM}

Het $\mathbb{H o f}$ neemt voor de uitleg van de Conventie de interpretatieregels ex art. 31 en 32 van het Weens Verdragenverdrag in acht. ${ }^{177}$ In zijn rechtspraak heeft het Hof regelmatig de belangrijkste uitgangspunten aangaande de interpretatie herhaald: de Conventie en zijn protocollen vormen één geheel en dienen in zijn geheel benaderd te worden. ${ }^{178}$ De visie van het Hof op de Conventie is dat het een rechtsscheppend karakter heeft, hetgeen met zich meebrengt dat de interpretatie erop gericht dient te zijn, de doelstellingen van de Conventie te realiseren en dat niet het conserveren van de staatssoevereiniteit van de verdragsluitende partijen voorop dient te staan. ${ }^{179}$ In een aantal uitspraken heeft het Hof deze benadering van de Conventie verfijnd:

Unlike international treaties of the classic kind, the Convention comprises more than mere reciprocical engagements between contracting states. It creates, over and above a network of mutual, bilateral undertakings, objective obligations which, in the words of the Preamble, benefit from a "collective enforcement". 180

Het Hof heeft gekozen voor een overwegend teleologische visie op de Conventie, waarin het de reële effectuering van de doelstellingen nastreeft. ${ }^{181}$ De tekstuele inter-

respective contentions on the problem of the protection of the confidential nature of commumications between undertakings and their legal advisers", zie Order of the Court in $A . M \& S$. Europe LAd, zalk 155/79. Zise ook par. 7.3.1.

177 Art. 31 lid 1 Weens Verdragenverdrag luid: "een verdrag moet te goeder trouw worden tiitgelegd overeenkomstig de gewone betekemis van de termen van het Verdrag in hun context en in het licht van linet voorwerp en doel van het Verdrag". Art. 31 lid 2 luidt: "Voor de uitlegging van een verdrag ormvat de context, behalve de tekst, met inbegrip van preambule en bijlagen [...]. Art. 32 van het Weerns Verdiragenverdrag verwijst naar de aanvullende middelen wan uitlegging: "Er kan een beroep worden gedaan op aanvullende middelen van vitlegging en het bijzonder op de voorbereidende werkzaambeden en de omstandigheden wasonder het verdrag is gesloten, om de betekenis die voortvloeit uit de toepassing van artikel 31 te bevestigen of de betekenis te bepalen indien de ulthegging, geschiedt overeenkomstig artikel 31 : a) de betekenis dubbelzinnig of duister laat; of b) leidt tot een resultat dat. duidelijk ongerijmd of onredelijk is ".

178 Golder 4. Verenigd Koninkryk, EHRM 21 februari 1975, Serie A vol. 18, par. 29-30; "The Court is pre pared to consider, as do the Govermment and the Commission, that it should be guided by Articles 31 to 33. of the Viema Convention of 23 May 1969 on the Law of Treaties. That Comvention has not yet entered into force and its specifies, at Article 4, that it will not be retroactive, but its Articles 31 10 33 enunciate in essence generally accepted principles of intermational law to which the Court has already referred on occastion".

179 Zie Wemhoff t. Duitsiand, EHRM 27 juni 1968, Serie A vol. 7 p. 21 : "As the word reasonable applies to the time whitin which a person is entitled to a trial, a purely grammatical interpretation would leave the judicial authorities with a choice between two obligations, that of conducting the proceedings until judgement within reasonable time or that of releasing the accused pending triall [...]. The Court is gutte certain that such an interpretation would not conform to the intention of the High Contracting Parties. It is inconceivable that they should have intended to permit their judicial authorities, at the price of release of the accused, to protract proceedings beyond a reasonable time'.

180 lerland t. Verenigd Koninkrijk, EHRM 18 januari 1978, Serie A vol. 25, par. 239 Zie voor nadere verfijning van deze regel Louizidou t. Turkije, EHRM 23 maart 1995, par. 70 en Soering $t$. Veremigd Koninkrijk, EHRM 7 juli 1989, Serie A vol. 161 par. 87.

181 Schokkenbroek 2000, p. 4. 
pretatiemethode speelt aldus een ondergeschikte rol in de uitleg van de bepalingen van de Conventie. De andere interpretatiemethoden hebben binnen de teleologische benadering hun betekenis. Het Hof heeft benadrukt dat de uitleg van de Conventie

"is a process of interpretation of a treaty is a unity, a single combined operation'.

Dit uitgangspunt wijst op een benadering van het EVRM als een eenheid. In de navolgende onderdelen wordt uiteengezet, welke technisch-juridische redeneerwijzen binnen die 'single combined operation' steeds terugkeren.

\section{Tekstuele en historische interpretatie}

Ook het EHRM neemt de tekst van de conventie als uitgangspunt voor de interpretatie ${ }^{1.82}$; het is echter nooit het doorslaggevende element in de uitleg van een artikel in de Conventie. ${ }^{183}$ De Franstalige en Engelstalige teksten van de Conventie zijn authentiek. Indien verschillende betekenissen naar voren komen vanwege de taalversies, dient de uitleg gekozen te worden die het doel van de Conventie het beste dient. ${ }^{184}$ Zoals voorheen reeds gesteld, kiest het Hof bij de uitleg van de Conventiebepalingen niet voor een formeeltekstuele benadering. De intenties van de verdragspartijen zijn, zoals ze zijn terug te vinden in de "travaux préparatoires", van een relatief geringe beteken is voor het Hof $^{185}$ In de periode net na inwerkingtreding van de Conventie was dat anders, maar met het verstrijken van de tijj heeft het Hof steeds minder vaak teruggegrepen op deze bron. Zij worden eventueel gebruikt als aanvullend argument. ${ }^{186}$ Zoals zal blijken, conflicteert de historische methode met de door het Hof veelgekozen teleologische en dynamisch-evolutieve uitlegmethoden, die het Hof meer mogelijkheden bieden om te komen tot een uitleg van de Conventie die past in de huidige Europese samenlewing. ${ }^{187}$ Dissentings, waarin de argumenten steunen op de 'travaux', pleiten overigens vaak voor een restrictievere uitleg van de bepalingen in de Conventie vergeleken met de uitleg waarvoor het Hof in de betreffende casus heeft gekozen. ${ }^{188}$ Kenmerkend voor de interpretatie is dat het Hof sommige termen beschouwt als 'autonome begrippen': deze

182 Jacot-Ouillarmod (Pettiti 1995), 43; Ost (Delmas-Marty 1992), p. 288

183 Ost (Dellnas-Marty 1992), p. 288, zie ook Pettiti 1995, p. 44.

184 Art. 33 lid 4 Weens Verdragenverdrag, Zie ook Ost (Delmas-Marty 1992), p. 293 .

185 Alkema 1978, p, 26. Zie ook Louizidow, 23 maart 1995, A. 310, par. 71.

186 Sommige auteurs beschouwen de travaux als "onbetrouwbare bron van informatie" voor verofrgsuitleg. (Jacobs en White 1996, p. 33). Zo ook: Ost (Delmas-Marty 1992), p. 289. Indien de door het Hof wastgestelde betekenis van een bepaling in de Conventie in strijd is met hetgeen is terug te winden in de "travaux", zal het Hof" aan de toermalige intentie van de verdragspartijen niet autonatisch voorrang. verlenen (zie bijvoorbeld Young, James en Webster 1. Werenigd Koninkrijk, EHIRM 13 augustus 1981, Serie A vol 44 par. 51 en 52 )

187 In zijn analyse van de rechtspraak van het Hof van Justitie van de EG stelde Kutscher: "An interpretation based on the situation at the time of inception is totally ill-adapted to community law which looks to the future'. Dit statement gat eveneens op voor de vitleg van de Conventie (zie Ost (DelmasMarty 1992), p. 290\%. Het Hor geef, bij wijze van thitzondering, in de zaak Johnston aan de travaux preparatoires doorslaggevende betekenis; het onderzoekt of de verdragstaten destijds de bedoeling hadden, in Art. 12 ECRM eveneens een recht op echtscheiding vast te leggen (Johnsion t. Jerland, EHRM 18 december 1986, Serie A vol. 112 par. 52 ).

188 Zle bijvoorbeeld Feldbrugge $t$. Nederland, EHRM 29 mei 1986, Serie A vol. 99, dissenting. 
kunnen maar hoeven niet noodzakelijkerwijze overeen te komen met temen die in het nationale recht worden gebezigd. Het toekennen van een autonome betekenis aan bepaalde EVRM-begrippen heeft tot doel dat niet alleen de effectiviteit van de verdragsbepalingen, maar ook de rechtseenheid en rechtsgelijkheid worden bevorderd. ${ }^{189}$

\section{Systematische imerpretatie}

De systematische uitlegmethode vormt een door het Hof veelvuldig gebruikte uitlegmethode en wordt vaak gebruikt in combinatie met de teleologische methode. "Het Hof heeft meermaals benadrukt, dat de interpretatie van de bepalingen in de Conventie in overeenstemming dient te zijn met de logica van de Conventie, hetgeen de stelling dat systematische interpretatie bijdraagt aan coherentie van de uitleg van de Conventie ondersteunt. ${ }^{191}$ Systematische interpretatie opent mogelijkheden voor extensieve interpretatie, maar heeft niet steeds vanzelfsprekend to gevolg. ${ }^{192}$ De context waarbinnen het Hof kiest voor systematische interpretatie is op geen enkele wijze in de Conventie vastgelegd. De keuze varieert van een enkele paragraaf tot de gehele Conventie, waarbij de Preambule en de Protocollen worden betrokken. Soms betrekt het eveneens het Statuut van de Raad van Europa of een resolutie van het Comité van Ministers of zelfs verdragen uit een rechtsorde waarvan het geen deel uitmaakt, in zijn systematische beschouwing van een artikel uit de Conventie. ${ }^{193}$ De context waarbinnen systematische interpretatie verkozen wordt, hangt dikwijls echter samen met de doelsteilingen die aan de bepaling ten grondslag liggen; In dit opzicht valt systematische interpretatie vaker samen met de teleologische uitlegmethode. ${ }^{194}$ Voor systematische uitleg heeft het Hof bijvoorbeeld gekozen wanneer een recht van een individu mogelijk wordt beschermd door een bepaling in één van de protocollen dat de aangeklaagde staat echter niet heeft ondertekend. In Abdulaziz t. Verenigd Koninkrijk konden de klagers zich verlaten op het recht op gezinsleven als neergelegd in art. 8 EVRM teneinde de Britse immigratiewetgeving aan te vechten; het Verenigd Koninkrijk had het Zevende Protocol niet ondertekend. ${ }^{195}$ De niet-ondertekening van een protocol kan kennelijk aan

189. Sichokkenbroek 2000, p. 9 .

190 Pettiti 1995, p. 44; Ost (Delmas-Marty 1992), p. 290; Jacobs en White 1996, p. 29. Alkema wijst erop, dat dit niet altijd zo geweest is; in 1978 stelde hij wast dat de contextuele benadering slechts zelden tol uiting Kwam (Alkena 1978, p. 22).

191 Leandert. Zweden, EHRM 26 maart 1987, Serie A vol. 116, par. 78.

192 Bijvoorbeeld in Johnston t. Verenigd Koninkrijk, EHRM 18 december 1986, Serie A vol. 12 , warin het Hof bepaalde dat het recht op echtscheiding niet kan worden ingelezen in het recht on te trouwen ex art. 12 van de Cowventie. Het kan mitsdien niet worden afgeleid tuit art. \& EVRM, Hetgeen een ruimer bereik heeft.

193 De Belgische poliriezack. EHRM 27 aktober 1975, Serie A vol. 19 verwijst bijvoorbeeld naar hent Europees Sociaal Handvest; in de zaak Van der Mussele t. Belgie. EHRM 23 november 1983, Serie A vol. 70 wordt verwezen natar de International Labour Organisation; in de zaak Marckx wordt verwezen nar verdragen betreffende buitenechtelijke kinderen (Marckx t. Belgie, EHRM 13 juni 1979, Serie A vol. 31, par. 41). Zie voor bronnen met betrekking tot de Raad van Europa: Pettiti 1995, p. 44.

194 Jacobs en White 1996, p. 31.

195 Abdulaziz e.a. Verenigd Koninkrik, EHRM 28 mei 1985, Serie A vol 94, zie aok Rasmussen t. Denemarken, EHRM 28 november 1984, Serie A vol. 87 wad het Hof est rume uilleg geeft aar Art. 8 EVRM en derhalve in het geheel niet behoefde toe te komen aan de beoordeling, of ant 5 wan het 
ruime interpretatie van een andere relevante bepaling in de Conventie niet altijd in de weg staan. ${ }^{66}$ Op deze uitspraken is kritiek gekomen van onder meer rechter Fitzmaurice, die stelde dat indien de bepalingen in de Conventie dermate extensief kunnen worden geinterpreteerd, de protocollen overbodig zijn, en de staten via deze redenering zijn onderworpen aan afspraken die zij expliciet niet hebben onderschreven. ${ }^{197}$ In Abdulcziz was het mogelijk, de vreemdelingenproblematiek te beschouwen onder het recht op gezinsleven ex Art. 8, omdat eveneens familierechtelijke betrekkingen een rol speelden in deze zaak. In het licht van de constitutionele verhoudingen tussen Hof en nationale staten is een uitspraak waarin het niet-ondertekenen van een protocol als het ware wordt omzeild een niet voor de handliggende operatie: het Hof bindt de staat in deze concrete zaak via het recht op familieleven aan aspecten van dat protocol.

\section{Teleologische interpretatie}

Overeenkomstig art. 31 lid 1 Weens Verdragenverdrag legt het Hof de bepalingen van de Conventie uit in het licht van het voorwerp en het doel van de Conventie. Deze teleologische benadering is de meest gebruikte redeneerwijze in de rechtspraak van het Hof. ${ }^{198}$ De wijze watrop het Hof de doelstellingen van de Conventie construeert, leidt tot op zekere hoogte eerder tot een extensieve interpretatie van de rechten. ${ }^{199}$ Een restrictieve constructie van deze rechten wordt in het algemeen afgewezen, hetgeen samenhangt met het vermoeden ten faveure van de individuele rechtsbescherming. ${ }^{200} \mathrm{Het}$ Hof heeft enkele doelstellingen geformuleerd die volgens het Hof ten grondslag liggen aan de Conventie, en die tot de ontwikkeling van enkele interpretatiemaximes, waaronder dat van de positieve verplichtingen en het effet utile, hebben geleid. Voor de vaststelling van de doelstellingen heeft het Hof gekozen voor een evolutief perspectief. Het Hof heeft zich in dat verband laten inspireren door de Preambule, die luidt als volgt:

Zewende Protocol yan toepassing was. Denernarken, de aangeklaagde staat in deze casus, had dit Protocol niet ondertekend.

196 Zie bijvoorbeeld Guzzarid t. Italiè, warin klager zich succesvol beriep op art. 5 EVRM. Hij leefde in gevangenschap op eên klein eiland waar hij een zeer klein bewegingsoppervllak tot zijn beschikking: had, hetgeen zijin recht op vrijheid ex art. 5 EVRM danig beperkte en het Hof het verweer van de Italianse stat op basis van niet-ondertekening van thet Vierde Protocol middels systematische interpretatie terzijde stelde (Guzzard 1. Malie, EHRM 6 november 1980, Serie A Vol. 39, par, 92).

197 Recluter Fitzmaurice in zin dissenting bij Guzzardi tikalie.

198 Pettiti 1995, p. 45, Ost (Delmas-Marty 1992), p. 292.

199 Ost (Delmas-Marty 1992), p. 293.

200 De uitkomst van eest ruime interpretatie van de bescherming van de rechten in de Conventie heeft tot gevolg, dat er slechts een smalle basis rest voor derogatie van deze rechten en eventuele voorbehouden op deze reclnten door de verdragstaten. In Airey bijvoorbeeld, was het Hof niet bereid het verweer varn de lerse regering te accepteren dat het een woorbehoud had gemaakt bij Art. 6 lid 3 EVRM (kosteloze rechtsbijstand in bepaalde gevalleny zie Airey t. lerland, EHRM 9 oktober 1979, Serie A vol. 32, par. 26. Het argument van de lerse regering werd gepareerd met een teleologisch argument van de zijde van het Hof: "The Court is aware that the further realisation of social and economic rights is largely dependent on the situation reigning in the state in question. On the other hand, the Convention [...] is designed to safeguard the individual in a real and practical way as regards those areas with which it. deals'. 
"[...] gelet op de Universele Verklaring van de rechten van de Mens [..]; overwegende "dat deze Verklaring ten doel heeft de universele en daadwerkelijke erkenning en toepassing van de rechten die daarin zijn nedergelegd te verzekeren; overwegende dat het doel van de Raad van Europa is het bereiken van een grotere eenheid tussen zijn Leden en dat een wan de middelen om dit doel te bereiken is de handhaving en de verdere verwezenlijking van de rechten van de mens en de fundamentele vrijheden?. ${ }^{201}$

Deze visie sluit niet uit dat opvattingen over een juiste beschermingsomvang onderhevig zijn aan veranderingen die worden ingegeven door matschappelijke en technologische ontwikkelingen. Wanneer bijvoorbeeld technologische ontwikkelingen een eventuele bedreiging vormen voor de beschermingsomvang van de fundamentele rechten dient ook het beschermingsmechanisme aangepast te kunnen worden. ${ }^{202}$ Voor de vaststelling van de doelstellingen van de Conventie wordt dan niet noodzakelijkerwijze vastgehouden aan de oorspronkelijke intenties van de opstellers van het verdrag, maar aan de condities van de huidige samenleving. Het EVRM wordt in deze optiek niet benaderd als een volmaakt, "af' einddoel, maar als een startpunt voor de doelstellingen die moeten worden nagestreefd en geconcretiseerd. ${ }^{203}$ De hier uit te werken doelstelling is gelegen in de bescherming van concrete en effectieve rechten. ${ }^{204}$ In dit verband is "s Hofs uitgangspunt van 'effet utile" van groot belang. Het Hof verkiest deze effectiviteit boven een formele benadering van de Conventiebepalingen. In de zaak Klass rees de vraag, in hoeverre was voldaan aan de eisen van ontvankelijkheid, meer specifiek het slachtoffervereiste. Niet was aangetoond, dat de klager daadwerkelijk slachtoffer was geworden van de door hem veronderstelde afluisteractiviteiten; mitsdien zou cen strikte interpretatie van Art. 35 leiden tot niet-ontwankelijkheid. Het Hof overwoog echter op basis van het effectiviteitsbeginsel het volgende:

\footnotetext{
"The question arises in the present proceedings whether an individual is to be deprived of the opportunity of lodging an application with the Commission because, owing to the secrecy of the measures objected to, he camnot point to any concrete measure specifically affecting him. In the Court's view, the effectiveness ( $l$ 'effet utile) of the Convention implies in such circumstances some possibility of having access to the Commission. If this were not so, the efficiency of the Convention's enforcement machinery would be materially weakened". 205
}

201 De preambule wan het Statuut van de Raad wan Europa verwijst eveneens naar de wens, het beginsel van vrijheid en de notie van de rechtsstaat op progressive wijze te vestigen; in de vierde alinea van de Preambule van de Conventie wordt een link gelegd naar het Statuut. Art. I van het Statuut luidt: 'a) Le but du Conseil d'Europe est de réaliser une union plus étroite entre ses Membres afin de sauvegarder et de promouvoir les idéaux et lies principes qui sont leur patrimoine commun et de favoriser leur progrès Economique et social'. Zie Van Boven (Pettiti 1995), p. 125-134.

202 Jacobs en White 1996, p. 32.

203 Alkema 1978, p. 21.

204 Twee andere belangwekkende doelstellingem, die van het proportionaliteitsbeginsel bij de belangenafweging en die van het bevorderen van de democratische uitgangspunten wan het EVRM worden hier niet besproken; zij zijn zijdelings aan de orde geweest bij de bespreking van de toetsingsmethodiek van het Hof (zie par. 3.5).

205 Klass t. Duitsland, EHRM 6 septemiber 1978, Serie A vol. 28, par. 34. 
Met name Art. 6 EVRM heeft via het effectiviteitsbeginsel relief verkregen in de rechtspraak van het Hof. ${ }^{206}$ In het verlengde van de hantering van het effectiviteitsbeginsel ligt enerzijds de opvatting van het Hof, dat beperkingen of derogaties door verdragsstaten op de fundamentele rechten in de Conventie restrictief dienen worden opgevat. Uit de rechtspraak van het Hof komt naar voren dat het effectiviteitsbeginsel niet specifiek aan éen EVRM-bepaling is gekoppeld, maar dat het om een meer algemeen uitlegmaxime gaat. ${ }^{207}$ De doelstelling van bescherming van concrete en effectieve rechten heeft veelvuldig tot de vaststelling geleid dat op het terrein van de EVRM-rechten voor de staat positieve verplichtingen bestaan. ${ }^{208}$ Het Hof heeft de positieve verplichting als het ware 'ingelezen' aan de hand van het vermoeden in het voordeel van de individuele rechtsbescherming in combinatie met het effectiviteitsbeginsel. Het Hof stelde in Marckx t. Belgiè, waarin klaagster de ongelijke benadering van wettige en onwettige kinderen op basis van art. 8 EVRM aan de kaak stelde:

\begin{abstract}
Nevertheless, it does not merely compel the state to abstain from such interference: in addition to this primarily negative undertaking, there may be positive obligations inherent in an effective "respect" for family life. This means, amongst other things, that when the State determines in its domestic legal system the regime applicable to detain family ties such as those between an unmarried mother and her child, it must act in a manner calculated to allow those concerned to lead a nomal family life' ${ }^{209}$
\end{abstract}

De leer van de positieve verplichtingen maakt het mogelijk, om tot op zekere hoogte een horizontale werking van de verdragsbepalingen aan te nemen. ${ }^{210}$ Daarnaast is het leerstuk van de positieve verplichtingen van groot belang voor de rechtsontwikkeling: het ste $1 t$ het Hof in staat om te voorzien in situaties waarin geen regelingen bestonden of actie werd ondernomen. Vooral op het terrein van het recht op privé-leven ex Art. 8 hebben positieve verplichtingen geleid tot vaststelling van verplichtingen op uiteenlopende terreinen - ook op terreinen waar de verdragspartijen aanvankelijk dachten soevereine rechtsmacht te hebben. ${ }^{211}$ In dat verband heeft het directe repercussies op de

206 zie bijvoorbedd Delcoum t. Frankrij, EHRM 17 januari 1970 , Serie A vol. 1., par. 25; Golder $t$. Verentgd Konimkrik, EHRM 21 februari 1975, Serie A vol. 18 par. 35; Arey 1. Jerland, EHRM 9 oktober 1979. Scrie A vol. 32, par. 24 (The Convention is intended to guarantee not rights that are theoretical of illusory but rights that are practical and effective").

207 Schokkenbroek 2000, p. 7.

208 Zie Van der Velde 2002 voor een overzicht op de actuelle stand van zaken in de jurisprudentie.

209 Marckx 4. Belgie, LHRM 13 jimi 1979, Serie A vol. 31, par. 31, zie ook Airey 1 Jerland, EHRM 9 oktober 1979, Serie A vol. 32 par. 32. Zie verder eveneens $X$ en $Y$ tegen Nederland, EHRM 26 maart 1985, Sierie A vol. 91 par. 23 (positieve verplichtingen in de sfeer van art. \& EVRM).

210 Breidde het Hof in deze casus via de teleologische uitleg de reikwijdte van een bepaling van de Conventive uit in de relatie tussen individu en staat; in een later stadium werd de notie war positieve verplich" tingen ingezet in horizontale contlicten. In Young, James en Webster kwam het Hof tot het oordeel, dat de staat zijn verplichting niet was nagekonen het recht ex art. 11 EVRM te garanderen waardooi klagers miet de vrijheid genoten, geen lid te hoeven worden van een wakbond. Zie Young, Jomes en Webster t. Verenigd Koninkrijk, EHRM 13 augustus 1981, Serie A vol. 44, par. 54 en Platform Arate fir das Leben t Oostenrijk, EHRM 21 jumi 1988, Serie A vol. 139, par. 32 (positieve verplichtingen in de sfeer van art. 10 EVRM).

211 In Boita t. Halie geeft het Hof een fraai overzicht van cen aantal belangwekkende arresten op dit vlak (Botta t. ltalie, EHRM 24 febuari 1998, 18 1998/70, par. 32-35. In Guerra t. Italie aanvaarde het Hof dat een stat kan worden verpliclat tot het geven van informatie over het leefnilien, omdat het achter- 
constitutionele verhouding tussen $\mathbb{H}$ of en nationale autoriteiten: het Hof ontleent aan het effectiviteitsbeginsel een extensieve interpretatie van zijn mandaat en stelt zichzelf in staat om nationale autoriteiten aan te spreken op falen of achterwege laten van wetgeving zonder dat het verdrag een expliciet mandaat ter zake inhoudt.

\section{Dynamisch-evolutieve interpretatie}

De teleologische interpretatie ontkent een statische dimensie van grondrechten. ${ }^{212}$ Het Hof grijpt in deze exercitie niet altijd terug op de intentie van de toenmalige verdragspartijen; het volgt veeleer sociaal-economische ontwikkelingen en veranderingen die gaande zijn in de huidige samenlevingen van de actuele verdragspartijen. ${ }^{213}$ Het Hof heeft van deze methode veelvuldig gebruik gemaakt op basis van de volgende argumentatie:

"The Court must also recall that the Convention is a living instrument which, as the Commission rightly stressed, must be interpreted in the light of present-day conditions. In the case now before it the court cannot but be influenced by the developments and commonly accepted standards in the penal policy of the member States of the council of Europe in this field". 214

Latere uitspraken reflecteren de veranderde opvattingen met betrekking tot bijvoorbeeld buitenechtelijke kinderen, homoseksuele activiteiten, erkenning van transseksualiteit en de visie op de doodstraf. ${ }^{215}$ Ook met betrekking tot de mechanismen in het EVRM die individuele rechtsbescherming in gang zetten heeft het Hof deze methode gebruikt. ${ }^{216}$ Evolutieve uitlegging doet de vraag rijzen, waar rechterlijke verdragsinterpretatie eindigt en techterlijke verdragswijziging aanvangt. In beginsel wordt aanvaard dat er grenzen zijn aan deze methode, die niet in de laatste plaats worden bepaald door de constitutionele verhouding tussen Hof en nationale autoriteiten. Het verdrag dient niet te worden uitgelegd op een wijze, die door de verdragspartijen expliciet niet bedoeld is. Uit de rechtspraak komt niet eenduidig naar voren, welke die grens is. De dynamisch-evolutieve uitleg opent mogelijkheden voor creatieve wetsuitleg, maar de interpretatieruimte van het Hof is kennelijk niet onbegrensd.

houden van informatie een schending kan betekenen van het prive-leven (Guerrat t. lalië, EHRM 19 februari 1998, JB 1998/49, par. 57).

212 Schokkenbroek 2000 , p. 13 en Prebensen 2000 , p. 1125 . De laatste stelt dat er uit de Preambulle een rechtvaardiging voor de dynamisch-evolutieve uitleg is af te leiden: 'that would hardly be consistent with the passage in its Preamble that "one of the methods by which the aim (of a European unity) is to be pursued is the maintenance and further realisation of human rights and fundamental freedoms", (cursief Prebensen), zie Prebensen 2000, p. 1125. Deze rechtvaardiging van dynamisch-evolutieve uitleg wordt door commentatoren ook met betrekking tot het $\mathbb{E G}$-Verdrag gehanteerd (zie par. $3.3 .3 \mathrm{en}$ Ukrow 1995, p. 93 e.w.).

213 Critici stellen echter dat het Hof dexe ontwikkelingen en veranderingen niet volgt, matar zelt initieert, Ost (Delmas-Marty 1995), p. 302.

214 Tyrer, EHRM 25 aprill 1978, Serie A vol. 26 par. 31.

215 Zie Marckx t. België, EHRM 13 juni 1979, Serie A vol. 31, Dudgeon d, Verenigd Koninhrijk, EHRM 22 oktober 1981, Serie A wol. 45) en Soering t. Verenigd Koninkrijk, EHRM 7 juli 1989, Serie A vol. 161.

216 Louizidou 8. Turkije, EHRM 23 maart 1995, Serie A vol. 310 par. 71. 
In Rees en Johnston was het Hof, nadat het op de uitspraken Feldbrugge en Dewmeland zware kritiek had gekregen, wat voorzichtiger geworden met de dynamisch-evolutieve uitleg. ${ }^{217}$ Dararmede werd deze uitleg niet terzijde gesteld, zij is te belangrijk voor de uitleg van de Conventie vanwege de verbondenheid met de uitleg naar de doelstellingen van de verdragstaten. Het Hof heeft echter wel getracht de indruk weg te nemen, dat het via deze uitleg aan creatieve rechtswinding deed. In Feldbrugge en Dewmeland waren de rechters die een dissenting articuleerden fel gekant tegen de dynamischevolutieve interpretatie van het begrip 'civil obligations' in een conflict over sociale zekerheidsuitkeringen, omdat het Hof in hun optiek met deze uitleg was gekomen tot een zeer extensieve uitleg. Zuj pleitten voor een beschouwing van de travaux préparatoires en kwamen mitsdien tot een engere opvatting van 'civill rights", omdat ter zake van sociale zekerheidsuitkeringen geen sprake is van een Europese consensus. Naar hun opvatting opereerde het Hof met deze uitspraak aan de rand van hetgeen binnen zijn jurisdictie ligt, en dienen politieke beslissingen hierover overgelaten te worden aan de nationalle wetgevers. ${ }^{218}$

In de literatuur zijn wel situaties onderscheiden waarin een evolutief argument van doorslaggevend belang wordt geacht. Prebensen onderscheidt drie situaties waarin het Hof deze methode hanteert: er zijn in de eerste plaats gevallen aan te wijzen waarin de dynamisch-evolutieve methode een aanvullende functie had naast hantering van de tekstuelle, systematische, historische en teleologische interpretatiemethoden; er is in de tweede plaats een aantal zaken waarin de dynamisch-evolutieve interpretatie terzijde werd geschoven door de andere interpretatiemethoden, en ten slotte onderscheidt Prebensen een aantal gevallen waarin het dynamisch-evolutieve argument het historische argument, en dan met name de travaux préparatoires, terzijde heeft geschoven. ${ }^{219}$ Om van doorslaggevende aard te kunnen zijn is het voor de dynamisch-evolutieve interpretatie van belang dat een 'common ground' kan worden aangewezen: aanwezigheid van een bepaalde standaard in de rest van Europa kan leiden tot de vaststelling, dat eern evolutieve uitlegging gerechtvaardigd kan zijn in het licht van gemeenschappelijke opvattingen. $^{220}$ Gemeenschappelijke opvattingen kunnen worden ontwaard in een

217 Rees betrof een zaak waar het Verenigd Koninkrijk weigerde, de geslachtsaanduiding op het geboortecertificalat wan de klager te veranderen nadat deze een operatie tot gesllachtsverandering had ondergaan. Het Hof achtte het besluit wan het Verenigd Koninkrijk in owereenstemming met Art. 8 EVRM, maar verklaarde the Convention has always to be interpreted and applied in the light of current circumstances [...]. The need for appropriate legal measures should therefore be kept under review having regard particullarly to scientific and societal developments" (Rees $t$. Verenigd Koninkrijk, EHRM 17 oktober 1986, Serie A vol. 106 par. 47). In Johnsion t. Jerlond, de zaak waarin het recht op echtscheiding niet werd erkend als een recht voortwloeiend uit het EVRM ondat de verdragstatem expliciet hadden gesteld aut een dergelijk recht niet werd bedoeld onder Art. 12 EVRM. Het Hof leidde dat af uat de travaux prepparatoires. Mits dien kon via de dynamisch-evolutieve interpretatie geen recht worden ingelezen dat expliciet uit de context van het EVRM was gelaten (Johnstons t. lerland, EHRM 18 december 1986, Serie A vol. 112 par. 52 en 53 ).

218 Feldbrugge t. Nederland, EHRM 29 mei 1986, Serie A vol, 99; Deumeland t. Dutsland, EHRM 29 mei 1986, Serie A vol. 100; zie eveneens de afwijkende opinie in Campbell en Casan t. Verenigd Koninkrijk, EHRM 25 februari 1982, Serie A vol 48.

219 Prebensen 2000 , p. 1127 e.v.

220 Dat wil echter niet zeggen, dat wanneer een consensus kan worden aangewezen, dynamisch-evolutieve 
onderzoek naar jurisprudentie van verdragsstaten of naar geldende normen in de wetgeving, alsmede in teksten en Resoluties van de Raad van Europa en internationale verdragen. ${ }^{221}$ Niet-bindende internationale teksten kunnen aldus eveneens een rol spelen. Denkbaar is daarentegen eveneens, dat het Hof in sommige gevallen afwijkingen van de consensus respecteert. Het zoeken naar een consensus lijkt eerst plaats te vinden als secundaire interpretatiemethode. ${ }^{222}$ Afwezigheid van een consensus is geen vaststaand gegeven, maar wanneer eenmaal een aanwezigheid is vastgesteld lijkt een weg terug niet meer goed mogelijk. ${ }^{223}$

Heringa oppert dat het Hof verschillende formuleringen gebruikt om vast te stellen of er sprake is van een consensus, en dat er variatie in de precisie bestaat. ${ }^{224}$ Het bestaan of de afwezigheid ervan wordt niet altijd even degelijk gemotiveerd. ${ }^{225}$ In het licht van de constitutionele verhouding tussen Hof en nationale autoriteiten is rechtsvinding aan de hand van consensus interessant: staten worden door het Hof als het ware gehouden aan hun eigen rechtsontwikkelingen en aan hun bijdragen in het internationale recht. Dit maakt het moeilijker voor staten om het Hof te beschuldigen van 'rechtsvinderlijk activisme': het Hof interpreteert het EVRM ten slotte vanuit hun eigen rechtsontwikkelingen en rechtsovertuigingen. ${ }^{226}$ Van een vaste lijn in de jurisprudentie kan echter niet gesproken worden, hetgeen het moeilijk maakt om algemene uitspraken te doen over een waardering van rechterlijk activisme of juist terughoudendheid in verband met het hanteren van de consensus.

interpretatie steeds prevaleert boven andere methoden (zie bijvoorbeeld Johnsion t. Jertand, EHRM 18 december 1986, Serie A vol. 112, par. 52-53 en Soering 1. Verenigd Koninkrijk, EHRM 7 julli 1989, Serie A vol. 161, par. 100-104). Zie Heringa 1999 over het consensus-beginsel.

22』 Zie onder meer Young, James en Webster $t$. Verenigd Koninkwijk, EHRM 13 angustus 1981, Serie A vol, 44; Bwrghartz t. Zwitserland, EHRM 22 februari 1994, Serie A vol. A 280-B; Keegan t. lerland, EHRM 26 mei 1994, Serie A vol. 290; Aydin t. Turkije, EHRM 25 september 1997, JV 1997/13 en Jane Snith t. Verenigd Koninkrijk, EHRM 18 januari 2001 , EHRC $2001 / 19$.

222 Heringa 1999 , p. 24.

223. Na de uitspraak in Goodwin t. Verenigd Koninkrijk ligt het niet voot de hand, dat het Hof zijn erkenning van de individuele aanspraak op erkenning wan positieve verplichtingen ter zake van de geslachtelijke identiteit zal terugdraaien.

224 Heringa 1999 , p. 30.

225 Het Hof is nawwelijks expliciet over de diepgang van het onderzoek naar de gemeenschappelijke praktijk, alsmede over het aantal stelsels en welke stelsels die worden betrokken in de rechtsvergelijking. Daardoor ontstaat de indruk, dat er willekeur sluipt in de redenering indien het argument van de rechtsvergelijking wordt gehanteerd. Bij de uitspraken van het Hof van Justitie is de functie die de Advocaat-Generaal vervalt daarom zo waardevol, omdat deze dergelijke onderzoekingen verricht en verantwoordt in zijn opinie. Het Hof ontbeent een dergelijk 'openbare' denktank. Zie ook Bernhardt (Matscher en Petzold 1988, p. 65-71) en de dissenting van rechter Martens bij Cassey t. Verenigd Koninkrijk, EHRM 27 september 1990, Serie A vol. 184; hij constateert een aantal "zwakke plekken" in de wijze waarop het Hof het rechtsvergelijkend perspectief hanteert in die zaak.

226 Heringa 1999, p. 33-34. 


\subsubsection{Nederland}

In de Nederlandse context wordt in het algemeen niet over grondrechtsinterpretatie als specificeerbare wijze van wetsuitleg gesproken ${ }^{227}$ Dat hangt naar mijn mening tot op zekere hoogte samen met het feit dat de Hoge Raad als hoogste rechter niet specifiek is belast met constitutionele rechtspraak. Hij oordeelt als een gewone rechter; er lijkt in beginsel niet $z o$ 'n spanningsveld tussen rechter en wetgever te bestaan zoals zich dat voordoet bijvoorbeeld bij het Hof in Duitsland of het Amerikaanse Hooggerechtshof. De directe spanning komt het sterkst tot uitdrukking wanneer de rechter formele wetgeving toetst aan de grondwet; het toetsingswerbod staat in Nederland daaraan echter in de weg. Toch is de vraag naar het waarom van de afwezigheid van een constitutionele interpretatiedoctrine niet onterecht; via toetsing aan verdragsnormen kan de rechter het toetsingsverbod tot op zekere hoogte te omzeilen. In de literatuur zijn soms suggesties te vinden voor "elementen" die wijzen op een constitutionele interpretatiedoctrine. ${ }^{228}$ De ontwikkelingen in de rechtsvinding zijn vooral in privaatrechtelijk verband te traceren; open normen die nader ingevuld dienen te worden in concrete toepassing zijn op dat terrein ook veelvuldig te vinden. ${ }^{229}$ Vooral de ontwikkeling van het Europese recht en het EVRM zijn van invloed geweest op de rechtsvindingspraktijk van de Hoge Raad ${ }^{230}$ Het Hof van Justitie heeft de Nederlandse rechter als het ware gedwongen mee te werken aan toepassing van EG-recht, ook als daardoor hogere wetgeving dient te wijken. Het Hof van Justitie tendeert in beginsel eerder naar een systematische en teleologische uitlegging van het EG-Verdrag, hetgeen in de regel een extensieve uitlegging van verdragsbepalingen oplevert.

Via de werking van Art. 94 Grondwet dringt de uitlegmethodiek van het EHRM de Nederlandse rechtsorde binnen; het EHRM hanteert systematische, teleologische alsmede evolutieve uitlegmethoden op het terrein van fundamentele rechten. ${ }^{231}$ Van het Hof van Justitie en het EHRM kan worden gesteld dat zij steeds vaker een beroep op algemene rechtsbeginselen zijn gaan doen in hun rechtsvinding en aan de wet als rechtsbron een geringere betekenis toekennen. ${ }^{232}$ Het toetsingsverbod, waarvan in hoofdstuk 3 werd gezegd dat het indirect in de weg staat aan rechterlijke rechtsontwikkeling, wordt vanwege een grotere toevloed van EG- en EVRM-uitspraken door de Nederlandse rechter

227 Kortmann 1994, p. 363 en Mendelts 2002 , met name hoofdstuk 2.

228 Zie bijwoorbeeld Jeukens 1970, p. 183 over het Goudse Rijschoolarrest (HR 10 december 1957, NJ 1958/176); hij stelde dat naarmate de grondwet zaken meer in detail regelt, en ver/eende rechten en bevoegdheden wan reserves voorziet, de Hoge Raad eerder zal tenderen naar technisch-juridische interpretatiemethoden als tekstuele of historische uitleg.

229 Koopmans (Wiarda) wijst in dit verband op de invoering wan het njeuw Burgerlijk Wetboek, waarin de wetgever ann verschuiving van heteronome naar meer attonome wijzen van rechtsvinding heeft bijgedragen (Wiarda 1999, p. 43 e.v). Zie ook Pitlo 1972, hoofdstuk 8.

230 Koopmans (Wiarda 1999), p. 34 e.v. Voor literatuur over rechtsvinding in de Nederlandse rechtspraak zie onder meer Polak 1953, Asser-Scholten (Algemeen Deel) 1974, Snijders 1978, Asser-Vranken (Algemeen Deel) 1995, Wiarda 1999, Pontier 1998, Bruggink 1990.

231 Zie bijvoorbeeld Wettige/onwettige kinderen, HR 18 januari 1980, NI 1980/463 waarin de Hoge Raad onder meer naar aanleiding van Marckx t. Belgie, EHRM 13 juni 1979, Serie A vol. 3.1 vaststelde dat een onderscheid tussen wettige en onwettige kinderen niet langer kan worden gehand haafd.

232 Koopmans (Wiarda 1999), p. 53. 
ietwat gerelativeerd: de terughoudendheid waartoe Art 120 Grondwet vanuit het oogpunt van toetsing dwingt, is vanuit dat gezichtspunt van de interpretatie niet meer zo vanzelfsprekend. Rechtsvindingsmethoden van andere rechters die niet of in mindere mate worden gehinderd door een demarcatielijn in de constitutionele verhoudingen dringen de rechtsorde binnen en hebben tot gevolg dat de wet als rechtsbron van geringere betekenis wordt, en maken een regelmatiger beroep op systematische en teleologische interpretatie mogelijk. ${ }^{233}$

\section{Tekstuele en historische interpretatie}

De betekenis van woorden naar het spraakgebruik staat in de Nederlandse rechtsvinding voorop. ${ }^{234}$ Interpretatie van de grondwet vergt echter een andere benadering vanwege het open karakter van de normen die daarin besloten liggen. In de wetshistorische uitlegmethode volgt de rechter de betekenis die de wetgever indertijd bij totstandbrenging van de wet voor ogen had. In Goudse Rijschool interpreteerde de Hoge Raad het begrip "onderwijs" in het voorschrift van Art. 208 Grondwet, voor zover daarin werd bepaald dat het geven van onderwijs vrij is behoudens het toezicht van de overheid. De Hoge Raad overwoog, dat

'dit in algemene bewoordingen vervatte woorschrift overigens niet onderscheidt tussen verschillende vormen van onderwijs, en ook de geschiedenis van zijn totstandkoning voor het maken van zodanig onderscheid geen grond biedt'. ${ }^{235}$

Jeukens wijst erop, dat de Hoge Raad zich richt op de door de grondwetgever gevolgde wetstechniek, hetgeen in het geval van de Goudse rijschool betekent dat de Hoge Raad rekening hield met het toentertijd relatief gedetailleerd geregeld grondrecht op onderwijs. Naarmate een grondwetgever meer in details treedt, en verleende rechten en bevoegdheden van reserves voorziet, zal de rechter eerder tenderen naar de technisch-juridische interpretatiemethode. ${ }^{236}$ Jeukens stelt dat de verklaring voor de regeling in detaill gezocht moet worden in de historische ontwikkeling van de Nederlandse staatkundige en politieke verhoudingen ter zake van de kwestie over de vrijheid van onderwijs. ${ }^{237}$

Het recht op de persoonlijke levenssfeer ex Art. 10 Grondwet en de lichamelijke onschendbaarheid ex Art. 11 Grondwet is niet van een dergelijk gedetailleerd karakter. Naarmate de wetgever zich abstracter heeft uitgedrukt neemt ook in de Nederlandse situatie de betekenis van taalkundige interpretatie af. ${ }^{238}$ De wetshistorische uitlegmethode is in het algemeen omstreden. De bezwaren zijn zowel praktisch als ook principieell van aard. ${ }^{239}$ Het is geen sinecure om de exacte will van 'de' wetgever te bepalen, omdat weging van het gewicht van de deelnemers aan het proces dat leidde tot de

233 Zie ook Koopmans (Wiarda 1999), p. 51 e.w.

234 Asser-Scholten (Algemeen Deel) 1974, p. 36.

235 MR 10 december 1957, NJ 1958, 176.

236 Jeukens 1970, p. 183.

237 Jeukens 1970, p. 183.

238 Asser-Scholten (Algemeen Deel) 1974, p. 60.

239 Vranken 1995, p. 93. 
totstandkoming vari de regel lastig is. Ook het moment waarop uitlatingen in dat proces zijn gedaan, is van belang bij het beschouwen van het totstandkomen van "de" wil. Vooralsnog is het in de constitutionele interpretatie een methode die voor de Nederlandse rechtsorde niet zonder belang is: de grondwet is in 1983 voor het laatst herzien. De Hoge Raad heeft in het Harmonisatiewetarrest ter zake van de interpretatie van Art. $120 \mathrm{GW}$ bijvoorbeeld expliciet teruggegrepen op de bedoeling van de grondwetgever:

\begin{abstract}
'tegenover woormelde argumenten voor restrictieve uitleg van het toetsingsverbod staat evenwel dat ter gelegenheid van de grondwetswijziging die in 1983 haar beslag heeft gekregen, de vraag of het grondwettelijk toetsingsverbod geheel of ten dele moest worden opgeheven, in de doctrine uitvoerig aan de orde is gesteld, door verscheidene adviesorganen is bezien en mede aan de hand daarvan in thet parlement principieel is besproken en ontkennend beantwoord. [...] Het [...] overwogene is doorslaggevend en noopt tot de conclusie dat, al valt niet te ontkennen dat de rechtsontwikkeling sedert het tot stand komen van de Grondwet van 1983 het gewicht van de voor restrictieve interpretatie van dat verbod pleitende argumenten heeft doen toenemen, moet worden geoordeeld dat de rechter de hem gestejde grenzen zou overschrijden door te oordelen dat art. 120 Grondwet zich niet (ook) tegen toetsing van de wet aan fundamentele rechtsbeginselen verzet' ${ }^{240}$
\end{abstract}

\title{
Systematische, teleologsiche en dynamisch-evolutieve interpretatie
}

In de systematische interpretatie kan de structuur van de wet ter hand worden genomen om de betekenis van de te interpreteren regel uit te leggen. Een voor Nederland belangwekkende systematische uitleg is te vinden in de interne rechtsvergelijking. De interpretatie van de Straatsburgse rechter van het EVRM heeft meer dan eens aanleiding gegeven voor aanpassingen als gevolg van inconsistentie tussen Nederlands burgerlijkof strafrecht en het EVRM. ${ }^{241}$ Het systeem van ouderlijke macht, zo stelde de Hoge Raad in 1985 vast, strookte niet meer met de interpretatie van Art. 8 EVRM ter zake van het recht op gezinsleven die het Europese Hof te Straatsburg erop nahield. De Nederlandse rechter paste airt. 1:161 lid $1 \mathrm{BW}$ naar de systematiek van het EVRM aan. ${ }^{242}$ Hanteert de rechter een interne rechtsvergelijking, dan kijkt hij over de grenzen van zijn eigen 'vakgebied' heen en zoekt voor de uitleg van het grondrecht aansluiting bij andere terreinen birmen het Nederlandse recht zoals het strafrecht, het bestuursrecht of het belastingreclit. ${ }^{243}$ Systematische uitleg dient in de Nederlandse optiek eveneens doelen van het vermijden van inconsistenties enerzijds en het versterken van de onderlinge samenhang van de rechtsnormen in het systeem anderzijds. ${ }^{244}$

240 MR 14 april 1989, NI 1989,469 (Mapwonisatiewetarrest). In Edamse Bijstandsmoeder interpreteerde de Raad eveneens bistorisch; hij interpreteerde het destijds nog niet in werking getreden Art. 10 Grondwet. Dat Artikel vornde de grondslag voor de gepleegde onrechtmatige daad. De Hoge Raxd overwoog: "Wat de begrenzing van het recht op eerbiediging van de persoonlijke levenssfeer betreft, zijin voor de onderhavige zank mede van belang de gedachten die daarover zijn te vinden in de MvT op het artikel dat tot het in 1983 tot stand gekomen, maar nog niet in werking getreden art. $10 \mathrm{Gr}$.w. heeft geleid' (HR 9 janurau 1987, NJ 1987, 928).

241 Vanwege het gematigd monistisch systeem worden rechtsnomen en uitspraken van het EHRM geacht deel wit te maken van het inteme rechtsnomensysteen van de Nederlandse rechtsorde.

242 HR 4 mei 1984, NJ 1985/510 en HR 2 l maart 1986, NJ 1986/585-588.

243 Vranken $1995, \mathrm{p}, 125$.

244. Vranken 1995, p. $81-84$ 
De dynamisch-evolutieve uitlegmethode wordt door de Hoge Raad ter zake van de uitleg van de constitutionele bepalingen zelden openlijk gehanteerd. Waar een dynamischevolutieve interpretatie leidt tot extensieve interpretatie van de grondwet is dat in de Nederlandse praktijk veelal het gevolg van de doorwerking van de uitspraken van het EHRM. Dit Hof maakte ter zake van bijvoorbeeld het personen-en familierecht onder Art. 8 EVRM gebruik van deze uitlegmethode; in dit verband paste de Hoge Raad de dynamisch-evolutieve uitleg van Art. 8 EVRM van het EHRM toe op familierechtelijke bepalingen uit het BW. ${ }^{245}$ Uit de uitspraak valt echter niet op te maken, bij welke interpretatie of uitspraak van het EHRM de Hoge Raad nu precies aanknoopte. De Hoge Raad volstond enkel met de vaststelling van strijdigheid met A.t. 8 EVRM. In de noot bij de uitspraak werd echter opgemerkt dat kan worden gesteld dat de rechtspraak van het EHRM niet direct aanleiding gaf tot de onderhavige uitspraak: de in de rechtspraak ontwikkelde notie van het belang van het kind is betrekkelijk vaag en behoefde nadere invulling door de Hoge Raad in het voorliggende geschil. ${ }^{246}$ De Hoge Raad knoopte voor het belang van het kind aan bij zijn eigen invulling van die notie onder verwijzing naar de interpretatie door het EHRM ter zake. In de uitspraak 'Gezamenlijke ouderlijke macht van ongehuwden' is de Hoge Raad open over de invloed van maatschappelijke ontwikkelingen:

"In hoeverre deze vooronderstelling - die ervan uitgat dat in de regel door echtscheiding: elke verhouding tussen de ouders onderling definitief wordt verbroken en dat natuurlijke kinderen normaliter alleen door de moeder worden opgevoed - in overeenstemming was met de toenmalige matschappelijke werkelijkheid, kan in het midden blijven. Van belang is slechts, dat zij onder de huidige maatschappelijke omstandigheden en opvatingen niet opgaat'. ${ }^{247}$

Er lijkt een terughoudendheid te bespeuren in het gebruiken van de dynamisch-evolutieve interpretatiemethode. Deze methode roept in het licht van de constitutionele verhouding tussen rechter en wetgever spanning op; zij stelt de rechter, meer dan bij een systematische of teleologische interpretatie, in staat om zijn subjectieve opvatting te verpakken in een juridische norm, zo luidt een opvatting. De beschrijvingen van de andere stelsels, die een toetsingsverbod van hogere wetgevingen niet kennen, laten een genuanceerd beeld zien: ook hier stuit de rechter op weerstand tegen dynamisch-evolutieve wetgeving vanwege de hier genoemde constitutionele verhouding tussen rechter en wetgever.

\section{Rechtsvergelijkende interpretatie}

In de uitspraken van de Hoge Raad zijn in de huidige jurisprudentie ter zake van wetsuitleg regelmatig verwijzingen gedaan naar de rechtspraktijk en opvattingen in andere rechtsstelsels. Opvallend in dit verband is, dat deze verwijzingen niet altijd in de uit-

245 HR 18 januari 1980, NJ 1980/463, HR 4 mei 1984, N』1985/510 en HR 21 maart 1986, NJ 1.986/585588.

246 Alkema in zijn noot bij HR 4 mei $1984, \mathrm{NJ} 1985,510$.

247 HR 21 maart 1986, NJ 1986, 585 (Ouderlijke macht ongehuwden). Art. 1:161 lid I BW, waarop in het citaat wordt gedoeld, is in werking getreden in 1901. 
spraak van de Hoge Raad zelf, maar in de conclusie van de Advocaat-Generaal terug te vinden zijn. De A-G knoopt daarbij niet alleen aan bij de uitspraken van de rechterlijke colleges in andere stelsels; eveneens worden in de conclusies soms uitvoerig doctrines en commentaren aangehaall. A-G Moltmaker beziet in de uitspraak 'Gezamenlijke ouderlijke macht voor ongehuwden" bijvoorbeeld voor de interpretatie van "gezinsleven" ex Art. 8 EVRM Duitse, Franse en Britse literatuur en rechtspraak van het EHRM ${ }^{248}$ Gezien het feit dat de Hoge Raad niet is gebonden aan de in de conclusie geboden bevindingen lijkt de betekenis van de analyse van de A-G op het eerste gezicht in betekenis af te nemen. Het staat de Hoge Raad betrekkelijk vrij om de conclusie op onderdelen te volgen - mits de consistentie in het eigen betoog niet in gevar komt. Daarnaast kunnen ideeën van de A-G fungeren als een 'proeftuin', om te bezien in welke mate er draagwlak bestaat voor een andere, wellicht nog niet eerder gehanteerde visie op het voorliggende geschil. Er bestaat geen verplichting voor de Hoge Raad om afwijzing van de conclusie te motiveren. Uitspraken waarin de Hoge Raad een rechtsvergelijkende analyse van grondwetsbepalingen bezigt treft met niet vaak aan; argumenten die worden ontleend aan deze rechtsvindingsmethode kunnen op zichzelf genomen geen doorslaggevende interpretatie geven van de Nederlandse rechtsregel. ${ }^{249}$ In Nederland wordt er vanuit gegaan dat er geen rangorde bestaat van te volgen interpretatiemethoden. $^{250}$

\subsubsection{Slot: het interpretatiedebat in de stelsels vergeleken}

Begrenzingen van rechterlijke interpretatievrijheid werden gevonden in onder meer de rechtsstaatgedachte: de rechter is gebonden aan de wet, en de rechterlijke uitleg dient rationaliteit, stabiliteit en consistentie naar grondwet of verdrag in zich te dragen. In de rechtsstelsels verschillen de opvattingen over de vraag hoe 'vrij' de rechter zich in de rechtsvinding ten opzichte van de vastgelegde normen mag gedragen. Er kan ter zake van de takkopvatting van de interpreterende rechter een schaalverdeling worden gemakt tussen een heteronoom interpreterende rechter enerzijds en een autonoom interpreterende rechter anderzijds. ${ }^{251}$ In alle stelsels komt in recentere literatuur sterk het beeld naar voren dat de rechter in de rechtsvindingsfase, waarin grondrechten dienen te worden geinterpreteerd, beschikt over een beperkte mate van beoordelingsvrijheid. ${ }^{252}$ De veronderstelde ruimte hangt in hoge mate samen met het vage karakter van grondrechtelijke normen. Voor dat specifieke vage karakter heeft de grondwetgever zijn redenen gehad: de normen dienen open te zijn naar toekomstige ontwikkelingen. ${ }^{253} \mathrm{De}$ rechtsvindingsactiviteit kan in principe in direct verband worden gebracht met de taakopvatting van de rechter naar de wetgever. Dat geeft het geschetste beeld ten aanzien

248 HR 4 nei 1984, NJ 1985, 510 (Gezanenlijke ouderlike mach ongehuwden). In Ouderlike mach no echischeiding was de A-G minder uitwoerig in zijn rechtsvergelijking, en betrok een witspraak wan het Duitse constitutionele Hof in de afweging tussen voor-en nadelen van mede-voogdij.

249 HR 8 juli 1992, NJ1992, 714 (door medische fout ontstane aids-besimeting).

250 Zie Conclusie wan Vranken bij Ferdi E (HR 21 januari 1994, NJCM 19-6 (1994)) an Plug 1997, p. 85.

$25 \Perp$ Wiarda 1999, p. 19.

252 Van Hoecke 1979, p. 1.

253 zie hooldstuk 2. 
van de interpretatie weer: in deze methoden wordt niet enkel de afzonderlijke wetsregel betrokken in de oplossing van het geschil. Wanneer de rechter zich genoodzaakt ziet om in een mogelijk geval zelf in een systematische, teleologische of evolutieve constructie van een rechtsnorm te voorzien kan het voorkomen dat hij wordt beticht van activisme. Deze kritiek komt vooral naar voren in het Amerikaanse debat: originalists en intentionalists stellen dat de rechter zo dicht als mogelijk bij de tekst dient te blijven. Andere methoden zouden hem in die optiek uitnodigen om subjectieve elementen in zijn rechtsvinding te verwerken. Omgekeerd stellen de non-interpretevists dat deze benadering het karakter van de grondwet tekort doet: die is in die optiek juist zo geredigeerd dat aanpassing naar tijd mogelijk blijft. Het afwijzen van deze taakopvatting is juist activistisch: er vindt rechterlijk ingrijpen plaats.

In de laatste twee decennia lijkt de nadruk in de Amerikaanse constitutionele interpretatie ter zake van 'liberty" en "privacy' soms vaker gelegd te worden op een 'originalist-benadering' van de grondwet dan in de daaraan voorafgaande periode. Tot begin jaren ' 70 werd niet gehecht aan een dergelijke benadering; en leek er juist ruimte te bestaan voor een meer teleologisch-dynamische benadering. Dat wil niet zeggen dat er complete tegenstellingen bestaan tussen de verschillende 'Courts'. Hiervoor is al aangeduid, dat er tendensen ter zake van de rechterlijke taakopvatting te zien waren, die varieerden met de wijze waarop het Hof is samengesteld. ${ }^{254} \mathrm{Er}$ zijn echter verschillen in voorkeur voor een bepaalde methode van rechtsvinding ten aanzien van een bepaalde materie. Er zijn zogenoemde 'grondrechtenvriendelijke' Courts geweest, die steeds een voorkeur voor de individuele rechtsbescherming bezigden. Het Warren-Court was vanwege dat uitgangspunt geneigd, in de rechtsvinding ver te gaan om aan dat uitgangspunt gestalte te geverf. ${ }^{255}$ Om dat te bereiken, werden rechtsvindingsmethoden gehanteerd die een extensieve lezing van de grondrechten mogelijk maakten. Binnen het kader van de technisch-juridische interpretatiemethoden knoopte dit Court eerder aan bij de systematische en de teleologische methoden. Het Warren Court bediende zich ook in een aantal gevallen van de analoge redenering, die hieronder verder zal worden uitgelegd.

Het Rehnquist Court vormt in dit verband met het Warren Court een interessant contrast. ${ }^{256}$ In het Relinquist Court zit onder meer rechter Scalia, die steeds benadrukt dat voor de vaststelling van de reikwijdte van grondrechten de 'originalist'-interpretatie dient te worden gevolgd. Een 'originalist'-interpretatie leidt in de regel niet tot extensieve interpretatie van grondrechten, maar eerder tot een enge uitleg ervan. Nu dient voor een uitspraak van het Hof een meerderheid gevonden te worden, en kan een enkele rechter met een dergelijke opvatting niet steeds de toon zetten, omdat de andere rechters ook hun visie op de "juiste' opvatting over rechtsvinding van grondrechten hebben. Wat in dit opzicht dan wel opvalt, is dat het huidige Hof in het algemeen grondrechten minder vaak extensief heeft geïnterpreteerd in vergelijking met het

254 Zie par 3.2 .6

255 Zie par. 3.2.4 en Ducat en Chase 1992, p. 625 e.\%.

256 Het Rehnquist Court startte zijn periode in 1986 en duurt nog steeds voort. 
Warren Court; individuele aanspraken op een extensieve lezing van het recht op 'liberty' of 'privacy' onder het Veertiende Amendement werden in verhouding door het Rehnquist Court vaker afgewezen dan door het Warren Court. In dit verband wordt wel gesproken wan een activistische opstelling van het Warren Court ten aanzien van grondrechten, en een terughoudende opvatting van het Rehnquist Court ten aanzien van grondrechten. 257

In de andere rechtsstelsels is vaak niet zichtbaar in welke mate er discussies bestaan in de rechterlijke instanties over de juiste interpretatiebenadering. Dat heeft in de Nederlandse en de Luxemburgse situatie te maken met de collegiale setting waarin de rechterlijke uitspraken worden gedaan, terwijl in de Duitse situatie meer zichtbaarheid in beginsel wel mogelijk is, maar daar niet vaak gebruik van wordt gemaakt. Zoals reeds aangegeven in Hoofdstuk 3 doet het Duitse Hof relatief zelden een uitspraak die niet wordt onderschreven door alle rechters. De Duitse rechter kan, in tegenstelling tot zijn Luxemburgse en Nederlandse collega, een dissenting of concurring uiten. Dergelijke meningen leggen de lijnen waarlangs het debat in het Hof wordt gevoerd over rechtsvinding bloot, en versehaffen een inzicht in de persoonlijke opvattingen van de rechters. Dat wordt in de Europese stelsels kennelijk niet alleen als een voordeel gezien; de openheid ter zake maakt ook kwetsbaar, in die zin dat de persoonlijke voorkeuren van de rechter onverbiddlelijk zichtbaar wordt. Het Duitse Hof heeft zelf eens aangegeven, niets voor gepersonaliseerde rechtspraak te voelen. Alleen het Europese Hof voor de Rechten van de Mens komen dissentings en concurrings regelmatig tot uitdrukking. Ook maken deze rechters wel gebruik van de mogelijkheid, een persoonlijke visie op de gevolgde rechtsvindingsmethode te geven. De rechters in het EHRM bevinden zich in een Hof dat zich op enkele belangwekkende aspecten onderscheidt van de Hoven in de andere stelsels. Het EHRM opereert niet in een setting waarin het constitutionele spanningsveld direct zichtbaar is. Er is niet direct een grondwetgever, waarmee het zich geconfronteerd ziet, maar het EHRM moet net als de rechters in de andere stelsels terdege rekening houden met het forum waarvoor het recht spreekt. Dat forum bestaat niet uit een democratisch gelegitimeerde wetgever, maar uit soevereine verdragspartijen die in beginsel alleen gebonden zijn aan de uitspraken, voor zover zij partij zijn bij het geschil.

257 Omgekeerd blijkt het Rehnquist Coun, afgaand op de jurisprudentielijnen, juist minder afwijzend te staan tegenover aanspraken van Staten op hun eigen soevereiniteit. Dit onderwerp valt buiten het bestek van dit onderzoek, maar werpt een interessant licht op de mate waarin een activistische taakopvalting samenhangt met de materie waarover het Hof zal oordelen. In kwesties die handelen over materie die samenhangt met de verticale machtenscheiding laat de jurisprudentie van het Rehnquist zien, dat het niet onwelwillend staat tegenover extersieve interpretatie. Hier lijkt een inconsistentie aanwezig, die ook in de literatuur fel wordt bekritiseerd (onder meer Tribe 1999, p. 137 e.4.): een rechter die voor de beoordeling van het ene geschil een rechtsvindingsmethode op principielle constitutionele gronden atkeurt, maar naderhand ter land neemt om een aanspraak van andere aard te beoordelen lijkt niet consistent te handelen. De inconsistentie kan niet worden opgeheven met een rechtvaardiging van de aard van de materie, juist omdat de rechtsvindingsmethoden aan de hand van constitutionele opvattingen werden geijkt. 


\section{Begrenzingen van de rechterlijke vrijheid in de rechtsvinding: uitlegmaximes}

In de rechtsstelsels is een aantal interpretatiemethoden opgespoord die de rechtsvindingsactiviteit van de rechter richting geven. De tekstuele interpretatiemethode blijkt in alle rechtsstelsels de methode die het eerst wordit gehanteerd; bij constitutionele interpretatie is deze methode echter zelden van doorslaggevende betekenis. De textuur van grondrechtsbepalingen wordt dermate open geacht dat een tekstuele benadering niet afdoende bescherming kan bieden - vooral niet indien de uitlegger een benadering ten faveure van individuele rechtsbescherming voor ogen heeft. De tekstuele interpretatie lijkt het vurigst te worden verdedigd in de Verenigde Staten. De discussie over deze methode als constitutionele rechtsvindingsmethode wordt tevens het meest open gevoerd in het Amerikaanse Hooggerechtshof; verdedigers van deze methode stellen dat tekstuele interpretatie het meest recht doet aan de positie van de rechter ten opzichte van de (grond)wetgever. Een tekstuele rechtswinding, zo luidt het argument van originalists en intentionalists, leidt eerder tot een terughoudende taakopvatting, terwijl een dynamisch-evolutieve interpretatie eerder duidt op een activistische houding van de rechter.

De grondwet en het verdrag geven niet veel concrete aanwijzingen over de te volgen interpretatiemethoden. Het Negende Amendement in de Amerikaanse grondwet is in dit verband wel aangehaald als interpretatiemaxime ${ }^{258}$ De Nederlandse grondwet kent het toetsingsverbod, dat tot op zekere hoogte richting geeft aan de wijze waarop de grondwetgever de verhouding tussen rechter en wetgever waarneemt. De Duitse grondwet kent een begrenzing van rechterlijke rechtsvinding in Ast. 79 lid $3 \mathrm{GG}$. In beginsel liggen nauwkeurige instructies van de wetgever die een vaste grondwetsinterpretatie voorschrijven ook niet voor de hand: controle van wetgeving of rechtspraak door een rechter zou in dat verband overbodig worden. Op het eerste gezicht wordt de rechter in het ongewisse gelaten. Teneinde de gevolgde interpretatie te verantwoorden in het licht van de constitutionele verhouding is een aantal interpretatiemaximes in de rechtspraak tot ontwikkeling gekomen, aan de hand waarvan de rechter zijn keuze voor een heteronome of juist meer autonome rechtsvinding motiveert.

Een aantal van deze maximes wordt hier kort besproken in het licht van de constitutionele verhouding tussen rechter en wetgever zonder overigens te willen treden in een beoordeling van de legitimiteit van het argument in de rechterlijke beslissing. In alle stelsels is in uiteenlopende mate de vooronderstelling van grondwettigheid aangetroffen als uitgangspunt bij beoordeling van de vraag of de gewraakte wet in strijd is met de grondwet of het verdrag. Het minst vaak lijkt dit maxime door het Luxemburgse en het Straatsburgse Hof te worden gehanteerd; daarentegen wordt het wel vaker gehanteerd door de Duitse en de Amerikaanse rechter. Uit deze presumptie vloeit bijvoorbeeld de bereidheid voort om aangevochten wetten grondwets- of verdragsconform te interpreteren. ${ }^{259}$ In beginsel duidt de presumptie van grondwettigheid op een terug-

258 Par, 2.3.2.

259 De bereidheid tot verdragsconforme interpretatie komt in dit verband van de zijde van de nationale 
houdende taakopvatting, maar voor activisme is eveneens iets te zeggen. De rechter sleutelt tenslotte aan (een deel yan) de inhoud van de formele wet om die in overeensternming te brengen met zijn perceptie van wat grondwettig is.

Een tweede maxime is het vermoeden ten faveure van de individuele rechtsbescherming. Dit wordt ook wel aangeduid als een gedachte van constitutionalisme: de meerderheidsopvatting dient terughoudend te worden gehanteerd om tot een zo compleet mogelijke bescherming van individuele rechten te komen - ook die van minderheden. ${ }^{260}$ Het lijkt er sterk op dat de rechters die een specifieker constitutioneel mandaat in de zin van individuele rechtsbescherming hebben, zich meer van dit maxime bewust zijn. Het Duitse Hof en het Straatsburgse Hof laten zich in dit opzicht het meest expliciet uit. Het Amerikaanse Hooggerechtshof laat een wat minder consistentie lijn zien, al wordt aangenomen dat dit Hof het maxime rekent tot de interpretatiedoctrine. 261 De minder consistente lijn hangt, bezien over langere periode, enigszins samen met de wisselende samenstellingen in het Hof: er zijn Courts die een accent hebben weten te leggen op individuele rechtsbescherming en Courts die daartegen het vermoeden van grondwettigheid zwaarder hebben laten wegen.

In dit opzicht vormt het maxime ten faveure van de individuele rechtsbescherming een tegenwicht tegen het eerstgenoemde maxime van de presumptie van grondwettigheid. Zij staan aldus in een spanningsverhouding met elkaar, die direct kan worden aangeknoopt bij de constitutionele verhouding: waar de presumptie van grondwettigheid uitgaat van een primaat van de wetgever, doet het tweede maxime dat niet vanzelfsprekend. Of er nu uit het tweede maxime steeds een activistische taakopvatting voortvloeit, kan worden betwijfeld: de rechter corrigeert de wetgever tenslotte aan de hand van de door de grondwetgever gegeven rechtsnormen. Correctie aan de hand van grondwets- of verdragsnormen kan in die optiek dan juist getuigen van terughoudendheid.

In alle stelsels wordt eveneens aangenomen dat de regelingen in de grondwet of thet verdrag moeten worden beschouwd in onderlinge samenhang bij de uitleg ervan. De eenheid van de grondwet kan als maxime worden aangenomen. Uit het geheel van de normen construeert de rechter de betekenis en de reikwijdte van de toepasselijke norm; isolering van de toepasselijke norm wordt als ongewenst gezien, zo lijkt dit maxime te dicteren. Consistentie en coherentie worden met het uitgangspunt van de eenheid van de grondwet gediend; de rechter helpt als het ware de constructie van het constitutionele rechtsnormensysteem consolideren met het uitgangspunt van eenheid. Een met de eenheid van grondwet of verdrag samenhangend maxime is de eis dat wanneer grondrechtelijke normen onderling met elkaar strijden om voorrang, de rechter zich moet beraden over een praktische concordantie. Hij dient grondrechten met elkaar te harmoniseren. Tegelijkertijd dient hij in de harmonisering van betrokken grondrechten

rechter, die gewnakte nationale regel ingen uitlegt in de geest wan het EVRM of van het EG-Verdrag.

260 Dworkin 1977, p. 142.

261 Dworkin 1977, p. 142. 
niet wit het oog te verliezen dat de ingeroepen grondirechtsnorm inhoudelijk zoveel als mogelijk overeind blijft. In de rechtspraak van het EHRM wordt de voorkeur voor de benadering die individuele rechtsbescherming voorop stelt, ingekleurd door het effectiviteitsbeginsel. In de rechtspraak van het Luxemburgse Hof is het beginsel van effectiviteit eveneens aangetroffen, maar niet in het bijzonder in de context van grondrechtelijke bescherming. In de Duitse en de Amerikaanse discussie komt eveneens een besef naar voren, dat grondrechten als zelfverwezenlijking van het individu in dienst staan van een optimalisering van het functioneren van de democratische uitgangspunten.

De individuele rechten dienen een zekere mate van effectiviteit te bezitten, en niet illusoir te zijn. Het 'Optimierungsgebot' in de Duitse doctrine wijst op een zelfde gedachte. In de EG-rechtspraak en de Nederlandse rechtspraak zijn dergelijke uitlegmaximes niet zo expliciet aangetroffen. Dat lijkt mij te verklaren vanuit het feit dat het EG-Verdrag in beginsel niet een bepaalde taakopvatting naar individuele rechten stipuleert en wanuit de sterke nadruk op de economische gemeenschapsdoeleinden in Art. 2 EG-Verdrag. Dat wil niet zeggen dat het Hof aan grondrechten geen waarde hecht; het is echter geen prioriteit in de doelstellingen van het verdrag. Van belang is hier ook, dat het Hof door de Lid-Staten, de verdragswetgever, tot dusverre redelijk expliciet een bindende lijst van grondrechten is ontzegd. ${ }^{262}$ Het ligt daardoor niet voor de hand, dat het Hof zelfstandig een constitutionalistische taakopvatting zal ontwikkelen. Er heeft in dit opzicht geen 'incorporatie' van grondrechten plaatsgevonden via de rechtspraak van het Hof van Justitie.

De Nederlandse rechter is niet primair en evenmin specifiek belast met constitutionele rechtspraak; de Hoge Raad functioneert als civiele of strafrechter in cassatie. Deze rechter krijgt evenwel te maken met constitutionele interpretatie, maar niet op een wijze als de rechters waarmede hij hier wordt vergeleken. Dat hangt samen met het mandaat van de Hoge Raad, meer in het bijzonder het ontbreken van grondwettigheidstoetsing van wetgeving in formele zin. In geschillen over lagere wetgeving doet zich de politieke context in beginsel niet in die mate gelden, als in geschillen waarin formelle wetgeving ter discussie staat bij de hoogste rechter. De verminderde aanwezigheid van dit constitutionele spanningsveld - in vergelijking met de mate waarin dat in de andere stelsels aanwezig is - dwingt de Nederlandse rechter niet dermate expliciet zijn constitutionele positie ten opzichte van de wetgever te definiëren aan de hand van een constitutionele interpretatiedoctrine.

In alle stelsels lijkt aanknoping bij een geldige rechtsnorm het uitgangspunt bij technisch-juridische interpretatie te zijn. Wanneer er geen rechtsgeldige norm is waarbij de individuele aanspraak kan worden aangeknoopt, wordt de mogelijkheid van interpretatie aan de hand van de technisch-juridische interpretatiemethoden in beginsel beperkt. In dergelijke gevallen wordt binnen de systematische, de teleologische en de dymamisch-evolutieve interpretatiemethoden gezocht naar richtinggevende structuren die

262 Het Handvest van de Europese Unie is als Verklaring gehecht aan het Verdrag van Nice, en heeft formeel geen bindende werking voor de Instellingen van de Gemeenschap. 
boven de eventueel toe te passen wettelijke norm uitstijgen. In dit verband wordt dan wel aansluiting gezocht bij bijvoorbeeld Preambules, rechtsvergelijking, rechtsbeginselen en normen die vergelijkbare rechtsculturen gemeenschappelijk hebben. De wijze waarop de rechter de toepasselijke rechtsnorm aan de hand van deze richtinggevende structuren invult of construeert, zal in het B-deel centraal staan.

\subsection{De analogie}

\subsubsection{De analoge redeneerwijze}

De analoge redeneermethode is een instrument dat behulpzaam kan zijn bij het vaststellen van de omtrekken van een toepasselijke rechtsnorm in de rechtsvindingsfase. Het biedt mogelijkheden om een systematische, teleologische of dynamisch-evolutieve interpretatiemethode inhoud te geven. In het geval de rechter voor zijn beslissing op normen als 'Menschenwürde', 'liberty", 'privé-leven' of 'persoonlijke levenssfeer' is aangewezen voor het te berechten geval, kan hij trachten zich naast het gegeven geval één of meer vergelijkbare gevallen voor te stellen aan de hand waarvan hij de omtrekken van een rechtsregel verantwoordt. Gaat het bijvoorbeeld om de vraag of een individuele aanspraak op een consensuele homoseksuele relatie onder 'liberty" kan worden gekwalificeerd en is de wijze waarop die vraag moet worden beantwoord niet evident, dan kan de rechter in een analoge redenering pogen een vergelijkbare variant te vinden die wel onder "liberty" kan worden gekwalificeerd, en daarna eén die er zeker niet onder valt. Een vergelijking van beide varianten zal dan tot een beslissing leiden. De analoge redeneermethode kan worden ingezet wanneer sprake is van een moeilijk geval. ${ }^{263}$ Hiervan is sprake wanneer de toepasselijke norm gegeven is, maar niet zonder meer toepasbaar op het voorliggende geschil, wanneer de gangbare interpretatie van de toepasselijke norm als achterhaald moet worden beschouwd, en ten slotte wanneer twijfels rijzen over het rechtskarakter van de ingeroepen norm. De analoge redenering lijkt in dergelijke gevallen vaak de aangewezen weg waarlangs een beslissing kan worden verkregen die de eisen van rechterlijke objectiviteit in de rechtsvinding zo dicht mogelijk benadert. ${ }^{264}$

\section{Wetsanalogie}

In de analoge redenerung is een aantal steeds terugkerende, specifiekere redeneerlijnen te ontwaren. Het uitgangspunt van het opsporen van identieke of vergelijkbare gevallen is voor de verschillende gevallen hetzelfde, maar het 'moeilijke geval" vraagt in de regel om een meer toegesneden benadering in de redenering. Wanneer de toepasselijke norm gegeven is, maar de vraag rijst of het voorliggende geschil kan worden gekwalificeerd onder de toepasselijk geachte norm, kan de rechter een wetsanalogie toepassen. Een wetsanalogie houdt in dat er een rechtsnorm voorhanden is; de omtrekken ervan 
zijn in het licht van het voorliggende geschil echter niet helder. Aan de hand van vergelijkingsmateriaal tracht de rechter te komen tot de formulering van een norm van hoger recht, die het vergelijkingsmateriaal en het voorliggende geschil met elkaar verbindt in het licht van de wettelijke bepaling en kwalificatie van de individuele aanspraak in het voorliggende geschil kan rechtvaardigen.

Het geschil kan dan worden opgelost met behulp van een nieuw gevormde regel die is georiënteerd aan de wettelijke norm. De wettelijke norm is door de wetgever destijds wellicht opgesteld voor een casus met een ander feitencomplex, maar de rechter acht toepassing van deze regel op het voorliggende geschil evenwel mogelijk en zinvol. De rechter verantwoordt de toepasselijkheid van de regel op het voor hem liggende juridische conflict aan de hand van een norm van hoger recht, bijvoorbeeld een rechtsnorm met het karakter van een rechtsbeginsel. ${ }^{265}$ Die norm van hoger recht is door de rechter gedestilleerd uit het vergelijkingsmateriaal. De grondwettelijke bepaling vormt het uitgangspunt voor de beoordeling van het geschil; diens reikwijdte wordt aan de hand van een hogere rechtsnorm bepaald en indien noodzakelijk toegesneden op het voorliggende geschil. Omdat er een wettelijke bepaling voorhanden is, kan in dit verband worden gesproken van een wetsanalogie. Het begrip 'recht op privé-leven' ex Art. 8 EVRM of het recht op persoonlijke ontplooiing ex Art. 2 lid 1 GG zijn rechtsnormen die een subjectiefrechtelijk karakter toekomt, maar de omtrekken ervan staan echter allerminst vast.

De term wetsanalogie wordt in de Duitse literatuur gekend als 'Gesetzesanalogie', al geldt deze redenering niet als een speciale methode van rechtsvinding in het constitutionele recht. ${ }^{266}$ De wetsanalogie is vooral in het privaatrecht een beproefde rechtsvindingsmethode op het terrein van vage normen die bijvoorbeeld besloten liggen in de redelijkheid en billijkheid, zorgvuldigheid en redelijk werkgeverschap. ${ }^{267}$ In de Nederlandse literatuur heeft Nieuwenhuis de aandacht gevestigd op 'singuliere analogie', een term die werd ontleend aan Larenz" begrip van de 'Gesetzesanalogie'. ${ }^{268}$ De singuliere analogie komt sterk overeen met de hiervoor gepresenteerde wetsanalogie. In de Nederlandse grondrechtelijke rechtspraak wordt aan de wetsanaloge methode geen speciale waarde gehecht; de analoge methode is evenwel van groot belang in het kader van de privaatrechtelijke rechtsvinding door de Nederlandse rechter. ${ }^{269}$ Analoge interpretatie van grondrechten vindt in Nederland echter veelvuldig plaats via open normen

265 Zie voor typering van deze normen par. 4.6 .

266 Larenz 1991 , 381. e.v. (Larenz pleit echter voor het hanteren van het begrip "Einzelanalogie", omdat de toepasselijke wettelijke norm niet in zijn oorspronkelijke vorm wordt aangewend).

267 MacCormick en Surmmers 1991, p. 471, Alexy en Dreier 1991, p. 89, Koopmans (Wiarda 1999), p. 110.

268 Nieuwenhuis 1976, p. 502. Wiarda spreekt van de "vergelijkingsmethode" indien de rechter wordt geconfronteerd met wage normen als 'goede zeden", "redellikkheid en billijkheid' of "zorgvuldigheid". De opbouw wan de vergelijkingsmethode wertoont sterke overeenkomsten met de wetsanalogie en de rechisanalogie (Wiarda 1999, p. 107 e.w.). Zie verder ook Groenewegen 1996, p. 108 e.w.

269 Bruggink 1990, p. 112 e.w. 
in het privaatrecht. ${ }^{270}$ In de literatuur ter zake van de rechtsvinding van het EHRM en het Hof van Justitie is de wetsanalogie nauwelijks een afzonderlijk thema.

In de Amerikaanse literatuur maakt de 'analoge redenering' als zodanig geen deel uit wan de 'gevestigde' interpretatiedoctrines. Het is echter wel steeds vaker onderwerp wan de constitutionele verhouding dat de laatste jaren in de volle belangstelling staat in het Amerikaanse constitutionele rechtvindingsdebat in verband met de rechterlijke taakopvatting in de constitutionele verhouding ${ }^{271}$ Betwijfeld wordt bijwoorbeeld in hoeverre de uitkomst van een analoge redenering kan worden aangemerkt als objectieve rechterlijke rechtsvinding. Aan de hand wan de analoge redenering zou de rechter zich in staat stellen zijn persoonlijke opvatting in een grondrechtelijke norm te laten doorklinken. Op gronden die legitiem lijken kan de rechter met een subjectieve invulling democratisch gelegitimeerde wetgeving terzijde stellen.

\section{Rechtsanalogie}

Het komt voor dat de rechter een individuele aanspraak moet beoordelen waarvan niet vaststaat of de ingeroepen norm wel behoort tot het bestaande kader van rechtsnormen. De rechter kan in de rechtsvindingsfase niet direct aanknopen bij een wettelijke norm. In deze redeneerwijze staat ter zake van de vraag naar toepasselijkheid van een wettelijke norm op de individuele aanspraak aldus niet, zoals in de wetsanalogie, een grondrechtsnorm centraal. Deze blijkt namelijk niet in de grondwet of het verdrag woorhanden te zijn. De rechter construeert aan de hand van een aantal vergelijkbare gevallen zelf een rechtsnorm, waarvan hij in de veronderstelling verkeert dat die past in het bestaande rechtsnormenkader. Die inpassing in het rechtsnormenkader dient de rechter in zijn motivering te verantwoorden, hetgeen geschiedt aan de hand van een norm van hoger recht. Het verschil met de wetsanalogie is gelegen in het feit dat de rechter in de rechtsanalogie een nieuwe rechtsnorm in de rechtspraak positiveert, hetgeen betekent dat de door de rechter geformuleerde rechtsnorm wordt verheven tot ongeschreven rechtsregel. ${ }^{272}$ In de wetsanalogie interpreteert de rechter de bestaande wetsnorm extensief. In de rechtsanalogie is van extensieve interpretatie geen sprake meer; de rechter verheft 'een norm' die wordt geconcretiseerd uit de norm van hoger recht tot een ongeschreven recht. Tegen de rechtsanalogie bestaat in beginsel een grotere weerstand vanuit het perspectief van de constitutionele verhoudingen: de rechter formuleert in dergelijke gevallen zelf een nieuwe rechtsregel - een activiteit die in principe voorbehouden is aan de wetgever.

270 Scholten 1974, p. 60 e.w.

271 Zive onder meer Cardozo 1921, p. 31-50 (Cardozo spreekt in dit verband over de "method of philosophy"): Black 1983 (Black spreekt in dit verband over structural reasoning); Sunstein 1993; Posner 1990 , p. 86 e.v.; Posner 1992, p. 433 e.v.; Tribe 2000, p. 40 e.w.

272 Nieurwenhuis 1976, p. 504 ; Laremz 1991 , p. 383. 


\subsubsection{Inductie in de amaloge redenering}

Het proces van de analoge redenering vertoont inductieve trekken. In de inductieve redeneertrant wordt aldus van het bijzondere [het vergelijkingsmateriaal] nar het bijzondere (het voorliggende geschil) geredeneerd. ${ }^{273}$ Aan de hand van de vergelijking van de door de rechter gevonden of bedachte varianten en het voorliggende geschil formulleert hij vervolgens een norm van hoger recht, die de varianten en het voorliggende geschill met elkaar verbindt. Die hoger gelegen norm inspireert hem, aan de toepasselijk geachte wettelijke norm een extensieve uitleg te geven, die kwalificatie van zowel de bijvoorbeeld uit de rechtsptaak of uit de wetgeving afgeleide varianten als de voorliggende individuele aanspraak rechtvaardigt. ${ }^{274}$ Van belang is, dat de inductieve redeneerwijze als het ware een stap heeft ingebouwd, die in de concrete toepassing van de analogie niet altijd naar voren komt. In de analogie wordt namelijk vaak rechtstreeks van het bijzondere (het door de rechter gevonden vergelijkingsmateriaal) naar het bijzondere (het voorliggende geschil) geredeneerd. Er moet echter altijd een tussenstap worden genomen, die de afzonderlijke individuele aanspraken of feitencomplexen met elkaar in verbinding brengt. In de wetsanalogie wordt deze verbinding tot stand gebracht door een norm van hoger recht. Deze norm vertoont soms sterke overeenkomsten met het rechtsbeginsel. ${ }^{275}$ De 'verbinding' die noodzakelijk is om de gevonden voorbeelden en de voorliggende individuele aanspraak met elkaar te vergelijken, wordt lang niet altijd expliciet genoemd, laat staan uitgewerkt door de rechter. Nieuwenlunis verwoordt dit probleem van de wetsanaloge redeneertrant op heldere wijze:

'Het is duidelijk, dat het argumentum per analogiam, gemeten naar deductief-logische maatstaven, niet door de beugel kan. Een analogie-argument heeft immers de volgende vorm: indien $p$, dan $q$; $r$ lijkt op $p$; indien $r$ dan $q$. De conclusie 'indien $r$ dan $q$ ' uit 'indien $p$ dan $q$ ' is slechts gerechtvaardigd op grond van het niet-deductieve, maar evaluatieve oordeel, dat aan situaties die op elkander lijken hetzelfde rechtsgewolg moet worden verbonden" ${ }^{276}$

De wetsanaloge redenering kan ten aanzien van de constitutionele verhoudingen de nodige spanningen oproepen. De rechter interpreteert een bestaande wetsnorm extensief, maar hij lijkt niet altijd en niet direct te willen tonen op welke grondslag die extensieve interpretatie nu precies is geschoeid. Dat zou te maken kunnen hebben met het feit, dat de rechter een evaluatief oordeel moet vellen over de vergelijkbarirheid van de varianten enerzijds en het voorliggende geschil anderzijds. Vanuit het oogpunt van de rechterlijke taakopvatting is het niet steeds gebruikelijk, aan te nemen dat de rechter een evaluatief oordeel toekomt waar het gaat om de toepasselijkheid wan de norm. Wat betreft het inductieve redeneerschema bestaat er geen principieel onderscheid tussen de wetsanalogie en de rechtsanalogie. In de laatste wordt eveneens een inductief redeneerschema gebezigd. Het verschil met de wetsanalogie is gelegen in de uitkomst: in de rechtsanalogie zoekt de rechter vanuit de hoger gelegen norm - gemeenschappelijk aan de varianten en het voorliggende geschil - geen aansluiting bij een wettelijke norm. In

273 Sumstein 1993 , p. 746.

274. Voor voorbeelden zie par. 4.43

275 Zie hierna par. 4.6 .

276 Nieuwenhuis 1976 , p. 503 . 
het geval van de rechtsanalogie vormt de hoger gelegen norm aldus de enige grondslag op basis waarvan het voorliggende geschil wordt beoordeeld.

Ter zake van de constitutionele verhoudingen bestaat een tweeledig probleem* niet alleen moet de rechter een evaluatief oordeel vellen over de vergelijkbaarheid wan de varianten en het voorliggende geschil; hij dient eveneens het bestaan van de norm van hoger recht te rechtvaardigen alsmede de concretisering vanuit die norm van hoger recht in te passen in het bestaande rechtsnormenkader. Met deze activiteiten kan een rechter zich in hoge mate rechtsvormend, zo niet regelgevend opstellen, hetgeen spanning in de constitutionele verhouding oproept. Gesteld zou kunnen worden, dat de hantering van een rechtsanalogte de spanning in verdergaande mate opvoert dan hantering van de wetsanalogie; het verschil is in belangrijke mate gelegen in het feit dat in de wetsanalogie nog wordt aangeknoopt bij een wettelijke bepaling. Een rechtsanaloge redenering is te vinden in Valkenhorst; er was geen gepositiveerde regel waarbij de rechter de individuele aanspraak - kennisneming van de biologische afstamming - kon aanknopen. Er bleken in dit geval echter wel regels in de grondwet of in het verdrag voorhanden, die gezamenlijk konden leiden tot de vaststelling van een uit een norm van hoger recht afgeleid ongeschreven recht. De norm van hoger recht ${ }_{\text {, }}$ in casu het persoonlijkheidsrecht vormde de grondslag voor het recht op kennis van de biologische afstamming. De rechter induceerde die uit een contaminatie van enkele grondwettelijke normen.

\subsubsection{Wetsanalogie: een voorbeeld wit de jurisprudentie}

Een fraai voorbeeld is te vinden in de Amerikaanse rechtspraak in de zaak Meyer $t$. State of Nebraska ${ }^{277}$ waarin het een leraar op een school bij de wet verboden werd in een andere taal dan het Engels onderwijs te verzorgen. Een leraar, die zijn lessen gedeeltelijk in de Duitse taal gaf (feitencomplex $r$ ) beriep zich op "liberty" in het Veertiende Amendement (de ingeroepen grondwetsnorm waarvan over toepasselijkheid twijfel bestond $\mathrm{q}$ ), omdat hij meende dat de wet daarmee in strijd was. Ouders en opvoeders dienen zelf te kunnen beslissen over de inhoud van de opvoeding, zo was de gedachte daarachter. De voorkeur voor een bepaalde taal in het onderwijs werd niet expliciet gedekt door "liberty" uit het Veertiende Amendement. Het Amerikaanse Hooggerechtshof $\mathrm{kwa}$ alificeerde $(\mathrm{q})$ onder het Veertiende Amendement $(\mathrm{r})$; het refereerde ter zake uitgebreid aan voorafgaande rechtspraak (de 'gevestigde' strekking en gevolgen van de toepassing van de rechtsregel (p)):

\footnotetext{
"While this court has not attempted to define with exactness the liberty thus guaranteed, the term has received much consideration and some of the included things have been definitely stated. Without doubt, it denotes that not merely freedom from bodily restraint but as the right of the undividual to contract, to engage in any of the common occupations of life, to acquire useful knowledge, to marry, establish a home and bring up children, to worship God according to the dictates of his own conscience, and generally to enjoy those privileges long recognized at common law as essential to the orderly pursuit of thappiness by free men.'
} 
Hierna volgde een verwijzing naar voorafgaande rechtspraak (p), waarin het recht op 'lliberty' (q) nadere invulling heeft gekregen. ${ }^{273}$ De klacht van Meyer (r) valt in de optiek van het Hof eveneens in de categorie claims, die bescherming van 'liberty' uit het Veertiende Amendement genieten. Met name het door het Hof benoemde recht 'to acquire useful knowledge' is in Meyer van doorslaggevend belang. Dat recht is echter niet terug te vinden in de door het Hooggerechtshof aangehaalde rechtspraak, die voor het leeuwendeel handelt over de onder "liberty" geclassificeerde contractsvrijheid en het recht op gelijke behandeling voor de wet. De norm van hoger recht van Meyers aanspraak - het recht "to acquire useful knowledge" - met de andere uit 'liberty' voortwoeiende rechten als erkend in voorafgaande jurisprudentie werd in casu gevonden onder "the orderly pursuit of happiness by free men'. Dit uitgangspunt lijkt hier als een norm van hoger recht te fungeren, waaruit de door het Hooggerechtshof opgesomde rechten als het ware voortvloeien als concretiseringen van "liberty". De voorafgaande zaken waarin het 'liberty' reeds had gedefinieerd, hebben, wat hun feitencomplex betreft, niet direct verband met het feitencomplex van Meyer. Het aanknopingspunt in Meyer is dan ook niet de specifieke vergelijkbare casusposities maar wordt aldus gevonden in de norm van hoger recht "the orderly pursuit of happiness by free men". Deze norm ligt kennelijk verscholen in de notie van "liberty" in het Veertiende Amendement, en is in staat zeer uiteenlopende aanspraken op het Veertiende Amendement te rechtvaardigen.

\subsubsection{Rechtsanalogie: een voorbeeld uit de jwrisprudentie}

In de zaak Valkenhorst paste de Hoge Raad de rechtsanalogie toe. ${ }^{279}$ In deze zaak claimde een kind het 'recht', te weten door wie het was werwekt. De moeder weigerde echter, het kind mede te delen wie de verwekker was, en de instelling waar het kind ter wereld was gekomen weigerde inzage in de gegevens te verstrekken die het in staat zouden kunnen stellen, van de afstamming kennis te nemen. In de Nederlandse grondwet is echter geen rechtsregel ter zake van de kennisneming wie de verwekker is. ${ }^{280} \mathrm{Er}$ was echter wel een recht op persoonlijke levenssfeer, maar dat werd in dit geval niet, athans voor de positie van het kind, als toepasselijke rechtsregel voor de individuele aanspraak aangehaald. De premisse inhoudende de keuze van de toepasselijke rechts-

278 Het Hooggerechtshof wijst in dit verband op dertien voorafgaande zaken, waatin het recht op 'liberly' nader had gedefinieerd In de Slaughterhouse-cases, in Mimnesota tegen Bar, Allgeyer t. Louisiana, Lochner I. New York, B. \& Q. R.R. t. MoGuire, New York Life Ins. Co. t. Dodge, en Adkins t. Children's Hospiral werd het "liberty'-aspect betreffende contractswrijheid genoetmd in verband met de wetgevende bevoegdheid van de federatie; in Twining $t$. New Jersey wordt als aspect van 'liberty' van het vermoeden van onschuld genoemd; in 'Truax t. Raich werd het recht op gelijke behandeling voor de wet onder "liberty" benoemd. Zie de uitspraak Meyer t. Nebraska; de door het Hof aangehaalde rechtspraak werd onderzocht wia de internetsite http://www.findlaw.com/casecode/supreme.html (laatstelijk geraadpleegd op 31 oktober 2002).

279 Valkenhorst, HR 15 april 1994, NJ 1994/608.

280 Op dat moment werden in verband met donorinseminatie wel debatten gevoerd over de mate waarin een kind dat uit kunstmatige inseminatie ontstaat, kennis moet kunnen verwerven over zijn afstamming. Die discussie was op dat moment nog niet beëindigd. De Hoge Raad gaf in Valkenhorst expliciet atan, niet op deze discussie in te gaan of vooruit te lopen op ophanden zijnde wetgeving. 
regel (g) was problematisch in Valkenhorst. Voor de "vorming' van de toepasselijke rechtsregel bouwde de Hoge Raad de volgende redenering op. Uit verschillende, niet voor onderhavig feitencomplex (r) geformuleerde rechtsregels werd een rechtsnorm gedestilleerd, waaruit een voor de aanspraak van het kind relevante nadere concretisering noortwloeide. De Hoge Raad constateerde, dat:

"aan grondrechten als recht op het respect voor het priwe-leven, het recht op wrijheid van gedachte, geweten en godsdienst en het recht op vrijheid van meningsuiting een algemeen persoonlijkheidsrecht ten grondslag ligt".

Achter een aantal grondwetsnormen werd aldus een algemeen persoonlijkheidsrecht ontwaard, waaruit de in de grondwet geexpliciteerde rechten voortvloeien. Dit algemene persoonlijkheidsrecht heeft een sterk beginselmatig karakter, dat zich in die hoedanigheid niet leent voor een directe toepassing op de aanspraak van het kind in Valkenhorst. Vervolgens construeerde de Hoge Raad uit dat algemene persoonlijkheidsrecht het recht om te weten van welke ouders men afstamt. De toepasselijke rechtsregel werd door de Hoge Raad geformuleerd aan de hand van een beginsel dat kennelijk eveneens de grondslag vormt voor andere grondrechten (p). ${ }^{281}$ Het persoonlijkheidsrecht was tot dan toe echter nooit als hoger gelegen rechtsnorm, die invulling geeft aan grondrechten, naar voren gehaald. De rechter moest de toepasselijke rechtsregel eerst nog "vinden'. De toepasselijke rechtsnorm construeerde hij aldus uit dat persoonlijkheidsrecht, dat enkele grondwetsbepalingen gemeen bleken te hebben. ${ }^{282}$

De invulling van de premissen lijkt in de rechtsanalogie niet op gelijke wijze op te gaan als in de wetsanaloge methode. Voor het door de rechter te beoordelen feitencomplex (r) is geen in de wet of rechtspraak gepositiveerde rechtsregel (q) voorhanden. Vergelijkbare gevallen in de jurisprudentie (p) zijn evenmin aanwezig: zij laten zich, voor zover voorhanden, lastig vergelijken met het feitencomplex. Rechtsregel $(q)$, waaraan in de wetsanalogie het rechtsgevolg van grondwettelijke bescherming werd toegekend, is evenmin voorhanden. In de rechtsanalogie wordt zichtbaar in welke mate de premissen $(q)$ en ( $r$ ) elkaar in hoge mate kruisbestuiven in de rechtsvindingsfase. De individuele aanspraak definieerde in Valkenhorst tot op grote hoogte de toepasselijke rechtsregel. Op deze wijze wordt de indruk gewekt, dat de rechter de mogelijkheid heeft willekeurige aanspraken te erkennen onder het grondwettelijke beschermingsregime.

281 De Hoge Rand haalde enkel de hiervoor geciteerde grondnechten aan. A-G Koopmans betrok eweneens andere gepositivecrde rechten in zijn rechtvaardiging van het bestann wan het persoonlijkheidsrecht. In zijn optiek ligt aan Art. I:I lid I BW (het genot op burgerlijke rechten), Art. 1 Grondwet (het nondiscriminatiebeginsel), Art. 2 lid I EVRM (recht op leven) het persoonlijkheidsrecht ten grondslag, die" "zonder dit uitgingspunt niet to begrijpen zijn" (Koopmans par. 19 in zijn Conclusie). Ook het feit dat het recht, de identiteit te kennen, door de Duitse rechter in thet Federale Constitutionele Hof erkend is, is it Koopmans' redenering van belang, het bestaan wan dat recht (voortkonnend uit dat algemene per. soonlijkheidsreclit) te vestigen (Conclusie, par. 19).

282 De Hoge Raad betrekt eveneens Art. 7 van het Verdrag van de Rechten van het Kind in zijn redenering, dat in de Engelstalige versie luidt: 'The child shall be registered immediately after birth and shall have. the right from birth to a name, the right to acquire a nationality and, as far as possible, the right to know and be cared for by his or her parents". Op het moment van de uitspraak (1994) was dit verdrag van 20 november 1989 door Nedetland nog niel geratificeerd. 
Die kwalificatie levert een aantal niet onbelangrijke neveneffecten op. Er lijkt een rechterlijke beoordelingsruimte te ontstaan wanneer een rechtsanaloge redenering wordt gebruikt. De rechter beroept zich bij de erkenning van de individuele aanspraak op een norm van hoger recht, die een extensieve uitleg van de grondrechtelijke norm of die de positivering van een nieuw recht dient te rechtvaardigen. Met deze constructie motiveert hij de keuze voor het rechtsvindingsproces, en legitimeert hij het bestaan van het zojuist ontdekte, ongeschreven recht.

\subsection{Enkele kanttekeningen bij de analoge redenering}

\subsubsection{Algemene opmerkingen naar aanleiding van de gegeven voorbeelden}

In de wetsamalogie is het evaluatieve oordeel van de rechter van groot belang, in het opzicht dat hij de vergelijkbaarheid van de casusposities of de toepasselijkheid van de regel op 'oude" en 'nieuwe' casusposities dient te motiveren. Aan de situaties die in de optiek van de rechter op elkaar lijken dient hetzelfde rechtsgevolg te worden verbonden. De vaststelling, dat $r$ op $p$ lijkt, is van cruciaal belang in verband met de toepasselijkheid van de rechtsregel. De wetsanalogie berust aldus op een vergelijking, waarbij de individuele aanspraak van de te beoordelen zaak niet in zijn totaliteit overeenstemt met de individuele aanspraak waarvoor de wetsregel initieel werd geformuleerd. De keuze voor de invalshoek van de vergelijking is van belang: deze benadering wordt namelijk bepaald door het doel van de vergelijking. Het doel van de vergelijking bepaalt in welk opzicht de vergelijkbaarheid van de feitencomplexen van de zaken (p) en (r) aan de orde en in orde is. De motivering, in welk opzicht (p) en (r) op elkaar lijken, blijkt in dit opzicht niet altijd bevredigend. Voorheen werd reeds gewezen op de verzwegen tussenstap in de analogieredenering, een tussenstap die te maken heeft met rechterlijke waardering van de vergelijkbaarheid van de 'oude' en de 'nieuwe' gevallen. De norm van hoger recht, die het cement vormt tussen de gevestigde omtrekken van het grondrecht enerzijds en de voorliggende individuele aanspraak anderzijds, lijkt een nadere motivering in sommige gevallen overbodig te maken. De redeneertrant in Meyer lijkt met een verwijzing naar het recht op het nastreven van geluk door de mens' relatief eenvoudig te kunnen worden gemotiveerd. Wie kan daar nu op tegen zijn?

\subsubsection{Analogie ter inulling van systematische, teleologische en dynamisch- evolutieve witleg}

De redeneermodellen 'wetsanalogie' en 'rechtsanalogie" overziend is het zinvol om hier stil te staan bij de parallellen met de systematische, de teleologische en de evolutieve interpretatiemethode. Indien de rechter de systematische methoden hanteert, zal hij voor de invulling van de wettelijke bepaling aanknopen bij rechtsnormen elders in de wet. Indien voor de omvang van de reikwijdte van de betrokken bepaling wordt aangeknoopt bij 'aanpalende' wetsbepalingen lijkt de rechter binnen bepaalbare kaders te interpreteren. Indien de rechter zich in een systematische interpretatie voor de vaststelling, of de wetsbepaling op het betrokken geschil van toepassing is, verlaat op ho- 
gere rechtsnormen, redencert hij wetsanaloog. Tussen de wetsanaloge redenering en de systematische interpretatie is het verschil dan weggevallen. Hetzelfde geldt voor een telleologische interpretatie. Hanteert de rechter deze methode, dan tracht hij het doel van de regeling te achterhalen. Het doel wan een wettelijke regeling kan bijvoorbeeld blijken uit de redenen die de wetgever had om de regeling tot stand te brengen. Deze redenen zijn bijwoorbeeld te traceren in Kamerstukken of in zogenoemde "travaux preparatoires", maar ook in Preambules. Het EG-Verdrag vermeldt in dit verband enkele centrale doelstellingen, die het Hof van Justitie van de $\mathrm{EG}$ in de vaststelling van de reikwijdte van verdragsbepalingen heeft betrokken. ${ }^{2 * 3}$ De doelstelling van een wettelijke bepaling kan een sterk beginselmatig karakter dragen. Indien dat het geval is, kan de teleologische interpretatie in dit opzicht sterke gelijkenis vertonen met de wetsanalogie: ook hier tracht de rechter in een abstracte, achter de grondwetsbepaling gelegen rechtsnorm het doel van die bepaling te achterhalen. De systematische en de teleologische interpretatiemethode en de wetsanaloge redenering kunnen in elkaars verlengde liggen. De wetsanalogie kan als redeneerwijze worden gehanteerd om aan de systematische of teleologische interpretatiemethode inhoud te geven. Voor de rechtsanalogie gaat dit niet op; een voorwaarde van het toepassen van de rechtsanalogie is dat er in het geheel geen toepasselijke wettelijke norm voorhanden is. Indien systematisch, teleologisch of evolutief wordt geinterpreteerd, is de wetsbepaling altijd het uitgangspunt.

Naast de analoge redeneermethoden zijn enkele andere redeneermethoden aan te wijzen, die behulpzaam kunnen zijn in het opsporen van toepasselijke rechtsnomen. Hiertoe behoren onder meer de pragmatische of redelijke wetsuitleg ${ }^{284}$ en het redeneren op basis van rationaliteit naar de gevolgen van een rechterlijke beslissing. ${ }^{285}$ Redelijke wetsuitleg is aan de orde, indien bijwororbeeld niet-toepassing (of toepassing) van de wet zou leiden tot een apert onbevredigend resultaat, of in het geval van onduidelijkheid van de wettelijke norm. De argumentatie die wordt aangewend om de (niet-) toepassing te rechtvaardigen, kan evenzeer worden ontleend aan een wetsanaloge redenering. Het redeneren op basis van de gevolgen die een bepaalde rechterlijke beslissing teweeg zouden kunnen brengen heeft een speculatief element in zich. De rechter kan zich afvragen, in hoeverre het uitsluiten van toepassing van het recht op vrijheid van meningsuiting in een geval leidt tot een 'chilling effect' op de algemene uitoefening van dat recht. Hij probeert dan in te schatten, in hoeverre afwijzing van toepasselijkheid op voorliggend geschil tot gevolg heeft dat niemand vervolgens meer gebruik 'durft' te maken van het recht. Ook bij het gebruik van deze redeneermethode kan de rechter zich verlaten op een analogie, maar dat hoeft niet. Deze opmerkingen plaatsen de analoge redeneerwijze in een bredere context van mogelijke instrumenten, die een rechter kan aanwenden voor de rechtvaardiging van een vaststelling van de omtrekken van een grondrecht.

283 Zie Art 2 EG-Verdrag.

284 Sunstein 1993, p. 750 e.v; Pontier 1998, p. 44 e.v.

285 Posner 1990, p. 105 e.v. Sunstein 1993, p. 758 e.v. en Gunther en Sullivan 1997, p. 1098. 


\subsubsection{Bedenkingen tegen de analoge redeneen wijze}

Met betrekking tot de analoge redeneerwijze zijn in de literatuur verschillende kritiekpunten geformuleerd. Het sterkst worden de bezwaren tegen de analoge redenering in de Amerikaanse literatuur geuit. Het is hier echter niet de bedoeling, de analoge redeneerwijze als zodanig normatief te beoordelen; in het kader van de betekenis van de methode voor de constitutionele verhoudingen waarbinnen de constitutionele rechter aan rechtsvinding doet, is het echter zinvol de belangrijkste kritiek te schetsen. Deze kritiek is verweven met aspecten van de taakopvatting van de rechter in het kader van de constitutionele verhoudingen. De bedenkingen tegen de analogie zullen hier kort worden uiteengezet en in verband worden gebracht met de constitutionele verhouding waarin de rechter opereert. Op deze punten wordt teruggekomen in de analyse van de jurisprudentie op het terrein wan het recht op persoonlijkheid. ${ }^{286}$

\section{De afwezigheid van externe wetenschappelijke toetsingsmaatstaven}

Een belangwekkende kritiek op de analoge redenering is dat zij onvoldoende wetenschappelijk is. Dat houdt in dat er elementen in de analogie verscholen zitten, die de legitimiteit van de norm van hoger recht soms onvoldoende verifieerbaar maken, of althans minder verifieerbaar dan wenselijk is. Dat is serieuze kritiek, omdat de rechter zich in zijn rechtsvinding dient te oriënteren aan bestaande, verifieerbare rechtsnormen. ${ }^{287}$ Wanneer de rechter zelf normen verheft tot rechtsnormen begeeft hij zich in beginsel in hoge mate op regelgevend vlak, een terrein dat in beginsel aan de wetgever is voorbehouden. Hiermee verbonden is de vraag, wat het karakter van de norm van hoger recht nu eigenlijk is: is het een rechtsbeginsel, een rechtsregel, of een norm die geen plaats toekomt in het bestaande normenstelsel? Tegen de kritiek op de niet-verifieerbaarheid van de norm van hoger recht pleit onder meer, dat de rechter, wanneer hij het relevante vergelijkingsmateriaal samenstelt, zich in beginsel baseert op bestaande overtuigingen in de samenleving. Hiertegen valt zeker bezwaar te maken vanuit het oogpunt, in hoeverre de rechter in staat is een gebalanceerde afweging te maken van bestaande overtuigingen. De rechter mist in beginsel het instrumentarium dat het mogelijk maakt, inzicht te verkrijgen in 'bestaande overtuigingen in de samenleving'. Een andere wijze waarop de kritiek van niet-verifieerbaarheid wel wordt gepareerd is de verwijzing naar het feit dat de rechter zich bij het scheppen van nieuw recht moet oriënteren aan de 'bestaande normenhiërarchie'. Vraag in dit verband is dan wat deze specifiek inhoudt, en wie vaststelt hoe die normenhiërarchie eruit ziet. De rechters in de verschillende stelsels hebben allen minder of meer frequent te verstaan gegeven, dat $z$ ij de hoogste uitlegger zijn van grondwet of verdrag. Daarmee lijken zij zich op het standpunt te kunnen stellen, dat zij tot op grote hoogte bepalen welke normen tot de 'bestaande normenhiërarchie' behoren. ${ }^{288}$ In dit verband betstaat een spannings-

286 Zie hoofdstuk 10 .

287 Sunstein 1993, 743.

288. In de praktijk bijijkt dit tot op grote hoogte op te gaan: de door de rechter gepositiveerde grondrechtsnormen of de extensieve interpretaties werden, althans op het terrein wan het recht op persoonlijkheid, niet gecorrigeerd (zie hoofdstuk 3 onder 'Checks van de wetgever op de rechtsmacht'). 


\section{HoorostuK 4}

verhouding tussen rechter en wetgever: degene die de grondwet of het verdrag bewaakt kan zichzelf er op deze wijze boven plaatsen.

\section{De criteria wan vergelijkbaarheid}

De wets- en rechtsanalogie houden beide onvermijdelijk een waarderingsmoment in, waarop de rechter moet vaststellen waarom de ene groep van gevallen vergelijkbaar is met de andere. Nu zijn de standpunten die in de analogie worden betrokken tot op zekere hoogte objectiveerbaar, maar dat neemt niet weg dat er geen vaste maatstaven zijn, volgens welke de norm van hoger recht dient te worden gedefinieerd. Een voorbeeld kan hier verheldering brengen. Stel, in een analogie worden twee zaken met elkaar vergeleken, om vast te stellen of een norm van hoger recht kan worden geconstrueerd. In een vroegere zaak theeft de rechter uitgemaakt dat het individu het recht toekomt, in zijn slaapkamer zelf te kunnen beslissen over het gebruik van voorbehoedmiddelen. In het voorliggende geschil moet worden beslist over het al of niet bestaan van een recht op homoseksualiteit en homoseksuele activiteiten in de slaapkamer. De grondwet stipuleert het nergens, en bij strafwet is het verboden. Dient de rechter nu te stellen, dat er aan het recht op vrij gebruik van voorbehoedsmiddelen een principièle keuzevrijheid ter zake van seksuele zelfbeschikking ten grondslag ligt, en dat die keuzevrijheid eveneens een recht op homoseksuele activiteiten in de slaapkamer inhoudt? of is de juiste opvatting dat er een vrije beslissing ten aanzien van het gebruik van voorbehoedmiddelen bestaat, en dat er een notie van een vrije keuze van wel of niet voortplanten aan ten grondslag ligt? We hebben in dit kader met twee normen van hoger recht te maken, waarbij het eerste - seksuele zelfbeschikking - van abstracter orde lijkt dan het tweede - de keuze om vrij te kunnen beslissen over de voortplanting. Het tweede beginsel zou een onderdeel kunnen zijn van het eerste, maar dat weten we niet zeker. De vraag die in dit verband rijst is wat het juiste abstractieniveau is voor de definitie van de norm van hoger recht. De rechtswetenschap lijkt hiervoor geen vaste formule te hebben ontwikkeld; de gekozen maatstaf van vergelijking blijft een kwestie van waardering

\section{Verhulling van rationaliteit: retoriek en metaforen}

De definitio van de norm van hoger recht dient zijn grondslag in bestaande rechtsnormen te vinden. Dit kunnen erkende, in het algemeen bewustzijn levende rechtsbeginselen zijn. Indien de rechter deze eis negeert zal de legitimiteit van zijn vaststelling gauw slinken: de grondslag van de norm van hoger recht lijkt dan vooral te zijn gebaseerd op subjectieve overwegingen en niet onvoorwaardelijk juridische kwaliteit te bezitten. Het lijkt vooral zaak voor de rechter dat hij zijn forum overtuigt van de aanwezigheid van de norm van hoger recht in het bestaande normenkader. Vraag is of en in hoeverre die overtuiging wordt overgebracht vanuit een juridisch kader. In het hiervoor geschetste voorbeeld van Meyer $t$. Nebraska bleek de rechtvaardiging voor de vergelijking op basis van het bronnenmateriaal (jurisprudentie) op zichzelf genomen redelijk tegemoet te komen aan de eis van juridische legitimatie. De inhoud van de jurisprudentie vertoonde nawwelijks gemeenschappelijkheid met het voorliggende geval: de jurisprudentie handelde bijna zonder uitzondering over contractsvrijheid, terwij] het voorliggende geschil over de vrijheid van keuze van onderwijs handelde. De ge- 
meenschappelijkheid tussen het vergelijkingsmateriaal en de voorliggende individuele aanspraak werd gevestigd door een norm van hoger recht: "the pursuit of happiness" ${ }^{289}$ In dit verband klemt dan de vraag in welke mate de gevolgde redenering vanuit jurdisch oogpunt rationeel is: is in verband met 'the pursuit of happiness' sprake van een rechtsnorm omdat een frase wordt geciteerd uit de Amerikaanse Preambule? of kan worden gesteld dat de rechter de zaak met een retorische benadering, die niet noodzikelijkerwijze een juridische kwaliteit bezit, heeft beslecht? In beginsel zullen er weinig tegenstanders zijn van het uitgangspunt dat het nastreven van geluk een belangrijk doel is van het individu. Retorische benaderingen behoeven in beginsel niet in de weg te staan aan de juridische kwaliteit van een redenering; zij kunnen de voorgestelde redenering aanzienlijk versterken. Een beroep op de natuurlijke rede en de vanzelfsprekendheid van bepaalde noties vormt een vast onderdeel van de retoriek die wordt. ingezet om nieuwe inzichten ingang te verschaffen. ${ }^{290}$

Ook metaforen behoren tot het instrumentarium van de rechter om een redenering te rechtvaardigen. Een voorbeeld van een metafoor is de veronderstelling in het Amerikaanse recht dat er 'penumbral rights' bestaan die het bestaan van een recht op 'privacy' legitimeren. ${ }^{291}$ ' Zij kunnen uitgroeien tot uitlegmaxime, of zelfs tot beginselen van constitutioneel recht. ${ }^{292}$ Een metafoor is een figuurlijke uitdrukking van een vergelijking. De kracht ervan is gelegen in de indruk die wordt gewekt, de waarheid te beschrijven. Het probleem met metaforen is tegelijkertijd dat zij een loopje kunnen nemen met de lezer:

'The trouble with metaphors is that they have a strong pull on our fancy. They tend to run away with us. Then we find that our thinking is directed not by the force of argument at hand, but at the interest of the image in our mind. ${ }^{293}$

De realiteit is vaak complex en de metafoor brengt haar terug tot proporties waarin de greep op de realiteit vergroot lijkt te worden. De lezer doet daarom node afstand van de metafoor. In de eigenschap, de realiteit grijpbaar te maken zit de overtuigingskracht besloten; het gevaar van een metafoor ligt in dezelfde kracht verscholen. Zij kan ver sluierend werken omdat de lezer de rechterlijke redenering, die met een metafoor werd

289 Nieuwenhuis 1997 , p. 48 e.w.

290 Nieuwenhuis 1997, p. 50 .

291 In andere rechtsstelsels wordt het bestatan van kernuechten en perifere rechten wkend, die tot op zekere hoogte vergelijkbaar zijm met de 'penumbra'.

292 Zie bijvoorbeeld de volgende netaforen in het Amerikaanse recht die de status var interpmetallemaxime wisten te bereiken en veelvuldig werden herhald. "the wall of separation between church and state", "First Amendment freedoms need breathing space to survive", hetgeen impliceert dat er voorzichtig moet worden omgesprongen met beperkingen op het recht op vrijheid van meningstuiting; een school is cen "marketplace of ideas"; dit idee verbindt diversiteit an pluriformiteit mat elkaar zonder te treden in een abstracte, theoretische beschouwing over de vrag in hoeverre dat aantoonbar is; daariatast hebben sommige beperkingen op de vrijheid wan meningsuiting hebben een 'chilling effect' op de uitoefening van dat recht zodat aan beperkingenspecifieke eisen mogen worden gesteld (zie Bosmajian 1992, hoofdstuk 1 woor voorbeelden). Zle ook Lakoff 1980 voor de verschillende typen metaforen; hij beschrijh $z$ vanuát een meer literaire achtergrond terwijl Bosmajlian metaforen en retoriek vanuit het juridisch perspectief beschrijft.

293. M. Beardsley, geciteerd door Bosmajian (Bosmajian 1992, p. 38). 


\section{HOOFDSTLK 4}

uitgewerkt, niet meer aan nadere vraagstelling onderwerpt. Alles lijkt voor de lezer duidelijk en grijpbaar. Metaforen en retoriek kunnen wersluierend werken in de rechterlijke uitspraak. Hantering van retoriek of van metaforen wordt bedenkelijk wanneer zij geheel treden in de plaats van een rationeel navolgbare redenering. ${ }^{294}$ Indien zij de rechtsgrondslag, warop het rechterlijk besluit wordt gefundeerd, vervangen neemt de juridische kwaliteit van de redenering evenredig af: retoriek en metaforen zijn zonder nadere motivering op basis van een zekere juridische kwaliteit niet eenduidig verifieerbaar. In beginsel zou dan ook een kritische houding kunnen worden verwacht vanuit het juridisch forum dat de rechter volgt in zijn redenering: aanvaardbaarheid van de uitspraak is voor hem in beginsel gelegen in de rationaliteit van de beslissing waarvan de rechtsvinding deel uitmaakt. Zo stelde ến commentator bij Valkerhorst dat hem niet duidelijk was, op welke wijze het nieuwe recht zijn grondslag heeft verkregen en hoe het dient te worden ingepast in het bestaande normenkader. ${ }^{295}$ Van retoriek en metaforen gaat overigens bijna altijd een sterke overtuigingskracht uit wanneer zij op juiste wijze worden gebruikt. Metaforen en retoriek zijn geen ornamenten in de uitspraak; hun sterke overtuigingskracht zit in de samensmelting van de stijl en de inhoud van de rechterlijke uitspraak. De stijl van overreding wordt door sommigen van even groot belang geacht als de inhoud van de uitspraak. ${ }^{296}$ De perceptie van de juistheid van de uitspraak hangt nauw samen met de stijl waarin de uitspraak wordt geuit. ${ }^{297}$

De metafoor is zeer bruikbaar in de analoge redenering. ${ }^{298}$ Voorheen werd de structuur van de analoge redenering voorgesteld: indien $p$ dan $q ; r$ lijkt op $p$, daaruit volgt vervolgens indien $\mathrm{r}$ dan $\mathrm{q}$. De vergelijkbaarheid van $\mathrm{p}$ en $\mathrm{r}$ dient te worden aangetoond; de metafoor kan in dit verband een harmoniërende functie vervullen, waarin $p$ en $r$ vergelijkbaar worden geacht. Een onderzoek naar de mate waarin zij werkelijk vergelijkbaar zijn kan dan worden afgesloten met de metafoor; deze stelt in een vereenvoudiging van de werkelijkheid voorop dat zij vergelijkbaar zijn. Het waarderingsmoment gaat op in de metafoor, waarbij de lezer wordt afgeleid van de verschillende keuzemogelijkheden die in het waarderingsmoment bestaan. Dat uitgangspunt is voor een rechter niet onaantrekkelijk, omdat hij in de constitutionele verhouding rekening dient te houden met het primat van de wetgever en met diens taken. Hij kan het waarderingsmoment versluieren via hantering van metafoor of retorische vraagstelling. De rechter kan met hantering van retoriek of metafoor sommige lastige kwesties als de vraag van de juridische

294 Zo ook Dosmujian 1992, p. 8.

295 Noot L. Verhey bij Valkenkorst, in NJCM-Billetin 19-6 (1994), p. 654 e.v.

296 'Style inevitably contributes to, and often controls, the present and future meaning of appellate opinions, even those not actually written by the judge who signs them. Cardozo's case dearly demonstrates. particularly, given his awareness of the integral place of style in the law, that the effective use of style, ass often as "logic", underlies succesful appellate advocacy and adjudication. [...]. Cardozo realized that the form of an opinoin actively contributes to its correctness; style thus conceived is an element to be evaluated as part of the correctness of a decision, not as ancillary or merely omamental element" (Weisberg $1979, \mathrm{p} .309$ ).

297 Cardozo $1931, \mathrm{p}, 9 \mathrm{e}, \mathrm{y}$ : "The opinion will need persuasive force, or the impressive virtue of sincerity and fire, or the mnemonic power of alliteration and antithesis, or the terseness and tang of the proverb, and the maxim. Neglect the help of these allies, and it may never win the day".

298 Johnson 1988 , p. 26 e.v. 
kwaliteit van de hogere norm of van de daaruit voortwloeiende extensieve interpretatie of concretisering omzeilen. Een uiting van een norm van hoger recht waarvan niet vaststaat of het een rechtsnorm is, kan eventueel aanvaardbaar worden gemaakt vila een retorische vraagstelling of een vergelijking met bijvoorbeeld een spitsvondig gezegde dat nauw aansluit bij de situatie in het voorliggende geschil. ${ }^{299}$

De rechter beoogt daarmee de situatie te bereiken dat over de grondslag van de extensieve interpretatie of het nieuwe recht geen nadere vragen worden gesteld: de metafoor of de retoriek zijn hem daarin behulpzaam. Deze strategie kan bijvoorbeeld aangewezen zijn wanneer een bepaald resultaat dringend gewenst is maar waarvan de juridische grondslag twijfelachtig is. Deze situatie kan zich voordoen wanneer de rechter constateert dat de wetgever niet in staat is tot wetgeving te komen, terwijl de voorliggende kwestie zich al verschillende keren heeft aangediend bij de rechter. Ook kan een retorische vraagstelling of metafoor behulpzaam zijn bij het vergroten van aanvaarding van de rechterlijke uitspraak in de samenleving meer in het algemeen: de rechter wenst in sommige gevallen niet alleen het juridisch forum, maar meer in het algemeen ook de publieke opinie overtuigen van zijn rechtsvinding. ${ }^{300}$ Het karakter van rechtspraak staat in zekere mate op gespannen voet met het uitgangspunt van wetenschappelijkheid: wetenschappelijkheid veronderstelt de voorlopigheid van conclusies, terwijl van de rechter wordt verwacht dat hij een beslissing neemt die finaal is. Dat maakt hem kwetsbaar in zijn besluitvorming, omdat hij het gehele forum in beginsel wenst te overtuigen wan de juistheid, en niet van voorlopige juistheid van zijn besluit. Voorlopigheid zou het rechterlijke besluit minder aanvaardbaar maken voor de verschillende fora. ${ }^{30 \%}$ Vraag is in hoeverre de rechters zich bedienen van metaforen of retorische vraagstellingen in hun redeneringen in de rechtsvindingsfase; hierop zal worden ingegaan in de afzonderlijke hoofdstukken waarin de rechtspraak wordt uitgewerkt.

\section{Afhankelijkheid van consensus}

Dit punt van kritiek op de analogie hangt samen met het punt van de verifieerbaarheid van de analogie. De rechter is gebaat bij een consensus ter zake van het bestaan van een norm van hoger recht of van de erkenning van een ongeschreven recht. In de rechtsstelsels zijn concrete aanwijzingen te vinden waaruit blijkt dat de rechter op die consensus een beroep doet, om de legitimiteit van zijn beslissing te versterken. ${ }^{302}$ Indien

299 Zie bijwoorbeeld Meyer $t_{*}$ Nebraska: "Without doubt, it (het recht op vrijheid, H.L. I) dernotes not merely freedom from bodily restraint but also the right of the individual to contract, to engage in trry of the common occupations of life [...] (Meyer t. Nebraska, 262 U.S. 390, 399 (1923).

300 Zie par. 4.2 .4 voor de typering van de verschillende tora. In Falkenhorst speelde het belang wan het kind bij de kennis van de afstamming niet alleen een rol in thet geschil, maar bleek het thema, afgande op de: Conclusie van A-G Koopmans, in de gehele samenleving te worden besprokem, Via een retorische vraag rechtvaardigde Koopmans honorering van de individulele aanspraak, de afstamming te willen kennen.

301 Zie ook Bosmajian 1992, p. 28.

302 Zie bijwoorbeeld Alkms t. Wirginia, nr. 00-8452 (20 juni 2002), waarin het Amerikaanse Hooggerechtshof oordeelde dat aan geestelijk gehandicapte personen de doodsuraf niet langer mag wordien opgelegd. Het Hof oordeelde in die zaak dat er inmiddels een consensus was gegroeid over deze kwestie, warin naar het oordeel van de meerderheid van het Hof overeenstemming was gegroeid over de 
ter zake van een opvatting of een norm van hoger recht geen consensus in de samenleving kan worden aangetoond, zal de analogie al gauw stranden omdat het dan wooral een gedachte lijkt die enkel is ontsproten aan de yoorkeur van de rechter. ${ }^{303}$ Een retorische benadering of een metaforische oplosing ligt dan niet zo snel voor de hand. Wanneer een consensus wel kan worden aangetoond, wordt de legitimiteit van het gedachtegoed dat wordt geuit in de hoger gelegen norm juist versterkt. In dit opzicht ligt er aldus een taak voor de rechter, zijn forum te overtuigen van het bestaan van een consensus over de norm van hoger recht en van de extensieve interpretatie (wetsanalogie) of van de concretisering (rechtsanalogie) die daaruit volgt. ${ }^{304}$

Indien men nu juist een voorkeur heeft voor het bestaan van een bepaalde mate van heterogeniteit van opvattingen, kan een consensus in de weg staan aan debatten die gevoerd worden ter zake van de voorkeur wan invulling van een rechtsnorm. In federale rechtssystemen als het Amerikaanse lijkt ten aanzien van bepaalde onderwerpen een voorkeur aarwezig woor het respecteren van uiteenlopende opvattingen over bepaalde rechtsideeen. ${ }^{305}$ Nu houdt dat niet in, dat in federale stelsels geen ruimte kan bestaan voor consensus. In de Duitse grondwet is gekozen voor een in beginsel overkoepelende, harmoniserende catalogus van grondrechten waardoor een rechterlijke taakopvatting, die uitgaat van harmonisering voor de hand ligt. In de Verenigde Staten ligt deze kwestie anders: daar heeft de grondrechtscatalogus nagenoeg geheel gelding verkregen via incorporatie door het Amerikaanse Hooggerechtshof: de staten werden via de ruime lezing van 'due process" eveneens gebonden aan de rechten die in de Bill of Rights zijn neergelegd, terwijl dit oorspronkelijk niet zo bedoeld leek door de wetgever. ${ }^{306}$ Het argument van harmoniëring is In de Verenigde Staten mede hierdoor niet tot axioma verheven waar het on grondrechtsinterpretatie gaat. De vraag is of de rechter de middelen tot zijn beschikking heeft om het bestaan van een consensus vast te stellen, of zijn vaststelling de juiste is en of het tot de rechterlijke taak behoort knopen door te hakken over het bestaan van een consensus. Ter zake van het recht op persoonlijkheid is het willem bereiken wan een consensus soms juist problernatisch. Er worden nu eenmaal regelmatig aanspraken op de aan het recht op persoonlijkheid gelieerde

afwijzing van de praktijk waarin ook nan geestelijk gehandicapten de doodstraf kon worden opgelegd. De kwestie in die zaalk was of deze praktijk houdbaar was onder het Achtste Amendement ( Cruel and unusual punishment'). Het EHRM heeft het argument van de consensus om aan te tonen dat een norm bestawnsirecht heeft, regelmatig gehenteerd (zie bijwoorbeeld Sigurjónsson t. IJsland, EHRM 30 juni 1993, Serie A vol. 264, par. 35, zie ook heringa 1999, p. 10 e.v. over deze zaak).

303 In Atkiks t. Virginia betoogden de rechters die in de minderheid waren in hun dissentings dat een consensus niet (Scaliaj of onvoldoende (Rehnquist) kon worden aangetoond.

304 In Atkins t. Virginia baseerde. rechter Stevens, schrijvend voor de meerderheid, zijn hypothese van het bestaan vari een consensus over de het 'cruel and unsual' karakter van de doodstraf voor geestelijk gehandicapten op relatief recente wetswijzigingen in een aantal staten (hier stelt Stevens dat niet het aantal staten maar de consistentie van de verandering van de richting van belang is) ein op het feit dat staten wasrin het mogelijk is om aan geestelijk gehandicapten de doodstraf op te leggen, deze straf reeds lange tijd niet meer werd opgelegd.

305 Sunstein 1993 , p. 769 .

306 Deze kwestie speelt met name een rol in geschillen ter zake van het Tiende Amendement dat de bevoegdheden tussen Staten en Federatie (zij het met zeer open bewoordingen) regelt. 
rechten gedaan waarvan een meerderheid van mening is dat de aanspraak geen rechtsbescherming dient te verkrigen. Het recht op abortus wordt in de samenleving niet door eenieder ondersteund; vraag is of dit voldoende is om de zwangere vrouw dit recht te ontzeggen. Lets dergelijks kan gesteld worden ter zake van de vraag, of homoseksuele echtparen een kind moeten kunnen adopteren. Een consensus mag ter legitimatie van de extensieve interpretatie of van de concretisering van een nieuwe norm dan dringend gewenst zijn vanuit democratisch oogpunt; tot het karakter van het recht op persoonlijkheid behoort het tot op zekere hoogte zelf invulling te geven aan levens= keuzes zonder inmenging van buitenaf.

Tegen de rechtsanalogie gelden in beginsel dezelfde bezwaren als tegen de wetsanalogie. Op de rechtsanalogie valt echter nog meer af te dingen, omdat de rechter in die analogie slechts indirect aanknoopt bij een grondwettelijke bepaling. De rechter lijkt hierdoor meer rechtsvindingsvrijheid uit te oefenen: niet een wettelijke bepaling is vertrekpunt, maar een door de rechter geconstrueerde rechtsnorm. In beginsel bieden de grondwetten en de verdragen voldoende grondslag voor deze taak; de rechter is immers gehouden naleving van "het recht" te eerbiedigen en te verzekeren. ${ }^{307}$ De vraag of "nieuwe' ingeroepen normen tot het recht behoren is echter van andere orde; de taak om vast te stellen welke normen tot het recht behoren lijkt niet aan de rechter te zijn voorbehouden. In de jurisprudentieanalyse in de hoofdstukken 5 tot en met 9 is met name gekozen voor uitspraken, waarin de rechter zich met name of exclusief verlaat op de wetsanaloge of rechtsanaloge redeneerwijze. Eerst wordt in het B-deel besproken welke het rechtskarakter is van grondrechten die gelieerd zijn aan het recht op persoonlijkheid, van de norm van hoger recht die in de wets- en rechtsanalogie wordt gehanteerd. In het B-deel komt vervolgens de wijze waarop de norm van hoger recht die voortvloeit uit de analogie aan de orde tegen de achtergrond van de constitutionele verhoudingen. In dit verband is van belang om een inzicht te verkrijgen in de vraag of en in welke mate de rechter een discretionaire ruimte heeft wanneer hij analoog. interpreteert. Daarnaast zal worden ingegaan op de wijze waarop een door de rechter gepositiveerde norm zijn plaats verkrijgt in het bestaande normensysteem. 


\section{Deel B \\ Grondslagen van de normen in de wetsanalogie en de rechtsanalogie}

\subsection{Het rechtskarakter van de in de analogie betrokken normen}

\subsection{Inleiding}

In dit onderzoek zijn de termen 'rechtsnorm', "norm van hoger recht" en 'rechtsbeginsel' verschillende keren aan de orde gekomen in het kader van de vaststelling van de reikwijdte van grondwetsnormen. Voor een goed begrip van de analoge redenering, die hierna in de jurisprudentie wordt belicht, is het van belang om na te gaan welke de eigenschappen zijn van de verschillende normen, en hoe de normen zich onderscheiden van elkaar. De typering van de verschillende normen speelt zoals hierna zal worden aangetoond, allereerst een belangwekkende rol in de coherentie van het rechtsnormenstelsel waarmee de rechter te maken heeft wanneer hij interpreteert, en in de tweede plaats geeft de typering van de door de rechter gehanteerde norm in de rechtsvinding in sommige gevallen zicht op de wijze waarop de rechter de constitutionele verhouding percipieert.

Allereerst hebben we te maken met de grondrechtsnorm waarop de individuele aanspraak berust en waarvan de rechter moet vaststellen deze onder de rechtsnorm te kwalificeren is. Grondrechtsnormen zijn dan wel deels door de wetgever gepositiveerd, maar dat verleent de norm nog niet vanzelfsprekend een regelkarakter. In de tweede plaats worden uit de norm van hoger recht die in de rechtsanalogie wordt gehanteerd, soms nieuwe rechtsnomen' geconcretiseerd. De vraag luidt in hoeverre die door de rechter gepositiveerde rechtsnormen nu deel uitmaken van het geldend recht, en in hoeverre het noodzakelijk is dat zij daarvan deel uitmaken om van een legitieme rechterlijke vitspraak te kunnen spreken. In de derde plaats hebben we in de analogie te maken met de 'norm van hoger recht', waaronder de door de rechter bedachte varianten en het voorliggende geschil onder én wettelijke norm worden verenigd. De vraag rijst, wat het rechtskarakter is van de norm van hoger recht die in de analogie wordt gehanteerd, van de grondwetsnormen die soms extensief worden uitgelegd en van de normen die worden geconcretiseerd uit de normen van hoger recht. Typering van deze drie normen is van belang voor de beoordeling van de kwaliteit van de rechtsvinding in het licht van de constitutionele verhouding tussen rechter en wetgever.

Twee voorbeelden kumnen het belang van de typering van de normen voor de constitutionele verhouding onderbouwen. Allereerst wordt veelal aangenomen, dat een rechtsbeginsel een nadere concretisering vergt voordat het zijn betekenis kan verkrijgen in een geschil. ${ }^{308}$ Vanuit het oogpunt van de constitutionele verhouding kan de indruk 
ontstaan dat de rechter in het proces van concretisering een bepaalde mate van interpretatievrijheid toekomt: waar een rechtsregel in principe klaar is voor toepassing, dient het beginsel te worden toegesneden op het geschil. Rechtsbeginselen hebben vaak een abstract karakter, zodat het gevaar kan ontstaan dat de rechter onder een dergelijke norm zijn persoonlijke voorkeur kan onderbrengen. De mate van abstroctie of van concreetheid is vanuit dit gezichtspunt van belang voor de constitutionele verhouding.

In de tweede platats is van belang, dat de norm die wordt gehanteerd in de rechtsvinding een juridische kwaliteit bezit: Met een juridische kwaliteit wordt gedoeld op de grondslag van de betrokken norm: deze dient te herleiden te zijn tot jurisprudentie, tot een rechtsregel, tot een systematiek van rechtsregels of wellicht een rechtsbeginsel. In dit verband is de bron van de norm van belang in het licht van de constitutionele verhouding. Wanneer de rechter een norm positiveert, die tot dusverre nog geen betekenis had verworven in eén van de genoemde bronnen, rijst de vraag wat de legitimiteit is van de uitspraak indien de rechterlijke beslissing (overwegend) is geschoeid op een dergelijke norm. De kwestie van de constitutionele verhouding doet zich hier eveneens gevoelen: vraag is wat de consequenties zijn van een door de rechter gepositiveerd recht in het licht van de activiteiten van de wetgever. Doorkruist de rechter activiteiten van de wetgever, of ondersteunt hij die juist, en in welke mate is er misschien sprake van een dialoog? 309

Het rechtskarakter van de in de analogie gehanteerde normen zal hieronder worden uiteengezet. Achtereenvolgens zullen typering van en onderscheid tussen rechtsregels en rechtsbeginselen aan de orde komen, waarna de norm van hoger recht in verhouding met andere normen zal worden belicht. Ten slotte zal een typering worden gegeven van de rechtsnorn van het recht op persoonlijkheid.

\subsubsection{Rechisnomen}

\section{Rechtsnomen}

In geen van de stelsels zijn precieze aanwijzingen te vinden over rechtsbronnen die de rechter dient te hanteren wanneer rechtsnormen met elkaar in botsing komen. Rechterlijke rechtswinding is legitiem indien deze leidt tot rechtvaardige beslissingen. Daarmee lijkt de rechter nog steeds nauwelijks een criterium te hebben aan de hand warvan hij kan vaststellen of hij nu een rechtsnorm hanteert, of een norm die dat karakter niet bezit. De rechterlijke uitspraak dient, wil zij rechtens verbindend zijn, gebaseerd te zijn op juridische bronnen. Tot deze bronnen behoren rechtsnormen. Rechtsnormen kunnen worden onderscheiden van andere normen: de eerste bezitten een juridische kwaliteit, die het laatste type in beginsel ontbeert.

spraak geefit, dat directe toepassing door subsumptie niet nogelijk is, dan is het eem beginsel'

309 Ook hier kan de kwestie van de legitimiteit van de rechterlijke uitspratk zich doen gevoelen: indien de bron wan het recht niet herkenbas is doet de rechter in beginsel een uitsprable die een juridische grondslag mist. 
Van juridische kwaliteit is sprake indien de normen hun oorsprong hebben in een bron, die rechtens herleidbaar en kenbaar is tot een rechtsbron in formele zin. ${ }^{310}$ Hiertoe worden in alle stelsels wet, verdrag en gewoonte gerekend. Jurisprudentie is in alle stelsels eveneens een belangrijke bron van recht; het is echter niet in alle stelsels een formele rechtsbron. ${ }^{311}$ Wanneer het formele karakter van jurisprudentie als bron echter ontbreekt, betekent dat niet dat deze bron geen waarde heeft voor de vaststelling, of er sprake is van een norm van geldend recht of van een norm die dat karakter niet heeft. Uit de jurisprudentie kan vaak worden opgemaakt, hoe het met het 'rechtsgehalte' van een norm is gesteld. ${ }^{312}$ Hiermee lijkt de betekenis van het begrip formele rechtsbron te worden gerelativeerd, en lijken eenduidige criteria die de rechter in moeilijke gevallen een richting kunnen wijzen voor toepasselijke normen, erg ver weg. Toch valt er in het algemeen wel een lijn te trekken in de opvattingen over het onderscheid tussen rechtsnormen en 'andere' normen. Over gezag van de rechtsbronnen en rechtsgeldigheid van normen wordt in de literatuur sinds jaar en dag gedebatteerd; de belangrijkste standpunten zullen hieronder worden toegelicht. ${ }^{313}$ Tot de rechtsnormen behoren in elk geval rechtsregels en rechtsbeginselen. $\mathrm{Zij}$ hebben ieder een eigen karakter, en worden onderscheidenlijk toegepast in de jurisprudentie.

\section{Rechtsregels en rechtsbeginselen}

De eigenschappen van rechtsregels en rechtsbeginselen worden vaak beschreven door ze in onderling verband aan elkaar te ijken op punten van toepassing, gelding en formulering. ${ }^{314}$ Die werkwijze wordt hier eveneens gehanteerd. Rechtsregels vergen in principe steeds een andere toepassing door de rechter dan rechtsbeginselen: bij de laatste categorie rechtsnormen zal bijvoorbeeld een nadere concretisering op het geschil noodzakelijk zijn, terwijl rechtsregels in principe 'klaar' zijn woor toepassing. ${ }^{15}$ Vanuit de constitutionele verhouding lijkt het er dan op dat de rechter bij rechtsvinding aan de hand van een rechtsbeginsel meer interpretatieruimte toekomt dan bij regeltoepassing. ${ }^{316}$ Hierop valt een belangrijke nuance aan te brengen: het werken met rechtsbeginselen hoeft niet noodzakelijkerwijze te leiden tot autonome rechtsvinding. Wel wijzen commentatoren op de onderscheidenlijke opvattingen die bestaan over de mate van interpretatieruimte. ${ }^{31}$ Sommige rechtsregels lijken een beginselkarakter te bezitten, terwijl sommige rechtsbeginselen dermate concreet zijn dat zij nauwelijks behoeven te worden gespecificeerd.

310 Tak 1994, p. 61 .

311 Zile par. 4.7.4.

312 McCormick 1997, p. 236; zie ook par. 4.7.3 hierna.

313 Zie par. 4.7 e.v.

314 Dworkin 1977, De Waard 1987, Bruggink 1990 en Alexy 1996.

315 Asser-Schoten, (Algemeen Deel 1974): 'indien de wetgever een zo algemene uitspraak geeft, dat directe toepassing door subsumptie niet mogelijk is, dan is het cen beginsel".

316 Asser-Scholten (Algemeen Deel 1974), p. 62 e.v.; Alexy 1996, p. 72 e.v.; Dworkin 1977, p. 24 e.v; Brouwer 1991, p. 41 e.v; De Waard 1987, p. 95.

317 Zie hierna de discussie tussen Dworkin en Hart over de mate waarin sprake is van autonome rechtsvinding, of juist van heteronome rechtsvinding (par, 4.7.3). 
Indien men met een rechtsnorm wordt geconfronteerd rijst de wraag hoe een rechtsregel of een rechtsbeginsel kan worden herkend. Rechtsbeginselen en rechtsregels zijn niet per definitie herkenbaar aan de formulering, maar een aantal karakteristieken van de beide soorten rechtsnormen is wel te geven. Rechtsregels bevatten in de earste plaats operationele aspecten, die een directe toepassing eerder mogelijk maken dan in het geval van rechtsbeginselen. Rechtsregels kennen in beginsel een mate van autoriteit, hun bron is te achterhalen en specificeren geadresseerden, situaties, inhoud en termen voor toepassing. In de tweede plaats voorzien rechtsregels in juridische consequenties van deze operationele aspecten. ${ }^{318}$ Indien beiden aanwezig zijn in een rechtsregel, voorziet deze rechtsregel in een oplossing in geval van juridisch conflict. Sommige rechtsnormen in Grondwet of Verdrag dragen beide kenmerken in zich. In enkele gevallen lijken sommige grondwettelijke normen zich soms te manifesteren als rechtsbeginselen; zij ontberen beide eigenschappen. Art. 1 lid 1 GG ontbeert een aantal operatieve aspecten, die directe toepassing op een concreet geval zouden kunnen vergemakkelijken. ${ }^{319}$ Een categorie van gevallen of geadresseerden wordt bijvoorbeeld niet geduid; evenmin worden de rechtsgevolgen gespecificeerd in deze regel. Over de scheidslijn tussen rechtsbeginselen en rechtsregels bestaat in geen van de stelsells een eensluidende opvatting. ${ }^{320}$ Door verschillende auteurs zijn maatstaven ter onderscheiding aangebracht, maar vooralsnog bevindt een aantal rechtsnormen zich in een grijs gebied van normen die niet onder de ene of de andere noemer kan worden gekwalificeerd. ${ }^{321}$ Naarmate een rechtsnorm meer abstractie vertoont zal die, wil de rechter de norm gebruiken voor toepassing op een concreet geschil, meer moeten worden verbijzonderd of geconcretiseerd met het oog op de feitelijke situatie.

Allereerst is voor de rechter de vraag naar het onderscheid van toepassing van een rechtsregel of een rechtsbeginsel relevant: rechtsregels en rechtsbeginselen vergen een verschillende benadering in de toepassing op een concreet geschil. ${ }^{322}$ De intensiteit wan

318 Bengoetxea 1993, p. 59. Zie ook Alexy, die een negental criteria beschrijft die in de rechtstheorelische literatuur worden gehanteerd om een onderscheid tussen rechtsregels en rechtsbeginselen te duiden. Hij wijst achtereenwolgens op de algemeenheid van beginselen versus de hogere grand van specificitei wan regels; op de bepaalbaarheid van gevallen waarin de rechtsnorm kan worden gebruikt; op de wijze van ontstaan van de rechtsnorm: regels worden meest gepositiveerd terwijl rechtsbeginselen 'ingegroeide' en niet noodzakelijkerwijze geexpliciteerde rechtsnormen zijn; daarnaast wijst Alexy op de aanwijzingen dat rechtsbeginselen uitdrukking zijn van een rechtsidee en het rechtssysteem faciliteren voor interpretatie en op het onderscheid tussen gedragsnormen of argumentatienomen (Alexy 1994, p. 73-74).

319 Zie par. 2.4.2.

320 Zie bijwoorbeeld Asser-Scholten (Algemeen Deel) 1974, p. 62 e.v., Alexy 1985, p. 72 e.v.; Dworkin 1977, p. 24 e.v.; Brouwer 1991, p. 41 e.v., Meuwissen 1991, p. 730 e.v.; Soeteman 1991, p. 44 e.v.

321 Ook is wel geopperd, om rechtsregel en beginsel tegenover elkar te stellen, zie bijwoorbeeld van het Duitse Hof Verhandlungsfahigkeit des Angeklagten, 51 BVerfCE 324, 350 (1979). Voorlopig wordt hier steeds gesproken over het onderscheid tussen regels en beginselen en wordt aangenomen dat beiden deel uitmaken van het rechtsnormensysteem. Een algemeen gedeelde opwatting is dat reclitsbeginselen eerder een algemeen en abstract karakter bezitten dan rechtsregels. Een andere gehanteerde typering komt naar voren uit concrete toepassing: waar regels strijden on voorrang en geldigheid, treden rechtsbeginselen terug en verliezen niet hun geldigheid wanneer zij geen toepassing op een concrete zaak verkrijgen (zie Dworkin 1977 , p. 24 e.v.).

322 Alexy 1994, p. 77 e.v. 
de rechterlijke rechtsvinding en de mate van autonomie in de rechtsvinding van de rechter bevindt zich in beginsel tussen twee polen: van rechtsvinding waarin mechanüsche toepassing van een rechtsregel uit een kenbare wetstoepassing plaatsvindt enerzijds tot rechtsvinding waarin rechtsbeginselen worden geformuleerd en verwolgens nader worden toegespitst op het concrete geschil anderzijds. Rechtsbeginselen kunnen door de rechter via een inductie worden ontwaard in verschillende rechtsbronnen: dat kunnen samenstellingen van wettelijke normen of rechterlijke uitspraken zijn, maar evengoed kumnen zij worden afgeleid uit preambules en uit contaminaties van internationaalrechtelijke bepalingen. ${ }^{323}$ Deze vaststellingen zijn bij een rechtsregel die voorhanden is in beginsel minder noodzakelijk. Wanneer rechtsbeginselen worden toegepast in de oplossing van een geschil, is het evenzeer noodzakelijk de juridische consequenties nader te concretiseren. Naarmate de toe te passen rechtsnorm een abstracter karakter heeft, lijkt nadere concretisering meer aangewezen.

\section{De norm van hoger recht}

De rechter concentreert zich bij analoge uitleg van grondwet of verdrag op de bijzonderheden van een aantal te vergelijken gevallen, om via de analogie een norm van hoger recht te ontwaren die aan de te vergelijken gevallen ten grondslag ligt. Het stellen dat een norm van hoger recht ten grondslag ligt aan bijvoorbeeld een wetsregel of aan een lijn in de jurisprudentie leidt in beginsel steeds tot het formuleren van een abstracte norm die uitstijgt boven het vergelijkingsmateriaal aan de hand waarvan de latere normtoepassing wordt gelegitimeerd. De normtoepassing vertaalt zich na concretisering van de norm van hoger recht in een extensieve uitleg van een bestaande rechtsnorm (wetsanalogie) of in de positivering van een nieuwe norm (rechtsanalogie). Zoals in de inleiding reeds werd aangegeven, is het begrip van de norm van hoger recht niet onproblematisch. Het is geen in de literatuur of rechtspraak gangbaar begrip. Toch wordt het hier zinvol geacht met dit begrip te werken; er wordt in beginsel geen keuze gemaakt ter zake van de vraag of de rechter nu een erkende rechtsnorm hanteert in zijn rechtsvinding, of dat hij een norm construeert die later eventueel gelding verkrijgt, maar het op het moment van positivering nog niet noodzakelijkerwijze heeft. Op deze manier wordt getracht inzichtelijk te maken op welke wijze de rechter soms lijkt te worstelen met de status van.de in de rechtsvinding betrokken normen. Daarnaast wekt het concept van de norm van hoger recht de indruk, dat alleen "hogere" normen worden betrokken in de analyse.

De notie 'normen van hoger recht' vormt een overkoepelend begrip van 'rechtsbeginselen' en 'andere beginselachtige normen'. Bij "andere beginselachtige normen' kan worden gedacht aan hogere normen die in een samenleving op een bepaald tijdstip gelden, maar die niet zijn gepositiveerd via wetgeving of rechtsprak. Ook is niet duidelijk of het een notie betreft die gelding heeft verkregen in het rechtsnormensysteem. 'Rechtsbeginselen' bezitten een zekere juridische kwaliteit; op dat punt onderscheiden zij zich van die andere beginselachtige normen. Met 'normen van hoger recht' wordt 
aldus in het midden gelaten met welk type norm we precies te maken hebben - met een rechtsbeginsel of een "andersoortige beginselnorm" - indien wordt gesteld dat de rechter de betekenis van een grondrecht tracht te achterhalen aan de hand normen van hoger recht. ${ }^{324}$ Het begrip 'norm van hoger recht' doet overigens vermoeden, dat het steeds om normen gaat die zich in letterlijke of in overdrachtelijke zin 'boven de constitutie' bevinden. Dat behoeft echter niet steeds het geval te zijn. Wanneer de rechter in de rechtsvinding bijwoorbeeld steunt op natuurrechtelijke noties, zou er inderdaad van normen die zich 'boven' de constitutie bevinden sprake kunnen zijn. Omgekeerd wijst de rechter in zijn rechtsvinding ook regelmatig op rechtsbeginselen die "ten grondslag liggen' aan de constitutie. ${ }^{32.5}$ In dergelijke gevallen ligt het minder voor de hand om te spreken van een norm wan 'hoger' recht, omdat beide concepten elkaar uit lijken te sluiten. Toch worden ook normen, die 'ten grondslag liggen' aan de constitutie geacht te vallen onder de "norm van hoger recht". Dat is mogelijk, omdat beide nomen op vergelijkbare wijze worden ingezet in de rechtsvinding: uit beiden worden concrete normen afgeleid die toepasbaar zijn op het voorliggende geschil. Op deze overeenkomst is de aanduiding 'hogere' norm van toepassing: de norm is abstract van karakter en beheerst de invulling van concrete normen. In die zin staat de norm van hoger recht in hiêrarchie boven de concreet toe te passen rechtsnormen.

Het rechtskarakter van de norm van hoger recht is van belang in verband met de legitimatie van de concretiseringen die eruit voortvloeien. De rechter kan besluiten de nog niet eerder toegepaste norm of de nieuwe uitleg van een bestaande regel, die voortvloeit uit de norm van hoger recht, een plaats toe te kennen in de bestaande normenhiërarchie. Vraag is wat precies het karakter is van de norm van hoger recht, en of de rechter aangeeft wat het karakter is van die norm. De rechter heeft bij de kwalificatie van individuele aanspraken en vaststelling van de reikwijdte van grondrechten te maken met een hièrarchie van rechtsnormen, die hij dient te respecteren wanneer hij over gaat tot erkenning van de aanspraken. Hij zal zich in zijn rechtsvinding dienen te orienteren aan rechtsnormen omdat die de legitimatie van het resultaat - de extensieve interpretatie of het onbenoemde recht - het meest solide kunnen onderbouwen. Een beroep op een norm van hoger recht die behoort tot het geldend recht behoeft in beginsel minder motivering dan wanneer een norm van hoger recht wordt ingeroepen die (nog) niet als rechtsnorm is "aanvaard". De grondslag van de norm van hoger recht zou in het laatste geval twijfelachtig zijn, en niet goed kunnen leiden tot een rechterlijke beslissing die is gebaseerd op geldend recht. Daarmee wordt de aanvaardbaarheid.

324 Er had eveneens voor een andere benarring - bijvoorbeeld fundamenteel recht of fundamentele notic kummen worden gekozen; doorslaggevend was het uitgangspunt dat begrippen die een bepaalde dogmatiek vooropstellen werden afgewezen. Met de keuze voor "norm vas hoger recht" kani een open benadering naar de wijze waarop de rechter "recht vindt" in het kader van constitutionele interpretutie worden? gehandhaafd. Het is bovenal een meer pragmatische benadering van de hogere nomen. Beantwoording van de vraag of de rechter zich nu op de juiste rechtsnom beroept sitaat milet centraal in dil boek.

325 Zie bijvoorbeeld in Valkerhorst: "Uitgangspunt voor de beoordeling wan het middel is dat het aan grondrechten als het recht op het respect voor het prive-leven, het recht op vrijheid wan gedachle, geweten en godsdienst en het recht op vrijheid van meningsiating ter grondslag liggende algemene persoonlijkheidsrecht mede omvat het recht om te weten wan welke ouders men atstamt." 
van de rechterlijke beslissing die is gebaseerd op een norm van hoger recht in het algemeen niet vergroot. Hieronder zal kort worden ingegaan op de wijze waarop door een aantal vooraanstaande commentatoren wordt gedebatteerd over de gelding van rechtsbeginselen in het recht.

\section{Nomen van hoger rech en rechisbeginselen}

Rechtsbeginselen vormen een deelverzameling van het groter gehee] van normen van hoger recht. Waar het onderscheid tussen regel en rechtsbeginsel niet scherp kan worden gemaakt, is het onderscheid tussen het rechtsbeginsel en de norm van hoger recht eveneens problematisch. Hier wordt als richtsnoer aangenomen, dat van een rechtsbeginsel sprake is indien de norm een in het algemeen rechtsbewustzijn erkende rechtsnorm betreft. ${ }^{326}$ Het is aldus onderdeel van het 'geldend recht'. Het rechtsbeginsel drukt tevens een normatief behoren uit, het draagt meestentijds een sterk ethische lading. ${ }^{327}$ Indien beide eigenschappen - ethische lading en rechtsgeldigheid - aanwezig kunnen worden geacht in de beschrijving van de norm, die de rechter hanteert om het vergelijkingsmateriaal in zijn rechtsvinding te harmoniseren, zal worden gesproken van een rechtsbeginsel. ${ }^{328}$ Indien é̉n van deze eigenschappen niet naar voren komt in zal in de hiernavolgende jurisprudentieanallyse de term "norm van hoger recht" worden gebruikt. Daarmee is niet gezegd dat de norm geen rechtsbeginselkarakter kan worden toegedicht: met de duiding "norm van hoger recht" wordt, afgaande op hetgeen in grondwet, verdrag of rechtspraak is gevonden, in het midden gelaten of van een rechtsnorm sprake is.

Een voorbeeld kan deze benadering verduidelijken. In de bewering dat 'ieder individu streeft naar geluk" ligt niet vanzelfsprekend een normatief behoren opgesloten. Vraag is of het een rechtsbeginsel betreft. Deze norm zou in dit verband worden aangemerkt als een norm van hoger recht die de Amerikaanse rechter hanteerde in de wetsanalogie in de zaak Meyer $t$. Nebraska. ${ }^{329}$ Het algemene persoonlijkheidsrecht - norm van hoger recht - zoals gepositiveerd in Valkenhorst lijkt vanwege herhaling in de rechtspraak de status van rechtsnorm te verkrijgen. Het persoonlijkheidsrecht had niet vanzelfsprekend gelding en was op het moment van de uitspraak nog niet gepositiveerd. Normen van hoger recht kunnen echter wel de status van rechtsbeginsel verwerven, bijvoorbeeld door erkenning in rechtspraak of door opneming in wetgeving. Zij beînvloeden het recht en kunnen doordringen in het systeem wan het geldende recht en langs die weg een juridische kwaliteit verkrijgen. De juridische kwaliteit lijkt deels af te hangen van

326 In dit verband onderscheidt een rechtsbeginsel zich van het gewoonterecht omdat er geen sprake behoeft te zijn van gewoonten. Het komt, zoals de rechtsprakanalyse aantoont, voor dat een rechtsbeginsel als rechisnorm door de rechter wordt 'gevonden' in een angeprecedeerde casus. Dat is bij cen norm van gewoonterectt ongebruikelijk (zie De Waard 1987, p. 84-85).

327 De Waard 1987, p. 92.

328 Deze opvatting sluit aan bij die van De Waard: "Tot de "rechtsbeginselen" zullen hier verder alleen beginselen gerekend worden, de een sterke ethische lading bevatten en: in het recht van een bepaalde tijd en binuen een bepaalde rechtsgemeenschap als toetsingsnorm voor de rechtmatigheid van een (voorgenomen) gedraging of (rechls) handeling fungeren (De Waard 1987, p. 92).

329 Zie par. 4.4.3 (Meyer t. State of Nebraska, 262 U.S. 390 (1923). 
de erkenning door wetgever of rechter. Er is geen harde waterscheiding die rechtsnormen afsluit van andere, in de samenleving geldende nomen. In Niemietz t. Duitsland deed zich een andere bijzonderheid voor: in die zaak werd de rechtsregel inhoudende het recht op privé-leven ex Art. 8 EVRM gehanteerd als een norm van hoger recht waaruit een nieuwe rechtsnorm werd afgeleid. Van het recht op prive-leven ex Art. 8 EVRM kan worden gesteld dat het een erkend, in het algemeen bewustzijn levende rechtsnorm is, en vanuit die gedachte dat er sprake was van een rechtsbeginsel. ${ }^{330}$

\section{Het belang van de rechtsnorm voor de constitutionele verhouding}

Het voorgaande over rechtsnormen betekent nog niet dat de rechter vrij is allerlei normen als juridisch verbindend te verklaren. Het recht, en meer in het bijzonder de rechtsvindingmethoden bepalen hoe de rechter recht dient te spreken; dat het recht in dit opzicht door in de samenleving bestaande opvattingen wordt ingekleurd doet daaraan niet af. De rechter heeft daarbij tot op zekere hoogte de mogelijkheid te bepalen wat de inhoud van het recht is. Dat hangt in belangrijke mate samen met de precedentwerking, die in alle onderzochte rechtsstelsels aanwezig is. ${ }^{331} \mathrm{Bij}$ de vorming van nieuw recht spelen normen die zich bevinden op het grensvlak van rechtsnormen enerzijds en andersoortige normen anderzijds een belangrijke rol. ${ }^{332} \mathrm{Van}$ autonome rechtsvinding is sprake wanneer de rechter het werkingsgebied van bestaande rechtsbeginselen wijzigt, of normen van hoger recht die nog geen vaste plaats hebben verworven in het geldend recht, als rechtsbeginsel gaat hanteren. In dit verband rijst de vraag of deze autonome rechtsvinding negatief beoordeeld dient te worden in het licht van de constitutionele verhouding tussen rechter en wetgever. Hierover bestaan uiteenlopende opvattingen in de rechtspraak en in de literatuur. Vraag is of hantering van een norm van hoger recht in de rechtsvinding steeds leidt tot positivering van een rechtsbeginsel. Kan er een transformatie plaatsvinden van norm naar rechtsnorm in de rechtspraak?

\subsubsection{Rechtskarakter van het recht op persoonlijkheid}

In het tweede hoofdstuk is ingegaan op wat er onder het recht op persoonlijkheid wordt verstaan. Daar bleek, dat het recht op persoonlijkheid een overkoepelende notie is voor grondrechten en ongeschreven rechten die allen centreren rond een kern van een recht op ontplooing van het individu, waarbij zelfbeschikking en persoonlijke autonomie onontbeerlijke elementen zijn en waarbij afscherming en het respectvol bejegend worden centraal staan. ${ }^{33 t}$ Het recht op persoonlijkheid verkrijgt met deze typering het karakter van een norm van hoger recht. Er kan niet voor alle stelsels definitief en eenduidig worden gesproken over algemene aanvaarding van een rechtsnorm van een recht op persoonlijkheid. Er bestaan aanwijzingen voor afzonderlijke elementen wan het recht op persoonlijkheid, maar nergens kan in dit verband worden gesproken van een

330 In dit verband zou er dan sprake zijn wan zowel een norm wan hoger recht alsook van een rechtsbeginsel.

331 Zie hierna par. 4.7.4.

332 De Waard 1987, p. 91

333 Zie par. 2.1.5. 
alomvattend rechtsbeginsel. Om die reden wordt gekozen voor typering van het recht op persoonlijkheid als een norm van hoger recht. Het recht op persoonlijkheid is een soort vergaarbak van rechtsnormen in de rechtspraak die allen te maken hebben met de persoonlijke ontplooiing en de zelfbeschikking van het individu. Dat kunnen zowel rechtsregels als rechtsbeginselen zijn.

\subsection{Gezag en gelding van rechtsnormen}

\subsubsection{Inleiding}

Het belang van de gelding van rechtsnormen is gelegen in de vraag naar de mate waarin de rechters zich bezighouden met het scheppen van "nieuwe rechtsnormen". Deze vraag wint aan verdere betekenis, indien $z \mathrm{ij}$ wordt beschouwd in het licht van de constitutionele verhoudingen waarbinnen de rechter opereert. In de rechtsstelsels is rechtsvinding door de rechter tot op zekere hoogte een erkend en geaccepteerd verschijnsel, al geeft de wijze waarop en de mate waarin de rechter bijdraagt aan rechtsontwikkeling aanleiding tot verhitte debatten over de juiste taakopvatting van de rechter. Vraag is of het tot de bevoegdheden van de rechter behoort, vast te stellen welke normen behoren tot het geldend recht. Als er in dit opzicht een taak voor de rechter is weggelegd, luidt de vraag waarop die bevoegdheid dan is gebaseerd. In dit verband doet de constitutionele verhouding tussen rechter en wetgever zich gevoelen vanwege het uitgangspunt dat de wetgever de regels vaststelt en de rechter deze regels interpreteert en toepast. Wanneer de rechter zich nu kan uitlaten over de vaststelling van de gelding van rechtsnormen begeeft hij zich op het werkterrein van de wetgever.

Om vast te stellen hoe normen tot het systeem van rechtsnormen worden toegevoegd is een korte excursie naar de theorie van gelding van rechtsnormen noodzakelijk. Onderzocht dient te worden welke regels de gelding beheersen, en in hoeverre de rechter een bevoegdheid toekomt om die gelding vast te stellen. De vraag naar gelding van rechtsnormen rijst in verband met dit onderzoek specifiek op twee terreinen. In de eerste plaats hebben we in de wetsanalogie te maken met een norm van hoger recht die een extensieve lezing van bestaande normen dient te rechtvaardigen. In de tweede plaats worden uhit de norm van hoger recht die in de rechtsanalogie wordt gehanteerd, nieuwe rechtsnormen geconcretiseerd. Welke juridische status verkrijgt de norm van hoger recht, welke juridische status komt de extensieve lezing (voortvloeiend uit de wetsanalogie) toe en welke is de juridische status van de nieuwe rechtsregel (voortvloeiend uit de rechtsanalogie) in het kader varn geldende rechtsnormen?

Wetgever en rechter leveren hun bijdrage aan het rechtsnormenkader via een voortdurend proces van rechtsschepping en rechtsvinding. In beginsel is de rechtsscheppende rol voor de wetgever weggelegd, terwijl de rechter zich eerder toelegt op de rechtsvinding. ${ }^{334} \mathrm{Nu}$ kan dit beeld ten aanzien van de Grondwet of het Verdrag worden genuan- 
ceerd; voorheen is aangetoond, dat Grondwet en Verdrag niet op regelmatige basis worden aangepast, maar dat aanpassing naar plaats en tijd als het ware door de wetgever is ingecalculeerd. ${ }^{335}$ In deze benadering is deels een belangrijke rechtsvindende taak voor de rechter weggelegd, maar daarmee is nog niets gezegd over de toelaatbare intensiteit van de modificatie van grondwettelijke regels door de rechter. Een andere benadering van aanpassing van grondwet of verdrag is ook mogelijk: sommige rechters zien het miet als hun taak deze aan te passen naar condities, maar geven er de voorkeur aan veranderingen door de grondwetgever te laten doorvoeren vanuit de gedachte dat dat het meest tegemoet komt aan vereisten van democratische legitimatie. In deze optiek levert rechtsvinding al gauw ongeoorloofd rechterlijk activisme op.

De rechtspraak op het terrein van het recht op persoonlijkheid geeft een aantal treffende voorbeelden weer waarin de rechter een uitgesproken rechtsscheppende bijdrage leverde. De Amerikaanse rechter kwalificeerde abortus onder privacy, het EHRM plaatste het recht op informatie over de kwaliteit van het leefmilieu onder 'privé-leven' ex Art. 8 EVRM, en de Hoge Raad positiveerde voor het recht op kennis van de biologische afstamming een hogere norm van het algemene persoonlijkheidsrecht. ${ }^{336}$ Deze voorbeelden schetsen niet een beeld van een rechtsnomen toepassende maar eerder van een rechtsvormende rechter. De vraag die zich opdringt ter zake van het karakter van het recht op persoonlijkheid en de daaruit geconcretiseerde rechten, is in hoeverre gesproken kan worden van normen van 'geldend recht": in hoeverre behoort een recht op abortus of een recht op kennis van de biologische afstamming tot het 'geldend recht" op het moment dat de rechter dat voor het eerst uitspreekt?

Hieronder zullen enkele standpunten in de literatuur ter zake van wanneer een rechtsnorm nu tot geldend recht behoort, worden geschetst. Daarmee samenhangend komen aspecten ter zake van de constitutionele verhouding aan de orde: in hoeverre komt in dit verband een bevoegdheid aan de rechter toe? In constitutioneel opzicht is deze vraag van cruciaal belang, omdat een bevoegdheid ter zake van het scheppen van normen tot op zekere hoogte een beoordelingsrumte impliceert. Vraag is of en in hoeverre de rechter als schepper van nieuw recht gebonden is aan grenzen. In hoofdstuk 2 en 3 zijn enkele grenzen in het kader van de constitutionele verhouding uitgewerkt. Sommigen menen dat de rechter niet ongelimiteerd en naar eigen üzicht nieuwe normen van hoger recht en rechtsregels 'uit de hoge hoed' tevoorschijn kan halen. Dit spanningsveld is in de rechtspraak vanuit uiteenlopende invalshoeken afwisselend positief en negatief benaderd. Het is hier uitdrukkelijk niet de bedoeling, de discussie over gelding van rechtsnormen definitief te beslechten; veeleer wordt hier getracht in kaart te brengen welke de belangrijkste lijnen zijn langs welke voornoemde problematiek van de rechtsvormende rechter wordt benaderd. In dat verband zal eerst aandacht worden geschonken aan de rechtspositivistische en de natuurrechtelijke visie op de gelding van rechtsnormen. In de tweede plaats wordt bekeken welke de belangrijkste denkrich-

335 Zie hoofdstuk 2 en 3 .

336 Zie respectievelijk Roe t. Wade, 410 U.S. 113; Guerra t. Halie, EHRM 19 februari 1998, JB 1998/70; Abstammungskenthis, 79 BVerfGE 256 (1989) en Valkenhorst, HR 15 april 1994, NJ 1994/608. 
tingen zijn over de vraag in hoeverre het tot de taak van de rechter behoort om geldigheid van rechtsnomen vast te stellen; in dit verband wordt het debat over gelding van normen en de functie van de rechter ter zake tussen Hart, Dworkin en MacCormick geschetst. Ten slotte wordt aandacht besteed aan de precedentwerking van rechterlijke uitspraken in de rechtsstelsels, ondat soms aan vaste jurisprudentie geldigheid wordt toegekend. ${ }^{337}$

\subsubsection{Gelding van rechtsnormen: de grens wan het recht}

Een gangbare definitie van geldend recht is het recht dat op een bepaald moment in een bepaalde samenleving is vastgelegd ${ }^{338}$ Geldend recht is in deze optiek te vinden in formele rechtsbronnen, waartoe in elk geval wetgeving, verdrag en gewoonte. Jurisprudentie wordt niet vanzelfsprekend tot de formele rechtsbronnen gerekend, maar komt in het algemeen een 'de facto' betekenis als rechtsbron toe. ${ }^{339}$ Rechtsbronnen ontlenen hun gezag aan de autoriteit, die de rechtsnormen in het leven heeft geroepen. Geldend recht wordt ofwel in een gevormde rechtsregel, ofwell in een rechtsbeslissing gevormd ${ }^{340}$ Bruggink makt een onderscheid tussen positief recht en geldend recht. Positief recht is in zijn optiek het recht dat is 'veruiterlijkt'; het recht heeft een min of meer vaste vorm in wettelijke regels en rechterlijke beslissingen gekregen. Positief recht kan geldend recht zijn wanneer dat blijkt uit zijn functioneren in de samenleving, maar positief recht behoort niet vanzelfsprekend tot het geldend recht. ${ }^{341}$ Deze visie op het geheel aan geschreven rechtsregels en jurisprudentie geeft slechts een statische momentopname van het geldende recht weer. Indien wordt onderzocht, welke rechtsnormen in een concrete situatie tot het geldend recht behoren, dient de wisselwerking. tussen rechtsregels en rechtsbeslissingen in de beschouwing te worden betrokken. In het proces van rechtsvinding worden positieve regels uit formele rechtsbronnen toegepast door de rechter, die met zijn rechtsbewustzijn deze regels toepast in een concreet geval. Hiermee verkrijgt een geschreven rechtsnorm gelding. Het geldend recht is voortdurend in beweging; het wisselt naar plaats en tijd - wil geldend recht functioneel blijven in een samenleving, dan zall het zich moeten aanpassen. In dit verband vervult de rechtsvindingsactiviteit van de rechter een brugfunctie tussen het statische geldende recht enerzijds en de eisen van een dynamische samenleving aan het geldend recht anderzijds. De vraag welk gezag toekomt aan een norm, is onderwerp van een debat tussen ruwweg twee stromingen in de rechtsfilosofie, die tussen aanhangers van het natuurrecht enerzijds en die van het rechtspositivisme anderzijds. ${ }^{342}$

337 De Waard 1987, p. 67

338 Bruggink 1990, p. 16.

339 Gribnu 1997, p. 197.

340 Daamaast word, om de dynamiek van het recht in de samenleving te onderkennen, eveneens erkend dat geldend recht zijn grondslag ook in niet-formele rechtsbronnen vindt. Hiertoe behoren liet volgen van rechtsnormen in de juridische praktijk en het recht dat wordt gevormd in de doctrine (Bruggink 1990, p. 16 e.w.).

341 Bruggink 1990, p. 12. Positief recht behoort in die optiek niet tot het geldend recht wanneer een rechtsnorm niet als geldend recht door de justitiabelen in de samenleving wordt aanvaard (Bruggink 1990, p. 24).

342 Van Oenen 1994, p. 16 en Smith 1998, p. 49. 


\section{Rechispositwisten}

De rechtspositivisten, die zich ten opzichte van de natuurrechtelijke aanhangers aan de ene kant van het spectrum manifesteren, hanteren een formele benadering van het gezag van de geldende rechtsnorm. Het rechtspositivisme neemt formele criteria als witgangspunt om te bepalen welke regels nu rechtskracht hebben. Deze opvatting kont voort uit de doctrine, dat de wetenschap enkel feiten die zintuiglijk waarneembaar zijn en die op geen enkele wijze door subjectieve opvattingen worden gekleurd, aangemerkt worden als wetenschappelijk relevante feiten. De subjectieve opvattingen en regels die niet waarneembaar zijn, zijn evenwel van belang, maar zij behoren niet tot geldend recht. Rechtsbeginselen behoren in deze optiek niet tot het geldend recht. Vraag is dan, welke het karakter van de norm van hoger recht is, waarop de rechter een beroep doet wanneer hij een wets- of rechtsanalogie hanteert. Rechtspositivisten wijzen het bestaansrecht van een dergelijke regel in beginsel af wanneer het geen rechtsregels zijn.

Rechtspositivisten zien hier evenwel aanleiding, een scheiding aan te brengen tussen de soorten regels. Zij onderscheiden recht zoals het 'feitelijk is', vastgelegd in de wet of in de rechtspraak enerzijds, en moraal, recht zoals het 'behoort te zijn' anderzijds. Rechtspositivisten onderkennen aldus, dat het recht enerzijds regels kent die worden gevolgd, terwijl er anderzijds regels bestaan die zouden moeten worden gevolgd. Toch staat gelding van de regel centraal voor de rechtspositivist: alleen normen die waarneembaar zijin, behoren tot het geldend recht: Het rechtspositivisme onderkent wel het belang van de morele normen, maar zij maken in deze optiek niet noodzakelijkerwijze deel uit van het geldend recht. Morele normen zijn subjectief, terwij] rechtsnormen objectief bepaalbaar zijn. Problematisch met de rechtspositivistische opvatting is nu juist, dat bijvoorbeeld in de rechtspraak met geldende rechtsregels niet alleen wordt geduid op normen die worden gevolgd $d_{2}$ maar ook op normen die moeten worden gevolgd. Rechtsregels houden bijvoorbeeld richtlijnen in voor toekomstige gedragingen, ook al zijn zij echter (nog) niet waarneembaar in die zin dat zij in de rechtspraktijk worden aangewend. Zo kunnen eveneens rechtsbeginselen worden betrokken in de rechtsvinding. Het geldende recht kont in dit verband niet alleen voort uit het "waaneembare" recht. Hiermee hangt een ander bezwaar samen. In de jurisprudentie komt het regelmatig voor dat de rechter afwijkt van een bestaande rechtsnorm voor de oplossing van een geschil. De scheiding van de rechtspositivist tussen het recht 'zoals het is' en het recht "zoals het behoort te zijn" lijkt in de praktijk van de oordelende rechter moeilijk vol te houden; zij lijkt althans niet zo scherp te trekken als de precieze rechtspositivist wil doen geloven. ${ }^{343}$

343 Smith 1998 , p. 52 . Uiteraard is binnen de groep aanhangers van het rechtspositivisme een onderverdeling aan te brengen van 'rekkelijken" en "preciezen", en zijn er genuanceerder meningen weer te geven. Het gaat er hier echter om, het uitgangspunt wan het rechtspositivisme te schetsen. Zie voor verwijzingen naar schakeringen binnen de rechtspositivistische opwatting byjwoorbeeld Bengoetxea 1993 , met name Hoofdstuk 1; Van Oenen 1994, Smith 1998, p. 49 e.v. 


\section{Nouurrechtsleer}

Aan de andere kant van het spectrum ter zake van de vraag hoe geldigheid van het recht kan worden vastgesteld, vinden we de aanhangers van de zogenoemde natuurrechtsleer. ${ }^{344}$ In de natuurrechtelijke opvatting wordt de theorie gehuldigd, dat aan rechtsnormen geen rechtskracht toekomt, voor zover zij in strijd zijn met de doelstelling waraan het recht volgens natuurrechtelijke filosofen dient te voldoen. ${ }^{345} \mathrm{Zij}$ hanteren voor de invulling van hun doelstellingen ethische beginselen; indien een rechtsnorm in strijd is met een dergelijk beginsel, kan deze norm geen gelding hebben in het recht. ${ }^{346}$ Een wet die in strijd is met een ethisch beginsel kan aldus geen kracht van wet verkrijgen. De natuurrechtsfilosoof hanteert aldus een materiële invulling van de vraag wat geldend recht is. Recht en moraal lopen door elkaar heen, en een scheiding wordt onmogelijk geacht. In de jurisprudentie zijn wel voorbeelden te vinden, waarin uitgangspunten van de natuurrechtelijke opvatting zijn te ontwaren. In een enkele zaak is deze benadering zelfs van doorslaggevende aard geweest in de rechtsvinding. In Duitsland is bijvoorbeeld de 'Radbruch"sche Formel' tot ontwikkeling gekomen, die inhoudt dat indien een wet strijdt met beginselen van menselijke waardigheid, zij nooit kan hebben gegolden, ook al leek de wet formele gelding te hebben.

De 'Formel' of formule van Radbruch vindt haar oorsprong in de beoordeling van misdaden begaan onder het nazi-regime, die gelegitimeerd leken vanwege het feit dat de formele wet voor dergelijke handelingen bevoegdheden verleende. Een fraai recent voorbeeld van de toepassing van deze 'Formel' door het Duitse Federale Constitutionele Hof is te vinden in de zaak Mauerschützen, waarin geoordeeld werd over de vraag, of voormalige DDR-grenswachten die vluchtende DDR-burgers hadden neergeschoten, strafrechtelijk konden worden wervolgd. ${ }^{347}$ Onder DDR-recht voerden deze grenswachten in beginsel hun plicht uit; niet echter in de opvatting van het Duitse Hof. Er gelden nu eenmaal rechtsbeginselen van menselijke waardigheid, die niet kunnen worden genegeerd, ook niet door grenswachten die in de veronderstelling verkeren dat zij de hun opgedragen takk uitvoeren, aldus het Hof Deze beginselen kunnen zijn vastgelegd in Grondwetten of verdragen, maar noodzakelijk voor de gelding van de rechtsnorm is dat niet. Het feit dat destijds intern een andere waarde werd gehecht aan die morele waarde in relatie tot de stantsveiligheid doet daar evenmin aan af: het beginsel van menselijke waardigheid en meer specifiek het recht op leven vormt een superieur rechtsbeginsel van de Grondwet van de DDR. ${ }^{348}$

344 Ook hier zijn uiteenlopende schakeringen van deze opvatting in de literatuur te vinden; zie onder meer Linsmayer 1963, Finnis 1980; Shiner 1992.

345 Smith 1998 , p. 54 .

346 Smith 1998, p. 54.

347 Mauerschizen, 95 BVerfGE 96,134 (1996).

348 Zie voor nadere beschouwingen van deze uitspraak bijvoorbeeld Mevis 1998. Naderhand heeft het Europese Hof voor de Rechten van de Mens zich uitgelaten over de legitimiteit van het oordeel van het Duitse Hof in het licht wan het legaliteitsbeginsel (zie K.-H. W. t. Duitsland, EHRM 22 maart 2001, EHRC 2001/31) 
In de jurisprudentie van de andere rechtsstelsels zijn eveneens uitspraken met natuurrechtelijke noties aangetroffen. Het Amerikaanse Hooggerechtshof hanteerde bijvoorbeeld in Griswold t. Connecticut een naturrechtelijke notie van privacy, die de gelding van een recht op abortus diende te ondersteunen:

'We deal with a right of privacy older than the Bill of Rights - older than our political parties, older than our school system". ${ }^{349}$

De Amerikaanse Grondwet expliciteert geen recht op privacy waaruit voortvloeit dat individuen zelf een keuze moeten kunnen maken ter zake van het gebruik van voorbehoedmiddelen. In Griswold was deze overweging overigens niet doorslaggevend, maar bood zij belangrijke ondersteuning aan de door de rechter toegepaste rechtsanalogie. ${ }^{350}$ Niet duidelijk was echter op welke rationeel traceerbare grondslag de gelding van de morele norm nu is gebaseerd. ${ }^{351}$ Er is niet noodzakelijkerwijze sprake van een systeem of methodologie, waaraan rechtsgeldigheid van de morele norm wordt ontleend. Dat blijkt ook uit de kritiek, die bijvoorbeeld werd geleverd op de natuurrechtelijke notie van privacy in Griswold t. Connecticut. ${ }^{352}$ De grondslag op basis waarvan een rechtsnorm tot geldend recht wordt verheven, is in de optiek van critici in hoge mate afhankelijk van de subjectieve opvatting van de rechtsvinder, waardoor rechtsonzekerheid en willekeur worden aanvaard, zo is de gedachte achter de afwijzing van natuurrechtelijke opvattingen. Er lijkt aldus veel te worden overgelaten aan de voorstelling van de rechtsvinder over de vraag wat rechtvaardig is en welke morele normen behoren tot het geldende recht. Over dat aspect in de rechtsvinding, interpretatieruimte van de rechtsvinder in relatie tot de gelding van rechtsnormen, wordt in de moderne rechtstheorie een debat gevoerd tussen de rechtspositivist Hart enerzijds en Dworkin anderzijds ${ }^{353}$ Hart is van mening, dat waar de wet ruimte laat voor rechtsvorming, de rechter een ruime mate van discretie wordt gelaten hetgeen in zijn optiek onwenselijk wordt geacht in het licht van de constitutionele verhouding tussen rechter en wetgever. Dworkin relativeert de stellingname over de discretie van de rechter. De kwestie van de mate van discretie is eveneens van belang in de vraag naar de ruimte die de interpreterende rechter toekomt in het kader van de constitutionele verhouding. ${ }^{354}$

349 Griswold t. Connecticut, 381 U.S. 479, 484 (1965).

350 Zie par. 5.3.2.

351 De herleidbaarheid wan deze norm naar een rechtsbron is niet eenduidig; het recht op privacy ten tijje van Griswold t. Connecticut heeft sterk het karakter van een norm wan hoger recht.

352 Tot de meest afwijzende critici van dit oordeel en met name de natuurrechtelijk getinte opnerking behoren onder meer Bork 1990, p. 95 e.v.

353 Hart 1961 en Dworkin 1977.

$354 \mathrm{Er}$ wordt in dit verband geen definitieve stelling betrokken met betrekking tot de vraag of de rechter nu wel of geen discretie toekomt in de constitutionele interpretatie. Van belang is hierna in de jurisprudentieanalyse veeleer inzichtelijk te maken, hoe de rechter worstelt met de onderliggende problematiek wan de constitutionele verhoudingen bij de vraag naar de mate van discretie. 


\subsubsection{Hart en Dworkin: vaststelling van geldigheid van rechtsnormen door de rechter}

De theorie van Hart vertoont ten opzichte van die van Dworkin sterke rechtspositivistische trekken. ${ }^{355}$ Dworkin heeft tegenover het rechtspositivisme gesteld, dat recht niet los kan worden gezien van moraal. Tevens bestrijdt hij de natuurrechtelijke notie, dat recht en morele beginselen één zijn: het recht kan in zekere mate in strijd komen met morele beginselen. Harts theorie komt in het kort op het volgende neer. Volgens Hart kunnen rechtsnormen als zodanig worden geïdentificeerd via secundaire regels. Secundaire regels zijn regels die aan ambtsdragers - wetgever en rechter - bevoegdheden verlenen om de rechtsregels gezaghebbend te identificeren, te veranderen en inbreuken erop te af te wijzen. De geldigheid van rechtsregels wordt ontleend aan de secundaire regels. ${ }^{356}$ De rechtsregels zijn als gevolg van de openheid van de taal en de dynamische aard van de samenleving nagenoeg altijd gebrekkig en geven lang niet altijd een eenduidige oplossing in een juridisch geschil. De rechter zal in die geschillen waarin rechtsregels geen eenduidige oplossing aanreiken, een discretionaire beslissing moeten nemen. Hierbij kan hij zich oriënteren aan rechtsregels en aan rechtsbeginselen. Rechtsregels maken deel uit van het recht volgens Hart, rechtsbeginselen vloeien in zijn optiek daarentegen voort uit een niet-juridische bron. Zij kunnen niet als juridisch worden aangemerkt, omdat rechtsbeginselen morele normen inhouden. Recht en moraal zijn, zoals hiervoor bij het rechtspositivisme beschreven, twee gescheiden thema's waarbij moraal geen onderdeel van het recht kan zijn. Indien de rechter nu rechtsbeginselen betrekt in zijn rechtsvinding, maakt de rechter in Harts optiek nieuw recht, en doet in ruime mate aanspraak op een discretie.

Dworkins kritiek op Harts theorie is dat de scheiding tussen recht en moraal niet juist is, en dat morele opvattingen evenzeer deell uitmaken van het recht. ${ }^{357}$ Rechtsbeginselen zijn juist een onderdeel van het recht; zij spelen zelfs een centrale rol in Dworkins opvatting over hoe een rechter dient te beslissen. In moeilijke gevallen, aldus Dworkin, blijkt dat rechters niet in de eerste plaats zoeken naar toepasselijke rechtsregels maar naar een oplossing die zo goed als mogelijk kan worden gerechtvaardigd. In de opbouw van de argumentatie van de rechtvaardiging worden rechtsbeginselen betrokken. Rechtsbeginselen vormen aldus een volwaardige rechtsbron in Dworkins optiek. Het betrekken van deze rechtsnormen in de argumentatie levert niet zozeer een rechterlijke discretie op; tenslotte is de rechter, afgaand op zijn taak, verplicht de meest rechtvaardige beslissing te nemen. Wanneer 'dwingende morele normen' deel uitmaken van het recht, hanteert een rechter die dergelijke normen interpreteert en toepast, geen discretie. Dworkins visie op rechtsbeginselen als erkende rechtsnormen in een rechtsorde sluit in sommige opzichten aan bij de erkenning van rechtsbeginselen zoals Hart die ziet. 
Hart stelt dat hetgeen recht is, beschreven kan worden in termen van sociale feiten. Een verwijzing van morele inhoud van de rechtsnormen is daarvoor niet noodzakelijk, all is die morele inhoud vaak wel te herkennen in de rechtsregel. Van belang is hier, dat voor identificatie van een rechtsnorm niet een morele inhoud noodzakelijk is. In Dworkins visie zijn beiden onlosmakelijk met elkaar verbonden. Dworkins probleem met deze visie van Hart is dan ook, dat Harts theorie van identificatie van rechtsregels bepaalde categorieën van rechtsbeginselen principieel niet kan omvatten, terwijl deze rechtsbeginselen van groot belang zijn voor de consistentie en de coherentie van het recht. Dworkin onderscheidt in dit verband rechtsbeginselen die reeds zijn gepositiveerd, en rechtsbeginselen die slechts gedeeltelijk of helemaal niet gepositiveerd zijn. ${ }^{338}$ In de laatste categorie liggen niet alleen rechtsbeginselen besloten die hun bevestiging vinden in het recht of in de samenleving, maar ook rechtsbeginselen die eerder een controversiële status hebben. In dit verband kan bijvoorbeeld worden gedacht aan morele noties, waarover in de samenleving geen consensus bestaat. Harts theorie kan, aldus Dworkin, zonder problemen de gepositiveerde rechtsbeginselen omvatten; zij zijn beschreven. ${ }^{359}$ Rechtsbeginselen die niet zijn gepositiveerd, met andere woorden, rechtsbeginselen die niet zijn geëxpliciteerd in de wet of in de rechtspraak, kunnen in Harts theorie niet zomaar worden geaccepteerd als rechtsnormen. Het gaat hier om rechtsbeginselen, die zich tot dusverre niet expliciet hebben gemanifesteerd in wet of rechtspraak maar die wel zichtbaar of voelbaar bewegen achter de erkende rechtsnormen:

'Het gaat dan om beginselen die als het ware de 'dieptegrammatica' van het recht vormen.

Ze liggen in de diepte van het recht besloten, maar pas als zij 'aan de oppervlakte komen" kunnen zij onderdeel worden wan een rechterlijke gewoonte, of bewust (reflectief) worden 'geaccepteerd'. 360

De rechter zal, wil hij zich in de optiek van een rechtspositivist op legitieme wijze oriênteren aan deze categorie van rechtsbeginselen, moeten waarmaken dat het betrokken rechtsbeginsel nog niet is geëxpliciteerd, maar dat het wel besloten ligt in het recht zoals dat door het systeem van de rechtsregels wordt gedicteerd. Het moeilijkst is de categorie van rechtsbeginselen, die kunnen worden aangemerkt als 'controversiele rechtsbeginselen". Met de controversiële rechtsbeginselen hebben positivisten de grootste problemen; zij zijn niet te herleiden, ook niet indirect, tot beschreven sociale feiten. Dat is, in Dworkins visie, ook niet noodzakelijk voor de gelding van deze rechtsbeginselen. Hart kiest voor de interpreterende rechter een uitgangspunt waarin rechten verschijnen als uitvloeisel van een arsenaal van gepositiveerde rechtsnormen. In Dworkins visie op het recht speelt echter rechtvaardiging een doorslaggevende rol in de rechtspraak. Rechtspraak dient altijd te streven naar rechtvaardiging van toegekende rechten. Wat deze rechten inhouden kan, aldus Dworkin, niet worden onderzocht aan de hand van de door Hart geïdentificeerde test, maar moet in concreto worden vastgesteld. De rechter zal volgens Dworkin, inherent aan de tak die hem is opgedragen, in 
beginsel altijd de best mogelijke oplossing nastreven. In die zin heeft de rechter geen discretie bij het kiezen van de oplossing: die dient rechtvaardig te zijn. ${ }^{361}$

Problematisch aan de theorie van Hart is, dat in principe voor ongeschreven rechtsbeginselen geen plaats is; zijn 'rule of recognition' staat daaraan in de weg. Dat is een van de voornaamste kritiekpunten van Dworkin.

MacCormick is gekomen met een tussenvariant van de opvattingen van Hart en Dworkin. ${ }^{362} \mathrm{Hij}$ stelt dat er wel een relatie bestaat tussen de "rule of recognition" en pechtsbeginselen, matar die relatie is indirect in zijn optiek. Rechtsregels hebben hun regelkarakter vanwege de afkomst, terwijl beginselen die rechtsgeldigheid hebben, deze geldigheid bezitten vanwege hun functie in relatie tot die rechtsregels. Rechtsbeginselen worden gebruikt bij het rationaliseren van rechtsregels. Volgens MacCormick kunnen beginselachtige normen op twee wijzen getransformeerd worden tot een rechtsbeginsel; zij kunnen worden opgenomen in de wet en op die wijze rechtsgeldigheid verkrijgen, terwijl zij daarnaast in de jurisprudentie kunmen worden opgenomen, en aldaar geldigheid verkrijgen. Dat laatste gebeurt niet plots; de rechter zal in beginsel in een reeks van uitspraken laten zien in welke mate hij de existentie van een norm als rechtsbeginsel aanmerkt. Het recht is, zoals ook Dworkin stelt, niet hermetisch afgesloten voor morele en politieke waarden ${ }^{363}$ Op deze wijze kan in een positivistische visie plaats zijn voor rechtsbeginselen als normen wan geldend recht.

\subsubsection{Legitimatie van rechisnormen in de rechtspraak: precedentwerking}

In de zaak Niemietz $t$. Duitsland werd via "het recht van het individu, met andere individuen relaties te vestigen en te onderhouden' via de wetsanalogie inhoud gegeven aan de rechtsnorm van het recht op privé-leven ex Art. 8 EVRM. ${ }^{364} \mathrm{Nu}$ bestaat over de geldigheid van Art. 8 EVRM als rechtsnorm geen twijfel; de vraag is echter, of de door het Hof geconstrueerde rechtsnorm van het recht op privé-leven kan worden aangemerkt als rechtsbeginsel. ${ }^{365}$ De norm die voortvloeit uit het recht op privé-leven kan

361 Barak definieert rechterlijke discretie als wolgt, dat de rechter uit twee of mieer legitieme altematieven Kain kiezen om een rechtsgeschil tot een oplossing te brengen. Hij onderscheidt in dit verband een ruime en een enge discretie, afhankelijk van de mate waarin de rechter keuzemogelijkheden theeft (Barak 1989, p. 7 e.v.). Barak onderscheidt rechterijike discretie naar de vaststelling van de feiten, naar de normvaststelling en de normtoepassing. In dit verband staat de rechterlijke discretie naar de normvaststelthing door de constitutionele rechter centraal. Dworkin stelt in dit verband dat de rechter nauwelijks tot geen discretie toekomt: hij dient te kiezen voor de meest rechtvaardige oplossing, en dat is er steeds maar ến. Hart stelt darentegen dat de rechter al gauw een ruime mate wan discretie heeft bij de vaststelling wan de toepasselijke norm, omdat er op een geschil meer juridisch verdedigbare normen van toepassing kunnen zijin.

362 MacComick 1997, p. 233.

363 MacCormick 1997, p. 236.

364 Niemietz d. Duirshand, EHRM 16 december 1992, Serie A wol. 251-B.

365 De wraag naar de getdigheid van rechtsnormen doet zich nog directer gevoelen in het geval dat de rechter een rechtsanaloge redenering hanteert. In het geval van de rechtsanaloge redenering was een toepasselijke grondwetsregel niet voorltanden; in dergelijke gevallen bestaat de noodzaak, een rechtsregel te construeren dic an te merken is als rechtsgeldig. In de Volkenhorst werd het rechr om kennis van de 
echter gelding verkrijgen via herhaling in de jurisprudentie. Jurisprudentie is niet alleen een belangwekkende bron van recht in de rechtsvinding. Jurisprudentie is tevens een onderdeel wan het recht waarin de gelding van het recht tot uitdrukking komt. De rechter kan bijvoorbeeld trachten de juridische concepten, die als het ware "verborgen" zitten in de precedenten, naar voren te halen. Het gezag dat jurisprudentie heeft in de rechtsstelsels kan een dergelijke benadering ondertussen tot op grote hoogte rechtvaardigen; zij heeft in de afgelopen decennia aan gezag gewonnen. Eén van de consequenties hiervan zou kunnen zijn dat wanneer een norm erkenning vindt in de rechtspraak het vermoeden bestaat dat deze tot het geldend recht behoort. Over de aard van de binding die uitgaat van jurisprudentie bestaat in de verschillende stelsels discussie; nieuwe normen die door de rechter zijn gepositiveerd kumnen niet vanzelfsprekend rekenen op erkenning in de rechtsgemeenschap.

Traditioneel wordt ter zake van de bindingswerking van jurisprudentie gesproken over de leer van 'stare decisis' of die van het precedent. Deze doctrine wordt in beginsel als een fenomeen van 'common-law' systemen aangemerkt. ${ }^{366}$ De continentale rechter is, zo gold lange tijd de gedachte, gebonden aan de wet, en is ter zake van precedenten relatief vrij. ${ }^{367}$ Intussen kan worden vastgesteld, dat de verschillen tussen 'common"aw' rechtsstelsels en 'civil-law' rechtsstelsels gradueel zijn, en met name in de praktijk veell genuanceerder zijn dan de uitgangspunten van beide typen rechtsorden doen vermoeden. ${ }^{368}$ Jurisprudentie is niet in alle rechtsstelsels al lange tijd aanvaard als zelfstandige bron van recht. In de Nederlandse rechtspraak wordt naar jurisprudentie pas sinds het begin van de jaren zeventig expliciet verwezen. ${ }^{369}$ Dat wil geenszins zeggen, dat jurisprudentie voorheen geen betekenis toekwam: in oudere rechtspraak treft men soms herhalingen aan van argumenten en formuleringen uit eerdere uitspraken. ${ }^{370} \mathrm{In}^{\mathrm{n}}$ middels is jurisprudentie in de Nederlandse rechtsorde aanvaard als zelfstandige bron van ongeschreven recht. Precedenten lijken in alle stelsels een belangwekkende functie te vervullen voor de rechtvaardiging van het bestaan van normen van hoger recht en daaruit voortvloeiende concretiseringen. ${ }^{371}$

Er is wel een aantal verklaringen te geven, waaron ook continentale rechtsstelsels jurisprudientie erkennen als bron wan recht. Het argument van rechtszekerheid is in dit

afstamming te kunnen vernemen afgeleid uit een norm van hoger recht, het nog niet eerder geuite algemene persoonlijkheidsrecht (Valkenhorst, HR 15 april 1994, NJ 1994/608).

366 Met 'Stare decisis' wordt gedoeld op de benaming "stare decisis et non quieta movere', hetgeen inhoudt dat vastgehouden dient te worden aarn precedenten en dat gevestigde zaken niet noeten worden getond. Met 'common-law" wordt gedoeld op een Angels aksisch georiënteerde rechtsorde.

367 Scholiten 1974, p. 85 e.\%.

368 Asser-Scholten (Algemeen Deel) 1974, p. 87; MacCormick en Summers 1991, p. 487.

369 Het Stierkalfarrest wordt wel aangemerkt als de uitspraak waarin eén van de eerste werwijzingen naar jurisprudentie werd gedaan, zie ERR 7 maart 1980, NJ 1980/353. Een expliciete verwijzing naar de toegenomen betekenis van precedenten in de Nederlandse rechtspraak is te vinden in HR 15 jarnuari 1988, NJ 1988/888.

370 Scholten 1974, p. 87.

371 Zie het voorbeeld van Meyer t. Nebraska, waarin het Hof op basis van jurisprudentie (en een regel uit de Preambule) een rechtsnorm inhoudende het individuele recht op nastreven vara geluk construeerde. 
opzicht van belang, evenals het beginsel van gelijke behandeling. Daarnaast wordt een argument dat enkel is gebaseerd op de wet in weel gevallen niet (meer) voldoende geacht; de rechter ziet kennelijk een noodzaak om met ondersteunende argumentatie te komen. In veel rechtssystemen wordt precedentwerking zinvol geacht omdat het tevens de coherentie van het recht als systeem versterkt. ${ }^{372}$ Vóór de benadering dat jurisprudentie een bron is van ongeschreven recht pleit dat rechterlijke uitspraken vaak ook een meer algemene, boven het concrete geschil uitstijgende betekenis hebben. Tegen de opvatting dat jurisprudentie een zelfstandige bron van ongeschreven recht vormt, pleit het titgangspunt dat de rechter zich enkel uitspreekt over een concreet geschil. ${ }^{373}$ Het tweede standpunt lijkt in belangrijke mate te worden gerelativeerd door het eerste, althans voor wat betreft de onderzochte stelsels. Wanneer de rechter nieuwe normen expliciet in de rechtspraak erkent en ontwikkelt, positioneert de rechter zich ten opzichte van de wetgever op een andere wijze dan wanneer hij herhaaldelijk aangeeft slechts in het onderhavige geval te willen beslissen en niet boven het concrete geschil uit te stijgen.

\section{De onvang van precedentenwerking}

Wanneer de rechter wordt beschouwd als louter wetsvertolker ligt het minder snel voor de hand dat aan precedentwerking van rechtspraak een zekere binding kan toekomen. Wanneer daarentegen juist wordt erkend dat rechterlijke uitspraken ook een rechtsvormende waarde hebben, kan binding van betekenis juist wel toekomen aan jurisprudentie. In de constitutionele rechtspraak of in de literatuur ter zake in de stelsels kon nauwelijks één lijn worden vastgesteld; de keuze voor de ene of de andere benadering hangt bijvoorbeeld samen met het onderwerp dat in het geschil aan de orde is, en met de mate waarin een rechtsopvatting van de rechter aanvaard is bij zijn forum. Wanneer aanvaardbaarheid van een rechtsvinding wordt afgetast, kan de rechter bijvoorbeeld opteren voor een casuistische benadering en aangeven dat hij met het voorliggende geschil niet voornemens is maatstaven voor de toekomst aan te leggen. ${ }^{374}$ De rechter kan hiermee uitdrukkelijk aangeven dat in dit opzicht een taak is weggelegd voor de wetgever. ${ }^{375}$ Er bestaat een gradatie van gezag van jurisprudentie. ${ }^{376}$ Van gebondenheid in de zin van een zelfde mate van onderwerping aan iedere uitspraak is geen sprake; in alle stelsels worden nu eenmaal belangwekkende en minder belangrijke uitspraken gedaan. In de rechtspraak kan erkenning van een gezag van de rechtsnorm plaatsvinden doordat de rechter deze in een reeks van gevallen herhaalt. In sommige gevallen is een reeks van uitspraken niet noodzakelijk, en wordt gezag toegekend aan één enkele rechterlijke uitspraak. Een dergelijke uitspraak kan herkend worden aan de wijze waarop het dictum is geformuleerd. Hoe meer dat betrekking heeft op de algemeenheid, hoe

372 MacCormick en Summers 1991, p. 488.

373 Zie bijvoorbeeld Art. 12 Wet Algemene Bepalingen.

374 Het uitgangspunt van de casuistiek is in de literatuur uitgewerkt door Sunste in 1999.

375 De wraag rijst of an deze uitspraak niet naderhand toch een groot gezag kan worden toegekend, bijvoorbeeld in een volgende uitspraak van de rechter. Die omstandigheid doet dan echther niet af aan het geringe gezag dat de rechter wil toekennen in het geschil dat op dat moment voor hem ligt.

376 Asser-Scholten (Algemeen Deel) 1974, p. 89. 
groter de draagwijdte van de uitspraak wordt: Indien de uitspraak verder af komt te staan van het feitencomplex dat de aanleiding vormde voor het geschil, ligt eerder voor de hand dat de rechter algemene lijnen formuleert.

Een fraai voorbeeld van het vaststellen van algemene lijnen is te winden in Roe $t$. Wade; waarin het Amerikaanse Hooggerechtshof kwam tot de ongrondwettigverklaring van het verbod op abortus. ${ }^{377}$ Het Hof ontwikkelde in die uitspraak tevens een trimestersysteem, aan de hand waarvan diende te worden beoordeeld welke criteria in acht moeten worden genomen bij het besluiten tot abortus. Van belang in dit verband is de mate waarin de rechter een beleid kan maken ter zake van de geschillen die het wenst te beslechten. Het Amerikaanse certiorari-systeem leidt er tot op grote hoogte toe, dat het Hooggerechtshof kan kiezen in welke zaken het uitspraken wenst te doen. ${ }^{378} \mathrm{De}$ bevoegdheid om te kunnen selecteren houdt in dit verband de keuzevrijheid in, te beslissen over de vraag óf een precedent dient te worden uitgesproken met het oog op bevestiging of juist het afbuigen van een jurisprudentiële lijn. Consequentie van certiorari is, dat nagenoeg iedere uitspraak een precedent van gewicht is. Van de uitspraken van de hoogste rechter, die daarentegen weinig discretie kent in zijn ontvankelijkheid, gaat in vergelijking met die van het Hooggerechtshof in minder dringende mate bindende werking uit. De jurisprudentie is in dat geval eerder een 'bijproduct', in vergelijking met de betekenis die zij heeft in de rechtspraak van het Amerikaanse Hooggerechtshof. Dit laatste lijkt vooral op te gaan voor de Duitse, de Nederlandse, de Luxemburgse en de Straatsburgse rechter. ${ }^{379}$

\section{Het Amerikaanse Hooggerechishof}

Het Hof kan ter zake van precedentwerking een zeker beleid voeren; het heeft een bepaalde mate van discretie. ${ }^{380}$ Het Hof is ter zake van constitutionele rechtspraak relatief vaak afgeweken van jurisprudentielijnen, zeker in vergelijking met oordelen van gewone wetsinterpretatie. ${ }^{381}$ Heringa voert dit verschil terug op de moeizame en

377 Roe Wade, 410 U.S. 113 (1973). Op de casus van Roe t. Wade had het trimestersysteem gew betrekking meer, ondat het kind inmiddels ter wereld was gekomen.

378 Zie par. 3.2.

379 Daarmee is echter miet gezegd dat aan die rechtspraak geen gezag kan toekomen; de uitspraak van het Luxemburgse Hof ter zake van bijwoorbeeld de rechtstreekse werking en de suprematie van het EGrecht, de Sitraatsburgse extensieve interpretatie van het recht op privé-lewen en het algemene persoonlijkheidsrecht in de rechtspraak van de Hoge Raad bewijzen het tegendeel.

380 De common law rechter dient afwijkingen van bestaande jurisprudentielijinen te rechtvaardigen. Dat doet hij met behulp van de techniek van het "overrulen" van de bestaande lijnen. Indien het voorlig" gende geschil overeenkomsten vertoont met gevallen in de jurisprudentie, maar er lijken geen redenen aanwezig om vergelijkbaarheid aan te nemen dan dient de rechter te motiveren - to distinguish -. waaron hij met zijn kewze afwigkt. Kern van de motivering is steeds de dwingendheid van de reder tot afwijking. Over de dwingendheld kun men de meningen ver uiteenlopen. Er is echter geen eensluidende doctrine stare decisis; in het algemeen kan worden gesteld dat de madistawen voor het "overrulen' en het "distinguishen' door de tijd heen variabel zijn geblleken (Llewellyn 1989, p. 50).

381 Zie Heringa 1996, p. 96 voor verdere verwijzingen. Heringa stelt hier naar aanleiding, van empiriseh onderzoek, dat constitutionele beslissingen twee keer zo vaak veranderd zijm in latere uitspraken dan oordelen over gewone wetsinterpretatie. 
gecompliceerde wijze waarop de Grondwet geamendeerd dient te worden; een gewone wet kan eenvoudiger door de wetgever worden aangepast. Daarnaast speelt er een democratisch aspect mee: de rechters genieten indirect een democratische legitimatie omdat zij direct door de president worden benoemd. ${ }^{382}$ De aanvaardbaarheid van de geringere binding an precedenten - en mitsdien een ruimere bevoegdheid van de rechter de lijnen van de grondwetsuitleg te wijzigen - wordt vanuit deze gedachten gerelativeerd. Voor het afwijken van een precedent kan een aantal factoren worden aangewezen. lin de eerste plaats kan het zijn dat er in de tussentijd een verandering in de regels heeft plaatsgevonden en in de tweede plaats kan een precedent een onwerkbare regel opleveren die bijstelling behoeft. Waar enerzijds gelijkheid, rechtszekerheid en consistentie waarden zijn die ten grondslag liggen aan de gedachte van precedientenwerking, wordt anderzijds erkend dat dezelfde eisen juist een bijstelling of afwijking van een lijn van precedenten kunnen rechtvaardigen. ${ }^{383}$

Er bestaat geen eensluidende invulling van de doctrine, en het is mitsdien lastig om eenduidig aan te geven in hoeverre gelding van nieuwe rechtsnormen in de jurisprudentie bevestiging verkrijgt. In dit opzicht verschaffen twee historische voorbeelden inzicht in de wijze waarop het Hof omgaat met precedentwerking ter zake van rechtsvinding met betrekking tot grondrechten. Vanaf Lochner t. New York verklaarde het Hof gedurende een aantal decennia sociaal-economische wetgeving ongrondwettig totdat het in West Coast Hotel Co t. Parrish resoluut brak met die kritische benadering. ${ }^{384}$ Vraag is hoe met de lijn van precedenten werd gebroken. Oordelend over de toelaatbaarheid van wetgeving over het minimumloon stelde het Hof dat de in West Coast Hotel gevolgde redenering reeds lang besloten lag in beginselen die ten grondslag liggen aan de Grondwet:

'It is manifest that this established principle is peculiarly applicable in relation to the employment of women in whose protection the state has a special interest. That phase of the subject received elaborate consideration in Muller $v$. Oregon (1908) where the constitutional authority of the state to limit the working hours of women was sustained. ${ }^{385}$

Uit de uitspraak kwam niet helder naar voren, hoe de hier 'nieuw' ontdekte beginselen zich verhouden met de door het Hof voorheen gehanteerde beginselen die steeds hadden geleid tot afwijzing van social-economische wetgeving. Een tweede belangrijk voorbeeld van de betekenis van precedentwerking is te vinden in één van de abortusuitspraken, Planned Parenthood t. Casey. ${ }^{386}$ Over de vraag of het recht op abortus zoals neergelegd in Roe t. Wade dient te worden bijgesteld bestaan al lang discussies in het

382 Shith Al. Alwright, 321 U.S. 649,665 (1944).

383 Over de mate waarin dat wenselijk is lopen de meningen zeer witeen. Rechter Douglas, die deel uitmakkte van het Warren Court dat rechtswernieuwing bracht op het terrein van fundamentele rechten, hanteerde cen flexibele bemadering ter zake, terwiji Scalia eerder een terughoudende opwatting aanneemt over de vraag of precedenten wijziging verdragen (zie woor verdere verwijzingen Heringa 1996, p. 98).

384 Lochner I. New York, 198 U.S. 45 (1905) en West Coast Hotel Co. t. Parrish, 300 U.S. 379 (1937).

385 West Coast Hotel Co. A. Parrish, 300 U.S. 379, 394 (1937).

386 Planned Parenthood of Southeastern P.A. 1. Casey, 505 U.S. 833 (1992). 
Hof ${ }^{387}$ In de periode tussen Roe en Casey had zich de opvatting in het Hof over de grondwettigheid van het recht op abortus gewijzigd, mede onder invloed van een veranderde samenstelling van het Hof. In bijna drie decennia had het Hof vanwege een veranderde samenstelling een conservatief 'gezicht' gekregen, hetgeen onvermijdelijk doorklonk in de wijze waarop werd gedelibereerd over het recht op abortus. Er leek net geen meerderheid te ontstaan, die voór het wegstemmen van abortus is. Tot op heden staat de kernoverweging van Roe t. Wade, het recht op abortus, nog overeind; daarentegen zijn flankerende maatregelen, die bijwoorbeeld het recht op abortus toegankelijk en effectief zouden kunnen maken, resoluut door het Hof van de hand gewezen. ${ }^{388}$ De gelding van de essentie van Roe - de concretisering uit het rechtsbeginselachtige privacy $^{389}$ - werd door de meerderheid bevestigd. De minderheid stelde dat het in de rechtspraak ontwikkelde recht op privacy waaruit het recht op abortus werd geconcretiseerd geen gelding toekomt omdat het geen grondslag heeft in de geschreven grondwet. ${ }^{390}$

\section{De continentale rechtsstelsels}

Voor het Duitse Federale Constitutionele Hof valt aan het uitgangspunt, dat van precedenten in beginsel geen bindende werking uit gaat, ook een en ander af te dingen. ${ }^{391}$ Formeel bindt jurisprudentie het Hof niet, maar volgens Art. 31 lid $1 \mathrm{BVerfGG}^{322}$ binden de uitspraken van het Hof de federale en statelijke wetgevers en rechters. Het Hof rekent zichzelf als gevolg van die formulering ook tol de instellingen die gebonden zijn aan de uitspraken, maar dat houdt niet in dat afwijking van eigen precedenten niet mogelijk is. Formeel zijn verder alleen de partijen bij het geding gebonden, hetgeen betekent dat individuen in principe niet gebonden zijn. ${ }^{393}$ De praktijk laat zien dat het Hof niet gauw van de eigen uitgezette lijnen in de jurisprudentie afwijkt. ${ }^{394}$ Het Hof heeft al snel aangegeven, dat het zich aan de 'tragenden Gründe' ter zake van de interpretatie van de Grondwet gebonden acht. ${ }^{395}$ Over de precieze betekenis van welke onderdelen van de uitspraak nu worden geacht te behoren tot de doorslaggevende

387 Zie bijvoorbeeld rechter Scalia in zjin afwijkende mening bij Webster t. Reproductive Healthservices, 492 U.S. 490 (1989).

388 Zie par. 5.3.3. In Casey komt de discussie over de betekenis van stare decisis fraai naar voren (met name in de uiteenzetting van rechter $O^{\prime}$ Connor). Zie voor de tussenliggende zaken onder meer Harris $f$. McRae, 448 U.S. 297 (1980) en Webster t. Repraductive Health Services, 492 U.S. 490 (1989).

389 Zie par. $5.3 .2 \mathrm{en} 5.3 .3$.

390 Relnnquist, dissenting bij Planned Parenthood of Southeastern P.A.t. Casey, 505 U.S. 833 (1992).

391 Brugger 1994, p. 412 .

392 Art 31 lid 1 BVerfGG luidt: 'Die Entscheidungen des Bundesverfassungsgerichts binden die Verfassungsorgane des Bundes und der Lander sowie alle Gerichte und Behorden".

393 Schlaich 1997 , p. 322.

394 Interessant in dit werband is wel, dat er tussen de Eerste en de Tweede Senaat verschillende betekenis wordt gehecht aan precedenten. De Tweede Senaat acht het niet mogelijk, dat de wetgever een norm tot stand brengt, die eerder door het Hof als ongrondwettig was aangemerkt. Deze norm is dan bij voorbaat nietig. De Eerste Senaat is in dit verband iets rekkelijker gebleken. Zie hierover Schlaich 199\%, p. 324 e.v.

395 Sïdwesturteil, 1 BVerfGE 14, 37 (1951) en Berlin-Warbehalt 11, 19 BVerfGE 377, 392 (1966). 
argumenten bestaat in de literatuur echter weinig duidelijkkeid. ${ }^{396}$ Obiter dicta behoren er niet toe, maar welke dicta nu precies bindend zijn wordt niet eensluidend beantwoord. ${ }^{397}$ Kijkend naar de jurisprudentie van het Hof blijkt, dat wanneer extensieve interpretatie wan grondrechten en ongeschreven rechten opduikt, deze veelvuldig wordt onderbouwd aan de hand van jurisprudentie. De vestiging van nieuwe nomen van hoger recht en de daaruit voortvloeiende extensieve interpretaties en ongeschreven rechten vindt eveneens plaats in de jurisprudentie. De rechtspraak van het Hof wordt in het algemeen aangemerkt als zeer gezaghebbend, hetgeen onder meer voortvloeit uit het feit dat diens uitspraken kracht van wet verkrijgen. De stellingname van het Hof ter zake van zijn rol in de constitutionele rechtsontwikkeling wordt deels bepaald door het ruime mandaat dat is toegekend aan het Hof. ${ }^{398}$

Het Luxemburgse Hof aanvaardt in beginsel geen binding aan de eigen rechtspraak ${ }^{395}$, al blijkt uit sommige uitspraken het tegendeel en worden juist belangrijke lijnen in de jurisprudentie ontwaard die in latere rechtspraak een grondslag bieden voor positivering van nieuw recht. ${ }^{400}$ Ook dit Hof is gebaat bij consistentie, rechitszekerheid en stabiliteit in zijn rechtspraak, maar evenzeer bij flexibiliteit. Het EVRM kent geen regel die het Hof formeel bindt aan de eigen uitspraken, maar vanuit de gedachte vam rechtszekerheid en consistentie van rechtsontwikkeling ${ }^{401}$ is in Cassey een regel ter zake van precedentwerking geformuleerd:

"it is true that [...] the Court is not bound by its previous judgements" indeed, this borne out by Rule 51 par. 1 of the Rules of Court. However, it usually follows and applies its own precedents, such as a course being in the interest of legal certainty and the orderly development of the Convention case-law. Nevertheless, this would not prevent the Court from departing from an earlier decision if it was persuaded that there were cogent reasons for doing $50^{\circ}{ }^{402}$

Uit de jurisprudentie van het Hof blijkt dat precedenten doorgaans keurig worden gevolgd. ${ }^{403}$ Daaruit blijkt eveneens dat eenmaal naar voren gehaalde rechtsbeginselen en daaruit voortspruitende extensieve interpretaties en ongeschreven rechten daarin kun nen worden bevestigd. ${ }^{404}$ Daarmee is nog niet de vraag beantwoord, in welke mate het

396 Sohlaich 1997 , p. 328.

397 Schltaich 1997, p. 328 e.w.

398 Sommige auteurs stellen in dit verband dat het Hof de individuele klachten die het moet beoordelen ziet als een atanleiding om het constitutionele recht verder te ontwikkelen en de inloud daarvan bindend vast te leggen (zie Schlaich 1997, p. 327 voor verwijzingen).

399 Uhrow $1994, \mathrm{p} .188$

400 Zie onder meer enkelle woor de Gemeenschap constituerende uitspraken als Fan Gend en Loos, zaak 26/62 (1963), Jur. p. I (1963) en Costat t. ENEL, zakak 6/64 (1964), Jur. p. 585 (1964). Beide zaken figureerden in latere rechtspraak ter rechtvaardiging van het bestaan van suprematie wan Europees recht en directe doorwerking van EG-reclit in de nationale rechtsorde.

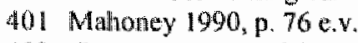

402. Cossey \&erenigd Koninkrijk, EHRM 27 september 1990, Serie A vol. 184, par. 35. Zie ook lerland t. Verenigd Koninkrijk, EHRM 18 januari 1978, Serie A vol. 25.

403 Schokkenbroek 2000, p. 5 . Zie Wildhaber 2000 , p. 1529 e.v. voor een fraai overzicht van de precedentwerking in de rechtspraak van het EHRM.

404 Voor het eerst werd de norm ingezet in Niemietz t. Duitsland EHRM 16 december 1992, Serie A vol 251-B, par. 29, naderhand werd deze in Burghartz t. Zwitserland, EHRM 22 februari 1994, Serie A vol. 
Hof opteert voor grote sprongen voorwaarts in de jurisprudentie, of juist voor een meer casuïstische benadering van concrete geschillen. Het Hof lijkt de laatste benadering te willen benadrukken omdat uit een 'minimalist approach' eerder een rechterlijke terughoudendheid blijkt. ${ }^{405}$ Door middel van minimaal 'aangroeiende' veranderingen in concrete zaken tracht het Hof een weerstand tegen schoksgewijze rechtsontwikkeling in de Verdragsstaten te voorkomen. ${ }^{406}$ Deze strategie ter zake van de rechtsvinding is door het Hof regelmatig herhaald, maar dat neemt niet weg dat er in de rechtspraak lijnen te erkennen zijn waaruit een rechterlijke bereidheid blijkt om ook uitspraken te doen die boven het concrete geschil uit stijgen. ${ }^{407}$

Aan de uitspraken van de Hoge Raad wordt in verschillende mate gezag gehecht. ${ }^{408}$ In principe wordt de jurisprudentie tot de rechtsbronnen gerekend, zij het dat daarbij wordt aangetekend dat er geen normatieve precedentenbinding bestaat, maar wel een feitelijke. ${ }^{409}$ In de jurisprudentieanalyse zal worden nagegaan, of en in hoeverre de door de rechter gehanteerde rechtsnormen op het terrein van het recht op persoonlijklieid bestendiging hebben gevonden in latere rechtspraak. Langs die weg kunnen in beperkt opzicht uitspraken worden gedaan over de wijze waarop deze nieuwe normen geldigheid verkrijgen.

\subsection{Slot}

\subsubsection{Inleiding}

In dit hoofdstuk zijn de verschillende soorten normen die in de rechtsvinding aan bod kunnen komen beschreven. De rechter heeft een aantal instrumenten voor de rechtsvinding tot zijn beschikking, waarbij een onderscheid werd gemaakt tussen technischjuridische rechtsvindingsmethoden en analoge redeneerwijzen. ${ }^{410}$ De analoge redeneerwijze lijkt in de te onderzoeken rechtsstelsels onder meer te worden benut om een extensieve lezing van rechtsnormen of ongeschreven rechten te legitimeren. Het lijkt er sterk op, dat met name de rechtsanaloge redeneerwijze in hogere mate kan leiden tot

A $280-B$ par. 24 gehanteerd on te onderzoeken of het recht op het kiezen van ben eigen naam deel witmaakt van de strekking en reikwijdte van Art. 8 EVRM. Na Burgharkz werd hel woor de albakemirig van Art. 8 EVRM onder meer gehanteerd in Stjerna t. Fimland, EHRM 25 november 1994 , Serie A vol. 299-B (ook met betrekking tot het kiezen wan een naam) en Mikulic t. Kroctie EHRM 7 februari 2002 , EHRC 2002/25, par. 53 (voor een recht van het kind op de vaststelling van biologisch vaderschap via een DNA-test). Zie voor verdere uitwerking par. 8.3 .5 .

405 Mahoney 1990, p. 77.

406 Boyle en Rice i. Verenigd Kominkrijk, EHRM 27 april 1988, Serie A vol. 139, par. 87.

407 Zie bijvoorbeeld par. 8.3.7 (lhulp bij zelfdoding); in hoofdstuk 8 zijn meer woorbeelden te vinden.

408 Naar aanleiding van een jurisprudentieonderzoek van de reclitspraak van de Hoge Raad in de periode $1996 / 1997$ stelde Barendrecht vast, dat een jaar 'rechtsvorming' scherpe regels, vuistregels, afwegingsregels en ander aanwijzingen had opgeteverd. (Barendrecht 1998, p. 16 e.v.); zie ook Asser-Wranken 1995, p. 45 e.v. en Asser-Scholten 1974, p. 90 e.v.

409 De Waard 1987, p. 67; Tak 1994, p. 176.

410 De technisch-juridische interpretatiemethoden zijn hiervoor reeds besproken in par. 4.3.6. 
rechtsvorming dan de wetsanaloge redenering. ${ }^{4 / \prime}$ Bij de wetsanaloge methode hanteert de rechter nog als uitgangspunt een wetsbepaling, waarvan hij zich afvraagt of deze een reikwijdte heeft die de individuele aanspraak en het bijbehorende feitencomplex nog kunnen dekken. In het geval de rechtsanaloge methode ter hand wordt genomen, is het brandpunt van een wettelijke bepaling niet meer aanwezig; de rechter construeert zelfstandig een rechtsnorm. Waar een beoordelingsruimte bij hantering van de wetsanalogie al enigermate aanwezig is, lijkt deze in de rechtsanalogie omvangrijkere proporties aan te nemen.

In alle stelsels worden de formuleringen van grondrechtelijke normen gerelateerd aan het recht op persoonlijkheid aangemerkt als problematisch in de rechtsvinding; in dat verband wordt wel gesproken van 'moeilijke gevallen'. ${ }^{412}$ De rechter, die de individuele anspraken op die rechten dient te beoordelen, heeft in sommige opzichten te maken met leemten, in andere met het maken van keuzes voor de invulling van open normen. ${ }^{413}$ Voor vaststelling van de inhoud van die open normen lijkt in de rechtsstelsels geen hiërarchie betreffende de interpretatiemethoden te bestaan. De analoge redeneermethode lijkt op het eerste gezicht niet het eerste instrument te zijn dat wordt gehanteerd bij het zoeken naar de betekenis van grondrechtsnormen.

Hantering van de analogie lijkt een aantal problemen met zich mee te brengen. Er werd bijvoorbeeld al gesteld dat niet steeds duidelijk is welke de juridische status is van de norm van hoger recht, die de rechter hanteert om zijn extensieve lezing of het ongeschreven recht te kunnen legitimeren. Een zelfde onduidelijkheid bestaat ten aanzien van het resultaat van de extensieve interpretatie en ten aanzien van de ongeschreven rechtsnormen. De juridische status van door de rechter gepositiveerde normen wordt in beginsel niet als een vanzelfsprekendheid aanvaard in de rechtsgemeenschap, hetgeen samenhangt met de oorspronkelijke bevoegdheid van de rechter: recht spreken, niet maken. Rechtstheoretici hebben op verschillende manieren getracht, tegemoet te komen aan de opvattingen die in de rechtsgemeenschap leven ten aanzien van de taakinvulling door de rechter. Er bestaat echter geen eensluidende opvatting over de wijze waarop deze activiteit moet worden beoordeeld. In de discussie tussen Hart en Dworkin wordt ziclhtbaar, hoezeer het vertrekpunt van de beoordelaar bepaalt, in welke mate de rechter nu een beoordelingsruimte toekont en hoe deze dient te worden gewaardeerd. De omvang die aan deze beoordelingsruimte wordt toegedicht in de bevoegdheid van

411 Er is steeds en onderscheid gernaakt tussen het wetsanaloge redeneernodel en hel rachtsanaloge redeneermodel, mar in de analyse van de rechtspraak hierna wordt bezien, in welke mate een thard onderscheid tussen beide modellen te handhaven is. Vooralsnog worden wets-en rechtsanalogie hier benaderd als twee te onderscheiden methoden.

412 Zito par. $4.2,3$.

413 Enkel het Lixemburgse Hof heeft te maken met een leemte ter zake van normen die verwant zijn aan het recht op persoonlijkheid; bij de totstandkoming van het Verdrag van Nice hebben de Lid-Staten niet gekozen voor een bindend Handvest. In welke mate deze leemte nu gevolgen heeft woor's Hofs rechtsvinding ter zake wan individuele aanspraken die aanknopen bij het recht op persoonlijkheid, wordit hierna in de rechtspratkanalyse verder uitgediept. 
de rechter vertoont samenhang met de wijze waarop men de constitutionele verhouding tussen rechter en wetgever percipieert.

\subsubsection{De juridische status wan het rechtsbeginsel en van de norm van hoger recht}

Het identificeren van een rechtsbeginsel of het definiëren van een norm van hoger recht lijkt in de analoge redenering tot op grote hoogte onvermijdelijk, omdat deze norm van hoger recht het brandpunt vormt van waaruit kwalificatie van de individuele aanspraak binnen de extensief geïnterpreteerde wetsnorm of onder het ongeschreven recht kan plaatsvinden. Aangenomen wordt dat er tussen de norm van hoger recht en het rechtsbeginsel een principieel onderscheid te maken is, dat met name gelegen is op het vlak van de erkenning van de norm op een bepaald tijdstip in de rechtsgemeenschap en de ethische lading die een rechtsbeginsel in zich draagt. Het is echter lastig uit te maken of er steeds daadwerkelijk sprake is van een rechtsbeginsel of van een norm van hoger recht. Ook over de definitie van een rechtsbeginsel ten opzichte van een rechtsregel bestaat in geen van de onderzochte rechtsstelsels overeenstemming. Op rechtsbeginselen zijn verschillende benaderingen denkbaar, waarbij de visies van Hart, Dworkin en MacCormick allen verdedigbaar zijn. Wanneer de rechter normen van hoger recht met het oog op uitlegging van rechtsregels hanteert, lijkt hij uit te gaan van Dworkins benadering. Hij gaan er impliciet vanuit, dat de door hen aangehaalde norm deel uitmaakt van de in het stelsel geldende rechtsnormen: een rechter kan nu eenmaal niet nietgeldige rechtsnormen betrekken in zijn rechtsvinding. Gesteld kan dan worden, dat de rechter tot op grote hoogte lijkt te kunnen bepalen, welke normen behoren tot het geldend recht. Voor de onderbouwing van de norm van hoger recht als norm van geldend recht $\mathrm{kan}$, indien de rechter dat noodzakelijk acht, worden teruggegrepen op uiteenlopende bromnen.

Naast constructies die worden afgeleid uit de wet om het bestaan van een norm van hoger recht te onderbouwen kunnen precedenten en het bestaan van een consensus ter zake een bron vormen voor de rechtvaardiging van het bestaan van de norm van hoger recht. Sommige rechters hanteren ook natuurrechtelijke opvattingen in hun rechtsvinding, al blijken zij dat niet in hoge mate te doen, of althans expliciet te stellen. Natuurrechtelijke overwegingen lijken in beginsel niet als zelfstandige legitimatie voor een rechtsgrondslag te worden aanvaard vanwege het bezwaar van oncontroleerbaar heid van de argumenten en het gevaar van rechterlijke subjectiviteit. De rechter zal zijn forum er in dat geval van moeten overtuigen, dat de norm van hoger recht en de concretisering al deel uitmaken van het geldend recht. In dit verband kunnen precedenten en consensus behulpzaam zijn: die verzekeren als het ware de inbedding van de norm van hoger recht in het kader van geldende rechtsnormen.

\subsubsection{De juridische status van het resultaat van de extensieve interpretatie en van hel nieuw gepositweerde recht}

Ook voor de rechtvaardiging van de extensieve lezing of het bestaan van nog niet eerder gepositiveerde normen kan de rechter uit bronnen van precedenten en consensus putten. De grondslag, de norm van hoger recht of het rechtsbeginsel, van waaruit de 
extensieve interpretatie of thet ongeschreven recht werd gelegitimeerd is dan reeds geformuleerd. De norm van hoger recht heeft in het algemeen steeds een meer abstract karakter, terwijl de daaruit geconcretiseerde rechten juist eerder een concreter, meer rechtsregelkarakter dragen. Omtrent de vraag of de rechter zelfstandig rechtsregels mag vastleggen bestalt geen overeenstemming. Aspecten van de constitutionele interpretatie pleiten zowel voor als tegen deze opvatting. Voor een ruimere taakopvatting pleit onder meer de open lextuur van de Grondwet of van het Verdrag. Eerder was al vastgesteld, dat aanpassing daarvan door de rechter naar plaats en tijd in concrete gevallen als het ware inherent kan worden geacht aan Grondwet en Verdrag; aanpassing ervan door de wetgever ligt minder voor de hand. Vanuit pragmatisch oogpunt lijkt het voor de hand liggend om hier een ruimte te aanvaarden binnen de rechterlijke bevoegdheid, maar over de vraag in welke mate de rechter grondrechtelijke normen kan modificeren in concrete toepassing lopen de meningen weer ver uiteen. De weerstand vloeit voort uit de gedachte dat het scheppen van rechtsregels buiten de taak van de rechter valt wanneer wordt aangenomen dat open textur van grondwet of verdrag wordt afgewezen. Ook hier kan de rechter dit bezwaar tot op zekere hoogte omzeilen door aan te tonen dat zijn bevindingen niet het resultaat zijn van zijn subjectieve opvatting maar dat zij als het ware Jogisch voortvloeien uit een systeem van rechtsnormen. De extensieve interpretatie of het ongeschreven recht zijn in die optiek logische consequenties wit het systeem van het recht. Het resultaat dat volgt uit de wetsanalogie bestond reeds, maar de rechter heeft het aan de hand van de analogie slechts 'zichtbaar' gemaakt.

\subsubsection{Constitutioneelrechtelijke bezwaren tegen de analogie in de rechtsvinding}

In hoeverre de activiteit, inhoudende een vaststelling welke normen deel uitmaken van het geldend recht, nu te kwalificeren is als discretionair, is niet op eenduidige wijze te beantwoorden. De perceptie van de omwang van de rechterlijke discretie hangt direct samen met het vertrekpunt van de toeschouwer: vanuit een positivistische visie komt een rechter, die analoog interpreteert, een grote mate van discretie toe. Hij voegt immers uit een niet-geldige catalogus van morele normen en rechtsbeginselen een nieuwe rechtsnorm toe aan de bestaande rechtsnormen. Wordt daarentegen een Dworkiniaanse visie als uitgangspunt genomen, dan lijkt discretie niet of nauwelijks te bestaan: de rechter dient in die optiek rechtvaardig recht te spreken. Dworkins optiek laat evenzeer morele normen en algemene rechtsbeginselen toe tot het arsenaal van rechtsnormen, die de rechter in zijn rechtsvinding dient te betrekken; het doel van het vinden van een rechtvaardige oplossing staat in dit verband centraal.

De analoge redeneerwijze, zo lijkt het, stelt de rechter in staat zijn rechtsvinding zó in te richten, dat de rechter niet anders doet dan logische consequenties trekken uit het systeem van geldige rechtsnormen. Dat geldt voor zowel de formulering van de norm van hoger recht of het rechtsbeginsel, als voor de extensieve interpretatie en het ongeschreven recht. In het licht van de constitutionele verhoudingen kan deze redeneertechniek goed van pas komen: op het moment dat de rechter erin slaagt, zijn gehoor te overtuigen van de het feit, dat hij niets anders aan het doen is dan toepassen van bestaande rechtsnormen, blijft hij binnen de grenzen van zijn taak. Punt is dan dat de rechter dat op overtuigende wijze moet aantonen, en de daaraan gekoppelde vraag is 
welke technieken en methoden de rechter ter beschikking staan, om die overtuigingskracht in zijn rechtsvinding te leggen. De overtuigingskracht ligt voor een deel besloten in de analoge redeneertrant zelf. Die gaat uit van het bestaan van een coherent rechtsnormensysteem waarvan een deel van de rechtsnormen in de wet is gepositiveerd. Daarnaast bevinden zich in het systeem rechtsnormen die niet zichtbaar zijn, maar wel onderdeel zijn van het geldend recht.

Voorheen werd gesteld, dat een belangrijk criterium dat de rechter begrenst in de vrijheid ter zake van rechtsvinding is gelegen in de eis van consistentie en coherentie van het rechtsnormensysteem. ${ }^{414}$ Indien de rechter een uitspraak doet, dient hij deze uitspraak in te passen in het bestaande stelsel van rechtsnormen. Het recht kan worden waargenomen als een systeem, waarin ook de rechter - naast de wetgever - zijn bijdrage levert met de concrete toepassing en verwerkelijking van het recht. De analoge redenering gaat zoals hiervoor gesteld, uit van het bestaan van een systeemopbouw. De rechter die de analogie toepast, zal zich in beginsel 'beschermd' weten door de gedachte dat zijn redenering een bijdrage levert aan het bestaande systeem van rechtsnormen. Hij verlaat zich - ook al ontbreekt een toepasselijke norm voor het concrete geschil voor hem - niet alleen op de rechtsnormen die in het systeem zijn vervat - de eis van consistentie - maar bestendigt dat systeem tevens, door te laten zien op welke wijze hij zijn redenering en uitspraak inpast in het systeem. Hij maakt het systeem als het ware zichtbaar met het resultaat van zijn rechtsvinding, die haar legitimatie vindt in het geldend recht het systeem. De rechter kan in een wetsinterpretatie voor de legitjmatie van de norm van hoger recht bijvoorbeeld stellen, dat zich achter de ingeroepen grondrechtsnorm een rechtsbeginsel 'voelbaar of zichtbaar' beweegt, hetgeen een extensieve lezing - en mitsdien kwalificatie van de voorliggende individuele aanspraak rechtvaardigt. ${ }^{415}$ Daarnaast kan een zekere overtuigingskracht uit gaan van de aanname, dat de rechter zich in zijn rechtsvinding enkel op geldende rechtsnormen lijkt te baseren. Lijkt te baseren, want de analogie laat nu juist toe, dat de toe te passen rechtsnorm niet direct 'zichtbaar' aanwezig is in het systeem. Daar tegenover staat, dat de rechter zijn redenering via de analogie tot op zekere hoogte inzichtelijk maakt, omdat hij aan zijn forum moet laten zien, op welk vergelijkingsmateriaal hij zich baseert.

4.4 Zie par. 4.3 .6

415 Zie bijwoorbeeld nogmaals de opmerking van Van Oenen, geciteerd in par. 4.6 .4 (Van Oenen 1994, p. 72). 


\section{Hoofdstuk 5}

\section{Analoge rechtsvinding in de jurisprudentie van het Amerikaanse Hooggerechtshof}

\section{$5.1 \quad$ Inleiding}

In de rechtspraak van het Amerikaanse Hooggerechtshof zijn op het terrein van het recht op persoonlijkheid de eerste wetsanaloge uitspraken aan het einde van de negentiende eeuw gedaan. Aanvankelijk deden de uitspraken zich voor op het terrein van de zogenoemde economische rechten. Het recht op eigendom en contractsvrijheid vormden in deze methode het belangrijkste aanknopingspunt. In de Amerikaanse rechtspraak wordt vaak gesproken van 'substantive due process'. 'Substantive due process' is een term in de Amerikaanse constitutionele rechtspraak waarmee wordt aangeduid dat niet expliciet in de grondwet genoemde rechten evenwel grondwettelijke bescherming genieten via de algemene clausules van 'due process' en 'equal protection'. 'Eén van de gebezigde redeneermethode via welke inhoud aan 'due process' wordt gegeven, is de wetsanalogie. Kort gezegd worden via deze redenering rechten in de clausules van de Bill of Rights ingelezen, die niet expliciet zijn opgenomen in de tekst, maar die een categorie van ongeschreven aanspraken vormen die constitutionele bescherming dienem te verkrijgen. ${ }^{2} \mathrm{De}$ eerste aanwijzingen voor 'substantive due process' doken reeds tegen het einde van de negentiende eeuw op, maar het duurde tot 1905 voordat het Hof statelijke wetgeving expliciet met het resultaat van een wetsanalogie ongeldig verklaarde. ${ }^{3}$ Naderhand inspireerde de wetsanaloge redeneermethode de rechtspraak op het terrein van de índividuele rechten, zoals bijwoorbeeld het recht van een ouder zelf te kunnen kiezen voor de opvoeding en opleiding van het kind, of recht op toegang tot een rechter. ${ }^{4}$ In de jaren ' 60 van de vorige eeuw werd het recht op 'privacy' met gebruikmaking van de rechtsanalogie in de Bill of Rights 'ingelezen'.

De vroege ontwikkelingen in de Amerikaanse constitutionele interpretatie lijken deels verklaarbaar uit het feit dat de Amerikaanse grondwet van ouder datum is en zeer beknopt is en de bereidheid van de rechter om op sommige momenten rechten te lezen in de op zichzelf beknopte Bill of Rights. De Bill of Rights werd in de zeer vroege

1 Zie het Vijfde en het Veertiende Amendement woor "due process.' en het gebod van gelijke behandeling in het Veertiende Amendement.

2 Currie 1989 , p. 335 .

3 In 1873 werd in de Slaughter-House-zaken, 16 Wall. (83 U.S.) 36, 21 L. Ed. 394 (1873), door concurrerende ondememers het recht op contractsvrijheid ingeroepen tegen een matregel van de staat Louisiana. Deze had beslist, dat slechts eén onderneming werd aangewezen voor het verwerken van slacht, waardoor de andere ondernemers met een vergelijkbare soort onderneming thun contractsvrijheid in zeer vergaande mate aangetast zagen. Dat recht op contractsvrijheid werd in deze zalak echter niet gehonoreerd; dat zou nog ruim een kwart eeuw duren. In de dissentings werden echter argumenten aangevoerd die in 1905 zouden leiden tot een omgaan vas het Hooggerechtshof ter zake van dat recht op contractsvrijheid. Zie ook Gunther en Sullivan, p. 421 e.v.; Tribe 2000 , p. 10. Meyer t. State of Nebraska, 262 U.S. 390 (1.923) en Bounds t. Smith, 430 U.S. 817 (1977). 
rechtspraak, onder invloed van een aanwezige natuurrechtelijke traditie die geschoeid was op Britse leest, in een enkel geval gezien als een geschreven constitutie die niet de initiele bron was, maar enkel een onderdeel vormde van een groter geheel van 'reeds bestaande' fundamentele rechten. Reeds eind achttiende eeuw is deze visie terug te vinden in de rechtspraak van het Hooggerechtshof:

Deze opvatting is sindsdien niet onbestreden gebleven - de rechtspraak die is voortgekomen uit extensieve interpretatie riep destijds en roept heden ten dage grote weerstand op bij "tegenstanders" van deze opvatting. Algemene kritiek in dit verband is dat de rechter zijn rechtsvormende taak te ruim opvat en naar believen rechten in een raamwerk van grondwettelijke bescherming 'inleest'. De discussie omtrent rechtsvinding door de rechter spitst zich in de Verenigde Staten toe op drie met elkaar samenhangende punten. Allereerst rijst de vraag, in hoeverre resultaten die voortvloeien uit de analogie te rechtvaardigen zijn als juiste interpretatie van de grondwet. In dit verband spreken enkele commentatoren van "non-interpretative interpretation', omdat de gebruikte rechtsvindingsmethode geen deel uitmaakt van de verzameling 'erkende" interpretatiemethoden. In de tweede plaats wijzen de tegenstanders van extensieve interpretatie erop dat de rechter aansluiting dient te zoeken bij morele, sociale of economische basisnormen in de samenleving. De kwestie die naar aanleiding van de vaststelling van deze basisnormen rijst is, in hoeverre het een goede zaak is aan de rechter over te laten een consensus vast te stellen. Grote verdeeldheid bestaat over de beantwoording van de vraag welke informatie de grondwet precies geeft over de omtrekken van de grondrechten. Dient de interpreet zich te oriënteren aan de tekst, of aan de bedoeling van de Framers? Hadden de Framers de rechtsvindingsmethode voor ogen die de non-interpretevists hanteren, en erkenden zij het bestaan van ongeschreven rechtsbeginselen? Indien dat het geval is, kan rechtsvinding aan de hand van de analoge redenering worden aanvaard; daarin wordt rechtsvinding (deels) bedreven aan de hand van ongeschreven rechtsnomen.

5 Zie bijwoorbeeld Calder t. Bwll, 3 Dall. (3 U.S.) 386 (1798), waarin enkele natuurrechtelijke noties werden betrokken in de rechtsvinding: rechter Chase stelde dat de constitutie dient te worden benaderd als een eenheid. Uit de textuur van die eenheid vloeit voort, dat de constitutie fundamentele rechten garandeert. Voor de vaststelling welke individuele rechten dataronder dienden te worden verstaan bood de eentheid van de grondwet voldoende aanknopingspunten. Expliciete opname van een recht in de grondwet zag hijj niet als voorwaarde voot grondrechtelijke bescherming. Zie eveneens Fletcher t. Peck, 6 Cranch (10 U.S.) 87 (1810). Zie ook Grey 1975, p. 703-718 en Grey 1978, p. 849 e.v. voor cen historisch overzicht van de discussie over dit thema.

6 Zic onder meer de meerderheidsopwatting in de Slaughter House zaken: "And it is sufficient to say that under no construction of that provision that we have ever seen, or any that we deem admissable, can the restraint imposed by [Louisiana] upon the exercise of their trade by the butchers of New Orleans be held to be a deprivation of property within the meaning of that provision' (16 Wall. ( 83 U.S.) 36,21 L.Ed. $394(1873)$. 


\subsection{Rechtsontwikkeling door het Amerikaanse Hooggerechtshof}

De uitspraken die zijn geselecteerd voor de analogie hebben allen gemeenschappelijk, dat het Hooggerechtshof voor de invulling van het grondwettelijke begrip "liberty" gezocht heeft naar normen van hoger recht, aan de hand waarvan de individuele aanspraken onder grondrechtelijke bescherming werden geschaard. 'Liberty' is een begrip dat is neergelegd in het Vijfde en in het Veertiende Amendement. Het Vijfde stipuleert de rechten van de verdachte in strafzaken. ${ }^{8}$ De voor de wetsanalogie relevante paragraaf van het Veertiende Amendement houdt een bescherming in van de burgerlijke rechten - van oorsprong op federaal niveau, maar sinds de incorporatie van een groot aantal grondrechten ook op statelijk niveau. ${ }^{9}$

\section{Liberty in het Veertiende Amendement: economische rechten}

In Lochner $t$. New York (1905) toonde het Hof de expliciete bereidheid het begrip "liberty" in het Veertiende Amendement van de Bill of Rights nadrukkelijk ruim te interpreteren dan voorheen. ${ }^{10}$ De staat New York beoogde met een wettelijke maximering van het aantal werkuren. Werkgevers eisten echter dat hun werknemers een groter aantal uren zouden werken en protesteerden bij de rechter tegen deze wet. Gezien de hoge mate van werkloosheid en de nauwelijks aanwezige sociale rechtsbescherming achtte de staat New York het om gezondheidsredenen van arbeiders noodzakelijk een dergelijke wet tot stand te brengen: zij had als oogmerk werknemers, ook al genieten zij contractsvrijheid, te beschermen tegen de machtige belangen van de werkgever. Het recht op contractsvrijheid tussen werknemers en werkgevers stond in de optiek van het Hooggerechtshof echter in de weg aan deze wetgeving. Voordat het Hof het recht op contractsvrijheid stelde tegenover de doelstelling van de wet diende het Hof eerst aan te geven op welke wijze en in welke mate contractsvrijheid is vastgelegd in de grondwet. Het Hof redeneerde als volgt:

[...] Is this a fair, reasonable and appropriate exercise with the right of the individual to his personal liberty, to enter into those contracts in relation to labor which indy seem to him appropriate or necessary for the support of himself and his family? Of course the liberly of contract relating to labor includes both parties to it. The one has as much right to purchase as the other to sell labor. Statutes of the nature of that under review, limiting the hours in which grown and intelligent men may labor to earn their living, are meddlesome interferences with the rights of the individual [...]."11

Het recht van het individu, in vrijheid te kunnen contracteren genoot in de optiek van het Hof de status van 'personal liberty'. In de Bill of Rights wordt het recht op contractsvrijheid echter nergens met zoveel woorden genoemd. Aan de 'vorming' van dat

8 Par. 2.3 .3

9 Par. $2.3,3$.

10 Locher 1. New York, 198 U.S. 45 (1905). Voorafgand wan Lochner had het Hof eveneens reeds in Algeyer t. Lowsiana, 165 U.S. 578 (1897) een rtime lezing van contractswrijheid geaccepteerd. In Lochner was, meer dan in Allgeyer, sprake van wetgeving met een controversicel karakter, waardoor atan Lochner in de rechtsgemeenschap meer aandacht werd besteed.

If Rechter Peckham, schrijvend voor de meerderheid in Lochner t. New York, 198 U.S. 45. 
recht besteedt het Hof niet veel woorden: het recht op contractsvrijheid wormt niet meer dan een onmisbare en logische schakel in de keten van opeenvolgende voorwaarden, die het mogelijk maken dat individuen overeenkomsten met elkaar slüten en daamede zichzelf in staat stellen, een familie te onderhouden. Wie kan daar nu op tegen zijn? De staat, die in dit verband beschermend optreedt, wordt vanwege de wetgeving een paternalistische rol aangemeten omdat de individuen ten slotte 'grown and intelligent men' zijn die zelfstandig overeenkomsten kunnen aangaan. Een constitutioneel recht op contractsvrijheid werd in deze uitspraak voor het eerst gepositiveerd. De wetsanalogie kan nu als volgt worden geconstrueerd. De grondwetsnorm waarvan moet worden vastgesteld of deze van toepassing is, wordt door het Hof betiteld als 'personal hiberty' uit het Veertiende Amendement. De concretisering van 'liberty' leunt sterk op de notie van contractsvrijheid: het individu dient zelf te kunnen besluiten met wie het een overeenkomst sluit. ${ }^{12}$ Daarbij wordt er vanuit gegaan, dat de contracterende partijen gelijkwaardig aan elkaar zijn. Er wordt verder nauwelijks vergelijkingsmateriaal (rechtspraak, wetgeving) opgevoerd, om de kwalificatie van de aansprak als 'personal liberty' te onderbouwen. ${ }^{13}$ Goedbeschouwd is de analogie gebrekkig: de norm wan hoger recht is niet direct te ontwaren, waardoor het lijkt alsof een stap werd overgeslagen in de analoge redenering.

In de daarop volgende jaren stelde het Hof talloze wetten met een beroep op de contractuele vrijheid buiten werking, waarbij regulering op het terrein van sociale wetgeving in het bijzonder kwetsbaar bleek. ${ }^{14}$ Rechter Holmes typeerde in zijn dissenting de uitkomst van Lochner echter als een uitspraak, die de contractswrijheid van de persoon perverteerde en waaruit gevolgtrekkingen voortkwamen die ruimte boden aan een - in Holmes' optiek - ongewenst grote interpretatieruimte van het Hof. Tot die consequenties rekende hij bijwoorbeeld dat het Hof zichzelf een instrument had verschaft om in de grondwet een voorkeur in te lezen voor een bepaalde economische theorie:

'Some of these laws [i.c. de wet die een maximum aantal werkuren voor bakkerspersonee] stelde] embody convictions or prejudices which judges are likely to share. Some may not. But a constitution is not intended to embody a particular economic theory, whether of patermalism and the organic relation of the citizen to the State or of laissez faire. It is made for people of fundamentally differing views, and the accident of our finding certain opinions

12 Dit is enigszins speculatief, ondat de uitsprak geen eenduidige aanknopingspunten geeft.

13 Een onderliggende kwestie die speelde bij deze zak was of de federale overheid zich diende in te laten met de statelijke overheid, meer specifiek of de federale rechter zich moest uitlaten over de statelijke wetgever. De meerderheid in Lochner erkende wel dat aan staten een "police power" (een autonomie) toekomt, maar dat deze zijn grenzen kent in de toepassing van onder meer heit Veertiende Amendement: dat richt zich expliciet tot de staten. De kwestic wan verdeling van bevoegdheden tussen federatie en staten speelt ila veel zaken, soms expliciet, een rol. Het Hof moet rekening houden met de autonomie van de staten, wasdoot grondrechtelijke bescherming op het terrein van het recht op persoonlijkheid sonus minder omvantend dan wenselijk is (zie ten aanzien van rechispraak over het gelijkheidsbeginsel door het 10 f Gerards $2002,0.372$ e.v.).

14 Gunther cn Sulliwan noemen in di verband een getal van bijna tweehonderd wetten, die ongrondwettig werden verklatard (Cunther en Sullivan 1997, p. 466). 
natural and familiar or novel and even shocking ought not to conclude our judgement upon the question whether statutes embodying conflict with the Constitution". "s

Van belang is dat Holmes de door de meerderheid gehanteerde rechtsvindingsmethode niet als zodanig afwees, maar dat hij zeer kritisch was over de gevolgtrekkingen die voortvloeiden uit de notie van "liberty". Het begrip "liberty", dat volgens het Hof mede de contractsvrijheid omvat, bood namelijk de ruimte de visie van de wetgever zonder al te veel argumentatie terzijde te stellen. Deze ruimte ontstond doordat verschillende hypothesen die aaneen werden geregen, die op zichzelf genomen in een logisch verband met elkaar staan, maar niet noodzakelijkerwijze moeten leiden tot én dwingende conclusie. ${ }^{16}$ In beginsel dient het individu vrij te zijn, overeenkomsten te kunnen slujten. Dat houdt echter niet in, dat het individu ook altijd vrij is om te contracteren met wie het wil. Belangen die hier over het hoofd werden gezien, zoals bijvoorbeeld het belang van een werknemer bij gezette rusttijden, werden niet meegenomen in de beoordeling van de in het geding zijnde belangen.

In de periode van Lochner kwam zeer veel kritiek op de "activistische' koers van het Hof ter zake van wetgeving ower arbeidsomstandigheden. Met "activisme" wordt in het geval van Lochner gedoeld op 's Hofs bereidheid nagenoeg alle sociaal-economische wetgeving ongrondwettig te verklaren. Veelal wordt daarbij gewezen op de interpretatiemethode die hieraan vooraf gaat: die zon "activistisch' zijn omdat deze immers leidt tot een interpretatieruimte waarin het Hof allerlei aanspraken als grondrechtelijk kan erkennen. ${ }^{17}$ Het Hof verliet later zijn benadering ter zake van statelijke wetgeving over arbeidsomstandigheden, maar daarmee nam het Hof zeker geen afscheid van de in Lochner gebruikte redenering. ${ }^{18}$ In de jaren twintig van de vorige eeuw werd deze namelijk gebruikt in geschillen omtrent individuele rechten niet zijnde economische rechten. Hiermee verkreeg 'liberty' in het Veertiende Amendement vanaf toen een fundamenteelrechtelijk reliêf verkreeg. In het hiervoor reeds uitgewerkte Meyer t. Nebraska, waarin werd geklaagd over het feit dat niet mocht worden onderwezen in een andere taal dan het Engels, werd door het Hof middels een wetsanalogie inhoud gegeven aan het begrip "liberty". ${ }^{19}$ In die uitspraak stond de norm van hoger recht, de "pursuit of happiness", centraal. ${ }^{20}$

I5 Rechter Holmes in zijm dissenting bij de uitspraak in Lochner.

16 Het Hof deed wel voorkomen alsof de door hem woorgestelde uitkonst de enige juiste is; in dit verband is de retoriek die wordt gehanteerd van groot belang: "Of course the liberty of contract welating to labor includes both parties to it. The one has as much right to purchase as the outher to sell labor. Statutes of the nature of that under review, limiting the hours in which grown and inteNigenr men may labor to eam their liwing, are meddlesome interferences with the rights of the individual [" .]" (cursiveringen H.1.J.).

17 Rechter Scalla, schrijvend woor de meerderheid in Bowers t. Hardwick, 478 U.5. 186, 193 (1986).

18 West Coast Hotel Co. t. Parrish, 300 U.S. 379 (1937); zie ook par 3.2.6.

19 'Liberty" en vrijheid(sbegrip) worden in het wervolg gebruikt als synoniemen. Zie voor de behandeling van deze zaak ook par. 4.4.3.

20 In Pierce t Sacieb of Sisters of the Holy Names of Jesus, 268 U.S. 510 (1925) bordunturde rechter McReynolds op dezelfde norm van hoger recht woort. In dit geval verplichtte de wetgever van de staat Oregon ouders wun kinderen natar openbare scholen te sturen. Enkele leiders van bijzondere scholen $\mathbb{k}$ wamen hiertegen op, hetgeen aanleiding was het wrijheidsbegrip van de ouders te definitren: "the liberty of parents and guardians to direct the upbringing and education of chilldren under their control. [....] 


\section{Liberty in het Viffe Amendement}

In Kent L. Dulles (1958) bleek het Hooggerechtshof bereid, het recht van het individu, zich te kunnen verplaatsen en vrij te kumnen reizen via een wetsamalogie in te lezen in "liberty". Voor dit 'recht' bestonden geen expliciete aanwijzingen in de Bill of Rights, maar met een wetsanalogie werd de individuele aanspraak "ingelezen' in 'liberty":

"In Anglo-Sax on law that right was emerging at least as early as the Magna Carta [...] Freedom of movement across frontiers in either direction, and inside frontiers as well, was a part of our heritage. Travel abroad, like travel within the country, may be necessary for a livelihood. It may be as close to the heart of the individual as the choice of what he eats, or wears, or reads. Freedom of movement is basic in our scheme of values. [...] Our nation [...] has thrived on the principle that, outside areas of plainly harmful conduct, every American is left to shape his own life as he thinks best, do what he pleases, go where he pleases. [... ] Foreign correspondents and lecturers on public affairs need first-hand information. Scientists and scholars gain greatly from consultations with colleagues in other countries. Students equip themselves for more fruitful careers in the United States by instruction in foreign universities. Then there are reasons close to the core of personal life - marriage, reuniting families, spending hours with old friends. Finally, travel abroad enables American citizens to understand that people like themselves live in Europe and helps them to be well-informed on public issues'. 21

Vrijheid van reizen blijkt, net als de contractsvrijheid in Lochner, een concretisering van 'liberty' te zijn. De rechter steunde voornamelijk op een aantal natuurrechtelijke overwegingen, die voor de positivering van het 'recht" op vrij reizen onder 'liberty' essentieel waren. De norm van hoger recht, die de wetsanalogie hier lijkt te beheersen, werd gevonden in de aanknoping bij reizen als 'part of our heritage'. De vergelijking met "noodzakelijkheden" in een mensenleven als eten, kleden of lezen, diende de lezing van vrijheid van relzen als een 'liberty' te rechtvaardigen: "freedom of movement is basic in our scheme of values". Daarnaast zijn er twee andere normen van hoger recht te herkennen: de eerste hangt met een zekere persoonlijke autonomie samen: 'Our nation has thrived on the principle that [...] every American is left to shape his own life as he thinks best'. De tweede is eveneens gelieerd aan 'the core of personal life'. In verband hiermee wordt een aantal (deels in de jurisprudentie erkende) occupaties in een mensenleven aangevoerd die van belang zijn, en die zonder vrijheid van revzen wellicht niet optimaal genoten zouden kunnen worden. Hierin schuilt een element van noodzakelijkheid van het bestaan van het recht op vrij reizen. ${ }^{22}$ De norm van hoger recht in

The child is not the mere creature of the state; those who murture him and direct his destiny have the right, coupled with the high duty, to recognize and prepare him for additional obligations: ${ }^{2}$. In deze uitsprak werd in het geheel geen voorafgaande rechtspraak angevoerd ter rechivaardiging wan de interpretatie wan "liberty".

21 Kent Dwhes, 357 U.S. 116,127 (1958).

22 Gevolg was de beslissingen van de verantwoordelijke stantssecretaris, inhoudende de weigering tot afgifte van een paspoort aan personen met communistische sympathieen, niet langer stand konden houden. De weigeringen vonden plaats op bashis van een federale wet die, in het geval van een noodtoestand als afgekondigd dcor de President, weigeringen van paspoortafgifte mogelijk maakte: De wet kon in stand blijven, man de statssecretaris bleek genoemde wet te ruim te hebben geinterpreteerd. 
Kent $t$. Dulles lijkt vooral te worden gewormd door een morele notie, althans niet door op het eerste gezicht herkenbare rechtsbeginselen. ${ }^{23}$

\subsection{Ontwikkeling van het recht op persoonlijkheid met analoge redeneringen}

\subsubsection{Inleiding}

Na de jaren ' 30 van de vorige eeuw breekt in de rechtspraak een periode aan warin de analogie regelmatig werd gehanteerd om de reikwijdte van 'liberty' als fundamenteel recht te kunnen vaststellen. Opvallend is dat de hoeveelheid rechtspraak waarin de grenzen van. 'liberty' worden afgetast, niet van grote omvang is. Daarmee is niet gezegd, dat het belang ervan voor het rechtsvindingsdebat navenant is. De kritiek houdt verband met de opvatting dat een rechter die via een analogie ongeschreven rechten toevoegt aan de bestaande rechtsnormen in de Bill of Rights zich "activistisch' opstelt. Hij voegt willekeurig normen aan de bestaande grondrechtsnormen toe, hetgeen vanuit het oogpunt van de constitutionele verhoudingen als onwenselijk wordt aangemerkt. Aanspraken als een recht op intiem privé-leven, een recht op familiebetrekkingen en een recht op fysieke en geestelijke integriteit werden door het Hof 'ontdekt' als onbenoemde maar wel aanwezige normen of "ingelezen" in de ongeschreven normen van de constitutie. Vraag is of de kwalificatie van een rechter die dergelijke normen inleest, wel als activistisch is aan te merken. Enkele individuele aanspraken kwamen daarentegen niet in aanmerking voor grondrechtsbescherming. Regelmatig speelde daarbij het argument van de terughoudende rechterlijke taakopvatting een prominente rol. Het is aldus zinvol om ook deze uitspraken te bespreken ondat zij laten zien welk debat in het Hooggerechtshof is gevoerd over de juiste wijze van interpretatie, en welke rol de constitutionele verhouding daarbij toekomt.

\subsubsection{Toegang tot het gebruik van voorbehoedmiddelen}

Op basis van een nergens in de grondwet expliciet neergelegd recht op 'privacy' heeft het Hof enkele uitspraken gedaan over een recht op keuzemogelijkheid met betrekking tot nageslacht tot zijn beschikking. Die rechtspraak had tot gevolg dat het staten niet werd toegestaan wetgeving tot stand te brengen, die verstrekking en gebruik van voorbehoedmiddelen en abortus verboden. De Bill of Rights bevat geen tekst over een recht op zelfbeschikking; evenmin zijn er impliciete of expliciete rechten met het oog op een vrije keuze ten aanzien van voortplanting in vastgelegd. In Poe t. Ullman (1961) rees de vraag voor het Hof, of en in hoeverre het verbod op verstrekking van voorbehoedmiddelen in de staat Connecticut inbreuk maakte op "een recht" van het individu. ${ }^{24}$ In Poe was geen sprake van een "case and controversy", omdat de klagers wegens mogelijke verwolging een klacht hadden ingediend. 25 Wegens 's Hofs opvatting ter zake van

23 Dat geldt eveneens voor de normen van hoger recht die werden gehanteend in de analogieen, voor zover aanwezig, in Lochner t. New Yark. Meyer t. Nebraska en Pierce 1. Saciety of Sisters.

24 Poe L UNman, 367 U.5. 497 (1961).

25 De klagers, twee echtparen, wensten in stant te worden gesteld op legale wijze voorbehoedmiddelen te 
"abstracte toetsing" was de meerderheid niet bereid het geschil in Poe inhoudelijk te beoordelen.

In zijn dissenting bij Poe t. Ullman gaat rechter Douglas echter wel in op de inhoudelijke aspecten van het geschil. Zijn uiteenzetting van het recht op 'privacy' is interessant, ondat die een aantal jaren later zal fungeren als basis voor de uitspraak in Griswold t. Connecticut, een zaak waarin het Hof wel overgaat tot beoordeling van een recht op het gebruik wan voorbehoedmiddelen. Voor de tuitkomst van Poe heeft Douglas" dissenting geen gevolgen. Douglas construeert in $P$ oe uit het recht op "liberty' onder het Veertiende Amendement van klagers wan vervolging vrijwaard te blijven indien zij over zouden gaan tot het gebruik van voorbehoedmiddelen. De eerste aanzet, waarin hij bintien de grondwet ruimte ziet voor een ongeschreven recht op het gebruik wan voorbehoedmiddelen, luidt als volgt:

"Though I believe that "due process" as used in the Fourteenth Amendment includes all of the first eight Amendments, I do not think it is restricted and confined to them. We recently held that the undefined "liberty" in the Due Process Clause of the Fifth Amendment includes freedom to travel. ${ }^{26}$ The right "to marry, establish a home and bring up children" was said in Meyer v. Nebraska ${ }^{27}[\ldots]$ to come within the "liberty" of the person protected by the Due Process Clause of the Fourteenth Amendment. [....] "Liberty" is a conception that sometimes gains content from the emanations of other specific guarantees [...] or from expevience with the requirements of a free society". ${ }^{28}$

Douglas geeft onder meer via jurisprudentie invulling aan het vrijheidsbegrip onder het Veertiende Amendement. De door hem aangehaalde rechtspraak handelt over feitencomplexen en individuele aanspraken, die op het eerste gezicht niets te maken lijken te hebben met de individuele aanspraak op het gebruik van voorbehoedmiddelen. Niet de feitencomplexen uit Meyer t. Nebraska en Kent t. Dulles, maar de toepasselijke normen van hoger recht die op die zaken van toepassing zijn, vormen voor de beoordeling van de aanspraak op het gebruik van voorbehoedmiddelen in Douglas' optiek het uitgangspunt. ${ }^{29} \mathrm{De}$ "experience with the requirements of a free society" verbindt hier impliciet Kent t. Dulles, Meyer t. Nebraska en Poe t. Ullman met elkaar. De norm van hoger recht, waaronder alle genoemde aanspraken vallen, is van een bijzonder hoog abstractiegehalte.

Douglas stelt vervolgens dat de gewraakte wet de intieme betrekking tussen twee echtelieden en mitsdien in de intimiteit van het huwelijk raakt. Teneinde echtparen te

kunnen verkrijgen vanwege gezondheidsredenen. Eên van de paren vreesde dat indien zij zich zouden voortplanten, hun kinderen hoogstwaarschijnlijk een erfelijke ziekte zouden dragen. Bij hen had zich deze situatie reeds eerder voorgedan. Van het andere echtpar zou een eventuele zwangerschap een grote en reèle bedreiging vormen voor het leven van de wrouw vanwege haar depressiviteit.

26 Kent t. Dulles, 357 U.S. $116(125-127)$, 1958.

27 Meyer 1. Nebraska, 262 U.S. 390 (399), 1923.

28. Rechter Douglas, dissenting in Poe c. Climan.

29 Zie voor Meyert. Nebraska en Kent t. Dulles ook par. 4.2. 
kunnen controleren op het gebruik van voorbehoedmiddelen, zou ter zake namelijk een onderzoek in de slaapkamer moeten plaatsvinden, hetgeen de ertoe leidt dat de staat

"enters the innermost sanctum of the home. If it can make this law, it can enforce it. And proof of its violation necessarily involves an inquiry into the relations between man and wife. That is an invasion of the privacy that is implicit in a free society". 30

Vier jaar na Poe t. Ullman sprak het Hof zich in Griswold t. Comnecticut wel uit over de grondwettigheid van een wet die gebruik van voorbehoedmiddelen verbiedt. ${ }^{31}$ Rechter Douglas schreef een korte, krachtige meerderheidsopinie, waarin hij zijn in Poe opgebouwde dissenting nader aanscherpte. Daartoe nam hij rechtspraak in owerweging, die wederom op het eerste gezicht met het feitencomplex of de individuele aanspraak in Griswold niets van doen heeft. Vanuit een vergelijkbare benadering als in Poe construeert hij een norm van hoger recht die de door hem gekozen jurisprudentie met het voorliggend geschil met elkaar in verband lijkt te kunnen brengen. Douglas speurt $\mathrm{nu}$, in tegenstelling tot $P o e$, naar een norm van hoger recht die aan de aanspraken in de verschillende zaken ten grondslag ligt. Die norm duidt hij aan als het recht op "privacy".

Douglas inventariseert daartoe de rechten die het Hof in het verleden heeft erkend onder het Eerste Amendement. Dat Amendement heeft onder meer tot doel, het recht op vrijheid van meningsuiting en vrijheid van vereniging te waarborgen. ${ }^{32}$ Daartoe behoren onder meer het niet expliciet in de grondwet genoemde recht, kinderen op te voeden naar eigen inzicht ${ }^{33}$ en het recht in een andere dan de Engelse taal te onderwijzen $^{34}$, evenals de onbenoemde rechten informatie te verspreiden, informatie te ontvangen, het recht te lezen en vrijheid van gedachte en onderwijskeuze. ${ }^{35}$ Van belang is in dit verband Douglas' toevoeging, dat de 'geexpliciteerde' rechten onder het Eerste Amendement zonder deze "perifere" rechten een mindere mate van protectie zouden genieten. De vertaalslag van de rechten onder het Eerste Amendement naar het geschil moet dan echter nog worden gemaakt: wat de in Griswold geclaimde 'privacy' van echtparen in de slaapkamer van doen heeft met het recht op vrijheid van gedachte, mening en godsdienst en vereniging onder het Eerste Amendement, komt in de volgende stap aan de orde. De verbinding tussen beide aanspraken wordt ingeleid met NAACP t. Alabama, een zaak waarin het Hof een claim op het recht op 'privacy" van een

30 Rechter Douglas, dissenting in Poe t. Ulman.

3 Griswold t. Connecilcut, 381 U.S. 479 (1965).

32 Het Eerste Amendement luidt: "Congress shall make no law respecing an establishment of religion, or prohibiting the free exercise thereof; or abridging the freedom of speech, or of the press; or the right of the people to peaceably assemble, and to petition the Government for a redress of grievances'.

33 Pierce t. Society of Sisters, 268 U.S. 510 (1925), In dit geval verplichte de wetgever van de staat Oregon ouders hun kinderen natar openbare scholen te sturen. Enkele لeiders van bijzondere scholen kwamen hiertegen op, hetgeen aanleiding was het vrijheidsbegrip van de ouders te definieren: "the liberty of parents and guardians to direct the upbringing and education of childrem under their control. [....] The child is not the mere creature of the state; those who nurture hin and direct his destiny have the right, coupled with the high duty, to recognize and prepare him for additional obligations".

34. Meyer t. Nebraska, 262 U.S. 390 (1923).

35 Voor de aangehaalde rechtspraak zie Griswold t. Connecricut, 381 U.S. 479 (1965). 
burgerrechtenvereniging honoreerde. ${ }^{36}$ Het Hof stelt in Griswold naar aanleiding van $N A A C P$, dat zich in de "halfschaduw", of in de perifere sfeer van het Eerste Amendement $^{37}$ kennelijk een recht op 'privacy' bevindt waarbinnen overheidsbemoeienis niet kan worden getolereerd. Zonder 'privacy' zou de vrijheid van vereniging niet volledig genoten kunnen worden. De norm van hoger recht van de aanspraken in $N A A C P$ t. Alabama en Griswold t. Connecticut lijkt aldus te zijn dat het inaividu een privé-sfeer toekomt waarin het zich kan afschermen voor ingrijpen van buitenaf.

Nu was in NAACP t. Alabama echter sprake van politieke belangen van de groepering in kwestie; op dat terrein ligt aanvaarding van de individuele aanspraak van $N A A C P$ ook wel voor de hand, gezien de betekenis van vrije meningsuiting en vrijheid van vereniging voor een democratische rechtsstaat. Douglas besteedde aan de politieke component van "privacy" geen aandacht, hetgeen $N A A C P$ en Griswold wellicht minder vergelijkbaar zou maken, of althans tot een nadere motivering ter zake zou nopen. In plaats daarvan wees hij op jurisprudentie van na $N A A C P$, waarin het Hof had erkend dat ook sociale, juridische en economische belangen van associaties in aanmerking kunnen komen voor bescherming van het recht op 'privacy'. Met andere woorden, de specifiek genoemde grondrechten in de Bill of Rights bevatten halfschaduwen, of perifere rechten, die aan de geëxpliciteerde grondrechten nadere inhoud geven:

"The foregoing cases suggest that specific guarantees in the Bill of Rights have penumbras, formed by emanations from those guarantees that help give them life and substance.'

De constructie rond het Eerste Amendement is slechts één voorbeeld in dit verband, aldus Douglas; ieder geexpliciteerd recht in de Bill of Rights kent zo zijn eigen halfschaduwen, of perifere terreinen van 'privacy'. Het Derde Amendement verbiedt inkwartiering van soldaten in particuliere woningen zonder toestemming van de eigenaar, hetgeen een ander facet van 'privacy' belichaamt ${ }^{38}$ Het Vierde en Vijfde Amendement bevatten eveneens elementen in de sfeer van 'privacy' als bescherming tegen inbreuken van de overheid ${ }^{39}$ :

"The Fourth and Fifth Amendments [...] as protection against all governmental inwasions "of the sanctity of a marn's home and the privacies of life". [....] We recently refered in [...] to the Fourth Amendment as creating a "right to privacy, no less important than any other right carefully and particularly reserved to the people" .40

3.6 NACP 1. Alabama, 357 U.S. 449, 462 (1958). In deze zak eiste de stant Alabama, dat NAACP een ledenlijst zon overleggen in verband met de activtteiten wan NAACP, die als doelstelling heeft het verbeteren van de positie van de zwarte burgers. Het Hof honoreerde de claim op het recht op "privacy" vam en assochatie: "This Court has recognized the wital relationship between freedom to associate and privacy in one"s associations. $1 . . .$. Inviolability of priwacy in-group associations may in many circumstances be indispensable to preservation of freedom of association, particularly where a group espouses dissent believes"

37 In dit geval is het recht op "the right of the people to peaceably to assemble" in het Eerste Amendement gexpliciteerd.

38 Het Derde Amendement lvidt: "No Soldier shall, in time of peace be quartered in any house, without the consent of the Owwer, nor in time of was, but in a manner to be prescribed by law".

39 Voor de tekst wan het Vierde en het Vijfde Amendement zie par. 2.3.1.

40 Griswold t. Connecticut, 381 U.S. 479, 484 (1965). 
Interessant in dit verband is, dat de zaken Boyd t. United States en Mapp t. Ohio in onderhavige uitspraak dienen als voorbeelden ter staving van het bestaan van het reclit op "privacy", omdat zij, net als de voorbeelden bij het Eerste Amendement, wat de individuele aanspraak of het feitencomplex betreft, niets van doen hebben met strafbaarstelling van het gebruik van voorbehoedmiddelen. ${ }^{41}$ Deze uitspraken, die refereren aan 'privacy" en het recht alleen te zijin, duiden aan dat het recht op 'privacy' intussen een bestaansrecht heeft verworven. ${ }^{42}$ Het Negende Amendement werd enkel geciteerd; de betekenis ervan voor Griswold werd niet nader gemotiveerd in de beslissing van het Hof. Het lijkt echter alsof Douglas met de verwijzing naar het Negende Amendement een discussie wenste aan te zwengelen over de betekenis van dit Amendement in de constitutionele interpretatie. Rechter Goldberg pleitte in zijn concurring voor een toepasbaarheid van het Negende Amendement, zonder dat dat een bedreiging van de constitutionele verhoudingen zou hoeven inhouden:

'The Ninth Amendment simply shows the intent of the Constitution's authors that other fundamental personal rights should not be denied such protection or disparaged in any other way simply because they are not specifically listed in the first eight constitutional amendments. I do not see how this broadens the authority of the Court; rather it serves to support what this Court has been doing in protecting fundamental rights. ${ }^{43}$

In zijn dissenting bij Griswold antwoordde rechter Black op die suggestie dat met hantering van het Negende Amendement juist het gevaar dreigt dat het Hof langs die weg kans ziet om alle statelijke wetgeving ongrondwettig te verklaren. ${ }^{44}$ Het verlenen van effect aan dit Amendement vormt in zijn optiek juist wel een bedreiging van de constitutionele verhoudingen:

"That Amendment was passed, not to broaden the powers of this Court [...], but, as every student of history knows, to assure the people that the Constitution in all its provisions was intended to limit the Federal Government [...]. If any broad, unlimited power to hold laws unconstitutional because they offend what this Court conceives to be the "[collective"] conscience of our people" is vested in this Court by the Ninth Amendment, the Fourteenth Amendment or any other provision of the Constitution, it was not given by the Framers, but has rather been bestowed on the Court by the Court". . $^{3}$

41 Bayd t. Unifed States, 116 U.S. 616, 630 (1886), Mapp t. Ohio, 367 U.S. 643, 656 (1961). Het Hof oordeelde de in deze geschillen gebruikte opsporingstechnieken als ongrondwettig.

42 Douglas voegt aan deze vaststelling, waarmee hij de meerderheidsopvatting afšluit, nog een natururrechtelijke notie toe, die grondwettelijke bescherming van 'privacy' in huwelijkse betrekkingen moet staven: "We deal with a right of privacy older than the Bill of Rights - older than our politcal parties, older than our schooll system', zie ook par 4.7 .2 woor natuurrechtelijke beschouwingen in de rechtsvinding.

43. In zijn concurring geeft rechter Goldberg weer - de rechters Warren en Brennan sluiten zich hierbij aan - hoe het Negende Amendement dient te worden verstaan. Hij acht op basis van beschouwingen van grondlegger van de grondwet Madison en Story (rechter in het Hof aan het einde van de negentiende eeuw) ruimte aanwezig om effectiviteit te verlenen aan dat. Amendement, en aanvaardt vanuit het Negende Amendement de mogelijkheid om nieuwe rechten te positiveren.

44 Zie ook DeRosa 1996, p. 87-109 voor een kritische beschouwing van Goldbergs standpunt

45 Black in zijn dissenting bij Griswold t. Connecticut 381 U.S. 479, 520 (1965). 


\section{HoOFDSTUK 5}

Het debat over de betekenis wan het Negende Amendement werd gevoerd in de concurrings en de dissentings.

De beschreven redenering heeft sterke kenmerken van een rechtsanalogie, omdat er geen invulling wordt gegeven aan een geschreven grondrecht. De norm van hoger recht is thet recht op 'privacy" die wordt ontwaard in de perifere sfeer van een aantal Amendementen en gerechtvaardigd aan de hand van rechtspraak ter zake. De concretisering die uit "privacy" voortvloeit, is in dit verband het recht op privé-sfeer in de echtelijke slaapkamer, waraan een vrije keuze op het gebruik van voorbehoedmiddelen gekoppeld wordt. Griswold wordt door sommigen samen met Lochner aangemerkt als één van de markantste interpretaties van de grondwet, omdat de interpretatie in zo vergaande mate losstaat van de gepositiveerde individuele rechten in de Bill of Rights. Het grondrecht op "privacy" in de echtelijke slaapkamer, is een recht dat met deze uitspraak voor de eerste maal is gepositiveerd. Het recht op 'privacy' had aldus, afgaande op de Douglas" redenering, al eerder als "onbenoemd" recht een plaats veroverd tussen de geldende rechtsnormen. Daarmee was het reeds een geldende rechtsnorm. De echtelijke privacy' blijkt vervolgens één van de logische voortvloeiselen van het recht op 'privacy".

Kritisch hierover bleek Rechter Black. Hij aanvaardde in zijn dissenting, dat het Vierde en Vijfde Amendement een recht op 'privacy" in zich bergen. Black stond bekend als een tekstualist, hetgeen inhoudt dat hij bij grondwettelijke interpretatie zich zeer strikt houdt aan de letterlijke tekst van de Bill of Rights. Black geeft aan het begrip 'privacy' in deze Amendementen echter een veel beperkter reikwijdte:

"There are, of course, guarantees in certain specific constitutional provisions which are designed in part to protect privacy at certain times and places with respect to certain activities. But I think it belittles that Amendment to talk about it as though it protects nothing but "privacy"."

Rechter Black vergeleek de wijze van redeneren in Griswold met die in Lochner, en stelde vast dat zij als overeenkomst hebben dat de rechter natuurrechtelijke overwegingen in zijn beschouwing betrekt, die tot gevolg hebben dat wetgeving op bijna elke grond terzijde kan worden gesteld. Het enige verschil tussen Griswold en Lochner is, aldus Black, dat in Lochmer aan economische rechten en in Griswold aan individuele rechten uitleg wordt gegeven. Douglas vreesde deze kritiek al, en nam een voorschot aan het begin van zijn meerderheidsopinie door te stellen dat hij aanknopingspunten voot het ongeschreven recht 'zo dicht mogelijk' bij de wet en de rechtspraak zou zoeken. Hij stelde geen uitspraken te willen doen die niet zijn terug te voeren op de grondwet of die ver af staan van het concrete geschil, zoals destijds in Lochner wel was gebeurd. In Griswold diende de overheidsbemceienis met én aspect van de intieme relatie tussen man en vrouw te worden beoordeeld, aldus Douglas:" dat is van concreter orde dan de afbakening van de individuele aanspraak destijds in Lochner. ${ }^{46}$ 
Na Griswold volgde in Eisenstadt t. Beard de claim, dat het recht op 'privacy' in de slaapkamer niet enkel voor gehuwden diende te gelden, maar eveneens voor ongehuwden in verband met de verspreiding van voorbehoedmiddelen. ${ }^{47}$ Het Hof honoreerde deze claim met een referentie aan het gelijkheidspostulaat en een toepassing van het recht op "privacy" in de slaapkamer op de positie van het niet gehuwde individu, waardoor het onderscheid tussen gehuwde en niet-gehuwde paren terzake van verkrijging van voorbehoedmiddelen onredelijk leek:

"It is true that in Griswold the right of privacy' in question inhered in the marital relationship.

Yet the marital couple is not an independent entity with a mind and heart of its own, but an association of two individuals each with a separate intellectual and emotional makeup. If the right to privacy means anything, it is the right of the individual, married or single, to be free from unwarranted governmental intrusion into matters so fundamentally affecting a person as the decision whether to bear or to beget a child". 48

Ook in Eisenstadt zat een analoge redenering verscholen: wanneer gehwwde paren voorbehoedmiddelen mogen gebruiken, mogen ongehuwde paren dat eveneens. In Griswold stond het gehuwde paar centraal; in Eisenstadt werd de aanspraak als het ware geindividualiseerd en gelijkgesteld met de aansprak van het echtpaar. Daarvoor moest wel een analogie worden geconstrueerd. Deze is gelegen im Brennan's vergelijking van de 'independent entity' van het gehuwde paar enerzijds en de 'intellectual and emotional make-up' van het individu anderzijds. Weinigen zullen betwijfelen dat beide individuen in een huwelijk ieder een afzonderlijke "intellectual and emotional makeup' hebben. Vraag is of met dit aspect van de vergelijking kan worden volstaan: simplificeerde Brennan de verschillen tussen de huwelijkse en de niet-huwelijkse staat, of kon worden volstaan met de door Brennan geconstrueerde vergelijking? Dat lijkt een kwestie van waardering. Brennan hanteerde een norm van hoger recht - "privacy" - die leidde tot erkenning van de vergelijkbaarheid en daaruit voortvloeiend toepasselijkheid van de rechtsnorm van Griswold op het feitencomplex van Eisenstadt.

Rechter Burger vreesde echter met de door Bremnan gebezigde redenering een terugkeer naar de tijd waarin het inllezen van fundamentele rechten aan de orde van de dag leek, en als gevolg daarvan een grenzeloze inperking van wetgevende prerogatieven van de staten. ${ }^{49}$ Eisenstadt maakte, tezamen met Griswold, de weg vrij voor én van de meest omstreden uitspraken van het Hof, de beslissing over het verbod van de staat Texas op abortus in Roe t. Wade. ${ }^{50}$ Sommige commentatoren benadrukken dat de uitkomst van de redenering in Eisenstadt - en dan met name de toevoeging van rechter Brennan ter zake van de vrijheid wel of niet voor nageslacht te kiezen - zelfs van doorslaggevend belang is geweest voor de uitkomst van Roe $t$. Wade. ${ }^{51}$ De opmerking in de

47 Eisenstadt t. Beard, 405 U.S. 438 (1972).

48 Erisenstadt t. Beard, 405 U.S. 438, 453 (1972).

49. "for these opinions seriously invade the constitutional prerogatives of the States and regrettably thatk back to the heyday of substantive due process' (Burger, dissenting bij Eisenstodt $t$. Beard).

50 Roe $t$. Wade, 410 U.S. 113 (1973). De witsprask Roe t. Wade werd beschouwd als controversieel vanwege het onderwerp dat aan de orde was alsook vanwege de gebruikte interpretatietechniek.

51 Gunther en Sulliwan 1997, p. 529 watin C. Fried wordt geciteerd: "Justice Brenan's passing remarks 
geciteerde passage, die verwijst naar "the decision to bear or to beget a child" lijkt namelijk wooruit te lopen op Roe; deze zaak diende zich een jaar later aan bij het Hof ${ }^{52}$ De opmerking wan Brennan over het woldragen van een zwangerschap was strikt gezien niet noodzakelijk woor de kwalificatie van de aanspraak onder 'privacy". Het obiter zou later echter de grondslag vormen woor Roe, dat reeds in behandeling was bij het Hof toen bet uitspraak deed in Eisenstadt. ${ }^{53}$

\subsubsection{Het recht op aborius}

In Roe t. Wade bestond die meerderheid uit 7 tegen 2, en in Eisenstadt $t$. Beard uit een meerderheid van 4 tegen $3 .^{54}$ Het draagvlak voor Blackmuns meerderheidsopinie mag in dit verband relatief ruim lijken, dat is het bij nader inzien niet. In Roe $t$. Wade werden scherpe concurrings en dissentings geuit die respectievelijk de gevolgde redenering als ook de redenering en de uitkomst afwezen. Blackmun begon de interpretatie met een historische uiteenzetting over wetgeving van en opvattingen in de samenleving over afbreking van zwangerschap. Uit het recht op 'privacy' werd vervolgens een recht van de vrouw, te beslissen of zij haar zwangerschap al of niet zal uitdragen geconcretiseerd. Het recht op "privacy" fungeerde hier als norm van hoger recht waaruit niet alleen een recht op gebruik van voorbehoedmiddelen, maar wellicht ook een recht op abortus kan woortvloeien.

Blackmun nam aan dat het recht op 'privacy' reeds tot de (in de jurisprudentie) gepositiveerde, geldende rechtsnormen behoorde. ${ }^{55}$ Ter zake van de legitimatie van de legitimatie van het bestaan van 'privacy' als geldend recht en de kwalificatie van de aanspraak op abortus onder het recht op 'privacy' werd vastgesteld dat het Negende Amendement daartoe voldoende ruimte biedt:

'This right of privacy, whether it be founded in the Fourteenth Amendment's concept of personal ]iberty and restrictions upon state action, as we feel it, or [...] in the Ninth Amendment"s reservation of rights to the people, is broad enough to encompass a woman"s decision whether or not to terminate her pregnancy, ${ }^{56}$

Critici wijzen op een strategie van het Hof: met de formulering zou worden getracht het Negende Amendement te incorporeren in het Veertiende Amendement. ${ }^{57}$ De verwijzing

in Eistonstadt planted the seed from which Roe grew".

52 "To bear' wijst op het dragen of het baren van kinderen; "to beget" wijst op het verwekken van een kind. Het earste is een voorbode van de benadering wan Roe, terwijl het tweede het standpunt in Eisenstadt verwoordt. Zie ook Lazarus 1999, p. 364.

53 "Brennan knew we:l the tactic of "burying bones"-secreting language in one opinion to be dug up and put to use in another down the road. Eisenstadt provided the ideal opportunity to build a rhetorical bridge between the rigltt to use contraception and the abortion issue pending in Roe' (zje Lazarus 1999, p. 364-365).

54 In Eisenstadt namern twee rechters namen geen deel aan de beslissing van de zaak.

55 Er werd in de uitsprak weinig andacht besteed aan "privacy" als rechtsnorn; hiermee wordt aangenomen dat "privacy" door de meerderheid al thans wordt verondersteld, een norm van geldend recht te zijn die is geposittiveerd in de rechtspraak.

56 Roe t. Wade, 410 U.S. $113,153(1973)$

57 DeRosa 1996, p. 93. 
naar het Negende Amendement lijkt eerder op een obiter dictum dat in latere rechtspraak wellicht zou kumnen worden opgenomen, waardoor het via precedentenwerking grondrechtelijke "autoriteit" zou kunnen verkrijgen.

Voor de omvang van het recht van de vrouw wordt vastgesteld, dat het hier niet gaat om een absoluut recht, hetgeen betekent dat het dient te worden afgewogen tegen de andere in het geding zijnde belangen. Ook de belangen van het ongeboren leven dienen te worden betrokken in die afweging. De vraag rees in hoeverre het Hof de keuze diende te expliciteren ter zake van de kwestie wanneer een recht op leven aanvangt; hiermee diende rekening te worden gehouden in de belangenafweging tussen die van de vrouw en het ongeboren leven:

'Texas urges that, apart from the fourteenth Amendment, life begins at conception and is present throughout pregnancy, and that, therefore, the State has a compelling interest in protecting that life from and after conception. We need not resolve the difficult question of when life begins. When those trained in the respective disciplines of medicine, philosophy, and theology are unable to arrive at any consensus, the judiciary at this point in the development of man "s knowledge, is not in a position to speculate as to the answer". 58

De grondslag voor dit standpunt - met name voor de afwijzing van bepaling wanneer het lever nu begint - werd gevonden in verwijzingen naar de oudheid tot en met hedendaagse opvattingen. Het Hof ontwierp op basis van de belangenafweging een 'trimestersysteem', waarin de belangen van het ongeboren leven steeds zwaarder gaan wegen naarmate de tijd in de zwangerschap verstrijkt. Naast de positivering van een nieuw recht uit "privacy" werkte het Hof de consequenties van dit trimestersysteem uit. Blackmun stelde dat een meerderheid van de Staten ter zake van de erkenning van abortus als recht inmiddels de gedachtegang van het Hof gebruikt:

"We note that those federal and state courts that have recently considered abortion law challenges have reached the same conclusion. A majority, in addition to the District Court in the present case, have held state laws unconstitutional, at least in part, because of vagueness or because of overbreath and abridgement of rights. ${ }^{59}$

Op het trimestersysteem dat het Hof ontwikkelde naar aanleiding van de belangen. afweging kwam, naast de beslissing over de legitimiteit van abortus zelf, een storm van kritiek: het Hof had zich in de ogen van commentatoren activistisch opgesteld door zelf in vergaande mate regelgevend op te treden. Als er al een recht op abortus bestond, diende de uitwerking ervan aan de statelijke of federale wetgever te worden overgelaten. ${ }^{60}$ Een bijkomend punt van kritiek was dat de beslissing die samenhangen met de vaststelling over levensvatbaarheid van het ongeboren leven in een ander forum dient te worden beslist dan in het rechterlijke.

Na de beslissing in Roe t. Wade bleef het niet stil rond de kwestie van abortus. Zowel ter zake van de vraag of kwalificatie van deze aanspraak onder 'privacy' terecht was, 
alsmede over de wijze waarop dat recht is gepositiveerd blijven de meningen sterk verdeeld. Die verdeling is eveneens letterlijk te traceren in de meerderheden en minderheden die werden gevormd: in veel gevallen is er éen doorslaggevende stem geweest die de kernoverweging Roe - het recht op abortus - als het ware sauveerde. ${ }^{62}$ In de rechtspraak wordt het recht op abortus betwist als geldige rechtsnorm ondat de rechtsgrondslag, 'privacy", door critici niet wordt aanvaard. Tot dusverre is het Hof nog niet volledig 'omgegaan' en heeft het de niet-strafbaarstelling van abortus in Roe $t$. Wade steeds bevestigd. Betwist kan worden in hoeverre het Hof heeft getracht, de kern van Roe te relativeren of terzijde te schuiven. Van de rechtspraak na Roe t. Wade kan bijvoorbeeld worden gesteld dat het recht op abortus tot op zekere hoogte is gerelativeerd of niet door alle vrouwen kan worden geeffectueerd. In Beal $t$. Doe rees bijvoorbeeld de vraag, in hoeverre de kosten van abortus door de staat dienen te worden vergoed. De wettelijke regeling stelde gelden beschikbaar voor individuen die niet in staat waren, een noodzakelijke medische behandeling te betalen. Volgens het Hof viel abortus niet onder de noodzakelijke medische behandelingen; mitsdien behoefde de staat dergelijke ingrepen niet te vergoeden aan deze personen; de staat heeft volgens het Hof bij de bepaling van de noodzakelijkheid van behandeling een discretionaire bevoegdheid. ${ }^{63}$ De keuze om niet te vergoeden is niet onredelijk, aldus het Hof. De dissenters hamerden in dat verband op het 'fundamentele belang' dat is gehecht aan het recht op abortus, en dat mitsdien aan de onthouding van dat fundamentele recht zware eisen dienen te worden gesteld. ${ }^{64}$ Ook in Harris 1 . McRae zag het Hof geen aanleiding aan het recht op abortus een positieve verplichting voor de staat te verbinden. Het argument dat enkel personen die zich financieel kunnen permitteren een dergelijke ingreep kunnen laten uitvoeren, snijdt volgens het Hof geen hout:

'It cannot be that because government may not prohibit the use of contraceptives [...], or prevent parents from sending their children to a private school [...], government, therefore, has an affirmative obligation to ensure that all persons have the financial resources to obtain contraceptives or send their children to private schools' ${ }^{65}$

61 Zie in de literatuur onder meer Ely 1980, p. 21 e.v., Bork 1991, p. 112 e.v., Tribe 1992, Dworkin 1994, p. 102-178, De Rosa 1996, p. 87 e.v., Gunther en Sullivan 1997, p. 530 e.v, in die rechtspraak zie onder meer Beal t Doe, 432 U.S. 438 (1977), Marris \&. McRae, 448 U.S. 297 (1980), Thomburgh t. American College, 476 U.S. 747 (1986), Webster t. Reproductive Health Servicex 492 U.S. 490 (1989), Planned Parenthood t. Casey, 505 U.S. 833 (1992) en Stenberg t. Carhart, 28 juni 2000.

62 De stemverhouding in de belangrijkste uitspraken was als volgt: Beal i. Doe, 432 U.S. 438 (1977), 6-3; Harris t. McRas, 448 U.S. 297 (1980), 5-4; Thornburght. American College, 476 U.S. 747 (1986), 54 ;. Vanall Webster \&. Reproductive Health Services, 492 U.S. 490 (1989) wordt het moeilijker om vast te stellen hoe de neerderheden zijn samengesteld, ondat rechters op onderdelen van de uitspraak instemmefi of afkeurem; datzelfde fenomeen deed zich voor in Planned Parenthoodi t. Casey, 505 U.S. 833 (1992) en Stenberg i. Carhart, 28 juni 2000. Deze opsplitsing in onderdelen hangt maar mijn mening tot op zekere hoogte samen met de krappe meerderheden die zich voordeden bij de abortusbeslissingen; zij zouden kunnen leiden tot verminderde legitimiteit wan de uitkomst wan de besluitvorming. Opsplitsing biedt een mogelijkheid om per onderdeel - constituerend of minder van belang voor bepaalde leerstukken, in casu voor bestendiging van het recht op abortus - een grotere meerderheid te vormen dan wanneer gestemd moet worden over het geheel (zie ook par. 3.2.5).

63 Beal t. Doe, 432 U.S. 438 (1977).

642 ie woor de betekenis van "fundamentality" par. 2.3.3.

65 Harris t. McRae, 448 U.S. 297 (1980). 
In dit citaat kan het verband dat wordt gelegd tussen de aanspraak op een positieve verplichting van de staat, abortus toegankelijk te maken enerzijds en een aanspraak op financiering van privé-scholen anderzijds opmerkelijk worden genoemd. Vraag is of beide aanspraken zich laten vergelijken: had het Hof in Roe t. Wade niet uitgemaakt dat het recht op abortus een fundamenteel karakter heeft? ${ }^{66}$ Ook een statelijk verbod op het inzetten van werknemers in overheidsdienst voor onderzoek dat is gericht op concrete abortusbeslissingen en het onthouden van subsidies aan campagnes die 'aanmoedigen tot abortus' werd door het Hof in Webster t. Reproductive Health Services in overeenstemming geacht met Roe t. Wade. ${ }^{67}$ Vier rechters waren voor het 'overrulen' van Roe, maar om redenen van precedentwerking werd daarvan afgezien. ${ }^{68}$ Rechter $O^{\prime}$ Connor, bij wie in dit verband de beslissende stem lag, stelde dat er terughoudendheid betracht diende te worden wanneer aan precedentwerking expliciet geen gevolg wordt gegeven. ${ }^{69}$ Scalia repliceerde dit argument van rechterlijke terughoudendheid met de opmerking dat precedentwerking niet zo ver kan gaan dat een verkeerde rechtsregel niet terzijde kan worden gesteld. ${ }^{70}$

Opvallend is dat de twijfel aan de fundering en het bestaan van het recht op abortus samenvalt met een vernieuwde samenstelling van rechters in het Hof die eerder een conservatief-liberale opvatting aanhangen. President Reagan stelde bij zijn aantreden dat hij zou zorgen voor een meer conservatief samengesteld Hof. ${ }^{71}$ De rechters die door conservatieve presidenten in het Hooggerechtshof werden gekozen keerden zich in beginsel af van het in Roe gepositiveerde recht op abortus en oefenden steevast kritiek uit op de in Griswold en Roe gevolgde redeneringen: zij stellen dat het Hof buiten zijn bevoegdheid om nieuwe grondrechten heeft gecreëerd op basis van vage noties die niet letterlijk zijn terug te vinden in de Bill of Rights. ${ }^{72}$

Planned Parenthood t. Casey is eveneens een belangrijke uitspraak: indien cen gehuwde vrouw, die voomemens is abortus te laten plegen, vooraf haar echtgenoot dient in te lichten is er een schending van de centrale overweging van Roe. ${ }^{73}$ Dat vond een meerderheid in het Hof te ver gaan; het recht in Roe zou met deze regeling in de kern worden aangetast omdat het zou leiden tot een hindernis die uitoefening van het recht illusoir maakt. ${ }^{74} \mathrm{O}^{\prime}$ Connor, schrijvend voor de meerderheid, hechtte aan het recht op

66 Van een fundamenteel recht op onderwijs aan een privé-school is geen sprake.

67 Webster t. Reproductive Health Services, 492 U.S. 490 (1989). Zie in dit verband eveneens Rust t Sullivan, 500 U.S. 173 (1991).

68 In casu wensten rechters Rehnquist, White, Scalia en Kennedy Roe t. Wade terzijde te stellen.

69 Rechter O'Connor, schrijvend yoor de meerderheid op dit punt, zie Webster t. Repraductive Health Services, 492 U.S. 490,525 (1989).

70 Dissenting van Scalia bij Webster t. Reproductive Health Services, 492 U.S. 490, 532 (1989).

71 Lazarus 1999 , p.329 e.*., Heringa 1996, p. 132.

72 Hiervoor geeft met name de jurisprudentie zelf de beste aanwijzingen; de meningen van de atzonderlijke rechters worden weergegewen in meerderheidsopvattingen, concurrings en dissentings waardoor zichtbaar wordt welke opvatting door een bepaalde rechter wordt aangehangen.

73 Planned Parenthood t. Casey, 505 U.S. 833 (1992).

74 Rechter O'Connor, schrijvend waor de meerderheid in Planned Parenthood t. Casey, 505 U.S. 833 (1992). 
'privacy' zoals gepositiveerd in Griswold en vanuit de precedentwerking aan de concretiseringen die uit het recht op "privacy" zijn voortgekomen. Ook hier volgt weer kritiek van rechter Rehnquist die van mening is dat over het bestaan van fundamentele rechten dient te worden beslist door de wetgever. Het recht op abortus wordt in zijn optiek beperkt door een legitiem belang van de staten bij regulering van het recht op leven. Rechter Scalia ontkent het bestaan van een grondwettelijk recht op abortus. Rechter Blackmun pleitte hartgrondig tegen de opvattingen van de (ruime) conservatieve minderheid ter zake van het argument van de democratische besluitvorming:

"The Chief Justice's narrow conception of individual Jiberty and stare decisis leads him to propose the same standard of review proposed by the plurality in Webster. But, we are reassured, there is always the protection of the democratic process. While there is much to be praised about our democracy, our country since its founding has recognized that there are certain fundamental liberties that are not to be left to the whims of an election." ${ }^{75}$

De meningen buitelden over elkaar heen in Casey; in de rechterlijke filosofieën spelen constitutioneelrechtelijke doctrines steeds een voorname rol. Het rechterlijk toetsingsrecht en de juiste rechterlijke taakopvatting naar de wetgever, de afwezigheid van een democratische legitimatie, de bescherming van de minderheid tegen de democratisch gekozen meerderheid, de structuur van de grondwet en de verticale en horizontale machtenscheiding vormen allen aspecten in de discussie over de juiste constitutionele interpretatie. Casey werd echter door iets 'eenvoudigs' als precedentwerking beslecht, hetgeen grotendeels aangeeft hoe ingewikkeld het is om aan de hand van voornoemde staatsrechtelijke begrippen te komen tot een kader waarbinnen geoordeeld moet worden. Compromissen blijken in een klimaat waarin de opvattingen dermate zijn gepolariseerd niet tot de mogelijkheden te behoren, waarmee het debat als zeer 'principieel' aangemerkt zou kunnen worden. ${ }^{76}$ Aan de basis van de stellingname in het debat ligt de vraag besloten, in hoeverre de in Griswold en Roe gehanteerde redeneringen tot op heden worden aanvaard. De blijvende verdeeldheid over de redenering en de stemmenverdeling ter zake over de uitkonst doen de bestendiging van het recht op abortus geen goed. Het nodigt statelijke wetgevers als het ware uit, de standpunten van het Hof te testen: van een status-quo lijkt vooralsnog geen sprake te zijn. ${ }^{77}$

\subsubsection{Vrije kewze van hwwelijksparther}

Tot het einde van de jaren " 60 bestond in verschillende staten wetgeving, die interraciale huwellijken verbood. In Loving werd een dergelijk statelijk voorschrift door het Hof ongrondwettig verklaard in verband met strijd met het recht op gelijke behandeling

75 Rechter. Blackmun, gedeeltelijk dissenting en gedeeltelijk concurring bij Planned Parenthood t. Casey, 505 U.S. $833(1992)$.

76 Heringa $1996, \mathrm{p}, 135$

77 In de meest recente zaak, Sienberg 1 . Carhart verbood de Staat Nebraska de zogenoemde 'partial birth abortion', een abortusmethode warbij de foetus niet in eén keer kan worden weggehaald en in delen dient te worden afgedreven. Het Hot achtte dat verbod eveneens een "undue burden" in de uitoefening vaw het recht op abortus, Stenberg $t$. Carthart, 28 juni 2000, no. 99-830. Een "undue burden" houdt in dat het recht niget langer praktisch wan betekenis is ondat het feitelijk (met een restrictieve interpretatie) onmogelijk wordt, het te kunnen uitoefenem. 
en met het uitgangspunt dat het huwelijk tot de basisgrondrechten van het individu behoort. Het Hof volstond voor onderbouwing van het laatstgenoemde aspect als een grondrecht in Loving t. Virginia met een verwijzing naar Skinner t. Oklahoma (1942). In die zaak had het Hof geoordeeld dat een statelijke wet, die eiste dat criminelen zich ter voorkoming van 'ongewenste voortplanting' lieten steriliseren, ongrondwettig was. In Skinner construeerde het Hof een 'basic liberty' die niet toelaat dat het individu beroofd zou worden van een recht op voortplanting:

"We are dealing here with legislation which involves one of the basic civil rights of man.

Marriage and procreation are fundamental to the very existence and survival of the race'. ${ }^{7 *}$

Skinner bood in de optiek van het Hof aanknopingspunten voor een vergelijking met de aanspraak in Loving onder een abstracte norm van hoger recht: de 'basic civil rights of man'. Rechter Warren plaatste de aanspraak van Loving onder de norm van hoger recht "basic civil rights of man" die eerder in Skinner al was gepositiveerd:

"these statutes also deprive the Lovings of liberty without due process of law [...]. The freedom to marry has long been recognized as one of the vital personal rights essential to the orderly pursuit of happiness by free men. Marriage is one of the "basic civil rights of man", fundamental to our very existence and survival', 79

Ter versterking van de gevolgde redenering trachtte Warren het Hof in Loving $t$. Virginia met de volgende retorische benadering te overtuigen:

"To deny this fundamental freedom on so unsupportable a basis as the racial classifications embodied in these statutes, classifications so directly subversive of the principle of equality at the heart of the Fourteenth Amendment, is surely to deprive all the State's citizens of liberty without due process of law. ${ }^{80}$

Hij slaagde daarin, want zijn opvatting werd door een ruime meerderheid van het Hof aanvaard. Interessant bij Lowing was nu, dat door geen van de rechters in een cancurring kritiek werd geleverd op de door Warren gevolgde redenering, terwijl die daartoe toch aanleiding lijkt te kunnen geven, bijwoorbeeld vanwege afwezigheid van verwijzingen naar constitutionele bepalingen. ${ }^{81}$ Het feit dat de aangevochten wetgeving de intieme sfeer raakte en het racistische karakter van de wetgeving wetgeving, alsmede het feit dat dit geschil rees voor het "Warren-Court" ${ }^{82}$ droegen waarschijnlijk bij aan de voortvarendheid waarmede de uitspraak in het Hof werd aanvaard.

De ongrondwettigheid van wetgeving die interraciale huwelijken verbood was afwezig in een in sommige opzichten te vergelijken zaak met Loving. Het ging in Zablocki t.

78 Sikinner t. Oklahoma, 316 U.S. 535 (1942).

79 Rechter Warten, schrijvend voor de meerderheid in Loving t, Virginia, 388 U.S. I (1967).

80 Lowing t. Virginic, 388 U.5. 1 (1967).

81 ln dit verband dient echter te worden opgemerkt, dat het bestreden voorschrift reeds ongrondwettig was

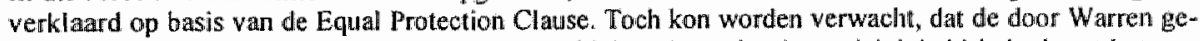
bezigde extensieve interpretatie zou leiden tot kritiek - al was het "voorzichtigheidshalve" met het oog. op toekomstige rechtsontwikkelingen.

82 Kenmerkend voor het Warren-Court, waarin rechter Warren optrad als president van het Hof, is dat " $\mathrm{s}$ Hofs rechtspraak over het allgemeen open stond voor erkenning wan fundamentele individuele rechten. 
Redhail niet om een interraciaal huwelijk, maar om noodzakelijke toestemming van de autoriteiten bij hertrouwen indien er kinderen uit een vorig huwelijk aanwezig waren. De staat Wisconsin had middels wetgeving bepaald, dat een ongehuwde ouder, die in het huwelijk wenst te treden met een ander dan degene met wie hij of zij een minderjarig kind heeft en waarvoor hij of zij financiële verplichtingen draagt, eerst toestemming dient te vragen aan de rechtbank alvorens het huwelijk kan plaatsvinden. In casu werd huwelijkssluiting geweigerd op basis van het feit dat er geen permissie was aangevraagd. De klager had dat achterwege gelaten omdat hij aan twee wettelijke vereisten niet voldeed: hij betaalde geen bijdrage voor zijn kind uit het vorige huwelijk, en omdat het kind overheidssteun ontving voor het levensonderhoud. ${ }^{83}$ Anders dan in Lowing was de huwelijkssluiting niet onmogelijk, en diende een persoon, die reeds een kind had en met een ander dan de ouder van dat kind in het huwelijk wilde treden, toestemming aan de rechter te vragen. Deze regeling was in het leven geroepen met het oog op de belangen van de financiële verplichtingen ter zake van het levensonderhoud van het kind. Het Hof kwam nu, in de meerderheidsopinie van rechter Marshall, met een aanspraak op "privacy'. 'Privacy' werd in casu onderbouwd op vergelijkbare wijze als in Griswold, namelijk op basis van een aantal Amendementen als in Griswold. Hier werd het recht, vrij te kunnen kiezen voor de huwelijkspartner afgeleid uit die Amendementen:

"More recent decisions have established that the right to marry is part of the fundamental
"right of privacy" implicit in the Fourteenth Amendment's Due Process Clause. In Griswold
[...] the Court observed: 'We deal with a right of privacy older than the Bill of Rights -
older than our political parties, older than our school system. Marriage is a coming together
for better or for worse, hopefully enduring, and intimate to the degree of being sacred".

Eén van de steunpilaren in de redenering bleek aldus gebaseerd op een natuurrechtelijke overweging in Griswold t. Connecticut. Het Hof onderbouwde de aanvaarding van de aanspraak op vrije keuze voor het huwelijk onder de norm van hoger recht 'privacy' verder met rechtspraak. ${ }^{85}$ Het onderzoek naar de kwalificatie van de aanspraak van Zablocki leidde op basis van de volgende vergelijking tot erkenning van een 'fundamentele' grondrechtelijke aanspraak:

"It is not surprising that the decision to marry has been placed on the same level of importance as decisions relating to procreation, childbirth, childrearing, and family relationships. As the facts of this case illustrate, it would make little sense to recognize a right of privacy with respect to other matters of family life and not with respect to the decision to enter the relationship that is the foundation of the family in our society ${ }^{86}$

Zabrocki t. Redhail, 434 U.S. 374 (1978).

Zablocki i. Redhail, 434 U.S. 374, 384 (1978).

Die werd afgeleid uit het Eerste, Vijfde, Negende en Veertiende Amendement en de toepasselijke rechtsprak, waaronder Meyer t. Nebraska, Skimer t. Oklahoma, Griswold t. Connecticut, Eisenstadt $t$. Beard, Pierce r. Society of Sisters, Roe t. Wade en Moore t. East-Cleveland. 
Norm van hoger recht was het recht op "privacy'. ${ }^{87}$ De kwalificatie van Zablocki's aanspraak onder "privacy" leidde tot de toepassing van een stringente toetsing van statelijke wetgeving. ${ }^{83}$ Het recht te huwen werd naar de mening van enkele concurrings echter te weinig toegespitst op de individuele aanspraak, waardoor de deur was geopend voor afkeuring van álle wetgeving die de kenze voor huwelijkspartners beperkt. ${ }^{89}$ De redenering wekte evenwel wrevel; Powell verwoordde in zijn concurring zijn kritiek als volgt:

"Our decisions indicate that the guarantee of personal privacy or autonomy secured against unjustifiable governmental interference by the Due Process Clause "has some extension to activities relating to marriage" [...]. But the Court has yet to hold that all regulation touching upon marriage "mplicates a "fundamental right" triggering the most exacting judicial scrutiny" 90

Van belang is aldus volgens Powell, dat indien op deze wijze rechtsvinding wordt bedreven, gezocht wordt naar een zo specifiek mogelijke kwalificatie van de aanspraak onder een grondrecht. Wetgeving die verbiedt dat ouders en kinderen of personen in de eerste familielijn met elkaar huwen, of het verbod van bigamie maken eveneens een inbreuk op dat recht, maar zijn wel degelijk te rechtwaardigen. Een meer specifieke benadering had in Zablocki tot gevolg kunnen hebben, dat het recht op vrije keuze van huwelijkspartners evenwel van toepassing was op de aanspraak, maar dat het recht moet worden ingeperkt vanwege bijvoorbeeld belangen van derden.

\subsubsection{Het recht familiebetrekkingen te vestigen en te onderhouden}

Een aantal uitspraken met betrekking tot de omvang van het recht, familiebetrekkingen te vestigen en te onderhouden heeft een scherpe verdeling van standpunten in het Hof over de juiste interpretatie van "liberty" en "privacy" teweeggebracht. Een dergelijke verdeling gaf de rechtspraak omtrent abortus ook al te zien, en het lijkt erop dat de rechtspraak over vestiging en onderhoud van familiebetrekkingen op dezelfde punten wordt bekritiseerd als de abortusrechtspraak. De woornaamste kritiek op beide is gelegen in de wijze van rechtsvinding van de toepasselijke normen: de rechten die door het Hof werden in eerdere jurisprudentie erkend, zijn volgens critici niet terug te voeren op de tekst of de historische achtergrond van de grondwet. Verder redenerend stellen zij dat deze normen geen grondslag kunnen vormen voor de beoordeling van grondwet-

87 Het recht op het hawen werd in belang gelijkgesteld met de andere "basic rights", die eveneens onder hel recht op 'privacy" waren aanward.

88 In het citaat is een aamtal voorbeelden wan retoriek en metaforen te herkennen. De retorische elementen zujn hier gecursiveerd: "It is not surprising that the decision to marry has been placed on the same level of importance as decisions relating to procreation, childbirth, childrearing, and family relationships. As the facts of this case illustrate, it wowld make lwhe serse to recognize a right of privacy with respect to other matters of family life and not with respect to the decision to enter the relationship that is the foundation of the family in our society. Het laatste wijst op een metafoor, die bet geclaimde belang op een hoog plan voor grondrechtelijke bescherming zet.

89 De meerderheid besloot met 8-1 „ rechter Rehnquist sloot zich niet alan bij de meerderheid.

90 Rechter Powell in zijn concuring, Zablockit. Redhail, 434 U.S. 374, 397 (1978). 
tigheid van wetgeving. In dit verband worden twee uitspraken behandeld wan het Hof: Moore t. East-Cleveland (1977) en Michael H. t. Gerald D. (1989).

In Moore $t$ East-Cleweland ${ }^{\text {pi }}$ werd een regeling van de staat Cleveland aangevochten; die stelde dat woningen in een bepaald gebied enkel mochten worden toegewezen aan gezinnen, waarbij het begrip 'gezin' zeer eng was gedefinieerd. De klaagster vormde samen met twee neven een gezin; deze samenstelling werd door East-Cleveland echter niet aangemerkt als "gezinseenheid" en kwam mitsdien niet in aanmerking voor een woning. De staat en later de statelijke rechter in East-Cleveland weigerde vergelijkbaarheid van de individuele aanspraak van mevrouw Moore met Pierce en Meyer vanwege de onderscheidenlijke feitencomplexen aan te nemen. Rechter Powell bestreed deze opvatting van de staat met referentie aan een rumer kader, namelijk dat van aanspraken die zijn geassocieerd met een "familie"begrip:

'But unless we close our eyes to the basic teasons why certain rights associated with the family have been accorded sheltter under the Fourteenth Amendment"s Due Process Clause, we cannot avoid applying the force and rationalle of these precedents to the family choice involved in this case ${ }^{*}{ }^{4}$

Powell vergeleek vervolgens niet de aan de kaak gestelde feitencomplexen van Meyer en Pierce met die van Moore, maar stelde de norm van hoger recht centraal, die de feitencomplexen van Meyer en Pierce beheerste enerzijds en toepasselijkheid daarvan op de aanspraak van Moore anderzijds. ${ }^{95}$ In het aangehaalde citaat werd retoriek gehantaerd om de op handen zijnde vergelijking overtuigingskracht bij te zetten. ${ }^{96}$ Powell herinnerde voorts met een verwijzing naar de dissenting van rechter Harlan in Poe t. Ullman aan het feit, dat via deze wijze van rechtsvinding reeds verschillende door het Hof als fundamenteel aangemerkte rechten zijn erkend:

'The full scope of liberty guaranteed by the Due Process Clause cannot be found in or limited by the precise terms of the specific guarantees elsewhere provided in the Constitution.

This 'liberty' is not a series of isolated points pricked out in terms of the taking of property, the freedom of speech, press and religion [... ]".

De keuze voor deze wijze van rechtsvinding mag dan te rechtvaardigen zijn, een passende begrenzing van "liberty" was in Powells optiek eveneens dringend gewenst vanwege de kritiek, dat 'liberty" in enkele gevallen willekeurige rechtsvinding had opge-

91 Moore t. East Cleveland werd met 54 beslist, Michaed H. t. Gerald D. werd eveneens beslist met $5-4$ ter zake van de interpretatievraag, of de aanspraak van de klager grondwettelijke bescherming dient te genicten.

92 Moore 1. East Cleweland, 431 U.S. 494 (1977).

93 "[...] any constitutional right to live together as a family extends only to the nuclear family - essentiaily a couple and their dependent children", zie Moore t. East Cleveland, 43 I U.S. 494 (1977).

94 Moore t. East Cleveland, 431 U.S. 494 (1977).

95 "That history counsels caution and restraint. But it does not counsel abandonment [...]".

96 De retorische elementen zijn gecursiveerd: 'But unless we close our eyes to the basic reasons why certain rights associated with the family have been accorded shelter under the Fourteenth Amendment's Due Process Clause, we cannot avoid applying the force and rationale of these precedents to the family choice involved in this case". 
leverd. Hij begrensde mogelijk vergaande gevolgtrekkingen uit het vrijheidsbegrip in de toekomst aan de hand van historische beschouwingen alsmede van "erkende basisnormen die ten grondslag liggen aan de in de samenleving heersende opvattingen'. Powell construeerde vervolgens op basis van die beschouwingen en basisnormen een ruime notie van het begrip 'gezin', waarin andere samenlevingswormen van familieleden dan die in het eng geformuleerde kerngezin worden erkend. ${ }^{97}$ Er volgde echter geen historische analyse of onderzoek naar de normen in de samenleving om deze vaststelling te staven. ${ }^{98}$ Rechter White merkte in zijn dissenting echter op dat voor oprekking van het in dit geval geclaimde recht geen basis voorhanden is in de tekst of textuur van de grondwet. Deze wijze van rechtsvinding zou volgens White mogelijkheden openen voor de meest willekeurige conclusies:

"That the Court has ample precedent for the creation of new constitutional rights should not lead it to repeat the process at will. The Judiciary, including this Court, is the most vulnerable and comes nearest to illegitimacy when it deals with judge-made constitutional law having little or no cognizable roots in the language or even the design of the Constitution"."9"

In Michael H. t. Gerald D. komen de consequenties van (afwijzing van) interpretatie mett een norm van hoger recht fraai naar voren. ${ }^{100}$ In deze zaak kwamen rechter Scalia en rechter Brennan tegenover elkaar te staan ter zake van de vraag, welke maatstaf nu de "juiste" interpretatiebenadering weergeeft in het licht van de constitutionele verhoudingen en de omvang van de grondrechtelijke bescherming. Een biologische vader, niet zijnde de echtgenoot van de moeder, claimde op basis van 'liberty" vaderschapsrechten ten aanzien van zijn dochter - de enige mogelijkheid voor hem omgang met haar te hebben. Deze dochter was in het huwelijk van de moeder ter wereld gekomen; moeder en echtgenoot wensten het vaderschap niet te betwisten. Rechter Scalia erkende, schrijvend voor de meerderheid, dat het begrip 'liberty' in het Veertiende Amendement meer omvat dan alleen vrijheid van fysieke inbreuk, maar duidde aan dat tegelijkertijd rechterlijke terughoudendheid past ten aanzien van toepasselijkheid. Uit de jurisprudentie citeerde hij een aantal uitspraken van rechters, die reeds hadden gewezen op richtlijnen en begrenzingen ter zake van constitutionele interpretatie: het geclaimde belang onder "liberty" diende, Scalia citeerde hierbij rechter Harlan in Griswold, stevige wortels te

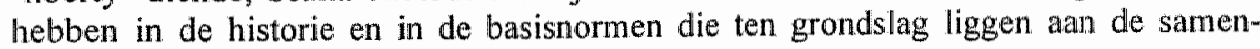
leving.

97 'The tradition of uncles, aunts, cousins, and especially grandparents sharing a housellold along with parents and children has roots equally venerable and equally deserving of constitutional recognition".

98. Een aanwijzing zou Belle Terre t. Boraas kunnen zijn, 416 U.S. I (1974), waarin eenzelfde soort verordening werd aangevochten door de eigenaar van een pand die dat verhuurde aan een groep studenten. Het Hof keurde in Belle Terre de wetgeving niet af, omdat de klagers geen recht konden aantonen dat constitutionele bescherming verdiende. $\mathrm{Zij}$ claimden onder andere het recht niet anders te worden behandeld dan gehuwden, die well als samenlevingsvorm werden aangemerkt. Het Hof stelde vast dat hun eis niet viel in de categorie van onder meer NAACP t. Alabama, Griswold t. Conmecticut of Eisenstadt $t$. Beard. Verder ging het hier om sociaal-economische wetgeving, waar het Hof de wetgever een ruime beoordelingsmarge toekent.

99 White, dissenting in Moore t. East Cleveland, 431 U.S. 494 (1977).

100 Michael H. t. Gerald D., 491 U.S. 110 (1989). 
Indien de rechter ervoor kiest het begrip 'liberty' in de lijn van historie en gevestigde traditie te interpreteren, wordt daarmee nog niet de voorkeur vastgelegd voor ruime of enge interpretatie van het begrip. Of die eng dan wel ruim uitvalt, hangt samen met de voorkeur voor hetgeen tot relevante historie en traditie wordt gerekend. Op het eerste gezicht lijken historische beschouwingen en traditie te pleiten voor een conservatieve benadering van het te interpreteren begrip, maar dit hoeft niet zo te zijn. ${ }^{101}$ Rechter Scalia koos in Michael H. t. Gerald D (1989) voor een historische tijdsspanne gelegen tussen 1569 en $1957 .{ }^{102}$ Scalia had bijvoorbeeld recentere rechtspraak over familiebetrekkingen in zijn beschouwing kumnen betrekken, om zo een completer beeld te schetsen van de ontwikkelingen in historisch en traditioneel perspectief. Enkele rechtsontwikkelingen in de rechtspraak boden op het terrein van familiebetrekkingen aanknopingspunten voor een meer progressieve benadering. Scalia's voorkeur voor de benaderingen van Bracton, Blackstone en Kent is daarmee niet bij voorbaat af te wijzen; vanuit het perspectief van de originalist is deze benadering juist de meest objectieve. ${ }^{103}$ Het geheel achterwege laten van een motivering van de afwijzing van meer recente ontwikkelingen wekt onder meer in het licht van precedentwerking echter bevreemdend.

Rechter Brennan pleitte voor een wetsanaloge benadering, waarbij een norm van hoger recht de "unitary family", waarin de ouder-kindrelatie centraal staat, dient te zijn. ${ }^{104}$ In dat kader dient vervolgens de relatie tussen biologische vader en zijn kind te worden beschouwd. Er bestaat niet a priori een grondrechtens te beschermen band tussen biologische vader en kind; de vader dient zijn best te doen om hier inhoud aan te geven. Hiervoor bestaan ook aanwijzingen in de jurisprudentie, aldus Brennan: ook al kwamen de feitencomplexen en de individuele aanspraken van die uitspraken niet geheel overeen, het bleek toch mogelijk om uit de jurisprudentie een gemeenschappelijke norm van hoger recht te destilleren. ${ }^{105}$ Rechter Scalia toonde zich zeer sceptisch over deze opzet van de redenering met een norm van hoger recht, die naar zijn zin te veel rechterlijke beoordelingsruimte liet. ${ }^{106}$

101 Zie bijvoorbeld rechler White in zijn dissenting bij Moore t. East-Cleveland. White keurde de historische beschouwing en traditie als matstaf af omdal zij zouden leiden tot willekeur. Hij doelde echter op het atrhalen var historische beschowwingen en tradities die in het recente verleden lagen - met
name Griswold en Roe.

102. "Wo have found nothing in the older sources, nor in the older cases, addressing specifically the power of the natural father to assert parental rights [...]. Since it is Michael"s burden to establish that such a power [...] is so deeply embedded within our traditions as to be findanental right, the lack of evidence alone might defeat his case. But the evidence shows that even in modern times - when, as we have noticed, the rigid protection of the nurital family has in other respects been rellaxed - the ability of a person in Michael's position to chaim paternity has not been generally acknowledged", Scalia schrij-

103 Zule par. 4.3.1.

104 Rechter Breman, dissenting bij Michaef H. t. Gerald D., 491 U.S. 110, 143 (1989).

105 Hierwoor werden Stanley ifllinois, 405 U.S. 645 (1972); Qwillon t. Walcolt, 434 U.S. 246 (1983), Caban *. Mohammed, 441 U.S. 380 (1979) en Leh" Robentson, 463 U.S. 248 (1983) aangehaald.

106 Zie voetnoot 6 in Scalia"s opinie: "Why should the relevant category not even be more general perhaps "ffumily rehationships"; or "personal relationships" [...]? Though the dissent has no basis for the ievel of generality it would select, we do: We refer to the most specific level at which an relevant tradition protecting, or denying protection to, the asserted right can be identified". 
Interessant is dat juist Scalia aan de hand van de passage van rechter Harlan in Griswold en Poe t. Ullman pleitte woor een historische en traditiebepalende benadering. Harlan doelde in zijn opinie op een traditiebenadering in het licht van de 'condities en eisen van de hedendagse samenleving', want 'that tradition is a living thing" 107 De dynamisch-evolutieve variant van de historische en traditionele interpretatie die Harlan aldus voorstond wees Scalia in Michael H t. Gerald D. juist expliciet af. Van belang is overigens dat hier niet wordt verondersteld dat de conservatieve benadering van historie en traditie beter of minder goed is dan een meer dynamisch-evolutieve benadering. Veeleer wordt zichtbaar dat waar interpretatie van 'liberty" wordt geijkt aan historische en traditionele beschouwingen, er evenzér ruimte blijft voor waarderingen. De aanhangers van de historische interpretatie pretenderen echter wel, een zo objectief mogelijke interpretatiemethode te volgen, terwijl zij de dynamisch-evolutieve benadering afkeuren als zou die teveel rechterlijke vrijheid ter zake wan grondwetsinterpretatie met zich meebrengen:

"This innovation paved the way, so the plurality hints, for judges to substitute their own preferences for those of elected officials. [...] It finds its limitation in "tradition". Apparently, oblivious to the fact that this concept can be as malleable and as elusive as "liberty" itself, the plurality pretends that the tradition places a discernible border around the Constitution. This pretense is seductive [...] ${ }^{108}$

In Michael $H$ t. Gerald $D$. wordt aldus zichtbaar, in welke mate de formulering onderdeel is van een 'interpretatiestrategie' in het licht van de constitutionele verhoudingen. ${ }^{109}$ Scalia noemt de claim van de eiser een 'nieuw' belang, terwijl deze karakterisering vatbaar lijkt voor betwisting. Indien de rechter een nog niet eerder ingeroepen claim benoemt tot een "nieuw" belang, ligt het eerder voor de hand, dat aangenomen wordt dat de rechter 'iets nieuws' gaat doen. Positivering van 'nieuwe' rechten duidt al gauw op rechterlijk activisme in de optiek van de originalist: via normen die niet te traceren zijn in de grondwet kan wetgeving terzijde worden gesteld.

In Washington 1. Ghucksberg, een zaak waarin het recht op hulp bij zelfdoding werd bepleit als concretisering van het recht op 'privacy', stelde rechter Rehnquist bijvoorbeeld:

'But we have alsways been reluctant to expand the concept of substantive due process because guideposts for responsible decisionmaking in this unchartered area are scarce ancl open ended. [...] We must therefore "exercise the utmost care whenever we are asked to break new ground in this field". lito

Nu kan de rechter, indien hij niet voelt voor honorering van een individuele aanspraak, duidelijk maken dat het niet zijn taak is, een dergelijk recht te 'formuleren'. Dat valt

107 Rechter Harlan, concurring in Poe t. Ullman, 367 U.S. 497, 523 (1961).

108 Zie Rechter Brennan, dissenting bij Michael H. t. Gerald D.

109 Dat wordt eveneens in andere uitspraken zichtbaar; hier wordt het genoemde arrest als uitgangspunt

genomen.
110 Rehnquist, sclrijwend voor de meerderheid, in Washington t. Glucksberg, 521 U.S 702 (1997). Hulp bij zelfdoding wordt hierna uitgewerkt in par. 5,3,7. 
immers, zoals te lezen is in Scalia"s benadering van interpretatie van 'liberty', buiten de taakopvatting van de rechter. In het algemeen blijkt, dat rechters die 'nieuwe' rechten intezen in de grondwet door tegenstanders van deze redeneertechniek als activistisch worden aangemerkt. Scalia formuleerde zijn standpunt ter zake als volgt:

'without that core textual meaning as a limitation, defining the scope of the Due Process Clause "has at times been a treacherous field for this Court", giving "reasons for concern lest the only limits to [...] judicial intervention become the predilections of those who happen at the time to Members of this Court'."

Vraag is of het terecht is dat een rechter die analoog redeneert aan te merken is als activistisch: er kan ook worden geredeneerd dat de grondwet met de open textuur juist veronderstelt dat de rechter onbenoemde rechten interpoleert in het geschreven normensysteem. Een rechter die dat nalaat kan in deze optiek juist als activistisch worden aangemerkt: hij sleutelt dan eveneens aan de bedoelingen van de constitutie. Een rechter zal zijn woorden waarschijnlijk voorzichtig kiezen indien hij bereid is een nog niet eerder geclaimd belang te erkennen als geldend grondrecht. Het is in dat geval van belang de indruk te wekken dat het geclaimde belang een logisch voortvloeisel is van het recht op "privacy" en past in een reeks van bestaande rechten, en op deze wijze een recht te positiveren in de rechtspraak. De indruk dat een nieuw recht wordt gepositiveerd dient zoveel mogelijk te worden weggenomen wanneer de rechter de indruk wenst te vermijden, 'de' constitutionele verhoudingen te negeren.

\subsubsection{Seksuele voorkeur}

Het Hof weigerde onder 'privacy' een recht op 'consensuele sodomie'112 te erkennen in Bowers t. Hardwick. ${ }^{1 / 3}$ Bowers werd vervolgd wegens het plegen van homoseksuele handelingen in zijn huis - in de staat Georgia was wetgeving van kracht die seksuele handelingen tussen personen van hetzelfde geslacht verbood. Rechter White schreef voor een nipte meerderheid. Onder de reeds onder 'privacy' erkende fundamentele rechten - familiebetrekkingen, hwwelijk, voortplanting - bevond zich geen recht, aldus White, dat zich op welke wijze dan ook zou kunnen lenen voor vergelijking met de individuele aanspraak in Bowers. White wees "privacy" als norm van hoger recht, die wellicht zou kunnen leiden tot het ontwaren van een seksuele vrijheid, expliciet af. De individuele aanspraak op 'liberty' werd toegespitst op familiebetrekkingen en gebaseerd op een historische en traditionele benadering van de reikwijdte van grondrech-

111 Rechter Scalia citeerde hier rechter Powell zoals die zich in Moore t. East-Cleveland had uitgesproken. Rehnquist formuleerde het als wolgt in Washington t. Gheksberg, "By extending constitutional protection to an asserted right or liberty interest, we, to a great extent, place the matter outside the arena of public debate and legislative action:"

1 . 12 De lagere rechter had het recht als volgt geformuleerd en erkend: "[...] the Georgia statute violated respondent's fundamental rights because his homosexual activity is a private and intimate association that is beyond the reach of state regulation by reason of the Ninth Amendment and the Due Process Clause of the Fourteenth Amendment", zie Boners t. Mardwick, 478 U.S. 186 (1986).

113 Bowers 6. Hardwick, 478 U.S. 186 (1986). De zaalk werd met 5 -4 beslist in het nadeel van de klager die een anspraak maakte op grondwettige bescherming van zijp seksuele voorkeur en seksuele handelingen in de privé-sleer. 
ten. ${ }^{114}$ De argumentatie voor deze enge definitie van 'liberty" werd in het midden gelaten. Een ruimere maatstaf zou bijwoorbeeld kunnen worden gevonden in een recht op seksuele vrijheid dat wel kan worden ontwaard in Griswold t. Connecticut, Eistenstadt t. Beard en in Roe t. Wade, maar in die zaken niet uitdrukkelijk wordt uitgesproken. In die zaken ging het om 'privacy' in de slaapkamer en de keuzevrijheid om wel of niet voor nageslacht te kunnen kiezen. Uit het recht op 'privacy' in de slaapkamer en een recht om seksuele handelingen te kunnen verrichten zonder dat die tot doel hebben, nageslacht te verwekken zou een aanspraak op homoseksuele handelingen kunnen worden gevestigd. Door de klager was deze zienswijze naar voren gebracht, maar het Hof taalde niet naar een dergelijke benadering en motiveerde de afwijzing van deze benadering verder niet. ${ }^{115}$ Er vond aldus geen analoge redenering plaats die aanleiding zou geven voor extensieve interpretatie.

Met de invulling van 'liberty', geënt op familierechtelijke betrekkingen zette het Hof lijnen uit voor het vervolg van de kwalificatie van de individuele aanspraak: grondwettelijke bescherming van seksuele voorkeur. Het recht op familierechtelijke betrekkingen - in dat vergelijkingskader werden aldus eveneens Griswold, Eistenstadt en Roe geplaatst - dient te worden ingevuld aan de hand van historische beschouwingen aan de hand waarvan de traditionele waarden van de Amerikaanse samenleving kunnen worden opgespoord, aldus het Hof. Aan de hand van historische beschouwingen in het licht van het consensusbeginsel kwam het Hof tot de conclusie, dat het verbod niet meer in alle Staten geldt maar dat een verbod, gezien het aantal staten dat een verbod hanteert, immer nog gerechtwaardigd kan worden:

"Against this background, to claim that a right to engage in such conduct is "deeply rooted in this Nation's history and tradition" or "implicit in the concept of ordered liberty" is at least facetious?. 116

Interessant is, verderop, de verwijzing door het Hof naar Lochner in Bowers: deze verwijzing hangt direct samen met 's Hofs visie op de rechterlijke taakopvatting ter zake van de constitutionele interpretatie in het voorliggende geschil. Lochner, aldus het Hof, is het schoolvoorbeeld van rechterlijk activisme, en dient vanwege de gebruikte redenering pertinent te worden afgewezen ondat die leidt tot willekeurige rechtsvinding. Dat komt in conflict met de constitutionele verhoudingen:

"The Court is most vulnerable and comes nearest to illegitimacy when it deals with judgemade constitutional law hawing little or no cognizable roots in the language or the design of the Constitution. That this is so was painfully demonstrated by the face-off between the Executive and the Court in the 1930's, which resulted in the repudiation of much of the

114 In dit opzicht werd geen dynamisch-evolutieve benadering gehanteerd.

115 Zie voor een extensieve uiteenzetting van' 's Hofs en klagers argumentatie op dit punt Tribe en Dorf 1991 , p. 73 e.v.

116 Het Hof geeft daarbij het volgende overzicht: ten tijde wan de ratificatie van de Bill of Rights was sodomie in alle 13 Staten verboden. In 1868 , toen het Veertiende Amendement werd geratificeerd, was sodomie verboden in 32 van de 37 Staten. In 1961 was sodomie in 50 staten verboden. 
substantive gloss that the Court had placed on the Due Process Clause [...]. The claimed right pressed on us today falls for short of overcoming this resistance'. 117

Met een verwijzing naar Lochner onderbouwde het Hof met de weigering, "nieuwe' fundamentele rechten te willen vaststellen." 118 raag is in hoeverre het Hof "nieuwe rechten' zou scheppen wanneer het de aanspraak van Bowers wel zou hebben erkend. Het Hof geeft in het citaat te kennen, bereid te zijn om rechten die hun wortel in de grondwettekst of in het "ontwerp" wan de grondwettekst hebben. Het Hof wilde evenmin aan een vergelijking met Stantey t. Georgia, volgens welke bezit van obsceen materiaal in de huiselijke privé-sfeer grondwettelijke bescherming genoot. ${ }^{119}$ Eén van de centrale argumenten in Stanley was namelijk, dat bezit van obsceen materiaal nitet strafbaar gesteld mag worden omdat het zich in de persoonlijke, huiselijke sfeer bevond. ${ }^{120}$ De seksuele handelingen in Bowers vonden eveneens in die sfeer plaats. Echter:

'Plainly enough, otherwise illegal conduct is not always immunized whenever it occurs in the home. Victimless crimes $[. .$.$] do not escape the law where they are committed at home.$ [...] And if respondent's submission is limited to the woluntary sexual conduct between consenting adults, it would be difficult, except by fiat, to limit the claimed right to homosexual conduct while leaving exposed to prosecution adultery, incest, and other sexual crimes even though they are committed in the home. We are unwilling to start down that road'. ${ }^{21}$

Van groot belang was het verschil, aldus de meerderheid in het Hof, dat Stanley $t$. Georgia werd beoordeeld onder het Eerste Amendement. Op zich behoeft dat niet problematisch te zijn, getuige de visie wan rechter Douglas op de verenigbaarheid van de perifere sfeer van verschillende Amendementen onder "privacy" in Griswold $t$. Connecticut. Het 'Burger Court' wilde die benadering in Bowers niet overnemen, hoewel in Stanley t. Georgia ook een aspect van 'privacy' werd erkend in de individuele aanspraak. ${ }^{122}$ In deze uitspraak komt het belang van de maatstaf van vergelijkbaarheid naar woren. Van groot belang is de keuze voor het niveau waarop twee casusposities met elkaar worden vergeleken: wordt de vergelijking gezocht op binnen een norm van hoger recht die de rechter kan toepassen op het voorliggende geschil, of wijst hij een dergelijke toepasselijkheid af? Naarmate aan hei vergelijkingsmateriaal, zoals in Bowers, meer gedetailleerde eisen worden gesteld voor wat de vergelijkbaarheid met het voor-

I H7 Bowers t. Hardwick, 478 U.S. 186, 193 (1986).

118 Hiemee appelleerde het Hof aan de werwerpelijkheid wan de rechtsvinding in de jurisprudentie die in die periode (tot de uhitsprak Parish t. West Coast Hotel in 1937). Deze reforentie alan Lochner dook steeds waker op in de rechtspraak, met name waar de rechter de indruk will vermijden dezelfde wijze van rechtsvinding te hanteren.

119 Sranley forgara, 394 U.S 557 (1969)

120 In Bowers stelt Rechter White echter, dat de uitspraak van Stanley voor het overgrote deel op het Eerste Amendennent berust, hetgeen betwist kan worden op basis var het feit dat in Stanley de uitspraak steunt op ther Eerste en tret Veentiende Amendement.

121 Bowers d. Hardwiek, 478 U.S. 186, 193 (1986). In dit citat schuilt een fraaie metafoor: "we are unt" willing to start down that rowd:

122 Moverover, in the context of this case - a prosecution for mere possession in the privacy of a person's own home - that right [het recht, informatie en ideeen te ontwangen, H.L.J.] takes on an added dimension. For also fundamental is the right to be free, except in very limited circumstances, from unwanted governmental ittrusions into one's privacy", rechter Marshall schrijvend voor de meerderheid in Stomley t. Georgia, 394 U.S. 557 (1969). 
liggende geschil, zal het lastiger worden om tot een vergelijk te kunnen komen. Indien twee casus onder een abstracte norm van hoger recht worden beoordeeld, Vigt vergelijkbaarheid eerder voor de hand.

\subsubsection{Hulp bij zelfdoding}

Heeft het Hof zich recentelijk uitgesproken over de grondwettigheid van wetgeving die hulp bij zelfdoding toelaat. ${ }^{123}$ Enkele staten waren overgegaan tot het scheppen van die mogelijkheid; op federaal niveau achtte men een dergelijke ontwikkeling echter onwenselijk. Het Hof heeft geweigerd, het recht op hulp bij zelfdoding te kwalificeren als een recht onder 'liberty' in het Veertiende Amendement. In de zaak Cruzan t. Director, Missowri Department of Health had de lagere rechter een vordering van de ouders van Cruzan om een einde te maken aan het kunstmatig voeden van hun dochter afgewezen. ${ }^{124}$ De lagere rechter achtte bewijs voor het bestaan van een wilsverklaring van de dochter onvoldoende aanwezig. Het Hooggerechtshof diende daarna de vraag te beantwoorden, in hoeverre een recht op hulp bij zelfdoding af te leiden is uit het Veertiende Amendement. Beoordeling van de aanspraak onder het Veertiende Amendement werd niet afgewezen, maar leidde evenmin tot de vaststelling dat er in casu inderdaad een recht was geschonden: een eenduidige wilsverklaring van de patiënt ontbrak im. mers. ${ }^{125}$ De principiële vraag naar toelaatbaarheid van hulp bij zelfdoding werd in Cruzan niet beantwoord.

In Washington t. Glucksberg rees enkele jaren later de vraag of een bepaling van de staat Washington waarin hulp bij zelfdoding wordt verboden, in strijd is met het Veertiende Amendement. De lagere rechter had in deze zaak hierover namelijk het volgende overwogen:

"In examining whether a liberty interest exists in determining the time and manner of one's death, we begin with the compelling similarities between right-to-die cases and abortion cases. [Both] types of cases raise issues of life and death, and both arouse similar religious and moral concerns. Both also present basic questions about an individual"s right to abortion. In deciding right-to-die cases, we are guided by the Court's approach to the abortion cases. 126

De 'issues of life and death' terzake van abortus en hullp bij zelfdoding leidden in de redenering van de lagere rechter tot een norm van hoger recht die invulling geeft aan "liberty" in het Veertiende Amendement:

123. Zie Cruzan t. Director, Missouri Department of Health, 497 U.S. 261 (1990), Washington t. Ghucksberg, 521 U.S. 702 (1997) en Vaccot. Qwill, 521 U.S. 793 (1997).

124 Cruzan t, Director, Missouri Department of Healt 4,497 U.S. 261 (1990).

125 Cruzan t. Director, Missouri Department of Health, 497 U.S. 261, 279 (1990).

126 Compassion in dying t. Washingion, 79 F.3 7 (9de Circuit) in 1996. In deze uitspravk wernietigde de recthter een wet die een verbod stelde op hulp bij zelfdoding. Later kwam deze zack terecht bij het Hooggerechtsthof onder Washingron $t$. Ghucksberg. 
'These matters, involving the most intimate and personal choices a person may make in a lifetime, choices central to personal dignity and autonomy, are central to the liberty protected by the Fourteenth Amendment?. ${ }^{27}$

De aanknoping van de claim van een individu, het moment van sterven zelf te kunnen bepalen, hangt samen met de abstracte begrippen menselijke waardigheid en zelfbeschikking. Over de aansluiting die de rechter bij abortus zoekt; kan worden gesteld dat die niet overtuigend wordt beargumenteerd - de reden, waaróm beide zaken vergelijkbaar zijn, werd door de lagere rechter gezocht op een hoog abstractieniveau zonder nadere motivering van de gronden van vergelijkbaarheid. Het Hooggerechtshof kon zich naderhand niet vinden in deze extensieve interpretatie.

Rechter Rehnquist, schrijvend voor de meerderheid in Washington t. Glucksberg onderzocht vanuit historisch perspectief de wetgeving ter zake en concludeerde dat die in elk geval geen aanleiding gaf voor de aanname van het bestaan van een dergelijk recht. Ook een onderzoek in enkele afzonderlijke staten gaf daartoe geen aanleiding. Rehnquist beschreef de ontwikkelingen in de wetgeving ten tijde van de ratificatie van het Veertiende Amendement. Hij erkende dat de houding ten opzichte van het verschijnsel zelfdoding is veranderd, maar dat de verboden ter zake van hulp daarbij immer nog existeren. Uitgangspunt voor de maatstaf voor het kwalificeren van een "nieuw" recht onder 'liberty' dient, in de optiek van de meerderheid, te zijn dat deze in elk geval in overeenstemming is met tradities, historische beschouwingen en dat deze wortels heeft in de samenleving. Het Hof hanteerde ook bij de vraag naar de erkenning van de individuele aanspraak het argument van de rechterlijke terughoudendheid; die zou gediend zijn bij de hantering van een specifieke maatstaf, en een beschouwing van de aanspraak in het licht wan historische beschouwingen en tradities. Rehnquist herimnerde in Washington t. Glucksberg aan het standpunt van het Hof, dat terughoudendheid dient te worden betracht bij het vaststellen van een nieuwe reikwijdte van "liberty":

"By extending constitutional protection to an asserted right or liberty interest, we, to a great extent, place the matter outside the arena of public debate and legislative action. We must therefore "exercise the utmost case whenever we are asked to break new ground in this field", [...] lest the liberty protected $[\ldots]$ be subtly transformed into the policy preferences of the nembers of this Court". 28

127 Rechter Reinhardts meerderheidopinie in Conpassion in dying t. Washington, 79 F.3d 7 (9de Circuit). p. 813-814. Hij halde daabij Plonned Parenhood t. Casey 505 U.5. 833.851 (1992) aan.

128. Washington d. Ghucksberg, 521 U.S. 702 (1997). Voor een witeenzerting van de kwestie in hoeverre er een onderscheid bestaat lussen Cnizan $t$. Direcror enerzijds, waarin het recht op weigering van een behandeling werd erkend (maar niet gehonoreerd ondat bewijsmateriaal ter zake ontbrak) en $W_{\text {ashing }}$

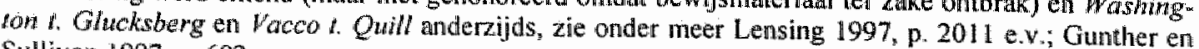
Sullivan 1997, p. 602 e.v. 


\subsection{Bevindingen}

\subsubsection{Inleiding}

De zaken vonden hun weg naar het Hof via de procedure van 'certiorari'. ${ }^{129}$ In een klein deel van deze gevallen beoordeelde het Hof in deze procedure beslissingen van federale rechters; daarnaast beoordeelde het Hof eveneens uitspraken van statelijke rechters. Wat de rechtsmacht over de statelijke rechters betreft, is een belangrijk criterium dat de uitspraak een eindbeslissing moet inhouden, en dat er een federale kwestie aan de orde moet zijn. ${ }^{130}$ De uitspraken van federale rechters bereikten het Hof via de federale Courts of Appeal ${ }^{131}$ en in enkele gevallen direct vanuit de District Courts. ${ }^{132}$ In enkele gevallen sprak het Hof over 'probable jurisdiction'; in deze gevallen was het geschil via de certiorari procedure direct na de uitspraak bij het District Court bij het Hof aangebracht. ${ }^{133}$ Het Hof geeft lang niet in alle gevallen aan, waarom het de zaak in behandeling nam. In enkele gevallen stelt het Hof in de uitspraak wel expliciet, dat er een dreigende ongelijke rechtsbedeling dreigt te ontstaan bij de lagere - federale Courts of Appeal - rechters. ${ }^{134}$ Ook kan het Hof het noodzakelijk vinden, een constitutionele vraag op te lossen; dit was de voornaamste reden om de zaken omtrent hulp bij zelfdoding toe te laten tot beoordeling. ${ }^{135}$ In bijna alle onderzochte gevallen werd geklaagd over statelijke wetgeving, die in strijd werd geacht met 'liberty' uit het Veertiende Amendement, of met 'privacy'. ${ }^{136}$

In de meeste zaken werd geklaagd over een schending van 'liberty'. Het begrip "privacy" veroverde pas na Griswold t. Connecticut een eigen plaats tussen de gepositiveerde individuele rechten. Vaak vormde strafrechtelijke vervolging een aanknopingspunt, om wetgeving als strijdig met het recht op 'liberty' - en later 'privacy' - aan het Hof voor te leggen. De strafrechtelijke vervolging, en in enkele gevallen de weigering tot afgifte van toestemming of vergunning, vormde de aanleiding om de onderliggende

129 Zie par. 3.2 .2 .

130 Een willekeurige greep: zie bijwoorbeeld Lochner t New York, 198 U.S. 45 (1905), Meyer t. Nebraska. 262 U.S. 390 (1923), Griswold t. Connecticut, 381 U.S. 479 (1965), Moore t. East-Cleveland 431 U.S. 494 (1977), Michael H. I. Gerald D., 491 U.S. 110 (1989).

131 Zie bijwoorbeeld Kent t. Dulles, 357 U.S. 116 (1958), en Vacco t. Quill, 521 U.S. 702 (1997).

132 Zie bijwoorbeeld Roe t. Wade, 410 U.S. 113 (1973).

133 Roe t. Wade, 410 U.S. 113 (1973), Zablockit. Redhail, 434 U.S. 374 (1978).

134 Bowers t. Hiandwick, 478 U.S. 186 (1986).

135 Cruzan t. Director, 497 U.S. 261 (1990). Daarnaast kan het eveneens woorkomen, dat het Hof een constitutionele kwestie op het terrein van de individuele rechten niet ter beslissing aam wil nemen. Hiervoor dienen de certiorari-beslissingen bestudeerd te worden, waarin het Hof besloot tot niet-beoordeling van het geschil. In casu zijn deze beslissingen niet afzonderlijk onderzocht. Er is verder geen specifiek onderzoek verricht naar de "certs deaied" waarin individuen aanspraken maakten op "privacy'; de afwijzingen behoeven niet te worden gemotiveerd waardoor het lastig is om een compleet beeld te krijgen van het aannamebeleid wan het Hof. Onderzoek hiernaar was in dit verband niet noodrakelijk; in dit onderzoek wordt enkel gekeken naar de zaken waarin het Hof zich wel heeft titgelaten over de grond wettelijke 'geldigheid' van individuele aanspraken.

136 Dat doet vermoeden, dat de constitutionele verhouding, woor zover die een rol speelde in de keuze voor de gewolgde interpretatie, niet alleen in de horizontale machtenscheiding ligt, maar waarschijnlijk ook aspecten van de werticale machtenscheid ing dekt. 
wetgeving die ten grondslag ligt aan het besluit te toetsen aan het Veertiende Amendement. Het Hooggerechtshof hanteert echter geen toetsing in concreto: wanneer het besluit is genomen of de vervolging wordt ingesteld op basis van ongrondwettige wetgeving, is daarmee de onderliggende wet in strijd met de grondwet. ${ }^{137}$ Het Hof bleek in Poe t. Ullman niet bereid zonder een concrete casus een toetsing uit te voeren, maar daarmee wordt niet iedere rechterlijke toetsing met een abstract karakter uitgesloten. ${ }^{138}$

Het debat in het Hof over constitutionele interpretatie laat zien, dat analoge redeneringen in de constitutionele interpretatie nuet vanzelfsprekend worden aanvaard. Originalists en intentionalists maken zich in de laatste twee decennia sterk voor een strikte lezing van de tekst zoals de 'Framers' die hebben neergeschreven. Die invalshoek wordt door anderen juist weer bestreden; zij voeren aan dat geredeneerd dient te worden vanuit aan de grondwet ten grondslag liggende rechtsbeginselen met een beroep op de bedoeling en huidige betekenis van een grondwet. Wanneer die rechten niet expliciet in de grondwet vastgelegd zijn maar wel kan worden aangetoond dat zij 'aanwezig' zijn in de rechtsorde, lijkt het Hof soms bereid om een analoge redenering te gebruiken: aan de hand van jurisprudentie en andere bronnen zal het Hof trachten die aanwezigheid te legitimeren. Het recht op 'privacy' zoals gepositiveerd in Griswold is niet tekstueel uit de grondwet af te leiden; het werd via de rechtsanaloge redenering 'ingelezen". 'Liberty' is een begrip dat niet behoefde te worden gepositiveerd; het bevond zich immers al in het Vijfde en het Veertiende Amendement. Dat houdt niet in dat de omvang van 'liberty' vaststaat; wanneer een nog niet eerder beoordeelde individuele aanspraak op 'liberty' wordt gedaan beziet het Hof in welke mate de aanspraak. door 'liberty" bestreken wordt, en dient zich de vraag aan hoe het Hof zijn lezing van 'liberty' in het gegeven geval rechtvaardigt.

\section{4 .2 Ontwikkeling van de grondslag voor de normen van hoger recht}

De erkenning van een recht op 'privacy' als geldende rechtsnorm in de Amerikaanse rechrspraak is niet goed vast te leggen op één moment in de jurisprudentie. "Privacy" werd in Griswold gepositiveerd, maar de gelding van 'privacy' als rechtsnorm leek daarmee niet direct aanvaard. ${ }^{139}$ In latere rechtspraak blijven rechters steeds zeer kritisch over het recht op 'privacy", maar het heeft meermaals als grondslag voor positivering van ongeschreven rechten gediend en is tot dusverre niet uit de rechtspraak verbannen. Ook voorafgaand aan Griswold lijken er aanwijzingen te bestaan dat een dergelijk recht gepositiveerd zou gaan worden. Een reeks concretiseringen uit 'liberty' stond model voor de wijze waarop naderhand uit 'privacy' individuele aanspraken zouden worden erkend. Skinner werd nog niet beschouwd onder het recht op 'privacy', maar had al wel elementen in zich terzake van de het belang van het individu om over zijn eigen voortplanting te kunnen beslissen. 'privacy' was ten tijde van deze uitspraak

137 Par. 32.5

138 Par, 3.2.3.

139 Dat leek tot op zekene hoogte ook te maken te hebben met de materie die in Griswold t. Connecticut en naderhand in Roe $t$. Wade werd bestreken; over het gebruik van voorbehoedmiddelen en het besluit om abortus te ondergaan bestonden (en over abortus bestaan) nog steeds scherp verdeelde opvaitingen. 
nog geen thema in de Amerikaanse constitutionele rechtspraak; het Hof knoopte aan bij de "basic identity" als norm van hoger recht om de reikwijdte van 'liberty' vast te stellen. Deze jurisprudentie onder 'liberty" vormde later de basis voor de ontwikkeling van het recht op 'privacy' zoals geconcipieerd in Griswold.

De eerste aanwijzingen voor de intentie om een zelfstandig constitutioneel recht op "privacy" te ontwikkelen zijn te vinden in Poe t. Ullman, waarin rechters Douglas en Harlan in hun dissentings een inhoudelijke visie op het geschil geef. ${ }^{140}$ Dissentings en comcurrings vormen soms een proeftuin waarin nieuwe visies worden ontwikkeld en vooral uitgezet om te bezien wat de reactie in de (juridische) gemeenschap darop is. Voorafgaand aan Poe t. Ullman bestond al een common law begrip van een recht op 'privacy'; de discussie van het recht op 'privacy' gaat in elk geval terug tot eind negentiende eeuw, toen Brandeis en Warren in een artikel pleitten voor het bestaansrecht van "privacy'. "14 De privaatrechtelijke notie speelt echter geen zichtbare rol in Griswold. In de jurisprudentie na Griswold werd 'privacy' in een reeks van uitspraken herhatd als grondslag voor andere aanspraken. Slechts een deel van die aanspraken werd uiteindelijk erkend, maar dat zegt niet per se iets over de gelding van "privacy" als rechtsnorm: het feit dat het Hof onderzoekt of de aanspraak kan worden gekwalificeerd als een aanspraak onder "privacy" is tot op zekere hoogte voldoende voor een bestendiging. In dit opzicht kan gesproken worden van een rationalisatie achteraf.

\subsubsection{Het recht op persoonlijkheid: bewindingen in interpretatie en reikwijate}

\section{Het recht op voortplanting}

Het Hof heeft, na de positivering van de rechtsnom 'privacy' als éen van de constitutionele 'unenumerated rights' in Griswold, een aantal nieuwe rechten onder 'privacy' erkend. Vraag is nu, of gezegd kan worden welke aanspraken 'privacy' bestrijkt en of voorspelbaarheid ter zake is af te leiden uit de rechtspraak. Het omvat volgens de rechtspraak van het Hof in ieder geval de mogelijkheid van het individu om zelf te kunnen beslissen over zijn woortplanting. In Griswold werd het recht op priveleven in de echtelijke slaapkamer gepositiveerd. Roe lijkt in dit verband een soort sluitsteen: het Hof erkende een recht op "personal privacy" dat kenmerken vertoont van een meer algemeen persoonlijkheidsrecht. In Roe ontbrak dat element van het binnendringen in de echtelijke 'privacy' geheel: in deze uitspraak leek het er sterk op dat de 'personal privacy', een individuele zelfbeschikking, van de vrouw centraal stond. Eisenstadt had voor deze invulling van 'privacy' de weg vrijgemaakt. ${ }^{142}$ 'To beget', of het doen ont-

140 Poe L. Uhmon werd door het Hof niet beoordeeld, omdat er geen sprake was vanu een concreet geschil. Hett Hof weigerde abstracte toetsing.

141 Warren en Brandeis, 4 H.L. Rev. $193(1890)$; zie par. 2.3 .4$.

142 In de literatuur wordt gesuggereerd, dat thet Hof in Eisensladi met opzet de formulering toespitste op het recht "to bear or beget a child" met het oog op hangende abortuszaken. Zie onder meer het wolgeride commentaar: "More important, Brennan added the crucial "bear or beget" language in Eistenstadt precisely because, while he was working on his Eisenstadt draft, the Court was already considering Roe Brenman knew well the tactic of "burying bones" - secreting language in one opinion to be dug up and put to use in another down the road. Eisenstadt provided the ideal opportunity to build a rhetorical 
staan of verwekken, refereerde in Eisenstadt aan het recht van een paar, anticonceptiva te gebruiken, terwijl "to bear", het dragen van een vrucht, enkel kon verwijzen naar een recht van de vrouw: De invulling van "privacy" in Roe leek op een ruime opvatting van het begrip 'privacy" van het Hof te duiden: een meer algemeen persoonlijkheidsrecht, waarin zelfbeschikkung van het individu over het eigen leven en keuzen ten aanzien daarvan centraal staat. Over de reikwijdte van "privacy" is het einde van de discussie echter niet in zicht. Het lijkt erop, dat het Hof een andere koers heeft gekozen na Roe t. Wade ter zake van de bereidheid, nieuwe concretiseringen van "privacy' te willen erkennen. Het recht op "privacy" omval bijvoorbeeld niet, zo bepaalde het Hof in Bowers t. Hardwick, een vrijheid van het individu, zelf in de prive-sfeer te beslissen over de eigen seksuele voorkeur. Het omvat evenmin een aanspraak op hulp bij zelfdoding.

\section{Huwelijk, gezinssamenstelling en het weigeren wan medische behandelingen}

Het recht te huwen met een partner van eigen keuze werd door het Hof erkend als individueel recht. In Loving werd dat recht nog afgeleid uit "liberty" uit het Veertiende Amendement; in Zablocki werd het recht te kunnen huwen gezien als én van de "personal decisions protected by the right of privacy". ${ }^{143}$ Skinner dat de grondslag bood voor de rechtsvinding in Loving werd beoordeeld onder "liberty". 144 Zogenaamd 'overspelige samenwonenden' die vanwege die reden waren ontheven uit hun functie van werknemer bij een overheidsinstelling deden later echter vergeefs een beroep op het recht op "privacy', 145 Zo lijkt het Hof de reikwijdte van 'privacy' heeft willen abakenen tot relaties tussen individuen die in de samenleving zijn aanvaard. Het opvoeden van kinderen en de vrije keuze van onderwijs werden door het Hof gepasitiveerd onder 'liberty', lang vóórdat het Hof het recht op 'privacy' had ontwikkeld. "46 Het recht van het individu, om zelf een gezinssamenstelling te kiezen werd onder het recht op 'liberty' erkend. Afwijkende samenstellingen van het 'kerngezin' mogen niet worden benadeeld bij de toewijzing van woningen, aldus het Hof in Moore t. East Cleveland. ${ }^{147}$

De keuze voor een andere grondslag dan 'privacy' - in de hier genoemde gevallen werd steeds 'liberty' gekozen - heeft deels te maken met het feit, dat 'privacy' tot Griswold niet de status had van gepositiveerde en geldige rechtsnorm. In de zaken ná Griswold is het lastiger te verklaren, waarom in het ene geval voor 'Hiberty' en in het andere voor "privacy" werd gekozen. In Cruzan t. Director werd geclaimd dat 'privacy" een

bridge betweet the right to use contraceptives and the abortion issue pending in Roe" , zie Lazarus 1999; p. $365-365$.

143 Loving I' Nirginia, 388 U.S. I (1967) an Zablocki t. Redhail, 434 U.S. 374 (1978).

144. Nasi Skimer werd Mamard t. HW, 125 U.S. 190, 205 en 210-211 (1888) aangevoerd voor het bestaan van het betang van het huwelijk als onderdeel van 'liberty".

145 Holenbaugh i. Castegie Free Library, 439 U.S. 1052 (1978); certiorari werd niet toegekend en Whisenhmo t. Spradlin, 464 U.S. 965 (1983); certiorari werd evenmin toegekend. In het eerste geval achtte het Hof het recht op gelijke behandeling niet geschonder; in het tweede geval liet hek Hof de beslissing van het Court of Appeals in stand, inhoudende dat er ten aanzien van het ontslag geen sprake was van een strafsanctie zoals vereist in het Veertiende Amendement.

146 Pierce t. Socieb of Sisters, 268 U.S. 510 (1925) en Meyert Nebraska, 262 U.S. 390 (1923).

147 Moore L. East Cleveland, 431 U.S. 494 (1977). 
recht op weigering van medische behandeling omvat, ook als het stopzetten van de behandeling tot gevolg heeft dat de patiènt komt te overlijden. ${ }^{148}$ In deze zaak lijkt het Hof erkenning onder 'privacy' te hebben afgewezen omwille van de connotatie van 'privacy' met een abstract algemeen persoonlijkheidsrecht. ${ }^{149}$ Uiteindelijk werd de aanspraak onder een common law concept van 'informed consent' beoordeeld alsmede onder het recht op 'bodily integrity", zoals gepositiveerd in Jacobson t. Massachusetts. ${ }^{150}$ Een recht op hulp bij zelfdoding werd door het Hof noch onder een recht op "privacy", noch onder "liberty" erkend. "151 De kwalificatie van Cruzan's aanspraak onder een common law concept, dat minder ruim is dan een constitutioneelrechtelijk concept van 'privacy' bood het Hof de gelegenheid Facco t. Quill naderhand op formele gronden af te wijzen onder "privacy'.

\section{Bestendiging}

"Liberty" als zodanig behoefde geen bestendiging in de constitutionele rechtspraak; het is immers vastgelegd in de Bill of Rights in het Vijfde en het Veertiende Amendement. Voor 'privacy" was die bestendiging minder vanzelfsprekend, ondat het zijn basis enkel heeft in de rechtspraak. In de jurisprudentie na Griswold werd 'privacy' in een reeks van uitspraken herhaald als grondslag voor andere aanspraken. Slechts een deel van die aanspraken werd uiteindelijk erkend, maar dat zegt niet steeds iets over de gelding van 'privacy' als rechtsnorm: het feit dat het Hof onderzoekt of de aanspraak kan worden gekwalificeerd als een aanspraak onder 'privacy' is tot op zekere hoogte voldoende voor een bestendiging. Het fungeerde, afgaande op de onderzochte rechtspraak, als een vertrekpunt voor de formulering van nieuwe afgeleiden. In de uitspraken van de laatste twee decennia is echter een tendens te zien waarin 'privacy' als grondslag voor individuele aanspraken nauwelijks wordt benut.

\section{De reikwijdte van privacy en liberty vergeleken}

Wat de omvang van 'liberty' betreft, heeft het Hof in Planned Parenthood t. Casey aangegeven dat "these matters, involving the most intimate and personal choices a person may make in a lifetime, choices central to personal dignity and autonomy, are central to the liberty protected by the Fourteenth Amendment". 152 Met de "most intimate and personal choices' doelde het Hof op huwelijk, voortplanting, gebruik van voorbehoedmiddelen, familiebetrekkingen, opvoeding van kinderen en de keuze voor hun opleiding. Nu blijkt uit de onderzochte rechtspraak, dat sommige van de hiervoor in Planned Parenthood t. Casey genoemde aanspraken werden erkend onder "liberty", en enkele onder "privacy". "Privacy" lijkt, afgaande op de onderzochte jurisprudentie,

148 Cruzan t. Oirector, 497 U.S. 261 (1990).

149 Cruzan t. Director, 497 U.S. 261,271 (1990).

150 Jacobson t. Massachusetis, 197 U.S. 11 (1905).

Is! Facca t. Quill, nr. 95-1858, 26 juni 1997.

152 Plonned Parenthood Casey, 505 U.S. 833 (1992).

153 Huwelijk werd eerst onder "liberty' en later onder 'privacy' beoordeeld; anspraken gerelateerd aan voortplanting tot Griswold onder "liberty", ema onder "privacy"; gebruik van voorbehoedmiddelen werd onder "privacy' beoordeeld, evenals abortus; familyebetrekkingen werden weer onder "liberty' beoor. 
een deelverzameling van aparte subnoties bìnnen "liberty" in het Veertiende Amendement te omvatten. Binnen alle gedragingen die 'liberty" omvat, houdt "privacy" een te onderscheiden categorie van gedragingen in. Uit de literatuur en de rechtspraak blijkt echter niet eenduidig, welke gedragingen in toekomstige individuele aanspraken binnen 'privacy' en welke binnen 'liberty' gekwalificeerd moeten worden. ${ }^{154}$ In de literatuur wordt overigens gesuggereerd, dat er een inhoudelijk wel verschil te maken is tussen "liberty" en "privacy".

'Privacy', zo stelt Ely, is een recht dat centraal stelt dat het individu een recht heeft op een eigen, afgeschermde ruimte van regulering van staatswege. De hiervoor uit Casey geciteerde rechten centreren zich allen rond dit thema: het individu komt een recht toe, op bepaalde terreinen autonome keuzes te maken zonder overheidsbemoeienis van buitenaf. Naast dit concept van zelfbeschikking in een beslotenheid bestaat er een notie van zelfbeschikking die zich in de publieke sfeer beweegt. Die tweede notie heeft betrekking op het maken wan autonome keuzes in de gemeenschap. Deze rol van het individu in de gemeenschap is van belang met het oog op betekenisvolle participatie van het individu in het politieke proces. ${ }^{155}$ Zo bezien staat 'liberty' in dienst van politieke rechten, en omvat mede het recht op vrijheid van meningsuiting en het recht op verenigingsvrijheid. 'Privacy' is in dit verband een negatieve uitdrukking van 'liberty" omdat het primair staatsonthouding stipuleert, terwijl de politieke rechten als bijvoorbeeld neergelegd in het Eerste Amendement juist een positieve uitdrukking zijn van 'liberty'.

Een belangwekkend verschil tussen kwalificatie van de individuele aanspraak onder 'privacy' of 'liberty' is gelegen in het feit dat erkenning onder 'privacy' een verzwaarde bescherming tot gevolg heeft. Het Hof laat in de laatstgenoemde situatie in het algemeen een intensieve beoordeling van de gewraakte wet volgen. Bij 'liberty' volgt deze verzwaarde bescherming niet altijd. ${ }^{156} \mathrm{De}$ in de Bill of Rights erkende rechten worden door het Hof in beginsel benaderd als 'fundamentele rechten'. Het Hof bezigt een aantal criteria om vast te stellen of een grondrecht een 'fundamental' karakter toekomt. Het meest, en wellicht het enige, pregnante criterium in de vaststelling van de 'fundamentality' van een recht in de huidige rechtspraak, is de mate waarin een recht voldoende wortel heeft geschoten in de historie en het bewustzijn van de natie. ${ }^{15 ?}$ Indien de individuele aanspraak nu wordt erkend als een fundamenteel recht, stelt het

deeld en opvoeding en keuze wan de opleiding wan kinderen door de ouders eveneens.

15.4. Zie bijwoorbeeld Hoffman 1997 , p. 202 e.v. en Ely 1980

155 Ely 1980 , met name hoofdstuk 3 .

156. Een aanspraak op 'privacy' inhoudende een recht, om zelf de haarlengte te kunner bepalen in het kader van werkzaamheden in politiedienst werd niet erkend onder 'privacy', matr wel onder "liberty" (Kelley t. Johnson, 425 U.S. 238 (1976)). Zie ook Whalen i. Roe, 429 U.S. 589 (1977), waarin het opslaan van gegevens van patienten met betrekking tot gebruik van medicijnen door klagers in strijd werd geacht met 'privacy'. Het Hof oordeelde in die zaak, dat het feitencomplex niet gekwalificeerd diende te worden onder "privacy" maar onder "liberty". Er vond een marginale toetsing plaats.

157 Ducat en Chase 1992 , p. 93 e.v. Hierover bestaat in de literatuur geen eensgezindheid. Een fraaie benadering terzake van de methodologie aan de hand waarvan het Hof het fundamentele karakter van een aanspraak vaststellt is te winden in Hofiman 1997: "The methodology is so indistinct that one is apt to conclude that a right is simply fundamental when a majority of the Court says it is ( $\mathrm{p}$. 179). 
Hof zware eisen aan het besluit dat inbreuk maakt op het geclaimde recht. De kwalificatie als fundamenteel recht is van groot belang voor de toetsingsintensiteit die het Hof naderhand zal aanwenden in de materiële beoordeling van grondwettigheid van het besluit.

Aanspraken onder 'liberty' worden aldus niet altijd als fundamenteel erkend. Aanspraken onder "privacy' worden daarentegen wel altijd als fundamentele rechten aangemerkt. Het is opvallend, dat het Hof geen uitleg heeft gegeven ter zake van de voorkeur voor 'privacy' in plaats van voor 'liberty'. De rechtspraak betreffende de erkenning van het recht op abortus is in dit verband exemplarisch. In Planned Parenthood t. Casey werd het recht op zwangerschapsarbreking onder 'liberty' geplaatst. ${ }^{158}$ Dat is vreend, omdat de positivering van dat recht in Roe t. Wade juist zo expliciet onder "privacy" plaatsvond. De vraag rijst of deze 'nieuwe' kwalificatie gevolgen kan hebben voor de toetsingsintensiteit die wordt gehanteerd bij aanspraken die direct of indirect op een recht op abortus zijn gelieerd. De uitspraken na Roe geven een wisselend beeld ter zake van de kernoverwegingen in Roe. ${ }^{159}$ De standaard van de 'undue burden' dient ervoor te waken dat het recht niet wordt uitgehold. Het Hof stelt in zijn latere rechtspraak. evenwel dat de kernoverweging van Roe $t$. Wade niet is aangetast; niet zeker is of dat zo zal blijven, gezien de nipte meerderheden waarmee de latere abortusuitspraken werden ondersteund. Ook kan worden gesteld, dat sinds de positivering van het recht in Roe geen positieve verplichtingen - 'affirmative rights'- kunnen worden afgeleid uit het recht op abortus. ${ }^{160}$ Daarnaast heeft het Hof in Planned Parenthood $t$. Casey een beslissing genomen ter zake van de termijnen van strafbaarstelling: het in Roe ontwikkelde trimestersysteem werd afgeschaft, en werd 'viability' of levensvatbaarheid van de foetus het belangrijkste criterium bij de vaststelling of abortus strafbaar dient te $\mathrm{zijn}^{161}$ Het recht is geen rustig bezit in de constitutionele rechtspraak.

\subsubsection{De analoge redenering}

De uitspraken van het Hooggerechtshof zijn interessant omdat de relatie tussen constitutionele interpretatie en de juiste verhouding tussen rechter en weigever waarneembaar wordt. Het Hof worstelt zichtbaar met de juiste rechterlijke taakopvatting waar het gaat om het oplossen en regelen van netelige ethische kwesties in de samenleving. Dient het Hof zich dergelijke kwesties aan te trekken, of juist aan de federale of statelijke wetgever over te laten? Wanneer het Hof besluit om voor het voorliggende geschil bij afwezigheid van toepasselijke grondwetgeving over te gaan tot een grond-

158 Planned Parenthood t Casey, 505 U.S. 833, 846 (1992).

159 De kemoverweging in Roe luidt: 'We, therefore, conclude that the right of personal privacy includes the abortion decision [...]', Roe i. Wade, 410 U.S. 113, 154 (1973), zie ook Planned Parenthood 1. Casey. 505 U.S. $833,87 \rrbracket(1992)$.

160 Recht op vergoeding van de ingreep van staatswege is er niet uit af te leiden (Beal't. Doe, 432 U.S. 438 (1977) en Rust t. Sullivan, 500 U.S. 173 (1991)). Statelijke ziekenhuizen kunnen niet worden verplicht tot het uitvoeren wan abortus (Maher t. Roe, 432 U.S. 464 (1977)).

161 Webster t. Reproductive Health Services, 492 U.S. 490 (1989) en Planned Parenthood 1. Casey, 505 U.S. 833 (1992). 
wettelijke constructie yoor oplossing van het geschil stelt hij zich activistisch op, zo leren dissentings en sommige concurrings ons wanneer de meerderheid besluit om het geschil op basis van een dergelijke constructie te beslechten. In het omgekeerde geval betichten de dissentings en concurring opinions de meerderheid van een te terughoudende taakopvatting: zij sluit de ogen voor de tekortkomingen van een democratisch gelegitimeerde wetgever en doen de rechtsbescherming van het individu tekort op oneigenlijke gronden. Deze is, zo deze critici, niet in staat om voldoende accuraat te reageren, terwijl het da:arnaast gezien de materie die aan de orde is niet wenselijk is dat een meerderheid zich uillaat over de vraag hoe een minderheid zich in zijn privé-leven dient te gedragen. ${ }^{162}$ In de interpretatiedebatten in het Hof wordt steeds gezocht naar de juiste benadering van individuele aanspraken die niet in eerste instantie lijken te kunnen worden geplaatst onder bestaande grondrechten. Het kamp waarin zich de pleitbezorgers wan de originalists en intentionalists bevinden, wijzen analoge redeneringen waaruit ongeschreven rechten naar voren komen steeds af vanwege de in hun optiek niet aanwezige wettelijke grondslag voor ongeschreven rechten. Zij stellen dat er zo nauw mogelijk dient te worden aangesloten bij de wettekst, omdat extensieve interpretatie kan leiden tot willekeurige positiveringen. ${ }^{163}$ De norm van hoger recht ontbeert een dergelijke basis al gauw, of is althans niet aanwijsbaar. De interpretevists stellen daarentegen dat wanneer extensief wordt geïnterpreteerd, er geen 'nieuwe' rechten worden gepositiveerd.

De vraag rijst warauit valt af te lezen of de rechter bereid is een aanspraak te erkennen - of elementen in de redenering duiden op een voorspelbaarheid in die richting. Opvallend is dat zowel de originalists en intentionalists alsook de interpretevists in hun rechtsvinding de analogie hanteren. Hierbij dient te worden aangetekend dat originalists en intentionalists die tot dusverre niet gauw gebruiken om onder turen te ontwaren waar het om grondrechten gaat. Zij hanteren de analoge redenering met een rechtsnom wan hoger recht indien nodig met name wanneer de inhoud van de zaak betrekking heeft op de horizontale of verticale machtenscheiding " ${ }^{164}$ Voorspel-

162. Dit komt mar voren in de dissenting van Brennan in Mohach H. G. Gerald D., 491 U.S. 110, 141 (1989).

163 In dit opzichnt zijn er rekkelijke en meer precieze pleitbezorgers van de tekstuele interpretatie, zie ook par. 4.3 .1

164 Er werd gezocht naar de mate watrin de recliters (meest origünalists) die hantering van een abstracte nom wan hoger recht afwijzen, consequent zijn. Een korte zoekactie leverde in het Amerikanse gewall direct een aantal interessante amwijzingern op dat van het consequent volhouden van het standpunt wan ean zo specifiek mogelijke norm van hoger recht door de rechters geen sprake kan zujn. Rechters die stellen dat het juist is om ter zake wan grondrechten een specifieke norm van hoger rechl te gebrutken vanuit hat oogpunt van objectiviteit en respect voor de oorspronkelijke grondwetgever, zijn evenwel bereid on ter zake van geschillen met dederalistische aspecten juist een abstracte vergelijkingsmaatstaf to hanteren. Uit he; oogpunt van objectivering van de rechterlijke rechtsvinding lijkt mij deze benadering niet houdbaar. Zie bijvoorbeeld Printz t. Unied Shates, 521 U.S. 898 (1997), waarin rechter Scalia sclrijuend voor te meenderheid zijn redenering opbowwt aan de hand van een wetsanaloge redenering. Scalia wijst deze wijze wan tedeneren pertinent af wanneet grondrechten in het geding zijn, maar acht deze kennelijk wel legitiem in kwesties met betrekking tot de verticale machtenscheiding. Zie eveneens Nevado t. Hal, 440 U.S. 410 (1979), waarin rechter Rehnquist, die eveneens afwijzend stat tegenower het gebruik yan de analogie in grondrechtelijke aanspraken, de analoge redenering harteerde. Hetzelfde geldi voor rechter Thomas (zie U.S. Term Limits, Inc. t. Thomton, 514 U.S. 779, 845 (1979)) die in zijn 
baarheid voor de erkenning van een individuele aanspraak als aspect van 'privacy' kan niet worden gegeven. Dat hangt tot op grote hoogte samen met de wijze waarop het Hof is samengesteld. De laatste twee decennia lijkt het Hof minder bereid, nieuwe aanspraken onder 'privacy' te kwalificeren, of een 'fundamentality' van 'liberty' te aanvaarden. Het onvoorspelbare element in deze is met name gelegen in het feit dat de onderwerpen veelal leiden tot $5-4$ beslissingen, waardoor de uiteindelijke urtkomst van de zaak afhankelijk is van de swingvoter. Daarnaast is niet altijd duidelijk hoe over een bepaalde uitspraak is gestemd: de laatste jaren geeft de jurisprudentie steeds vaker 'gedeelde meerderheden' of 'gedeelde minderheden' te zien: in één uitspraak geven rechters afzonderlijk aan of zij een onderdeel in de besluitvorming steunen of niet. Planned Parenthood t. Casey is in dit verband een goed voorbeeld. ${ }^{165}$ Gevolg is dat er grote onzekerheid kan bestaan over de interpretatiedoctrine die het Hof volgt.

Het zogenoemde 'Lochnerizing' ontwikkelde zich tot een praktijk waarmee latere rechters zich zeker niet mee wilden associëren: het Hof had zich via deze formule naar de zin van velen te activistisch opgesteld. Het activisme was daarin gelegen, dat de erkenning van de individuele aanspraak - vanwege de 'fundamentality' van het recht 'privacy' - tot ingrijpen in federale of statelijke wetgeving. Bij de positivering van 'privacy' in Griswold t. Connecticut rees de vraag of het Hof zich niet weer aan 'Lochnerizing' schuldig maakte. Rechter Douglas, schrijvend voor de meerderheid van het Hof vond zelf van niet: Lochner was het voorbeeld waarin het Hof als een opperwetgever bepaalde hoe wetten op terrein van economische en zakelijke kwesties en sociaal-economische vraagstukken moesten worden opgelost, terwijl in Griswold een inbreuk van staatswege aan de orde was op de intieme relatie tussen twee individuen. ${ }^{166}$ De inhoudelijke problematiek was van andere orde, maar dat neemt niet weg dat het Hof in Griswold eveneens een analoge redenering hanteerde voordat het recht op 'privacy' kon worden gepositiveerd. De analogie waarop Lochner steunde lijkt echter wel van andere kwaliteit te zijn dan Griswold: in Lochner werden nauwelijks precedenten aangehaald als basis voor het bestaan van een recht op vrij contracteren, terwijl rechter Douglas zijn argumentatie voor het bestaan van een recht op 'privacy' in Griswold steunde op andere Amendementen en rechtspraak. Douglas expliciteerde zijn vergelijkingsmateriaal en motiveerde de gekozen bronnen in de jurisprudentie. Hij rechtvaardigde zijn keuze op een uitvoeriger wijze dan het Hof in zijn redenering in Lochner, maar de oorsprong van de redenering, de analogie, bleef dezelfde.

\section{Penumbral reasoning}

De redenering zoals gebruikt in Griswold wordt in de Amerikaanse literatuur ook wel 'penumbral reasoning' genoemd. ${ }^{167}$ Met 'penumbral' wordt bedoeld, dat met deze vorm redeneren logische gevolgtrekkingen voortvloeien uit de relevante onderdelen

dissenting de analogie hanteerde voor een door hem gewenste uitleg van het Tiende Amendement in een verticale machtenscheidingkwestie.

165 Planned Parenthood t Casey, 505 U.S. 833 (1992).

166 Griswold t. Connecricut, 381 U.S. 479 (1965).

167 Denning en Reynolds 1997, p. 1092. 
van de constitutie, of uit de constitutie als geheel, eventueel ondersteund met rechtspraak. Heel simpel gezegd betekent "penumbral reasoning" dat nieuwe rechten worden ingevoegd tussen de uitgesproken uitgangspunten in de Constitutie. De onuitgesproken uitgangspunten vormen dan 'logische aanwezigen' in de structuur van de Constitutie. 168 De analoge redeneerwijze zoals hier onderzocht is hiermee identiek: daarin wordt eveneens de structuur van de constitutie tot uitgangspunt genomen voor het detecteren van nieuwe rechten, en kan de rechtspraak aanknopingspunten opleveren voor positivering van nieuwe rechten. Het Amerikaanse Hof heeft met betrekking tot federalisme-vraagstukken reeds in het begin van de negentiende eeuw gebruik gemaakt van analoge redeneringen teneinde vast te stellen of het voorliggende geschil nu wel of niet door de grondwet werd bestreken en hoe het diende te worden opgelost. ${ }^{169}$ Toch wordt Griswold het vaakst aangemerkt als 'penumbral' "waarschijnlijk mede omdat daar expliciet werd gesproken over de 'penumbras', of halfschaduwen van Amendementen die allen iets van een sfeer van 'privacy" in zich dragen. ${ }^{170}$ "Penumbral reasoning' wordt door de interpretevists in het debat over positivering van grondrechten aanvaard. De originalists en intentionalists wijzen de interpolatie aan de hand van "penumbral reasoning" daarentegen af waar het gaat or constitutionele interpretatie op het terrein van grondrechten. Zij wijzen daarmede niet de analoge redenering in alle kwesties af; zij maken daar evenzeer gebruik van.

\section{Algemeenheid en specificiteit in de analogie}

De juiste mate van algemeenheid en specificiteit van de analoge redenering zijn in het Amerikaanse debat met name sinds Bowers $t$. Hardwick onderwerp van discussie. In de interpretatie van de begrippen 'liberty' en 'privacy' heeft de analoge redenering zoals voorheen aangetoond regelmatig extensieve interpretatie van bestaande rechten en soms positivering van nieuwe rechten door het Hof tot gevolg gehad. De initiatieven tot rechtsontwikkeling werden niet steeds positief ontvangen. Een deel van het $\mathrm{Hof}$ betwijfelde rechtsgeldigheid van de norm van hoger recht als zou die niet op geldend recht gebaseerd zijn, het betwistte de uit die norm wan hoger recht afgeleide geconcretiseerde resultaten en het liet een zeer kritisch geluid horen over de wijze van rechtsvinding. Dat laatste slaat terug op het gevaar dat verschillende rechters en commen-

168 Zie bijwoonbeeld rechter Harlan in zijn dissenting bij Poe t. Ullwan: "This "liberty" is not a series of isolated points pricked out in terms of [stich specific guarantees as speech and religion]. It is a rational continum which, broadly speaking includes a freedom from all substantial arbitrary impositions and purposeless restraints" (367 U.S. 497,523 (1961).

169 Zie bijvoorbedd McCwloch t. Maryland, 4 Wheat. (17 U.S.) 316, 4 L. Ed. 579 (1819). In deze zatak rees de vratg; of het Amerikaanse Congress de bevoegdheid had, zelf cen bank op te richten, en of de statelijke overheid deze federale bank fiscaal zou kunnen aanslaan. De grondwet laat zich over deze twee kwesties niet expliciet ait. Rechter Marshall formuleerde de oplossing aan de hand van de gehele structuur van de Constitutie die hij afleidde uit de relatie van de verschillende normen met elkaar, en uit algemene rechtsbeginselen. Zie voor een uitwerking ook Gunther en Sullivan 1997, p. 89 e.v. Zie eveneens Hans \&. Lowisian, 134 - U.S. I (1890), warin het Hof stelde: "Belhind the words of the constitutional provisions are postulates which limit and control. There is the essentiall postulate that the controversies, as contemplated stall be found to be of a justiciable character [... ]".

170 Onterecht, aldus bijvoorbeeld Denning en Reynolds 1997, p. 1092-11093. 
tatoren zien in de wijze van rechtsvinding: analoge redeneringen kunnen al gauw leiden tot vaststelling van gemeenschappelijke beginselen en positivering van rechten, waarwan de strekking en inhoud niet te overzien zijn. Het is eerder een taak voor de wetgever, de consequenties van positiveringen te exploreren. Het ongeschreven recht vormt al gauw, zo luidt het bezwaar, 'an argument that proves too much'. Die karakterisering houdt in dat uit de samentrekkingen van expliciete grondrechten allerlei fraate theorieên kunnen worden afgeleid, die op hun beurt ruimte creêren voor extensieve interpretatie. ${ }^{171}$ Het nieuwe recht kent geen nadere afbakeningen zodat geen overeenstemming bestaat over de vraag, welke feitencomplexen moeten worden bestreken door de rechtsgevolgen van het nieuwe recht. ${ }^{172}$ Wanneer het Hof zelf overgaat tot het aanbrengen van grenzen en afbakeningen, wordt het aangesproken op zijn rechtsvindende tak: het houdt zich in dat verband dan niet alleen meer bezig met het beslechten van het concrete geschil, maar laat zich expliciet in met rechtsvorming. ${ }^{173}$ Nu lijkt rechtsvorming door de rechter niet onder alle omstandigheden te worden afgewezen; een inlaten met aspecten van het recht die verder af staan van het concrete geschil wordt in beginsel echter al gauw gezien als een activistische rechterlijke taakopvatting.

Vanuit deze optiek wordt wel gepleit voor een zo specifiek mogelijke benadering van de toepassing van wage normen of van normen van hoger recht op nog niet eerder opgeworpen individuele aanspraken. ${ }^{174}$ In de onderzochte rechtspraak leidde de hantering van een specifieke norm van hoger recht steeds tot afwijzing van vergelijkbaarheid, waardoor een extensieve interpretatie of positivering van een nieuwe rechtsnorm niet meer mogelijk was. Extensieve interpretatie en positivering van een nieuwe norm kunnen slechts tot ontwikkeling komen wanneer een abstracte norm van hoger recht wordt gehanteerd. De pleiters voor het gebruik van een zo specifiek mogelijke norm van hoger recht stellen dat hun benadering eerder leidt tot objectieve interpretatie. Indien de wetgever ruimte had laten bestaan voor normen van hoger recht, dan zou dat in de tekst van de wet of in de structuur ervan te traceren moeten zijn. ${ }^{175}$ In dat uitgangspunt ligt een probleem besloten, dat steeds de kern van de interprefatiediscussie lijkt uit te maken: wanneer kan nu worden gesproken van de vaststelling dat een individuele aanspraak behoort tot de structuur van de wet? Een puur tekstuele benadering wordt vaak verbonden met de opmerking, dat rechterlijke terughoudendheid in acht

171 Zie de dissenting van rechter Holmes bij Lochner t. New York, 198 U.S. 45 (1905).

172 "to limit the breath of issues which must be dealt with in particular litigation, this Cout has generally insisted that parties rely only on constitutional rights which are personal to themselves. I... I this rute is related to the broader doctrine that constitutional adjudication should where possible be avoided $[\ldots . !$, M.A.A.C.P. I. Alabama, 357 U.S. 449, 459 (1958).

173 Zie bijvoorbeeld het Hof ontwikkelde trimestersystem in Rae $t$. Wade. 410 U.S. 113 (1973) waarwan naderhand werd gesteld dat het Hof zijn taakopvatting te buiten was gegaan.

174 Zonder te claimen dat een scherpe afbakening mogelijk is tussen niveaus van algemeenheld of wan specificiteit in de analoge redenering, geeft de rechtspraak wan het Hof toch trends te zien van hetgeen als "abstracte" norm van hoger recht of juist als specifieke benadering moet worden getypeerd. Zie bijwoorbeeld rechter Scalia schrijvend woor de meerderheid in Mchael H. t. Gerald D., 491 U.S. 110 (1989). Hij bepleitte een zo specifiek mogelijk niveaw wan vergelijking, omdat alleen op die wijze de voor het geschil relevante traditie varn de Amerikanse natie kan worden gedetecterd.

175 Zie par. 5.3.6 en Bowers t. Hardwick, 478 U.S. 186, 193 (1986). 
wordt genomen. ${ }^{176}$ De rechtspraak van het Hof laat in dit opzicht echter een wisselend beeld zien. Soms wordt nadrukkelijk gepleit voor het specifieke vergelijkingsniveau, terwijl het Hof zich in enkele gevallen juist sterk heeft gemaakt voor een meer abstracte vergelijkingsmaatstaf. ${ }^{177} \mathrm{Er}$ is evenzeer jurisprudentie waarin expliciet wordt gesteld dat een specifieke benadering niet gewenst is, of althans tekort zou doen aan 'de consistentie van het constitutionele recht'. ${ }^{778}$ In die gevallen werd benadrukt dat er constitutionele leemten zijn waarvan de reikwijdte en strekking niet worden gekend, en dat een specifieke benadering niet in overeenstemming is met de reeds gepositiveerde rechten als huwelijk en lichamelijke integriteit.

Meyer t. Nebraska bood, met zijn opsomming van menselijke handelingen die onder "the orderly pursuit of happiness by free men" vielen, een veelvuldig gehanteerd vertrekpunt voor het Hof bij beoordelung van nieuwe individuele aanspraken onder "liberty" ${ }^{179}$ De norm van hoger recht in Meyer verloor in de loop van de tijd zijn abstracte karakter niet. Het recht op voortplanting vormde, aldus de meerderheid in het Hof, én van de 'basic liberties of man'. ${ }^{80}$ Ook deze norm van hoger recht kan worden aangemerkt als een abstracte norm die verschillende casus verenigt onder 'liberty'. In Kent t. Dulles werd een abstracte norm van hoger recht geformuleerd, dat de grondslag vormde voor erkenning van de individuele aanspraak onder "liberty". ${ }^{181}$ De individuele aanspraak op geheimhouding van ledenlijsten van de $N A A C P$ werd onder 'liberty' erkend vanwege een analogie met voorafgaande jurisprudentie. ${ }^{182}$ Een vergelijking die een norm van hoger recht tussen jurisprudentie en de aanspraak van de $N A A C P$ legitimeerde, leidde ertoe dat niet alleen naturlijke personen, maar ook verenigingen een aanspraak konden maken op het Eerste Amendement en dat zij bepaalde gegevens niet hoefden onthullen. ${ }^{183}$ De norm van hoger recht die de zaak $N A A C P$ en de andere door het Hof aangehaalde zaken gemeenschappelijk hadden zou als volgt geformuleerd kunnen worden: vrijheid van meningsuiting of vereniging mag niet worden beperkt, omdat

176 Zie bijvoorbeeld Black in zijn dissenting bij Griswold t. Connecticut, en Scallia, schrijvend voor de meerderheid bij Michael H. t. Gerald D. 491 U.S. 110 (1989).

177 Een voorbeeld van de voorkeur voor een meer specifieke matstaf van vergelijking is te vinden in $K e l l y$ 4. Jolnson, 425 U.S. 238 (1976); Bowers t. Hardwick, 478 U.S. 186 (1986); Michael H. t. Gerald D, 491 U.S. 110 (1989); Vacco U. Qwill, 521 U.S. 793 (1997) en Washingtont. Ghcksberg, 521 U.S. 702 (1997). In geen van deze uitspraken werd de aansprak gekwalificeerd onder 'privacy' of onder de 'fundamentele Wariant' van 'liberty'. De overige onderzochte uitspraken vertoonden verder allen kenmerken van een meer algemene vergelijkingsmatstat in de analogie.

178 Planmed Parewhood t. Casiey, 505 U.S. 833.

179 Pience . Socieb of Sister, 268 U.S. 510 (1925). Ook in latere zaken bleek Meyer aanknoping te bieden voor positwering door het Hof. Zie onder meer Griswold t. Connecticut, Boddie ". Connecticut, Roe t. Wade, Kelly 1. Johnson, Whaten 1. Roe, waarin Meyer I. Nebraska werd aangehald voor de erkelnning Van de indiwiduele anspraken.

180 Skinner t. Oklahoma, 316 U.S. 535,541 (1942)

181 zie Kent t. Dulles, 357 U.S. 116, 125-126 (1958). De analogie in die zaak werd gevormd op bas is van uitingen in de Magna Carta en uitspraken un de rechtsliteratum (357 U.S. 116, 125-126 (1958) enerijds en de individuele aansprak anderzijds.

182 N.A.A.C.P. A. Alabama, 357 U.S. 449 (1958).

183 De andere zaken in dit verband waren Girlow t. People of State of New York, 268 U.S. 652 (1925) en Stanb : City of Baxley, 355 U.S. 313 (1958). 
de mening of de doelstellingen van de betrokkenen niet worden gedragen door een meerderheid in de samenleving. 184 De positivering van 'privacy' moest toen nog tot stand komen. 'Privacy' als grondslag voor positivering van nieuwe individuele aanspraken leek in het beginstadium van zijn ontwikkeling in de rechtspraak een "individueel zelfbeschikkingsrecht' in zich te dragen. Vanaf de jaren ' 80 werden de individuele aanspraken op 'privacy" benaderd met een meer 'specifieke vergelijkingsmaatstaf'. Het gevolg was, althans voor de aanspraken op "privacy", dat de aanspraken niet werden erkend. ${ }^{185}$

\subsubsection{Terminologie}

Het Hof lijkt zich de laatste jaren meer thuis te voelen bij een specifieker invulling van "privacy". De status van 'privacy' ten opzichte van andere grondrechten, met name 'liberty', blijkt niet eenduidig uit de rechtspraak. Uit de onderzochte rechtspraak blijkt niet of "privacy" zich als een overkoepelend rechtsbeginsel 'boven' de Bill of Rights beweegt, of dat het een gelijke is van de andere Amendementen uit de Bill of Rights. De wijze waarop "privacy" is ingezet voor het positiveren van nieuwe rechten doet eerder vermoeden, dat het " $t$ karakter van een rechtsbeginsel heeft. Met die vaststelling is nog niets definitiefs gezegd over de status ten opzichte van andere grondrechten. Anderzijds zijn er uitspraken aan te wijzen waarin het Hof 'privacy' een aan het recht op 'liberty' complementair karakter heeft gegeven. ${ }^{186}$ 'Liberty' wordt gezien als een overkoepelend recht van de in de Amendementen genoemde rechten, en tegelijkertijd als rechtsbeginsel waaruit verschillende concrete, niet in de Bill of Rights genoemde grondrechten kunnen voortvloeien. ${ }^{187}$

184 Dit uitgangspunt werd bevestigd in Aptheker t. Secretary or State, waarin vrij reizen ook mogelijk dient te zijn voor personen die ideeen uitdragen (i.c. communistische sympathieen) die niet worden aangehangen of geaccepteerd door brede lagen van de bevolking (378 U.S. 500 (1964)). Een meer specifiek element in de analoge redenering van Aptheker was, dat kon worden aangehaakt bij een uitspraak die het Hof al eerder had gedaan in Kent $x$. Dulles. Die zaak had een vergelijkbar feitencomplex. Het Hof achtte het echter kennelijk toch noodzakelijk, de erkenning van de individuele aanspraak te rechtwardigen met het hiervoor aangehaalde rechtsbeginsell.

185 Bowers t. Hardwick, 478 U.S. 186 (1986); zie ook par. 5.3.6, Michaet H. t. Gerald D., 491 U.S. 110 (1.989), par. 5.3.5 en Vacco t. Quill, 52 । U.S. 793 (1997), par. 5.3.7.

186 Zo ook Nieuwenhuis 2001, p. 66.

187 Gitlow $t$. People of State of New York, 268 U.S. 652, 666 (1925): 'For present purposes we may and do assume that freedom of speech and of the press - which we are protected by the First Amendment from abridgement by Congress - are among the fundamental personal rights and 'liberties' protected by the due process clause of the Fourteenth Amendment from impairment by the States'. Zie ook Rechter Douglas in zijn dissenting bij Poe t. Ullman: "Though I believe that "due process" as used in the Fourteenth Amendment includes all of the first eight Amendments, I do not think it is restricted and confined to them. We recently held that the undefined "liberty" in the Due Process Clause of the Fifth Amendment inclades freedom to travel [...]', 367 U.S. 497, 516 (1961). 


\section{Hoofdstuk 6}

\section{Analoge rechtsvinding in de jurisprudentie van het Duitse Federale Constitutionele Hof}

\subsection{Inleiding}

In de rechtspraak van het Duitse Federale Constitutionele Hof zijn veel voorbeelden aangetroffen waarin het Hof aan de hand van een analoge redenering onderzoekt of de individuele aanspraak op een grondrecht kan worden gerechtvaardigd. Hier wordt met name gekeken naar de rechtspraak van het Hof op het terrein van de menselijke waardigheid ex Art. 1 lid $1 \mathrm{GG}$, het recht op vrije ontplooiing van de persoonlijkheid ex Art. 2 lid $1 \mathrm{GG}$ en ten slotte het algemene persoonlijkheidsrecht dat voortvloeit wit een contaminatie wan Artt. 2 lid $\mathbb{1}$ GG en 1 lid 1 GG.' Alle drie rechten hebben in de jurisprudentie concrete toepassing gekregen: aan de open begrippen is nadere invulling gegeven. Vraag is welke inhoudelijke aanknopingspunten het Hof voor die invulling hanteerde, en hoe het zijn interpretatiebevoegdheid heeft ingezet voor het onderzoek naar de reikwijdte van voomoemde rechten. Deze kwestie staat in direct verband met de constitutionele verhouding waarin het Hof zich bevindt met de federale wetgever en in beginsel ook met de wetgevers van de Länder. ${ }^{2}$ De vraag rijst hoe het Hof is omgegaan met verhouding tussen rechter en wetgever en in welke mate het aandacht besteedde aan aspecten wan de rechterlijke taakopvatting. Het Duitse Hof is in de grondwet en enkele specifieke wetten een omvangrijke bevoegdheid toegekend; het kan onder meer wetgeving in abstracto toetsen, en zijn uitspraken hebben expliciet de kracht van wet. ${ }^{3}$

De opzet van dit hoofdstuk ziet er als volgt uit. Allereerst wordt aandacht geschonken aan een aantal voor de Duitse grondrechtspraak constituerende uitspraken van het Hof. Deze uitspraken zijn later van groot belang gebleken bij de invulling van het recht op vrije ontplooiing van de persoonlijkheid of het algemene vrijheidsrecht ex Art. 2 lid 1 $\mathrm{GG}$ en van het algemene persoonlijkheidsrecht ex Art. 2 lid 1 jo. 1 lid $1 \mathrm{GG}^{4}$ Daarna volgt een uiteenzetting over de ontwikkeling van de interpretatie wan het recht op ontplooiing van de persoonlijkheid en van het algemene persoonlijkheidsrecht. Tenslotte wordt in de bevindingen een verband gelegd tussen de gevonden resultaten in de rechtspraak en de wijze waarop het Hof inhoud heeft gegeven aan zijn rechterlijke taakopvatting.

Zie par. 2.4.2, 2.4.3 en 2.4.4.

2 De meeste onderzochte uitspraken van het Hof hebben betrekking op toetsing van federale wetgeving; er wordt hierna wooral gesproken over de constitutionele verhouding tussen het Hof en de federale wetgever.

3 Zie par. 3.3

4. Met het recht op vrije ontplooïng van de persoonlijkheid wordt hetzelfdle uitgedrukt alls met het algemene wrijheidsrecht. 


\subsection{Rechtsontwikkeling door het Duitse Federale Constitutionele Hof}

In de rechtspraak van het Hof zijn reeds vanaf het begin van de jaren " 50 , kont na de installatie wan het Hof, contouren te vinden die aan de begrippen 'Menschenwurde" en wan 'freie Entfaltung der Persönlichkeit' zijn gegeven. In de eerste uitspraken zijn analoge redeneringen in rechtsvinding aangetroffen die hebben geleid tot een constructie van rechtsnormen. Er bestond echter nog weinig rechtspraak die kon worden benut bij de opbouw van de analogie, hetgeen tot gevolg had dat het Hof teruggreep op andere (rechts)bronnen. In enkele van deze vroege uitspraken gaf het Hof algemene bespiegelingen weer over deze begrippen, die later van grote betekenis zouden zijn voor de ontwikkeling van het recht op persoonlijke ontplooing en het algemene persoonlijkheidsrecht. In de uitspraken Investitionshilfe (1954), KPD-Verbotsurteil (1956), Elfes (1957) en Homosexuelle (1957) schetste het Hof welke de betekenis van voornoemde begrippen is in het kader van een democratische rechtsstaat en in het kader van een sociale rechtsstaat." Deze uitspraken vormen namelijk een zeer belangrijke basis voor veel latere uitspraken waarin het Hof tot erkenning van individuele aanspraken als subjectieve grondrechten komt. In de Amerikaanse literatuur over de rechtsvinding van het Hof aan de hand van voornoemde begrippen wordt wel gesproken van de Duitse variant van 'substantive due process' omdat het Hof in staat is gebleken met de vage constitutionele begrippen te werken aan een catalogus van ongeschreven rechten. ${ }^{6}$

\subsubsection{Constituerende witspraken van het Hof over Art. I lid I en Art. 2 lid I GG}

\section{Art. 2 lid I}

In de zaak Investitionshilfe (1954) gaf het Hof zijn visie op de inhoud en reikwijdte van het recht op ontplooing van de persoonlijkheid ex Art. 2 lid 1 GG. In de economische opbouwfase na de Tweede Wereldoorlog profiteerden vele ondernemingen van de fikse groei- en afzetmogelijkheden, maar bleven enkele industrièle sectoren als de staal- en kolenbedrijven sterk achter. Op bondsniveau werd de wet 'Investitionshilfe' tot stand gebracht, die de minder succesvolle sectoren met een financiële prikkel zou ondersteunen. Succesvolle ondernemers ageerden hiertegen omdat de subsidies de markt en hun verworven marktposities negatief zouden beinvloeden. Dat zou ben treffen in hun recht op het vrije ondernemerschap. De aanspraak op het vrije ondernemerschap leidden zij af wit het recht op persoonlijke ontplooiing ex Art. 2 lid 1 GG. Het Hof erkende de aanspraak van het recht op het vrije ondernemerschap onder Art. 2 lid 1 GG zonder problemen. Het honoreerde de aanspraak echter niet. Het Hof opende de overweging met de opmerking, dat het recht op het vrije ondernemerschap in casu geen inbreuk was gemaakt, ondat dat recht geen onbegrensde vrijheid betreft. Het individu is ingebonden Elfes, $6 \mathrm{BVerfCE} 32$ (1957) en Homosexwelle, 6 BVerfGE 389 (1957).

6 Currie 1989, p. 358 en Kommers 1997, p. 359 (Kommers vergelijkt Art 2 lid 1 GG met het recht op 'liberty" in de Anverikaanse grondwet).

8 Investifionshiffe, 4 BVertGE 7, 15 (1954) 
in een gemeenschap; mitsdien moeten beperkingen op de reikwijdte van grondrechten worden getolereerd:

'Das Menschenbild ist nicht das eines isolierten souveränen Individuums; das Grundgesetz hat vielmehr die Spanung Individuum - Gemeinschaft im Sinne der Gemeinschaftsbezogenheit und Gemeinschaftsgebundenheit der Person entschieden, ohne dabei deren Eigenwert anzutasten. Das ergibt sich insbesondlere aus der Gesamtsicht der Art. 1, 2, 12, 14, 15, 19 und $20 \mathrm{GG}^{\prime \prime}$ ?

Vanwege de gebondenheid van het individu in een samenleving met anderen bestaan er soms redenen, aldus het Hof, de algemene handelingsvrijheid te beperken. Het Hof leidde dat af uit een samentrekking van respectievelijk de rechten op menselijke waardigheid, het algemene vrijheidsrecht, de beroepsvrijheid, het eigendomsrecht, de wijze waarop grondrechten kunnen worden beperkt - Art. $19 \mathrm{GG}$ - en de constitutionele rechtsbeginselen ex Art. $20 \mathrm{GG} .{ }^{10}$ Uit de samentrekking van deze artikelen volgde een norm van hoger recht die stipuleert dat bij de vaststelling van de reikwijdte van een grondrecht rekening moet worden gehouden met de gebondenheid van het individu in de gemeenschap. Art. 2 lild 1 GG geeft zelf geen duidelijke richtlijn voor de omvang van de beperkingen in het kader van de individuele aanspraak. De beperkingsmogelijkheden moeten ruim worden opgevat. De analogie leidde in Investitionshilfe tot een afweging tussen het individuele en het algemene belang. Uiteindelijk liet het Hof de gewraakte wet voortbestaan. In deze zaak bestond nog geen vaste aanpak voor de vestiging van de aanspraak van het individu, mar Investitionshilfe zou in latere rechtspraak een argument opleveren aan de hand waarvan een beperking van de reikwijdte van Art. 2 lid 1 GG werd gerechtvaardigd. De vaststelling dat de mogelijkheid tot beperkingen ruim dient te worden geïnterpreteerd is van groot belang voor de constitutionele verhouding tussen wetgever en rechter: ter zake van de algemene handelingsvrijheid bestaat in beginsel geen vermoeden ten faveure van de individuele rechtsbescherming. 11

\section{Art. lid l}

Een jaar later volgde een voor de omvang van Art. 1 lid $1 \mathrm{GG}$ belangwekkende uitspraak, waarvan de afloop in de context van de Koude Oorlog enigszins te voorspellen was. In 1956 verzocht de toenmalige Bondsregering onder $\mathrm{K}$. Adenauer het Hof

$9 \quad$ Investitionshilfe, 4 BVerfGE 7, p. 15-16 (1954).

10 Het Hof doelde, on aan te geven dat de grondwel ook ruimte laat voor beperkingen op grondrechten, liner op Art. 19 lid 1: 'Soweit nach diesem Grundgesetz ein Grundrecht durch Gesetz oder aur Grund eines Gesetzes eingeschrankt werden kani, muß das Gesetz allgemein und nicht nur fur den Einzelfall gelten?. Art. $20 \mathrm{GG}$ is van algemener strekking, en geeft enkele constitutionele uitgangspunten weer. Art. 20 lid 1 GG luidt: 'Die Bundesrepublik Deutschland ist ein denokratischer und sozialer Bundesstaat". Art. 20 lid 2 GG luidt: "Alle Staatsgewalt geht vom Volke aus. Sie wird vom Volke in Wahlen und Abstimmungen und durch besondere Organe der Gesetzgebung, der vollziehende Gewalt und der Rechtsprechung ausgevibt'.

Par. 2.4 .3 en 3.3.5. 
on grondwettigheidstoetsing van een verbod van de communistische partij KPD. ${ }^{12}$ Het Hof honoreerde dat verzoek nadat het onder meer onderzocht had, hoe de ideeên van de KPD - met als vooropgesteld einddoel de overwinning van het proletariaat - zich verhielden met de in de grondwet neergelegde rechtsbeginselen democratie en Menschenwhirde' " Een democratie verdraagt zich niet, aldus het Hof, met een door de staat vooropgesteld einddoel waaraan maatschappelijke ontwikkeling ondergeschikt moet worden gemaakt. Hieruit vloeit namelifk voort, aldus het Hof, dat alle beslissingen in de samenlewing die van staatswege worden genomen, aan dat einddoel moeten bijdragen. De vrijheid van het individu wordt aan dat einddoel ondergeschikt geacht en mitsdien kan het vanuit deze gezichtshoek onherroepelijk worden beperkt. In een denocratie daarentegen vormt dat vooropgestelde einddoel van de KPD een hindernils in de vrijheid van het individu. Het individu behoort in het KPD-einddoel tot een bepaalde sociale klasse, die door de staat wordt opgelegd om het door de KPD gestelde einddoel te kunnen bereiken, aldus het Hof:

"Der Mensch witd in diesem System als mitglied einer Klasse gesehen. Er tritt zur Gesamtheit nur auf dem Weg uber seine KJasse in Beziehung, die Ordnung der Gesellschaft ist im wesentlichen eine Ordnung der Klassenverhaltnisse. [...] Das macht jeden Eingriff grundsătzlich zulässing, der aus der Klassenzugehörigkeit des Einzelnen und der Klassensituation im ganzen yon der herschenden Klasse hergeleitet wird ${ }^{14}$

De in de grondwet neergelegde individuele rechten verliezen hun materiële betekenis in dit systeem, omdat zij enkel gelden met de beperking, dat zij niet in tegenspraak mogen komen te staan met de door de staat uitgetekende doelstellingen. Deze visie op de verhouding tussen de staat en het individu doet bijwoorbeeld niet alleen de inhoud van politieke grondrechten teniet, zij raakt eveneens aan het uitgangspunt van de menselijke waardigheid, aldus het Hof:

"In der freiheitlichen Demokratie ist die Wïrde des Menschen der oberste Wert. [...] Der Mensch ist danach eine mit der Făhigkeit zu eigenverantwortlicher Lebensgestaltung begabte "Persönlichkeit". [...] Um seiner Würde willen muß inm eine möglichst weitgehende Entfaltung seiner Persönlichkeit gesichert werden. [... ] Der Staat hat ihm dazu den Weg zu offinen $[\ldots . . .]^{\prime \prime}$.

Menselijke waardigheid en grondrechten vormen in de optiek van het Hof onmisbare elementen voor de ontwikkeling van de democratische rechtsstaat:

Die Geistesfreiheit ist für das System der freiheitlichen Demokratie entscheidend wichtig. sie ist geradezu eine Voraussetzung für das Funktionieren dieser Ordnung; sie bewahrt es

$12 K P D-V e r b o r s u r t e i l, 5$ BVerfGE 85 (1956). Deze witspraak is van groot belang geweest woor de uitleg van het begrip van de "wehthafte Demokratie" (zie par. 2.4.1).

13 Art. 21 lid 2 GO. 'Parteien, die nach ihren Zielen oder nach dem Verhalten ihrer Anhagnger daruaf ausgehsen, die freilheitliche demokratische Grundordnung zu beeintrachtigen oder za beseitigem oder den Bestand der Burndesrepublik Deutschland zu gefahrden, sind verfasstungswidrig. Ober die Frage der Verfassungswidrigkeit entscheidet das Bundesverfassungsgericht'.

1.4 KPD-Ferbowswrtel, 5 VBerfGE 81, 201 (1956).

15 KPD-Verbotswreil. 5 B VerfGE 85,204 (1956). 
insbesondere vor Erstarrung und zeigt die Fulle der Lösungsmöglichkeiten für die Sachprobleme auf. ${ }^{16}$

Het Hof keurde het partijverbod goed; de hierboven geciteerde overwegingen vormden belangrijke argumenten in het kader wan de democratische ordening van de staat om aan te nemen, dat de ideeën van de KPD een bedreiging vormden voor de Duitse democratie. Het Hof knoopte in de beschouwingen over democratie niet expliciet aan bij afzonderlijke individuele rechten. Een aantal grondrechten, zoals de politieke grondrechten, het recht op persoonlijke ontplooiing en menselijke waardigheid passeerde in een meer natuurrechtelijke benadering de revue. Deze overwegingen in het KPD-Urteil zouden later in een aantal uitspraken van doorslaggevend belang blijken voor de argumentatie om een individuele aanspraak als recht onder Art. 1 lid 1 GG te erkennen.

\section{Art. 2 lid 1 en Art. I lid I}

Waar Investitionshilfe en KPD-Verbotsurteil een aantal belangrijke lijnen trokken voor de omvang van de algemene handelingsvrijheid en de 'Menschenwürde, zou de zaak Elfes (1957) later van grote betekenis blijken voor de ontwikkeling van het algemene persoonlijkheidsrecht. ${ }^{17}$ Er werd in Elfes echter nog niets gezegd over aanspraken op of erkenning van een 'recht' op het algemene persoonlijkheidsrecht; dat zou het Hof eerst in Tomband, Soraya en Eppler in 1980 positiveren. ${ }^{18}$ In Elfes werd een aanspraak gedaan op Art. 2 lid $1 \mathrm{GG}$, dat werd geïnterpreteerd 'in verbinding met' Art. 1 lid 1 GG. Parlementslid Elfes was de mogelijkheid ontnomen, vrij te kunnen reizen. Hij was een actief lid van de Christen Democratische Unie (CDU) en gekozen in het parlement van Noordrijn-Westfalen. Hij was tevens woordvoerder van een rechts-radicale organisatie, en liet zich in die functie verschillende keren zeer kritisch wit over de Duitse defensiepolitiek en over hereniging met Oost-Duitsland. Vanwege het feit dat hij zowel in binnen- en buitenland forse kritiek leverde op de toenmalige regering van de Bondsrepubliek, werd bezoek door hem aan het buitenland niet wenselijk geacht. De geldigheidsduur van zijn paspoort werd met een beroep op de paspoortwet niet. verlengd, waardoor hij niet naar onder meer politieke bijeenkomsten in het buitenland kon reizen. Hij vormde met zijn uitlatingen een bedreiging voor de buitenlandse veiligheid van de Duitse Bondsrepubliek. ${ }^{19} \mathrm{Op}$ Art. $11 \mathrm{GG}$, dat het recht op vrij reizen in de Bondsrepubliek regelt, vormde de inbreuk geen onacceptabele beperking. De klager had echter eveneens een beroep gedaan op Art. 2 lid 1 GG in verband met het reizen uit de Bondsrepubliek. Het Hof diende daartoe voor het eerst de betekenis, en vervolgens. de reikwijdte van Art. 2 lid 1 GG te bepalen. Art. 2 lid 1 GG moet, aldus het Hof, meer omvatten dan alleen een intieme persoonlijke sfeer omdat anders niet valt in te zien hoe

16 KPD-Verbotsurteid, 5 BVerfGE 85, 203 (1956)

17 Elfes, 6 BVerfGE 32 (1957).

18 Zile hierna par. 6.3 .2 en 6.3 .5 .

19 Art. 7 lid 1 van de federalle Paswet (1954) luidde: 'Der PaB ist zu versagen, wenn Tatsachen die Annahme rechtfertigen, dab a) der Antragsteller als Imhaber eines Passes die innere oder die duBare Sicherheit oder sonstige erhebliche Belange der Bundesrepublik Deutschland oder eines deutschen Landes gefahrder [... $]^{*}$. 
de ontplooiing van de persoonlijkheid met rechten van anderen of met de goede zeden zou kumnen strijden:

"Gerade diese, dem Individuum als Mitglied der Gemeinschaft auferlegten Beschrärikungen zeigen vielmehr, daß das Grundgesetz in Art. 2 Abs. $1 \mathrm{GG}$ die Handlungsfreiheit im umfassenden sinne meint".

Maar in welke mate 'umfassend'? Wat was het rechtskarakter van de grondrecht? Binnen welke kaders dient de ontplooing van het individu vrijelijk tot stand kunnen komen? Art. 2 lid $1 \mathrm{GG}$ is éen van de onder Art. $1 \mathrm{GG}$ vallende grondrechten, aldus het Hof. De andere grondrechten die zijn opgesomd in de grondwet, vormen eveneens uitvloeiselen van Art. 1 GG. In die zin is Art. 2 lid 1 GG een 'gewoon' grondrecht:

"Damit ist jedoch nichts anderes gesagt, als daß Art. $\| G G$ in der Tat zu den tragenden Konstitutionsprinzipien gehört, die - wie alle Bestimmungen des Grundgesetzes - auch Art. 2 Abs. 1 GG behersschen', 21

Het Hof zegt hiermee niet alleen dat Art. 2 lid $1 \mathrm{GG}$ een subjectief grondrecht is; Art. 1 GG wordt eveneens een bijzondere plats in de grondwetsorde toegekend. ${ }^{22}$ Art. 2 lid 1 GG vormt in de optiek van het Hof een soort 'opvanggrondrecht' voor individuele aanspraken, die grondwettelijke bescherming dienen te krijgen, maar die niet behoren tot de in de grondwet gestipuleerde grondrechten:

Neben der allgemeinen Handlungsfreiheit, die Art. 2 Abs. 1 GG gewährleistet, hat das Grundgesetz die Freiheit menschlicher Betätigung fur bestimmte Lebensbereiche, die nach den geschichtlichen Erfahrungen dem Zugriff der öfentlichen Gewalt besonderes ausgesetzt sind, durch besondere Grundrechtsbestimmungen geschützt [...]. Soweit nicht solche besonderen Lebensbereiche grundrechtlich geschutzt sind, kann sich der Einzelne bei Eingriffen der 8 ffentlichen Gewalt in seine Freiheit auf Art. 2 Abs. 1 GG berufen. ${ }^{23}$

Hiermee vestigde het Hof de mogelijkheid, individuele aanspraken die niet direct aansluiten bij de geschreven grondrechten eventueel onderdak te bieden onder Art. 2 lid 1 GG. Het Hof leidde, na de vaststelling van de functie van Art. 2 lid $1 \mathrm{GG}$ in de grondwet, de reikwijdte van Art. 2 lid 1 GG af uit de structur van de grondwet in zijn geheel. De formulering van Art. 2 lid $1 \mathrm{GG}$ geeft daartoe immers alle aanleiding: de omtrekken van het recht worden bepaald door de rechten van anderen, door de "verfassungsmaßige Ordnung' en de goede zeden. De vaststelling van de betekenis van het begrip 'verfassungsmatßige Ordnung'. was in dit verband van groot belang, omdat deze orde, naast de genoemde goede zeden en de rechten van anderen, een handvat biedt voor de vaststelling van de reikwijdte van het recht op persoonlijke ontplooing. Het Hof bepaalde, dat tot die "grondwettelijke orde" ${ }^{24}$ uiteenlopende grondwettelijke normen behoren:

22 Het verkrijgt met de uitspraak van het Hof zoals hiter uit het citaat blijkt het karakter van een thorm van hoger reclit.

23 EVes, 6 B VeritoE 32, 37 (1957).

24 Vertaling van het begrip "verfassungsmaBige Ordnung" 
[...] der Bürger aber wird in seiner allgemeinen Handlungsfreheit legitim eingeschrankt nicht nur durch die Verfassung oder gar nur durch "elementare Verfassungsgrundsatze", sondern durch jede formell und materiell verfassungsmäBige Rechtsnorm" ${ }^{25}$

Deze formulering hield een wel zeer algemene beperking van de reikwijdte van Art. 2 GG in, zo luidde de kritiek. Wat met "verfassungsmäßige Ordnung (hierna: de grondwettelijke ordening) werd bedoeld, was niet direct helder; deze onduidelijkheid zou voor wat betreft de materiele gelding van de grondrechten een rechtsonzekerheid met zich mee kunnen brengen. De door het Hof bijwoorbeeld in KPD-Parteiverbot gehuldigde opvatting, dat de staat niet willekeurig mag tornen aan de reikwijdte van grondrechten ${ }^{26}$, leek gemakkelijk met een ruimhartige invulling van de grondwettelijke ordening terzijde te kunnen worden geschoven. Het Hof zag echter in de 'Ewigkeitsklausel' ex Art. 79 lid $3 \mathrm{GG}$ een belangwekkende barrière tegen dit gevaar; deze beschermt namelijk de belangrijkste beginselen van de grondwettelijke orde, waartoe Art. $1 \mathrm{GG}$ ook wordt gerekend, tegen verandering. ${ }^{27}$ Art. 2 lid $1 \mathrm{GG}$ geniet indirecte bescherming van Art. 79 lid 3 GG vamuit de hypothese, dat Art. 1 GG een overkoepelend beginsel is waronder de grondrechten ex Artt. 2-19 GG zijn gevestigd, aldus het Hof. ${ }^{28}$ Concluderend stelde het Hof wat de inroepbaarheid en de reikwijdte van Art. 2 lid $1 \mathrm{GG}$ betreft het volgende vast:

"Verfahrensrechtlich bedeutet das: Jedermann kann im Wege der Verfassungsbeschwerde geltend machen, ein seine Handlungsfreiheit beschränkendes Gesetz gehöre nicht zur verfassungsmäßige Ordnung, weill es (formell oder inhaltlich) gegen einzelne Verfassungsbestimmungen oder allgemeine Verfasssungsgrundsätze verstoße; deshalb werde sein Grundrecht aus Art. 2 Abs. 1 GG verletzt'. ${ }^{29}$

Verder was van belang hetgeen het Hof stelde over de inhoud van het recht op ontplooiing van de persoonlijkheid ex Art. 2 lid 1 GG. In Elfes bepaalde het Hof, dat het individu een recht op privé-leven toekomt. ${ }^{30}$ Dat recht op privé-leven vornt één van de voorwaarden, die ontplooiing van het individu mogelijk maken. Het Hof werkte in twee stappen van een zeer abstracte aanspraak naar een concreet recht: in de eerste stap bevestigde het Hof het bestaan van een algemene aanspraak op vrijheid van persoonlijke ontplooiing; in de tweede stap werd dat recht nader gespecificeerd naar de in het geding zijnde individuelle aanspraak, in casu het recht vrij het land uit te kunnen reizen, op een privé-leven. Over de vraag, aan welke begrenzingen de reikwijdte van het begrip privé-leven onderworpen is, gaf het Hof in Elfes geen uitsluitsel; enkel een algemene beschouwing over het recht op privéleven: 
"Hieraus ergibt sich, dafl dem einzelnen Bürger eine Sphare privater Lebensgestaltung verfassungskrätig worbehalten ist, also ein letzter unantastbarer Bereich menschlicher Freiheit besteht, der der Einwirkung der gesamten offentlichen Gewait entzogen ist." ${ }^{\text {"t }}$

De grondslag voor de extensieve interpretatie leidde het Hof af uit de ontstaansgeschiedenis van Art. 2 lid $1 \mathrm{GG}$; het leidde uit een aanwijzing van de grondwetgever het volgende af:

"Jeder kann tun und lassen was er will" ${ }^{32}$

\subsubsection{Grenzen aan het recht op persoonlijke ontplooing ex Art. 2 lid I GG}

De vrijheid behoeft niet beperkt te blijven tot een intieme persoonlijke sfeer, aldus het Hof. Met Elfes leek het Hof de deur voor extensieve interpretatie van het recht op persoonlijke ontplooiing te hebben opengezet. Art. 2 lid 1 GG beschermt niet alleen rechten die in de kern gelegen zijn maar ook aanspraken die meer in de periferie van het recht te vinden zijn. Met de uitgangspunten die het Hof in Elfes had neergelegd, bestond in beginsel een basis woor rechterlijke toetsing van alle handelingen van de wetgever. In die zin vertoonde deze ontwikkeling in de rechtspraak overeenkomsten met de in de Verenigde Staten ontwikkelde 'substantive due process formule ${ }^{33} \mathrm{De}$ begrenzingen van Art. 2 lid $1 \mathrm{GG}$ kumnen worden gevonden in de "verfassungsmäßige Ordnung'. 34 In de interpretatiefase kan op basis van Elfes in beginsel elke individuele aanspraak worden ingelezen in Art. 2 lid 1 GG, maar in de toetsingsfase bestaan ruime mogelijkheden om de individuele aanspraak te beperken. ${ }^{35}$ In de daaropvolgende jurisprudentie zou blijken, welke de betekenis was van deze benadering door het Hof. Vraag was of er aanspraken bestonden die het Hof niet zou erkennen onder Art. 2 lid 1 GG. In Homosexuelle, een zaak uit 1957, bleek het Hof bereid, een individuele aanspraak op homoseksuele activiteiten als onderdeel van het privé-leven ex. Art. 2 lid I GG te erkennen:

'Zu dem Bereich der in Art. 2 Abs. I GG als Grundrecht gewährleisteten freien Entfaltung der Persönlichkeit gehort auch das Gebiet des Geschlechtlichen" 36

In deze zaak bezwaarden enkele homoseksuelen zich over het feit, dat homoseksuele activiteiten met straffen werden bedreigd - zij achtten dat in strijd met hun recht op de vrije ontplooiing van hun intieme persoonlijke seksleven. In hun optiek behoorde dat recht tot de kern van het recht op het privé-leven, zoals het Hof dat in Elfes had geformuleerd. Het Hof erkende de aanspraak op bescherming van het privé-leven als recht maar plaatste de aanspraak niet in de kernsfeer, volgens welke geen enkele inbreuk op het recht zou kunnen worden getolereerd:

3. Elfes, 6 B VerfGE 32, 41 (1957).

32 Zie Von Mangoldt, Parlamentarischer Rat, 42. Sitzung des Hauptausschussess, p. 533.

33 Currie 1989, p. 359.

34 Zie par. 2.4.3.

35 Zie hiervoor bij Investitionshilfe en zie ook Von Münch 2000, p. 136-13\%.

36 Homosexuelle, 6 BVerfOE 389, 432 (1957). 
"Sicherlich gibt es, wie in dem urteil (Elfes, H.L.J.) ausgefürt, einen "letzten, unantastbaren Bereich menschlicher Freiheit..., der der Einwirkung der gesamten offentlichen Gewalt entzogen", in den einzudringen also dem Gesetzgeber schlechthin verwehrt ist. Dieser Bereich wird aber verlassen, wenn Handlungen des Menschen in den Bereich eines andern einwirken $[\ldots]^{37}: 3$

Hier zag het Hof zich genoodzaakt, een grens te trekken tussen aanspraken die behoren tot het 'letzten, unantastbaren Bereich menschlicher Freiheit' en aanspraken die niet daaronder vallen. Aanspraken die duiden op seksuele handelingen worden in beginsel door Art. 2 lid 1 GG beschermd; homoseksuele handelingen behoren daar volgens het Hof niet toe. Het Hof beargumenteerde zijn opvatting aan de hand van beschouwingen over de goede zeden: homoseksuele handelingen worden beschouwd als flagrante schendingen van het 'Sittengesetz'. ${ }^{38}$ De samenleving, aldus het Hof, beschouwt de homoseksuele activiteiten ondubbelzinnig in strijd met de goede zeden. ${ }^{39}$ De sanctie op de handeling verkrijgt in die optiek een noodzakelijk karakter. Het Hof trachtte het verwijt, dat in het begrip 'de samenleving' ruimte bestond voor de subjectieve opvatting van de rechter, te voorkomen door religieuze opvattingen en historische beschouwingen ter zake in te brengen. Het in de overwegingen betrokken historisch vergelijkingsmateriaal dateerde van 1869 tot en met $1927^{40}$

In Cannabis (1994) rees later de vraag, of het gebruik van softdrugs gerekend kan worden tot een recht dat bescherming geniet als één van de uitvloeiselen van de algemene handelingsvrijheid; de klacht hield onder dat recht een aanspraak op zelfbeschikking in ${ }^{41}$ Het Hof weigerde deze aanspraak te erkennen onder Art. 2 lid $1 \mathrm{GG}$. De klager eiste erkenning van een 'recht op een roes'. Het Hof plaatste die aanspraak nadrukkelijk niet in de kernsfeer van het recht op prive-leven:

"Art. 2 Abs. 1 GG schützt jede Form menschlichen Handelns ohne Rücksicht darauf, welches Gewicht der Betätigung für die Persönlichkeitsentfaltung zukommt [...]. Absolut geschützt und damit der Einwirkung der öffentlichen Gewalt entzogen ist allerdings nur ein Kernbereich privater Lebensgestaltung [...]. Dazu kanm der Umgang mit Drogen, ins* besondere auch das Sichberauschen, aufgrund seiner vielfältigen sozialen Aus- und Wechselwirkung nicht gerechnet werden".

Het Hof onderzocht niet of het gebruik van cannabis in een perifere sfeer wan de algemene handelingsvrijheid zou kunnen vallen. De vraag naar het bestaan van een "recht op een roes' werd ontkennend beantwoord met het argument, dat aan het gebruik van cannabis negatieve sociale gevolgen kleven. Deze gevolgen rechtvaardigen de plaatsing buiten Art. 2 lid $1 \mathrm{GG}$, aldus het Hof.

38 "Dieses Grundrecht ist aber durch die verfussumgsmaBige Ordinung begrenzt", Homosexuelle, 6 BVerf GE 389, 432 (1957).

39. Homosexuelle, 6 BVerforE $389,432(1957)$.

40 Homosexuelle, 6 BVerfGE 389,434 (1957).

41 Cannabis, 90 BVerfGE 145, 153 (1994).

42 Cannabis, 90 BVerfGE 145,171 (1994). 


\subsubsection{Constitutioneel recht en privaatrecht}

De laatste uitspraak die in het kader van de constituerende uitspraken wordt besproken, is de zaak Lith (1958). ${ }^{43}$ Luth had theaterdirecteuren, bioscoopeigenaren en het Duitse publiek opgeroepen tot een boycot van een film, die door een regisseur, die tijdens het nationaal-socialistische regime voor Hitler had gewerkt, was geproduceerd. Deze oproep werd door de civiele rechter beoordeeld als strijdig met de goede zeden ex Art. $826 \mathrm{BGB}$ en werd mitsdien verboden. ${ }^{44}$ Ter zake van de klacht van Luth had het Hof vastgesteld, dat de grondrechten als 'objektive Wertordnung' eveneens de privaatrechtelijke voorschriften beinvloeden en via de algemene bepalingen hun gelding doen gevoelen. ${ }^{A S}$ Het recht op vrije meningsuiting is één van de rechten, dat eveneens via privaatrechtelijke bepalingen doordringt in horizontale verhoudingen. Het Hof werkte vervolgens uit, op welke wijze dat recht in privaatrechtelijke geschillen dient te worden benaderd, namelijk via een belangenafweging. ${ }^{46}$ Om tot de vaststelling van de omtrekken van het recht op vrije meningsuiting te kunnen komen, onderzocht het Hof de betekenis van het recht op vrije meningsuiting in de 'freiheitliche demokratische Ordnung'. Dat onderzoek naar de omtrekken is nu juist interessant, omdat het Hof later een aantal uitspraken doet die in individuele aanspraken die tegen de staat werden gedaan, zouden terugkeren. De meningsuiting, aldus het Hof, is één van de grondrechten die ressorteren onder de 'Menschenwürde' ex Art. 1 lid 1:

"Für eine freiheitlich-demokratische Staatsordnung ist es (het recht op vrije meningsuiting, H.L.J.) schlechthin konstituierend, denn es ermöglicht erst die ständige geistige Auseinandersetzung, den Kampf der Meinungen, der ihr Lebenselement ist (BVerfGE 5, 85 (205)). Es ist in gewissem Sinn die Grundlage jeder Freiheit überhaupt, "the matrix, the indispensible condition of nearly every other form of freedom" (Cardozo) ${ }^{47}$

Vrije meningsuiting is één van de grondrechten, die in aanmerking komt als een 'allgemeines Gesetz', dat andere privaatrechtelijke rechten en vrijheden kan beperken. Deze Jezing van de 'allgemeine Gesetze' die het Hof als maatstaf voor de goede zeden ex Art. 826 BGB hanteert, verschafte het Hof de mogelijkheid, de uitspraken van de gewone rechter te controleren op grondwettigheid. Deze aanvullende werking van grondrechten in het privaatrecht werd door het Hof met Lüth gevestigd. ${ }^{48}$ Echter, niet alleen beinvloedt het constitutionele recht het privaatrecht, maar heeft het privaatrecht omgekeerd ook zijn invloed en betekenis gehad woor het constitutionele recht - zeker daar waar het de interpretatie van grondrechtsnormen betreft. Dat bleek toen het Hof zich in Soraya uitsprak over een rechtsnorm van het algemene persoonlijkheidsrecht, die al wel in het privaatrecht was gepositiveerd, maar nog niet als zodanig in con-

44 Art. 826 BGB huidt: "Wer in einer gegen die guten Sitten verstoßenden Weise einem anderen vorsatzlich Schaden zufügt, ist dem anderen zum Ersatze des Schadens verpflichtet?

45 Luth, 7 BVerfGE 198, 214 (1958).

46 Lith, 7 BVerfGE 198, 210 (1958): 'Es wird deshalb eine "Gutterabwagung erforderlich: des Recht zur Meimungstuberung muB zuricktreten, wenn schutzwardige Interessen eines anderen von höherem Rang durch die Betatigung der Meinungsfreiheit verletzt wörden'. Zie ook Schneider 1979, p. 28.

47

48
Lüh, 7 B VerfGE 198, 208 (1958).

Schneider 1979, p. 27. 
stitutionele context betekenis had verkregen. ${ }^{49}$ In Tonbard, kort voor de uitspraak in de zaak Soraya, had het Hof evenwel in een obiter aangegeven dat het algemene persoonlijkheidsrecht een rechtsnorm is die reeds zijn bestaansrecht heeft verworven in de straf-en het privaatrechtelijke rechtspraak wan het Bundesgerichtshof: ${ }^{50}$

\subsection{Ontwikkeling van het recht op persoonlijkheid met analoge redeneringen}

\subsubsection{Inleiding}

Hieronder wordt een aantal concretiseringen uit de algemene handelingsvrijheid en het algemene persoonlijkheidsrecht beschreven. Met name de wijze waarop het Hof zijn rechtsvinding fundeert staat hier centraal. Op basis van welke normen geeft het Hof een extensieve uitleg, en wat doet het Hof wanneer juridische noties tekort lijken te schieten? Welke beschouwingen wijdde het Hof aan de constitutionele verhouding tussen rechter en wetgever? Er wordt zoveel mogelijk een chronologische volgorde aangehouden in de onderwerpen, maar het bleek niet goed mogelijk om de onderwerpen geheel los te laten ten faveure van de chronologie. Hier zullen achtereenvolgens het recht op zelfbeschikking, het recht om met rust te worden gelaten in het kader van resocialisatie van voormalig gedetineerden, het recht op het eigen beeld en het gesproken woord, een recht op 'informationele zelfbeschikking', het recht op kennis van de biologische afstamming en aspecten van fysieke, geestelijke en seksuele integriteit aan de orde komen.

\subsubsection{Het recht op zelfbeschikking.}

Centraal in de ontwikkeling van een recht op zelfbeschikking staat de uitspraak Mikrozensus (1969), omdat het Hof in deze zaak voor het eerst uitdrukkelijk een aanspraak op zelfbeschikking kwalificeerde als een rechtens te beschermen belang. ${ }^{51}$ De rechtwaardiging voor de uiteindelijke erkenning van deze aanspraak steunde op een analoge redenering. In een prejudiciële beslissing vroeg de strafrechter in eerste aanleg om een beslissing van het Hof over de vraag, of van burgers kan worden verlangd dat zij informatie over hun privé-leven prijsgeven voor een van staatswege gewenste statistiek. De rechter had bij de wet de volgende opmerking:

'Die Bestimmung [...] des Änderungsgesetzes [...] widerspreche Art. 1 und Art. 2 GG insoweit, als die Auskunftpersonen zu Angaben über Urlaubs- und Erholungsreisen verpflichtet seien. [...] Derartige Fragen [...] verletzen die Intimsphäre der Befragten " .

Enkele burgers had namelijk geweigerd gegevens prijs te geven en werden mitsdien strafrechtelijk vervolgd. De klacht richtte zich tegen vermeende ongrondwettigheid van een wet, die burgers verplichtte mee te werken aan dergelijke ondervragingen. Ter be- 
antwoording van de voorgelegde grondwettigheidsklacht over de wet, gaf het Hof eersit zijn visie op Artt. 1 lid 1 en 2 lid 1 GG. Art. $1 \mathrm{GG}$ wormt de hoogste norm; aldus het Hof in antwoord op de prejudiciele vraag, onder verwijzing naar Elfes. Deze norm beheerst Art. 2 lid 1, zodat aan eventuele inbreuken op Art 2 lid 1, in het bijzonder op de prive-sfeer van het individu, strenge eisen moeten worden gesteld. Vervolgens stelde het Hof vast, dat het individu een waardigheid en respect toekomt:

In Lichte dieses Menschenbildes kommt dem Menschen in der Gemeinschaft ein sozialer Wert- und Achtungsanspruch zu. Es wiederspricht der menschlichen Würde, den Menschen zum bloßen Objekt im Staat zu machen (vgl. BVerfGE 5, 85 (204); 7, 198 (205)),

Voor dit standpunt putte het Hof achtereenvolgens uit KPD-Verbotsurteil en Lüh. In die zaken was de vraag in welke mate het individu een object van de staat is echter in een andere context aan de orde dan in Mikrozensus. In KPD-Verbotsurteil beoordeelde het Hof de vraag in hoeverre de communistische doelstellingen van de KPD in overeenstemming waren met het mensbeeld van de grondwet. Kennelijk was de vaststelling, dat het individu niet tot object van de staat mag verworden, eveneens relevant in de context van de ondervragingen door de staat. Deze abstracte norm van hoger recht 'Menschenwirde' - lijkt zich te lenen voor onderscheidenlijke invulingen. Het Hof spitste deze overweging direct toe op de individuele aanspraak die aan de orde was in Mikrozensus:

'Mit der Menschenwürde wäre es nicht zu vereinbaren, wenn der Staat das Recht für sich in Anspruch nehmen kơnnte, den Menschen zwangsweise in seiner ganzen Persönlichkeit zu registrieren und zu katalogisieren, sei es auch in der Anonymitat einer statistischen Erhebung, und damit wie eine Sache zu behandeln, die einer Bestandsaufnahme in jeder Beziehung zugänglich ist. ${ }^{3.3}$

Het Hof concretiseerde de norm in een volgende stap naar de aanspraak in Mikrozensus on duidelijk te maken dat niet alleen "catalogisering" tegen de menselijke waardigheid indruist, maar dat dat aspect tevens eist dat voor het individu een ruimte bestaat, waarin het volledig zichzelf kan zijn, zonder vrees voor bemoeienis of opdringerigheid van de zijde van de staat. Dit onderdeel van de menselijke waardigheid was echter tot dusverre nog niet naar voren gekomen in de rechtspraak. Het Hof verliet zich in dit verband op normen die niet direct kunnen worden getypeerd als rechtsnormen:

"Ein solches Eindringen in den Personnlichkeitsbereich durch eine umfassende Einsichtsnahme in die persönliche Verhältnisse seiner Bürger ist dem Staat auch deshalb versagt, weil dem Einzelnen um der freien und selbstverantworlichen Entfaltung seiner Persönlichkeit willen ein "Innenraum" verbleiben muB, in dem er "sich selbst besitzt" und "in den er sich zurückziehen kann, zu dem die Umwelt keinen Zutritt bat, in dem man in Ruhe gelassen wird und ein Recht auf Einsamkeit genieBt" $[\ldots]{ }^{\text {s.4 }}$

Het Hof erkende in deze overweging de door de rechter in eerste aanleg voorgestelde aansprak inhoudende een recht op een intieme sfeer ter zake van ondervragingen voor statistische doeleinden. In de volgende stap dienden de omtrekken van het recht te wor-

54 Miknozensus, 27 BVertGE 1, 6(1969) 
den begrensd - de afbakening van het recht moest worden afgestemd op het voorliggende feitencomplex. Daartoe ging het Hof over tot de vaststelling van de reikwijdte van het recht op een intieme sfeer. Niet iedere onderviaging, aldus het Hof, vormt daarop een ontoelaatbare inbreuk; er zijn inbreuken die het individu moet tolereren omdat het nu eenmaal in een gemeenschap leeft:

"Nicht jede statistische Erhebung über Persönlichkeits- und Lebensdaten verletzt jedoch die menschliche Persönlichkeit in ihrer Würde oder berührt ihr Selbstbestimmungsrecht im innersten Lebensbereich. [...]"

Tot dusverre had het Hof enkel de elementen 'Menschenwirde", "algemeen persoonlijkheidsrecht' en 'privé-leven' in het kader van Artt. $\mathbb{l}$ lid 1 en 2 lid 1 GG uitgewerkt. In deze overweging werd echter een recht op zelfbeschikking aangehaald, dat niet zou mogen worden geraakt door ondervragingen. Wat allereerst opvalt, is dat die zelfbeschikking in dit verband direct werd verheven tot een recht: het Hof spreekt immers van een 'Selbstbestimmungsrecht'. Uit de uitspraak blijkt niet precies welke de bron van dat recht is. Het Hof baseerde zich voor de vestiging van dat recht noch op voorafgaande rechtspraak, noch op grondwetsartikelen of samentrekkingen van grondwetsartikelen en/of vroegere uitspraken. Daarnaast kende het Hof het recht, afgaande op de formulering, dat recht in een nevenschïking gelijk met de in de grondwet gepositiveerde rechten. In Mikrozensus werden de erkende aanspraken echter niet gehonoreerd. Het vereiste van proportionaliteit kon niet leiden tot ongrondwettigverklaring van de wet. De wet raakte niet de kern van de privé-sfeer; er bleken voldoende grondwettelijke waarborgen ingebouwd om willekeur te voorkomen. Er was voldoende anonimiteit gegarandeerd, waardoor het gevreesde misbruik van gegevens werd gereduceerd. ${ }^{55}$

Mikrozensus vormde naderhand in verschillende individuele aanspraken aanleiding, om nieuwe individuele aanspraken te erkennen onder de reikwijdte van Art. 2 lid 1 GG. Het stramien voor de redenering naar de erkenning van nieuwe rechten was neergelegd in Mikrozensus: vooreerst stelde het Hof wast, dat het individu een rech heeft op een privé-sfeer, waarvan de beschermingsonvang per situatie - afhankelijk van de aanspraak en het feitencomplex - dient te worden vastgesteld. Een andere concretisering werd bijvoorbeeld uitgewerkt in Ehescheidungsakten, een zaak waarin het Hof beoordeelde of de verplichte opening van een echtscheidingsdossier in het licht van een ontslagzaak in overeenstemming was met het recht op priwé-sfeer ex Art. 1 lid 1 en 2 lid $1 \mathrm{GG}^{56}$ De betrokkene was ontslagen ondat hij een buitenechtelijke affaire had gehad met een collega; de informatie in het echtscheidingsdossier leverde bewijsmateriaal voor een ontslaggrond. Het Hof hanteerde hier eveneens de hiervoor genoemde benadering: de aanspraak diende te worden beoordeeld onder het privé-leven, meer in het bijzonder het recht op geestelijke integriteit: het individu dient voor zover mogelijk zelf te kunnen kiezen voor openbaring van intieme gegevens. Geestelijke integriteit maakte echter nog niet vanzelfsprekend deel uit van Art. 2 lid 1 GG, maar het Hof 
vergeleek het recht op geestelijke integriteit met het recht op fysieke integriteit zoals het dat had erkend onder Art. 2 lid 2 GG:

"Dabei karnn von den Grundsätzen, die das Bundesverfassungsgericht in seiner bisherigen Rechtsprechung uber die verfassungsrechtliche Zulässigkeit von Eingriffen in die körperliche Unwersehtheit entwickelt hat $[. .$.$] , ausgegangen werden. Jedoch ist dem Schutz der$ Integrität der menschlichen Person in geistig-seelischer Beziehung ein besonders hoher Wert beizumessen $[\ldots . . .]^{37}$

Een zelfde redenering werd gevolgd in de zaak Arztliche Schweigepflicht, waarin succesvol werd geklaagd over de inbeslagname van staatswege van medische informatie van een patient: het Hof beoordeelde de aanspraak op bescherming van de intieme sfeer onder Art. 2 lid 1 en 1 lid $1 \mathrm{GG}$ en stelde vast dat de aanspraak binnen de privé-sfeer viel ${ }^{58}$ De concretisering hield in dat het individu recht heeft op geheimhouding van medische gegevens:

'Ärztliche Karteikarten [...] betreffen mit ihren Angaben über Anamnese, Diagnose und therapeutische Maßnahmen zwar nicht die unantastbare Intimsphäre, wohl aber den privaten Bereich des Patienten. Damit nehmen sie teil an dem Schutz, den das Grundrecht aus Art. 2 Abs. 1 in Verbindung mit Art. 1 Abs. 1 GG dem Einzelnen vor dem Zugriff der öffentlichen Gewalt gewährt. Insbesondere gilt das für die Erkentnisse, die der Arzt durch seine berufliche Tátigkeit aber den Gesundheitszustand des Patienten gewinnt und schriftich niederlegt'. 59

Ook Jeidde het Hof uit het bestaan van de privé-sfeer af, dat in sommige gevallen andere dan de in de wet genoemde personen een aanspraak kunnen maken op een verschoningsrecht. ${ }^{60}$ In Zeugnisverweigerungsrecht werd aangenomen, dat maatschappelijk werkers, die in een strafrechtelijke procedure zouden moeten getuigen, onder omstandigheden een verschoningsrecht toekomt in verband met de privê-sfeer van hun cliënten. In deze zaak werd een man verdacht van ontucht met zijn minderjarige zoon. De maatschappelijk werker die het kind had begeleid, weigerde verklaringen van het kind te onthullen. Het Hof baseerde zich voor de vaststelling van toepasselijkheid van een recht op privelleven op Elfes, Mikrozensws, Ehescheidungsakten en Arztliche Schwergephlichr. ${ }^{61}$ De vraag rees, in welke mate de privé-sfeer van de cliënt in concreto zou worden geraakt, indien maatschappelijk werkers immer zouden worden gedwongen te getuigen in strafrechtelijke procedures. De toelaatbaarheid van de inbrenk hangt nu, aldus het Hof, af van de sfeer waarbinnen de aanspraak wordt geplaatst:

'Das gilt schon deshalb, weil der Einzelne den innersten Bezirk, der hihm um seiner freien und selbstwerantwortlichen Persönlichkeitsentfaltung willen verbleiben muß (BVerfGE 27, 1 (6)), zwangsläufig verlâBt, sobald er sich Anderen freiwillig mitteilt" ${ }^{32}$ 
Het Hof ging er hierna toe over te bepalen of de aanspraak van de maatschappelijk werker in de kern of in een meer perifere sfeer van het begrip prive-leven moest worden beoordeeld. Het Hof koos voor de perifere sfeer, waarin op grond van zwaarwegende redenen inbreuken op dat privé-leven mogen worden gemaakt. Van een vrijwillige mededeling kan onder deze omstandigheden niet immer sprake zijn. Dit aspect in de verhouding tussen cliënt en maatschappelijk werker kan echter niet tot gevolg hebben, aldus het Hof, dat maatschappelijk werkers in het algemeen een verschonimgsrecht toekomt. ${ }^{63}$

In Tonband werd het 'allgemeines Persönlichkeitsrecht' voor de eerste keer door het hof genoemd. ${ }^{64}$ In deze zaak werd geklaagd over het gebruik van een geluidsband die zonder toestemming van de klager was wervaardigd. Tegen deze klager was eem strafrechtelijk onderzoek ingesteld; in het onderzoek naar belastingfraude werd de band gebruikt. De klacht was gebaseerd op Art. 2 lid $1 \mathrm{GG}$; het Hof aanvaardde de aanspraak onder het 'unantastbaren Bereich privater Lebensgestaltung". ${ }^{65} \mathrm{De}$ juridische grondslag waarop de kwalificatie van de aanspraak berustte, behoefde voor de beslissing van de zaak geen verdere uitwerking. Het Hof werkte echter uit in welke context de aanspraak eveneens kon te worden bezien, zonder dat die context direct noodzakelijk was voor de beslechting van het geschil:

'Private Gespräche müssen geführt werden können ohne den Argwohn und die Befürchtung, daß deren heimliche Aufnahme ohne die Einwilligung des Sprechenden oder gar gegen dessen erklärten Willen verwertet wird. Dem tragen im materiellen Strafrecht [...] und im Zivilirecht [...] die Rechtsprechung des Bundesgerichtshofs zum allgemeinen Persönlichkeitsrecht seit langem Rechnung?.66

Het 'allgemeines Persönlichkeitsrecht' werd zoals hiervoor gesteld genoemd, maar niet als dragend argument voor de beslissing gebezigd. Dit obiter zou later van grote betekenis zijn voor de positivering van die rechtsnorm. Uit dat 'allgemeines Persönlichkeitsrecht" Jeidde het Hof later in de zaak Sorcya een grondslag voor toewijzing van immaterièle schadevergoeding af. ${ }^{67}$ In deze zaak claimde een uitgever dat hij bij afwezigheid van een wettelijke grondslag voor immateriele schadevergoeding in het privatatrecht niet kon worden gedwongen, een dergelijke schadevergoeding te betalen. Soraya had schadevergoeding in een onrechtmatige daadsactie op basis van Art. 823 lid 1 BGB geëist omdat een aantal gefingeerde interviews zogenaamd intieme details over haar

63 Er kunnen zich situaties voordoen, waarin onder de gegeven omstandigheden cen afweging moet worden gemaakt tussen enerzijds het priwé-leven van de client en anderzijds een volwaardige strafprocesorde. In casu deed zich een uitzonderingssituatie voor: vanwege de bijzondere verhouding tussen deze client en maatschappelijk werker week het Hof af van de wettelijk vastgestelde groep wan persomen, die een beroep kunnen doen op het verschoningsrecht, Zeugnisuemweigerungswecht, $33 \mathrm{BVerfGE}$ $367,386(1972)$

64 Tomband, 34 BVerfGE 238 (1973).

65 Tomband, 34 BVerfGE 238, 241 (1973).

66 Tonbawd, 34. BVerfGE 238, 243 (1973).

67 Sorrya, 34 B VerfoE 269 (1973). 
privé-leven onthulden ${ }^{68}$ In beginsel bood Art. 823 lid 1 BGB aanknopingspunten voor een grondslag tot schadevergoeding ${ }^{69}$ maar stond Art. 253 BGB in de weg aan toekenning van immateriele schadevergoeding, omdat die bij wet moet zijn geregeld. ${ }^{70}$

Het Bundesgerichtshof (BGH) had in deze zaak voorafgand aan het Federale Constitutionele Hof erkend, dat 'een algemeen persoonlijkheidsrecht' kan dwingen tot het betalen van een immaterièle schadevergoeding, ook al heeft de wetgever hiervoor geen regeling getroffen. Het Hof bevestigde de opvatting van het BGH. Nieuw in deze zaak was de erkenning van het door het BGH gehanteerde 'algemene persoonlijkheidsrecht' door het Federale Constitutionele Hof. Het Federale Constitutionele Hof stelde zich zeer terughoudend op naar het $\mathrm{BGH}$ en nam de door het $\mathrm{BGH}$ gevolgde redenering over, zonder daaraan expliciet de consequentie te verbinden dat het 'allgemeines Persőnlichkeitsrecht' als rechtsnorm deel voortaan uitmaakt van de constitutionele rechtsorde. ${ }^{71}$ Het Constitutionele Hof trachtte zich met zijn aansluiting bij het BGH enigszins terughoudend op te stellen in verband met de constitutionele verhouding tussen Hof en wetgever: ten slotte was er op een twee decennia eerder gelanceerd parlementair wetsvoorstel voor immateriële schadevergoeding voor slachtoffers van de pers een storm van kritiek gekomen. ${ }^{72}$ Met bevestiging van de uitspraak van het $\mathrm{BGH}$ zou het Hof die keuze van de wetgever terzijde stellen. 's Hofs beroep op het verstrijken van de tijd en de groeiende noodzaak van immateriële schadevergoeding diende de destijds gemaakte keuze tegen immateriële schadevergoeding terzijde te stellen:

'Diesem Schutzzweck dient im Bereich des Privatrechts auch die Rechtsfigur des allgemeinen Persönlichkeitsrechts; sie fullt Lücken im Persönlichkeitsrecht aus, die hier trotz Anerkennung einzelner Persönlichkeitsrechte verblieben und im Laufe der Zeit aus verschiedenen Gründen immer fühlbarer geworden waren: ${ }^{73}$

De benadering van het Hof laat zien dat een voorzichtige aanpak werd gekozen bij de introductie van het 'allgemeines Persönlichkeitsrecht' als constitutionele rechtsnorm. De prudente benadering is verklaarbaar vanuit de gedachte, dat deze vage norm nauwelijks omtrekken kent en mitsdien naast Art. 2 lid 1 GG een nieuwe 'due process'clausule in het Duitse constitutionele recht zou kunnen binnenloodsen. In het licht van de constitutionele verhouding zou dat een met de Amerikaanse situatie vergelijkbare kritiek uitlokken: de rechter verschaft zich met het scheppen van een dermate onbepaald recht, een vrijbrief om iedere willekeurige wet te onderwerpen aan een grondwettigheidstoets. In Tonband werd het recht geintroduceerd in een obiter dictum en niet

68 Art. 823 lid I BGB luidt: 'Wer vorsatzlich oder fahrlassig das Leben, den Korper, die Gesundheit, die Freiheit, das Eigentum oder ein sonstiges Recht eines anderen widerrechtlich verletzt, ist dem anderen zum Ersatze des daraus entstehenden Schadens verpflichtet".

69 Het aspect "ein sonstiges Recht' kwam hierwoor het eerst in aanmerking.

70 Art. 253 BGB luidt: "Wegen eines Schadens, der nicht Vermögensschaden ist, kann Entschadigung in Geld nur in den durch das Gesetz bestimnten Fallen gefordert werden'

71 Het Hof aanvaardde de redenering onder werwijzing naar Elfes en Lüth; Soraya, 34 BVerfGE 269, 281 (1973).

72 Soraya, 34 BVerfGE 269, 272-273 (1973).

73 Soraya, 34 BVerfGE 269, 281 (1973). 
expliciet als constitutioneelrechtelike norm aan de orde gesteld; Sor wa herhaalde deze betekenis van de norm van privaatrechtelijke komaf en stelde in onduidelijke bewoordingen dat het ook een norm van constitutioneelrechtelijke betekenis zou kunnen zijn. De meest duidelijke aanwijzing, dat het Hof het 'allgemeines Personlichkeitsrecht' als grondrechtelijke norm aanvaardde volgt uit deze passage:

\footnotetext{
"Gehört das allgemeine Persönlichkeitsrecht nach der verfassungsrechtlich nicht zu beanstandenden Auslegung dieser Bestimmung zu den hier aufgefuhrten Rechten, so kommt ihm nach dem Willen der Verfassung die Fähigkeit zu, das Grundrecht der Pressefreiheit [...] einzuschränken. Diese potentiellen Wirkkraft [...] erhält hier [...] eine verfassungsrechtliche Verstärkung aus dem Schutzauftrag der Art. 1 und $2 \mathrm{Abs} .1 \mathrm{GG}$ ',
}

Hieruit volgt dat het Hof de nieuwe 'benaming' van de contaminatie van Art. 1 lid 1 en 2 lid $1 \mathrm{GG}$ een rumere reikwijdte toekent dan het hiervoor steeds gehanteerde "unantastbarer Bereich privater Lebensgestaltung' ${ }^{74}$ Het algemene persoonlijkheidsrecht zou enkele jaren later in Eppler (1980) daadwerkelijk worden gehanteerd als juridische grondslag voor een individuele aanspraak.

\subsubsection{Het recht, alleen te worden gelaten en het recht op resocialisatie}

Het recht op een "unantastbarer Bereich privater Lebensgestaltung" bood in 1973 een grondslag voor erkenning wan een recht op resociallisering. ${ }^{75}$ Een aantal personen had een roofoverval op een munitiedepot gepleegd, waarbij ook enkele doden waren gevallen. Voor de aanslag en de gevolgen daarvan werden de betrokkenen strafrechtelijk veroordeeld. Toen tweederde van de duur van de veroordeling was verstreken, wenste een televisiestation uitgebreid aandacht te schenken aan deze roofoverval, die zes jaren eerder had plaatsgevonden. De daad en het strafproces hadden destijds veel opzien gebaard; in de media was in ruime mate aandacht besteed aan deze zaak. ${ }^{76}$ Eén van de gedetineerden beriep zich voor de civiele rechter op een recht op 'privé-leven" ex Alt. 2 lid $\mathbb{G G}$, dat onder meer een aanspraak niet publiekelijk vanwege zijn daad in het verleden te worden blootgesteld zou omvatten. Het Hof erkende de individuele aanspraak van de gedetineerde als een belang dat wordt beschermd onder het recht op ontplooiing van de persoonlijkheid ex Art. 2 lid l GG:

'Das Recht auf freie Entfaltung der Persönlichkeit und die Menschenwürde sichen jedem Einzelnen einen autonomen Bereich privater Lebensgestaltung, in dem er seine Individualität entwickel.n und wahren kann. Hierzu gehört auch das Recht, in diesem Bereich "fïr sich zu sein", "sich selber zu gehören"'[...], ein Eindringen oder einen Einblick durch andere auszuschließen (vgl. BVerfGE 27, $1(6) ; 33,367$ (367))".77

Voor het recht, "op zichzelf te zijn', "tot zichzelf te behoren" zocht het Hof aldus aanknoping bij passages uit Mikrozensus en Zeugnisverweigerungsrecht, die naar derge- 
lijke rechtsnormen zouden werwijzen. ${ }^{78}$ In Mikrozensus had het Hof zich echter niet expliciet uitgelaten over het bestaan van rechtsnormen uitgelaten:

'Ein solches Eindringen in den Persönlichkeitsbereich durch eine umfassende Einsichtnahme in die persönlichen Verhältnisse seiner Bürger ist dem Staat auch deshalb versagt, weil dem Einzelnen um der freien und selbstverantwortlichen Entfaltung seiner Personnlichkeit willen ein "Innenraum" verbleiben muB, in dem er "sich selbst besitzt" und "in den er sich zurtuckziehen kann, zu dem die Unwelt keinen Zutritt hat, in derm man in Ruhe gelassen wird und ein Recht auf Einsamkeit genieBt" $[\ldots]^{79}$

's Hofs verwijzing in Mikrozensus gaf hoogstens enkele contouren van een recht om met rust te worden gelaten. Een nadere concretisering diende nog plaats te vinden. Daartoe boden eerdere feitencomplexen en aanspraken in de jurisprudentie niet direct aanknopingspunten. De abstracte formulering van het bellang van het individu bij het alleen zijn bood echter veel ruimte voor vergelijking van uiteenlopend vergelijkingsmateriaal om het bestaan van recht op resocialisering te rechtvaardigen. Met dit recht kon het recht op vrijheid van meningsuiting, dat door het televisiestation werd geclaimd, in omvang worden gerelativeerd.

'Vom Täter aus gesehthen erwåchst dieses Interesse an der Resozialisierung aus seinem Grundrecht aus Art. 2 Abs. 1 in Verbindung mit Art. $1 \mathrm{GG}^{\prime}$.

De analogie met Mikrozensus en Zeugnisverweigerungsrecht levert een abstracte nom van hoger recht op, die inhoudt dat het individu een recht heeft met rust te worden gelaten. Uit die norm van hoger recht werd vervolgens een recht op resocialisering en een rustige terugkeer in de samenleving afgeleid. De norm van hoger recht bezit hier een hoge mate van abstractie, waardoor zij uiteenlopende aanspraken lijkt te kunnen herbergen.

Het Hof had eveneens oog voor de belangen van het televisiestation ${ }^{81}$, maar de balans sloeg uiteindelijk door in het voordeel van de veroordeelde. Het recht om alleen te worden gelaten verkrijgt in de tijd een groter belang, naarmate een groter deel van de straf is uitgezeten door de persoon die wenst te reîntegreren in de samenleving. ${ }^{82}$ Die samenleving dient bereid te zijn, deze persoon op te nemen; een televisie-uitzending als voorgesteld door het station zou daaraan afbreuk kunnen doen. Uit het recht op resocialisering nadat de straf is uitgezeten wloeide in Gefangenenentlohnung een positieve verplichting voor de staat voort, werkelijk inhoud te geven aan de voorbereidingen die moeten worden getroffen voor de terugkeer in de samenleving. ${ }^{83}$ Het Hof laat in dit verband een grote discretie aan de wetgever wat betreft de wijze waarop die verplichting dient te worden ingevuld. De verplichting vloeit voort uit een contaminatie van

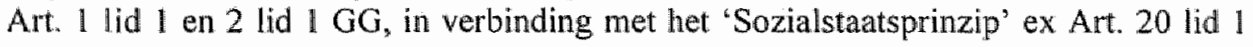


$\mathrm{GG}^{84}$ Resocialisering was hiermee gevestigd als norm van geldend recht waaraan tot op zekere hoogte zelfs positieve verplichtingen kunnen wotden ontleend. ${ }^{85}$

\subsubsection{Het recht op abortus}

In twee verzoeken om abstracte toetsing keurde het Hof federale wetgeving af, die abortus tot op zekere hoogte zou legaliseren. Vooral het eerste besluit (1975) van het Hof wordt wel aangemerkt als schoolvoorbeeld van rechterlijk activisme. In 1975 werd op initiatief van een groep parlementariërs een wet die abortus decriminaliseerde, een abstracte herziening door het Hof uitgevoerd. ${ }^{86} \mathrm{Zij}$ waren van mening dat abortus in strijd was met het recht op leven ex Art. 2 lid 2 GG en een recht op menselijke waardigheid. De eerste Senaat in het Hof achtte de wet ongrondwettig en steunde daarbij in belangrijke mate op het argument dat enerzijds het ongeboren kind een recht op leven toekomt, en anderzijds op een recht van de moeder op algemene handelingsvrijheid dat een beperkte reikwijdte toekomt nu zij verantwoordelijk is voor het ongeboren kind. Het ongeboren leven komt een zelfstandig rechtsbelang onder Art. 2 lid 1 GG toe. Het Hof onderbouwde dit standpunt met verwijzingen naar de gebeurtenissen onder het nationaal-socialisitische regime, waarin aan sommige mensenlevens, aldus het Hof, geen waarde werd gehecht. ${ }^{87}$ Daarnaast markeerde het recht een grens vanaf welk

84 'Das Bundesverfassungsgericht hat dieses Gebot aus dem Selbstwerstandnis einer Rechtsgemeinschaft entwickelt, die die Menschenwurde in den Mittelpunkt ihrer Wertordnung stellt und dem Sozialstaatprinzip verpflichtet ist. [...] Die Resozialisierung dient auch dem Schutz der Gemeinschaft selbst: Diese hat ein unmittelbares eigenens Interesse daran, daß der Tatter nicht wieder rückffallig wird und erneut seine Mitbarger und die Gemeinschaft schadigt (vgl. BVerfGE 35, 202 [235) - Lebach)', zie Gefangenenentlohnung, BVerfG 2 BvL. 17/94, 1 juli 1998, par. 132.

85. De zaak Lebach zou overigens ruim twee decennia later weer tot leven worden gewekt en beoordeeld onder het 'allgemeines Personlichkeitsreclut'. Een commerciële zender was voornemens, een documentaire getiteld "Verbrechen, die Geschichte machten" wit te zenden. Hierin zou geput worden uit het materiaal van het televisiestation dat over de moord in Lebach had willen berichten in 1973 ( Lebach $/ \mathrm{H}$, BVerIG I BuR 755/98, 25 november 1999). Het recht op resocialisering en het recht, alleen te worden gellaten verkregen in deze zaak een andere betekenis. Nu werden met name invulling van het tijdswerloop, de mate en intensiteit waarin burgers zich laten voorlichten door het medium televisie, alsmede afwezigheid van gevaar van onthulling van de identiteit van de klager op een andere wijze ingevuld dan destijds. Ook kan de daad waarvoor het individu strafrechtelijk is veroordeetd ${ }_{\text {n }}$ een rol spelen in de mate waarin blootstelling van een dader acceptabel is via het medium televisie aan het publiek. In MißBbrachbezichtrgung deed tijdverlowp er juist minder toe dan in Lebach. De uiting van een vrotuw, die haar vader in een televisie-uitzending had aangewezen als dader van incest, werd in dit verband door het Hof anders becordeeld dan de klacht in Lebach, ook al lag de daad verder terug in het verleden dan Lebach, zie Mißbrauchbezichtigung, 97 BVerfGE 391 (1998).

\$86 Schwangerschaftsabbruch I, 39 BVerfGE I (1975). De groep van 193 parlementariers bestond woor het grootste deel uit Christendemocraten en betwistte de grondwettigheid van Art. 218 a van een herziening van het Wetboek van Strafrecht ter zake wan abortus. De wet hield in dat abortus niet langer strafbaar was en dat de zwangere vrouw voorafgaand aan haar besluit verplicht werd om hasi keuze: met een arts of ander bevoegd persoon te overleggen. Na de derde maand van zwangerschap zou abortus wel weer strafbaar worden, behalve in gewallen waarin sprake was van gevaar voor het leven van de vrouw, of wanneer de zwangerschap was ontstaan uit verkrachting of incest. 
moment de ongeborene een recht op leven toekomt: na de veertiende dag na de conceptie start het menselijke leven. ${ }^{88}$

'Er (het ontwikkelingsproces, H.L.J.) ist auch nicht mit dem Geburt beendet; die für die menschliche Persönlichkeit spezifischen Bewußtseinsphänomene z.B. treten erst längere Zeit nach der Geburt auf. Deshalb kann der Schutz des Art. 2 Abs. 2 Satz I GG weder auf den "fertigen" Menschen nach der Geburt noch auf den selbständig lebensfähigen Nasciturus beschränkt werden" ${ }^{89}$

Vraag is of deze benadering een algehele afwijzing van afbreking van de zwangerschap kan rechtvaardigen. Echter, de veronderstelling dat het ongeboren leven een recht op leven toekomt, maakt dat een dergelijke vraag slechts op één wijze beantwoord kan worden. Vanuit de door het Hof geschetste benadering komt het ongeboren leven een primordiale plaats toe. Het Hof stelde dat de grondleggers van de grondwet deze invulling van het recht op leven eveneens voor ogen hadden. De vraag, of voor de staat in dat verband een positieve verplichting bestaat werd positief beantwoord; middels strafrecht dient dat recht op leven te worden beschermd, aldus het Hof:

'Das menschliche Leben stellt, wie nicht näher begründet werden muß, innerhalb der grundgesetzlichen Ordnung einen Höchstwert dar; es ist die vitale Basis der Menschenwïrde und die Voraussetzung aller anderen Grundrechte? ${ }^{\text {? }}$

Bij de positionering van het recht van het ongeboren leven diende rekening te worden gehouden met het recht van de zwangere vrouw. De zwangerschap behoort in beginsel tot haar intieme privé-sfeer ex Art. 2 lid 1 en 1 lid 1 GG, maar omdat het embryo een zelfstandige aanspraak op het recht op leven toekomt, kan een inbreuk door de wetgever op die intieme privé-sfeer grechtvaardigd zijn. Beëindiging van de zwangerschap heeft een sociale dimensie vanwege het belang van het ongeboren leven die de intimiteit van de privé-sfeer in hoge mate relativeert. ${ }^{91}$ Eerst na deze constatering stelde het Hof de contouren van het recht op privé-leven van de zwangere vrouw vast:

'Dieses Recht ist aber nicht uneingeschränkt gewäht - die Rechte anderer, die verfassungsmaBige Ordaung, das Sittengesetz begrenzen es. Von vornherein kann es niemals die Befugnis umfassen, in die geschutzte Rechtssphäre eines anderen ohne rechtfertigenden Grund einzegreifen oder sie gar mit dem Leben selbst zu zerstören, am wenigsten dann, wenn nach der Natur der Sache eine besondere Verantwortung gerade für dieses leben besteht". ${ }^{2}$

"Leben im Sinne der geschichtlichen Existenz eines mensclilichen Individuums besteht nach geischerter biologisch-physiologischer Erkenntnis jedenfalls vom 14. Tage nach der Empfangnis [...] an $[\ldots]$. Der damit begonnene Entwicklungsprozeß ist ein kontinuierlicher Vorgang, der keine scharfen Einschnitte aufweist und eine genaue Abgrenzung der verschiedenen Entwicklungsstufen des mensch. lichen Levens micht zulabe', Schwangerschaftsabbruch 1, 39 BVerfGE 1, 37. Schwangerschafisabbruch 1, 39 BVerfoE 1, 37 (1975).

90 Schwangerschafisabbruch 1, 39 BVerfGE 1, 42 (1975).

91 Waar het Hof eerst sprak van het recht op leven van de "ongeborene" of van het "embryo", refereerde het verderop in de uitspraak aan het recht van het 'kind' (Schwangerschaftsabbrach I, 39 BVerfGE I. $44(1975))$.

92 Sohwangerschaftsabbrach I, 39 BVerfGE 1, 43 (1975). 
De verwijzing naar de 'Natur der Sache' werd niet toegelicht; aangenomen wordt dat hier werd gewezen op de verantwoordelijkheid van de zwangere vrouw voor het on geboren leven. De vraag welke de consequentie is van de verantwoordelijkheid die de vrouw draagt wordt hier slechts op én manier beantwoord: zij kan wameer zij zwanger is de verantwoordelijkheid voor de ruimte die de staatsvrije privé-sfeer kent kennelijk niet alleen dragen. ${ }^{93}$ De aard van de zaak verlangt vanuit die gedachte overheidsingrijpen. ${ }^{94}$ De uitkomst van de belangenafweging werd met deze opbouw van de rechtsvinding voorspelbaar.

In het Hof was men het in beginsel eens over de omtrekken van vastgestelde belangen - met name die van de zwangere vrouw. Er ontstond hevige strijd over de vraag in hoeverre het Hof zich in zijn interpretatie en ter zake van de gevolgen die daaruit voortvloeiden, te activistisch had opgesteld. ${ }^{95}$ In de optiek van de dissenters dient de invulling van de "objektive Wertordnung" aan de wetgever te worden overgelaten. Met name de positieve verplichting in de vorm van een "recriminalisering" die het Hof verbond aan het recht op leven was hen een doorn in het oog; de dissenters waren van mening dat grondrechtelijke bescherming niet tot gevolg kan hebben dat de rechter strafrechtelijke consequenties aan een grondrecht kan verbinden. ${ }^{96}$ Het is aan de wetgever om te beoordelen of op die wijze invulling aan grondrechten wordt gegeven. Het standpunt van het Hof, dat het leven na de veertiende dag na conceptie aanvangt, werd door de dissenters niet betwist. Wel stelden zij vragen ter zake van de vergelijking met de gebeurtenissen tijdens het nazi-regime; de omstandigheden waaronder abortus daar plaatsvond, en die waarin de wetgever in de jaren zeventig abortus in het eerste trimester wilde toestaan laten een vergelijking niet toe, althans niet zoals het Hof poneert:

'Hieraus Schlubfolgerungen fur die verfassungsrechtliche Bewertung einer nicht vom Staat, sondern von der Schwangeren selbst oder mit ihrem Willen von Dritten vorgenommenen Abtötung der Leibesfrucht zu ziehen, ist um so weniger am Platze, als das nationalsozialistische Regime entsprechend seiner biologisch-bevölkerungspolitischen Ideologie gerade dazu einen rigorosen Standpunkt eingenommen hatte".

Normaliter heeft een verwitzing naar de eigen verantwoordelijheid van het individu onder Art. 2 \id $\mathrm{GG}$ een andere comnotatie: het individu wordt in stat geacht, zijn staatsvrije sfeer op een wijze in te richten die hem het beste past. Afgand op de eigen verantwoordelijherd van het individu past in beginsel geen staatsingrijpen. Hier wordt de verantwoordelijkheid op een andere wijze uitgelegd en toegepast, en gaat het Hof er wanuit dalt de verwijzing naar de "Natur der Sache" - verantwoordelijkheid van de vrouw voor het ongeboren lewen - een benadering wan de staat past. De vrouw kan kennelijk geen of onvoldoende eigen verantwoordelijkheid dragen voor het ongebonen lewen. Uitzonderingen op het werbod van abortus blijven mogelijk, bijwoorbeeld wanneer het leven of de gezondheid van de zwangere vrouw in gevarar is.

95 Allus de dissenters bij deze uitspraak die met 6-2 werd beslist (Schnangerschaftsabbruch 1, 39 BVerfGE 1,68 en met name 73 e.v. (1975)).

96 In $X$ en $Y$ t. Nederland (EHRM 25 maart 1985, Serie A vol 91) leek sprake te zijn van een vergelijkbaar fenomeen: hier achte het EHRM strafrechtelijke consequenties van schending van een grondrecht noodzakelijk. In $X$ en $Y$ t. Nederland bestond de strafrechtelijke sanetie techter al. Het Hof was vooral van mening dat die stanctie ook geëfectueerd moest kunnen worden door werstandelijk gehandicapten. Het klachytrecht diende aldus op enkele aspecten anders te worden ingericht. 
Hier wordt de vergelijking die door de meerderheid werd gehanteerd als argument voor afwijzing van abortus in twijfel getrokken; de dissenters brengen een argument met een andere en evenzeer legitieme invalshoek in, namelijk de wil van de zwangere vrouw de zwangerschap te beeindigen. ${ }^{97}$ Zij toonden met hun vergelijking aan, dat de door de meerderheid woorgestelde analogie met de gedwongen abortus onder het nazi-regime mank gaat. Na de hereniging met voormalig Oost-Duitsland diende zich in 1993 de tweede abstracte herziening aain. ${ }^{98}$ De constitutionele vereisten ter zake van de voormalige meest liberaler Oost-Duitse abortuswetgeving zouden eerst twee jaar na toetreding tot West-Duitsland gaan gelden. Gedurende die twee jaren werd gewerkt aan een uniformerende wet; het compromis tussen de twee Duitse abortusbenaderingen hield uiteindelijk in dat abortus gedurende het eerste trimester niet meer strafbaar was, maar dat de zwangere vrouw die abortus overwoog zich uitgebreid moest laten voorlichten. De positieve verplichting van de staat in de vorm van een strafbaarstelling werd omgezet in uitgebreide voorlichtings- en beshitvormingsprocedures. Er werd bezwaar gemaakt door een groep van 250 parlementariërs. Op hoofdlijnen van het recht op leven en het recht van de vrouw op handelingsvrijheid werd Schwangerschaftsabbruch l bevestigd, en de decriminalisering van abortus in het eerste trimester van de zwangerschap aanvaard. ${ }^{99}$ Het parlement aanvaardde uiteindelijk een regeling waarin de verplichte voorlichting zich specifiek toesneed op invloeden van buitenaf die een gevaar zouden kunnen betekenen voor de beslissing van de zwangere vrouw.

De beslissing van het Duitse Hof is wat de uitkomst betreft diametraal tegenovergesteld aan de beslissing van het Amerikaanse Hooggerechtshof in Roe t. Wade. ${ }^{100}$ Twee uitgangspunten liggen hieraan ten grondslag: in de eerste plaats kent de Duitse rechter aan de ongeborene vanaf het begin van conceptie een recht op leven toe, en in de tweede plaats verbindt de Duitse rechter een positieve verplichting aan dat recht, namelijk strafbaarstelling van abortus. ${ }^{101}$ Beide aspecten zijn voor wat betreft de materiële invul-

Uiteindelijk stelde de wetgever een nieuwe wet op waarin de straftatarstelling zoals door het Hof voorgeschreven werd gehandhated. Abortus was voortaan strafbaar, maar kon worden ondergaan indien medische, genetische, sociale en ethische gronden daartoe noopten. Abortus op medische indicatic kon worden uitgevoend tot 22 weken, terwijl de abortussen met een andere indicatie na overleg met aen deskundige konden worden ondergaan. Bijna $80 \%$ van de ondergane abortussen had een sociale indicatie (Konmers 1997, p. 347). Abortus wordt, om het even orn welke reden, vergoed door de staat.

98 Schwangerschafssabliruch II, 88 BVerfGE 203 (1993).

99 Schwamgerschaftsabbruch II, 88 BVerfGE 203, 252 e.v. (1993).

100 Par 5.3.3.

$10 \mathrm{l}$ Overigens is het Duitse Hof ma de eerste abortusbeslissing in 1975 niet meer zo ver gegaan, een strafbaarstelling te verbinden aan een positieve verplichting, ook niet op andere grondrechtelijke terreinen. Het Hof werd opgeroepen in een zaak ower de stationering van kernwapens op Duitse bodem tot het invulling geven aan een positieve verplichting van de staat die zou inhoudern dat de staat op een andere wijze zou moeten komen tot de best mogelijke afweer ervan (66 BVerfGE 39, 60 e.v. (1983). Het Hof wees die eis af met een beroep op de beoordelingsvrijheid van de politieke organen in deze beslissing. In de zaak Schleyer, 46 BVerfGE 160 (1977) werd het Hof gevraagd te oordelen over het recht op leven van de ontwoerde Schleyer. De ontwoerders dreigden hun slachtoffer te doden als de regering niet snel zou besluiten om enkele RAF-leden uit gevangenschap vrij te laten. De regering weigerde dit echter, waardoor het leven van Schleyer op het spel kwam te staan. De zoon spande een kort geding aan bij het Hof met een aanspraak op thet reclit op leven ex Art. 2 lid 2 GG, die verder inhield dat de 
ling in de Amerikaanse variant nagenoeg afwezig. Minstens zo interessant zijn de overeenkomsten. Zowel het Duitse Hof als het Amerikanse Hooggerechtshof interpreteerden de individuele aanspraken aan de hand van zeer open normen. Beide rechters werden beticht van rechterlijk activisme: aan de hand van een extensieve invulling van rechtsnormen werd in beide gevallen wetgeving in formele zin terzijde gesteld.

Toch kan over de juistheid van de kwalificatie 'activisme' of 'terughoudendheid" in dit verband worden getwist, los van de al of niet gewenste uitkomst. De dissenting in de Duitse zaak pleitte tegen rechterlijke interventie vanwege de 'hercriminalisering' van abortus door de rechter. Zo twijfelden de dissenters in Roe $t$. Wade eveneens de indeling van de zwangerschap in trimesters aan de hand waarvan abortus legitiem kon worden geacht. Deze aspecten hadden, zo stelden de Duitse en Amerikaanse pleiters voor een terughoudende opstelling, overgelaten moeten worden aan de wetgever. Opvallend daarbij is, dat het kennelijk niet echt verschil maakt of het on een geschreven (het recht op leven ex Art. 2 lid $2 \mathrm{GG}$ ) of een ongeschreven grondrecht (privacy en het ongeschreven recht op abortus) ging: het feit dat de rechter zich voor de beoordeling van de concrete zaak ver weg bewoog van het concrete geschil wordt in dit verband doorslaggevend geacht voor de mate van activisme. ${ }^{102}$ Vraag is dan, of de beslissingen van de rechters zónder 'recriminalisering' (Duitsland) of trimestersysteem (Verenigde Staten) wel stand hadden kunnen houden zonder verwijt van activisme. In dit verband blijkt uit de redeneringen, dat het van groot belang was dat het in het geding zijinde recht kennelijk nader diende te worden geconcretiseerd, en dat aan de concretisering de genoemde 'recriminalisering' respectievelijk het trimestersysteem onlosmakelijk verbonden waren. Uit de reactie van de wetgever in beide stelsels blijkt de onzekerheid over de juistheid van de rechterlijke taakopvatting. In beide stelsels werd relatief kort na de beslissing wetgeving tot stand gebracht die deze op de proef stelle.

\subsubsection{Het recht op het eigen beeld en het gesproken woord}

Een aanspraak op de beschikking van het individu over het eigen gesproken woord en beeld dat het van zichzelf wil afgeven, bevestigde het Hof als recht in Eppler. ${ }^{10: 3}$ Deze uitspraak wordt hier nader belicht, omdat het Hof uiteen zet welke de betekenis is van Art. 1 lid 1 in combinatie met Art. 2 lid 1 GG. Het in Soraya erkende algemene persoonlijkheidsrecht werd hier tot maatstaf verheven voor grondrechtelijke beoordeling van de individuele aanspraak. Eppler, lid van de Sozialdemokratische Partei (SPD), zag zichzelf beschadigd door een speech van de Christendemokratische Union (CDU); hem werden uitlatingen en een gedachtegoed toegedicht die hij niet had geuit en die evenmin zo zouden kunnen worden afgeleid uit zijn bewoordingen. ${ }^{104}$ De CDU meende uit

regering werplicht was om aan de eis tegemoet te komen. Hel Hof wees die eis af, ook hier gatat een positieve verplichtung niet zover. Het Hof stelde zich terughoudend op, al wees het de anspraak op eev recht op leven niet af. Deze werd echter niet gehonoreerd.

102 In de Amerikaanse situatie was de herkomst van het recht op abortus zeer omstreden; dat was met het recht op leven van het 'ongeboren leven' in de Duitse situatie nauwelijks het geval.

103 Eppler, 54 BVertGE 148 (1980).

104 Eppler, 54 BVerfCE 148, 149 (1980). 
de woorden van Eppler te kunnen afleiden, dat de voorstellen van de SPD onmisKenbaar socialistisch zouden zijn, in die zin dat de partij, eenmaal aan de macht, voornemens was de banken en de industrieên te nationaliseren. Het Hof zag in deze civiele zaak woor zichzelf "enkel een interpretatiefunctie" weggelegd. Uitgangspunt, aldus het

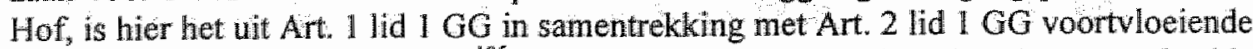
algemene persoonlijkheidsrecht. ${ }^{105}$ Dat algemene persoonlijkheidsrecht, zo herhaalde het Hof, valt de in de guond wet benoemde vrijheidsrechten aan:

"Dieses ergänzl als "unbenanntes" Freiheitsrecht die speziellen ("benannten") Freiheitsrechte, die, wie etwa die Gewissens- oder die Meinungsfreiheit, ebenfalls konstituierende Elemente der Persorilichkeit schutzen".

Naast deze vaststelling achtte het Hof het noodzakelijk de vangnetachtige functie van Art. 2 lid $1 \mathrm{GG}$ te onderstrepen. Vanwege bijwoorbeeld voortschrijdende technische ontwikkelingen bestaat de noodzaak, om langs de niet in de grondwet geèxpliciteerde rechten te komen tot een zo volledig mogelijke rechtsbescherming van het individu:

Seine Aufgabe ist $\left.e_{,}, \ldots\right]$ die engere persönliche Lebenssphăre $[\ldots]$ zu gewährleisten, die sich durch die traditionellen konkreten Freiheitsgarantien nicht abschließend erfassen lassen diese Notwendigkeit besteht namentlich auch im Blick auf modeme Entwicklungen und die mit ihnen verbundenen neuen Gefährdungen für den Schutz der menschlichen Persönlichkeit" 107

Deze overweging naar 'moderne ontwikkelingen' lijkt niet direct in verband met het feitencomlex of met de beoordeling van de aanspraak van Eppler te staan; zij heeft meer weg van een obiter dictum. In de latere rechtspraak, zo zall hierna blijken, vormde deze overweging echter vaak een belangrijke aanleiding voor de ontwikkeling wan nieuwe rechten uit het algemene persoonlijkheidsrecht. Het algemene persoonlijkheidsrecht dat wordt afgeleid uit Art. 1 lid 1 en 2 lid 1 GG tezamen, dient verder op andere wijze benaderd te worden dan bijvoorbeeld de algemene handelingsvrijheid ex Art. 2 lid $1 \mathrm{GG}$, aldus het Hof ${ }^{108}$ Art. 2 lid $1 \mathrm{GG}$ vormt een actieve component van het algemene persoonlijkheidsrecht, welke de staat verplicht zich te onthouden van het treden in de algemene handelingsurijheid. De andere, meer passieve componenten van het algemene persoonlujkheidsrecht dienen echter nog nader omschreven te worden. Het Hof duidde aan niet een uitputtend algemeen persoonlijkheidsrecht te willen positiveren, maar dat dat recht zich op casuistische wijze zal ontwikkelen in de rechtspraak. ${ }^{109}$ Op deze wijze zijn verschillende 'Schutzguter' in het persoonlijkheidsrecht reeds erkend, aldus het Hof. ${ }^{110}$ De aanspraak van Eppler kon, aldus het Hof, echter niet worden

105 Eppler, 54 BVertGE $148,153(1980)$.

106 Eppler, 54 BVertGE $148,153(1980)$.

107 Eppler, 54 B VerfGE 148, 153 (1980).

108 Epphler, 54 B VerfGE $148,153(1980)$.

109 Eppler, 54 BVerfGE $148,153-154$ (1980).

110 Het Hof vestigde in Eppler de aandacht op de erkenning onder het algemene persoonlijkheidsrecht wan de privesfeer, geheinhouding en intieme sfeer (onder meer Mikrozensus, Ehescheidungsakien, Arzikartei, Sexualkamdewhterricht en Transsexuelle); het recht op persoonlijke eer, het recht op beschikking wan het individu terzake van de afbeelding (Lebach), thet recht op beschiiking over het eigen gesproken woord en onder bepaalde omstandigheden het recht verschoond te blijven van niet gedane uitingen 
gekwalificeerd onder één van de tot dusverre in de rechtspraak tot ontwikkeling gekomen 'Schutzguter':

\begin{abstract}
"Den bisherigen Konkretisierungen des durch Art, 2 Abs. 1 GG geschützten Personlichkeitsrechts unterfallt der der Verfassungsbeschwerde zugrunde gelegte Sachverhalt nicht: [...] Sofern ein solches Schutzgut nicht beeintrachtigt ist, bedeutet es gleichfalls einen Eingriff in das allgemeine Persönlichkeitsrecht, wenn jemandem ÄuBerungen in den Mund gelegt werden, die er nicht getan hat und die seinen won ihm selbst definierten sozialen Geltungsanspruch beeinträchtigen "111
\end{abstract}

Het leek er even op, dat Epplers aanspraak zou worden gekwalificeerd onder het recht om verschoond te blijven wan niet gedane uitingen, dat reeds in bijvoorbeeld Soraya tot ontwikkeling was gekomen, maar dat achtte het Hof voor Epplers aanspraak niet voldoende dekkend. In Epplers aanspraak school volgens het Hof een ander aspect van zelfbeschikking dat was geschonden: de uiting was niet alleen schadelijk voor Eppler als persoon - in zover was zijn aanspraak vergelijkbaar met die van Soraya. ${ }^{122}$ De uitingen waren eveneens schadelijk voor het sociale verband - de kiezerskring die Eppler wenste aan te spreken. Het Hof definieerde dit belang van Eppler als volgt:

'[...] wenn jemandem Äußerungen in den Mund gelegt werden, die er nicht getan hat und die seinen von ihm selbst definierten sozialen Geltungsanspruch beeinträchtigen?. 113

De analogie die het Hof in Eppler hanteerde voor de legitimatie van de norm van hoger recht, in casu het algemene persoonlijkheidsrecht, als norm was gebaseerd op twee grondwetsartikelen en op rechtspraak. Opvallend is, dat het Hof in Eppler uitspraken aanhaalde die tot ontwikkeling waren gekomen onder het dan toe gehanteerde recht op een 'unantastbarer Bereich privater Lebensgestaltung". De positivering van het algemene persoonlijkheidsrecht had reeds in Tonband en Soraya zijn beslag gekregen; als zelfstandige rechtsgrondslag fungeerde het voor de eerste keer expliciet in Eppler. Epplers aanspraak vloeit, aldus het Hof, logisch uit dat algemene persoonlijkheidsrecht voort, evenals de andere door het Hof aangehaalde rechten. Het Hof koos hierbij voor het algemene persoonlijkheidsrecht als norm van hoger recht. De bestaande concretiseringen die tot ontwikkeling waren gekomen in het kader van het recht op een 'unantastbarer Bereich privater Lebensgestaltung' werden nu als het ware opnieuw geschikt onder het algemene persoonlijkheidsrecht. Een nadere motivering voor de vergelijkbaarheid van de verschillende casus werd niet gegeven; die achtte het Hof waarschijnlijk voldoende onderbouwd met het feit dat de genoemde jurisprudentie was gevestigd onder het recht op een "unantastbarer Bereich privater Lebensgestaltung". Het was echter niet duidelijk of dat recht hetzelfde inhield - in beschermingsomvang bijvoorbeeld - als het algemene persoonligkheidsrecht.

(Soraya).

111 Eppler, 54 BVerfGE 148, 154 (1980).

112 Eppler, 54 BVerGE 148, $155-156$ (1980).

113 Epplew, 54 BVerfGE 148, 155 (1980). 


\subsubsection{Het recht op "informationele zelfbeschikking'}

Een volgende opzienbarende uitspraak deed het Hof in Volkszählung (1983). ${ }^{114} \mathrm{Na}$ in 1969 in Mikrozensus ${ }^{115}$ negatief geoordeeld te hebben over de vraag, of een ondervraging over levensstijl een inbreuk zou kunnen betekenen op het algemene persoonlijkheidsrecht, oordeelde het Hof in 1983 in Volkszahlung dat een wettelijke verplichting om daaraan mee te werken wel kan indruisen tegen het algemene persoonlijkheidsrecht. ${ }^{16}$ In een spoedprocedure besliste het Hof, dat de klacht ter zake van een dreigende inbreuk op het algemene persoonlijkheidsrecht toelaatbaar was; uitputting van de rechtsmiddelen was niet noodzakelijk omdat de gevreesde schade dan reeds zow zijn geleden. ${ }^{117}$ Het Hof achtte de wet niet strijdig met het recht op onschendbaarheid van de woning ex Art. 13 GG. Dat recht, aldus het Hof, ziet enkel toe op de ruimtelijke privé-sfeer en beschermt tegen fysiek binnendringen tegen de wil van de bewoner. ${ }^{118}$ Evenmin wordt een negatief recht op vrijheid van meningsuiting ex Art. 5 lid 1 GG de vrijheid om een mening niet te uiten - geraakt door de wet: het Hof beschouwt het doen van mededelingen over feiten niet als het uiten van een mening in enge zin. ${ }^{119}$

Toetsingsmaatstaf was hier het algemene persoonlijkheidsrecht ex Art. 1 lid $1 \mathrm{en} 2$ lid 1 GG. De kwalificatie van de aanspraak onder het algemene persoonlijkheidsrecht leek zonder problemen gerechtvaardigd te kunnen worden aan de hand van een analogie:

'Es umfaBt - wie bereits in der Entscheidung BVerfGE 54, 148 (155) unter Fortfuhrung früherer Entscheidungen (BVerfGE 27, 1 (6) - Mikrozensus; 27, 344 (350 f.) - Scheidungsakten; 32, 373 (379) - Artzkartei; 35, 202 (220) - Lebach; 44, 353 (372 f.) - Suchtkrankenberatungsstelle) angedeutet worden ist - auch die aus dem Gedanken der Selbstbestimnung folgendende Befugnis des Einzzelnen, grundsätzlich selbst zu entscheiden, warn und innerhalb welcher Grenzen persönliche Lebenssachverhalte offenbart werden (vgl. ferner BVerf GE [ ... 63, 131 (142) Gegendarstellung). ${ }^{120}$

Het Hof nam de aanspraken uit deze zaken samen en concludeerde tot een norm van hoger recht inhoudende dat het individu zelf moet kunnen beslissen over het wel of niet afstaan van persoonlijke informatie. Nu komt dat recht, aldus het Hof in Volkszahlung,

114 Volkszähing, 65 BVerfGE 1 (1983).

115 Mikrozensus;, 27 BVerfoE I (1983).

116 Middels federale wetgeving werd een volkstelling georganiseerd om data te werkrijgen over de demografische en sociale structuren in de Bondsrepubliek. Niet alleen werden basisgegevens met betrekking tot de identiteit gevraggd, maar eveneens werkgerelateerde gegevens onder meer over inkomen, opleiding, werktijden, wijze van transport van en naar het werk. In de wet was vastgelegd, dat delen van de statistische verzameling data konden worden overgenomen door lokale overheden, die aan de hand van die data hun beleid op het terrein valu milieu en ruimtelijke ordening zouden kumnen bepalen en aanpassen.

117 Volksähiturg, 65 BVerfGE 1, 37 (1983).

118 Volkszdhlaurg, 65 BVerfGE 1, 40 (1983). Tot fysiek binnendringen van de woning rekent het Hof eveneens het inbouwen van afluisterapparatuur en het gebruik daarvan in een woning maar niet het vragen naar informatie omtrent activiteiten die in en am de woning worden ondernomen (zie bijvoorbeeld Betriebsbetretungsrech, 32 BVerfGE 54,72 (1971)).

119 Volkszahlhug, 65 BVerfGE 1,41 (1983).

120 Volkszidhlumg; 65 BVerfGE 1, 42 (1983). 
in het kader van de huidige technologische ontwikkelingen, een bijzondere mate van rechtsbescherming toe. ${ }^{121}$ Met de komst van moderne dataverwerkingsprocessen en mogelijke koppelingen van bestanden dreigt de 'Befugnis' van het individu, zoals het Hof hierboven aanduidt, in beginsel zelf te kunnen beslissen aan wie het welke informatie openbaart, illusoir te worden. Indien het individu niet met een minimale zekerheid kan overzien, welke informatie over hem in zijn sociale omgeving bekend is, zal het zich in zijn vrijheid wezenlijk geremd kunnen voelen, alldus het Hof. ${ }^{122}$

Het Hof erkende een recht op 'informationele zelfbeschikking' als onderdeel van het algemene persoonlijkheidsrecht. Het bestaan van dat recht werd in de eerste plaats afgeleid uit de analogie met genoemde jurisprudentie, en nader gerechtvaardigd aan de hand van algemene beschouwingen over de gevaren van data-opslag en verwerking van gegevens van burgers. De norm van hoger recht, hiervoor aangeduid als een recht van het individu, zelf te kunne beschikken over persoonlijke informatie, is van abstract karakter. De genoemde uitspraken werden door het Hof niet vergeleken naar feitencomplex, maar naar de norm waardoor zij worden beheerst, en onder welke zij werden beoordeeld.

Nadat het Hof het recht op 'informationele zelfbeschikking' had gepositiveerd, ging het over tot de vaststelling van de reikwijdte van dit recht; ten slotte diende aan de hand van de "informationele zelbeschikking" te worden bezien in hoeverre de federale wet grondwettig was. ${ }^{123}$ Mikrozensus had voor de honorering van de aanspraak op het recht op 'informationele zelfbeschikking' in Volkszählung nog een barrière kuntnen opwerpen. In de eerste zaak had het Hof namelijk wel aangenomen dat het individu evenwel een zelfbeschikkingsrecht heeft, maar dat het door verplichte medlewerking aan onderwraging niet in te vergaande mate zijn persoonlijkheidsrecht zou worden getroffen. Dertien jaren later dacht het Hof daar kemnelijk anders over. De opmerking, dat de technologische stand van zaken dwong tot een tuimer mate van bescherming van het recht op 'informationele zelfbeschikking', was in de optiek wan het Hof voldoende:

'Whrem Schutz dient [...] das allegemeine Persönlichkeitsrecht, das gerade auch im Blick auf moderne Entwicklungen und die mit ihnen verbundenen neuen Gefährdungen der menschlichen Persönlichkeit Bedeutung gewimmen kann (wgl. 54, 148(153): ${ }^{124}$

Zoals hiervoor aangegeven leek de opmerking over 'moderne ontwikkelingen' in Eppler het karakter van een obiter dictum te dragen. In Volkszahlung bleek deze zeer bruikbaar. Het recht op 'informationele zelfbeschikking" bleek naderhand in zeer uit" eenlopende grondrechtsconflicten uitkomst te bieden. Een onder curatele gesteld individu hoefde aan zijn verhuurder bij het aangaan van het huurcontract niets mede te delen over de curatele; de verhuurder behoefde niet te vrezen voor consequenties van de niet-nakoming van het huurcontract. Het onder curatele staande individu is inmers 


\section{HoOFGSTUK 6}

via een vertegenwoordiger contractueel gebonden. Een individu dat onder caratele staat kan een belang hebben bij verzwijging daarvan, omdat een eventuele verplichting tot mededeling stigmatiserend kan werken en tenugkeer naar een 'gewone' burgerstatus bemoellijken.

Het Hof erkende in Transsexuelle $/ /$ onder verwijzing naar "informationele zelfbeschikking' uit Volkszahlung eveneens de aanspraak van transseksuelen jonger dan 25 jaar, de voornaam aan te kunnen aanpassen aan de nieuwe geslachtelijke identiteit, ${ }^{126}$ De wet sloot tot dusverre naamsverandering voor transseksuelen jonger dan 25 jaar uit. De bedoeling van de wet was juist, het recht op 'informationele zelfbeschikking' te beschermen, aldus het Hof. ${ }^{127}$ De gelijkstelling van transseksuelen van jonger en van ouder dan 25 jaar werd overigens beslist op basis van het recht op gelijke behandeling. De 'informationele zelfbeschikking' werd in Transsexuelle $I I$ toegespitst op het recht van het individu op privé-sfeer op het terrein van intimiteit en seksualiteit. Dit aspect van de seksuele zelfbeschikking in de privé-sfeer, en meer van het algemene persoonlijkheidsrecht, had het Hof reeds erkend in Sexualkundeunterricht en bevestigd in Transsexuelle I. ${ }^{128}$

In de zaak Psychologisches Gutachten rees de vraag, of een medisch-psychologisch onderzoek, dat werd ingesteld wanneer een automobilist werd betrapt het besturen van een voertuig na drugsgebruik, in overeenstemming was met het algemene persoonlijkheidsrecht. ${ }^{129}$ De betrokken bestuurder weigerde zich aan een dergelijk onderzoek te onderwerpen, met onder meer een beroep op 'informationele zelfbeschilkking', en een bezwaar over het feit dat een dergelijk onderzoek niet werd ingesteld indien een bestuurder betrapt was op alcoholgebruik. ${ }^{130}$ Het Hof erkende de aanspratak onder het algemene persoonlijkheidsrecht, meer in het bijzonder de 'informationele zelfbeschikking". ${ }^{131}$ De vragen die tijdens het psychologische onderzoek werden gesteld, drongen in te hoge mate binnen in het privé-leven van de klager, aldus het Hof. ${ }^{132}$

125 Entmindigten, 84 BVerfGE 192, 195-196 (1991). In dit verband vormde de constitutionele variant van het aigemene persoonlijkheidsrecht de norm van hoger recht waarmee de rechter ook in zuiver horizontale en dus priwatrechtelijke verhoudingen rekening dient te houden. De informationele zellbeschikking is én van de concretiseringen daarvan, die echter voor de beoordeling wan concrete geschillen wederom dient te worden gespecificeerd.

126 Transsexwelik 17,88 B VerfGE 87 (1993)

127 Transsexulle II, 88 B VerfGE 87, 97 (1993).

128 Zie respectievelijk 47 BVerfGE 46, 73 (1977) en 49 BVerfGE. 286, 289 (1978).

129 Psychologisches Gutachten, 89 BVerfCE 69 (1993).

130 Psychologisches Gutachren, 89 BVerfGE 69, 76 (1993).

131 'Dieses Recht schutzt grundsatzlich vor der Erhebung und Weitergabe von Befunden uber den Gesundheitszustand, die seelische Verfassung und den Charakter (vgl. BVerfGE 32, 373 ( 378 ff.)); 44, 353 (372 ff.); 65, 1 (41f.) (...]). Der Schutz ist um so intensiever, je nablher die Daten der Intimsphase des Betrofienen stehen, die als unantastbarer Bereich privater Lebensgestaltung gegenüber aller staatlicher Gewalt Achtung und Schutz beansprucht (vgl. [...] $65,1(45 \mathrm{f})$ )."

132 Gevraagd werd naar het ouderlijk huis, opleiding, beroep, burgerlijke status, kinderen, ziekten, operaties, alcohol, roken, financiele achtergronden en vrijetijdsbesteding. 
Uit het recht op zelfbeschikking leek op het eerste gezicht verder eveneens voort te vloeien, dat het individu in beginsel een recht heeft, dagboekaantekeningen voor zichzelf te behouden. In Tagebuch diende het Hof te beoordelen, in hoeverre deze aanspraak zou worden erkend als recht:

Das in Art. 2 Abs. 1 in Verbindung mit Art. 1 Abs. 1 GG verbürgte allgeneine Persönlichkeitsrecht gewathrleistet die aus dem Gedanken der Selbstbestimmung folgende Befugnis des Einzelnen, grundsatzlich selbst zu entscheiden, wann und innerhalb welcher Grenzen persönliche Lebenssachverhalte offenbart werden (vgl. BVerfGE 65, 1. (41))". "

In deze kwestie was de vraag gerezen of dagboekaantekeningen nu wel of niet moesten worden geopenbaard in een strafproces. De lagere rechter had hierom verzocht, ondat de aantekeningen een inzicht zouden geven in de geestelijke toestand van de verdachte; deze werd verdacht van moord. Het Hof erkende niet een zelfstandig recht op geheimhouding van dergelijke aantekeningen, maar knoopte direct aan bij de norm van hoger recht zoals geformuleerd in Volkszähung." De aanspraak werd gevestigd onder een recht op informationele zelfbeschikking. Hierna diende te worden vastgesteld, welke de reikwijdte van dat recht in Tagebuch zou zijn. Daartoe bepaalde het Hof, in welke sfeer de aanspraak van de klager zich bevond. Kon de aanspraak op geheimhouding van intieme details worden geplaatst in een kern, die een absoluut onaantastbaar recht op privé-leven garandeert? Of diende de aanspraak te worden geplaatst in een meer perifere prive-sfeer waarin het individu - doordat het gedachten en gevoelens had opgetekend - in contact was gekomen met de buitenwereld? In de tweede sfeer kan zich de situatie voordoen, dat eventuele inbreuken op het recht op privé-leven - zij het op basis van zeer zwaarwegende redenen - moeten worden getolereerd. In dat geval zou de klager, na afweging van het algemene - het belang van een goede strafprocesorde - en het individuele belang van de klager, kunnen worden verplicht tot openbaring van de dagboekaantekeningen.

Het Hof kwam niet tot overeenstemming in de kwestie van de sferen: vier rechters stemden voor plaatsing van de aanspraak in de absolute kern van het recht waarin ingrijpen op geen enkele manier gerechtvaardigd kan zijn, en vier rechters voor de plaatsing van de aanspraak in de meer perifere sfeer. Het gevolg was, dat de grondrechtsaanspraak werd afgewezen door het Hof. ${ }^{134}$ Kern van het meningsverschil was de vraag, of het opschrijven van ervaringen en gevoelens nu wel of geen sociale betekenis toekwam. ${ }^{135}$ Plaatsing in de kernsfeer zou tot gevolg hebben gehad, dat de dagboek-

133. Tagebuch, 80 BVerfGE 367,373 (1989).

134 Tagebuch, 80 BVerfOE 367 (1989). Zie ook Art. 15 lid 3 BVerfGG, derde volzin: "Bei Stimmengletheit kamn ein Verstob gegen das Grundgesetz oder sonstiges Bundesrecht nicht festgestellt werden".

135 Zie ook Schabar, 82 BVerfGE 236 (1990). Hel Hof moest in deze zaak beoordelen, of een persoon werantwoordelijk kan worden geacht voor rellen die ontstaan tijdens eet demonstratie, indien hij een oproep doet tot een offensieve demonstrativ. De vraag rees, of bestraffing van deze persoon niet inruisi tegen zijn recht op vrijheid wan meningsuiting ex Art. 5 lid $10 \mathrm{G}$. Ook hier kwam het Hof niet tot overeenstemming. (82 BVerfCE 236, 269 (1990)). 
aantekeningen miet onthuld zouden hoeven worden, terwijl plaatsing in de perifere sfeer juist rulimte voor inbreuken van staatswege zou hebben gecreèerd.

\subsubsection{Het recht, de biologische afstamming te kennen}

Het algemene persoonlijkheidsrecht wormde in Kennthis der eigenen Abstammung (1989) de grondslag voor erkenning van de aanspraak, de waarheid over de biologische afstamming te kunnen yernemen. ${ }^{136}$ Enkele civielrechtelijke bepalingen stonden in de weg aan het vernemen van die kennis: een meerderjarige vrouw wilde van haar ouders weten of haar wettelijke vader eveneens haar biologische vader was. Art. 1593, 1598 en $1596 \mathrm{BGB}$ stonden onderzoek naar de kennisneming van de afstamming - tegen de wil van de ouder(s) - enkel toe in de gevallen waarin het kind meerderjarig was, de vader overleden was, de ouders gescheiden waren of indien kennisname vanwege erfelijke ziekten van de biologische vader aangewezen was en kon worden gerechtvaardigd. Van één van deze gronden was in voornoemde zaken geen sprake; de ouders hadden aangegeven, niet te willen scheiden. ${ }^{137}$ De wetgever had in dit verband met mame het belang dat het grondwettelijk beschermde instituut van 'familie' heeft bij rust en harmonie, voorrang willen verlenen boven het recht van het kind. ${ }^{138}$ In dit verband erkende de wetgever enkel een 'belang' van het kind bij het kennen van de afstamming.

De opbouw van de redenering voor de erkenning van het belang van het kind bouwde het Hof in verschillende stappen op. Allereerst stelde het Hof vast, dat de aangevochten uitzonderingsloze wettelijke bepalingen in strijd met het algemene persoonlijkheidsrecht zijn. ${ }^{139}$ Het Hof vervolgde met de vaststelling van de omvang van het algemene persoonlijkheidsrecht. Het zette daarin een aantal ijkpunten uit, die voor de vaststelling. van de reikwijdte van het belang bij de kennis van de afstamming van belang zijn:

'Das allgemeine Persönlichkeitsrecht ergänzt als "unbenanntes" Freiheitsrecht die speziellen ("benannten") Freiheitsrechte, die, wie etwa die Gewissens- oder die Meinungsfreiheit, ebenfalls konstituierende Elemente der Persönlichkeit schützen. Seine Aufgabe ist es, im Sinne des obersten Konstitutionsprinzips der Wurde des Menschen (Art. 1 Abs. 1 GG) die engere persönliche Lebenssphäre und die Erhaltung ihrer Grundbedingungen zu gewährleisten, die sich durch die traditionellen Freiheitsgarantien nicht vollständig erfassen lassen; diese Notwendigkeit besteht namentlich auch im Blick auf moderne Entwicklungen und die mit ihnen verbundenen neuen Gefährdungen für den Schutz der menschlichen Persönlichkeit (vgl. BVerfGE 54, $148(153))^{140}$

136 Kenwwis der eigenen Abstammang, 79 BVerfoE 256 (1989).

137 Kenntwis der ejgenest Abstammung, 79 BVerfOE 256, 257-258 (1989).

138 "Grund fur die Begrenzung des Anfechtungsrechts des Kindes sei es, den Familientrieden und den Bestand der Ehe def Mutter nicht durch Prozesse a gefahrden oder gar zu zerstoren. Damit werde das. aus dem Personlichkeitsrechts des Kindes abzuleitende Interesse an der Feststellung seiner wahren Abstammung sowic an einer entsprechenden familienrechtlichen Zuordnung zurückgestelti", Kennowis der ergenen Abstammung, 79 B VerfOE 256, 260 (1989).

139 Kemnis der eigenen Abstammung, 79 B VerfGE 256, 268(1989)

140 Kennthis der eigenen Abstanwmung, 79 BVertOE 256, 268 (1989). 
Vier zaken vallen op. In de eerste plaats maakt het Hof onderscheid tussen 'onbenoemde' en 'benoemde' fundamentele rechten. Het algemene persoonlijkheidsrecht omvat als onbenoemd recht een aanvullende categorie rechten die de in de constitutie benoemde rechten aanvult. Het Hof creëert aldus ruimte voor de tussenvoeging van een ongeschreven recht. De ruimte voor onbenoemde rechten is van belang ondat de "traditionele" vrijheidsrechten niet altijd in staat zijn, aldus het Hof, een voldoende bescherming van het beginsel van de menselijke persoonlijkheid te garanderen. Het Hof heeft het persoonlijkheidsrecht juist daarom niet uitputtend beschreven: het houdt de weg open woor mogelijke rechtsontwikkelingen. In de tweede plaats vestigt het Hof de aandacht op het belang van een dynamisch-evolutieve benadering van het persoonlijkheidsrecht. De weg voor deze benadering had het Hof reeds geopend in Eppler, waarin het aangaf, dat moderne technologsiche ontwikkelingen een bedreiging zouden kunnen gaan vormen voor grondrechten. Nu werd de dynamische benadering in Eppler ingegeven door die technologische ontwikkelingen. In Kenmtnis der Abstammung verkreeg de dynamische benadering een ietwat merkwaardige functie. Aan de hand van het argument van de bedreigingen die voortvloeien uit technologische ontwikkelingen werd in Eppler geconcludeerd dat de uitoefening van het grondrecht tezeer werd beperkt, terwijl deze ontwikkelingen in onderhavige zaak juist leidden tot een potentiele uitoefening van een grondrecht. Ten derde werd ter zake van de interpretatie van het algemene persoonlijkheidsrecht de casuistische benadering benadrukt door het Hof. Deze benadering wordt wellicht gehanteerd, om de indruk weg te nemen dat de rechter zelf wetgevende activiteiten tot stand brengt. Het punt van de casuïstiek is van belang, omdat het Hof het eventuele verwijt van rechterlijk activisme in de kiem wenst te smoren. Hij oordeelt immers in een concreet geschil:

'Wegen der Eigenart des allgemeinen Persönlichkeitsrechts hat die Rechtsprechung des Bundesverfassungsgerichts den Inhalt des geschützten Rechts nicht abschließend umschrieben, sondern seine Ausprägungen jeweils anhand des zu entscheidenden Falles herausgearbeitet". 141

Deze aanloop naar het recht op kennis van de eigen afstamming is niet zonder belang, omdat de aanspraak, die tot dusverre nog geen gepositiveerde rechtsnorm kende in de Duitse constitutionele orde, een plaats moest veroveren in het geheel van reeds benoemde fundamentele rechten. In de vierde plaats werd hier de analogie gehanteerd: het Hof grijpt terug op de reeds in andere zaken veelgeciteerde passage uit Eppler. Die verwijzing lijkt door zijn zeer algemene inhoud mogelijk te maken te komen tot de hiervoor genoemde dynamisch-evolutieve benadering. Het Hof vervolgde deze passage met een overweging waarin het tot een op de casus toegespitste interpretatie van het persoonlijkheidsrecht komt:

"Das Recht auf freie Entfalturng der Persönlichkeit und die Menschenwürde sichern jedem Einzelnen einen autonomen Bereich privater Lebensgestaltung, in dem er seine Individualität entwickeln und wahren kann (vgl. BVerfGE 35, 202 (220)). Verständnis und Entfältung der Individualität sind aber mit der Kenntnis der für sie konstitutiven Faktoren eng verbunden. Zu diesen zählt neben anderen die Abstammung. [ ...] Als Indiwidualisierungsmerk- 
mal gehört die Abstammung zur Persönlichkeit, und die Kenntnis der Herkunft bietet dem Enzelnen unabhangig wom $A$ usmaß wissenschafticher Ergebnisse wichtige Anknüpfungspunkte fur das Verståndnis und die Entfaltung der eigenen Individtualität. Daher umfaBt das Persơnlichleitsrecht auch die Kenntnis der eigenen Abstammung: ${ }^{4} 2$

In deze passage, die van doorslaggevend belang is woor de vaststelling van het belang bij het kennen van de afstamming, ontbreken directe verwijzingen naar concretere, juridische rechtsnormen. ${ }^{143}$ Een eveneens veelgeciteerde passage uit Lebach vormde de grondslag woor de vestiging van het recht, de afstamming te kunnen kennen. De norm van hoger recht die Lebach en Kenntnis der elgenen Abstammung gemeenschappelijk hebben werd als volgt gedefinieerd:

'Das Recht auf die freie Enfaitung der Persönlichkeit und die Menschenwirde sichern jedem Einzelnen einen autonomen Berich privater Lebensgestaltung, in dem er seine Individualitat entwickeln und wahren kann. Hüerzu gehört auch das Recht, in diesem Bereich "für sich zu sein" "sich selber zu gehören" [...]."144"

In Lebach leidde het Hof uit het recht 'für sich zu sein' en 'sich selber zu gehören' echter iets anders af dan in Kenntnis der eigenen Abstammung: Lebach, beoordeeld onder het recht op privé-leven, vestigde het recht op resocialisatie. In Kenntmis der eigenen Abstammung werd het belang van het individu, de biologische afstamming te kennen, erkend. De uitspraken Lebach en Eppler handelden beide over een norm van hoger recht van het individu te kiezen voor het persoonlijkheidsbeeld waarmee het in de openbaarheid wenst te treden. Dit element vormt in de optiek van het Hof een nadere concretisering van het algemene persoonlijkheidsrecht, dat een vergelijkbare grondrechtelijke status heeft met het recht, de afstamming te kennen. De rechtens relevante gemeenschappelijkheid van de uitspraken werd niet afgeleid uit de feitencomplexen maar uit de hier genoemde norm van hoger recht. Het Hof gaf in Kenntnis der eigenen Abstammung enkele algemene beschouwingen omtrent de invulling van het belang bij een recht op kennis van de afstamming. Juridische overwegingen spelen daarin niet direct een zichtbare rol:

'Sie (de afstamming) legt nicht nur die genetische Ausstattung des Enzelnen fest und präg" so seine Persönlichkeit mit. Unabhangig davon nimmt sie auch im BewuBtsein des Einzelnen eine Schlusselstellung fur Individualitatsfindung und Selbstverständnis ein". ${ }^{2}$

Enkele jaren later werden dezelfde bepalingen uit het BGB wederom aangevochten; deze keer werd geklaagd over het feit, dat het kind slechts gedurende een periode van twee jaren na het bereiken van de volwassen leeftijd, een procedure voor het achter-

142 Kanntnis der ergenen Abstammung, 79 BVerfOE 256, 268-269 (1989)

143 Zeer kritisch over deze uitspratk die in Kenmmis der eigenew Abstamwung werd ged aan is Ramm 1989, p. $1594 \mathrm{e}, \mathrm{v} . \mathrm{Hij}$ stelt dat er geen enkele varwizing werd gemaakt natar een juridische norm. De norm van hoger recht is in dit verband het anknopingspunt voor de vergelijkbaarheid wan beide zaken. Deze norm heef een dermate hoge graad wan abstractie, dat men zich kan afragen of da nom exn juridische kwaliteit heeft.

144 Lebach, 35 BVertog 202, 220 (1973)

145 Kenmtris der etgenen Abstammung, 79 BWertGE 256, 269 (1989). 
halen van de precieze identiteit kon opstarten. ${ }^{146}$ Deze beperking in de tijd was ingevoerd met de gedachte, dat een onbeperkte mogelijkheid, de wettigheid aan te vechten, rechtsonzekerheid zou kunnen opleveren. ${ }^{147}$ Het Hof achtte de periode van twee jaren echter disproportioneel met het recht van het kind op de afstammingskennis. Die kennis is van belang om de volgende reden:

\begin{abstract}
' $Z u$ den Elementen, die für die Entfaltung der Persőnlichkeit von entscheidender Bedeutung sein können, gehört die Kenntnis der eigenen Abstammung. [...] Die Kenntnis der Herkunft kann wichtige Anknüpfungspunkte für das Verständnis des familiären Zusammenhangs und für die Entwicklung der eigenen Persönlichkeit geben. Die Unmöglichkeit, die eigene Abstammung zu klären, kann den Einzelnen erheblich belasten und verunsichern. Daher umfaßt das allgemeine Persönlichkeitsrecht das Recht auf Kenntnis der eigenen Abstammung'. ${ }^{43}$
\end{abstract}

Het gevolg van deze vaststelling was, dat het Hof dat deel van de bepaling dat de periode van twee jaren aangaf, ongrondwettig verklaarde. De wetgever werd opdracht gegeven, de bepaling, met inachtneming van hetgeen in deze uitspraak en in Kennthis der Abstammung was besloten, met de grondwet in overeenstemming te brengen ${ }^{149} \mathrm{In}$ 1997 werd het bestaan van dat recht herbevestigd, en heeft het voorgoed bij de erkende constitutionele rechten een plaats verworven. ${ }^{150}$

\title{
6.3.8 Aspecten van de geestelijke, fjsieke en seksuele integriteit
}

In Transsexuelle I (1978) werd geklaagd over het feit dat de nieuwe geslachtelijke identiteit van een transseksueel niet werd erkend in de burgerlijke stand. De ambtenaar had geweigerd, een bij het nieuwe geslacht passende nieuwe naam op te nemen in het register van de burgerlijke stand. Een naamsverandering kon slechts worden doorgevoerd indien de nieuwe geslachtelijke identiteit in het bevolkingsregister was aangepast, maar daaraan stond de in beginsel onveranderlijkheid van de geslachtelijke identiteit in de weg. Het Hof was echter van mening, dat de aanspraak op een bij het geslacht passende naam diende te worden bezien als persoonlijkheidsrecht:

'Dabei sind selbst unter Berücksichtigung des geschlechtsneutralen Vornamens Konfliktsituationen für den Beschwerdeführer nicht auszuschließen; die Sphäre, die diese berihhren,

146 Ehelichkeitsanfechnung, $90 \mathrm{BV}$ erfOE 263 (1994).

147 Ehelichkeitsanfechtung, 90 BVerfGE 263, 271 (1994).

148 Ehelichkeissanfechtung, 90 BVerfGE 263, 270-271 (1994).

149 Ehelichkeitsanfechtung, 90 BVerfGE 263, 275 (1994). In Vaterschafisaushunft in 1997 nam het Hof het bestaan van een recht, kennis van de afstamming te kunnen vernemen, wederom aan; ditmoal speelde de aanspraak in een horizontale verhouding. De klaagster in deze zaak weigerde haar dochter mede te delen, wie haar biologische vader zou kunnen zijn. In de zaak Vaterschafisauskumft stonden andere belangen tegenover elkaar dan in Kenntmis der Abstammung en Ehelichkeissanfechrung. De moeder had in Vaterschafisauskanft eem zelfstandig recht bij de niet-onthulling van de identiteit van de vader - een recht op privé-leven. Dat recht op privế-leven - geconstrueerd uit het algemene persoonlijkheidsrecht ex Art. 1 lid 1 en 2 lid $1 \mathrm{GG}$ - onvatte eveneens de aanspraak van de moeder. De lagere rechters hadden naar de mening van het Hof aan het belang van de moeder niet het juiste gewicht toegekend. In Vaterschafisauskunft besteedde het Hof met name aandacht ann het algemene perscon* lijkheidsrecht van de moeder.

150 Vaterschajtscuskinff, 96 BVerfGE 56 (1997). 
gehört zum intimsten Bereich der Persönlichkeit, der prinzipiell staatlichen Zugriff entzogen

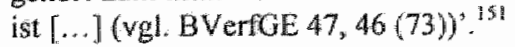

De norm van hoger recht, het algemene persoonlijkheidsrecht, die Transsexwelle I beheerste is abstract van karakter. Meer concreet is de aanspraak gericht op een seksueel intieme privé-sfeer onder het algemene persoonlijkheidsrecht. De wetgever creèerde als gevolg van de uitspraak van het Hof een wet; die het mogelijk maakte de nieuwe identiteit van transseksuelen wast te leggen. Echter, enkele jaren na de inwerkingtreding van deze wet kwam er een klacht ter zake van de leeftijdsgrens, die was gesteld voor de mogelijkheid om een namsverandering door te voeren in de burgerlijke stand. In Transsexuelle $I I$ kon de na Transsexuelle $I$ aangepaste wet, die transseksuelen eerst. vanaf de leeftijd van 25 jaren toestond de naam aan het geslacht aan te passen, geen genade vinden in de optiek van het Hof. ${ }^{152}$ Hier bracht het Hof het recht op erkenning van de nieuwe geslachtelijke identiteit in verband met het recht op infomationele zelfbeschikking dat het in Volkszählung had erkend.

Daarentegen was het Hof niet bereid, het recht op huwelijkssluiting van partners van gelijk geslacht te erkennen als recht dat voortvloeit uit het algemene persoonlijkheidsrecht. $^{153}$ Steundend op Transsexuelle $I$ hadden de klagers gehoopt een aanspraak te kunnen vestigen op die geslachtelijke identiteit. Het Hof had in Transsexuelle I namelijk enkele overwegingen gewijd aan de mogelijkheid van transseksuelen in het hwwelijk te treden met een partner die het geslacht had dat zij voorheen zelf hadden gehad. In Transsexuelle $I$ liet het Hof doorschemeren, niet te willen overgaan tot erkenning van het homohuwelijk onder het algemene persoonlijkheidsrecht:

"Es mag sein, daß in der Bevölkerung die Eheschließung eines männlichen Transsexuellen mit einem Mann aus der unterschwelligen Vorstellung heraus abgelehnt wird, dies sei sittlich zu mißbilligen. [...] Hinzu kommt, daß nach dem Stand der wissenschaftlichen Erkentnisse der männliche TranssexuelJe keine homosxuellen Beziehungen wünscht, sondern die Verbindung mit einem heterosexuellen Partner sucht [... . ".154

Het Hof weigerde in een latere zaak over het homohuwelijk uberhaupt een aanspraak op een huwelijk tussen partners van gelijk geslacht te erkennen onder het algemene persoonlijkheidsrecht (1993). ${ }^{155}$ Hier leek de grens van hetgeen mogelijk is in het kader van rechterlijke rechtsvinding ter zake van het algemene persoonlijkheidsrecht bereikt. Uit de uitspraak blijkt verder niet in hoeverre het Hof rekening houdt met de constitutionele verhoudingen; het maakt geen verwijzing naar discussies die in de samenleving worden gevoerd of over eventuele wetgeving in voorbereiding. Dat hoefde het Hof ook niet te doen: de kwalificatie van de aanspraak was immers afgewezen zodat aan genoemde discussies geen afzonderlijke aandacht behoefde te worden besteed.

151 Transsexwelle $\mathbb{I}, 49$ BVerfGE 286 (298).

152 Transsexuellengeseit, 88 BVerfGE 87 (97).

153 Kein Recht anf Eheschlie/ung fiir gleichgeschlechtiche Partmer, BVerfGE I BVR 640/93, 1993 NJW 47, p. 3058.

154 Transsexuelle I, 49 B VerfoE 286, 300 (1978).

155 Kein Recht auf Eheschließrang fur gleichgeschlechlliche Partmer. BVerfGE 1 BvR 640/93, 1993 NIW 47, p. 3058 . 
Ten slotte wordt de aandacht gevestigd op een analogie waarin de vergelijkbaarheid tussen de casus nauwelijks aanvaardbaar kan worden geacht. Het Hof heeft de aanspraak op het naamrecht expliciet erkend als uitvloeisel van het algemene persoonlijkheidsrecht. ${ }^{156}$ De klagers in Familienname achtten het stelsel van naamtoewijzing na hwwelijkssluiting echter niet in overeenstemming met het algemene persoonlijkheidsrecht: echtgenoten werden verplicht een dubbele naam te voeren. $\mathrm{Zij}$ wensten echter jeder de eigen achternaam te behouden. De rechter in eerste aanleg legde het Hof de prejudicièle vraag voor in hoeverre de wetsbepalingen dienaangaande in overeenstemming waren met de grondwet. Het Hof erkende een recht de eigen naam te kunnen kiezen als uitvloeisel van het algemene persoonlijkheidsrecht onder verwijzing naar een uitspraak waarin het had geoordeeld over gemeentelijke herindeling in Söhlde. ${ }^{157}$ De feitencomplexen van Familienname en Söhlde boden echter nauwelijks aanknopingspunten voor een gemeenschappelijkheid in de vorm van een norm van hoger recht, ware het niet dat het Hof in Söhlde vast had gesteld dat het kiezen van een eigen naam onderdeel van de gemeentelijke autonomie vormt. In Sohlde werd namelijk geklaagd over het feit dat het Ministerie van Binnenlandse Zaken van het Land Niedersachsen bij besluit na samenvoeging van enkele gemeenten een nieuwe naam voor de samengevoegde gemeenten had bepaald. De klagende gemeenten konden zich niet vinden in de nieuwe naam, die door het Ministerie was gekozen omdat deze naam de grootste voormalige gemeente vertegenwoordigde. Het Hof stelde in Söhlde aldus vast:

'Gesetzliche Beschränkungen der Selbstwerwaltung sind zulässig, wenn und soweit sie deren Kernbereich unangetastet lassen. [...] Teil der historisch überkommenen Gemeindehoheit ist das Recht der Gemeinden zur Führung ihres einmal bestimmten Namens. Dieser vermittelt der Gemeinde rechtliche Identität und ist zugleich Ausdruck ihrer Individual tät [...]. ${ }^{5 \&}$

Deze overweging vormde in Familienname het doorslaggevende argument voor de erkenning van de aanspraak op de keuzevrijheid voor de naam:

'Er dient nicht mur als Unterscheidungs- und Zuordnungsmerkmal,, sondern ist daruberhinaus Ausdruck der Identität und Individualität (vgl. BVerfGE 59, $216(226)$ ). ${ }^{59}$

De norm van hoger recht in beide zaken is aldus het belang van individualiteit en identiteit bij de naam; in het ene geval betrof het een recht van een gemeente, in het andere het recht van een individu. Deze vindt zijn toepassing aldus in twee zeer uiteenlopende indiviudele aanspraken, reden om hier een hoge mate van abstractie van de norm van hoger recht aan te nemen. In Familiemname leidde de erkenming van de aanspraak als recht overigens niet tot honorering. Er bestaan, aldus het Hof in Familienname, voldoende redenen om aan te nemen dat de inbreuk op het recht niet onevenredig is. ${ }^{160}$ Belangrijk achtte het Hof in dat verband het feit dat twee namen konden worden samengevoegd; samenvoeging van de namen was voldoende het aspect van de identiteit te handhaven. De ene naam behoefde immers niet te wijken voor de andere.

156 Familienname, 78 B VerfGE 39 (1988).

157 Söhlde, 59 BVerfGE 216 (1982).

158 Söhlde, 59 BVerfGE 216,226 (1982).

159 Familienname, 78 BVerfGE 39,49 (1988).

160 Familienname, 78 BVerfGE 39, $50-52$ (1988). 


\subsection{Bevindingen}

\subsubsection{Inleiding}

De aanspraken op de algemene handelingsvrijheid en het algemene persoonlijkheidsrecht kwamen via verschillende procedures bij het Hof terecht. In de onderzochte rechtspraak gebeurde dat het vaakst via de 'Verfassungsbeschwerde', de procedure ex 93 lid 4 sub a GG volgens welke het individu zijn klacht na uitputting van de rechtsmiddelen direct kan richten tot het Hof. ${ }^{161}$ Enkele zaken werden voorgelegd in de prejudiciele procedure. In deze procedure schorst de civiele-, straf- of bestuursrechter de aanhangige procedure, en legt zijn vraag ter zake van de grondrechtelijke aspecten in het geschil voor aan het Hof. In KPD-Crteil legde de regering een partijverbod voor aan het Hof. In de onderzochte rechtspraak was abstracte toetsing in de abortusuitspraken aan de orde. De "Verfassungsbeschwerde" vormde in de onderzochte zaken veruit de belangrijkste aanleiding voor het Hof, zich te buigen over de vraag of en in welke mate een "allgemeines Persönlichkeitsrecht" was geschonden. In Mikrozensws en Volks$z$ ăhlung werden enkele bepalingen uit de relevante formele wetten direct betwist, dat wil zeggen niet via de aanvechting van een besluit of een beschikking. Ook vormden strafrechtelijke vervolgingen aanleiding, enkele strafrechtelijke bepalingen of daaruit voortvloeiende besluiten te onderwerpen aan de toets van onbenoemde individuele rechten die voortwloeien uit het algemene persoonlijkheidsrecht. In enkele gevallen werd de overeenstemming van een wetsbepaling met een concretisering van het algemene persoonlijkheidsrecht in een horizontaal conflict betwist.

\section{4 .2 Ontwikkeling van de grondslag voor de normen van hoger recht}

\section{De algemene handelingsurijheil}

Art. 2 lid $1 \mathrm{GG}$ is vastgelegd in de grondwet en heeft ten opzichte van de andere grondrechten in sterke mate een vangnetfunctie. ${ }^{162}$ Dat houdt in dat het wat de toepassing betreft een subsidiair karakter heeft en aldus aanvullend werkt ten aanzien van de andiere grondrechten.

\section{Het algemene persoonlijkheidsrecht}

De ontwikkeling van het algemene persoonlijkheidsrecht is in de jurisprudentie tot stand gekomen uit de contaminatie van Art. 1 lid $1 \mathrm{GG}$ en Art. 2 lid 1 GG. ${ }^{163}$ Beide grondwetsartikelen vormen samen de basis voor het algemene persoonlijkheidsrecht. ${ }^{164}$

161 Par. 3.3 .1 .

162 Pieroth en Silnlink 1999 , p. 85. Zeer uiteenlopende activiteiten, die het Hof onder Ant. 2 lid 1 GG heef beoordeeld, waren onder meer het aangaan van overeenkomsten (Preisgese 2,8 BVerfGE 274 (1958)), brommertijoen zonder helm (59 BVerfGE 274 (1982), autorijden zonder veilligheidsgordel (BVerfG. NJW 1980, p. 180), paardrujden op bospaden (Reiton im Walde, 80 BVerfGE 137 (1989), het houden van honden (Humdensitewergasetze, $7 \mathrm{~B}$ VerfGE 89 (1958)) en het voeren wan dwiven (Toubenfuitern, 54 BVerfGE $143(1980))$

163 Hesse 1991, p. 175

164 Scholr 1975, p. 90-91. 
Het Hof geeft veeivuldig in zijn jurisprudentie aan dat het algemene persoonlijkheidsrecht niet uitputtend kan worden beschreven, omdat de ontwikkeling ervan een voortdurende is. De Duitse grondwet maakt van dat algemene persoonlijkheidsrecht geen melding. Het Hof noemde de norm die voortvloeide uit contaminatie tot aan Sorayg en Eppler een recht op privé-sfeer of recht op een persoonlijke levenssfeer. In Tonband, een uitspraak die kort voor Soray a werd gedaan, werd het algemene persoonlijkheidsrecht door het Hof genoemd als materiele rechtsnorm die door het Bundesgerichtshof reeds werd gehanteerd in de strafrechtelijke en de privaatrechtelijke context. ${ }^{165}$ In Tonband was sprake van een obiter dictum, dat duidde op de waarschijnlijke komst van een nieuwe grondrechtelijke notie. In Soraya was de status van het algemene persoonlijkheidsrecht als zelfstandige grondslag voor de aanspraak van Soroja niet eenduidig, maar aangenomen mag worden dat het inderdaad de basis bood voor de erkenning van immateriele schadevergoeding.

Een eerste basis van het algemene persoonlijkheidsrecht lijkt het Hof, afgaande op Eppler (1980) al in Elfes (1957) te hebben neergelegd. In Elfes werd het algemene persoonlijkheidsrecht echter nog niet genoemd. ${ }^{166}$ Tot aan Eppler werd steeds gesproken over een recht op een 'unantastbarer Bereich privater Lebensgestaltung" die voortvloeit uit Art. 1 lid 1 en 2 lid 1 GG. ${ }^{167}$ Of dit recht en het later tot ontwikkeling gekomen algemene persoonlijkheidsrecht elkaars gelijke zijn is niet eenduidig af te leiden uit de rechtspraak. De concretiseringen die voortvloeien uit het algemene persoonlijkheidsrecht en de overige, in de grondwet benoemde grondrechten zijn in rangorde gelijk. In de toetsingsfase beslist het Hof welk grondrecht in het concrete geval de doorslag moet geven. De rechtspraak die volgde op Eppler bevestigt deze indruk." ${ }^{168}$

Het algemene persoonlijkheidsrecht is in de jurisprudentie steeds gehanteerd als een rechtsnorm met een rechtsbeginselachtig karakter: het persoonlijkheidsrecht alls zelfstandig recht concretiseert geen norm en het creëert als zodanig nog geen rechtsgevolgen. Waar het Hof in Eppler en in direct daarna volgende jurisprudentie telkens uitlegt wat de grondslag is van het algemene persoonlijkheidsrecht, volstaat het een de-

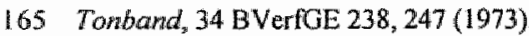

166 Elfes, 6 BverfGE: 32, 36 (1957).

167 Tussen Soraya en Eppler bleef het Hof een recht op privé-leven uit de contaminatie van Art. 2 lid 1 en I lid 1 GG gebruiken. De steeds terugkerende formule was het 'unantastbarer Bereich privater Lebensgestaltung'. Dat begrip heeft in Eppler als het ware een "herformulering" ondergaan tot een constitutioneel algemeen persoonlijkheidsrecht. Eppler, 54 BVerfGE 148, 153 (1980). Zie Maunz en Zippelius 1998 , p. 173; Alexy 1996, p. 333; Hesse 1991, p. 95.

168 Zie in dit verband ook Maunz 1962, Art. 2 lid 1, nr. 3 en Scholz 1975, p. 87. Zie ook de ontstaransgeschiedenis van Art. 2 lid I GG bood hiertoe aanleiding; centraal in de opmerkingen hierover wan de Parlemetaire Raad: 'Jeder kann tun und lassen was er will' (V. Mangoldt, Parlamentarischer Rat, 42. Sitzung des Hauptausschussess, p. 533). Verder leverden de historische ervaringen het Hof eveneenis aanknopingspunten voor de mogelijkheid, Art. 2 hid 1 GG zeer extensief te interpreteren (zie Eljes, 6 BVerfGE 32, $37(1957)$ ). 
cennium na Eppler enkel met het noemen van het algemene persoonlijkheidsrecht als grondslag voor positivering van nieuwe aanspraken. ${ }^{16 \%}$

\subsubsection{Het recht op persoonlijkheid: bevindingen in interpretatie en reikwijdte}

\section{Algemene handelingswrigheid}

In Elfes heeft het Hof uitgewerkt, wat de reikwijdte van het recht op privé-leven omvat: de 'ganse Umfang der persönlicher Betätigung', waaronder contractswrijheid, economische activiteiten, geestelijke, artistieke en sportieve activiteiten worden verstaan. Deze handelingen zijn in de jurisprudentie na Elfes tot ontwikkeling gekomen, maar in Elfes had het Hof al wel een basis voor extensieve interpretatie gelegd. Een belangrijke aanleiding voor de extensieve uitleg vond het Hof in de ontstaansgeschiedenis van Art. 2 lid $1 \mathrm{GG} .{ }^{170}$ Er zijn nauwelijks handelingen, die geen bescherming vinden onder de algemene handelingsvrijheid; de extensieve interpretatie heeft veel kritiek te verduren gekregen. ${ }^{171}$ Het Hof is eenmaal expliciet op deze kritiek ingegaan met de stelling dat een beperking van de reikwijdte niet in overeenstemming zou zijn met de ontstaansgeschiedenis alsmede met de opmerking dat iedere poging, de reikwijdte te beperken zou leiden tot een verlies van de omvang van de vrijheid van het individu. ${ }^{172}$ De extensieve wijze waarop het Hof de algemene handelingsvrijheid interpreteert, doet de indruk ontstaan dat het Hof uitgaat van een gesloten grondrechtensysteem waarin geen leemten bestaan.

De begrenzingen van de algemene handelingsvrijheid worden echter nog niet ten volle gesteld bij de kwalificatie, maar in de toetsingsfase die volgt na de interpretatiefase. De rechtspraak laat zien dat ter zake van de beperkingen op het erkende recht ruime mogelijkheden bestaan. Het extensieve interpretatiebeleid van het Hof onder Art. 2 lid I GG waarin het Hof zich een onbeperkt toetsingskader van wetgevende handelingen lijkt aan te meten wordt tot op zekere hoogte gerelativeerd in de toetsingsfase. Het Hof hanteert in die fase twee uitgangspunten waarmee het in belangrijke mate tegemoet kan komen aan de wetgever. Het uitgangspunt van het vermoeden ten faveure van de individuele rechtsbescherming geldt niet wanneer een aanspraak wordt gedaan op de algemene handelingsvrijheid; in beginsel wordt in dat verband an wetgeving steeds een presumptie van grondwettigheid toegekend. Daarnaast bevindt zich in de toetsingsfase de belangenafweging alsmede de mogelijkheid om de uitspraak te relativeren. ${ }^{173}$ Wanneer het Hof de aanspraak onder Art. 2 lid 1 GG aldus erkent, wil dat niet zeggen dat de aanspraak steeds wordt gehonoreerd. ${ }^{174}$ De beperkingsmethodiek die in Art. 2

169 De positivering van de individuele aanspraak naar een recht lijkt, afgaande op de onderzochte rechtspraak, eerder het karakter te hebben wan een rationalisatie achteraf.

170 Elfes, 6 BVerfGE 32 (1957).

171 Hesse 1991 , p. 173 e.v. en Scholz 1975, p. 80 e.v. en 267 e.w.

172 Reiten in Walde, 80 BVertGE 137, 154 (1989).

173 Zie par. 3.3.3.

174. In Mikrozensus werd bijwoorbeeld naast een recht op zelfbeschikking tevens erkend dat inzage in persoonlijke data een inbreuk kan betekenen op de persoonlijke levenssfeer. De aanspraak werd aldus erkend, maar in die zank niet gehonoreerd (zie par. 5.3.2). Ook heeft de sferenleer, waarin diwerse "la- 
lid $1 \mathrm{GG}$ beslloten ligt, draagt een aantal verschuifbare maatstaven in zich warmee het Hof eventuele bezwaren die kunnen voortvloeien wit de constitutionele verhouding tussen rechter en wetgever kan relativeren.

\section{Algemeen persoonlijkheidsrecht}

Erkenning van individuele aanspraken onder het algemene persoonlijkheidsrecht vindt in vergelijking met erkenning van aanspraken onder de algemene handelingsvrijheid minder vanzelfsprekend plaats. De reikwijdte van het algemene persoonlijkheidsrecht is tot dusverre wat minder omvangrijk dan die van de algemene handelingsvrijheid. ${ }^{175}$ Het belang van de vrouw in de kwestie over abortus werd in 1975 niet onder het algemene persoonlijkheidsrecht erkend; deze werd onder de algemene handelingsvrijheid ex Art. 2 lid 1 GG beoordeeld. ${ }^{176}$ Het zou denkbaar geweest zijn dat de aanspraak, wel of niet te kunnen kiezen voor het voldragen van de zwangerschap in verband met de keuzevrijheid van de inrichting van het leven onder het algemene persoonlijkheidsrecht zou zijn beoordeeld. De abortuszaak in 1993 laat in het midden of het algemene persoonlijkheidsrecht als interpretatiemaatstaf gold: er wordt wel gesproken over een recht op persoonlijkheid, maar het Hof refereerde niet aan het algemene persoonlijkheidsrecht. 177

Het verschil in kwalificatie is evenwel dat beperkingen van het algemene persoonlijkheidsrecht in beginsel strikter worden getoetst dan beperkingen op de algemene handelingsvrijheid. Dat hangt tot op grote hoogte samen met het feit dat aan het recht op algememe handelingsvrijheid in principe geen vermoeden ten gunste van de individuele vrijheid wordt toegekend, terwijl dat wel geldt voor aanspraken op het algemene persoonlijkheidsrecht. ${ }^{178}$ Daarnaast geldt voor beperking van het algemene persoonlijkheidsrecht dat deze slechts via een wet in formele zin tot stand kan worden gebracht. ${ }^{179}$

\subsubsection{De analoge redenering}

\section{Aard en omvang}

Van de wetsanaloge redenering is sprake, indien een rechtsnorm gegeven is maar niet zonder meer toepasbaar op de voorliggende individuele aanspraak. Wanneer de vraag rijst of de voorliggende aanspraak kan worden gekwallificeerd onder de eventueel van toepassing zijnde rechtsnorm kan een wetsanalogie uitkomst bieden. ${ }^{180}$ Aan de hand van vergelijkingsmateriaal tracht de rechter dan te komen tot de formulering van een

gen' van de intieme sfeer te onderscheiden zijn (zie bijvoorbeeld Psychologisches Gutachten, par. 5.2) bijgedragen aan de gevolgen van de erkenning van aanspraken onder de algemene handelingswrijheid.

175 Zo ook A.J. Nieuwenhu is 2001, p. 98.

176 Schwangerschaftsabbruch 1, 39 BVerfuE 1, 43 (1975).

177 Schnargerschaft.sabbruch II, 88 BVerfGE 203, 254 (1993).

178 Zie par. 2.4.3.

179 Zie par. 2.4.4. Verder gelden dezelfde beperkingsmechanismen als woor de algemene handelingsvrijheid ex Art. 2 lid $1 \mathrm{GG}$.

180 Par. 4.4.1. 
norm van hoger recht, die vervolgens de toepassing van de rechtsnorm op de voorliggende individuele aanspraak dient te rechtvatardigen.

Het Hof heeft werschillende normen wan hoger recht gehanteerd om aanspraken onder Art. 2 lid $1 \mathrm{GG}$ te kwalificeren. De norm 'alleen te worden gelaten' fungeerde büvoorbeeld als een norm van hoger recht, waaronder uiteenlopende aanspraken konden worden samengebracht omdat zij die norm gemeenschappelijk hadden. Omdat Art. 2 lid $1 \mathrm{GG}$ onder meer wordt beheerst door die norm, kon de voorliggende individuele aanspraak eveneens worden gekwalificeerd onder Art. 2 lid $1 \mathrm{GG}$. Nu heeft deze norm van hoger recht een abstract karakter, waardoor het mogelijk wordt om er zeer uiteenlopende aanspraken onder te brengen: het recht om alleen te worden gelaten was aanleiding om in Soraya, Lebach en Kenntnis der eigenen Abstammung achtereenvolgens een recht op schadevergoeding wegens publicatie van niet-gedane uitspraken, een recht op resocialisering en een recht op kennis van de afstamming te erkennen. In Mikrozensus werd een abstracte norm van hoger recht gehanteerd voor de erkenning van het recht van het individu, zich niet aan willekeurige ondervragingen door de staat te hoeven laten onderwerpen. De norm van hoger recht inhoudende dat het individu niet een object van de stat is, lag eveneens ten grondslag aan de individuele rechten als gepositiveerd in KPD-Verbotsurteil en Liith. Niet duidelijk is of deze norm die de drie zaken gemeenschappelijk hebben kan worden getypeerd als een beginselachtige notie of als "algemeen erkend rechtsbeginsel". De constante herhaling in de rechtspraak lijkt op een rechtsbeginselachtig karakter te duiden.

Aan de aanspraak in Ehescheidungsakten, waarin het recht op geheimhouding van persoonlijke documenten werd erkend, lag eveneens een abstracte norm van hoger recht ten grondslag. Het Hof maakte in die zaak een vergelijking tussen Art. 2 lid 2 GG en Art. 2 lid 1 GG. Het eerste omvat een recht op fysieke integriteit. Het tweede bood in de optiek van het Hof voldoende ruimte om een recht op geestelijke integriteit te kunnen omvatten. De overeenkomst tussen geestelijke en fysieke integriteit werd niet expliciet genoemd, maar aan beide aspecten van integriteit lijkt een norm van hoger recht ten grondslag te liggen die stelt dat het individu een privé-sfeer toekomt warin het ongestoord zichzelf kan zijn zonder angst voor ingrijpen van staatswege. In de zaken Arztliche Schweigepflicht en Zeugnisverweigerungsrecht werden eveneens normen van hoger recht door het Hof tot uitgangspunt verheven in een analoge redenering; in beide zaken werd de die gevormid door "s Hofs aanname van het bestaan van een 'unantastbarer Bereich privater Lebensgestaltung'. Het begrip is gepositiveerd in de rechtspraak en heeft naderhand bij de beoordeling van uiteenlopende aanspraken gediend als maatstaf om te beoordelen of de aanspraken onder Art. 2 lid 1 GG en Art. 1 lid $1 \mathrm{GG}$ konden worden erkend.

De aanspraak van de zwangere vrouw op een recht, ingrijpende keuzes ten aanzien van het eigen leven te kunnen maken, werd in beide zaken gebaseend op Art. 2 lid $1 \mathrm{GG}$, maar verkreeg geen nadere uitwerking. Het recht op leven ex Art. 2 lid 2 GG van het ongeboren kind wend doot alle rechters aaangenomen. Aan de afwijzing van abortus werd daarentegen uitvoerig aandacht besteed in de interpretatiefase. Het niet motiveren 
van de aanspraak van de zwangere vrouw maakte de afweging tussen het belang van de zwangere vrouw enerzijds en dat van het ongeboren leven anderzijds misschien well iets minder zwaar: door uitgebreid aandacht te besteden aan de betekenis van abortus in de het regime in de Tweede Wereldoorlog werd de kans op sympathie voor voorrang van het recht op leven boven de aanspraak van de vrouw vergroot.

In Transsexuelle $I$ gebruikte het Hof een analoge redenering voor de positivering van de aanspraak van transseksuelen op de nieuwe geslachtelijke identiteit. Het recht op erkenning van die nieuwe identiteit behoort tot de rechten die het algemene persoonlijkheidsrecht beoogt te beschermen. De analogie met Sexualkundeunterricht was niet toevallig gekozen: de individuele aanspraak in die zaak was een andere dan in Transsexuelle 1 , maar bood het Hof niettemin aanknopingspunten voor erkenning van de aanspraak op een seksuele intiene sfeer in Transsexuelle I. De gemeenschappelijkheid van deze norm van hoger recht werd niet nader gemotiveerd; niet werd uitgesproken op welke punten beide zaken vergelijkbaar waren. Het noemen van een seksuele intieme sfeer zou voldoende aanknopingspunten voor de kwalificatie bieden. Dat onuitgesproken gemeenschappelijke kenmerk leek nadere toelichting overbodig te maken. Het zwijgen over de nadere inhoud van die norm van hoger recht kon in dit verband ook worden opgevat als een weigering, verder vorm te geven aan dit aspect van het algemene persoonlijkheidsrecht. Een expliciet noemen zou bijwoorbeeld aanspraken kunnen uitlokken ter zake waarvan het Hof (nog) geen mening wil uitspreken. In Transsexuelle II deed zich die situatie voor: het recht op een seksuele intieme sfeer hield geen recht op huwelijkssluiting van homoseksuele paren in. De klacht ter zake lag bij het Hof op de stapel om te worden beoordeeld, op het moment dat het een uitspraak deed in Transsexuelle $I I$.

In Soraya constateerde het Hof aan de hand van een abstracte analogie dat de privaatrechtelijke notie van het algemene persoonlijkheidsrecht eveneens een constitutioneelrechtelijke variant kende. De privaatrechtelijke notie werd door het BGH gebaseerd op Artt. 2 lid 1 en 1 lid $1 \mathrm{GG}$, maar was tot dusverre als zelfstandige aanspraak in de privaatrechtelijke orde tot ontwikkeling gekomen. ${ }^{182}$ Deze grondslag bood het Hof in beginsel een relatief eenvouduge mogelijkheid, het algemene persoonlijkheidsrecht te verheffen tot constitutionele notie. Het Hof liet in Soraya echter niet expliciet blijken, aan de bestaande grondrechtelijk erkende aanspraken een nieuwe toe te voegen. Het Hof koos, afgaande op formuleringen die in de gehele witspraak terug te vinden zijn, voor een lijn waarin het algemene persoonlijkheidsrecht al onderdeel uitmaakte van de constitutionele rechtsorde. Achter deze keuze speelde wellicht de strategie niet teveel ineens te willen positiveren: in Soraya kende het Hof namelijk schadevergoeding voor immateriele schade toe, een erkenning die niet kon worden gebaseerd op dan toe bestaande wetgeving.

181 In dit aspect lag everwwell een analogie opgestoten; de vraag rijst echter of zij armaardbaar is (zie par $6.3,4)$.

182 Leserbrief, $13 \mathrm{BGHZ} 334,25$ mei 1954, was de eerste zaak waarin het Bundesgerichtshof het algemene persoonlijkheidsrecht als individuele alanspraak in een civielrechtelijk conflict erkende. 
De eerste "echte" toepassing van het constitutionele algemene persoonlijkheidsrecht vond echter pas zijn beslag in Eppler. Ook hier werd dat recht als zelfstandige rechtsgrondslag voor positivering van nog niet eerder gedane aanspraken via een analoge redenering erkend. Ook in Eppler kon geen sprake zijn van specificiteit; er werden bijvoorbeeld geen feitencomplexen vergeleken. Het enige aanknopingspunt voor de vergelijkbaarheid was, dat de daar genoemde aanspraken allen waren erkend onder Art. 2 lid 1 jo. Art. 1 lid 1 GG. In Eppler was sprake van een rechtsanaloge redenering. Het Hof had in die zaak geen afzonderlijke wettelijke bepaling die moest worden geinterpreteerd, maar construeerde zelfstandig een toepasselijke notie die was gebaseerd op twee wetsartikelen. In Eppler positiveerde het Hof aldus een nieuw grondrecht - het algemene persoonlijkheidsrecht - alsmede een concretisering daaruit - het recht om geen uitspraken in de mond gelegd te krijgen die niet zijn gedaan. Van de jurisprudentie na Eppler waarin werd aangeknoopt bij het algemene persoonlijkheidsrecht kan worden gesteld dat er sprake was van een wetsanalogie. Het algemene persoonlijkheidsrecht was nu immers gepositiveerd in de rechtspraak. Voor wat betreft de gelding van het algemene persoonlijkheidsrecht kan worden gesteld dat de reeks uitspraken waarin het heeft gediend als grondslag voor concretisering van individuele aanspraken, zijn gelding heeft verkregen. ${ }^{183}$

Een voorbeeld waarin het Hof een onaanvaardbare analogie bezigde onder een norm van hoger recht is te vinden in Familienname. ${ }^{184}$ De naam als een indivualiseringskenmerk van het individu werd afgeleid uit Söhlde, een zaak waarin dat belang eveneens was erkend. In Söhlde stond echter niet een aanspraak van een individu centraal, maar die van een openbaar lichaam. ${ }^{185}$ Het Hof achtte vergelijking van gemeentelijke autonomie ter zake van het kiezen wan een naam en naam als individualiseringskenmerk mogelijk en concludeerde daaruit tot een recht van een individu, de eigen naam te kunnen kiezen.

De analogie werd in veruit de meeste gevallen gebaseerd op de eigen rechtspraak. In Soray a vormde de rechtspraak van het Bundesgerichtshof voor het onderzoek naar het algemene persoonlijkheidsrecht, dat tot Soraya bij uitstek een privaatrechtelijke notie was, een belangrijke grondslag voor verkenningen maar een constitutioneel persoonlijkheidsrecht. Het Hof schuwt natuurrechtelijke bronnen niet in het interpretatiestadium, indien zij van pas komen bij de kwalificatie van de individuele aanspraak onder de handelingsvrijheid of het algemene persoonlijkheidsrecht. ${ }^{186}$ In enkele onderzochte zaken, waaronder Investitionshilfe, werden enkele uiteenlopende rechtsnormen uit de grondwet tezamen genomen om het bestaan van een opvatting te rechtvaardigen. Bij de

183 Voor wat betreft de interpretatie van de algemene handelingsvrijheid is sprake wan wetsanalogie: hier had de rechter wel steeds een wettelijke bepaling tot zijn beschikking.

184 Familiennowne, $78 \mathrm{BV}$ erfGE 39,49 (1988).

185 Sohlde, 59 BVerfaE 216,226 (1982).

186 Zie bijvoorbeeld de wijze waarop het recht op kennis van de afstamming werd geformuleerd en gevestigd par. 6.3.7. 
positivering van het algemene persoonlijkheidsrecht werden Art. 2 lid 1 en 1 lid I GG tezamen genomen. Bronnen van internationaal recht werden, afgaand op de onderzochte rechtspraak, in het interpretatiestadium niet aangehaald.

Wat betreft het onderscheid van algemeenheid en specificiteit in de analogie kon worden onderscheiden naar respectievelijk vergelijking van feitencomplexen enerzijds en vergelijking van toepasselijke normen van hoger recht - hetzij rechtsbeginselen of andere, niet juridische noties - anderzijds. Gerichte kritiek op de normen die het Hof hanteert, als zouden zij te weinig conreet zijn zoals in het Amerikaanse Hof wel werd geopperd, heeft zich niet in vergelijkbare mate voorgedaan. Dat is althans niet af te leiden uit de dissentings en concurrings. ${ }^{187}$ De meest felle oppositie tegen de opvatting van de meerderheid werd gevoerd in de eerste abortuszaak; de dissenters ageerden tegen zowel de vergelijkingen alsook tegen de consequentie die het Hof verbond aan de ongrondwettigheid van het toelaten van abortus. Het verwijt als zou het Hof te zeer wetgevend optreden is evenmin veelvuldig teruggevonden in dissentings of concurrings in de onderzochte rechtspraak. Dat is opmerkelijk, omdat in de wijze waarop het Hof Art. 2 lid 1 GG heeft uitgewerkt, een gevaar op de loer ligt dat inhoudt dat het individu zich met ieder bezwaar tot het Hof kan richten om onwelgevallige wetgeving aan te vechten. Eénmaal is het Hof ingegaan op kritiek die in de literatuur werd geuit. ${ }^{188}$ Het Hof lijkt zelfbewust om te springen met de interpretatieruimte die de algemene handelingsvrijheid ex Art. 2 lid 1 GG en het algemene persoonlijkheidsrecht ex art. 2 lid $1 \mathrm{GG}$ in zich dragen. Het heeft meermaals gewezen op de casuïstische benadering die het hanteert bij de uitleg van deze rechten. De passage uit Kenntnis der eigenen Absiammung is tekenend in dit verband: in de rechtspraak, aldus het Hof, is dat persoonlijkheidsrecht niet uitputtend omschreven, maar worden de uitdrukkingen ervan op casuistische wijze uitgewerkt. ${ }^{189}$ Het Hof heeft, afgaande op de onderzochte rechtspraak, zich nooit aan een omschrijving van het algemene persoonlijkheidsrecht gewaagd. Steeds zijn er onderdelen beschreven, waarbij de concretiseringen onderdelen van de algemene handelingsvrijheid en het persoonlijkheidsrecht vormen.

In Eppler leek de opvatting, dat moderne ontwikkelingen beantwoord dienen te worden met een passende individuele grondrechtsbescherming, het Hof de gelegenheid te bieden om een dynamisch-evolutieve lezing te geven aan bestaande rechten. ${ }^{190}$ Steeds werd daarbij verwezen naar Eppler, hoewel dit argument in die uitspraak het karakter had van een obiter dictum. De rechtspraak waarin dat argument werd opgebracht had op het materieelrechtelijke terrein of naar het feitencomplex weinig tot geen raakvlakken met Eppler; enige overeenkomst was dat het Hof constateerde dat moderne ontwikkelingen de grondrechtelijke positie van het individu bedreigde. Het argument van

187 In het Duitse Hof wordt van deze mogelijkheid beduidend minder gebruikgemaakt dan in het Amerikaanse Hooggerechtshof.

188 Reiten im Walde, 80 BVerfGE 137 (1989).

189 Vaterschaftsauskumft, 96 BverfGE 56, 63 (1997)

190 Volkszählung. 65 BVerfGE 1, 42 (1983); Kennnis der eigenen Abstanmung, 79 BVerfGE 256, 268 (1989). 
moderne ontwikkelingen is geen juridische norm en lijkt zich te kunnen lenen woor uitbreiding van grondrechtelijke bescherming zoals het Hof dat noodzakelijk acht. Het speelt waarschijnlijk met name een rol in kwesties waarin de wetgever (bewust) niet voorzien heeft.

Het formuleren van obiter dicta in een uitspraak lijkt soms een belangwekkende functie te krijgen: zij kunnen in latere uitspraken kennelijk worden aangehaald om nieuwe wegen in te slaan die vanwege verwijzing naar jurisprudentie niet nieuw lijken. Zo lijken zij een vergelijkbare functie te vervulen als dissentings en concurrings: zij vormen een proeftuin warin nieuwe ideeên kunnen worden gelanceerd en waarop reacties in de rechtsgemeenschap kunnen worden afgewacht. ${ }^{192}$

\subsubsection{Terminologie}

Het Hof rechtvaardigde in Elfes zijn vaststelling van de reikwijdte van Art. 2 lid 1 GG aan de hand van een retorische vraag. Met het recht op algemene handelingswrijheid, aldus het Hof, kan niet alleen een absoluut, onaantastbaar recht op prive-sfeer bedoeld zijn. Waarom zou de wetgever anders begrenzingen hebben gesteld aan de uitoefening van dat recht? Er moest, met andere woorden, nog een andere, niet absolute onaantastbare prive-sfeer bestaan waarop inbreuken moeten worden getolereerd. Het Hof creèerde met deze vaststelling verschillende sferen, waarbinnen het de verschillende aanspraken zou kunnen gaan beoordelen. Deze verschuifbare maatstaf bood de mogelijkheid, aanspraken die niet binnen de onaanraakbare privé-sfeer te kwalificeren waren, toch te beoordelen binnen het grondwettelijk beschermingsregime. De onderscheiding tussen een kernsfeer en een perifere sfeer bleken naderhand handige instrumenten in de belangenafweging: rechten die zich buiten de kemsfeer bewegen, kunnen onderworpen worden aan een belangenafweging. Naarmate een aanspraak zich in de periferie van de tweede sfeer beweegt, kunnen beperkingen op dat recht wat gemakkelijker kunnen worden gerechtvaardigd. Omgekeerd kunnen aanspraken die zich eerder naar het kernrecht toe bewegen moeilijker worden beperkt. De redenen om een inbreuk te tolereren moeten van zwaarwegender aard zijn dan wanneer de aanspraak zich in de periferie van het recht bevindt.

In de terminologie is het Hof wat de positivering van nieuwe rechtsnormen betreft niet unmer eenduidig. Dit geldt zowel voor de rechtspraak op het terrein van de algemene handelingsvrijheid als die van het algemene persoonlijkheidsrecht. De precieze status van de "nieuwe' normen - is het nu een 'recht' of een 'belang' - is niet steeds eenduidig. Het Hof formuleerde de "nienwe" rechtsnorm meestal niet direct als "recht". Het spreekt niet over een recht op resocialisering, of een recht van het individu de afstamming te kennen. Het 'belang' bij de kennis van de afstamming wordt gedekt door het

\91 In Songya speelde dit dumamisch-ewolutieve aspect aspect eveneens; het leidde tot het aanvarden van de mogelijkheid van inmateriele schadevergoeding in gevallen warin het individu beschadigd. is gerakt door de pers.

$\$ 92$ Vergeljik hier de 'burying bones"-tactiek van rechter Brennan zoals geformuleerd door Lazarus, zie par, 5.3.2 en Lazarus 1999, p. 364-365. 
algemene persoonlijkheidsrecht, het 'belang" bij een rustige terugkeer in de samenleving vormt een 'onderdeel' van het algemene persoonlijkheidsrecht en patientgegevens behoren tot het 'privé-domein' wan de patiënt. ${ }^{193}$ In Homosexuelle werd de aanspraak van de klagers - een recht op 'freie geschlechtliche Betatigung des Indivi. duums" - door het Hof vertaald naar het tot Art. 2 lid $1 \mathrm{GG}$ behorende "Gebiet des Geschlechtlichen?. 194

In andere uitspraken zijn voorbeelden van retoriek en metaforen aangetroffen; zij werden gehanteerd met het oog op ondersteuning in de overtuigingskracht van de door het Hof gevolgde redenering. Een prangend voorbeeld werd aangetroffen in Kenminis der eigenen Abstammung. ${ }^{195}$ Het Hof stelde daarin dat ontplooing van liet individu sterk verbonden is met de kennis van de biologische afstamming. Deze kennis is "persônlichkeitsprägend" en "nimmt im Bewwßtsein des einzelnen eine Schlusselstellung fur Individualitätsfindung und Selbstverständnis ein. ${ }^{196}$ De bron voor de nadere motivering van het Hof vertoonde in mening opzicht natuurrechtelijke kenmerken: in de passage die de doorslag gaf voor de erkenning van de aanspraak werd niet verwezen naar juridische bronnen. Het Hof heeft zich wellicht om die reden steeds woorzichtig getoond in zijn formulering waar het gaat om het erkennen van 'rechten' die tot dusverre nog niet waren gepositiveerd. In Elfes werd bijvoorbeeld nog geen recht op privéleven geformuleerd, maar 'eine Sphäre privater Lebensgestaltung". ${ }^{197}$ Het begrip "sfeer" laat waarschijnlijk meer ruimte voor het aanbrengen van een bandbreedte waarin verschillende aanspraken kunnen worden erkend, dan het begrip 'recht'. Verder formuleerde het Hof in Elfes niet een recht op uitreizen naar het buitenland, maar een beginsel van vrij reizen - 'das Prinzip der freien Ausreise'. ${ }^{988}$ Dat werd als ến van de "uitvloeiselen' van het recht op individuele ontplooiing ex Art. 2 lid 1 GG erkend. In dit verband kan de vraag worden gesteld, in hoeverre sprake is van een niet-juridische notie of van een recht. In het proces van de erkenning van nieuwe rechten zijn ondanks deze onhelderheid en eventuele verhulling verschillende fasen aan te wijzen, die duiden op een 'proces' van positivering van rechtsnormen in de rechtspraak.

In Mikrozensus echter, de zaak over verplichte medewerking aan een enquête, formuleerde het Hof voor het eerst direct een recht op zelfbeschikking. ${ }^{199}$ Dat recht positiveerde het Hof in een fase, waarin het de aanspraak van het individu al als uitvloeise van de algemene handelingsvrijheid had erkend. Het Hof had het zelfbeschikkingsrecht dus niet meer primair "nodig" in zijn argumentatie; het steunde de redenering hoogstens 'zijdelings'. De plaats van deze overweging doet eerder vermoeden dat het Hof in een obiter dictum wilde aanreiken, wat meer in het algemeen met inbreuken op het alge-

193 Zie bijvoorbeeld Kenntmis der engenen Abstanumug, 79 BVerfoE 256, 268-269 (1989), Lebach, 35 BVerfGE 202, 220 (1973)en Aratiche Schweigepflich, 32 BVerfGE 373, 379 (1972).

194 Homosenuelle, 6 B VertGE 389,342 (1957).

195 Zie par. 6.3.7.

196 Zie par. 5.3 .7 en zie Kennthis der evgenen Abstammung, 79 BVerfGE 256, 268-269 (1989)

197 Elfes, 6 BVerfoE 32, $41(1957)$

198 Elfes, 6 BVerfGE 32, 42 (1957)

199 Mikrozensus, 27 BVerfGE 1, 7 (1969). 
mene persoonlijkheidsrecht werd bedoeld. Het Hof werkte in Mikrozensus niet de betekenis van het zelfbeschikkingsrecht uit, en evenmin de plaatsing van dat recht ten opzichte van de andere benoemde en onbenoemde grondrechten. Later zou dat recht op zelfbeschikking verscheidene keren terugkeren in de rechtspraak als argument voor de plaatsing van een individuele aanspraak onder het algemene persoonlijkheidsrecht. Naderhand bleek het recht op zelfbeschikking aanleiding voor kwalificatie van uiteenlopende aanspraken onder de algemene handelingsvrijheid en het algemene persoonlijkheidsrecht. Dit fenomeen deed zich eveneens voor bij het aspect van de 'moderne ontwikkelingen'.

Uit deze benadering zou een terughoudendheid ter zake van de interpretatie kumnen worden afgeleid. Vermoed wordt hier, dat het Hof met de erkenning van de aanspraken onder het algemene persoonlijkheidsrecht, zonder ze de meer heldere status van 'rechten' toe te kennen, voor zichzelf de ruimte behoudt om bepaalde aanspraken verder wit te werken en anderen te laten rusten. Een vestiging van een aanspraak als een 'recht' heeft gevolgen, die het Hof nog niet kan overzien op het moment van eventuele positivering. Het uitspreken van het benoemen van nieuwe rechten kan bijvoorbeeld leiden tot de vaststelling dat het Hof zich op wenst te stellen als grondwetgever. Aan een recht kunnen positieve verplichtingen kleven. Het nieuwe recht biedt wellicht aanknopingspunten voor mieuwe aanspraken. De rechter kan in dit verband kiezen voor een beleid van interpretatie, waarbij de vagere termen 'Schutzgut', 'Gebiet des Geschlechtlichen', 'Bereich' meer ruimte bieden voor navigatie en koersaanpassing dan 'harde' rechten. Die 'rechten' bieden in termen van rechtszekerheid een duidelijker handvat om aanspraken aan op te hangen, dan de genoemde vagere termen. 


\section{Hoofdstuk 7}

\section{Analoge rechtsvinding in de jurisprudentie van het Hof van Justitie van de EG}

\subsection{Inleiding}

In de jurisprudentie van het Hof werd op het terrein van het recht op persoonlijkheid een aantal uitspraken aangetroffen, waarin een analogie in de rechtsvinding te ontwaren is.' Het aantal uitspraken dat het Hof heeft gedaan op het terrein van het recht op persoonlijkheid en die hebben geleid tot rechtsontwikkeling is overzichtelijk. Over een aantal aspecten van dat recht - privé-leven, een recht op medische geheimhouding en erkenning van transseksualiteit in het licht van EG-burgerrechten - heeft het Hof zich evenwel uitgelaten. Deze uitspraken zullen worden onderzocht op de wijze waarop het Hof voornoemde aspecten positiveerde aan de hand van normen van hoger recht als rechtsnormen van communautair recht. Eerst zal worden stilgestaan bij de context waarin een recht op 'privé-leven', medische zelfbeschikking en erkenning van transseksualiteit tot ontwikkeling konden komen. Het EG-Verdrag kent geen specifieke rechtsnorm die een recht op persoonlijkheid vastlegt. ${ }^{2}$

\subsection{Rechtsontwikkeling door het Hof van Justitie van de EG}

Een belangrijke bijdrage aan de opkomst van fundamentele rechten als rechtsbeginselen van de Europese Gemeenschap is geleverd via de analoge redenering. Over de opkomst van fundamentele rechten als beginselen van Gemeenschapsrecht is reeds veel geschreven. ${ }^{3}$ In 1960 stelde het Hof, dat Gemeenschapsrecht zoals dat voortvloeit uit de EGKS geen algemene rechtsbeginselen inhoudt die fundamentele rechten garanderen. ${ }^{4}$ Een eerste teken van bereidheid, fundamentele rechten als rechtsbeginselen van Gemeenschapsrecht te aanvaarden werd later evenwel gegeven in Stauder. ${ }^{5}$ Het Hof merkte in een obiter dictum op dat fundamentele rechten deel uitmaken van het Gemeenschapsrecht. ${ }^{6}$ Door verschillende auteurs wordt geopperd dat dit dicturn het ge-

1 Zie ook Langenbucher 1998, p. 481-521 over analoge redeneringen in de rechtsvinding van hiat Hof van Justitie van de EG.

2 Par. 2.5.

3 Zie voor verdere verwijzingen onder meer Craig en De Bürca 1998, p. 296 e.v., Schermers 2000, p. 61 e.v., Toth 2000 , p. 73 e.v.; Cassese, Clapham en Weiler 1991 , p. $5 \rrbracket$ e.v. en Weiler en Lockhart 1995 , p. 579 e.v.

4 Shork t. Hoge Autoriteit van de EGKS, zaak 1-58 (1959), Jur. p. 43 (1959); Brescia t. Hoge Autoriteit van de EGKS, zaak $31 / 59$ (1960), Jur. p. 98 (1960); Geilling, Nold e.a. t. Commissie, zaken 36/59, $37 / 59,38 / 59$ en $40 / 59$ (1960), Jur. p. 885 (1960).

5 Stauder t. Ulm, zaak 29169 (1969), Jur. p. 419 (1969).

6 Het obiter luidde: 'Interpreted in this way the prowision at issue contains nothing capable of prejudicing the fundanental human rights enshrined in the general principles of Community Law and protected by the Court", Stouder t. Ulm. 
volg was van de aanhoudende druk op het Hof uit Duitsland na de uitspraak van het Federale Constitutionele Hof in "Solange", ${ }^{7}$ In die zaak werd gesteld dat nationale grondrechtelijke bescherming vanwege suprematie van het Gemeenschapsrecht aan datzelfde Gemeenschapsrecht ondergeschikt werd gemaakt terwijl datzelfde Gemeenschapsrecht geen grondwettelijk kader biedt. De Duitse Solange-zaak die bij het Hof als Internationale Handelsgesellschaft arriveerde, zou de eerste uitspraak zijn waarin het Hof bevestigde dat fundamentele rechten als onderdee] van rechtsbeginselen van de Gemeenschap deel uitmaken en dat het Hof een taak toekwam, deze rechtsnormen te warborgen:

'However, an examination shoujd be made as to whether or not any analogous guarantee inherent in community law has been disregarded. In fact, respect for fundamental rights forms an integral part of the general principles of law protected by the Court of Justice' 8

Her legde het Hof zijn mandaat zoals neergelegd extensief uit: onder het recht ex Art. 220 EG-Verdrag dient niet alleen geschreven, maar ook ongeschreven recht te worden verstaan. Wanneer we nu de analogie bezien, ontstaat het volgende beeld. Het Hof ontleent het toepasselijke rechtsnormenkader aan de gemeenschappelijke constitutionele tradities van de Lid-Staten. Deze verwijzing wordt hier aangemerkt als norm van hoger recht, die pas later dienst zou gaan doen als bron voor concretisering van rechtsnormen die niet 'zichtbaar' deel uitmaken van het EG-Verdrag. In Internationale Handelsgesellschaft leidde het Hof uit deze norm geen op het voorliggende geschil toe to passen rechtsnormen af. In Internationale Handelsgesellschaft knoopte het Hof niet aan bij een in het EG-Verdrag neergelegde rechtsnorm. ${ }^{9}$ Dat sterkt het vermoeden, dat in deze zaak niet een wetsanalogie, maar een rechtsanalogie werd gehanteerd.

Het Hof verwees ter zake van het toepasselijke rechtsnormenkader naar het obiter in Stauder. In Nold zou het Hof aan de constitutionele tradities van de Lid-Staten het normenkader van het Europese Verdrag voor de Rechten van de Mens aan toevoegen. ${ }^{10}$ Het beginselenkader van fundamentele rechten werd aldus geschoeid op de gemeenschappelijke tradities en op het EVRM dat door alle Lid-Staten was geratificeerd, hetgeen uit het oogpunt wan erkenning van de extensieve interpretatie door het Hof van de eigen taak voor de Lid-Staten niet ongelegen kwam. De herkenning van twee gemeenschappelijke elementen - traditie en bescherming van fundamentele rechten in het EVRM - zouden aanwaarding van 's Hofs includering van fundamentele rechtsnormen als beginselen van gemeenschapsrecht versnellen. De verwijzing naar de traditie zou nog kunnen duiden op een terughoudendheid in interpretatie van de rechtsbeginselen die nu op instigatie van het Hof deel uitmaakten van het rechtsnormenkader: traditie wijst in zekere zin op respect voor het tot dan toe bestaande en impliceert op het eerste gezicht geen progressieve benadering. Daarnaast dient de traditie ook gemeenschappe-

7 Zle onder meer Schernuers 2000, p. 65. Voor Solange / zie 37 BVerfGE 271 (1974).

8 Internationale Mandelsgeselschaf, zaak 11770 (1970), Jur. 1.1125 (1970).

9 Een vraag of de individuele aanspraak kon worden gekwalifceerd onder én van de rechten wit het Verdrag werd hier niet gesteld.

10 Nold t. Commissie, zaak 4/73 (1974), Jur. p. 917(1974). 
lijk te zijn, hetgeen lijkt in te houden dat het Hof zich op de hoogte stelt van bijvoorbeeld de strekking en reikwijdte van fundamentele rechten in de Lid-Staten.

Werd in de voorafgaande uitspraken werd enkel een toepasselijk normenkader gecreeerd - in Nold werd een rechtsregel, namelijk het recht op bescherming van de eigendom afgeleid uit dat normenkader en erkend als beginsel van gemeenschapsrecht. In Nold is sprake van een rechtsanalogie. Een rechtsanalogie wordt gehanteerd indien de rechter voor de formulering van een toepasselijke rechtsnorm niet meer aanknoopt bij een wettelijke norm; hij leidt de toe te passen rechtsnorm daarentegen rechtstreeks af nit de norm van hoger recht. Het Hof leidde de in Nold toepasselijke rechtsregel preciezer af uit de constituties van de Lid-Staten en Art. 1 lid 1 van het Eerste Protocol van het EVRM. Eventueel van toepassing zijnde beperkingen op dat recht werden door het Hof echter in een 'eigen' EG-rechtelijke context geplaatst. Het Hof aanvaardde een 'kernrechtgedachte' uit het toepasselijke rechtsbeginsel, maar het liet zich voor bijvoorbeeld een toepasselijke beperkingsmethodiek niet inspireren door het EVRM of constitutionele doctrine van enige Lid-Staat. Het deinsde terug voor een meer integrale overname van de EVRM-beperkingsdoctrines; een uitwerking van een dergelijk toetsingskader leek gezien de afwezigheid van een grondrechtelijk normenkader niet haalbaar. In dit verband kan dan ook niet worden gesproken van een incorporatie van het EVRM in het EG-recht zoals die heeft plaatsgevonden in het Amerikaanse constitutionele recht." Het Hof had dan zeer algemene uitspraken moeten doen over normen die niet expliciet behoren tot het EG-recht. In het licht van het EG-Verdrag leek dat waarschijnlijk niet verdedigbaar jegens de aan het Verdrag gebonden partijen: zij hadden immers gekozen woor een EG-Verdrag zonder grondrechtencatalogus.

Het bestaan van een normenkader inhoudende fundamentele rechten als rechtsbeginselen van EG-recht was nu evenwel door het Hof erkend. Het Hof concretiseerde daarna mondjesmaat uit die norm van hoger recht concrete rechtsnormen die vooral in formulering steeds sterke gelijkenis vertoonden met rechten uit het EVRM ${ }^{12}$ De Instellingen bevestigden de consequentie van 's Hofs extensieve interpretatie - includering van fundamentele rechten als beginsel van Gemeenschapsrecht - later in algemene termen. ${ }^{13}$ In 2000 werd door de Lid-Staten het Handvest met daarin een aantal grondrechten aanvaard, maar dat heeft tot dusverre geen bindende werking. ${ }^{14}$

\section{$\llbracket \mathbb{Z}$ Zie par. 2.3.3.}

12 Hiertoe behoren onder meer het recht op vrijheid van meningsuiting, ERT, zaak C-260/89 (1991), Jur. p. 1-2925 (1991); het recht op respect woor de wrijheid wan godsdienst, Prais $t$. Racrd, zaak 130/75, (1976), Jur. p. 1589 (1976); het recht op vrijheid van vereniging, Rustiti t. Minster van Binnentandse Zaken, zaak 36/75 (1975), Jur. p. 1219 (1975); Union Syndicale 1. Raad, Zaak 175/73 (1974), Jur. p. 917 (1974); het Hof vestigde het recht op vakbondsactiviteiten op een algemeen beginsel van arbeidsrecht en Union Royale Belge t. Bosman, zaak C-415/93 (1995), Jur. p. I-4921 (1995); het recht op "privéleven" en bescherming van de woning Panasanic t. Commissie, zaak 136/79 (1980), Jur. p. 2033 (1980), het beginsel van het verbod van terugwerkende kracht van wetgeving, Regina t. Keft Kirk, zaak 63/83 (1984), Jur. p. 2689 (1984), het recht op toegang tot een rechter, Johnston t. Chief Constable of the Royal Ulster, zaak 222/84 (1986), Jur. p. 1651 (1986) en het recht op verdediging in strafzaken, Orkem 1. Commissie, zaak 374/87 (1989), Jur. p. 3283 (1989).

13. Zie de Joint Declaration by the European Parliament, the Council and the Commission on fundamental 
In 1975 bood de zaak Rutili voor het Hof een belangrijke aanleiding, aan te duiden welke normen op de beperkingen die Lid-Staten wensen aan te brengen op het vrije verkeer van werknemers, van toepassing zijn. ${ }^{15}$ Beperkingen op dat vrije verkeer kunnen worden gesteld op grond van openbare orde, openbare veiligheid en volksgezondheid. De aangebrachte beperkingen dienen echter evenzeer te worden getoetst aan normen, die niet in het EG-Verdrag zijn geëxpliciteerd, maar die wel als rechtsbeginselen onderdeel zijn van de EG-rechtsorde. Daarvoor staan de Artikelen 8, 9, 10 en 11 EVRM model, evenals het op Rutili van toepassing zijnde Art. 2, Vierde Protocol. ${ }^{16}$ Het Hof haalde de beperkingsgronden die gelden voor grondrechten binnen de EGrechtsorde als rechtsbeginselen, waarmede bij de uitleg van Art. 39 lid 3 EG-Verdrag rekening dient te worden gehouden.

"Taken as a whole, these limitations placed on the powers of member States in respect of control of aliens are a specific manifestation of the more general principle, enshrined in Articles $8,9,10$ and 11 of the Convention for the protection of human rights and fundamental freedoms, signed [... j by all Member States, and in Article 2 of Protocol No. 4 [...] which provide, in identical terms, that no restrictions in the interests of national security or public safety shall be placed on the rights secured by the above quoted articles other than such as are necessary for the protection of those interests "in a democratic society".

Rutili leverde de eerste verwijzing op naar die EVRM-verdragsartikelen, maar het was het Hof te doen om de eisen die samenhangen met de noodzaak van beperkingen in een democratische samenleving, die het tweede lid van de Artt. 8 tot en met 11 gemeen hebben. Met 's Hofs verwijzing naar deze EVRM-artikelen was echter al wel een openingszet gegeven voor de substantiële rechten die zijn vastgelegd in de Artt. 8 tot en met 11 . Het Hof benutte ze in Rutili echter niet. Daartoe zouden latere geschillen in latere rechtspraak aanleiding geven.

\subsection{Ontwikkeling van het recht op persoonlijkheid met analoge redeneringen}

\subsubsection{Het recht op 'prive-leven'}

Verplichtingen van rechtspersonen in het kader van mededinging onder Art. 81 EG-Verdrag

Het recht op 'privé-leven' werd in Panasonic voor het eerst expliciet gevestigd als rechtsbeginsel van de communautaire rechtsorde in het kader van een concreet geschil omtrent de uitleg van de bevoegdheden van de Commissie Art. 81 EG-Verdrag. ${ }^{18}$ Het

rights, 5 april 1977 , Pb. C 103/』 (1977).

14 Par. 2.5.2.

15 Rutli t. Minister wan Binnenlandse Zaken, zaak 3675 (1975), Jur. p. 1219 (1975).

16 Art. 2 lid 1, Vierde Protocol EVRM luidt: 'Everyone lawfully within the territory of a State shall, within that territory, have the right to liberty of mowement and freedom to choose his residence:.

17 Ruili, par, 32.

18 Zie onder meer Panasonic t. Commissie, zaak 136/79 (1980), Jur. p. 2033 (1980); Hoechst t. Commissie zaak 46/87 (1989), Jur. p. 2859 (1989). 
recht op 'privé-leven' als een rechtsbeginsel van Gemeenschapsrecht werd afgeleid uit het arsenal van rechtsbeginselen van Gemeenschapsrecht. De norm van hoger recht waaruit het recht op 'privé-leven' werd afgeleid - 'fundamentele rechten als rechtsbeginselen van gemeenschapsrecht" - heeft een abstract karakter. Het Hof motiveerde zijn vondst niet uitputtend: het recht op 'prive-leven' is immers in de meeste grondwetten gecodificeerd en vastgelegd in het EVRM. Na de vraag van de toepassing rees de vraag van de reikwijdte in Panasonic, meer specifiek toepasselijkheid van het recht op 'privé-leven' op rechtspersonen. Het Hof liet een duidelijke keuze in het midden, al leek het te aanvaarden dat rechtspersonen eveneens onder de reikwijdte vallen. Voor wat betreft de toetsingsmethodiek wees het Hof op het toetsingskader zoals het EHRM dat hanteert, al kon vervolgens niet worden gesproken van een parallelle toepassing van het toetsingskader. Had het Hof dat overgenomen, dan had een indringende toetsing van het handelen van de Commissie waarschijnlijk voor de hand gelegen: de benadering ten faveure van de individuele rechtsbescherming had in dit verband voorgeschreven dat beperkingen op het individuele recht in beginsel restrictief dienen te worden geinterpreteerd. De proportionaliteitstoets zou daarna evenwel een relativering kunnen aanbrengen. Het Hof paste in Panasonic een marginale toets toe die werd gebaseerd op het belang dat in het EG-Verdrag wordt gehecht aan de onderzoeksbevoegdheden in verband met de Verdragsdoelstellingen. De marginale toets leidde tot instand laten van de gewraakte beschikking van de Commissie.

In Panasonic werd de aanspraak van de rechtspersoon op het recht op "privé-leven" zonder meer aanvaard. In Hoechst $t$. Commissie en enkele andere zaken in de late jaren " 80 was de bereidheid om het recht op 'privé-leven' op dit punt extensief te interpreteren minder vanzelfsprekend. A-G Mischo had in het kader van Hoechst $t$. Commissie een rechtsvergellijkend onderzoek verricht, en was tot de conclusie gekomen dat rechtspersonen in de meeste Lid-Staten geen bescherming van een recht op 'privé-leven' genoten, of dat het althans niet zover strekte, dat dat recht in gelijke mate van toepassing was op rechtspersonen in vergelijking met individuen. ${ }^{19}$ Het doorslaggevende argument voor deze benadering was gelegen in de rechtsvergelijking van rechtspraak in de Lid-Staten, hetgeen lijkt te duiden op een consensubenadering van het Hof.

Tevens stelde A-G Mischo dat het EHRM ter zake geen beslissende jurisprudentie kende. Met name dat laatste punt is niet onomstreden. ${ }^{20}$ Het Hof koos nu expliciet voor

19. Hoechst, Dow Benehx NF, Dow Jberica SA, ea., gevoegde zaken 46/87 en 227/88, zalak 85/87 en gevoegde zaken 97, 98 en 99/87; Opinie van A-G Mischo, 21 februari 1987, par. 49-100. A-G Mischo onderzocht in alle Lid-Staten wetgeving en rechtspraak ter zake.

20 De Europese Commissie voor de Rechten van de Mens had in 1989 zijn standpunt gewijzigd en erkend, dat een rechtspersoon aanspraak kan maken op de vrijheid wan godsdienst ex Aut. 9 EVRM (Ann. XXII 1979, p. 246). Het EHRM had in Chappell witspraak gedan ower de toepasselijkhe id van Art. 8 EVRM op bedrijfsactiviteiten in Chappell t. Verenigd' Koninkrijk, EHRM 30 maart 1989, Serie A val. I52-A. In die uitspraak ging het on een samenloop van ingrepen in de privé-sfeer en in de sfeer van bedrijfsactiviteiten. De ingrepen waren voomamelijk gericlst op de bedrijfsactiviteiten van Chappell in werband niet vermeende overtreding van auteursrechten. Zie woor een uitwerking wan een vergelijking van beide witspraken Cath 1991, p. 28-54. Zie eweneens par. 8.3.4 van dit boek. 
een benadering ten faveure van de achterliggende doelstellingen bij de bevoegdheild van de Commissie en beriep zich voor zijn keuze eveneens op het loyaliteitsartikel ex Art. 10 EG-Verdrag. "Het motiveerde de strengere invulling ter zake van de rechtsbescherming van rechtspersonen ten opzichte wan Panasonic verder niet; kennelijk werden de resultaten uit de rechtsvergelijking geacht voldoende onderbouwing te bieden. ${ }^{22}$ Het feit dat het recht op 'privé-leven' als rechtsbeginsel deel uitmaakt van de geldende rechtsnormen van EG-recht is daar tot op grote hoogte debet aan. Rechtsbeginselen bezitten een andere geldingskracht dan rechtsregels; rechtsbeginselen zijn bijvoorbeeld niet in dezelfde mate inroepbaar en afdwingbaar als rechtsregels. De rechter lijkt met een rechtsbeginsel een 'rekkelijker' norm tot zijn beschikking te hebben dan met een rechtsregel. Het dient te worden afgewogen tegen de andere beginselen van Gemeenschapsrecht, die hun beslag hebben in het EG-Verdrag, zoals de verplichting tot loyale samenwerking ex Art. 10 EG-Verdrag in het kader van Verordening 17 over de verificatiebevoegdheden van de Commissie ter zake van het opsporen van mogelijke inbreuken op het mededingingsbeleid. ${ }^{23}$

In $A M \& S$ t Commissie was een rechtsvergelijking een belangrijke aanleiding tot het aanvaarden van een rechtsbeginsel, dat op dat moment niet in het EVRM of in één van de EG-Verdragsbepalingen, maar wel in sommige Lid-Staten was geexxpliciteerd. ${ }^{24}$ In de constitutionele tradities van de Lid-Staten is, aldus klagers in $A M \& S$, een rechtsbeginsel te ontwaren, dat het recht op vertrouwelijkheid van de correspondentie tussen een advocaat en een rechtspersoon garandeert. Het Hof was in eerste instantie niet overtuigd van het bestaan van dit rechtsbeginsel in de Lid-Staten, temeer daar bijvoorbeeld van Franse zijde werd beargumenteerd, dat het hier enkel om een commonlawbegrip ging en dat het niet voorkwam in de continentale rechtstraditie. ${ }^{25}$ Het Hof had de partijen verzocht, bewijzen van het al dan niet bestaan van dat beginsel voor te leggen. $\mathrm{Na}$ bestudering van de rechtsvergelijking werd een rechtsnorm gepositiveerd in de communautaire rechtsorde:

'Community law, which derives from not only the economic but also the legal interpenetration of the Menber States, must take into account the principles and concepts common to the laws of those states concerning the observance of confidentiality, in particular, as

21 Hocchst t. Commissie, gevoegde zaken $46 / 87$ en $227 / 88$, par. 5 en Dow Chemical Ibéria e.a. t. Comm missie, gevoegde zaken 97/87, $98 / 87$ en 99/87 (1989), Jur. p. 3165 (1989), par. 5.

22 Het Gerecht deed recentelijk uitspratak in Limburgse Vinyl e.a. I. Commissie (GwEA 20 april 1999, Jur. $1999, \mathrm{p}$. [1-93\%) en hield vast aan het standpunt, dat er geen abialeiding bestond de rechtsopvattungen ter zake van aanspraken wan het recht op "privé-leven" door rechtspersonen bij te stellen. Zie pari. 8.3.4 voor de uitwerking van deze uitsprakk in verband met EVRM-rechtspraak.

23 De lijn in het Hoechstwarrest is recentelijk bevestigd in Roqwette Frëres S.A. t. Commissie, zaak C-94/00 (HvJ EG 22 oktober 2002, zie www curia.int; laatstelijk geraadpleegd op 1 november 2002).

24 AM\&S 1. Commissie, zaak 155/79 (1982), Jur. p. 1575 (1982). Zie ook Forrester 1983, p. 75-85 en Pagone 1984, p. 663-683 voor een rechtsvergelijking met Australie en Canada.

25 AMAS 1 Commissie, zatak 155/79, par. 12. Frankrilk ondersteunde de Commissie in de argumentatie maar was zelf geen partij in de zaak. 
regards certain communications between lawyer and elient. [... ] That confidentiality serves the requirements, the importance of which is recognized in all Member States [...]. ${ }^{26}$

Ook hier hanteerde het Hof een rechtsianalogie: wederom ontbrak een expliciete norm in het EG-Verdrag aan de hand waarvan het Hof had kumnen onderzoeken in welke mate aan de individuele aanspraak rechtsbescherming dient te worden toegekend. De norm van hoger recht die ten grondslag lag aan de erkenning van het recht op vertrouwelijkheid van correspondentie tussen advocaat en onderneming wordt hier gevormd door 'principles and concepts common to the laws of those states' die te ontwaren zijn als het gevolg van "legal interpenetration". Uit deze norm van hoger recht vloeide het rechtsbeginsel van vertrouwelijkheid van correspondentie voort. De consequenties van. aanwezigheid van dit beginsel in de communautaire rechtsorde moesten echter nog nader worden vastgesteld. Deze gevolgen hielden in een nadere concretisering van het rechtsbeginsel naar het voorliggende geschil in $A M \& S$. Niet elke correspondentie genoot overigens grondrechtelijke bescherming: indien de advocaat bijvoorbeeld gelieerd was aan de onderneming, kon de bescherming van vertrouwelijkheid bijvoorbeeld al niet meer opgaan.

\subsubsection{Het recht op medische zelfbeschikking}

\section{Art. 30 EG-Verdrag: uitzonderingen op het verbod van invoerbeperkingen}

Het Hof erkende in Commissie t. Duitsland voor het eerst een recht op medische geheimhouding als aspect van het recht op "privé-leven" dat in Panasonic was erkend als rechtsbeginsel van Gemeenschapsrecht. In het kader van de analogie werkte het Hof het rechtsbeginsel van het recht op 'privé-leven' uit en concretiseerde daaruit het recht op medische geheimhouding dat door het Hof werd "ontdekt" in de Duitse rechtsorde. Het Hof ontkwam er niet aan om in te gaan op het door de Duitse regering opgebrachte beginsel van medische zelfbeschikking bij de uitleg van de uitzonderingen op de invoerbeperkingen ex Art. 30 EG-Verdrag. Het vormde immers de grondslag op basis waarvan Duitsland een uitzondering rechtvaardigde. Het Hof positiveerde het recht op medische vertrouwelijkheid als een norm van de Europese rechtsorde als volgt:

"The right to respect for private life and, as one of its aspects, the right to protection of medical confidentiality constitute fundamental rights protected by the legal order of the

Community (see judgement in [...] National Pamasonic t. Commission [...] $)^{27}$

Het is, net als $A M \& S t$. Commissie, een fraaie illustratie van het feit dat op deze wijze dergelijke nationale grondrechtsbegrippen het EG-recht binnendringen: het in Duitsland erkende recht op medische vertrouwelijkheid wordt uit het EG-rechtsbeginsel van een recht op "privé-leven" - dat op zijn beurt is afgeleid uit het EVRM en gepositiveerd in Panasonic ${ }^{28}$ - verheven tot recht in de communautaire orde. In het conflict tussen Duitsland en de Commissie bestreed de Commissie een Duitse maatregel inhoudende 
zeer stringente beperkingen met betrekking tot invoer van medicijnen voor privé-gebruik uit een andere Lid-Staat. De Duitse regering had deze maatregel getroffen met het oog op bescherming van de volksgezondheid met een beroep op Art. 30 EGVerdrag. Zij achtte een dergelijke invoerbeperking noodzakelijk omdat de volksgezondheid op geen andere wijze zonder inbreuk te maken op de eis van medische geheimhouding kon worden gegarandeerd. In Duitsland gelden strikte voorschriften met betrekking tot de verpakking van medicijnen die apothekers in acht dienen te nemen. Deze vereisten zouden in de andere Lid-Staten, aldus de Duitse regering, niet worden gesteld hetgeen een bedreiging zou kunnen vormen voor de gezondheid van Duitse onderdanen indien zij in andere Lid-Staten medicijnen voor eigen gebruik aankopen. De Duitse regering betoogde dat een invoerverbod de enige mogelijkheid bood om die bedreiging te ondervangen. Elke andere wijze van bescherming van volksgezondheid - bijvoorbeeld controle aan de grens op invoer wan een maximale hoeveelheid medicijnen - zou inbreuk maken op het recht op medische vertrouwelijkheid van het individu, aldus de Duitse regering.

In de rechtsvinding van het Hof is sprake van een wetsanalogie: de strekking en reikwijdte van de uitzonderingen - met name bescherming van de gezondheid - in Art. 30 EG-Verdrag dienden nader te worden vastgesteld. De Verdragsnorm waarbij aldus werd aangeknoopt was Art. 30 EG-Verdrag. De norm van hoger recht, met behulp waarvan het Hof de nieuwe rechtsnorm van medische geheimhouding kwalificeerde als eventueel van toepassing zijnde grondslag voor een beperking, werd in casu gevormd door het recht op 'privé-leven'. 'Privé-leven' had in dit verband een abstracte betekenis: er werd bijvoorbeeld niet gerefereerd aan een enger begrip waarin plaats is voor de ruimtelijke afscherming van het 'privé-leven', maar eerder aan een notie waarin het ruimtelijke aspect van afscherming juist werd losgelaten.

Het recht op medische geheimhouding werd door het Hof verder uitgewerkt in $X t$. Commissie. ${ }^{29}$ Een sollicitant klaagde over het feit dat de Commissie in een medisch onderzoek ter zake van de aanstelling ongevraagd een aids-test had uitgevoerd. Uit die test bleek dat klager seropositief was. Het Gerecht van Eerste Aanleg had de Commissie na een klacht van $X$ in het gelijk gesteld ter zake van de vraag of een dergelijke test zonder instemning van de betrokkene was toegestaan ${ }^{30}$, maar het Hof van Justitie vernietigde deze uitspraak met een erkenning van het recht van het individu gegevens omtrent zijn gezondheid geheim te houden:

"The Court of Justice has held that the right to respect for private life, embodied in Article 8 of the EHRC and deriving from the common constitutional traditions of the Member States, is one of the fundamental rights protected by the legal order of the community (Commission v. Germany). It includes in particular a person's right to keep his state of health secret' 31

$29 X$ t. Commissie, zank C-404/92 (1994), Jur. p. 1-4737 (1994); zie ook Hendriks 1995, p. 231-238 en Twomey 1995, p. 1013-1023.

30 X1. Conmissie, zaak T-121/89 en T-13/90 (1992), Jur. p. II-2195.

31 Xi. Commissie zaak $\mathrm{C}-404 / 92$, par. 17. 
Waar het Gerecht in Eerste Aanleg ter zake de individuele aanspraak niet had gekwalificeerd onder een nadere concretisering van Art. 8 EVRM - Art. 8 EVRM werd enkel genoemd $^{32}$ - was het Hof van Justitie bereid om aan het recht op "prive-leven" een nadere uitwerking te geven. De vestiging van het recht op medische geheimhouding alls beginsel van Gemeenschapsrecht werd gestoeld op de hiervoor genoemde zaak Commissie t. Duitsland. De in Commissie t. Duitsland aan de orde zijnde individuele aanspraak vertoont geen directe gelijkenis met de casus in $X t$. Commissie, maar het Hof zag hier toch een aanleiding om het recht op medische geheimhouding analoog te interpreteren. Om de analogie mogelijk te maken hanteerde het Hof een abstracte norm van hoger recht die werd uitgewerkt door $A-G$ Van Gerven. Hij kwalificeerde de individuele aanspraak onder het recht op medisch geheim - hetgeen volgens hem afgeleid wordt uit het in Art. 8 EVRM erkende recht op lichamelijke integriteit:

"It seems to me that this argument of the Commission must be examined on the basis of the principle of medical law in accordance with which the informed consent of the person concerned is required for any medical action. [...] This principle, frequently referred to by the expression 'informed consent', which comes from the United States [...], appears to be generally accepted in the medical law of the Member States [...] and is generally deduced from the right to physical integrity and from a (wider) right of self-determination'. ${ }^{33}$

Van Gerven put voor de rechtvaardiging van het bestaan van dat recht zowel uit communautaire als niet-communautaire bronnen. Naast de gemeenschappelijke tradities van de Lid-Staten vormde een niet-communautaire rechtsbron - een uitspraak van het Amerikaanse Hooggerechtshof over het begrip 'informed consent' - een inspiratiebron. ${ }^{34}$ In de Opinie werkte de A-G uit op welke manier het recht dient te worden begrepen en paste ter zake van de toepassing van het recht op de individuele aanspraak een test toe die de toets van het EHRM Art. 8 lid 2 EVRM zeer dicht nadert. ${ }^{35}$ De norm van hoger recht behelst in casu het recht op 'privé-leven' ex Art. 8 EVRM en meer specifiek erkenning van het bestaan van een recht op lichamelijke integriteit. Deze norm geeft invulling aan het beginsel van gemeenschapsrecht dat een recht op medische geheimhouding stipuleert. De redenering van Van Gerven wordt hier getypeerd als een rechtsanalogie: ook hier ontbrak een uit het EG-Verdrag toepasselijke rechtsnorm die een grondslag zou kunnen bieden aan de individuele aanspraak op medische geheimhouding. Het Hof volgde de A-G grotendeels in de toepassing. Opvallend is dat het Hof in $X$ t. Commissie een meer individueelrechtelijke oriëntatie volgde, warin bescherming van individuele rechten voorop staat. Dat heeft tot op grote hoogte te maken met de context waarin de individuele aanspraak werd gedaan - in een geschil tussen een communautaire Instelling enerzijds en het individu anderzijds. Van geprioriteerde beleidsterreinen zoals in Panasonic en Hoechst - waarin mediedinging centraal stond - was geen sprake.

33 Opinie van A-G Van Gerwen bij X. Commissie, zaak C-404/92 van 27 april 1994, par. 23

34 Opinie van $A-G$ Van Gerven bij $X$. Commissie, par. 23 en bijbehorende referentie natr voetnoot 21 in de Opinie. 


\subsubsection{Het recht op de naam}

In Konstontinidis rees de vraag, in welke mate het recht op de eigen naam als rechtsbeginsel van de EG-rechtsorde invalling kan geven aan het recht op vrijheid van vestiging ex Art. 43 EG-Verdrag. ${ }^{36}$ In het geschil legde de Duitse rechter aan het Hof de prejudiciele vraag woor, in hoeverre een van staatswege verplichte herschrijving van de naam van een onderdaan uit een andere Lid-Staat, die bedrijf houdt in Duitsland, in strijd is met EG-recht. ${ }^{37}$ Als gewolg van die herschrijving onderwond de klager naar eigen zeggen hinder in zijn beroepsuitoefening. De individuele aanspraak werd door het Hof gekwalificeerd onder Art. 43. EG-Verdrag, maar het Hof hield een zuiver economische interpretatie van dat artikel aan. Voor de analoge redenering met een recht op persoonlijkkeid is niet zozeer de redenering van het Hof, maar de Opinie van $A-G$ Jacobs toonzettend. Hij bepleitte in zijn opinie een meer fundamenteelrechtelijke benadering van de individuele aansprak: hij leidde een recht op de eigen naam af uit een alomvattend rechtsbeginsel op menselijke waardigheid. ${ }^{38}$ Het bestaan van dat rechtsbeginsel met daaruit voortvloeiend het recht op de eigen naam in de EG-rechtsorde rechtvaardigdle Jacobs aan de hand van het EVRM en het IVBPR, die volgens Jacobs ieder op hun eigen wijze een specifieke betekenis hebben in de EG-rechtsorde. Als norm van hoger recht kan hier 'menselijke waardigheid" worden aangewezen, waaruit een nadere concretisering, namelijk een recht op de eigen naam voortwloeit. Jacobs hanteert een rechtsanalogie vanwege het feit dat hij niet aanknoopt bij een recht wit het EG-Verdrag.

Het beginsel van menselijke waardigheid bevindt zich als een gemeenschappelijk beginsel in de constitutionele tradities van de Lid-Staten. ${ }^{39}$ Hoewel A-G Jacobs niet alle constitutionele tradities op dit terrein citeert, is hij evenwel van mening dat dat rechtsbeginsel ook in die stelsels bestaat waarin het niet expliciet is uitgesproken in constitutie of rechtspraak:

'A person's right to his name is fundamental in every sense of the word. After all, what are we without a name? It is our name that distinguishes each of us from the rest of humanity. It is our name that gives us a sense of identity, dignity and self-esteem. To strip a person of his rightiul name is the ultimate degradation [...]."

Vraag is vervolgens in hoeverre een aanspraak op een keuze van een naam onder het recht op menselijke waardigheid wordt anvaard. Jacobs stelt dat het om een subjectief recht gaat en rechtvaardigt dat aan de hand van een retorische vraag, die nauwelijks kan leiden tot een andere vaststelling dan dat het recht op een naam bestaansrecht heeft onder het recht op menselijke waardigheid. Hij putte daarnaast uit verschillende rechts-

36 C/mristos Konstantindis t. Stadt Altensteig, zaak C-168/91 (1993), Jur, p. 1.1191 (1993); zie ook Lawson 1994, p $395-412$ en Schermers $1994,0.267-275$.

37 De herschrijving wan de Griekse naam van de klager voor de Duitse rechter vond plaats in het kader van een strikte toepassing wan een nationale $1 \mathrm{SO}$-standaard.

38 Opinie van A-G Jacobs bij Konstantintis, zaak C-168/91 van 9 december 1992, par. 24.

39 Opinie A.G. Jacobs bij Konstantinidis, par. 37.

40 Opinie A.G. Jacobs bij Konsiantinidis, par. 40. 
bronnen, waaronder een rechtsvergelijkend onderzoek en onderzoek naar de rechtspraak van het EHRM. ${ }^{41}$ Tevens werden andere internationale verdragen als rechtsbron angehaald; uit het IVBPR stond in het bijzonder Art. 24 lid 2 model, hetgeen een recht van het kind op een naam omvat en uit het de Amerikaanse Conventie voor de Rechten van de Mens werd het concrete recht op de naam van het individu overgenomen. ${ }^{42}$ De Gemeenschap heef zich niet formeel aan het IVBPR verbonden, maar al wel eerder is betekenis toegekend aan dit verdrag in de zaak Orkem. ${ }^{43} \mathrm{~A}-\mathrm{G}$ Darmon had het Hof reeds eerder al gewezen op de betekenis van het IVBPR als één van de bronnen van het EG-recht. ${ }^{44}$ Het feit dat het Hof het IVBPR - meer in het bijzonder Art. 14 lid 3 sub g reeds in Orkem tot rechtsbron had verheven kon, afgaand op de redenering van Jacobs, in dit geval toepassing van een ander recht uit het IVBPR rechtvaardigen.

De aanhaling van de Amerikaanse Conventie voor de Rechten van de Mens lag minder voor de hand. De laatste diende waarschijnlijk de universaliteit van het belang van het recht op de eigen naam te onderstrepen. De opmerkingen van de A-G geven een overzicht van de normen, die kunnen worden beschouwd als bronnen voor de argumenten voor het vestigen van een nieuwe norm. Ook bronnen, waartoe de Gemeenschap zich niet verbonden heeft, worden ingeroepen om de alomgeldendheid ervan te onderstrepen teneinde het draagvlak voor het bestaan van een nieuwe norm te vergroten. De verwevenheid van de verschillende bronnen wordt op deze manier benadrukt. Dat die toevoegingen uit andere Verdragen in de rechtspraak plaatsvinden is heel wel mogelijk, aldus A-G Darmon bij de zaak Orkem, omdat het Hof nimmer heeft besloten tot een uitputtende lijst van internationaal-rechtelijke rechtsbronnen. ${ }^{45}$ Het feit dat één LidStaat het IVBPR toentertijd nog niet had ondertekend staat volgems Darmon niet in de weg aan het toevoegen van dit instrument aan de bronnen van EG-recht. Het Hof liet zich in Orkem overigens niet uit over het aantal Lid-Staten dat een bron moet hebben erkend, voordat de bron van betekenis kan zijn voor de communautaire rechtsorde.

Het Hof kwam echter niet toe aan de vraag, in hoeverre de nieuwe spelling in overeenstemming is met het door Jacobs voorgestelde normenkader van EG-recht: zij voldoet reeds niet aan eisen van een EG-Verdragsbepaling. Deze casus biedt een voorbeeld van de subsidiariteit van de analoge redeneermethode ten opzichte van technisch-juridische methoden. Indien interpretatie van een regel uit het EG-Verdrag mogelijk is, zal het Hof waarschijnlijk eerst uit dat kader een toepasselijke rechtsregel putten. ${ }^{46}$

41 Opinie A.G. Jacobs bij Konstantinidis, par. 35 tot en met 39.

42. Art. 18. Amerikaanse Conventie van de Rechten van de Mens luidt: "Every person has the right to a given name and to the surnames of his parents or that of one of them. [...]", zie Van Dijk, Flinterman en Janssen 1998, p. 224.

43 Zaak 374/87, Orkem t. Commissie (1989), Jur. p. 3283 (1989), par. 31. In Orkem werd daarnaast Art. 6 EVRM inhoudende het recht op vooronderstelling van onschuld en meer in het bijzonder het verbod van zelf-incriminatie aangehaald in werband met de onderzoeksbewoegdheden van de Commissie in het kader van Art. 81 ( 85 oud) EG-Verdrag.

44 Opinie A-G Darmon bij Orkem t. Commissie van 18 mei 1989, parr. 126.

45 Opinie A-G Darmon bij Orkem t. Commissie van 18 mei 1989, par. 127

46 Zo ook Flynn 1997, p. 383. 


\subsubsection{Erkenning wan de transseksuele en homoseksuele identiteit}

Art. $141 \mathrm{EG}-$ Verdrag is voor individuen in het recente verleden verschillende keren aanleiding geweest, om een ruime notie van gèlijke behandeling van mannen en vrouwen ter zake van beloning en in arbeidsverhoudingen te claimen. ${ }^{47}$ Het Hof is steeds terughoudend geweest met het erkennen van een extensieve interpretatie - buiten de context van arbeidsrechtelijke verhoudingen - van Art. 141 EG-Verdrag, al is een enkele uitzondering die duidt op een ruimere benadering van gelijke behandelingskwestie opgespoord. In P I. S en Cornwall County aanvaardde het Hof aan de hand van een analoge redenering een ruime strekking van Art. $141 \mathrm{EG}-$ Verdrag. ${ }^{48}$ De individuele aanspraak behelsde gelijke behandeling van de nieuwe geslachtelijke identiteit na het ondergaan wan een geslachtsveranderende operatie. Vraag was in hoeverre een richtlijn, die het beginsel van gelijke behandeling van mannen en vrouwen ter zake van arbeid en beloning ex Art. 141 implementeert, van toepassing was op een individuele aanspraak van een klager die was ontslagen op grond van de geslachtsveranderende operaties. ${ }^{49}$ De extensieve interpretatie van Art. 141 EG-Verdrag werd in dat kader gebaseerd op een individueelrechtelijke notie van gelijkheid van mannen en vrouwen, die niet expliciet in Art. 141 is terug te vinden. Het gelijkheidsbeginsel ter zake van beloning van mannen en vrouwen, een constituerende EG-Verdragsnorm die is gepositiveerd in Art. 141 EG-Verdrag, werd in $P t . S$ geïnterpreteerd tegen de achtergrond van een norm van hoger reclit van menselijke waardigheid:

'To tolerate such discrimination would be tantamount, as regards such a person, to a failure to respect the dignity and freedom to which he or she is entitled, and which the Court has a duty to safeguard." so

Ter ondersteuning van de opvatting, dat het in casu om een gelijkheidsbeginsel met fundamenteelrechtelijk karakter ging stelde het Hof:

'Moreover, as the Court has repeatedly held, the right not to be discriminated against on grounds of sex is one of the fundamental human rights whose observance the Court has a duty to ensure $[\ldots . . .51$.

Het Hof baseerde zich voor de rechtvaardiging van deze fundamenteelrechtelijke benadering van Art. 141 EG-Verdrag op Defrenne t. Sabena en Razzouk en Beydoun t. Commissie. ${ }^{52}$ Voor de analogie is het interessant te bekijken welke aspecten uit De-

47 Zie voor een overzicht en verwijzingen Craig en De Búrç 1998, met name hoofdstuk 19.

48 P t. S en Cornwall County, zaak C-13/94 (1996), Jur. P. I-2143 (1996). Zie voor verwijzingen en bespreking van de uitspraak onder meer Campbell en Lardy 1996, p. 412-418, Craig en De Búrca 1998, p. 333 te. ., Canor 2000 , p. 269 en Flynn 1997, p. 367-387.

49 Richtlijn vain de Rad van 9 februari 1976 ter zake van de inplementatie van het beginsel van gelijke behandeling van mannen en yrouwen in werband met toegang tot werkgelegenheid, opleidingen, promotie en werkomstandigheden (76/207 EEG), Pb 1976, Nr. L 39/40. Deze richtijn is cen concretisering

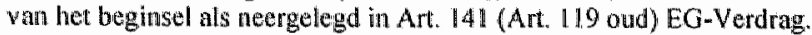

50 Pt. S, zaak C-13/94, par. 22

51 Pl. S, zaak C-13/94, par. 19.

52 Defreme A. Sabena, zaak $149 / 77$ (1978), Jur. p. 1365 (1978) en Razzouk en Beydoum t. Commissie, gevoegde zaken 75 en $117 / 82$ (1984), Jur.p. 1509 (1984). 
frenne en Razzouk het Hof voor die fundamenteelrechtelijke benadering precies relevant acht. Defrenne klaagde over het feit dat het contract van vrouwelijke werknemers bij het bereiken van de veertigjarige leeftijd niet werd verlengd. Deze regel gold niet voor mannelijke werknemers, hetgeen naar national recht was geoorloofd. Dat laatste vormde nu volgens Defrenne een inbreuk op Art. 141. De prejudiciele vraag luidde, in welke mate Art. 141 extensief kon worden geìnterpreteerd - aanspraak op een eis van algemene gelijkheid ter zake van werkomstandigheden - zodat de aanspraak van Defrenne onder het beschermingsregime zou vallen van het discriminatieverbod ex Art. 141. Leeftijdsdiscriminatie tussen mannen en vrouwen was tot dusverre niet erkend als één van de gronden voor toepassing van Art. 141. In de optiek die Defrenne woorstelde, werd aangeknoopt bij een norm van hoger recht die ten grondslag ligt aan Art. 141. Die norm houdt een algemeen discriminatieverbod ter zake van mannen en vrouwen in werkomstandigheden in. Art. 141 EG-Verdrag is, aldus klaagster, slechts één van de uitingen van dat beginsel.

Het Hof koos in Defrenne niet voor deze analoge benadering maar voor hantering van een systematische benadering van Art. 141. Artt. 136 en 137 (Artt. 117 en 118 oud) werden in een contextuele benadering gelezen. Het Hof concludeerde uit de systematiek van het sociale hoofdstuk van het EG-Verdrag dat het programmatische karakter van Artt. 136 en 137 in de weg stond aan extensieve interpretatie. ${ }^{53}$ De discretie van de Lid-Staten op dit terrein diende te worden gerespecteerd, en de gekozen uitleg leidde in dit verband tot een afwijzing van de door Defrenne voorgestelde toepassing van de norm van hoger recht door het Hof.

In Defrenne is echter, naast de vaststelling van de strekking en reikwijdte van Art. 141 door het Hof op een ander vlak een analoge redenering te herkennen. De uitkomst daarvan was van groot belang voor de redenering in $P$ t. S. Het Hof aanvaardde in Defreme namelijk dat het Gemeenschapsrecht inderdaad een abstracte norm van hoger recht, inhoudende verbod van onderscheid op grond van geslacht kent:

"The Court has repeatedly stated that respect for fundamental personal human rights is one of the general principles of law, the observance of which it has a duty to ensure'. 54

In Defrenne had deze observatie echter geen gevolg voor de aanspraak van de klaagster, omdat her zijn werking enkel deed gevoelen in rechtsrelaties tussen individuen en gemeenschapsinstellingen, aldus het Hof in die zaak. ${ }^{55}$ De opmerking verkreeg in dit verband eerder het karakter van een obiter dictum, dat in het kader van $P$ t. $S$ aanknopingspunten voor een extensieve uitleg van Art. 141 kon rechtvaardigen.

55 Sabbatini t. Europees Parlement, zaak 20/71, (1972), Jur. p. 345 (1972) en Airola t. Commissie, zaak $21 / 74$ (1975), Jur. 221 (1975) en Razzouk en Beydoun t. Commissie, gevoegde zaken 75 en $1 \| 7 / 82$ (1984), Jur. p. 1509 (1984). Zie Defrenne, zalak 149/77, par. $29-30$. 
Een zuiver EG-Verdragsrechtelijke benadering als in Konstantinidis van een EG-Verdragsbepaling werd in P t. S achterwege gelaten bij de formulering van de toepasselijke regel voor de kwalificatie van de individuele aanspraak. Het Hof richtte zich voor de invulling wan een aanspraak op geslachtelijke identiteit op de fundamenteel rechtelijke benadering die het EHRM had gehanteerd in Rees 1. Verenigd Koninkrijk:

"The term "transsexual" is usually applied to those who, whilst belonging physically to one sex, feel convinced that they belong to the other; they often seek to achieve a more integrated, unambiguous identity by undergoing medical treatment and surgical operations to adapt their physical characteristics to their psychological nature. Transsexuals who have been operated upon thus form a fairly well defined and identifiable group'. ${ }^{56}$

De fundamenteelrechtelijke benadering van het gelijkheidsbeginsel leidde tot een $a b$ stracte formulering van de oorspronkelijk enger geformuleerde eis, dat mannen en vrouwen gelijkelijk dienen te worden beloond voor gelijke arbeid. ${ }^{57}$ Daaropvolgend rees de vraag, in hoeverre erkenning van de aanspraak betreffende het ontslag wegens geslachtsveranderende operaties terecht was onder Art. 141. Het Hof stelde vast, dat het onderscheid een direct gevolg was van discriminatie naar geslacht. Het Hof knoopte voor deze benadering aan bij Art. 3 lid 1 van Richtlijn 76/207:

\footnotetext{
"Application of the principle of equal treatment means that there shall be no discrimination whatsoever on grounds of sex in the conditions, including selection criteria, for access to all jobs or posts, whatever the sector or branch of activity, and to all levels of the occupational hierarchy". 58
}

Het Hof voegde hieraan toe dat discriminatie van transseksuelen ontoelaatbatr was in het licht van het recht op menselijke waardigheid waarop ook deze personen een geldige aanspraak hebben die het Hof dient te waarborgen. In de literatuur rees de vraag hoe discriminatie naar geslacht in deze casus diende te worden beoordeeld: in hoeverre hing het ontslag samen met de operatie, of met het feit dat $\mathrm{P}$ een operatie ondergaan had en vrouw was geworden $?^{59}$ Zouden vrouwen die na een operatie als man door het leven gaan, meer moeilijkheden ondervinden? Verdedigd had kunnen worden dat de aanspraak in casu niet handelde over onderscheidenlijk handelen ten aanzien van mannen en vrouwen, maar ten aanzien van transseksuelen en niet-uransseksuelen. Het hangt ervan af waarop in de vergelijking de nadruk wordt aangebracht, al dient deze well te passen in het door Verdrag en Richtlijn gegeven kader. Een meer abstracte benadering van gelijkheid zoals die in casu werd aanvaard door het Hof \iet ruimte voor kwalificatie van P's aanspraak onder het recht op gelijke behandeling van mannen en vrouwen. Het Hof koos voor de laatste benadering, waarin het maken van onderscheid dat op welke wijze dan ook is gerelateerd aan de sekse, wordt afgewezen.

56 Reest Ferenigd Koninkmij, EHRM 17 oktober 1986, Serie A vol. 106, par. 38.

57 Die eis is neergelegd in Richtijn van de Raad 76/207 wan 9 februari 1976 ter zake van de implementatie van het beginsel wan gelijke behandeling voor mannen en vrowwen voor wat betreft de toegang tot arbeid, opteidingen en promotie en werkomstandigheden (Pb 1976, L 39, p. 40). Deze richtijn werd in Pt. Sigemterpritieerd.

58 In de hier gecursiveerde tormullering zag het Hof aanteiding de aanspraak onder het gelijkheidsbeginsel te kwalificeren (Defrenne, zaak 149/77, par. 21).

59 Zite onder meer Flynn 1997, p. 373 e.v. Canor 2000, p. 277 Campbell en Lardy 1996, p. 413. 
Het Hof werd echter al gauw gedwongen tot een principiele standpuntbepaling, immers: bij een dergelijk abstracte benadering door het Hof van het gelijkheidsbeginsel ex. Art. 141 kon immers spoedig worden verwacht, dat ook klachten van individuen over discriminatie wegens bijvoorbeeld seksuele voorkeur bij het Hof terecht zouden komen. ${ }^{60}$ A-G Tesauro had in zijn opinie bij $P$ t. S en Cornwall County extensieve interpretatie bepleit van Art. 141. maar tegelijkertijd benadrukt dat de bedreigde groep van transseksuelen een kleine en zeer bepaalbare groep individuen is die mogelijk hinder ondervindt. ${ }^{61}$ In $P$ t. S en Cornwall Coumb erkende en honoreerde het Hof de individuele aanspraak op gelijke behandeling ex Art. 141. Vanwege het feit dat hier invulling van een richtlijn op basis van Art. 141 plaatsvond, wordt hier gesproken van een wetsanalogie. De norm van hoger recht is in dit verband de notie van "dignity and freedom', hier vertaald als menselijke waardigheid, ten aanzien waarvan het Hof de plicht heeft deze te beschermen.

In Grant t. Sout-West Traims Ltd. beoordeelde het Hof in hoeverre een seksuele voorkeur werd beschermd door Art. 141 EG-Verdrag; de uitspraak in $P$ t. $S$ had hoge verwachtingen gewekt. ${ }^{62}$ In Grant werd een beroep gedaan op Art. 141 EG-Verdrag; klaagster achtte een recht op gelijke behandeling van mannen en vrouwen in werkgerelateerde verhoudingen geschonden omdat haar werkgever weigerde, voordelen toe te kennen aan de partner die van hetzelfde geslacht was als klaagster. Deze voordelen werden in beginsel wel toegekend aan de gehuwde of samenwonende partner van de werknemer. De nationale rechter vroeg het Hof in dat verband om uitleg van Art. 141: in hoeverre bood dat aanknopingspunten voor rechtsbescherming aan de aanspraak van klaagster? Het Hof bleek niet bereid Grants aanspraak te kwalificeren onder het gelijkheidsbeginsel. Het handhaafde in dit verband het gellikheidsbeginsel in enge zin, dat wil zeggen onder discriminatie tussen werknemers naar geslacht. ${ }^{63}$

Een beroep op $P$ t. $S$ slaagde niet: daar ging het om geslachtswerandering, die een aanleiding vormde voor ongelijke behandeling, terwijl in Grant seksuele voorkeur de grond was yoor ongelijke behandeling. Seksuele identiteit en seksuele voorkeur zijn in de optiek van het Hof geen vergelijkbare aanspraken onder Art. 141. Het Hof versmalde aldus zijn opvatting over de reikwijdte van Art. 141 van ruim in $P$ t. $S$ naar eng in Grant. ${ }^{64}$ Vergelijkbaarheid van de individuele aanspraken was in dit verband eveneens te verdedigen: erkenning van zowel seksuele identiteit als seksuele voorkeur maken

60 Dat duurde ook niet lang, zie Grant t. Sowh-West Trains Lid, zaak C-249/96 (1998), Jur. p. I-621 (1998).

6ll Opinie van A-G Tesauro bij P t. S en Cormall County Council, zaak C-13/94 van 14 december 1905 , par. 9.

62 Campbell en Lardy 1996,p.417: "The decision of the Court [...] represents a major breaktlinough for all those campaigning for an improvement in the legal status of transsexuals. [...] If toleratimg discrimination against a transsexual person would be a "fallure to respect the dignity and freedom lo which he or she is entitled", then to permit diserimination against someone on the grounds that he or she is gay or lesbian must surety also represent such a failure of respect."

63 Grant t. South-West Trains, zaak C-249/96, par. 28.

64 Zeer kritisch hierover De Werd in zijn noot bij Gran, JB $1998 / 109$. 
allebel deel uit van het recht op menselijke waardigheid, zo zou kunnen worden verdedigd: Het Hof gaf echter de voorkeur aan de meer specifieke benadering waardoor een recht op seksuele voorkeur niet kon gelden als basis voor aanspraken op gelijkheid. Vragg is waarom aan de specifieke benadering de voorkeur werd gegeven. Deze zou kunnen worden verklaard uit de weigering om aan de soevereine Lid-Staten een positieve verplichting op te leggen, aanspraken op seksuele voorkeur te moeten honoreren. Het verband tussen het rechtskader van de $E G$ en de individuele aanspraak werd in dit verband wellicht niet aanwezig geacht.

Vormen $P$ t. S en Grant voor de kwalificatie van de individuele aanspraak onder Art. 141 nu elkaars complement, of is hier juist sprake van inconsistente interpretatie van Art. $141 ?^{65}$ In $P$ t. $S$ werd een fundamenteelrechtelijke invulling gegeven met behulp van het rechtsbeginsel van menselijke waardigheid; in Grant een EG-rechtelijke invulling zónder aanvullende interpretatie van menselijke waardigheid. Hantering van de norm van hoger recht uit $P$ t. S en Cornwall County zou in Grant wellicht hebben kunnen leiden tot het scheppen van een precedent dat op weerstand zou stuiten in de LidStaten. Afgezien van het feit dat een gelijkstelling van homoseksuele met heteroseksuele paren niet aanvaardbaar is in verschillende Lid-Staten, zou deze gelijkstelling eveneens verstrekkende consequenties hebben op verschillende terreinen wan wetgeving. ${ }^{65}$ De afwijzing van de analogie met $P$ t. $S$. is in dit verband aldus ingegeven door de constitutionele verhouding tussen rechter en nationale wetgevers. De consequenties van de interpretatie in $P t . S$ waren daarentegen veel minder ingrijpend, zoals A-G Tesauro en Hof daarover opmerkten. ${ }^{67}$ Tégen het standpunt van het Hof, dat 'geslachtsverandering" wel en "seksuele voorkeur" niet onder Art. 141 EG-Verdrag kon worden gekwalificeerd kan worden aangevoerd dat beide kenmerken of gronden voor ongelijke behandeling in ieder geval worden beschermd door het rechtsbeginsel van menselijke waardigheid.

De motivering van de gevolgde redenering werd met name gebaseerd op uitspraken van de Europese Commissie voor de Rechten van de Mens in het kader van een recht op familie- en gezinsleven ex Art. 8. Het EHRM had op dat moment reeds erkend dat een recht op seksuele voorkeur een aspect is dat Art. 8 EVRM beoogt te beschermen, maar heeft daaraan tot op heden geen positieve verplichtingen van de staat aan verbonden. ${ }^{6 \%}$ In vergelijkbare zaken betekent dat, dat het EHRM de indivuele aanspraak op een recht op seksuele voorkeur onder Art. 8 EVRM wel zal erkenmen, maar niet zal honoreren. ${ }^{6}$ In de meeste gevallen beroept het EHRM zich in de toetsingsfase op af-

65 Flynn 1997, p. 367-387.

66 Canor 2000 , par. $2.2 \mathrm{ev}$.

67 A-G EImer pleitte in zijn opinie bij Grant eveneens voor en extensieve interpretatie van Art. 141 EGVerdrag aan de hand wan hell rechtsbeginsel human dignity. Hij nam daarbij de redenering van het Hof in $P$ t. $S$ als uitgangspunt (Opinie van A-G Elmer bij Grant t. South-West Trains, zaak C-249/96.

68 De door het Luxemburgse Hof aangehaalde uitspraken behelzen allen individuele aanspzaken waarin de Conmissie beoordeelde of ter zake van de aanspraak in de familierechtelijke context positieve verplichtingen voor de staat bestonden.

69 Zie par. 8.3 .2 
wezigheid van een consensus hierover in de staten die lid zijn bij het EVRM: In casu werd de aanspraak door het Hof te Luxemburg niet erkend en werd aan de wraag over honorering niet toegekomen.

Recentelijk werd in D. $t$. Raad geklaagd over het achterwege laten door de Raad van kostwinnerstoelage wanneer de partner van hetzelfde geslacht is. ${ }^{70}$ In dat verband diende het Hof het statuut ter zake van de begrippen "gehuwde ambtenaar" en "echtgenoot" uit het ambtenarenstatuut te interpreteren: klager had zijn relatie in de vorm van een partnerschapsregistratie gevestigd die in het land van herkomst geldt als gelijkwaardig aan de huwelijkse staat. Naar het oordeel van het Hof is er wel een gemeenschappelijke trend te onderkennen, maar kan nog niet worden gesproken van een gemeenschappelijke erkenning van het partnerschap als huwelijkse staat. Een abstracter benadering wan het gelijkheidsbeginsel ex Art. 141 EG-Verdrag met inspiratie uit een recht op menselijke waardigheid als norm van hoger recht werd door het Hof niet aangenomen. Deze zou gelijkstelling van partners van werknemers onder het kostwimnersbeginsel kunnen rechtvaardigen, waarmee de vraag naar vergelijkbaarheid - zoals in $P$ t. S. vermeden had kunnen worden. De analoge redenering werd in dit geval afgewezen op gronden van afwezigheid van consensus.

Op het terrein van het recht op persoonlijkheid is slechts een klein aantal uitspraken aangetroffen waarin het Hof een rechtsanaloge redenering heeft gehanteerd, of waarin het werd geconfronteerd met een voorstel tot extensieve interpretatie of positivering van nieuwe normen. De analogie is van constituerend karakter gebleken voor de vestiging van fundamentele recht als rechtsnorm van EG-recht. Analogieèn zijn vooral ook gehanteerd ter zake van vaststelling van de institutionele verhoudingen in horizontale en verticale zin. Een kleine excursie naar een fraai voorbeeld op het terrein van de verticale machtenscheiding is dat van 'wederzijdse verplichting tot behoorlijke samenwerking". "Het Hof leidde uit Art. 10 EG-Verdrag ten aanzien van de Lid-Staten een ruimhartige verplichting tot samenwerking met de Instellingen af, ${ }^{72}$ hetgeen niet vreemd is aan de tekst van het EG-Verdrag op dit punt. Het Hof vestigde omgekeend vanuit Art. 10 EG-Verdrag eveneens een verplichting van de Gemeenschapsinstellingen, zich coöperatief op te stellen naar de Lid-Staten. Een dergelijke verplichting volgt echter niet direct uit de tekst van Art. 10 EG-Verdrag; voor de rechtvaardiging van deze lezing van Art. 10 was een analogie noodzakelijk. De wederzijdse verplichting werd door het Hof al opgemerkt in Luxemburg $t$. Parlemem. In deze zaak werd door de Luxemburgse regering geklaagd over een Resolutie van het Europees Parlement, waarin het Europees Parlement had besloten de zetel voor de vergaderingen van het Parlement te verplaatsen van Luxemburg naar Straatsburg. De Lid-Staten hebben namelijk

70 D. t. Raad, gevoegde zaken C-122/99 en C-125/99 (2001), Jur. P. I-4319 (2001).

71 Zie eveneens De Witte 2000, p. 146 en Mortelmans 1998 , p. 67-88.

72 Art. 10 EG-Verdrag luidt: 'De Lid-Staten treffen alle algemene of bijzondere maatregelen welke geschikt zijn om de nakoming van de uit dit werdrag of uit handelingen van de instelingen der Gemeen schap voortvloeiende verplichtingen te verzekeren. Zij vergemakkelijken de vervulling van haar taak. $Z \mathrm{ij}$ onthouden zich van alle maatregelen welke de verwezenlijking van de doelstellingen wan dit Verdrag in gevaar kunner brengen". 


\section{Hoofostuk 7}

de bevoegdheid de zetel van het Parlement te bepalen, maar het Parlement is omgekeerd bevoegd, ex Ant. 142 (oud) EG-Verdrag geschikte maatregelen te treffen om behoorlijk functioneren wan het orgaan te verzekeren. Teneinde de twee bevoegdheden op elkaar aan te laten sluiten, bestaat volgens het Hof een wederzijdse verplichting tot samenwerking. Het Hof stelde in een obiter dictum:

'Furthermore, the Partiament is authorized, [...] to adopt appropriate measures to ensure the due functioning and conduct of its proceedings. However, in accordance with the abovementioned mutual duties of sincere cooperation, the decisions of the Parliament in turn must have regard to the power of the governments of the Member States to determine the seat of the institutions and to the provisional decisions taken in the meantime". ${ }^{73}$

Voor de beslechting van het geschil voegde het obiter van wederzijdse verplichtingen geen nieuw gezichtspunt toe. ${ }^{74}$ Het zou echter later in Zwartveld het doorslaggevende argument blijken voor het Hof, de Commissie te dwingen tot samenwerking met de Lid-Staten. ${ }^{75}$ Zwartveld, die als rechter-commissaris betrokken was bij het onderzoek naar een beschuldiging van valsheid in geschrifte op het terrein van de Europese visserijmarkt, verzocht de Commissie om inzage van de inspectierapporten. De Commissie wees dit verzoek af met een beroep op het Protocol inzake privileges en immuniteiten van de Europese Gemeenschap. Het Hof verplichtte de Commissie echter tot medewerking, onder verwijzing naar verplichting tot samenwerking als neergelegd in Art. 10 EG-Verdrag. Dat wekte verwondering, omdat de tekst van die bepaling enkel wijst op de samenwerkingsverplichting van de Lid-Staten naar de Gemeenschapsinstellingen:

'That principle not only requires the Member States to take all the measures necessary to guarantee the application and effectiveness of Community law, $[\ldots]$ but also imposes on Member States and the Community institutions mutual duties of sincere cooperation" "

Het Hof baseert zich voor deze vaststelling uitsluitend op Luxemburg $t$. Parlement en Commissie t. Griekenland. ${ }^{77}$ Op basis van de wederzijdse verplichtingen interpreteerde het Hof in Zwartveld de relevante bepalingen in het Protocol ${ }_{4}$ warop de Commissie zich beriep, restrictief. ${ }^{78}$ In deze reeks van uitspraken is te zien hoe het Hof aan Ant. 10 via een wetsanaloge redenering een extensieve interpretatie geef. Norm van hoger recht in dit verband was het bestaan van een norm die dicteert, dat er wederzijdse regelen te treffen teneinde de toepassing en effectiviteit van EG-recht te verzekeren, zelfs indien dat betekent dat naar het aationale recht een strafrechteligke procedure dient te worden gestart. Deze witspraak wijst op de verplichting vin de Lid-Staat; Luxemburg t. Parlement wijst daarentegen op de verplichting van de instellingen.

78 'When analysed in the light of those principles, the privileges and immunities which the Protocol grants to the European Communities have a purely functional character [...]. The Protocol therefore does not permit the Community institutions to neglect the duty of sincere cooperation with the national atuhorities, and in particular the judicial authorities [.. . ]', Zwartweld, zaak C-2/88, par, 19-21. 
verplichtingen bestaan, en niet alleen verplichtingen van de Lid-Staten jegens de Instellingen van de Gemeenschap.

\subsection{Bevindingen}

Het Hof heeft het bestaan van een nieuwe toepasselijke rechtsnorm aanvaard die tot dusverre nog niet was gepositiveerd in Verdrag, lagere regelgeving of rechtspraak. De wijze waarop de zaken bij het Hof arriveerden vertoont een wisselend beeld: de klachten gebaseerd op de bevoegdheden van de Commissie inzake mededinging kwamen allen bij het Hof via de individuele klachtprocedure ex Art. 230, de zaken $P, t . S$, Grant en Konstantinidis werden in het kader van een prejudicielle procedure ex Art. 234 beoordeeld en twee geschillen speelden zich af in de arbeidsrechtelijke verhoudingen tussen individuen en Instellingen, namelijk $X t$. Commissie en D. $t$. Commissie. Een bijzonderheid is dat een Lid-Staat een beroep doet op een fundamenteelrechtelijke norm, maar verklaarbaar binnen de Verdragsrechtelijke verhoudingen waarin een grondrechtelijk kader voor de toetsing van handelingen ontbreekt. Het Hof was zeer kritisch over de door Duitsland ingeroepen rechtsnom; het Hof vermoedde achter de maatregel een ontoelaatbare importrestrictie.

\subsubsection{Ontwikkeling van de grondslag voor de normen van hoger recht}

De vraag naar de ontwikkeling van normen van hoger recht voor de positivering van nieuwe grondrechten is in verband met het EG-recht een vraag naar de erkenning van alle niet in het Verdrag genoemde fundamentele rechten. De basis voor de erkenning van grondrechten werd gelegd in de uitspraken Stauder, Internationale Handelsgesellschaft en Nold. De openingszet werd gegeven in het obiter in Stauder. Een obiter kan in beginsel niet een zelfstandige grondslag grondslag vormen voor positivering van een nieuwe norm. Kennelijk dragen zij soms een overtuigingskracht in zich die in latere jurisprudentie van pas kan komen. Er was opvallend vaak sprake van een rechtsanalogie, hetgeen samenhangt met het feit dat de individuele aanspraken in de onderzochte zaken niet konden worden ondergebracht onder één van de Verdragsrechten. In dat verband had het Hof ervoor kunnen kiezen, jurisdictie af te wijzen. Het koos echter voor een extensieve interpretatie van zijn mandaat ex Art. 220. Die keuze werd in belangrijke mate ingegeven door de steeds luidere kritiek in de Lid-Staten op het feit dat hun rechtsordes, de grondwet incluis, ondergeschikt werden geacht aan het Gemeenschapsrecht.

De rechtsbronnen die dienden ter legitimatie van rechtsbeginselen wan gemeenschapsrecht werden gebaseerd op gemeenschappelijke tradities in de Lid-Staten, het EVRM en andere internationaalrechtelijke bepalingen. Dat was retorisch gezien een handige keuze van het Hof: de bronnen boden de Lid-Staten vertrouwd materiaal, terwijl het Hof tegelijkertijd vanwege het vage karakter van de uit die bronnen woortvloeiende rechtsnormen niet gebonden was aan de door de Lid-Staten gegeven uitleg van de 'constitutionele tradities'. Het Hof achtte zich evenmin gebonden aan de uitleg die het EHRM geeft aan het EVRM; het ontleent er normen aan maar lijkt er in concreto een 
autonome invulling en toepassing van te geven. De verwijzing in Rutili naar EVRMrechtelijke normen, hoewel niet toegepast in Rutili, is in dit opzicht enigszins merkwaardig; het Hof aanvaardde de begrenzing zoals die is neergelegd in het EVRM - de rechtspraak laat nauwelijks zien dat de beperkingsmethodiek van het EVRM wordt gehanteerd. ${ }^{79}$ De grondslag waaruit de normen van hoger recht werden geput was van abstract karakter.

\subsubsection{Het recht op persoonlijheid: concretiseringen}

Onder het recht op persoonlijkheid werd allereerst het rechtsbeginsel op "privé-leven" met daaruit voortvloeiend onschendbaarheid van de woning, het recht op geheime correspondentie tussen advocaat en zijn onderneming en het recht op medische geheimhouding beschouwd. Het Hof typeert het recht op "prive-leven" als een rechtsbeginsel van gemeenschapsrecht, terwijl de specificeringen eruit worden aangemerkt als toepasselijke rechtsnormen. Het recht op de naam werd door de A-G voorgesteld als rechtsnorm, maar niet door het Hof aanvaard en kan mitsdien (nog) niet worden aanvaard als een door het Hof gepositiveerd recht. Tenslotte erkende het Hof een recht op transseksuele identiteit en de verplichting van Lid-Staten onder art. 141 EG-Verdrag. Seksuele identiteit en seksuele voorkeur worden aldus niet gelijkelijk onder Art. 14 \ bescherma.

In de onderzochte zaken heeft het Hof aldus een wisselende bereidheid getoond tot erkenning van de individuele aanspraken. ${ }^{80}$ In de zaak $X t$. Commissie bleek het Hof het sterkst een benadering ten faveure van de individuele rechtsbescherming te aanvaarden - niet alleen werd de aanspraak onder 'privé-leven' erkend; daarenboven aanvaardde het een ruime reikwijdte en een meer uitgewerkte toepassing van het recht in concreto. Dat had waarschijnlijk te maken met de aard van de partijen, die in een voor grondrechten meer gebruikelijke verhouding tegenover elkaar stonden en de aard van het geschil, dat niet één van de door het $\mathbb{E G}$-Verdrag geprioriteerde beleidsterreinen betrof. Het Hof behoefde geen rekening te houden met beleids- en beoordelingsruimte die vaak met geprioriteerde beleidsterreinen samenhangen. Dat speelde waarschijnlijk eerder wel een rol in de onderzochte mededingingszaken.

Het onderscheid in erkenning en uiteindelijke honorering is van belang voor verdere rechtsontwikkeling van grondrechtelijke aanspraken in verband met Gemeenschapsrecht. Het Hof lijkt, afhankelijk van het beleidsterrein waar het geschil zich voordoet en aanwezigheid van consensus over het onderwerp in de Lid-Staten, bereid te zijn tot erkenning van indiwiduele aanspraken. Het gaat echter niet gauw over tot honorering van de aanspraken. Het onderzoek naar honorering van de individuele aanspraak vindt plats in de toetsingsfase: hierin wordt de rechtsregel in concreto toegepast. Een uit-

79 In een recente zak lijkt de bereidheid om de beperkingsmethodiek van de Artt. 8 tot en met 11 lid 2 EVRM wel anwezig (Connolb $t$. Commissie, zaak C-274/00, HwJ EG 21 maart 2001).

80 Expliciete erkenning van de itudividuele aanspraak vond plats in Panasonic t. Commissie, AMaS 1 . Conmissie, Commisste t. Duitsland, $X$ t. Commissie en $P$ t. S en Commall Commy. In de overige zaken werd de individuele aansprank niet erkend. 
gewerkt toetsingskader van grondrechtelijke aanspraken ontbreekt tot dusverre, hetgeen tot op grote hoogte samenhangt met afwezigheid van een grondrechtelijk toetsingskader in het EG-Verdrag.

\subsubsection{De analoge redenering}

De formulering van "individuele rechten als rechtsbeginselen van communautair recht" bleken voor het Hof een nuttig instrument bij de beoordeling van de individuele aanspraken: rechtsbeginselen bieden het Hof mogelijkheden om te laveren tussen enerzijds de kritiek uit de Lid-Staten op handelingen van de Instellingen vanwege ondergeschiktheid van de nationale grondrechten aan EG-recht dat een dergelijk normenkader ontbeerde, en anderzijds de weigerachtigheid van de dezelfde Lid-Staten te komen tot een bindende lijst van fundamentele rechten. Ook dicteren de verdragsdoelstellingen andere prioriteiten - grondrechten maken daarvan vooralsnog geen deel uit. Deze situatie geeft deels een invulling aan de constitutionele verhouding waarmee het Hof rekening moet houden. Het positiveren van rechts'regels' op het terrein van het recht op persoonlijkheid door het Hof zou in dit verband minder voor de hand hebben gelegen. Rechtsbeginselen lijken in beginsel een grotere flexibiliteit in zich te dragen dan rechtsregels. Rechtsregels dicteren in beginsel rechtsgevolgen. Rechtsbeginselen zijn niet direct inroepbaar en afdwingbaar; de rechter dient ze eerst to concretiseren voordat zij toepassing kunnen verkrijgen. Nu valt daarover in het licht van de onderzochte rechtspraak te twisten: het recht op 'privé-leven' is niet dermate abstract van aard dat het steeds nader geconcretiseerd dient te worden. Gesteld kan worden, dat het Hof het recht op 'privé-leven' in enkele gevallen toepaste als rechtsregel, terwijl het steevast bleef spreken over een beginsel van gemeenschapsrecht. Hetzelfde geldt woor het recht op medische geheimhouding en de erkenning van de geslachtelijke identiteit.

Er was in wisselende mate sprake van wets- en rechtsanalogieën. Van de onderzochte zaken lijken soms beide karakteriseringen te kunnen worden gegeven. Een wetsanalogie was aan de orde, wanneer het Hof de reikwijdte van een Verdragsbepaling of een bepaling van secundair recht uitlegde aan de hand wan een ongeschreven grondrechtsnorm. Omdat het nauwelijks ging over de uitleg van een grondrechtelijke aanspraak die kent het EG-Verdrag niet - werd bijna steeds gesproken over rechtsanalogieën. Een wetsanalogie deed zich in de andere stelsels voor wanneer de rechter een analogie hanteert om de reikwijdte van een aan het recht op persoonlijkheid gelieerde rechtsnorm vast te stellen. Nu kan bijvoorbeeld worden gesteld, dat het recht op medische zelfbeschikking als in Commissie t. Duitsland een invulling geeft aan een recht op persoonlijkheid, namelijk de in Art. 30 neergelegde derogatie ter zake van gezondheid en het leven van het individu. In de mededingingszaken en de aanstellingszaak $X t$. Commissie bleek een dergelijke norm die nader moest worden ingevuld niet aranwezig, en lijkt eerder sprake van een rechtsanalogie. De zaken over de seksuele identiteit en de seksuele voorkeur kunnen worden getypeerd als wetsanalogieën: het Hof legde Art. 141 uit aan de hand van menselijke waardigheid in $P$. $t . S$.

Teneinde het bestaan van een algemeen rechtsbeginsel van Gemeenschapsrecht te rechtvaardigen hanteerde het $H$ of steeds een abstracte norm van hoger recht. De grond- 
slag werd gevormd door gemeenschappelijke constitutionele tradities van de LidStaten, rechtsnormen uit het EVRM en andere internationale verdragen. In de periode na Nold werd aan de hand van deze grondslag het ene nat het andere grondrecht gepositiveerd als rechtsbeginsel wan gemeenschapsrecht. Meestentijds vormden de normen uit het EVRM de grondslag voor de erkenning. Aan het IVBPR, dat eveneens belangrijke waarborgen op het terrein van fundamentele rechten vastlegt, werden minder vaak normen ontleend. Waar het kon zocht het Hof aansluiting bij het EVRM. In enkele gevallen werd het IVBPR tot uitgangspunt verheven, met name in die gevallen waarin het gezochte beginsel niet was geexpliciteerd in het EVRM. ${ }^{81}$ Ook het ESH heeft gediend als bron van recht. Zodra erkenning wan het recht in de jurisprudentie werd anwaard, greep het Hof in een volgende casus terug op zijn eigen rechtspraak. ${ }^{82}$ Op die wijze verkrijgen de gepositiveerde normen gelding in het EG-recht. ${ }^{83}$

Slechts in twee casusposities - Hoechst $t$. Commissie en Grant $t$. South-West Trains kon worden waargenomen dat het Hof een specifieke vergelijkingsmaatstaf hanteerde en dat een analogie met het vergelijkingsmateriaal werd afgewezen. De vergelijkingen op meer concreet niveau leidden tot een ontkoppeling van de gevonden normen in het vergelijkingsmateriaal enerzijds en de ingeroepen norm in de individuele aanspraak anderzijds. In Hoechst werd die ontkoppeling tot stand gebracht met een rechtsvergelijking, terwijl in Gront de ontkoppeling tot stand kwam door het recht op seksuele identiteit enerzijds en het recht op seksuele voorkeur anderzijds niet te beschouwen onder een recht op menselijke waardigheid. In de opinies werd enkele keren een abstracte maatstaf voor de behandeling van het vergelijkingsmateriaal en de aanspraak in het voorliggende geschil voorgesteld; deze maakte het mogelijk om nieuwe individuele aanspraken via rechts- of wetsanalogie te positiveren. Het Hof volgde die voorstelling van zaken niet wanneer er dichter bij het Verdrag liggende mogelijkheden waren om het geschil op te lossen.

\subsubsection{Terwinologie}

Hierboven zijn het recht op "privé-leven", het recht op inedische geheimhouding en het recht op seksuele identiteit getypeerd als rechtsnormen die deel uitmaken van het Gemeenschapsrecht als rechtsbeginsel. De typering van het Hof als rechtsbeginsel kan worden verklaard vanuit het vermoeden, dat dit het Hof wat meer ruimte oplevert voor

81 Zle Orkem 1 . Commissie, zaak $374 / 87$, par. 31 waarin een verbod op zell-incriminatie door het Hof werd erkend; in het EVRM was die norm op dat moment nog niet gepositiveerd. Ook in Defreme t. Sabena. zaak 149/77 werden normen aau het ESH en uit Conventie 111 van de Internationale Arbeids Orgamiatie ontleend. Alle Lid-Staten hebben het IVBPR geratificeerd, maar niet duidelijk is welke status het ESH in de Lidl-Staten had op het moment van de uitspraak van Defreme; dat blijkt althans niet nittrukkel ijk in de uitsprak.

82 Zle bijvoorbeeld $X$ t Commissie, waar ter zake van het recht op medische zelfbeschikking werc verwezen narar Commissie t. Duitsiland.

83 Zle ook de zaken Panasomic en Hoechst, waarin werd verwezen voor het bestaan van een recht op "privé-leven" naar Nold voor het normenkader waaraan dat recht werd ontleend. Daama werd het bestam van die nom in Commissie t. Duitsland an $X$. Commissie bevestigd. 
erkenning van individuele aanspraken ${ }^{84}$ Rechtsbeginselen vragen in het algemeen een nadere concretisering, terwijl in een rechtsregel wel operatoren aanwezig zijn yoor toepassing in concreto. In de toepassing van rechtsbeginselen bestaat aldus een beoordelingsruimte voor de rechter, terwijl van daarvan bij rechtsregels minder snel sprake is. Afgewacht dient te worden hoe de invulling van toepasselijke rechtsnormen zal plaatsvinden, wanneer het Handvest bindende werking verkrijgt: het Hof heeft dan te maken met rechtsregels en een toetsingsmethodiek die bij deze rechtsnormen is vastgelegd. 


\section{Hoofdstuk 8}

\section{Analoge rechtsvinding in de jurisprudentie van het Europese Hof voor de Rechten van de Mens}

\subsection{Inleiding}

Wanneer het EHRM overgaat in de rechtsvinding tot het hanteren van een wetsanalogie, zal hij voor de oplossing van het geschil zoveel mogelijk aansluiting zoeken bij bestaande verdragsbepalingen; ter zake van rechtsvinding op het terrein van het recht op persoonlijkheid komt dan eerst Art. 8 EVRM in aanmerking. De bewoordingen van Art. 8 EVRM lijken niet altijd direct toepasbaar op de individuele aanspraken die worden gedaan. ${ }^{1}$ De rechter kan in dat geval besluiten, over te gaan tot de vorming van een rechtsregel die in hoge mate is geënt op Art. 8 en die een beoordelingsmaatstaf inhoudt die aan Art. 8 verwant is. Langs die weg onderzoekt hij aldus in hoeverre de individuele aanspraak gedekt wordt door de rechtsbescherming die Art. 8 biedt. De legitimatie van deze constructie wordt gevonden in een rechtsbeginsel dat ten grondslag ligt aan enerzijds vergelijkingsmateriaal - bijvoorbeeld jurisprudentie waarop Art. 8 van toepassing is, en anderzijds het voorliggende geschil dat met het vergelijkingsmateriaal overeenkomt en waarop de 'nieuwe' rechtsregel wordt gebaseerd. Een norm van hoger recht legitimeert aldus de kwalificatie van de individuele aanspraak onder een rechtsnorm die niet zichtbaar deel uitmaakt van Art. 8, maar die wel kan leiden tot toepassing op de voorliggende individuele aanspraak.

Onderzocht wordt, in hoeverre het EHRM een analoge benadering heeft gebezigd in de rechtsvindingsfase, om vast te stellen wat de omtrekken van Art. 8 zijn. De rechtspraak van het EHRM kan op uiteenlopende manieren worden benaderd. In de literatuur is het niet ongebruikelijk, de rechtspraak te verdelen naar verschillende aspecten van Art. 8 waaraan bescherming wordt geboden. Deze lijn wordt hier in principe ook aangehouden, zij het dat ook de chronologie zoveel mogelijk wordt gerespecteerd. Analoge interpretatie van andere verdragsbepalingen zal kort worden geschetst indien zij belangwekkende gezichtspunten opleveren voor de analoge redeneerwijze.

\section{2}

Rechtsontwikkeling door het Europese Hof voor de Rechten van de Mens ${ }^{2}$

Het EVRM stipuleert in de tekst geen specifiek recht in ter zake wan het reclit op persoonlijkheid van individuen. Aangenomen wordt echter dat vanuit een systeembenadering van de algehele individuele rechtsbescherming van het EVRM een aantal

I Zie bijvoorbeeld Niemietz t. Duitsland, EHRM 16 december 1992, Serie A vol. 251-B, zie ook hoofdstuk $\downarrow$ in het voorbeeld van de wetsanalogie en hiema par. 8.3.4.

2. In deze schets wan de rechtsontwikkeling door hel EHRM zijn ook enkele uitspraken van de 'oude' Europese Commissie voor de Rechten van de Mens opgenomen. 
aspecten wan de persoonlijkheid af te leiden is ${ }^{3}$ De Preambule verwijst naar de Universele Verklaring woor de rechten van de Mens. Velu wees in 1970 al op Art. 8 als een recht waaronder varschillende persoonhijkheidsrechtelijke aanspraken waren gevestigd. ${ }^{4}$ Het Hof heeft in de afgelopen decennia steeds nieuwe aanspraken erkend onder Art. 8 en daarbij afgezien van een uitputtende beschrijving van Art. \&. Deze benadering, tezamen met het uitgangspunt dat het EVRM dient te worden uitgelegd als een "living instrument' waarvan de interpretatie zicli ontwikkelt in de tijd, wijst op het in standhouden van een verdragsnorm die open staat voor erkenning van nieuwe rechten onder het recht op prive-leven wanneer omstandigheden in de samenlewing daartoe nopen. ${ }^{5}$ De eerste extensieve uitlleg van het recht op privé-leven werd door de Europese Commissie gegeven ter zake van een individuele aanspraak met de vraag of het houden van honden behoort tot bellangen die Art. 8 beoogt te beschermen. ${ }^{6}$ In haar opinie legde de Commissie uit hoe het recht op privé-Jeven dient te worden verstaan:

'In the opinion of the Commission, however, the right to respect for private life does not end there. It comprises also, to a certain degree, the right to establish and to develop relationships with other human beings, especially in the emotional field for the development and fulfilment of one's own personality".

Niet lang daarna beoordeelde de Commissie een individuele aanspraak op het recht op privé-leven ex Art. 8 in verband met de strafbaarstelling van abortus. ${ }^{8}$ Vraag was in hoeverre deze strafbaarstelling ingreep in het persoonlijk leven van de zwangere vrouw. De Commissie interpreteerde het recht op privé-leven en stelde dat er grenzen bestaan aan dat recht:

"The right to respect for private life is of such a scope as to secure to the individual a sphere within which he can freely pursue the development and fulfilment of his personality. To this effect, he must also have the possibility of establishing relationships of various kinds, including, sexual, with other persons. [...] However, there are limits to the personal sphere. $[\ldots]$ the claim to respect for private life is automatically reduced to the extent that the individual himself brings his private life into contact with public life or into close connection with other protected interests".

Enkele constituerende uitspraken over de reikwijdte van Art. 8 EVRM werden door het Hof gedaan in de jaren $70 .{ }^{10}$ Daarna ontwikkelden zich verschillende categorieën van aanspraken op het privé-leven, die gedeeltelijk parallel lopen met de vier in Art. 8 op-

3 Loucaides 1995, p. 176; Doswald-Beck 1983, p. 286 e.v.

4 Velu 1970 (im: Robertson 1973), p. 92 e..

57 zit bijwoorbeeld Tyrex t. Verenigd Koninkrijk, EHRM 25 april 1978, Serie A vol. 26, par. 31

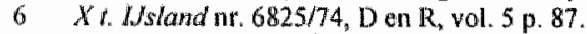

$7 X$ t. Jsland nr. 6825/74, D en R, vol. 5 p. 87. Er was geklaagd over een verbod tot het houden wan honden, warop slechts een minimale uitzondering was geformuleerd. De Comminsie achtte het houden wan honden weliswari een onderdeel van het recht op prive-leven, maar dat vertinderde niet dat de staat op sommige terreinen kan ingrijpen amdat het houden van honden deels de publieke sfeer raakt.

8 Briggemann en Scheuten t. Duitsiand, nr. 6959/75, D en $\mathbb{R}$, vol. 10, p. 100 e.w.

$9 \quad$ Briggemarn en Scheuten f. Dwisland, nr. $6959 / 75, \mathbb{D}$ en $\mathbb{R}$, vol. 10 , par. 55 e.v. Zie ook $X$ t. Verenigd Konimkrijk, wr. 8416/79, D en $\mathbb{R}$, vol. 19, p. 244 e.v. voor de vratg in hoeverre het recht op prive-leven wan de toekomstige vader geschonden is wanneer de vrouw besluit haar zwangerschap te beeindigen. 
gesomde aspecten van het privé-leven. In de eerste plaats erkende de Commissie dat gedetineerden een recht hebben op geheime correspondentie. Dat recht is gelieerd aan een op de persoonlijkheid betrokken belang:

\footnotetext{
"In the context of present-day conditions of imprisonment, the requirements of a democratic society involve the striking of a balance between the legitimate interests of public order [...] and that of the rehabilitation of prisoners (e.g. encouragement of and assistance to a prisoner 'to lead a good and useful life', to maintain his 'self-respect and a sense of personal respon-. sibility" and to "establish and maintain such relations with persons and agencies outside. prison as may [...] best promote the interests of his family and his own sociall rehabilitation). $\|$
}

Het Hof bevestigde later in Golder het belang van gedetineerden bij geheime correspondentie. $^{12}$ Privé-leven houdt eveneens een aspect van erkenning van de seksuele identiteit en voorkeur in, evenals een recht op geestelijke en fysieke integriteit. Tot op zekere hoogte heeft het Hof in Art. 8 ook een recht op culturele identiteit ingelezen. Daarnaast worden bedrijfsmatige activiteiten beschermd onder Art. 8, al varieert de mate waarin die bescherming wordt toegekend met de mate waarin de activiteiten zich in de privé-sfeer bevinden. Aspecten van de persoonlijke identiteit als de naam en kennisneming van het ejgen verleden werden eveneens aangemerkt als zaken die door Art. 8 worden bestreken. In de laatste jaren werd door het Hof het recht van het individu op adequate informatie over het leefmilieu onder Art. 8 erkend en uitgewerkt. De wijze waarop aanspraken werden gekwalificeerd onder Art. 8 EVRM wordt hieronder uiteen gezet.

\subsection{Ontwikkeling van het recht op persoonlijkheid met analoge redeneringen}

\subsubsection{Geestelijke en fysieke integriteit}

Het concept van privé-leven omvat het recht op geestelijke en fysieke integriteit wan het individu. Op zich niet opzienbarend, maar bijzonder is dat het Hof in uiteenlopende gevallen vaststelde dat voor de staat ter zake een positieve verplichting bestaat. De staat wordt in dergelijke gevallen verplicht te zorgen voor een minimum waarborg voor een effectieve bescherming van dat recht: het dient voor het individu voorwaarden te creëren werkelijk van het recht te kunnen genieten. De staat heeft ter zake van de bescherming van geestelijke en fysieke integriteit een positieve verplichting, aldus het Hof in $X$ en $Y t$. Nederland. ${ }^{13} \mathrm{Y}$, een minderjarig geestelijk gehandicapt kind, was seksueel misbruikt in de instelling waarin zij verbleef in verband met haar handicap. Haar vader klaagde bij de nationale rechter over het seksuele misbruik teneinde een vervolging te laten instellen. De klacht werd afgewezen onder verwijzing naar een strafrechtelijk-procedureel vereiste, dat het slachtoffer zelf een klacht moest indienen. De aanspraak van vader en kind op Art. 8 EVRM werd bij het Hof onderbouwd met de

$11 \mathrm{Nr} .5947 / 72, \mathrm{D}$ en $\mathrm{R}_{3}$ voแ. 3, p. 475.

12 Golder t. Verenigd Koninkrijk, EHRM 21 februari 1975, Serie A vol. 18, par. 43 e.W"

$13 X$ wen $Y$, Nederlard, EHRM 26 maart 1985, Serie A vol 91, par. 21 e.w. 
stelling, dat ouders in de gelegenheid moeten worden gesteld een strafrechtelijke procedure in te stellen indien hun kinderen het slachtoffer zijn van seksueel misbruik, ook indien de kinderen volgens de wet oud genoeg zijn on zelf een klacht in te dienen. Het Hof erkende deze aanspraak onder Art. 8:

"the facts underlying the application to the Commission concern a matter or "private life", a concept which covers the physical and moral integrity of the person, including this or her sexual life, ${ }^{\text {lid }}$

De aanspraak werd niet alleen erkend, maar eveneens gehonoreerd:

"The Court finds that the protection afforded by the civil law in the case of wrongdoing of the kind inflicted on Miss $Y$ is insufficient. This is a case where fundamental values and essential aspects of private life are at stake. Effective deterrence is indispensable in this area and it can be achieved by criminal-law provisions $[\ldots]^{\text {. }}$.

Voor de vaststelling, dat voor de optimale verwezenlijking van het privế-leven ex Art. 8 positieve verplichtingen bestaan, haalde het Hof de zaak Airey 4. Ierland aan. In die zaak had het Hof geoordeeld dat de staat verplicht is om kosten voor rechtsbijstand te dragen indien de echtscheidingsprocedure rechtsbijstand eist, en gesteld dat de mogelijkheid tot echtscheiding niet afhankelijk mag zijn van de financiële draagkracht van het individu. ${ }^{16}$ Airey bezat niet de financiële middelen om de rechtsbijstand te bekostigen in verband met de echtscheidingsprocedure.

"As regards marriage, husband and wife are in principle under a duty to cohabit but are entitled, in certain cases, to petition for a decree of judicial separation; this amounts to the recognition of the fact that the protection of their private or family life may sometimes necessitate their being relieved from the duty to live together'. ${ }^{17}$

Het Hof haalde Airey t. Lerland aan in $X t . Y$ om aan te tonen dat positieve verplichtingen kunnen bestaan ter zake van het recht op privé-leven. Airey had een ander feitencomplex dan $X$ en $Y t$. Nederland. Er werd een gemeenschappelijkheid gevonden in $X$ en $Y t$. Nederland en Airey $t$. lerland in het bestaan van een positieve verplichting. Met deze wetsanalogie - de vraag of kwalificatie onder Art. 8 mogelijk is - was echter nog niets gezegd over het inhoudelijke karakter van de positieve verplichting ex Art. 8 die in $X$ en $Y$ t. Nederland bestond. In Airey stond effectuering van het recht op een keuze in de persoonlijke levenssfeer - beëindiging van het huwelijk - centraal, terwijl in $\mathcal{X}$ en $Y$ het indienen vam een klacht mogelijk zou moeten zijn door de ouders namens hun geestelijk gehandicapt kind. Het Hof nam in $X$ en $Y$ aan dat lichamelijke integriteit door art. 8 wordt bestreken. Nieuw was in die zaak echter, dat het Hof daaraan voor de staat de verplichting verbond, dat recht ook afdwingbaar te maken in het strafrecht. ${ }^{18}$

14 Xen Y Nederland, par. 22.

IS Xen Y $t$. Nederland, par, 27.

16 Airey terland, EHRM 9 oktober 1970, Serie A vol. 32, par. 32.

17 Ainey, par. 33.

18 De vasitstelling door de rechter, dat bepaalde gedragingen strafbaar dienen te worden gesteld die dat woorheen niet waren, werd al eerder aangetroffen in de jurisprudentie van het Duitse federale Constitutionele Hof in Schwangerschaftsabbruch 1, 39 BVerfGE 1 (1975). In die zaak was de verplichting 
Om Airey en $X$ en $Y$ te kunnen vergelijken, diende een aanknopingspunt te worden gevonden waardoor kwalificatie van de aanspraak van Airey onder Art. 8 logisch was. De 'fundamental values and essential aspects of private life' vormden het belangrijkste aanknopingspunt tussen $X$ en $Y$ enerzijds en de casuspositie anderzijds, en kan hier worden aangemerkt als norm van hoger recht die de kwalificatie van Airey's aanspraak onder Art. 8 rechtvaardigde.

De grenzen van het privé-leven ter zake van de geestelijke en fysieke integriteit werden verder door het Hof in de zaak Botta t. Italië onderzocht. ${ }^{19}$ In die zaak rees de vraag, in hoeverre Art. 8 EVRM een recht inhoudt, dat stipuleert dat voor de staat een positieve verplichting bestaat, publieke voorzieningen voor lichamelijk gehandicapten toegankelijk te maken. Botta eiste dat de staat maatregelen zou treffen, om bezoek van lichamelijk gehandicapten aan het strand mogelijk te maken. De Italiaanse wetgever had een wet uitgevaardigd die beoogt de toegankelijkheid van privé-gebouwen en instellingen te vergroten. Aan Botta's verzoek maatregelen te treffen die strandbezoek voor hem mogelijk zouden maken werd echter geen gehoor gegeven. Botta's aanspraak op Art. 8 voor het EHRM was als volgt geformuleerd:

"he was unable to enjoy a normal social life which would enable him to participate in the life of the community and to exercise essential rights, such as his non-pecuniary personal rights $[\ldots]$ on the account of its (de staat, H.L.J.) failure to discharge its positive obligations to adopt measures $[\ldots], 20$

Het Hof wees de aanspraak van Botta onder Art. 8 EVRM echter af. Het zag, wat de afwijzing betreft, geen direct verband tussen de geëiste positieve verplichting van de staat enerzijds en de ingeroepen 'non-pecuniary personal rights'. Botta doelde op de verplichting van de staat, het recht van gehandicapten op menselijke waardigheid inhoudende het recht op vrijheid, onafhankelijkheid, integratie in het gezinsleven, in opleidingen, werkgelegenheid en in de samenleving effectief te waarborgen. ${ }^{21}$ In de optiek wan de Commissie waren deze rechten echter te onbepaald om onder Art. 8 rechtsgevolgen in het leven te roepen:

"The rights asserted by the applicant were social in character, concerning as they did participation by disabled people in recreational and leisure activities associated with beaches, the scope of which went beyond the concept of legal obligation inherent in the idea of 'respect" for "private life" contained in [...] Article $8^{3}, 22$

('recriminalisering' van abortus) die het Hof afleidde uit het recht op leven zeer omstreden omdat de wetgever in formele zin juist had besloten, abortus gedeeltelijk uit de strafrechtelijke sfeer te halen. In de Nederlandse situatie, waarover het EHRM in $X$ en $Y^{\prime}$ t. Nederland oordeelde, lijkt er eerder sprake te zijn wan een omissie in de strafwet waardoor in mindere mate sprake is van een rechterlijk ingrijpen in keuzes die de wetgewer heeft gemaakt. Ook is de aard wan de materie verschillend: het reclut op abortus is niet onomstreden, terwijl in beginsel wordt aanvaard dat seksueel misbruik wan geestelijk gehandicapten strafbaar is.

19 Bolta t. Italie, EHRM 24 februari 1998, JB 1998/70.

20 Botta t. Nalie, par. 27.

21 Botta t. Italie, par. 27.

22 Bonta t. Italië, par. 28. 
De staat opperde dat aanvaarding van Botta's aanspraak zou kunnen leiden tot een rechtsontwikkeling op het terrein van Art. 8 die buiten de bedoeling van de verdragswetgevers zou treden. Daarnaast zou het in de optiek van de verwerende staat lastig kunnen worden de grenzen van Art. 8 te bepalen. Daarmee doelde zij op het gevaar van het "argument that proves too much", hetgeen inhoudt dat wanneer een recht dermate extensief wordt geinterpreteerd, het kan worden uitgehold omdat het alle mogelijke aanspraken lijkt te kunnen dekken. Het recht is dan een lege huls geworden en kan worden ingeroepen tegen iedere willekeurige nationale wet. Het Hof wijdde vervolgens een substantieel deel van zijn uitspraak aan de interpretatie van Art. 8 ter zake van Botta's claim. Het Hof typeerde Botta's aanspraken uiteindelijk als "te onbepaald" om voor toepassing wan en beoordeling onder Art. 8 in aanmerking te kunnen komen.

Vraag is, in hoeverre het Hof in Botta een analoge redenering toepaste in het onderzoek naar de kwestie of onder Art. 8 positieve verplichtingen kunnen bestaan. Het Hof verrichte een onderzoek naar enkele aan Botta voorafgaande uitspraken, die allen positieve verplichtingen betroffen die niet rechtstreeks waren te herleiden uit de tekst van Art. 8 EVRM. In $X$ en $Y$ t. Nederland werd het recht op lichamelijke en geestelijke integriteit tot een belang verheven, dat bescherming verdient onder Art. $8 .^{23}$ Airey $t$. lerland figureerde in de context met Botta als de erkenning van een positieve verplichting van de overheid, dat een echtscheidingsprocedure daadwerkelijk toegankelijk dient te zijn - de toegankelijkheid mag niet afhankelijk zijn van de vraag of het individu rechtsbijstand kan betalen. Ook López Ostra t. Spanje en Guerra t. Iraliè werden door het Hof aangehaald als voorbeelden waarin daadwerkelijk woongenot en een schone leeforngeving aanspraken van het individu vormen, ter zake waarvan de staat ex Art. \& een positieve verplichting heeft. ${ }^{24}$

Het Hof zocht aldus aanknoping bij bronnen van positieve verplichtingen in de eigen jurisprudentie. Het stelde echter geen norm van hoger recht vast, die kon leiden tot toepassing van Art. 8 op Botta's aanspraak enerzijds en de andere genoemde aanspraken anderzijds. Daarwoor ontbrak het verband tussen de geclaimde positieve verplichting en de 'interpersoonlijke relaties. te zeer, aldus het Hof. Die werd, zij het onuitgesproken, wel aanwezig geacht in de andere uitspraken waarbij het Hof aanshuiting trachtte te vinden. Men kan zich afvragen, in hoeverre het terecht is dat Hof in zijn redenering vasthoudt aan de opvatting dat strandbezoek in een dermate ver verwijderde relatie stat met het begrip "interpersoonlijke relaties", dat van bescherming van die aanspraak onder Art. 8 geen sprake kan zijn. ${ }^{25}$ De beoordeling van het Hof was wellicht anders geweest, indien Botta op interpersoonlijke relaties had gedoeld ter zake van bezoek aan vrienden en familie. Het Hof hanteert aldus een criterium waarmee het vaststelt of van interpersoonlijke relaties sprake is. Er dient een 'direct verband' te bestaan tussen

$23 X$ Xen Y t. Nederlond, EHRM 26 maart 1985 , Serie A woll. 91, par. 22.

24 Lopez Ostra t. Spmye, EHRM 9 december 1994, Serie A vol. 303-C, par. 51, zie JB 1995/67 en Guerra 4. Italie, ELIRM 19 februari 1998 , par. 40, zie JB 1998/49. Botta levert in dit verband een fraai overzich wan erkende aanspraken, die in eerste instantie niet vanzelfsprekend onder Art. 8 te kwalificeren wareri. Botia, par. 35. 
aanspraak en Art. 8. Dat criterium was in eerdere rechtspraak nog niet naar voren gekomen. ${ }^{26}$

\subsubsection{Sieksuele orientatie en seksuele identitert}

Seksuele oriëntatie houdt onder meer seksuele voorkeur en bescherming van seksuele activiteiten ün de privé-sfeer in. Begin jaren ' 80 werd in Dudgeon het recht van het individu op een seksuele voorkeur onder Art. 8 EVRM expliciet erkend. ${ }^{27}$ Het seksuele leven van het individu is een aspect van het privé-leven, met name waar het uitingen van homoseksualiteit betreft die in de privé-sfeer plaatsvinden. Het Hof baseerde deze constatering deels op Marckx $t$. België, dat in feitencomplex geen overeenkomst vertoont. De vergelijkbaarheid was gelegen in het enkele feit dat in beide gevallen een wet bestond die, ook al werd deze niet meer toegepast, leidde tot een voortdurende schending van respectievelijk het recht op gezinsleven en het recht op prive-leven. ${ }^{28}$ Enkele rechters gaven in hun dissenting te kennen dat zij het niet eens waren met de kwalificatie; rechter Matscher gaf aan dat hij de vergelijking met Marckx niet voldoende overtuigend achtte om de aanspraak van Dudgeon onder Art. 8 te kwalificeren. ${ }^{29}$ Zijn grootste kritiek is dat het Hof zich met een te vage en algemene norm een vergelijking permitteert van beide aanspraken onder Art. 8. Hantering van de vage norm van hoger recht zonder de vergelijkbaarheid van beide feitencomplexen te specificeren leidt in casu een vaststelling van een positieve verplichting, aldus Matscher, wartoe Art. \& niet verplicht. ${ }^{30}$ Hij wees vergelijkbaarheid en daarmee de analogie aldus af. ${ }^{31}$

26 Zie onder meer Lawson, noot bij Botta t. Italie, (1998), p. 603 en Heringa, noot bij Bota t. Italie in JB $1998 / 49$.

27 Dudgeon t. Verenigd Koninkrijk, EHRM 22 oktober 1981, Serie A vol. 45, par. 37.

28 In Marckx betrof dat het recht van het buitenechtelijke kind op volledige erkenning. In Dudgeon was dat de aanspraak om niet geconfronteerd te worden met een wet die homoseksuele handelingen verbood: "The maintenance in force of the impugned legislation constitufes a continuing interference with the applicant's right to respect for his private life (which includes his sexual hife) within the meaning of Article 8 par. 1 . In the personal circumstances of the applicant the wery existence of this legislation continuously and directly affects his private life (see, mutatis mutandis, the Marck-judgement of 13 June 1979, Series A no. 31, p. 13, par. 27): either he respects the law and refrains from engaging - even in private with consenting male partners - in prohibited sexual acts to which he is disposed by reason of his homosexual tendencies, or he commits such acts and thereby becomes liable to criminal prosecution', Dudgeon t. Nerenigd Koninkrijk, EHRM 22 okiober 1981, Serie A vol. 45, par. 41.

29 Dissenting van Matscher bij Dudgeon t. Verenigd Koninkrijk.

30 Matscher wees in dit verband op het fundamentele verschil tussen Marckx t. Belgie en Dudgeon $t$. Verenigd Koninkrijk. In het eerste geval betekende de wet een directe en constante inbreuk op het familieleven van klaagster, terwijl hij de mate van de inbreuk op het privê-leven van Dudgeon betwijfelde: "In these circumstances, the existence of if fear, suffering and psychological distress" experienced by the applicant as a direct result of the laws in force-something which the Commission and the Court saw no treason to doubt [...] seems to me [...] to be extremely unlikely".

31 Een andere dissenter (rechter Walsh) vestigde de aandacht op ontwikkelingen in de rechtspraak van het Amerikaanse Hooggerechtshof ter zake van het recht op privacy, en stelde dat dat recht aiet alle seksuele activiteiten beschermt, maar wel seksuele activiteiten in het kader van het huwelijk: 'Outside marriage, there is no such compelling interest of privacy which by its nature ought to prevail in respect of such activities' (par. 23). 
De aanspraken op seksuele voorkeur hielden afwisselend negatieve en positieve aanspraken in. Ter zake van de negatieve aanspraken was het Hof kritisch over ínbreuken op het recht op een eigen seksuele voorkeur van het individu ${ }^{32}$; waar aanspraken op positieve verplichtingen in het geding waren stelde het Hof zich echter terughoudender op. Wanneer homoseksuelen een aanspraak maken op bijwoorbeeld het vestigen van familiebanden is het Hof niet snel bereid aan te nemen dat er ter zake positieve verplichtingen bestaan. $^{33}$

De seksuele voorkeur omvat eveneens tot op zekere hoogte bescherming wan sadomasochistische activiteiten. Het hof beoordeelde in Laskey e. a. $t$. het Verenigd Koninkrijk de vraag in welke mate sadomasochistische activiteiten onder bescherming van het privé-leven ex Art. 8 kunnen worden gebracht. ${ }^{34}$ Sadomasochistische uitingen vormen een aspect van het intieme privé-leven, maar het Hof kwalificeerde de individuele aansprakk buiten de privé-sfeer ex Art. 8 voor zover de gezondheid van de betrokkenen in het geding kan raken. Kennelijk was ook hier een grens bereikt in de omtrekken van het recht op privé-leven:

"However, a considerable number of people were involved in the activities in question which included, inter alia, the recruitment of new "members" the provision of several specially-equipped "chambers" and the shooting of many video-tapes which were distributed among the "members"[...]. It may thus be open to question whether the sexual activities of the applicants fell entirely within the notion of "private life" in the particular circumstances of the case." ${ }^{35}$

In de interpretatie aanvaardde het Hof de aanspraak in zijn geheel onder Art. 8, maar $\mathrm{kwam}$ daar in de toetsingsfase bij de beantwoording van de vraag van noodzakelijkheid van de beperking in een democratische samenleving deels op terug. Het feit dat betrokkenen gewond raakten of konden raken - het belang van de gezondheid van anderen ex Art. 8 lid 2 - diende te worden afgewogen tegen het persoonlijke zelfbeschikkingsrecht van het individu, aldus het Hof ${ }^{36}$ Het door de klagers opgebrachte argument, dat de betrokkenen in casu hadden ingestemd met de handelingen die eventueel tot verwonding konden Jeiden verwoordde het Hof onder "personal autonomy". Aan betekenis of rechtskarakter van deze notie werd verder door het Hof geen aandacht besteed; zij werd ook niet gehonoreerd in de toetsingsfase. De analogie speelde geen zichtbare rol van betekenis in de interpretatiefase in Laskey. Dat houdt niet in dat zij daarmee geheel afwezig is in de vaststelling van de reikwijdte van Art. 8. Dudgeon werd aangehaald ter bevestigung van het bestaan van het recht op een seksuele voorkeur. Laskey lijkt echter niet zozeer over seksuele voorkeur te gaan, maar over seksuele activiteiten en seksuelle orièntatie. ${ }^{37}$ Vanwege vergelijkbaarheid met Dudgeon onder een norm van hoger recht inhoudende 'an intimate aspect of private life' lijkt Laskey's aanspraak aanvaard.

Lustig. Prean en Becket t' Verenigd Koninkrik, EHRM 27 september 1999, EHRC $2000 / 2$.

Frete to Framkij, EHRM 26 februari 2002, EHRC 2002/30.

Laskey, Jaggard en Brown t. Ferenigd Koninkuijk, EHRM 19 februari 1997, 1997-1, par. 35 e.v.

Laskey, par. 36 .

Laskey, par. 44 .

37 Naderhand deed het Hof uitsprask in A.D.T. I. Verenigd Koninkrijk, warr bij wet was verboden dat meer 
Het Hof heeft ondertussen een zestal uitspraken gedaan over transseksualiteit, die hier wordt aangemerkt als aspect van seksuele identiteit. ${ }^{38}$ In de eerste vier zaken ging het om de vraag of de vermelding van geslacht in het geboorte- of persoonsregister dient te worden gewijzigd vanwege de gewijzigde geslachtelijke identiteit. Waar het Hof tot aan Goodwin t. Verenigd Koninkrijk slechts in én zaak een schending van Art. 8 vaststelde, oordeelde de Commissie in vijf zaken tot een schending. ${ }^{39}$ In Rees $t$. Verenigd Koninkrijk boog het Hof zich voor de eerste keer over de kwestie in welke mate transseksuelen aan Art 8 EVRM aanspraken op een huwelijk kunnen ontllenen in verband met hun nieuwe geslachtelijke identiteit. ${ }^{40}$ De Britse staat weigerde de nieuwe identiteit van klager op te nemen in het geboorteregister, zodat hij op officiële documenten steeds werd geconfronteerd met zijn oude geslacht. Dit zou, aldus klager, in de weg staan aan volledige integratie in het maatschappelijke verkeer, omdat hij het als vernederend ervoer dat hij het verschil tussen de vermelding van zijn geslacht in officiëlle documenten en de werkelijkheid steeds toe moest lichten. Het Hof aanvaardde de individuele aanspraak onder Art. 8, maar honoreerde deze in Rees niet. De aanspraak behelsde in casu een positieve verplichting van de staat: deze dient volledige integratie van transseksuelen in de samenleving te faciliteren en een huwelijk mogelijk te maken. In Rees wilde het Hof echter niet zover gaan, mar recentelijk heeft het in Goodwin t. Verenigd Koninkrijk vastgesteld dat een dergelijke verplichting bestaat. ${ }^{41}$

Ter zake van positieve verplichtingen op dit terrein laat het Hof aan de verdragsstaten een ruime beoordelingsruimte die voortvloeit uit afwezigheid van consensus. ${ }^{42} \mathrm{De}$ ruime beoordelingsmarge wordt door het Hof ter zake van positieve verplichtingen in beginsel wat eerder aangenomen, al lijkt er de laatste jaren geen groot verschil meer te bestaan ten opzichte van de negatieve verplichtingen. Er bestaat, aldus het Hof in Rees, geen overeenstemming in de verdragsstaten over de wijze waarop het respect voor deze aanspraak zou moeten worden verwerkelijkt. Mitsdien genieten de staten bij de wijze waarop de geslachtelijke identiteit van het individu geïntegreerd moet worden in de samenleving, een grote beoordelingsruimte. Het Hof gaf signaleerde in Rees evenwel dat de consensus in de verdragsstaten groeiende is:

"However, the Court is conscious of the seriousuess of the problems affecting these persons and the distress they suffer. The Convention has always to be interpreted and applied in the light of current circumstances [...]. The need for appropriate legal. measures should there-

dan twee mannen met elkaar seksuele handelingen werrichten. Het Hof aclutte Art. 8 volledig toe pasbaar en eveneens geschonden; in deze zaak speelde niet het aspect van de gezondheid van anderen (A.D.T. $t$. Werenigd Konink kifk, EHRM 31 juli 2000, EHRC 2000/69).

38 Van Oosterwijck t. België, EHRM I maart 1979, Serie B vol. 36; Rees t. Verenigd Koninkrijk, EHRM 17 oktober 1986, Serie A vol. 106; Cossey t. Verenigd Koninkijik, EHRM 27 september 1990, Serie A vol. 184, B t. Frankrijk, EHRM 25 maart 1992, Serie A vol. 232-C, $X$, Y en Z $t$. Verenigd Koninkrijk, EHRM 22 april 1997, NJCM 1998, p. 316-331 en Goodwin t. Verenigd Koninkrijk, EHRM 11 juli 2002. EHRC 2002/74.

39 Noot Forder bij $X$, Y en ZL Veremigd Koninkrijk, N.JCM 1998, p. 328.

40 Rees t. Verenigd Kaninkrijk, EHTRM 17 oktober 1986, Serie A vol. 106.

41 Goodwin t. Verenigd Koninkrijk, EHRM 11 juli 2002, EHRC 2002/74.

42 Rees t. Verenigd Koninkrijk, par. 35. 
fore be kept under review having regard particularly to scientific and societal developments. ${ }^{43}$

De zaak Cossey t. Verenigd Koninkrik bood het Hof de eerstvolgende gelegenheid. ${ }^{44}$ Gezien het feit echter, aldus het Hof, dat zich in de tijdsspanne tussen Rees en Cossey geen belangwekkende wijzigingen hadden voorgedaan in de verdragsstaten ter zake van de opvattingen over erkenning van de geslachtelijke identiteit van transseksuelen in officiele documenten, zag het Hof geen reden af te wijken van Rees. ${ }^{45}$ De aanspraak werd wederom erkend, maar niet gehonoreerd. ${ }^{46}$ In Goodwin t. Verenigd Koninkrijk tenslotte, aanvaardde het Hof het bestaan van woldoende consensus om over te gaan tot honorering van de aansprak.

Afwezigheid van consensus heeft veelal tot gevolg dat aan de staten een beoordelingsmarge wordt toegekend; er bestaat onzekerheid over de aard van de aanspraak en de gevraagde bescherming. Indien een consensus niet kan worden ontwaard, blijft het Hof bij de erkenning van de aanspraak onder Art. 8, maar wordt honorering van de aanspraak bijna onmogelijk, omdat de staten ter zake van de bepaling van de reikwijdte van het recht een ruime beoordelingsmarge toekomt. Het Hof handhaafde een opening naar erkenning en honorering in Rees en Cossey in de toekomst. ${ }^{47}$ Het bestaan van voldoende consensus noopte recentelijk in Goodwin t. Verenigd Koninkrijk tot een bijstelling van de opvatting dat een consensus afwezig is.

In verband met de analoge redenering zijn de uitspraken over transseksualiteit ter zake van "s Hofs vaststellingen van de reikwijdte van Art. 8 in de interpretatiefase niet opzienbarend: het Hof stelde zonder veel omhaal vast dat de aanspraak onder Art. 8 bescherming geniet. Een fraaie, hier te bespreken analogie is te vinden in de dissenting van Martens. ${ }^{48}$ Martens bepleitte in zijn dissenting een expliciete erkenning van een norm van menselijke waardigheid bij Rees en Cossey. Het recht op respect voor de geslachtelijke identiteitsbeleving dat, net als Art. \& EVRM, voortvloeit uit het rechtsbeginsel van menselijke waardigheid, behoeft een volwaardige bescherming. Hij ontleende zijn redenering aan de Duitse rechtspraak:

'Human dignity and everyone's fundamental right to develop bis personality freely make it imperative to assign a man's personal status to the sex to which he belongs according to his psychological and physical constitution, ${ }^{49}$

Raes to Venenigd Koninkwik, par. 47.

Cossey 8. Fenenigd Kontwkrijk, ETRM 27 september 1990, Serie A vol. 184.

Cossey i, Verenigd Koninkrijk, par. 40.

Porder vatagt zich in haar noot bij $X, Y$ en $Z$ a. Veremigd Koninkrizk af hoeveel overeenstemming er moet bestaan voordat van een consensus kan worden gesproken; zij onderzocht welke landen op dit terrein wetgeving ter zake kennen en welke initiatieven door de Raad van Etropa zijn genomen (Forder 1998 , p. 330 voor verwijzingen)

Zo ook Heringa 1999, p. 21.

Martents, dissenting bij Cossey t. Verenigd Koninkrijk.

Martens, dissening bij Cossey t. Venenigd Koninkrijk, par. 3.6 .3 in de dissenting en refererend ann de voorheen besproken Duitse transseksuelenzak (Transsexwelle 1, 49 BVerfGE 286, 1978, zie par, 6.3.8). 
Martens gebruikte in de analogie een norm van hoger recht die hier werd ingevuld door de menselijke waardigheid; deze norm werd gevonden in een uitspraak van het Duitse Federale Constitutionele Hof. Ook leverde de Amerikaanse rechtspraak een aantal bruikbare gezichtspunten op:

\footnotetext{
"In so ruling we do no more than give legal effect to a fait accompli based upon medical judgement and action which are irreversible. Such recognition will promote the individual's quest for inner peace and personal happiness, while in no way disserving any societal interest, principle of public order or precept of morality. ${ }^{50}$
}

Het Hof richtte zich vooral op het bestaan van een positieve verplichting, terwijl Martens zich met name richtte op de psychologische aspecten van transseksualiteit: Martens constateerde net als het Hof dat overeenstemming over het thema ontbreekt in de verdragsstaten, maar dat wierp in zijn redenering geen barricade op voor de honorering van de in Rees opgeworpen aanspraak. In het verleden, aldus Martens, is gebleken, dat eensgezindheid over een thema niet noodzakelijk is voor de aanname van een consensus over dat onderwerp van verdragsstaten. De analoge redenering van Martens creëerde evenwell ruimte voor honorering van de aanspraak: de opvattingen zouden met elkaar in overeenstemming kunnen worden gebracht onder het uitgangspunt van menselijke waardigheid; die norm is overwegend in alle verdragsstaten aanvaard als rechtsbeginsel. Vraag is of er aan de constatering, dat de aanspraak te kwalificeren is onder dat rechtsbeginsel, ook consequenties moeten worden verbonden. Hiermee samenhangend had de vraag beantwoord moeten worden, in hoeverre het legitiem is dat het Hof een vaststelling doet die uitstijgt boven de concrete vraag. In beginsel is het Hof daartoe niet zeer bereid.

\subsubsection{Culturele identiteit}

Een recentere uitwerking van Art. 8 EVRM is te vinden op het terrein van de erkenning. van de etnische identiteit. Een zigeunerfamilie werd door de Britse autoriteiten permissie geweigerd om in een woonwagen op het door haar aangekochte stuk land te leven. De vraag die in Jane Smith $t$. Verenigd Koninkrijk rees, was of de staat met de weigering tot afgifte van de vergunning een inbreuk had gemaakt op Art. $8{ }^{51}$ Tot dusverre had het Hof de wijze waarop zigeuners leven, niet gerekend tot én van de belangen, die Art. 8 beoogt te beschermen. In 1996 werd deze aanspraak nog in Buckley, waarin een vergelijkbare aanspraak door het Hof werd beoordeeld, afgewezen. ${ }^{52}$ In Jone Smith achtte het Hof echter voldoende consensus aanwezig, de individuele aanspraak onder het recht op privé-leven Art. 8 te kwalificeren en de in Buckley gehuldigde opvatting bij te stellen. De notie "woning" ex Art. 8 EVRM was volgens het Hof niet voldoende ruim om de aanspraak van Jane Smith te dekken:

Martens, disseming bij Cossey t. Verenigd Koninkmijk, refererend aan een utispraak var het Superior Court, New Jersey (1976)

51 Jane Smith $t$. Werenigd Koninkrijk, EHRM 18 januari 2001, EHRC 2001/19. Tezelfdertijd werd in vicer andere zaken, die op een zeer wergelijkbaar feitencomplex betrekking hadden, witspraak gedaan door het Hof. De interpretatie van Art. 8 was in alle zaken dezelfde.

52 Buckley t. Verenigd Koninkrijk, EHRM 25 september 1996, NJCM 23 (1998), p. 303 e.v. 


\section{HoOFDsTuK \&}

"The count considers that the applicant's occupation of her caravan is an integral part of her ethnic identity as a gipsy, reflecting the long tradition of that minority of following a travelling lifestyle. [...] Measures which affect the applicant's occupation of her caravan have therefore a wider impact than on the right to respect for home. They also affect her ability to maintain her identity as a gypsy and to lead her private and family life in accordance with that tradition".

Het Hof doelde met "etnische identiteit' op een traditionele nomadische levensstijl. De aanspraak, die door het Hof onder privé-leven ex Art. 8 werd erkend, werd echter niet gehonoreerd. Het Hof concludeerde in de toetsingsfase dat er geen sprake was van een positieve verplichting van de zijde van de staat, de verzochte wergunning af te geven zodat de familie haar levensstijl op legale wijze zou kunnen voortzetten. De staten hebben een ruime beoordelingsmarge waar het gaat om besluiten op sociaal-economisch terrein. De toewijzing van vergumningen ter zake wan woonwagens valt volgens het Hof binnen die sociaal-economische context.

In Buckley hield het Hof nog strikt vast aan de kwalificatie van de casus onder het begrip "woning" ex Art. 8, hoewel die zaak wat de feiten betrof nagenoeg geheel overeenkwam met Jane Smith. ${ }^{53}$ Met de strikte toepassüng van het begrip 'Woning' in Buckley kon het Hof destijds een discussie over de reikwijdte van Art. 8 in verband met de etnische identiteit vermijden. ${ }^{54}$ Het begrip "woning" werd voor wat de kwalificatie van de individuele aanspraak betreft in Jane Smith losgelaten. In Jane Smith werd echter niet expliciet aangewezen op welke leest de koerswijziging van het Hof na Buckley was geschoeid. Vast staat, dat in de laatste jaren op internationaalrechtelijk terrein veel aandacht is gekomen voor specifieke problemen van zigeuners in de staten waarin zij leven.. De aangehaalde internationale documenten in de uitspraak hebben hoogstwaarschijnlijk een belangrijke rol gespeeld in 's Hofs besluitvorming ter zake van het belang van de traditionele nomadische levensstijl als uitvloeisel van het invullen van een onderdeel van het persoonlijk leven. ${ }^{55}$ De rechtsbron waaruit het Hof het recht inhoudende de bescherming van de etnische identiteit destilleerde, werd in casu net name gevormd door resoluties van de Raad van Europa:

53 In Buckley wenste cen zigeunerfamilie op een door haar aangekocht stuk land te gaan wonen in een woonwagen. Vanwege planbeleid en veiligheidsbeleid mochten de families daar niet langer verblijwen in hun woonwigens.

$\$ 4$ De anknoping bij de identiteit was door de kagers wel voor het voetlicht gebracht, maar het Hof besteedde h"er geen asudacht aam. Het Hof merkte dan ook op, dat de aspecten "prive-leven" en 'gezins." leven' niet apart onderzocht hoefden te worden. Uit latere rechtspraak lijkt echter naar voren te komen. dat het Hof wol een onderscheid makt tussen bijvoorbecld het privé-leven en het recht op gezinsleven (zie bijvoorbeeld Frette t. Frankrijk, EHRM 26 februari 2002, EHRC 2002/30).

55 Jane Swith t. Kerenigd Koninkrik, par. 62-74. Hierin zijn onder meer opgenomen 'The Framework Convention for the Protection of National Minorities', een verdrag van de Raad van Europa wit 1995 , een Aanbeveling van de Raad wan Europa (nr. 1203 uit 1993), een Resolutie van het Europese Parlement van de Europese Unie (van 21 aprï 1.994) en een rapport over zigeuners van een sub-organisatie Vwn de OVSE ( 7 april 2000$)$. 
"The Parties undertake to promote the conditions necessary for persons belonging to nationall minorities to maintain and develop their culture, and to preserve the essential elements of their identity, namely their religion, language, traditions and cultural heritage'. ${ }^{56}$

De andere in de uitspraak aangehaalde bronnen verwijzen naar zigeuners als een specifieke bevolkingsgroep met de nomadische (woon)traditie die dee] uitmaakt van hun levensstijl:

"It must be emphasised that whether an individual is nomadic, semi-nomadic or sedentary should, like other aspects of his or her ethnic identity, be solely a matter of personal choice., 57

Ook heeft de Raad van Europa aandacht besteed aan zigeuners als minderheidsgroep, die speciale bescherming verdient in de Partijstaten bij de Raad van Europa:

"Guarantees for equal rights, equal chances, equal treatment and measures to improve their situation will make a revival of Gypsy language and culture possible, thus enriching the European cultural diversity'. 58

De betekenis van deze documentatie voor de vaststelling, of Smith onder Art. 8 EVRM een aanspraak heeft lijkt evident. Uit de citaten kon een beginsel worden geconstrueerd, dat het belang van culturele diversiteit en het bestaan van een etnische identiteit onderstreept. Uit dat beginsel vloeit voort, dat ook de nomadische levensstijl behoort tot de belangen die Art. 8 beoogt te beschermen, omdat die levensstijl wordt beleefd in het privé- en gezinsleven van de betrokkenen en daar aldus een belangrijk onderdeel in is. ${ }^{59}$ Wat de aangehaalde rechtsbronnen betreft is van belang dat in de optiek van het Hof de aangehaalde documenten vooral belangrijke richtsnoeren zijn voor de nationale wetgevers. Zij houden in deze formulering geen voor het individu afdwingbare verplichtingen in. Het feit dat de verdragssluitende partijen geen overeenstemming konden bereiken over de wijze van implementatie van deze richtlijnen doet sterk vermoeden dat het hier niet om een afdwingbare verplichting kàn gaan. Een consensus ter zake lijkt aldus te ontbreken. Erkenning van dit recht in de Stratsburgse rechtspraak, hoe beperkt ook, geeft wellicht een belangrijk signaal af aan de Europese verdragspartijen die zich verbinden aan de richtsnoeren en kan wellicht leiden tot een prikkel echt werk te maken wan het recht op identiteit.

De wetsanalogie werd niet opgebouwd aan de hand van jurisprudentie maar aan de hand van volkenrechtelijke besluiten. ${ }^{60}$ In Buckley werden geen internationaalrechte-

56 The Framework Convention for the Protection of National Minorities (1995), Art. 5. Aarbeveling 1203 van de Raad van Europa en de aangehaalde Resolutie wan het Europese Parlement van de Europese Unie refereren aan de verplichting van de Lid-Staten om de sociale omstandigheden van zigeuners te verbeteren.

57 High Commissioner's Report on the Situation of Rona and Sinti in the OSCE Area, 7 april 2000, deel IV.

58 Aanbeveling 1203 (1993) wan de Parlementaire Vergadering over zigeuners in Europa.

59 Jame Smith t. Verenigd Koninkrijk, par. 80.

60 Het Hof achtte geen vergelijkbaarheid aanwezig met Dudgeon t. Verenigd Koninkrijk (zie hierboven): in Dudgeon was sprake van criminalisering van gedrag dai door het EVRM wordt beschermd. In Jame 
Ijke besluiten tot uitgangspunt verheven. Interessant was overigens in Buckley dat de dissenting van rechter Lohmus destijds al refereerde aan het bestaan van een Resolutie van de Raad van Europa, die wees op het recht op bescherming van het culturele erfgoed van minderheden. ${ }^{6 i}$ Vasthouden aan precedenten als Buckley en Gillow zou in Jane $S$ mith hebben geleid tot niet-erkenning van het recht op de identiteit van deze minderheidsgroep. De precedenten vertoonden, zoals voorheen gesteld, sterke overeenkomsten met Jane Smith wat het feitencomplex betreft, maar kennelijk wilde het Hof Jane Smich niet onder hetzelfde gezichtspunt, recht op genot van de woning, beoordelen. Het loslaten van het begrip woning en aanknoping bij prive-leven leidde in Jane Smith tot ruimere omtrekken van Art. 8. Dat loslaten werd door het Hof niet expliciet verantwoord, maar aangenomen wordt hier dat het Hof zich door internationale ontwikkelingen bij de invulling van het recht op privé-leven heeft laten inspireren. Afgaande op de door het Hof relevant geachte internationalle teksten wordt een norm van hoger recht, die inhoudt dat individuen recht hebben op het behoud van hun eigen culturele identiteit, aanvaard. ${ }^{62}$ Er lijkt sprake te zijn van een abstracte norm van hoger recht. De vraag rijst, in welke mate nu kan worden gesproken van positivering van een rechtsnorm inhoudende een recht op etnische identiteit. Rechtspraak na Jane Smith zal duidelijk moeten maken, of en in hoeverre dit recht wortel schiet in het kader van afdwingbare rechten van het EVRM.

\subsubsection{Bescherming van bedriffsmatige activiteiten}

De zaak Niemietz t. Duitsland is in de inleiding als uitgangspunt genomen om te illustreren hoe de wetsanalogie werkt. In Niemietz t. Duitsland legde het Hof het recht van het individu op privé-leven in de interpretatiefase extensief uit. ${ }^{63}$ Het had voor de lhand gelegen, het begrip 'genot van de woning' als uitgangspunt te nemen, maar het Hof voorzag dat in de verdragsstaten zeer uiteenlopende interpretaties mogelijk waren van het begrip woning, en dat het lastig zou worden een eenduidig criterium voor de toepassing ervan te bedenken. ${ }^{64}$ Wellicht speelde hier een rol het feit dat het Europese Hof van Justitie te Luxemburg reeds enkele jaren voor Niemietz had vastgesteld, dat ter zake van het begrip 'woning' ex Art. 8 EVRM in verband met de kwalificatie daat-

Smith $t$. Ferenigd Koninkwijk was hiervan geen sprake: de zigeuners hadden (zij het zeer beperkt) een alternatiof om de door hun gewensite levensstijl te kunnen nastreven (zie par. 84 in Jane Smith 1 . Ferenigd Koninkrijk).

61 Zie Buckley, afwijkende mening van rechter Lohmus. Lohmus verwees nat thesolutie wan het Comits van Ministers (75) 13 van de Raad van Europa.

62 Zie Donders over het recht op culturele identiteit en bespreking wan Jane Smith t. $V K$, Donders 2002 met mame p. 292-300.

63 Niemietz $t$, Duitsland, EHRM 16 december 1992, Serie A vol. 251 -B.

64 Niemietz $t$. Dritsland, par. 28: "The Court shares the Government"s doubts as to whether thas factor can serve as a workable criterion for the purposes of delimiting the scope of the protection afforded by Article 8. Virtually all professional and business activities may involve, to a greater or lesser degiree, matters that are confidential, with the result that, if that criterion were adopted, disputes would frequently arise as to whetre the line should be drawn'. 
onder van zakelijke en professionele activiteiten geen consensus in de Lid-Staten bestond. ${ }^{65}$

Het begrip 'privé-leven' bood daarentegen meer aanknopingspunten, de individuele aanspraak van Niemietz onder Art. 8 te kwalificeren. Voordat het Hof het begrip "privéleven' toespitste op de individuele aanspraak, stelde het eerst vast, dat het begrip zich niet leent voor een uitputtende definitie. Het Hof benaderde het begrip privé-leven als een concentrische cirkel, waarin een kern van intieme privé-sfeer besloten ligt. ${ }^{66}$ Het zou echter, in de optiek van het Hof, niet juist zijn de reikwijdte van Art. 8 te beperken tot deze kern. Het stelde vast, dat buiten deze kern van de intieme privé-sfeer een zone ligt, waarin het individu weliswaar in contact treedt met de buitenwereld, maar waarin immer nog sprake is van een privé-sfeer waarin het zichzelf kan zijn. In de kern van intiem privé-leven mag het individu in beginsel zijn persoonlijke leven leiden zoals hij dat zelf wenst in te richten. De meer perifere zone buiten de kern, waarin het individu zich in een verdergaande mate begeeft in de openbare sfeer, tolereert verdergaande inbreuken op het privé-leven dan de kern van de intieme privé-sfeer.

De vraag rees, indien kan worden gesproken over een kernsfeer en een meer perifere sfeer, in welke van de twee sferen Niemietz' aanspraak zich bewoog. In beginsel zijn privé-activiteiten die zich afspelen in de woning van intieme aard, ware het niet dat de klager zich in dit geval via de publicaties had begeven in de openbare sfeer. De huiszoeking in het advocatenkantoor vormde een inbreuk van ander kaliber dan huiszoeking in een privé-woning, en pleitte op het eerste gezicht voor kwalificatie van Niemietz' aanspraak in de meer perifere sfeer van het privé-leven. De vraag was of de beslissing, het doorzoeken van een advocatenkantoor te plaatsen binnen de intieme privé-sfeer, gerechtvaardigd kon worden. Het Hof beantwoordde deze vraag bevestigend. Professionele activiteiten vormen in beginsel een aspect van "de buitenwereld' of de meer openbare sfeer, en worden niet geacht binnen de intieme sfeer van bet begrip privé-leven te vallen. Echter, zo stelde het Hof vast, ook binnen de intieme sfeer van het privé-leven moeten individuen interpersoonlijke relaties met anderen kunnen vestigen en ontwikkelen.

Het Hof spitste het begrip privé-leven toe op professionele activiteiten van het individu. Het Hof creëerde een opening ter zake van de kwestie onder welke omstandigheden professionele activiteiten kunnen worden beschouwd binnen de intieme sfeer. ${ }^{67}$ Het vergelijkingsmateriaal voor de wetsanalogie werd opgebouwd uit jurisprudentie. In andere zaken had eveneens de kwestie gespeeld, in welke mate professionele activiteiten konden leiden tot kwalificatie van Art. 8. Daartoe werden Chappell t. Verenigd

65 Niemietz t. Duitsland, par. 22.

66 Niemietz t. Duitsland, par. 29.

67 ' $[\ldots]$ it is, after all, in the course of their working lives that the majority of people have a significant, if not the greatest, opportunity of developing relationships with the outside world. This wiew is supported by the fact that [...] it is not al ways possible to distinguish clearly which of an indiwidual's activities form part of his professional or business life and which do not', Niemietz t. Duitsland, par. 29. 
Koninkrijk en Huvig it. Frankrijk aangehaald. ${ }^{63}$ In Chappell werd een onderneming doorzocht op aanwijzingen van overtreding van auteursrechten; de politie beperkte zich daarbij niet alleen tot onderzoek in de bedrijfsruimten, maar doorzocht eveneens een slaapkamer die aanwezig was in eén van de bedrijfsruimten. Het Hof kwalificeerde de Chappell-casus onder het bereik van de termen woning en privé-leven ex Art. 8, conform de aanspraak van de klager en met instemming van de staat. In de zaak Huvig was eveneens sprake van een onaangekondigde huiszoeking, waarbij de onderzoekers zich, net als in Chappell, evenmin beperkten tot de bedrijfsruimten. In Howig werden naast bedrijfsruimten echter ook privé-ruimten onderzocht en zakelijke- en privé-telefoongesprekken getapt. In Niemietz werd alleen het kantoor, dat de advocaat bij zijn woning had, doorzocht. Het Hof argumenteerde aan de hand van deze zaken, dat er rechtsongelijkheid zou kunnen ontstaan, indien Niemietz niet onder Art. 8 zou worden gekwalificeerd, en Chappell en Huvig wel. Er bestond echter aanleiding om ongelijkheid ussen Hwig en Chappell enerzijds en Niemietz anderzijds aan te nemen; schending. van het privé-leven aannemen lag eerder voor de hand in beide eerste zaken omdat daar ook werkelijk privé-ruimten betrokken werden in de huiszoeking. Het Hof achtte gemeenschappelijk in deze zaken een inbreuk van staatswege op het privé-leven dat in het algemeen professionele activiteiten kan omvatten. Die gemeenschappelijkheid is enkeJ te verdedigen indien men uitgaat van een abstracte norm van hoger recht. ${ }^{69}$

Van belang is dat het Hof niet in het algemeen heeft gesteld, dat rechtspersonen bescherming onder Art. 8 verkrijgen. ${ }^{70}$ Het Hof stelde recentelijk in Stés Colas Est t. Frankrijk vast dat deze zaak zich fundamenteel onderscheidt van Funke e.a. t. Frankrijk; in Funke klaagden natuurlijke personen, terwijl in Stés Colas werd geklaagd over inbreuk op Art. 8 door rechtspersonen. ${ }^{71}$ Het Hof aanvaardde in Niemietz $t$. Duitsland een extensieve interpretatie van Art. 8 ter zake van het doorzoeken van de bedrijfsruimte van een persoon met een vrij beroep. In Chappell t. Verenigd Koninkrijk beoordeelde het Hof een onderzoek in een bedrijfspand waarin zich eveneens een privé-vertrek vond dat ook werd doorzocht. In Stés Colas Est was enkell sprake van doorzoeken van bedrijfspanden. In alle zaken stelde het Hof een schending van Art. 8 vast. Het Hof aanvaardt nu dat rechtspersonen 'onder omstandigheden' een aanspraak kunnen doen op Art. 8.

In het licht van dynamisch-evolutieve interpretatie en rechtsontwikkelingen op andere terreinen blijkt een oprekking volgens het Hof verantwoord. Het Hof knoopte hierwoor aan bij de rechtsontwikkelingen betreffende inroepbaarheid van Art. 41 in combinatie met Art. 6 lid 1, in het bijzonder het recht op schadevergoeding door rechtspersonen.

68 Huwg f. Frankrijk, EHRM 24 april 1990, Serie A vol 176-B, par. 41 en Chappell t. Verenigd Koninkrijk, EHRM 30 maart 1989 , Serie A vol. 152-A, par. 26.

69 Gesteld had bijwoorbeeld kunnen worden, dat de zaken niet vergelijkbaar waren op het punt dat in Chappell t. Kevenigd Koninkrijk en Hwig t. Frankrijk ook privé-ruimten en gesprekken in het onderzoek waren betrokken, terwijl hiervan in Niemietz geen sprake was. De rechter zou dan een specifheke martsitaf tet hand hebben genomen.

70 Zo ook Lawson en Schermers 1997, p. 498. Anders: Cath 1991, p. 28 e.w.

71 Stes Colas Est th Frankrijk, EHRM 16 april 2002, EHRC 2002/46. 
De toepassing van andere EVRM-rechten op ondernemingen overziend, acht het Hof ruimte aanwezig om aan te nemen dat ondememingen onder omstandigheden - het Hof specificeert niet welke - aanspraak kunnen maken op Art. 8. Het lijkt de grenzen aldus ietwat verschoven te hebben: in de andere zaken was steeds sprake van een aspect wan een privé-vertrek of natuurlijk persoon, in onderhavige zaak zijn die aspecten geheel afwezig:

'La Cour rappelle que la Convention est un instrument vivant à interpréter à la lumière des conditions de vie actuelle [...]. S'agissent des droits reconnus aux sociétés par la Convention, ill y a lieu de souligner que la Cour a déjả, au titre de l'article 41 , reconnu le droit à réparation du préjudice moral subi par une société sous l'angle de l'article 6 par. 1 de la Convention [...] Dans le prolongement de l'interprétation dynamique de la Convention, la Cour considère qu'il est temps de reconnaitre, dans certains circonstances, que les droits garantis sous l'angle de l'article 8 de la Convention peuvent être interprétés comme incluant pour une société, le droit au respect de son siège social, son agence ou ses locaux professionnels $[\ldots]^{1}$ ?

Het Hof houdt in beginsel steeds een casuistische benadering ter zake van de kwalificatie van de individuele aanspraak onder Art. 8 aan.

Niet alleen het EHRM, maar ook het Hof van Justitie en het Gerecht in Eerste Aanleg hebben hun interpretatie van Art. 8 gegeven. ${ }^{73}$ De Luxemburgse rechters lijken aan Art. 8 een beperkter reikwijdte toe te kennen waar het gaat om bescherming van bedrijfsactiviteiten dan de Straatsburgse rechter, ook daar waar sinds Hoechst en Dow Benelwx sprake was van rechtsontwikkelingen in de jurisprudentie van het EHRM ${ }^{74}$ Recentelijk heeft het Luxemburgse Hof zijn visie op toepasselijkheid van het recht op privé-leven op rechtspersonen in Limburgse Vinyl Maatschappij gegeven. Het verschil in opvatting tussen de Luxemburgse en Straatsburgse interpretatie bleef in die zaak voortbestaan ${ }^{75}$, maar de motivering van het GEA laat in eerste instantie raden op basis waarvan de verschillen nu werden aanvaard:

'Aangezien de middelen en argumenten die thans door LVM en DSM worden aangevoerd, identiek of nagenoeg identiek zijn aan die welke destijds door Hoechst zijn aangevoerd, zijn er volgens het Gerecht geen redenen om af te wijken van de rechtspraak van het Hof (Hof van Justitie, H.L.J.). Bovendien is deze rechtspraak [...] gebaseerd op een algemeen beginsel van gemeenschapsreclit dat van toepassing is op rechtspersonen. Dat de rechtspraak van

72 Stés Colas Est t. Frankrijk, EHRM 16 april 2002, EHRC 2002/46, par. 41. Het Hof makt overigens wel een onderscheid tussen het Engelse begrip home" an hat Franse "domicile", Het lantste is voldaende ruim om als uitgangspunt te nemen voor de kwalificatievraag; het Engelse begrip is daarentegen te eng aldus het Hof in par. 40 van de uitspraak.

73 Zie woor de interpretate van het recht op prive-sfeer als beginsel van EG-recht door het Hor wan Justitio en het Gerecht in Eerste Aanleg par. 6.2.2.

74 In Siés Colas Est t. Frankrijk, par. 26 en 27 werd door de Franse regering geopperd, dat bedrijtsactivite iten een bescherming op het recht van het privé-leven niet kunnen rekenen, ondat het Gerecht van Eerste Aanleg van de EG in Limburgse Kiny Maatschappij lyad beslist dat Art. 8 geen gevolgen heeft voor de gegrondheid van de onderzoeken door de Commissic. Het EHRM ging in zijn uitspratk in Stés Colas Est t. Frankrijk geheel voorbij aan de beschouwing van het GEA ter zake van de reikwijdte van $A$ rt. 8 bij rechtspersonen in 1999.

75 Zie Hoechst t. Commissie, zaak $46 / 87$ (1989), Jur. p.2859 (1989); zie ook par. 7.3.1. 
het Europees Hof woor de rechten van de mens betreffende de vraag, of artikel 8 EVRM van toepassing is op rechtspersonen [...] is geevolueerd, heeft derhalve geen rechtstreekse gevolgen woor de gegrondheid van de oplossingen die in die arresten zijn gegeven " ${ }^{76}$

Een motivering van verschillen ligt in dit vetband - door een rechter die stelt dat hij zich laat inspireren door het EVRM - wel voor de hand; al kan afwezigheid ervan echter niet worden arngemerkt als een omissie. Het feit dat het Hof of het GEA EVRM-rechten als rechtsbeginselen betrekt in zijn interpretatie, wil niet zeggen dat er overeenstemming bestaat of dient te bestaan tussen Luxemburg en Straatsburg over de reikwijdte en de toepassing ervan. ${ }^{77}$ Daarnaast lijkt het verschil van belang, dat het Straatsburgse Hof rechtsregels interpreteert, terwijl de Luxemburgse rechter 'fundamentele rechten als rechtsbeginselen van communautair recht' interpreteert. De Luxemburgse typering van de EVRM-rechten als rechtsbeginselen van Gemeenschapsrecht lijkt ruimte te bieden woor divergenties in de interpretatie. Wellicht komt de kwalificatle van privé-sfeer als 'beginsel van gemeenschapsrecht' gelegen: de Luxemburgse rechter kan van de concretisering van het beginsel zelf nadere vorm en inhoud bepalen. In het licht van het mandaat van het Luxemburgse Hof, dat mede wordt ingekleurd door de economisch georiënteerde verdragsdoelstellingen, kan worden gesteld dat het primaat niet bij rechtsbescherming van rechtspersonen ligt, althans niet waar die rechtspersonen onder Artt. 81 en 82 EG-verdrag verplichtingen hebben.

De Franse regering steunde in de Straatsburgse zaak Stés Colas t. Frankrijk bij verdediging van de wet die vergaande opsporingsbevoegdheden inhield, op voomoemde rechtspraak van het Hof van Justitie en van het Gerecht van Eerste Aanleg. ${ }^{78}$ Aan die rechtspraak besteedde het Straatsburgse Hof bij de vaststelling van de reikwijdte van Art. 8 EVRM geen aandacht. ${ }^{79}$

De notie van de verschillende privé-sferen werd in Niemietz voor het eerst gehanteerd. Het Hof lijkt minder zware eisen aan de rechtvaardiging van inbreuken op het privéleven te stellen wanneer een aanspraak zich meer in de openbare sfeer bevindt. Wordt de individuele aanspraak daarentegen gekwalificeerd in de intieme sfeer, dan stelt het Hof zware eisen aan de inbreuk op de privé-sfeer. ${ }^{80}$ Uit de formulering van "het recht,

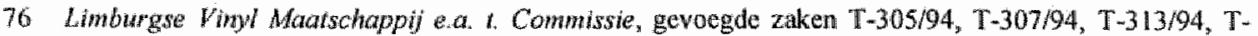
316/94, T-318/94, T-325/94,T-328/94, T-329/94 en T-335/94 (1999), Jur. p. II-93 419420

77 Cralgen De Búrca 1998, p. 314 ev.

78 Niet duidelijk is in hoeverie de bevoegdheden van de economische anbtemaren in verband stan met de inmiddels nagenoeg geheel door het EG-recht beheerste mededingingsregels. In casu werd de wet wit 1945 aangevochten; die zal tot op grote hoogte van Franse hand zijn. Niet helemal ondenkbaar is dat nationgle regels die op instigatie vary de Europese wetgever in het mationale recht tot stand zijn gebracint, laings deze weg terecht zouden kunnen komen bij het EHRM. In deze uitspraak heeft het thof een precedent geschapen - en aangegeven dat het te ruime onderzoeksbevoegdheden streng beoordeelt "Het is atwachten of het zover komt.

79 Skes Colas Est Frantirik EHRM 16 april 2002, EHRC $2002 / 46$.

80 Zie eveneens Lustig-Prean en Becker L. Ferenigd Koninkrijk, EHRM 27 september 1999, JB 1999/ 26!. In deze zaak refereerde het Hof aan de intieme sfeer op de volgende wijze: "Concerning as it did a mast intimate aspect of an individual's private life, particularly serious reasons by way of justification were 
relaties met anderen te vestigen en te onderhouden' blijkt overigens niet helder, of het dat "recht" wel juridische kwaliteit toekomt. ${ }^{31}$ Naderhand werd het recht, relaties met anderen te vestigen en te onderhouden gebruikt voor de vaststelling van de reikwijdte in andere individuele aanspraken. Daar werd het recht op dergelijke wijze ingezet: zo werden bijwoorbeeld het recht op het kiezen van een eigen naam, alsmede een recht op de kennis van de biologische afstamming gelegitimeerd op basis van dat recht. ${ }^{2}$ Deze norm lijkt daarmee via de rechtspraak definitief een plaats te hebben verworven als "rechtsnom van geldend recht".

\subsubsection{Persoonlyke identiteit}

Het Hof achtte de mogelijkheid van het individu, kennis te kunnen vernemen over zijn persoonlijke ontwikkeling, gedocumenteerd in overheidsdossiers, van groot belang. De aanspraak op een dergelijk recht werd in $\mathrm{Gaskin}^{83}$ beschouwd onder Art. 8 EVRM. Voor de overheid bestaat in beginsel de positieve verplichting het individu in staat te stellen kennis te verwerven van zijn persoonlijke ontwikkeling. Gaskin had het grootste deel van zijn jeugd doorgebracht in pleeggezinnen. Tijdens zijn ondertoezichtstelling echter, zou Gaskin volgens eigen zeggen meermalen zijn mishandeld. Om zijn problemen uit het verleden te kunnen verwerken wenste hij informatie over de personen waarbij en de omstandigheden waarin hij zijn jeugd had doorgebracht. Het Hof leunde bij beantwoording van de vraag, of deze claim onder Art. 8 diende te worden beschouwd, sterk op de bevindingen van de Commissie:

"in the opinion of the Commission, "the file provided a substitute record for the memories and experiences of the parents of the child who is not in care"s".84

Voor Gaskin vormde inzage in zijn dossier de enige mogelijkheid, kennis te vernemen wan zijn eigen verleden. Dat was kennelijk voldoende aanleiding, een recht onder Art. 8 te vestigen:

'it no doubt contained information concerning highly personal aspects of the applicant's childhood, development and history and thus could constitute his principal source on in-

In deze zaak refereerde het Hof aan de intieme sfeer op de volgende wilyze: 'Concerning as it did a most intiknate aspect of an individual's private life, particudarly serious reasoms by way of justification were required:. In deze zakk waren enkele homosexucle werknemers in het leger ontsh agen op basis van hum seksuele wookkeur. Het is niet geheel duidelijk, in hoeverre het Hof binnen de reeds bestaande kern wan intiem privé-lewen nog een afbakening wil aanbrengen waarbinnen nog zwaardere eisen aan de in. breuken worden gesteld, dan al het geval is bij inbreuken op de 'gewone' intieme sfeer. Vooralsnog lijkt het er niet op dat het Hof een derde sfeer heeft willen creeren; reeds in Dudgeon hanteerde het Hof de in Lustig Prean and Becketu geformuleerde "zeer" intieme sfeer. Dudgeon loandelde over de lerse wet, die homoseksualiteit verbood en door het Hof in strijd werd geacht met Art. 8 (EHRM 22 oktober 1981, Serie A vol. 45 , par. 52).

81 Het recht op privé-leven is abstract van karakter en behoeft nadere uitwerking voordat het kon worden toegepast op een concrete casus; hiertoe werd het in Niemietz onderscheid wssen professionele alctiviteiten en privé-leven binnenshuis gemaakt.

82 Zie Burghartz 1. Zwirserfand, EHRM 22 februari 1994, Serie A vol. A 280-B, par. 24 en Mikulict. Kroafiè, EHRM 7 februari 2002, EHRC 2002/25 (zie woor beide zaken hieronder par. 8.3.5).

83 Gaskin t. Verenigd Koninksijk, EHRM 7 juli 1989, NJ 1991, 659.

84 Gaskin, par. 36. 
formation about his past and formative years. Consequently, Jack of access thereto did raise issues under Art. $8^{, 85}$

Vraag was, hoe deze problematiek nu binnen het bereik van Art. 8 paste. Het hierwoor aangehaalde citaat plaatste de individuele aanspraak al onder Art. 8. Het Hof leek-geinspireerd door de bevindingen van de Commissie - een op menselijke waardigheid en persoonlijke identiteit geschoeid beginsel in te roepen, alvorens de individuele aanspraak onder Art. 8 nader kan worden beschouwd:

'respect for private life requires that everyone should be able to establish details of their identity as individual human beings and that in principle they should not be obstructed by the authorities from obtaining such wery basic information without specific justification'. ${ }^{86}$

Kort voor Gaskin had het Hof uitspraak gedaan in Leander $t$. Zweden over een aanspraak op het recht op privé-leven door een individu ter zake van de inzage van door de overheid verzamelde gegevens. Die gegevens waren door de veiligheidsdienst aangelegd in een dossier. ${ }^{87} \mathrm{Zij}$ vormden aanleiding, Leander te weigeren voor een betrekking in overheidsdienst. In Leander was het recht op privé-leven geschonden door overheidshandelen. Vraag was, of Gaskin in het kader van positieve verplichtingen diende te worden beschouwd. Het Verenigd Koninkrijk pleitte voor dat uitgangspunt, er vanuit gaande dat het Hof bij positieve verplichtingen vaak wat meer geneigd was om een ruimere beoordelingsruimte voor de staat aan te nemen. ${ }^{88}$ Het Hof weerlegde dat argument met de opvatting, dat Gaskin niet de opslag van gegevens betwistte, maar dat de geweigerde toegang tot die gegevens een inbreuk vormde op het recht op kennisneming van die gegevens. ${ }^{89}$

Het Hof differentieerde de twee zaken met de hypothese, dat de gevraagde informatie in Gaskin betrekking had op zijn 'basic identity', terwijl de gevraagde gegevens in Leander een ander karakter droegen. Het Hof zag zich in Gaskin genoodzaakt, dit onderscheid nader uit te werken, omdat de staat betoogde dat de aanspraak van Gaskin niet zoals die van Leander onder Art. 8 te kwalificeren was. Die uitwerking leverde enkele fraaie aankmopingspunten op voor de constatering, dat het Hof het recht op privé-leven ex Art. 8 soms lijkt te interpreteren als een meer algemeen recht op persoonlijkheid. Het belang van Gaskin bij kennisneming van de opgeslagen gegevens vond het Hof in een rechtsbelang wan het individu, de "basic identity" te kennen." De reden waarom 'basic identity' een belang is dat bescherming verdient onder Art. 8 werd owerigens niet ontwaard aan de hand van voorafgaande rechtspraak. Het belang van de kenmisneming ervan werd met name ondersteund door gebruik van retoriek en metaforen die niet of niet direct zijn terug te voeren op juridische argumentatie.

85 Gaskim, par. 36.

86 Gaskin, par. 39.

87 Leander 1. Zmeden, EHRM 26. mant 1987. Serie A vol. 116.

88 Gaskin, par. 40 .

89 Gaskin, par. 41.

90 Het kemen van de 'basic identiry' speelde niet in Leander $\$$. Zweden; het Hof achte de vergelijking in het licht van de vrang naar positieve verplichtingen met die zaak niet mogelijk.

91 Zie de citaten voor retoriek: "it no doubt contained information" en voor metaforen. "principal source", 
Het Hof werkte in Gaskin het belang in de toetsingsfase nader wit vanwege de noodzaak van belangenafweging. Die afweging betrof de belangen van Gaskin tegenover de belangen van de pleegouders. Beide belangen worden namelijk gedekt door Art. $8 . \mathrm{Er}$ was aldus sprake een grondrechtencollisie. De belangenafweging noodzaakte het Hof tot het nader uitwerken van Gaskins belang:

"In the Court's opinion, persons in the situation of the applicant have a vital interest, protected by the Convention, in receiving the information necessary to know and to understand their childhood and development. ${ }^{92}$

Het Hof benadrukte in de toetsingsfase het belang van Gaskin bij het kennen van de gegevens nogmaals. De kwalificatie van Gaskins aanspraak onder Art. 8 had reeds plaatsgevonden in de interpretatiefase. In de toetingsfase werd onderzocht in hoeverre de aanspraak gehonoreerd diende te worden. Het grondrechtsconflict tussen de belangen van Gaskin enerzijds en het recht op geheimhouding van deze gegevens van de pleegouders anderzijds dwong het Hof tot een specifiekere afbakening van Gaskins aanspraak onder Art. 8, teneinde tot een genuanceerde afweging van de belangen in kwestie te kunnen komen. De betekenis van een 'vital interest' werd echter niet uitgewerkt; de juridische status van deze formulering is niet duidelijk.

Een combinatie van toepassing van de normen in Gaskin en die in Niemietz deed zich voor in Mikulic $t$. Kroatie..$^{93}$ In die zaak eiste een buitenechtelijk kind dat de vermoedelijke vader een DNA-test zou ondergaan ter vaststelling van het vaderschap. Het nationale recht maakte dit mogelijk, en het Hof onderzocht in hoeverre een niet meewerken door de vermoedelijke vader aan die test nu een inbreuk vormde op het recht van het kind. De zaak werd beschouwd onder het recht op privé-leven en niet onder het recht op familie- en gezinsleven. Dat privé-leven, aldus het Hof, omvat het vestigen en onderhouden van relaties met anderen. ${ }^{94}$ In dat verband ligt het niet voor de hand dat vestiging wan een (juridische) relatie met de biologische vader wordt uitgesloten. Daarnaast dient het individu in staat te worden gesteld om details van zijn identiteil vast te stellen:

"The Court has held that respect for private life requires that everyone should be allole to establish details of their identity as individual human beings and that an individual's entitlement to such information is of importance because of its formative implications for his or her personality $[\ldots]^{3}, 9.5$

Dit onderdeel in de analoge redenering ter vestiging van het recht van het kind op kennis van de afstamming en mitsdien medewerking van zijn vermoedelijke werwekker roept de vraag op, ten aanzien van welke aspecten Gaskin en in Mikulic nu vergelijkbaar zijn. Het Hof laat de waardering van de vergelijking in het midden. Het kind in Mikuliç was ten tijde van de eerste vraag om een DNA-test nog geen jaar oud, en ten

'such wery basic information' en 'vital interest' (zie voor het citaat in de tekst in de volgende paragraaf).

\section{Gaskin, par. 49.}

Mikuliç t. Kroatië, EHRM 7 februari 2002, EHRC 2002/25.

Dit is het recht dat in Niemietz $t$. Dwitsland werd geconcretiseerd uit het recht op privé-leven ex Art. 8.

Mikwliç t. Kroatiè, EHRM 7 februari 2002, EHRC 2002/25, par. 54. 
tijde van de uitspraak van her Hot 6 jaren oud. Gaskin keek daarentegen terug naar een verleden waarin hij (deels) gevormd was door zijn opvoeders. Dat verleden 'bestond' al, terwijl het kind in Mikulic zijn 'formtive years" nog moest ondergaan. Het leek in Mikuliç te gaan om de kennis van de genetische afstamming terwijl un Gaskin naar de omstandigheden van het milieu waarin hij opgroeide werd gezocht. Het Hof lijkt in deze zaak een abstracte, niet nader uitgewerkte gemeenschappelijkheid tussen Gaskin en Mikulic te danvaarden; deze maakt kwalificatie van Mikuliç op basis van de formule uit Gaskin mogelijk. De gemeenschappelijkheid tussen beide zaken lijkt aldus te zijn gelegen in de vaststelling dat kennis van de afstamming van belang is "because of its formative implications for his or her personality'. De kwestie in hoeverre Art. 8 van toepassing is op de aanspraak van Mikulic, werd door het Hof als volgt benaderd:

"In the Court"s opinion, persons in the applicant's situation have a vital interest, protected by the Convention, in receiving the information necessary to uncover the truth about an important aspect of their personal identity. ${ }^{.66}$

Het "vitale belang" van het kind is kennelijk het aanknopingspunt in de kwalificatie van de aanspraak onder Art. 8; wat onder "de waarheid' en 'belangwekkend aspect van de persoonlijke identiteit' moet worden verstaan laat het Hof aan de verbeelding van de lezer over.

In verband met de persoonlijke identiteit en het recht relaties te vestigen en te onderhouden heeft het Hof het recht op de naam van het individu erkend. Hoewel Art. 8 geen expliciete bepaling bevat ter zake van voornamen, zijn zij een middel van identificatie van personen, evenals achternamen. Zij worden dan ook beschermd onder Art. 8 EVRM in verband met het recht op prive- en gezinsleven. In Burghartz stelde het Hof:

'As a means of personal identification and of linking to a family, a person's name none the less concerns his or her private and family life. The fact that society and the state have an interest in regulating the use of names does not exclude this, since these public law aspects are compatible with private life conceived of as including; to a certain degree, the right to establish and develop relationships with other human beings, in professional or business contexts as in others [...]?

Van belang was, dat de klager zich vanwege de door de staat verplichte achtemaamswijziging belemmerd achtte in zijin professionele leven. Deze belemmering werd veroorzaakt doordat volgens de Zwitserse wet klagers achternaam kwam te vervallen bij de aanvaarding van de achternaan van zijn echtgenote, hetgeen bij naamsbekendheid vanwege publicaties niet van pas $\mathrm{kwam}$. Het handhaven van de eigen naam voor of na die van de echtgenote zou in dit verband geen belemmering opleveren, aldus klager. Het Hof accepteerde het verband tussen het belang van de identiteit via de naam middels een recht op identificatie van afkomst van een familie. Dat aspect inspireerde het Hof als norm van hoger recht bij de invulling van een recht op privé-leven. 
De kwalificatie hield daar echter niet op: het Hof droeg nog een tweetal argumenten aan, die het recht op de naam op Burghartz' aanspraak toespitsen. Deze argumenten vormden belangrijke elementen in de wetsanalogie, ondat zij een recht op de naam vestigden, dat sterk geënt is op de strekking van Art. 8, maar dat evenwel als "nieuw" recht kon worden aangemerkt. Als relevante bronnen van recht voor het vestigen van een recht op de naam werden andere internationale verdragen aangehaald, die allen op een recht op de naam stipuleren: het IVBPR $^{98}$ en de Conventie van de Rechten van het $\mathrm{Kind}^{99}$ werden naar voren gebracht, die beiden in het algemeen ook door de Verdragsstaten van het EVRM zijn erkend. Ook de Amerikaanse Conventie voor de Rechten van de Mens werd door het Hof genoemd. ${ }^{100}$

Het tweede argument voor de erkenming van het recht op de naam wordt gevonden in de uitspraak Niemietz $t$. Duitsland. ${ }^{101}$ Nu vertoont het feitencomplex van Niemietz niet direct overeenkomst met Burghartz, maar aanvaardde het Hof wel vergelijkbaarheid van de individuele aanspraak op de in Niemietz toegepaste norm bij de beoordeling van Burghartz. De vergelijkbaarheid van Niemietz en Burghartz werd gevonden in het recht op bescherming van professionele activiteiten. Burghartz werd ter zake van de erkenning van het recht op de naam onder Art. 8 EVRM voortaan vaste rechtspraak van het Hof. ${ }^{102}$ In Guillot $t$. Frankrijk werd aan het belang van de naam als identificatie in het maatschappelijk leven toegevoegd, dat de naam ook in het privé-leven een eigen betekenis heeft die bescherming verdient onder Art. 8. In Guillot t. Frankrijk speelden. professionele activiteiten in verband met het recht op de naam geen rol meer. ${ }^{103}$

\subsubsection{Aspecten van de leefomgeving}

Het EVRM bevat geen specifiek recht op een behoorlijke kwaliteit van de leefomgeving van het individu. Het Hof heeft zich bij de interpretatie van Art. 8 EVRM echter laten leiden door een norm van hoger recht die inhoudt dat een individu belang heeft bij een 'minimumkwaliteit' van zijn leefomgeving. Het Hof betrok in dat verband met name het genot van de woning ex Art. 8 EVRM bij de vraag, of de aanspraken van het individu onder Art. 8 konden worden gekwalificeerd. In 1990 oordeelde het Hof dat de aanspraak van twee klagers ter zake van sterk toenemend vliegtuiglawaai als gevolg van sterk gestegen economische activiteit op een nabijgelegen vliegveld onder Art. 8 EVRM diende te worden beschouwd:

98 Art. 24 lid 2 IVBPR luid: "Every child shall be registered immediately after birth and shall have a mame"

99 Art 7 lid $\|$ van de Conventie van de rechten van het Kind luidt: "The child shall be registered immediately after birth and shall have the right from birth to a name, the right to acquire a nationality and, as far as possible, the right to know and be cared for by his or her parents". Art. 8 lid 1 لvidt: "States Parties undertake to respect the right of the child to preserve his or her identity including nationality, name and family relations as recognized by law without unl aw ful interference'.

100" Art. I8 van deze Conventie luidt: "Every person has the right to a given name and to the sumames of his parents or that of one of them'.

101. Zie Burghartz t. Zwitserland, par. 24 en Niemietz t. Durisland.

102 Zie Stierna t. Finland, EHRM 25 november 1994, Serie A vol. 299-8, par. 37.

103 Guillot t. Frankrijk, EHRM 24 oktober 1996, NJ 1997/324, par. 22. 
[...] the quality of the applicant's private life and the scope for enjoying the amenities of his home have been adversely affected by the noise generated by aircraft using Heathrow Airport [...]. Article 8 is therefore a material provision in relation to both $\mathrm{Mr}$ Powell and $\mathrm{Mr}$ Rayner".

Het begrip 'home' vormde in de kwalificatie van de aanspraak onder Art. 8 de sluitsteen. het recht op daadwerkelijk genot van de woning wordt geschaad door het lawaai. Het begrip 'home' werd in Powell ruim uitgelegd. In Powell kwam voor het eerst een aspect aan de orde, dat eerder refereerde aan de notie dat van staatswege een kwaliteit van de leefomgeving dient te worden gewaarborgd. Het Hof aanvaardde dat andere aspecten dan enkel het binnendringen van staatswege het begrip 'genot van de woning" konden betreffen. De wetsianalogie werd hier gehanteerd, om aan te tonen dat Art. 8 op dit terrein eveneens positieve verplichtingen kan behelzen. Het Hof knoopte aan bij Rees 1 . Verenigd Koninkrijk, een zaak die wat betreft feitencomplex niet te vergelijken is met Powell, maar waarin het Hof een standaardformulering gebruikt om aan te tonen dat een positieve verplichting kan bestaan. ${ }^{105}$ Voor de legitimatie van de extensieve lezing van het recht op onschendbaarheid van de woning werden verder geen argumenten aangevoerd.

Enkele jaren later werd in Lopez Ostra geklaagd over de stank die een leerlooierij verspreidde in een woongebied. ${ }^{106}$ De staat had een milieuvergunning afgegeven, maar de klagers meenden dat het toestaan van de miliewoverlast een inbreuk vormde op hun recht op ongestoord woongenot ex Art. 8. Hier stond niet langer het begrip 'home' centraal, maar was 's Hofs referentie aan 'privé-leven' centraal in de vaststelling:

\footnotetext{
'Naturally, severe environmental pollution may affect individual's well-being and prevent them from enjoying their homes in such a way as to affect their private and family life adversely, without, however, seriously endangering their health'. ${ }^{107}$
}

Dat leek te duiden op een ontwikkeling: het privé-leven leek een rümere categorie van individuele aanspraken te kunnen herbergen dan het recht op genot van de woning, hetgeen in latere rechtspraak zou worden uitgewerkt. In Guerra $t$. Italie werd eveneens geklaagd over milieuverontreiniging, die consequenties had voor de kwaliteit van de leefongeving van individuen. ${ }^{108}$ Hier hield het Hof niet langer wast aan het begrip "home", maar werd de aanspraak onder het recht op "privé-leven' beoordeeld. In Gwerra bracht het Hof daartoe het begrip van de fysieke integriteit naar voren om de verwijzing naar het prive-leven te versterken:

"giving information to the applicants, all of whom lived barely a kilometre away from the factory, could have had a bearing on their private and family life and their physical integrity" 109

104 Powell en Rayner t. Ferenigd Koninkrijk, EHRM 21 feburari 1990, Serie A vol. 172, par. 40.

105 Powell en Rayner t. Ferenigd Koninkrijk, par. 41.

106 Lopez Ostra t. Spanje, EHRM 9 december 1994, Serie A vol. 303-C, JB 1995/67.

107 Lopez Osira, par. 51.

108 Gwerra t. Vtalie, EHRM 19 tebruari 1998, JB $1998 / 49$ en NJCM-Bulletin 1998, p. 848.

109 Guerra t. Iratie, par. 45. 
Na Powell en Lopez Ostra, waarin het genot van de woning werd bedreigd door respectievelijk geluidsoverlast en stank, kon beoordeling van Gwerra onder de notie "home" worden verwacht. Het liep echter anders, mede omdat de aanspraak op andere wijze was geformuleerd dan in Powell en Lopez Ostra. De beoordeling van Guerra's aanspraak onder Art. 8 EVRM verliep via een omweg: de klagers probeerden hun aanspraak via Artikel 10, een recht op informatie, erkend te krijgen. De klacht hield een aanspraak in op een positieve verplichting van de staat, essentièle informatie over de leefomgeving te verstrekken. Zo zouden de klagers de gezondheidsrisico's die zij liepen vanwege de milieuverontreiniging zelf kunnen inschatten ter zake van het verblijf in de omgeving waarin die milieuverontreiniging was opgetreden. Zij maakten aanspraak op rechtsbescherming ex Art. 10 EVRM, maar het Hof wilde niet zover gaan, een positieve verplichting tot informatieverschaffing door de staat te erkennen onder Art. 10. De Commissie was vooraf evenmin bereid gebleken tot erkenning van de aanspraak onder Art. 10. ${ }^{\text {110 }}$

Uit de uitspraak wan het Hof blijkt echter, dat 8 leden van de Commissie in drie afwijkende opimies pleitten voor beschouwing van de klacht onder Art. 8 EVRM. ${ }^{11 "}$ Het Hof was daartoe bereid, ook al betwistte de Italiaanse regering deze mogelijkheid. Het Hof repliceerde dit bezwaar - onder verwijzing naar Art. 32 EVRM - dat het laatste woord heeft ter zake van meningsverschillen over de rechtsmacht. ${ }^{112}$ Van belang was de opmerking, dat het Hof voor wat betreft de toepasselijke verdragsbepaling niet enkel let op de rechtsgronden die klager aanvoert, maar dat het Hof de bevoegdheid heeft, rekening houdend met de feiten, deze gronden aan te vullen. ${ }^{113}$ Het Hof stelde vast, dat van de vervuilende fabriek een bedreiging uitging naar klagers privé- en familieleven en hun fysieke integriteit en dat voor de staat ter zake een positieve verplichting bestond. ${ }^{114}$ Normen van hoger recht spelen in Powell en López Ostra geen zichtbare rol, omdat het Hof in die zaken redelijk gemakkelijk kon aanknopen bij de terminologie van Art. 8.

De klagers in Guerra brachten hun bezwaren tegen het nalaten van informatieverstrekking door de staat niet onder Art. 8 voor het Hof. De wetsanalogie werd in casu gehanteerd voor de vaststelling, of een positieve verplichting kan bestaan ter zake van Art. 8 . De wetsanalogie in Guerra werd gevonden in de aanknoping bij Powell en Royner; deze vergelijking gaat echter niet over de materiële invulling van Art. 8 maar over het

\10 Guerra t. Malie, ontrankelijkheidsbeslissing 14967/89,6 juli 1995.

111 Guerra t. Ilolie, par. 40.

112 Art 32 lid 2 EVRM: "In geval wan een meningsversichil met betrekking tot de vraag of het Hof rechtsmacht heeft, beslist het Hor.

113 Guerra ti Italië, par. 44.

114. Guerra t. Ilalie, par. 58. Latere toepassingen van Art. B. EVRM in verband met een (dreigende) inbreuk op het recht op een mininnum kwaliteit van de leefomgeving volgden onder meer in McCrinley en Egan 4. Verenigd Koninkrijk, EHRM 9 juni 1998, NJB 1998, p. 1313. In deze zaak werd geklaagd over blootstelling aan radioactivite it, waarbij de staat had verzwegen welke consequenties aan die blootstelling kleefden. Toegang tot informatie was essentieel voor het privé-leven en familieleven ex Art. 8 EVRM. 
standpunt van het Hof dat het bevoegd is, de rechtsgronden - in casu met een recht op prive-leven, omdat daarop oorspronkelijk geen beroep was gedaan - aan te vullen:

In the instant case the grounds based on Articles \& [..] were not expressly set out in the application [...]. Clearly, however, those grounds were closely connected with the one pleaded, namely that giving information to the applicants, all of whom lived barely a kilometre away from the factory, could have had a bearing on their private and family life and their plysical integrity"." 15

Ten slotte deed het Hof in 2001 uitspraak in de Hatton t. Verenigd Koninkrijk. "In deze zaak werd geklaagd over vliegtuiglawaai door omwonenden van de luchthaven Heathrow. Er was een systeem van geluidsquota opgezet, maar dat werd in de loop der tijd overschreden. De Britse rechter achtte uiteindelijk geen grondrecht geschonden, maar het Hof dacht hier anders over: staten zijn verplicht om inbreuken op het recht op privé-leven zo ver als mogelijk te beperken. Staten kunnen zich ter zake van aspecten die gerelateerd zijn aan milieubescherming niet langer beroepen op het belang van het economisch welzijn: de staat dient afdoende maatregelen te treffen om schadelijke effecten zoveel mogelijk te beperken. Deze norm werd afgeleid uit Lopez Ostra. ${ }^{117}$

Vraag is op basis warvan Lopez Ostra kan dienen als vergelijkingsmateriaal voor beoordeling van de undividuele aanspraak in Hattom. Was de economische impact van het beperken van de leerlooierijen in Lorca vergelijkbaar met de beperking van het aantal vliegbewegingen "s nachts op Heathrow? En In welke mate was "s Hofs afweging, dat economische belangen soms moeten terugtreden als het in strijd komt met een recht op privé-leven - terecht? Rechter Kerr liet zich in zijn dissenting zeer kritisch uit over de beslissing van het Hof. In zijn optiek zijn milieubelangen perifere rechten in de sfeer van Art. 8, en kunnen mitsdien niet zelfstandig leiden tot een beperking van het economisch welzijn. Hij bepleitte dat niet een abstract beginsel tot maatstaf verheven diende te worden: dat leidde in onderhavige zaak vooral tot ongeoorloofde rechterlijke discretie bij de vaststelling van rechtsnormen. Er diende in zijn optiek een meer specifieke vergelijking tussen Lopez Ostra en Hatton plaats te vinden, die gebaseerd is op vergelijking van feitencomplexen. ${ }^{18}$ Een meer specifieke wergelijking onder de norm van hoger recht had warschijnlijk geleid tot een onderscheidenlijke waardering van het vergelijkingsmateriaal Hatton en Lopez Ostra: het economisch welzijn dat zich uitte in de activiteiten op de belangrijkste nationale luchthaven was in de Britse zaak van ander kaliber dan de meer locale economische belangen die werden gediend in de Spaanse zaak. In deze zaak komt een onderscheid tussen vergelijking aan de thand van feitencomplexen enerzijds en vergelijking aan de hand van individuele aanspraken naar voren. Het lijkt er daarbij sterk op, dat vergelijking van feitencomplexen eerder een specifieke vergelijkingsmaatstaf opleveren dan vergelijking van individuele aanspraken, die noodzakelijkerwijze een wat abstracter karakter hebben in de context van de

115 Guerrat italie, par. 45.

116 Hatton t. Herenigd Koninkrijk, EHRM 2 oktober 2001, EHRC 2001/79.

117 Hatron t. Herenigd Koninkrijk, par. 94-98.

118 Dissenting rechter Kerr bij Hatron t. Verenigd Koninkrijk. 
vergelijking. Dat hangt samen met het feit, dat de individuele aanspraak is getransformeerd naar een rechtsaanspraak of een aanspraak op een norm waarvan de rechter nog moet onderzoeken of deze wel opgaat onder het geldend recht.

\subsubsection{Hulp bij zelfdoding}

Recentelijk erkende het Hof, zij het met veel reserves, een aanspraak op hulp bij zelf= doding onder het recht op privé-leven. ${ }^{19}$ Klaagster had in het zicht van een naderende verstikkingsdood gevraagd om hulp bij zelfdoding, maar de Britse rechter wees dat verzoek af vanwege wettelijke verboden ter zake. Hij baseerde zich in dat verband vooral op het argument van de constitutionele verhoudingen: ondanks het afschuwelijke vooruitzicht van mevrouw Pretty achtte de rechter zich niet bevoegd om in de bestaande wetten wijzigingen aan te brengen. ${ }^{120}$ Het Hof onderzocht in hoeverre die afwijzing in stand kon worden gelaten onder het EVRM. ${ }^{12 !}$ Het Hof onderstreept dat het recht op privé-leven een norm is die open staat voor rechtsontwikkeling, waarna een opsomming volgt van de reeds onder Art. 8 erkende aanspraken in de jurisprudentie. Aan de basis van Art. 8 ligt een recht van zelfbeschikking van het individu ten grondslag; Art. 8 staat borg voor het kunnen kiezen van een kwalliteit van het leven. ${ }^{122}$

Het Hof maakt een vergelijking van de aanspraak van Pretty onder Art. 8 met de aanspraken in Laskey e.a. t. Verenigd Koninkrijk: in beide zaken is de kwestie aan de orde, in hoeverre de staat rechtmatig kan ingrijpen in de intieme privé-sfeer, meer specifiek in de gekozen levensstijl en de gevolgen van die keuze. In Laskey waren de gevolgen riskant voor de gezondheid van de betrokkenen, terwijl ze in het geval van Prety fataal zouden zijn.

Het Hof stelt twee uitgangspunten die naar zijn oordeel aan het EVRM ten grondslag liggen voorop, namelijk het recht op respect voor menselijke waardigheid en menseUijke vrijheid. Hieruit vloeit onder meer het recht op leven voort, maar het omvat eveneens noties die refereren aan de kwaliteit van het leven die nader worden uitgewerkt onder Art. 8, aldus het Hof. ${ }^{123}$ Die kwaliteit van het leven kan verloren gaan wanneer het individu wordt gedwongen volgens een bepaalde, in dit geval afhankelijke manier te leven: de persoonlijke autonomie komt dan in het gedrang. Het Hof lijkt de aanspraak op een recht op hulp bij zelfdoding onder Art. 8 EVRM te erkennen, maar honoreerde de aanspraak niet. ${ }^{124}$

119 'The Court is not prepared to exclude that this constitutes an interference with her right to respect for private life as guaranteed under Art. 8 par. 1 of the Convention', Preity t. Verenigd Koninkrijk, EHMM 29 april 2002, EHRC 2002/47, par. 67.

120 Zie de overwegingen van de House of Lords die zijn afgedrukt in de uitspraak Pretty t. Verengd Koninkrijk, par. 14.

121 Pretty t. Verenigd Koninkrijk, par. 61-78.

122 Pretty t. Verenigd Koninkrijk, par. 61 en 65.

123 Pretry t. Verenigd Koninkrijk, par. 65.

124 Dat hangt sterk samen met de uitleg die werd gegeven aan Art. 2, het recht op leven; het Hof aanvaardde niet dat daaruit een recht op hulp bij zelfdoding kan voortvloeien. Zie ook verclerop in deze paragraaf. 


\section{HoOFDSTUK 8}

In de toetsingsfase werd door klaagster aansluiting gezocht bij de wijze waarop het Hof met inbreuken op het seksuele privé-leven pleegt on te gaan. ${ }^{125} \mathrm{Zo}$ werd voorgesteld, de vergelijkingsmaatstaf aan de hand waarvan de beoordelingsmarge voor de staat moet worden vastgesteld, te ijken aan de toetsingsmaatstaf die bij het seksuele priveleven pleegt te worden gebezigd. In beginsel wordt bij aanspraken op het intieme seksuele leven een smalle beoordelingsmarge voor de staat toegekend, maar volgens het Hof kan onderhavige zaak niet worden gelijkgestell met aanspraken op de seksuele privé-sfeer. De afwijzing van de vergelijking heeft in casu, al zegt het Hof het niet met zoveel woorden, tot gevolg dat er een ruime beoordelingsmarge voor de staat ontstat: De gebrekkige motivering ter zake van de vergelijking wekt, gezien de bereidheid tot vergelijking met Laskey in de interpretatiefase, wat bevreemdend. Vraag is of het Hof er vanuit galat, dat het forum aanneemt dat seksuele intimiteit en hulp bij zelfdoding niet dezelfde feitencomplexen bestrijken. Wat betreft feitencomplex gaat het natuurlijk om verschillende zaken, maar wat de individuele aanspraken betreft zouden de verschillen wel eens minder groot kunnen zijn. De gemeenschappelijke norm van hoger recht die beide aspecten van het prive-leven beheerst houdt een recht op zelfbeschikking in een zeer intieme privé-sfeer van het individu in.

Van groot belang is hier de contextuele samenhang met Art. 2 EVRM. Klaagster stelde namelijk dat Art. 2 niet alleen het recht op leven beschermt, maar ook een recht omvat om te kunnen kiezen, al dan niet verder te leven. Het Hof wilde een dergelijke lezing niet aan Art. 2 verbinden: Art. 2 is primair bedoeld om burgers te beschermen tegen levensbeneming door de staat, terwijl het daarnaast voor de staat soms een plicht kan impliceren maatregelen te treffen. Vraag in dit verband is of het Hof een negatief aspect aan dit recht wenste te verbinden: omvat het recht op leven ook een recht om te sterven? Het recht op leven zoals neergelegd in Art. 2 heeft geen verband, aldus het Hof, met de kwaliteit van het leven of met hetgeen iemand met zijn leven wenst te doen. Dergelijke aspecten worden beschermd in andere verdragsbepalingen, zoals Art. 8. Een vergelijking met landen die wel hulp bij zelfdoding toestaan leidt evenmin tot een vaststelling van een positieve verplichting ter zake: zelfs wanneer dergelijke wetgeving met Art. 2 verenigbaar is, dan betekent dit nog niet dat de staat in casu zijn verplichtingen schendt door hulp bij zelfdoding niet toe te staan. ${ }^{126}$

\subsubsection{Het recht op menselije wardigheid als grondslag voor opheffing van strafrechtelijke immuniteit}

De afwezigheid van strafrechtelijke immuniteit van de echtgenoot die zijn vrouw verkrachtte werd door het Hof gebaseerd op een norm van hoger recht van menselijke waardigheid. In de zaak $C, R, t$. Verenigd Koninkrijk kwam bij het Hof een klacht over terugwerkende kracht van wetgeving aan de orde. ${ }^{127}$ Tot ver in de jaren 80 vormde

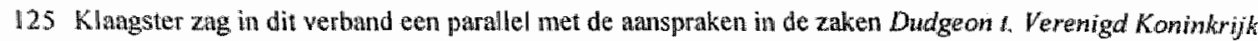
en A.D.T. t. Ferenigd Koninkrik, die hiervoor in par. 8.3 .2 werdem uitgewerkt.

126 Prethy 1. Fepewigd Konimkrijk, par. $37-42$

127 C. R. $t$. Wemenigd Koninkrijk, EHRM 22 november 1995, NJ $1997 / 1$. 
verkrachting binnen het huwelijk in het Verenigd Koninkrijk geen strafbaar feit. In die opvatting kwam echter een kentering aan het begin van de jaren ' 90 . De voortschrijdende ontwikkeling van het strafrecht op basis van rechterlijke interpretatie die uitmondde in aanpassing van de rechtspraak aan de veranderende opvattingen, werd door het Hof in C.R. $t$. Verenigd Koninkrijk niet in strijd geacht met de voorzienbaarheidseisen in Art. 7 EVRM. ${ }^{128}$ De veranderde opvatting ter zake diende echter wel aan te sluiten bij de essentie van het delict en voorzienbaar te zijn, aldus het Hof. Het recht had in het Verenigd Koninkrijk het stadium bereikt waarin het loslaten van de immuniteit van de echtgenoot redelijkerwijze voorzienbaar werd geacht:

\footnotetext{
"The essentially debasing character of rape is so manifest that the result of the decisions of the Court of Appeal and the House of Lords [...] cannot be said to be at variance with the object and purpose of Article 7 of the Convention, namely to ensure that no one should be subjected to arbitrary prosecution, conviction or punishment $[. . .]^{129}$
}

Het afwijzen van de immuniteit van de echtgenoot werd volgens het Hof materieel gerechtvaardigd op basis van het beginsel van menselijke waardigheid en vrijheid. De vraag naar de legitimiteit van de nieuwe interpretatie werd beantwoord aan de hand van die norm van hoger recht:

'What is more, the abandonment, of the unacceptable idea of a husband being immune against prosecution for rape of his wife was in conformity not only with a civilized concept of marriage but also, and above all, with the fundamental objectives of the Convention, the very essence of which is respect for human dignity and human freedom". ${ }^{130}$

In verband met de analogie kan hier worden gesproken van de invulling van Art. 7 lid 1 aan de hand van een norm van hoger recht van menselijke waardigheid. Dat ligt volgens het Hof aan de basis ligt aan het gehele verdrag. De menselijke waardigheid vormt eveneens de grondslag woor de rechtvaardiging van de strafbaarheid van verkrachting door een echtgenoot. Wellicht heeft het Hof hier de schijn willen vermijden, in een strafrechtelijke context gebruik te maken van een analogie. Hantering van analogieên in het strafrecht wordt in beginsel als ongewenst beschouwd vanwege de strenge eis van legaliteit: de rechter vormt immers een ongeschreven strafrechtsregel. ${ }^{13 i} \mathrm{Hij}$ zal moeten aantonen dat de ongeschreven regell voorzienbaar was en deel uitmaakt van het bestaande normenkader.

128 Art. 7 EVRM luidt: lid 1: "Niemand mag worden veroordeeld wegens een handelen of nallaten, dat geen stratbaar feit naar nationaal of internationaal recht uitmaakte ten tijde dat het handelen of nalaten geschiedde. Evenmin mag een zwaardere straf worden opgelegd dan die, die ten tijde van hel begaan van het strafbare feit van toepassing was'. Lid 2: 'Dit artikel staat niet in de weg aan berechiting en bestraffing van iemand, die schuldig is aan een handelen of malaten, dat ten tijde van het handelen of nalaten, een misdrijf ws overeenkomstig de algemene rechtsbeginselen die door de beschafde volken worden erkend:.

129 C.R. t. Verenigd Koninkrik par. 42.

130 C.R. I. Verenigd Koninkrijk par. 42.

:31 Ook: Bruggink 1990, p. 115. 


\subsubsection{Het recht op leven als grondslag woor afwijzing van een beroep op de wet bij verdediging van de staal}

Er is in de context van Art. 7 nog een zaak aan te wijzen, waarin het Hof een analoge benadering gebrukte. In $K-H . W$ t. Duitstand werd geklaagd over terugwerkende kracht van Duitse wetgeving ten aanzien van woormalige $D D R$-soldaten. $Z$ ij dienden in opdracht van hun socialistische regering vluchtelingen die de DDR trachtten te ontwuchten neer te schieten. ${ }^{132}$ De klager in deze zaak was ten tijde van het socialistische regime in de DDR soldaat bij het nationale volksleger, en in die hoedanigheid gedurende enige tijd in 1972 gestationeerd als grensbewaker aan de grens tussen de DDR en de West-Duitse Bondsrepubliek. Tijdens zijn dienst gebruikte hij zijn vuurwapen, om een vluchteling die de DDR wilde verlaten, te verhinderen de grens te passeren. Personen die trachtten het land te verlaten, werden aangemerkt als staatsgevaarlijk, en in de optiek van het oude regime was het neerschieten van dergelijke subversieve individuen gerechtwaardigd. Door het Duitse BGH werd deze soldaat in 1995 veroordeeld tot bijna twee jaren gevangenisstraf vanwege het doodschieten van de vluchteling; het Federale Constitutionele Hof bevestigde deze uitspraak, die niet werd beschouwd als ongrondwettig. ${ }^{133}$ De klacht voor het Hof te Straatsburg luidde, dat de Duitse rechter terugwerkende kracht had verleend aan strafwetgeving, die in 1972 - ten tijde van het neerschieten van de vluchteling - geen gelding had in de DDR.

Het EHRM onderzocht de toenmalige nationale DDR-wetgeving, om te bezien in welke mate het recht op leven van personen die de DDR trachtten te verlaten werd beschermo in de toenmalige DDR-wetgeving, en welke de verplichtingen waren van de grensbewakers. Art. 258 van het DDR-wetboek van strafrecht luidde:

"Members of the armed forces shall not be criminally responsible for acts conmitted in execution of an order issued by a superior save where execution of the order manifestly wiolates the recognized rules of public international law or the written criminal law'.

Vervolgens werd ter invulling van 'the recognized rules of public international law' de in de DDR toepasselijke internationale regelgeving in de redenering betrokken. Het IVBPR, dat het recht op leven in Art. 6 stipuleert, werd door de DDR pas in 1974 geratiliceerd. Het schietincident had echter in 1972 plaatsgevonden. Een argument dat gebaseerd was op dit verdragsartikel zou falen, maar het Hof omzeilde de vraag in welke mate ratificatie van bellang was woor de geldigheid van dit argument met een verwijzing naar Art. 258 DDR-wetboek van strafrecht, dat in de voornoemde zeer algemene termen een recht op leven kon omvatten. ${ }^{134}$ Daarnaast waren in de DDR-constitutie eveneens aanwijzingen te vinden voor het bestaan van een recht op leven. ${ }^{135}$ De belang-

$132 K-$ W. W . Dwitsland, EHRM 22 maart 2001, EHRC 2001/31. Zie ook Mevis 1998, p. 144 e.w. voor cen beschouwing over deze zak uit het oogpunt van de wijze van rechtsvinding.

133 Manerschuraen, 95 BVerfGE 96 (1996).

134 Lie hiena.

135 De DDR-grondwet hield enkele bepalingen in, die in de optiek vam het Hof dat recht omvatten: "These provisions, which therefore expressly included the principle of proportionality and the principle that human life should be preserved, should be also read in the light of the principles enshined in the 
rijkste kwestie was nu, op welke wijze dat recht op leven diende te worden ingevuld. Dat onderzocht het Hof aan de hand wan de - destijds en immer nog geldende internationale rechtsbeginselen. Art. 258 DDR-wetboek van strafrecht liet daartoe in de optiek van het Hof voldoende ruimte:

"The convergence of the above-mentioned instruments is significant: it indicates that the right to life is an inalienable attribute of human beings and forms the supreme value in the hierarchy of human rights, ${ }^{\text {. }}$.

Het Hof doelde met de term 'instruments' op de Universele Verklaring voor de rechten van de Mens van 1948, alsmede op het IVBPR. De in deze verdragen neergelegde bescherming van het recht op leven drong in "s Hofs optiek onder meer door via het hierboven geciteerde Art. 258 DDR-wetboek wan strafrecht, dat sinds 1968 reeds wees op het bestaan van 'recognized rules of public international law'. Hierin las het Hof een erkenning van algemene internationaal aanvaarde rechtsbeginselen. Het schaarde daaronder een soort universeel rechtsbeginsel, dat inhoudt dat het recht op leven de hoogste waarde heeft in de hiërarchie wan mensenrechten. De expliciete erkenning van het IVBPR in de DDR-rechtsorde bleek niet een noodzakelijke voorwaarde voor de gelding van deze rechtsbeginselen; het recht op leven, en de internationale invulling daarvan, golden toch. In de formulering verkreeg dit recht bijna een naturrechtelijke status.

Het Hof spreekt zich niet uit over de vraag welke andere rechten "inalienable attributes' zijn van het individu, of welke normen behoren tot de categorie van universeel geldende normen. In "s Hofs optiek vormde het recht op leven én van deze 'inalienable attributes'. Het Hof leek een rechtsbron te hanteren, die genoemd wordt in Art. 38 lid I sub $\mathrm{c}$ van het Statuut van het Internationale Gerechtshof: als grondslag voor de interpretatie van het recht op leven werd tot uitgangspunt verheven een door de beschaafde naties erkend algemeen rechtsbeginsel. ${ }^{137}$ Met de vaststelling van het bestaan van het recht op leven in de wettelijke bepalingen in het DDR-recht kon het Hof aldus niet vollstaan; het diende de gekozen interpretatie te legitimeren in de context van het EVRM omdat de DDR geen lid was bij het verdrag. Het Hof stelde vast dat de invulling van het recht op leven diende te geschieden aan de hand van Straatsburgse maatstaven, en niet naar de maatstaven zoals die zouden zijn toegepast door een rechter in de voormalige DDR. Met de vaststelling, dat het recht op leven in de DDR gold zoals dat geldt in 'beschaafde naties', kon het Hof de veroordeling van de soldaat door het Federale Constitutionele Hof toetsen aan de vereisten van legaliteit ex Art. 7 EVRM.

Constitution of the GDR itself. Article 89 par. 3 of the Constitution provided: "Legal rules shall not contradict the Consitution"; Article 19 par. 2 provided: "Rhespect for and protection of the dignity and liberty of the person are required of all State bodies, all forces in society and every citizen"; lastly, Article 30 paras. 1 and 2 provided: "The person and liberty of every citizen of the German Democratic Republic are inviolable" [...]', zie overweging 56 in K-H.Wt. Duitsland.

136 K-H.Wt. Duitsland, par. 96.

137 De casus werd door het Hof echter niet beoordeeld onder Art. 7 lid 2 EVRM (K.-H.W. t. Duirslond, par. 114). De wijze wan rechtsvinding doet echter well sterk denken aan toepassing wan Art. 7 lid 2. 
Daarnaast beoordeelde het Hof eveneens de aansprakelijkheid van de individuele soldatat, die orders opvolgde van de staat. Bij die beoordeling nam het Hof het intemationailirechtelijke recht op leven tot uitgangspunt en oordeelde, dat zelfs waar een gehoorzaamheidsplicht bestaat ter zake van statelijke orders, een soldaat niet of niet geheel vrij te pleiten is van zijn eigen verantwoordelijkheid. Hij kon of had kunnen weten dat het neerschieten van ongewapende vluchtelingen in flagrante strijd was met de nationaalrechtelijke en internationaalrechtelijke normen. Hiermee beoordeelde het Hof de voorzienbaarheid van de straf; in dit opzicht was Art. 7 EVRM evenmin geschonden." ${ }^{138}$

Deze uitspraak duidt aan dat de interpretatiefase zeer beslissend was. Het recht op leven fungeerde hier als norm van hoger recht voor de beantwoording van de vraag, of DDR-recht kon worden geinterpreteerd met die norm van hoger recht. Indien het recht op leven niet als richtinggevende norm was gehanteerd, had vaststelling van schending van het legaliteitsbeginsel ex Art. 7 EVRM eerder voor de hand gelegen. De dissentings en concurrings in het Hof ageerden over het algemeen tegen de mate van verantwoordelijkheid van de soldaat voor zijn daad binnen het bewakingssysteem. Een dissenter was kritisch over de door het Hof gegeven interpretatie van het recht op leven:

"According to the dominant ideology at the time in the GDR, and to the world view and outlook on life which prevailed there, the applicant ${ }^{2} s$ action, though regrettable, as I must reiterate, was regarded not as a crime but as a praiseworthy deed. 139

Deze rechter pleitte voor de meer objectief-historische benadering van het recht. De loop der dingen in deze zaak zou daarvoor kumnen pleiten: de soldaat was destijds voor zijn handelen beloond; hij kreeg een bonus voor zijn actie en werd gelauwerd met een onderscheiding. ${ }^{\star \$ 0}$ Indien een objectief-historische interpretatiemethode was gevolgd, was de beslissing voor wat betreft de legaliteit van de straf waarschijnlijk anders uitgevallen. Of dit correct zou zijn geweest in het licht van het positieve recht vait te bezien: het Hof heeft zijn invulling van de norm van hoger recht juist de indruk willen geven, dat het oordeelde aan de hand van de normen die destijds ook al golden. De vraag rijst dan, of in de objectief-historische benadering de invulling van het recht op leven van de toenmalige DDR-rechtsorde had moeten worden gevolgd, of die van de destijds kennelijk al geldende normen van international recht. Bepleit kan worden, dat de regeling zoals die destijds binnen de DDR-rechtsorde gold, ook al in strijd was met de geldende normen van intermationaal recht.

Het Hof beoordeelde eveneens aanspraken van personen die participeerden in de besluitvorming op het gebied van de grenspolitiek, en hield dezelfde redeneerwijze aan ter zake van de invulling van het recht op leven. ${ }^{14} \mathrm{Zij}$ waren volgens het Hof, gezien

138 K lager was door de Duitse rechter veroordeeld tot een jaar gevangenisstraf. Belangrijke aanle iding voor de strafverlaging was het feit dat klager bevelen moest opwolgen. Dat pleitte hem echter niet geheel vrij van zijn werantwoodelijkheid. In casu werden de zogenoemde 'Radbruch'sche Formel' toegepast (zio "matwurrechtsleer" in par. 4.7.2).

139 Dissenting van rechter Barreto bij $K-K$. W I Durishand.

140 K.H. W L Duisland, par. 17.

141 Sireletz, Kessler en Krenz \#. Duisiand, EHRM 22 maart 2001, nis. 34044/96, 35532/97 en 44801/98. 
hun verantwoordelijke positie, echter goed op de hoogte van de rechten van het individu in internationaalrechtelijk verband en konden zich mitsdien niet beroepen op een niet-weten. In de uitspraken over de reikwijdte van Art. 7 gaf het Hof invilling aan de materiele eis van legaliteit en voorzienbaarheid van een wet. De invulling van die maatstaf vond plaats aan de hand van normen van hoger recht: in $C . R$. $t$. Verengig Koninkrijk het rechtsbeginsel van menselijke waardigheid, dat ten grondslag ligt aan de gehele Conventie, in $K .-H . W t$. Duitsland het rechtsbeginsel van het recht op leven zoals dat geld in het rechtsbewustzijn in beschaafde naties. De vraag in welke mate de rechter een ongeschreven strafrechtsregel 'vindt', lijkt in deze uitspraken in zoverre van belang, dat het Hof zijn best doet de schijn te vermijden dat het op creatieve wijze aan het interpreteren is door aan te knopen bij beginselen, die het plaatst in het kader van de algehele Conventie of in het kader van internationaal recht. Het Hof laat zich uit ower de constitutionele normenhièrarchie voor zover dat noodzakelijk is voor de waardering van de in het geding zijnde rechten en verplichtingen.

\subsection{Bevindingen}

Voordat het Hof te Straatsburg kan worden verzocht om een uitspraak, dient de klager eerst de nationale rechtsgangen te hebben uitgeput. In bijna alle zaken deden de klagers een beroep op Art. 8 EVRM, meer specifiek op het recht op privé-leven. Er deed zich in een aantal gevallen een bijzonderheid voor; in Dudgeon t. Verenigd Koninkrijk leek er bijvoorbeeld sprake van een abstracte toetsing door het Hof. Er was namelijk nog geen sprake van vervulling van het slachtoffervereiste. Het Hof interpreteerde dat vereiste echter op rekkelijke wijze. ${ }^{142}$ Guerra $t$. Italië arriveerde niet bij het Hof onder Art. 8, maar onder Art. 10 EVRM. De daarin geponeerde aanspraak op een recht op essentiële informatie van de overheid over de leefomgeving werd door het Hof op eigen initiatief onder Art. 8, in het bijzonder het recht op privé-leven en gezinsleven, beschouwd. Uitzonderingen ter zake van de aanspraken op Art. 8 zijn de zaken C.R. $t$. Verenigd Koninkrijk en K.-H.W. t. Duitsland; in deze zaken werd de klacht geformuleerd onder het legaliteitsbeginsel ex Art. 7 EVRM. Deze uitspraken zijn, hoewel ze niet gaan over interpretatie van het begrip privé-leven toch betrokken in de beschouwingen omdat het Hof in deze zaken een rechtsnorm heeft erkend, dat niet is gestipuleerd in het verdrag (C.R. $t$. Verenigd Koninkrijk) of dat vanwege tijdverloop niet van toepassing was op het feitencomplex $(K .-H . W . t$. Duitsland $)$. In dat opzicht onderscheiden de te interpreteren rechtsnormen in deze zaken zich van de rechtspraak ter zake van het recht op privé-leven: dat is wel neergelegd - in bewoordingen, niet in precieze

142 In Klass t. Duitsland had het Hof gesteld dtat het geen abstracte toetsing zal uitvoeren (Klass t. Duirsland, EHRM 6 september 1978, Serie A vol. 28, par. 33). In Aarckx t. Belgte werd vervolgens een soort 'uitzonderingsregel' op deze algemene regel geconstrueerd: "Articts 25 of the Convention entitles individuals to contend that a law violates their rights by itself, in the absence of an individual measure of" implementation, if they run the risk of being directly affected by it" (Marckx $t$. Belgie, EHRM "13 juni 1979, Serie A vol. 31, par. 27). In de kwestie in Dudgeon was niet sprake van een constante omwettigheid wan de handelingen; de wet werd immers niet toegepast. Het Hof achtte echter de mogelijke effecwieve criminalisering voldoende grond on slachtofferschap aan te nemen. 
strekking - in het verdrag. Verder werd een aantal aanspraken aangebracht onder een recht op onschendbaarheid van de woning. ${ }^{143}$ Later werd een aantal feitencomplexen Guerra t. Italie en Jane Smith t. Verenigd Koninkrijk - onder het recht op privé-leven gekwalificeerd, terwijl de kwalificatie, gezien een aantal precedenten, onder onschendbaarheid van de woning voor de hand had gelegen. ${ }^{144}$ Privé-leven bood het Hof in die zaken echter een ruimer beoordelingskader dan onschendbaarheid van de woning of recht op gezinsleven. Het Hof wijzigde de aanspraak op dat punt zelfstandig. ${ }^{145}$

Het karakter van de klachten varieerde - in verschillende zaken werd geklaagd over afwezigheid van wetgeving, terwij】 in een ongeveer gelijk aantal werd geklaagd over bestaande wetgeving die strijdig zou zijn met het EVRM. Opvallend maar ook vanzelfsprekend is de afwezigheid van horizontale conflicten. Het Hof beoordeelt schendingen van het verdrag door staten, niet door andere individuen. Toch kan het Hof indirect wel iets zeggen over horizontale verhoudingen, namelijk via de positieve verplichtingen die een staat heeft ter zake van het recht op privé-leven. Een staat dient voldoende te waken over de aspecten van het privé-leven van het individu; andere individuen kunnen daar, indien er niet voldoende waarborgen bestaan, heel wel inbreuken op maken. Aan de staat is het om daar een einde aan te maken. Sommige zaken, zoals bijvoorbeeld Airey t. Verenigd Koninkrijk, X en Y t. Nederland, Gaskin t. Verenigd Koninkrijk en Mikuliç t. Kroatie leken horizontale aspecten in zich te dragen. Het Hof beoordeelde deze zaken via de positieve verplichtingen.

\subsubsection{Ontwikkeling van de grondslag voor de normen van hoger recht}

Het recht op privé-leven bleek aanzienlijke ruimte te bieden als aanknopingspunt voor de positivering van afgeleide individuele rechten. De eerste expliciete aanwijzing in de rechtspraak van het Hof, voor de extensieve interpretatie van het begrip 'privé-leven' is te vinden in Airey t. Ierland in 1979. Een motivering voor de extensieve lezing ontbrak, maar dat verhinderde niet dat die uitspraak naderhand een belangrijke aanleiding vormde voor de vestiging van veel meer positieve verplichtingen onder het recht op privéleven. ${ }^{146}$ De ontwikkeling van het begrip positieve verplichtingen onder het recht op privé-leven kwam niet onmiddellijk na Airey op gang; ruim vijf jaren later vestigde het Hof een nieuwe positieve verplichting in $X$ en $Y t$ t. Nederland. ${ }^{147}$ De positieve ver-

\43 Powell en Rawnex t. Verenigd Kominkrijk, EHRM 21 februari 1990, Serie A vol. 172 en Lopez Ostra t. Spanje, EHRM 9 december 1994, Serie A vol. 303-C, JB $1995 / 67$.

144 Lopez Ostra t. Spanje. EHRM 9 december 1994, Serie A vol. 303-C (stank van leerlooierij) en Buckley 1. Verenigd Koninkrijk, EHRM 25 september 1996 (feitencomplex zeer vergelijkbaar met Jane Smith's feitencomplex). Guerra t. Italie, EHRM 19 februari 1998, JB 1998/49 en Jane Smith t. Verenigd Koniakkrjk, EHRM 18 januari 2001, EHRC 2001/19.

145 In Guerra $t$. Iralie verliep dat niet zonder problemen; de staat achtte het Hof hiertoe niet bevoegd. Zie par. 8.3.6.

146 Strikt formeel geredeneerd werd in Airey 1. Ierland de positieve verplichting opgehangen aan Art. 6 EVRM.

147 Andere zaken waarin het Hof nieuwe rechten positiveerde uit de positieve verplichtingen in het kader van het recht op privé-leven ex Art. 8 EVRM: onder meer $X$ en $Y$ t. Nederland; Rees, $t$. Verenigd Koninkrijk; Gaskin t. Verenigd Koninkrijk; Powell en Rayner t. Werenigd Koninkrijk; Cossey t, Verenigd 
plichtingen en de rechten die daaruit voortvloeien hebben ook tot gevolg gehad, dat niet alleen verticale, maar ook horizontale geschillen tot de jurisdictie van het Hof konden worden gerekend. Voorafgaand aan Airey had het Hof in Marckx $t$. Belgiè al aangegeven, dat het verdrag niet alleen een onthoudingsplicht stipuleert maar ook, wil een effectief respect voor het gezinsleven kunnen worden gegarandeerd, positieve verplichtingen.

Een belangrijk sleutelbegrip voor de hypothese van het bestaan van positieve verplichtingen is het effectiviteitsbeginsel. Het recht op privé-leven in Art. 8 EVRM is in beginsel geredigeerd als onthoudingsplicht. In rechtspraak voorafgaand aan Airey had wooral ook de Commissie al een ruimere uitleg aan het recht op privé-leven gegeven. Het Hof duidde in Airey aan dat de rechten in het verdrag niet illusoir dienen te zijn, maar ook werkelijk - effectieve - bescherming aan het individu moeten kumnen bieden. Het beginsel van de effectieve bescherming verleende aan de uitleg van verdragsrechten een ongekende dynamiek. Omdat de consequenties die uit de eis van effectiviteit voortvloeien nog nader moeten worden geconcretiseerd, bestaat in dit verband een zekere beoordelingsruimte voor het Hof ten aanzien van de reikwijdte van het recht dat aan de orde is het concrete geschil. Samen vormen positieve verplichtingen en het effectiviteitsbeginsel twee interpretatiemechanismen, die het mogelijk maken om aan het betreffende recht een variabele betekenis toe te kennen - afhankelijk van het concrete geschil dat voor de rechter ligt. De aard van de individuele aanspraak en het individu zijn bijvoorbeeld factoren, die van invloed zijn op de vaststelling van de reikwijdte van het recht. 's Hofs afbakening van verschillende sferen, zoals in Niemietz weergegeven, wijst op deze benadering.

Niemietz t. Duitsland bleek een belangwekkende uitspraak voor de vestiging van de grondslag voor een extensieve interpretatie van het recht op privé-leven ex Art. 8 EVRM. Het recht op het vestigen en onderhouden van relaties vloeit voort uit het recht op privé-leven. Dat bleek naderhand een aanknopingspunt te bieden voor de erkenning van aanspraken die op het eerste gezicht niet onder Art. 8 te kwalificeren waren. Niemietz werd daarbij consequent aangehaald als uitgangspunt voor de extensieve lezing van het recht op privé-leven. De uitspraak is van belang voor de extensieve interpretatie omdat het Hof in deze uitspraak expliciet aangaf, het begrip 'privé-leven' niet te willen beperken tot een Angelsaksische notie van privé-leven waarin de nadruk ligt op geheimhouding van persoonlijke informatie en de mogelijkheid wan het individu te kiezen voor afzondering. ${ }^{148}$ De jurisprudentie laat echter zien dat het Hof, en dat geldt voor enkele ontvankelijkheidsbeslissingen van de Commissie, ruim vóór Niemietz deze opvatting ter zake van het privé-leven al eerder was toegedaan. In de recente uitspraak over het recht op hulp bij zelfdoding gaf het Hof een overzicht van de stand van zaken in de jurisprudentie. Het Hof stelde dat het recht op respect voor menselijke waardigheid en menselijke vrijheid, alsmede een notie van persoonlijke autonomie ten grondslag liggen aan de rechten van het EVRM. Het erkende expliciet dat daarmee een norm

Konimkrijk en Burghartz t. Zwitserland.

148 Harris, O Boyle en Warbrick 1995, p. 305-6. 
wan hoger recht op zelfbeschikking aan de basis ligt van de rechten in het EVRM. Dat leidde het Hof af wit de positiveringen die vooraf zijn gegaan aan Pretty: het laat op fraaie wijze zien hoe het Hof uit een inductieve benadering van reeds gepositiveerde aanspraken een dergelijk rechtsbeginsel afleidt.

De onderzochte rechtspraak ter zake van het legaliteitsbeginsel heeft geleid tot positivering van níeuwe noties die leiden tot concretiseringen die uiteindelijk staten binden en kunnen leiden tot een inperking van individuele aanspraken op grondrechten. Om te kunnen komen tot een beoordeling van de toelaatbare terugwerkende kracht van rechtsnormen, betrok het Hof materiêle normen in zijn beschouwingen, die tot dusverre niet in het verdrag zijn opgenomen. Uit normen van hoger recht kunnen eveneens verplichtingen voort voor staten en hun burgers voortvloeien, ook al hebben de staten de relevante verdragen waarin het recht op leven is vastgelegd, niet geratificeerd. In beide zaken positiveerde het Hof overigens niet de individuele aanspraken zoals die door de klagers aan het Hof waren voorgelegd; zij beriepen zich op Art. 7 EVRM. De normen die het Hof formuleerde uit de normen van hoger recht van menselijke waardigheid en uit het recht op leven keerden zich namelijk als het ware 'tegen' de klagers.

\subsubsection{Het recht op persoonlijkheid: concretiseringen}

Het Hof heeft tot dusverre nooit een limitatieve opsomming willen geven van de positieve verplichtingen die voortwloeien uit het begrip privê-leven ex Art. 8 EVRM. ${ }^{149}$ Het Hof lijkt in dit verband koers te kiezen die casuilstisch georienteerd is. ${ }^{150}$ Dat houdt echter niet in dat er geen algemene uitspraken worden gedaan over de systematiek van de rechten in het verdrag of de normen van hoger recht. Het Hof lijkt met algemene opmerkingen over het systeem van het EVRM echter wel enigszins terughoudend om te springen; wooral wanneer het zich genoopt ziet om kwalificaties van aanspraken te motiveren kan het Hof soms genegen zijn om de erkenning van de aanspraak in een ruimer kader te plaatsen. In Niemietz en Pretry gaf het Hof blijk van meer algemene bespiegelingen over het systeem van de Conventie. Tot dusverre heeft het Hof bijna alle aanspraken erkend. De aanspraak van Botta bleek een uitzondering: die was te weinig bepaald om bij het recht op privé-leven te kunnen aanknopen.

Vanwege een recht om relaties te kunnen vestigen en te onderhouden werden naderhand andere aanspraken onder privé-leven erkend. Het recht op een naam, het recht de identiteit van de biologische vader te kennen vormden andere concretiseringen uit die norm. Er lijkt vooral een rationalisatie van de gelding van de norm achteraf plaats te vinden. In Pretty werd een recht op zelfbeschikking erkend en een notie van persoonlijke autonomie. De uitspraak is van zo recente datum dat nog geen uitspraken over concretiseringen daaruit kunnen worden gedaan. De andere aanspraken volgden niet uit een zichtbare constructie zoals dat het geval was in Niemietz. Het recht op geestelijke en fysieke integriteit vloeide voort uit 'fundamental values and essential aspects of

149 Harris, O'Boyle en Warbrick 1995, p. 303; Niemierz t. Duitsiand, par. 29.

150 Abdulaziz, Cabales en Balkondali, EHRM 28 mei 1985, Serie A wol. 94, par. 67. 
private life'; volgens rechter Martens wloeide het recht op erkenning van de geslachtelijke identiteit voort uit menselijke waardigheid en het recht op ontwikkeling van de persoonlijkheid $^{151}$ en positivering van de culturele identiteit volgde volgens het Hof uit een aantal internationaalrechtelijke bronnen en vormde de grondslag voor de erkenning van de nomadische levensstijl van zigeuners. De kennis van de persoonlijke identiteit volgde uit een grondslag die niet nader te definiëren lijkt; het Hof gebruikte daar voornamelijk een op retoriek en metaforen geschoeide redenering. Milieubelangen lijken nu ook deel uit te gaan maken van het recht op privé-leven; de kwalificatie van dergelijke aanspraken volgde uit een constructie van het recht op privé-leven en recht op fysieke integriteit.

Het recht op privé-leven wordt door het Hof steeds extensief uitgelegd. ${ }^{152}$ Aspecten van bijvoorbeeld de identiteit van een individu en het daarmee verbonden recht op respectvolle bejegening vallen onder privé-leven. Daartoe nodigt de formulering van Art. 8 EVRM ook enigszins uit: de aspecten die onder het meer 'traditionele", Angelsaksische begrip van privé-lleven vallen, worden benoemd als aparte categorieën van het privéleven. Het Hof heeft niet expliciet geuit, hoe het de verschillende rechten in Art. 8 ten opzichte van elkaar positioneert; het begrip privé-leven is niet perse een overkoepelend recht waaruit de andere rechten deelaspecten vormen, maar de wijze waarop het Hof de specifieke rechten uit Art. 8 hanteert sterkt dat vermoeden echter wel. Het Hof bezigt een enigszins pragmatische benadering; in Marckx t. België sprak het Hof nog van een 'inbreuk op het privé- en gezinsleven'. ${ }^{53}$ In Jane Smith maakte het Hof later echter wel een onderscheid tussen woning en privé-leven: het privé-leven kon meer omvatten dan het recht op onschendbaarheid van de woning. Privé-leven is evenmin een statisch begrip; de mogelijkheid van een evolutieve benadering van verdragsrechten is in de jurisprudentie een aantal keren expliciet geuit door het Hof. ${ }^{154}$ Wanneer een dynamischevolutieve lezing van het recht op privé-leven wordt gebruikt, lijkt het Hof naar een consensus over de uitleg van dat recht op zoek te gaan. ${ }^{1.55}$

In 's Hofs rechtspraak is de interpretatiefase, waarin wordt besloten de individuele aanspraak wel of niet te beoordelen onder het recht op privé-leven, in beginsel steeds te onderscheiden van de toetsingsfase. In de gevallen waarin het Hof een feitencomplex beoordeelde, dat zich op het eerste gezicht niet direct leek te lenen woor kwalificatie onder privé-leven, werd relatief veel ruimte besteed aan de rechtvaardiging van die $k$ walificatie. Daarnaast vond in sommige gevallen nog een nadere precisering van de aanspraak in de toetsingsfase plaats. In Gaskin was de individuele aanspraak in de interpretatiefase erkend, maar in de toetsingsfase vond nadere afbakening plaats in verband met de noodzakelijke belangenafweging tussen de aanspraak van Gaskin en de rechten van zijn pleegouders. Opvallend is dat het Hof steeds bereid is individuele

151 Het Hof volgde dit standpunt niet, zie par. 8.3.2.

152 Zie ook Costello-Roberts t. Verenigd Koninktijk, EHRM 25 maart 1993, Serie A vol. 247-C par 36

153 Marckx $t$. België, par. 30.

154 Marckx t. Begiè, par. 41 en 48.

I55 Zie bijvoorbeeld de reeks over de erkenning van de geslachtelijke identiteit van transiseksuellen. 
aanspraken te erkennen; met de honorering van die aanspraken is het echter minder scheutig. Dat hangt tot op zekere hoogte samen met twee zaken. Allereerst is er de samenhang met het mandaat op het terrein van fundamentele rechten: het Hof hanteert de benadering ten faveure van de individuele rechtsbescherming. $\mathrm{De}$ " margin of appreciation" warmee het Hof tegemoet kan komen aan de constitutionele verhouding tussen het Hof en de nationale autoriteiten bevindt zich echter in de toetsingsfase.

\subsubsection{De analoge redenering}

Het Hof hanteerde in de onderzochte rechtspraak steeds een wetsanalogie. Dat lijkt voor de hand te liggen, omdat de open formulering van het recht op privé-leven ex Art. 8 het Hof de gelegenheid biedt voor erkenning van uiteenlopende aanspraken. Hierbij dient evenwel te worden aangetekend dat het Hof aan het recht op privé-leven eveneens een enge uitleg had kunnen geven. Het Hof benadert de rechten in de Conventie, afgaand op de onderzochte zaken, in contextuele zin en niet als een lijst specifieke rechten. Wanneer extensieve interpretatie - afgaand op de formulering en de bedoeling van de verdragswetgever - zeer wel mogelijk was, zag het Hof zich soms genoodzaakt om de extensieve lezing van Art. 8 kracht bij te zetten met argumenten ontleend aan de normen van hoger recht. De analogie biedt hiertoe zoals de rechtspraak laat zien, mogelijkheden.

Er is een aantal heldere analogieën gewonden in de rechtspraak van het Hof. Voor de rechtvaardiging van het bestaan van de norm van hoger recht werd steeds naar de eigen rechtspraak verwezen. Dat ligt voor de hand: ook het Hof hecht in het algemeen grote waarde aan precedentenwerking van zijn uitspraken. ${ }^{156}$ De feitencomplexen van de aangehaalde jurisprudentie en van het voorliggende geschil behoefden niet overeen te stemmen om tot vaststelling van een norm van hoger recht te kunnen komen. Overeenstemming van de individuele aanspraken lijkt belangrijker te zijn. De vergelijkbaarheid werd in sommige gevallen niet nader gemotiveerd, hetgeen leidde in een enkel geval tot grote onvrede onder aissenters. Het Hof lijkt er bij summiere motivering vanuit te gaan dat het forum als vanzelfsprekend de door het Hof opgebouwde redenering volgt, en dat alternatieve benaderingen van de individuele aanspraak niet voor de hand liggen. In sommige gevallen werd de redenering met dat doel kracht bijgezet met behulp van metaforen en retorische formuleringen, waardoor de door het Hof gekozen benadering de enige correcte lijkt. Tot op zekere hoogte kan dat te maken hebben met een kwetsbaarheid die verbonden is aan positivering van individuele aanspraken als geldend recht: de rechter voegt een nieuwe witleg toe, hetgeen zou kunnen duiden op een activistische benadering. Het gaat bij de analogie steeds om de legitimatie van de norm van hoger recht ter zake waarvan de verdragswetgever geen expliciete regels heeft vastgelegd. Niet motiveren maakt het Hof eveneens kwetsbaar. Een juridische motivering gebaseerd op erkende rechtsnormen of op precedenten die concreet aanknopen bij het voorliggende geschil is niet steeds mogelijk. De afwezigheid van deze motivering 
wordt tot op zekere hoogte gecompenseerd met retoriek en metaforen. Vraag is, in welke mate de argumenten overtuigen.

Een uitgesproken voorkeur voor een concrete vergelijkingsmaatstaf is niet aangetroffen in de onderzochte rechtspraak, afgezien van de dissenting van rechter Matscher bij Dudgeon t. Verenigd Koninkrijk en die van rechter Kerr in Hatton t. Verenigd Koninkrijk. ${ }^{\text {is7 }}$ Hij pleitte voor een specifieke benadering, die tot gevolg zou hebben gehad dat Lopez Ostra en Hatton onderscheidenlijk beoordeeld zouden zijn op het punt van het gewicht van de economische belangen. De toepassing van abstracte normen van hoger recht leidde steeds tot de erkenning van de aanspraken. Kortom: het Straatsburgse Hof is ruimhartig met de erkenning van individuele aanspraken, die via wetsanaloge redeneringen worden gelegitimeerd. De ruimhartigheid in de erkenningen kan echter worden gerelativeerd in de toetsingsfase: in die fase zijn verschillende mechanismen aan te wijzen waarin het Hof kan inspelen op de constitutionele verhouding tussen Hof en nationale autoriteiten. ${ }^{158}$ Met name de beoordelingsmarge is in dit verband van belang. Het mandaat zoals neergelegd in het verdrag en de rechterlijke uitwerking ervan in de jurisprudentie laat de aanwezigheid van een aantal verschuifbare maatstaven zien die ertoe leiden uit erkenning van een aanspraak niet tevens een honorering volgt. Daarmee is niet gezegd dat het erkende mar niet gehonoreerde recht geen rechtsgeldigheid bezit. Herhaling van erkenning van normen zonder honorering, zoals in Goodwin $t$. Verenigd Koninkrijk, kan op den duur onder invloed van veranderende opvattingen wel leiden tot gelding in het recht. Het recht op hulp bij zelfdoding is niet erkend als geldend recht, maar wel kan worden gesteld dat het is gepositiveerd in de jurisprudentie van het Hof. Het is echter niet precies helder, welke de juridische status is: over de 'gelding' van het recht kunnen geen zekere uitspraken worden gedaan. De onzekerheid over de juridische status bestaat ook ten aanzien van het recht op zelfbeschikking zoals in Pretty gepositiveerd. De gelding en de afdwingbaarheid staan allerminst vast. Daarmee is de voorspelbaarheid voor het rechtszoekende individu niet direct gediend; het lijkt hier niet om rechtens afdwingbare normen te gaan.

\subsubsection{Terminologie}

Het Hof is niet steeds eenduidig in de terminologie die wordt gehanteerd in de wetsanalogie. Het niet hanteren van eenduidige termen in het proces van de rechtsvinding is éen van de aspecten die dat proces minder transparant maken. Het achterwege laten van de motivering waarom zaken vergelijkbaar zijn vanuit het gezichtspunt van de norm van hoger recht zijn daar mede debet aan. Het Hof spreekt niet altijd even consequent van 'rechten' die worden geconcretiseerd vanuit een norm van hoger recht. ${ }^{159}$ Ter zake van de toepassing lijkt er tot dusverre niet echt sprake van grote inconsis-

157 Zie par. 8.3.6.

158 [n vergelijikbare zin Wiarda 1986

159 De norm van hoger recht wordt niet in die termen aangeduid. In Pretty sprak het Hof achtereenvolgens over een 'recht' op zelfbeschikking, over een 'notie' van persoonlijke autonomie dat als teén van de vooraanstaande beginselen ten grondslag ligt aan de uilleg van de waarborgen in het verdrag, en over een 'essentie' van menselijke waardigheid. 


\section{Hoofostuk 8}

tenties, mar das hangt tot op zekere hoogte ook samen met het feit dat het Hof de karakterisering wan de normen in het algemeen vaag houdt. Dat kan soms handig uitkomen: rechtsnormen die eerst in de toepassing als rechtsregel door het leven gaan, kunnen wanneer dat aangewezen lijkt worden getransformeerd tot rechtsbeginsel. ${ }^{160}$ Uit een rechtsbeginsel liggen nadere concretiseringen eerder voor de hand dan uit ean rechtsregel.

160 Zoals bijwoorbeeld in Niemietz: daar werd het recht op privé-leven, dat in beginsel wordt aangemerkt als een rechtsregel ${ }_{\text {}}$ gehanteerd als een rechtsbeginsel waaruit naast de benoemde concretisering ook andere, nog niet benoemde concretiseringen kunnen voortvloeien. 


\section{Hoofdstuk 9}

\section{Analoge rechtsvinding in de jurisprudentie van de Hoge Raad}

\section{$9.1 \quad$ Inleiding}

Grondrechten uit de grondwet kunnen vanwege het toetsingsverbod geen uitkomst bieden wanneer een wet in formele zin strijdig wordt geacht met een bepaling uit de grondwet. In dergelijke gevallen wordt in het algemeen, indien mogelijk, steeds aangeknoopt bij een eenieder verbindende verdragsbepaling. In de regel worden het EVRM en het IVBPR ingeroepen; in verband met aanspraken op het recht op persoonlijkheid vormt Art. 8 EVRM het belangrijkste aanknopingspunt. In een aantal gevallen werd de grondrechtelijke aanspraak ingekleed in éfn van de civielrechtelijke open normen; deze figuur deed zich met name voor wanneer sprake was van een horizontale verhouding. Hiertoe lenen zich verschillende civielrechtelijke bepalingen, zoals bijvoorbeeld de onrechtmatige daad ex Art. 6:162 BW. Grondrechten werken in deze aanspraken indirect door, omdat zij invulling geven aan de open privaatrechtelijke norm.

De Hoge Raad heeft aan grondrechten die gerelateerd zijn aan een recht op persoonlijkheid zowel via aanspraken op de grondwet als via civielrechtelijke bepalingen uitwerking gegeven. Het onderscheid tussen directe en indirecte aanspraken op grondrechten wordt gehandhaafd bij het bespreken van de jurisprudentie. Grondrechten hebben in verticale verhoudingen onverkorte gelding. In horizontale verhoudingen gelden echter andere toepassingsregels, met name wat de beperkingsmechanismen en de rechtvaardiging van een eventuele inbreuk op het grondrecht betreft. ${ }^{1}$ Indien de grondwet de in verticale verhoudingen toe te passen beperkingsmechanismen heeft omschreven, zal de rechter in een horizontale verhouding moeten nagaan in welke mate deze mechanismen zijn toe te passen in een conflict tussen individuen. De rechter zal in deze categorie conflicten een belangenafweging hanteren, om te komen tot oplossing van het geschil. Voor de juiste belangenafweging zijn in de grondwet in beginsel geen op horizontale conflicten toegesneden maatstaven vastgelegd. De rechter zal in dat horizontale verband zelf moeten komen tot een vaststelling van de omvang van de door het individu ingeroepen belangen. De te onderzoeken uitspraken centreren zich bijna allemaal rond Artt. 10 en 11 Grondwet en Art. 8 EVRM. Enkele uitspraken, die op andere grondwets- of verdragsartikelen betrekking hebben, zullen aan de orde komen voor zover zij interessante gezichtspunten opleveren voor de analogie en het vaststellen van de reikwijdte van grondrechtelijke bepalingen. 


\subsection{Ontwikkeling van bet recht op persoonlijkheid met analoge redeneringen}

\subsubsection{Het recht op fysieke integriteit}

In het Fluorideringsarrest ${ }^{2}$ (1973) was Hoge Raad de mening toegedaan, dat voor een regeling van de gemeente Amsterdam - toevoeging van fluor aan het drinkwater - geen formeelwettelijke grondslag bestond. ${ }^{3}$ De Waterleidingwet stipuleert in Art. 4 dat de leverancier een verplichting heeft, deugdelijk drinkwater te leveren. De bedoeling van de fluoridering was nu om de gezondheid van de consument te bevorderen. Art. 4 Waterleidingwet sloot wat strekking betreft niet perse het woorstel wan de gemeente Amsterdarn uit: de verplichting tot levering van 'deugdelijk' zou ook 'gezond' drinkwater kunnen inhouden. Het begrip 'deugdelijk drinkwater' diende aldus te worden uitgelegd, om vervolgens vast te kumnen stellen of het voomemen van de gemeente een wettelijke grondslag ontbeerde. De Hoge Raad stelde in zijn uitspraak dat toevoeging van fluoride een zo ingrijpende maatregel is dat zij verboden is, tenzij deze bij formele wet wordt toegestaan.

Vraag was waardoor de 'ingrijpendheid' van de regeling nu werd veroorzaakt. De Hoge Raad liet dat niet expliciet blijken. Hij deed de zaak af op de monopoliepositie wan het waterleidingbedrijf: de klagers hadden geen alternatief voor het verkrijgen van drinkwater. Niet werd uitgesproken waarom het bestaan van een alternatief voor het gefluorideerde drinkwater zo wezenlijk was.

Het privé-leven, meer specifiek het uitgangspunt van lichamelijke onschendbaarheid, speelt in de rechtsvinding in Fluoridering een niet zichtbare, maar waarschijnlijk wel doorslaggevende rol. De Hoge Raad achtte het niet noodzakelijk in te gaan op het cassatiemiddel dat stelde dat de fluoridering in strijd is met Art. 8 EVRM. ${ }^{*}$ Het lijkt in de uitspraak echter wel ten grondslag te liggen aan de belangen waarop inbreuk werd gemaakt met de fluoridering. De betekenis van het recht op privé-leven in de kwestie van fluoridering van het drinkwater op basis van besluiten van gemeenten verkreeg wat meer diepte in een uitspraak van de Arnhemse Rechtbank De aanspraak op fysieke integriteit bleek in de weg te staan aan de geldigheid van deze wet:

"Boven dit alles uit stijgt echter het bezwaar [...] dat [...] inbreuk wordt gemaakt op het behoudens zeer bijzondere noodsituaties, die echter thans niet aanwezig zijn, aan ieder mens toekomende recht en voorbehouden vrijheid om zelf te beslissen of hij al dan niet een geneesmidde", ook indien de hem behandelende arts hem dat voorschrifft, zall innemen en of zich al dan niet aan een door hem behandelde arts noodzakelijk geachte of aangeraden physieke ingreep zal onderwerpen:"

2 HR 22 juni 1973, NJ 1973/386.

3 Zie voor een uitgebreide beschouwing over dit arrest Leijten 1975, p. 289-315.

4 De anaspraak varn de klagers luidde dat het verschaffen van gefluorideerd drinkwater onder de gegeven omstandigheden (er was geen altermatief om niet-gefluorideerd drinkwater te verkrijgen) een inbreuk op de uitoefening van de rechten, toegekend in Art. 8 EVRM (zie de grief onder punt $I$ d in HR 22 juni 1973, NI 1973/386).

$5 \quad \mathbb{R}$ b. Arnhem 18 december 1973, NJ 1974/64. 
De rechtbank motiveerde de grondslag van de individuele aanspraak letwat uitgebreider dan van de Hoge Raad eerder had gedaan. Voor de rechtsvinding wan de Rechtbank zijn wel aanknopingspunten in de jurisprudentie te vinden, maar het is gissen of die overwegingen ten grondslag lagen aan de rechtsvinding van de Rechtbank. Verschillende commentatoren zagen in de uitspraak van de Hoge Raad de aanleiding aan te nemen dat er een grondrecht op fysieke integriteit bestaat, ook al was die destijds nog niet opgenomen in de grondwet. ${ }^{7}$ Het Fluorideringsarrest is naderhand een belangrijke aanleiding geweest het recht op lichamelijke onschendbaarheid in de grondwet op te memen bij de herziening van de grondwet. ${ }^{8}$ Vraag is of ter zake van de uitspraak van de Arnhemse rechtbank gesproken zou kunnen worden van een rechtsanalogie. In een rechtsanaloge redenering is een eventueel toepasselijke wettelijke grondslag afwezig, maar deze kan soms worden geconstrueerd aan de hand van én of meer argumenten ontleend aan jurisprudentie of rechtsnormen. Het recht op lichamelijke onschendbaarheid, zo zou kunnen worden gesteld, fungeerde in dit verband als norm van hoger recht. Deze lijkt met name in de optiek van de Arnhemse rechter 'voelbaar' achter de geconstrueerde norm te functioneren, die het individu vrijwaart van medisch ingrijpen tegen diens wil. Van een analogie kan echter nauwelijks worden gesproken: noch de Hoge Raad noch de Rechtbank Arnhem vergeleek de aanspraak in het voorliggende geschil met aanspraken in de jurisprudentie of anderszins relevant vergelijkingsmateriaal.

\subsubsection{Hulp bij zelfdoding}

In drie belangwekkende uitspraken heeft de Hoge Raad zich uitgelaten over hulp bij zelfdoding, maar is van een 'grondrechtelijke uitwerking' van dat recht - zoals aangetroffen in de Amerikaanse of Straatsburgse rechtspraak - nauwelijks sprake. ${ }^{9}$ In dat verband wordt hier onderzocht, waarom in de Nederlandse jurisprudentie in mindere mate sprake is van een vergelijkbaar grondrechtelijk debat over recht op hulp bij zelfdoding. In de eerste uitspraak (1985) werd aangevoerd dat materiële wederrechtelijkheid wan hulp bij zelfdoding ontbrak op grond van de gedachte, dat de verdachte in die zaak het zelfbeschikkingsrecht van de patiënt had willen eerbiedigen. Dat zelfbeschikkingsrecht bestond daaruit, dat aan het individu een recht toekomt op waardig sterven

62 Zo beschouwde de Hoge Raad het afnemen van bloed, bil gebreke van toestemming wan de betroklkene, als een onrechmatige aantasting van diens lichamelijke integriteit (UR 26 juni 1962, NJ 1962/470); in een andere zaak sprake de Hoge Raad uit dat een arts als regel niet gerechügd is een patient een door hem niet gewenste behandel ing te laten ondergaan (in die zaak betrof het een netroctirurgische ingreep bij een persoon die ter beschilkking van de regering was gesteld, HR 14 juni 1974, NI 1974/436). In die zaak werd niet expliciet gewezen op een recht op lichamelijke onschendbarheid.

7 Lejiten 1975, p. 310, Zwart 1985, p. 255 en Alkema 1996, p. 92.

8. Zwart 1985, p. 255 en Heringa en Zwart 1991, p. 60. Zie ook over de vragg of een bepaling over het recht op onaantastbaarheid van het menselijk licham in de grondwet zon moeten wouden opgenomen TK 1978-1979, 15463, nrs. 1-2 en MvT bij het voorstel om een grondrecht op lichamelijke onsehendbaatheid op te nemen, TK 1979-1980, 16086 , nr. 3 (p. 5).

9 Met "grondrechtelijke uitwerking" wordt hier bedoeld, dat in de rechtspraak is geoordeeld over de aanspraak op een recht op zelfdoding, bijvoorbeeld wan een patient. In de Nederlandse discussie is een dergelijke aanspraak tot dusverre niet beoordeeld onder enig grondrecht of, voor zover relevant, verdragstecht (zie HR 27 nobember 1984, NJ 1985/106, HR 21 oktober 1986, NJ 1987/607 en HR 21 juni 1994, NJ 1994/656). 
en verlichting of beéindiging van zijn ondraaglijk lijden. ${ }^{10}$ De raadsman had in die zaak aandacht gevestigd op een recht op zelfbeschikking maar de Hoge Raad sloot de discussie over een verband met dat recht af:
Mede gelet op dit betoog van verdachtes raadsman moet worden aangenomen, dat het Hof [...] tot uitdrukking heeft willen brengen, dat verdachtes opvatting dat hij onder de gegeven omstandigheden gerechtigd was te voldoen aan de [...] vermelde twee normen - zijnde a. eerbiediging van het zelfbeschikkingsrecht en b. hulpverlening aan de mens in nood, het behoeden van diens waardigheid en het verlichten of beeindigen van zijn ondraaglijk lijden - niet kan worden beschouwd als een maatschappelijk zo algemeen als juist aanvaarde opvatting, dat op grond daarvan euthanasie [...] reeds op zich zelf rechtens toelaatbaar zou zijn en mitsdien van een strafbaar handelen als in art. $293 \mathrm{Sr}$ omschreven geen sprake zou kunnen zijn'.

Er is volgens de rechter sprake van 'normen', hoewel niet duidelijk is of die gelijk te stellen zijn aan "rechtsnormen". De Hoge Raad onderbouwde de afwezigheid van maatschappelijke consensus met een verwijzing naar het oordeel van het Hof, dat "onbegrijpelijk noch onvoldoende gemotiveerd' was - volgens de Hoge Raad. De overweging van het Hof hield evenmin een motivering in ter zake van de vraag wat het rechtskarakter was van de normen en afwezigheid van consensus daarover. Een 'recht' op zelfbeschikking of een 'recht' op hulp bij zelfdoding werden niet erkend. De Hoge Raad erkende de mogelijkheid dat de door de arts toegepaste hulp bij zelfdoding naar objectief medisch inzicht als een in noodtoestand verricht handelen gerechtvaardigd was te achten. Deze meer pragmatische constructie liet de vraag of het individu een recht op hulp biij zelfdoding toekomt, buiten beeld; een principièle grondrechtelijke discussie kon worden vermeden." Dat hing tot op grote hoogte samen met de aard van de partijen en het kader waarin het geschil rees: in deze zaken werd niet door een individu een aanspraak gemaakt op het recht op euthanasie, maar werden artsen vervolgd wegens het inwilligen van de wens van luun patiënten en beriepen zich op "noodtoestand". Het beroep op de noodtoestand houdt in dat men een strafbepaling, in casu Art. $293 \mathrm{Sr}$, mag overtreden - en het daardoor beschermde rechtsbelang opofferen - om een rechtsgoed dat van hoger orde is te redden of te bevorderen. ${ }^{12}$ De eerste vraag in dit verband is, welke belangen in het geding zijn. In dit geval is dat het belang van de arts in 'noodtoestand' die vanuit een medisch-ethisch principe 'goed wil doen', en niet van een recht op zelfbeschikking van de patiënt. Vraag is dan op welke wijze de belangen - bescherming van het recht op leven en bescherming van de belangen van de arts - tegen elkaar worden afgewogen. De rechter liet er zich niet expliciet over uit.

In de zaak van 1986 beoordeelde de Hoge Raad de vraag of een psychisch lijden een grond kan zijn voor toelating van hulp bij zelfdoding; ook deze aanspraak werd positief beoordeeld binnen de voornoemde constructie van de noodtoestand. ${ }^{13}$ In de zaak. Chabot tenslotte besloot de Hoge Raad dat bij het beëindigen van het leven van een

10. HR 27 november 1984 , NJ $1985 / 106$.

11 Bood 1998, p. 187.

12 Opticiemarrest, HR 15 oktober 1923, NJ 1923, p. 1329

13 HR 21 oktober 1986 , NJ 1987607. 
psychiatrische patiënt een beroep op noodtoestand gerechtvaardigd kan zijn. ${ }^{14}$ Met de twee uitbreidingen na 1985 lijkt de door de Hoge Raad geconstrueerde noodtoestand; aldus enkele commentatoren, te kunnen leiden tot aanvaarding van een regel van een aanvaard recht op hulp bij zelfdoding, waarbij strafbaarheid in de huidige vorm niet langer past. ${ }^{15}$ Van een erkend recht op hulp bij zelfdoding kan echter niet worden gesproken; althans niet in de jurisprudentie.

Vraag in dit verband is - indien een 'recht' op hulp bij zelfdoding wenselijk of noodzakelijk zou zijn - of deze kwestie nu zou moeten worden geconstitutionaliseerd. Constitutionalisering van een kwestie houdt in dat zowel de achterliggende waarden die in het recht op zelfdoding tot uitdrukking komen als het recht zelf, een 'constitutionele status' verkrijgen. ${ }^{16}$ Wat kan van constitutionalisering worden verwacht? Indien wordt besloten tot het uit de strafrechtelijke sfeer halen van hulp bij zelfdoding zal daarvoor een rechtvaardiging moeten worden aangedragen. ${ }^{17}$ Die zou gelegen kunnen zijn in éen van de grondrechten, bijvoorbeeld in het recht op lichamelijke onschendbaarheid. In beginsel is dat een keuze die aan de wetgever is, voor zover deze voelt voor een erkenning. Daarvan lijkt echter geen sprake te zijn. ${ }^{18}$ Deze expliciete afwijzing staat kennelijk niet in de weg aan de praktische consequenties die kleven aan de rechterlijke constructie met de noodtoestand: hierdoor wordt hulp bij zelfdoding een activiteit die, afhankelijk van de omstandigheden, niet langer strafbaar is. Het lijkt er hier op dat de politiek hier een primaat aan de rechter heeft gelaten in het 'regelen' van een moeilijke ethische kwestie waarover in de samenleving en in de politiek geen eenduidigheid bestaat.

De Hoge Raad zag tot dusverre geen aanleiding, de tot op heden gebruikte constructie met de noodtoestand terzijde te stellen. De fundamentele keuzes ter zake van een recht op hulp bij zelfdoding laat de Hoge Raad in beginsel over aan de wetgever. Die heeft tot dusverre de situatie gehandhaafd. ${ }^{19}$ Ondertussen klemt de vraag of de Hoge Raad zich bij de beoordeling van deze materie nu terughoudend of juist activistisch heeft opgesteld ten opzichte van de wetgever. Er is via de constructie met de noodtoestand een opening gecreëerd voor een casuïstiek die heeft geleid tot vaste lijnen in de jurisprudentie die de wetgever moeilijk kan negeren: terugdraaien van de ontstane praktijk zou waarschijnlijk niet zonder meer worden aanvaard in de samenleving. Gesteld zou kunnen worden dat de Hoge Raad in dit verband aan rechtsontwikkeling heeft gewerkt via een 'achteringang' - in vergelijking met de benadering van de aanspraak op hulp bij zelfdoding door het Amerikaanse Hooggerechtshof of het Straatsburgse Hof. ${ }^{20}$ Het niet

HR. 21 juni 1994, NJ 1994/656.

Kelk 1997, p. 101.

Kritisch over het constitutionaliseren van rechten is Cliteur 2000, p. 20 e.\%.

Zie voor decriminalisering van hulp bij zelfdoding Griffiths 1997 , p. 619 e.v.

Zie par. 2.7.2.

Zie voor een bespreking van régeringsstandpunten Kelk 1997, p. 103

Zie voor een vergelijking van de rechtspraak omtrent euthanasie in de Verenigde Staten en Nederland Bood 1998, p. 177 e.v. 
bezigen van een constitutionele benadering door de rechter lijkt tot op zekere hoogte te kunnen leiden tot het vermijden van een discussie over het al dan niet bestaan van een recht op zelfuloding en over de constitutionele verhouding tussen rechter en wetgever. ${ }^{21}$

Het gaat in de Nederlandse situatie dan ook niet, zoals in de Amerikaanse rechtspraak orntrent recht op hulp bij zelfdoding, om de vraag naar rechterlijke toetsing van wetgeving in formele zin, maar om gewone strafrechtelijke jurisdictie. ${ }^{22}$ Het niet hanteren van de 'constitutionele' variant van recht op hulp bij zelfdoding doet wellicht juist ruimte ontstaan voor rechtsontwikkeling op het terrein van dat recht. Het debat over de juiste rechterlijke taakopvattingen lijkt minder in de weg te staan aan voortschrijdende inzichten over hulp bij zelfdoding. Indien wetgeving voor rechterlijke toetsing wordt voorgellegd aan de rechter, verschuift de vraag van een recht op hulp bij zelfdoding al gauw naar de taakverdeling tussen rechter en (federale of statelijke) wetgever, vooral waar hel gaat om zeer uiteenlopende inzichten over zulke ingewikkelde ethische kwesties. Terughoudendheid van de Amerikaanse rechter ter zake van erkenning van een autonomiebeginsel is verklaarbaar vanuit het perspectief dat het lastig is om via een dergelijk ruime rechtsnorm op casurstische basis aan rechtsontwikkeling te bouwen. Nadere specificatie van de aanspraak zou noodzakelijk zijn, hetgeen duidt op een activistische opstelling van de rechter omdat erkenning tot nadere begrenzingen van het recht zou noodzaken. In de tweede plaats heeft een erkenning van een aanspraak direct tot gevolg dat alle statelijke wetgevers gebonden zijn; een enkele rechter geeft in dat verband de woorkeur aan het overlaten van rechtsontwikkeling door de statelijke wetgever. ${ }^{23}$

\subsubsection{Verplichtingen van de werkgever jegens de werknemer}

In de sfeer van arbeidsrechtelijke verhoudingen heeft de Nederlandse rechter aanleiding gezien, privaatrechtelijke normen in te vullen aan de hand van constitutionele rechten, die fungeerden als beginselen in de privaatrechtelijke rechtsvinding. In een zaak over permanente controle van bedrijfsruimten door middel van een gesloten TV-cameracircuit oordeelde het Hof Den Basch (1986), dat deze praktijk eveneens in strijd was met een constitutioneelrechtelijk uitgangspunt. Permanente bewaking via een gesloten $T \mathrm{~V}$-cameracircuit druist in tegen hetgeen 'uit een oogpunt van menselijke bejegening acnvaardbaar is'. "In casu werd gerefereerd aan eén van de facetten van het recht op persoonlijkheid, hoewel dat niet werd geexpliciteerd door het Hof:

21 Lensing 1997, p. 2011; Lensing stelt dat deze kwesties in de rechtspraak onderbelicht zijn gebleven, mar dat zij werborgen liggen achter noties als noodtoestand, medische ethiek en medische wetenschap.

22 Deze "constitutionele' gevalgen wan het debat over recht op hulp bij zelfdoding zijn in thet Nederlandse deball niet naar voren gekomen. Er vond aldus geen interpretatie van grondwettelijke nomen platats; van analoog redeneren kan - op het terrein van grondrechten geen sprake zijn. Desalniettemin zijn deze uitspraken interessant in het licht van de ontwikkelingen in de rechtspraak van het Amerikannse Hooggerechtshof en van het EHRM.

23 Rechter $O^{\prime}$ Comor verwoordde het als volgt" "the [...] challenging task of crafting appropriate procedures for safeguarding [...] liberty interests is entrusted to the "laboratory" of the States", $O^{\prime} \mathrm{Connor}^{\circ}$ corcurring bij Washington t. Gincks berg, 521 U.S. 702 (1997).

24 Hof's-Hertogenbosch, 2 juli $1986, \mathrm{NJ} 1987 / 451$. 
"De werknemers [...] die in de bedrijfsruimten werkzaam zijn worden door de aanwezigheid van camera's bij voortduring blootgesteld aan een mogelijk langdurige en gericlite observatie wasurop zij [...] geen enkele invloed hebben. Naar het voorlopig oordeel van het hof blijft een dergelijke werksituatie [...] verre ten achter bij wat uit een oogpunt van normale menselijke bejegening aanvaardbaar is'.

Dat privé-leven lijkt hier als beginsel de invulling van Art. $1638 \mathrm{z}$ BW (oud) te inspireren. Hoewel niet expliciet geuit, behoort het recht op privé-leven tot de belangen van de werknemer, die de werkgever dient te respecteren. De rechter werkte de reikwijdte van dat recht niet verder uit. Wellicht werd er vanuit gegaan dat hier een constante en flagrante schending wan dat recht voor de hand lag en dat nadere uitwerking niet nood. zakelijk bleek. Er werd niet gerefereerd aan jurisprudentie die iets zegt over 'hetgeen vanuit een oogpunt van normale menselijke bejegening aanvaardbaar is', noch werd aansluiting gezocht een rechtsnorm die mogelijk hieraan ten grondslag zou liggen. ${ }^{25}$

Er zijn echter zaken aan te wijzen waarin de rechter zijn rechtsvinding uitgebreider en aan de hand van een analogie motiveerde. De aanspraken bevinden zich niet op het terrein van het recht op persoonlijkheid maar op het terrein van het recht op gelijke behandeling. In de zaak Agfa t. Schoolderman (1994) vulde de Hoge Raad het begrip 'goed werkgeverschap' ex Art. $1638 \mathrm{z} \mathrm{BW}$ (oud) in aan de hand van het gelijkheidsbeginsel ex Art. 1 grondwet. ${ }^{26}$ Schoolderman werkte gedurende een aantal jaren op basis van een arbeidsovereenkomst voor bepaalde tijd, die telkens werd verlengd. Soms werkte zij via een uitzendbureau, en soms in rechtstreekse dienst van de onderneming. $Z \mathrm{ij}$ werkte praktisch voor de volledige werktijd, en verrichte dezelfde werkzaamheden voor Agfa als personeel dat in vaste dienst van Agfa was en op wier arbeidsverhouding Agfa-voorwaarden van toepassing waren. Klaagsters honorering voor de werkzaamheden was echter lager dan die van het vaste personeel. Op zich behoeft een verschil in salaris geen probleem op te leveren tegen de achtergrond van gelijke behandeling, maar in casu was een situatie ontstaan waarin de werkverhouding tussen klaagster en werkgever feitelijk niet meer verschilde van die van overig personeel bij dezelfde werkgever. Het gelijkheidsbeginsel werd hier gehanteerd - via $1638 \mathrm{z}$ (oud) BW en Art. 3:12 $\mathbb{B W}$ - als een norm van hoger recht die bij de beoordeling van goed werkgeversichap in aanmerking genomen dient te worden. ${ }^{27}$

Het gebod tot gelijke behandeling ex Art. 1 grondwet werd via Art. 3:12 BW herleid tot een in het algemeen rechtsbewustzijn levend rechtsbeginsel dat nadere invulling geeft aan het begrip van goed werkgeverschap ex Art. $1638 \mathrm{z} \mathrm{BW}$ (oud). Het gevolg was, dat het in beginsel in verticale verhoudingen geldende gebod van gelijke behandeling eveneens dicteert op welke wijze goed werkgeverschap wordt ingevuld in horizontale ver.

25 Vrag is watom de gevolgde redenering niet zichtbaar wordt gemaakt. In casu was sprake wan een beroep in kort geding; hetgeen in de praktijk niet altijd leidt tot uitgewerkte overwegingen. Dat rechtvaardigt echter niet het achterwege laten van motivering, althans niet wanneer het het doorslaggevende argument betreft.

26 Agfa i. Schoolderman, Hoge Raad 8 aprill 1994, NJCM-Bulletin 19-6 (1994).

27 Agfa t. Schoolderman, met name overweging 3.5. 
houdingen. Hier werd een wetsanalogie voltrokken voor de invulling van een vage privaatrechtelijke norm uit het BW, waarbij de norm wan hoger recht werd gevormd door het gelijkheidsbeginsel. Vergelijkingsmateriaal werd evenwel niet geput uit jurisprudentie met vergelijkbare individuele aanspraken of vergelijkbare toepassingen van de norm, maar uit het feitencomplex zelf: de feitelijke omstandigheden van werknemers in vaste dienst en die van de werkneemster in tijdelijke dienst werden vergeleken. De rechter concludeerde dat omstandigheden de facto geen verschillende behandeling konden rechtvaardigen. ${ }^{28}$ De norm van hoger recht had in dit verband een abstract karakter, maar er was sprake van een vergelijking op concreet niveau vanwege de vergelijking van feitencomplexen.

Een ander fraai voorbeeld van een wetsanalogie in een zaak over gelijke behandeling door werkgevers is te vinden in de Antilliaanse salariëringszaak (1995). ${ }^{29}$ Hogere salariëring van gehuwden is slechts geoorloofd indien daarvoor een redelijke en objectieve rechtvaardiging kan worden aangewezen, zo oordeelde Hoge Raad. Hoewel deze stelling voor de hand ligt, zag de rechter zich genoodzaakt een expliciete rechtvaardiging te geven. A-G Koopmans reikte (gedeeltelijk) een mogeljjk redeneerschema voor de kwalificatie van de aanspraken aan. ${ }^{30}$ Het Hof was in beroep nameliik van oordeel dat een dergelijk onderscheid in het algemeen wel te rechtwaardigen was. De Hoge Raad knoopte echter aan bij Art. 26 IVBPR dat stipuleert dat discriminatie, op welke grond ook verboden is. ${ }^{31}$ In beginsel is deze verdragsbepaling eenieder verbindend in de Nederlandse rechtsorde. ${ }^{32}$ De opvatting van het Hof werd bestreden met een nadere invulling van Art. 26 IVBPR aan de hand van Art. 7 IVESCR inhoudende het recht op billijke en gunstige arbeidsvoorwaarden.

Art. 7 mist echter het karakter van eenieder verbindendheid ${ }^{33}$, maar de Hoge Raad stelde daartegenover dat de doelstelling die achter Art. 7 schuilgaat - waarborg van cen gelijke beloning voor gelijke arbeid - er én is die nagestreefd dient te worden. De wetsanalogie die hier ontstaat is dat de toepasselijke norm van Art. 26 IVBPR wordt ingevuld aan de hand van een beginselachtige notie die werd afgeleid uit Art. 7 IVESCR. De norm van Art. 7 IVESCR kon op zichzelf genomen geen toetsingsmaat-

28. Zie ook de Conclusie van A-G Koopmans, die de constructie van invulling van het begrip van goed werkgeverschap met een in het algemeen bewustzijn levend rechtsbeginsel van gelijke behandeling.

29 Antillaanse zaak, HR 7 mei 1993, NJ 1995/259.

30 Conclusie van A-G Koopmans bij Amilliaanse zaak.

31 Art. 26 IVBPR luidt: 'Allen zijn gelijk voor de wet en hebben zonder diseriminatie aanspraak op gelijke bescherming door de wet. In dit verband verbiedt de wet discrminatie van welke aard ook en garandeert een ieder gelijke en doelmatige bescherming tegen discriminatie op welke grond ook, zoals ras, huidskleur, geslacht, taal, godsdienst, politieke of andere overtuging, nationale of maatschappelijke afkomst, eigendom, geboorte of andere status?.

32 De rechter zag zich gedwongen de aanspraak op gelijke behandeling onder dit verdragsartikel te kwalificeren, ondat een algemene gelijkheidsbepaling als Art. 1 Grondwet terzake van het discriminatieverbod ontbrak in de Staatsregeling voor de Nederlandse Antillen. Art. 26 IVBPR wordt echter wel geacht, direct door te werken voor de Nederlandse Antillen (zie de Conclusie van A-G Koopmans bij Antilliaanse zaak).

33 Hoogenraad, HR 20 april 1990, NJ 1992/636. 
staf bieden, maar als norm van hoger recht bleek Art. 7 wel inspiratie te kunnen geven aan de invulling van Art. 26 IVBPR. In eerdere jurisprudentie had de Hoge Raad zich al uitgelaten over de eenieder verbindendheid van Art. 7, maar kende er geen rechtstreekse werking an toe ${ }^{34}$ A-G Koopmans besteedde in zijn conclusie niet zoveel woorden als de Hoge Raad aan de kwalificatie van de aanspraak onder Art. 26. Koopmans bepleitte beoordeling van het onderscheid in beloning van gehuwden onder Art. 26 IVBPR aan de hand van uitspraken van het Human Rights Committee van de VN dat eerder in enkele Nederlandse klachtprocedures had aangeduid, dat een onderscheid in behandeling toelaatbaar is onder 'reasonable and objective criteria'. De Hoge Raad stelde dat het criterium van de eenieder verbindendheid minder geen barrière behoeft te zijn wanneer de betrokken norm niet als rechtsnorm, maar als 'doelstelling waarnaar gestreefd dient te worden' wordt ingezet. De vraag is overigens of de Hoge Raad deze constructie nodig had om invulling te geven aan het gelijkheidsbeginsel ex Art. 26. Deze lijkt sterk ondersteunend van karakter, in dit verband geeft zij invulling aan de dynamisch-evolutieve interpretatie van Art. 26.

\subsubsection{Het medisch inzagerecht}

In 1987 erkende het Hof te Amsterdam in een kort geding via de onrechtmatige daad het bestaan van een persoonlijk recht van het individu op inzage van medische gegevens die over hem zijn vastgelegd. Uit dat persoonlijk recht vloeit voort, aldus het Hof, dat de burger een recht kan doen gelden op inzage van een over hem bestaand medisch dossier. ${ }^{35}$ De klager had een, belang bij een spoedige beslissing of hij al dan niet kennis mocht nemen van het door een psychomedisch centrum over hem bijgehouden dossier. Hij was gedwongen opgenomen in een psychiatrische kliniek, en wenste de redenen gefundeerd op het advies van het centrum - te kennen voor de machtiging tot verlenging van de gedwongen opname. Het bestaansrecht van het recht op inzage werd niet nader gemotiveerd:

'De president heeft als beginsel vooropgesteld dat het recht van de burger om te worden geïnformeerd over gegevens welke over hem zijn vastgelegd meebrengt, dat appellant recht kan doen gelden op inzage van een over hem bestaand medisch dossier.,

Hiertoe bestond wellicht minder noodzaak, omdat het bestaan van het door de Rechtbank aangehaalde beginsel niet werd betwist. Het Hof concentreerde zich verder enkel op de vraag, of er bijzondere omstandigheden zijn, die beperking van het recht op inzage rechtvaardigen. In de jurisprudentie liet de rechter een bereidheid zien om dit recht nader vorm te geven, met name op het gebied van inzage in medische dossiers. Art. 10 grondwet vormde daarbij een belangrijk aanknopingspunt voor de rechtvaar-

HR 20 april 1990 , NJ 1992/636. In deze zaak werd geklaagd over inhouding van loon krachtens de Wet interim inhouding salarissen onderwijs. Art. 7 IVESCR bestreek, zo de Hoge Rad in die zaak, een dermate omwangrijk terrein dat rechtstreekse werking niet voor de hand ligt. Er werd aan de Memorie vasn toelichting bij de goedkeuringswet bij het IVESCR gewezen: deze stelde, zo de Raad, dat dit verdrag in het algemeen geen rechtstreekse werking zal hebben.

35 Hof Amsterdam 6 augustus: 1987, NJ 1988/567.

36 Hof Amsterdam 6 augustus 1987, r.o. 5.2. 
diging van het bestaan van 20 "n recht. In een conflict met een RIAGG-instelling, die weigerde aan de ouder van een kind inzage te geven in het psychologisch dossier over haar kind beriep een klaagster zich direct op een recht op inzage. De president van de Amsterdamse rechtbank kwalificeerde deze aanspraak op inzage onder het recht op de eerbiediging van de persoonlijke levenssfeer, alsmede op het in Art. 10 lid 3 Grondwet geregelde kennisneming van gegevens. Dit laatste verwoordt, althans naar lezing van lid 3, overigens geen recht van het individu. ${ }^{37}$ De contaminatie van de leden 1 en 3 van Art. 10 deed in de optiek van de rechter echter wel het wermoeden rijzen, dat een aanleiding bestaat in de grondwet een 'recht' op inzage te lezen:

"dat thans algemeen wordt anvaard dat in beginsel - mede gelet op Artikel 10 lid 1 en lid 3 Grondwet - aan een patiênt het recht toekomt het over hem alangelegde dossier in te zien". ${ }^{38}$

Ruim een jaar later (1988) vestigde de Hoge Raad het inzagerecht ter zake van medische dossiers als een zelfstandig afdwingbaar recht. ${ }^{39}$ Twistpunt in die zaak was het feit, dat de betrokken medische instantie weigerde de gegevens van de klager toe te sturen. De instantie had richtlijnen opgesteld ter zake van de inzage, en wenste er in het onderhavige geval niet van af te wijken. Stukken waarom was verzocht, werden in beginsel njet opgestururd naar de verzoeker. In de onderhavige casus had de klager om de stukken verzocht in verband met voorbereidingen van een civiele procedure. De Hoge Raad erkende het bestaan van een recht op inzage:

"Het hof is er terecht wan uitgegaan dat degene [...] in beginsel recht heeft op kennisneming van de inhoud van de zich daarin bevindende stukken [...]. Een zodanig recht strookt met de rechtsontwikkeling, zoals deze blijkt uit rechterlijke uitspraken, medische en juridische literatuur $[\ldots]$ '.

De Hoge Raad haalde voor het bestaan van dit recht onder meer 'de rechtspraak' als bron aan, maar specificeerde in de uitspraak niet welke jurisprudentie in dit verband van belang was. Enkele lagere rechters hadden zich reeds uitgelaten over het belang dat het individu kan hebben bij inzage. Ook een procesbelang, zoals dat in casu aanleiding was om de stukken op te vragen, vormde voldoende aanleiding het inzagerecht te honoreren. Instructief was een uitspraak van de Rechtbank Amsterdan in kort geding in 1985, waarin het belang van de inzage verband hield met de toekenning van een uitkering:

"In casu is het in art. 10 lid 1 Grondwet neergelegde Grondrecht op eerbiediging van de persoonlijke levenssfeer in het geding. In het algemeen omvat dit grondrecht tenminste deze twee aspecten, $[\ldots]$ dat de betrokken burger zelf zoveel als mogelijk is wordt geönformeerd over de gegevens, die over hem bij anderen berusten, zodat hij bij de inrichting van zijn loven hiermee rekening kan houden', 40

37 Art. 10 iid 3 luidt: "De wet stelt regels inzake de aanspraken wan personen op kennisneming van over hen vastgelegde gegevens en van het gebuik dat daarvan wordt gemaakt, alsmede op verbetering van zodanige gegevens'.

38 Rechibank Amsterdam, 10 september 1987, KG 1987/423.

39 HR 2 december 1988, NJ 1989/752. Zie ook Kuitenbrouwer 1989, p. 92 e.v.

40 Zie onder meer Rechtbank Amsterdam, 13 juni 1985, KG 1985/188. Ook de hiervoor uitgewerkte uitspraak van Hof" "s-Hertogenbosch, 2 juli 1986, NJ $1987 / 451$ erkent het bestaan van een recht op inzage. 
Het recht op inzage van medische dossiers is ontstaan uit het recht op eerbiediging van de persoonlijke levenssfeer, maar het werd echter eerst in de rechtspraak met de uitspraak van de Hoge Raad gepositiveerd als onderdeel van het recht op de persoonlijke levenssfeer. In de constitutionele orde lijkt het ongeschreven recht op inzage zich ondertussen, zo blijkt uit de bewoordingen vain de Hoge Raad, op een zelfde niveau te bevinden als het (geschreven) recht op eerbiediging van de persoonlijke levenssfeer:

"Voormeld recht, dat wel samenhangt met het recht op eerbiediging van de persoonlijke levenssfeer maar een zelfstandig karakter draagt, geldt ook wanneer - zoals hier - hot de betrokkene niet om eerbiediging van zijn persoonlijke levenssfeer is te doen, mar om het verkrijgen van gegevens in verband met een aanhangige of nog aan te spannen procedures"

De opmerkingen van de rechter over de juridische status van het inzagerecht als enerzijds 'aspect' van Art. 10 lid 1 Grondwet - zoals de Rechtbank formuleerde - en anderzijds als zelfstandig grondrecht naast Art. 10 Grondwet - uit de koker van de Hoge Raad - lijken te duiden op een rechtsontwikkeling. Van belang is dan dat de rechtsnorm zoveel mogelijk op eenduidige wijze wordt gebezigd; dit is wenselijk in verband met de afdwingbaarheid van het recht en bij zekerheid die bestaat bij vastere omtrekken van het recht.

Het inzagerecht, dat in de jaren tachtig met name een medische achtergrond had, is in het recentere verleden ingeroepen in situaties die die medische achtergrond ontberen. Uit enkele wan die uitspraken blijkt, dat de Hoge Raad het inzagerecht inderdaad is gaan beschouwen als een zelfstandig recht. In het ene geval wilde een persoon inzage in de eigen persoonsdossiers nadat derden het GAK informatie hadden doorgegeven over relevante vermogensveranderingen; in het andere geval eiste een kind, dat een halve eeuw geleden ter wereld was gekomen in een opvangstichting voor alleenstaande moeders, inzage bij die stichting in haar persoonsdossier om zo te kunnen achterhalen wie haar verwekker was. ${ }^{42}$ In het eerste geval werd de reikwijdte van het inzagerecht bepaald door Art. 29 W/PR. De aanspraak van die klager werd niet onder het inzagerecht erkend, omdat hij wenste te weten te komen welke de oorsprong was van de gegevens die over hem bekend waren bij het GAK. De klager kon inzage verkrijgen over zijn gegevens die bij het GAK bekend waren, maar het inzagerecht strekte niet zover dat ook de oorsprong van die gegevens moest worden onthuld. In het geval van de dochter werd de reikwijdte van het inzagerecht ingevuld door een ruimere notie dan het recht op eerbiediging van het privé-leven alleen - het werd met name bepaald door het persoonlijkheidsrecht. ${ }^{43}$

41 HR 2 december 1988 , NJ 1989/752, owerweging 3.2. Zie ook de noot bij dit arrest.

42 Respectievelijk HR 16 juni 2000 en HR 15 april 1994, NJ 1994/608.

43 Zie hierna in par 9.2 .6 . 


\subsubsection{Het geestelijk welzijh van het individw}

De Centrale Raad van Beroep heeft zich recentelijk in een sociale verzekeringszaak uirgelaten over de reikwijdte van Art. $8 \mathrm{EVRM}^{44}$ In beginsel is het onderzoek naar rechtsantwikkeling in de rechtsvinding op het terrein van het recht op persoonlijkheid beperkt gebleven tot de Hoge Raad; de bestuursrechters hebben zich op dat terrein tot op heden terughoudend getoond. De Centrale Raad beoordeelde in de zaak DSW $t$. Sentges een aanspraak op een hulpmiddel voor gehandicapten onder het recht op privéleven ex Art. 8 EVRM. Dat hulpmiddel is uitgezonderd van de lijst met verstrekkingen wartoe de zorgverzekeraar verplicht is. ${ }^{45}$ In verband met de positie van de klager rees de vraag in hoeverre niet-verstrekking van de robotarm, en aldus het in concreto toepassen van de wet, zou kunnen indruisen tegen het recht op privé-leven. Het gevraagde hulpmiddel zou klager minder afhankelijk maken van anderen waardoor de sfeer van zijn privé-leven, in het bijzonder de ontwikkeling van zijn persoonlijkheid in relatie tot anderen, wordt vergroot.

Conform de uitspraak van het EHRM in de zaak Botta t. Italie onderzocht de Centrale Raad, in hoeverre er een verband bestaat tussen het recht op privé-Jeven van klager enerzijds en de aanspraak op het verlangde hulpmiddel anderzijds. ${ }^{46}$ De Raad ging er vanuit, dat het toekennen van de arm het privé-leven van klager ten goede zou komen: deze stelt hem in staat zelfstandig te functioneren en zelf te kunnen kiezen voor het vestigen en onderhouden van relaties met anderen. De aanspraak werd erkend, maar in de toetsingsfase niet gehonoreerd: de rechter stelde dat aan de overheid een beoordelingsruimte toekomt. Er werd echter nawwelliks inzicht gegeven in de omvang van deze beoordelingsruimte en de in de beoordeling betrokken afwegingen. ${ }^{47}$ Interessant in deze zaak was de extensieve interpretatie van Art. 8 EVRM, die op het terrein van het privé-leven in de Nederlandse rechtspraak niet direct een voorganger kent. ${ }^{48}$ De rechter sloot zich aan bij de Straatsburgse uitleg van Art. 8 zoals die door het EHRM in Bottat. Italië was gegeven. Van belang in die uitspraak was dat het EHRM in Botta het EHRM geen onmiddellijk verband erkende tussen Botta's aanspraak en Art. 8, terwiji de Centrale Raad dat verband in onderhavige zaak wel erkende. De feitencomplexen van DSW t. Sentges en Botta t. Italie lijken te verschillen op het punt van de ernst van de beperkingen relaties met anderen te kunnen vestigen en te onderhouden. Hoe het Straatsburgse Hof zou oordelen over de Nederlandse zaak is niet duidelijk; een dergelijke zaak is nog niet ter beoordeling voorgelegd.

44. Zorguerzekeraa" DSW r. Sentges, CRVB 29 januari 2002, 01/515 ZFW. Zie in vergelijkbare zin ook Zorgwerzekeratar $\mathrm{ZAO}$ t. Hesper, CRvB \ oktober $2002,01 / 2882 \mathrm{ZFW}$.

45 In casu ging het om een ministeriele regeuling.

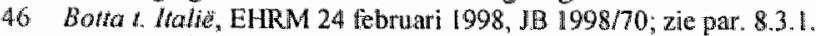

47 Zo ook in Zorgverzekeraar ZAO t. Hesper, CRwB 1 oktober 2002,01/2882 ZFW.

48 Op het terrein van het familieleven ex Art. 8 EVRM heef de Hoge Raad in het verleden enkele extensieve uitspraken gedaan (zie bijvoorbeeld Gezamenlike ouderlike mocht, HR 4 mei 1984, NJ $1985 / 510$ en Crezamentike ouderlijhe mach ongehwden, HR 21 maart 1986, NJ 1985/585-588). 


\subsubsection{Het recht om de biologische afstamming te kenwen}

In de zaak Valkenhorst deed de Hoge Raad een uitspraak die kan worden betiteld als een rechtsanalogie." In deze zaak eiste een buitenechtelijk kind, dat in 1935 was geboren in 'Moederheil' - een destijds door rooms-katholieken gedreven inrichting met als doelstelling het verlenen van zorg aan ongehuwde moeders en hun kinderen, inzage in dossiers die haar op de hoogte zouden kunnen stellen van de identiteit van haar biologische vader. De inrichting werd gedreven door stichting De Valkenhorst; deze weigerde inzage in de gegevens die tot de onthulling van de identiteit zouden kunnen leiden. Kernargument in deze weigering was de verplichting tot geheimhouding, voortvloeiend uit de vertrouwelijke aard van de informatie. Eventuele onthulling zou enkel kunnen plaatsvinden met toestemming van de moeder, en die weigerde tot dusverre in te stemmen met de inzage. Enkele jaren voordat het kind de aanspraak voor de Hoge Raad bracht, is de moeder van het kind overleden. Het Hof "s-Hertogenbosch kende in beroep aan het belang van Valkenhorst het grootste gewicht toe, met het argument dat een absolute opvatting over het recht van kinderen op afstammingsgegevens zulke ingrijpende gevolgen zou hebben, dat van het bestaan van een dergelijk recht bij gebreke van een wettelijke regeling niet mag worden uitgegaan. ${ }^{50}$ Het Hof erkende wel het bestaan van het belang van het kind, doch wenste niet ower te gaan tot de erkenning van dat belang als afdwingbaar recht. De Hoge Raad kwam in cassatie echter tot een andere uitkomst.

Eiseres maakte aanspraak op een belang, kennis van de afstamming te kunnen vernemen. De Hoge Raad knoopte in dit verband echter niet aan bij een inzagerecht. In de Nederlandse grondwet is een belang bij de kennis van de afstamming niet als zodanig erkend. Een toepasbare bepaling ontbrak aldus, maar aan de hand van de rechtsanalogie werd geconcludeerd tot het bestaan van een grondrecht dat dit belang beoogt te beschermen. De Hoge Raad woog opnieuw de belangen van de Valkenhorst en van het kind af en kwam tot een nieuwe vaststelling van de aard en de omvang van de aanspraken van het kind en van de instelling. Teneinde tot toekenning van het juiste gewicht aan de belangen te kunnen komen, werd de aanspraak van het kind - kennis omtrent de afstamming te kunmen vernemen - in een meer constitutioneelrechtelijke context geplaatst:

"Uitgangspunt woor de beoordeling van het middel is dat aan grondrechten als het recht op respect voor het privé-leven, het recht op wrijheid van gedachte, geweten en godsdienst en het recht op vrijheid van meningsuiting ten grondslag liggende persoonlijkheidsrecht mede onvat het recht om te weten van welke ouders men afstamt ${ }^{\text {s. }}$.

Er is aldus een aantal grondrechten, geschreven en ongeschreven grondrechten, die allen een gemeenschappelijke noemer kennen, een beginsel waaruit zij voortvloeien. In dit geval "ontwaarde" de Hoge Raad achter deze grondrechten het zogenoemde per-

49 HR 15 april 1994, NJ 1994/608. Zie voor titwerking ook par. 4.4.4.

50 Hof 's-Hertogenbosch, 18 september 1991 , NJ 1991/796, overweging 4.3.

51 Overweging 3.2 


\section{Hodrostuk 9}

soonlijkheidstecht, waarvan de genoemde grondrechten concretiseringen vormen. Om de grondslag van het recht de afstamming te kennen, te onderbouwen wees de rechter eveneens internationaliachtelijke regels aan:

Dit recht heeft ook internationaal erkenning gevonden in artikel 7 van het-door Nederland nog niet geratificeerde - Verdrag inzake de Rechten van het Kind $[. .]^{52}$

De grondslag van het recht om de afstamming te kennen werd aldus in twee normen "gevonden": in de norm van hoger recht, hier aangeduid als "het persoonlijkheidsrecht" die via een inductie werden afgeleid uit bestaande rechten, en in een rechtsnorm in een internationaal verdrag dat door Nederland destijds nog niet was geratificeerd. A-G Koopmans motiveerde in zijn conclusie zijn vergelijkingen en vergelijkingsmateriaal wat uitgebreider dan de Hoge Raad. Koopmans betrok voor het aantonen van het bestaan en de vaststelling van de reikwijdte van het recht de afstamming te kennen, diverse bronnen in zijn argumentatie. Allereerst stelde Koopmans vast, dat het kind een beschermenswaardig belang heeft bij de kennis van de afstamming. Hij baseerde zich op algemene historische en hedendaagse beschouwingen. Teneinde te overtuigen tot een beschemenswaardig belang deed Koopmans meer psychologisch en sociologisch georiënteerde uitspraken, en stelde hij vragen met een retorisch karakter:

'Ik kan me nauwelijks een fundamenteler recht voorstellen dan te weten wie ervoor verantwoordelijk is dat men op deze aarde rondloopt".53

Een voorbeeld van Koopmans" beschouwing op de ontwikkelingen van de laatste jaren ter zake van het belang, de biologische afstamming te kennen:

'Dat belang heeft de laatste tijd een grotere betekenis gekregen, nu meer en meer blijkt dat mensen die in onzekerheid verkeren over hun afstamming, op zoek gaan naar hun wortels.

Dat is [...] in de huidige tijd een heel belangrijk iets'. $\$ 4$

Met het bestaan van een belang was echter nog geen erkenning van een recht tot stand gekomen. Koopmans ontwaarde echter wel contouren van het recht op kennis van de afstamming bruikbare bepalingen uit het BW, het EVRM en het Verdrag voor de Rechten van het Kind, die de erkenning van het belang als afdwingbaar recht zouden kunnen rechtvaardigen. Art. $1: 225$ lid 2 sub a $\mathrm{BW}$ gaat er vanuit dat het kind belang heeft bij die Kennis, aldus Koopmans; Gaskin t. Verenigd Koninkrijkss dient als illustratiemateriaal voor het bestaan van het recht op kennis van het eigen verleden en het Verdrag voor de Rechten van het Kind van 1989 stipuleert expliciet een recht op kennis van de afstamming. ${ }^{56}$ Vanuit de erkenning van het belang als recht maakte Koopmans de over-

52 Art. 7 lid I wan dit verdrag luidt: "Het kind wordt onmididelijk tha de geboorte ingeschrewen en heeft vanaf de geboore het recht op een nam, het recht een nationaliteit te verwerven en, voor zover mogelijk, thet recht zijn of has ouders te kennen door hen te worden verzorgd.

53 Zie Conclusie, overweging 4; hier citeerde Koopmans A.C. van den Blink, Handelingen NJV 120 $(1990)$, p. 55 .

\$4 Zie Conclusie, overweging, 6.

55 Goskin t. Verengd Kominkrijh. EHRM 7 juli 1989, NJ 1991,659.

56 In de. Antiliaanse zak schoof A-G Koopmans de mogelijkheid, nog riet in werking getreden verdragen te beschourwen als bron voor de argumentatie, terzijde. 
stap naar de vestiging van dit recht als grondrecht. Daarmee kwam de belangenafweging door de Hoge Raad in een ander daglicht te staan dan in de uitspraak van het Hof; er bleek sprake van botsing van grondrechten. Voor de vestiging van de aanspraak als recht zocht Koopmans inspiratie in de Duitse rechtspraak, omdat het Duitse Federale Constitutionele Hof reeds eerder in een vergelijkbare zaak had moeten oordelen over de toekenning wan het juiste gewicht aan de geclaimde belangen en over de erkenning van de aanspraak als recht. ${ }^{57}$ Hij hevelde de Duitse redenering, waarin het Duitse Hof het onbenoemde recht op kennis van de afstamming concretiseert uit het persoonlijkheidsrecht ex Art. 2 lid 1 en 1 lid 1 GG, over naar de Nederlandse situatie. Van een gepositiveerd persoonlijkheidsrecht was tot op dat moment in de Nederlandse grondwet of in het EVRM geen sprake, maar het vormt, aldus Koopmans, één van de onuitgesproken uitgangspunten van onze rechtsorde:

"Bepalingen als art. 1:1 lid I BW, art. 1 Grondw., art. 2 lid 1 en art. 4 lid 1 EVRM zijn zonder dit uitgangspunt niet te begrijpen. Ook de gedachte van de autonomie van het individu, die aan een groot deel wan ons vermogensrecht ten grondslag ligt, steunt op het bestaan van een persoonlijkheidsrecht." ${ }^{38}$

Koopmans' redenering ontsteeg daarmee de eventuele tegenstellingen die zouden kunnen bestaan op het terrein van publiekrecht en privaatrecht; het persoonlijkheidsrecht ligt immers ten grondslag aan de verschillende aangehaalde gepositiveerde rechten. Het persoonlijkheidsrecht is een abstracte norm van hoger recht, die op zichzelf niet lijkt te kunnen functioneren als normvoorschrift. Aannemende dat het functioneert als interpretatiebron voor privaatrechtelijke- en publiekrechtelijke normen, zal het persoonlijkheidsrecht in ieder concreet geval nader moeten worden toegespitst op de omstandigheden van het geval. In de fase van de belangenafweging werd door de Hoge Raad overigens niet uitgebreid uitgewerkt, waarom het belang van het kind diende te prevaleren boven dat van de moeder. De rechter bleef bij de vaststelling, dat het kind een 'vitaal belang' heeft bij de kennis. Aan de preciezere bepaling van de omvang van het recht op privacy van de moeder werd in de uitspraak weinig aandacht besteed, waardoor het recht van de moeder ondergeschikt leek te worden aan dat van het kind. ${ }^{39}$

De Hoge Raad heeft in Valkenhorst in navolging van A-G Koopmans vastgesteld dat het belang te weten van wie men biologisch afstamt, een rechtens afdwingbare norm behelst. Daartoe moest in de hiërarchie van grondwettelijke normen worden vastgesteld, welke plaats dit recht toekomt ten opzichte van de andere normen, welke de bronnen zijn van dit recht en wat de reikwijdte van het recht is. Het persoonlijkheidsrecht als norm van hoger recht rechtvaardigt het bestaan van het recht om de afstamming te kennen, dat net als het vergelijkingsmateriaal - het recht op geloof, geweten en vrijheid van meningsuiting - uit dat algemene persoonlijkheidsrecht voortvloeit. Het persoonlijkheidsrecht rechtvaardigt als het ware bestaan van benoemde en onbenoemde zalak werd besproken in par. 6.3.7.

58 Zie Conclusie, overweging 19.

59 Ook: Verhey in zijn noot bij de zaak Valkenhorst, in: NJCM-Bulletin 19-6 (1994), p. 657. 
rechten, maar nog niet alle onbenoemde rechten worden gekend. De benoemde en onbenoemde rechten bevinden zich hièrarchisch gezien zogezegd 'onder' het algemene persoonlijkheidsrecht. ${ }^{60}$ In rechtspraak na Valkenhorst werden uiteenlopende aanspraken op het algemene persoonlijkheidsrecht gedaan. ${ }^{61}$ Valkenhorst werd daarbij als uitgangspunt genomen om het bestaan van het onbenoemde grondrecht kracht bij te zetten. Het bestaan van het persoonlijkheidsrecht als norm van hoger recht is in geen van deze uitspraken betwist.

De benoemde en onbenoemde grondrechten bewegen zich op eenzelfde niveau en dienen als zodanig ook ten opzichte van elkaar te worden beschouwd. In de Duitse grondwet en de rechtspraak is het algemene persoonlijkheidsrecht eveneens in de rechtspraak gepositiveerd. De vraag die bij Valkenhorsf rijst is of de vaststelling van een hiërarchie van rechten en de positivering van een onbenoemd recht de rechtsvormende taak van de rechter niet te buiten gaat. Het Hof was die mening toegedaan, en meende juist dat hier een taak voor de wetgever was weggelegd. ${ }^{62}$ In de Nederlandse rechtsliteratuur is aandacht besteed aan de wijze waarop het algemene persoonlijkheidsrecht en het recht,

60 Zj vloeien immers uit de norm van hoger recht voort: het persoonlijkheidsrecht staan dan 'boven" de rechten, zoals in een hierarchie gebruikelijk is. In Falkenhorst stelde de Hoge raad echter, dat het persoonlijkheidsrecht 'ten grondslag' ligt aar de genoemde rechten (zie par. 3.2 in de witspraak). Dat zou betekenen dat de hierarchie niet consistent is. Met de benadering van de Hoge Raad wordt naar mijn mening eveneens gedoeld op het uitgangspunt dat de rechten voortvloeien uit het persoonlijkheidsrecht; daarbij is het zowel mogelijk een metafoor te hanteren die aangeeft dat het persoonlijkheid als het ware 'boven' de rechten zweeft alsook een metafoor die inhoudt dat het persoonlijkheidsrecht 'ten grondslag ligt aan". De 'norm van hoger recht' is in dit verband eveneens een metafoor die doelt op het uitgangspunt dat concretiseringen in rang lager staan. Met de norm van hoger recht wordt eveneens gedoeld op het voortvloeien van rechten uit een dergelijke norm (zie par. 4.6).

61 Voor latere uitspraken waarin de rechter aan de hand van het persoonlijkheidsrecht met nieuwe individuele aanspraken te maken kreeg, zie bijwoorbeeld Van Gasteren t. het Parool (HR 6 januari 1995, NJCM 20-7 (1995), p. 903 e.v.) hierna in par. 9.2 .7 alsmede de zaak over de beroepsmatige ontplooing (HR I juli 1997, NJ 1997/156, hiema onder par, 9.2.8). Zie werder ook een medische tuchtzaak (Hof " $s$ Hertogenboscla 24 februari 1998, NJ 1998/927), waarin het Hof stelde: 'Klaagsters geestelijke en psychische constitutie is onvervreemabaar van hasarel en daarop mag - evenmin als op haar fysieke integriteit - door derden geen inbrewk worden gemaakt [... ]. Klaagster wordi daarin beschernd door haar persoonlijkheidsrecht. Door zonder klaggsters toestemming aangaande haar psyche aan derden te rapporteren theeft de arts wederrechtelijk gehandeld'. In deze zaak werd niet expliciet aangeknoopt bij de Yakkemhorsi; in het midden bleef welke het karakter was van het aangehaald persoonlijkheidsrechi. Zic voorts ITR 22 december 1995, RvdW $1996 / 10$ (ongangsregeling verzocht doot moeder namens kind) warin het recht, de afstamming te keinen in reikwijdte werd beperkt. Het persoonlijkheidsrecht werd verder nog ingeroepen in een zaak waarin werd geklagd over het gevangenisregime in een TEB-instelling, de beperkingen op de vitoefening wan grondrechten bleef binnen de gnenzen van Art. 8 EVRM. Het Hof benoemde de grondrechten ox Art. 8. EVRM onder de algemene noemer 'persoonlijkheidsrechten als bedoeld in art. 8 EVRM' (zie Hof 's-Gravenhage, 19 mei 1994, NJ 1996/97) maar werkte miet nader wit hoe het begrip persoomlijkheidsrechten een functie had in het kader van Art. 8 . Zie eveneens Wrongful birh, een zaak waarin A-G Vranken een recht op gezinsplanning, dat voortvioeit uit het algennene persoonljikheidsrecht erkende (HR 21 februari 1997, NJ 1999/45, par. 23 van de Conclusie) en Baby Joost (HR 8 september $2000,2000 / 734$ ), waarin A-G Langemeijer een recht op persoonlijkheid aanhaalde in verband met medische fouten bij een behandeling van een kind; de ouders zouden in dit opzicht in hun persoonlijkheidsrecht getrotfen zijn (par. 2.23 van de Conclusie) en eisten immateriele schadevergoeding. De Hoge Rand wilde zover echter niet gaan.

Verhey in zijn noot bij de zaak Valkenhorst, in: NJCM-Bulletin 19-6 (1994), p. 656. 
de afstamming te kennen werden gepositiveerd. ${ }^{63}$ De vraag of de "Valkenhorstse wijze van rechtsvinding" repercussies heeft voor de constitutionele verhouding is minder voorwerp van discussie geweest. ${ }^{64}$ Het positiveren van een nieuw recht en het scheppen van een norm van hoger recht met een dermate open karakter dat het zich kan lenen voor allerlei nieuwe positiveringen, lijken niet een discussie teweeg te hebben gebracht die bijvoorbeeld vergelijkbaar is met het debat in de Verenigde Staten of in Duitsland. Valkenhorst speelde zich af in horizontale verhouding, en leek niet direct te raken aan aspecten die de constitutionele verhouding beheersen. Ten tijde van Valkenhorst had de wetgever echter al enkele stappen ondernomen op het terrein van kunstmatige donorinseminatie en de eventuele verplichting van een biologische verwekker, zijn identiteit te onthullen. ${ }^{65}$ Daaruit blijkt dat de regering geen voomemens had, een grondrecht op afstammingskennis te positiveren. ${ }^{66}$ Niet kan worden gesteld, dat de Hoge Raad een dergelijk grondrecht hier heeft erkend. De rechter dwingt de wetgever evenwel tot het maken van principiële keuzen: aangetoond dient te worden, waarom en in welke gevallen een recht op kennis wan de afstamming - volgens de Hoge Raad een 'vitaal belang' - dient te wijken. ${ }^{67}$ Op deze wijze kan een dialoog ontstaan tussen rechter en wetgever.

\subsubsection{Het recht na boetedoening niet te worden geconfronteend met beschuldigingen}

In 1995 deed de Hoge Raad uitspraak in Het Parool t. Van Gasteren. ${ }^{68}$ In deze zaak stonden twee grondrechtelijke aanspraken tegenover elkaar: enerzijds het recht op vrijheid van meningsuiting ex Art. 10 EVRM van Het Parool c.s. en anderzijds het - uit het algemeen persoonlijkheidsrecht af te leiden - recht om na veertig jaar niet opnieuw te worden geconfronteerd met beschuldigingen die betrekking hadden op misdrijven die in de tweede wereldoorlog waren begaan. Van Gasteren stelde tegen Het Parool een civiele vordering op basis van belediging ex Art. 1408 (oud) BW in. De vraag rees wat de precieze inhoud was van de aanspraak onder Art. 1408, en in welke mate dat belang bepalend was voor de reikwijdte van het recht op vrijheid van meningsuiting. Naast de eer en goede naam ex Art. 1408 (oud) BW van Van Gasteren was volgens de Hoge Raad verder in het geding:

63 Er is wel gepubliceerd over de inhoudelijke aspecten wan het recht op persoonlijkheid (zie onder meer Nehmelman 2001, p. 141 e.v., Hartkamp 2000, p. 34-35) of het recht de afstamming te kennen (zije: Wolfhagen 1997 , p. 98 e.v.).

64 Kritisch over de gevolgde redenering: zie Verhey 1994 (nook bij Valkenhorst, NJCM-Bulletin $\downarrow 9-6$ (1994), p. 656) en Kortmann 1995, p. $₫ 55$ e.,., J.H. Nieuwenluuis 2000 , p. 205; positief over de wijze van rechtsvinding, zie Martens 2000, p. 749 e.v.

65 Wetsvoorstel voor Wet donorgegevens kunstrnatige inseminatie, Zie Kamerstukken II 1992-1993, 23 207 , nr. 1 en 2.

66 Zie Kamerstukken II 1993-1994, 23207 , nr. 6, p. 28 e.v.).

67 Tot dusverre besteedde de regering met name aandacht aan aspecten van volkgsgezondheid, en speedde bij de keuze om donors niet te verplichten hun identiteit te onthullen een rol dat grotere toegankelijkheid tot afstammingsgegevens zou kunnen leiden tot een daling in het aantal donors. Vraag is in dit verband, of deze overwegingen kunnen leiden tot inperking van een recht, de afstamming te kennen. De Hoge Raad merkte dit recht ten slotte als "vitaal belang" aan.

68 Het Paroolt. Van Gasteren, HR 6 januari 1995, NJ 1995/422. 
'tevens en zelfs in de eerste plaats diens - uit zijn algemene persoonlijkheidsrecht af te leiden - recht om niet, méer dan veertig jaar nadat hij voor het ombrengen van Oettinger werd veroorded d, zijn straf ter zake had ondergan en voor het overige gratie had gekregen, in het openbaar wederom met deze op jeugdige leeftijd, onder oorlogsomstandigheden beganc - daad te worden geconfronteerd". [...] aan de zijde van V. G. diens recht op eer en goede naam en vooral diens [...] nader aangeduide recht on "alleen te worden gelaten" $[\ldots]$. .

Met cleze overweging werd het door Van Gasteren geclaimde belang erkend in een recht; dat voortwloeit uit het algemene persoonlijkheidsrecht. Dat persoonlijkheidsrecht werd nauwelijks een jaar eerder in Valkenhorst als grondslag voor enkele geschreven en ongeschreven grondrechten aanvaard. ${ }^{70}$ Eén van die ongeschreven grondrechten, aldus de Hoge Raad, die voortvloeien uit het persoonlijkheidsrecht vormt het hierboven geformuleerde recht van het individu na zeer lang tijd niet meer te worden geconfronteerd met beschuldigingen voor een daad, waarvan de straf reeds lang geleden is uitgezeten. De aanspraak van Van Gasteren werd in deze uitspraak gepositiveerd tot grondrecht. ${ }^{71}$ Om de aanspraak van Van Gasteren kracht bij te zetten werd het volgende opgemertht:

'Eerbied voor de menselijke persoon brengt mee dat aan een veroordeelde zijn daad, nadat hij haar heeft beboet, in beginsel niet meer wordt nagehouden'?

Dit is een fraai voorbeeld van rechterlijke retoriek: de Hoge Raad wenst zijn beoordeling aanvaardbaar te maken, zonder dat er een pasklare oplossing bestond voor de wijze waarop in dit verband de in het geding zijnde belangen van Van Gasteren en van Het Parool moeten worden afgewogen. ${ }^{73}$ De rechter dient in de context van Van Gasteren rekening te houden met de maatschappelijke aanvaardbaarheid van de uitleg van het recht, omdat men in deze zaak in alle redelijkheid van mening kan verschillen over de vraag, welk standpunt voorrang verdient. Retoriek kan in dat geval de overredingskracht van het standpunt danig versterken. ${ }^{74}$

\subsubsection{Een recht op beroepsmatige ontplooing}

In een zaak over een concurrentiebeding werd de Hoge Raad gevragd te oordelen over het bestaan wan een recht op beroepsmatige ontplooing. ${ }^{75}$ Tussen twee personen was een overeenkomst gesloten terzake van de overdracht van een handelsonderneming. In die overeenkomst was een concurrentiebeding opgenomen, inhoudende dat de rechtsopvolger de overdiager geen concurrentie in de directe omgeving mocht aandoen. Niet nader was schriftelijk gespecificeerd welke de precieze omvang van het beding zou zijn. De vraag rees, in welke mate het betwiste concurrentiebeding toelaatbaar was

69 Overweging 5.10 .

70 Zie hiervoor par. 9.2.6.

71 Overweging 5.11: "Voor zover in het middel de klacht zov moeten worden gelezen dat van deze beide

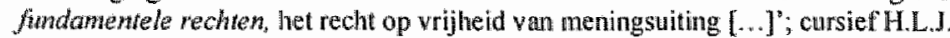

72 Her Parool t. Kan Gasieven, overweging 5.12.

73 Zie ook Boukerna 1997, p. 195.

74 Boukema 1997, p. 196.

75 HR 1 juli 1997, NJ 1997/156. 
tegen de achtergrond van een recht op beroepsmatige ontplooiing dat werd afgeleid uit Art. 19 lid 3 Grondwet:

${ }^{t}$ Het Hof heeft onvoldoende gewicht toegekend aan het in artikel 19 lid 3 Grondwet neergelegde recht van $\mathrm{K}$. op wrije keuze van arbeid en zijn algemene persoonlijkheidsrecht dat zijn recht op beroepsmatige ontplooiing insluit $[\ldots]^{\prime}$.

De invulling van Art. 19 lid 3 met het algemene persoonlijkheidsrecht leek om een aantal redenen aangewezen. Art. 19 lid 3 Grondwet omvat namelijk niet vanzelfsprekend een aanspraak op beroepsmatige ontplooing; het grondrecht heeft in beginsel een sociaal karakter dat niet afdwingbaar is. ${ }^{76}$ De klager specificeerde de inhoud van zijn persoonlijkheidsrecht voor zijn aanspraak nader met invulling van Art. 22 lid 3 Grondwet. ${ }^{77}$ Dat grondrecht houdt echter voor de overheid de positieve verplichting in dat voorwaarden moeten worden geschapen voor maatschappelijke en culturele ontplooiing. De Hoge Raad erkende de aanspraak van de rechtsopvolger van de handelsonderneming - buitenwerkingstelling van het concurrentiebeding wegens strijd met een fundamentee] recht op beroepsmatige ontplooiing - niet als een grondwettelijk ongeschreven recht. Dat zou, gezien de betekenis die de ingeroepen grondrechten hier toekomt, te ver voeren.

\subsection{Bevindingen}

\subsubsection{Inleiding}

Het grootste deel van de besproken zaken werd door de Hoge Raad beoordeeld. Enkele uitspraken van lagere rechters werden meegenomen in de beschouwingen, omdat die van belang zijn gebleken voor de rechtsontwikkeling van het persoonlijkheidsrecht en het recht op persoonlijke levenssfeer. Van de onderzochte zaken kwam het grootste deel via civielrechtelijke weg bij de Hoge Raad terecht. Eén aanspraak - op gelijke behandeling - vond een ingang via een directe aanspraak op een verdragsbepaling. In dat geval werd aanspraak gemaakt op het éénieder verbindende Art. 26 IVBPR. ${ }^{78}$ Deze be. paling werd nader ingevuld met het nimet-eenieder verbindende Art. 7 IVBPR, al bleek het binnenhalen van dit element in de redenering wezenlijk voor de vestiging van de

76 Art. 19 lid 3 Grondwet lundt: "Het recht van iedere Nederlander op vrije keuze van arbeid wordt erkend, behoudens de beperkingen bij of krachtens de wet gegteld".

77 Ant. 22 hd 3 Grondwet luid: $Z \mathrm{Zj}$ (de overheid) schept voorwarden voor maatschappelijke en culturele ontplooing en voor vrijettjidsbesteding.".

78 Etr zijn meer zakem aan te wijzen waarin aanspraak werd gedaan op internationale verdragen temake van het non-discriminatie-beginsel in horizontale verfoudingen. In HR 20 april 1990, NJ 1992/636 werd in verband met gelijke beloning voor gelijkaardige arbeid een aanspraak gedaan op Art. 7 IVESC, mast de rechter ontzegde dat verdragsartikel eeniederverbindende werking. Dat verdragsantikel behoeft, aldus de rechter, nadere witwerking. In verband met woningdistributie heeft de Hoge Raad wel erkend, dat het non-discriminatiebeginsel een functie kan vervullen in horizontale verhoudingen (zie HR 10 december 1982, NJ 1983/687, KG). In die zaak klaagde een allochtone inwoner over het feit, dat hem geen, maar autochtone stadsgenoten wel cen woning kregen toegewezen. 
aanspraak. ${ }^{79}$ In het geval van voorzieningen voor gehandicapten deed de CRvB een opmerkelijke erkenning van een aanspraak, al leidde die niet tot honorering. ${ }^{80}$ In de civielrechtelijke zaken wendde de klagende burger zich tot de Hoge Raad via de weg van de onrechtmatige daadsactie of goed werkgeverschap. Voor de rechtsontwikkeling van constitutionele persoonlijkheidsrechten en privé-leven werd - of het in dit verband nu om extensieve interpretatie of om positivering van nieuwe normen gaat - de ingang overwegend aangeknoopt bij het privaatrecht en niet bij een direct beroep op grondrechten.

Op het terrein van het strafrecht heeft de Hoge Raad gewerkt aan de legalisering van recht op hulp bij zelfdoding vanuit het perspectief van de behandelend arts. De geschillen bereikten de rechter niet via individuele aanspraken op de grondwet, maar via strafrechtelijke vervolging van artsen die zich beriepen op het bestaan van een noodtoestand. Een constitioneelrechtelijke benadering was tot dusverre niet aan de orde omdat de Hoge Raad niet werd geconfronteerd met de vraag naar grondwettigheid van afwezigheid van een recht op hulp bij zelfdoding.

\subsubsection{Ontwikkeling van de grondslag voor de normen van hager recht}

Valkenhorst is in het kader van de analoge rechtsvinding een opvallende uitspraak: hierin werd het algemeen persoonlijkheidsrecht gepositiveerd. Dat algemene persoonlijkheidsrecht fungeerde vervolgens als grondslag voor een recht om kennis te kunnen vernemen van de biologische afstamming. Naderhand werd het algemene persoonlijkheidsrecht een aantal keren ingeroepen als grondslag voor uiteenlopende individuele aanspraken, maar de Hoge Raad erkende de aanspraken slechts een enkele keer als ongeschreven recht. Het algemene persoonlijkheidsrecht draagt - afgaande op de wijze van redeneren door de Hoge Raad - het karakter van een norm van hoger recht. In Van Gasteren werd de aanspraak, na lange tijd verschoond te blijven van beschuldigingen waarvoor straf reeds is uitgezeten, gebaseerd op het algemene persoonlijkheidsrecht. In Concurrentiebeding werd de aanspraak op beroepsmatige ontplooiing eveneens gebaseerd op persoonlijkheidsrechten, maar ging de rechter niet over tot erkenning. De aanspraak in de laatste zaak werd niet erkend en evenmin gehonoreerd door de rechter, hetgeen samenhing met de onmogelijkheid aan Art. 19 lid 3 Grondwet, inhoudende het recht op vrije arbeidskeuze, in horizontale verhouding effect toe te kennen.

Aan de omvang van het persoonlijkheidsrecht zelf werd door de Hoge Raad geen begrenzing gesteld; aangenomen wordt hier dat dat begrip in de rechtspraak verdere uitwerking kan en zal verkrijgen. Een constitutionele status van het persoonlijkheidsrecht

80 Zorgverzekeraar DSW t. Sentges, CRvB 29 januari 2002, 01/515 ZFW. Andere bestuursrechters deden geen uitspraak die van vergelijkbare strekking was in het licht van rechtsontwikkeling op het terrein wan het recht op persoonlijkheid. In de rechtspraak van de Raad van State zijn geen uitspraken aangetroffen, die hebben bijgedragen tot rechtsontwikkelingen op het terrein van individuele rechten op het terrein van persoonlijkheidsrechten ex Art. 10 of 11 Grondwet of Art. 8 EVRM. 
werd niet zozeer door de Hoge Raad benadrukt, als wel door Koopmans. ${ }^{81}$ Tot op heden heeft de grondwetgever het persoonlijkheidsrecht niet opgenomen in de grondwet, en lijkt ook niet voomemens dat te doen. ${ }^{82}$ Er zijn bij de wetgever in formele zin wel aanwijzingen te vinden ter zake van de aanvaarding van het bestaan van een persoonlijkheidsrecht. ${ }^{83}$ Het constitutionele algemene persooniljkheidsrecht heeft aldus pas recentelijk zijn neerslag gekregen. Van een bestendiging in de vorm van een reeks uitspraken kan tot op zekere hoogte wel worden gesproken. De rechter behoeft de grondslag van dat persoonlijkheidsrecht in de toekomst niet nogmaals te benadrukken; waarschijnlijk zall worden volstaan met de motivering van het bestaan van het te concretiseren recht dat eruit voortvloeit. ${ }^{84}$ Herhaling van de legitimatie van het algemene persoonlijkheidsrecht lijkt overbodig. In de jurisprudentie zal waarschijnlijk verdere verduidelijking komen van individuele aanspraken die wel en aanspraken die er niet onder vallen.

\subsubsection{De analoge redenering}

In de onderzochte jurisprudentie kwamen in enkele gevallen analoge redeneringen naar voren. ${ }^{85}$ In de sommige gevallen bestond er reeds een wettelijke bepaling, waarop de indviduele aanspraak kon worden gebaseerd, een belangrijke eis om de redenering als wetsanaloog te bestempelen. ${ }^{86}$ In Valkenhorst was geen gepositiveerde constitutionele norm voorhanden; die construeerde de Hoge Raad zelf. ${ }^{87}$ Valkenhorst is een voorbeeld van een rechtsanaloge redenering. In de onderzochte uitspraken boden het non-discriminatiebeginsel alsmede de Artt. 10 en 11 Grondwet en Art. 8 EVRM als norm van

81. De Hoge Raad plaatste het recht in het constitutionele kader door te wijzen op reeds gepositiveerde grondrechten die voortwloeien uit dat recht, terwijl Koopmans het recht in zijn Conclusie in een breder kader plaatst: bepalingen uit het BW, het vermogensrecht en het EVRM zijn 'zonder dit uitgangspunt (het persoonlijkheidsrecht, H.L.J.) niet te begrijpen', Koopmans in zijn conclusie bij Valkenhorst, punt 19.

82 Nieuwenhuis 2001 , p. 179.

83 Zie bijvoorbeeld Kannerstukken II 1997/1998, 25892, nr. 3, p. 10; Memorie van toelichting in verband met de WBP; hierin werd verwezen naar de ontwikkelingeru in de rechtspraak en het persoonlijkheidsrecht in Valkenhorst. In het Rapport van de Conmissie Franken wordt echter weer miet verwezen naar het persoonlijkheidsrecht, zie eveneens de MvT bij de Wijziging wan Boek I van thet BW (adoptie door personen van hetzelfde geslacht), Kamerstukken Il $1999 / 2000,26673$, nt. 5, p. 44.

84 Zie de uitspraken van na Valkenhorst waarin een aanspraak op het algemeen persoonlijkheidsrecht werdh gedaan; de rechter zette niet steeds de grondslag wan dat recht uiteen (bijwoorbeeld Het Parool t. Van Gasteren, HR 6 januari 1995, NJ 1995/422, overweging 5.10).

85 Als analoge redenering werden aangemerkt de volgende uitspraken: Fhoridering, Rb. Amluem 18 december 1973, NI 1974/64; Bedrijfsruimaten, Hof Den Bosch 2 juli 1986, NJ 1987/451; Inzage I, Hof Amsterdam, 6 augustus 1987, NJ 1988/567, Inzage II, pres. Rb. Ansterdam 10 september 1987, KG 1987/423; Inzage III, HR 2 december 1988, NJ 1989/752 (kort geding); Anilliaanse zaak, 7 meil 1993, NJ 1995/259" Valkenhorst, HR. 15 april 1994, NJ 608/94 en AGFA, HR 8 april 1994, NJCM 19-6 (1994).

86 Agfa t. Schooldernacan (1994), zie par. 9.2 .3 (interpretatie van Art. 1638z BW); Antillaanse zaak (1993), zie par. 9.2 .3 (uitleg van Art. 26 IVBPR) en Paroolt. Vam Gasteren (1995), par. 9.2 .7 (interpretatie van Art. $1408 \mathrm{BW}$ ).

87 Als rechtsanaloge redenering kunnen eveneens worden aangemerkt de vitspraken Fhoridering, Rechtbank Amhem 18 december 1973, NJ 1974/64 en (in mindere mate expliciet) HR 22 juni 1973, NJ 1973/386 en Valkenhorst, 15 april 1994, NJ 1994/608. 
hoger recht bij de rechtsvorming op het terrein van het recht op persoonlijkheid een kapstok voor de wetsanalogie. De redeneerwijze in de verschillende uitspraken werd door enkele commentatoren geprezen omdat de rechter bijvoorbeeld de mogelijkheid schiep om ingewikkelde vraagstukken wan rechtstreekse werking van niet-eenieder verbindende verdtagsbepalingen of horizontale werking wan het non-discriminatiebeginsel te omzeilen. ${ }^{88}$

De analoge redeneermethode komt overigens niet in alle uitspraken helder naar voren; in de oudere uitspraken lijkt deze soms geheel afwezig te zijn. Vanaf Inzage $I I I$, waarin de Hoge Raad een zelfstandig recht op inzage vestigde, werd de motivering van de norm van hoger recht al wat uitgebreider: de rechter betoogde aan de hand van het bestaan van jurísprudentie, medische en juridische literatuur, overheidsadviezen en privacyregels bij medische instanties dat een recht op informatie over gegevens die bij (medische) instellingen benst, bestond. De rechter gaf echter geen specifieke jurisprudentie aan; volstaan werd met 'rechterlijke uitspraken'. "Nu was rechterlijke motivering aan de hand van jurisprudentie in de rechtspraak van de Hoge Raad pas sinds 1980 een vaker gesignaleerd verschijnsel. ${ }^{90}$

Het aantal zaken waarin de Nederlandse rechter werkte aan rechtsontwikkeling op het terrein van het recht op persoonlijkheid is klein. De belangrijkste bronnen in de uitspraken warin analoge redeneringen voorkwamen, waren rechtspraak en rechtsnormen. Het aantal uitspraken warin die bronnen zichtbaar zijn en waarin uitspraken werden gedaan over de vergelijkbaarheid onder de norm van hoger recht, is zeer klein. In $A G F A$ vormden de feitencomplexen - die van klaagster en van medewerkers in een vergelijkbare positie - de crux in de analoge redenering. In Valkenhorst dienden rechtsregels eveneens als vergelijkingsmateriaal in de analogie, maar werd Gaskin $t$. Verenigd Koninkrijk aangehaald als rechtvaardiging voor de grondslag voor de positivering van het persoonlijkheidsrecht en het recht, kennis te kunnen vernemen van de afstamming. De wijze warop de Nederlandse rechter zijn grondslag voor zijn bijdrage in de rechtsontwikkeling motiveert lijkt betrekkelijk mager. De Hoge Raad lijkt zich zo snel niet in een woellig vaarwater te bevinden waarin van een aanvaring met de wetgever dreigt zoals bijvoorbeeld wel het geval is in het Amerikaanse stelsel. De meeste kwesties kwamen bij de Hoge Raad vanuit privaatrechtelijke aanspraken in horizontale verhoudingen.

\subsubsection{Terminologie}

Grondrechtelijke aanspraken werden niet steeds erkend als rechten. In de rechtspraak is te zien, dat de rechter de individuele aanspraken bij erkenning uiteenlopend betitelt als belangen, rechten of beginselen. Aan de toepasselijke rechtsnormen wordt in de juris-

88 Zie Alkema in zijn noot onder Anthiaanse zaak, HR 7 mei 1993, NJ 1995/259 en Heringa in zujn noot. bij AGFA, 8 april 1994, NJCM 19-6 (1994).

89 inzage HI, HR 2 december 1988, NJ $1989 / 752$.

90 Zie het Siterkalfarrest. HR 7 maart 1980, NJ 1980353. 
prudentie uiteenlopende rechtskracht toebedeeld. In Bedrijfsruimten achtte de rechter de aanspraak op persoonlijke levenssfeer een argument dat diende te worden meegenomen in de afweging van alomvattender 'belangen'. In enkele uitspraken kregen de ingeroepen grondrechten, afgaand op het analoge redeneerpatroon, als het ware een status van 'norm van hoger recht' toegekend. ${ }^{91}$ In die uitspraken fungeerde het grondrecht ter inspiratie van het ingeroepen civiele recht. Slechts in vier uitspraken werd op het terrein van de persoonlijke levenssfeer een nieuwe 'rechtsnorm' ontwikkeld, waaraan het individu direct aanspraken kan afleiden. ${ }^{92}$ De vraag rijst in welke mate de rechter een ruimte toekomt, aan een aanspraak de kwalificatie van 'recht' toe te kennen. Deze wijze van erkenning van een aanspraak lijkt - in vergelijking met de toekenning van belangen of beginselen - het meest vergaand te zijn, omdat deze direct rechtsgevolgen creëert en consequenties kan hebben voor reeds gepositiveerde rechten. Het persoonlijkheidsrecht draagt in de rechtspraak niet het karakter van een rechtsregel, maar van een rechtsbeginsel. ${ }^{93}$ Dat vloeit voort uit de noodzaak tot nadere concretisering en de wijze waarop de Hoge Raad het positioneert ten opzichte van andere rechtsnormen. ${ }^{94}$

9] Inzage I, Hof Amsterdam 6 augustus 1987, NJ 1988/567; Anilliaanse zack, HR 7 mei 1993, NJ 1995/259 en $A G F A$, HR 8 april 1994, NJCM 19-6 (1994).

92 Fluoridering, Rb. Arnhem 18 december 1973, NJ 1974/64; Inzage MI, HR 2 december 1988, N.J 1989/752; Valkenharst, HR 15 april 1994, NJ 1994/608 en Van Gasteren, 6 juni 1995, NK 1995/422.

93 Zo ook Nieuwenhuis 2000 , p. 205, Kortmann 1996, p. 152 en Verhey in zijn noot bij Valkenhorst, NJCM 19-6 (1994), p. 655.

94 Het persoonlijkheidsrecht werd aangemerkt als een norm van hoger recht, die zowel erkende rechtsbeginselen alsook noties kan omvatten (zie par. 4.6). Normen van hoger recht zijn geen rechtsregels: uit normen van hoger recht vloeien rechtsregels voont, zo ook uit het persoonlijkkeidsrecht. 



\section{Hoofdstuk 10}

\section{Bevindingen en conclusies}

\subsection{Inleiding}

In het onderzoek heb ik getracht, de wijze waarop een deel van de constitutionele rechtsvinding tot stand komt - met name die waar sprake is van extensieve interpretatie of van de schepping van ongeschreven rechten op het terrein van het recht op persoonlijkheid - zichtbaar te maken en verschillen tussen de rechtsstelsels tegen de achtergrond van de constitutionele verhouding te verklaren. Centrale uitgangspunt daarbij is, op welke wijze rechterlijk redeneren aan de hand van normen van hoger recht tot stand komt. Voor de norm van hoger recht is gekozen omdat uitdrukkelijk in het midden is gelaten of de analogie tot stand kwam met behulp van een norm van

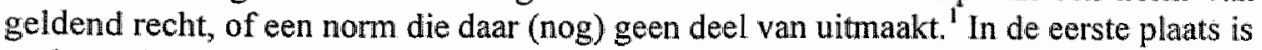
onderzocht, wat de aard en de omvang zijn van de hantering van de analoge redeneermethode op het terrein van het recht op persoonlijkheid. Vervolgens is nagegaan hoe variaties in hantering van de analogie in het betreffende rechtsstelsel zouden kunnen worden verklaard. Tenslotte is nagegaan in hoeverre de rechterlijke bereidheid, een nieuwe individuele aanspraak te aanvaarden als grondrechtelijke aanspraak samenhangt met de constitutionele verhouding tussen rechter en wetgever, en of de analogie in dit verband een bijzondere betekenis toe kan komen.

Aangetoond is op welke wijze de onbenoemde rechten die deel uitmaken van de overkoepelende notie van het recht op persoonlijkheid zich langzaam maar zeker hebben genesteld in de systemen van rechtsnormen in de rechtsstelsels. De analoge redenering biedt voor dit proces regelmatig bruikbare aanknopingspunten. Ook is geschetst, op welke wijze enkele op persoonlijkheid gestoelde normen van hoger recht zich ontwikkeld hebben in de jurisprudentie tot bronnen van ongeschreven recht. In deze inleiding zullen in het kort de belangrijkste conclusies worden geschetst, waama een uitgebreider uiteenzetting volgt. In de conclusie wordt meer in het algemeen nagegaan hoe wanuit rechtsvergelijkend perspectief variaties in aard en omvang van hantering van de analogie kunnen worden verklaard, en of uit de bevindingen meer algemene gevolgtrekkingen ter zake van constitutionele interpretatie kunnen worden afgeleid.

\section{De analogie levert steeds een constitutionele extensie op}

De analoge redenering blijkt in alle rechtsstelsels te worden gehanteerd; regelmatig bleek de analogie duidelijk herkenbaar aanwezig in de rechterlijke besluitvorming. De analogie heeft ten aanzien van de uitleg van grondrechtelijke normen steeds een uitbreidende werking gehad. Gesteld kan worden, dat wanneer de analogie met een abstracte norm van hoger recht als rechtsvindingsinstrument wordt gehanteerd, deze 
steeds een extensieve interpretatie van die normen tot gevolg heeft. Omgekeerd blijkt een extensieve interpretatie. van grondrechtelijke normen niet mogelijk wanneer een analogie onder een norm van hoger recht werd afgewezen. ${ }^{2}$

\section{Vamuit de constitutionele verhouding kunnen variaties in hantering van de analogie worden verklaard}

In alle rechtsstelsels is de analoge redeneerwijze aangetroffen. In verreweg de meeste gevallen kan deze worden afgeleid uit de structuur van de redenering in de rechtsvindingsfase. Interessant is de constatering dat de bereidheid tot een analoge redenering, die zoals hiervoor gesteld steeds een extensieve interpretatie en in enkele gevallen zelfs mieuwe rechtsnormen tot gevolg heeft, in beginsel niet met de omvang van het in de wet vastgelegde rechterlijk mandaat samen lijkt te hangen. Niet kan worden gesteld, dat de Duitse rechter die vanuit een 'ruim' mandaat interpreteert, in constitutionele interpretatie enkel de analogie hanteert. De Nederlandse rechter, wiens mandaat deels wordt beperkt door het toetsingsverbod, heeft eveneens de analoge redeneerwijze gehanteerd. Alle rechters blijken - evenwel wisselend - bereid, hun mandaat ruim te interpreteren. De variatie in de regelmaat waarin de analogie wordt gebruikt laat zich echter wel verklaren vanuit het rechterlijk mandaat en de rechterlijke taakopvatting.

De constitutionele verhouding tussen rechter en wetgever is een belangwekkende factor van betekenis in de mate waarin de analoge redenering wordt gehanteerd. Er zijn sterke verschillen aan te wijzen in de omvang van het mandaat van de rechters; zij worden allen bij constitutionele interpretatie door institutionele, interinstitutionele en normatieve grenzen beperkt. ${ }^{3}$ Een rode draad in deze grenzen is de constitutionele verhouding tussen rechter en wetgever:. de rechter mag geen rechtsscheppende bevoegdheden op zich nemen, die zijn voorbehouden aan de democratisch gelegitimeerde wetgever. De institutionele, interinstitutionele en normatieve begrenzingen zijn in alle rechtsstelsels tot op zekere hoogte interpretabel gebleken. De rechters in de stelsels hebben ieder op hun eigen wijze mogelijkheden gecreëerd - ofwel voornoemde begrenzingen geïnterpreteerd - om individuele aanspraken die in eerste instantie niet leken te kunnen worden erkend onder de erkende grondrechten, toch te beoordelen.

Van belang in dit verband is de wijze waarop de rechter zelf zijn rechterlijke taakopvatting percipieert. De termen 'activisme' en terughoudendheid', die in alle rechtsselsels zijn terug te vinden, blijken voor de beoordeling van de rechterlijke perceptie van de taakopvatting niet eenduidig bruikbaar. Zo is bijvoorbeeld geconstateerd dat de rechter zeer bereid kan blijken, in de interpretatiefase de meest uiteenlopende individuele aanspraken te aanvaarden onder erkende grondrechtsnormen of te positiveren, waardoor hij activistisch mag voorkomen. Daarmee is nog niets gezegd over de uit-

3 Deze begrenzingen zijn besproken in hoofdstuk 3 (institutionele begrenzingen tussen hogere en lagere rechters en interinstitutionele begrezingen tussen rechter en wetgever) en hoofdstuk 4 deel $\mathrm{A}$ (interpretatiemethoden als normatieve begrenzingen). 
eindelijke bereidheid, de individuele aanspraak ook te honoreren in de toetsingsfase. Sommige rechters blijken voorzichtig met de honorering van de individuele aanspraak met een beroep op "gepaste terughoudendheid jegens de wetgever" vanwege bijvoorbeeld het feit dat de wetgever over het betreffende thema wetgeving tot stand aan het brengen is. ${ }^{4}$ De Straatsburgse rechter heeft bijvoorbeeld aangegeven dat verdragsstaten ter zake van sociaal-economische wetgeving een beoordelingsruimte moet worden gelaten vanwege de politieke keuzemogelijkheden die mogelijk zijn op dit terrein. ${ }^{5}$ Tussen de stelsels bestaan in dit verband opmerkelijke verschillen.

\section{Aanvarding van de analogie impliceert aawaarding van een open constitutioneel normenstelsel}

Het gebruik yan de analoge redenering in de interpretatie geeft in zekere zin een visie van de rechter weer op de betekenis van de grondwet en de wijze waarop deze dient te worden ingezet in de individuele rechtsbescherming. Indien de rechter een analogie hanteert en daaruit een extensie van een grondwettelijke norm afleidt of een nieuw recht positiveert, gaat hij er vanuit dat er een systematiek aan grondrechtsnormen ten grondslag ligt. Uit die systematiek leidt hij structuren af, die hij zal benutten bij de invulling van grondrechtelijke normen. Uit de rechtspraakanalyse waarin een analogie werd benut kwam regelmatig expliciet naar voren, dat niet alle normen, die volgens de rechter in dat systeem aanwezig zijn, kunnen worden gekend. Sommige normen zijn (nog) niet zichtbaar; enkele rechters hebben de aandacht gevestigd op het bestaan van onbenoemde normen. ${ }^{6}$ Die onbenoemde normen komen in sommige gevallen een constitutionele betekenis toe die te vergelijken is met de betekenis die een geschreven grondrecht heeft.

Deze perceptie kan ervoor zorgen dat rechterlijke activiteit die leidt tot extensieve uitleg of positivering van nieuwe normen, past in het kader van de rechterlijke taakopvatting. ${ }^{7}$ Gesteld kan worden, dat een rechter die vanuit deze optiek extensief interpreteert of nieuwe regels toevoegdt aan het normensysteem, voor een "terughoudende opstelling" opteert omdat hij aan de grondwetssystematiek verplicht is om op zoek te

4 De Straatsburgse rechter aanvaardt bijvoorbeeld zeer uiteenlopende aanspraken als beschermenswathig onder Art. 8; in de toetsingsfase bevindt zich echter de 'margin of appreciation' (zie par. 2.6 en 3.5) waarmee an de constitutionele vethouding tegemoet kan worden gekomen. De Amerikanse rechter is veel minder rekkelijk in de interpretatiefase en erkent veel minder anspraken alls "fundanental rigluts" in die fase. Is cen aanspraak eenmal exkend als 'fundantental', dan kan deze doorgans rekenen op honorering in de toetsingsfase (hiema par. 10.5.2).

5 Zie onder meer par. 8.3.3 en 8.3.6.

6 Zie bijvoorbeeld par. 5.3.2 (het Amerikaanse Hooggerechtshof), par. 6.3.7 (het Duitse Federale Constitutionele Hof) en 8.3 .9 (Europees Hof voor de Rechten wan de Mens). Zie ook de Conclusie wan $A-C$ Koopmans bij. Yalkenhorst.

7 Rechtsontwikkeling houdt in dit verband in dat de nog niet eerder opgeworpen individuele anspraken door de rechter werden erkend als aanspraken die niet onder een gepositiveerd recht konden worden erkend, maar waarwoor grondwetteljke bescherming toch aanwezig moest worden geacht. Voorbecldien zijn de ontwikkeling wan het hiervoor genoemde Amerikaanse begrip warl "priwacy", huet Duitse algemene persoonlijkheidsrecht an het Nederlandse algemene persoonlijkheidsrecht. Hetzelfde geldt voor Wet recht op "privacy" in de rechtspraak van het Luxemburgse Hof van Justitie. 
gatan naar onderliggende structuren die richtinggevend zijn bij de uitleg van de normen. Ongekeerd zou deze rechter vanuit voomoemde optiek beticht worden van een "rechterlijke activisme", wanneer hij grondwet of verdrag bijwoorbeeld strikt tekstueel zou benaderen, en het bestaan van onderliggende structuren zou ontkennen. Hij zou de grenzen van zijn taak te buiten gaan indien hij de door de grondwetgever gegeven ruimte niet benut om een zo volledig mogelijke individuele rechtsbescherming uit te werken.

Omgekeerd impliceert een afwijzing van de analogie de aanvaarding wan een gesloten constitutioneel normenstelsel. In de stelsels zijn uitspraken aangetroffen waarin de analoge redenering juist ferm werd afgewezen vanuit de overtuiging, dat 'het grondrechtssysteem' onvoldoende duidelijke richting geeft voor constitutionele interpretatie, en dat voomoemde visie op constitutionele interpretatie het gevaar in zich draagt dat een rechter op basis van vage "structuren" een ruimte creêert om rechtsvinding te bedrijven naar eigen goeddunken." Ook deze benadering van constitutionele interpretatie geeft een visie weer van de rechterlijke opvatting over de manier warop de grondwet dient te worden gehanteerd in het kader van de individuele rechtsbescherming.

Aan deze benadering ligt de opvatting ten grondslag dat grondwet en verdrag behoren te worden geïnterpreteerd naar de expliciet gegeven intentie van de grondwetgever. Indien die niet blijkt uit de tekst of anderszins direct uit grondwet of verdrag is af te leiden, dient de rechter de individuele aanspraak af te wijzen. Er is dan geen plaats voor een analoge redenering waaruit extensieve interpretatie voortvloeit, of voor constructie van nieuwe rechten die passen in het systeem van grondwet of verdrag. Het hanteren en toepassen van de analoge redenering is in deze optiek onverenigbaar met het uitgangspunt dat het recht een vaste betekenis heeft. Het zou in strijd komen met het democratische karakter van de grondwet indien de rechter daarop excllusief toezicht heeft; er is geen behoefte aan een 'toegevoegde wetgever'. De rechter die een individuele aanspraak op basis van expliciete afwezigheid daarvan in de tekst van grondwet of verdrag afwijst, zal zich in deze opvatting als terughoudend aanmerken. Activistisch is de rechter in deze optiek, die zich verlaat op concepten en algemene beginselen en daaruit nomen voor toepassing afleidt.

8 Rechter Holmes verwoordt deze opvatting in Missouri t. Holland (252 U.S. 416 (1920) als volgt: 'When we are dealing with words that are also a constituent act, like the Constitution of the United States, we must realize that they have called into life a being the development of which could not have foreseen completely by the most gifted of its begetters. It was enough for them to realize and hope that they had created an organism [...]. The case before us must be considered in the light of our experience and not merely in that of what was sid a hundred years ago*.

9. Zie bijvoorbeeld in hoofdstuk 1 het citaat van Ramm en het citaat van rechter Rehnquist (dissenting) in Bounds t. Smith, 430 U.S. 817 (1977). 
De analogie levert soms een strategie om lastige kwesties in de constitutionele interpretatie, die samenhangen met de constitutionele verhouding, te vermijden

De analoge redenering nam op sommige momenten de indruk weg, dat er niet zozeer extensief werd geïnterpreteerd of dat er nieuwe rechtsnormen werden gepositiveerd door de rechter: de rechter trachtte het juridisch forum te overtuigen van het uitgangspunt dat de door hem gehanteerde normen reeds onderdeel zijn van het geldend recht. In het licht van de taakverdeling tussen rechter en wetgever lijkt dat een bruikbaar instrument te zijn: vanuit de gedachte van aanwezigheid van onzichtbare of onbenoemde normen in het 'systeem' van het recht kan de een spanning in de taakverdeling tussen rechter en wetgever enigszins worden gerelativeerd. In deze opvatting dient dan wel door het juridisch forum te worden aanvaard, dat de rechter niet anders doet dan onbenoemde normen in het systeem zichtbaar maken. Een grond voor hantering van de analogie lijkt te zijn gelegen in de vergroting van de aanvaarding van de rechterlijke uitspraak.

De rechter heeft bij aanvaarding van zijn uitspraak niet alleen te maken met een juridisch forum, maar ook met een 'breder publiek' dat hij wenst te overtuigen van de rechtvaardigheid van zijn uitspraak. De rechter is gebaat bij aanvaarding en naleving van zijn uitspraak bij een zo breed mogelijk forum. Dit algemene forum richt de aandacht vooral op de uitkomst van het rechterlijk besluitvormingsproces, waarbij rechtvaardigheidsgevoel eerder voorop staat. Die rechtvaardigheid behoeft niet altijd te zijn ingegeven door normen van geldend recht - niet wanneer rechtvaardigheid en geldigheid van rechtsnormen met elkaar in strijd komen. Bezwaren tegen consequenties die volgen uit het hanteren van een norm waarvan de gelding in het recht niet vaststaat lijken voor dit forum van minder groot belang. Juridische rationaliteit in legitimiteit op basis van geldende rechtsnormen kan in sommige gevallen tegenover het rechtvaardigheidsgevoel komen te staan. De analoge redenering kan in sommige gevallen een oplossing bieden wanneer juridische rechtvaardigheid en rechtvaardigheid die niet is gebaseerd op juridische grondslag uiteenlopen. Het is dan zaak dat de rechter beide fora ervan weet te overtuigen dat hij rechtsnormen hanteert en aan de hand daarvan tot een 'rechtvaardige' eindbeslissing komt. In sommige kwesties lijkt een rechtvaardige uitkomst niet voor de hand te liggen omdat over de problematiek die aan de orde is in de samenleving grote verdeeldheid bestaat. ${ }^{30}$

\subsection{Het recht op persoonlijkheid in Grondwet en Verdrag}

\subsubsection{Recht op persoonlijkheid: positiveringen in Grondwet en Verdrag}

Het recht op persoonlijkheid dekt, afgaande op de grondwettelijke- en verdragsbepalingen, een breed scala aan aspecten die op de één of andere manier te maken hebben

10 Zie bijvoorbeeld de abortuskwesties, de aanspraak op een recht op hulp bij zelfdoding en het reclat van transseksuelen op erkenning van de veranderde geslachtelijke identiteit. 
met het recht op zelfbeschikking en autonomie wan het individu. Algemene gemeenschappelijke classificaties werden in dit onderzoek afgewezen. In hoofdstuk 2 werd gesteld dat vilf deelaspecten van het recht op persoonlijkheid in alle stelsels terugkeerden. De gekozen classificatie van het recht op persoonlijkheid zoals voorgesteld bleek niet volledig, maar naar sluitendheid van een opsomming wordt niet gestreefd voor dit onderzoek. Van belang was jurisprudentie die rechtsontwikkeling te zien geeft met betrekking tot aspecten van het recht op persoonlijkheid. Nu wisselt de mate waarin deze elementen in Grondwet of Verdrag door de betrokken wetgever zijn gepositiweerd. In de Amerikaanse, de Duitse, de Nederlandse Grondwet en het EVRM zijn deelaspecten van persoonlijkheid in afzonderlijke bepalingen gecodificeerd. Hierbij kan een onderscheid worden gemaakt tussen algemene formuleringen enerzijds en nader gespecificeerde aspecten van persoonlijkheid anderzijds. Zeer algemeen en daarmee dichter in de nabijheid komend van een algemeen vrijheidsrecht zijn het Amerikaanse "liberty" uit het Veertiende Amendement, het recht op persoonlijke ontplooing

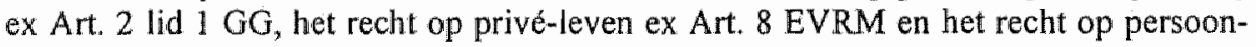
lijke levenssfeer ex Art. 10 Grondwet. Hoewel deze rechten reeds een vaag karakter dragen en mitsdien ruimte kunnen bieden aan uiteenlopende aanspraken, achtten de Amerikaanse, de Duitse en de Nederlandse rechters het toch noodzakelijk, een notie van het recht op persoonlijkheid aan de bestaande grondrechten toe te voegen: zij ontwikkelden het recht op 'privacy' (het Amerikaanse Hooggerechtshof) en het algemene persoonlijkheidsrecht (het Duitse Federale Constitutionele Hof en de Nederlandse Hoge Raad). Het EG-Verdrag positiveert geen recht op persoonlijkheid, maar via Art. 6 lid 2 EU-Verdrag maken grondrechten die de Lid-Staten gemeenschappelijk hebben en die in het EVRM zijn vastgelegd als rechtsbeginselen deel uit van de orde van communautair recht. Het recht op "privacy" behoorde tot die rechtsbeginselen, zoals het Luxemburgse Hof besliste in Panasonic in 1980. Het begrip privé-leven ex Art. 8 EVRM blijkt een zeer uiteènlopend scala aan individuele aanspraken te kunnen beschermen. Het lijkt op het eerste gezicht minder omvattend te zijn dan het Duitse begrip, omdat het van oorsprong de persoonlijkheid van het individu niet als uitgangspunt stelt en qua formulering meer lijkt te doelen op afscherming van het privéleven. Intussen blijken de ontwikkelingen in de rechtspraak van het EHRM echter te wijzen op een notie die de persoonlijkheid van het individu in meer aspecten dan alleen afscherming van de buitenwereld beschermt.

\subsubsection{Reikwijdte van de Grondwettelijke en Verdragsbepalingen}

Hoewel ter zake van de verschillende rechtsnormen in de stelsels geen definitieve reikwijdte kon worden vastgesteld, kan toch worden gesteld dat het Duitse recht op ontplooiing van de persoonlijkheid ex Art. 2 lid 1 GG de meest omvangrijke reikwijdte lijkt te hebben. Dit grondrecht ziet van oorsprong niet op aspecten van het recht op persoonlijkheid zoals een afgeschermde ruimte of een fysieke integriteit; het stelt de persoonlijkheid van het individu voorop. De in de andere stelsels genoemde rechtsnormen hebben evenwel de potentie om uit te groeien naar een vergelijkbare ruime strekking. Het Amerikaanse wrijheidsbegrip lijkt een minder ruime strekking te hebben dan het Duitse recht op persoonlijke ontplooiing. De Amerikaanse rechtspraak vertoont op dit punt een wisselend beeld. Gedurende enkele 'Courts' bleek het Hooggerechtshof bereid 
het recht op "liberty" in het Veertiende Amendement extensief wit te leggen. "De laatste twee decennia heeft het Hooggerechtshof echter paal en perk gesteld aan de reikwijdte van 'liberty'. De Nederlandse rechter heeft aan het recht op persoonlijke levenssfeer niet een uitwerking gegeven die te vergelijken is mel de mate watrin het Duitse Hof aan Art. 2 lid $1 \mathrm{GG}$ of het EHRM aan Art. 8 EVRM witleg hebben gegeven. Art. 10 en 11 Grondwet lijken wel een op de persoonlijkheid gerichte bescherming in zich te dragen, maar de rechter heeft niet zoals de Stratsburgse of de Duitse rechter wel hebben gedaan, de grenzen van dat recht onderzocht.

\subsubsection{Reikwijdie van de ongeschreven rechten}

Ook voor de in de rechtspraak gepositiveerde rechten bestaat geen definitieve en uitputtende vaststelling van de reikwijdte. Het begrip 'privacy' in de Amerikaanse constitutionele rechtspraak, het algemene persoonlijkheidsrecht in de Duitse constitutionele rechtspraak, het persoonlijkheidsrecht in de Nederlandse rechtspraak en het begrip "priwacy" in de Luxemburgse rechtspraak zijn allen in rechterlijke rechtsvinding tot stand gekomen. Het lijkt erop dat het EHRM tot dusverre geen aanleiding heeft gezien om op dit vlak met een eigen notie te komen; het achtte Art. 8 EVRM tot dusverre voldoende ruim om uiteenlopende nieuwe individuele aanspraken te erkennen. Toch zijn er in de Straatsburgse rechtspraak ook ontwikkelingen gesignaleerd die wijzen op een langzame erkenning van constituerende rechtsbeginselen die invulling geven aan ongeschreven rechtsnormen; in dit verband kan worden gedacht aan bijvoorbeeld het recht op menselijke waardigheid en het recht op leven als primordiale beginselen die het gehele EVRM beheersen. Daarnaast theeft het EHRM het recht op privé-leven ex Art. 8 in enkele gevallen als een rechtsbeginselachtige notie gehanteerd waardoor het tot een ruimere notie kon witgroeien dan de meer beperkte notie van een recht op afscherming van het privé-leven. ${ }^{12}$ Het lijkt, afgaande op de wijze waarop de rechter privé-leven in zijn rechtsvinding hanteert, steeds meer het karakter te verkrijgen van een met het Duitse of Nederlandse 'algemene persoonlijkheidsrecht'.

Het privacybegrip van de Amerikaanse rechter en het algemene persoonlijkheidsrecht van de Duitse rechter hebben beiden onmiskenbaar een kleinere reikwijdte dan respectievelijk 'liberty' wit het Veertiende Amendement en het recht op persoonlijke ontplooiing ex Art. 2 lid 1 GG. De beperkingsmogelijkheden zijn bij de wettelijk vastgelegde begrippen ruimer. Dat ligt minder woor de hand bij kwalificatie onder respectievelijk 'privacy' of het algemene persoonlijkheidsrecht; beiden hebben een beduidend minder ruime reikwijdte dan de grondwettelijk werankerde rechten op 'liberty' en persoonlijke ontplooiing.

11. Dat hangt grotendeels samen met de vraag naar de 'fundamentality' van de individuele aamspraak onder 'liberty'. Sinds Bowers t. Hardwick wordt deze vrag beantwoord an de hand wan de maalstaf van de mate waarin de aanspraak een plaats heeft verworven twssen de rechten die diepe wortels hebben in de Amerikaanse samenleving (zie par. 5.3.6).

12 Zie bijvoorbeeld Niemietz t. Duitsland, uitgewerkt in de inleiding onder 'wetsanalogie', par. 8.3.4. 


\subsubsection{Beperkingsmogelijkheden}

Wanneer de individuele aanspraak door het Amerikaanse Hooggerechtshof eenmaal is erkend als aanspraak onder 'privacy', volgt in beginsel steeds een intensieve toetsing van de aangevochten wetgeving. Aanspraken die onder "privacy" worden erkend, worden tot dusverre steeds als 'fundamental' aangemerkt. Aanspraken die onder 'liberty" worden gekwalificeerd worden niet in alle gevallen als 'fundamental' aangemerkt. "In de toetsingsfase bij het recht op vrijheid en het recht op 'privacy' lijkt nauwelijks ruimte te bestaan voor flexibiliteit ter zake van de intensiteit wan de toetsing. Een marginalle toets leidt vrijwel steeds tot het instandhouden van de wet. Omgekeerd leidt een intensieve toetsing vrijwel altijd tot vaststelling van ongrondwettigheid van de aangevochten wet. Er komt in de Amerikaanse situatie vanwege de nagenoeg algehele afwezigheid van variabele toetsingsmaatstaven veel nadruk te liggen op de kwalificatie van de individuele aanspraak in de interpretatiefase. ${ }^{14}$

De Europese rechtsstelsels vertonen in dit opzicht een wat genuanceerder beeld: een unarginale toets hoeft niet immer te leiden tot vaststelling van grondwettigheid van de wet. Omgekeerd leidt een intensieve toets niet steeds tot vaststelling van ongrondwettigheid van de aangevochten wet. Met name in het Nederlandse, het Straatsburgse en het Duitse grondwettelijke systeem blijken toetsingsmaatstaven aanwezig, die de honorering van de in de interpretatiefase erkende individuele aanspraken enigszins kunnen differentièren. Het EHRM, de Duitse en de Nederlandse rechter hanteren - weliswaar met wisselende intensiteit - een proportionaliteitstoets ter zake van rechten die gelieerd zijn aan het recht op persoonlijkheid. Het EG-Verdrag legt zelf geen toetsingsmethodiek voor beperkingen op het recht op "privacy" vast. Het Luxemburgse Hof heeft wel enkele lijnen uitgezet ter zake van beperkingen op het recht op 'privacy', maar de rechtspraak laat geen uitgewerkte beperkingsmethodiek zien. Aangenomen wordt dat de afwezigheid van een uitgewerkte toetsingsmethodiek deels samenhangt met de afwezigheid van een toetsingskader in het EG-Verdrag. ${ }^{15}$

Een belangrijke toetsingsmatstaf voor de beantwoording van de vraag of een schending van het grondrecht te rechtvaardigen is, wordt zoals hiervoor reeds gesteld gevormd door de proportionaliteitstoets. Met name de Duitse en de Straatsburgse rechter hanteren dit mechanisme en hebben de proportionaliteitstoets in de rechtspraak verder uitgewerkt. Zij zijn het meest ruimhartig met de erkenning van nieuwe aanspraken onder respectievelijk het recht op persoonlijke ontplooiing ex Art. 2 lid 1 GG en het recht op privé-leven ex Art. 8 EVRM. De mate waarin de effecten van extensieve interpretatie of van positivering van nieuwe normen kunnen worden ingeperkt door de proportionaliteitstoets lijkt van invloed op de bereidheid, uiteenlopende individuele

13 Par. 3,3.3.

14 Dit geldt voor de vraag of een individuele aanspraak onder "liberty" of onder "privacy" moet worden gekwalificeerd.

15 Deze situatie zal zich waarschijnlijk wijzigen wanneer het Handvest van de fundamentele rechten in werking treedt; hisrin kenwen de afzonderlijke rechten wel een beperkings- en toetsingsmethodiek. Tot op heden is het Hof zeer terughoudend gebleken met het aanhalen van het Handwest als rechtsbron. 
aanspraken te aanvaarden rechtsnormen. Stelsels als het Amerikaanse, het Luxemburgse en het Nederlandse, waarin niet of in mindere mate wordt gewerkt met een proportionaliteitstoets, ontberen een mechanisme on in de gevolgen van de erkenning te relativeren. 16

\subsection{De analogie levert steeds een grondrechtelijke extensie op}

De toepassing van een analoge redenering aan de hand van een norm van hoger recht leidt in de onderzochte rechtspraak steeds tot een extensie of uitbreiding van de catalogus van grondrechten: in de wetsanalogie wordt aan de te interpreteren wettelijke norm een nieuwe betekenis toegevoegd. De nieuwe betekenis van de grondwettelijke norm is althans tot dusverre nog niet in de rechtsprak, grondwet of verdrag tot uitdrukking gebracht. In de rechtsanalogie is steeds sprake is van positivering van nieuwe rechten: er worden rechtsnormen toegepast op het concrete geval, die tot op dat moment nog niet waren benoemd in rechtspraak, grondwet of verdrag. ${ }^{17}$ Met grondrechtelijke extensie wordt aldus gedoeld op het fenomeen, dat aan het grondrechtelijke normensysteem, voor zover dat tot op moment van de rechterlijke uitspraak kan worden gekend aan de hand van rechtspraak en wetgeving, een nieuwe norm wordt toegevoegd. ${ }^{18}$

Een belangrijke voorwaarde voor constitutionele extensie is dat de norm van hoger recht, die als vergelijkingspunt fungeert in de analoge redenering, een abstract karakter heeft. In geen van de gevallen leidde de analogie met een abstracte norm tot een restrictieve uitleg van bestaande bepalingen. Indien de rechter niet wilde overgaan tot extensieve interpretatie of tot positivering van een nieuw recht, bestond in de eerste plaats de mogelijkheid om een analoge benadering af te wijzen met als voomaamste reden dat het niet aan de rechter is om bestaande bepalingen dermate extensief te interpreteren of nieuwe rechtsnormen tot stand te brengen. ${ }^{19}$ Een tweede mogelijkheid om niet over te

16 Gedoeld wordt hier op het thanteren van de proportionaliteitstoets ter zake wan de fechten gelieerd ann het recht op persoonlijkheid; er worden geen vitspraken gedasn over het hanteren wan de proportionajiteitstoets in het algemeen in de stelsels.

17 Vraag is in hoeverre in grondwettelijke context, wawin met name op het terrein van het recht on peroonlykheid nomen met een open textuur zijn opgenomen, kan worden gesproken van hat al of niet benoemd zujj. Er werd met rame gezocht maar rechterlijke uhtspraken, waarin de gehantecrde norm voor het eerst werd gehanteerd in de rechtsprak; dat is hier met name de belangrijkste adtuwijzing woor de kwestie of sprake is wan een "extensieve" interpretatie of wan een "nieuwe" rechtsnorm.

18. In deze benadering wordt uitgegaan wan de veronderstelling dat de lijst van grondrechtten een zeker systeem kent. Tot het grondrechtelijk systeem behoren de in de grondwet of werdrag gepositiveerde grondrechten, gewoonterecht en ongeschreven, in die jurisprudentie gepositiveerde rechten (zic par. 2.2.4). Rechtsbeginselen horen in elk geval wel tot de constitutionele normen, maar maken niet wanzelfsprekend deel uit wan de grondrechten. Een reden om rechtsbeginselen buiten hel systeem van de grondrechten te platsen is hun rechtskarakter: rechtsbeginselen orukken in het allgemeen geen concreet toepashare rechtsnomen uit, maar dienen daaraan voorafgaand te worden geconcretiseerd.

19. Zie bijvoorbeeld het recht op tulp bij zelfdoding in het Amerikanse debat, par. 5.3 .7 of het recht op seksuele voorkeur, eveneens in de Ametikaanse rechtsprak, par. 5.3.6. Zie verder ook par. 6.3.8 warim het Duitse Hof een analoge benadering van transseksualiteit (de aanspraak op erkening van de ge- 
gaan tot een extensieve uitleg van een bestaande rechtsnorm of tot positivering van een nieuwe norm was gelegen in de afwijzing van abstracte normen van hoger recht. In sommige gevallen opteerden de rechters voor hantering van meer concrete, specifieke normen. Er werd dan een analogie voltrokken, al bleek die niet langer gebaseerd op een abstracte norm van hoger recht.

Vooral in de rechtspraak van het Amerikaanse Hooggerechtshof werd expliciet gesteld, dat de voorkeur woor hantering van een zo 'specifiek' mogelijke norm werd verbonden aan een 'terughoudende taakopvatting' van de rechter. ${ }^{20}$ In de gevallen waarin een analogie onder een abstracte norm van hoger recht (bijvoorbeeld onder "privacy") werd afgewezen werd daarvoor als reden gegeven dat de rechter zijn rechtsvinding dient te uit te voeren aan de hand van zo specifiek mogelijke normen. Specifieke normen, zo luidt de opvatting, zijn beter te objectiveren en te herleiden tot geschreven normen. ${ }^{2 \Downarrow}$ Vanuit die gedachte blijft de rechter dan "zo dicht als mogelijk" bij de oorspronkelijke bedoeling van de grondwetgever. 'Privacy' is volgens sommige rechters niet te herleiden wit de grondwet en kan derhalve geen rechtens geldige grondslag bieden voor rechtsvinding. Vraag is dan, of de stelling dat analoge redeneringen met een norm van hoger recht altijd leiden tot een grondrechtelijke extensie zijn geldigheid behoudt. In dit onderzoek is in de Amerikaanse rechtspraak de norm 'privacy' tot ontwikkeling gekomen als grondslag voor ontwikkeling van concrete individuele rechten. Het recht op "privacy" werd getypeerd als norm wan hoger recht: het fungeerde in de analogie als katalysator voor de positivering van uiteenlopende nieuwe rechtsnormen. Vanuit die optiek heeft het recht op 'privacy' een abstract karakter: uiteenlopende rechten kunnen eronder worden gekwalificeerd. Het is een postulaat dat op krachtige wijze een morele norm to gelding brengt. Een dergelijke typering komt sommige specifieke normen eveneens toe, maar zij zijn doorgaans minder abstract van aard en kunnen mitsdien het bestaan van minder uiteenlopende individuele aanspraken rechtvaardigen.

De laatste jaren lijkt de hier geschetste benadering dominant te zijn in de rechtsvinding van het Amerikaanse Hooggerechtshof ten aanzien van individuele aanspraken op het recht op 'privacy'. Op de claim dat hantering een zo specifiek mogelijke norm in de contitutionele rechtsvinding leidt tot objectivering van die rechtsvinding is echter kritiek te geven vanuit de gedachte, dat de grondwetgever bedoeld heeft dat ook abstracte normen van hoger recht deel uitmaken van het grondrechtelijk normensysteem. Deze positie wordt met name verdedigd door de "non-interpretevists' in het Amerikaanse rechtsvindingsdebat. ${ }^{22}$ Het standpunt van de Amerikaanse 'originalists' en 'intentionalists" daarentegen gaat er vanuit dat de grondwetgever die bedoeling niet heeft gehad, of dat we althans niet zeker weten of het tot het mandaat van de rechter behoort deze

slachelijke identiteit) en homoseksualiteit (de aanspraak op seksuele voorkeur en erkenning wan een recht on te huwen).

20 Zie bijwoorbeele par. 5.3.5 en 5.3.6. In de rechtspraak van het EHRM pleitten dissenters een enkele keer voor hantering van een meer specifieke matstaf (zie par. 8.3.6).

21 Zie par. 5.3.5.

22 Par. 4.3.1. 
wet op te tuigen met beschermingsmechanismen die tegemoet komen aan de eisen van de hedendaagse samenleving. Zij trekken althans sterk in twijfel dat het de taak wan de rechter is om die beschermingsmechanismen in het leven te roepen. De 'originalists" claimen dat zij met de afwijzing van hantering van abstracte normen van hoger recht in beginsel de "meest objectiverende" rechtsvindingsmethode hanteren. Hen kan echter worden tegengehouden dat de grondwetgever juist niet de bedoeling heeft gehad, dat strikt aan de tekst van de grondwet zou worden vastgehouden, maar dat deze met de condities van de samenleving mee dient te groeien. Het staat allerminst vast, dat de grondwetgever destijds een verbod op hantering van normen van hoger recht in de rechtsvinding heeft willen uitvaardigen. ${ }^{23}$

\subsubsection{Technisch-juridische en analoge rechtsvinding}

In hoofdstuk 4 is de structuur van de rechtsvinding aan de orde gekomen om te onderzoeken, in welke mate er controlemechanismen in het rechtsstelsel aanwezig zijn die de rechterlijke vrijheid bij (analoge) constitutionele rechtsvinding enigszins aan banden kunnen leggen. Dergelijke mechanismen lijken aangewezen omdat de te interpreteren grondwetsnormen een open textuur kennen, en de rechter in beginsel aldus steeds vage normen dient te interpreteren. De rechter heeft een aantal instrumenten ter zake van rechtsvinding tot zijn beschikking, waarbij een onderscheid werd gemaakt tussen technisch-juridische en analoge rechtsvindingsmethoden. Beide methoden sluiten elkaar niet uit; zij overlappen elkaar deels. De overlapping met de wetsanalogie is mogelijk bij de toepassing van de systematische, de teleologische en de dynamischevolutieve interpretatie. In een wetsanalogie zoekt de rechter aanknoping bij een bestaande wetsnorm, en onderzoekt in een concreet geval aan de hand van achterliggende systemen in de wet of rechtsbeginselen welke de omvang van de norm is. Een vergelijkbaar uitgangspunt wordt gehanteerd bij de systematische interpretatiemethoden. De overlapping met de teleologische methode is daarin gelegen, dat de rechter met de analogie tracht te ontwaren, welke onderliggende doelstellingen invulling geven aan de te interpreteren rechtsnorm. In de dynamisch-evoutieve interpretatie is de analogie van betekenis wanneer die bijvoorbeeld wordt gehanteerd om een consensus ter zake van bestaande opvattingen te ontwaren voor de rechtvaardiging van een bepaalde interpretatie van een rechtsnorm. ${ }^{24}$

De analoge redeneerwijze wordt, zij het met uiteenlopende regelmaat en wisselende intensiteit in alle rechtsstelsels benut, om een extensieve lezing van rechtsnormen of ongeschreven rechten te legitimeren. Met wisselende intensiteit wordt hier gedoeld op het onderscheid tussen de wetsanalogie en de rechtsanalogie. Het lijkt er sterk op dat de rechtsanaloge redeneerwijze in hogere mate kan leiden tot innovatieve rechtswinding dan de wetsanaloge redenering. Als onderscheid kwam in de rechtspraakanalyse naar

23. Zie hiema par. 10.4 over de variaties in haritering van de analogive in de rechtsstelsels en par. 10.5.2 over de werklaring van de variaties fusser de stelsels in hantering van de norm van hoger rechit.

24 Zie bijvoorbeeld de rechtspraak van het EHRM, par. 8.3.2 (transseksuelen) en par. 8.3.3 (culturele identiteit). 
voren dat de rechter bij de wetsanaloge methode als uitgangspunt een wetsbepaling hanteert, waarvan hij zich afvraagt of deze een reikwijdte heeft die de individuele aanspraak en het bijbehorende feitencomplex nog kunnen dekken. In de gevallen waarin de rechtsanaloge methode ter hand werd genomen, was het brandpunt van een wettelijke bepaling niet zichtbaar aanwezig; de rechter lijkt zelfstandig een rechtsnorm te construeren op basis van nomen van hoger recht.

Het onderscheid van wets- en rechtsanalogie bleek in de jurisprudentieanalyse overigens niet steeds scherp te maken; in sommige uitspraken was niet duidelijk of er nu een wets- of rechtsanalogie werd gehanteerd. Zeker is wel, dat van hantering van de rechtsanalogie minder vaak met stelligheid kon worden gesproken dan in het geval van een wetsanalogie. In het algemeen lieten rechters zich niet expliciet uit over het hanteren van de ene of de andere interpretatiemethode. Er werden soms enkele aanwijzingen gegeven die bijwoorbeeld duidden op de noodzaak, de grondrechtsbescherming te brengen op het niveau van de 'present day conditions', of op het bestaan van een systeem van verschillend soorten rechtsnormen waaruit een rechtsnorm voor het voorliggende geschil kan worden geconcretiseerd. In geen van de uitspraken gaf de rechter aan dat hij een wets- of rechtsanaloge redenering zou gaan interpreteren. De analoge redeneermethode wordt als zodanig niet aangekondigd. Uit de onderzochte rechtspraak kwam echter steeds een vast redeneerpatroon ter zake van de rechtsvinding naar voren.

\subsubsection{Rationalisatie achteraf}

Opvallend in alle rechtsstelsels is, dat de toepasselijke normen niet steeds op éen moment expliciet door de rechter aan het bestaande normenkader werden toegevoegd. Er lijkt steedls een legitimatie achteraf plaats te vinden van deze normen als rechtsnorm. ${ }^{25}$ Met legitimatie achteraf wordt hier bedoeld, dat de rechter zijn motivering op die wijze inricht, dat het lijkt alsof de extensieve interpretatie voor de hand lag of dat het gepositiveerde recht al aanwezig was in het rechtsnormenkader. Het leek er in sommige uitspraken zelfs even op, alsof de norm van hoger recht al eerder was gehanteend. Is de norm van hoger recht eenmaal door de rechter gemtroduceerd, dan volgt het stadium warin deze zich moet zien te bestendigen. Bestendiging ervan is mogelijk door toepassing in concreto en vindt plats wanneer de rechter een eenmaal gehanteerde norm van hoger orde in latere individuele aanspraken gebruikt om aanspraken te concretiseren tot rechten. Daamee is de norm van hoger recht niet een gefixeerde norm gebleken die toepasselijk is voor éen bepaalde categorie van individuele aanspraken,

25 Zis bijvcorbeeld Eppler wanrin het Hof verwees naar Touband en Soraya en andere voorafgaande jurisprudentie warin tekstueel geen sprake was van een algemeen persoonlijkheidsrecht, maar het Hof" het wel "ontwaarde" (zie par. 6.3.2 er 6.4.4). In de Amerikaanse rechtspraak werd privacy ook ontwaard in voorafgande rechtspraak aan Griswold t. Conmecticu via de constructie als opgezet door rechter Douglas (zie par. 5.4.2). Ook het algenene persoonlijkheidsrecht van Valkenhorst heeft dergelijke trekken: de rechter wilde zijn gehoor overtugen van zijn standpunt, dat het recht al bestond, maar nog niet was geuit of benoend (zie par. 9.27). In de Strantsburgse rechtspraak is rationalisatie achteraf ook te herkennen (par. 8.4,1). Het Luxemburgse Hof hanteent hiervoor zijn beginselenconstructie die dee: uitmaakt van het EG-rechtsnormenkader, waar het tot op grote hoogte kan putten uit het bestaande normenkader van het EVRM. 
maar vormt voor toekomstige rechtspraak een grondslag waaruit in het concrete geval nieuwe rechtsregels kunnen worden afgeleid: De mate van abstractie draagt in dit verband bij aan een ruimer toepassingsbereik van de norm van hoger recht: een abstracte norm kan meer 'rechten' in zich herbergen dan een norm met een specifieker toepassingsbereik. ${ }^{26}$

\subsubsection{Bestendiging}

Vaak is er enige tijd gelegen tussen het eerste moment van positivering en de tweede keer waarin de norm van hoger recht dienst doet als grondslag voor concretisering van andere of gelijkaardige individuele aanspraken. Die periode kan deels worden verklaard door het incidentele karakter van rechtspraak. De positivering van de norm van hoger orde moet worden opgemerkt en, indien relevant, worden verwerkt in de individuele aanspraak. De rechtspraak vertoont in dit opzicht een redelijk overzichtelijk beeld: wanneer die norm van hoger orde voor een tweede of volgende keer wordt benut, wordt het bestaan van de norm van hoger recht nauwelijks meer toegelicht: verwijzing naar het relevante precedent geeft dan voldoende rechtvaardiging voor de aanname van het rechtskarakter van de norm van hoger recht. Indien het bestaan van deze norm echter betwist wordt, geeft de rechtspraak een ander beeld te zien: er vindt dan soms een herhaling of nadere toelichting van de oorsprong van de norm van hoger recht plaats. ${ }^{27}$ Heeft extensieve interpretatie van een grondwettelijke norm geleid tot verhitte debatten over de takkopvatting geleid, dan kan dat tot gevolg hebben dat de rechter zich genoopt ziet de betekenis van de extensief geïnterpreteerde norm te verantwoorden, zoals in Reiten im Walde. ${ }^{28}$ Andere tekenen van onvrede met de positivering van nieuwe rechtsnormen of extensieve interpretaties zijn bijvoorbeeld debatten over voor te nemen wetgevingsactiviteiten ter zake. ${ }^{29}$ Zoals voorheen al gesteld is amendering nauwelijks een reële optie, maar kan de wetgever met een voornemen wel een signaal afgeven ter zake van de gewenste uitleg over de reikwijdte van een grondrecht. Omgekeerd kan de rechter met zijm rechtsvinding eveneens een voor de door de wetgever voorgenomen rechtsvorming belangwekkend signaal afgeven over de wijze waarop hij een bepaalde problematiek zal benaderen. ${ }^{30}$ De wijze waarop nieuwe rechtsnormen op het terrein wan het recht op persoonlijkheid steeds worden gepositiveerd in de con-

26 Zie bijvoorbeeld in de zaak Michael H.t. Gerald $D_{\text {., }}$ par. 5.3 .5 warin de discussie tussen Scallia en Brennan wordt gevoerd over de juiste invulling van de toepasselijke normen: Brennan opteerde voor een abstracte norm van hoger recht, terwijl Scalia een zo specifiek mogelijke benadering van de wergelijking bepleitte.

27 Zie bijwoorbeeld het recht op 'privacy' in de Amerikaanse rechtspraak, dat na de positivering in Griswold r. Connecticut niet steeds varizelfsprekend deel uit leek te maken van thet rechtsnormensystem.

28 Reiten im Walde, 80 BVerfGE 137 (154), zie par. 5.4.3.

29 Zie bijvoorbeeld de discussie in de Verenigde Staten over het voomemen, het Hof rechtsmacht over abortus of over andere kwesties te ontnemen (par. 3.2.6)

30 In Valkenhorst stelde de Hoge Raad dat zijn bevindingen ter zake van het recht op afstammingskennis. geen gevolgen zouden hebben woor op handen zijnde wetgeving op het terrein van kunstmatige donorinseminatie. Indien over dat thema nu echter aanspraken bij de rechter terecht komen, lijkt het wiet houdbaar een aanspraak op afstammingskennis geheel af te wijzen, terwijl personen waarvan de ouders niet hebben gekozen voor kunstmatige inseminatie wel een aanspraak op dat recht kunnen laten gelden. De Hoge Raad heeft imeers gesteld, dat de kennis van de afstamming een 'vitaal belang" is. 
stitutie vertoont sterke gelijkenis met MacCormicks visje op ontwikkeling van de wijze warop nieuwe rechtsnomen betekenis verkrijgen in het positieve recht. ${ }^{31}$

\subsection{De rechterlijke houding naar de analoge redeneermethode}

Het debat over expliciete aanvaarding of afwijzing van de analoge redeneermethode waarin aan de hand van een norm van hoger recht extensief wordt geinterpreteerd of nieuwe normen worden gepositiveerd is het meest zichtbaar geworden aan de hand van de Amerikaanse jurisprudentie. Dat houdt niet in, dat de problematiek in de andere rechtsstelsels geheel afwezig is. ${ }^{32}$ Zoals voorheen gesteld heeft extensie van bestaande normen of schepping van nieuwe rechtsnormen op het terrein van het recht op persoonlijkheid repercussies op het rechtsnormenkader: de tussenvoeging van nieuwe normen leidt tot kleine of grote verschuivingen in bet bestaande systeem, en de vraag rijst of met de nieuwe tussenvoegingen de coherentie van het systeem wordt gediend of dat dat juist leidt tot inconsistenties in het systeem. Vanuit de constitutionele verhouding klemt dan de vraag, of extensie van bestaande rechtsnormen of positivering van nieuwe normen tot de taak van de rechter behoort. De beantwoording van deze vraag verdeelt de voor- en de tegenstanders van de analoge redenering aan de hand van normen van hoger recht in het Amerikaanse debat in hoge mate. De wijze waarop deze vraag wordt beantwoord is echter niet alleen relevant voor de Amerikaanse rechter, maar ook voor de overige Europese rechtsstelsels. Ook zij hebben te maken met het feit, dat de analoge redenering leidt tot een uitbreiding van de lijst van grondrechten en dat een dergelijke rechterlijke activiteit niet vanzelfsprekend aanvaardbaar wordt geacht in het kader van de constitutionele verhouding. Vraag is, indien wordt aangenomen dat we hier te maken hebben met een belangwekkend constitutioneel spanningsveld, op welke wijze de Europese rechters bezwaren tegen rechterlijke rechtsvinding, die uit constitutionele spanningsveld voortvloeien, tegemoet treden.. ${ }^{33}$ Eerst zal het brandpunt van de discussie tussen voor- en tegenstanders van de analoge redenering in het Amerikaanse debat worden uiteengezet.

\subsubsection{Aanvaarding of ofwijzing van de analoge redeneermethode}

'Voorstanders' van de analoge redeneermethode waarin abstracte normen van hoger recht worden gehanteerd zien problemen in de algehele afwijzing van de analoge redenering met een norm van hoger recht of in hantering van de specifieke normen bij constitutioneelrechtelijke vraagstukken; zij stellen dat afwijzing van een analoge redenering met een norm van hoger recht niet gewenst is omdat deze tekort doet aan de

31 Zie par. 4.7.3.

32 De Duitse grondwet kent en begrenzing in Art. 79 lid $3 \mathrm{GG}$, dat dicteent dat grondwetswijzigingen tekstueel dienen te worden vastgelegd (par. 2.4.1); in de rechtspraak van het EHRM hebben dissenters zich een enkele keer zeer kritisch witgelaten over de hantering wan een abstracte norm van hoger recht in de rechtsvinding omdat deze in casu leidde tot vaststelling van rechten waartoe de rechter niet bevoegd was (par. 8.3 .6 en 8.3 .9 ).

33 Op deze vraag wordt een antwoord gezocht in par. 10.5.2. 
consistentie van het constitutionele recht. Juist de open textuur van het constitutionele recht waartoe ook de rechten die gelieerd zijn aan het recht op persoonlijkheid behoren, laten tot op zekere hoogte een tussenvoeging van ongeschreven rechten door de rechter toe. Vanuit die optiek kan worden gesteld, dat de rechter die zich bedient van abstracte normen van hoger recht zich juist op correcte wijze van zijn taak kwijt: hij dient nu eenmaal grondrechtsbescherming te bieden aan het individu en daartoe kan het soms noodzakelijk zijn om bij interpretatie terug te grijpen op normen die ten grondslag liggen aan de structuur van de constitutie. De coherentie van grondwet of verdrag kan juist in het gedrang komen wanneer het bestaan van een systematisch normenkader wordt afgewezen. Het gevaar bestaat dat grondrechten geissoleerd, afzonderlijk van elkaar, beoordeeld en geïnterpreteerd worden. In dat verband kan men zich afvragen, hoe deze benadering zich verhoudt met het in alle stelsels aanwezige constitutionele uitgangspunt, dat de constitutie als eenheid dient te worden beschouwd, en dat de daarin vervatte rechten elkaar niet alleen ondersteunen maar ook onderling versterken. ${ }^{34}$

Op het standpunt van de woorstanders van analoge interpretatie aan de hand van een abstracte norm van hoger recht valt zeker één en ander af te dingen. De consequenties van deze innoverende wijze van rechtsvinding kunnen van grote betekenis zijn voor de constitutionele verhoudingen, zoals onder meer bleek in of na Roe t. Wade, Niemietz $t$. Duitsland, Eppler, Valkenhorst of $P . t$. S en Cornwall County. ${ }^{35}$ Zowel voor de norm van hoger recht als voor de concretisering dienen reikwijdte en rechtsgevolgen te worden vastgesteld. De in de analogie gehanteerde norm van hoger recht opent soms letterlijk ongekende mogelijkheden voor positivering of extensileve interpretatie van grondwettelijke normen. Onder 'privacy' werd in de rechtspraak van het Amerikaanse Hooggerechtshof een recht op het gebruik van voorbehoedmiddelen gepositiveerd; later werd eveneens een aanspraak op vrijheid van homoseksuele activiteiten geclaind. De erkenning van de nieuwe geslachtelijke identiteit bleek in P.t. S. en Cornwall County aanleiding voor aanspraak op positieve verplichtingen van de stat op het terrein van gelijke behandeling. De ongekende reikwijdte van de norm van hoger reclit leidde in sommige situaties tot de afbakening van de reikwijdte, al lijkt deze vooral op casuistische basis tot stand te komen. Er kan aldus rechtsonzekerheid ontstaan over de vraag welke gedragingen er nu wel, en welke niet door de norm van hoger recht worden bestreken. Indien de rechter niet overgaat tot het formuleren van enige - voor het voorliggende geschil relevante - begrenzingen, ligt het verwijt dat hij een norm hanteert die voor iedere willekeurige aanspraak kan opgaan, voor de hand.

Tevens dient in de meeste gevallen te worden bepaald welke de reikwijdte van de concretisering is. Omdat er over de concretiseringen door de wetgever (nog) niet in ex-

34 In alle stelsells zijn interpretatienaximes aangetrofien die dicteren dat de Grondwet of het Verdrag als eenheid dient te worden beschouwd, zie par. 4.3.1, 4.3.2, 4.3.3 en 4.3.4.

35 Zie respectievelijk Roe t. Wade, 410 U.S. 113 (1973), zie par. $5.3 .3 ;$ Niemietz t. Duitsland" EHRM 16 december 1992, Serie A vol. 251-B, zie par. 8.3.4; Eppler, 54 BVerfGE 148 (1980), zie par. 6.3.5; Valkenhorst, HR 15 april 1996, NJ 1994/608, zie par. 9.2.6; P. d. S. en Cornwall County, zaak 13/94, Jur. p. 1-2143 (1996), zie par. 7.3.4. 
teriso is nagedacht ziet de rechter zich voor de taak gesteld, zelf deze grenzen alan te geven: om de concretisering uit de norm van hoger recht toe te kunnen passen dienen de reikwijdte en de rechtsgevolgen te worden vastgesteld. Wanneer de rechter daartoe overgat bevindt hij zich in beginsel direct op het terrein van de werkzaamheden van de wetgever: de rechter positiveert een rechtsnorm, en stelt haar reikwijdte vast. De mate waarin de rechter zich in laat met de werkzaamheden van de wetgever hangt in beginsel tot op grote hoogte samen met de vraag in hoeverre hij cen algemene normstelling geeft: Indien wordt gekozen voor een op de individuele casus toegesneden vaststelling van de reikwijdte en beperking zal hij zich minder snel op dat terrein begeven dan in het geval waarin hij een algemene, boven het geschil uitstijgende vaststelling doet van de omtrekken van de toepasselijke norm. In sommige gevallen benadrukten de rechters de casuístische benadering in het concrete geschil, hoewel niet in alle onderzochte gevallen kan worden gesproken van afwijzing wan meer algemene, boven het concrete geschil uitstijgende beoordeling. ${ }^{36}$ In sommige gevallen werd die reikwijdte eerst in een later concreet geschil nader afgebakend.

De reikwijdte van de norm van hoger recht in de analoge redenering laat in de Europese rechtsstelsels geen grote verschuivingen zien. Deze rechters aanvaarden, afgaand op de onderzochte rechtspraak steeds een ruime omvang van de norm van hoger recht; in enkele gevallen werd de grens evenwel bereikt, maar een debat over de reikwijdte vindt vooralsnog niet met dezelfde intensiteit als in de Verenigde Staten plaats. In de rechtspraak van de Hoge Raad is deze op het terrein van het recht op persoonlijkheid eerst recentelijk tot ontwikkeling gekomen met Valkenhorst. Een debat over de omvang van het persoonlijkheidsrecht heeft nauwelijks plaatsgevonden; afgewacht dient te worden hoe het recht zich verder zal ontwikkelen in de rechtspraak. In enkele gevallen heeft de wetgever al wel verwezen naar het persoonlijkheidsrecht. ${ }^{37}$ De rechtspraak van het EHRM laat in de ontwikkeling van de rechtsvinding aan de hand van normen van hoger recht geen grote variaties zien; het is een maatstaf die, indien noodzakelijk, werd gehanteerd en waartegen binnen de gelederen van het Hof relatief weinig weerstand lijkt te bestaan. ${ }^{38}$ Hetzelfde gaat op voor het Hof van Justitie van de EO. Dit Hof kent geen systeem van dissentings en concurrings, waardoor onduidelijk is of er binnen de gelederen van het Hof een debat wordt gevoerd over de juiste interpretatiemaatstaf. Het Duitse Hof kent wel een dergelijk systeem, maar uit de rechtspraak komt geen exphiciete afwijzing naar voren van de analoge redenering aan de hand van een norm van hoger recht ter zake van normen op het terrein van het recht op persoonlijkheid. De veelvuldige hantering van de analoge redenering met het "allgemeines Persönlichkeitsrecht' als norm van hoger recht lijkt juist te duiden op een aanvaarding van die norm. ${ }^{39}$

36 De Hoge Ratad beperkte bijvoorbeeld de reikwijdte van het recht op het kunnen venemen van de afstammingskennis door te stellen dat deze niet zou opgaan voor kunstmatige donorinseminatic (zie par. 9.2.6).

37 Par. 2.7.4

38 De grens van hetgeen het recht op prive-leven kan onvatten, werd afgetast in Botta t. Italie; verder hanteerdle het Hof het recht op prive-leven steeds als een norm met een hoge abstractiegraad waaronder zeer uiteenlopende kwalificaties mogelijk zijn (par. 8.2.1).

39 Er is wel discussie geweest over de te ruime uitlegging van het recht op persoonlijke ontplooiung ex Art. 
De rechtspraakanalyse laat zien, dat de afwijzing van de analogie of het teruggrijpen op normen van meer specifieker karakter een fenomeen is dat zich in de Amerikaanse rechtspraak manifesteert. Er lijken zich daar het duidelijkst variaties in aanvaarding of afwijzing van de analoge redenering met een norm van hoger recht af te tekenen. De wisselende koers ter zake van de aanvaarding van de analogie in de Amerikaanse rechtspraak is deels te verklaren vanuit het benoeminsproces dat grotendeels plaatsvindt op basis van de lideologische kleur wan de rechters. De onderzochte uitspraken op het terrein van het recht op persoonlijkheid staan steeds centraal in het maatschappelijke en politieke debat. Ook spelen in de kwalificatie van de aanspraak in de rechtsvindingsfase aspecten een rol die te maken hebben met de constitutionele verhouding tussen rechter en democratisch gelegitimeerde wetgever. Wanneer met zulke complexe aspecten in de rechtsvinding rekening moet worden gehouden, en de president de mogelijkheid heeft om rechters van de eigen ideologische kleur te kunnen benoemen, is het voor hem van groot belang om invloed uit te oefenen op de visie waarmee de rechter de beoordeling van een individuele aanspraak op "privacy" tegemoet treedt. Nu kan niet worden gesteld, dat de ideologische kleur van een president synchroon loopt met die van de meerderheid in het Hof. De wisselingen in de visie op de wijze waarop constitutionele interpretatie dient plaats te vinden zijn minder spectaculair dan de wisselingen van de presidenten. Zoals voorheen aangestipt kan er wel worden gesproken van zogenoernde 'Courts' die evenwel een extensief dan wel een restrictief interpretatiebeleid voerden. ${ }^{40}$

Met de politieke benoeminsprocedure heeft de ideologische voorkeur van een rechter een tot op zekere hoogte een bestaansrecht verkregen, hetgeen doorklinkt in het stemgedrag van de rechters." Dat heeft gevolgen voor de rechtspraak. Veelal werden de onderzochte zaken beslist met een stemverhouding van 5-4. De betekenis van dissentings en concurrings neemt in deze stemverhoudingen toe ${ }^{42}$ Deze laten zien welke discussies er in het Hof worden gevoerd over de juiste interpretatie en de daaraan verbonden rechterlijke takkopvatting. Met deze zichtbaarheid stelt het Hof zich kwetsbaar op; aanvaard wordt dat er niet én benadering denkbaar is maar dat et werschil lende wijzen van interpretatie bestaan en dat wijziging in opvatting over constitutionele interpretatie mogelijk is. Om de tegenstander van het eigen argument te overtügen komen de rechters die de opvatting van de meerderhied niet volgen met scherp geformuleerde dissentings en concurrings. De meerderheidsopinie boet in beginsel aan kracht in wanneer deze, zoals in veel van de onderzochte gevallen, op een minimale meerderheid steunt en in twijfel wordt getrokken door dissentings en concurrings. De afwijzing of juist aanvaarding van normen van hoger recht als normen die de rechter mag hanteren in zijn rechtsvinding wordt in de Amerikaanse constitutionele rechtspraak vanuit een zeer principieel oogpunt gevoerd. Hierdoor is een compromis, dat zou kunnen worden gebaseerd op een gemeenschappelijke visie, niet goed mogelijk.

2 lid 1 GG (Reiten im Walde, zie par.6.4.3).

40 Par. 3.2.4.

41 Par. 3.2.5.

42. Par. 3.2.5. 
De huidige samenstelling van het Hooggerechtshof overziend lijkt een dergelijke benadering ver weg. ${ }^{43}$

Het onderscheid tussen enerzijds de mogelijkheid, de analogie in haar geheel af te wijzen en anderzijds de mogelijkheid, de analogie met een abstracte norm van hoger recht af te wijzen lijkt eveneens een verschijnsel dat met name in het Amerikaanse debat wortel heeft geschoten. ${ }^{44}$ De tweede vorm van afwijzing van analoge rechtsvinding lijkt een soort "tussenfiguur" te zijn tussen algehele afwijzing van interpretatie met een abstracte norm van hoger recht en aanvaarding daarvan. Wellicht is deze tussenvariant tot ontwikkeling gekomen omdat constante, algehele afwijzing van het bestaan van normen van hoger recht niet steeds aanvaardbaar leek.

\subsubsection{Constitutioneelrechtelijke bezwaren tegen de analoge redeneermethode}

Hantering van de analogie blijkt een aantal constitutionele bezwaren met zich mee te brengen. Vastgesteld werd, dat niet steeds duidelijk is, welke de juridische status is van de norm van hoger recht die de rechter vaststelt. Een zelfde onduidelijkheid bestaat ten aanzien van de geldigheid van de extensieve interpretatie en de gepositiveerde norm. De juridische status van door de rechter gepositiveerde normen wordt in beginsel niet als vanzelfsprekend aanvaard in de rechtsgemeenschap, hetgeen tot op grote hoogte samenhangt met de oorspronkelijke constitutionele bevoegdheid van de rechter: recht spreken, niet maken. De extensie die ontstaat vanwege de analogie met een norm van hoger reclit heeft in beginsel tot gevolg dat de rechter vaker in de gelegenheid zal zijn om te beoordelen of en in welke mate wetgeving in overeenstemming met grondrechtelijke normen. In de Verenigde Staten wordt dit proces van constante uitrekking van het Veertiende Amendement wel onder het debat over 'substantive due process' gevoerd. ${ }^{45}$ Bezwaren vanuit de constitutionele verhouding tegen de oprekking van grondwetsnormen of tegen positivering van nieuwe rechten hangen direct samen met de wijze waarop de rechter zijn positie ten opzichte van de wetgever waarneemt.

De voorstanders van de analoge redeneermethode aanvaarden in beginsel een open visie van grondwet of verdrag: deze dient aldus te kunnen worden aangepast naar de eisen en condities van de huidige samenleving. Zij accepteren in dit verband tevens een taak voor de rechter. De tegenstanders van de analoge redeneermethode wijzen openheid van grondwet of verdrag niet steeds af. Met name de beantwoording van de vraag

43 De "origiualists" en de "intentionalists" wijzen de opvatting af; dat niet alleen de letterlijke tekst van de grondwet centraal staat maar dat ook rechtsnormen die niet direct zichtbaar zijn in de grondwet deel uitmaken van de hormen die de rechter in zijn rechtsvinding mag hanterery. De "non-interpretevists" aanvaarden lwantering van rechtsnomen die kunnen worden afgeleid uit het systeem van de grondwet juist wel.

44 In de rechtspraak van het Hof van Justitie yan de EG is de tweede variant wel aangetroffen in Gran $t$. Sowhwess Traiws ter zake van de concretisering welke erkenning ten aanzien van geslachtelijke identiteit onder de reikwijdte van Art. $141 \mathrm{EG}$-Verdrag kon worden gekwalificeerd (par. 7.3.4) en in de reclutsplaak van het EHRM in Botha t. Italiè (waarin een 'direct link' werd vereist tussen de undividwete aanspratak en de onder Ant. 8 gevraagde bescherming, zie par. 8.3.1).

Par. 2.3.3. 
of in dit verband aan de rechter een taak toekomt, scheidt de voor-en de tegenstanders van de analogie met een norm van hoger recht. Al eerder hadden we gezien, dat aan de rechter in alle rechtsstelsels een rechtsvindende taak toekomt die soms autonone aspecten kent. ${ }^{46}$ Dat houdt echter niet in, dat de rechter ook ruimschoots gebruik maakt van een autonome ruimte in de rechtsvinding. De onderzochte rechtspraak geeft eerder een beeld waarin de rechters zich genoodzaakt zien, activiteiten die duiden op rechtsontwikkeling, te doseren. Rechtstheoretici hebben op verschillende manieren getracht, tegemoet te komen aan de opvattingen die in de rechtsgemeenschap leven ten aanzien van de invulling van rechtsvinding door de rechter. Er bestaat geen eensgezinde opvatting, over de wijze waarop deze activiteit moet worden ingevuld. In de discussie tussen Hart, Dworkin en MacCormick wordt zichtbaar, hoezeer het vertrekpunt van de beoordelaar bepaalt, in welke mate de rechter in zijn rechtsvindingsproces ter zake van de toepasbare rechtsregel een beoordelingsruimte toekomt. ${ }^{47}$

Het debat over aanvaarding of afwijzing van de analoge redenering aan de hand van de norm van hoger recht wordt zoals gesteld het felst en het meest zichtbaar gevoend in het Amerikaanse Hooggerechtshof. De rechtspraak van dit Hof laat in dit opzicht een variëteit zien: in sommige gevallen werd zij expliciet afgewezen, terwijl in andere uitspraken de analogie met een norm van hoger recht uitdrukkelijk en door alle rechters in het Hof werd aanvaard als grondslag voor de rechtsvinding. In de volgende paragrafen zal een vergelijking worden gemaakt om de variaties tussen de verschillende stelsels te verklaren.

\subsection{De rechterijke taakopvatting in constitutionele interpretatie}

\subsubsection{Rechterlijke terughoudendheid of activisme}

Een algemene en sluitende definitie van de rechterlijke taakopvatting woor alle stelsels of voor de afzonderlijke stelsels werd niet gegeven. De kwestie, wanneer nu sprake is van 'rechterlijke terughoudendheid' of van 'rechterlijk activisme' is op verschillende wijzen te beantwoorden. Afwezigheid van een eendwidige benadering hangt niet zozeer samen met het feit dat in de rechtsstelsels verschillend wordt gedacht over de juiste invulling van de rechterlijke taak, maar is met name gelegen in de visie op en perceptie van het grondrecht en de wijze waarop dit zijn geldigheid in de huidige samenleving verkrijgt en behoudt. Centrale vraag is of in dit verband een taak aan de rechter toekomt.

In die zin lijken de inschatting van de rechterlijke taakopvatting en de perceptie van de grondwet communicerende vaten, aan de hand waarvan de begrippen "activisme" en 'terughoudendheid' kunnen worden beoordeeld. Dit geldt voor alle rechtsstelsels, ook all lijkt de ene perceptie van de grondwet in een stelsel duidelijk te domineren over de

47 Zie par. 4.7.3. 
andere en bestaan er in dit opzicht verschillen tussen de stelsels. 'Activisme" en "terughoudendheid" lijken soms zelfs uitermate manipulatieve concepten. Een rechter die bijvoorbeeld kiest voor instandhouding van een wet (waarvan ongrondwettigheid werd vastgesteld) met een beroep op rechterlijke terughoudendheid, kan als activistisch worden bestempeld indien hij daarmee een wettelijk gebod tot vernietiging negeert. Omgekeerd lijkt een rechter die voor instandhouding van een wet opteert waar vemietiging aangewezen zou zijn 'terughoudend', indien vanuit zijn mandaat blijkt dat een dergelijke mogelijkheid is vastgelegd. Zoals in hoofdstuk 3 reeds werd geschetst, biedt het rechterlijk mandaat geen klare grenzen en zijn rechterlijke activiteiten tot op zekere hoogte eveneens interpretabel. ${ }^{48}$ In hoofdstuk 4 bleken ook de rechtsvindingsmethoden geen eenduidige begrenzingen aan te kunnen leggen die de rechterlijke rechtsvinding 'binnen de perken' dient te houden.

Een centraal element in de perceptie van de rechterlijke taakopvatting in het debat over constitutionele interpretatie is aldus de visie van de uitlegger op grondrechten: is dat een lijst met specifieke rechten, of dient de uitlegger juist ook oog te hebben voor de algemene context van de specifieke rechten? Indien men van de opvatting uitgaat dat grondwet of verdrag specifieke rechten opsommen, ligt de aanname dat een rechter die via een analoge redenering rechtsnormen tussenvoegt in de lijst specifieke rechten activistisch is. Wanneer grondwet of verdrag niet worden gezien als een normensysteem dat vooropstelt dat alleen de gespecificeerde normen gelden maar dat tussen de geschreven normen ruimte bestaat voor tussenvoeging van nieuwe normen, zal het minder gauw voor de hand liggen dat een rechter die en beroep doet op het recht als systeem als activistisch wordt aangemerkt. Tussen beide uitgangspunten lijken verschillende schakeringen mogelijk. De nuance hangt samen met de vraag, in welke mate de rechter zich bij constitutionele interpretatie aan de gespecificeerde rechten in de tekst houdt, of zich op meer algemene aan de specifieke rechten ten grondslag liggende normen verlaat. Deze lijn vinden we eveneens terug in het debat tussen Hart en Dworkin. 49

\subsubsection{De constitutionele verhouding en de variatie in hantering van de analogie}

De discussie over de "juiste' rechterlijke taakopvatting in de rechtsvindingsfase lijkt zich het scherpst in de Amerikaanse constitutionele rechtsvinding af te tekenen. Een shitende verklaring is hiervoor niet gevonden, maar er lijken sterke aanwijzingen te zijn dat dat samenhangt met het feit dat het Hooggerechtshof na de kwalificatie van de

48. Wast de omvang van het mandaat in de interpretatiefase zijn in de toetsingsfase ook aspecten gevonden die dulden op rechterlijke terughoudendheid of activisme. In dit verband kan bijwoorbeeld worden gedacht aan het feith dat de rechter het nodig acht, zelf met een lijst van mogelike uitspraakeffecten te komen, aan de "margin of appreciation" bij het EHRM, het feit dat sommige rechters de casuistische benadering accentueren, de presumptie wan grondwettigheid van de aangevochten wet, het vermoeden ten faveure van de indiwduele rechtsbescherming en de ontwikkeling van de - overigens niet meer zo belangwekkende - political question doctrine. Deze elementen houden geen onveranderlijke maatstaven in. $\mathrm{Zij}$ bieden de rechter enige speelruimte on de rechterlike takopvating te laten varieren al naar gelang een numite woor de wetgever passend wordt geacht. 
individuele uitspraak onder 'privacy" nauwelijks de mogelijkheid ziet, de consequenties van die kwalificatie in de toetsingsfase te relativeren. Die mogelijkheid bestaat in de andere rechtsstelsels wel. Ten aanzlen wan de mogelijke dicta bestaan er in die stelsels variabelen. Indien een individuele aanspraak onder het algemene persoonlijkheidsrecht wordt gekwalificeerd en aldus erkend, bestaat voor het Duitse Hof in de toetsingsfase de mogelijkheid om die aanspraak niet te honoreren. Door toepassing van de proportionaliteitstoets kan het voorkomen dat een nog niet eerder gedane aanspraak aldus wel wordt erkend, en dat mitsdien sprake is van een extensieve interpretatie van het algemenen persoonlijkheidsrecht, maar dat honorering niet als vanzelfsprekend volgt. Ook de ontwikkeling van de sferentheorie in de Duitse constitutionele rechtspraak duidt op de behoefte van een soort 'verschuifbare maatstaven' waardoor" het mogelijk wordt om eenmaal erkende aanspraken op de eigen, specifieke merites te kunnen beoordelen. ${ }^{\text {so }}$

Een variatie in de toetsingsmethodiek zien we terug in de rechtspraak van het EHRM, dat tot dusverre bereid was om zeer uiteenlopende aanspraken onder het recht op privéleven te kwalificeren, maar in lang niet alle gevallen de aanspraak heeft gehonoreerd. ${ }^{51}$ Hieraan stond in veel gevallen de toetsingsfase de "margin of appreciation" in de weg: het EHRM zag aanleiding om ter zake van sommige aanspraken een beoordelingsruimte aan de staat te laten. ${ }^{52}$ Deze 'margin' kan bestaan als gevolg van uiteenlopende omstandigheden: in sommige gevallen bestaat er bijvoorbeeld te weinig consensus tussen de staten over de vraag of aan een schending consequenties moeten worden verbonden. ${ }^{53}$ Erkenning van de aanspraak maar afwijzing van honorering is ook terug te vinden in de rechtspraak van de Hoge Raad: ook deze rechter hanteert de opvatting dat de gevolgen van erkenning in de toetsingsfase niet steeds leiden tot honorering ${ }^{54}$ De onderzochte voorbeelden geven daarvan nu juist geen helder beeld; de erkende aanspra-

50 In de discussie in zowel Tagebuch als Schubart stond de vraag centraal, in welke sfeer de aanspraak diende te worde gehonoreerd, en mitsdien welke loetsingsintensiteit diende te worden gehanteerd in de toetsingsfase (par. 6.3.6), zie ook Zeugnisvernweigerungsrecht (par. 6.3.2), Ook de eerste abortusw uitspraak heefi aspecten van werschillende sferen, waardoor het mogelijk werd de aanspraak van het 'ongeboren leven' te plaatsen in een kernsfeer terwijl het recht van de zwangere wrouw in een meer perifere sfeer werd gekwalificeerd (par. 6.3.4).

51 Zie bijvoorbeeld de zaken over de erkenning van de geslachtelijke identiteit, waarin het Hof tot aan Goodwin t. Verenigd Koninkrijk de aanspraak onder Ant. $8 \mathrm{kwalificeerde,} \mathrm{maar} \mathrm{er} \mathrm{vamwege} \mathrm{de} \mathrm{'margin}$ of appreciation' geen consequenties aan werbond in de toetsingsfase (par. 8.3.2) Zie verder ook de zaak over de zigeuners en het recht op culturele identiteit (par. 8.3.3) en in het kader van Art. 8 EVRM een voorzichtige erkenning van het recht op hulp bij zelfdoding (par, 8.3.7).

52 Voor de 'margin of appreciation' zie par. 3.5.4.

53 Cossey t. Ferenigd Koninkrijk en Rees 1. Verenigd Koninkrijk, par. 8.3.2; Jane Sinith $t$. Verenigd Konimkrijk, par. 8.3.3.

54 HR 12 mei 1999 , NJ 2000/170, overweging 3.14 e.v. Andere voorbeelden van zaken warin de Hoge Raad een schending van een grondrecht (in dit geval steeds Art. 26 IVBPR) in het midden liet wanwege de rechterlijke taakopvatting zijn Optierecht (HR 12 oktober 1984, NJ 1985/230), Nacamrech (HR 23 september 1988, NJ 1989/740), Brieven van wettiging (HR 24 februari 1995, NJ 1995/468), Erfenis onwettig kind (HR 17 januari 1997, NJ 1997/483) en Adoptie door een poar van hetzelfde geslach (HR 5 september 1997, NJ 1998/686). 
ken werden steeds gehonoreerd..$^{35}$ De rechter kan zich geroepen voelen om over te gaan tot afwijzing van de honorering indien de rechtsvormende taak wordt overschreden. Overigens dient hierbij te worden aangetekend, dat nagenoeg alle bestudeerde kwesties van de Hoge Raad op het terrein van het recht op persoonlijkheid zich in horizontaal verband afspeelden. In geen van de onderzochte gevallen werd lagere wetgeving direct aangevochten; in geen wan de uitspraken werd een wet in formele zin aangevochten. Vanwege het toetsingsverbod ligt hel laatste zeker niet voor de hand, al dient te worden bezien of de Hoge Raad niet ook onder art. 8 EVRM aanspraken kan honoreren die er in eerste instantie niet door lijken te worden beschermd.

Het Europese Hof van Justitie kent geen 'margin of appreciation' in de toetsingsfase ter zake van aanspraken op grondrechten. Allereerst heeft deze rechter geen uitgewerkte toetsingsmethodiek tot zijn beschikking, al lijkt het EU-Handvest hem dat in de toekomst wel te kunnen gaan bieden. Het is tot op heden allerminst vanzelfsprekend dat de Luxemburgse rechter een proportionaliteitstoets hanteert in grondrechtenkwesties, ${ }^{36} \mathrm{De}$ indruk bestaat dat het Hof kwesties op het terrein van het recht op persoonlijkheid eerst tracht te beoordelen aan de hand van verdragsnomen. ${ }^{57}$ Indien dat niet mogelijk is, kan het recht op 'privacy' als rechtsbeginsel van gemeenschapsrecht betekenis verkrijgen in de beoordeling van de individuele aanspraak. Hantering van "privacy" in de rechtsvinding van het Hof van Justitie houdt niet steeds in dat in het toetsingsstadium een proportionaliteitstoets wordt gehanteerd om de mate van de inbreuk toe te lichten en te rechtvaardigen of af te wijzen.

De bereidheid om de proportionaliteitstoets te hanteren en te komen tot een afweging van individuele belangen tegenover die van de staat of van de Gemeenschapsinstellingen lijkt te varièren met het soort belangen - de beleidsterreinen waarop het geschil betrekking heeft - dat in het geschil aan de orde is. ${ }^{58}$ Wanneer het geschil betrekking heeft op eén van de door de Commissie geprioriteerde beleidsterreinen zoals dat van landbouw of handel, lijkt het Hof zich in het algemeen voorzichtig op te stellen. Met voorzichtig wordt in dit verband bedoeld dat het Hof de Europese wetgever veel ruimte

55 Het recht op beroepsmatige ontplooing werd niet erkend en mitsdien kwan de rechter aan honorering niet toe. De twee zaken over het geestelijk welzijn van het individu in het kader van een beroep op sociale verzekeringen door gehandicapten werd beoordeeld door de CRvB; deze erkende evenwel de anspraak max honoreerde deze niet met het oog op een beoordelingsruimte die de staat toekomt bij de keuze ten anzien wan de middelen die titt de sociale verzekeringen vergoed dienen te worden (zie par. 9.2.5)

56 Een zak waar het Hvy EG een 'grondrechtelijke' benadering hanteerde in de toetsingsfase is bijvoorbeeld: Connolly 1. Commisnie, zaak C-274/00, EHRC 2001/11. Het Hof hanteerde nagenowg de toetsingstnethodiek zoals die door het EHRM wordt benut bij de belangenafweging ter zake van Art. 10 EVRM (de kwestie handelde over vrijheid van meningsuiting). In dit grondrechtelijke geschil bestond een "Klassieke' verhouding tussen een overheidsinstelling en een individu.

57 Konstantiwlis; par. 7.3.3.

58 Het bewijs op het terrein wain de rechtspraak wan het recht op persoonlijkheid kan nier als doorslaggevend worden aangemerkt, maar is cerder indicatief voor wat er ten aanzien wan interpretatie van grondrechten en de toepassing daarwan door het Hof van Jusitie reeds langer wordt bevroed (zie par. 3.4). De bewindingen in dit boek lijken de vermoedens aldus te bevestigen (zie ook par. 7.4.2). 
laat en marginal toetst. ${ }^{59}$ Wanneer omgekeerd een geschil bestaat tussen een individu en een instelling op een niet-geprioriteerd beleidsterrein lijkt het Hof juist eerder bereid een grondrechtelijke toetsingsmaatstaf te hanteren. ${ }^{\circ 0}$ Niet kan worden gezegd dat dit steeds een betrouwbare maatstaf is; er lijken zich in dit verband enkel contouren af te tekenen. $^{\text {Gl }}$ Met de (summiere) verwijzingen in de onderzochte rechtspraak van het Hof van Justitie naar de Stratsburgse interpretatiemaatstaven zou kunnen worden gesteld dat het Luixemburgse Hof op zoek is naar een consensus in de Lid-Staten waar het gatat om aanvaarding van grondrechtelijke aanspraken. De interpretatieconstructie met grondrechten als 'rechtsbeginselen van EG-recht' lijkt een variabele toepassing van het recht op 'privacy' toe te laten. Rechtsbeginselen zijn in mindere mate afdwingbatar dan rechtsregels; tot dusverre is geen rechtsregel van een recht op persoonlijkheid in het EG-Verdrag gecodificeerd. ${ }^{6.2}$ Een mechanisme on tegemoet te komen aan de constitutionele verhouding tussen Hof van Justitie enerzijds en Verdragswetgever of communautaire Instelling anderzijds lijkt te zijn gelegen in ontvankelijkheidssfeer. Het Hof doet wanneer het dat gepast acht - wanneer er aanwijzingen bestaan dat de kwestie louter met nationaal recht verband houdt - afstand van zijn rechtsmacht en van zijn toezichthoudende taak. ${ }^{63}$ Die benadering is niet te vergelijken met een rechter die rechtsmacht wel aanvaardt en in de toetsingsfase een beoordelingsmarge voor de wetgever (of de staat in het geval van het EHRM) laat bestaan. ${ }^{64}$

In de Nederlandse, Duitse en Straatsburgse rechtspraak bestaan ter zake van de dicta aldus mogelijkheden om de consequenties van een vaststelling van een schending van een recht te relativeren. Dit geldt eveneens ten aanzien van schendingen van rechten die volgen uit extensieve interpretatie of uit door de rechter gepositiveerde nomen. De analoge redenering is een instrument waarmee de premissen van de toepasselijke rechtsregel worden ingevuld of geconstrueerd. Is die toepasselijke regel eenmall "ge-

59 In Pamasonic t. Commissie (1980) aanvaardde het Hof een aanspraak onder "privacy" maar paste het

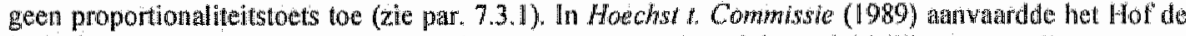
kwallicatie van de aanspraak van rechtspersonen op "privacy' in onduideldke bewoordingen, nain wees het honorering in ieder geval af.

60 Zie bijvontbeeld de geschillen tussen individuen en de Commissie ter zake van personeelskwesti (par. 7.3 .2 en Connoly t. Commissie zaak C-274/00, EHRC 2001/11 en eerder prais 1. Raad, zalk $130 / 75$ (1976) Jur. p. $1589(1976))$.

61 Par. 3.4.5.

62 Het Hof van Justitie heeft tot duswere aan het Handwest geen consequentios verbonden; zowel in de interpretatiefase als in de toetsingsfase wordt steeds gerefereerd aan het recht op "privacy" zorals dat in het EVRM is vastgelegd.

63. In dergelyke gevallen onderzokt het Hof of aan het connexiteitsvereiste is voldatan ( $\%$ ie par. 3,4.2). In de beoordeling van deze vragg lijkt een beoordelingsrumte te bestan wardoor het Hof enige gheelrumte heeft on vast te stellen of een kwestie wel of niet to zijn rechtsmacht behoort. Ter zalke wan het recht op "privacy" springen in dit verband de zaken Demirel (hereniging gezinslewen) en Grogan (ver. bod op informatieverspreiding ower abortus) in het oog. Hot Hof wees rechtsmacht in beide gevallen omwille van de afwezigheid van connexiteit af.

64 Ter zake van het recht op toegang tot een rechter wees het Hof in het licht van de constitutionele verhouding tussen Hof van Justitie en Verdragswetgever (de Lid-Staten gezamenlijk) recentelijk de oprekking van Art. 230, vierde allinea af. Indien aan deze bepaling een rumere reikwijdte moet worden toegekend, aldus het Hof, dienen de Lid-Staten het Hof daartoe expliciet bewoegd te werklaren (Union de Pequeños Agricoliores t. Raad, Zaak C.50/00 van 25 juli 2002). 
vonden' of gevormd, en ingevuld, dan dient in het rechterlijk bestuitvormingsproces de toetsing te volgen. Ten aanzien van de beoordeling van "controversièle" individuele aanspraken kan het wenselijk zijn dat de rechter zich beraadt over de gevolgen van de vaststelling van de schending. Teneinde de gevolgen van een schending te lenigen worden soms overgangsmaatregelen of termijnen waarbinnen de strijdigheid moet zijn opgeheven door de rechter vastgesteld. Ook wordt in sommige gevallen schending vastgesteld, maar er geen gevolg aan verbonden. De rechter zal voor deze benaderingen kiezen met het oog op de constitutionele verhouding waarin hij verkeert met de wetgever. In Duitsland heeft de rechter de variatie in de dicta tot op grote hoogte zelf gecreëerd; in principe dicteert de Duitse grondwet dat strijdigheid leidt tot nietigheid van de aangevochten wet of het rechterlijke besluit. Het EG-Verdrag kent een aantal verschillende dicta. ${ }^{65}$ Voor de Nederlandse rechter geldt ten aanzien wan wetgeving in formele zin het toetsingsverbod, waardoor de kwestie van de dicta op het eerste gezicht vanuit grondwettelijk oogpunt niet relevant is. Indien de Hoge Raad echter strijdigheid van een wet in formele zin vaststelt met eenieder verbindende verdragsbepalingen dient hij vanwege Art. 94 Grondwet de gewraakte wetsbepaling buiten toepassing te laten. De Nederlandse rechter hanteert echter ook een grotere variëteit aan dicta dan zijn mandaat in eerste instantie voorschrijft. ${ }^{66}$ Door het Amerikaanse Hof blijken deze 'strategieën", althans met betrekking tot de jurisprudentie op het terrein van het persoonlijkheidsrecht, faliekant te worden afgewezen. Afwijking van de mogelijke dicta wordt gezien als onwenselijk rechterlijk activisme, en betiteld als een strategie om extensieve interpretaties aanvaardbaar te maken.

\subsubsection{Uitgangspunt: voorkeur voor een 'terughoudende' taakopvatting}

Een algemene opvatting lijkt te zijn dat wanneer constitutionele interpretatie in het juridisch forum als activistisch wordt aangemerkt, de stellingname ten opzichte van de rechtspraak die daaruit volgt in beginsel steeds negatief is. Zoals hiervoor reeds gesteld, is niet eenduidig vast te stellen wanneer nu van activisme sprake is. In het Amerikáanse debat komen de verschillen tussen de opvattingen over de rechterlijke taakopvatting helder naar voren. De belangrijkste methoden van grondwetsuitleg in de jurisprudentie van het Amerikaanse Hooggerechtshof kunnen worden aangeduid met enerzijds de benadering van de 'original intent' en de 'intentionalists' en anderzijds de 'non-interpretevists' ${ }^{67}$ Aanhangers van beide opvattingen bevinden zich in het Hooggerechtshof. In de rechtspraakanalyse kwam naar voren dat de aanhangers van beide groeperingen elkaar betichten van activisme door tegen de bedoeling van de grondwetgever in een opvatting te hanteren ter zake van het grondrechtelijke systeem. ${ }^{68}$ In de rechterlijke instanties van de andere stelsels wordt het debat over de juiste balans tus-

Zie par. 3.4.3.

Zie par. 3.6.3.

Zie par 4.3 .1 .

Zie bijwoorbeeld de discussie over de betekenis van het Negende Amendement, par. 2.3.2 en in de abortusuitspraken (zie par, 5.3.3) en het debat tussen rechter Scalia (aanhanger van de "original intent"methode) en rechter Brennan (aanhanger van de "non-interpretevist"-methode) in Michael H. $t$. Gerold" D. in par. 5.3.5. 
sen rechterlijk activisme en rechterlike terughoudendheid in de interpretatiefase in veel mindere mate gevoerd. Wat evenwel uit de geanalyseerde rechtspraak van alle stelsels is af te leiden, dat de rechter zich in geen van de onderzochte uitspraken expliciet profileerde als 'activistisch'. Rechters zullen alleen, indien zij dat noodzakelijk achten, aangeven dat zij een terughoudende taakopvatting hanteren. ${ }^{69}$

Rechterlijk activisme of terughoudendheid hangt niet steeds samen met de voorkeur voor een bepaalde politieke stroming. Deze opmerking is vooral van belang voor het Amerikaanse Hof, waarbinnen afwisselend liberale en conservatieve politieke voorkeuren heersen en ook zichtbaar zijn. Aan meer sociale politieke stromingen wordt in beginsel eerder een voorkeur voor een vermoeden ten gunste van de individuele rechtsbescherming toegedicht dan aan een meer liberale of conservatieve stroming. In het algemeen kan echter niet worden gesteld, dat een Hof met cen meer conservatieve politieke opvatting steeds - ten aanzien van alle mogelijke onderwerpen die aan bod komen - een terughoudender takkopvatting hanteert en mitsdien minder of niet bereid is te speuren naar mogelijkheden van extensieve rechisvinding of ongeschreven rechten. ${ }^{70}$

\subsection{De analogie als strategie om netelige kwesties in de constitutionele verhouding te omzeilen}

In hoofdstuk 4 is het forum an de orde gekomen: vraag was wie de rechter met zijn rechtsvinding en met zijn uiteindelijke besluit tracht te overtuigen. Het juridisch forum is, zo werd daar gesteld, niet alleen geïnteresseerd in de uitkomst, maar ook in het rechterlijke besluitvormingsproces dat daaraan vooraf gaat: zij willen weten of en op welke wijze dat proces cohereert of interfereert in het bestaande normensysteem. ${ }^{71}$ Vraag is, in hoeverre de rechters in de onderzochte rechtspraak aan het juridisch forum tegemoet komen; dit forum is voor het vormen wan zijn opinie gebaat bij motivering van de verschillende stappen in het besluitvormingsproces. De rechter lijkt er soms, afgaand op de onderzochte jurisprudentie, vanuit te gaan dat hij zijn juridisch forum in sommige gevallen niet meer behoeft te overtuigen van zijn standpunt dat de ingeroepen norm van hoger recht al bestaat: hij besteedt in zijn motivering niet veel ruimte aan de geldigheid van de norm van hoger recht of van de concretiseringen daaruit.

Uit de soms povere motivering kunnen worden afgeleid, dat de rechter geen inzicht wil verschaffen in de redeneertechniek en de mogelijke gevolgen daarvan: dat kan hem komen te staan op verwijten van rechterlijk activisme. Het zwijgen of het niet motiveren van keuzes ten aanzien van het rechtskarakter van de gehanteerde normen kan in dit verband dienen om de aandacht van de gelding van de norm van hoger recht af te

69 Zie bijvoorbeeld Reiten im Wolde, 80 BVerfGE 137 (1989) waran het Duitse Federale Constitutionele Hof met een beroep op terughoudendheid is ingegaan op het verwijt dat het Art. 2 lid 1 GG activistisch zou interpreteren; zie ook Griswold t. Connecficut, 381 U.S. 479 (1965), par, 5.3.2.

70 Zie voetnoot 164 in par. 5.4 .4

71 Zie par. 4.2 .4 . 
leiden. Wanneer de toe te passen norm niet op het eerste gezicht deel lijkt uit te maken van het geldend recht, zijn soms andere technieken aangewezen om de grondslag van de rechtswinding rond te krijgen. Wanneer de rechter overtuiging van de rechtsgemeenschap noodzakelijk acht, kunnen precedenten en consensus in een behoefte voorzien: die verzekeren, indien zij accurat worden ingezet, als het ware inbedding van de norm van hoger recht in het systeem van geldende rechtsnomen, die werden getraceerd in de rechtspraak. Ook voor de rechtvaardiging van de extensieve lezing van een grondwetsbepaling of voor positivering valn mieuwe normen kan de rechter uit precedenten putten. Een vooral voor het EHRM belangwekkende bron van recht bleek het consensusbeginsel te zijn. Doel van de inbedding van de norm in een systeem is de aanvaarding van de norm te versterken en te versnellen. Het hanteren van juridische bronnen versterkt de noodzakelijke rationaliteit, terwijl ondersteuning van argumenten uit consensus op andere wijze kan bijdragen aan de overtuiging van de gevolgde redenering. Nu kan van rechtspraak niet steeds gezegd worden dat het behoort tot de formele rechtsbronnen, maar inmiddels lijkt aanwaard dat het een voorname bron van recht is. ${ }^{72}$ Van het consensusbeginsel staat allerminst vast of het behoort tot de bronnen van recht. Rationaliteit kan aan een consensus niet a priori worden ontzegd. Vraag is of het onderzoek naar het ontwaren van een consensus dusdanig wordt ingericht, dat de vaststellingen controleerbaar zijn. Dat laatste blijkt niet uit de motivering in het overgrote deel van de onderzochte gevallen.

De in de rechterlijke besluitvorming vereiste rationaliteit kan in sommige opzichten tegenover het rechtvaardigheidsgevoel komen te stalan. Idealiter is het rechtvaardigheidsgevoel in balans met juridische rationaliteit. In de analyse van de rechtspraak kwam naar voren, dat afzonderlijke groepen binnen het algemene forum moeten worden overtuigd. ${ }^{73}$ In het bijzonder bij de beoordeling van geschillen omtrent het recht op persoonlijkheid ligt het voor de hand dat bepaalde groepen in het forum moeten worden overtuigd van de rechtvaardigheid van de rechterlijke beslissing. Allereerst dient de samenleving te worden overtuigd van de norm die wordt toegepast op het concrete geval. In veel gevallen blijkt dit geen sinecure. Dat hangt samen met het karakter van de individuele aanspraak op een aspect wan het recht op persoonlijkheid: er bestaan in de samenleving zeer uiteenlopende opvattingen over de mate warin de staat zich mag of moet inlaten met persoonlijke keuzen van het individu. Met beoordeling van het recht op persoonlijkheid worden, zoals blijkt uit de onderzochte jurisprudentie, regelmatig kwesties met een hoog ethisch gehalte beslist. Juist individuele aanspraken samenhangend met de persoonlijkheid kunnen niet altijd rekenen op de instemming van een meerderheid als het gaat om erkenning van bijvoorbeeld voorkeur voor homoseksuele of interraciale relaties, het willen ondergaan van een abortus, de erkenning van het nieuwe geslacht of het willen kennen van de biologische afstamming. Er dient echter soms, on de aanvaarding van de uitspraak te vergroten in de onderscheidenlijke

72 Pat. 4.7.4.

73 Met het algemene forum wordt gedoeld op alle fora tezamen: het juridisch forum, de bij het geschil betrokken partijen, de stantsrechtelijke en politieke actoren, en de samenleving als geheel (zie par. 4.2.4). 
fora, gelaveerd te worden tussen de twee uitgangspunten van juridische rationaliteit en het rechtvaardigheidsgevoel; zij kunnen soms zelfs diametraal tegenover elkaar komen te staan.

In de vervulling van deze taak lijken retoriek en metaforen tot op zekere hoogte te kunnen bijdragen aan aanvaarding van de uitkomst van het rechterlijk besluitvormingsproces. De rechter heeft bij hantering van de analogie belang bij het beklemtonen wan de geldigheid van de gehanteerde norm, terwijl niet eenduidig uit grondwettelijke normen of uit jurisprudentie blijkt dat daarvan in het gegeven geval gesproken kan worden. Indien een redenering nu wordt opgebouwd op basis van een erkende rechtsnorm behoeft de gelding ervan niet te worden gemotiveerd. De rechter die een "nieuwe" rechtsnorm hanteert, waarvan hij vermoedt dat deze op weerstand zal stuiten omdat de norm nog geen gelding heeft, zal een uitweg uit de discussie over de gelding erwan kunnen vinden in de opmerking, dat de nieuwe norm een "logische" tussenvoeging vormt de geschreven grondrechtsnormen. De wijze waarop het Hooggerechtshof het recht op 'privacy' in Griswold t. Connecticut een plaats toekent tussen de geschreven normen in de Amendementen leunt sterk op deze techniek. ${ }^{74}$ In die zaak diende te worden aangetoond dat de nieuwe norm 'privacy" reeds bestond, maar pas door de rechter zichtbaar werd gemaakt. Uit de "halfschaduwen", of "perifere sferen" van enkele Amendementen werd een recht op 'privacy' afgeleid.

Soms worden retoriek en metaforen gehanteerd om de validiteit van de norm van hoger recht of wan de concretiseringen ervan te staven. Retoriek en metaforen kunnen de rechter een grondslag bieden om tot krachtige en overtuigende formuleringen to $\mathrm{kO}^{-}$ men. ${ }^{75}$ Een retorische benadering van een probleem kan leiden tot de conclusie dat er slechts éen oplossing voor het probleem voor de hand ligt, die gevolgd dient te worden. De door de rechters in de analogie gehanteerde argumenten om de normen van hoger recht overtuigingskracht bij te zetten hebben steeds een sterk retorisch karakter. In Gaskin stelde het Straatsburgse Hof bijvoorbeeld, dat de dossiers waarvan openbaarmaking werd gevraagd, 'ongetwijfeld' informatie bevatten met betrekking tot 'hoogst persoonlijke aspecten' van de jeugd van de klager. ${ }^{76}$ Ook het in Meyer ". Nebraska aan-

74. Zo doet cok de wijze waarop het recht op kennis van de biologische afstamming werd gepositivecrd sterk aan deze benadering denken; daar kende de Hoge Raad expliciet cen grondirechulijke status loe aan dat reclit (par, 9.2.6). Zie verder onder meer de wijze waarop het Duitse Hof het recht op "informationele zelfbeschikking' en het 'algemene persoonlij|kheidsrecht' positiveerde (par. 6.3 .2 en 6.3 .7 ) $\mathrm{cn}$ de rechtspraak van het EHRM waarin een recht op menselijke waardigheid werd gepositiveerd (par. 8.3 .7 en 8.3.8). Het Hol van Justitie van de EG hanteerde deze benadering in de positivering van een recht op medische zelfbeschikking (par 7.32) en van een recht op erkenning wan de transseksuele identiteit (pair. 7.3.4).

75 Zie par. 4.5.3.

76 Gaskin t. Verenigd Koninkrijk, EHRM 7 juli 1989, NJ 1991/659, par. 36 (par. 8.3.5), Zie ook Kenwnis der eigenen Abstantmung, 79 BVerfGE 256 (1989): "Als Individualisierungsmerkmal gehort die Abstammung zur Persơnlichkeit, und die Kenntnis der Herkunft bietet dem einzelnen unabhangig von AusmaB wissenschaftlicher Ergebrisse wichtige Ankntopfungspunkte ftir das Verstandnis und die Entfalfung, der eigenen Indiwidualitat' (zie ook par. 6.3.7). Hier zijn het retorische element - de kenniss vart de afstamming is 'Personlichkeitspragend'- en de metafoor - kennis van de afstamming neemt in het 
gehaalde voorbeeld van het streven van het individu naar geluk als "oergrondslag' voor het recht zall door weinigen worden tegengesproken.

Een metafoor geeft een vereenvoudigde figuurlijke uitdrukking van het probleem, die berust op een vergelijking. In Gaskin werd eveneens een metafoor aangetroffen: de dossiers vormden zijn 'voornaamste bron' ter zake van de informatie over zijn verleden en zijn vormende jaren. ${ }^{n}$ Retoriek en metafoor hebben gemeenschappelijk, dat zij enerzijds tot vereenvoudiging en een soort grijpbaarheid van het geschetste probleem leiden; maar anderzijds ook dat dat tot versluiering van de complexiteit van het feitencomplex en de individuele aanspraak, het normensysteem of van de constitutionele verhouding kan leiden. Voor de rationaliteit is hantering van versluierende argumenten in beginsel niet wenselijk. Met zowel de vereenvoudiging als ook de versluiering van de complexiteit kan het forum worden overtuigd, hoewel het juridisch forum in beginsel kritisch staat ten opzichte van deze wijze van legitimatie. Met name het Amerikaanse juridisch forum is zeer kritisch over hantering van argumenten gebaseerd op retoriek en metaforen. In de andere rechtsstelsels lijkt er relatief weinig kritiek vanuit het juridisch forum te komen op de genoemde argumentatietechniek.

De metafoor en retoriek dragen naast vereenvoudiging het vermogen in zich de vragen naar exacte waardering van de gemaakte keuzes onder de norm van hoger recht - het vergelijkingsmateriaal en de mate waarin de voorliggende individuele aanspraak te vergelijken is met de resultaten uit de norm van hoger recht - tot op zekere hoogte te vermijden. In dit verband rijst de vraag in hoeverre beweringen die enkel zijn gebaseerd op een metafoor of die hun kracht ontlenen aan retoriek; juridisch hout kunnen snijden in een argumentatie. Een juridische kwaliteit kan een metafoor niet in alle gevallen worden ontzegd, maar deze is in elk geval niet vanzelfsprekend aanwezig in een metafoor of in retoriek. In een aantal gevallen vormden retoriek en metafoor echter de enige legitimatie voor het bestaan van een grondrechtelijke aanspraak. ${ }^{78} \mathrm{Er}$ kon dan bijvoorbeeld niet op andere wijze een norm van hoger recht worden gevonden die het vergelijkingsmateriaal en de individuele aanspraak in het voorliggende geschil bestreek. Wanneer retoriek en metaforen dienen om vragen naar rationaliteit voorgoed uit de weg te gaan - de functie is het vervangen of omzeilen van een argument op juridische gronden - klemt de vraag of redeneringen die exclusief zijn opgebouwd rond een metafoor of retoriek houdbaar zijn in het licht van de eisen van rationaliteit die aan een cleugdelijke motivering worden gesteld.

bewustzijn van het individu een 'Schlihsselstellung fur Individualitattsfindung und Selbstversttindnis' in - beiden nadrukkelijk aanwezig. Zle verder voor voorbeelden par. 5.3.3 (recht op abortus in de Amerikaanse rechtspraak); par. 6.3 .4 (abortus in de Duitse rechtspraak), par. 6.3.8 (het bellang van de naam voor de identiteit in de Duitse rechtspraak), par. 7.3.3 (warin de A-G het belang bij rechit op de naam mede aan de hand van retoriek onderbouwt) en par. 9.2.6 (waarin de Hoge Raad het belang bij de afstammingskennis onderstreept als 'vitaal belang').

77 Zie bijwoorbeeld Gaskin t. Verenigd Konimkrijk (erkenning van een 'vitaal belang"), maar ook Griswold t. Connecticut (pasitivering van "privacy" aan de hand van haflschaduwen in de Amendementen).

Zie bijwoorbeeld Lochner t. New York, 198 U.S. 45 (1905). 


\section{Summary}

\section{Background}

This study, conducted on the basis of case law and scholarly literature, examines the way in which the constitutional concept of "personal rights" is interpreted by the US Supreme Court, the German Federal Constitutional Court, the Netherlands Supreme Court, the European Court of Justice and the European Court of Human Rights. In all systems examined comparable interpretation methods - textual, historical, systematic and teleological - have been developed. They assist the court in its search for an applicable legal norm for the dispute in hand. However, inasmuch as in some instances these methods fail to offer a satisfactory interpretation of the norm invoked by the applicant, in interpreting personal rights the courts are sometimes forced to go beyond the above interpretation methods in order to establish the correct scope of a personal right. This need is felt in particular, if the court does not have at its disposal a norm that is readilly applicable to the dispute in hand, where it is most desirable and possible to resolve the dispute. In judging a dispute, the court weighs the individual claims at issue against the suitability of judicial decision making to resolve the dispute and considers whether they may be protected in ways other than by judicial intervention. If it proves not possible in a concrete case to readily apply a particular norm, the court may opt for extensive interpretation of an existing norm, or may proceed to create an appropriate legal norm itself to resolve the dispute. The extent to which the court deems its decision making appropriate to resolve a concrete dispute, depends to a certain extent on the constitutional relation existing in the legal system in question between the (highest) court and the Jegislature. In the case of the European Court of Human Rights (ECHR) and the European Court of Justice, strictly speaking, a constitutional relation exists between the Court and the parties to the Convention and the Treaty, respectively. As regards the European Court of Justice, the Institutions also exercise legislative powers.

In cases, in which the court decides to extensively interpret a personal right or to create a new legal norm in relation to a personal right, a common pattern of reasoning is observed. This pattern is referred to as 'analogous reasoning' or 'analogy" and involves a reasoning technique which is sometimes used to answer the question as to whether an individual claim must be considered as constitutional in nature or not. If the court decides to use extensive interpretation, or to 'stretch" an existing legal norm applying to a personal right, this is referred to by the author as analogous reasoning based on legislation (wetsanalogie). In such cases, the individual claim is based on a constitutional provision. However, the provision must be made to fit the individual claim, because it was not written with such a dispute in mind. At first sight at least, it is not clear whether the provision is applicable to the individual claim, but its applicability may be justified in some cases by the court's analogous reasoning based on legislation. There are also cases in which the individual claim is not based on any discernible concrete legal norm. If, for the resolution of such a dispute, no legal norms are available and judicial resolution is an option, the court may proceed to create a legal norm, which then becomes part of operative law. In that case, it practices analogy based on 
principles of superordinate law (rechtsanalogie). The author uses 'analogy', 'analogy based on legislation' and 'analogy based on principles of superordinate law" to indicate a pattern of reasoning shared by the systems examined.

Analogous reasoning based on legislation or principles of superordinate law means that the court, on the basis of comparative material collected by it, examines whether there is a superordinate legal norm which may lend a constitutional character to the individual claim. The question of the constitutional character of the individual claim is very important; because recognising the claim as 'constitutional' entails that the court subjects existing legislation to review. This premise touches on the essence of the constitutional relation between the judiciary and the legislature: by testing against a constitution or a treaty, there is a chance that the court may declare unconstitutional particular legislation, with the inclusion of statutes. Analogous reasoning in this context works as follows: the court formulates, what is called here, a superordinate legal norm, which it distils from comparative material. This may be a legal principle, although the status of such a norm is not always clear, hence the term "superordinate legal norm". This comparative material may consist of case law, existing legal rules not readily applicable to the individual claim, indications of a consensus on the subject, or the travaux preparatoires pertaining to a constitution or a treaty. As a rule, norms of superordinate law need to be tailored to the concrete case; the court will have to specify why the norm of superordinate law applies to the concrete case.

In the next step, the norm of superordinate law legitimises application of the norm deemed appropriate to the dispute in hand: the superordinate norm governs both the existing constitutional provision and its extensive application as envisaged by the court. In the event of analogy based on legislation, the norm of superordinate law justifies the classification of the individual claim at issue as falling within the scope of existing written legal norms, although they were not written for this individual claim. This is premised on the idea that equal cases must be judged equally. In the event of analogy based on principles of superordinate law, the norm of superordinate law singly legitimises the court's rendering operative of unwritten legal norms; in that case, a possible applicable constitutional norm is not available. The norm of superordinate law is then the exclusive legal ground on which to justify the creation of a new legal norm.

\section{Aim of the Study}

This dissertation examines the nature and scope of law finding in the area of personal rights through analogy based on legislation or principles of superordinate law. The study shows that the use of these two types of analogy produce a suitable law-finding instrument, with which disputes can be judged. In the case of constitutional interpretation, the court finds itself in an area of tension with the legislature, because law finding by extensive interpretation may lead to judge-made law. The question is whether the constitutional relation permits such law-making activity. The author has examined whether there is a relation between the courts' preparedness to interpret extensively or 
create new norms on the basis of analogous reasoning and the nature of the constitutional relations.

\section{Results: theory}

The analysis shows that courts employ analogous reasoning based on legislation or principles of superordinate law to classify individual claims, where applying a legal norm to a concrete dispute does not rum smoothly. An individual claim to, for instance, the right to be informed of the identity of the biological father cannot be directly linked to an existing legal norm. In this particular case, the court construed a legal norm - a general personal right - by analogous reasoning, which lend the claim validity. The courts practise analogous reasoning based on legislation more frequently than analogous reasoning based on principles of superordinate law. This may be partly explained by the fact that in the case of analogy based on legislation, more so than in the case of analogy based on principles of superordinate law, the reasoning is partly derived from norms of operative law. The more legal norms construed by the court are founded on norms of superordinate law, of which we do not know whether they are part of operative law, the more dubious the legitimacy of the norm derived from superordinate law. This uncertainty about the norm of superordinate law relates to the idea that the scope, the purpose and the validity of legal principles are not always absolutely certain, which gives the appearance that the court can wrap its personal opinions in legal norms derived from principles of superordinate law at will.

The critical attitude towards constitutional interpretation relates to the constitutional premise of a division of labour between the judiciary and the legislature. For the most part, the norms to be interpreted were written with foresight and therefore are a quite open. The court that still has something to add to such open norms, seems to ignore the existing constitutional norms and relations. The issue here is the way in which the judiciary should exercise its duties. The way in which those duties are discharged, is directly related to the interpreter's perception of the extension of the constitution or treaty; if it is deemed to express an exhaustive tist of basic rights, the court that reads norms into it on the basis of unwritten principles of law will more readily be regarded as activist. An important aspect of the above way of law finding by interpretation is the premise that constitutional review in principle entails that the court subjects legislation that violates a constitutional right to strict scrutiny. To a large extent, this is related to the fact that constitutional rights are the highest-ranking rights of all the rights enjoyed by the individual; solid legal protection is therefore called for in cases of violation of these rights. The result is also a tense relation with the legislature: in constitutional interpretation, the court assigns itself the role of lawmaker (analogy based on principles of superordinate law), or allows itself room to explore the boundaries of existing constitutional rights (analogy based on legislation). The question has arisen as to whether the legislature ever intended this to be so and whether there are mechanisms within the constitutional relation to somewhat lessen this threat. 
For constitutional reasons, the use of analogy comes with an objection. In many instances, it is difficult, for example, on the basis of a judicial decision to exactly establish the 'legal status' of the norm of superordinate law that legitimises extensive interpretation or turning the newly found norm into operative law. The legal quality of the principle detected by the court is not always unambiguous and in a number of legal systerns is qualified by some commentators as plainly dubious. The legal status of the norms that have been made operative with the aid of a norm of superordinate law is not always accepted as a matter of course by the legal community. This is narrowly related to the constitutional division of labour between the judiciary and the legislature, as above pointed out. When establishing the legal status of norms of superordinate law and the legal rule extrapolated from it, the question is to what extent they form part of the norms of existing constitutional rights.

In spite of these objections of a fundamental nature, analogy based on principles of superordinate law has proved to be an attractive method for arriving at a solution in difficult cases. One reason for using analogous reasoning is greater acceptance of the outcome. This conclusion about analogy seems to contradict the objection to analogous reasoning outlined earlier. There is a feature of analogy, however, that renders it a suitable method to reflect a convincing result of law finding. In having its decision accepted, the court not only has to contend with a critical legal forum, but also needs to convince the general public that the outcome is just. It is in the court's interest that its decisions are accepted and observed by the widest possible forum. The legal forum is furthermore interested in the whole judicial decision-making process. This process must be rationally sound, meet the requirements of legal coherence and consistence, and must be just, in accordance with the norms of existing law. The legal forum is always critical, in principle, of the court's use of analogy, in any case, for the legal theoretical and constitutional reasons discussed above. The general forum, with the inclusion of the interested parties and, more in general, society, is mainly focused on the outcome of the judicial decision-making process, the just nature of the decision being paramount. Such justice does not always need to be inspired by norms of existing law. This is the case, for instance, if what is held to be just conflicts with the validity of legal norms. The objections from a perspective of constitutional law discussed earlier are of little relevance to this forum. They may be of major relevance, but they are not consciously felt to be. The case law based on extensive interpretation or the creation of new legal norms studied in this dissertation shows that justice and validity of legal norms do not necessarily coincide: the cases examined are about judicial solutions which had not yet been found in operative law or.judicial solutions for which there was no operative law at the time. In such cases, legal rationality - legitimacy on the basis of existing legal norms - may be poles apart from a sense of justice.

Analogy may contribute towards acceptability of the judicial decisions. It is an instrument by which the preferences of the various forums can be taken into account. Analogy, in that case, must be employed convincingly: not only must it render the final decision convincing, but the law-finding process preceding the decision as well. The court, for that matter, will have to demonstrate that the extensively interpreted or newly 
construed norm 'follows logically' from existing law. For this to be so, the court needs to convincingly demonstrate that extensive interpretation of the existing norm, or the norm made operative, did already exist, and all it did was make it visible. If it succeeds in demonstrating the legitimacy of the norms used, it will be seen as more readily respecting the constitutional relation and the division of labour between the judiciary and the legislature. If it fails to so do, it runs the risk of giving the impression that it is putting forward its own subjective opinton, not norms of existing law. The latter is undesirable, in view of the fact that there is no democratic legitimisation where the judiciary is concerned; laying down norms is the duty of the legislature.

A reason for the persuasive force of analogy is that it has a strong obfuscating effect. This can be explained by the way in which the analogy has been developed. In order to convince the reader of the comparability of the materials, the appropriateness of extensive interpretation or of creating a legal norm, the courts on occasion use rhetoric or metaphors. The technique of employing rhetoric and metaphors enable both the author to render a complex (legal) reality comprehensible and the reader to comprehend such a reality. However, the use of rhetoric and metaphors has its downside; it may negatively affect the reasons stated by the court for finding law. They are certainly not allways reducible to applicable legal norms, whereas the judicial decision-making process must meet the requirements of rationality, coherence and consistence. The court's further defining of a norm of superordinate law through rhetoric or metaphors removes the constitutional objection to law-finding by the courts, because it makes it appear as if the legal norms employed were already part of operative law, or in any case that they logically form part of it. The margin of appreciation afforded to the court in the interpretation phase seems to be reduced by this technique to a single option, or at the most two alternatives, where this is not necessarily the case. The court that opts for settling the dispute from this angle will less readily be accused of assuming a legislative role than the court that shows in the interpretation phase that there is a large number of alternatives capable of resolving the dispute and subsequently opts for a particular one. From a constitutional- law perspective, analogous reasoning with the aid of rhetoric and metaphors may serve as an instrument for working out an interpretation strategy.

\section{Results: most important findings}

All the courts examined employ analogy. The case law showed variations both within and between systems. In the constitutional debate in the United States, law finding through analogous reasoning is viewed with a jaundiced eye. Thus far, the US Supreme Court has employed analogous reasoning based on legislation or principles of superordinate law in varying degrees. In analogous reasoning based on legislation, the concept of 'liberty" from the Fourteenth Amendment led to the classification of individual claims that had not been recognised until that time by the Supreme Court. The right to "privacy" in US constitutional law is a legal norm made operative through analogy based on principles of superordinate law. In particular, "privacy and the rules derived from it are still a controversial topic in American constitutional discourse, inter alia, 
because of the objections based on the absence of democratic legitimisation of the judiciary and the vertical separation of powers. In the American debate, there are, in short, two opposite views of interpretation. The "interpretevists" assert that the text of the Constitution must be strictly adhered to, whereas the "non-interpretevists" see possibilities of moving away from its literal wording and in consequence do not reject law finding based on principles of superordinate law off hand. The author argues that analogous reasoning with regard to the notions 'privacy' and 'liberty' will be more readily accepted by 'non-interpretevists" than by 'interpretevists'.

In Germany, the Federal Constitutional Court has also applied analogous reasoning based on legislation and principles of superordinate law, but it has encountered less criticism. The right to personal development pursuant to Article 2 of the German Constitution has been a regular feature in the Court's analogous reasoning based on legislation, whereas a general individual right has been brought about through analogy based on principles of superordinate law. The case law of the European Court of Human Rights shows frequent employment of analogous reasoning based on legislation with regard to Article 8 of the European Convention on Human Rights (ECHR), by which the Strasbourg court legitimises classifying very disparate individual claims as falling within the scope of Article 8 (the right to privacy). Where law finding in connection with Article 8 ECHR is concerned, the ECHR is rather characterised as a court with a 'non-interpretevist' perception of its duties.

The European Court of Justice of the European Community has rarely used analogy in the area of personal rights. To a certain extent, this may be explained by the fact that this Court does not interpret, in principle, on the basis of a mandate, which counts fundamental rights as part of its formal sphere of activities. The preparedness by the European Court to recognise and award claims depends very much on the type of dispute brought before it and the policy area governed by the legislation at issue. In disputes between individuals and the Institutions not involving prioritised policy areas, the Court has proved to be prepared to recognise and award claims on the basis of standards of constitutional law. Generally speaking, the Luxembourg Court can be characterised as a 'non-interpretevist' court, also where the personal rights examined in this dissertation are concerned. The Court has relatively often recognised claims. It has shown restraint, however, in awarding these.

The Netherlands Supreme Court has used analogy based on legislation in a few cases only, in connection with Articles 10 and 11 of the Netherlands Constitution. Analogy based on principles of superordinate law is found in the rendering operative of a general individual right, as a result of which concrete individual claims were recognised in a handful of cases. In all instances, the rendering operative of norms through analogous reasoning based on principles of superordinate law occurred in a horizontal conflict or in cases in which subordinate legislation was contested. Restraint on the part of the Netherlands Supreme Court in the Jatter situation can be explained for a large part by the prohibition against judicial review of acts of parliament. The absence of such review has been somewhat compensated for by the possibility to test acts of parliament 
against generally applicable treaty norms. However, also in this case, the Dutch Court exercises restraint in using analogy based on legislation.

Analogous reasoning implies acceptance of a 'non-interpretevist' approach to constitutions and treaties. Law finding based on norms of superordinate law, which are almost always abstract in nature, seems to be more readily accepted, if it is acknowledged that constitutional rights must be assessed in context and in their interrelation. In the view that constitutions contain a list of specific, isolated rights, acceptance of analogous law finding based on norms of superordinate law is much less obvious. The 'non-interpretevist' approach of the courts in the European legal systems has been mainly accepted by the legal forum. One of the most important reasons for this difference in approach between the European courts and the US Supreme Court is the fact that the US Supreme Court will make the assessment and the solution of a dispute virtually contingent on the choices made in the interpretation phase. If the Court recognises an individual claim in the interpretation phase as falling within the scope of 'privacy', award of the claim nearly always follows in the testing phase. There is hardly any room in a later phase of the judicial decision-making process, for instance in the testing phase, to take into account the relation between the judiciary and the legislature.

In the European legal systems, the constitutional area of tension is not 'limited' to the phase in which the court selects the applicable norm. Once an individual claim has been characterised as constitutional, this does not result, as in the American situation, in the annulment of the statute challenged. In order to meet constitutional tensions, the European courts may in subsequent phases of the judicial decision-making process make concessions to the constitutional relations between the judiciary and the legislature. In the European systems the standards employed in the testing phase are movable, which may mitigate the impact on the constitutional relation created in the normselecting phase. The emphasis placed on the constitutional relation between the legislature and the judiciary in the European situation occurs therefore less in the phase in which the applicable norm is selected than is the case in the American context. This does not reduce the relevance of the interpretation phase for the constitutional relation between the judiciary and the legislature in the European systems. Compared to the United States, the European debate on the perception of the judiciary's duties where constitutional relations are concerned takes place in various phases, including the testing phase. 


\section{Lijst van verkort aangehaalde literatuur}

Aarnio 1987: A. Aarnio, The rational as reasonable. A Treatise on Legal justification, Dordrecht: Kluwer 1987.

Abraham 1982: H.J. Abraham, Line-Drawing between Judicial Activism and Restraint: A "Centrist" Approach and Analysis, in: Supreme Conrt activism and restraint, S.C. Halpern en C.M. Lamb (red), Lexington: Heath and Company 1982, p. 201-219.

Ackerman 1991: B. Ackerman, We the People: Foundations, Cambridge: Harvard University Press 1991.

Advies Hoge Raad 1992: Advies Hoge Raad inzake toetsingsrecht, NJCM-Bulletin 1992, p. 243-260.

Alexy 1991: R. Alexy, Theorie der juristischen Argumentation. Die Theorie des rationalen Diskurses als Theorie der juristischen Begrundung, Frankfurt am Main: Suhrkamp Verlag 1991.

Alexy 1996: R. Alexy, Thearie der Grundrechte, Frankfurt am Main: Subrkamp Verlag 1996.

Alexy en Dreier 1991: R. Alexy en R. Dreier, 'Statutory Interpretation in the Federal Republic of Germany', in: Interpreting Statutes, A Comparative Study, N. MacCormick en R.S. Summers (red.), Dartmouth: Aldershot 1991, p. $73-121$.

Alkema 1978: E.A. Alkema, Studies over Europese Grondrechten. De invloed van de conventie op het Nederlandse recht (diss. Leiden), Deventer: Kluwer 1978.

Alkema 1996: E.A. Alkema, Constitutionele interpretatie van grondrechten en bepalingen inzake buitenlandse betrekkingen - facetten, factoren en actoren, in: RegelMaat 1996, p. $91-98$.

Alkema 2000: E.A. Alkema, The European Convention as a constitution and its Court as a constitutional court, in: Protecting Human Rights, The European Perspective, Studies in memory of Rolv Ryssdal, P. Mahoney, F. Matscher, H. Petzold en L. Wildhaber (red.), Keulen: Carl Heymanns Verlag 2000, p. 41-63.

Anweiler 1997: J. Anweiler, Die Auslegungsmethoden des Gerichtshofs der Europäischen Gemeinschaften (diss. Göttingen), Frankfurt am Main: Peter Lang 1997.

Arnull 2001: A. Arnull, Private applicants and the action for annulment since Codorniu, in: Common Market Law Review 2001, p. 7-52.

Asser-Scholten (Algemeen Deel) 1974: P. Scholten, Algemeen Deel, met feitelijke gegevens aangevuld door G.J. Scholten, Zwolle: W.E.J. Tjeenk Willink 1974.

Asser-Vranken (AIgemeen Deel) 1995: J.B.M. Vranken, Algemeen Deel, Zwolle: W.E.d. Tjeenk Willink 1995.

Barak 1989: A. Barak, Judicial discretion, New Haven: Yale University 1989.

Barendrecht 1992: J.M. Barendrecht, Het constitutionele toetsingsrecht van de rechter, in: Toetsing (Handelingen Nederlandse Juristen-Vereniging 1992-1), Zwolle: W.E.J. Tjeenk Willink 1992, p. 85-172.

Barendrecht 1998: J.M. Barendrecht, De Hoge Raad op de hei: Kwaliteitsbewaking en leiding aver de rechtspraak door de civiele cassatie: een analyse van denkrichtingen woor de toekomst; Zwolle: Tjeenk Willink 1998.

Barents en Brinkhorst 2001 : R. Barents en L.J. Brinkhorst, Grondijnen wan Europees Recht, Deventer: W.E.J. Tjeenk Willink 2001.

Battis en Gusy 1991: U. Battis en C. Gusy, Einfihrung in das Staatsrecht, Heidelberg: Müller Juristischer Verlag 1991. 
Beatty 2001 : D.M. Beatty, The Forms and Limits of Constitutional Interpretation, in: The American Journal of Comparative Law 2001, p. 79-120.

Benda 1979. E. Benda, BVerfG und Gesetzgeber im dritten Jahrzehnt des $G G$, in: Die offentiche Verwaltung 1979, p. 471 e.v.

Bengoetxea 1993: J. Bengoetxea, The legal reasoning of the European Court of Justice: towards a European jurisprudence, Oxford: Clarendon Press 1993.

Bernhardt 1988: $\mathbb{R}$. Bernhardt, Thoughts on the interpretation of human-rights treaties in: Protecting Human Rights: The European Dimension, Studies in honour of GerardJ.

Wiarda, F. Matscher en H. Petzold (red.), Keulen: Carl Heymanns Verlag 1988, p. 65-72.

Bettermann 1981: K.A. Bettermann, Opposition und Verfassungsrichterwahl, in: Festschrift fiur Konrad 2weigert zum 70. Geburtstag, $\mathrm{H}$. Bernstein, U. Drobnig en H. Kötz (red.), Tübingen: Mohr 1981, p. 723-746.

Bickel 1962: A. M. Bickel, The least dangerous branch, The Supreme Court at the Bar of Polivics, New Haven: Yalle University Press 1962.

Bijdrage van het Hof en het Gerecht aan de Intergouvernementele Conferentie 2000: Bijdrage van het Hof en het Gerecht aan de Intergouvernementele Conferentie 2000, zie www.curia.eu.int.

Black 1960: C.L. Black, The People and the Court. Judicial review in a Denocracy, New York: Macmillan 1960.

Black 1983: C.L. Black, Structure and relationship in constitutional law, Baton Rouge: Louisiana State University Press 1983.

Blok 2002: P. Blok, Het recht op privacy. Een onderzoek naar de betekenis wan he begrip 'privacy' in het Nederlandse en het Amerikaanse recht, Den Haag: Boom Juridische Uitgevers, 2002.

Bloustein 1964: E.J. Bloustein, Privacy as an aspect of human dignity: an answer to Dean Prosser, in: New York Uniwersity Law Review 1964, p. 962-1007, herdrukt in:

Philosophioal dimensions of privacy: an anthology, F. D. Schoeman (red.), Cambridge: Cambridge University Press 1984, p. 156-202.

Bobbitt 1982: P. Bobbitt, Constitutional Fate, theory of the constitution, New Yark: Oxford University Press 1982.

Böckenförde 1976: E. W. Böckenförde, Die Methoden der Verfassungsintepretation Bestandsaufnahme und Kritik, in: Newe Juristische Wochenschrift 1976, p. 2089-2099.

Böckenförde 1993: E. W. Böckentörde, Anmerkungen zum Begriff des Verfassungswandels, in: Wege und Verfahren des Verfassungslebens, Fesischrift fiur $P$. Lerche zum 65. Geburtstag, P. Badura en R. Scholz (red,), Munchen: Beck 1993, p. 3-14.

De Boer 1990: J. De Boer, Artikel 8 EVRM Deel I en Deel $I$, Preadvies Nederlandse Juristen Vereniging 1990, Zwolle: W.E.J. Tjeenk Willink 1990.

Bood 1998: A. Bood, 'Euthanasie' in de Verenigde Staten, in: RM Themis 1998, p. $177-188$.

Bork 1971: R. Bork, Neutral Principles and Some First Amendment Problems, in: Indiana Law Journal 1971, p. 1 e.v.

Bork 1990: R. Bork, The tempting of America, the political seduction of the law, New York: Simon \& Schuster 1990.

Bosmajian 1992: H. Bosmajian, Metaphor and reason in judicial opinions, Illinois: Board of Trustees of Southern Illinois University 1992. 
Boukema 1997: H.M.M. Boukena, Rechterlijke retorica, in: Op Goede Gronden, Bidragen aan het Tweede symposium juridische argumentatie, E.T. Feteris, H. Kloosterhuis, H.J. Plug en J.A. Pontier (red.), Nijmegen: Ars Aequi 1997, p. 191-197.

Van Boven 1995: Th. Van Boven, Convention de sauvegarde des droits de lthomme et des libertếs fondamentales, in: La convention europeenne des droits de l'homme: commentaire article par article, L. Pettit, E. Decaux, P. Imbert, P. Teitgen (red.), Parijs: Economica 1995, p. 125-134.

Bovend'Eert 2000: P.P.T. Bovend'Eert, Benoeming en ontslag van rechters (oratie Nijmegen), 2000.

De Brauw 1965: P.J.W. De Brauw en Th. W. Van Veen, Behoort de wetgever maatregelen te treffen ter bescherming van de individu tegen het doen, het gebruiken, en het openbaarmaken van waarnemingen, diens persoonlijke sfeer betreffende? Praegdwiezen NJV 1965, Zwolle: W.E.J Tjeenk Willink 1965, p. 1-74.

Bredimas 1978: A. Bredimas, Methods of Interpretation and Community Law, Amsterdam: North-Holland Publishing Company 1978.

Brest 1980: P. Brest, The Misconceived Quest for the Original Understanding, Boston University Law Review 1980, p. 223 e.v.

Brouwer 1991: P.W. Brouwer 1991, Rechtsbeginselen en rechtspositivisme, in: Rechtsbeginselen, M. Dolman (red.), Nijmegen: Ars Aequi 1991, Nijmegen 1991, p. 757-772.

Brugger 1994: W. Brugger, Legal Interpretation, Schools of Jurisprudence, and Anthropology: Some Remarks From a German Point of View, in: The American Journal of Comparative Law 1994, p. 395-421.

Bruggink 1992: J. J. H. Bruggink, Op zoek noar het recht: rechtsvinding in rechtstheoretisch perspectief, Groningen: Wolters Noordhoff 1992, p. 136-153.

Bryde 2000: B. Bryde, Art 79 GG (Änderung des Grundgesetzes), in: GrundgesetzKommentar (Band 3), Ph. Kunig (red.), Munchen: C.H. Beck'sche Verlagsbuchhandlung 2000, p. $227-263$.

Burgess-Jackson 1989: K. Burgess-Jackson, Constitutional Interpretation (diss. University of Arizona), University of Arizona 1989.

Burkens, Kummeling, Vermeulen en Widdershowen 2001: M.C. Burkens, H.R.B.M. Kummeling, B.P. Vermeulen en R.J.G.M. Widdershoven, Beginselen wan de democratische rechisstaat: Inleiding tot de grondslagen van het Nederlandse staats en bestuursrecht, Zwolle: W.E.J. Tjeenk Willink 2001.

Campbell en Lardy 1996: A. Campbell en H. Lardy, Discrimination against Transsexuals in Employment, in: European Law Review 1996, p. 412-418.

Canor 1998: I. Canor, The Limits of Judicial Discretion in the European Court of Justice: Security and Foreign Affairs Issues (diss. Saarbrìcken), Baden Baden: Nomos Verlag 1998.

Canor 2000* $\mathbb{L}$. Canor, Equality for Lesbians and Gay Men in the European Community Legal Order - "they shall be male and femalle", in: Maastricht Journal of European and Comparative Law 2000, p. 273-299.

Canor 2000: I. Canor, Primus inter pares. Who is the ultimate guardian of fundamental rights in Europe? in: European Law Review 2000, p. 3-21.

Cardozo 1921: B.N. Cardozo, The nature of the judicial process, New Haven: Yale University Press 1921 .

Cardozo 1931: B.,N. Cardozo, Law and Literature and other esseays and addresses, New York: Harcourt, Brace and Co., 1931. 
Cassese, Clapham en Weiler, Methods of Protection, 1991: A. Cassese, A. Clapham and I. Weiler, Human Righis and the European Community: Methods of Protection, Baden-Baden: Nomos 1991.

Cassese, Clapham en Weiler, The Substantive Law, 1991: A. Cassese, A. Clapham and J. Weiler, Hwwan Rights and the European Community: The Substantive Law, Baden-Baden: Nomos 1991

Cath 1991: 1.G.F. Cath. Hebben ondernemingen recht op bescherming van de privesfeer? De zaken Hoechst en Chappel vergeleken, in: NJCM-Bulletin 1991, p. 28-54.

Cliteur 2000: P. B. Cliteur, Steeds maar nieuwe rechten. Over de schaduwzijden van een wijdverbreide praktijk, in: Rechistheorie en Rechtsfilosofie 2000, p. 20-31.

Commissie Franken: Rapport Commissie Grondrechten in het digitale tijdperk, Handelingen TK 27460, nr. 1, 2000.

Cooley 1972: T. Cooley, A Treatise on the Constitutional Limitations Which Rest Upon the Legislative Power of the States of the American Union, New York: Da Capo Press 1972.

Coppel en O'Neill 1992: J. Coppel en A. O'Neill, The European Court of Justice: Taking rights seriously? In Common Market Law Review 1992, p. 669-692.

Cox 1987: A. Cox, The Court and the Constitution, Boston: Houghton Mifflin Company 1987.

Craig en De Búrca 1998: P. Craig en G. de Búrca, EC law: text, cases, and materiaís, New York: Oxford University Press 1998.

Craig 2001: P. Craig, Constitutions, Constitutionalism, and the European Union, in: European Law Journal 2001, p. 125-150.

Currie 1989: D.P. Currie, Lochner Abroad: substantive due process and equal protection in the Federal Republic of Germany, in: The Supreme Court Review 1989, p. 333-372.

Curtin 1993: D. Curtin, The constitutional structure of the Union: a Europe of bits and pieces, un: Comman Market Law Review 1993, p. 17-69.

Delmas-Marty 1992: M. Delmas-Marty, The European Convention for the Protection of Human Rights, International Protection versus National Restrictions, Dordrecht: Martinus Nijhoff 1992.

Denning en Reynolds 1997: B.P. Denning en G.H. Reynolds, Comfortably Penumbral, in: Boston University Law Review: 1997, p. 1089-1120.

DeRosa 1996: M.L. DeRosa, The Ninth Amendment and the politics of creative jurisprudence, disparaging the fundamental right of popular control, London: Transaction Publishers 1996.

Dixon 1971: R.G. Dixon, The Griswold Penumbra: constitutional charter for an Expanded Law of Privacy? in: The Right of Privacy $A$ Symposium on the Implications of Griswald w. Connecticut 381 U.S. 479 (1965), R.G. Dixon (red.), New York: Da Capo Press 1971, p. 1-22.

Donders 2002: Y.M. Donders, Towards a Right to Cultural Identity? (diss. Maastricht), Antwerpen: Intersentia 2002.

Dorf 1997: M.. Dorf, Integrating Normative and Descriptive Constitutional Theory: The Case of Original Meaning, Georgetown Law Joumal 1997, p. 1765-1777.

Doswald-Beck 1983: Doswald-Beck, The meaning of the "Right to respect for Private Life" under the European Convention on Human Rights, in: Human Rights Law Journal 1983 , p. 283 e.v.

Dreier en Schwegemann 1976: R. Dreier en F. Schwegemann, Probleme der Verfassungsinterpretation, Baden Baden: Nomos 1976. 
Van Dijk en Van Hoof 1998: P. van Dijk en G.J.H. van Hoof, Theory and Practice of the European Convention on Human Rights, Den Haag: Kluwer Law international 1998.

Dubinsky 1994: P.R. Dubinsky, The essential Function of Federal Courts: The European and the United States Court Compared, in: The American Journal of Comparative Law 1998 , p. 295-346.

Ducat en Chase 1992: C. Ducat en H.W. Chase, Constitutional Interpretation, St. Paul: West Publishing Company 1992.

Duijkersloot 1997: A.P.W. Duijkersloot, Nationale maatregelen, communautaire grondrechten en de vrij verkeersjurisprudentie, in: Weekblad Saciaal-economische Wetgeving 1997 , p. 218-224.

Dworkin 1977: R. Dworkin, Taking Rights Seriously, Cambridge: Harvard University Press 1977.

Dworkin 1992: R. Dworkin, The Concept of Unenumerated Rights, in: The Bill of Rights in the Modern State, G. R. Stone, R.A. Epstein, C.R. Sunstein (red.) Chicago: Chicago University Press 1992, p. 381-450.

Dworkin 1993: R. Dworkin, Life 's Dominion, An argument about abortion, eumanasia, and individual freedom, New York: Vintage Books 1993.

Ely 1980: J.H. Ely, Democracy and distrust, a theory of judicial review, Cambridge: Harvard University Press 1980.

Esser 1970: J. Esser, Vorverständnis und Methodenwahl in der Rechtsfindung, Rationalitätsgarantien der richterlichen Entscheldungspraxis, Frankfurt am Main: Athenaeum Verlag, 1970.

Everling 1988: U. Everling, Rechtsanwendungs- und Auslegungsgrundsätze des Gerichtshofs der Europäischen Gemeinschaften, in.: Zölle, Verbrauchsstewern, europäisches Marktordnungsrecht; H.W. Kruse (uitgever), Keulen: Carl Heymanns Verlag 1988 , p. $51-73$.

Fallon 1987: R. Fallon, A constructivist coherence theory of constitutional interpretation, Harvard Law Review 1987, p. 1189-1286.

Fierstra 2001: M.A. Fierstra, Een nieuw toekomstperspectief woo het Hof van Justitie; de tussenstand na het Verdrag van Nice, in: Nederlands tijdschrift voor Europees rech 2001 , p. $95-103$.

Fimnis 1980: J. Finnis, Natural Law and Natural Rights, Oxford: Clarendon Press 1980.

Flinterman 1995: C. Flinterman, Judicial control of foreign affairs: the political question doctrine, in: Judicial control. Comparative essays on judicial review, R. Bakker, A.W. Heringa en F.A.M. Stroink (red.), Antwerpen: Maklu 1995, p. 45-54.

Flynn 1997: L. Flynn, Annotatie bij P. t. S. en Cornwall County Council, Common Marker Law Review 1997 , p. $367-387$.

Forsthoff 1959: E. Forsthoff, Die Umbildung des Varfassungsgesetzes, in: Festschiff fuer Carl Schmitt zum 70. Geburtstag dargebracht von freunden und Schilern, H. Barion, E. Forsthoff en W. Weber, Berlijn: Duncker \& Hurnblot 1959, p. 35-62.

Forrester 1983: I.S. Forrester, Legal professional privilege: limitations on the Commission's powers of inspection following the AM\&S judgement, in: Common Market Law Review 1983, p. 75-85.

Fried 1968: C. Fried, Privacy, in: Yale Law Jowrwal 1968, p. 475-493.

Frowein 1992: J.A. Frowein, The Federal Republic of Germany, in: The Europeav Convention for the Protection of Human Rights: International Protection Versus national Restrictions, M. Delmas-Marty en C. Chodkiewickz (red.), Dordrecht: Martinus Nijhoff 1992, p. 121-129. 
Frowein en Peukert 1996: J. Frowein en W. Peukert, Europäische MenschenRechtsKonvention, EMRK-Kommentar, Kehl: Engell 1996.

Gerards 2002: J.H. Gerards, Rechterlijke toetsing aan het gelijkheidsbeginsel (diss. Maastricht), Den Haag: SDU 2002.

Gerstein 1970: R.S. Gerstein, Privacy and self-incrimination, in: F.D. Schoeman (red), Philosophical Dimensions of Privacy, An Anthology, Cambridge: Cambridge University Press 1984, p. 245-264.

Van Gerven en Leijten 1981: W. van Gerven en J.C.M. Leijten, Theorie en praktijk wan de rechtsvinding, Zwolle: W.E.J. Tjeenk Willink 1981.

Van Gerven 2000: W. van Gerven, Het voor en tegen van een Europese Grondwet, in: Publikaties wan de Shatsrechtkring. Bijdragen aan een Europese grondwet, A. Koekkaek (red.), Deventer: W.E.J Tjeenk Willink 2000, p. 27-44.

Goerlich 1973: H. Goerlich, Wertordnung und Grundgesetz, Kritik einer Argumentationsfigur des Bundesverfassugsgerichts, Baden Baden: Nomos 1973.

De Graaf 1977: F. De Graaf, Bescherming van de persoonlijkheid, privé-leven, persoonsgegevens (diss. Utrecht), Alphen aan den Rijn: H.D. Tjeenk Willink 1977.

Grey 1975: Th. C. Grey, Do we have an unwritten constitution? in: Stanford Law Review 1975 , p. 703-718.

Grey 1978: Th. C. Grey, Origins of the Unwritten Constitution: fundamental law in American revolutionary thought, in: Stanford Law Review 1978, p. 843-893.

Grey 1984: Th. C. Grey, The Constitution as scripture, in: Stanford Law Review 1984, p. $1-15$.

Gribnau 1997: J.L.M. Gribnau, Des Pudels Kern? Rechtsbeginselen als fundamentele rechtsbron, in: Op Goede Gronden, Bijdragen aan het Tweede symposium juridische argumentatie, E.T. Feteris, H. Kloosterhuis, H.J. Plug en J.A. Pontier (red.), Nijmegen: Ars Aequi 1997, p. 197-204.

Griffiths 1997: J. Griffiths, Euthanasie: legalisering of decriminalisering? In: Nederlands Juristen Blad 1997, p. 619-627.

Groenewegen 1997: F.T. Groenewegen, Analogie, in: Op Goede Gronden, Bijdragen aan het Tweede symposium juridische argumentatie, E.T. Feteris, H. Kloosterhuis, H.J. Plug en J.A. Pontier (red.), Nijmegen: Ars Aequi 1997, p. 108-114.

Guild 2000: E. Guild, European Community Law From a Migrant's Perspective (diss. Nijmegen), Den Haag: KLluwer law International 2000.

Gunther 1972: G. Gunther, Foreword. In Search of Evolving Doctrine on a Changing Court: A Model for A Newer Equal Protection, in: Harvard Law Review 1972, p. 8.

Gunther en Sullivan 1997: G. Gunther en K.M. Sullivan, Constitutional Law, New York: Foundation Press 1997.

Haak 2002: W.E. Haak, Rechterlijke toetsing. Voordracht door de President van de Hoge Raad der Nederlanden ter ere van Arthur Chaskalson, President van thet Constitutionele Hof in Zuid-Afrika, op 11 januari 2002 te Amsterdam, <http://www rechtspraak.nl>, bericht van 16 januari 2002.

Hahberle 1974: P. Häberle, Zeit und Verfassung, in: Zeitschrift fur Politik 1974, p. 111 e.v.

Häberle 1976: P. Häberle, Grundprobleme der Verfassungsgerichtsbarkeit, in: Verfassungsgerichtsbarkeit, $\mathrm{P}$. Häberle (red.), Darmstadt: Wissenschaftliche Buchgesellschaft 1976.

Häberle 1989: P. Häberle, Grundrechtsgeltung und Grundrechtsinterpretation im Verfassungsstaat, JuristenZeitung 1989, p. 913 e.v. 
Häberle 1994: P. Häberle, Europäusche Rechtskultur, Baden Baden. Nomos 1994.

Harding 1980: C. Harding, The Private Interest in Challenging Community Action; European Law Review 1980 , p. 354 e.v.

Harris, O'Boyle en Warbrick 1995: D. I. Harris, M. O'Boyle and C. Warbrick, Law of the European Convention on Human Rights, London: Butterworths 1995.

Hart 1961: H.L.A. Hart, The Concept of Law; Oxford: Clarendon Press 1961.

Hart en Wechsler 1996: H.M. Hart en H. Wechsler, The Federal Coumt and the Federal System, New York: Mineola 1996.

Hartkamp 2000: A.S. Hartkamp, De Nederlandse rechter en het EVRM, in: S0 jaor EVRM, R.A. Lawson en E. Myjer (red.), NJCM-Bundel Leiden". 2000, p. 23-38.

Hartley 1994: T.C. Hartley, The foundations of European Community law: an introduction to the constitutional and administrative law of the European Community, Oxford: Clarendon Press 1994.

Heidenheimer en Kommers 1975: A.J. Heidenheimer en D.P. Kommers, The Governments of Germany, New York: Crowell 1975.

Hendriks 1995: A. C. Herdriks, noot bij X t. Commissie, in: NJCM-Bulletin 1995, p. 231-238.

Herdegen 1994: M. Herdegen, Maastricht and the Gernuan Constitutional Court: Constitutional Restraints for an Ever Closer Union, Cammon Market Law Review 1994, p. 235 e.v.

Heringa 1990: A.W. Heringa, Constitutionele schijnbewegingen, in: Publiekrechtelijke Bewegingen, A.W. Heringa en N. Verhey (red.), Deventer: Kluwer 1990, p. 67-81.

Heringa en Zwart 1991: A.W. Heringa en 'T. Zwart, De Nederlandse Grondwet, Zwolle: W.E.J. Tjeenk Willink 1991.

Heringa 1996: A.W. Heringa, Het Amerikaanse Hooggerechtshof, Deventer: Kluwer 1996.

Heringa 1999, Katern 2.6: A.W. Heringa, Het *consensus principle', De rol van 'gemeenschappelijk recht' in de jurisprudentie van het EHRM, Katern 2.6, in: EVRM Rechtspraak en Commentaar, Lelystad: Koninklijke Vermande 1999.

Heringa 1999, Katern 3.8: A.W. Heringa, Privé-leven en gezinsleven, Katern 3.8 in: EVRM Rechtspraak en Commentaar, Lelystad: Koninklijke Vermande 1999.

Heringa 2000: A.W. Heringa, Horizontale werking, Katern 2.3 in: EVRM Rechtspraak en Commentaar, Lelystad: Koninklijke Vermande 2000.

Hesse 1990: K. Hesse, Grundzüge des Verfassungsrechis der Bundesrepublik Dewtschiand, Heidelberg: Mulller Verlag 1990.

Hirsch Ballin 1988: E.M.H. Hirsch Ballin, Onafhankelijke rechtsvorming. Staatsrechtelijke aantekeningen over de plaats en functie van de Hoge Raad in de Nederlandse rechtsorde, in: De plaats van de Hoge Raad in het huidige staatsbestel, Zwolle: W. E.J. Tjeenk Willink 1988 , p. $211-240$.

Hirsch Ballin 2000 (I): E.M.H. Hirsch Ballin, Vervlochten constituties. Nederland in de Europese rechtsorde, in: Publikaties wan de Staatsrechtkring. Bijdragen aan een Europese grondwet, A. Koekkoek (red.), Deventer: W.E.J Tjeenk Willink 2000, p. 11-20.

Hirsch Ballin 2000 (II): E.M.H. Hirsch Ballin, Het EVRM in de $21^{\text {se }}$ eeuw, in: 50 joar EVRM, R.A. Lawson en E. Myjer (red.), NJCM-Bundel Leiden: 2000, p. 61 1-622.

Van Hoecke 1979: M. van Hoecke, De Interpretatievrijheid van de rechter (diss. Gent), Antwerpen: Kluwer 1979 .

Hoge Raad, Toelichting op de jaarcijfers 1995 en 1996: Hoge Raad der Nederlanden, Toelichting op de Jaarcijfers 1995-1996, Den Haag 1997, p. 13-21. 
Hoffman 1997: D. Hoffman, Our Elusive Constitution, Silences, Paradoxes, Priorities. Albany: State University of New York Press 1997.

Van Houten 1997: M.L.P. van Houten, Meer zicht op wetgeving: Rechterlijke toetsing van wetgeving aan de Grondwet en fundamentele rechisbeginselen (diss. Tilburg), Zwolle: Tjeenk Willink 1997.

Huber 1971: H. Huber, Probleme des ungeschriebenen Werfassungsrechts, in: K. Eichenberger, $\mathbb{R}$. Bäumlin en J.P. Muller (red.), Rechtstheorie Verfassungsrecht Volkerrecht, Ausgewdihlte Aufsätze 1950-1970, zum 70. Geburtstag des Verfassers, Bern: Staempfli \& Cie 1971, p. 329-348.

Hubmann 1953: H. Hubmann, Das Persönlichkeitsrecht, Keulen: Böhlau Verlag 1953.

Huussen en Van der Vellde 1999: L.B. Huussen en J. Van der Velde, Het toezichtsmechanisme van het EVRM, Katern 1.1 tot en met 1.3 in: EVRM Rechtspraak en Commentaar, Lelystad: Koninklijke Vermande 1999.

Isensee 1996: J. Isensee, Bundesverfassungsgericht - quo vadis? In: JaristenZeitung 1996, p. $1085-1093$.

Jacobs en White 1996: F.G. Jacobs en R.C.A. White, The European Convention on Human Righis, Oxford: Clarendon Press 1996.

Jacot-Guillarmod 1995: O. Jacot-Guillarmod, Règles, méthodes et principes d'interprétation dans la jurisprudence de la Cour européenne des droits de l'homme, in: $L a$ Convention Européenne des droits de l'homme: commentaire article par article, $\mathrm{L}$. Pettiti, E. Decaux, P. Imbert, P. Teitgen (red.), Parijs: Economica 1995, p. 41-63.

Jarass 1989: H. D. Jarass, Das allgemeine Persönliclakeitsrecht im Grundgesetz, in: Neue Juristische Wochenschrift $1989, \mathrm{p} 857-884$.

Jeukens 1970: H.J.M. Jeukens, De interpretatie van de grondwet, in: Rechtsvinding, opstellen aangeboden aan J.M. Pieters, Deventer: Kluwer 1970, p. 171-185.

Johmson 1988: M. Johnson, Some constraints on embodied analogical understanding, in: Analogical reasoning, Perspectives of Artifical Intelligence, Cognitive Science, and Philosophy, D.H. Helman (red.), Dordrecht: Kluwer Academic 1988, p. 25-40.

Kaufman 1982: A. Kaufman, Analogie und "Natur der Sache", Zugleich ein Beitrag zur Lehre vom Typus, Heidelberg: Decker en Muller Verlag 1982.

Kelk 1997: C. Kelk, De praktijk van de euthanasie: het einde van een rijpingsproces? In: Nederlands Juristen Blad 1997, p. 101-107.

Klein 2000: E. Klein, Should the binding effect of the judgenients of the European Court of Human Rights be extended? In: Protecting Human Rights, The European Perspective, Studies in memory of Rolv Ryssdal, P. Mahoney, F. Matscher, H. Petzold en L. Wildhaber (red.)., Keulen." Carll Heymanns Verlag 2000, p. 705-714.

Koch 1986: H.J. Koch, Die Begründung von Grundrechtsinterpretationen, Europäische Grwndrechte-Zeitschrift 1986, p. 345-361.

Kommers 1997: D.P. Kommers, The constitutional jurisprudence of the Federal Republic of Germany, Durham; Duke University Press 1997.

Kommers 1998: D.P. Konmers, American Constiturional law: essays, cases and comparative notes, Chicago: Wadsworth Publishing Belmont 1998.

Koopmans 1988: T. Koopmans, The roots of judicial activism, in: Protecting Human Rights: The European Dimension, Studies in honour of Gerard J. Wiarda, F. Matscher en H. Petzold (red.), Keulen: Carl Heymanns Verlag 1988, p. 317-328.

Koopmans 1991: T. Koopmans, Rechtsbeginselen in het Europese Gemeenschapsrecht, in: Rechtsbeginselen, M. Dolman (red.), Nijmegen: Ars Aequi 1991, p. 927-933. 
Koopmans 1992 (I): T. Koopmans, The Future of the Court of Justice of the European Communities, in: Yearbook European Law 1991, Oxford Clarendon Press 1992, p. $15-32$.

Koopmans 1992: $\mathbb{T}$. Koopmans, Toetsing, in: Toetsing (Handelingen Nederlandse Juristen-Vereniging 1992-I), Zwolle: W.E.J. Tjeenk Willink 1992, p. 35-84.

Koopmans 1994: T. Koopmans, Rechter, D-Mark en democratie: het Bundesverfassungsgericht en de Europese Unie, in: Nederlands Jwristen Blad 1994, p. $245-251$.

Kortmann 1994: C.A.J.M. Kortmann, Grondwetsinterpretatie, in: RM Themis 1994, p. 363-370.

Kortmann 1996: S.C.J.J. Kortmann, Zijn grondrechten subjectieve rechten? In: Op recht: bundel opstellen, aangeboden aan prof. mr. A.V.M. Struycken ter gelegenheid" van aijn zilveren ambtsjubileum aan de Katholieke Universiteit Nijmegen, S.C.J.J. Kortmann (red.) Zwolle: W.E.J. Tjeenk Willink 1996, p. 145-155.

Kortmann 2001: C.A.J.M. Kortmann, Constitutioneel recht, Deventer: Kluwer 2001.

Kotulak 1988: T.D. Kotulak, Rights retained by the People: the changing role of the Ninth Amendment in constitutional adjudication (diss. Michigan), Michigan State University 1988.

Kuitenbrouwer 1989: F. Kuitenbrouwer, Het (medisch) inzagerecht: de rechter ging de wet voor, in: Computerrecht 1989, p. 92-95.

Kumm 1999: M. Kumm, Who is the final arbiter of constitutionality in Europe? Three conceptions of the relationship between the German Federal Constitutional Court and the European Court of Justice, in: Common Market Law Review 1999, p. 351-386.

Kunig 2000: P. Kunig, Art. 1 (Würde des Menschen, Grundrechtsbindung), in: Grundgesetzkommentar, I. Von Münch en P. Kunig (red), München: Beck'sche Verlag 2000 , p. 65-122.

Kunig 2000: P. Kunig, Art. 2 (Freie Entfaltung der Persönlichkeit, Recht auf Leben, körperliche Unversehrtheit, Freiheit der Person), in: Grundgesetzkommentar, 1. Von Münch en P. Kunig (red.), München: Beck'sche Verlag 2000, p. 123-192.

Lakoff 1980: G. Lakoff, Metaphors we live by, Chicago: University of Chicago Press 1980.

Lamb 1982: C.M. Lamb, Judicial Restraint on the Supreme Court, in: Supreme Court' Activism and Restraint, S.C. Halpern en C.M. Lamb (red.), Lexington: Heath and Company, 1982 , p. 7-36.

Langenbucher 1998: K. Lachenbucher, Argument by analogy in European law, in: Cambridge Law Journal 1998, p. 481-521.

Larenz 1991: K. Larenz, Methodenlehre der Rechtswisserschaft, Berlijn: Springer-Verlag 1991

Lawson 1994: R. Lawson, Annotatie bij zaak C-168/91 (Konstantinidis), in: Common Market Law Review 1993, p. 395-412.

Lawson en Schermers 1997: R.A. Lawson, H.G. Schermers, Leading Cases of the European Court of Human Rights, Nijmegen: Ars Aequil Libri 1997.

Lazarus 1999: E. Lazarus, Closed Chambers, the Rise, Fall and Furure of the Modern Supreme Court, New York: Penguin Putnam 1999.

Leijten 1975: J.C.M. Leijten, Het fluorideringsarrest, in: 't Exempel dwinght, Opstellen aangeboden door wrienden en vereerders aan Prof mr. I Kisch ter gelegenheid van zijn $70^{\text {ite }}$ verjaardag, Zwolle: W.E.J. Tjeenk Willink 1975, p. 289-315.

Lensing 1997: J.A.W. Lensing, Het Amerikaanse Federale Hooggerechtshof, hulp bij zelfdoding en euthanasie, in: Nederlands Juristen Blad 1997, p. 2011-2019. 
Lenz 1993: C.O. Lenz, Der europäische Grundrechtsstandard in der Rechtsprechung des europäischen Gerichtshofes, in: Europaische Grundrechte-Zeitschrift 1993, p. 585-589.

Lerche 1990: P. Lerche, Kompetenz-Kompetenz und das Maastricht-Urteil des Bundesverfassungsgerichs, in: Das akzeptierte Grundgesetz, Festschrift fur $G$. Dürig zum 70. Geburtstag, H. Maurer P. Häberle, W. Schmitt Glaeser, W. Graf Vitzthum (red.), Munchen: Beck, 1990 , p. $401-411$.

Linsmayer 1963: E. Linsmayer, Das Naturrecht in der deutschen Rechtsprechung der Nachkriegszeit (diss. Munchen), München 1963.

Llewellyn 1989: K. Llewellyn, The Case Law System in America, Chicago: The University of Chicago Press 1989.

Loucaides 1995: L. G. Loucaides, Personality and Privacy under the European Convention of Human rights, in: Essays on the developing law of human rights, L.G. Loucaides (red.), Dordrecht: Nijhoff 1995, p. 83-107.

Luisa Fernandez Esteban 1995: M. Luisa Fernandez Esteban, Constitutional Values and Principles in the Community Legal Order, in: Maastricht Journal of European and Comparative Law 1995, p. 129-144.

MacCormick en Summers 1991: N. MacCormick and R.S. Summers, Interpretation and Justification, in: Interpreting Statutes, A Comparative Study, N. MacCormick en R.S. Summers (red.), Dartmouth: Aldershot 1991, p. $511-544$.

MacCormick 1997: N. MacCormick, Legal reasoning and Legal theory, Oxford: Clarendon Press 1997.

Magiera 1983: S. Magiera, The interpretation of the Basic Law, in: Main Principles of the German Basic Law, C. Starck (red.), Baden Baden: Nomos 1983, p. 89 e.v.

Mahoney 1990: P. Mahoney, Judicial activism and judicial self-restraint in the European Court of Human Rights: two sides of the same coin, in: Human Rights Law Journal 1990, p. $57-88$.

Mancini en Keeling 1994: G. F. Mancini en D.T. Keeling, Democracy and the European Court of Justice, in: The Modern Law Review 1994, p. 175-190.

Martens 2000: S.K. Martens, De grenzen van de rechtsvormende taak van de rechter, in: Nederlands Juristen Blad 2000, p. 747-758.

Maunz/Durig 1962: Th. Maunz, Grundgesetz: Konmenar, München: Beck 1962 (losbl.), 2001.

Maunz en Zippelius 1998: Th. Maunz en R. Zippelius, Deutsches Staatsrecht: ein Studienbuch, Munchen: Beck 1998.

McKay 1965: R.B. McKay, The Right of Privacy: Emanations and Intimations, in: The Right of Privacy. A Symposium on the Implications of Grismold v. Connecticut 381 U.S. (1965), R.G. Dixon (red.), New York: Da Capo Press 1971, p. 63-86.

Mendelts 2002: P. Mendelts, Interpretatie van grondrechten. Grondrechtenclaims en verschuivingen in de reikwijdte van grondrechten (diss. Leiden), Deventer: W.E.J. Tjeenk Willink 2002.

Meuwissen 1991 : D.H.M. Meuwissen, Rechtsbeginselen en natuurrecht, in:

Rechtsbeginselen, M. Dolman (red.), Nijmegen: Ars Aequi 1991, p. 730-743.

Mevis 1998: P.A.M. Mevis, De ultieme triomf van Radbruch? De berechting van ex-DDRleiders: kanttekeningen bij het 'Grensregime-oordeel' van het Bundesverfassungsgericht, in: Nederlands Tijdschrift voor Rechtsfilosofie en Rechtstheorie 1998, p. 144-154. 
Mortelmans 1998: $\mathrm{K}$. Mortelmans, The principle of Loyalty to the Community (Article 5 EC) and the Obligations of the Community Institutions, in: Maastricht Joumal of European and Comparative Law 1998, p. 67-88.

Von Münch 2000: 1. Von Münch, Die Grandrechte, Vorbemerkungren zu den Avt. $1-19$, in: Grundgesetzkommentar, I. Von Münch en P. Kunig (red.), Munchen: Beck"sche Verlag 2000, p. 21-64.

Murphy, Fleming en Barber 1995: W.F. Murphy, J.E. Fleming en S.A. Barber, American Constitutional Interpretation, New York: Foundation Press 1995.

Nagel 1989: R.F. Nagel, Constitutional Cultures, The Mentality and Consequences of Judicial Review, Berkeley: University of California Press 1989:

Nehmelman 2001: R. Nehmelman, The Notion of Personality-Right in Germany and the Netherlands, Studie- en Informatiecentrum Mensenrechten (SIM) Special 2001 (nr. 21). p. 141-151.

Nehmelman 2002: R. Nehmelman, Het algemeen persoonlijkheidsrecht. Een rechtsvergelijkende studie naar het algemeen persoonlijkheidsrecht in Duitsiand en Nederland (diss. Utrecht), Deventer: Kluwer 2002.

J.H. Nieuwenhuis 1976: J.H. Nieuwenhuis, Legitimatie en heuristiek van het rechterlijk oordeel, RM Themis 1976, p. 494-515.

J.H. Nieuwenhuis 1997: J.H. Nieuwenhuis, Confrontatie en compromis - recht, retoriek en burgerlijke moraal, Deventer: Kluwer 1997.

J.H. Nieuwenhuis 2000: J.H. Nieuwenhuis, De Constitutie van het burgerlijk reeht, in: RM Themis 2000, p. $203-211$.

A.J. Nieuwenhuis 2001: A.J. Nieuwenhuis, Tussen privacy en persoonlijkheidsrecht, een grondrechtelijk en rechtsvergelijkend onderzoek, Nijmegen.: Ars Aequi Libri 2001.

Nipperdey 1954: H.C. Nipperdey, Die Würde des Menschen, un: Die Grundrechte: dee! II, Neumann/Nipperdey/Scheuner (red.), Berlijn: Ducker en Humblot 1954, p. 1-50.

Nipperdey 1962: H.C. Nipperdey, Die freie Entfaltung der Persönlichkeit, in: Die Grundrechte: deel IV, Bettermann/Nipperdey (red.), Berlijn: Duncker en Humblot 1962. p. $741-907$.

Van Oenen 1994: G. H. van Oenen, Conventie en rechtsintrige, een visie op de rechtstheorie van Ronald Dworkin, Zwolle: W.E.J. Tjeenk Willink 1994.

Ossenbihi 1976: F. Ossenbuhl, Die Interpretation der Grundrechte in der Rechtsprechung des Bundesverfassungsgerichts, 46 Neue Juristische Wochenschrift 1976, p. 2100-2107.

Ost 1992: F. Ost, The Original Canons of Interpretation of the European Court of Human Rights, in: The European Convention for the Protection of Human Rights: International Protection versus National Restictions, M. Delmas-Marty (red.), Dordrecht: Martinus Nijhoff 1992, p. 283-305.

Overkleeft-Verburg 2000: G. Overkleeft-Verburg, Art. 10 Grondwet, in: De Grondwet, een systematisch en artikelsgewijs commentaar, A.K. Koekkoek (red.), Zwolle: W.E.J. Tjeenk Willink 2000, p. 155-178.

Pagone 1984: G.T. Pagone, Legal professional privilege in the European Communities" the AM\&S case and Australian law, in: International and Comparative Law Quarterly 1984, p. 663-683.

Perelman 1983: C. Perelman en L. Olbrechts-Tyteca, Traité de l'argumentation. La nouvelle rhétorique, Brussel: Universiteit van Brussel 1983.

Perry 1991: H.W. Perry, Deciding to Decide. Agenda setting in the United States Supreme Court, Cambridge: Harvard University Press 1991. 
Pettiti 1995: L. Pettiti, Reflexions sur les principes et les méchanismes de la Convention, in: La Convention Européenne des droits de l'homme: commentaire article par article, L. Pettiti, E. Decaux P. Imbert en P. Teitgen (red.), Parijs : Economica 1995, p. 27-40.

Pieroth-Schlink 1999: B. Pieroth en B. Schlink, Grundrechte - Sraatsrecht II, Heidelberg: Muller-Verlag 1999.

Plug 1997: H.J. Plug, Een pragma-dialectische analyse van afwegingsstrategieën voor de rechtvaardiging van interpretatieve beslissingen, in: Op Goede Gronden, Bijdragen aan het Tweede symposium juridische argumentatie, E.T. Feteris, H. Kloosterhuis, H.J. Plug en J.A. Pontier (red.), Nijmegen: Ars Aequi Libri 1997, p. 80-89.

Polak 1953: J.M. Polak, Theorie en praktijk der rechtsvinding (diss. Leiden), Zwolle: W.E.J. Tjeenk Willink 1953.

Pitlo 1972: A. Pitlo, Evolutie in het privaatrecht, Groningen: Tjeenk Willink 1972.

Ponthoreau 1993: M.C. Ponthoreau, La reconnaissance des droits non-écrits par les cours constitutionnelles italienne et française: essai sur le powvoir créateur du juge constitutionnel (diss. Florence), Parijs: Economica 1993.

Pontier 1995: J.A. Pontier, Rechtsvinding, Nijmegen: Ars Aequi Libri 1998.

Posner 1992: R.A. Posner, Legal Reasoning From the Top Down and From the Bottom Up: The Question of Unenumerated Constitutional Rights, in: The Bill of Rights in the Modern State, G.R. Stone, R.A. Epstein en C.R. Sunstein (red.), Chicago: University of Chicago Press 1992, p. 433 - 450.

Posner 1995: R.A. Posner, The Problems of Jurisprudence, Cambridge: Harvard University Press, 1995.

Prakke 1992: L. Prakke, Bedenkingen tegen het toetsingsrecht, in: Toetsing (Handelingen Nederlandse Juristen-Vereniging 1992-I), Zwolle: W.E.J. Tjeenk Willink 1992, p. 1-33.

Prebensen 2000: S. Prebensen, Evolutive interpretation of the European Convention on Human Rights, in: Protecting Human Rights: The European Perspective, Studies in memory of Rolv Ryssdal, P. Mahoney, F. Matscher, H. Petzold en L. Wildhaber (red.), Keulen: Carl Heymanns Verlag 2000, p. 1123-1137.

Prosser 1984 (1960): W.L. Prosser, Privacy [a legal analysis], in: Philosophical Dimensions of Privacy, An Anthology, F.D. Schoeman (red.), Cambridge: Cambridge University Press 1984, p. 104-155.

Ramm 1989: T. Ramm, Ehelichkeitsanfechtung und Bundesverfassungsgericht, in: Neue juristische Wochenschrif 1989, p. 1594-1597.

Rasmussen 1980: H. Rasmussen, Why is Article 173 Interpreted against Private Plaintiffs? In: European Law Review 1980, p. 112-127.

Rasmussen 1988: H. Rasmussen, Between Self-Restraint and Activism: A Judicial Policy for the European Court, in: European Law Review 1988, p. 28-38.

Raz 1998: J. Raz, On the Authority and Interpretation of Constitutions: Some Preliminaries, in: Constiturionalism: Philospohical Foundations, L. Alexander (red.), Cambridge: Cambridge University Press 1998, p. 152-193.

Rotundan en Nowak 1995: R.D. Rotunda en J.E. Nowak, Constitutional Law, St. Paul Minnesota: West 1995.

Rodriguez Iglesias 2000: G.C. Rodriguez Iglesias, Het Hof van Justitie en de institutionele hervorming van de Europese Unie, April 2000, <www.curia.eu.int>.

Rossinelli 1987: M. Rossinelli, Les Libertés non Écrits, contribution à l'étude du pouvoir createtr du juge constitutionnel, Lausanne: Payot 1987.

Rozemond 1998: N. Rozemond, Strafvorderlijke rechtsvinding (diss. VU Amsterdam), Deventer:" Gouda Quint 1998. 
Von Savigny 1840: F. C. von Savigny, System des heatigen Rômischen Rechts, Vol. I, Berlijn: Veit 1840 .

Scalia 1997: A. Scalia, A matter of imerpretation, Federal Courts and the law. An essay by Antonin Scalia, Pinceton, New Jersey: Princeton University Press 1997.

Sehermers en Waelbroek 1992: H. G. Schermers en D. Waelbroeck, Judicial Protection in the European Communities, Deventer: Kluwer 1992.

Schermers 2000: H.G. Schermers, Human Rights as General Principles of Law, in: General Principles of European Community Law, U. Bernitz en J. Nergelius (red.), Den. Haag: Kluwer Law International 2000, p. 61-71.

Schick 1982: M. Schick, Judicial Activism on the Supreme Court, in: Supreme Court activism and restraint, S.C. Halpern en C.M. Lamb (red.), Lexington: Heath and Company 1982, p. 37-56.

Schilling 1996: T. Schilling, Treaty and Constitution: A Comparative Analysis of an Uneasy Relationship, in: Maastricht Journal of European and Comparative Law 1996, p. $47-68$.

Schlaich 1997: K. Schlaich, Das Bundesverfassungsgericht, Stellung, Verfahren, Entscheidungen: ein Studienbuch, München: Beck Verlag 1997.

Schneider 1979: H. Schneider, Die Güterabwägung des Bundesverfassungsgerichts bei Grundrechiskonflikte, Baden Baden: Nomos 1979.

Schokkenbroek 1996: J.G.C. Schokkenbroek, Toetsing aan de wijheidsrechten van het Europees Verdrag van de Rechten wan de Mens: een onderzoek naar de toetsing aan de beperkingsclausules bij de Europese wijheidsrechten in de Europese en in de Nederlandse rechtspraak (diss. Leiden), Zwolle: W.E.J. Tjeenk Willink 1996.

Schokkenbroek 2000: J.G.C. Schokkenbroek, Methoden van interpretatie en toetsing, een overzicht van beginselen toegepast in de Straatsburgse jurisprudentie, Katern 2.1 in: EVRM Rechtspraak en Commentaar, Lelystad: Koninklijke Vermande 2000 .

Scholz 1975: R Scholz, Das Grundrecht der freien Entfaultung der Persönlichkeit in der Rechtsprechung des Bundesverfassungsgerichts, in: Archiv des Öffentlichen Rechts 1975: deel 1 p. $80-130$ en deel 2: p. $265-290$.

Scholz en Konrad 1998: R. Scholz en K. Konrad: Meinungsfreiheit und allgemeines Persönlichkeitsrecht - Zur Rechtsprechung des Bundesverfassungsgerichts, in: Anmerkungen des öffentlichen Rechts 1991, p. 60-121.

Schuyt 1988: C.I.M. Schuyt, De veranderende plats wan de Hoge Raad in de samenleving, in: De plaats van de Hoge Raad in het huidige staatsbestel: de veranderingen in de rol van de Hoge Raad als rechtsvormer, Baardman, Bloembergen e.a. (red.), Zwolle: W.E.J. Tjeenk Willink 1988, p. 297-334.

Shiner 1992: R. Shiner, Norm and Nature. The movements of legal Though, Oxford: Clarendon Press 1992.

Smend 1968: R. Smend, Verfassung und Verfassungsrecht, in: Staatiche Abhandlungen und andere Awfsätze, Berlijn: Duncker en Humblot 1968, p. 188-196.

Smith 1998: C.E. Smith, Feit en rechtsnorm: een methodologisch onderzoek naar de betekenis van de feiten waar de rechtsvinding en legitimatie van het rechtsoordeel (diss. Leiden), Maastricht: Shaker Publishing 1998.

Snijders 1978: H.J. Snijders, Rechtsvinding door de burgerlijke rechter: een kwantitatief rechispraakonderzoek bij de Hoge Raad en de gerechtshoven (diss. Leiden), Deventer: Kluwer 1978.

Soeteman 1991: A. Soeteman, Hercules aan het werk, over de rol van rechtsbeginselen in het recht, in: Rechtsbeginselen, M. Dolman (red.), Nijmegen: Ars Aequi 1991, p. 28-41 
Staal 1995: CJ. Staal, De Vaststelling van de reikwijte wan de Rechten van de Mens (diss. Maastricht), Nijmegen: Ars Aequi Libri 1995.

Starck 1995: C. Starck, Constitutional Interpretation, in: Studies in Germon canstitutionalism: the German contributions to the fourth world congress of the International Association of Constitutional Law, C. Starck (red), Baden-Baden: Nomos $1995(p \cdot 47-70)$.

Starck 1997: C. Starck, Rechtsvergleichung im öffentlichen Recht, in: JuristenZeitung 1997, p. $1021-1030$.

Stolker 1993: C.J.M.M. Stolker, De politieke rol wan de rechter in het burgerlijke recht; in: Rechters en politiek, nationale en internationale beschouwingen, M.G. Rood (red)., Zwolle: W.E.J Tjeenk Willink 1993, p. 53-84.

Sunstein 1993: C.R. Sunstein, Commentary: on analogical reasoming, in: Harvard Law Review 1993, p. 741-791.

Sunstein 1999: Sunstein, One case at a time: judicial minimalism on the Supreme Court, Cambridge: Harvard University Press 1999.

Tak 1994: P.J.P. Tak, Rechtsvorming in Nederland, een inleiding. Alphen aan den Rijn: Samsom H.D. Tjeenk Willink 1994.

Thayer 1967: J.B. Thayer, The Origin and Scope of the American Doctrine of Constitutional Law, in: Judicial review and the Supreme Court: selected essays, L.W. Levy (red), New York: Harper en Row 1967.

Toth 2000: A.G. Toth, Human Rights as General Principles of Law, in the Past and in the Future, in: General Principles of European Community Law, U. Bernitz en J. Nergelius (red.), Den Haag: Kluwer Law International, p. 73-92.

Tribe 1985 (1): L. H. Tribe, God Save This Honorable Court, How the choice of Supreme Court Justices Shapes Our History, New York: Random 1985.

Tribe 1985 (II): L.H. Tribe, Constitutional choices, Cambridge: Harvard University Press 1.985.

Tribe en Dorf 1991: L. H. Tribe and M. C. Dorf, On reading the Constitution, Cambrdige: Harvard University Press, 1991.

Tribe 1992: L. H. Tribe, Abortion: the clash of absolutes, New York: Norton \& Company 1992.

Tribe 1999: L. H. Tribe, Saenz sans prophecy: does the privilliges or immunities revival portend the future - or reveal the structure of the present? In: Harward Law Review 1999, p. 110-198.

Tribe 1988: L. H. Tribe, American Constitutional Law, New York: Foundation Press 1988.

Tribe 2000: L. H. Tribe, American Constirutional Law, New York: Foundation Press 2000.

Tridimas 1999: T. Tridimas, The General Principles of EC Law, Oxford: Oxford University Press 1999.

Tushnet 1999: M. Tushnet, The possibilities of Comparative Constitutional Law, Yale Law Joumal 1999, p. 1225-1309.

Twomey 1995: P. Twomey, Annotatie bij by $\mathrm{X}$ t. Commissie, Common Market Law Review 1995, p. 1013-1023.

Ukrow 1995: J. Ukrow, Richterliche Rechtsfortbildung durch den EuGH: Dargestellt am Beispiel der Erweiterung des Rechtsschützes des Marktbürgers im Bereich des vorläufigen Rechtsschutzes und der Staatshaftung (diss. Saarbricken), Baden Baden: Nomos 1995 . 
Van der Velde 1997: J van der Velde, Grenzen aan het toezicht op de naleving wan het Europees Verdrag tor bescherming van de rechten van de mens en de fundamentele wrijheden (diss. Leiden), Leiden: Stichting NJCM Boekerij 1997.

Van der Velde 2002: $\mathrm{J}$. Van der Velde, Positieve verplichtingen, Katern 2.2, in: EVRM Rechtspraak en Commentaar, Lelystad: Koninklijke Vermande 2002.

Velu 1973: J. Velu, The European Convention on Human Rights and the Right to respect for private Life, the Home and Communications, in: Privacy ard Human Rights Reports and communications presented at the third international colloguy about the Earopean Convention on Human Rights, A.H. Robertson (red.), Manchester: Manchester University Press 1973 , p. 12 e.v.

Verhey 1992: L.F.M. Verhey, Horizontale werking van grondrechten, in he bijzonder" van het recht op privacy (diss. Utrecht), Zwolle: W.E.J. Tjeenk Willink 1992.

Verhey 1994: L.F.M. Verhey, Valkenhorst: het recht op afstammingskennis als persoonlijkheidsrecht, in: NJCM-Bulletin 1994, p. 652-658.

Verhey 1995: L.F.M. Verhey, Privacy en lichamelijke integriteit: op zoek naar evenwicht, in: De Grondwet als voonwerp van aanhoudende zorg, J.B.J.M Ten Berge e.a. (red.), Zwolle: W.E.J. Tjeenk Willink 1995, p. 145-168.

Viehweg 1974: Th. Viehweg, Topik und Jurisprudenz, Ein Beitrag zur rechtwissenschafilichen Grundlagenforschung, München: Beck Verlag 1974.

Vile 1994: J.R. Vile, Constiturional change in the United States: a comparative siudy of the role of constifutional amendments, judicial inverpretations and legislative and executive actions, Westport: Praeger Publishers 1994.

De Waard 1987: B.N.W. de Waard, Beginselen van behoorlijke rechtspleging, met name in het administratief procesrecht (diss. Utrecht), Zwolle: W.E.J. Tjeenk Willink 1987.

Walter 2000: C. Walter, Huter oder Wandler der Verfassung? Zur Rolle des Bundesverfassungsgerichts im Prozeß des Verfassungswandels, in: Archiv des öffentlichen Rechts 2000, p. 517-550.

Warren en Brandeis 1890: S.D. Warren en L.D. Brandeis, The right to privacy 'the implicit made explicit', in: Harvard Law Review 1890, p. 193 e.v.

Wassermann 1984: R. Wassermann, Reihe Alternativommentare: Kommentar zum Grundgesetz fiur die Bundesrepublik Deutschland, Band I (Art. 1-20 GG), Darmstadt: Luchterhand 1984.

Wechsler 1961: H. Wechsler, Toward Neutral Principles of Constitutional Law in Principles, Politics, and Fundamental Law, in: Harvard Law Review 1961, p. 1-35.

Weiler 1991 : J.H.H. Weiler, The Transformation of Europe, Yale Law Jownal 1991 , p. 2403-2483.

Weiler en Lockhart 1995: J.H.H. Weiler en N.J.S. Lockhart, "Taking rights seriously" seriously: The European Court and its fundamental rights jurisprudence, part I en II, in respectievelijk Common Market Law Review 1995, p. 51-94 en Common Market Law Review 1995, p. 579-627.

Weiler 1999: J.H.H. Weiler, The Constitution of Europe, Cambridge: Cambridge University Press 1999.

De Werd 1994: M.F.J.M. de Werd, De benoeming van rechters, constitutionele aspecten van de toegang tot het rechtersambt in Nederland en in de Amerikaanse deelstaat New" York (diss. Maastricht), Arrahena: Gouda Quint 1994.

Westin 1967: A.F. Westin, Privacy and Freedom, in: in: Philosophical Dimensions of Privacy, An Anthology, F.D. Schoeman (red.), Cambridge: Cambridge University Press 1984, p. 56-74. 
Wiarda 1986: G. J. Wiarda, Rechterlijke voortvarendheid en rechterlijke terighouding bij de toepassing van de Europese Conventie tor bescherming van de rechten van de mens (oratie Rotterdam), Den Haag: VUGA, 1986.

Wia rda/Koopmans 1999: G.J. Wiarda, Drie typen van rechtsvinding, bewerkt en van een nabeschouwing voorzien door T. Koopmans, Zwolle: W.E.J. Tjeenk Willink 1999.

Wildhaber 2000: L. Wildhaber, Precedent in the European Court of Human Rights, in: Protecting Human Righs: The European Perspective, Studies in memory of Ralv Ryssdal, P. Mahoney, F. Matscher, H. Petzold en L. Wildhaber (red), Keulen: Carl Heymanns Verlag 2000, p. $1529-1545$.

De Witte 1995: B. de Witte, Interpreting the EC Treaty like a constitution: the role of the European Court of Justice in comparative perspective, in: Judicial Control, Comparative essays on judicial review, R. Bakker. A.W. Heringa en F. Stroink (red.), Antwerpen: Maklu 1995, p. 133-152.

De Witte 2000: B. de Witte, Institutional Principles: A Special Category of General Principles of EC Law, in: General Principles of European Commumity Law, U. Bernitz en J. Nergelius (red.), Den Haag: Kluwer Law International, p. 143-159.

De Witte 2001: B. de Witte, The Legall Status of the Charter: Vital Questions or Non-Issue? In: Maastricht Journal of European and Comparative Law 2001, p. 81-98.

Wolfhagen 1997: D. Wolfhagen, Wat niet weet, wat niet deert: het recht op afstammingsgegevens, in: Nemesis 1997, p. 98-103.

Zeidler 1981: W. Zeidler, Grundrechte und Grundentscheidungen der Verfassung im Widerstreit, in: Verhandlungen des 53. Deutschen Juristentages, Mïnchen: Beck Verlag 1980.

Zwart 1985: T. Zwart, Onaantastbaarheid van het menselijk lichaam: slag in de lucht of afdwingbaar recht? in: NJCM-Bulletin 1985, p. 254-259. 


\section{Jurisprudentie}

\section{Verenigde Staten}

\section{Supreme Court of the United States}

Calder t. Bull

Marbury t. Madison

Fletcher t. Peck

Martin t. Hunters Lessee

McCulloch t. Maryland

Dred Scott t. Sandford

Slaughterhouse-cases

Boyd t. Verenigde Staten

Maynard t. Hill

Hans t. Louisiana

Allgeyer t. Louisiana

Lochner t. New York

Pavesich 4. New England Life Insurance

Twining t. New Jersey

Chicago, B. en Q. R. Co. t. McGuire

New York Life Insurance Co. t. Dodge

Adkins t. Children's Hospital of Disctrict of

Columbia

Meyer t. Nebraska

3 Dall. 3 U.S. 368

1798

1 Cranch 137, 2L. Ed. 60, 1803

6 Cranch (10 U.S.) $87 \quad 1810$

1 Wheat. (14 U.S.) $304 \quad 1816$

17 U.S. (4. Wheat.) $316 \quad 1819$

60 U.S. (19 How.) $393 \quad 1857$

16 Wall. (83 U.S.) 36, 21 L. Ed. $394 \quad 1873$

116 U.S. 616

125 U.S. 190

1886

134 U.S. 1

165 U.S. 578

1888

1890

198 U.S. 45

$122 \mathrm{Ga} 190,50 \mathrm{SE}, 68$

211 U.S. 78

219 U.S. 549

246 U.S. 357

261 U.S. 525

1897

1905

1905

1908

1911

1918

1923

262 U.S. 390

1923

268 U.S. $652 \quad 1925$

$\begin{array}{ll}\text { Gitlow t. People of State of New York } & 268 \text { U.S. } 652 \\ \text { Pierce t. Society of Sisters of the Holy Names } 268 \text { U.S. } 510\end{array}$

1925

of Jesus and Mary

Buck t. Bell

Olmstead t. Verenigde Staten

274 U.S. 200

1927

277 U.S. $438 \quad 1928$

Nebbia t. New York

291 U.S. 502

1934

297 U.S. $288 \quad 1936$

Ashwander t. Tennessee Valley Authority

West Coast Hotell t. Parrish

300 U.S. 379

1937

302 U.S. 319

Palko t. Connecticut

304 U.S. 144

1938

United States t. Carolene Products Co.

Railroad Commission t. Verenigde Staten

312 U.S. 496

1941

316 U.S. $535 \quad 1942$

Skinner t. Oklahoma

319 U.S. 624

West Virginia Board of Education t. Barnette

Smith t. Allwright

321 U.S. 649

1943

1944

Brown t. Board of Education

347 U.S. 483

1954

Sweezy t. New Hampshire

354 U.S. 234

1957

Staub t. City of Baxley

Kent t. Dullies

355 U.S. 313

1958

357 U.S. $116 \quad 1958$

NAACP t. Alabama

357 U.S. 449

1958

367 U.S. 497

1961

Poe t. Ullman

367 U.S. 643

1961

369 U.S. 186

1962

Baker t. Carr

378 U.S. 500

1964

381 U.S. $479 \quad 1965$

Griswold t. Connecticut

383 U.S. 663

1966 
Lowing t. Virginia

Katz t. Verenigde Staten

Duncan t. Louisiana

Stanley t. Georgia

Powell t. Maccormack

Eisenstadt t. Beard

O'Brien t. Brown

Roe t. Wade

Belle Terre t. Boraas

DeFunis t. Odegaard

Cox Broadcasting Company t. Cohn

Warth t. Seldin

Kelley t. Johnson

Whalen t. Ros

Moore t. East-Cleveland

Beal t. Doe

Maher t. Roe

Zablocki t. Redhail

Holenbaugh t. Carnegie Free Library

Nevada t. Hall

Smith t. Maryland

Harris t. McRae

Richmond Newspapers, lnc. t. Virginia

Christian College t. Americans United

United States t. Mendoza

Whisenhunt t. Spradlin

Thornburg t. American College

Bowers t. Hardwick

Michael H. t. Geralld D

Texas t. Johnson

Webster t. Reproductive Health Services

Burnham tt. Supperior Court

Verenigde Staten t. Eichman

Cruzan t. Director, Missouri Department of Health

Rust t. Sullivan

Planned Parenthood of Sowtheastern

P.A. 1. Casey

U.S. Term Limits, Ine. t. Thornton

M.L.B. T. S.L.J.

Washington t. Glucksberg

Printz t. Verenigde Staten

Vacco t. Quill

Stenberg t. Carhart, 28 juni 2000

Atkins t. Virginia

Compassion in Dying t. Washington
388 U.S. 1

1967

389 U.S. 347

1967

391 U.S. 145

394 U.S. 557

395 U.S. 486

405 U.S. 438

409 U.S. 1

410 U.S. 113

416 U.S. 1

416 U.S. 312

420 U.S. 469

422 U.S. 490

425 U.S. 238

429 U.S. 589

431 U.S. 494

432 U.S. 438

432 U.S. 464

434 U.S. 374

439 U.S. 1052

440 U.S. 410

442 U.S. 735

448 U.S. 297

448 U.S. 555

545 U.S. 464

464 U.S. 154

464 U.S. 965

476 U.S. 747

478 U.S. 186

491 U.S. 110

491 U.S. 397

492 U.S. 490

495 U.S. 604

496 U.S. 310

497 U.S. 261

1968

1969

1969

1972

1972

1973

1974

1974

1975

1975

1976

1977

1977

1977

1977

1978

1978

1979

1979

1980

1980

1982

1984

1983

1986

1986

1989

1989

1989

1990

1990

1990

500 U.S. 173

1991

1992

1995

1996

1997

1997

26 juni 1997

28 juni 2000

20 juni 2002

000 U.S. $00-8452$

1996 


\section{Duitsland}

\section{Bundesgerichtshof}

Leserbrief

13 BGHZ 334

Paul Dahlke

20 BGHZ 345

Herrenreiter

$26 \mathrm{BGHZ} 349$

25 mei 1954

8 mei 1956

14 februari 1958

\section{Bundesverfassungsgericht}

Suddweststaat

Wohnungsbaubeförderung

I BVerfGE 14

1 BVerfGE 299

2 BVerfGE 266

Notaufnahme

3 BVerffGE 225

Gleichberechtigung

Investitionshilfe

KPD-Verbutsurteil

4 BVerfGE 7

5 BVerfGE 85

Elfes

Homosexuelle

Luth

Apotheken-urteil

Besoldungsrecht

Parteispenden

Bestimmtheit einer Rechtsverondnung

Preisgesetz

Gehör bei Haftbefehl

Nachkonstitutioneller Bestâtigungswille

Kurchenbausteuer

Berlin-Vorbehalt II

EWG-Verordnungen

6 BVerfGE 32

6 BVerfGE 389

7 BVerfGE 198

7 BVerfGE 377

8 BVerfGE 28

8 BVerfGE 51

8. BVerfGE 71

8 BVerfGE 274

9 BVerfGE 89

11 BVerfGE 126

19 BVerfGE 206

19 BVerfGE 377

22. BVerfGE 293

25 BVerfGE 256

$27 \mathrm{BV}$ erfGE 1

Mikrozensus

Ehescheidungsakten

Dienstfplichtwerweigerung

Abhörurteil

Mephisto

Betriebsbetretungsrecht

Arztliche Schweigeptlicht

27 BVerfGE 344

28 BVerfGE 243

30 BVerfGE 1

30 BVerfGE 173

32 BVerfGE 54

32 BVerfGE 373

Zeugnisverweigerungsrecht

33 BVerfGE 367

Förderstufe

Tonband

34 BVertGE 165

34 BVerfGE 238

Soraya

34 BVerfGE 269

Lebach

35 BVerfGE 202

Grundlagenvertrag

$36 \mathrm{BV}$ erfGE 1

Solange I

Schwangerschaftsabbrich I

37 BVerfGE 271

39 BVerfGE 1

Inkompatibilitat/Kirchliches Ambt

42 BVerfGE 312

Klientenkarten

44 BVerfGE 353

45 BVerfGE 187

46 BVerfGE 160

47 BVerfiCE 46

49 BVerfGE 286

23 oktober 1951

21 mei 1952

7 mei 1953

18 december 1953

20 julli 1954

17 augustus 1956

16 januari 1957

10 mel 1957

15 januari 1958

11 juni 1958

11 juni 1958

24. juni 1958

10 juli 1958

12 november $\$ 958$

8 januari 1959

17 mei 1960

14 december 1965

20 januari 1966

18 oktober 1967

26 februari 1969

16 juli 1969

15 januari 1970

26 mei 1970

15 decenber 1970

24 februari 1971

13 oktober 1971

8 maart 1972

19 juli 1972

6 december 1972

31 januari 1973

14 februar 1973

5 juni 1973

31 juli 1973

29 mei 1974

25 februari 1975

21 september 1976

24 mei 1977

21 juni 1977

16 oktober 1977

21 december 1977

11 oktober 1978 
Ausweisung aurs generalpräventiven Grunden

Mitbestimmung

Verhandlungsfahigkeit des Angeklagten

Taubenfuttern

Eppler

Aussageverpflichtung

Sothlde

Bundestagsauflösung

Gegendarstellung

Volkszăhlung

$\mathrm{G} 10$

Zivildienst

Finanzausgleich

Erziehungsmaßregeln

Unschuldsvermutung

Familiennachzug

Gemeinsamer Familienname

Lugendetektor

Rastede

Kenntnis der eigenen Abstammung

Reiten im Walde

Tagebuch

Schubart

Offenbarung der Entmündigung

Transsexuelle II

Schwangerschaftsabbruch II

Kein EheschlieBung für gleichgeschlechtliche

Partner

Psychologisches Gutachten

Maastrichturteil

Cannabis

Ehelichkeitsanfechtung

Entziehungsanstalt

Erich Honecker, Fernsehen im Gerichtssaal.

Mauerschitzen

Vaterschaftsauskunft

Stasi-Frragen

Sterillisation

Mißbrachsbezichtigung

Gefangenenentlohnung

Lebach ]I

\section{Europese Gemeenschappen}

\section{Gerecht van Eerste Aanleg}

T-121/89, T-13/90 Xt. Commissie

T-305/94 Limburgse Vinyl t. Commissie

T-54/99 max.mobil Telekommunikation

T-254/99 Jégo-Quéré t. Commissie
50 BVerfGE 166

$50 \mathrm{BVerfGE} 290$

51 BVerfGE 324

54 BVerfGE 143

54 BVerfGE 148

56 BVerfGE 371

59 BVerfGE 216

62. BVerfGE 1

63 BVerfGE 131

65 BVerfGE 1

67 BVerfGE 157

69 BVerfGE 1

72 BVerfGE 330

74 BVerfGE 102

74 BVerfGE 358

76 BVerfGE 1

$78 \mathrm{BVerfGE} 39$

79 BVerfGE 29

79 BVerfGE 127

79 BVerfGE 256

80 BVerfGE 137

80 BVerfGE 367

82 BVerfGE 236

84 BVerfGE 192

88 BVerfGE 87

88 BVerfGE 203

1 BvR 640/93

89 BVerfGE 69

89 BVerfGE 155

90 BVerfGE 145

90 BVerfGE 263

91 BVertGE 1

91 BVerfGE 125

95 BVerfGE 96

96 BVertGE 56

96 BVerfGE 171

96 BVerfGE 375

97 BVertGE 391

BVerfG 2 BvL 17/94

BVerfG I BvR 755/98
17 januari 1979

1 maart 1979

19 juni 1979

23 mei 1980

3 juni 1980

13 januari 1981

12 Januari 1982

16 februari 1983

8 februari 1983

15 december 1983

20 junii 1984

24 april 1985

24 juni 1986

13 juni 1987

26 maart 1987

12 mei 1987

8 maart 1988

11 oktober 1988

23 november 1988

31 januari 1989

6 juni 1989

14 september 1989

26 juni 1990

11 juni 1991

26 januari 1993

28 mei 1993

47 NJW 1993

24 juni 1993

12 oktober 1993

9 maart 1994

26 april 1994

16 maart 1994

14 juli 1994

24 oktober 1996

6 mei 1997

8 juli 1997

12 november 1997

24 maart 1998

1 juli 1998

25 novenber 1999
GEA 18 september 1992

GEA 20 april 1999

GEA 30 januari 2002

GEA 3 mei 2002
Jur. 1992, p. II-2195

Jur. 1999, p. II-931

EHRC 2002/54 (JG)

EHRC 2002/55 (HJ) 
Hof van Justitie van de EG

\begin{tabular}{|c|c|}
\hline $3 / 54$ & Assider t. Hoge Autoriteit \\
\hline $4 / 54$ & Isa t. Hoge Autoriteit \\
\hline $1 / 58$ & Stork t. Hoge Autoriteit \\
\hline $30 / 59$ & Steenkolenmijnen \\
\hline $31 / 59$ & Brescia t. Hoge Autoriteit \\
\hline $40 / 59$ & Nold I \\
\hline $6 / 60$ & Humblet \\
\hline $26 / 62$ & Van Gend en Loos \\
\hline $25 / 62$ & Plaumann \\
\hline $75 / 63$ & Unger \\
\hline $6 / 64$ & Costa t. E.N.E.L. \\
\hline $29 / 68$ & Eierkontor \\
\hline $29 / 69$ & tauder $t$. Stadt Ulm \\
\hline $11 / 70$ & Internationale \\
\hline & Handelsgesellschaft \\
\hline $40 / 70$ & Sirena \\
\hline $22 / 70$ & ERTA \\
\hline $20 / 71$ & Sabbattini t Europees Parlement \\
\hline $4 / 73$ & Nold t. Commissie \\
\hline $175 / 73$ & Union Syndicale t. Raad \\
\hline $21 / 74$ & Airola t. Commissie \\
\hline $36 / 75$ & Rutili \\
\hline $59 / 75$ & Manghera \\
\hline $87 / 75$ & Bresciani \\
\hline $130 / 75$ & Prais t. Raad \\
\hline$\$ 2 / 76$ & Benedetti \\
\hline $26 / 76$ & Metro t. Commissie \\
\hline $149 / 77$ & Defrenne III \\
\hline $44 / 79$ & Hauer \\
\hline $104 / 79$ & Foglia \\
\hline $136 / 79$ & Panasonic t. Commissie \\
\hline $66 / 80$ & International Chemical \\
\hline & Corporation \\
\hline $155 / 79$ & AM\&S t. Commissie \\
\hline $230 / 81$ & Luxemburg t. Parlement \\
\hline $283 / 81$ & Cilfit \\
\hline $87 / 82$ & Rogers \\
\hline $43 / 82$ & $\begin{array}{l}\text { Vlaams Boekwezen } t \\
\text { Commissie }\end{array}$ \\
\hline $75 / 82$ & $\begin{array}{l}\text { Razzouk en Beydoun t. } \\
\text { Commissie }\end{array}$ \\
\hline $63 / 83$ & Regina t. Kent Kirk \\
\hline $112 / 83$ & Société de Produits de Maüs \\
\hline $264 / 82$ & Timex Corporation t. Raad \\
\hline $60 / 84$ & Cinetheque \\
\hline $44 / 84$ & Hurd \\
\hline $169 / 84$ & Cofaz t. Commissie \\
\hline $294 / 83$ & Les Verts t. Europees Parlement \\
\hline $222 / 84$ & Johnston \\
\hline
\end{tabular}

HvJ EG 11 februari 1954 HvJ EG 11 februari 1954 HwJ EG 4 februari 1959 HvJ EG 23 februari 1961 HvI EG 4 april 1960 Hv] EG 15 juli 1960 HvJ EG 16 december 1960 HvJ EG 5 februari 1963 HvJ EG 15 juli 1963 HvJ EG 19 mart 1964 HvJ EG 5 juli 1964 HvJ EG 24 juni 1969 HvJ EG 12 november 1969 HvJ EG 17 decenber 1970

HwJ EG 18 februari 1971. HvJ EG 31 maart 1971

HvJ EG 7 juni 1972

HvJ EG 14 mei 1974 HvJ EG 8 oktober 1974 HvJ EG 20 februari 1975 HvJ EG 28 oktober 1975 HvJ EG 3 februari 1976 HvJ EG 5 februari 1976 HvJ EG 27 oktober 1976 HVJ EG 3 februari 1977 HvJ EG 25 oktober 1977 HvJ EG 15 juni 1978 HvJ EG 13 december 1979 HvJ EG 11 maart 1980 HWJ EG 26 juni 1980 HVJ EG 13 mei 1981

HuI EG 18 mei 1982 HvJ EG 10 februari 1983 HvJ EG 6 oktober 1982 HvJ EG 11 mei 1983 HwJ EG 17 januar: 1984

HvJ EG 20 maart 1984

HvJ EG 10 juli 1984 HvJ EG 27 februari 1985 HwJ EG 20 maart 1985 HivJ EG 11 juli 1985 HvJ EG 15 januari 1986 HvJ EG 28 januari 1986 HwJ EG 23 april 1986 HyJ EG 15 mei 1986
Jur. 1954, p. 285 Jur. 1954, p. 191 Jur. 1959, p. 43 Jur. 1961, p. 93 Jur. 1960, p. 98 Jur. 1960, p. 885 Jur. 1960, p. 1160 Jur. 1963, p. I Jur. 1963, p. 126 Jur. 1964, p. 369 Jur. 1964, p. 585 Jur. 1969 , p. 165 Jur 1969 , p. 419 Jur. 1970, p. 1125

Jur. 1971, p. 69 Jur. 1971, p. 263 Jur. 1972 , p. 345 Jur. 1974, p. 491 Jur. 1974, p. 917 Jur. 1975, p. 221 Jur. 1975, p. 1219 Jur. 1976, p. 91 Jur. 1976, p. 129 Jur. 1976 , p. 1589 Jur. 1977, p. 163 Jur. 1977, p. 1875 Jur. 1978, p. 1365 Jur. 1979, p. 3727 Jur. 1980, p. 745 Jur. 1980, p. 2033 Jur. 1981, p. 1191

Jur. 1982, p. 1575 Jur. 1983, p. 255 Jur. 1982, p. 3415 Jur. 1983 , p. 1579 Jur. 1984, p. 19

Jur. 1984, p. 1509

Jur. 1984, p. 2689 Jur. 1985, p. 719 Jur. 1985, p. 849 Jur. 1985, p. 2605 Jur. 1986, p. 29 Jur. 1986, p. 391 Jur. 1986, p. 1339 Jur. 1986, p. 1651 


\begin{tabular}{|c|c|}
\hline $12 / 86$ & Deminel \\
\hline $314 / 85$ & Potofrost \\
\hline $302 / 87$ & Comitalogiebeslut \\
\hline $46 / 87$ & Hoechst t. Comm ssie \\
\hline $68 / 88$ & Conmmssie 1. Griekenland \\
\hline $97 / 87$ & $\begin{array}{l}\text { Dow Chemical Iberia t. } \\
\text { Commissie }\end{array}$ \\
\hline $374 / 87$ & Orken t. Commissie \\
\hline $\mathrm{C}-262 / 88$ & Barber \\
\hline $\mathrm{C}-2 / 88$ & Zwartveld \\
\hline $\mathrm{C}-358,89$ & Extramel t. Raad \\
\hline $\mathrm{C}-260 / 89$ & $E R T$ \\
\hline$C-70 / 88$ & Europees Parlement $t$ Raad \\
\hline$C-159 / 90$ & SPUC \\
\hline $\mathrm{C}-62 / 90$ & Commissie t, Duitsland \\
\hline$C-343 / 90$ & Lorenco Dilas \\
\hline $\mathrm{C}-168 / 91$ & Konstantinidis \\
\hline $\mathrm{C}-309 / 89$ & Codomíu t. Raad \\
\hline $\mathrm{C}-404 / 92$ & X t Commissie \\
\hline$C-422 / 93$ & Zabala \\
\hline $\mathrm{C}-415,93$ & Bosman \\
\hline$C-13 / 94$ & P. t. S. en Cornwall County \\
\hline $\mathrm{C}-249 / 96$ & Grant t. Sout-West Trains Ltd. \\
\hline $\mathrm{C}-274 / 00$ & Connolly t. Commissie \\
\hline $\mathrm{C}-122 / 99$ & $25 / 99$ D.t. Raad \\
\hline$C-340 / 00$ & Cwik t. Commissite \\
\hline $\mathrm{C}-50 / 00$ & Unión de Pequeños t. Raad \\
\hline $\mathrm{C}-94 / 00$ & Roquette Fines \\
\hline
\end{tabular}

HvJ EG 30 september 1987

HvJ EG 22 oktober 1987

HwJ EG 27 september 1988

HvJ EG 21 september 1989

HvJ 21 september 1989

HvI EG 17 oktober 1989

Hv」 EG 18 oktober 1989

HvJ EG 17 mei 1990

HvJ EG 13 juli 1990

HvJ EG 16 mei 1991

HvJ EG 18 juni 1991

HVJ EG 4 oktober 1991

HVJ EG 4 oktober 1991

HVJ EG 8 april 1992

HvJ EG 16 juli 1992

HvJ EG 30 maart 1993

HvJ EG 18 mei 1994

HvJ EG 5 oktober 1994

HvJ EG 15 juni 1995

HvJ EG 15 december 1995

HvJ EG 30 april 1996

HvJ EG 17 februari 1998

HvJ EG 6 maart 2001

HvJ EG 31 mei 2001

HVJ EG 13 december 2001

HvJ EG 25 juli 2002

HvJ EG 22 oktober 2002
Jur. 1987, p. 3719

Jur. 1987; p. 4199

Jur. 1988 , p. 5615

Jur. 1989 , p. 2859

Jur. 1989 , p. 2965

Jur. 1989 p. 3165

Jur. 1989 , p. 3283

Jur. 1990 , p. I-1889

Jur. 1990, p. I-3365

Jur. 199I, p. I-3893

Jur. 1991, p. I-2925

Jur. 1991, p. I-4529

Jur. 1991, p. I-4685

Jur. 1992, p. I-2575

Jur. 1992, p. $\llbracket-4673$

Jur. 1993, p. I-1191

Jur. 1994, p. I-1853

Jur. 1994, p. I-4737

Jur. 1995, p. I-1567

Jur. 1995, p. I-492 I

Jur. 1996, p. I-2143

Jur. 1998, p. I-621

EHRC 2002/11 (HJ)

Jur. 2001, p. 1-4319

n.n.g.

EHRC 2002/78 (HJ)

n.II.g.

\section{Raad van Europa}

\section{Ontwankelijkheidsbeslissingen van de Europese Commissie voor de Rechten van de Mens}

Zaak 6825/74

Zaak 6959/75

Zaak $7289 / 75$

Zaak 8416/78

Zaak 9369/81

\section{$X t$. IJsland}

Bruggemann en Scheuten t.

Duitsland

$X$ en Y t. Zwitserland

$X$ t. Verenigd Koninkrijk

$X$ en $Y$ t. Verenigd Koninkrijk ECRM 3 mei 1983

\section{Europees hof voor de Rechten van de Mens (EHRM)}

$\begin{array}{lll}27 \text { juni 1968 } & \text { A vol. } 7 & \text { Wemhoff t. Duitsland } \\ 17 \text { jantari 1970 } & \text { A vol. 11 } & \text { Delcourt t. Belgie } \\ 18 \text { juni 1971 } & \text { A vol. 12 } & \text { De Wilde e.a. t. België } \\ 21 \text { februari 1975 } & \text { A vol. 18 } & \text { Golder t. Verenigd Koninkrijk } \\ 27 \text { oktober 1975 } & \text { A vol. 19 } & \text { Belgische politiezaak } \\ 7 \text { december 1976 } & \text { A vol. 24 } & \text { Handyside t. Verenigd Koninkrijk } \\ 18 \text { januari 1978 } & \text { A vol. 25 } & \text { Ierland t. Verenigd Koninkrijk }\end{array}$

27 juni 1968

17 jantari 1970

18 juni 1971

21 februari 1975

7 december 1976
D\&R vol. 5 p. 86

D\&R vol. 10 p. 100

niet gepubliceerd NJ $1981 / 110$ (EAA) D en R vol. 19 p. 244
ECRM 18 mei 1976

ECRM 14 juli 1977

ECRM 13 mei 1980

Den R vol 19.24 
JURISPRUDENTIE:

25 april 1978
6 september 1978
13 juni 1979
9 aktober 1979
6 november 1980
6 november 1980
13 augustus 1981
22 oktober 1981
25 februari 1982
23 november 1983
28 november 1984
26 maart 1985
28 mei 1985
29 mei 1986
29 mei 1986
17 oktober 1986
18 december 1986
26 maart 1987
21 juni 1988
26 oktober 1988
30 maart 1989
7 juli 1989
7 juli 1989
21 februari 1990

24 april 1990

27 september 1990

29 november 1991

25 maart 1992

25 maart 1992

16 december 1992

25 februari 1993

25 maart 1993

30 juni 1993

22 februari 1994

26 mei 1994

25 november 1994

9 december 1994

23 maart 1995

22 november 1995

25 september 1996

22 oktober 1996

24 oktober 1996

19 februari 1997

22 april 1997

25 september 1997

27 september 1999

8 december 1999
A vol. 26

A vol. 28

A vol. 31

A vol. 32

A vol. 39

A vol. 40

A vol. 44

A vol. 45

A vol. 48

A vol. 70

A vol. 87

A vol. 91

A vol. 94

A vol. 99

A vol. 100

A vol. 106

A vol. 112

A vol. 116

A vol. 139

A vol. 142

A vol. 152-A

A vol. 160

A vol. 161

A vol. 172
Tyrer t. Verenigd Koninkrijk

Klass t. Duitsland

Marckx t. Belgie

AA 1979327 (EAA)

NJ $1980 / 462$ (EAA)

NJ 1980/376 (EAA)

Guzzardi t Italie

Van Oosterwijck t. Belgie

Young e.a. t. Verenigd Koninkrijk NICM 1982400(MdB)

Dudgeon t. Verenigd Koninkrijk

Campbell e.a.t. Verenigd Koninkrijk

Van der Mussele t. Belgię

Rasmussen t. Denemarken

$\mathrm{X}$ en $\mathrm{Y}$ t. Nederland

NJ $1986 / 4$ (EAA en EAAL)

NJCM 1985, 410 (JGCS)

Abdulaziz e.a. t. Verenigd Koninkrijk NJ 1988/187 (EAA)

Feldbringe t. Nederland

Deumeland t. Duitsland

Rees t. Verenigd Koninkrijk

Johnston t. Ierland

Leander $t$. Zweden

Ärzte für das Leben t. Oostenrijk

Norris t. Verenigd Koninkrijk

Chappell t. Verenigd Koninkrijk

A vol. A 176-B Huvig t. Frankrijk

A vol. 184 Cossey t. Verenigd Koninkrijk

A vol. 214-C Vermeire t. Belgie

A vol. 232-C B. t. Frankrijk

A voll. 233 Campbell t. Verenigd Koninkrijk

A vol. 251-B Niemietz t. Duitsland

A wol. 256-A Funke t. Frankrijk

A wal. 247-C Costello Roberts t. Verenigd

A vol. 264 Sigurjonsson t. IIstand

A vol. A 280-B Burghartz t. Zwitserland

A vol. 290 Keegan t. lerland

A vol. 299-B Stjemat. Finland

A voll 303-C López Ostra t. Spanje

A vol $310 \quad$ Louizidou t. Turkije

A vol. $335-C$ C.R.t. Verenigd Koninkrijk

1996-IV Buckley t. Verenigd Koninkrijk

1996-IV

$1996-\mathrm{V}$

1997-I

1997-II

1997-VI

1999-VI.

1999-VIII
Gaskin t. Verenigd Koninkrijk

Soering t. Verenigd Koninkrijk

Powell en Rayner t. Verenigd

Koninkrijk

Koninkrijk

Stubbings e.a. t. Verenigd Koninkrijk

Guillot t. Frankrijk

Laskey e.a. t. Verenigd Koninkrijk

NJ $1987 / 432$ (EAA)

AA 1987242

NJ $1987 / 945$ (EAA)

NJ 1989/97 (EAA)

NJCM 1988, 148 (ThLB)

NJCM 1988, 566

NJCM 1989,365 (JGCS)

NJCM 1990206 (LFMV)

NJ 1990/158 (EAA)

NJCM 1990692 (CJS)

NJ 1991/523 (EJD)

NJ 1995/678 (EAA)

NJCM 1992673 (PL)

NJ 1.995/679 (EAA)

NJ $1993 / 400(E J D)$

NJ $1993 / 485$ (KN)

NJ 1995/725 (EAA)

NJ $1996 / 12$ (EAA)

N』1995/37

IB $1995 / 67$ (AWH)

NJCM 1995801 (JWdV)

NJ 1997/L (KN)

N. $997 / 555(\mathrm{END})$

NJ $1997 / 449$ (JdB)

NJ $1997 / 324$

$X, Y$ en $Z$ t. Verenigd

NJCM 1998, p. 316 e.v (CF)

Koninkrijk

Lustig Prean t. Verenigd Koninkrijk

EHRC 2000/2 (HJ)

Smith en Grady t. Verenigd Koninkrijk

Pellegrin t. Frankrijk

EHRC 2000/13 (AWH) 
15 februari 2000

31 juli 2000

22 maart 2001

18 januari 2001

2 oktober 2001

7 februari 2002

26 februari 2002

16 april 2002

29 apprill 2002

11 juli 2002
Garcia Manibardo t. Spanje

A.D.T. t. Verenigd Kaninkrijk

K. H. W. t. Duitstand

Jane Smith t, Verenigd Koninkrijk

Hatton t. Verenigd Koninkrijk

Mikuliç t Kroatie

Frette i. Frankrijk

Stés Colas Est e.a. t. Frankrijk

Pretty t. Verenigd Koninkrijk

Goodwin t. Verenigd

Koninkrijk
EHRC 2000/30 (AWH)

HRC 2000/69 (JVdV)

EHRC 2001/31 (HI)

EHRC 2001/19 (HJ)

EHRC 2001/79 (HJ)

EHRC 2002/25 (HJ)

EHRC 2002/30 (JG en HJ)

EHRC 2002/ 46 (HJ)

EHRC 2002/47 (JG en HJ)

EHRC 2002/74 (JvdV en HJ)

\section{Nederland}

\section{Rechtbanken}

Rb. Arnhem 18 december 1973

NJ 1974/64

Rb. Amsterdam 13 juni 1985

KG 1985/188

KG 1987/423

NJ $1991 / 370$

Valkenhorst II

Rb. Breda 5 maart 1991

\section{Gerechtshoven}

Hof Den Bosch 2 juli 1986

NJ $1987 / 451$

NJ 1988/567

NJ $1991 / 796$

NJ $1993 / 73$

NI $1998 / 927$

Hof Den Bosch 18 september 1991

Hof Amsterdan 3 december 1992

Hof Den Bosch 25 februari 1998

\section{Hoge Raad}

HR 15 oktober 1923

HR 10 december 1957

HR 30 jicnuari 1959

HR 26 juni 1962

HR 22 juni 1973

HR I 4 juni 1974

HR I2 april 1978

HR 18 januari 1980

HR 7 maart 1980

HR 4 mei 1984

HR 12 oktober 1984

HR 27 november 1984

HR 21 maart 1986

HR 30 mei 1986

HR 16 juni 1986

HR 21 oktober 1986

HR 9 januari 1987

HR 15 januari 1988

HR 23 september 1988

HR 2 december 1988
NJ 1923, p. 1329

NJ 1958/176

NJ $1959 / 548$

NJ $1962 / 470$

NJ $1973 / 386$

NJ 1974/436

NJ $1979 / 533$

NJ 1980/463

NJ $1980 / 353$

NJ $1985 / 510$

NJ $1985 / 230$

NJ $1985 / 106$

NJ 1986/585-588

NJ 1986/688

NJ 1987/25॥

NJ 1987/607

NJ $1987 / 928$

NJ 1988/888

NI 1989/740

NJ $1989 / 752$
Opticienarrest

Goudse rijschoolarrest

Quint/Te Poel

Doorbraak

Wettig/onwettig

Stierkalfarrest

Gezamenlijke ouderlijke macht

Optierecht

Euthanasie

Gezamenlijke ouderlijke macht ongehuwden

NS-stakingsarrest

Landbouwvliegers

Edamse Bijstandsmoeder

Naamrecht 
HR 14 april 1989

HR 20 april 1990

HR 8 juli 1992.

HR 7 mei 1993

HR 18 juni 1993

HR 21 januari 1994

HR 8 maart en 10 mei 1994

HR 8 april 1994

HR 15 april 1994

HR 21 juni 1994

HR 6 januari 1995

HR 24 februari 1995

HR 22 december 1995

HR 17 januari 1997

HR I juli 1997

HR 5 september 1997

HR 12 mei 1999

HR 16 juni 2000
NJ $1989 / 469$

NJ 1992/636

NJ $1992 / 714$

NJ 1995/259

NJCM 18-7 (1993)

NJCM 19-6 (1994)

N』 $1996 / 467$

NJCM 19-6(1994)

N. $1994 / 608$

NJ 1994/656

NJ 1995/422

NJ $1995 / / 468$

RvdW 1996/10

NJ 1997/483

NJ $1997 / 156$

NJ $1998 / 686$

NJ $2000 / 170$

NJ 2000/613

\section{Centrale Raad wan Beroep}

CRvB 29 januari 2002

CRvB 1 oktober 2002
$01 / 515 \mathrm{ZFW}$

01/2882 ZFW
Harmonisatiewetarrest

Hoogenraad

Door medische fout ontstane aidsbesmetting

Antilliaanse zaak

HIV-test

Ferdi $\mathrm{E}$

Agfa t. Schoolderman

Valkenhorst

Chabot

Van Gasteren

Brieven van wettiging

Erfenis onwettig kind

Adoptie door lesbisch paar

Zorgverzekeraar DSW t. Sentges Zorgverzekeraar ZAO t. Hesper 



\section{Zaken register}

Abortus, recht op-

Abstracte rechterlijke toetsing, zie toetsing

$5,59,85,88,109,138,258,307$

Activisme, rechterlijk-, zie rechterlijk activisme

Afstamming,

- recht op kennisneming van de-

Algemeen persoonlijkheidsrecht, zie persoonlijkheidsrecht

'Allgemeines Gesetz"

Ambtshalve aanvulling van de rechtsgronden door de rechter

Amendement

- het Vierde-

- het Vijfde-

- het Negende-

- het Veertiende-

$8,141,151,205,317,332,379,411$

Analogie

- afwezigheid van een vaste vergelijkingsmaatstaf

- afwijzing van de-

- bedenkingen tegen de-

- en constitutionele verhouding

- en interpretatiemethoden

- en norm van hoger recht

- vergelijkingsmateriaal in de-

eigen jurisprudentie

wetgeving, volkenrechtelijke besluiten

consensus

natuurrechtelijke overwegingen

- waarderingsmoment van de rechter in de-

- werkwijze van-

Amerikaanse Hooggerechtshof

Duitse Federale Constitutionele Hof

Hof wan Justitie van de EG

Europees Hof voor de Rechten van de Mens

Hoge Raad

'Ausstrahlungswirkung"

$79,93,126,132,134$

33,38

$32,33,35,38,161,250$

$31,35,40,197,255,259$

$3,32,36,66,81,85,151,161,204,247,273$

Autonome rechtsvinding, zie rechtswinding

Autonomie, persoonlijke-, zie persoonlijke autonomie

'Basic liberty"

Bedrijfsruimten, recht op bescherming van-, zie rechtspersoon

Beginselen van Gemeenschapsrecht

Benoeming van de rechter

$180,252,258,331,356,374,386,396$

$336,345,372,381,388,407,411,413$

$143,154,214,241,351,355,369,375,435,445$

$228,241,250,256,390,412$

$207,210,241,242$

$243,247,249,250,257,282,283$

$291,306,310,314,315,320,323,328,330$

$337,345,348$

$364,367,371,374,389$

$404,406,408,410,413$

Beperkingsgronden

Beroepsmatige ontplooiing, recht op-

Beschuldigingen,

- een recht om na boetedoening niet te worden geconfronteerd met-

$52,102,176,335,339,353,375$

$83,86,96,103,129,137$

$37,47,49,55,67,429$

'Bill of Rights'

$3,5,13,19,31,162,214,245,250$

Casuistiek $34,60,234,239,319,331,375,403,404,437$

Certiorari, systeem van-

"Common ground", zie consensus 


\section{ZAKENREGISTER}

Concretisering wit norm van hoger recht

$8,34,48,66,123,142,150,163,204,214$ $299,394,412,435,437,440,447$

'Concurring ${ }^{*}$

Connexiteit wan grondrecht met EG-verdragsrecht

Consensus

- in interpretatiefase

- in toetsingsfase

$53,67,143,188,189,214,241,259,271,351,367,369,395,448$

Constitutie

$121,128,154,367,443,448$

- definitie

- toepasselijkheid van het begrip op het rechtsstelsel

Constitutionele verhouding

$69,124,153,157,172,179,184,193,198,204,209,213$, $216,223,229,241,427,436,442,445,446,447$

Hooggerechtshof van de Verenigde Staten

251,267

Het Duitse Federale Constitutionele Hof

Europese Hof van Justitie

EHRM

385,396

Hoge Raad

Contractsvrijheid

'Court', zie 'rechter', samenstelling van rechterlijke macht

Culturele identiteit, recht op-

$37,211,247,326$

Deductieve redenering

152,369

Direct beroep

'Dissenting"

149,203

'Double standard"

'Due Process'

Dynamisch-evolutieve interpretatie

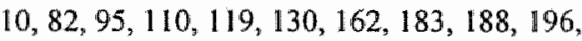
$252,256,311,365,372,397,438$

\section{Dualisme}

Duatisme

Eeuwigheidsclansule

Effectiviteitsbeginsel, zie "effet utile"

'Effet utile'

58,119

'Einheit der Verfassung'

Erkenning van rechtsnormen

$42,97,150,170,197,295$

$60,77,157,177,185$ 164,177

EU-Handvest van fundamentele rechten

Extensieve interpretatie

$5,34,45,90,101,133,142,152,163,213,241,423,431$

Forum,

- algemeen

$153,161,197,210,241,427,446$

- ideaaltypisch

- juridisch

"Fundamentality"

Fysieke integriteit, recht op-

$38,80,286,429$

Geestelijke integriteit, recht op-

Gelijke behandeling van mannen en wrowwen, recht op-

$5,29,37,214,220,222,230,241,276,301$, $325,357,360,395,418,420,429$

55,444

Geprivilegieerde klager

$21,33,42,59,63,363,400,428$

$19,21,56,63,251,302,329,365$ 
Geslachtelijke identiteit, recht op-

Gesloten grondwetssysteem

Gezinssamenstelling, erkenning van wrije keuze op-

Grondrecht

- benoemde-

- onbenoemde-

Grondwet

- wijziging wan de-
$22,316,322,348,367,395$

146,148

$23,36,85,278$

29

$45,326,333,413$

$45,333,413$

$28,51,57$

$43,85,97,130,136$

$151,218,230,240$

$4,168,173,182,191,269$

390

168

$47,324,356,368,370,396,418,425,430,443$

$51,61,186,298,399,405,415,418,420,444$.

263,367

Huwelijkspartner, vrije keuze van-

Immuniteit, afwezigheid van- voor verkrachtende echtgenoot

Incorporatie van grondrechten

$32,35,37,118,133,199,247,337$

Individuele rechtsbescherming, vermoeden ten faveure van-

$120,184,198,291,327,341,356$, $359,396,425,447$

Inductieve redenering

$149,203,220,394,412$

Informationele zelfbeschikking, recht op-

$21,151,299,313,315$

Institutionele interpretatiebegrenzing

'Intentionalists'

Interinstitutionele interpretatiebegrenzing

$68,132,424$

Interpolatie

$160,195,197,276,282,284,432,446$

$68,132,139,143,424$

Interpretatie,

- constitutionele-

45,284

- debat

- maximes

$4,12,95,145,157,164,190,199$

157,284

- methoder, zie tekstuele, systematische, historische, teleologische en dynamisch-evolutieve interpretatie

- restrictieve

'Interpretevists"

$79,134,163,183,184,431$

$160,282,284$

407,409

Inzagerecht, medisch-

$113,153,157,172,180,185,197,211$

'Judicial activism'- zie activisme

'Sudicial restraint'- zie terughoudendheid

Iuridische kwaliteit

- van de rechtsnorm

$1,210,213,217,220,377,450$

- van de redenering in de rechtsvinding

212,449

Kwalificatie van de individuele aanspraak

Kernrecht, zie sferenleer

$3,6,8,201,207,221,241,429,442$

Leemte $2,146,177,240,286,326$

Legaliteitsbeginsel

$387,389,394$ 
Legitimatie wan cen rechtsnorm

Leven, recht op

Lichamelijke onschendbaarheid, recht op-, zie fysieke integriteit

"Liberry"

Loyaliteitsbegingel

Machtenscheiding

'Majority vote'

'Margin of appreciation'

Medisch inzagerecht

Medische behandeling, weigering van-

Medische zelfbeschikking, recht op-

Menselijke waardigheid

Metafoor

Milieu, recht op informatie aver-

'Moeilijke gevallen', zie 'hard cases'

Naam, recht op de-

Natuurrechtelijke normen

'Non-interpretevists'

Norm van hoger recht

- Rechtspraak van het Amerikaanse Hooggerechtshof

- Rechtspraak van het Duitse Federale Constitutionele Hof

- Rechtspraak van het Hof van Justitie.

- Rechtspraak van het EHRM

- Rechtspraak van de Hoge Raad

Obiter dicta

Onaantastbare kern van prive-leven Ongeschreven recht, zie rechtsnormen

Ongrondwettigwerklaring

Ontvankelijkeidscriteria

Open grondwetssysteem

"Originalists"

Partijverbod

"Penumbra"

Persoonlijke autonomie

Persoonlijke levenssfeer

Persoonlijke ontplooiing, recht op-

Perifere sfeer van privê-leven
$15,40,114,215,221,232,241,258$, $313,353,359,419,434$

$19,45,85,228,259,307,385,388,429$

$3,34,66,75,83,151,161,195$, $200,205,247,250,279,429$

$75,149,342$

$27,31,52,97,136,148,169,282,351$

82

$60,120,396,443$

407,409

279

341,342

$42,44,88,97,228,274,289,307$,

$344,3.46,363,369,386$

$211,213,450$

$21,225,361,380,395$

$324,344,354,380$

$1_{1} 45,221,225,227,241,246,264,293,333,374,389$

$161,195,246,432,446$

$2,6,8,10,201,203,209,216,220,222$,

$241,405,423,431,435,438$

$249,253,258,263$,

$266,271,274,285$

$306,313,320,324,328$

$347,356,359$

$363,364,369,374,384,386,387$

$405,406,412,418$

$13,125,238,258,299,303,305$,

$312,316,324,330,347,352$

$97,317,332,337$

$47,84,89,99,25,126,236,255$,

$263,276,321,430,442$

$70,75,91,105,116,126,133,185,445$

146

$160,195,268,282,432$

293,324

$40,211,254,284$

$11,26,223,250,385,393$

$19,26,36,52,62,192,200,325,363,408,421,429$

43,45

$21,40,123,253,272,297,318,332,373,384,449$ 
Persoonlijkheid,

- actieve component van de48,312

- definitie

- elementen van het recht op-

- identiteit van de-

- passieve component wan de-

$25,48,312$

- privaatrechtelijk begrip van-

Persoonlijkheidsrecht

- begrip in de Nederlandse rechtspraak

- begrip in de Duitse rechtspraak

- privaatrechtelijke notie van-

Political question-doctrine

Positieve verplichting

$41,50,64,277,305,328$

$64,123,141,411,417,419,428$

$47,93,293,298,304,312,322,324,330$

50,65

78,120

$61,121,186,260,281,307,350,361$,

$365,377,383,392,437$

Positivering van rechtsnormen

- Rechtspraak van het Amerikaanse Hooggerechtshof

- Rechtspraak van het Duitse federale Constitutionele Hof

$250,259,269,276$

- Rechtspraak van het Hof wan Justitie

$313,330,331,332$

- Rechtspraak van het EHRM

352,354

- Rechtspraak van de Hoge Raad

$373,392,394$

$414,418,420$

Precedentwerking

$234,236,396$

- in continentale rechtsstelsels

- in de Verenigde Staten

235,259

Prejudicięle procedure

Presumptie van grondwettigheid

$53,104,107,111,324,353$

$38,79,198,326$

Privaatrechtelijke notie van persoonlijkheid, zie persoonlijkheidsrecht

Privacy

Amerikaans begrip van-

32,40

EG-rechtelijk begrip van-

38,354

'Privater Lebensgestaltung, Sphare einer-'

Privé-leven

- recht op-, EVRM

- recht op- Nederland

- recht op-, Duitsland

Proportionaliteitstoets

$6,32,56,360,366,370,378,382,385,392,395$

$52,56,63,206,400,409$

$4,296,299,303,308,317,320,326,332$

$38,47,60,100,301,340,430,443$

Rationaliteit, zie rechterlijk besluitwormingsproces

'Rational basis test"

$37,39,80$

Rechter,

- benoeming, zie benoeming rechter

- politieke klewr

$83,87,439$

- samenstelling rechterlijke macht

Rechterlijk activisme

$81,85,116$

$79,114,128,138,190,198,225,249,269$, $283,307,319,424,426,441,446,448$

Rechterlijk besluitvormingsproces,

- fasen in het-

$70,71,84,144,154$

- rationaliteit in het-

$13,156,427$

- coherentie

$13,154,427$

Rechterlijke taakopvatting

$70,78,89,113,120,130,134,138,158,172,195,209,224$,

$242,262,281,289,311,404,424,432,439,441,446$ 
oudendheid

喓

analogic

zie rechtsnormen

shalve aanvulling van de-, zie ambtshalwe aanvulling 1 rechtsnorm, zie rechtsnormen

de omvang door de wetgever
$74,79,81,98,106,117,127,130,137,190,198$, $239,261,274,286,336,404,424,441,447$

$12,33,38,45,47,54,60,73,79,88$ $104,110,120,124,132,138$

$53,58,71,123,133$ $84,96,112,129,138$ $72,87,102$ $102,115,187$

wan-

, zie erkerning

is

recht

van het Amerikaanse Hooggerechtsh of

van het Federale Constitutionele Hof

van het Hof van Justitie

van het EHRM

: van de Hoge Raad

1

$30,239,262,277,279,419,424,434,435$

$98,142153,218,226,228,230,239,285$, $397,427,432,440,448$

$144,218,224,226,227,230,233$

$8,26,27,37,40,43,45,53,98,141,147,164$, $202,214,233,240,418,429,433,437$

$256,276,285$

$290,319,336$

338

387,391

409,417

$5,142,144,200,202,206,217,224,230,241$ $241,337,345,355,359,398,420,435,445$

$1,28,30,37,44,51,97,144,161$, $201,209,216,216,224,230,238,241,428$

$13,174,287,332,356,397,420$

sepasselijkheid van fundamentele rechten opide interpretatie

$57,104,338,374$ $144,171,179,193,340,356$ $9,30,141,152,170,189,191,197,209$, $217,227,426,429,432,433$

heid van de$153,217,220,225,234,242$ $195,197,218,223$ 195,197 $9,10,25,124,209$ $250,293,333$

wan$24,293,305,320$

sht op$114,210,266,333,378,395,397,416,449,450$

sit, zie geslachtelijke identiteit

ait

ur

liteitt

ime

$11,22,40,210,270,322,349,364$ $20,85,123,137,157,200,210,215,296,322,349,363$ 368 
'Sondervotum', zie "dissenting' en 'concurring'

Sferenleer

$49,25,60,326,372$

'Strict scrutiny test'

Subsidiariteit

$46,79,89,101,120,324$

"Swingvoter"

Systematische interpretatie

Tekstuele interpretatie

$114,168,174,183,192,208,433$

Teleologische interpretatie

$159,167,173,182,197$

Terughoudendheid, rechterlijke-, zie rechterlijke terughoudendheid

Textuur van grondwetsnormen

$98,139,146,168,242,270,433,437$

Toetsing,

- abstracte-

$74,89,96,120,252,305,322$

- verkapte abstracte-

$77,117,391$

- concrete-

89,98

- als fase in het rechterlijke besluitvormingsproces

- intensiteit

- verbod van rechterlijke-

'Topik'

"Travaux préparatoires"

- als rechtsvindingsinstrument-

$144,157,168,184,192,207,433$

Transseksualiteit, zie geslachtelijke identiteit

Uitspraakbevoegdheden

- erga omnes werking

- variatie in de-

- wettelijke-

$84,11,118$

$18,31,49,60,70,80,120,144$, $327,352,366,379,430,443$

$60,101,121,281$

$125,132,138,190,197,399,424,444,446$

165,166

$21,174,182,182,188,208$

'Undue burden'

Vaderschapstest, recht op-

Vangnetfunctie van grondrechten

'Verfassungsmäßige Wertordnung'

Vergelijkbaarheid onder de analogie, zie analogie

"Vitaal belang'

Voorbehoedmiddelen, recht op gebruik van-

$93,127,129,135,446$
$92,110,117,127,135$

$84,92,110,117,127,135$

- door gehuwde paren

318,379

$46,312,325$

$67,46,90,168,294$

- door ongehuwden

$379,413,415$

Werkdefinitie van het recht op persoonlijkheid, zie persoonlijkheid

Wetsanalogie, zie analogie

Woning, onschendbaarheid van de-

Zelfbeschikking, recht op-

Zelfdoding, recht op hulp bij-

Zelfinciminatie, recht om niet te hoeven meewerken aan-
$6,58,66,254,314,354,370,372,382$

$19,26,40,63,150,210,223,251,274$, $280,299,313,332,394,401$ $40,83,137,269,273,385,401,418$ 



\section{Dankwoord}

Ik heb aan het schrijven van mijn proefschrift veel plezier beleefd. Je schrijft je boek zelf, maar deze studie was zonder steun en inspiratie van anderen niet tot stand gekomen. Er zijn momenten van eurofie die je wilt delen, maar ook momenten van het niet meer weten hoe nu verder. Allereerst will ik Aalt Willem Heringa hartelijk bedanken, die mij als promotor bij dit onderzoek steeds gestimuleerd heeft verder te denken en verbanden te zoeken. Hij wist als geen ander de vinger op zere plekken te leggen, terwijl hij mij bij de verbetering of unvulling daarvan steeds een grote vrijheid liet. Ik ben je daar erg dankbaar voor; een onderzoeker moet leren leven met een grote mate van onzekerheid en in leren zien dat onzekerheid juist mooie gedachtenvorming kan opleveren. Het is daarbij van belang dat er lemand achter je staat die daar vertrouwen in heeft, vooral ook op momenten dat dat vertrouwen niet steeds aanwezig is bij jezelf. De leescommissie, Luc Verhey, Cees Flinterman, Jeroen Schokkenbroek, Frits Stroink en Bruno de Witte, wil ik gaarne bedanken woor het lezen van het manuscript - in de zomervakantie. Mijn collega's in de capgroep publiekrecht zijn zowel inhoudelijk als moreel van grote steun geweest. Ik zal de ütstapjes, borrels en de heel prettige sfeer die in deze groep heerst niet gauw vergeten; zij maakten geconcentreerd en gedreven werken heel erg aangenaam. En Nettie, veel dank ook voor het mooi opmaken van mijn verhaal:

In het bijzonder wil ik een aantal (oud-)aio's bedanken voor hun trouwe steun. Martha, de lunches waarin de dips en de trips van het proefschriftschrijven worden geventileerd, zal ik node missen. Janneke, jij bent met je enorme gedrevenheid een inspirerend voorbeeld en met je kritische gezichtspunten een bijzonder fijne sparring partner. Yvonne, je niet aflatende enthousiasme over het plezier in het promoveren afgelopen maanden en je peptalks hebben mij regelmatig een noodzakelijk relativeringsvermogen gebraclit. En Frederike, als oud-kamergenoten hebben we heel wat (promotie)lief en -leed gedeeld, waarvoor mijn dank.

Daarnaast will ik de faculteit der rechtsgeleerdheid bedanken, die het mogelijk maakte dat ik kon kennismaken met het Amerikaanse recht aan Harvard Law School in de Verenigde Staten. Het is bijzonder waardevol om met buitenlandse en A.merikaanse juristen het Amerikaanse constitutionele recht te leren begrijpen - iets wat ik niet uit literatuur en rechtspraak had kunnen halen. In het bijzonder wil ik in dit verband Prof. $C$. Fried van Harvard Law School en Prof. P. Rubin van Georgetown University bedanken voor respectievelijk het mogen volgen van de cursus 'American Constitutional Law' en voor de gedachtewisselingen over mijn onderwerp. Last but sure not least wil ik Karijn, Désireé, Esther, Brigitte en Wiea en mijn andere vrienden en vriendinnen bedanken, jullie hebben eindeloos geduld gehad en ik realiseer me dat ik met het vooropstellen van het proefschrift regelmatig het kostbare krediet heb aangesproken dat ik bij jullie heb. Karijn, jouw karavanserai in Afrika voelt als een heerlijke thuishaven waar ik regelmatig heb bijgetankt. En flamencomeiden, jullie vormen samen met de dans een prachtige contratiempo bij het proefschriftschrijven. Het dankwoord is ook een mooie gelegenheid om vooral ook het thuisfront te bedanken; pap en mam - voor jullie onvoorwaardelijke steun en vertrouwen.

Tijd voor een feestije! 



\section{Curriculum vitae}

Heleen Janssen werd in 1970 geboren te Geldrop. In 1989 behaalde zij haar atheneumdiploma aan het Rythovius College te Eersel, waarna zij van 1989 tot 1995 Nederlands recht studeerde aan de Universiteit Maastricht en de Panepistimiou University te Thessaloniki. Daarna verbleef zij als bursaal op uitnodiging van de Deutsche Akademische Austauschdienst een jaar in Duitsland voor een verdieping in het Duitse recht, waarna zij begin 1997 naar de Universiteit Maastricht terugkeerde om als docente staats- en bestuursrecht onderwijs te verzorgen bij de capaciteitsgroep publiekrecht. Vanaf september 1997 was zij eerst als aio, later als junior onderzoeker aan de capaciteitsgroep publiekrecht verbonden. In 2000 bracht zij in verband met haar onderzoek een studiebezoek aan Harvard Law School in de Verenigde Staten. Na afronding van het proefschrift heeft zij de laatste maanden van 2002 gewerkt aan een in 2003 te publiceren onderzoek naar wetgeving in Europese landen over genetische privacy en discriminatie. 